

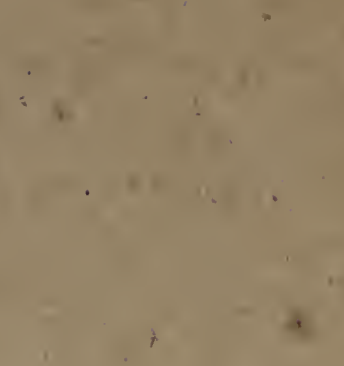

$\checkmark$

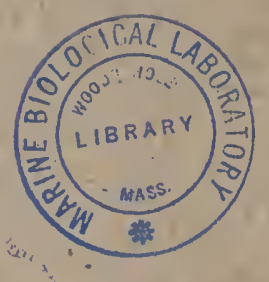




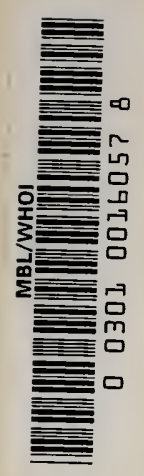



SMITHSONIAN INSTITUTION

UNITED STATES NATIONAL MUSEUM

Bulletin 82

\title{
A MONOGRAPH OF THE EXISTING CRINOIDS
}

BY

\begin{abstract}
AUSTIN HOBART CLARK
Curator, Division of Echinoderms,

United States National Muserm
\end{abstract}

VOLUME 1

THE COMATULIDS

PART 2

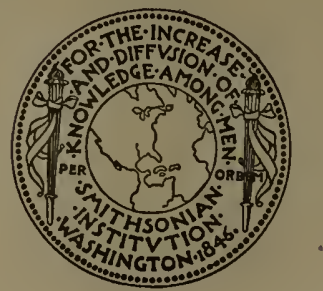

WASHINGTON

GOVERNMENT PRINTING OFPICE 1921 

UNITED STATES NATIONAL MUSEUM

Bulletin 82

\section{A MONOGRAPH OF THE EXISTING CRINOIDS}

AUSTIN HOBART CLARK

Curator, Division of Echinoderms,

United States National Museum

VOLUME 1

THE COMATULIDS

PART 2

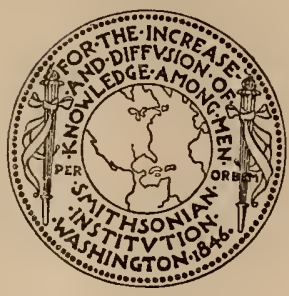

WASHINGTON

GOVERNMENT PRINTING OFFICE 1921 
BULLETIN OF THE UNITED STATES NATIONAL MUSEUM. 


\section{TABLE OF CONT'EN'L'S.}

Structure and anitomy-Continued.

Radials-Contlnued.

Family Comasteridæ-_..... 4

Subfamlly Caplllasterine

Comatella nlgra

Comatella stelligera_-_._-

Comatella maculata__._. $\quad 7$

Neocomatella pulchella_._ . _........ 7

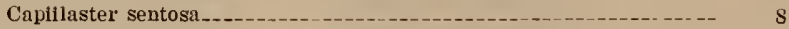

Capillaster multiradiata__-_._. $\quad 9$

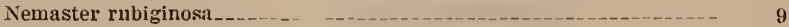

Nemaster discoidea______._. 9

Leptonemaster venustus____... 10

Comatilia lrldometriformis_._..... 11

Subfamily Comactinifnæ _..._. 12

Comatula rotalaria _..._-_- 12

Comatuia solaris _._-_._- 12

Comatula pectinata_-_a

Comutula micraster-_-_-_-_-_-_- 13

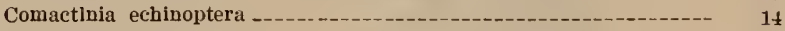

Comactinia meridionalis _..._... 16

Subfamlly Comasterine_-_-_- 16

Comaster fruticosus_._-

Comaster parvus_... 17

Family Zygometrid:e-_-_- 18

Zygometra comatil_...- 19

Catoptometra hartlaubi

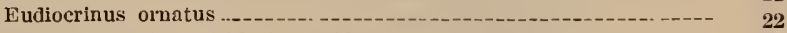

Families Himerometridæ and Mariametridie _................

Family Himerometridre.-_-_-_._-

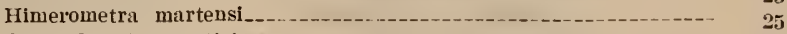

Craspedometra acuticirra -... 25

Heterometra reynaudii

Heterometra phillberti

Amphimetra enslfer-_.- 29

Famiiy Mariametridæ_........... 30

Pontiometra andersoni $\quad 30$

Mariametra suhearinata_._. 31

Lamprometra protectus _-_._.

Family Colobometridæ

Cenometra unicornis _.......... 36

Cyilometra albopurpurea

Cyllometra disciformis__..... 37

oligometra serriplnna 
Structure and anatony-Continued.

Rudials-Contiuued.

Articular fuces of the radials-Cintimerl.

Fumily Tropiometridse

T'ropiometra macrodiscus

Tropionetra encrinus.-_.

'Tropionetra jicta

'Tropiometra caliuata

Family Calometrid:e--_-_-_-_-

Neometra multicolor

Fumilies Thalassumetridie and Charitometridit.

l'anliy Thalassometridze

Subfamily Ptilometring

Ptilonetra nüllieri

Ptilometra macronem:

Asteronetru macropoda

Subfamily T'ualassometrina _.

'Tlalassometra villosu__.

'Tlualassometra agassizi i__._.

Styiometra spinifera

Parametra orion.

Stenometra quinquecostata___.

Stiremetra breriradia___-

Family Charitometrldis______ 49

Crinometra insculpta_-_-_- 49

Pachylometra in requalis _... 49

l'erissometra angusticalyx _. 49

P'oecilometra acola

Charitometra basicurvat _- 49

Chn ritometra incisit__

Family Antedonidie-_. 50

Subfamily Antedoninie_-_- 50

Antedon petasus_-_-

Antedon mediterranen

Antedon adriatica _.

Anterion bifida__-

Compsonietra lovêni

Subfamily Thysanometrinæ. 54

Thysanometra tenelloides

Coccometra bagenil

Subfamily Perometrina _-

Perometra diomeder_____. 56

Erythrometra ruber -

Subfumily Heliometrince _. 58

Promachocrinus kerguelensis _._. 58

Solanometra antaretica _. 58

Florometra asperrima

Florometra perplexa_._. 60

Florometra tamnerí _._. 60

Subfamily Zenonetring

Zenometra columnaris._. 61

Psathyrometria fragilis _.

Subfamily Batlymetrinæ_-_ 63

Hatlirometra prolixa

Hatliometri tenella 
Structure and anatomy-Continued.

Radials-Continued.

Articular faces of the radials-Continued.

Family Antedonidx-Continued.

Subfamlly Bathymetrine-Continued. Page.

Trichometra cubensis _. 65

Nanometra bowersi

Thaumatometra tenuis _. 66

Family Pentametrocrinidæ

Pentametrocrinus japonicus _. 68

Pentametrocrinus semperi

Key to recent comatulids based upon character found in articular faces of radials _..._ 6 ?

Post-radial elements _._-

General features........ 78

Post-radial homologies.

First brachial pair._____- 103

Homologies of the division series of two ossicles___. 104

Eudiocrlnus and Uintacrinus.

Pentametrocrinidæ and Atopocrinus

Homologies of the division series of four ossicles

Irregularities in the occurrence of the division series of $4(3+4)$

Systematic distribution of the division series of $4(3+4)$

Capillaster and Nemaster._-_-_- 110

Comatella, Neocomatella, and Palieocomatella_______.___._. 114

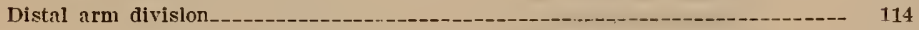

Nomenclature of the different types of post-radial structure

Adolescent autotony and the reduplication of the arms

Young of the comatulids

Interpolated division series

Process of arm reduplication

Phylogenetic sequence of the arms on each ray-____- 123

Ontogenetical, plyylogenetical, and morpliological sequence of the first brachial pairs and their reduplications

Brachials of the free undivided a rm beyond the first pair

Brachials of the arms of the multibrachiate species.

Arm tlps__.

Pinnules _-

General features

Oral or proximal pinnules

Middle or genital pinnules

Distal pinnules

Pinnules and cirri

Types of intersegmental union

General features _._.

Union of radials with each other and with centrodorsal, and union of calyx plates_ 160

Nonmuscular unions

General remarks__-__- 162

Syzygy-_--_-

Pseudosyzygy _._._- 174

Synarthry-_-_-_-_-_-_- 176

Cryptosynarthry 
Structure and anatomy-Continucd.

Muscuiar articulations

Generai remarks.

Straight muscular articuiations

Obique muscuiar articuiations

Articuiations of the pinnules

Articulations of the cirri

Analysis of ambuiacrai ossicles_...

The arm as a whole. 18 ?

The arm in detali

The comatulids and the Fexibilia Impinnata

The arms of the $A$ telecrinidx and Pentametrocrinidx

Pinnuies_._._.

Divislon series and pairing of the ossicles in the ambulacrai serles._........ 196

Nonmuscular articuiations _........

Radials _._.

Radianal _._.

Ornamontation

Perisomic piates.......

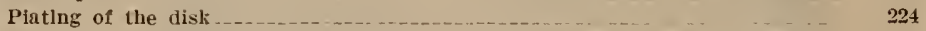

Side and covering plates.

Family Comasteride.

Comateila nigra_._.

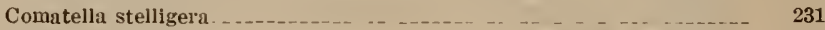

Comatelia macuiata _..

Neocomateiia puicheila___._._.

Neocomatelia alata_._._.

Capillaster sentosa _.

Capiliaster multlradlata_...

Capiliaster coccodistoma

Nemaster graudis _._.

Nemaster iowensis_______._.

Nemaster rubiginosa _ _ _ _ _ _ _

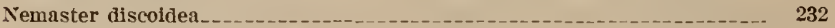

Comissia peregrina

Comissia lütkeni

Comissi littoralis._.

Leptonemaster venustus

Comatonia cristata

Comatilia iridometriformis._. 232

Comatuia rotaiaria.._.

Comatula solaris _._._._.

Comatula pectiuata

Comactinia meridionalis _.

Comutulides austraiis_... . . _

Comaster novæguinere

Comaster minimus_._. 234

Comaster multibrachlata _._.

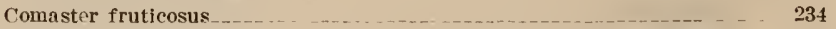

Comaster distlncta _...

Comaster parrus _...

Comaster taviana _........ 234

Comaster delicata 
Structure and anatomy-Continued.

Perisomic plates-Continued.

Side and covering plates-Continued.

Family Comasterida - Continued.

Comantheria briareus.-

Page.

Comantheria polycnemis _-_-_-_._. 234

Comanthina schlegelii_._-_____._._... 236

Comanthus pinguis _...-. 236

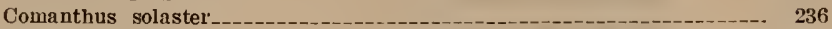

Comanthus japonica

Comanthus trichoptera

Comanthus benhami

Comanthus wahlbergii

Comanthus samoana

Comanthus annulata _........... 236

Comanthus parvicirra _._._.

Family Zygometridx_-_._._. 236

Zygometra microdiscus

Zygometra elegans

Zygometra comata _-_._. 238

Eudiocrinus indivisus _._-_-_-_-_-_. 238

Eudiocrinus junceus _-_-_-_-_-_-_-_. 238

Eudiocrinus pinnatus ... 235

Eudiocrinus venustulus

Catoptometra magnifica__.___._. 238

Catoptometra rubroflava

Catoptometra hartlaubl _.-. 238

Catoptometra ophiura

Family Himerometridæ _._- 239

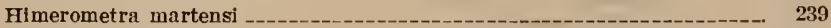

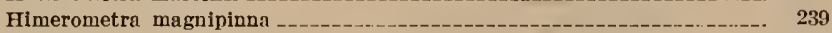

Himerometra bartschi _...

Himerometra robustipinna _._-_._. 239

Craspedometra acuticirra _._._. 239

Heterometra crenulata

Heterometra sa vignil

Heterometra philberti ... 239

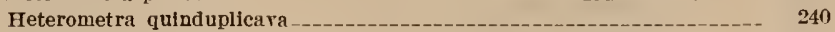

Heterometra bengalensis ._. 240

Heterometra compta

Heterometra pulchra

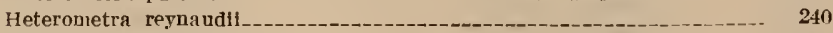

Heterometra quinduplicava

Homalometra denticulata

Amphimetra spectabilis .

Amphimetra discoidea _._. 241

Amphimetra parilis....._-_._._. 241

Amphimetra papuensis ........... 241

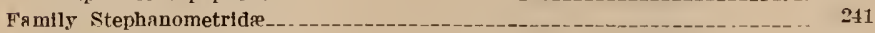

Stephanometra monacantha _._.

Stephanometra echinus _.......... 241

Family Mariametridæ

Pontiometra andersoni

Oxymetra finschii

Oxymetra aranea 
Structure and anatomy-Continued.

lerisomic plates - Continuet.

Side and covering plates-Continuel.

Family Mariametride-Continutel.

Dichrometria cilintr.

Dlchrometra flagellata

Dichrometra dë̉er]einí_...

Marianetra subearinatit_____ 242

Marlametra delieatissima _._.

Lamprometra palmata __..._._._._.

Lamprometra jrotectus _.

Iamprometra gyges_......._

Famlly Colobometride

Cenowetra delicata _.....

Cenometra herdmanl_._. 244

Cenometra unlcormis _._.... 244

Cyllometra disciformis _. _ _ _ _ _ _ _ _

Crllometra albopurpurea

Decametra taprobanes _._. 244

Decametra mylitti____- 246

Decrmetra parva _._.

Decauretra tigrima _._.

Colobometra vepretum

Colobometra dlscolor

Prometra chadwicki _.

Cotylometra gracilicirra_._. 246

Oligometrides adeonie..._...

Oligometra carpenterí_._.

Oligometra serriplnna__._.

Famlly Tropiometridin _.

Tropiometra macrodiscus

Troplometra afra

Troniometra carinata

Tropiometra picta _-_.-. 218

Troplometra indica _..... 248

Famlly Calometridie _.

Neomctra alecto

Neometra acanthaster._._.

Neometra conaminis _ _.

Neometra gorgonia

Calometra callista

Calometra discoidea

fephyrometra propinqua

Pectlnometra carduun _._.

Pectinometra flaropurpurea

Family Thalassometrldie

Ptilometra macronema _.

Ptilometra miilleri._.

Asterometra anthus

Asterometra macropoda

Asterometra cristata

Tterometra magnipeda _..._._.

Pternmetra splendida ...

Pteronetra pulcherrima

Pterometra trichopoda _. 
Struture and anatomy-Continued.

r'erisomic plutes-Continned.

Side and covering plates-C'ontinuel.

Family Thalassometrida-Contimuet. Page.

Cosmiometra crassicirra____

Cosmiometra delieata _.

Stylometra spinifera _..._._.

Stenometra quinquecostata

Stenometra cristati _...

Stenonetra diadema____.

Daidalometra hana _._.

Parametra orion

Parametra granulata ....... 250;

Oceanometra gigantea______ 256

Oceanometra anuandalei _.

Thalassometra villosa__.

Thalassometra agassizii _._.

Aglaometra eupedata _._._.

Agalaometra incerta _._.

Fimily Charitometridre _. 259

Crossometra helius _._.

Perissonetra selene

Perissometra patula

Perissometra lata__._.

Pachrolouretra distincta.

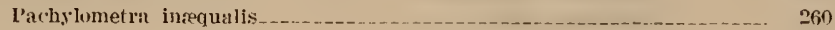

Chondrometra rohusta

Calyptometra Iateralis _.

Givptometra tuberosa _.._.

Crinometra insculpta

Monachometra fragilis _...

Precilnmetra scalaris________ 263

('hlorometra Garrettianat_..__- 261

Strolometra hephurniana__...

Charitnmetril hasieurvil_...

Family Antedonida

Antedon petasus_._.

. Intedon bifidis _..._-

Ainedon adriatica

C'ompsnmetral lovéni

Compsometra incommodi1 _._.

Tosometra panpera

Dorometra parvicirra____

Eumetra chamberlaini

Iridometra adrestine._.

Iridometra melpomene.-_...

Andrometra psyche

'Thysanometra tenelloides____

Coccometra guttata_-__.

Coccometra nigrolineata

Coccometra bagenii

Perometra diomedere

Eirsthrometro australis _.

Erythrometra ruber

Hypalometra defecta 
Structure and anatomy-Continued.

Perisomic plates-Continued.

Side and covering plates-Continued.

Family Antedonidx-Continued.

Nanometra bowersi

Nanometra clymene-.- 267

Hellometra maxima _.

Hellometra glacialis . _........... 268

Promachocrinus kergulensis_..._._._._. 268

Anthometra adrianl _.............. 270

Florometra marlæ.

Florometra laodice -.......... 270

Florometra asperrima _............. 270

Florometra serratissima _._. _ _... _...

Florometra magellanica_.................. 271

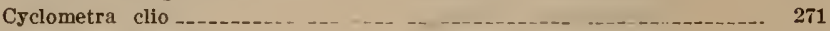

Sarametra trlserialis_____._._._... 271

Zenometra columnaris _...... _............ 271

Psathyrometra borealis...._. _..._........ 271

Psathyrometra fragilis_._._._. 271

Psathyrometra antarctica _... _._.

Psathyrometra gracillima____._._._. 271

Eumorphometra concinna _...

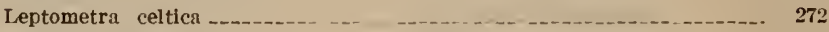

Leptometra phalangium

Notocrinus vlrilis_..._._.

Isometra vivipara

Hathrometra prolixa _._._. . _ _............ 274

Hathrometra tenella__._._.

Hathrometra sarsil _._._. 275

Fariometra explicata _._._._._._. 275

Trichometra cubensis _._____._. 275

Trichometra vexator

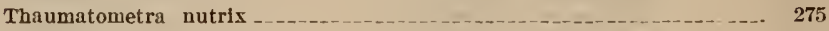

Thaumatometra tenuis_________________._. 275

Family Pentametrocrinidæ

Thaumatocrinus rugosus _._._._. 275

Thaumatocrinus borealis_______..... 275

Pentametrocrinus faponicus___............ 275

Pentametrocrinus tuberculatus _._...._._. 27 .

Pentametrocrinus varians _._._.

Fumily Atelecrinidæ -

Atelecrinus sulcatus _._-_-_ 277

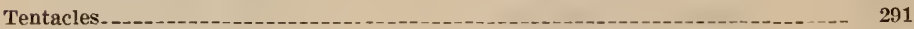

Subambulacral plates _._- 291

Visceral skeleton

$\begin{array}{ll}\text { Inorganic constituents of skeleton of recent crinoids } & 296\end{array}$

Disk_-_._. 302

Organic base of the skeleton 313

Connective tissue -... 313

Pigment_-...-_ 314

Visceral mass____ 314

Body cavlty

Alimentary canal _. 316

Chambered organ $\quad 320$ 
Structure aud anatomy-Continued.

Page.

Axial organ

Central organ -

Cirrus nerves.-. 324

Brachial nerves__

Nerves of the division series

Finer structure of the brachial nerres_______. 325

Branching of the axial cord in the arms

Wandering cells _-_.-. 330

Ventral nervous system

Innervation of the tentacles_-_._- 331

Neurilemma

Epithelial nerves _._- 332

Physiology of the crinoidal nervous system -... 333

Interbrachial muscles

Epithelial muscles__-_. 339

Ligaments_-_--- 339

Ligaments in the cirri

Water-vascular system

Blood-rascular system-_-_-__-_ 345

Labial plexus and spongy organ

Schizocœle cavities_-_.- $34 \mathrm{~S}$

Ciliated epithelium of the ambulacral grooves -350

Ciliated sacks

Ambulacral mucus cells_______- 351

Sacculi

Tentaclc papillie

Forsal glands ..._. 356

Brachial and piunule cysts of Antedon

Genital cord___ 358

Cement secreting cells

Genital pores of the male

Spermatogenesis and the spermatozoa

Genital organs of Isometra rivipara

Genital organs of Notocrinus virilis

Marsujium

Sexual differentiation -

Spawning season

Comatella nigra_-_- 369

Comissia spanoschistum_-_-_-_- 369

Comissia littoralis_-_-_-_-_- 370

Comactinia meridionalis - 370

Comanthus japonica

Comanthus anuulata _._._. 371

Catoptometra ophiura _-_-_- 371

Anphimetra spectabilis _....... 371

Amphimetra parilis

Cenometra delicata _-_-_-_-__- 371

Tropiometra macrodiscus_____._- 371

Tropiometra picta_-_- 371

Calyptometra lateralis _-___- 371

Antedon bifida__... 371

Antedon mediterranea

Antedon adriatica 
Suruwing season-Continner.

Compsometra lovénl.

Coccometra nigrolineat

Coccometra hagenii

Psathyrometra fragllis.

Leptometra phalangium

Hathrometra sarsil

Pentametrocrinus tubcrculatus.

Pentametrocrinus japonicus _.

Pentamctrocínus varinus _...

Copulation _...

Passage of the spermatozon into the recpitacuium seminis in Isometra vivipara

Nevelopment of the eggs

Growth of the oöcyte

Ripening of the eggs

Extrusion of the eggs

Fgg case

Eggs

Regeneration

Possible extent of regeneration

Influence of different factors on regeneration

Color of regenerating parts__

Visceral mass_____- 417

Detalls of arm regeneration... 424

Closure of the wound and degeneration of the cell elements

Rebuilding of the water tube and of the colomic canal

Dorsal and rentral nervous srstems___

Genital cori._...- 429

Muscles and liganchts _ _ _ _

Skeletal structures

Details of the regcneration of the cirri

Embryology and development

Cleavage -

Gastrulation

Closure of the blastopore

Division of the primitive gut into mesenteron, neritomeal sac, and primary by lrocele _- 440

formation of clliated hands, larral nervous system, amd alteration in position of internal organs ( 60 to 84 hours)

Last period of embryonal dcvelopment: formation of calcarcous skeleton (4S to 120 hours) (n-

Free swimming larva

Eictoderm

Ectodernal epithelimm, ciliater bands; and intermediate arcas

Apical pit and nervous system

Attachment disk and vestibular invagination

Intestinal canal

Colome and chambered organ.

Hydrocœle and parietal canal

Mesenchyme

Attachment of larva and its transformation inth stalked form $\ldots$

Description of larva up to fifth day after escape from egg membrane................. Ectoderm. 
Attachment of larva and ita transformation into stalked form-Continued.

Intestinal canal-_-_-

Coelome and its derivatives (axial and chambered organs) -

Hydrocele

Parietal canal

Mesenchyme

Calcareous skeleton

Sacculi

Connective tissue

Stallied larva after rupture of vestibule, up to appearance of rudinents of arms_______-_- 482

Deseription of larva from fiftl day to sixtl week after rupture of egg membrane_..... $45:$

Vetoder'm

Ectoderm of body wall.

Vestibular lining and nervous system

Ectoderm of the tentacles.

Intestinal canal

Ccelome and its derivatives_-_-_-_- 491

Chambered organ

Axial organ

Hydrocele ...-. $4: 44$

Parietal canal__.

Mesenchyme

Sacculi

Connectlve tissue --_---_-_-_- 498

Dorsal nervous system_-_-_- 499

Antedon medlterranea

Antedon bifida

Antedon moroccana_-_-_-_- 509

Comactinia meridionalis_......._- 509

Tropiometra macrodiscus

Tropiouletra picta_..............- 510

Isometra viripara

Notocrinus virilis _-___-

Abnormal embryos and larvie_._-

The pentacrinoid young

Comissia littoralis _.- 513

Comlssia hartmeyeri.

Comanthus wahlber'gii _.......-...

Comactinia merldionalis__.______. 514

Comasterid pentacrinoids____________.. 517

?Lamprometra, sj -

Tropiometra picta _-

Ptilometra mïlleri_-_-_-_- 520

Crotalometrin norrectit_._-_._.

Glyptometra tulierosa _-_.

Antedion petasus_-__

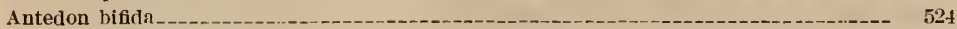

Antedon moroccana _-_- 526

Antedon mediterianea

Antedon adriatica -

Compsometra serratia__-_-_-_-_- 527

Compsometra lovéni _-_-_-_-_-_-_-_- 527

Leptometra celtica_-_-_-_-_._- 528

Leptometra phalangium -_-_-_-_- 528 
The pentacrinoid young-Continued. $\quad$ Page.

Isometra vlvipara

Heliometra glaclalis___._._._. .

Promachocrinus kergueleusis_..._.

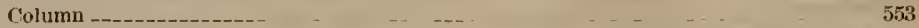

Terminal stem plate_....

Iufrabasals____.

Basals _......

Radianal____.

Radlals _..._.

Interradials _.

Brachials_._. 556

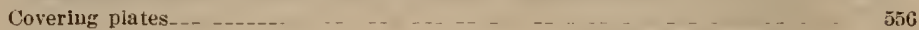

Pinnules _._.

Orals _...

Anthometra adriani _._.

Florometra serratissima _._.

Hathrometra prolisa____ _.

Hathrometra tenella_._._. . _ _ _ _

Hathrometra sarsii_________._. 564

Thaumatometra nutrix _.

Thaumatometra, sp___ _........ 575

Doubtful specles_._._ _. _

Summary -

Size-_-

Column --

Terminal stem plate_....

Attachment_____. 581

Cirrl-_-_-

Infrabasals_...

Basals - -

Radials - -

Radlanal-_-_-_-_-

Interradlals_._._. 586

Arms -

Pinnules _-

Side and covering plates..._.

Orals _--

Perisomic plating of the disk-_._. 589

Spicules in the tentacles._- 590

Hybrids between crlnoids and echinoids__-__- 590

Asymmetry-_.-_-_-_-_-_- 592

Habitat of the litioral eriuvids.

Species found swimming at the surface_.

Species found between tide marks_-_-

Species found on coral reefs._-_-_-___ 597

Occurrence of comatulids among sea weeds_______

Occurrence of comatulids in half submerged caves________ 599

Absence of comatulids from rock pools ____ 599

Occurrence of comatulids beneath stones_-_____. 599

Occurrence of comatulids on piling -

Breakwater's _._- 599

Uccurrence of comatullds un mangrove roots_____ 599

Occurrence of comatullds on mud_-_- 599 
Habitat of the littorai crinoids-Coutinued.

Possibie occurrence of a comatulid on sand.

Occurrence of Antedon biflda at Roscoff-

Locomotion

Notes on the habits of Antedon_

liood

Parasites aud Commensals

Tunicata

Enteropneusta

Rhabdopleura mirabilis

Family Aipheida

Synalpheus comatularum

623

Synaipheus stimpsonii var. maldivensis___

624

625

Sjnaipheus carinatus var. binongcensis _

Synaipheus brucei__._.

Synaipheus, sp _. 627

Family Hippolytidæ

Hippolyte, sp _. 628

Family Pontoniidix

Pericimenes (Periclimenes) commensalis_._._. 628

Periclimenes (Laomenes) cornutus____-_-_-_- 629

Periclimenes (Lamenes) ceratophthalmus_. 629

Periciemenes (Cuapetes) brocketti_.... 629

Pericimenes (Cuapetes) pottsi

Pontoniopsis comanthi

Decapoda Anomura___- 630

Family Gaiatheidæ _. 630

Galathea elegans _... 630

Gaiathea inflata__..... 631

Gaiathea minuta _. 631

Undetermined Galatheid

Problematical Decapod

Isopoda_-

Family Cymothoidæ

Anilocra, sp

Family Cirolanidæ

Ciroiana lineata

A mphipoda

Family Amphilochidæ_._. 633

Cyciotelson purpureum 633

Family Laphystiopsidæe _. 634

Laphystiopsis iridometræ. 634

Copepoda _.

Family Ascomyzontidæ._..... 635

Collocheres gracliicauda _. 635

Famiiy Ascidicolida

Enterognathus comatulse_... 636

Piouodesmodes phormosomæ_._. 636

Echinocheres violaceus__.__- 636

Echinocheres minutus_____. 636

Echinocheres giobosus _._.

Sancerilla tubulata 
Parasites and Commensals- (ontimupl.

Crustacen-Contlnued.

Copepoda-Contlinued.

Phllichthys anphiure-

Page.

$6: 36$

Chordeumlum obesum

Arthrochordeumium nppendlcolosuı _.

Astericola clausil.

r.lucklomolgus coeruleus

Ostracoua

Cirripedia

Family lepadida

Subfamily Scalpellinat

Scalpellum album

Scalpellun balanolutes _...

Scalpelluu dlceratum

Scalpellum goujonotum -

Sealpellum pentacriuarum

Scaipelium weltueriauum__._.

Scalpellum, sp_-_-_-_-_-

Scalpelluin, sp_._.

Family Verruclda

Verruca uitida

Verruca, sp

Verruea, sp

Verruca, sp

Fomily Balanidae

Pachylasma crinoidophllum

Obscure Iarval Cirriperle

Undetermiued crustaceans

636

6.36

636

G.:

637

637

633

638

638

638

G:3

638

638

638

638

634

639

6.34

639

639

639

639

639

639

640

640

Ecbinoderma

Ophluroidea

Family Trichasterida _...

Family Gorgouocephallda.

Astrogomphus vallatus

Asteroporit annulatis.

Family Hemieuryalidx

Family Ophiacanthidie

Ophiolebes seorteus.

Family Ophiocomidre.

Ophiocoma, sp-

Fa unily Amphiurida

Ophlactis delicata

Ophiactis, sp

Ophiopholis nirabilis

Family Ophiotrichlde._.

Ophlomaza _._.

Ophioma\%a cacaotica

Ophiomaza cacaotica var. picta_.

Ophiomaza obscura _...

Ophlomaza eataphracta _.

Ophlomaza mœrens

Ophioxthiops unicolor

Ophiosthlops elegans 
Parasites and Commensals-Continuet.

Echinoderma-Continued.

Ophiuroidea-Continued.

Fanily Ophiotrichidæ-Continued.

Page.

Ophiophthirius actinometræ..... 644

Ophiosphæra insignis ........ 644

Family Ophiolepididæ-_. 644

Ophiomusium, sp_....... 644

Ophiuran

Ophiuran pluteus

Mollusea --

Gasteropoda_.- 645

Stllifer bathymetre

Stillfer, sp _- 647

Stillfer, sp _... 647

Stilifer, sp

Stylina comatulicola _...... 645

Sabinella ptilocrinicola _._..... 648

Sabinella capillastericola_____ 648

Sabinella, sp -

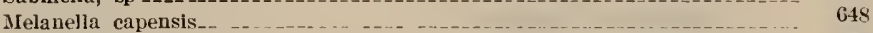

Melanelia, sp_.................. 648

Melanella, sp_- _... 649

Melunella, sp ... _..._. 649

Melanella, sp_..

Parasitic gasteropod

Egg capsules of a gastervpud

Pelecypoda

Polyzoa -

Family Bicellarildre-_. 650

Gemellaria loricata

Family Loxosomatide__._. 650

Loxosomella antedonis_... _..._. 650

Annelida Polychæta _._._._.....

Family Polynoidæ

Polynoë crinoidicola____

Polynoë minuta var, oculata____ 650

Family Serpulidee-(-

Myzostomida_.................

Myzostomum horologium_... 658

Myzostomum longipes_-_-_._._. 659

Myzostomum chinesicum__..... 659

Myzostomum labiatum _...... 659

Myzostomum echinus ___ 659

Myzostomum alatum__._- 659

Myzostomum costatum ....

Myzostomum plicatum _-_...6 660

Myzostomum rubrofasciatum _... 660

Myzostomum parasiticum_-_._- 660

Myzostomum glgas__._-_._. 660

Myzostomum giganteum_........ 660

Myzostomum testudo____ 661

Myzostomum chelonium

$1421411-21-$ Bull. $82-2$ 
Parasites and Commensals-Continuerl.

Annelida Polychreta-Continued.

Myzostomida-Continued.

Myzostomum chelonoidium

Myzostomum liitkeni

Iyzostomum pallidum

Myzostomum marginatuu

Myzostomum grafli

Myzostomum brevipes...

Myzostomum carpenteri

Myzostomuiu areolatun

Myzostomum triste

Myzostomum coriaceun

Myzostorum radiatum.

Myzostomum pulrinar

662

662

662

662

Myzostomum calycotyle

Myzostomum compressum

Myzostomum orevicirrum

My\%ostomum pictum .-.

Myzostomum nigrescells.

Myzostomum cirriferum_

Myzostomum cerriferoidun

Iyzostomum crenatum

Myzostomum longicirrum_-

Myzostonum wyvillethousoni

Myzostomum eircinatum

Myzostomum vastum.

Myzostomum agassizii

Myzostomum dublum.

Myzostonum mocbianun

Myzostomum elongatum .

Myzostomum verrucosum

Mrzostomum dentatum.-

Myzostomum fimbriatum

Myzostomum excisum - .

Myzostomum irregulare _._. _........

Myzostomum caribbeauum

Iyzostomum rotundum -_-

Myzostomum oblongum

Myzostomum abundans

Myzostomum elegans.-

Myzostomum evermanni

Myzostomum antennatuu ___ _._. 666

Myzostomum ambiguum_ _ 666

Myzostomum cornutum _. 667

Myzostomum brachiatum_____._. 667

Myzostomum fissum _._._. 667

Myzostomum intermedium_____._._._._. 667

Myzostomum quadrifilum_._._. 667

Myzostomum quadricaudatum _ _ 667

Myzostomum lobatum_........ 667

Myzostomum furcatum________._. 668

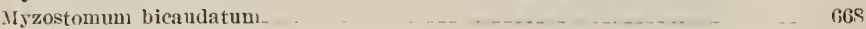

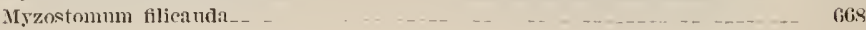


Parasites and Conmensals-Contiuued.

Annelida Polychata-Continuer.

Myzostomida-Continued.

Myzostomum filiferum _-

Page.

Myzostomum carinatum

668

Myzostomum coronatum

668

Myzostomum vincentinum

Myzostomum follum.

668

Myzostomum membranaceum

668

Myzostomum bucchlchii

669

Myzostomum cirripedium

669

Myzostomum nanseni

669

Myzostomum japonicum.

669

Myzostomum smithi

669

Myzostomum wheeleri

669

Myzostomum metacrini

669

669

Myzostomum cubanum_._.

Myzostomum deani _..._.

Myzostomum crosslandi.

Myzostomum antarcticum

Myzostomum asymmetricum.

670

Myzostomum platypus

670

Myzostomum pentacrini _.... 671

Myzostomum clarki._._.

Myzostomum eremita___..... 671

Myzostomum cryptopodium___... 671

Myzostomum beardi._...... 671

Myzostomum belli._._. 671

Myzostomum deformator _._. _ _

Myzostomum cysticolum____._. 672

Myzostomum cysticolum var, cystihymenodes___._. . 672

Myzostomum cysticolum var. orientale_____

Myzostomum tenuispinum ........... 672

Myzostomum willemœsii__ _

Myzostomum inflator._._. 673

Myzostomum murrayi__. 673

Myzostomum asterie__._. 673

Mazostomum fisheri_... 673

Myzostomum, sp_........ 673

Myzostomum, sp_.__ 673

Myzostomum, sp_._. 674

Myzostomum, sp__._. 674

Myzostomuru, sp__._. 674

Myzostomum, sp__........ 674

Protomyzostoma polynephris _.............. 674

Stelechopus hyocrini _._. 674

Undetelmined worm _... 675

Parasite of Doubtful Affinities_.

Celenterata____

Family Campanularildre

Calycella syringa _......

Stegonoma fastiqutm _ _ _ _

Cuspidelia, sp_..... 6 
Parasites and Commensals-Continued.

Coelenterata - Continued.

Family Perisiphonidæ.

Corals

Lafoëa fruticosa

(670

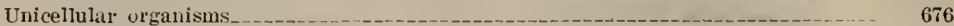

Dinoflagellata _._.

Suborder Adinida___.___._. 677

Family Prorocentridx-_._.

Prorocentrum micans _._. 677

Prorocentrum dentatum

Proroceutrum rostratum _.

Prorocentrum, sp _.................... 677

Ciilata_-_-_-_- 677

Order Trichostomata _........ 677

Suborder Aspitotricha_............................... 67

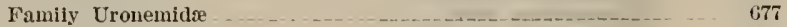

Uronema echini _._. 677

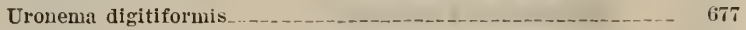

Hemisjeira asteriasi

Suborder Spirotricha___-_- G78

Section Peritricha _-___- 678

Faniily I.ichnophoridæ -

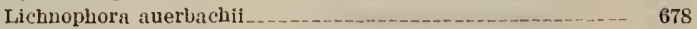

Family Urceolarildx_........ 678

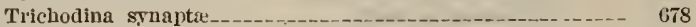

Hemispel ropsis antedonis _._._. 678

Cyclochzeta asterisci _..._........ 678

Cyclocheta ophiothricis____._._._._. 678

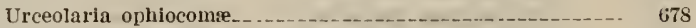

Family Vorticellide_-_._._. 678

Vorticella amphiure _._........ 678

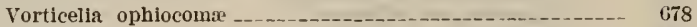

Vurticella, sp_____

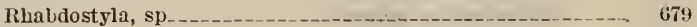

Rhabdostyla arenaria _-_-_- 679

Rhabdostyla, sp_..._.

Cothnrniopsis, sp _... 679

Sporozoa____... 679

Order Gregarinida___._-_-_-_- 679

Suiorder Monocy'stidet _._._. 679

Syueystis synaptie $\ldots 679$

Syncystis millleri _... 679

Syncystis holothuriz...... 679

Lithocystis schneideri____ 679

Foraminifera_a

Family Rotaliidie_- 679

Truncatulina lobatula _______. 6 (6)

Polytrema miniacenm

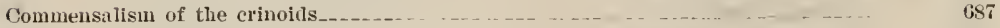

Avoidance of crinoids by fishes_.___._.

Dependence of comatulids upon pure, well-aërited water- _.... . . . . . 
Responses to changes in salinity.

Response to iight.

Response to heat

Observations at Maër Island, Torres Strait

Observations at Tobago

Response to chemical stimuli

Response to mechanical stimuli.

Geotropism.

Effect of the rain of cinders in the Bay of Napies in April, 1906.

Lxperimental investigation of the dorsal nervous system

Color of crinoids

Family Comasteridae

Subfamily Capillastering

Comatella nigra

Comatella stelligera

Comatella decora

Capiliaster miriæ

Capillaster nultiradiata

Capillaster clarki.

Nemaster lowensis.

Nemaster discoirlea

Comissia peregrina

Comissia lïtkeni.

Comissia horridus

Comissia hisnida

Comissia scitulus

Leptonemaster venustus

Subfamily Comactiniinse

Comatula rotalaria

Comatula purpurea.

Comantula pectinata

-

Comatulella brachlolata

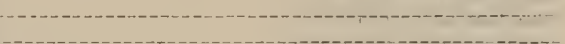

Comactinia meridionalis_...

Subfamily Comasterinæ___

Comaster fruticosus _.

Comaster taviana

Comaster parvus

Comaster serrato

Comaster minima

Comaster belli

Comaster novaguinere

Comantheria briareus.

Comantheria alternans

Comantheria weberi -

Comanthina schlegalii.

Comanthus bennetti

Comanthus solaster.

Comanthus japonicus

Comanthus wahlbergii

Comantlus samoana ---

Comanthus parvicirra. 
Color of crinoids-Continued.

Family Zygometridæ.

Zygometra microdiscus

Zygometra elegans.

Zygometra comata

Zygometra punctata

Zygometra pristlna_

Catoptometra magnifica

Catoptometra rubroflava

Catoptometra hartlaubi

Catoptometra ophlura

Family Hlmerometridæ

Himerometra magnipluua

Heterometra nematodon.

Heterometra crenulnta.

Heterometra affinis...

Heterometra saviguli.

Heterometra bengalensis

Amphimetra discoldea -.

Homalometra denticulata.

Famlly stephanometridæ.

Stephanometra echinus ---

Stephanometra oxyacantha

Stephanometra spleatr.

Stephanometra monacantha

Famlly Marlametridæ

Pontiometra andersonl

Oxymetra aranea._.

Dichrometra birnaculata_..

Dlchrometra döderleini

I $a$ mprometra protectus .

Jamprometra palmata

Mariametra delicatissima

Fimily Colobometride _._.

Cenometra unicornis_._.

Cenometra delicata _._._.

Cyllometra albopurpurea

Prometra chadwicki ........ _ _ _

Oligometrides adeonæ _............ 719

Fauily Tropiometride _... _ _ _ _ 719

Tropiometra afra

Tropiometra macrodiscus .... 719

Tropiometra carinata ___ _. _ _ _ _ _ _

Troplometra picta

Fimily Calometridxe_..... 720

Neometra conaminis _ _ _...

Neometra gorgonia _._.

Neometra multicolor

Pectinometra flavopurpurea

Gephyrometra propinqua

Gephyrometra versicolor

Calometra discoidea _...

Calometra callista__...

Calometra separata 
Color of crinoids--Continued.

Family Thalassometridx

Subfamily Ptilometrinx

Ptilometra macronema

Ptilometra magnipeda

Pterometra pulcherrima

Pterometra venusta_____

Asterometra macropoda_..._.

Asterometra anthus_._-

Subfamily Thalassometrinæ -

Crotalometra porrecta____-

Crotalometra flava____-__- 721

Oceanometra gigantea.___._. 721

Cosmiometra philippinensis__ _...

Cosmiometra aster.-_-

Stenometra diadema______

Daidalometra arachnoides._._.

Daidalometra hana __

Parametra orion____

Parametra fisheri

Lissometra alboflava____

Aglaometra propinqua____

Aglaometra eupedata____

Thalassometra villosa__._...

Thalassometra lusitanici_._._.......

Thalassometra omissa ... 721

Family Charitometridse-_-_._- 722

Perissometra lata

Pachylometra levigata _-_-_- 722

Calyptometra lateralis _._._-

Pœcilometra scalaris

Chlorometra garrettiana _-__-

Strotometri hepburniana______- 722

Family Antedonidre-_-

Subfamily Antedoninie.

Antedon petasus___- 722

Antedon bifida _.

Antedon mediterranea _-_- 723

Antedon adriatica _-_-

Toxometra paupera_.___._.

Iridometra melpomene

Eumetra chamberlaini _.___- 723

Dorometra mauritiana _..._... 723

Dorometra nana_-_-__-_-_._. 723

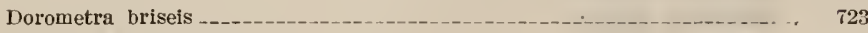

Annametra occidentalis_-_______- 723

Subfamily Thysanometring-_-_. 723

Thysanometra tenelloides _._.

Subfamily Zenometrinæ_...___.

Sarametra triserialis _-_._.

Psathyrometra erythrizon__-_- 724

Psathyrometra fragills________... 724 
Color of crinoids-Cintinuetl.

Family Antedonida-Continued.

Subfamily Zenometrina-Contimed.

Balanometra elongata.-

Leptometra celtica

-

Leptometra phalangium_...

Subfamily Perometrina

Perometra diomedex. _._. 724

Erythrometra australis _....

Erythrometra ruber _...

Nanometra bowersi....... _ _

Subfamily Heliometrinæ _._.

Heliometra glacialis

Promachocrinus kerguelensis_ _. _ _ _ 724

Forometra asperrima........

Florometra seratissima ... _.. _...

Forometra perplexa__ _

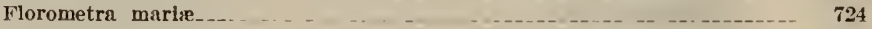

Florometra laodice _.

Cyclometra clio_............... 724

Subfamily Bathymetring _.

Hathrometra prolixa___ 724

Hathrometra tenella_... 724

Hathrometra sarsii__._.

Trichometra vexator._.

Trichometra isis _._._.

Thaumatometra tenuis. ......... 725

Family Pentametrocrinida.

Thaumatocrinus borealis___.

Pentametrocrinus varians._.

Pentametrocrinus japonicus .

Pentametrocrinus diomedeæ.

Family Holopodidx.

Holopus rangli _._.

Family Pentacrinitidæ

Metacrinus acutus____

Metacrinus angulatus____._. 726

Metacrinus cingulatus _._. 726

Metacrinus costatus _

Metacrinus moseleyi._...

Metacrinus nobllis

Metacrinus nobilis sumatranus _.

Metacrinus nodosus_____

Metacrinus rotundus ___

Metacrinus varians

Metacrinus wgrillii _ _ _

Isocrinus decorus _....

Endoxocrinus wyvillethomsoni _.

Endoxocrinus alternicirrus._.

Comasterocrinus asper

Hypalocriuus naresianus _...

Isocrinus decorus and Fndoxocrinus parra 
Color of crinoids-Continuel.

Family Phrynocrinida.

Phrynocrinus nudus

Fanily Bourgueticrinidre

Bathycrinus pacificus

Ilycrinus carpenteri :

Rhizocrinus lofotensis

Democrinus rawsonii.

Family Apiocrinida

Proisocrinus ruberrimus

Family Plicatocrinidae

Ptilocrinus pinnatus

Ptilocrinus antareticus

Gephyrocrinus grimaldii

Thalassocrinus pontifer.

Purple nentacrinin

Red pentacrinin

Antedonin

Ptilometra nitilleri

Palreocomatella diflicilis and other species

$\Lambda$ glaometra valida and other spccies____ 754

Comasterid from Banda

Large comasterid from Banda

Comatula rotalaria from Cape York

Comatella stelliger $a$ _.

Econonic value of the recent erinoids _

Explanation of plates

Index 



\title{
A MONOGRAPH OF THE EXISTING CRINOIDS.
}

\author{
By Austin Hobart Clank, \\ Curator, Division of Echinoderms, United Statcs National Aluseum.
}

STRLCTURE AND ANATOMY.

Ranias: : continued.

[Part 2 of volume 1, Bulletin 82, is a direct continuation of part 1 published in 1915, taking up the discussion of the structure and anatomy of the unstalked crinoids at the point at which it was left in 1915 . In this part the introductory matter is concluded.

For assistance in the preparation of the following pages I am especially indebted to Dr. Hubert Lyman Clark, who had the kindness to read through the entire manuscript; to Prof. William Morton Wheeler, who was so good as to examine for me the section dealing with parasites and commensals; to Prof. Charles Branch Wilson, who revised my list of parasitic copepods; to Mr. William F. Clapp, who revised my account of the parasitic Mollusca; and to Dr. Henry A. Pilsbry, to whom I submitted my list of commensal barnacles. Mr. Frank Springer has, as before, kept constantly in touch with the work as it progressed, and I am deeply indebted to him for a very large number of most helpful suggestions-indeed, whatever merit there may be in those portions dealing with crinoidal morphology is very largely the result of his advice and inspiration. I am also under obligations to Dr. Herrick E. Wilson for his kindness in reading the greater part of the manuscript, as well as for numerous suggestions.]

\section{Articular Faces of the Radials.}

No detailed comparative study of the sculpture of the articular faces of the radials has as yet been attempted; in fact, only three authors have even so much as mentioned them. W. B. Carpenter in 1866 described minutely the conditions found in Antedon bifida: P. H. Carpenter in 1888 figured and described them in such species (distributed among several families) as he was able to dissect; and C. Hartlaub in 1895 and in 1912 published some additional facts concerning them based upon his study of various species from Panama, the Galápagos Islands, and the West Indies.

Yet a detailed and accurate comprehension of the characters of the articular faces of the radials is essential in the study of the comatulids as a whole, for in very many cases the fossil species are represented only by specimens consisting of the centrodorsal and the radial pentagon, and without a true conception of the fundamental and diagnostic features involved, and of the limits of vari- 
ability, all attempts to correlate these fossil forms with their recent representatives can be little else than pure guesswork.

Unfortunately, I lave not becn able to examine the radial pentagon of nearly so many species as I would have wished, nor have $I$ becn able to examine large series of specimens except in a very few instances, and it has therefore been impossible for me to arrive at many conclusions of a real and permanent value. A great many facts have been brought out, howerer, which show the importance of this line of work, especially in its bearing upon the fossils, and it is greatly to be hoped that every student of the comatulids (as well as of the stalked types) will seize every opportunity to make dissections of such species as may be available so that data may gradually accumulate whereby the true systematie importance of the various features of radial joint face sculpture may properly be appreciated.

It has seemed best to unitc in one place the detailed descriptions of the radial articular faces of all the species which $I$ have been so fortunate as to be able to examine. This will render them much more readily comparable with each other than if the descriptions were incorporated with the general descriptions of the species, and at the same time will facilitate their use in connection with the fossils. Furthermore, for purposes of identification and detcrmination the external characters are the ones upon which reliance is chiefly placed, and it seems therefore inadvisable to burden the systematic descriptions with a detailed account of internal structures. I have ineluded, however, in the descrip. tion of each species of which $I$ have been able to examine the radial pentagon a synopsis of its salient features in order to indicate the correlation between these internal and the more familiar external characters.

The most generalized type of radial articular face, and that toward which the radial articular faces of all young specimens converge, consists of a large, deep, semicircular dorsal ligament fossa, in the middle of the anterior (ventral) border of which, just under the transverse ridge, there is a circular or transversely oval, usually somewhat sudden, excavation, known as the ligament pit, which may involve a portion of the proximal (dorsal) side of the transverse ridge in its formation; beyond the middle of the transverse ridge, which is high, is the large opening of the central canal, surrounded by a raised calcareous platform on a level with the transverse ridge which is continued laterally so as to form a ventral border to the ridge; on either side of the central canal lie the interarticular ligament fossæ, which are typically isosceles triangles with their bases resting on the transverse ridge; beyond these are the large distally rounded muscular fossæ, the area of which is at least as great as that of the interarticular ligament fossæ; these are separated interiorly from each other by a high narrow ridge joining the platform about the central canal (which is raised so high above the lower apices of the muscular fossæ that the central canal appears to lie in a sort of tube or tunnel) which decreases in height, at first very rapidly but later more gradually, until distally it sinks to the level of the adjoining fossæ; a slight notch separates the distal edges of the muscular fossæ interiorly. 
The articular faces of adjacent radials are separated from each other laterally by a narrow groove, which usually is closed distally by the apposition of the outer edges of the muscular fossæ.

The plane of the joint face as a whole typically makes an angle of about $45^{\circ}$ with the dorsoventral axis of the animal; if the radials become nearly or quite horizontal this angle decreases so that the plane of the joint face becomes almost or quite parallel to the dorsoventral axis; but conversely it inclines more to the horizontal if the radials slant upward and outward as in the pentacrinites. The proximal portions of the muscular fossæ slope inward so as to make an angle of about $90^{\circ}$ with each other.

There are two lines of divergence from this generalized type-(1) there may be an increase in flexibility at the articulation, inducing a corresponding modification of the joint face, or (2) there may be a gradual decrease in flexibility, reaching a maximum in a practically immovable union.

The first line of divergence is rare and is only found among certain 5 or 10 armed species belonging to various macrophreate groups, such as the Pentametrocrinidæ (figs. 114, p. 67, and 1006, pl. 4), the Atelecrinidæ, and the Heliometrinæ (figs. 95,97, p. 62 , and $997,999,1000$, pl. 4) and in the young of certain other types. It is characterized by a great increase in the size of the muscular fossa, coupled with more or less reduction in the size of the interarticular ligament fossæ, and a marked deepening in the sculpture of the joint face as a whole.

Instances of the second line of divergence are much more common, some progress along this line having been made by almost all of the oligophreate and by many of the macrophreate types. The first modification noticeable is a dininution in the size of the muscular fossæ, which may become narrow laterally as in the Thalassometridæ (figs. 69-75, p. 43) and in the Charitometridæ (fig. 76, p. 53, and figs. $984-993, \mathrm{pl} .3$ ), or very short as in most of the other groups (figs. $25-38$, p. 20 ). Shortening of the muscular fossæ is correlated with a decrease in the size of the dorsal ligament fossa, which becomes transversely semielliptical; an increase in the size of the interarticular ligament fosse, which almost always develop an obtuse angle on their inner margins (figs. 39-50, p. 26); a progressive shallowness of the joint face sculpture, the intermuscular ridge at the same time becoming an intermuscular furrow; and a flattening and eversion of the joint face as a whole, so that it becomes more and more nearly parallel with the dorsoventral axis of the animal. This line of development leads to a joint face more or less parallel with the dorsoventral axis of the animal, showing a narrow semielliptical dorsal ligament fossa with a transversely linear shallow ligament pit, two approximately square interarticular ligament fossæ internally separated by a shallow furrow about as wide as the central canal, and very narrowly linear muscular fossæ, or even no muscular fossæ at all. The relief of the joint face is now so shallow that the rim or platform about the central canal and along the distal (ventral) border of the transverse ridge is not evident.

In connection with the following detailed account of the radial articular faces of the comatulids I have included reproductions of all the figures which have been published by previous authors. It has seemed best not to attempt to include de- 
scriptions taken from these figures in the text on account of the possibility of crror in the drawings; and for the same reason I have refrained from making comparisons between these and the drawings made by Miss Dandridge under my supervision.

\section{COMASTERID正.}

The articular faces of the radials lie in planes nearly or quite parallel to the dorsoventral axis of the animal.

The excavation of the various elements of the joint face is very slight.

Just ventral to the transverse ridge there is a broad flat area, narrow laterally but centrally increasing in height so as to encompass the central canal; anteriorly this sinks almost imperceptibly into the interarticular ligament fossæ.

The elements of the joint face on either side of the transverse ridge are usually on the same plane, but the dorsal ligament fossa sometimes makes a slightly greater or lesser angle with the dorsoventral axis than the distal elements.

The dorsal ligament fossa is almost always lower than the interarticular ligament fossa, and its proximal border is more or less flattened; the ligainent pit is strongly marked, broadly oval, larger than the central canal.

The central canal is broadly oval and rather small.

The joint face elements distal to the transverse ridge and the central canal are separated by a broad and shallow intermuscular furrow which is usually constricted between the muscular fossæ.

The distal border of the interarticular liganent fossæ is straight, or slightly convex: it is commonly parallel to the transverse ridge, but it may be slightly lower interiorly than exteriorly; more commonly it is slightly lower exteriorly than interiorly.

The muscular fossæ are small, always smaller than the interarticular ligament fossæ (usually less than half the height of these), transversely elongate with nearly or quite parallel distal and proximal edges and a projecting distal outer angle; the distal edge is horizontal, or, if it is somewhat convex, the chord of the convexity is horizontal.

The ventral face of the radial pentagon as a whole is bluntly stellate, the radial incisions being usually less than one-third, never more than one-half. of the distance from the center to the interradial apices.

The ventral plug is well developed, with a flat or slightly concave surface which is nearly or quite on a level with the distal edge of the nuscular fossæ; it almost or quite conceals the inner surface of the radials. The radial canals are very broad; there is no free central canal.

\section{CapillaAsterinie.}

The following features appear to be characteristic of the radial articular faces of the specics of Capillasterinæ.

The interarticular ligament fossæ are much broader than high.

The distal border of the interarticular ligament fossæ is usually lower exteriorly than interiorly. 
There is a more or less abrupt change in direction between the outer edge of the interarticular ligament fossæ and that of the muscular fossæ, the latter projecting more or less outward.

The muscular fossæ do not extend inward beyond the inner distal angle of the interarticular ligament fossæ.

The muscular fossæ slope more or less downward from the center of the joint face to the periphery.

In addition to these characters the centrodorsal usually bears more than one row of cirrus sockets. If only one row is present the sockets composing it are more or less isolated and irregular in position.

\section{COMATELLA NIGRA.}

Figs. 1,2, p. 6 .

The dorsal liganent fossa is narrow, nearly or quite five times as broad as ligh, the proximal edge mostly parallel to the transverse ridge but curving upward somewhat strongly at either end.

The articular faces are separated in the interradial angles by a moderate, slightly rhombic, groore. The transverse ridges of adjacent faces are entirely separated.

The lateral edges of the interarticular ligament fossæ retreat rapidly from the ends of the transverse ridge, with which they make an angle of approximately $45^{\circ}$; just below the muscular fossæ they turn upward and outward rather sharply. The distal enge of the interarticular ligament fossæ rises inward from the outer distal corners until a height is reached which is about half again as far from the transverse ridge perpendicularly as is the distal outer corner. From this point the anterior edge makes a broad curve inward and downward. passing over into the parallel inner edges of the interarticular ligament fossæ. These parallel inner edges are separated by a broad shallow furrow, which may have a low, rounded, median convexity indicated, which is about as broad as the transverse diameter of the strongly oval central canal, from which it is separated proximally by a narrow ill-defined rim.

The muscular fossæ are small, rounded triangular in shape; their lateral edge makes a right angle with the lateral edges of the interarticular ligament fossæ, but soon curves upward and inward rather sharply, then running inward almost horizontally or slightly downward, almost straight or slightly convex, to a point slightly orer one-third of the way across the distal edge of the articular face, where it becomes suddenly decurved to the distal border of the interarticular ligament fossa, terminating the muscular fossæ in a rounded apex interiorly.

The center of the radial pentagon is occupied ventrally by a scanty loose calcareous deposit which barely concenls the rosette from ventral view; the ventral sutures between the radials are prominent.

Diameter of radial pentagon at base, $8 \mathrm{~mm}$.; height of articular face, $3.3 \mathrm{~mm}$.; width, at transverse ridge, $6 \mathrm{~mm}$.; distance from center of rosette to middle of dorsal 


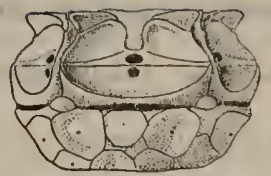

I
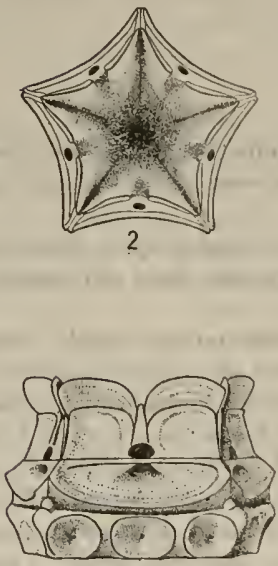

3

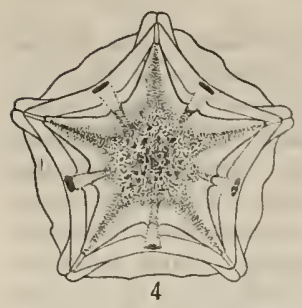

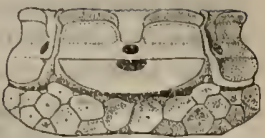

9
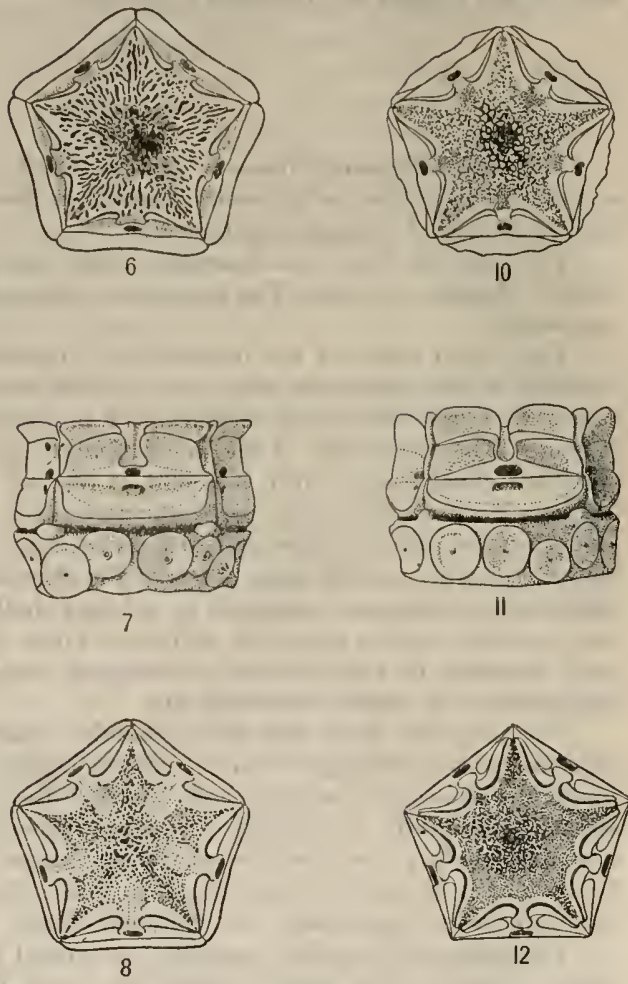

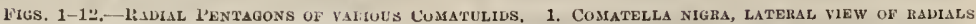
aNd centrodobsal. 2. Same, ventrat, view of Radil pentagon. 3. Neocomatella pulchella, LATERAL TIEW OF RADIALS AND CEYTRODORSAL, 4. SANE, VeNTral VIDW OF RADIAL PENTAGON. 5. CAPILLASTER SENTOSA, LATERAL VIEW OF RADIALS AND CENTRODORSAL. 6. SAME, VENTRAL VIEW ON RADIAL

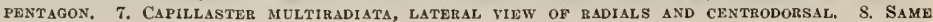
ventral view of badial peNTAgon. 9. Nemaster discoidea, lateral View of radials aNd centroDORSAL. 10. SAME, ventral, view of radial pentagon. 11. Lemponemaster venustus, latehat VIEW OF RADIALS AND CENTIODORSAL. 12. SAME, VENTRAL VIEW OE KADIAL PENTAGON. 
outer edge of radial, $3.8 \mathrm{~mm}$; distance from center of ventral face of radial pentagon to middle of ventral outer edge of radial, $3 \mathrm{~mm}$; to angle between radials, $4.8 \mathrm{~mm}$.

\section{COMATELLA . STELLIGERA.}

See figs. $950-952$, pl. 1.

COMATELLA MACULATA.

See figs. 953, 954, pl. 1.

NEOCOMATELLA PULCHELLA.

Figs. 3,4 , p. 6 , and 955 , pl. 1 .

The dorsal ligament fossa is narrow, about four times as broad as long, somewhat blunted at the lateral angles; the lateral edges of the interarticular ligament fossæ may retreat at first rather rapidly from the transverse ridge, but, gradually curving, at the distal corner these edges make only a small angle with a line perpendicular to the ventral surface of the centrodorsal, or they may be only slightly concave.

The interarticular ligament fossæ are squarish to nearly one-third broader than long, with the distal edge turned outward, horizontal, slightly and evenly convex, or sloping slightly downward from a point about one-third of the distance from the inner corner. The inner corner is broadly rounded so that the inner edges are parallel, about as far apart as the diameter of the central canal. Just before or just after the consummation of the curve of the inner distal angle the projection of the distal edge rather suddenly disappears, so that the inner lateral edges are scarcely raised above the general surface of the broad shallow groove which separates them.

The muscular fossæ are approximately twice as broad as high. They are separated basally by the continuation of the broad shallow groove which separates inwardly the interarticular ligament fossie. The floor of this groove, at tirst flat, at about the middle of the interarticular ligament fossæ begins to be slightly convex, and where it passes between the muscular fossæ to the ventral surface of the radials, gradially curring so as to become parallel with the latter, it may become carinate and bear a few long spicules. It leaves the plane of the radial face and begins to curve downward (in reference to the latter) at about the middle of the inner edges of the muscular fossæ; because of its gradual curve at first the exact spot is somewhat difficult of determination. The outer edge of the muscular fossæ is usually a straight line, but may be slightly concave. It usually makes about the same angle with a line perpendicular to the centrodorsal as that made by the outer edge of the interarticular ligament fossæ, but reversed, so that it projects outward making an obtuse angle with the outer edge of those fossa; the outer edge of the muscular fossæ is about one-half to two-thirds as long as that of the interarticular ligament fossæ. The muscular fossæ as a whole are usually from two-thirds to threefourths of the height of the interarticular ligament fosse, usually twice as broad 
as long, sometimes longer, the distal edge convex and broadly rounded off at the inner, abruptly rounded at the outer corners, in general parallel to the distal edge of the interarticular ligament fossa, which forms the proximal edge of the muscular fossa. The whole distal edge is convex, but less so toward the outer border. The highest point is usually at about one-third of the distance from the inner to the outer edge, from which point the height gradually decreases outwardly. The internal gap between the muscular fossæ is only about half as large as that between the interarticular ligament fossæ.

Ventrally the space between the radials is filled with a spongy calcareous filling, almost flat, reaching to about the height of the middle of the muscular fossæ. The central canal through this spongy calcareous mass is very small.

Diameter of radial pentagon at base, $4.1 \mathrm{~mm}$.; height of articular face, $2 \mathrm{~mm}$.; width, at transverse ridge, $2 \mathrm{~mm}$; distance from center of rosette to middle of dorsal outer edge of radial, $1.3 \mathrm{~mm}$; distance from center of ventral face of radial pentagon to middle of rentral outer edge of radial, $1 \mathrm{~mm}$; to angle between radials, $1.6 \mathrm{~mm}$.

\section{CAPILLASTER SENTOSA.}

Figs. 5, 6, p. 6.

The dorsal ligament fossa is between three and one-half and four times as broad as high, with the proximal edge evenly and gently convex and the lateral edges truncated and sharply rounded. The ligament pit is reniform, and much larger than the transversely oval central caual.

The transverse ridges of adjacent articular faces are in apposition, but the dorsal ligament fossæ are entirely separated from each other.

The outer edges of the interarticular ligament fossæ have a general slight inward slope. They are nearly straight, but curve outward both at the base and distally. The distal edge is straight, or very slightly convex; the outer distal angle is sharply, the inner broadly, rounded; the inner edges form an S-shaped curve, coming together just over the central canal, from which they are separated by a narrow septum with parallel sides. The intermuscular furrow just over the central canal is nearly as wide as the interarticular ligament fossæ at the same level, but it becomes constricted distally so that between the distal inner angles of the interarticular ligament fossa it is only about $t$ wo-thirds of the proximal width.

The muscular fossæ are narrow, about as broad as the transverse (greater) diameter of the central canal. The distal outer edges are approximately parallel to those of the interarticular ligament fossæ; but the muscular fossæ may be slightly broader exteriorly than interiorly. The distal outer angles project considerably beyond the lateral edge of the interarticular ligament fossi. The distal outer angles are sharply rounded; the distal inner angles are broadly rounded, the inner edges curving downward to the distal inner angles of the interarticular ligament fossæ.

The ventral surface of the radial pentagon is more or less obscured by a loose calcareous deposit, which in the center forms a broad plug; its surface is radially striate. 
Diameter of radial pentagon at base, $6.3 \mathrm{~mm}$; height of articular face, $2.8 \mathrm{~mm}$.; width (at transverse ridge), $3.8 \mathrm{~mm}$.; distance from center of rosette to middle of dorsal outer edge of radial, $2.9 \mathrm{~mm}$.: distance from center of ventral face of radial pentagon to middle of rentral face of radial, $1.9 \mathrm{~mm}$; to apex of interradial angle, $2.9 \mathrm{~mm}$.

\section{CAPILI.ASTER MULTIIADIATA.}

Figs. 7,8, p. 6 .

The articular faces of the radials are in general similar to those of $C$. sentosa.

The dorsal ligament fossa is somewliat more flattened proximally. The interarticular ligament fossæ are relatively lower and broader, their maximum height being about equal to that of the dorsal ligament fossa. Their distal edges slope downward from the intermuscular furrow, making a slight angle with the transverse ridge. Their maximum height is but very slightly greater than one-half of the distance from the center of the central canal to the end of the transverse ridge. Owing to the outward and downward sloping of the distal edges of the interarticular ligament fossæ the muscular fossæ are narrowly triangular : their greatest transverse diameter is about three times their greatest (outer) vertical diameter; their distal border is parallel to the transverse ridge; and their distal outer angle projects strongly. The interradial space between the articular faces is broader than in C'. sentosa, as the outer edge of the interarticular ligament fossæ retreats more rapidly basally from the ends of the transverse ridge. The ventral surface of the radial pentagon shows a slightly deeper incision in the radial areas than is seen in C. sentosa.

Diameter of radial pentagon at base, $4.2 \mathrm{~mm}$; ; height of articular face, $1.9 \mathrm{~mm}$.; width, at transverse ridge, $2.3 \mathrm{~mm}$.; distance from center of rosette to middle of dorsal outer edge of radial, $2 \mathrm{~mm}$.; distance from center of ventral face of radial pentagon to middle of ventral edge of radial, $1.5 \mathrm{~mm}$; to apex of interradial angle, $2.2 \mathrm{~mm}$.

\section{NEMASTER ROBIGINOSA. \\ See figs. $956,95 \pi$, pl. 1. \\ YEMASTER DISCOIDFA.}

Figs. 9, 10, p. 6.

The dorsal ligament fossa is very narrow, about four times as broad as high, with the proximal border evenly curved. The ligament pit is reniform, narrow, rather longer transversely than the greater (transverse) diameter of the oval central canal.

'The transverse ridges of adjacent joint faces are separated from each other interradially; the interarticular and muscular fossæ are separated interradially by a moderately wide shallow furrow. 
The interarticular ligament fossa are about twice as broad as high, approximately oblong, with the inner distal angle well roundecl. The outer edges are more or less concave, especially proximally, the chord of the concavity slanting somewhat inwardly from the transverse ridge. The distal edges may be more or less convex, especially inwardly, the chord of the convexity rising slightly inwarlly. The inner edges are short, parallel, separated by a broad, shallow furrow about as wide as the greater (transverse) diameter of the central canal.

The muscular fossæ are very narrow, being about as broad as the transverse diameter of the central canal. Their inner edges are parallel, continuing upward the inner edges of the interarticular ligament fosse. Their distal edges follow the contour of the distal edges of the interarticular ligament fossa and are straight or slightly convex. The distal outer angles are well rounded and project somewhat beyond the sides of the interarticular ligament fossæ.

The ventral surface of the radial pentagon is filled with a coarse and loose calcareous deposit eren with the distal edge of the muscular fossæ. There is no central opening.

Diameter of radial pentagon at base, $4.8 \mathrm{~mm}$; height of articular face, 1.3 $\mathrm{mm}$.: width, at transverse ridge, $3.3 \mathrm{~mm}$; distance from center of rosette to mirldle of dorsal outer edge of radial, $1.9 \mathrm{~mm}$.; distance from center of ventral face of radial pentagon to middle of ventral edge of radial, $1.5 \mathrm{~mm}$; to apex of interradial angle, $2.6 \mathrm{~mm}$.

\section{LEPTONEMASTER VENUSTUS.}

Figs. 11, 12, p. f.

The dorsal ligament fossa is broad and low, four or five times as broad as high The proximal border is moderately convex, passing into a slightly stronger curre at either end. The ligament pit is wider than the transversely oval central canal, but narrow and slightly reniform.

The dorsal ligament fossæ are not in lateral contact, and the transverse ridges of arljacent joint faces are rather widely separated. Distal to the transverse ridge the elements of the joint face are entirely and somewhat widely separated by a deep furrow which appears to extend inward to the central plug.

The interarticular ligament fossæ are about twice as broad as high. Taking the transverse ridge as their proximal border, they are approximately oblong but with the outer edges at first retreating rather rapidly and soon becoming perpendicular; the distal edge may be slightly convex, and there may be a slight upward slant toward the interior of the joint face.

The muscular fossæ are about as high as the distance from the distal margin of the central canal to the distal edge of the interarticular ligament fossæ; their distal margin is parallel to the distal margin of the interarticular ligament fosse, but often slightly more convex. Their rounded outer distal corners project slightly beyond those of the interarticular ligament fossæ, and their inner distal angles are well rounded; the intermuscular furrow is about as wide as half the 
transverse (greater) diameter of the central canal. It is slightly constricted between the muscular fossie.

The cavity on the ventral surface of the radial pentagon is filled nearly to the height of the distal edges of the muscular fossæ with a loose calcareous cieposit showing no central canal.

Diameter of radial pentagon at base, $3 \mathrm{~mm}$; height of articular face, $1.3 \mathrm{~mm}$.; widlh, at transverse ridge, $2 \mathrm{~mm}$; distance from center of rosette to middle of dorsal outer edge of radial, $1.3 \mathrm{~mm}$.; distance from center of ventral face of radial pentagon to middle of rentral edge of radial, $0.8 \mathrm{~mm}$.; to apex of interradial angle, $1.5 \mathrm{~mm}$.

COMATILIA IRIDOMETRIFORMIS.

Figs, 13, 14, p. 15.

The articular faces of the radials are entirely and widely separated from each other, just as in Neometra, by broad interradial processes formed by the produced lateral edges of two adjacent radials. The outline of each radial face as a whole is approximately semicircular. The production of the lateral edges of the radials has produced a corresponding distortion of the elements of the articular faces, these being laterally curved outward and somewhat elongated transversely.

The dorsal ligament fossa is deep, and about two and one-half times as broad as high. The ligament pit is very narrow, though nearly as wide as the transversely oval central canal.

The interarticular ligament fossa are triangular, with their inner apices on the level of the distal border of the central canal. The proximal and distal edges make approximately the same angle with the horizontal, and are nearly straight; the outer edges, which are about two-thirds the length of the other two, are somewhat convex.

The muscular fossæ form elongated triangles with their apices outward. Their greatest height is equal to the distance from their lower borders to the transverse ridge; their inner edges are strongly convex.

A broad undifferentiated area incloses the central canal and extends laterally in the form of a long angle to the ends of the transverse ridge, its distal border following, and being delimited by, the proximal border of the interarticular ligament fossæ; anteriorly (distally) this area is continued as a narrow intermiscular septum concave on the summit which rapidly diminishes in height, being replaced after the proximal third of the muscular fosse by a narrow intermuscular furrow.

The ventral surface of the radial pentagon, which is sharply stellate, is covered by a somewhat concave loose calcareous deposit showing a small central canal. The produced interradial angles, and a border equal to one-half of the width of these interradial processes about the distal edges of the radial faces. are free from any secondary calcareous covering. 
Diameter of radial pentagon at base, $1.5 \mathrm{~mm}$; median height of articular face, measured along the inclination, $0.3 \mathrm{~mm}$; maximum width, $0.7 \mathrm{~mm}$; distance from center of rosette to middle of dorsal outer edge of radial, $0.6 \mathrm{~mm}$; distance from center of ventral face of radial pentagon to middle of ventral edge of radial, $0.5 \mathrm{~mm}$.; to apex of interradial angle, $1 \mathrm{~mm}$.

\section{Comictinin.e.}

The interarticular ligament fosse are nearly or quite as high as broad.

The distal border of the interarticular ligament fossie is usually slightly lower interiorly than exteriorly.

There is a more or less abrupt change in direction between the outer edge of the interarticular ligament fosse and that of the muscular fosse, the latter projecting more or less outward.

The inner ends of the muscular fossæe are more or less within the inner distal angles of the interarticular ligament fosse.

The muscular fossæ in general slope more or less upward from the median axis of the joint face to the periphery.

In addition to these characters the centrodorsal has no cirri, or (except in Comatulides) possesses a single crowded and regular row; in some cases the radial cirri are suppressed, leaving one or two in each interradial angle.

COMATULA ROTALARia.

See figs. 958, 959, pl. 1.

COMATULA SOLARIS.

See figs, $960-962$, pl. 1.

Comatula pectinata.

Figs. $17,1 S$, p. 15.

The articular faces of the radials lie in a plane parallel to the dorsoventral axis of the animal and including the proximal edge of the radials. The sculpture is moderate in relief.

The dorsal ligament fossa is wide laterally and narrow dorsoventrally, nearly oblong. It is nearly or quite five times as broad as high. The proximal border is not at all, or only slightly, convex, curving sharply upward at either end. The ligament pit is large and reniform, much larger than the transversely oval central canal.

The transverse ridges of adjacent articular faces are in lateral contact, and the ends of the dorsal ligament fossæ may be more or less confluent. Interrarlially the interarticular ligament fossæ are separated by a narrow parallel sided furrow, which is closed distally by the apposition of the muscular fossæ.

The interarticular ligament fossæ are about as high as broad. Their lateral edges slope inward at the base, but are nearly or quite vertical for most of their 
length. The distal edges are gently concave, the chord of the arc formed rising slightly inwardly; at the inner corners the distal edges curve downward into the inner edges; these inner edges from the distal to the proximal part of the interarticular ligament fossa diverge slightly, proximately curving around and meeting just above the central canal, over which the proximal end of the intermuscular furrow is somewhat convex, following the outline of the canal. The broad shallow furrow separating the interarticular ligament fossæ at the distal border of the latter is about half as wide as they are at that point, or even slightly wider. It increases slightly in width proximally; its center may be more or less elevated.

The muscular fossæ are very narrow, with parallel sides and rounded ends. Their width is about equal to the transverse (greater) diameter of the central canal; their distal edges follow the curve of the distal border of the interarticular ligament fossæ; their rounded outer angle extends somewhat beyond the distal outer angle of the interarticular ligament fossæ; their inner termination extends slightly beyond the inner distal angle of the interarticular ligament fossæ so that the intermuscular furrow is constricted at this point; their inner boundary joins the rounded inner angle of the interarticular ligament fossæ at about the center of its curve.

The ventral surface of the radial pentagon is covered with a moderately dense calcareous deposit which shows faint radial striations. The central canal is rather small.

In the specimen at hand the general coloration is yellow brown, the transverse ridges and the rays of the basal star being violet in conspicuous contrast.

Diameter of radial pentagon at base, $4.6 \mathrm{~mm}$; height of articular face, 2 $\mathrm{mm}$.; width, at transverse ridge, $3 \mathrm{~mm}$.; distance from center of rosette to middle of dorsal outer edge of radial, $2 \mathrm{~mm}$.; distance from center of ventral face of radial pentagon to middle of ventral outer edge of radial, $1.8 \mathrm{~mm}$; to angle between radials, $2.5 \mathrm{~mm}$.

COMATULA MICRASTER.

Figs. 15, 16, p. 15.

The dorsal ligament fossa is about two and one-half times as broad as high, only slightly convex proximally, curved upward with moderate abruptness at either end. The ligament pit is transversely oval, considerably larger than the central canal.

The transverse ridges of adjacent joint faces are in apposition, but the dorsal ligament fossæ are entirely separated. The elements distal to the transverse ridge are separated in the interradial angles by a shallow furrow about as broad as the shorter (vertical) diameter of the central canal.

The interarticular ligament fossæ are slightly higher than wide, approximately oblong. The outer edges retreat rather rapidly for a short distance from the ends of the transverse ridge, then becoming parallel to the dorsoventral axis, or leaning slightly outward in the distal portion. The distal border is practically 
straight or slightly convex; the inner distal corncrs are well rounded; the inner sides are parallel and are separated by a rather broad, shallow, intermuscular furrow, somewhat wider than the transversc (greater) diameter of the ccntral canal.

The muscular fossæ are narrow, about as broad as the dorsorentral diameter of the central canal, or slightly broader, with their distal cdges parallel to the distal edges of the interarticular ligament fosse; their inner edges are well rounded and project somewhat farther into the intermuscular furrow than the inner angles of the interarticular ligament fossa; the outer distal angles are more sharply rounded and project beyond the corresponding angles of the interarticular ligament fossw.

The central portion of the ventral surface of the radial pentagon is occupied by a very coarse calcareous reticulation the meshes of which are somewhat more dense than is usually the case.

Diameter of radial pentagon at base, $3 \mathrm{~mm}$; height or articular face, 1.4 mm.; width. at transverse ridge, $2 \mathrm{~mm}$; distance from center of rosette to middle of dorsal outer edge of radial, $1.3 \mathrm{~mm}$.; distance from center of ventral face of radial pentagon to iniddle of rentral edge of radial, $1 \mathrm{~mm}$; to apex of interradial angle, $1.3 \mathrm{~mm}$.

\section{COMACTINIA FCHINOPTERA.}

Figs. 19, 20, 23, 24, 1) 15.

The dorsal ligament fossa is about three times as broad as high, with the proximal border broadly and evenly curved; the ligament pit is oval, considerably larger than the central canal.

The transverse ridges of adjacent articular faces are in contact laterally; the lateral ends of the adjacent dorsal ligament fossæ are also in apposition. The interarticular ligament fossæ are separated in the interradial angles by a narrow groove, which is continued outward between the muscular fossæ.

The interarticular ligament fosse are about one-third broader than high, approximately oblong, with the inner distal angle rounded, sometimes broadly so. The distal margin may be more or less convex, and the outer margin retreats somewhat basally from the ends of the transverse ridge. The inner edges are parallel and straight, about as far apart as the transverse (greater) diameter of the oval central canal.

The muscular fosse, which are comparatively large, arc nearly as high as the interarticular ligament fossæ. Their distal border is broadly convex; their inner borders straight and parallel, not much more than half as far apart as those of the interarticular ligament fossæ. Their outer border makes an angle of nearly $30^{\circ}$ with that of the outer erlge of the interarticular ligament fosse. The chord of the distal convexity of the muscular fossa may be horizontal, or inclined slightly inward.

The ventral surface of the radial pentagon is entirely covered with a rather coarse and loose calcareous deposit through which there is no special central canal. 


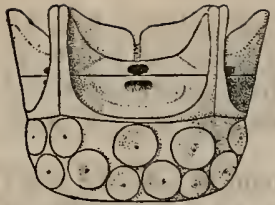

13

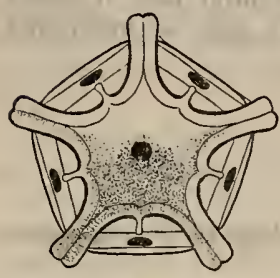

14

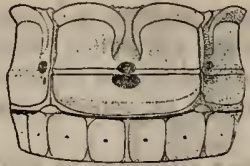

17

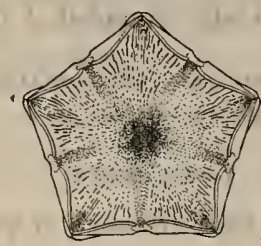

18

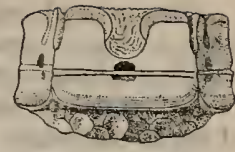

21

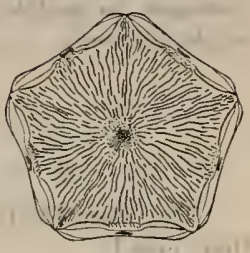

22

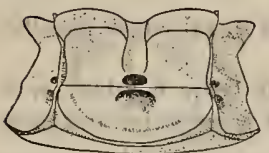

15

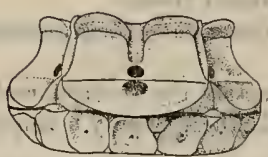

19

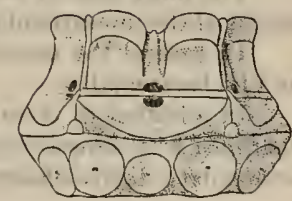

23
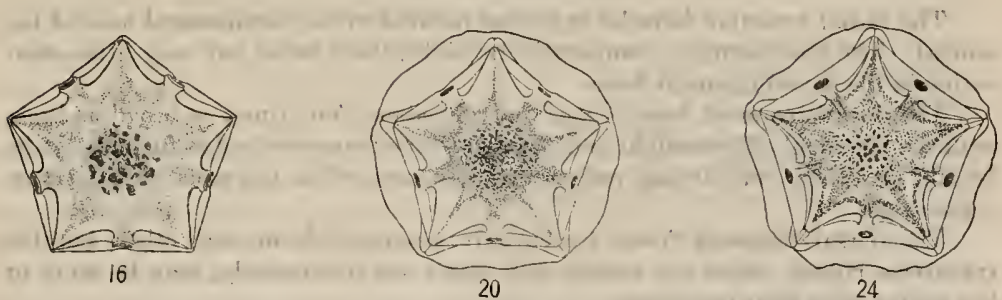

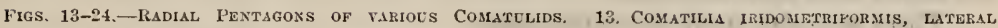
VIEW OF RADIALS AND CENTRODORSAL. 14. SIME, TENTRAL VIEN OF RADIAL PLXTAgON. 15. COMATULA MICRASTER; LATERAL VIEW OF RADIALS AND CENTRODORSAL, 16, SAME, VENTRAL VIEW' OF R.ADIAL

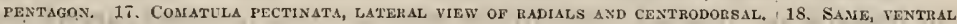
IIFW OF RADIAL PENTAGON, 19. COMACTINIA ECHINOPTERA, LATERAL VIEW OF RADIALS AND CBNTTZODORSAL. 20. Same, ventral riew of radial pentagon. 21. Comastei fruticosts, lateral vifi of radials

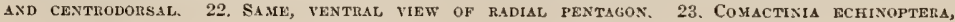

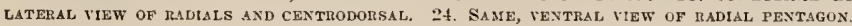


Diameter of radial pentagon at base, $4.7 \mathrm{~mm}$; height of articular face, 2.3 $\mathrm{mm}$.; width, at transverse ridge, $2.9 \mathrm{~mm}$. ; distance from center of rosette to middle of dorsal outer edge of radial, $1.9 \mathrm{~mm}$.: distance from center of ventral face of radial pentagon to middle of ventral edge of radial, $1.3 \mathrm{~mm}$; to apex of interradial angle, $2.2 \mathrm{~nm}$.

Another specimen measures: Diameter of radial pentagon at base, $3.8 \mathrm{~mm}$.; height of articular face (measured along the inclination), $1.7 \mathrm{~mm}$; width, at transverse ridge, $2.3 \mathrm{~nm}$.; distance from center of rosette to middle of dorsal outer edge of radial, $1.6 \mathrm{~mm}$; distance from center of ventral face of radial pentagon to middle of rentral edge of radial, $1 \mathrm{~mm}$.; to apex of interradial angle, $1.5 \mathrm{~mm}$.

COMACTINIA MERIDIONALIS.

See figs, 963,94, pl. 1.

\section{Comasterina.}

The interarticular ligament fossæ are nearly or quite as high as, or even higher than, broad.

The distal edges of the interarticular ligament fossæ are horizontal, or are somewhat higher exteriorly than interiorly.

There is no change in direction between the interarticular ligament fossæ and the muscular fossæ.

The inner ends of the muscular fossæ are inserted well within the inner distal angles of the interarticular ligament fossæ.

In general the muscular fossæ have their proximal and distal edges parallel, and lie horizontally.

In addition to these characters the centrodorsal usually bears no cirri, or is equipped with several rows. If there is only a single row it is irregular and more or less irregularly deficient.

\section{COMASTER FRUTYCOSUS.}

Figs. 21, 22, p. 15.

The radial articular faces lie in planes parallel to the dorsoventral axis of the animal. The sculpturing is comparatively slight, there being but very little excavation in the dorsal ligament fossa.

The dorsal ligament fossa is very narrow, about four times as broad as high, with the proximal edge straight and parallel to the transverse ridge for most of its length, at either end curving rather abruptly upward to the ends of the transverse ridge.

The dorsal ligament fossæ are entirely separated from each other, but the transverse ridges, which are narrow and stand out prominently, may be more or less united with their neighbors.

There is no rim about the central canal.

Shortly beyond the apposed ends of the transverse ridges the lateral borders of the interarticular ligament fossæ diverge somewhat, soon becoming parallel again, 
so that, viewed interradially, they are seen to be separated by a narrow $U$ reaching downward nearly to the transierse ridge. Their distal edges, which are struight or very slightly convex and parallel to the transrerse ridge, run inward for a distance equal to between one-half and three-quarters of the height of the interarticular ligament fossæ, then sweep downward in the form of a concave margin to the upper part of the central canal; this margin is usually more or less irregular. The space between the interarticnlar ligament fossæ is very broadly $U$-shaped to semicircular, and is somewhat larger than the adjacent part of the interarticular ligament fossæ. It is only shightly depressed below the general surface, and is marked with more or less irregular strong longitudinal (dorsoventral) striations, which are continuations of the radiating striations on the ventral surface of the radial pentagon.

The muscular fossæ are linear and narrow, lying along the distal edge of the interarticular ligament fossæ and just rounding their inner distal angles.

The rentral surface of the radial pentagon is covered by a spongy calcareous mass marked ventrally with more or less regular fine radial striations which reach to the height of the distal border of the muscular fossi. The central canal is moderately large.

Diameter of radial pentagon at base, $6.1 \mathrm{~mm}$.; height of articular face, $2.5 \mathrm{~mm}$.: width, at transverse ridge, $4 \mathrm{~mm}$.; distance from center of rosette to middle of dorsal outer edge of radial, $2.8 \mathrm{~mm}$.; distance from center of ventral surface of radial pentagon to middle of ventral outer edge of radial, $2.3 \mathrm{~mm}$.; to apex of interradial angle, $3 \mathrm{~mm}$.

\section{COMASTER PARIUS.}

Figs. 25, 26, p. 20.

The dorsal ligament fossa is about three times as broad as high, with the proximal border regularly elliptical. The ligament pit is transversely oval, and about as large as the central canal.

The ends of the transverse ridges of adjacent joint faces are joined, but the dorsal ligament fossæ are widely free; the joint face elements distal to the transverse ridge are separated by a broad shallow $\mathbf{V}$-shaped gap.

The outer borders of the interarticular ligament and muscular fossæ make an angle of about $60^{\circ}$ with the transverse ridge. The edges of the interarticular ligament fossa are more or less concare. The maximum (outer) height of the interarticular ligament fossæ is abont equal to that of the dorsal ligament fossa. From the outer distal angles the distal edges of the interarticular ligament fossæ run inward and slightly downward to the intermuscular furrow, which they join at a point about as higlı above the distal border of the central canal as the horizontal (greater) diameter of the canal. They may be nearly straight, evenly convex, or nearly straight outwardly and becoming more convex inwardly. If the convexity is strong they may join the intermuscular furrow at a point above the distal border of the central canal about as far distant as the median (shorter) diameter of the canal. 
Proximally the intermuscular furrow is about as broad as the central canal, from which it is separated by a narrow rim, or it may be slightly broader. It gradually narrows distally, being scarcely half as broad between the muscular fossæ.

The muscular fossæ are small and narrow, slightly crescentic, with the distal edges almost parallel with the proximal. The inner angles are inserted within the distal inner angles of the interarticular ligament fossæ; they are about as broad as the width of the intermuscular furrow between them.

The inner portion of the radial pentagon is obscured by a deposit of calcareous matter, the surface of which is marked witl narrow radiating furrows. There is no open central canal. This deposit, thongh entirely concealing the inner ends and surfaces of the radials and obliterating the sutures between them, is thin. and follows the contour of the inner snrface of the radials, so that in a general view the ventral surface of the radial pentagon appears deeply hollowed.

Diameter of radial pentagon at base, $3 \mathrm{~mm}$; height of articular face, $1 \mathrm{~mm}$.; width, at transverse ridge, $2 \mathrm{~mm}$.; distance from center of rosette to middle of dorsal outer edge of radial, $1.7 \mathrm{~mm}$; distance from center of ventral face of radial pentagon to middle of ventral edge of radial, $0.9 \mathrm{~mm}$.; to apex of interradial angle, $1.3 \mathrm{~mm}$.

\section{ZYGOMETRIDÆ.}

The articular faces of the radials lean inward at an angle of approximately $4.5^{\circ}$ to the dorsoventral axis.

The excaration of the rarious elements of the joint face is moderate, as there is but a limited amount of motion to be accommodated.

The relatively deeper and more extensive excavation of the joint faces has tended to narrow the broad flat area distal to the transverse ridge, as seen in the Comasteridx. making of it a narrow rim about the central canal which slopes downward on either side to the transverse ridge.

The joint face elements on either side of the transverse ridge are in the same plane, or, if not, the dorsal ligament fossa makes a smaller angle with the dorsoventral axis of the animal than the elements distal to the transverse ridge.

The dorsal ligament fossa is as high as, or slightly higher than, the interarticular ligament fossæ, and its proximal border is usually slightly flattened. The ligament pit is strongly marked, broadly oval, larger than the central canal.

The central canal is moderately large and broadly oval.

The joint face elements distal to the transverse ridge are separated in the median line by a rather narrow intermuscular furrow which does not exceed one-third of the transrerse diameter of the central canal in proximal width; distally its sides diverge slightly, and it is not constricted between the muscular fossæ.

The interarticular ligament fosse are approximately triangular, with the proximal inner angles broadly truncated by the elevation about the central canal.

The muscular fossæ are narrow and crescentic, their greatest diameter being less than one-third of the height of the interarticular ligament fosse. Their inner ends rest upon the distal portion of the rim about the central canal; their 
imner halves are nearly parallel with the median axis of the joint face, and their outer approximately at right angles to it. The vertical and horizontal portions are united in a broad curve, in which the muscular fossæ attain their maxinum width.

The ventral face of the radial pentagon is pentagonal or decagonal in outline. The radial portions are not incised.

The central plug may cover only the inner ends of the radials, or it may cover their entire inner surface and rise to the level of the distal edge of the muscular fossæ; it is coarser in structure in the center than toward the periphery, but there is no free central canal. The radial canals, when not obscured by the deposition of calcareous matter, are very broad.

\section{ZXGOMETRA COMATA.}

Figs. $27,28,1,20$.

The dorsal ligament fossa is between two and one-half and three times as broad as the median length, evenly conrex proximally, but at the corners bending upward rather more strongly so as to join the ends of the transverse ridge approximately at a right angle.

The ends of the transverse ridges of adjacent joint faces are just in apposition, but the dorsal ligament fosse are entirely closed and do not communicate laterally with each other.

The outer edges of the interarticular ligament fossa run inward at a rather small angle with the dorsoventral axis of the animal. They are usually more or less concare, this concavity being most marked proximally and dying away distally. Just beyond the somewhat large transversely oval central canal is a horizontal slightly raised ridge about one-fourth or one-third again as broad as the diameter of the central canal which marks the proximal border of the muscular fossæ. From the ends of this rim the inner edges of the interarticular ligament fossæ run perpendicularly (parallel with each other) upward to a point about as far from the ridge as that is from the nearest part of the dorsal ligament fossa, then turn outward somewhat abruptly and run to the outer edge at a slight angle to the horizontal. The greatest (exterior) height of the interarticular ligament fossæ is about equal to the greatest (proximal) width, which itself is about equal to the maximum height of the dorsal ligament fossa. The portions of the interarticular ligament fossæ beyond the central canal are separated by a rectangular gal equal in breadth to the diameter of the interarticular ligament fossæ at this point, and not quite twice as broad as long.

The distal edges of the muscular fossi form a straight line with each other. The outer corners are curved downwarl to the outer distal angles of the interarticular ligament fossæ; the inner distal angles are rounded off, the inner edges being parallel and running to the ridge mentioned above as just beyond the central canal. The inner edges of the muscular fossæ reach this ridge in such a way as to divide the space between the interarticular ligament fossæ into thirds. 


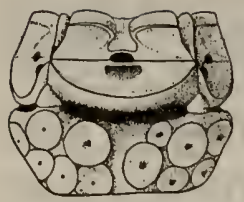

25
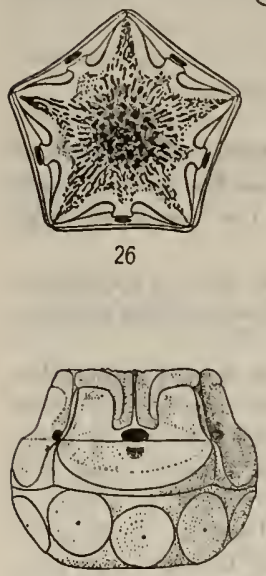

27

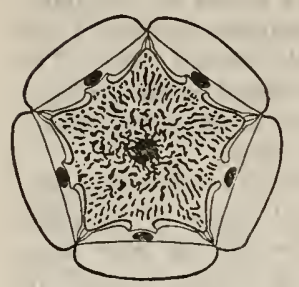

28

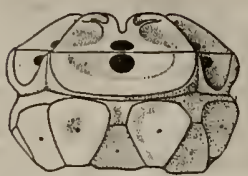

29

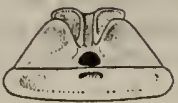

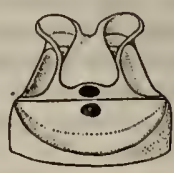

36
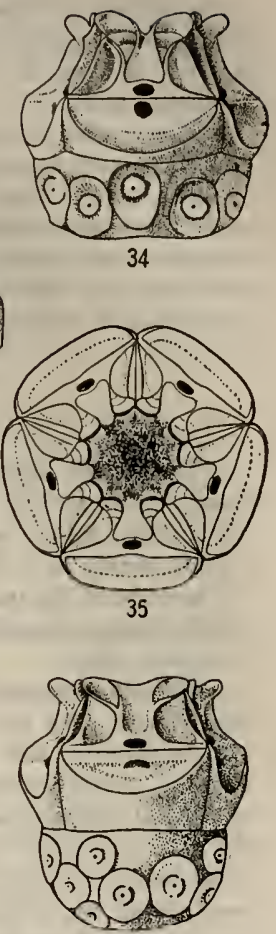

37

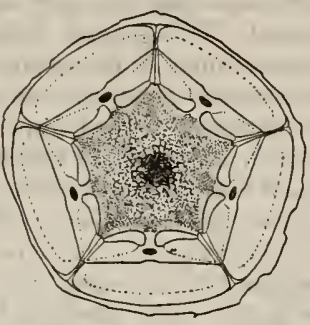

33

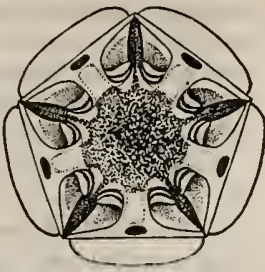

38

Figs, 25-38, - Radia Pentagons and Radial artictlar Faces of fariogs Comatelidos. 25. Comaster

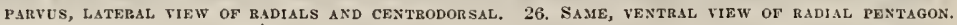
27. Zrgometra COMATA, LATFRAL TIEW OF RADIATA AND CENTRODORSAL. 2S. SAME, VENTRAL VIEW OF RADIAL PENTAGON. 29. EUDIOCRINUS ORNATUS, LAFERAL VIEW OF RADIALS AND CENTRODORSAL. 30. SAME, rentral VIEW of Radial pentagoN. 31. SAME, a Rabial articular face. 32. Catoptohetra hartlaUbi, LATERAL TIEW OF RADIALS AND CENTRODORSAL. 33. SAME, vexTRAL VIET OF RADIAL PENTAGON. 34 .

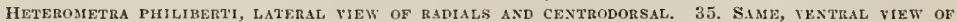
RADIAL PENTAGON, 36. SAME, A RADIAL ARTICULAR FACE. 37. AAPHIMETRA PAPUENSIS, LATFRAL VIEW OF radials and centrodorsal. 38. SaMz, rentral tiew of radial pentagon. 
The muscular fossæ are separated by a shallow groove about as wide as their inner downward extensions. This groove may be more or less carinate at the bottom. The inner edge of the muscular fossæe is about as long as the distal, and is perpendicular to it. Both are about as long as the distance between the inner distal angles of the interarticular ligament fossa and the transverse ridge. The muscular fossæ in shape resemble a boomerang, or broad gamma, the horizontal limb being somewhat thicker than the vertical.

The space between the radials ventrally is filled with an open calcareous filling the surface of which is plane and on the same level with the distal edges of the muscular fossæ. It is covered with small papillæ. The central canal is moderately sinall, as in Catoptometra hartlaubi.

Diameter of radial pentagon at base. $4 \mathrm{~mm}$.: height of articular face (measured along the inclination), $1.7 \mathrm{~mm}$; ; width, at transverse ridge, $2.1 \mathrm{~mm}$.; distance from center of rosette to iniddle of dorsal outer edge of radial, $1.9 \mathrm{~mm}$.; distance from center of ventral face of radial pentagon to middle of outer ventral face of radial, $1 \mathrm{~mm}$.; to apex of interradial angle, $1.3 \mathrm{~mm}$.

\section{CATOPTOMETRA HARTLAUBI.}

Figs. 32,33, p. 20.

The dorsal ligament fossa is narrow, about four times as broad as long. The proximal edge is comparatively slightly convex, and the lateral angles are truncated, so that lateral edges are formed which are about half as long as the median diameter of the dorsal ligament fossa, or slightly longer.

The interarticular ligament fossæ are about as high as broad, the height being about equal to that of the dorsal ligament fossa. The lateral edges retreat sharply from the transverse ridge, taking the same general direction as the lateral edges of the dorsal ligament fossa, and, like them, being more or less concave, rather more prominently so than they. The inner angle is broadly truncated by the rim about the somewhat large central canal. The inner edges run outward and upward at an angle of about $45^{\circ}$ to a point slightly beyond the niddle of the horizontal portion of the distal edge, then curves and runs almost or quite parallel to the transverse ridge to the outer edge. The distal inner corners of the interarticular ligament fossæ are separated by the distance equal to the horizontal diameter of the central canal.

The muscular fossæ may be described as forming roughly a right-angled triangle, the distal edge forming the base, with the hypothenuse concave (being formed by the distal edge of the interarticular ligament fossæ), the angles broadly rounded, and the base somewhat convex. The greatest (innermost) height is about onethird less than the greatest horizontal diameter. The distal edges are slightly convex or almost straight, running in a general horizontal direction, outwardly curving downward to the distal outer corner of the interarticular ligament fossæ, inwardly, with a similar or somewhat broader curve, running into the parallel inner edges which reach the raised rim about the central canal between, and slightly above, the inner distal angles of the interarticular ligament fossæ, in such a way as 
to divide the space between these angles approximately into thirds. The muscular fosse are separated by a furrow, the diameter of which is about one-third the diameter of the central canal. This furrow may carry a rounded carination in the median line, on the highest part of which are a few spicules. The greatest (interior) height of the muscular fossæ is somewhat less than the greatest dorsoventral height of the interarticular ligament fosse. The distal diameter of the muscular fossæ is not quite so great as the proximal cliameter of the interarticular ligament fossæ.

The ventral surface of the radial pentagon is covered by a spongy calcareous mass, very shightly concave on its surface, which reaches nearly to the upper edges of the muscular fossæ. The central canal is rather small.

Diameter of radial pentagon at base, $4.7 \mathrm{~mm}$.; height of articular face (measured along the inclination). $1.9 \mathrm{~mm}$.; width, at transverse rilge, $2.2 \mathrm{~mm}$.; distance from center of rosette to middle of dorsal outer edge of radial, $2.2 \mathrm{~mm}$.; distance from center of ventral face of radial pentagon to middle of ventral edge of radial, $1 \mathrm{~mm}$.; to apex of interradial angle, $1.3 \mathrm{~mm}$.

\section{EUDIOCRINUS ORNATUS.}

Figs. 29, 30, p. 20.

The dorsal ligament fossa is rather low, between three and four times as broad as high. The proximal border is but stightly convex, at either end turning upward in a moderately broad curre to the ends of the transverse ridge. The ligament pit is rounded oval, abont as large as the central canal.

The ends of the transverse ridges of adjacent articular faces are entirely separated from each other, though the distance between them is small. The dorsal ligament fosse are well separated; distal to the transverse ridge the articular faces are separated by a narrow interradial groore which slowly increases in width distally.

The outer edges of the interarticular ligament fossæ slope inward at an angle of about $45^{\circ}$ and continue this direction until they reach a length nearly or quite equal to the distance from the central canal to the end of the transverse ridge. They then turn inward, and this anterior or distal border takes a direction toward the opposite side of the transverse ridge (on the other side of the central canal) until about two-thirds of the distance to the perpendicular passing through the nearer end of the central canal is accomplished, when it turns rather abruptly downward, reaching a point just above the central canal, but at the side of the median axis of the joint face.

A narrow but rather deep intermuscular furrow reaches to the upper border of the central canal. The sides of the interarticular ligament fossæ which border this furrow are somewhat thickened.

The muscular fossæ are much reduced and crescentic. The outer edge of the interarticular ligament fossæ is continued in the same direction as the outer edge of the muscular fossæ, but almost immediately begins to curre gradually inward, the radius of the curve gradually shortening until it bends downward into the inner 
border of the muscular fossæ. These inner borders are parallel and are separated by a narrow intermuscular furrow. The muscular fossæ reach just to the distal border of the central canal.

The central part of the interior of the radial pentagon ventrally is occupied by a loose calcareous deposit concealing the inner ends of the radials and the rosette from ventral view.

Diameter of radial pentagon at base, $3.3 \mathrm{~mm}$.: height of articular face (meas. ured along the inclination, $1 \mathrm{~mm}$; width, at transverse ridge, $1.7 \mathrm{~mm}$.; distance from center of rosette to middle of dorsal onter edge of radial, $1.5 \mathrm{~mm}$.; distance from center of ventral face of radial pentagon to middle of ventral edge of radial, $0.6 \mathrm{~mm}$; t to apex of interradial angle, $1.2 \mathrm{~mm}$.

\section{HIMEROMETRID E and MARIAMETRID}

The Himerometridæ and Mariametridæ may well be consdered together, as they differ but little in their structure, except in regard to the arms and pinnules. I have never been able to dissect a representative of the Stephanometridæ, but it seems probable that the radial articnlar faces in this family will be found to be very similar to those in the Mariametridæ.

The relation of the articular faces of the radials to the dorsoventral axis of the animal varies from nearly parallel to an angle of about $60^{\circ}$.

The excavation or relief of the several joint face elements varies more or less in different species, and is more or less inversely proportionate to the size of the angle between the plane of the joint face and the dorsoventral axis, and more or less directly proportionate to the size of the muscular fossæ. In large species with numerous arms where the muscular fossæ are considerably reduced and the articular faces are nearly parallel to the dorsoventral axis the excavation of the joint faces as a rule is slight, as in the Comasteridæ, for, as in that family, there is little motion to be accommodated here; but in smaller species with few arms, where the muscular fossæ are proportionately large, the basal portion of the postradial series not having become semirigid, restricting the arm movement to beyond the bases of the free undivided arms, as is the case with the species with numerous arms, and there is a considerable angle between the articular faces and the dorsoventral axis, the sculpture of the joint faces is deep. The relief of the articular faces is, in the portion distal to the transverse ridge, deeper exteriorly than interiorly.

In large species, or in species with numerous arms, where there is but little proximal interarticular motion, there is no definite raised area bordering the transverse ridge anteriorly and encircling the central canal, so that the interarticular ligament fossæ appear to extend proximally quite to the transverse ridge, as in certain comasterids; but there is always a high ridge between the central canal and the deep intermuscular furrow which adjoins it distally.

Progressive excaration begins first along the outer edge of the interarticular ligament fossæ and gradually extends inward and downward, so that, little by little, a raised area bordering the transverse ridge anteriorly and surrounding the central canal becomes evident which is at first broad, but later becomes, with increasing differentiation, narrower and narrower, finally assuming the form of a 
high narrow rim about the lateral and distal edges of the central canal, which is continued laterally in the shape of a high border along the transverse ridge more or less broad interiorly but tapering gradually to a point at either end of the transverse ridge. The presence of a rim about the central canal, therefore, is due to the amount of action between the radials and the $\mathrm{IBr}_{1}$ and the correlated amount of excavation, and has no systematic significance of itself apart from this. The depth of the dorsal ligament fossa and the depth of the ligament pit is in general proportionate to the depth of the interarticular ligament fossæ and the correlated size of the muscular fosse.

The elements of the joint face on either side of the transverse ridge are usually in the same plane; if there is any difference, the plane of the dorsal ligament fossa makes a slightly greater angle with the dorsoventral axis than the plane of the distal elements.

The dorsal ligament fossa is large, with the proximal border well rounded and never flattened. The ligament pit is strongly marked, reniform, oval, or circular, usually about the size of the central canal, which is broadly oval and moderate in size.

The joint face elements distal to the transierse ridge and the central canal are separated interiorly by a broad and shallow intermuscular furrow as broad as to very much broader than the central canal, which may have parallel sides, may be very broad proximally and strongly constricted between the muscular fossæ, or may increase gradually in width distally.

The interarticular ligament fossæ are usually considerably higher than the dorsal ligament fossa, higher than broad, irregularly quadrate or oblong. They are usually deeply hollowed, at least exteriorly. Their outer edges are more or less strongly concave, at least basally; their distal edges are straight, or more or less strongly convex, and may be parallel to the transverse ridge, but usually run more or less inward and downward, sometimes almost directly from the outer distal angles to the central canal. The inner distal angles, however, are never obliterated, though they may be very broadly rounded.

The muscular fossæ are variable in size, but are always smaller than the interarticular ligament fossæ. They may be greatly reducel and narrowly linear, or even apparently absent, but are usually comparatively broad exteriorly, gradually narrowing to a point just at, or somewhat within, the distal angles of the interarticular ligament fossæ; they may have two slight ridges across them parallel to their distal margin which probably represent the limits of annual growth before maturity or full size is reached. Their outer distal angle always projects strongly outward beyond the outer edge of the interarticular ligament fossæ.

The ventral face of the radial pentagon is pentagonal or bluntly stellate. In small 10-armed species or in 10-armed young it is sometimes rather deeply stellate, so that the interradial radius may be twice as long as the radial radius.

The ventral plug is well developed and has a flat or slightly concave surface, which is nearly or quite on a level with the distal edges of the muscular fossæ. It almost or quite conceals the inner surface of the radials. The radial canals are short, narrow, or quite obliterated; there is rarely a free central canal. 


\section{HIMEROMETRID $\mathrm{X}$.}

The intermuscular furrow is broad proximally and is usually strongly constricted distally; rarely the sides are parallel.

The interarticular ligament fossæe are oblong to irregularly quadrate, considerably higher than the dorsal ligament fossa.

\section{HIMEROMETRA MARTENSI.}

Figs. 41, 42, p. 26.

The dorsal ligament fossa is large, twice as broad as long, regularly and strongly conca ve dorsally.

The ends of the transverse ridges of adjacent joint faces do not meet and the dorsal ligament fossæ are entirely separated from each other interradially.

There is no distinct rim about the central canal.

The lateral borders of the interarticular ligament fossæ at first retreat rapidly from the ends of the transverse ridge, but soon curve, so that in the distal half they are nearly or quite parallel to the dorsorentral axis of the animal, or may even turn outward somewhat. Viewed perpendicularly to their surface the interarticnlar ligament fossæ are seen to be about as high as the distance between the central canal and the end of the transverse ridge. The distal edges, which are horizontal, straight, or very slightly convex, are about as long as the distance from the central canal to the inner distal angle; outwardly they pass over in a moderately sharp curve into the lateral edges, which at first are approximately at right angles to them, but very gradually begin to turn outward in the proximal third, running outward rather rapidly to the ends of the transverse ridge; inwardly the distal edges curve downward rather sharply, the two inner edges being practically parallel and separated by a broad deep furrow which is wider than the horizontal diameter of the central canal. At the distal edge of the central canal the lateral edges of the interarticular ligament fossæ curre inward and meet each other, forming a broadly $U$-shaped proximal end to the median furrow.

The miscular fossæ are exceedingly reduced, narrowly linear, and sometimes inore or less interrupted. They run along the distal edge of the interarticular ligament fossæ, disappearing at the interior and exterior distal angles, and are so inconspicuous that a close examination is necessary to discover them.

Diameter of radial pentagon at base, $6.6 \mathrm{~mm}$; height of articular face (measured along the inclination), $2.9 \mathrm{~mm}$.; width, at transverse ridge, $3.5 \mathrm{~mm}$.; distance from center of rosette to middle of dorsal outer edge of radial, $3.1 \mathrm{~mm}$.; distal from center of ventral face of radial pentagon to middle of outer ventral edge of radial, $1.6 \mathrm{~mm}$; t to apex of interradial angle, $2.2 \mathrm{~mm}$.

\section{CRASPEDOMETRA ACUTICIIRA.}

Figs. 43, 44, p. 26.

The dorsal ligament fossa is large, somewhat over twice as broad as long, with the proximal border strongly convex and the lateral angles slightly truncated. 


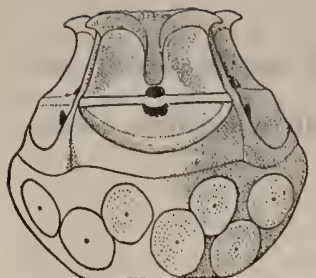

39
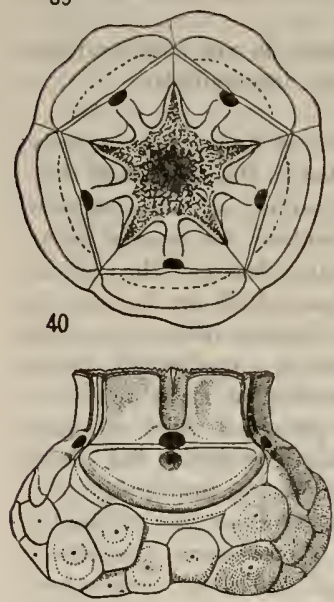

41

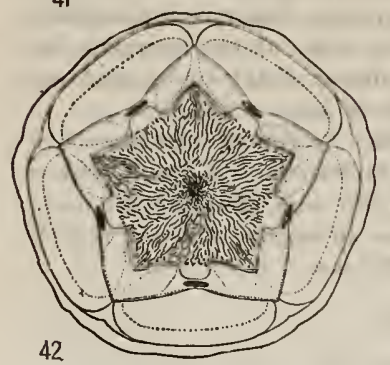

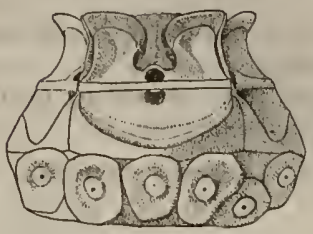

43
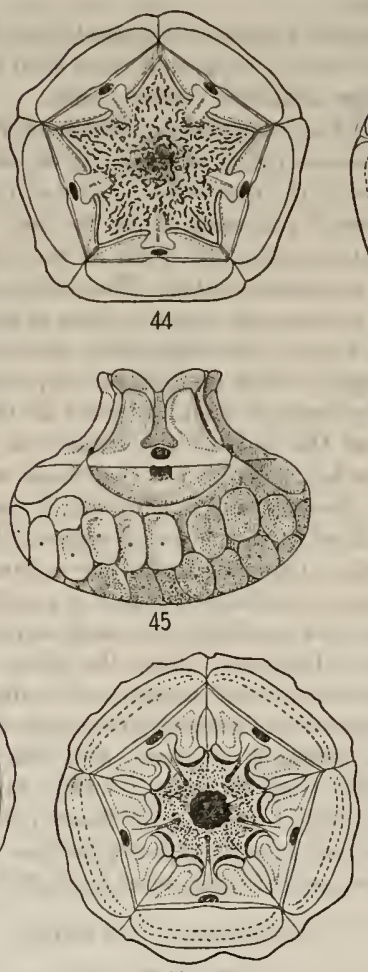

46
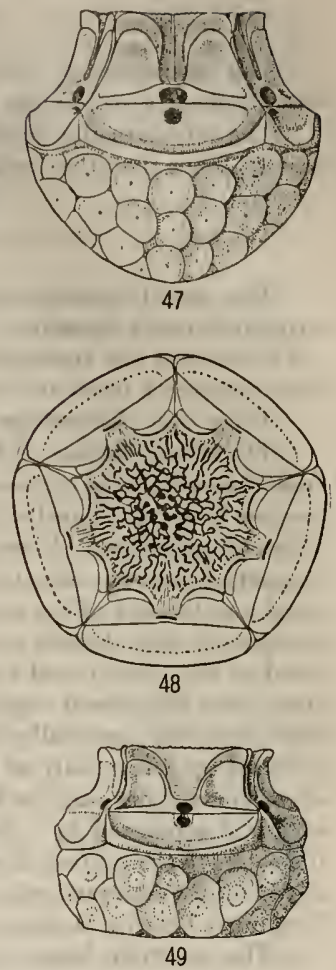

Figs. 39-50.-RAdIAL PENT.gons of VARIOUS COMATULIDS, 39. AMPHIMETRA ENSIFER, LATERAL VIETV OF RADIALS AND CENTRODORSAL. 40. SAME, VEXTRAL VIEW OF RADIAL PFNTAgON. 41. HIMEROMETRA MAR. TENSt, LATERAL FIEW OF TADIALS AND CENTRODORSAL, 42, SAME, VENTRAL VIEW OF RADIAL PENTAGON. 43. CraspFo METra ACUTICtRRA, LATERAL VIEW OF RADIALS AND CENTRADORSAL, 44. SAME, IENTR.IL VIEW OF RADIAL PENTAGON, 45. HETEROMETRA REXXANDI, LATERAL VIEW OF RADIALS AND CENTRADORSAL. 46.

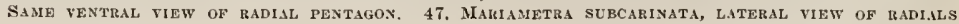
AND CENTRODORSAL, 48. SAME, VEXTHAL VIEW OF R.IDIAL PENTAGON, 49. L.IMPROMLIR.A PROTECTUS, CATERAL VIEW OF RADIALS AND CENTRODORSAL, 50. SAME, VENTRAL VIFW OF RADIAL PENTAGON. 
The lateral borders of the interarticular ligament fossæ are rather strongrly concave, the curve being somewhat stronger in the distal than in the proximal halves. The outer distal corners of the muscular fossæ are very nearly directly above the ends of the transverse ridge. Viemed perpendicularly the interarticular ligament fosse appear about as high as the distance from the end of the transverse ridge to the central canal. The lateral edges are concave and, as a whole, slope slightly inward; the distal borders are more or less convex with the chord of the convexity slightly inclined, so that the inner distal corners are about one-fifth of the length of the lateral border below the outer. The inner distal angles are broadly rounded and the inner borders are $\mathbf{S}$-shaped, the distal lobe of the $\mathbf{S}$ being formed by the inner corners and the lower by a broadly rounded notch of about the same size, which inwardly reaches the distal margin of the central canal. There is no raised rim about the central canal. The furrow between the interarticular ligament fossæ is therefore of a broad double $\mathbf{S}$ or gourd shape, the diameter of the expanded basal portion being approximately equal to the width of the interarticular ligament fossæe at that point.

The muscular fossæ are narrow, with parallel sides; outwardly they project in the form of an acute angle beyond the outer distal corners of the interarticular ligament fossa; inwardly they run to just beyond the inner distal angles of the interarticular ligament fossæ, where they taper to a point. The distance between the inner sides of the muscular fossæ as they curve downward is about equal to their own width and is considerably less than the distance between the inner distal corners of the interarticular ligament fossæ just below.

The space between the radials rentrally is filled to the height of the distal edges of the muscular fossæe with a spongy calcareous mass, almost plane on the ventral surface, with a small central canal.

Diameter of radial pentagon at base, $5 \mathrm{~mm}$. ; height of articular face (measured along the inclination), $2.5 \mathrm{~mm}$.; width, at transverse ridge, $2.8 \mathrm{~mm}$; distance from center of rosette to middle of dorsal outer edge of radial, $2.3 \mathrm{~mm}$; distance from center of ventral face of radial pentagon to middle of ventral outer edge of radial, $1.4 \mathrm{~mm}$. ; to apex of interradial angle, $1.8 \mathrm{~mm}$.

\section{HETEROMETRA REYNAODII.}

Figs. 45,46, p. 26.

The edges of the dorsal ligament fossa lie in a plane making only a small angle with the dorsoventral axis. From the ends of the transverse ridge onward the sides of the interarticular ligament and muscular fossæ together form a strongly concare line, so that the outer ends of the muscular fossæ are not much within the ends of the transverse ridge, being in about the same plane in reference to the dorsoventral axis as the inner border of the central canal.

The dorsal ligament fossa is somewhat orer twice as broal as long; the proximal border is slightly flattened. 
The fossæ distal to the transverse ridge are separated intcradially by a narrow lenticular gap running from ncar the ends of the transverse ridge to the outer angles of the muscular fossi.

The outer border of the interarticular ligament fossie is rather strougly concave, and has a general trend inward, so that the outcr distal angles of the interarticular ligament fossa lie orer a point about lialfway between the central canal and the ends of the transverse ridge. The distal border is slightly convex and runs inward and downward at an angle of approximately $45^{\circ}$ : inwardly the edges make a rather broad curve and the inner edges run parallel to the outer (thus diverging) until the level of the distal border of the central canal is reached, when they turn in a rather sharp but regular curve and reach the central canal just below its distal edge. The shallow groove between the interarticular ligament fossæ is, at the inner distal angles of the latter, about as wide as the diameter of the interarticular ligament fossæ at that point.

The muscular fossæ are narrow, about as wide as the space between them (which is less than that between the distal inner angles of the interarticular ligament fosse). The proximal and distal borders are parallel; inwardly they turn downward rather abruptly, their outer borders running parallel or diverging very slightly, meeting the border of the interarticular ligament fosse at the inner angle in a slarp point; outwardly the muscular fossæ project beyond the outer distal corners of the interarticular ligament fossæ in the form of a rounded triangle the length of which is about equal to the length of the distal edge of the interarticular ligament fossæ.

The space between the radials ventrally is filled to the level of the distal edges of the muscular fossie with a porous calcareous filling marked on the surface with indistinct radiating lines or papilla and with a comparatively large central canal, in comparison with the relatively small size of the ventral face of the radial pentagon.

Diameter of radial pentagon at base. $5 \mathrm{~mm}$.; height of articular face (measured along the inclination), $2.3 \mathrm{~mm}$.; width, at transverse ridge, $2.5 \mathrm{~mm}$.; distance from center of rosette to middle of outer dorsal edge of radial, $2.3 \mathrm{~mm}$.; distance from center of rentral face of radial pentagon to middle of outer rentral edge of radial, $0.8 \mathrm{~mm}$.; to apex of interradial angle, $1.2 \mathrm{~mm}$.

heterouftra PHILIBERTt.

Figs. $31-36$, ‥ 20 .

The dorsal ligament fossa is about twice as broad as high, nearly semicircular. The ligament pit is circular, somewhat larger than the transversely oval central canal.

The transverse ridges of adjacent joint faces join in the interradial angles, but the dorsal ligament fossæ are widely free. The interarticular ligament fossæ are separated in the interradial angles by a narrow $V$-shaped opening, which is bridged over distally by the apposition of the muscular fossæ. 
The outer edges of the interarticular ligament fossæ make an angle of approximately $60^{\circ}$ with the transverse ridge and are slightly and uniformly concave. The outer distal angles are rery sharp, the distal borders of the fossæ running inward and downward at an angle of about $60^{\circ}$. After reaching a length equal to nearly or quite one-half that of the outer border the distal edges turn abruptly downward and, after making a deep S-shaped curre, the two edges join just abore the central canal. This lower edge of the intermuscular furrow is bowed upward, following the curvature of the central canal from which it is separated by a very narrow isthmus.

The muscular fossæ are small. rounded triangular, with the apex at the inner distal angle of the interarticular ligament fossæ. Their distal edges are convex, the chord of the convexity being approximately parallel with the transrerse ridge. Their rather sharply rounded outer angles project somewhat beyond the outer distal angle of the interarticular ligament fossæ; their broadly rounded inner angles are rery widely separated. The intermuscular furrow is shallow, but rery broad; its lateral borders vary from parallel with the lateral borders of the interarticular ligament fossæ to almost parallel with each other; as a rule the condition is nearer the latter. At the lerel of the distal edge of the central canal the width of the intermuscular furrow is about equal to the distance from the end of the transverse ridge to a perpendicular from the transverse ridge to the outer border of the furrow; distally the width of the furrow decreases, being not much more than one-half as great between the inner angles of the muscular fossæ.

The rentral surface of the radial pentagon is covered with a loose calcareous deposit which reaches nearly to the height of the distal edges of the muscular fossæ.

Diameter of radial pentagon at base, $3.6 \mathrm{~mm}$; height of articular face (measured along the inclination), $1.9 \mathrm{~mm}$; width, at transverse ridge, $1.9 \mathrm{~mm}$.; distance from center of rosette to middle of dorsal outer edge of radial, $1.8 \mathrm{~mm}$.; distance from center of rentral face of radial pentagon to middle of ventral face of radial, $0.8 \mathrm{~mm}$.; to apex of interradial angle, $1.1 \mathrm{~mm}$.

\section{AMIPHIMETRA ENSIFER.}

Figs. 39 40, p. 26.

The dorsal ligament fossa is deep, not quite twice as broad as high, evenly eurred proximally. The ligament pit is rounded reniform, about the size of the central canal.

The ends of the transverse ridges just join laterally, but the dorsal ligament fossæ are widely free, owing to the low angle at which their proximal borders join the ends of the transverse ridges.

The interarticular ligament fossæ are about as high as the distance from the central canal to the ends of the transrerse ridge; their outer borders are slightly concave and slope inward, making an angle of about $60^{\circ}$ with the transverse ridge: 
the distal edges are strongly convex and may be nearly semicircular; the chord of their curvature is usually horizontal and parallel to the transverse ridge, though it may slant more or less inward and downward; the distal inner angles are strongly rounded; the inner borders are more or less strongly S-shaped, meeting below in a straight or slightly convex line just above the central canal.

The muscular fossa are subtriangular or more or less crescentic. Their outer edges make an angle of nearly $90^{\circ}$ with those of the interarticular ligament fossæ and are about as long as the distal edges of the latter; the distal edges curve evenly inward and downward, meeting the distal edges of the interarticular ligament fossæ at the inner distal angles of the latter.

The inner portion of the ventral surface of the radial pentagon is filled to the height of the distal edges of the muscular fossæ with a loose calcareous deposit showing a tuberculated surface and with a moderately large central canal.

Diameter of radial pentagon at base, $5 \mathrm{~mm}$.; height of articular face (measured along the inclination), $2.3 \mathrm{~mm}$.; width, at transverse ridge, $2.5 \mathrm{~mm}$.; distance from center of rosette to middle of dorsal outer edge of radial, $2.3 \mathrm{~mm}$.; distance from center of ventral face of radial pentagon to middle of ventral edge of radial, $0.9 \mathrm{~mm}$; to apex of interradial angle, $1.2 \mathrm{~mm}$.

\section{MARIAMETRIDA.}

The intermuscular furrow widens distally. The interarticular ligament fossæ are but little higher than the dorsal ligament fossæ and approach the triangular in shape.

\section{Pontiometra.}

The radial articular faces in the only known species of this genus differ very markedly from those of any other comatulid.

\section{PONTIOMETRA ANDERSONI.}

Figs. 51, 52, p. 33.

The radial articular faces are entirely and widely separated from each other, the distance between them being about one-third of their transverse diameter and the space between them forming a right-angled groove.

The border of the articular face dorsal to the transverse ridge forms a semicircle; distal (ventral) to the transverse ridge the sides converge slightly and then turn outward just before the outer distal corners.

The distal edges of the articular face as a whole lie entirely in the same straight line.

The entire articular face lies in the same plane, which makes an angle of about $30^{\circ}$ with the dorsoventral axis.

There is no rim about the central canal.

The transverse ridge is uniform in width, very broad, about as broad as the transverse diameter of the large central canal which entirely bisects it. On either side of the central canal it carries a ligament fossa, triangular in shape, the base 
against the outer border of the articular face, one side nearly coinciding with the proximal border of the transverse ridge, but slightly inclined upward, and the other running diagonally from the outer upper corner of the transverse ridge to a point just below the center of the side of the central canal, where it forms with the opposite side a sharp angle. In some cases these fossæ take the form of narrow isosceles triangles, the bases coinciding with the ends of the transverse ridge and the apices lying near the center of the sides of the central canal.

This pair of fossa has not previously been described in any comatulid, nor does it appear to exist in any genus other than Pontiometra. It is probable from their structure and situation that these fossæ lodge an additional pair of interarticular ligaments. They may be known as fulcral ligament fossæ from their position on the fulcral line of the joint face. Their appearance is possibly a step in the direction of the disintegration of the joint face as a muscular articulation and the formation therefrom of a pseudosyzygy such as is seen between the elements of the $\mathrm{IBr}$ series in certain species of Comatula and Comaster.

The dorsal ligament fossa is large, nearly semicircular in outline, about twice as broad as long. The ventral border is not straight but forms a very broadly obtuse angle, of which the apex is just below the central canal.

The interarticular ligament fossæ are equal in height to the dorsal ligament fossa; their edges are straight and converge slightly but turn outward rather abruptly at the distal outer corners. The distal border is somewhat convex, straight, or slanting slightly inward and downward. The inner distal angles are broadly rounded off, and the fossæ are separated interiorly by a U-shaped gap with parallel sides, which is about equal in width to the transverse diameter of the central canal. This gap contains a shallow groove with a more or less bluntly carinate ridge in the center.

Muscular fossæ are entirely absent.

The space between the radials ventrally is filled with a spongy calcareous deposit with a roughly radial arrangement which is slightly depressed in the center and pierced by a small central channel.

Diameter of radial pentagon at base. $7.5 \mathrm{~mm}$; height of articular face (measured along the inclination), $3.1 \mathrm{~mm}$.; width at transrerse ridge, $3 \mathrm{~mm}$.; nearest approximation of adjacent articular faces. $0.8 \mathrm{~mm}$.; distance from center of rosette to middle of outer dorsal edge of radial, $4 \mathrm{~mm}$; distance from center of ventral surface of radial pentagon to middle of ventral outer edge of radial, $2.5 \mathrm{~mm}$.; to apex of interradial angle, $3 \mathrm{~mm}$.

\section{MARIAMETRA SUBCARINATA.}

Figs. 47,48, p. 26.

The interarticular ligament and muscular fossæ slope regularly and evenly inward from the transverse ridges, their planes making an angle of about $30^{\circ}$ with the dorsoventral axis of the animal, and the plane touching the rim of the dorsal ligament fossa has only a very slightly greater inclination. 
The torsal ligament fossa is about two and one-half times as broad as long, gently conrex proximally but turning up more sharply at either end to the ends of the transverse ridge. The dorsal ligament fossæ do not communicate with each other interradially, but the transverse ridges are in contact. Interradially the interarticular ligament and muscular fossæ of adjacent joint faces are separated by a very narrow $\mathrm{V}$ - or $\mathrm{U}$-shaped gap which reaches down almost to the transverse ridge.

The height of the interarticular ligament fossæ measured from the proximal border of the transverse ridge is approximately equal to the height of the dorsal ligament fossa measured from the same point. The outer edges of the interarticular ligament fossie are nearly straight; the distal edges are more or less, usually strongly, convex, and the inner edges are nearly or quite straight and run, converging slightly, to a point just above the lateral borders of the central canal, then turn inward and meet each other in a straight line just beyond the central canal.

The broadly $\mathrm{U}$-shaped space between the interarticular ligament fossæ, the sides of which flare slightly, is almost or quite equal in area to that portion of the interarticular ligament fossæ beyond the central canal, and is usually not greatly different from it in shape.

The distal borders of the interarticular ligament fossæ may be quite semicircular, so that no inner or outer corners are evident, but they are usually not quite so convex, in which case the chord of the curve is usually horizontal-that is, parallel to the transverse ridge.

There is no rim about the central canal.

The muscular fossæ are small and narrow; their greatest width is about equal to the transverse diameter of the central canal, or is rather less. The outer margin, which runs in the same direction as that of the interarticular ligament fossæ, is more or less convex, sometimes almost semicircular. The distal edges run parallel to those of the interarticular ligament fossæ, gradually turning downward and approaching the edge of those fosse, making with them a sharp angle with the apex about halfway distant between the distal border of the intcrarticular ligament fossæ and that of the central canal.

The free borders of the muscular fossæ are approximately semicircular, and the fossæ themselves are crescentic, but the crescent is truncated at its broadest part, just over the outer distal angles of the interarticular ligament fossæ.

The shallow furrow beween the inner edges of the interarticular ligament and muscular fossæ is in general slightly less broad than the dorsal canal. Its sides are approximately parallel but are slightly further apart below the inner ends of the muscular fossæ; through the center of this furrow there runs a sharp high longitudinal ridge, dividing it into two parallel furrows.

The ventral surface of the radial pentagon is covered with a porous calcareous mass which is nearly flat on the surface and reaches to the height of the highest portions of the muscular fossæ; it contains a rather small central perforation. 

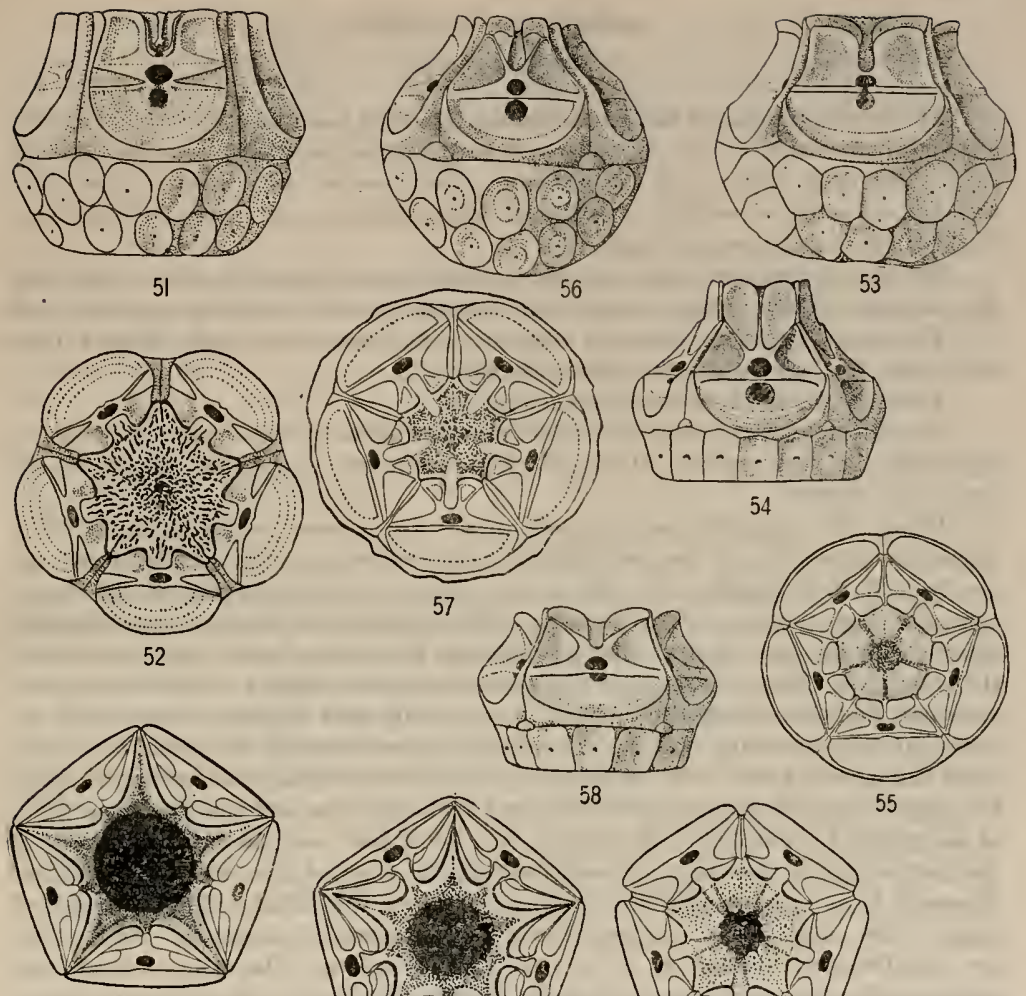

61

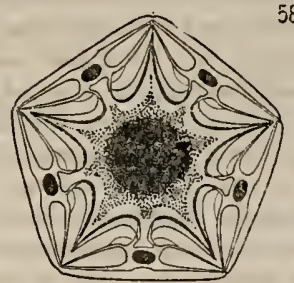

58

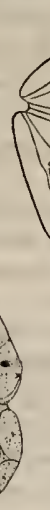

60
62

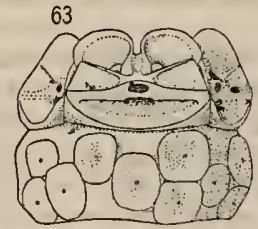

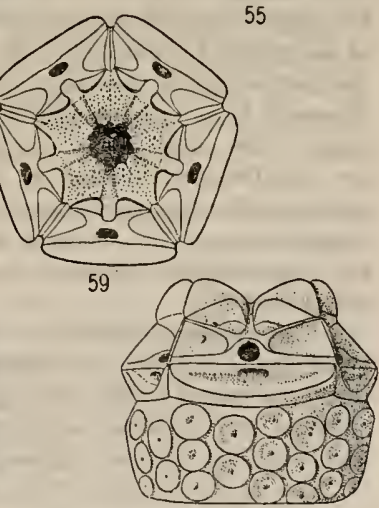

64

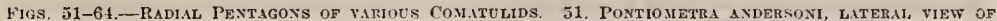
RADIALS AND CENTKODORSAL. 52. SAHE, VENTKAL VIEW OF RADIAL PENTAgON. 53. CENOMETRA UNICORNIS, LATERAL VIWW OF BADIALS AND CFITRODORSAL. 51. CYLlOMETRA ALBOPURPUREA, LATKRAL VIET OF ILADIAS AND CENTKODORSAL. 55. S.ME, VENTIAL VIEF OF RADIAL PENTAGON. 56. COLOBOMETRA DISCOLOR, LATERAL VIEW OF RADIALS AND CEXTRODORSAL. 57. S.IAE VENTRAL VIEW OF RADIAL PHNTAGON. 58. OLIGONETRA SERIPINAA, LATERAL TIEW OF RIDILE AND CENTRODORSAL. 59. SAJE, VZNTRAL VIWW

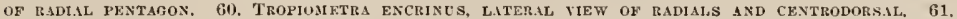
SAME, VENTRAL VIEW OF RADLAL PENTAgON, 62, ThOPIOMETRA PICTA, LATERAL VIEW OF RADIALS AND

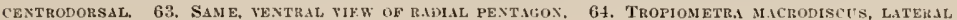
VIEW OF TADIALS AYD CENTRODORS.IL. 
LAMPROMETRA PROTECTUS.

Figs. 49,50 , p. 26.

The outer margins of the interarticular ligament fossæ at first retreat rapidly, but just before the middle curve around and become parallel to the dorsoventral axis. The outer corners of the muscular fossa project somewhat so that their tips are on a plane parallel with the dorsorentral axis and passing through the distal border of the central canal.

The dorsal ligament fossa is narrow, about three times as broad as high, with the proximal border evenly curved and turning upward abruptly at either end.

The dorsal ligament fossa of adjacent joint faces are entirely distinct from each other, but the transverse ridges just meet.

There is no rim about the central canal.

In the interradial planes the interarticular ligament and muscular fossw are separated by very nalrow $U$-shaped gaps extending downward nearly to the transverse ridges.

When the interarticular ligament fosse are viewed perpendicularly their lateral borders are seen to run diagonally inward at an angle of about $30^{\circ}$ for nearly half their length, and then turn upward, running parallel to the dorsoventral axis to the outer distal corners. The height of the interarticular ligament fossæ is about equal to the distance between the central canal and the end of the transverse ridge. From the outer distal angles the distal borders of the interarticular ligament fossæ run inward in an evenly and slightly convex line, the chord of the convexity making an angle of approximately $30^{\circ}$ with the transrerse ridge, until nearly half the distance to the dorsoventral plane passing through the central canal is covered, when they make a broad turn and run nearly straight, at an angle of about $30^{\circ}$ to that plane, to a point just over the lateral borders of the central canal, then turn inward, meeting the edge of the other interarticular ligament fossa in a straight line passing just over the distal edge of the central canal. The inner distal angles, typically well rounded angles of about $120^{\circ}$, are sometimes so blunted as to be practically obsolete. The space between the interarticular ligament fossæ is broadly $U$-shaped with the sides diverging at an angle of about $60^{\circ}$, the area involved being approximately equal to the area of the interarticular ligament fossæ beyond the level of the distal borders of the central canal.

The muscular fossæ are very small, their greatest diameter, just above the outer distal angles of the interarticular ligament fossa, being about the same as the dorsoventral width of the central canal; from this point they extend diagonally outward in a semicircle or short half-ellipse; inwardly they taper to a point which lies at the distal inner angle of the interarticular ligament fossæ.

The ventral surface of the radial pentagon is covered with a spongy calcareous mass which has an irregularly radiating surface structure and of which the surface is plane or very slightly concave, on a level with the highest point reached by the muscular fosse. The central perforation is rather small. 
Diameter of radial pentagon at base. $3.8 \mathrm{~mm}$; height of articular face (measured along the inclination), $1.5 \mathrm{~mm}$.: width, at transverse ridge, $2 \mathrm{~mm}$.; distance from center of rosette to middle of clorsal outer edge of radial. $1.9 \mathrm{~mm}$.; distance from center of ventral surface to middle of ventral outer edge of radial, $0.9 \mathrm{~mm}$.; to apex of interradial angle, $1.2 \mathrm{~mm}$.

\section{COLOBOMETRID.Æ.}

The articular faces of the radials lean inward so that the plane of the interarticular ligament fossæ makes an angle of nearly or quite $60^{\circ}$ with the dorsoventral axis of the animal; the plane of the muscular fossæ, however, is nearly or quite parallel with the dorsoventral axis, and thus makes an angle of approximately $120^{\circ}$ with the plane of the interarticular ligament fossæ.

In Cenometra, which in many ways approaches the genera of the Mariametridx, the conditions found in the radial articular faces are not greatly different from what is found in that family.

The excavation of the various elements of the joint faces is, except in Cenometra, deep, and the anterior border of the transverse ridge and the rim about the central canal are high and well marked, though not particularly narrow.

The elements on either side of the transverse ridge are in the same plane in Cenometra, but in the other genera the dorsal ligament fossa makes a lesser angle with the dorsoventral axis than the interarticular ligament fossæ.

The dorsal ligament fossa is large and deep, with the proximal border well rounded. The ligament pit is strongly marked and more or less circular, its area being usually approximately that of the central canal.

The central canal is oval or nearly circular, moderate in size or rather large.

The intermuscular furrow has parallel, slightly converging, or slightly diverging sides; it is never broader than the transverse diameter of the central canal. In one genus it is replaced basally by a narrow intermuscular septum which at first is high, but rapidly decreases in height distally, and in the outer part passes over into a narrow intermuscular septum.

In Cenometra the distal edge of the interarticular ligament fossa is slightly convex, the chord of the convexity being slightly lower interiorly than exteriorly. In the other genera it is straight and runs downward and inward, usually at an angle of about $60^{\circ}$ to the transverse ridge, to the distal portion of the rim about the central canal. In Oligometra the angle between the transverse ridge and the distal borders of the interarticular ligament fossæ is only about $45^{\circ}$, and the inner distal angle of the interarticular ligament fossæ is more or less indicated.

The muscular fossæ are very variable. In Cenometra they are very narrow, about as wide as the dorsoventral (shorter) diameter of the central canal, and their distal borders are parallel to the distal borders of the interarticular ligament fossæ. The outer distal angles project beyond the outer distal angles of the interarticular ligament fossæ, as in the Mariametridæ, and the inner angles are inserted just within the inner distal angles of the interarticular ligament fossæ; they 
decrease very slightly in width inwardly. In Oligometra the muscular fossie are very small, rounded triangular, with the distal borders convex and approximately parallel to the trausverse ridge; the maximum length is about one-half the breadth. In Colobometra and in Cyllometra they are trapezoidal with the acute angle downward and inward; in all of the genera except Cyllometra they are smaller than the interarticular ligament fossæ.

The ventral surface of the radial pentagon is pentagonal or very bluntly stellate in outline. Except in C'enometra the ventral plug is very poorly developed and usually more or less confined to the central portion of the radial pentagon. There may or may not be a free central canal.

\section{CENOMETRA UNICORNI8.}

Fig. 53, p. 33 .

The dorsal ligament fossa is broad and well rounded, slightly over twice as broad as high: the proximal border is strongly and very evenly curved. The ligament pit is considerably smaller than the central canal, and is circular; the central canal is moderate in size and slightly oval.

The transverse ridges of adjacent joint faces are slightly separated from each other; the dorsal ligament fossæ are widely separated; the elements distal to the transverse ridge are separated interradially by a shallow furrow, at first about as wide as the intermuscular furrow, but distally becoming slightly wider.

The interarticular ligament fossæe are large, their distal borders being about as high above the transverse ridge as one-half the length of the ridge. The distal and the inner edges of the interarticular ligament fossae are of about the same length; the inner edges are parallel and straight, and are separated by a rather deep intermuscular furrow, which is about as broad as the ligament pit. The distal edges are straight and parallel to the transverse ridge, or are slightly convex, the chord of the convexity being parallel to the transverse ridge; the inner distal angles are more broadly rounded than the outer; the outer borders are nearly straight.

The muscular fossæ are narrow, being usually about as broad as the longitudinal (shorter) diameter of the central canal. Their distal borders are parallel to those of the interarticular ligament fossæ, but are usually somewhat more convex. The inner distal angles are broadly rounded, so that the intermuscular furrow is not appreciably constricted; the outer borders of the muscular fossæ usually do not project beyond the line of the outer borders of the interarticular ligament fossæ.

The interior of the radial pentagon is occupied by a calcareous deposit which rises to the height of the distal edge of the muscular fossæ: it is irregularly radially striate on the surface and is slightly depressed centrally in the region of the moderately developed funnel-shaped central canal.

Diameter of radial pentagon at base, $5.4 \mathrm{~mm}$; height of articular face (measured along the inclination), $2.8 \mathrm{~mm}$.; width, at transverse ridge, $3 \mathrm{~mm}$.; dis- 
tance from center of rosette to middle of dorsal outer edge of radial, $2.7 \mathrm{~mm}$; distance from center of ventral surface of radial pentagon to middle of ventral outer edge of radial, $1.3 \mathrm{~mm}$; to apex of interradial angle, $1.8 \mathrm{~mm}$.

CYLLOMETRA ALBOPURPCREA.

Figs. 54, 55, p. 33.

The radial articular faces up to the proximal borders of the muscular fossæ lie in the same plane, which is inclined at an angle of nearly $45^{\circ}$ to the dorsoventral axis of the animal. The muscular fossæ, forming an obtuse angle with the remaining elements of the joint face, are parallel to the dorsoventral axis. The radial faces are entirely separated interradially by a uniform narrow $V$-shaped groore.

The dorsal ligament fossæ are moderate in size, about two and one-half times as broad as long. The proximal border is uniformly convex and turns up rather abruptly at the ends.

The interarticular ligament fossæ are equilateral triangles, but their inner angles are rather broadly truncated by the prominent rim of the central canal.

The muscular fossæ are trapezoidal in shape, with the distal angles rounded off. The lateral edges beyond the interarticular ligament fossæ are equal in length to the distal edges and are at right angles to them; the inner edges are nearly twice as long, rumning down to the ridge about the central canal upon which the apices of the trapezia abut.

The muscular fossa are separated interiorly by a narrow rounded ridge, at first as high as the rim about the central canal, but gradually decreasing in height and distally dying a way altogether.

The interior of the radial pentagon is filled with a spongy calcareous mass which reaches to the level of the distal edges of the muscular fossa through which there is a rather small central channel.

Diameter of radial pentagon at base, $3 \mathrm{~mm}$; height of articular face (measured along the inclination), $1.7 \mathrm{~mm}$; width, at transrerse ridge, $1.3 \mathrm{~mm}$.

\section{CYLLOMETRA DISCIFORMIS.}

See figs. $: 60,970$, pl. 2.

OLIGOMETRA SERRIPINNA.

Figs. 58, 58, p. 33.

The dorsal ligament fossa is rather narrow, about three times as broad as high, with the proximal border strongly flattened but strongly curved upward at the ends. The ligament pit is almost semicircular, about half as large as the transversely oval central canal.

In the interradial angles the ends of the transverse ridges are well separated and the dorsal ligament fossæ are very widely separated. The elements of the joint faces distal to the transverse ridges are separated by a rather deep inter- 
radial furrow which is about as broad as the longer (horizontal) diameter of the central canal.

The outer borders of the interarticular ligament fossæ make an angle of about $60^{\circ}$ with the transverse ridge, and are straight or slightly concave. The distal edges run from the outer distal angles toward a point on the transverse ridge halfway between the central canal and the end until near the central canal, when they turn downward somewhat, the inner edges of the two fosse together forming a broad rounded $Y$ just over the central canal.

The muscular fossæ are triangular, the apices at the outer distal angles of the interarticular ligament fossæ. The distal borders are horizontal, or slope inward very slightly; the inner distal angles are rather broadly rounded and the inner sides are parallel, separated by a shallow intermuscular furrow, which is about as broad as the ligament pit in the dorsal ligament fossa.

The central plug is represented by a loose calcareous meshwork in the center of the ventral surface of the radial pentagon which conceals the rosette.

Diameter of radial pentagon at base, $2 \mathrm{~mm}$.; height of articular face (measured along the inclination), $0.8 \mathrm{~mm}$. : width, at transverse ridge, $1.4 \mathrm{~mm}$.; distance from center of rosette to middle of dorsal outer edge of radial, $0.8 \mathrm{~mm}$; distance from center of ventral face of radial pentagon to middle of ventral border of radial, 0.6 $\mathrm{mm}$.; to apex of interradial angle, $0.9 \mathrm{~mm}$.

\section{TROPIOMETRID A.}

The dorsal ligament fossa is semielliptical, four or five times as broad as high. The ligament pit is slightly marked, but large; in shape it is transversely elongate.

The distal borders of the interarticular ligament fossæ are parallel to the transverse ridge, though they may curve downward somewhat inwardly.

The muscular fosse are large and well rounded, about twice as high as the interarticular ligament fossæ. Their lower inner corners are occupied by large supplementary muscle plates.

The ventral surface of the radial pentagon is devoid of calcareous deposits.

TROPIOMETRA MACRODISCUS.

Fig. 64, p. 33.

The radial articular faces of Tropiometra macrodiscus do not differ greatly from those of $T$. encrinus, as described below. The dorsal ligament fossa is narrower, with more pointed ends; it is about five times as broad as high; the central canal is more nearly circular; the distal borders of the interarticular ligament fossæ run in a straight line from the distal angles to the proximal end of the intermuscular furrow, and in the angle between these rather large second supplementary muscle plates are developed. The first supplementary muscle plates are larger than those of T. encrinus, occupying about half of the area of the muscular fossæ instead of one-fourth or one-third. The muscular fossæ as a whole are proportionately slightly smaller and are rather less rounded. They are in general proportionately 
higher exteriorly and lower interiorly. The inner portion of the radial pentagon has but little secondary calcareous deposit, and there is none on the ventral surface of the rosette. The interior of the radial pentagon is well rounded and is scored with shallow narrow meandering grooves.

Diameter of radial pentagon at base, $10.6 \mathrm{~mm}$.; height of articular face (measured along the inclination), $3.7 \mathrm{~mm}$; width, at transverse ridge, $5.5 \mathrm{~mm}$.; distance from center of rosette to middle of dorsal outer edge of radial, $5 \mathrm{~mm}$.; distance from center of ventral face of radial pentagon to middle of ventral edge of radial, $1.9 \mathrm{~mm}$.; to apex of interradial angle, $2.8 \mathrm{~mm}$.

TROPIOMETRA ENCRINUS.

Figs. 60, 61, p. 33.

The dorsal ligament fossa is very narrow, about four times as broad as high, regularly elliptical. The ligament pit is considerably broader than the central canal, transversely elongate, but only slightly marked.

From either end the transverse ridge gradually thickens so that it increases in breadth to the middle, where it encompasses the central canal; this increase in diameter is very even, so that only a very slight broad concavity of the anterior borders on either side of the central canal is discernible.

A narrow and shallow intermuscular furrow runs outward from the distal portion of the rim about the central canal, which is usually not quite so broad as half the width of the canal; its sides are parallel, or very slightly divergent.

The distal border of the interarticular fossæ is parallel to the transverse ridge, and shows a slight convexity near the intermuscular furrow. The proximal part of the low septum forming the distal border begins to curve gradually downward at about half the distance from the outer border to the intermuscular furrow, joining the distal border of the transverse ridge to one side of the perpendicular passing through the lateral border of the central canal, usually about as far distant as the dorsoventral (lesser) diameter of the central canal. The height of the interarticular ligament fossæ is a little less than that of the dorsal ligament fossa.

The muscular fossæ are large and well rounded; they are about twice the height of the interarticular ligament fossæ. The distal margin may be a broadly rounded triangle with the apex near the outer side, or it may be nearly trapezoidal with the inner distal angle more rounded than the outer. The lower inner corners of the muscular fossæ are occupied by a supplementary muscle plate which rises rather suddenly to about half the height of the interarticular ligament fossæ, makes a broad curve and extends outward and downward nearly in a straight line to the distal outer angle of the interarticular ligament fossæ. The inner portion of the distal border of the interarticular ligament fossæ is frequently depressed almost to the proximal edge of this distal border, and this sunken area is somewhat raised in the center and convex on the outer edge, so that it becomes a second supplementary muscle plate resembling that seen in Perometra diomedex.

There is no calcareous deposit on the inner surfacc of the radial pentagon or upon the rentral surface of the rosette.

142140-21-Bull. $82-5$ 
Diameter of radial pentagon at base, $6 \mathrm{~mm}$.; height of articular face (measured along the inclination), $2.5 \mathrm{~mm}$; width, at transverse ridge, $3.7 \mathrm{~mm}$.; distance from center of rosette to middle of dorsal outer edge of radial, $3 \mathrm{~mm}$; distance from center of ventral face of radial pentagon to middle of ventral edge of radial. $0.8 \mathrm{~mm}$; t to apex of interradial angle, $2.5 \mathrm{~mm}$.

TROPIOMETIA I'ICYA.

Figs. 62,68, p. 33.

TROPIOMETRA CARINATA.

Figs. 971, 972, pl. 2.

CALOMETRIDA.

The articular faces of the radials are approximately crescentic and arc entirely separated from each other as in Comotitia.

The dorsal ligament fossa is nearly semicircular.

The interarticular ligament fossæ have the distal border deeply concave, parallel to the distal border of the joint face; the outcr borders are about as high as the median height of the dorsal ligament fossa.

The muscular fossa are rery narrow, about as broad as the dorsoventral diameter of the central canal, forming a band-like border along the distal edges of the interarticular ligament fossæ.

The ventral surface of the radial pentagon is very widely open; there is a small central plug in the middle.

\section{NEOMETRA MULTYCOLOR.}

Figs. 65,66, p. 43.

The radial faces are approximately crescentic; the outer (dorsal) edge forms almost a semicircle, while the inner (rentral) border is strongly and evenly concave, the concavity in the median line reaching almost down to the central canal. The plane of the radial faces makes only a very slight angle with the dorsoventral axis. The radial faces are entirely and rather widely separated by a bare, slightly hollowed interradial area, which is rounded and sometimes more or less spatulate distally. The radials are in unusually close apposition, so that the suture between them is rarely visible.

The dorsal ligament fossa is about two and one-half times as broad as long. The proximal edge is evenly curved, and its curve is regularly continued anteriorly.

The central canal is more flattened than usual, being elliptical and about twice as broad as long. It is bordered laterally and distally by a narrow, low, and more or less inconspicuous ridge.

The distal border of the interarticular ligament fossæ is narrow, low, and inconspicuous; arising from a point on either side of the median distal portion of the ventrolateral ridge about the central canal it runs outward, deeply concave and 
parallel to the outer edge of the radial face, reaching the lateral edge of the joint face at a point as high above the ends of the transverse ridge as the maximum depth of the dorsal ligament fossa.

The muscular fossæ are very narrow, uniform in width, strongly concave, about as broad as the dorsoventral diameter of the central canal, and run along the outer edges of the interarticular ligament fossæ. Interiorly their distal edges are curved downward, so that their interior edges, which are parallel and run to the rim about the central canal, are separated by a shallow furrow about equal to half the horizontal diameter of the central canal in width; this shallow furrow has a very broadly open $\mathrm{V}$ - or U-shaped median notch distally, and may contain a slight narrow median ridge.

The ventral surface of the radial pentagon is hollowed out in the form of a deeply concave broad pit, the edges of which are coincident with the edges of the muscular fossæ. A small area on the floor of this pit, just above the rosette, is formed by a porous calcareous deposit.

Diameter of radial pentagon at base, $3.7 \mathrm{~mm}$; median height of articular face, $1.2 \mathrm{~mm}$; d distance from base of radial pentagon to end of interradial process, $2 \mathrm{~mm}$.; width of articular face, at transverse ridge, $1.9 \mathrm{~mm}$.; distance from center of rosette to middle of dorsal outer edge of radial, $1.8 \mathrm{~mm}$; diameter of ventral surface of radial pentagon, $3.2 \mathrm{~mm}$.

\section{THALASSOMETRID $\cong$ and CHARITOMETRID}

The radial articular faces of the species of these two families have much in common and may advantageously be discussed together.

The interarticular ligament fosse make an angle with the dorsoventral axis of the animal of about $60^{\circ}$, and are themselves approximately equilateral triangles with their inner angles truncated.

The muscular fossa are usually trapezoidal or rounded triangular and are parallel to the dorsoventral axis, or lie in the same planes as the interarticular ligament fossæ.

The excavation of the rarious elements of the joint face is moderately deep.

The rim about the central canal and the distal border of the transverse ridge are narrow and stand well up from the deep interarticular ligament fossæ.

The dorsal ligament fossa may be in the same plane as the interarticular ligament fossæ, or it may make a slightly lesser angle with the dorsoventral axis of the animal.

The dorsal ligament fossa is well rounded proximally and is about as high as the interarticular ligament fossæ.

The central canal is oval, moderate in size, or rather large.

The muscular fossæ are usually separated interiorly by an intermuscular septum, which at first is high, but soon becomes low, and which is often concave or grooved along its apex. In Stylometra there is an intermuscular furrow with parallel sides, carrying in its center a rounded ridge, which is about half as wide as the central canal. 
The muscular fossæ are always higher than the interarticular ligament fossæ, sometimes much higher, and they may include one or two pairs of supplementary fosse, or may show two or three ridges parallel to their distal borders. There is an intermuscular notch, which may be broad and shallow, or deep and very narrow.

There is a loose deposit of calcareous matter on the inner surface of the radials, but it rarely conceals them entirely, or obscures the central canal.

The ventral surface of the radial pentagon is stellate in outline, but the incisions are rarely deep.

\section{THALASSOMETRIDA.}

The muscular fossa lie in a plane nearly or quite parallel to the dorsoventral axis of the animal, which makes an angle of nearly or quite $120^{\circ}$ with the plane of the interarticular ligament fossæ. They are more or less trapezoidal in shape. Their area is almost always somewhat, usually much, greater than that of the interarticular ligament fossæ.

The distal (inner) borders of the interarticular ligament fossæ make an angle of $60^{\circ}$ or rather less with the transverse ridge.

In the immature stages the radial articular faces of the species of Thalassometridæ appear to resemble those of the species of Charitometridæ, suggesting, as do the cirri, that the Thalassometridxe are more specialized than the Charitometridæ.

Ptilonetrine.

PTILOMETRA MÜLLERI.

Figs. 67,68, p. 43.

The radial articular faces are, in reference to the dorsoventral axis of the animal, inclined at an angle of about $45^{\circ}$, so that they are about at right angles to each other.

The portion distal to the transverse ridge is rectangular, about three times as broad as long. Interradially the dorsal ligament fossæ are entirely separated, but the ends of the transverse ridges and the elements of the joint faces distal to them are in contact with the same parts of the adjacent joint faces.

The plane of the dorsal ligament fossa makes a very broadly obtuse angle with the plane of the other elements of the joint face.

The dorsal ligament fossa is usually not quite twice as broad as long; the proximal border is evenly curved.

The ridge about the central canal is broad and prominent, laterally falling away, sometimes almost in a straight line, to the ends of the transverse ridge.

The interarticular ligament fossæ are nearly or quite triangular, the distal edges being nearly or quite horizontal, and the greatest (horizontal) length being about twice the maximum vertical height; the outer borders are usually somewhat concave; the inner apices rest on the distal side of the dorsal part of the rim about the central canal, and are separated by a gap equal in breadth to about half the horizontal diameter of the central canal. 


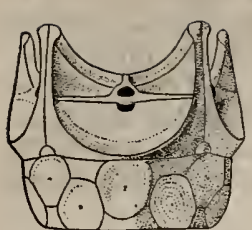

65
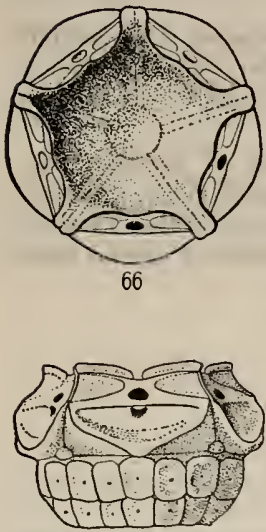

67

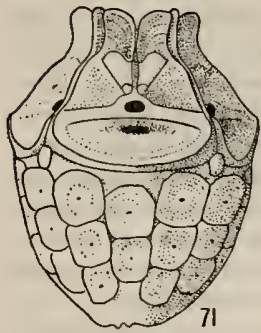

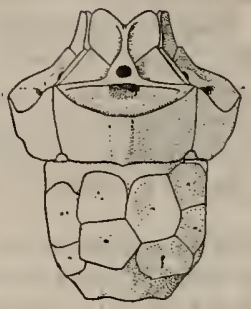

69
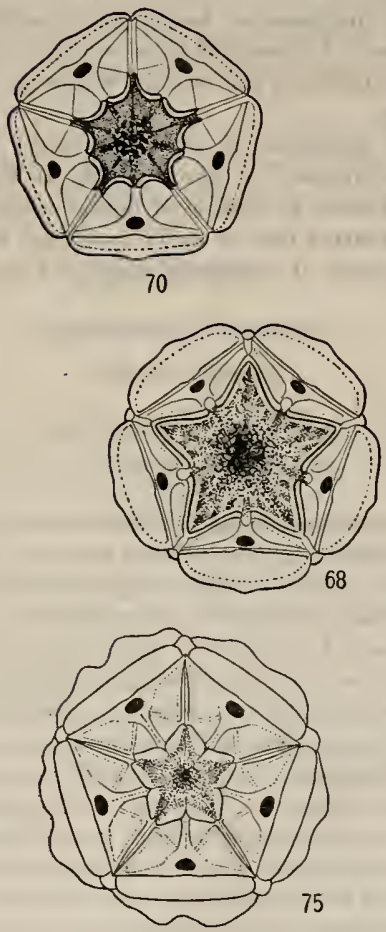
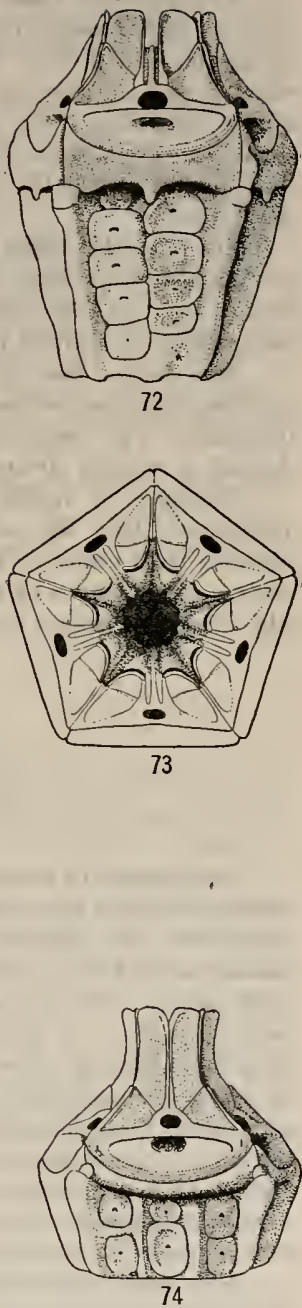

Figs, 65-75.-Radal Pentagons of rariocs Conatclids, 65. Neometra multicolor, lathral view of radials aNd centrodorsal, 66. Same, tentral view of radial pentagon. 67, Ptilometra aitlleri,

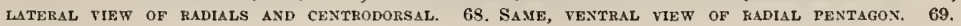

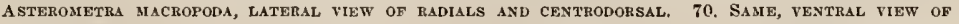

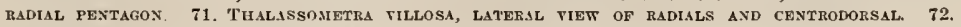

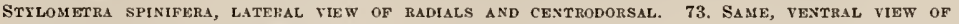
radil pentagon. 74. Paraietra orion, lateral view of radials and centronorsal. 75. Same, TENTRAL VIEW OF RADIAL PENTAGON. 
The muscular fossæ are usually narrowly linear, but the distal edge may be more or less strongly convex. They are in breadth equal to about one-half the horizontal diameter of the central canal. The outer elge inwardly turns downward, so that the short inner edges are parallel; these run downward to the junction of the distal edge of the interarticular ligament fossie and the rim about the central canal, and are separated by a shallow rounded furrow of about their own width. This furrow is usually carried back for a slight distance over the ventral side of the radials.

The muscular fossæ lie in the same plane as the interarticular ligament fossæ and are always perfectly evident when the latter are viewed perpendicularly. They do not, so far as $I$ have seen, incline toward the horizontal so as to be with difficulty recognizable in a direct view, as described by Carpenter.

The ventral face of the more or less stellate radial pentagon is moderately concave, with more or less of a deposit of loose calcareous matter, especially toward the center. The ventral surface of the radials, where not concealed by a secondary deposit, is radially striate.

Diameter of radial pentagon at base, $5.5 \mathrm{~mm}$; height of articular face (measured along the inclination), $2 \mathrm{~mm}$; width, at transverse ridge, $2.6 \mathrm{~mm}$.; distance from center of rosette to middle of dorsal outer edge of radial, $2.7 \mathrm{~mm}$; distance from center of ventral face of radial pentagon to middle of ventral outer edge of radial, $1 \mathrm{~mm}$.; to apex of interradial angle, $1.5 \mathrm{~mm}$.

PTILOMETRA MACRONEMA.

Figs, $973,9 \pi 4, \mathrm{pl}, 2$.

ASTEROAETRA MACROPODA.

Figs, 69, 70, D. 43 .

The portion of the radial articular face between the transverse ridge and the distal end of the interarticular ligament fossæ lies in a plane making an angle of only about $30^{\circ}$ with the plane at right angles to the dorsoventral axis of the animal, so that this portion of the radial articular face as a whole makes an angle of about $120^{\circ}$ when the radial pentagon is viewed from the side. The dorsal ligament fossa lies in a plane which makes a slight angle with the plane of the other joint face elements. The muscular fossa stand up somcwhat abruptly, inclining at an angle of about $30^{\circ}$ to the dorsoventral axis and at an angle of about $60^{\circ}$ to each other. The dorsal ligament fossæ are entirely separated from each other, but the ends of the transverse ridges are in contact. The lateral borders of the interarticular ligament fossæ recede gradually from each other, forming between them a narrow V-shaped interradial gap, but the outer edges of the muscular fossæ. curving outward, meet and are in apposition for almost their entire length.

The dorsal ligament fossee are about three times as broad as long, the proximal border being regularly curved.

The rim about the central canal is broad and moderately high. 
The distal borders of the interarticular ligament fossæ arise on the dorsal side of the rim about the central canal and run outwardly at an angle of about $45^{\circ}$ with the transverse ridge to the outer edgc of the joint face. 'The distal angle may be somewhat rounded.

The muscular fossæ are roughly rhombic in shape, the greater diameter being about twice the lesser. The distal and outer sides are convex and the inner and outer distal angles are well rounded, especially the former. The inner sides, inward from the inner distal angles, are parallel and are well separated by a shallow furrow equal in width to about half the horizontal diameter of the central canal, which bears in the median line a narrow longitudinal ridge. In the proximal portion the floor of this shallow furrow gradually rises and at the same time the sides gradually diverge, so that it merges, by a sort of triangular base, into the rim about the central canal.

The ventral surface of the radial pentagon is strongly concave; the depressed center is occupied by a plug of porous calcareous deposit; the ventral surface of the radials is longitudinally striate.

Diameter of radial pentagon at base, $4 \mathrm{~mm}$; height of articular face (measured along the inclination), $2.8 \mathrm{~mm}$.; width, at transverse ridge, $3 \mathrm{~mm}$; distance from center of the rosette to middle of dorsal outer edge of radial, $2 \mathrm{~mm}$.; diameter of ventral interarticular space, $2 \mathrm{~mm}$.

\section{Thalassometrine.}

THAIASSOMETRA VILLOSA.

Fig. 71, p. 43.

The portion of the radial articular face distal to the transverse ridge lies in a plane making an angle of approximately $60^{\circ}$ with the dorsoventral axis of the animal until the distal half of the muscular fossæ is reached; these are parallel with the dorsoventral axis, and at the tip turn slightly outward. The plane touching the edges of the dorsal ligament fossa lies at an obtuse angle with the plane of the interarticular ligament fossæ, and makes only a small angle with the dorsoventral axis. The adjacent radial articular faces are in close contact with each other except distally, where the eversion of the tips of the muscular fossæ cause the formation of narrow $V$-shaped gaps between them.

The dorsal ligament fossa are about two and one-half times as broad as long, moderately and evenly curved proximally, but turning up rather abruptly at the ends. They are entirely separated from their neighbors, but the ends of the transverse ridges are just in contact.

The rim about the central canal is strong and very prominent, as high as the distal part of the transverse ridge. The distal border of the interarticular ligament fossi is formed by a sharp ridge considerably lower than the rim about the central canal which arises on the side of that rim midway between its distal center and the place where it joins the transierse ridge and runs, making an angle of $60^{\circ}$ with the transverse ridge, to the edge of the joint face. 
The muscular fossæ are very long and narrow. The sides at first converge, as the outer edges continue the direction of the lateral edges of the interarticular ligament fossæ, but soon become parallel, and near the tip diverge very slightly. The length of the muscular fossa is somewhat over twice the length of their proximal border, which latter is nearly twice their distal width. The two muscular fossæ are separated internally by a narrow rounded ridge arising from the median distal portion of the rim about the central canal, at first as high as that rim, but gradually decreasing in height and terminally, as the rounded distal ends of the muscular fossæ begin to separate, branching, and dying away in a slight thickening of the inner side of the distal edge.

There is no ventral calcareous deposit between the radials.

Diameter of radial pentagon at base, $3.9 \mathrm{~mm}$; height of articular face (measured along the inclination), $2.5 \mathrm{~mm}$; width, at transverse ridge, $2 \mathrm{~mm}$.; distance from center of rosette to middle of dorsal outer edge of radial, $1.6 \mathrm{~mm}$.; diameter of ventral interarticular space, $1 \mathrm{~mm}$.

THALASSOMETRA AGASSIZII.

See figs. 9S1-983, pl. 3 .

STYLOMETRA SPINIFERA.

Figs. 72,73, p. 43.

The joint face elements distal to the transverse ridge slant inward at an angle of nearly $45^{\circ}$ with the dorsoventral axis of the animal, so that they make almost a right angle with each other; the plane of the edges of the dorsal ligament fossa makes a very broadly obtuse angle with the remaining elements of the joint face; the sides of the interarticular ligament and muscular fossæ together are slightly and evenly concare. The rim about the central canal, which is large and more nearly circular than usual, is prominent but low.

Adjacent radial articular faces are separated slightly orer the interradial planes by very narrowly V-shaped gaps which extend downward nearly to the transverse ridges.

The dorsal ligament fossa is narrow, nearly or quite three times as broad as long, moderately curved proximally, but becoming more nearly straight toward either side; the ends are slightly truncated, so that the ends of the dorsal ligament bundles, as well as the ends of the transverse ridges, are in contact interradially.

The outer sides of the interarticular ligament fossæ are somewhat concave; the general shape of the interarticular ligament fossæ is that of an equilateral triangle of which the inner angles would be, if not broadly truncated, at the center of the proximal border of the central canal; the distal angle is rendered especially acute by the concavity of the onter side.

The muscular fossæ are comparatively small, their area being approximately the same as that of the interarticular ligament fossæ. Their shape suggests that of the shells of such genera as Pinna; their inner borders are straight and parallel, 
nearly as far apart as the dorsoventral diameter of the central canal; their proximal edges are delimited by the raised distal inner edges of the interarticular ligament fossæ, and make an angle of about $30^{\circ}$ with the inner edges; the inner edges are about one-third longer than the proximal edges; the distal edges, connecting the inner and the proximal edges, make a very full curve, in some cases almost or quite a semicircle. The muscular fossæ are inwardly separated by a shallow furrow which runs up to the level of the distal angles of the interarticular ligament fossæ; beyond the end of this furrow the muscular fossæ are separated merely by a gap; this furrow is outwardly bordered by the raised inner edges of the muscular fossæ, and along its center carries a median ridge of the same width and height.

There is no calcareous deposit on the ventral surface of the radials.

'Diameter of radial pentagon at base, $4.5 \mathrm{~mm}$; height of articular face (measured along the inclination), $2.4 \mathrm{~mm}$.; width, at transverse ridge, $2.3 \mathrm{~mm}$.; distance from center of rosette to middle of dorsal outer edge of radial, $2 \mathrm{~mm}$.; diameter of ventral interarticular space, $1.5 \mathrm{~mm}$.

\section{PARAMETRA ORION.}

Figs. 74, 75, p. 43 .

The plane of the joint face elements distal to the transverse ridge at first makes an angle of $45^{\circ}$ with the dorsoventral axis, but the muscular fossæ gradually curve upward beyond the middle, becoming almost parallel with the dorsoventral axis, and turning outward rather abruptly at the tip; the dorsal ligament fossa is not quite in the same plane as the other joint face elements, making with them a very broadly obtuse angle. The rim about the central canal is high, prominent, and rather broad. The radial faces are separated from each other in the interradial angles by very narrow slits which extend downward almost to the transverse ridges.

The dorsal ligament fossæ are low, about three times as broad as long, slightly convex proximally, very broadly rounded at either end so as to appear more or less semielliptical. They are entirely separated from their nejghbors, but the ends of the transverse ridges of adjacent joint faces meet interradially.

The interarticular ligament fossæ are in the form of equilateral triangles, with the interior angles broadly truncated by the rim about the central canal. The outer and distal borders are rather prominently raised.

The muscular fossæ are long and narrow, inwardly about four, outwardly about three, times as long as broad. The inner and outer edges are almost parallel, the latter being only very slightly coneave; the distal ends are well rounded. Inwardly the muscular fossæ are separated by a narrow double ridge, which at first is as high as the distal portion of the rim about the central canal but gradually decreases in height and soon becomes low, composed of the upturned and appressed inner edges of the muscular fossæ.

There is no calcareous deposit on the ventral surface of the radials. 
Diameter of radial pentagon at base, $3.7 \mathrm{~mm}$; height of radial articular face (measured along the inclination), $2.6 \mathrm{~mm}$; widtl, at transrerse ridge, $2 \mathrm{~mm}$.; distance from center of rosette to middle of outer dorsal edge of radial, $1.5 \mathrm{~mm}$; diameter of ventral interarticular space, $0.8 \mathrm{~mm}$.

\author{
STENOMETRA QUINQUECOSTATA. \\ See figs. 979, 9S0, pl. 2. \\ STIREMIETRA BREVIRADIA.
}

See figs. $975-978$, pl. 2.

\title{
CHARITOMETRIDÆ.
}

The muscular fossæ lie in the same plane as the interarticular ligament fossæ, and are rounded triangular in shape; their area is but slightly when at all, greater than that of the interarticular ligament fossæ; the distal (inner) edges of the interarticular ligament fossæ make an angle of rather more than $60^{\circ}$ with the transverse ridge.

\section{CRINOMETRA INSCULPTA.}

Figs. 76,77, p. 53.

The portions of the radial articular faces distal to the transverse ridge make an angle of about $30^{\circ}$ with the dorsoventral axis. The muscular fossa lie in the same plane as the interarticular ligament fossæ and do not curve outward distally. The plane of the dorsal ligament fossa makes a broadly obtuse angle with the plane of the other elements of the joint face. In the interradial angles the radial faces are separated from each other by a rather broad lenticular gap extending from the ends of the transrerse ridges to the distal angles of the interarticular ligament fossæ. The muscular fossæ are separated interiorly by a V-shaped gap, the ends of which curve outward.

The dorsal ligament fossa is about two and one-half times as broad as long, with the proximal border evenly curved. The dorsal ligament fossæ are entirely separated laterally, but the ends of the transverse ridges join across the interradial angles.

The proximal outer and distal angles of the interarticular ligament fossæ, together with the middle of the proximal edge of the central canal, form the three apices of an equilateral triangle. The inner angles of these triangles are very broadly truncated by the very broad, though rather low, lateral portion of the raised rim about the central canal. The distal portion of this rim is narrow, low, and poorly defined. The outer borders of the interarticular ligament fossæ are very strongly concave, so that these fossæ appear narrow with very acute distal angles.

The muscular fossæ are comparatively small, triangular or Pinna-shaped, with the distal (inner) apex broadly rounded off, the outer borders being the continuation of the line from the end of the transverse ridge through the distal 
angle of the interarticular ligament fossæ. The muscular fossæ are separated interiorly by a shallow furrow, which expands somewhat at the proximal end, the sides of which are parallel and about as far apart as one-half the horizontal diameter of the central canal. The muscular fossæ bear three strongly marked equidistant narrow ridges parallel to the distal border.

The ventral surface of the radial pentagon is obscured by a small plug of spongy calcareous deposit, which is almost completely separated from the radials themselves by five large circular radial gaps and numerous smaller ones.

The furrow between the radials extends to the height of the most distal of the three ridges on the face of the muscular fossæ.

Diameter of radial pentagon at base, $5.6 \mathrm{~mm}$; height of articular face (measured along the inclination), $2.9 \mathrm{~mm}$; width, at transverse ridge, $2.2 \mathrm{~mm}$.; distance from center of rosette to middle of dorsal outer edge of radial, $2.3 \mathrm{~mm}$; diameter of ventral intermuscular space, $1.2 \mathrm{~mm}$.

\section{PACHYLOMETRA INEQUALIS.}

See figs. $9 \$ 6,9 \$ 7$, pl. 3 .

PERISSOMETRA ANGUSTICALYX.

See figs, 984, 9\$5, pl. 3 .

PCECILOMETRA ACELA.

See figs. 988,989, pl, 3.

CHARITOMETRA BASICURVA.

See figs. 990,991, pl. 3.

CHARITOMETRA INCISA.

See figs. 992, 993, pl. 3.

\section{MACROPHREATA.}

The radial articular faces of the Macrophreata exhibit a remarkable homogeneity, in sharp contrast to the plasticity apparent in the same structures in the oligophreate families; in fact, the entire range of variation found in the Macrophreata is less than that seen in any of the larger oligophreate families, excepting only the Zygometridæ.

Thus an examination of the radial articular faces, no less than a close examination of the other structures, emphasizes the homogeneity of this group as now understood.

The radial pentagon of the macrophreate forms differs from that of the oligophreate species in three essential particulars: (1) There is no calcareous deposit on the inner surface of the radials nor upon the ventral surface of the rosette, so that there is no trace of any central plug; (2) the plane of the muscular fossa is nearly or quite parallel to the dorsoventral axis of the animal, so 
that the muscular fossæe are only separated from the very large central cavity by thin calcareous lamina, which are quite different from the more or less thick wedges seen in the Oligophreata ; (3) the joint face elements distal to the transverse verse ridge are strongly excavated, especially interiorly, so that they meet in the median dorsoventral line at an angle of usually $90^{\circ}$. This results in the formation of a sort of tube or tunnel about the central canal, for the rim about the central canal and the associated structures are always on the same articular level as the transverse ridge, no matter how deep the excavation of the joint face may be.

The dorsal ligament fossa usually equals the interarticular ligament fossæ in height, and its proximal border is rather strongly convex, sometimes even roundedtriangular. It is deeply excavated, so that the ligament pit is usually rendered more or less obsolete, sometimes being erident only as a shallow and broad groove on the lower (dorsal) side of the transverse ridge.

The interarticular ligament fossæ are usually triangular with their inner angles truncated, but their distal border rarely makes so great an angle as $60^{\circ}$ with the transverse ridge Frequently the distal border inwardly makes an angle of from $45^{\circ}$ to $60^{\circ}$ with the transverse ridge, bnt gradually curres outward so that outwardly it is almost or quite parallel to the transverse ridge, or even slopes more or less downward.

The septum bounding the interarticular ligament fossæ anteriorly is inwardly very high and rather narrow. In profile it is seen to decrease very rapidly in height at first, then to make a broad curre and to decrease gradually and evenly to its outer end: in a few forms this septum is so reduced as only to be indicated by a low narrow ridge, or it may entirely disappear before the outer edge of the joint face is reached. The outer edge of the interarticular ligament fossa is usually straight, but it may be strongly concave or strongly convex.

The muscular fossæ are always larger, usually much larger, than the interarticular ligament fossæ, and they are always very thin and broadly rounded; they are separated interiorly by a septum which is usually narrow and high, and their tips are separated by a more or less developed intermuscular notch.

The central canal is large and well rounded, and is bordered by a high narrow rim.

\section{ANTEDONID $A$.}

\section{Antedoninæ.}

The articular faces of the radials are broader than high. They are inclined inward at an angle of approximately $60^{\circ}$ with the dorsoventral axis and are entirely, though slightly, separated from each other interradially. All of the joint face elements lie approximately in the same plane. The muscular fossæ are but slightly larger than the interarticular ligament fossæ, which are of about the same height as the dorsal ligament fossæ. The proximal border of the dorsal ligament fossæ is strongly convex. The distal borders of the interarticular liga- 
ment fossæ may make an angle of $45^{\circ}$ with the transverse ridge, are usually more nearly horizontal. They may carry a supplementary boss at the inner angles. The outer borders are usually slightly convex; the muscular fossæ are broadly rounded, quadrilateral, usually broader than high, though they may be slightly higher than broad if the distal border of the interarticular ligament fosse is very oblique. Their lateral edges project slightly, if at all, beyond those of the interarticular ligament fossæ and maintain the same general direction. The muscular fossæ are separated interiorly by a broad intermuscular septum which is more or less concave at its summit and is broader proximally than distally. The intermuscular notch is shallow and broadly rounded proximally.

\section{ANTEDON PETASUS.}

Fig. 78, p. 53 .

The dorsal ligament fossa is about two and one-half times as broad as high, with the proximal border semielliptical. The ligament pit is shallow, somewhat larger than the central canal, with which it is confluent distally.

The outer edge of the interarticular ligament fossæ is nearly or quite straight and makes an angle of about $60^{\circ}$ or $70^{\circ}$ with the transverse ridge. It is about half as long as the distance from the end of the transverse ridge to the edge of the central canal. From the distal corner the distal edge of the interarticular ligament fossæ slopes inward, making a small angle with the transverse ridge and joining the intermuscular septum at a level about as far above the level of the distal border of the central canal as the median diameter of the canal. This distal border of the interarticular ligament fossæ is straight or slightly convex; in profile it is seen to be a high ridge rapidly decreasing in height outwardly, with a prominent broad, shallow, rounded notch about halfway between its inner and outer ends. Its inner portion bears on the outer side a prominent supplementary muscle plate which extends ontward about halfway to the outer end.

The intermuscular septum is very broad, just over the ceutral canal being nearly as broad as the diameter of that canal. It narrows distally and beyond the supplementary muscle plates is only about half as wide, with parallel sides. It carries a broad, shallow median groove, which, just over the central canal, is more or less expanded and somewhat deepened.

The muscular fosse are about as high as the dorsal ligament fosse; the outer side is broadly rounded; the intermuscular notch is well rounded, its sides making with each other an angle of approximately $90^{\circ}$.

The elements of the joint face distal to the transverse ridge make, when viewed in profile, an angle of about $90^{\circ}$ with each other.

There is little or no calcareous deposit within the ventral portion of the radial pentagon.

Height of articular face (measured along the inclination), $1.4 \mathrm{~mm}$.; width, at transverse ridge, $2 \mathrm{~mm}$. 


\section{ANTEDON MIFDITERRANEA.}

Fig. 79 , p. 53.

The radial articular faces of this species differ but very slightly from those of A. petasus.

The chief difference is in the intermuscular septum, which diminishes rapidly distally instead of being parallel sided as in $A$. petasus.

The ridge forming the distal border of the interarticular ligament foss $x$ is not nearly so high and well developed, and the angle which it makes with the transverse ridge is somewhat greater.

The muscular fosse are proportionately smaller than those of $A$. petasus, and the ends of the dorsal ligament fossie are much more acute.

The difference in the shape of the muscular fossæe as shown in the figures is merely a matter of individual variation, the muscular fosse being the most variable elements of the joint face.

As in A. petasus, there is little or no calcareous deposit within the ventral surface of the radial pentagon.

Height of articular face (measured along the inclination), $1.4 \mathrm{~mm}$; width, at transverse ridge, $2.2 \mathrm{~mm}$.

\section{ANTTDON ADRIATICA.}

Fig. 80, p. 53.

There appears to be but little difference between the radial articular faces of this species and those of $A$. mediterranea. The muscular fossæ are proportionately slightly smaller with the outer distal angles more broadly rounded, and the interarticular ligament fossæ are narrower as a consequence of their anterior border making a considerably less angle with the transverse ridge.

\section{ANTEDON BIFIDA. \\ Figs. $994-996$, pl. 4 . \\ COMISOMETRA LOWENI.}

Fig. $\$ 1$, p. 53.

The dorsal ligament fossa is about three times as broad as high, with the proximal border well rounded. The ligament pit is about as large as the central canal, but is not strongly marked.

The ends of the transverse ridges are not quite in contact interradially. The interarticular ligament fossæe are separated interradially by a narrow, shallow, parallel-sided groove, which becomes narrower or almost closed between the muscular fossæ.

The outer edge of the interarticular fossæ is straight and makes an angle of about $60^{\circ}$ with the transverse ridge. The distal edge is straight and makes an angle of about $45^{\circ}$ with the transverse ridge. 


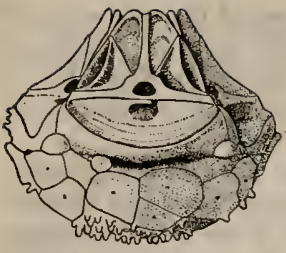

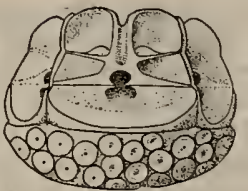

78

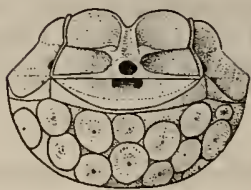

80
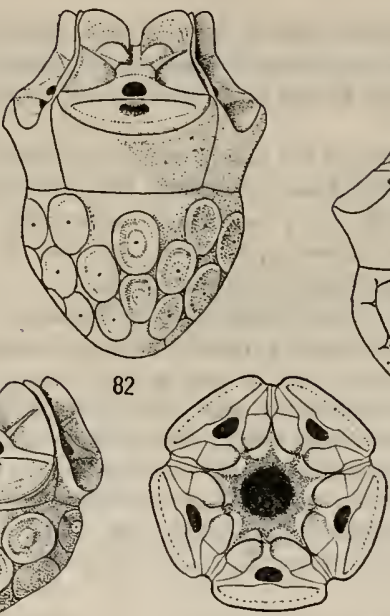

88

88

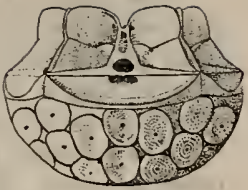

79

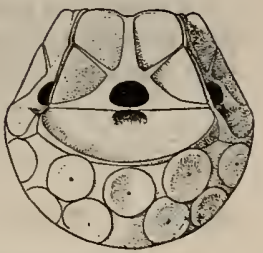

81

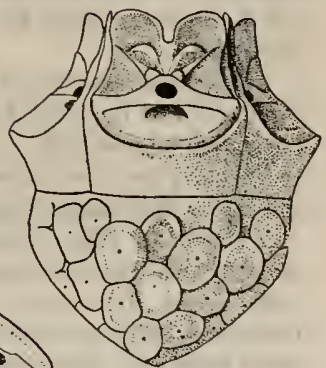

83

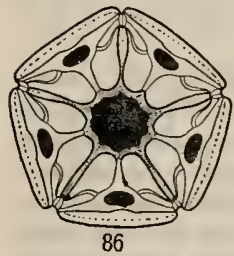

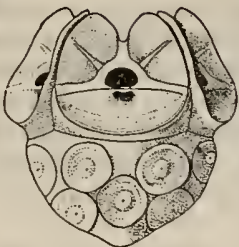

87

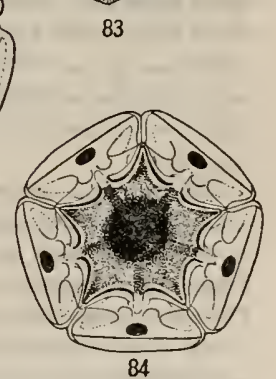

Higs, 76-88.-Radial Pentagons of various Comatulids. 76. Crinometra coxcixina, hatlral view of radials aND Centrodorsal, 77. Same, ventral vifw of radial pentagon, 78. ANTedon petasus, LATERAL VIEW OF RADIALS AND CENTRODORSAL. 79. ANTEDON MIRDITERRANFA, LATERAL TIEW OF RADIALS and centrodorsal. 80. ANtedon adriatica, lateral view of radials and centrodorsal. 81. Comp. sometra lovent, lateral view of radils aNd CeNtrodorsal. 82. Perometra diomedef, Lateral VIEW OF radias aNd CENTRODORSAL. 83. SAME, From aNOTHEI SPECIBIEN. 84. SAME SPECIES, VENTRAL VIEW OF RADIAL PENTAGON, 85. HYPALOMETRA DEFECTA, LATERAL VIEW OF RADIALS AND CENTRODORSAL.

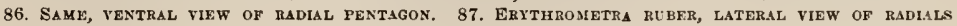
and centrodorsal. 88. Same, tentral View of radial pentagon. 
The height of the muscular fossæ is about equal to that of the interarticular ligament fossæ. Their inner and proximal edges are about equal in length and make an angle of about $45^{\circ}$ with each other. The outer and distal edges also are of equal length, but shorter than the others, so that the outer edges continue the direction of the outer edges of the interarticular ligament fossæ.

The muscular fosse are separated interiorly by a broad and rather high intermuscular ridge. The intermuscular notch is small and shallow, or nearly obsolete.

There is no calcareous deposit within the ventral surface of the radial pentagon.

Diameter of radial pentagon at base, $1.5 \mathrm{~mm}$.; height of articular face (measured along the inclination), $0.8 \mathrm{~mm}$.; width, at transverse ridge, $0.7 \mathrm{~mm}$.; distance from center of rosette to middle of outer distal edge of radial, $0.6 \mathrm{~mm}$.

\section{Tirsanometrina.}

THYSANOMETRA TENELLOIDES.

Figs. $89,90, \mathrm{p}, 62$.

The dorsal ligament fossa is very narrow, four times as broad as high, or even somewhat broader; the proximal border is regularly semielliptical. The ligament pit is about as large as the transversely oval central canal, but is only faintly marked.

The transverse ridges are nearly or quite confluent across the interradial planes, but the dorsal ligament fossæ are widely free; the interarticular ligament fossæ are separated interradially by a moderately wide deep furrow. The muscular fossæ are usually in close lateral apposition, but they may be separated in a manner similar to the interarticular ligament fossæe.

The outer edge of the interarticular ligament fossæ is usually more or less strongly concave, and makes typically a general angle of about $60^{\circ}$ with the transverse ridge. It is about half as long as the distance between the outer ends of the transverse ridge and the outer edge of the central canal, or slightly shorter. The distal edge runs inward and upward at an angle of nearly or quite $30^{\circ}$ to the transverse ridge, soon beginning to curve and making a broad sweep to a point on the intermuscular structures slightly farther from the transversc ridge than the distal lateral angles of the interarticular ligament fossie. The height of the convexity is rather over one-third of the distance along the septum from the inner to the outer end.

Beyond the central canal, separated from it by a narrow ridge, there is a more or less rhombic area, depressed centrally, the proximal sides of which are delimited by the converging inner ends of the distal borders of the interarticular ligament fossæ, which stand up as low, narrow, rounded ridges above the general surface. The maximum width of this area, which is at the point where the distal borders of the interarticular ligament fossæ in curving outward become free, is about equal to the transverse (greater) diameter of the central canal. From this point onward it gradually narrows anteriorly and comes almost to a point at the proximal end of the intermuscular notch. 
The muscular fossæ are nearly or quite half again as broad as high, subquadrangular, with broadly rounded distal corners and distal edge. There is a very narrow, but very deep, intermuscular notch which reaches downward for about half the distance from the distal edge of the muscular fossæ to the distal edge of the central canal. This notch is rounded proximally and is always more or less obscured by the closing together of the muscular fossæ over it.

The joint face elements distal to the transverse ridge slope inward, at first making an angle of about $45^{\circ}$ with the plane passing through the middle of the joint face and including the dorsoventral axis of the animal, but they gradually curve around and at the middle of the joint face are parallel to the transverse ridge, so that the inner portion of the joint face, instead of being a reentrant right angle, is broadly rounded. This also results in a considerable shortening of the distance of incision of the reentrant angles of the stellate border of the ventral surface of the radial pentagon.

There is scarcely more than a trace of calcareous deposit within the ventral surface of the radial pentagon.

Diameter of radial pentagon at base, $5 \mathrm{~mm}$.; height of articular face (measured along the inclination), $2.7 \mathrm{~mm}$; width, at transverse ridge, $3.8 \mathrm{~mm}$.; distance from center of rosette to middle of dorsal outer edge of radial, $2.1 \mathrm{~mm}$; d diameter of ventral interarticular space, $1.9 \mathrm{~mm}$.

\section{COCCOIETRA HAGENII.}

Figs. 112, 113, p. 67.

The dorsal ligament fossa is about three times as broad as long, with the proximal border semielliptical. Only that part of the ligament pit just under the transverse ridge is indicated; this is very narrow, somewhat broader than the central canal.

The ends of the transverse ridges just join over the interradial planes, but the dorsal ligament fossæ are entirely free laterally. The interarticular ligament fossæ are laterally separated by a moderately deep narrowly V-shaped furrow, which is almost or quite bridged over by the distal half of the muscular fossæ.

The interarticular ligament fossæ are rather deeply excavated and are practically equilateral triangles with their inner angles truncated by the rim about the central canal. The distal border is slightly convex.

The intermuscular ridge is high and broad proximally, but decreases rather rapidly in height and breadth in the proximal third, more gradually from that point onward.

The muscular fossæ are narrow and high, rounded triangular. Their height is somewhat over twice their maximum width, and about the same as the height of the interarticular ligament and dorsal ligament fossæ combined. Their outer edge has practically the same direction as the outer edge of the interarticular ligament fossæ.

There is no calcareous deposit within the ventral surface of the radial pentagon.

$$
\text { 142140-21-Bull. } 82-6
$$


Height of articular face (measured along the inclination), $1.9 \mathrm{~mm}$.; width, at transverse ridge, $1.5 \mathrm{~mm}$; distance from center of rosette to middle of outer dorsal edge of radial, $0.9 \mathrm{~mm}$.

\section{Perometrina.}

The radials project much more than usual from the centrodorsal, so that the proximal border of the dorsal ligament fossæ is considerably beyond the periphery of the ventral rim of the centrodorsal.

The exposed dorsal surface of the radials is slightly concave in profile instead of, as usual, more or less convex.

The radial articular faces are broader than high and are inclined inward at an angle of approximately $60^{\circ}$ with the dorsoventral axis.

They are entirely, though slightly, separated from each other interradially.

All the joint face elements lie in the same plane. The muscular fossæ are not greatly larger than the interarticular ligament fossæ, which are about the same height as the dorsal ligament fossa. The proximal border of the dorsal ligament fossa is slightly flattened. The general direction of the distal border of the interarticular ligament fossæ is upward and outward, at an angle of $45^{\circ}$ to the transverse ridge. The distal border of the interarticular ligament fossæ is, owing to the comparatively small amount of excavation of the inner portion of the joint face, rather low; it may bear a supplementary boss at its inner end; the outer border may be straight, slightly convex, or moderately concave. The muscular fossæ are separated interiorly by a broad low intermuscular septum with parallel sides, which may be more or less concave along its summit. The intermuscular notch is broad, not very deep, and well rounded proximally.

The inner sides of the radials slope inward, so that the inner part of the radial pentagon is funnel-shaped instead of a hollow cylinder as usual, and the free central canal is therefore comparatively small. There is more or less of a deposition of calcareous matter within the radial pentagon and on the ventral surface of the rosette.

\section{PEROMETRA DIOMEDEF.}

Figs. 82-84, p. 53.

The dorsal ligament fossa is narrow, about three times as broad as high, with the proximal border semielliptical or slightly flattened. The ligament pit is reniform or broadly oval, somewhat larger than the central canal but not strongly marked.

Each articular face is entirely separated from its neighbors by a shallow furrow, which at the ends of the transverse ridges is about as broad as the central canal, becoming slightly broader between the interarticular ligament fossæ and considerably narrower between the muscular fossæ.

The interarticular ligament fossæ are somewhat higher than the dorsal ligament fossa. Their outer border is more or less concave and makes a general 
angle of about $60^{\circ}$ with the transverse ridge, this angle being somewhat less in small specimens.

The inner edges of the ridges forming the distal borders of the interarticular ligament fossæ are swollen and stand out as rounded bosses.

The intermuscular furrow is shallow and about half as broad as the central canal.

The muscular fossæ are but little larger than the interarticular ligament fossæ and are approximately rhombic in shape, with the outer and inner distal angles well rounded. Their outer edge is less than that of the interarticular ligament fossæ.

There is more or less of a calcareous deposit within the ventral concavity of the radial pentagon, so that the rosette is not visible in ventral view.

Diameter of radial pentagon at base, $2.3 \mathrm{~mm}$.; height of articular face (measured along the inclination), $1.4 \mathrm{~mm}$.; width, at transverse ridge, $1.8 \mathrm{~mm}$.; diameter of ventral interarticular space, $1.8 \mathrm{~mm}$.

\section{ERYTHROMETRA RUBER.}

Figs. S7, SS, p. 53.

The dorsal ligament fossa is about two and one-half times as broad as high, well rounded proximally. The ligament pit is about the size and shape of the central canal, but is only faintly marked.

The adjacent articular faces are separated interradially by a narrow shallow furrow, which is about half as wide as the central canal. The sides of this furrow are parallel, or it may be more or less constricted between the muscular fossæ. Proximally it is not constricted at the transverse ridge but gradually bends outward, the edges continuing into the proximal borders of the dorsal ligament fossæ.

The outer edge of the interarticular ligament fossæ is slightly convex and is continued, as in Hathrometra prolixa, into the outer edge of the muscular fossæ. It makes a general angle of about $60^{\circ}$ with the median axis of the joint face. The distal edge makes an angle of about $45^{\circ}$ with the transverse ridge; it consists of a low ridge which rapidly decreases in height, so that in its outer fourth or fifth it is barely indicated, or is absent altogether. It takes its origin relatively low down on the sides of the rim surrounding the central canal so that a line parallel to the transverse ridge passing through the distal border of the canal also passes through the inner bases of the distal borders of the interarticular ligament fossæ.

The muscular fossæ are small, being only slightly larger than the interarticular ligament fossæ. Their distal edges are about as long as, and are parallel with, the distal edges of the interarticular ligament fossæ, making, therefore, an angle of about $90^{\circ}$ with each other; outwardly they sweep in a broad curve and are continued downward into the outer edges of the interarticular ligament fossæ.

The muscular fossæ are separated interiorly by a broad, low intermuscular ridge. 
There is more or less of a calcareous deposit within the ventral surface of the radial pentagon, but it is scarcely sufficient to conceal the rosette from ventral view.

Diameter of radial pentagon, $1.4 \mathrm{~mm}$; height of articular face (measured along the inclination), $0.7 \mathrm{~mm}$; width, at transverse ridge, $0.7 \mathrm{~mm}$; distance from center of rosette to middle of outer dorsal edge of radial, $0.6 \mathrm{~mm}$.; diameter of ventral interarticular space, $0.7 \mathrm{~mm}$.

\section{HeLiometrine.}

The articular faces are usually about as high as broad, or somewhat (never over one-fourth) higher than broad.

The interarticular ligament and the muscular fossæ usually make approximately the same angle with the dorsoventral plane of the radial, but the latter may be more nearly parallel with the dorsoventral axis than the former, in which case the inclination of the dorsal ligament fossa in reference to the dorsoventral axis is intermediate between the two.

The interarticular ligament fossæ are about as high as the well-rounded or subtriangular dorsal ligament fossa, and about half as high as the muscular fossæ. Their outer border is usually more or less strongly concave; their distal border usually makes an angle of from $30^{\circ}$ to $45^{\circ}$ with the transverse ridge, at least inwardly; outwardly it may become horizontal.

The muscular fossæ are usually rounded triangular, though their sides may be more or less parallel, at least proximally. Their distal angle is usually broadly rounded, but its outer side may be more or less flattened.

The muscular fossæ are separated interiorly by an intermuscular septum which is usually high proximally but rather low for most of its length. It is commonly very narrow but may be considerably broadened in correlation with a general broadening of all the central calcareous structures, especially the inner ends of the distal border of the interarticular ligament fossæ. Distally the muscular fossæ are separated by an intermuscular notch which is narrow and sharp pointed proximally if the intermuscular septum is narrow, but proportionately broad and rounded proximally if the intermuscular furrow is broad.

The central canal is large, circular to broadly oval in shape; the liganent pit is large, considerably larger than the central canal, but only slightly marked.

PROMACHOCRINUS KERGUELENSIS.

See figs. 1001,1002 , pl. 4

SOLANOMETRA ANTARCTICA.

See figs, 997,998, pl. 4.

FLOROMETRA ASPERRIMA.

Figs. 97,98, p. 62.

The dorsal ligament fossa is narrow, rounded triangular, three or four times as broad as high. The ligament pit is about twice as broad as the central canal, reniform, but only faintly marked. 
The transverse ridges of adjacent articular faces join interradially, and the ends of the dorsal ligament fossæ are slightly truncated and more or less confluent. The interarticular ligament fossæ are separated interradially by a narrow parallel sided groove, but the thin lateral edges of the muscular fossæ are in close contact.

The lateral borders of the interarticular ligament fossæ make an angle of, in general, about $30^{\circ}$ with the dorsoventral axis of the animal. Their central portion is straight; proximally they at first retreat rather strongly from the ends of the transverse ridge, and distally they retreat, less strongly, from the lower outer angles of the muscular fossæ. The interarticular ligament fossæ are about as high as the dorsal ligament fossa ; their distal borders run from the distal angle inward and downward, making an angle of between $30^{\circ}$ and $40^{\circ}$ with the transverse ridge, joining the central calcareous structures at a height above the central canal which is about equal to its horizontal (greater) diameter.

The calcareous prominence about and above the central canal is large and broad; roughly, it may be described as an equilateral triangle, the base of which rests upon the transrerse ridge, the apex being continued anteriorly into the narrow intermuscular septum. From the outer half of each side arise the ridges forming the anterior borders of the interarticular ligament fossæ. These are at first broad, but narrow rapidly and are slender in their outer half. The portion of the central calcareous structures distal to the central canal is more or less excavated, so that its edges are raised into a more or less marked rim proximally and laterally. It also slopes inward at a considerable angle, so that the intermuscular septum at its inception is only about one-lalf the height of the ridges forming the distal border of the interarticular ligament fossæ.

The intermuscular septum is comparatively low; it decreases slowly and evenly in height distally, ending at the intermuscular notch. Its sides are nearly or quite parallel.

The outer borders of the muscular fossæ are parallel to the dorsoventral axis of the animal, and are about as long as the outer edges of the interarticular ligament fossæ. The distal edges make an angle of about $40^{\circ}$ with the transverse ridge until near the median axis of the joint face, when they turn rather abruptly downward to form a rather broad intermuscular notch which reaches a depth of from one-third to one-half of the length of the intermuscular septum. The outer distal angle of the muscular fossæ, between the outer and the distal edges, like the distal angle on either side of the intermuscular notch, is only moderately rounded, rather less so than the latter.

The elements of the joint face distal to the transverse ridge on either side of the median line of the joint face make with each other an angle of about $90^{\circ}$, so that the inner part of the joint face is very deep; but the apex of the groove is rather broadly rounded off, so that the inner part of the articular faces encroaches comparatively little upon the ventral face of the radial pentagon.

There are at most only a few threads of calcareous matter within the central cavity of the radial pentagon, so that the rosette is in plain view from the ventral side. 
Diameter of radial pentagon at base, $7 \mathrm{~mm}$.; height of articular face (measured along the inclination), $4 \mathrm{~mm}$; width, at transverse ridge, $3.7 \mathrm{~mm}$.; distance from center of rosette to middle of dorsal outer edge of radial, $3 \mathrm{~mm}$.; diameter of ventral interarticular space, $1.9 \mathrm{~mm}$.

\section{FLOROMETRA PERPLEXA.}

Figs. 95, 96, p. 62, and 1009-1014, pl. 5.

In general the radial articular faces in this species resemble those of $F$. asperrima. The central calcareous structures, however, are much larger, their base occupying a distance along the transverse ridge equal to one-half the entire length of the ridge. The central portion of these structures is roughly oblong, half again as broad as high, with the distal angles produced outward and slightly upward. On account of the large size of these central structures the interarticular ligament fossæ are much restrieted, and do not extend inward more than halfway to the median axis of the joint face. The proximal border of the interarticular ligament fossæ is more evenly curved than in $F$. asperrimu. There is a slight development of calcareous matter within the rentral cavity of the radial pentagon.

Diameter of radial pentagon at base, $6 \mathrm{~mm}$.; height of articular face (measured along the inclination), $3.4 \mathrm{~mm}$.; width, at transverse ridge. $3 \mathrm{~mm}$.; distance from center of rosette to middle of dorsal outer edge of radial, $2.6 \mathrm{~mm}$.; diameter of ventral interarticular space, $1.6 \mathrm{~mm}$.

\section{FLOROMETRA TANNERI.}

Fig. 1005, pl. 5 .

\section{Zenometrine.}

The articular faces of the radials are about one-third again as high as broad. The interarticular ligament fossæ are inclined inward at an angle of from $60^{\circ}$ to $80^{\circ}$, but the muscular fossæ are nearly or quite parallel with the dorsoventral axis of the animal. The inclination of the dorsal ligament fossa is intermediate between that of the interarticular ligament and the muscular fossæ.

The interarticular ligament fossæe are about as high as the well-rounded dorsal ligament fossa, but less than one-half as high as the muscular fossæ. Their distal borders make an angle of about $45^{\circ}$ with the transverse ridge, at least inwardly. The outer portion may curve about so as to become nearly or quite horizontal (that is, parallel to the transverse ridge).

The muscular fossæ are narrow or broad, according to the angle made by the interarticular ligament fossæ with the dorsoventral axis; they are well rounded, everywhere convex, their rounded lateral edges projecting considerably beyond the straight or slightly convex ends of the interarticular ligament fossæ.

The muscular fossæ are separated interiorly by a high but rather narrow intermuscular septum, and distal to it by a wide intermuscular notch, broadly rounded 
proximally and with but slightly diverging sides, which is in depth equal to from one-third to the entire length of the intermuscular furrow.

There is no deposit of calcareous matter within the ventral cavity of the radial pentagon.

\section{ZENOMETRA COLUMNARIS.}

Figs. 93, 94, p. 62 .

The dorsal ligament fossa is about three times as broad as high, with the proximal border moderately convex, becoming more strongly curved at the ends. The ligament pit is very large and narrowly reniform, but shallow and ill defined. The transverse ridges join across the interradial angles. The lateral ends of the dorsal ligament fossæ are slightly confluent; the lateral edges of the interarticular ligament fossæ are separated by a narrow but deep furrow, which is bridged over distally by the lateral expansion of the muscular fossæ.

The interarticular ligament fossæ are in shape almost equilateral triangles, the inner ends of which are truncated by the broad high rim about the central canal. Their height is equal to the height of the dorsal ligament fossa.

The central canal is large and slightly oval. It is surrounded by a raised area, which at the sides takes the form of a high narrow rim continuous with the distal portion of the transverse ridge; the central canal thus appears to be sunken for about half its height below the distal edge of the transverse ridge. Distal to the central canal this border becomes wider, and may equal in width the diameter of the central canal. From it run the distal edges of the interarticular ligament fossæ in the shape of high narrow septa, gradually decreasing in height and finally turning rather abruptly downward; between these lies the median intermuscular septum, which at first decreases rather rapidly in height, then more slowly, continuing as a prominent ridge to the distal intermuscular notch.

The muscular fossæ are large, but comparatively narrow. Their inner (apposed) edges are about twice as long as their lower edges, which border the interarticular ligament fossæ. They are roughly triangular in form, with the outer edges well rounded and projecting well beyond the outer edges of the interarticular ligament fossæ. The distal inner angles are much more broadly rounded than the lateral angles.

Distal to the transverse ridge the two lateral halves of each joint face make an angle of $90^{\circ}$ with each other, so that the inner part of the interarticular ligament and muscular fossæ is very deeply excavated.

There is no deposit of calcareous matter on the inner portions of the radials.

Height of the articular face (measured along the inclination), $3.4 \mathrm{~mm}$.; width, at transverse ridge, $2.6 \mathrm{~mm}$.

\section{PSATHYROMETRA FRAGILIS.}

Figs. 91, 92, p. 62 .

The dorsal ligament fossa is large, about two and one-half times as broad as long, well rounded proximally. The ligament pit is wider than the central canal, but very narrow and but slightly marked. 

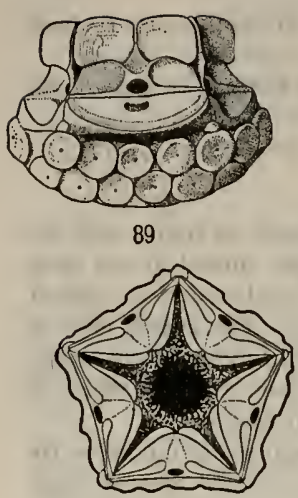

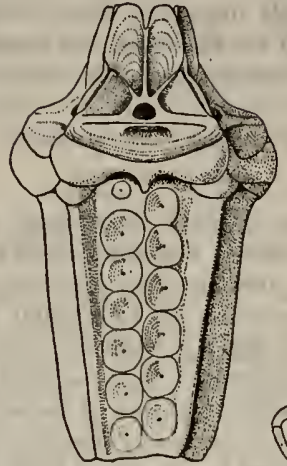

93
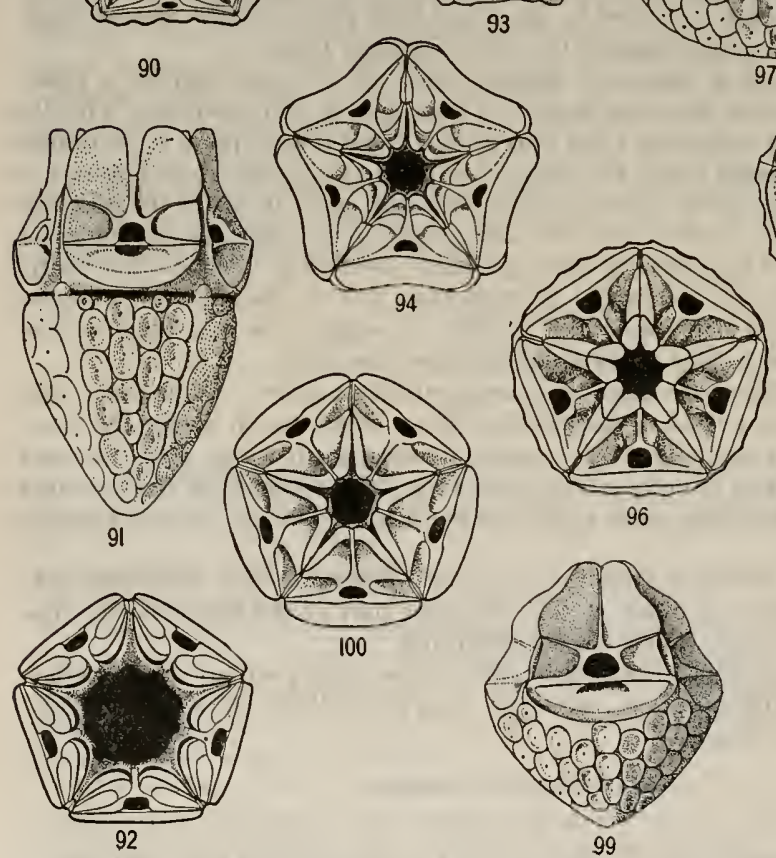

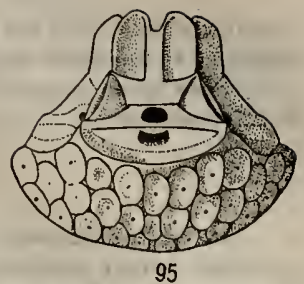

95
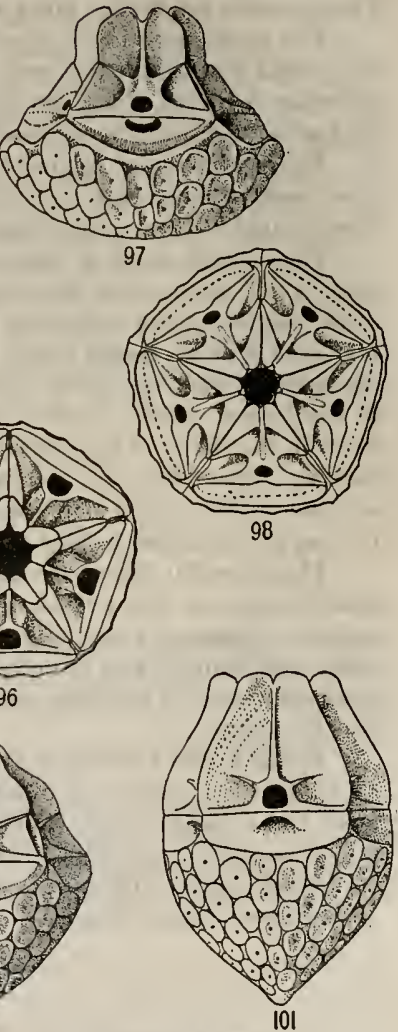

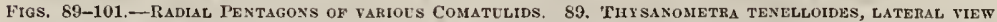

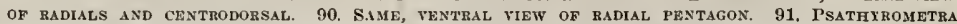
FRAGILIS, LATERAL VIEW OF RADIALS AND CENTRODORSAL, 92. SAME, VENTRAL VIEW OF RADIAL PENTAGON, 93. ZENOMETRA COLUMNARIS, LATDRAL VIEW OF RIDIALS AND CENTRODORSAL. 94. SAME, TENTRAL VIEW OF RADIAL PENTAGON, 95. FLOROMETRA PERPLEXA, LATERAL VIEW OF RADIALS AND CENTRODORSAL.

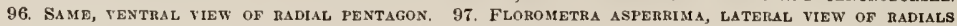
and Centrodorsal. 98. S.IME, ventral view of radial pentagon. 99. Trichometra cubensis, latERAL VIEW OF RADIALS AND CENTRODORSAL, 100. SAME, VENTRAL YiEW OF RADIAL PENTAGON. 101. Hathrometra prolixi, lateral view of radils and Centrodors.al. 
In the interradial angles the articular faces are separated, proximal to the lower fourth of the mascular fossæ, by a triangular space, slightly excavated, the sides of which make with each other an angle of about $30^{\circ}$, the apex lying at the distal end of the proximal fourth of the muscular fossæ. The sides are straight and regularly divergent as far as the transverse ridge; they then very gradually begin to turn, passing over into the curved proximal borders of the dorsal ligament fossæ.

The interarticular ligament fossæ are small, and scarcely equal in height the dorsal ligament fossa; the onter half of their distal border is nearly or quite parallel to the transverse ridge; the inner half curves gradually downward, so that it joins the rim about the central canal at an angle of about $45^{\circ}$.

The intermuscular septum is low and comparatively broad, extending distally to the intermuscular notch. At first it decreases in height rapidly, then more gradually.

The maximum height of the muscular fossæ is equal to that of the dorsal ligament and the interarticular ligament fossæ combined. They are separated interiorly by a broad and deep intermuscular notch, rounded proximally, which extends downward for two-fifths, or even one-half, of the distance from the outer border to the distal rim about the central canal. They are very broadly rounded.

The joint face elements on either side of the dorsorentral plane distal to the transverse ridge make with each other a much broader angle than usual, the angle approximating $120^{\circ}$, so that the excaration of the reentrant angles of the rentral star of the radial pentagon is comparatively slight. The outer three-fourths of the muscular fossæ lie in a plane parallel to the dorsoventral axis of the animal.

There is no deposition of calcareous matter on the inner sides of the radials.

Diameter of radial pentagon at base, $4.3 \mathrm{~mm}$; height of articular face (measured along the inclination), $2.5 \mathrm{~mm}$; width, at transverse ridge, $2 \mathrm{~mm}$.; diameter of ventral interarticular space, $2 \mathrm{~mm}$.

\section{BATHYMETRINE.}

\section{HATHROMETRA PROMXA.}

Fig. 101, p. 62 .

The dorsal ligament fossa is more flattened proximally than in H. tenella.

The interarticular ligament fossæ are only partially separated from the muscular fossæ distally. The septum is of the same character as that in $H$. tenella, but it rapidly decreases in height and terminates halfway between the rim about the central canal and the outer edge of the joint face. The outer edge of the area occupied by the interarticular ligament, instead of being strongly concave as in H. tenella, is convex.

The muscular fossæ are longer and narrower than in $H$. tenella, being onethird longer than the distance from the inferior border of the dorsal ligament fossa to the distal border of the interarticular ligament fossæ. The outer edge of the muscular fossæ is slightly concave, or nearly straight. 


\section{HATHROMETRA TENELLA.}

Figs. 102-105, p. 67 .

The dorsal ligament fossa is narrow, from three to three and one-half times as broad as high, with the proximal border regularly elliptical or slightly flattened. The ligament pit is somewhat, usually considerably, broader than the central canal, but narrow dorsoventrally.

The transverse ridge is narrow, rising somewhat inwardly to meet the narrow but very high rim about the central canal. The central canal is large and transversely oval. The rim about the central canal is broader distally than laterally. From the middle of the distal edge arises the intermuscular septum; this at first is as high as the rim and comparatively broad, but it rapidly decreases in height and width for a short distance until it becomes a low, narrow septum, when it rather abruptly assumes a very gradual decrease in height. It extends to the intermuscular notch. On either side of the intermuscular septum, nearly over the lateral borders of the central canal, arise the ridges forming the distal border of the interarticular ligament fossæ. These run outward, making an angle of about $40^{\circ}$ with the transverse ridge, and are practically straight; like the intermuscular septum they are at first high and comparatively broad, but gradually become low and narrow; as a rule their decrease in height and width is very regular, there being no abrupt change as in the case of the intermuscular septum.

The interarticular ligament fossæe are of the same height as the dorsal ligament fossa. Their outer edges are strongly and regularly concave and their general direction makes an angle of from $70^{\circ}$ to $80^{\circ}$ with the transverse ridge; their distal edges make an angle of about $40^{\circ}$ with the transverse ridge; their inner angles are truncated. The interarticular ligament fossa are separated interradially by a narrow shallow furrow with parallel sides which is bridged over distally by the muscular fossæ, these being in close lateral contact.

The muscular fossæ are rounded triangular and very large; they are about twice as high as the interarticular ligament fossa, or as high as the distance from the proximal edge of the dorsal ligament fossa perpendicularly to the distal apex of the interarticular ligament fosse. Their distal angles are more rounded than their lateral angles, but are relatively sharp. Distally the muscular fossæ are separated interiorly by an intermuscular notch, which is usually about as deep as the dorsoventral (lesser) diameter of the central canal, narrow, and sharply pointed proximally. It may, however, be closed by the approximation of the muscular fossæ on either side, or it may make a rather wide rounded $\mathbf{V}$; occasionally it may extend considerably downward.

The excavation of the joint face elements is deep, so that the halves on either side of the dorsoventral plane distal to the transverse ridge make an angle of about $90^{\circ}$ with each other.

There is no calcareous deposit on the inner surface of the radials.

Diameter of radial pentagon at base, $2.8 \mathrm{~mm}$; height of articular face (measured along the inclination), $1.9 \mathrm{~mm}$; width, at transverse ridge, $1.6 \mathrm{~mm}$; distance 
from center of rosette to middle of dorsal outer edge of radial, $1.3 \mathrm{~mm}$.; diameter of ventral interarticular space, $0.2 \mathrm{~mm}$. to $0.4 \mathrm{~mm}$.

The preceding description is based upon a comparative study of 10 specimens.

In five larger specimens the narrow septum forming the distal border of the interarticular ligament fossæ, instead of being straight and making an angle of about $40^{\circ}$ with the transverse ridge as in those just described, makes a broad curve, and in the outer portion becomes parallel to the transverse ridge. The outer border of the muscular fossæ also is more convex, and the intermuscular notch is less deep and less variable in form.

Height of articular face (measured along the inclination), $2 \mathrm{~mm}$; width, at transverse ridge, $1.8 \mathrm{~mm}$; diameter of ventral interarticular space, $0.4 \mathrm{~mm}$.

TRICHOMETRA CUREASIS.

Figs. 99, 100, p. 62 .

The radial articular faces of this species are essentially like those of Hathrometra tenella.

The chief clifferences are that the outer edge of the interarticular ligament fossæ is nearly straight instead of strongly concave; the distal edge of the interarticular ligament fossæ, which is straight, makes a somewhat less angle with the transverse ridge; and the muscular fosse hare both the proximal outer and distal angles broadly and equally rounded, the outer border between them being slightly concave; the intermuscular notch is only slightly indicated.

Diameter of radial pentagon at base, $2 \mathrm{~mm}$; height of articular face (measured along the inclination), $1.2 \mathrm{~mm}$.; width, at transverse ridge, $1.1 \mathrm{~mm}$.; diameter of ventral interarticular space, $0.3 \mathrm{~mm}$.

\section{NANOMETRA BOWERSI.}

Figs. 106,107, p. 6 i.

The dorsal ligament fossa is about three times as broad as high, with the proximal border rather strongly flattened. The ligament pit is only faintly indicated.

The articular faces are separated interradially by a narrow shallow groove of uniform width, which is about half as broad as the central canal. The transverse ridges of adjoining joint faces are in contact with each other, but the interradial groove is not bridged by the muscular fossa.

The interarticular ligament fossæ are approximately equilateral triangles, with their inner angles broadly truncated. Their distal border is only faintly indicated by a very narrow, almost obsolete, ridge.

The intermuscular septum is rather broad, with parallel sides, and is never much raised above the general level of the muscular fossæ.

The muscular fossæ are slightly less in height than the distance from the distal angle of the interarticular ligament fosse to the proximal border of the dorsal 
ligament fossæ; in general they are rounded triangular, their outer edge continuing in the same direction as the outer edge of the interarticular ligament fossæ. The distal angle is strongly rounded, this involving usually the outer portion of the lateral edge. The intermuscular notch is moderately deep, and rounded proximally; its sides may be nearly parallel, or they may make an angle of nearly $90^{\circ}$ with each other.

There is no calcareous deposit within the ventral surface of the radial pentagon.

Diameter of radial pentagon at base, $2 \mathrm{~mm}$.; height of articular face (measured along the inclination), $1.1 \mathrm{~mm}$; width, at transverse ridge, $1.2 \mathrm{~mm}$.; distance from center of rosette to middle of dorsal outer edge of radial, $0.8 \mathrm{~mm}$.

\section{THAUMATOMETRA TENUIS.}

Figs. 108-111, p. 67.

The dorsal ligament fossa is narrow, about four times as broad as high, with the proximal border regularly semielliptical, sometimes slightly flattened. The ligament pit is very narrow transversely and faintly marked, but is broader than the central canal.

The ends of the transverse ridges are in contact in the interradial angles, but the dorsal ligament fossæ are widely free. The interarticular ligament fossæ are separated interradially by a moderately broad $\mathrm{V}$-shaped space, the sides of the $\mathrm{V}$ being slightly incurved, which is closed anteriorly by the apposition of the muscular fossæ.

The high narrow ridge forming the distal border of the interarticular ligament fossæ at its inner end makes an angle of from $30^{\circ}$ to $40^{\circ}$ with the transverse ridge. In young individuals, as in small specimens of Hathrometra tenella, this direction is maintained throughout its entire length, but in large individuals it gradually curves about so that its outer half becomes parallel to the transverse ridge, or even slopes slightly downward. In profile the crest of the ridge forming the anterior border of the interarticular ligament fossæ is seen to be at the inner end strongly concave, from this curved portion running straight to the outer end, so that the ridge gradually diminishes in height. The height of the interarticular ligament fossæ is about equal to that of the dorsal ligament fossa.

The central calcareous structures of the joint face resemble those found in Florometra asperrima, but the triangular area is slightly smaller.

The muscular fossæ are large and well rounded, their height being somewhat greater than that of the interarticular ligament and dorsal ligament fossæ combined. They are subtriangular, with the distal angles very broadly rounded, especially in the larger specimens. The intermuscular notch, which is moderately broad and may be either acute or rounded proximally, extends inward for somewhat more than one-third the distance from the distal edge of the muscular fossæ to the central canal.

There are only a few slender strands of calcareous deposit within the ventral surface of the radial pentagon, so that the rosette is in plain view from the ventral surface. 


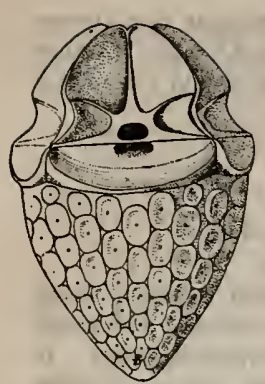

102

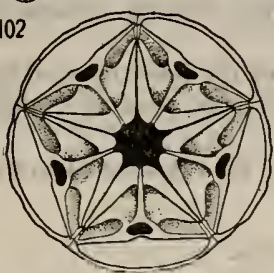

103

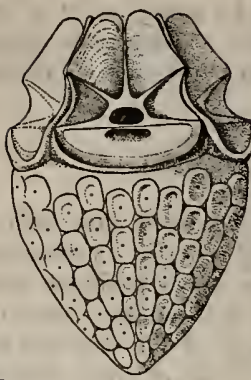

104

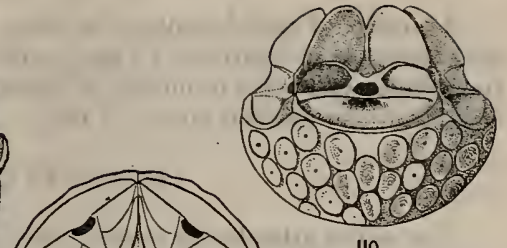

110

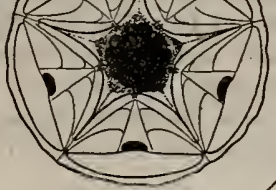

III
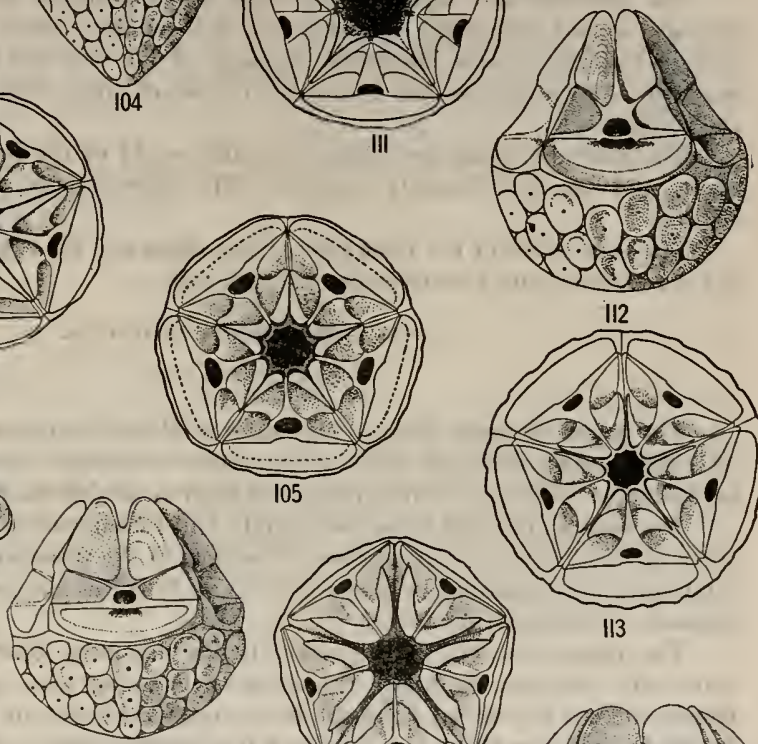

108
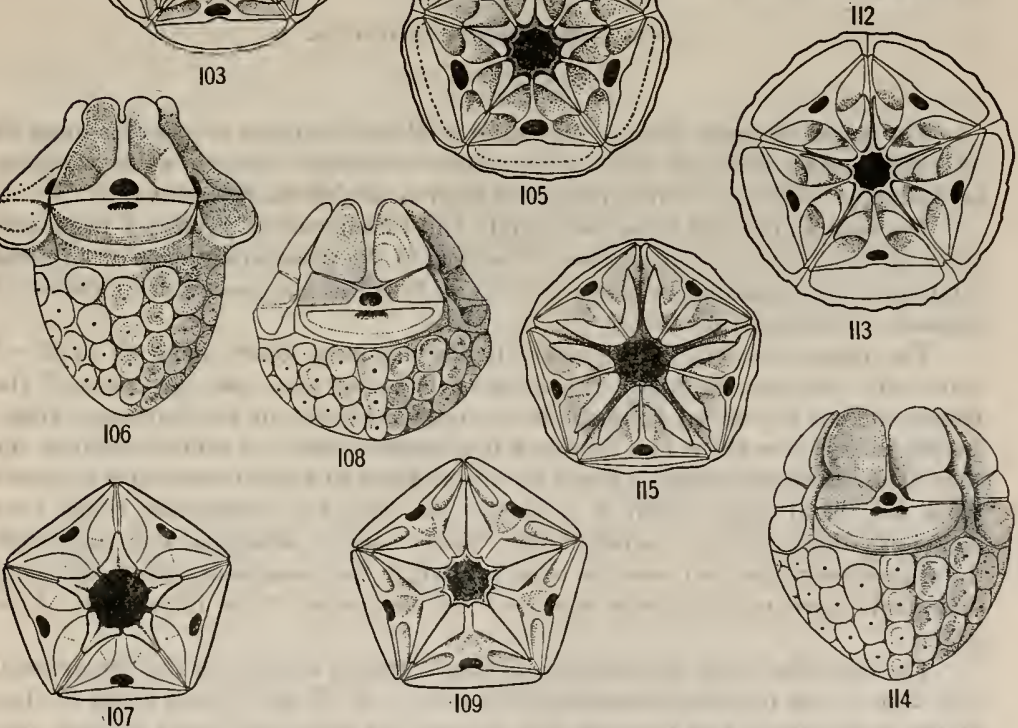

113

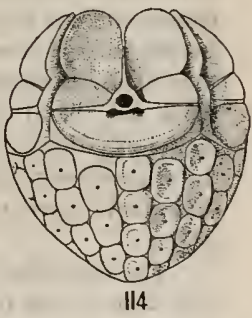

Figs. 102-115.-Radial Pentagons of tariots Comatelids. 102. Hathrometra tenella from Grand BANKS, LATFRAL VIEW OF RADIALS AND CENTRODORSAL. 103. SAME SPECIMEN, VENTRAL VIEW OF RADIAL pentagon. 104. Hathrometra texella, lateral view of radils ayd centrodorsal. 105. SaMe SPECTMEN, VENTRAL VIEW OF RADIAL PENTAGOX. 106. NANOMETRA BOWERSI, LATERAL VIEW OF RADIALS AND CENTRodorsal. 107. SaMe, ventral View of radil pentagon. 108. Thac Matometra texdis, a SMALL INDIVIDUAL, LATERAL VIEW OF RADIALS AND CENTRODORSAL. 109. SAME SPECIMEN, VENTRAL VIEW

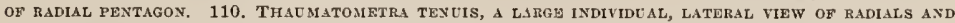
cextrodorsal. 111. Same specisies, ventral view of radial pentagon. 112, Coccometra Higenit,

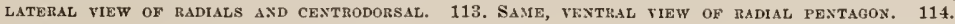
Pentametrocrinus Japonicus, lateral view of radils and centrodorsal. 115. Saje, ventral riEW OF RADIAL PENTAgON. 
Diameter of radial pentagon at base, $4.7 \mathrm{~mm}$.; height of articular face (measured along the inclination), $2.3 \mathrm{~mm}$.; width, at transverse ridge, $2.8 \mathrm{~mm}$.; distance from center of rosette to middle of dorsal outer edge of radial, $2 \mathrm{~mm}$.; diamcter of ventral interarticular space, $1.7 \mathrm{~mm}$.

\section{PENTAMETROCRINIDÆ.}

The radial articular faces are widely separated from each other.

The dorsal ligament fosse are broadly rounded proximally.

The interarticular ligament fosse are lower than the dorsal ligament fossa, strongly convex exteriorly, the very low and narrow septum forming the distal margin making, at least interiorly, an angle of $45^{\circ}$ with the transverse ridge. It may curve downward so that it makes but a small angle with the transverse ridge exteriorly.

The muscular fossæ are about twice the height of the interarticular ligament fossæ, and are very broadly rounded. The intermuscular septum is high and narrow.

The excaration of the joint face is very deep, and the calcareous lamina forming the various joint face elements are very thin.

\section{PENTAMETROCRINUS JAPONICUS.}

Figs. 114, 115, p. 67 .

'The dorsal ligament fossa is very narrow, about five times as broad as long, its proximal border from the ends of the transwerse ridge forming a very regular half ellipse. The fossa is very deep, and there is no definite ligament pit.

The radial articular faces are entirely and rather widely separated from each other interradially by deep groores. The ends of the transverse ridges of adjacent joint faces are separated by a space about as broad as the dorsoventral (shorter) diameter of the central canal.

The lateral borders of the interarticular ligament fossæ make an angle of about $45^{\circ}$ with the transverse ridge, basally passing over into the curve of the lateral ends of the dorsal ligament fossa around the ends of the transverse ridge. In length they are about two-thirds of the distance from the central canal to the ends of the transverse ridge. From the distal angle of the interarticular ligament fossæ the distal edge, which is a narrow and low, but prominent, ridge, runs diagonally downward in a straight line, which makes a somewhat less angle with the transverse ridge than does the outer border, to the prominent raised rim about the central canal which it joins at a level just above that of the distal edge of the latter.

The muscular fossæ lean inward, making a greater angle with the dorsoventral axis than do the proximal elements of the joint face. When viewed along the line of the dorsorentral axis they are seen to have the lower and inner borders (the latter on the intermuscular septum) at right angles to each other and of the same length. The outer border is a broad curve approaching a quadrant of a circle, 
but slightly flattened in the center. The two muscular fossæ of each joint face slope inward toward the median dorsoventral plane, so that they make with each other an angle of $90^{\circ}$. The interarticular ligament fossæ make with each other a slightly greater angle; thus the central canal, which opens on a level with the transverse ridge, is covered over where it passes by the muscular and interarticular ligament fossæ by a thin partition forming a rounded tunnel or tube, the proximal end of which forms the rim about the central canal.

The intermuscular septum is thin, but very high. Its proximal end adjoins the rim about the central canal, whence it runs straight to the intermuscular notch, thus gradually decreasing in height distally.

The ventral surface of the radial pentagon is almost or quite devoid of any calcareous deposit, so that the rosette is more or less visible in ventral view.

Diameter of radial pentagon at base. $4.4 \mathrm{~mm}$.; height of radial articular face (measured along the inclination), $2 \mathrm{~mm}$; width, at transverse ridge, $2.2 \mathrm{~mm}$.; distance from center of rosette to dorsal outer edge of radial, $2 \mathrm{~mm}$.: diameter of ventral interarticular space, $1.2 \mathrm{~mm}$.

\section{PENTAMETROCRINUS SEMPERI.}

See figs. 1006,1007 , Il. 4 .

In the following key are included all of the recent comatulids of which the radial articular faces are known.

It is understood that this key is purely tentative, for the knowledge of these structures is as yet far too fragmentary to enable us to say with any degree of certainty what are and what are not the most fundamental differential characters. It will be noticed that in certain cases quite unrelated species stand side by side, and again closely related forms are widely separated; the probability is that when these structures have been more extensively studied characters will come to light by the use of which a key to the radial articular faces can be drawn up in which the species will fall more in accordance with their systematic position as it is known from other data.

KEY TO RECENT COMATULIDS BASED LPON CHARACTERS FOEND I. ARTICLLAR FACES OF RADIALS,

$a^{1}$. The radial articular faces are approximately crescentic and widely separated from each other interradially; the dorsal ligament fossa is nearly semicircular; the distal edge of the joint face is strongly coucare and parallel with the proximal border of the dorsal ligament fossa; the outer borders of the interarticular ligament fosse are parallel; the muscular fossi form curved bands of uniform width along the concave distal edges of the interartleular ligament fossse. CAIOMETRIDA.

$a^{2}$. The radial articular faces are never crescentic.

$b^{1}$. The radial articular faces resemble a very thick horseshoe, the borders of the interarticular ligament fossæ, which converge distally, passing in a broad curre imperceptibly into the proximal border of the dorsal ligament fossa, and the furrow between the structures distal to the transverse ridge being very broad; they are widely separited interradially ; the dorsal ligament fossa is nearly semicircular; the distal border of the joint face is straight and parallel with the transverse ridge; the transverse ridge is very broad and carries on either side a supplementary ligament fossa in the form of a long narrow triangle, the apex of which lies near the lower border of the central canal; there are no muscular fosse Pontiometra. 
$b^{2}$. The radial articular faces are never horseshoe shaped; there is aiways an abrujt change in direction between the outer borders of the interarticular ligament fosse and the proxlmal border of the dorsal ligament fossa.

$c^{2}$. The muscular fosse are much smaller thin the interartlcular ligament fossæ.

$d^{i}$. The muscular fossi, whlch are boomerang shaped with the two arms of the boonerang approximately of the same length, curve about the inner distal angle of the interarticular ligament fosse and pass downward aiong their inner edges nearly or quite

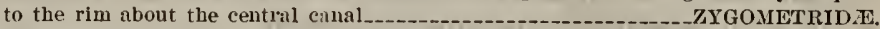

$e^{a}$. The interarticular ligament fosse are roughly oblong, higher than broad, wlth their inner and outer edges more or less perpendicuiar to the transverse ridge.

Zygometra comata.

$e^{z}$. The interarticular ligament fossae are trianguiar, with their Inner and outer borders making approximately the same angle with the transverse ridge.

$f$. The inner side of the interarticular ligament fosse is convex and the outer slde is concave; the proxlmal border of the dorsal ligament fossa is eveniy convex and the dorsal ligament fossie are nutually united by their broadly truncated

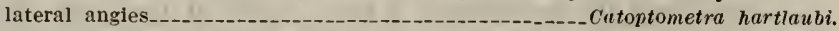

$f$. The inner and outer sides of the interarticular ligament fosse are straight; the proximal border of the dorsal ligament fossa is strongly tlattened; the dorsai ligament fosse are entireiy separated from their neighbors__Eudiocrinus ornatus.

$d^{2}$. The muscular fosse are not boomerang shaped; in the rare cases in which they are transvelsely elongate and extend around the inner distal angle and downward along the inner sides of the interartlcular iigament fossæe the vertical arm is much shorter than the horizontai.

$e^{1}$. The interarticuiar ligament fosse are iarge and rectangular, with their inner and outer sides parallel and (except just at the base) perpendicular to the transverse ridge and their distal sides parallel to the transrerse rldge; the muscular fossæ are very narrowly linear and searcely evident.-.-.-.-.-. Himerometra martensi.

$e^{2}$. The interarticular ligament fosse are not rectangular, but their dlstal or inner borders, or both, are more or less convex, and their outer borders are more or less convergent; the muscuiar fosse are conspicuous, broadly linear, or of various shapes.

$f^{2}$. The distai border of the interartlcular ligament fosse is horizontal, convex with the chord of the convexity horizontal, or slopes downward from the inner to the outer distai angles. COMASTERID.E.

$g^{1}$. The muscular and interarticular ligament fossa are neariy of the same size.

Leptonemaster venustus.

$g^{2}$. The muscular fosse are much smaller than the interarticular ligament fosse.

$h^{2}$. The muscular fosse ale triangular, with the inner apices of the triangles at the sides of the intermuscular notch.

$i^{1}$. The dorsal ligament fosse are regularly semielliptical.

Comatella nigra and $C$. stelligera.

$i^{2}$. The dorsal llgament fosse have the proximal border strongly flattened.

Capillaster multiradiata.

$h^{2}$. The muscular fossæ are more or less band-like with approximately parallel sides.

$i^{i}$. The muscular fossæ run rather strongly downward from their inner to thelr

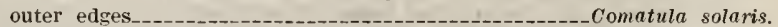

$i^{2}$. The muscular fossæ are horizontai or convex with the chord of the convexity horizontal.

$j^{2}$. The interarticular ligameut fossa are as high as, or higher than, broad at their narrowest part. 
$k^{1}$. The muscular fossie extend inward for some distance around the inner distal angles of the interarticular ligament fossæ and down along their inner border's.

$l^{1}$. The outer portions of the interarticular ligament fossæ are separated interiorly by a space approximately equal to their own width and the muscular fosse are very widely separated interiorly.

Comaster fruticosus.

$l^{2}$. The outer portions of the interarticular ligament fosse are separated by a space equal to less than half their own width and the inner edges of the muscular fosse are almost in contact.

Comatula pectinata.

$k^{2}$. The nıuscular fosse do not extend inward beyond the inner distal angles of the interarticular ligament fossie.

$l^{1}$. The inner borders of the interarticular ligament fosse are $\mathbf{S}$-shaped, so that the space between them is broadest proximally becoming much narrower distally between their inner distal angles.

Capillaster sentosa.

$l^{2}$. The inner horders of the interarticular ligament fosse are approximately parallel.

$m^{1}$. The distal portion of the onter borders of the interarticular ligament fossæ is strongly concave, so that the nuscular fosse extend outward for some distance beyond them_...-_Comatella maculata.

$m^{2}$. The outer borders of the interarticular ligament fosse are approximately straight.

$n^{1}$. The outer borders of the muscular fosse slant upward and outward, so that a more or less pointed distal outer angle results.

Comatula micraster.

$n^{2}$. The outer borders of the muscular fosse are straight and perpendicular to the transrerse ridge, or evenly convex, the chord of the convexity being perpendicular to the transverse ridge.

Comactinia echinoptera.

$j^{2}$. The interarticular ligament fosse are not so high as their minimum width.

$k^{2}$. Interarticular ligament fosse more than twice as broad as high.

Nemaster discoidea.

$k^{2}$. Interarticular ligament fosse much less than twice as broad as high.

$l$. The outer borlers of the interarticular ligament fosse are markedly convergent, so that the articular faces of the radials beyond the transverse ridge are separated by a comparatively wide $V$-shaped gap_-______-_omaster parvus.

$l^{2}$. The outer borders of the interarticular ligament fosse are more nearly parallel, so that the articular faces beyond the transverse ridge are separated by a rary narrow $v$, or by a parallel-sided furrow.

$m^{2}$. The nutuscular fosse are slightly S-shaped, the inner half convex, the outer half concave and curring upward and outward.

Nemaster rubiginosa.

$m^{*}$. The muscular fosse are uniformly convex.

$n^{2}$. The muscular fosse are very strongly conrex, the distal borders of the interarticular ligament fosse being very strongly borred ontward

Comatula rotalaria.

$n^{2}$. The nuscular fosse are only slightly convex, the distal borders of the interurticular ligament fosse heing almost straight.

Neocomatella pulchella. 
$f^{3}$. The distal borders of the interarticular ligament fosse slope downward and inward from the outer to the inner distal ansles, or from the former to the rim about the central canal.

$g^{1}$. The interarticular ligament fosse are triangular, their inner sides forming a straight line from the outer distal angle to the rim about the central canal.

$h^{2}$. The muscular fosse are very narrowly linear, forming narrow bands of uniform width along the distal border's of the interarticular ligament fosste. Ptilometra mülleri.

$h^{2}$. The muscular fossie are larger, triangular or trapezoidal.

$i^{1}$. The outer borders of the interarticular ligament fosse are rery strongly convergent, so that the distance across the distal border of the articular face is much less than balf the length of the transverse ridge; the muscular fossie are relatively high, their maximum (inner) beight being twice their width Colobometra discolor.

$i^{2}$. The outer sides of the interarticular ligament fossie are much less convergent, so that the distance across the distal border of the articular face is equal to three-quarters of the lengtb of the transverse ridge; the muscular fossie are very low, their maxiuum (inner) height heing much less than their width Oligometra serripinna.

$g^{2}$. The interarticular ligameut fossie are four sided, or have the distal border very broadly rounded; they are never triangular.

$h^{2}$. The muscular fosse are broully roumled listally and outwardly, tapering to a point inwardly and proximally; their border is everywhere evenly curved, its continuity not heing interrupted by the interarticular ligauent fosse.

$i^{2}$. The intermuscular notch has parallel sides________Amphimetra papucnsis.

$i^{2}$. The intermuscular notch is at least twice as broad proximally as distally. Heterometra philiberti.

$h^{2}$. The muscular fosse are narrow and more or less band-like: the distal edge of the interarticular ligament fosse always cuts away more or less of their proximal border.

$i^{1}$. The intermuscular furrow is suddenly lroadened out proximally just over the central cinal, being constricted between the outer portions of the dorsal ligament fossre.

$j^{2}$. Tbe interarticular ligament fossa are unusually narrow, being more than twice as high as the minimum wilth________-Heterometra reynaudii.

$j^{2}$. The interirticular ligament fossa are nuch broader, being not more than half again as high as the minimum width___Craspedometra acuticirra.

$i^{2}$. The sides of the intermuscular furrow are parallel, or diverge regularly from the hase.

$j^{1}$. Tbe sides of the intermuscular furrow diverge rapidly from the base outward

$j^{2}$. The sides of the intermuscular furrow are parallel.

$k^{2}$. The intermuscular furrow is broad, with a median carinate ridge. Mariametra subcarinata.

$h^{2}$. The intermuscular furrow is uirrow, with no median carination.

$l^{1}$. The distal borders of the interarticular ligament fosse are more or less regularly convex; the muscular fosse extend inward and downward so that their proximal apex is half way between the maximum height of the interarticular ligament fossie and the base of the intermuscular furrow Amphimetra ensifer.

$r^{2}$. The distal horlers of the interarticular licament fosse are flattened; the inner ends of the muscular fossa do not pass berond the inner distal angles of the interarticular ligament fossa. 
$c^{2}$. The muscular fossie are at lenst as large as, and usually much larger than, the interarticular ligament fossie.

$d^{2}$. The total height of the articular fossæ is much less than the length of the transverse ridge.

$\epsilon^{2}$. The distal bortlers of the interarticular ligament fosse rum in a broad curve from the distal border of the central canal outward and upward to the distal outer angles of the joint face; as the distal bordel of the joint face is only slightly concave the muscular fossa are highest interiorly and taper to a point resting on the outer distal angles of the interarticular ligament fossie.

Comatilia iridometriformis.

$e^{x}$. At least the distal half of the outer borders of the joint face is formed by the edges of the muscular fossie.

$f^{1}$. The distal borders of the interarticular ligament fossæ are more or less decurved in their outer halves or two-thirds, so that the muscular fossie are higher ontwardly than inwardly; there are no supplententary muscle plates or bosses in the inner proximal angles of the muscular fossie.

$g^{\mathbf{x}}$. The muscular fosse are about twice as large as the interarticular ligament fosse; the distal horders of the interarticular ligament fosse are very strongly conrex; the proximal halves of the muscular fosse are separated interiorly by the distal portion of a broad elevated triangular structure of which the strongly convex base reaches nearly to the central canal, and the distal halres by a narrow space with parallel sides_-Thysanometra tenclloides.

$g^{2}$. The muscnlar fosse are about the same size as the interarticular ligament fosse; the distal borders of the interarticular ligament fosse are only sligltty convex; the joint face elements are separated in the median line by a promiment furrow which is more or less constricted between the muscular fosse.

Leptonemaster venustus.

$f$. The distal borders of the interarticular ligament fossæ are straight and are usually directed more or less upward and outward so that the interarticular ligament fossa are triangular and the inner proximal angle of the nuscular fosse is nearer the transverse ridge than the outer; a prominent supplementary nuscle plate or rounded boss occupies the inner proximal angle of the muscular fosse.

$g^{2}$. The distal borders of the muscular fossie are flattened and nearly parallel to the transverse ridge, or convex with the chord of the convexity parallel to the transverse ridge; a broadly rounded outer distal angle is always erident; the centrodorsal is well rounded in lateral view Antedon.

$h^{2}$. The sides of the intermuscular furrow are parallel, or diverge slightly distally.

$i^{2}$. The outer distal angles of the muscular fosse are vers broadly rounded. Antedon petasus.

$i^{2}$. The outer distal angles of the muscular fossa are less broadly rounded.

$h^{2}$. The sides of the intermuscular furrow converge distally.

Antedon bifia.

$i^{1}$. Distal border of muscular fossie strongly convex; distal border of inter articular ligament fosse nearly parallel to the transverse ridge.

Antedon adriatiea.

$i^{2}$. Distal border of muscular fosse flattened; distal border of interirticular ligament fosse running upward and outward, making a considerable angle with the transverse ridge Antedon mediterranea.

$g^{2}$. The distal borders of the muscular fosse are very broadly rounded witlout any indication of a distal outer angle, or slope dowuward and inward to the end of the intermuscular furrow; the centrodorsil is a short cylinder--_Tropiometra. 
$h^{2}$. The proximal borders of the muscular fossie are parallel to the transverse ridge.

$i^{2}$. The height of the interarticular ligament fossie is much less than balf the distance from the middle to the ends of the transverse ridge.

Tropionetra encrinus.

$i^{2}$. The height of the interarticular ligament fosse is much more than half the distance from the midile to the ends of the transverse ridge.

Tropiometra carinata.

$h^{2}$. The proximal borders of the muscular fosse run upward and outward, making a considerable angle with the transverse ridge.

$i$. The distal borders of the muscular fossie run parallel to the distal borders of the interarticular ligament foss:e inward and downward from the distal outer angles; large supplementary muscle plates, in addition to bosses,

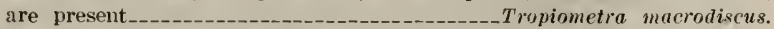

$i^{2}$. The distal borders of the muscular fossie are very broadly rounded aud show no relation to the distal borders of tbe interarticular ligament fosse; there are no supplementary muscle plates_._-_-_-__-_-_-_Tropiometra picta.

$d^{2}$. The total height of the articular fosse is nearly or quite as great as, or much greater than, the length of the transverse ridge.

$e^{3}$. The outer borders of the muscular fossa are straight or slightly concave and are at right angles to the transverse ridge and parallel to each other; the sides of the interarticular ligament fosse are strongly convergent.

$f^{1}$. The nuscular fossie are short, the distance from the outer angles of the interarticular ligament fosse to the line parallel with the transverse ridge touchiug the most distal portion of the unscular fossie being no greater than the width.

$g^{2}$. The intermuscular furrow is very broad with parallel sides: in the middle it bears a conspicuous and high keel_-___________-_-_Stylometra spinifera.

$g^{2}$. An intermuscular ridge instead of an intermuscular furrow is present.

$h^{2}$. At the inner proximal angles of the muscular fosse are prominent bosses and also lirge supplementary muscle plates; the outer distal angles of the muscular fossie are well rounded and the outer borders of the interarticular ligament fosse are concave and make a relatively large angle with the

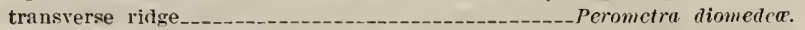

$h^{2}$. No bosses or supplementary muscle plates are present; the outer distal angles of the muscular fosse are relatively sharp; the outer borders of the interarticular ligament fossa are straight and uake a relitively small angle

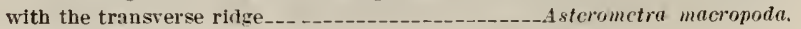

$f$. The muscular fosse are longer, the heisht being greater than the width.

$g^{1}$. The muscular fosse are very high, the maximum height being more than three times the width

$g^{2}$. The muscular fosse are lower, the maximum beight being never but slightly greater than twice the width.

$h^{1}$. The distal border of the muscular fosse rises from the distal outer corners upward and inward to a rounded inner distal angle near the intermuscular noteh.

$i^{4}$. The muscular fosse are uarrow, about twice as high as wide, and are separated by a very broad rounded intermuscular ridge; the interarticular ligament fosse are separated by a space enual to twice their width.

Florometra perplexa.

$i^{2}$. The muscular fosse are broad, much less than twice as high as wide, and are separated by a very narrow intermuscular ridge; the iuterarticular ligament fosse are separated by a space approximately equal to their own width. Florometra asperrima. 
$h^{2}$. The distal border of the muscular fosse is convex with the chord of the convexity parallel to the transverse ridge, or rises from the inner to the outer distal angles.

$i^{2}$. The outer borders of the muscular fossie are straight; the centrodorsal bears a single row of cirrus sockets.

$j^{2}$. The muscular fosste are separated interiorly by a narrow intermuscular ridge - -

$j^{2}$. The muscular fosse are separated interiorly by a broad intermuscular groove -

$i^{2}$. The outer borders of the muscular fosse are more or less concave; the centrodorsal bears regular columns of cirrus sockets, at least two to a column.

$j^{2}$. The uuscular fosse have the inner distal angle very broadly, and the outer distal angle very narrowly, rounded, and the outer borders rather strongly concave: the centrodorsal bears the cirrus sockets in 15 crowded columns Thalassometra villosa.

$j^{2}$. The muscular fosse have the distal horder evenly convex.

$k^{1}$. The interior length of the muscular fosse is three times their width; the cirrus sockets are in 10 well spaced columns.

Stiremetra breviradia.

$k^{2}$. The interior length of the muscular fosse is much less than three times their width; the cirrus sockets are in 10 columns which are separated by high ridges Stenometra quinquecostata.

$e^{2}$. The outer horders of the uiuscular fosse are couvex, more rarely nearly straight, and converge more or less, usually markedly, distally.

$f^{1}$. The inner sides of the interarticular ligament fosse are straight and run upward and outward at a relatively large angle with the transverse ridge so that the acute distal angle of the interarticular ligament fosse reaches a level at or beyond the halfway point between the inuer proximal and distal angles of the narrow and usually more or less sharply triangular muscular fosse.

CHARITOMETRIDA.

$g^{2}$. The outer borders of the interarticular ligament fosse are very strongly concave, so that the interarticular ligament fosse are separated by broadly lenticular gaps iuterradially_-_._-_-_-_-__-__-_-_-_Crinometru concinna.

$g^{2}$. The outer borlers of the iuterarticular ligament fossa are nearly or quite straight, so that the interarticular ligament fossæ are separated by narrow furrows iuterradially.

$h^{1}$. Muscular fosse very narrow, about three times as long interiorly as broad.

$h^{2}$. Muscular fosse wider, about twice as long interiorly as broad.

Prcilometra acala.

$i^{1}$. Outer border of muscular fosse louger than outer border of iuterarticular ligament fosse-_._._._._._._._._. Pachylometra incqualis.

$i^{2}$. Outer border of iuterarticular ligament fossie longer than outer border of unuseular foss:e.

$j^{1}$. Lines of growth couspicuous

Charitometra basicurva.

$j^{2}$. Lines of growth iuconspicuous or obsolete_._._Perissometra angusticalyx.

$f$. The flistal outer angles of the iuterarticular ligament fossæ are nerer so high above

the transverse ridge as the halfway point between the proximal ends and the

distal borders of the muscular fosse.

$g^{2}$. The height of the articular faces is approximately equal to the length of the transverse ridges.

$h^{1}$. The nuscular and interarticnlar ligameut fossa are about of the same size.

$i^{1}$. The outer border of the interarticular ligament and muscular fosse combined is evenly convex; the ridge forming the distal border of the inter- 
articular ligament fossae does not reach the outer edge of the joint face: the inner halves of the free borders of the muscular fossie slope inward and downward at an angle of about $90^{\circ}$ with each other, forming a broad right-angled notch. Erythrometra ruber.

$i^{2}$. The outer borders of the interarticular ligament and muscular fosse form a discontinuous line which is aluost straight but slightly indented at the junction of the fossa; the ridge forming the distal border of the interarticular ligiment fossie reaches the outer edge of the joint face; the distal borders of the muscular fosse are nearly straight and parallel with the transverse ridge Compsometra lovéni.

$h^{2}$. The muscular fosse are much larger than the interarticular ligament fossa.

$i^{1}$. The outer borders of the interarticulitr ligaluent and muscular fosse form continuous straight lines and are nearly parallel ; the distal borders of the uuscular fossae are flattened and parallel to the transverse ridge; the intermuscular noteh is smill and shallow, well rounded proximally.

Hypalometra defceta.

$i^{2}$. The outer borders of the interarticular ligament and muscular fosse are discontiuuous, hoth being strongly convex, or those of the muscular fossie strongly convex and those of the interarticular ligament fossie straight; the distal borders of the muscular fosse are strongly rounded; the intermuscular notch is deep and sharply pointed proxiually.

$j^{1}$. The intermuscular septum is relatively broad and is expanded proximally just over the central canal; the outer borders of the interarticular liganent fosse are straight; the muscular fossie are rounded triangular, their outer borders being more or less flattened and converging to the well-rounded distal angles Thaumatometra tenuis.

$j^{3}$. The internuscular septum is high and very narrow, and it is not expanded basally; the outer borders of the interarticular ligament fossæ are strongly convex; the muscular fosse are much more broadly rounded, especially distally Pentametrocrinus.

$k^{2}$. The muscular fossa are very broad, the maximum wilth being more than three quarters of the maximum (inner) height; the outer borders of the interarticular ligament fosse form a continuous curve with the border of the dorsal ligament fossre.

Pentametrocrinus japonicus.

$k^{2}$. The muscular fossæ are narrower, the maximum height being uot much more than twice the maximum width; the maximum height of the convexity of the lateral borders of the interarticular ligament fossæ extends to beyond the ends of the transverse ridge, which lie iu a rounded concavity between the borders of the interarticular and dorsal ligament fossie Pentametrocrinus semperi.

$g^{3}$. The height of the articular faces is much greater than the length of the transrerse ridge.

$h^{1}$. The muscular fossie are high and narrow, more than twice as long interiorly as their maximum width.

$i^{2}$. The plane of the muscular fossie is almost parallel to the dorsoventral axis of the animal, while the plane of the interarticular ligament fossie makes a considerahle angle with it, the latter therefore leaning inward at a greater angle than the former; the outer distal angle of the interarticular ligament fosse reaches a height equal to abont one-third of the distance from the inner proximal to the inner distal angles of the muscular fosse ; the centrodorsal is long, columnar, with the cirrus sockets in 5 pairs of regular columns which are separated by high ridges. 
$i^{2}$. The muscular and interarticular ligament fosse lie in the same plane; the outer distal angles of the interarticular ligameut fossæe are at a height much less than one third of the distance between the inner proximal and distal angles of the muscular fosse; the centrodorsal is rounded, and the cirrus sockets are irregularly placed; the radial areas are not differentiated.

$j^{2}$. The distance from the proximal border of the transverse ridge to the proximal border of the dorsal ligament fossa is about equal to onethird of the distance from the former to the distal border of the muscular fossæe Coccometra hagenii.

$j^{2}$. The distance from the proximal border of the transverse ridge to the proximal border of the dorsal ligament fossa is much less than one-third the distance from the former to the distal border of the mnscular fossa.

Leptometra.

$h^{2}$. The musenlar fossæe are lower and broader, nsually much less than twice as high as the maximnm width.

$i^{1}$. The distal borders of the interarticular ligament fosse are straight and parallel to the transverse ridge Solanometra antarctica.

$i^{2}$. The distal borders of the interarticnlar ligament fosse are directed more or less upward and ontward.

$j^{1}$. The ridge forming the distal border of the interarticular ligament fosse does not reach the outer border of the joint face, which makes an uninterrupted eurve.

$k 1$. The distal borders of the interarticular ligament fosse make an angle of abont $60^{\circ}$ with the transverse ridge; the tips of the mnscular fossæe are abruptly swollen Nanomctra bowersi.

$k^{2}$. The distal borders of the interarticnlar ligament fosse make an angle of about $30^{\circ}$ with the transverse ridge; the tips of the muscular fosse are not ahruptly swollen Hathrometra prolixa.

$j^{2}$. The ridge forming the distal border of the interarticular ligament fosse reaches the onter border of the joint face where it causes an interruption of the continnity.

$k^{2}$. The outer portion of the muscular fossie is constricted.

Trichomctra cubensis.

$k^{2}$. The onter border of the muscnlar fossa is regularly convex.

$T^{1}$. Ten radials -Promachocrinus kerguelensis.

$l^{2}$. Five radials.

$m^{1}$. The musenlar fossa are very broad and broadly ronnded, rounded trapezoidal in shape; their planes make a relatively small angle with the dorsoventral axis so that the central space between the radials is very large, the diameter of the circle delimited by the ends of the muscular fosse being nearly one-half the diameter of the radial pentagon_-__-_-_-_-_-_-_-_Psathyrometra fragilis.

$m^{2}$. The muscnlar fossic are narrower and less broadly ronnded, rounded triangnlar in shape; their planes make a larger angle with the dorsoventral axis so that the diameter of the circle delimited by the ends of the muscular fosse is never more than one-third the diameter of the radial pentagon and is usually much less.

$n^{x}$. The diameter of the circle delimited by the distal ends of the muscular fosse is about one-third that of the radial pentagon.

Heliometra glaeia7is.

$n^{2}$. The diameter of the circle delimited by the distal ends of the mnscular fosse is abont one-fifth that of the radial pentagon. 
POST-BADIAL ELTMENTS.

General features.

Following the radials there is in all recent erinoids a regularly linear series of ossicles which usually forks, giving rise to two similar series, on the second (figs. 183-185, pp. 98-102); each of these secondary series may again fork, giving rise to four similar series (figs. 181, 186, pp. 94,101 ), and the proeess may be repeated, in extreme eases, as many as eight or nine times (figs. 180, 188, 194, pp. 92, 108, 120).

The number of the arms has always been used as a basic eharacter for the differentiation of the comatulid species since the days of Linck and Seba. P. H. Carpenter in his monograph divided his "series" of "Antedon" and "Actinometra" into various groups aceording to the number of arms and the number of ossicles found in the division series. He believed that there was a definite line of demarkation between speeies with 10 arms and those with more than 10, and between species with the IIBr series of two elements and those with the IIBr series of four. He was forced to admit, however, the existence of several speeies which fell into two, or even three, of his groups through heing both 10 -armed and multibrachiate, and through having the IIBr series sometimes of two and sometimes of four ossicles. In regard to the number of the component ossicles of the IIBr series he admitted a certain amount of variability, but placed the species in one group or in another on the basis of a majority of their series. This procedure resulted in the inclusion of Comanthus parvicirra (under different names) both in the "Valida group" and in the "Parvicirra group" of "Actinometra."

The availability of the number of arms and of the number of the ossieles in the division series for systematic purposes varies very greatly in the different groups. Speaking broadly, the number of arms may be said to be a systematic index of prime importance, but at the same time one which must be used with eonsiderable caution.

In the Comasteridre (figs. 180-188, pp. 92-108) the number of arms is, as a rule, perfectly true to speeies within relatively narrow limits and, taken in conneetion in multibrachiate genera with the second, or third, division series, furnishes the most obvious differential eriterion, and one that may be used with perfeet eonfidence; for no comasterid is known whieh is both 10 -armed and multibrachiate, and no comasterid has ever been found whieh is variable in both the second and third division series, though many are more or less variable in one or the other.

Even more fixed are the number of arms and the types of division series in the speeies of Himerometrida (figs. 123, 141, 192, 193. pp. 79, 83, 115, 117), Stephanometridæ (figs. 125, 130. p. 79), Mariametridæ (figs. 191-198, pp. 120-127), and Colobometridæ, and in most of those of the Zygometrida (figs. 12 $, 136.143,189$ 191, pp. 79. 82. 109-112). furnishing, so far as they go, the best systematic charaeters to be found: but their availability here is restricted by the relatively slight variability within eaeh family.

Praetically the same is true in the Calometridæ (figs. 200-202, pp. 130-134), but in one of the genera of this family (Calometre) species occur whieh are both 10 armed and multibraehiate. 


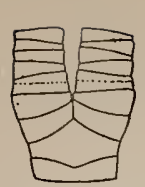

116

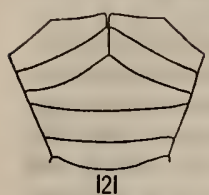

121

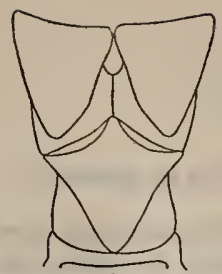

II7

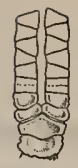

118

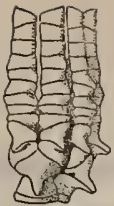

119

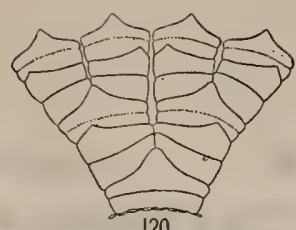

120

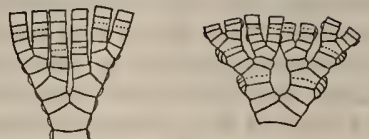

123

122 .

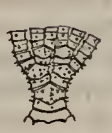

124

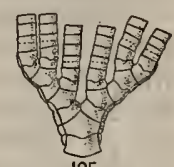

125

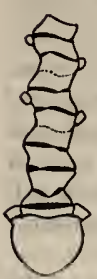

126

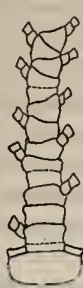

127

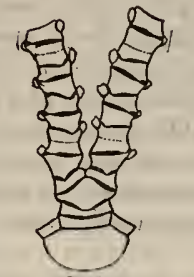

128

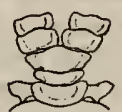

132

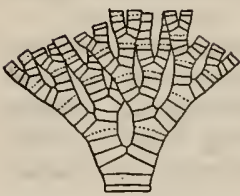

136

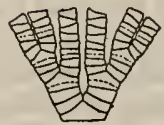

133

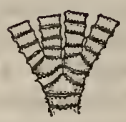

129

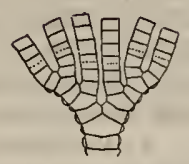

130

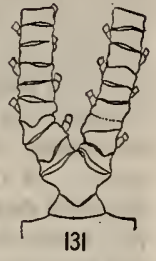

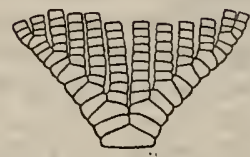

134

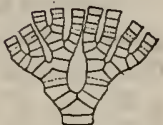

135
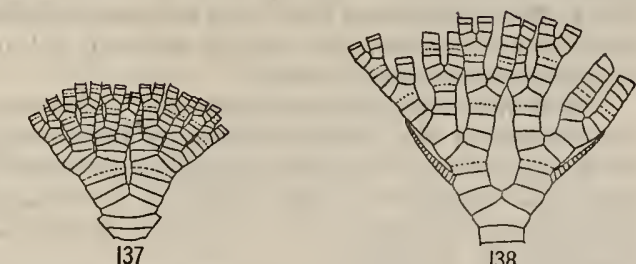

138

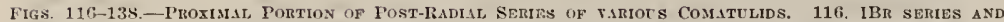
proximal brachIals of Tropiometra afra. 117. Radials, lib series and first two biachials of Psathyometra frithrizon. 118. IBr semies and loter brachials of Pecilomitra scalaris. 119.

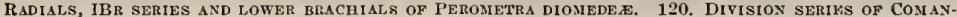
tius trichoptera, 121. Radial and division series of Comatela roralaria. 122. Radial, division SDRIES AND LOWER BRACHIALS OF CEXONETRA UXICURNIS. 123. IBR AXILLART, DIVISION SERIES AND LOWER BRACHIALS OF HideKOMETRA MARTENSI. 124. RADIAL, DIVISION SERIEs AND LOWER BRACHIALS OF STYLO METRA SPINIFERA. 125. DIVISION SHRIES AND LOWEI BRACHISLS OF STEPHANOMETRA ECHINUS. 126. Centrodorsal and aril base of Pentametrocrinus tubercelatus, 127. Centrodolisal and pruxialal

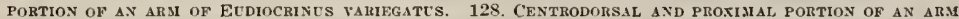
PAir of ThaU Matometra tentis, 129. RADial, division series aNd arai bases of Mariasietra mar.

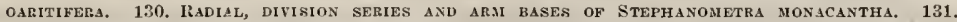
ProxiMal PORTION OF CENTRODORS.LL, IBR SLRIES AND PROXIMAL PORTION OF AN ARM PAIR OF FLOROMETRA PERPLEXA SHOWING, ON THE LEFT ARM BRANCH, AN ADDITONAL FIRST BRACHIAL PAIR OF WHICH THE DISTAL ELEMENT IS NOT AXILLARY. 132. IBR SERIES AND FIRST TWO BRACHIALS OF PCECILOMIETRA SCALARIS, SHOWING AN ADDITIONAL ELEMENT INSERTED BETWEEN THE IBR AND IBR . 133. IBR AXILLARY, DIVISION SERIES AND PROXIMAL BRACHIALS OF A SPECIMEN OF COMANTHUS PARVICIRRA. 134. IBR AXILLARY, DIVISION SERIES AND PROXIMIA BRACHIALS OF ExDOXOCRINUS PARRX. 135. RADIAL, DIVISION SERIES

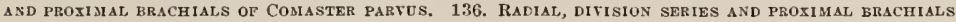
OF ZYGOSLTRA MICRODISCUS, 137. RADIAL, HVISION SERIES AND PROXIMAL DRACHIALS OF COMANTIEHIA

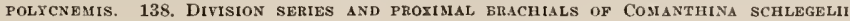


It is in the families Thalassometridæe and Charitometridæ that we find the greatest variability in the number of arms between the component genera, and apparently also in the different species.

In the family Thalassometridæ (figs. $124,145,165,203-225$, pp. 79, 83, 86, 139179) the species of the genera Aglaometra (fig. 225, p. 179) and Stiremetra have 10 arms only, those of the genera Asterometra (fig. 209, p. 149), Thalassometra (figs. 223, 224, pp. 175-177), Daidalometra (fig. 212, p. 153), and Parametra (figs. 217, 218, pp. 163-164), 10 or more, and those of the genera Ptilometra (fig. 204, p. 139, and pl. 53, fig. 1346), Pterometra (fig. 203, p. 137), IIorcometra, Oceanometra (figs. 145, 220-222, pp. 83, 168-173), Stylometra (fig. 219, p. 166, and pl. 53, fig. 1345), Lissometru (fig. 216, p. 161), Crotalometra (fig. 210, p. 150), and Cosmiometra (figs. $213-215$, pp. 155-159), always more than 10, ranging from fewer than 15 in Lissometra to between 20 and 30 in Oceanometra and Stylometra. The division series, however, are always all of two ossicles except in the species of Thalassometra and of the closely related Oceanometra, where the IIBr series are usually, though not always, of four. As the species of Thalassometra may have 10 or more arms it happens that single species are found to be represented by individuals which fall into three of Carpenter's groups, the "Basicurva group," the "Spinifera group," and the "Gramulifera gromp."

In the Charitometridæ (figs. 122, 198, 199, pp. 79, 127, 129) the species of the genera Strotometra (figs. 230-232, pp. 188-192), Pccilometra (fig. 229, p. 186), Charitometra, Chondrometra (part 1, fig. 99, p. 160), and Calyptometra (fig. 676, p. 338 , and pl. 54, fig. 1347) have 10 arms only, those of the genera Perissometra (fig. 227, p. 182, fig. 658, p. 329, and fig. 670, p. 335) and Chlorometra (fig. 228, p. 184) 10 or more, and those of the genera Crinometra (figs. 678-683, p. 338), Crossometra (figs. 226, p. 180, and 673, 675, p. 335), Monachometra, and Pachylometra (figs. 671, 672 , p. 335) always more than 10 , in the case of Crossometra from 26 to 33 ; in this family the IIBr series, when present, are rarely 2 , being almost invariably $4(3+4)$, at least in the majority of cases.

With only two exceptions, outside of occasional sporadic instances, the postradial series of the species belonging to the Macrophreata divide once or, more rarely, not at all, so that the great majority of the forms in this group have 10 arms, two arising from each radial; a few 5 arms, one being borne by each radial; a few 10 arms, one on each of 10 radials; and one 20 arms, two arising from each of 10 radials.

Perometra afra, of the subfamily Perometrinæ, has from 11 to 14 arms with all the division series 2, and the only known specimen of Adelometra angustiradia, belonging in the subfamily Zenometrinæ, has 13 arms with the three $\mathrm{IIBr}$ series present $4,4(3+4)$ and 2 .

In Antedon bifida several specimens with more than 10 arms have been reported, most of these having 11 , and one of them 12 . The IIBr series are usually 2 , but occasionally $4(3+4)$.

In one macrophreate family, the Pentametrocrinidæ (figs. 126, p. 79, and 1016, pl. 6), division series are not developed at all, so that the arms are undivided, 5 or 10 in number according to the number of the radials. These undivided arms 
have nothing in common with the undivided arms in the zygometrid genus Eudiocrinus, in which $\mathrm{IBr}$ series are present as usual, although the second segment is not axillary.

In the Macrophreata there are two instances of a curious and interesting condition which occur in two widely different groups. Promachocrinus, belonging to the Heliometrinæ, and Thaumatocrinus (part 1, figs. 113, 114, p. 181), belonging to the Pentametrocrinidæ, have each 10 radials and consequently 10 post-radial series, resulting in 20 arms in the former and 10 in the latter.

It would seem that this 10-rayed condition is unstable, for several specimens of a species of Thaumatocrimus which I have examined have one or more of the interradial arms absent, a large interradial occupying the position of the normal interradial radial, and of the specimens of Promachocrinus kerguelensis brought home by the Gauss no less than 56 per cent had less than 10 rays, most of them having 6 only and one having 5 ; but no mature specimens of this species have ever been found with less than 10 rays, and the normal pentacrinoids appear to acquire all five additional rays practically simultaneously.

The pentacrinoids of Promachocrinus kerguelensis (figs. 881-937, pp. 533-549) resemble those of related species until a considerable size is reached, when five interradials alternating with the five primary radials make their appearance. These rapidly increase in size and give rise to postradial series in exactly the same way as the original radials; but it is not until almost the full size has been reached that both radial and interradial radials and arms become of the same size and indistinguishable.

Apparently the increase in the number of radials and arms in Thaumatocrinus takes place exactly as in Promachocrinus; and the process described and figured by P. H. Carpenter on the posterior interradial of the young of Thaumatocrinus renovatus is undoubtedly merely the rudiment of the posterior interradial arm.

The so-called interradial radials arising between the primary radials are therefore situated exactly over the basals and are truly interradial in position.

The interradial radials are apparently connected with the radials to their right as viewed from the center of the disk; their skeleton is entirely independent of that of the radial radials on either side, but the ambulacral grooves and associated ventral structures are derived as offshoots from those running to the radial radials to the right. In the case of 6-rayed individuals, therefore, the additional ray is inserted behind the left posterior normal ray, just as in the case of the 6-rayed specimens of Tropiometra picta to be later described (p. 82).

Although in Promachocrinus and in Thaumatocrinus there are 10 radials and postradial series, the basals and infrabasals and the rays of the basal star remain 5 in number.

I once dredged a specimen of II eliometra maxima with 12 arms (fig. 164, p. 86, and pl. 54, fig. 1348), two postradial series arising from a partially divided radial, and P. H. Carpenter has recorded a specimen of Neocomatella pulchella in which there were six postradial series, two of them originating on an enlarged and axillary radial. These may represent a step toward the conditions found in Proma- 
chocrinus and Thaumatocrinus, though it is more probable that they are merely cases of the radial assuming the characteristics of its subsequent reduplications, the axillaries.

It occasionally, though rarely, happens that individuals occur with six radials and six postradial series. Such cases are usually sporadic, and instances have been recorded in a number of widely separated groups.

Among 340 specimens of Tropiometra picta from Rio de Janeiro which I examined at the Museum of Comparative Zoölogy at Cambridge, Massachusetts, no less than 17 , or 6 per cent, were 6-rayed, though among the hundreds of specimens of other species of this genus which I have studied I never found one with more than five rays.

These 6-rayed specimens are all but one of comparatively small size, the diameter across the outstretched arms being between $100 \mathrm{~mm}$. and $120 \mathrm{~mm}$., the exception having an expanse of $190 \mathrm{~mm}$. and being the only one sexually mature; normal specimens of this species average between $230 \mathrm{~mm}$. and $270 \mathrm{~mm}$. in expanse.

An examination of the disks of 12 of the specimens (figs. 729-733, p. 346) shows that in three cases it is quite impossible to determine which is the extra ray, as there are six ambulacral groove trunks converging toward the mouth all exactly alike; one specimen has the interpolated ray between the two on the left side, one has it behind the right posterior, while seven have the extra ray inserted behind the left posterior.

In the Challenger report P. H. Carpenter mentions a small dry 6-rayed "Antedon" in the collection of the British Museum. Suspecting that it was probably an example of this species, and also that it cane from Brazil, I wrote to Prof. F. J. Bell for information concerning it. He very kindly replied that it was, as I had surmised, a Tropiometra, but that there was no record of the locality whence it had come.

These 6-rayed specimens of Tropiometra picta a re 6-rayed throughout, possessing a 6-rayed rosette and basal star (part 1, fig. 480, p. 363), in contrast to the conditions found in Promachocrinus and in Thaumatocrinus, where the rosette and the basal star are both 5 -rayed.

Tropiometra picta is an extraordinarily variable form, its peculiarities being such as to suggest that the very large proportion of 6-rayed individuals is not an inherent character of the species but is merely on a par with the relative number of individuals aberrant in other equally noteworthy ways.

Among the recent stalked crinoids the two species of the genus Rhizocrinus, $R h$. lofotensis and $R h$. verrilli, are very variable in the number of their rays. Among 75 specimens of $R h$. lofotensis, Sars found found 43 with 5 rays, 15 with 4 rays, 15 with 6 rays, and 2 with 7 rays. In the related genus Monachocrinus (fig. 179 . p. 91, and part 1, fig. 122. p. 203) one species $M$. sexradiatus (fig. 179, p. 91), is only known with six rays, but of the species in the other living genera of Bourgueticrinide, Bathycrimus, llycrinus, Bythocrinus (part 1, fig. 131, p. 203), and Democrinus (part 1, fig. 133, p. 203), all appear to be 5-rayed without any deriation, specific or individual. In Monachocrinus sexradiatus the basals are five in number. In the two species of Rhizocrinus it has never been determined 


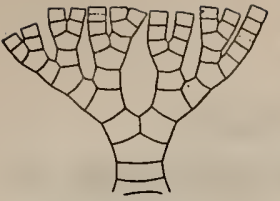

139

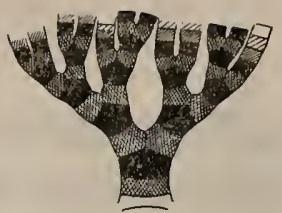

140
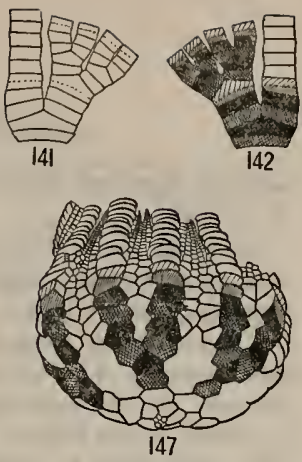
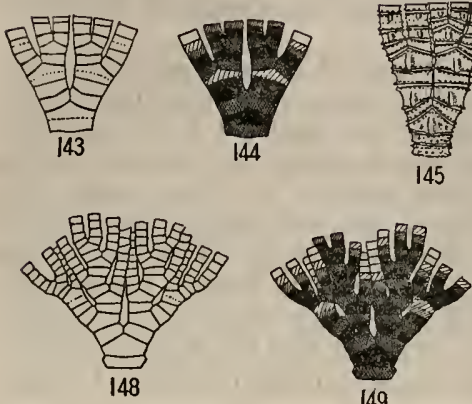

149

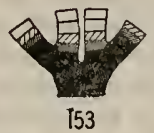

152

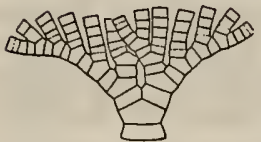

156
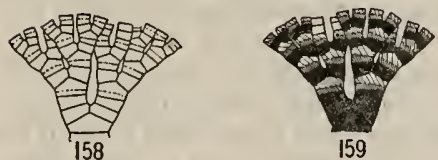

159

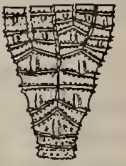

145
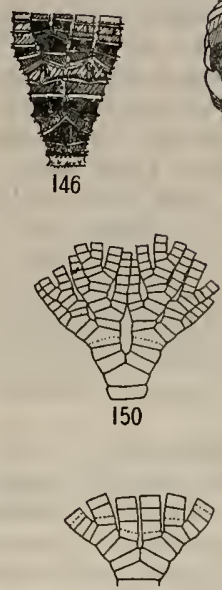

154
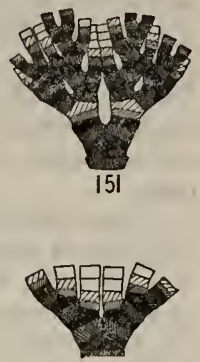

155
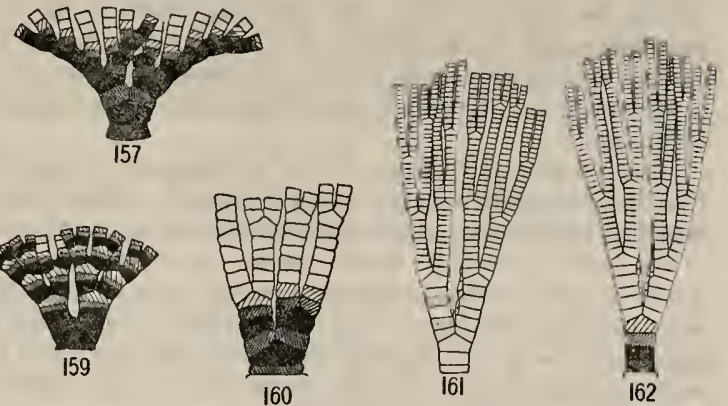

160

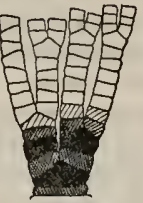

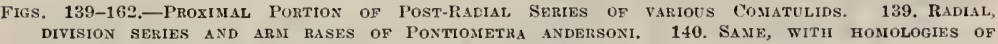
OSSIClES INDICATED. 141. DIJISION SERIES AND PROXIMIL DRACHIALS OF CRASTEDOMETRA aCUTICIMRA. 142. SAME, WITIF HOMLLOGIES OF OSSICLES INDICATED, 143. DIVISION SERIES AND ARM

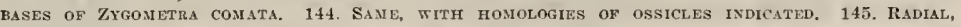

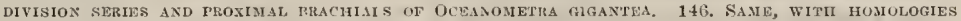
OF OSSICles INDiCATED. 147. PLATES OF BASE AND OF POST-RADIAL SERIES OF URNTACRINUS SOCIALIS, WITH HOMOLOGIES IXDICATED (ADAPTRD FROM SPRINGER). 14S. MIVISION SERIES AXD ARM BASES

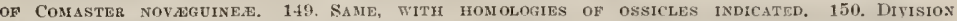
SERIES AND ARM BASES OF ANOTHFi, SPECIMEN OF COMASTER NOVAGUINE.E. 151. SAME, WITH HOMOLOGIES OF OSSICLES INDICATFD. 152. DIFISION SERIFS AND ARM BASES OF COMATELIA MACULATA. 153. SAME, WITH HOMFLlgies OF OSSICles INDICATED, 154. DIVISION SERIES AND ARM BASES OF

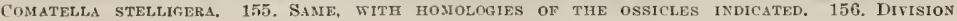
SERIES AXD ARM BASES OF COMATELLA NIGRA. 15T. SAMF. WITH HOMOLOGIES OF OSSICLES INDICATED. 158. DIVISION SERIES AND ARM BASES OF CAPILlASTER SENTOSA, 159. SAME, WITH HOMOLOGIES OF OSSICLES IXDICATED, 160. DIVISION SERIFS AXD ARM BASES OF ISOCRINUS DECORES, WITH FOMOLOGIES

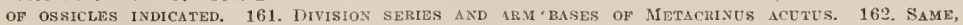
WITH HOMOLOGIES OF OSSICLES INISITED. 
whether there are always five basals, or whether the basals agree in number with the radials.

Among the remaining recent stalked crinoids specimens with more than five rays are practically unknown, though $I$ have at hand an example of Metacrinus rotundus with eight rays and six basals.

A number of 4-rayed specimens have been reported in widely separated comatulid groups. There is no suggestion that their occurrence is anything but fortuitous. In all cases where the missing ray has been identified it is the anterior.

Only in the littoral fauna of the warm seas do highly multibrachiate species with more than 40 arms occur, and the great majority of all the species with more than 10 arms are found only in tropical and subtropical regions within 100 fathoms of the surface. A number of the genera characteristic of intermediate depths in water of moderate temperatures belonging to the families Calometridæ, Thalassometridx, and Charitometridæ include species with between 15 and $30 \mathrm{arms}$; but in the deep-sea and in cold water species with more than 10 arms are very rare, and specimens with from 11 to 13 arms are usually variants of normally 10-armed types.

Since the periphery of the disk always reaches the level of the second brachials of the free undivided arms, it is evident that, as the elements of the division series are always of approximately the same relative size, the number of arms is more or less strictly proportionate to the volume of the visceral mass, and the larger the visceral mass proportionately, the greater the number of arms. Furthermore, a very large number of arms is usually correlated with additional coils in the digestive tube. But since the length of the individual arms decreases proportionately to the number of arms present, due to a reduction both in the number and in the length of the component brachials, the food-collecting surface in 10 -armed and in multibrachiate types of the same actual size can not be greatly different.

An obvious advantage of the multibrachiate condition for such species as inhabit the tropical littoral is that in case of accident from storms or other causes resulting in the loss of arms much less damage proportionately would be done than in the case of 10-armed forms, for in one of the latter the loss of a single arm would decrease the food-collecting ability 10 per cent, while with a species with 150 arms 15 arms would have to be lost to cause a comparable amount of injury; and since the arms of the 10-armed types are relatively much longer than those of the multibrachiate forms, the lesser radius of the latter enables them to escape many blows which would injure the former.

It is probably that the multibrachiate condition owes its origin or its perpetuation to some factor in the ecology of the tropical littoral comatulids which does not in like degree affect those living in deep or cold waters, and this factor very possibly has to do it with an excess of regetable plankton and silt in the food which would require for its assimilation an enlarged digestive system, necessitating an enlarged visceral mass.

The solubility of calcium carbonate $\left(\mathrm{CaCO}_{3}\right)$, of which the skeletons of the crinoids are chiefly composed, increases with the decrease in the temperature of 
the water. It is because of this that lime-depositing organisms are more abundant in the warmer than in the colder waters, and that the lime deposited by organisms in the warmer regions is incomparably in excess of that laid down in colder.

Promachocrinus and Thaumatocrinus both inhabit water which is cold, abnormally cold for species of their respective groups, yet abounding in available food, and it may be that, through the relative difficulty in extracting the necessary lime from solution in the regions where they live, the formation of the skeleton can not keep pace with the growth of the visceral mass, this tending to render more difficult the closure of the radial circlet and permitting, or even inducing, the formation of the interradials upon which the interradial postradial series eventually are formed. It is worthy of note in this connection that the related genera Solanometra and Anthometra which occur with Promachocrinus, as well as other unrelated genera, exhibit marked features which may be logically attributed to cold. In Solanometra all the skeletal elements are abnormally short, just as in many other species occurring in water abnormally cold for their groups, in Comatulella brachiolate (part 1, fig. $7 \tau$, p. 130, and pl. 50, fig. 1332) and in Antedon petasus (part 1, fig. 103, p. 165 ; compare with figs. 105 , p. 169 , and 106 , p. 171), for example, and in Anthometra the radials and postradial series remain spinous and carinate, never assuming the mature smooth form. Florometra comes nearest to the normal type from which Promachocrinus, Solanometra, and Anthometra are derivatives.

The number of postradial ossicles or brachials in each linear series beyond the outermost axillary is usually from 150 to 180 , though in certain genera, such for instance as Asterometra (figs. 206, 207, 209, pp. 143, 145, 149, and part 1. fig. 94, p. 155) and Ptilometra (fig. 204, p. 139, pl. 53, fig. 1346, and part 1, fig. 93, p. 153), there may be as few as 70 , and in certain others, such as Heliometra (fig. 233, p. 193), Florometra, and the larger comasterids as many as 270 , or even nearly 300 . In the fossil Uintacrinus, which has excessively elongated arms, the number is vastly greater. P. H. Carpenter counted 140 in an arm of Antedon bifida 4 inches long.

The shape of the brachials, as seen in a dorsal view, varies from triangular with the length equal to the width through wedge-shaped to oblong with a width of many times the length, or with a length of many times the width and more or less strongly incurved sides.

The first syzygial pair, composed of the third and fourth brachials, is ordinarily rectangular; occasionally, however, it is more or less wedge shaped and, when this is the case, the inner side is longer than the outer. Only in rare instances, as in Atelecrinus (part 1, figs. 123, p. 192, and 124, 125, p. 193), is the additional inner length distributed equally on the hypozygal and on the epizygal. Usually it is confined mostly, or even entirely, to the epizygal, which becomes very obliquely wedge shaped or triangular, the hypozygal remaining nearly or quite oblong.

Typically in 10-armed forms the anterior sides of the axillaries are slightly concave and the two chords of these concave sides meet at the anterior angle in such a way that this measures about $90^{\circ}$. In certain cases, usually correlated with a similar production of the interradial angles of the radials, the anterior angle 

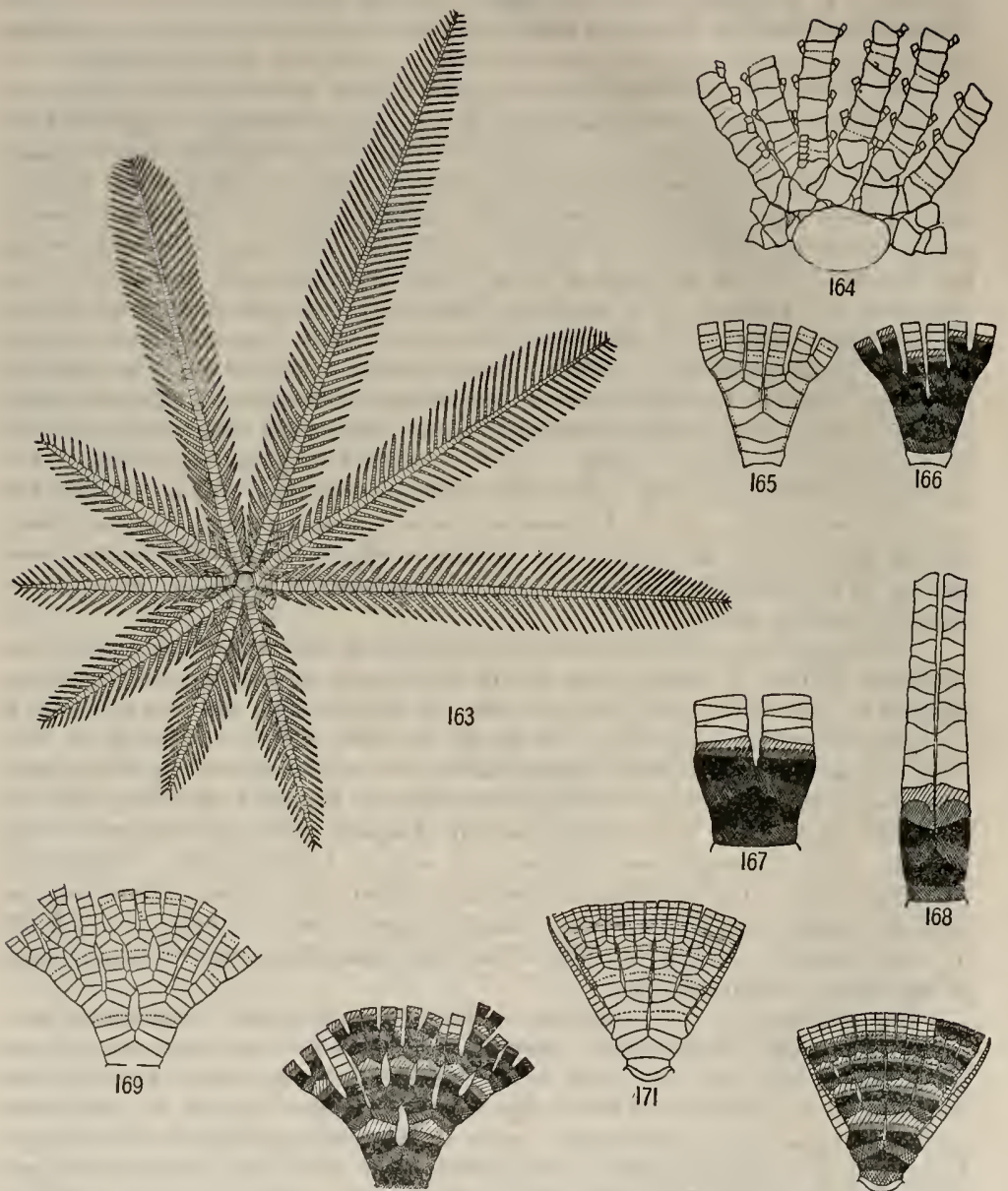

170
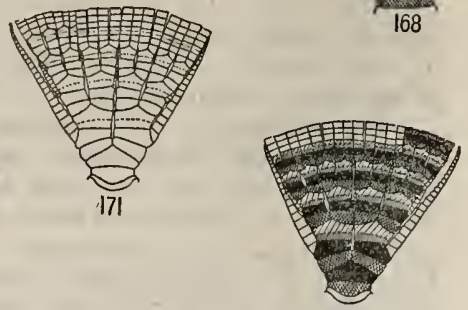

Figs, 163-172.-Figures illustrating ara structuie of Comatulids. 163. Dons.le view of

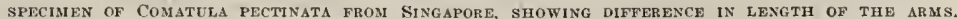

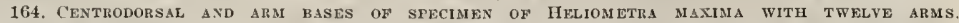
165. RADIAL, DIVISION SERIES AND ARM BASES OF PTILOMETRA MÜLLERT. 166. SAME, WITH HOMOLOGIES OF OSSICles SHOWN. 167. IBR SERIES AND PROXIMAL BRACHIALS OF TROPIOMETRA AFRA, WITH HOMIOLOGIES OF OSSICLES INDICATED (SEE FIG, 116), 168. PROXIMAL PORTION OF AN ARM PAIR OF IIYPALOCRINUS NARESIANUS, WITH HOMOLOGIES OF OSSICLES INDICATED. 169. IBr AXILLARX, DIVISION SERIES AND PROXIMAL PRACHIALS OF COMLANTHERIA ALTERXANS, 170. SAME, WITH HOMOLOGIES OF OSSICles INDICATED. 171. RADIAL, DIVISION SERIES AND PROXIMIL BRACHIM.S OF COMANTHES BEXNETTI. 172. SAME, WITH HOMOLOGIES OF OSSICLES INDICATED. 
may be narrowly produced, so that lines drawn from its tip to the outer ends of the anterior sides of the axillary make considerably less than a right angle with each other. Increase in the breadth of the arm bases, because of the slight curvature of the anterior sides of the axillary, always broadens out the anterior angle, which may become broadly obtuse and, through the gradual approximation of the distal articular faces of the axillary and those of the first postaxillary ossicles, may come to have nearly or quite straight sides. When there are several axillaries in a single postradial series the anterior angle becomes progressively more and more acute from the proximal outward.

In four comatulid genera, Eudiocrinus (figs. 189-191, pp. 109-112), Thaumatocrinus (part 1, figs. 113, 114, p. 181), Pentametrocrinus (part 1, figs. 119, p. $185 ; 120$, p. 187; and 121, p. 189), and Atopocrinus, the arms do not divide at all. In the majority of cases there is a single division, which is invariably on the second brachial; if subsequent divisions occur they consist normally always of two or four ossicles, excepting only in the genera Capillaster and Nemaster (figs. 180-182, pp. 92-96), in which in the third and following divisions the first element in the series of four is absent.

In the multibrachiate species the amount of division of the series of ossicles following each of the five radials is as a rule approximately the same, especially if the divisions be numerous; thus if a specimen of Comaster novaguinece be found to have eight division series following one radial, it will be found to have eight following the other four also; or if an example of Mariametra subcarinata be found to have three division series following one of the radials, it will have three following all the others. Also it is generally true that both derivatives of the first division series and all the branches arising from them or their successors divide exactly the same number of times, or, if the number of divisions be exceptionally large, approximately the same number of times.

Among certain species there is a tendency for each postradial series, after dividing once, to divide a second time, but only on one side. When perfectly developed this method of division would result in the formation of 15 arms, 3 borne upon each radial; but it is seldom that all of the postradial series are equally developed. In Comatula, Ncocomatella, Capillnster, Nemaster, Catoptometra, Craspedometra, Heterometra, and especially in Ptilometra, Asterometra, Thalassometra, Parametra, Glyptometra, Chlorometra, Perissometra, and Pachylometra, there are species which when adult may have anywhere from 10 to 15 arms, the second division series being developed on only one side of from one to all five of the first division series. This condition has also been noted in Antedon bifida and in Tropiometra picta. I have been unable to find any definite sequence in the place of appearance of these additional arms. In some of these species the number of arms frequently rises above 20 , in which case we usually find that the second division series are developed one to each postradial series until the number of arms rises to 15 , when the remaining second division series one by one appear, the whole series of the second division being completed before the appearance of any of the divisions of the third series. 
In many species of Heterometra, in C'raspedometra acuticirra, and in Stephanometra tenuipinna the adults are often exceedingly variable in regard to the disposition of their division series beyond the first; whereas one or more of the postradial series may divide as many as four times, others may divide only once, so that, while one or two radials may support from 4 to 8 or even $10 \mathrm{arms}$, the others may bear no more than 2. I have endeavored to trace out the radials in which this excess of vegetative power is most developed, and for this purpose have gathered data from scores of specimens; but an examination of the data taken from endocyclic species shows that excess of vegetative power may be displayed by any one of the radials indiscriminately, though there is some indication that if one postradial series divides an abnormal number of times its fellow is likely to be similarly modified. Bateson's specimen of Antedon bifida with palmate arms is an interesting example of this. In Comanthus parvicirra P.H. Carpenter has found that when the arm division is unequal it is usually carried farther on the so-called posterior radii, $\mathrm{C}, \mathrm{D}$, and $\mathrm{E}$, than on the anterior radii, $\mathrm{A}$ and $\mathrm{B}$; and this appears to be a more or less general rule throughout the Comasteridæ.

In many species of the genera Craspedometra, Heterometra, Thalassometra, Perissometra, Pachylometra, and Crinometra, in Zygometra comata and Stylometra spinifera, and more rarely and irregularly in certain species of Comanthus and Capillaster, there is ordinarily a third division series developed on the inner branch of each of the second division series, the counterpart of which is absent from the outer (fig. 226, p. 180). Excepting only in Stylometra spinifera (fig. 219, p. 166) this condition is only found in species which have the second division series consisting of four ossicles, and the added division series is always of two ossicles. In species in which this arrangement is the rule there are occasionally developed, excepting in Stylometra spinifera, external third division series, these usually consisting of four ossicles like the second division series instead of being composed of two like the internal. In the species of the genus Himerometra (fig. 123, p. 79), which have very numerous arms, but which belong to a family in which the majority of the species typically have 30 arms as a result of each postradial series dividing three times internally and twice externally, this peculiar arrangement has become fixed. All of the third division series are always present, but the two internal are almost invariably 2 , the two external always $4(3+4)$. There are commonly one or two division series present beyond the third, and it is interesting to note that, in spite of the great number of arms, the family character shows itself in the almost invariable occurrence of one more division series on the innermost branch from each of the second division series than is found on any of the other branches. The many-armed species of Zygometra (fig. 136, p. 79) hold the same relation to $Z$. comata (fig. 143, p. 83 ) that Himerometra does to Craspedometra and Heterometra, although usually it is not quite so easily seen; but it is curious that nothing of the kind is observed in the closely allied Catoptometra.

In Comatella (figs. 154, 156, p. 83). Cenometra (fig. 122, p. 79), Cyllometra, Ptilometra (figs. 165, 204, p. 86), Pterometra (figs. 203, 208, pp. 137, 146), Asterometra, Stephanometra (figs. 125, 130, p. 79), Pontiometra, Dichrometra, Lamprometra, Mariametra, Parametra, and Cosmiometra (fig. 214. p. 157), and in several 
of the genera of the Calometridæ, one, or even two or three, more division series are developed externally than internally. This arrangement is rather more stable in the species in which it occurs than that just discussed, and is definitely characteristic of many forms, while very frequent in others. The additional external

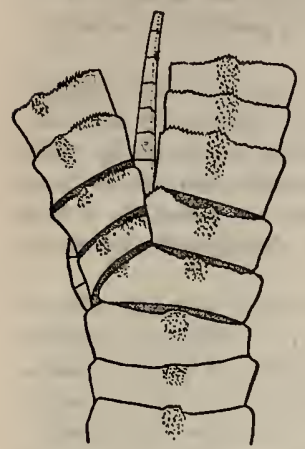

173
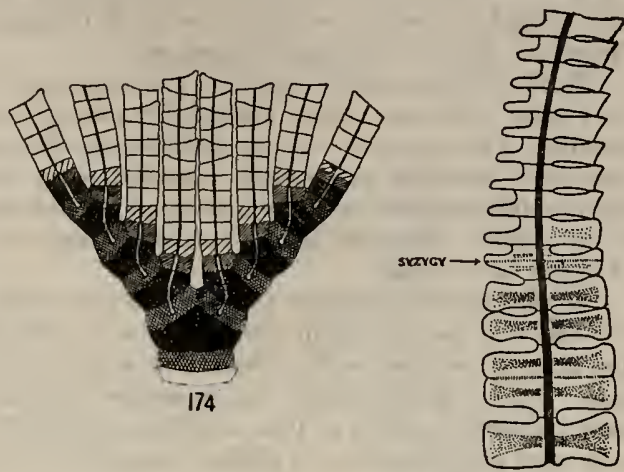

175

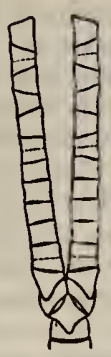

176

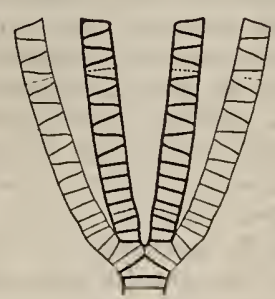

177

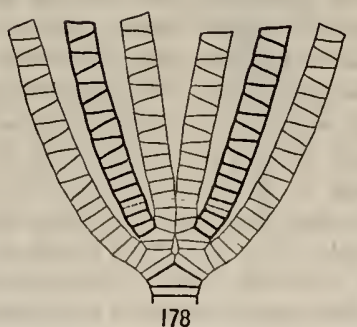

178

Figs. 173-178.-Figures illustrating ara strocture of comatulids, 173. Distal aris division in SPECIMEN OF Tropiometra picta From Rio dE JANeiro (DRAWING BY AOTHOR). 174. DiagraM ILLOSTRATING HOMOLOGIES OF POST-RADIAL OSSICLES IN GENUS COMIATELLA. 175. LONGITUDINAL SECTION THRODGH DIVISION SERIES AND BASE OF ARM IN HIMEROMETRA MARTENSI. 176. SiNGLE ARM PAIR OF $A$ 10-ARMED COMATULD. 177. BASE OF POST-RADAL SERINS OF a 20-ARMED COMATULID SHOWING, HEAVILY ODTLINED, OSSICLES HOMOLOGIES WITH THOSE OF A 10-ARMED SPECIES, 178. BASE OF POST-RADIAL SDRLES OF A 30-ARMED COMATULID SHOWING, HEAVILI OUTLINED, OSSICles hoMOLOGOUS WITH THOSR OF A 10- $\triangle R M E D$ SPECLES.

division series, like the additional internal just considered, are always composed of two elements, but, contrary to what was found to be the rule in that case, they are never dereloped except in species having all the division series of two elements.

The reason for the normal occurrence of additional division series externally-that is, along the outer branches arising from the IIBr axillaries-is 
easily seen. I have elsewhere given reasons for believing that of the arms arising from the IIBr axillaries those which are external are phylogenetically more advanced as they are more perfected than those which are internal. This holds good, of course, for all the derivatives from these axillaries. It is therefore to be expected that the outer branches, being phylogenetically more advanced, will be more subject to division, exactly as we see is the case in such genera as Comatella, Cenometra, Ptilometra, Endoxocrinus, etc.

In the Himerometridæ and in certain zygometrids, as just explained, exactly the reverse is the case; there are usually more division series internally than externally. This also is to be expected, for the Himerometridæ, as shown by their very short brachials and curious pinnulation, are retrogressive derivatives from highly multibrachiate stock, and we should therefore assume the retention of this multibrachiate character longer internally than on the phylogenetically more advanced outer arms.

In the genus Comanthina (fig. 138, p. 79) the third division is normally of both two and four ossicles, as in Himerometra, but the order in which they occur in that genus is reversed, so that the IIIBr series are 2 externally and $4(3+4)$ internally. On the left posterior ray, sometimes on both posterior rays, the arrangement commonly reverts to that of Himerometra, $4(3+4)$ externally and 2 internally, and may later be still further simplified by the reduction of all the series of four ossicles to two.

In the larger species of the genus Comaster, as Comaster novaguinex (figs. 148,150, p. 83 ), the first division series gies rise to two similar branches as usual; the second division series, however, bear undivided arms externally and third division series internally, the third division series bear undivided arms internally and fourth division series externally, and so on, this alternation sometimes continuing for eight or nine division series. The resulting appearance is as if each second division series gave rise to two stout main trunks, each of these trunks giving off arms on alternate ossicles, first on one side and then on the other, and finally terminating in a pair of arms themselves. The first arm is always given off externally from the main trunk, so that the arrangement of the arms along the trunk is exactly like the arrangement of the pinnules along one of the terminal undivided arms, excepting only that the arms are given off from alternate ossicles, whereas the pinnules occur on every ossicle; but as the ossicles of the division series are united by nonmuscular articulations, the arrangement of the arms is precisely what the arrangement of pinnules would be on an arm with every alternate articulation a syzygy.

In the smaller species of Comatella the second division series always gives off internally an undivided arm and externally a third division series (fig. 154, p. 83). When a fourth division series is present it is always given off from the outer side of the third division series, the inner derivative of the third division series remaining undivided. In Comatella nirra (fig. 156, p. 83), which may have six or seven division series beyond the radials, the same peculiarity is found, but it begins with the second division series instead of with the first, so that the axillary of each second division series gives rise to two main trunks, each 
of which gives off internally, on every alternate ossicle, an undivided arm, eventually terminating in a pair of arms which, contrary to the case in Comaster, are not quite alike. In their method of division the arms of the species of the genus Neocomatella agree with those of the smaller species of the genus Comatella.

In the genera Capillaster (figs. 180, p. 92, and 181, p. 94) and Nemaster (fig. 182$, p. 96$)$ the division series beyond the second are always $3(2+3)$, this type being derived from the more usual $4(3+4)$ by the omission of the first ossicle.

The arms usually taper evenly and gradually from the base to the tip, but often they slowly increase in size from the base to the twelfth or fourteenth brachial and from that point slowly taper to the extremity; this condition is especially prevalent in the Oligophreata, though more or less characteristic of many of the more specialized of the macrophreate forms, such as Antedon petasus or Heliometra glacialis. It is commonly correlated with the degree of recumbency of the radials, reaching its extreme form, in the recent comatulids, in those comasterids in which the radials lie horizontally. It is particularly well seen in Comatulella brachiolata (part 1, fig. 77, p. 130; pl. 50, fig. 1332), Comatula rotalaria, and $C$. solaris, though almost equally well marked in many other types (fig. 184, p. 100).

In a number of recent comatulids, most marked, perhaps, among the species of Comactiniinæ, the arms are so swollen in their lower portion that the brachials do not reach entirely across them but terminate in a point somewhere between the median line and the outer margin. This is not due to a persistence of the original biserial arrangement, as might appear at first sight, but instead, as is shown by the development of the individual, is a purely secondary condition, a sort of pseudo-biserialism. In the very young brachials the proximal and distal edges are strongly oblique, and one of the lateral edges is much longer than the other, so that in dorsal view the brachials appear to be trapezoidal in shape;

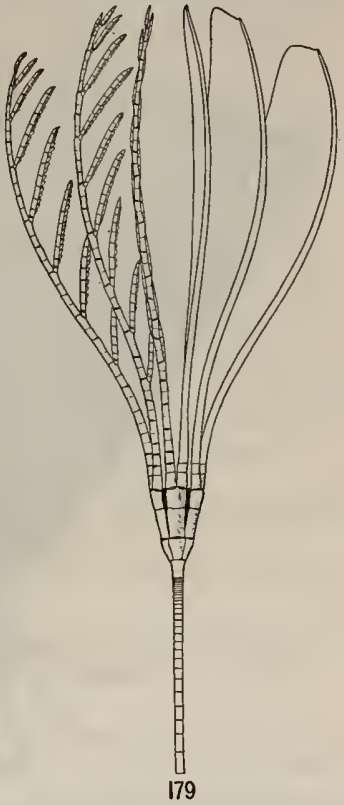

Fig. 179.-Crown $\triangle$ ND PBOXIMAL PORTION OE COLUMN OE SPECIMEN OF MONACHOCRINUS SEXRADIATUS. during growth material is added on each lateral border. As the ends always maintain their original obliquity, addition of calcareous matter on the lateral borders causes the longer side to become still longer and the shorter side to become still shorter until it finally becomes a point beyond which the horizontal (transverse) suture line between the proximal border of the succeeding and the distal border of the preceding brachials runs to the edge of the arm.

Usually, and always in the endocyclic species, all of the arms in a single specimen are just alike, or at least the various arms arising from each radial 
are exactly like the corresponding arms arising from all the other radials. But in certain of the comasterids the arms arising from the one, two, or three posterior radials are modified in various ways and have become curiously specialized, so that they are no longer strictly comparable to the more primitive arms arising from the one or two anterior radials (fig. 163, p. 86).

As noticed by P. H. Carpenter these posterior arms (part 1 , fig. $45, b$, p. 79 ) differ in numerous particulars from the anterior arms (part 1, fig. 45, $a$, p. 79). These latter taper very slowly, contain far more numerous brachials, and are much

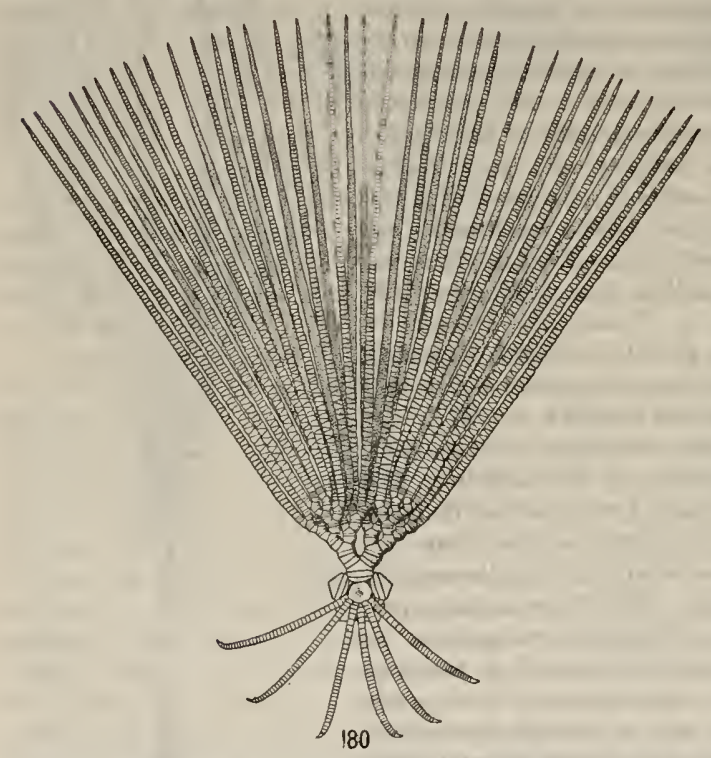

Fig. 180. Central PORTION AND ONE POST-RADIAL SERIES OF SPECIMEN OF Capillaster sentosa from "Albatross" Station 5166. longer than the former, while the form of their terminal portions and of the pinnules which they bear is altogether different (figs. 1034, 1035, pl. 12). When viewed from the dorsal side the basal portions of the two kinds of arms are precisely similar: they widen slightly between the first and second syzygies, remaining uniform until the third syzygy, after which they begin to taper. Up to about the twenty-fifth or thirtieth segment the anterior and the posterior arms decrease in width at about the same rate, but from this point onward there is a great difference between them. The arms borne by the anterior radials taper very slowly, the length of their segments increasing considerably while the breadth only diminishes very gradually; at the same time the middle and terminal pinnules in which no gonads are developed become very long and filiform and remain so until the last few brachials, when their length suddenly diminishes very considerably. The extreme end of the arm is a growing tip, continually, though very slowly (the rate decreasing with the age of the individual), giving rise to new brachials, in every way similar to the growing tip of very young arms, or to the growing tip of the arms of Antedon bifida as described by W. B. Carpenter (fig. 1035, pl. 12). 
With the posterior arms of many of the comasterids the case is quite different. From the twenty-fifth brachial onward they taper very rapidly, and in Comanthus parvicirra, instead of reaching a length of $145 \mathrm{~mm}$. as the anterior arms with some 150 brachials may do, they have only some 80 brachials, and rarely attain a greater length than $60 \mathrm{~mm}$. or $70 \mathrm{~mm}$. At the same timc thcir terminal pinnules are little, if at all, longer than those of the middle portion of the arm, and the center of the dorsal half of each of their segments is occupied by a dark brown, egg-shaped body of a peculiar cellular nature, a so-called spherode, which Carpenter was inclined to consider a sense organ (fig. 1034, pl. 12). The pinnules of the last few segments decrease very slowly in size, and the arm ends in an axillary which bears two pinnules of the ordinary character, each provided with the brown ovoid bodies or spherodes (part 1, fig. 47, p. 81).

Between these two kinds of arms, the long anterior with a wide ambulacral groove and a well-developed respiratory apparatus (fig. 1038, pl. 12) and the short posterior with a closed groove and no external respiratory apparatus (fig. 1037, pl. 12), all possible forms of transition occur.

In Comanthus parvicirra, as a general rule, more or fewer of the anterolateral arms, $\mathrm{C}_{1}$ and $\mathrm{E}_{2}$, are tentaculiferous, but they never reach such a great length as the anterior arms, and their terminal pinnules are by no means so long and slender. At the same time the posterolateral arms, $\mathrm{C}_{2}$ and $\mathrm{E}_{1}$, although generally nontentaculiferous, have, except in rare cases, a more or less open groove for the greater part of their length, which, while greater than that of the posterior arms of the radius $D$, is less than that of the anterolateral arms $C_{1}$ and $E_{2}$, and their pinnules increase slightly in length from the middle until near the end of the arm.

Carpenter thus classifies the arms of Comanthus parvicirra:

Anterior, on radii $\mathrm{A}$ and $\mathrm{B} ; 120-150$ brachials; pinnules increasing in length to the terminal, which are very long and slender; tcntaculiferous.

Anterolateral, on $\mathrm{C}_{1}$ and $\mathrm{E}_{2} ; 100-120$ brachials; terminal pinnules long and slender; tentaculiferous.

Posterolateral, on $\mathrm{C}_{2}$ and $\mathrm{E}_{1} ; 80-100$ brachials: terminal pinnules stout and rather longer than the middle pinnules; pinnules usually with spherodes and narrow ambulacral grooves, but nontentaculiferous.

Posterior, on radius D; $60-80$ brachials; terminal pinnules stout, but shorter than the middle pinnules; spherodes are present; usually no ambulacral grooves; nontentaculiferous.

Carpenter noted that another difference between the anterior and the posterior arms is that the gonads on the latter are far more developed than those on the former; not only is their number greater, although the total number of pinnules on a posterior arm may not be much more than half that on an anterior arm, but they attain a very much greater size, the proximal and middle pinnules of an anterior arm being very much less swollen than the corresponding pinnules of a posterior arm.

In larger species of Comasteride Carpenter noticed that sometimes all the arms might be grooved and bear tentacles, yet the posterior might be considerably shorter than the others. In one species he noticed that, though all the arms are 
equal and grooved, the distribution of the syzygies is quite different on the posterior arms.

In the species of Comasteridæ possessing grooveless arms it is usually only the two posterior rays which carry them, but in large species with very numerous arms a number may be found on each ray. In Comanthus parvicirra from the Philippine Islands Carpenter found that the distribution of the ungrooved arms, as well as their number, varies to a very great extent. He notes that in any case they always occur on the odd (left) posterior radius, D; when more are developed they may occur on the posterior divisions, $\mathrm{C}_{2}$ and $\mathrm{E}_{1}$ of the two lateral radii, $\mathrm{C}$ and $\mathrm{E}$;

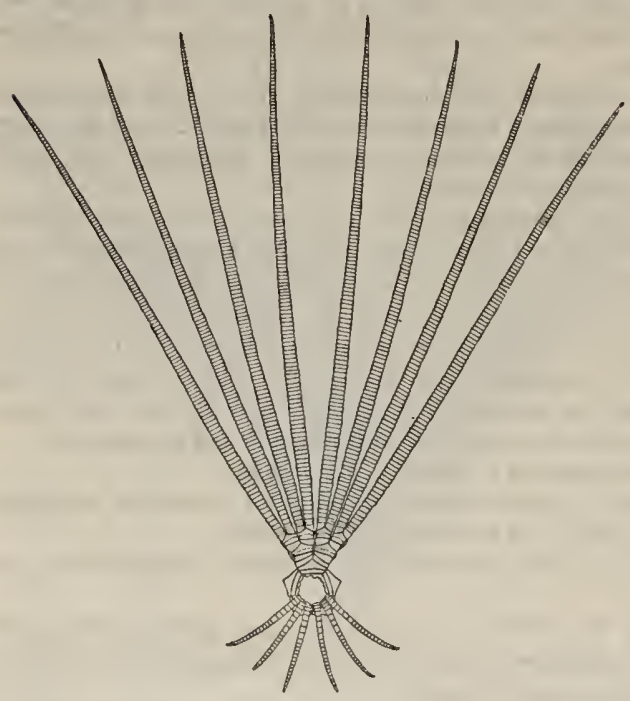

181 and when the proportion of nontentaculiferous to tentaculiferous arms becomes very great, more or fewer of the anterolateral arms $\mathrm{C}_{1}$ and $\mathrm{E}_{2}$ belong to the former class, while in exceptional cases nontentaculiferous arms may even occur on the anterior radii.

In only one individual did Carpenter find a nontentaculiferous arm on one of the two anterior radii. In this specimen out of 31 arms 19 were entirely devoid of a tentacular apparatus, and in 15 of these the fusion of the two sides of the ambulacral grooves had taken place either on the disk or on the proximal brachials, so that an ambulacral nerve was wanting in nearly half of the total number of arms. In the other four nontentaculiferous arms the groove remained open for

Fig. 181. - Central portion and one post-radial semies of specimen of Capillaster meltiradiata from "Albatross" Station 5139.

a short distance and then closed in the usual manner. Three of these four arms constituted the anterior division $\left(\mathrm{E}_{2}\right)$ of the left lateral ambulacrum, but the fourth was the first arm of the left anterior ambulacrum, and was borne upon the same IIIB $\mathrm{r}$ axillary as a well-developed ordinary tentaculiferous arm.

In some specimens of Comanthus parvicirra Carpenter found that the arms are all alike in possessing open ambulacral grooves fringed with crescentic lappets and groups of tentacles.

In Comatula solaris he found that the arms may be all grooved, or anywhere from one to four may be nontentaculiferous. 
In Comatula pectinata all the arms may be grooved, or from one to six may be ungrooved; and the same is true in $C$. micraster, though in this little species the a verage frequency of ungrooved arms is rather higher than in $C$. pectinata. In both these species the difference in length between the grooved and the ungrooved arms is often very great, the former being sometimes as much as three times as long as the latter (fig. 163, p. 86).

In the multibrachiate species the character of the division series giving rise to these ungrooved arms is commonly different from that of the division series supporting the ordinary grooved arms, this difference being in the direction of greater simplicity of structure evidenced by the general substitution of division series of two elements for those ordinarily of four. Sometimes in those species in which, as in Comanthina schlegelii and Comaster belli, the IIIBr series are normally $4(3+4)$ internally and 2 externally, there is a reversion of this order on the posterior arms, the arrangement here being then 2 internally and $1(3+4)$ externally, an arrangement duplicated in Himerometra and in the very many armed species of Zygometra.

The radials from which these modified arms arise are sometimes dwarfed, though usually they appear to be no different from the others. The length and thickness of the division series is, however, often considerably less (fig. 1017, pl. 7 ). This diminution in size is not gradual, but very sudden, so that the ossicle following the radial appears disproportionately small, as if the postradial series had been broken off at the radial and subsequently regenerated.

Ludwig noticed that the terminal segments of the arms and pinnules of Heliometra glacialis are devoid of ambulacral grooves, and P. H. Carpenter found that this obliteration of the ambulacral grooves is brought about by the approximation and fusion of the elevated folds of perisome at their sides, correlated with a loss of tentacles and associated structures, just as in the Comasteridæ, the only difference being that it takes place much farther from the disk.

Within the same or closely related species the proportionate length of the brachials and arms is to a large degree correlated with the proportionate length of the cirrals and of the cirri. This is well illustrated by such species as occur in localities where the temperature and salinity are above or below that ordinarily or typically normal for the genus or family. Thus in the warm Adriatic and Mediterranean Seas we find Antedon adriatica (part 1, fig. 106, p. 171) and A. mediterranea (part 1, fig. 105, p. 169), both of which, especially the former, are remarkable for the length and slenderness of the arms, as well as for the length and slenderness of the cirri and cirrals, characters by which they are sharply separated from A. petasus (part 1, fig. 103, p. 165) and A. bifida (part 1, fig. 104, p. 167) of the colder waters of the east Atlantic, which, especially the former, possess relatively short and stout arms, and short, stout, strongly curved and short-segmented cirri. On the muddy bottoms in the shallow, warm, and fresh Java Sea many of the wide-ranging East Indian types, such as Capillaster sentosa, C. multiradiata, Comatula purpurea, Comaster fruticosus, Heterometra producta, Oxymetra finschii, and Dichrometra fagellata, are represented by parallel types, in which the cirri, and usually also, though commonly to a somewhat lesser degree, the arms, are exceedingly elongated and very slender. On the 
southern consts of Australia we find Comatulella brachiolata (part 1, fig. 77, p. 130), a curious species with very short and very stout arms and very short cirri composed of very short segments, which is evidently a cold-induced form derived from the Comatula type (figs. 1St, 185, pp. 100, 102). In Comanthus wahlbergii of South Africa and in C. trichoptera and its allies of southern Australia, New Zealand, and Tasmania the sane feature is evident, though in the C.trichoptera group a distinctive type of cirrus structure prevents these organs from being strictly comparable with those of the other species of the genus.

Although an unusually warm habitat ordinarily induces the lengthening of

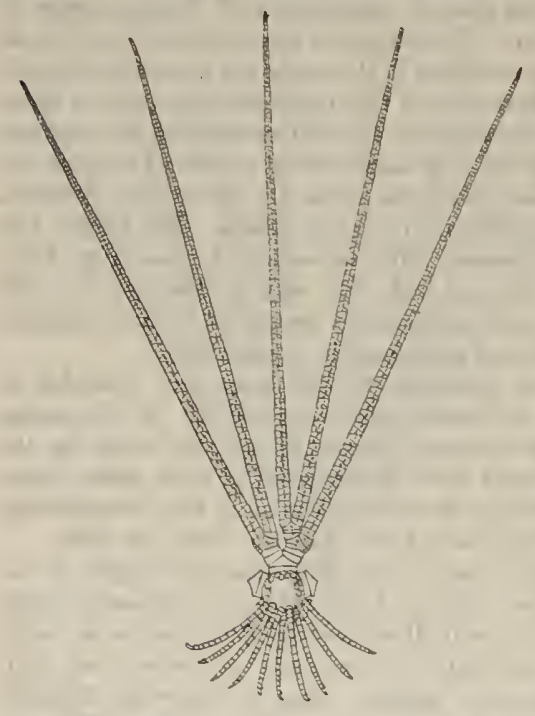

182

Fig. 182.-CEXTRAL portiox AND ONE POST-RADIAL SERIES OF SHECIMES OE NEMASTER RCBIGINOSA COLLected by the "Challexger," at Bahia, Brazil, the comatulid arm, under certain conditions and upon certain arms it has exactly the opposite effect, causing these arms to become short and stout. The effect of a cold habitat appears to be to render slower and more difficult the formation of the skeleton, retarding the deposition of lime to a much greater degree than it inhibits the other body processes, possibly as a result of the increased solubility of calcium carbonate $\left(\mathrm{CaCO}_{3}\right)$ at low temperatures. Hence, in cold water forms during the growth of the arms the various organs attain their definitive form when the brachials are still relatively short, and the brachial skeleton never attains the weight and density of the brachial skeletons of warmwater species. The shortening of the brachials and therefore of the arms also as a result of the action of cold always affects all the arms to the same degree.

The species of Comasteridæ in which the posterior arms are short and ungrooved all occur in the littoral zone of the Tropics, where the temperature of the water is high. Species from deep or relatively cold water always have all of the arms of the same length and similar, as in the endocyclic forms. There seems to be a definite connection, therefore, between a high temperature and modification of the posterior arms.

Ungrooved arms are especially remarkable for the great development upon them of the sexual orgaus, which are more numerous and larger than those upon the other arms. 
In the exocyclic species the mouth is situated at or near the middle point in a horseshoe-shaped ring running about the margin of the disk and giving off branches to the various arms. As the central rings of the water-vascular, bloodvascular, and ambulacral nervous systems, as well as of the ambulacral grooves, retain their original position about the mouth, it is evident that the posterior arms are at a considerable disadvantage, for while the circumoral rings lie directly at the base of the anterior arms, the bases of the posterior arms are distant from them half the periphery of the disk.

The genital cords of the different arms are at first connected by a ring about the mouth, but this soon atrophies, so that in the adults the gonads on each arm are entirely independent of those on the other arms. Thus the disadvantages under which the brachial organs actively connected with ring systems about the mouth are placed are inoperable in the case of the genital organs.

Heat has been shown to have the effect of stimulating the growth of the genital organs, and there is no reason to support that this is not the case in the crinoids as well as in other animals.

If it be so the stimulation of the gonads would naturally result in the atrophy of the brachials and of the ventral systems and the more or less complete suppression of the latter in the posterior arms on account of the aggressive assimilation of the available nutriment by the stimulated gonads and the relative difficulty of supplying additional nutriment because of the elongation of the channels through which it has to pass.

In those species of the Comasteridx in which the mouth is central and the ambulacral grooves converge to it in five furrows of equal length all the structures on all the arms are equally balanced and no opportunity is offered for the genital organs to develop abnormally at the expense of the other systems. In such types, no matter what the temperature of the water in which they occur, the arms are always of equal length, as in the endocyclic species belonging to other families.

Cold appears to have an inhibiting effect upon the genital organs, so that exocyclic species found in cold water have all the arms, though short, of the same length.

Carpenter believed that the condition of the respiratory apparatus was the determining factor in deciding the condition on the posterior arms, and that when this is well developed the arm seems to have the power of indefinite growth.

The division series and arms may stretch out horizontally (figs. 184, 185, pp. 100, 102), or they may be closely appressed, making but a small angle with the dorsoventral axis of the animal (figs. 206-209, pp. 143-149). These variations are not correlated with the angle made by the radials with the plane passing at right angles through the dorsoventral axis, as might be expected, both extremes occurring in the Oligophreata where this angle is always comparatively low.

When the division series and arm bases are widely divergent and approach the horizontal the component elements are comparatively shallow and broad and their ventrolateral edges are narrow and rounded, or more or less produced into 
rounded or denticulate flange-like processes, not coming into direct contact with those of the neighboring ossicles (part 1, figs. 41, 42, 78, 85, 87, pp. 77, 131, 139, 143). When, however, the division series and arm bases are more or less turned upward they come into contact with those adjacent on either side, with the result that the possibility of lateral growth is greatly limited, and the ossicles become sharply flattened or "wall-sided" laterally but, in compensation, deep dorsoventrally (part 1 , figs. 43,44, p. 77 ). Ordinarily, this lateral flattening is confined to the elements proximal to the first brachial syzygy, ossicles which for phylo-

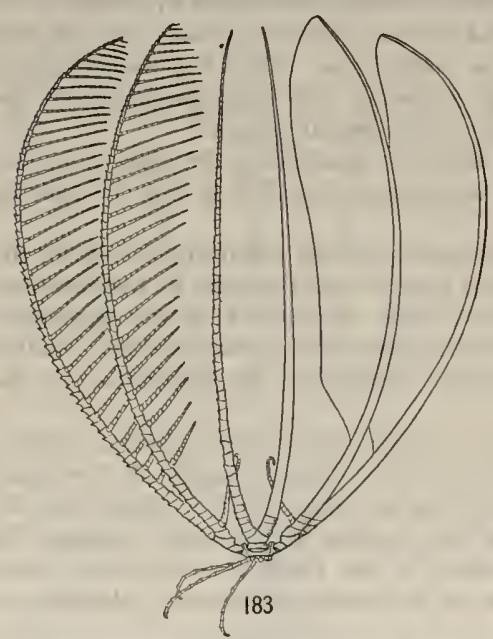

Fig. 1S3.-IaAteral view of specisien of CoMatilia imidonetriformis from "ALBatross" Station 2670 . genetic reasons are broader than those following, but in extreme cases it may be traced almost as far as the twentieth brachial of the free undivided arm (fig. 208 , p. 146).

In a few instances species with broad and patent central structures have dereloped an excessive broadening of the division series and first two brachials, and in these cases the ossicles which have become broad have come into lateral contact and have developed the sharply flattened sides. A good example of this is seen in Comanthus solaster.

Carpenter believed that the lateral flattening of the division series and lower brachials of the free arms, or "wall-sidedness" as he called it, was, together with the commonly correlated presence of strongly developed side and covering plates, an attribute of deep water species, and that it was a systematic character of the highest significance; in fact, his "Basicurva," "Spinifera," and "Granulifera" specific groups are based chiefly upon it, though the two last invariably possess in addition "plated" ambulacra.

Carpenter was to a considerable extent justified in this conclusion at the time he wrote, but subsequent investigation has shown that this character, however suggestive it may be, is far too uncertain to be relied upon, appearing in widely divergent groups and being suddenly suppressed in certain species belonging to others in which it is usually seen.

In the Comasteridx (figs. 120, 133, 137, 138, 148, 150, 152, 154, 156, 158, 169, $171,180-188$, pp. 79-108) the division series are almost invariably widely free laterally and strongly rounded dorsally and laterally, the only exceptions being in a few species of Comanthus (compare fig. 171, p. 86) in which the elements of the division series are especially broad. 
In the Zygometridæ (figs. 127, 136, 143, 189-191, pp. 79, 83, 109-112), as in the Himerometridæ, the division series and arm bases are usually in apposition laterally with the lateral borders of the component elements sharply truncated. In Catoptometra, however, they are narrow, strongly rounded, and well separated.

In Craspedometra (fig. 141, p. 83), Heterometra, Homalometra, and Amphimetra (figs. 192, 193, pp. 115, 117) of the Himerometridæ the division series and arm bases are closely appressed against their neighbors and more or less extensively truncated laterally; but in IIimerometra (fig. 123, p. 79) they are narrow, strongly rounded, and widely free.

In the Mariametridæ Pontiometra (figs. 139, p. 83, and 194, p. 120) has the division series very narrow, very strongly rounded, and widely free laterally, while in Oxymetra (fig. 195, p. 122), Liparometra, Dichrometra, and Mariametra (figs. 129 , p. 79,196, p. 124,197, p. 125 , and 684 p. 338 ) they are broad and in lateral contact. The latter condition is usually found in Lamprometra also, though in this genus the division series, through individual variation, are sometimes narrow and separated from each other.

In the Colobometridæ the conditions are very diversified; the division series and first two brachials are narrow, very strongly rounded and widely separated, and each of the component elements bears a broad ventrolateral flange, as in the species of Stephanometridæ (figs. 125, 130, p. 79), in Cenometra (part 1, fig. 87, p. 143); they are entirely separated laterally and well rounded in Epimetra, Cyllometra, Colobometra, Decametra, Oligometra, and Prometra; and they are in lateral contact in Petasometra (fig. 198, p. 127), Cotylometra (fig. 199, p. 129), Austrometra, Oligometrides, and Analcidometra.

In the Calometridæ (figs. 200, p. 130, 201, p. 133, 202, p. 134, and part 1, fig. 89, p. 147) the postradial series are usually very narrow and widely separated, though in certain cases they may be just in apposition through the broad lateral expansion of the borders of the component elements.

In the Tripiometridæ (fig. 116, p. 79, and part 1, fig. 88, p. 145) the division series are remarkably broad, though thin dorsoventrally, and are sharply truncated laterally.

In the Thalassometridæ there is a considerable range of diversity. The extreme of lateral flattening and of depth of rays and lower brachials is reached in Asterometra (figs. 206. p. 143, 207, p. 145 , and part 1, figs. 43, 44, p. 77 , and 94 , p. 155), though, curiously enough, in the two most closely related genera, Ptilometra (fig. 204, p. 139, and part 1, fig. 93. p. 153) and Pterometra (fig. 208, p. 146), the elements of the division series and arm bases, though broad, are very thin, so that their truncated lateral borders are very narrow as in Tropiometra. In most of the genera of this family the character is well marked, but in some of the more delicate species, or individuals, of Thalassometra (fig. 224, p. 177) and Stylometra (figs. 124, p. 79. and 219, p. 166), and in Parametra (figs. 217, p. 163, and 218, p. 164), the ossicles of the division series and arm bases may be of only moderate depth, rounded dorsally and laterally, and more or less separated from their neighbors.

In the Charitometridæ (figs. 226-232, pp. 180-192, 658, p. 329, 670-675, p. 335, 676-682, p. 338, and part 1, figs. 99, p. 160, 100, p. 162, and 101, 102, p. 163) the 
lateral flattening of the rays is more generally and uniformly developed than in any other family; but it is not very marked in Pocilometra (fig. 229, p. 186), and is even less evident in Strotometra (figs. 230-232, pp. 188-192).

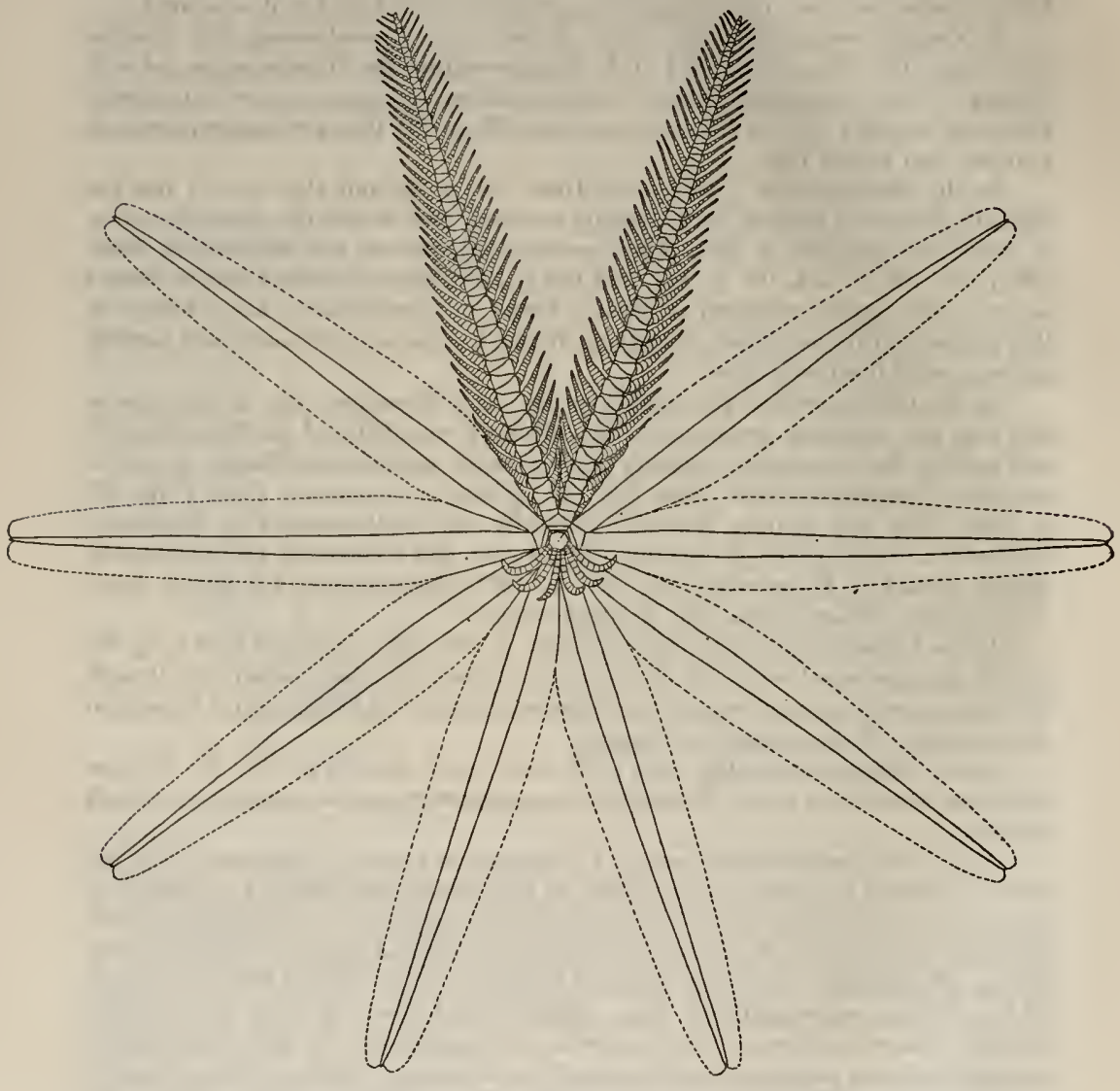

184

Fig. 184.-Broad-armed variety of Comatula pectinata, from specimen from Singapore.

In the Macrophreata the postradial series are usually strongly rounded dorsally and laterally and quite free, without the marginal processes commonly developed in the Oligophreata to a greater or lesser extent when the elements of these series 
are well separated; but in Perometra (part 1, fig. 112, p. 179), Balanometra, Zenometra, certain species of Trichometra, Nanometra, and related types, and in certain specimens of the species of Leptometra, the postradial series are in close apposition and more or less, sometimes very greatly, flattened, this lateral flattening reaching in Zenometra columnaris and in Trichometra cubensis almost the same extreme as in the most characteristically "wall-sided" species of the Thalassometridæ. In Atelecrinus (part 1, figs. 123, p. 192, 124, 125, p. 193, and 414, p. 319) and in Hypalometra the constriction of the lower part of the animal is so great that, though no great flattening occurs, thanks to the very considerable depth of the brachials, the lower pinnules have no room in which to develop, and are therefore absent.

An instructive side light on the uncertainty of the "wall-sidedness" as a specific character is given by an examination of the "Basicurva group" as constituted by Carpenter in the Challenger report. All of the included species but two fall in the families Thalassometridæ and Charitometridæ, as now understood. Of these two, one belongs to the genus Perometra (pusilla) of the family Antedonidæ and the subfamily Perometrinæ, and the other to the genus Homalometra (denticulata) of the family Himerometridæ, both being much more closely related to species placed by Carpenter in his heterogeneous "Milberti group" than to any of the species with which they were associated.

In the groups in which the lower portions of the postradial series are flattened against each other and thus definitely fixed in position the general contour of the lower part of the animal comes to present valid systematic characters which are unsurpassed in reliability by any of the characters offered by any of the other structures. This is especially true in Crossometra (figs. 226, 673, pp. 180,335), Perissometra (figs. 227, 670, pp. 182, 335, and part 1, fig. 100, p. 162) and Pachylometra (figs. 671, 672, p. 335) in the Charitometridæ, and in Pterometra (fig. 203, p. 137 ) and Asterometra (figs. 206, 207, 209, pp. 143-149, and part 1, fig. 94, p. 155) in the Thalassometridæ. It was first used as a differential character by Carpenter in distinguishing Perissometra angusticalyx, in which, as in certain more or less related species, and in certain species of Pterometra, that part of the animal just above the radials is strongly constricted.

When the lower portions of the postradial series are not flattened against each other the contour of the proximal portion of the body depends mainly, in preserved specimens, upon the state of contraction and distortion of the visceral mass, and has either no, or only a very general, significance.

The close apposition and the strong flattening of the earlier postradial elements against each other would result, were it not for some special adaptation, in the cutting off of the medium inhabited by the animals from contact with the surface of the visceral mass, entirely from its sides and more or less completely from its ventral surface. This would result in the partial stagnation of the fluid whence the contents of the water vascular system are drawn, and would undoubtedly give rise, directly or indirectly, to serious pathological conditions. But in most cases obvious provision has beeu made against such a contingency. The $\mathrm{IBr}_{1}$ and all 
the reduplications of that ossicle have the outer distal angles sharply cut away, and the $\mathrm{IBr}_{2}$ and all of its reduplications have the outer proximal angles similarly truncated, so that numerous rhombic intersegmental pores are formed which pass

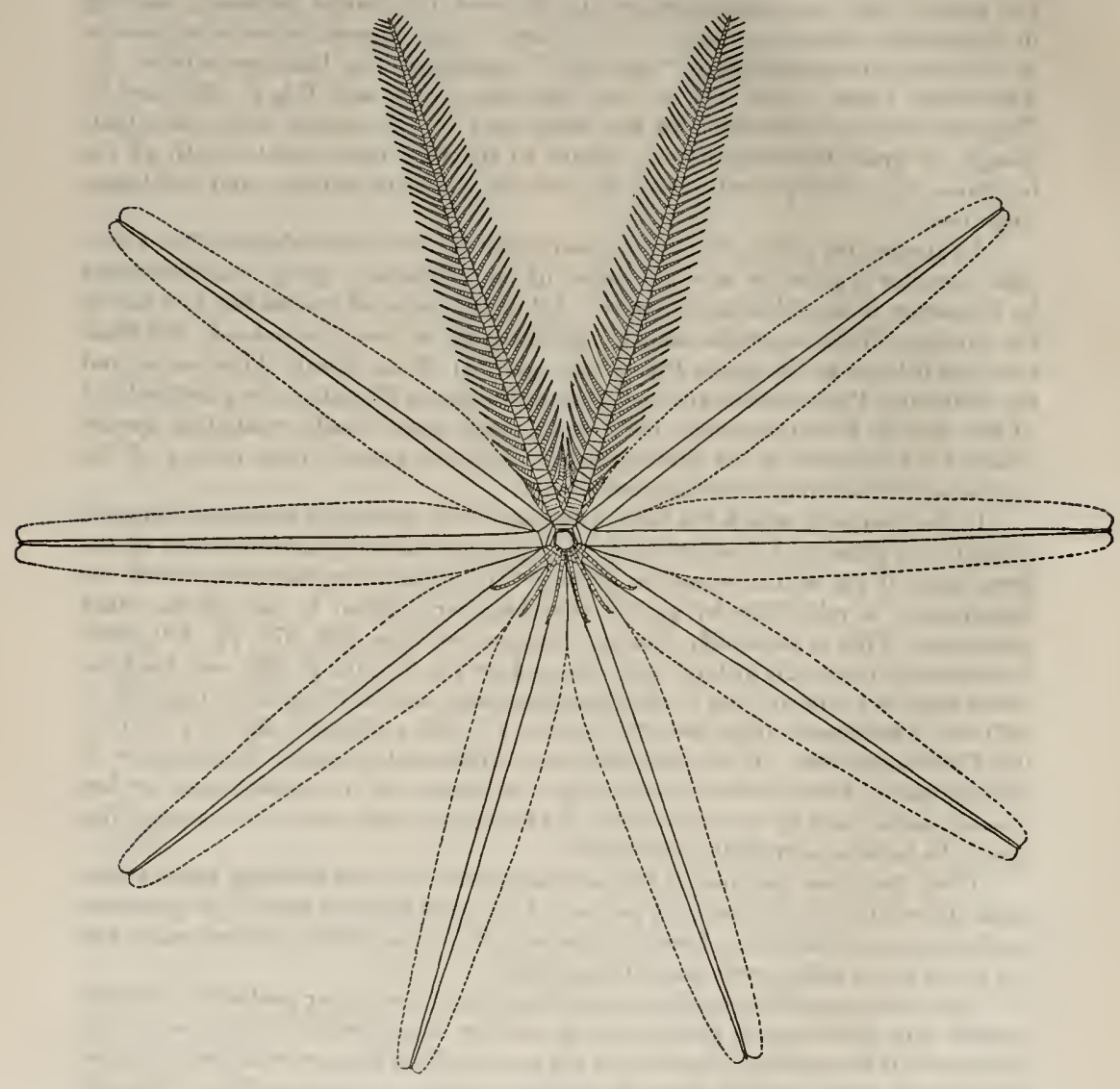

185

Fig. 185,-Slender-armed vabiete of Comatula pectinata, from specisien from Singapore.

from the exterior through the thick calcareous wall formed by the postradial series to the disk. These pores are especially evident in the species of Thalassometridæ, in which the division series are composed of two elements, as in many species of 
Thalassometra (fig. 223, p. 175, and part 1, fig. 95, p. 157), in Crinometra (figs. 678, 683 , p. 338), and in Atelecrinus (part 1, figs. 14, p. 65, 123, p. 192).

In very many species it is noticeable that the lateral angles of the axillaries project beyond the sides of the ossicles preceding; or that, if the axillaries are long, their sides make with the sides of the preceding segments a more or less deep obtuse reentrant angle. The first condition is well seen in Antedon bifida and in $A$. petasus (part 1, fig. 103, p. 165) ; the second in Pontiometra andersoni (fig. 194, p. 120), and in many of the Comasteridæ, Himerometridæ (fig. 123, p. 79), Mariametridæ, and Colobometridæ. This appears to be, like the intersegmental pores, a provision for insuring an adequate supply of fresh water to the sides of the disk.

POST-BADIAL HOMOLOGIES.

First brachial pair.

The first two ossicles of the free undivided arms of the comatulids always differ in size, form, ornamentation (if present), and mode of union from all the succeeding brachials; the outer (second) is always situated just on the border line between the perisome of the ventral disk and the ventral perisome of the arm and bears a highly specialized pinnule; and the two following brachials are always united by syzygy, forming the first syzygial pair.

The constant structural peculiarities and associations of this pair of brachials, the larger size, greater width, straighter proximal and distal borders, which are more nearly at right angles to the axis of the arm, and consequently more regularly wedge-like shape, and the possession of special ornamentation or modification, ventrolateral, or dorsolateral flanges, more deeply and sharply flattened sides, or synarthrial tubercles, combined with the presence of the only synarthry occurring in the undivided arm between them, their invariably fixed position on the border of the disk, the occurrence upon the outer of a highly specialized pinnule differing widely in size, structure, and function from the succeeding pinnules, and the invariable presence of a syzygial pair beyond them, leave no room for doubting that this pair of ossicles is strictly homologous throughout the whole group, and furthermore render it very readily identifiable.

With the definite identification of a pair of ossicles wherever it may be found, the elucidation of the brachial homologies of the comatulids becomes an easy matter.

But the study of the post-radial homologies is sometimes rendered more or less difficult by the projection of certain of the characters of the first brachial pair, though always in a modified form, upon several of the succeeding ossicles, which then form a transition zone of greater or lesser length between the first two and the distal brachials. Especially the pinnule upon the outer element of the syzygial pair immediately following the outer element of the first brachial pair usually resembles more or less closely the pinnule borne by the latter; but the succceeding pinnules are ordinarily markedly different, although in large species (as in the species of Heliometrinæ) they may have some of the characteristics of 142140-21-Bull. 82-9 
the first pinnule projected upon them. But no matter how much modification of the following brachials there may be, a close examination soon reveals the fact that

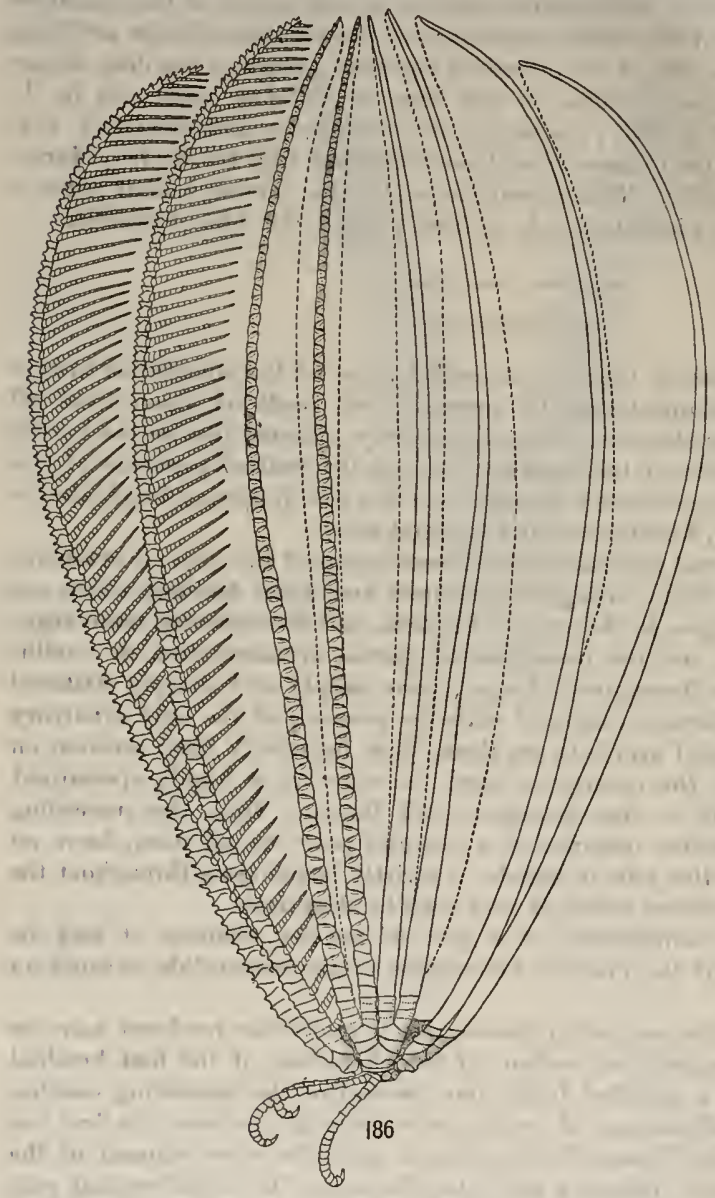

Fig. 186.-Lateral View of SPECiMex of Neocomatella polchella. there are very important differences between them and the brachials of the first pair.

\section{Homologies of the division serics of two ossicles.}

In all the ways in which the first two brachials differ from the brachials succeeding them they agree with the elements of the division series preceding when these are composed of two ossicles only. This correspondence is emphasized in such species as $A m p h i$ metra ensifer (part 1, fig. 86, p. 141), Perometra afra, and Perometra diomedere (fig. 119, p. 79 , and part 1 , fig. 112 , p. 179), in which the apposed fulcra of the synarthrial articulation are greatly produced, forming a high conical tubercle, which is repeated on the line of union of all the pairs in the division series; the species of Tropiometra (fig. 116, p. 79 , and part 1 , fig. 88 , p. 145) in which the first two brachials are disproportionately large, and the elements of the division series are disproportionately large also; the species of Stephanometra (figs. 125,130 , p. 79 , Cenometra (part 1, fig. 87, p. 143), and Cyllometra, in which the first and second brachials each bear a broad rounded ventrolateral 
flange, which assists in supporting the visceral mass and which is repeated on all the ossicles of the division series; the species of Precilometra (figs. 132, p. 79 , and 229, p. 186), in which the first and second brachials bear a broad dorsolateral process, which is reduplicated on all the elements of the division series; Oceanometra gigantea (figs. 145, p. 83 , and 220 , p. 168), in which the second brachial (but not the first) bears a high median keel, which is repeated on the outer elements of all the pairs in the division series; many species of Mariametra, Parametra, Lissometra (fig. 216, p. 161), and Stiremetra, and certain species of Asterometra (figs. 206, 207, pp. 143, 145), Cosmiometra (fig. 213, p. 155), and Thalassometra (fig. 224, p. 177), in which the first two brachials and the elements of the division series are conspicuously carinate; many species of Thalassometra (fig. 223, p. 175), Stylometra (fig. 219, p. 166), and Sarametra, in which both are covered with long spines; certain species of Mariametra (fig. 684, p. 338), Crinometra (figs. 678-683, p. 338), Glyptometra, Calyptometra (figs. 676, 677, p. 338), and Perissometra (fig. 658 , p. 329 ; part 1, fig. 100 , p. 162), in which both bear a characteristic tubercular ornamentation; and in many other less conspicuous ways in other types.

There can therefore be no doubt whatever that the division series of two ossicles, no matter how many of them there may be, are strictly homologous with the first two brachials of the free undivided arm and represent reduplications of that pair of brachials interpolated between it and the radials.

The comatulids, in which the division series are invariably of two ossicles, which are simple reduplications of the first brachial pair, include the majority of all the known forms. All 10-armed species, except those in the genus Thaumatocrinus, fall in this category, as well as all the multibrachiate species in the Stephanometridæ, Mariametridæ, Ptilometrinæ, and Perometrinæ, and many of those in the Zygometridæ, Colobometridæ, Calometridæ, Thalassometrinæ, and Charitometridx. Promachocrinus also belongs here.

Eudiocrints and Uintacrinus.

In Eudiocrinus (figs. 127 , p. $79 ; 189$, p. $109 ; 190$, p. $111 ; 191$, p. 112 , and part 1 , figs. 83, p. 136, and 84, p. 137) the arms are undivided, but both the first and second pairs of brachials present the same features. The second pair is followed by a syzygial pair, and is easily recognizable as homologous with the first pair of brachials in the free undivided arms of other types.

It is therefore clear that the arm structure of Eudiocrinus is strictly comparable with that of the 10 -armed species in which the first pair of brachials is preceded by a $\mathrm{IBr}$ series, differing only in the circumstance that in Eudiocrinus the outer element of the IBr series is not axillary and therefore bears a single undivided arm plus a pinnule instead of a pair of arms.

The distal element of each pair of ossicles united by a nonmuscular articulation always bears two processes on its distal border, an arm and a pinnule (as in the case of the first brachial pair), two exactly similar arms (as in the case 
of all the outermost axillaries), an arm and a division series, or, abnormally but not infrequently, two exactly similar pinnules.

While ordinarily a definite and fixed pair of structures is found on the distal end of the distal element of any given pair of ossicles united by nonmuscular articulation, these pairs of structures are more or less interchangeable, and such interchange is a common source of variation.

In Antedon bifida and in Leptonemaster venustus nine-armed specimens have been recorded in which, throngh variation, one of the post-radial series was undivided, but possessed at the base two exactly similar pairs of brachials. In these cases it is evident that the normal $\mathrm{IBr}$ series were actually present, but the $\mathrm{IBr}_{2}$,

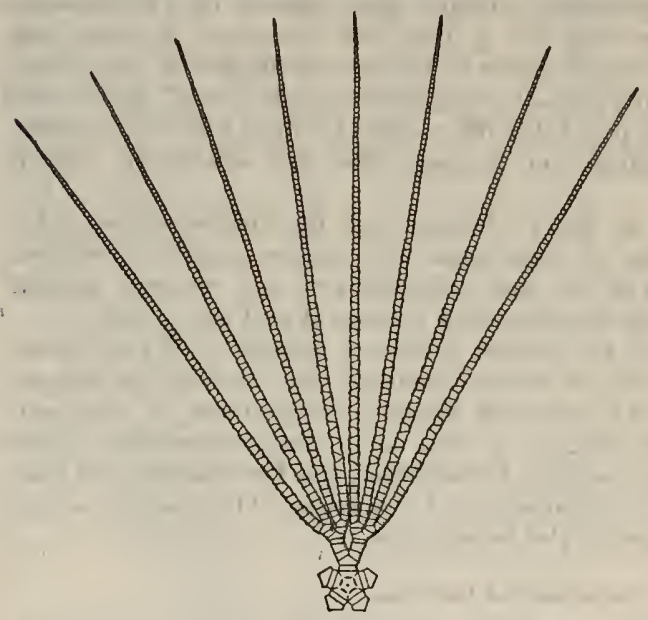

187 instead of being axillary and carrying two arms on the distal border, carried a single arm and a pinnule.

Thus through variation resulting in the replacement of one of the two arms normally following a IBr series by a pinnule, 10 armed species may on one ray occasionally assume the brachial structure characteristic of Eudiocrinus.

The 10-armed comatulid genus Uintacrinus (fig. 147 , p. 83 ) has a peculiar arm structure, at first sight apparently differing from that of any other comatulid. The arms divide once, upon the second postradial osFig. 187,-Central poetion axd one post-radial series oz typa sicle. The first pinnule is specimen OF COAASTER MiNIMA.

on the second postaxillary ossicle on the outer side of the arm; the second on the fourth, on the inner side; the third on the fifth, on the outer side; and the following pinnules occur alternatingly on succeeding brachials. The third and fourth postaxillary ossicles resemble the first and second in size and in the direction across the arm of the suture line between them, and in these features differ from the ossicles succeeding. The second pinnule is more like the first than like the third.

The absence of pinnules on the first and third postaxillary ossicles, the similarity between the pinnules on the second and fourth postaxillary ossicles, the similarity between the third and fourth and first and second postaxillary ossicles, and the similarity in the direction taken by the joint lines between the third and fourth and first and second postaxillary ossicles, leare no room for 
doubting that the first brachial pair, normally situated at the base of the free undivided arm, is here represented by the third and fourth postaxillary ossicles, while the first and second represent a reduplication of this pair situated between it and the axillary or distal element of the most proximal pair.

The structure of the arm of Uintacrinus from the axillary onward, therefore, is identical with that of the entire arm in Eudiocrinus. A reduplication of the first brachial pair is present in which the distal element is not axillary.

Judging from its universal presence in all other genera, the absence of the second arm on the reduplication of the first brachial pair situated between the normal first brachial pair and the axillary would seem to be a retrogressive character; we should therefore expect that in the young of Uintacrinus the second postaxillary ossicle would appear more like an axillary than in the adult, and we find that such is the case.

The correctness of this interpretation of the arm structure of Uintacrinus is shown by a specimen with 11 arms in which one of the second postaxillary ossicles is an axillary bearing two arms instead of an arm and a pinnule as usual; and another, with nine arms, in which the second postradial ossicle instead of being axillary bears an arm and a pinnule, so that three similar pairs of ossicles, each bearing a continuation of the postradial series and a pinnule on the distal border of the outer element, are present.

Of interest in this connection is a specimen of Florometra perplexa (fig. 131, p. i9) at hand, in which on one of the arms arising from a IBr axillary and immediately following the latter there are two pairs of ossicles exactly alike. This arm therefore possesses the structure characteristic of the arms of Uintacrinus.

Pentometrocrinida and Atopocrinus.

In Thaumatocrinus (part 1, figs. 113, 114, p. 181; 115-118, p. 183), Pentametrocrinus (fig. 126 , p. 79 , and part 1 . figs. 119 , p. $185 ; 120$, p. 187 ; and 121 , p. 189), and Atopocrinus (part 1, fig. 227, p. 245) the arms are undivided. Examination shows that the first two ossicles following the radials correspond exactly to the first two brachials in the free undivided arms of other types.

Therefore Thaumatocrinus, Pentametrocrinus, and Atopocrinus are simple forms in which the $\mathrm{IBr}$ series are absent, and the free undivided arms arise directly from the radials.

The species of these three genera have the simplest arm structure of any of the comatulids.

In Thaumatocrinus and Pentametrocrinus, and to a lesser degree in Atopocrinus, the ventral disk runs for a considerable distance up the arms, these radial tapering prolongations giving it a sharply stellate shape, and merges into the rentral perisome of the arms at a point far beyond the second brachial. In no other types does this occur. Also in these three genera, alone among the recent comatulids, the first syzygial pair does not immediately follow the first two hrachials but is separated from them by an interpolated brachial. 
Honologies of the division scries of four ossicles.

A study of the species in which the division series are $4(3+4)$ shows that in these division series the first two elements are obviously strictly comparable with the first pair of brachials on the free undivided arms. Where special marks which serve to identify the elements exist, as in the distinctive ornamentation in Oceanometra gigantea (fig. 220, p. 168), 0.magna (fig. 221, p. 171), and 0 . annandadei (fig. 222 , p. 173), in other species of Thalassometridæ, and in certain forms in the Charitometridæ (figs. $679,680,681$, p. 338), it is equally certain that the two outer ele-

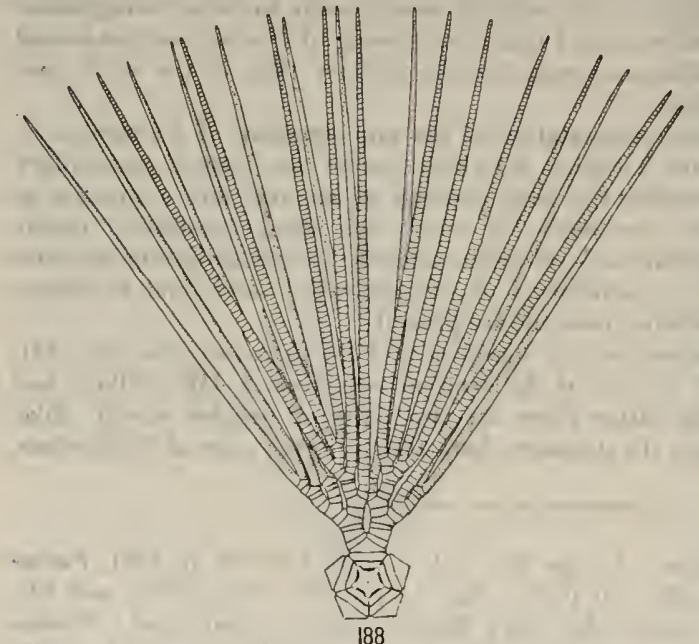

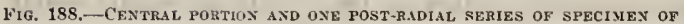
Comantheria alternass from Philippine Islands. ments in the division series of $4(3+4)$ are st rictly comparable with the first syzygial pair of the free undivided arms. Thus whereas the division series of two ossicles are reduplications of the first two brachials of the free undivided arms, the division series of four ossicles are similarly reduplications of the first four brachials of the free undivided arms.

Since the distal element of the first brachial pair and of all the reduplications of this pair situated proximal to it always bear two derivatives on the outer border, two arms, two division series, a division series and an arm, an arm and a pinnule, or, abnormally, two pinnules, it is easy to see why in division series of $4(3+4)$ the second element always bears a pinnule.

Occasionally division series of four ossicles occur in which the elements of both pairs are similarly united by synarthry. These are unusual and abnormal, but they have been reported in Cyllometra albopurpurea (" $C$. anomala"), in Heterometra quinduplicava ("Antedon anceps"), and in Adelometra angustiradia. They represent two division series of two ossicles each, in which the outer element of the first bears a pinnule instead of a second arm.

Irregularities in the occurrence of the division series of $4(3+4)$.

Division series of $4(3+4)$ appear to be correlated with a very broad and patent habit, exceptionally reduced radials, and an exceptionally large visceral mass, the 
border of which is attached to the distal edge of the third brachial instead of to the distal edge of the first, so that the larral arms are discarded at the first syzygy instead of at the preceding synarthry, as in the case of multibrachiate species in which all the division series are 2.

Correlated with a high state of specialization in other structures, they appear themselves to represent a high state of brachial specialization, and to be a considerable phylogenetic advance over the division series composed of two ossicles only.

In all the species in which they occur they are relatively unstable, and are subject to more or less extensive replacement by division series of two ossicles; in fact, in most forms in which the IIBr series are normally $4(3+4)$ it is a relatively rare circumstance to find a specimen in which at least one of the IIBr series is not 2 .

Division series of $4(3+4)$ are relatively rare beyond the $\mathrm{IIBr}$ series, for in a majority of the species in which IIBr series of $4(3+4)$ occur the IIIBr series are mostly or entirely 2 . This is well illustrated in the genera Crinometra (figs. 679-681, p. 338), Cros8ometra (figs. 673, 675, p. 335), Perissometra, Pachylometra (fig. 672, p. 335), Glyptometra, Thalassometra, Zygometra (fig. 143, p. 83), Craspedometra (fig. 141, p. 83 , and part 1 , fig. 85 , p. 139), Heterometra, and Catoptometra.

Sometimes beyond the IIIBr series of 2 there are IVBr series of $4(3+4)$ resembling the IIBr series, and there may be a continuation of this alternation. This is illustrated by species of Himerometra and Zygometra, but more

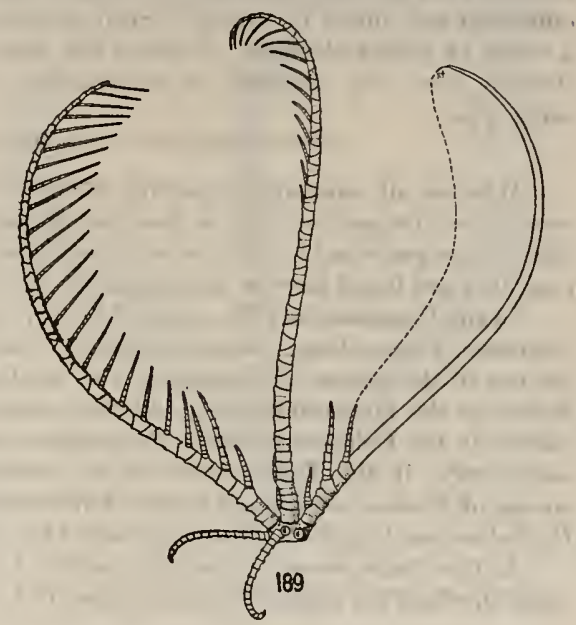

Fig. 189.-Lateral view of Type SPECiMen of Eudio. CRINUS GRACILIS. especially by the species of Comantheria where it reaches its greatest perfection in the form known as Comantheria altermans (fig. 169, p. 86).

In Himerometra (fig. 123, p. 79), Craspedometra, and in the large species of Zygometra (fig. 136, p. 79) the IIIBr series are usually 2 on the inner branch from each IIBr series, and $4(3+4)$ on the outer. The IVBr and following series, if present, are indiscriminately $4(3+4)$ or 2 , usually with a majority of the former.

In Comanthina schlegelii (fig. 138, p. 79) the conditions in the IIIBr series are reversed, the inner being $4(3+4)$ and the outer 2 ; but on the posterior arm the inner are commonly 2 and the outer $4(3+4)$ as in Himerometra.

In genera and species characterized by the presence of IIBr series of $4(3+4)$ in which IIIBr series occur these latter are often much more stable and more re- 
liable for systematic purposes than the IIBr series, as is well illustrated in the genera Nemaster, Capillaster, Comaster, Comanthina, Comantheria, Comanthus, Himerometra, and Heterometra.

In none of the comatulids are the IBr series, the oldest and presumably the most primitive of the division series, of more than two ossicles normally, but two cases have been reported where they were $4(3+4)$. One of these was in a specimen of Heterometra quinduplicava ("Antedon anceps") recorded by Carpenter, the other in a specimen of Comanthus parvicirra recorded by Hartlaub. I have personally verified both of these observations on the original specimens.

In many of the multibrachiate species of the Comasteridæ it not infrequently happens that division series of six or even of eight ossicles occur in which the two outermost are united by syzygy. Such aberrant division series always consist of a series of paired elements, of which the distal invariably bears a pinnule, and there is never any difficulty in homologizing them with division series of the usual type.

$$
\text { Systematic distribution of the division series of }+(3+4) \text {. }
$$

Whereas all comatulids excepting the species of Thaumatocrinus, Pentametrocrinus, and Atopocrinus have at least one division series of 2 , the division series of $4(3+4)$ are restricted in their occurrence entirely to the Oligophreata, where, however, they are found more or less commonly in a considerable number of genera.

In the Comasteridæ IIBr series of $4(3+4)$ are found in Capillaster, Nenaster, Comaster, Comanthina, Comantheria, and Comanthus; in the Zygometridæ in all but one of the species of Zygometra, and in all but one of the species of Catoptometra; in the Himerometridæ in all the species of all the genera except Amphimetra; in the Colobometridæ in Petasometra only; in the Calometridæ in Oreometra only; in the Thalassometridæ in Oceanometra, Crntalometra, and a few species of Thalassometra; and in the Charitometridæ in Crossometra, Perissometra, Pachylometra, Glyptometra, and in most of the species of Crinometra.

In the Macrophreata there is a record of an 11-armed specimen of Antedon bifida in which the single IIBr series was $4(3+4)$.

\section{Capillaster and Nemaster.}

In the species of Capillaster (figs. 158, p. $83 ; 1022$, pl. $9 ; 1026$, pl. $10 ; 180$, p. 92 ; and 181, p. 94) and Nemaster (fig. 182, p. 96) the $\mathrm{IBr}$ series are 2 and the IIBr series $4(3+4)$, exceptionally 2 ; but the following series are always $3(2+3)$, while on the free undirided arms there is only a single brachial preceding the first syzygial pair.

It is erident that here the first ossicle of the first brachial pair has been suppressed, and with its suppression has gone the suppression of its counterparts in the third and following division series.

In Capillaster and Nemaster the arms arising from the IBr axillaries always have both elements of the first brachial pair present, and also the division series arising from the same axillaries are always $4(3+4)$ or 2 , never $3(2+3)$; but in both arms and division series arising from the $\mathrm{IIBr}$ and subsequent axillaries the 
first element of this pair is always missing, so that the latter are $3(2+3)$, or occasionally 1.

The suppression of the first element in the first brachial pair and its reduplications occurs from the pair immediately following the IIBr axillary onward, regardless of whether the pairs be incorporated in a division series or form the basis of an arm. The division series and arms following IIBr series of 2 do not differ from those following IIBr series of $4(3+4)$.

In Capillaster and Nemaster we have normally IBr series of $2 ; \mathrm{IIBr}$ series of $4(3+4)$, rarely of 2 ; IIIBr series (in which the first ossicle is suppressed) of $3(2+3)$, or 1 . In addition to these we sometimes find division series of $2(1+2)$ where in the IIBr series the two ossicles have been exceptionally closely joined, and where in the IIIBr and following series of the normal type $4(3+4)$ both elements of the first pair have been suppressed, leaving a division series composed of the syzygial pair only, $2(1+2)$. In the arms as well as in the outer division series both elements of the first brachial pair may be omitted, so that the arms may begin with a syzygial pair.

Bearing in mind the relative instability of division series of more than two elements as a result of the constant tendency to a reduction in the number of their elements to the more primitive two, and the fact that no ferrer than five types of division series, $4(3+4), 3(2+3), 2(1+2)$,

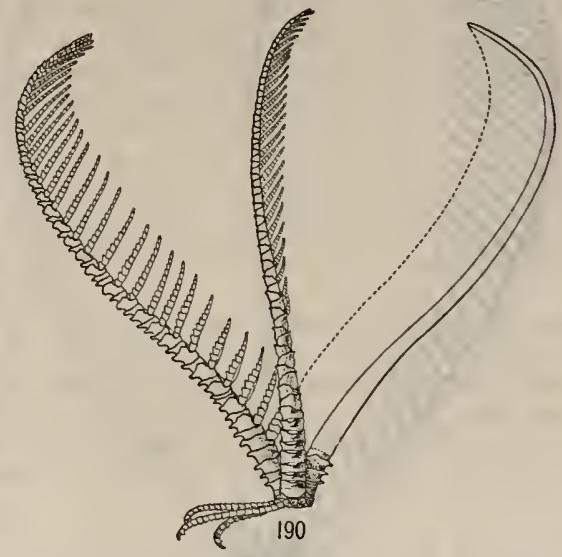

Fig, 190.-Latheal view of trpe specimen of EudioCRINUS ORNATUS.

2 and 1 are of normal occurrence in these genera, we are prepared to find individnals of the component species in which extraordinary variability occurs.

P. H. Carpenter records a specimen of a species of Nemaster closely allied to $N$. ribiginosa which was dredged by the Flake in the Caribbean Sea in which the IIIBr series are 1 , and the IVBr series may be 1 , or $2(1+2)$; the second and third brachials are usually united by syzygy on the outer arms of each ray, and sometimes also on the adradial arm which is on the inner side of each IIBr series; but the other arms generally have the first two brachials united by syzygy.

The explanation of this condition is very simple. Whereas usually the IIIBr and $I V B r$ series in this genus are $4(3+4)$ minus the first ossicle, leaving $3(2+3)$, in this case they are 2 minus the first ossicle, leaving 1 ; the IVBr series of $2(1+2)$ are series of $4(3+4)$ minus the first two ossicles; and this feature is characteristic of most of the arms where both of the elements of the first brachial 
pair are suppressed, leaving the first syzygial pair, composed of the third and fourth brachials, at the base of the arm.

In a specimen of Nemaster iovensis (which I originally called Nemaster irregularis) from Dominica the IIBr series are $4(3+4)$, and the $\mathrm{IIIBr}$ series usually 1 , rarely $2(1+2)$.

In a magnificent specimen of Capillaster marice which $\mathbf{I}$ dredged in Kagoshima Bay one of the IIBr series is $4(3+4)$, one is $2(1+2)$, four are 2 and three

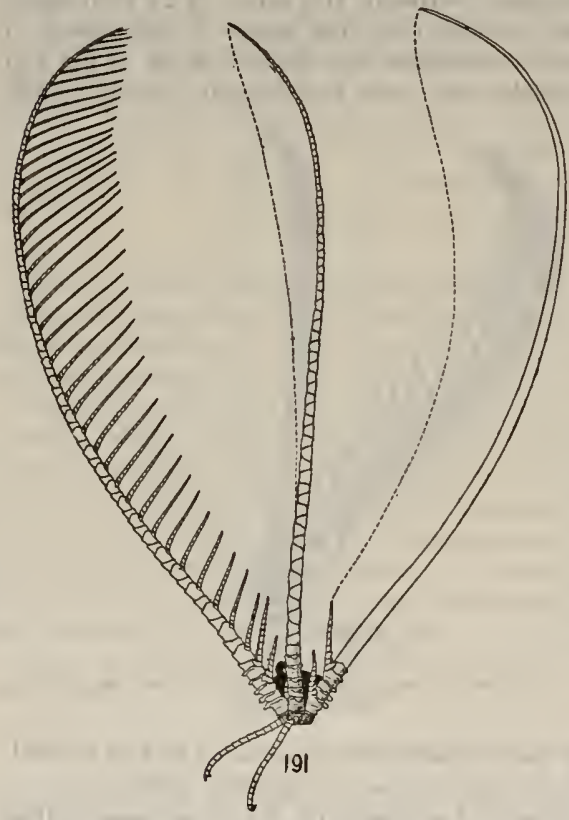

Fig. 191.-Lateral view of tYpe speciaren of Eudio. CRINUS VENUSTULUS. are 1 ; of the IIIBr series one is $4(3+4)$, three are $3(2+3)$, two are $2(1+2)$, and one is 2 ; usually the second and third brachials form the first syzygial pair, but sometimes the first and second.

In a 28 -armed specimen of Capillaster multiradiata fro: Ruck, Caroline Islands, recorded by Hartlaub, two of the IIBr series are $4(3+4)$ and eight are $2(1+2)$; the IIBr series of $2(1+2)$ are commonly followed by IIIBr series of $3(2+3)$, with one of $4(3+4)$ in which, as occasionally happens, the first ossicle has not been suppressed.

A specimen of Capillaster multiradiata from the Malay Archipelago in 160 fathoms has the details of the arm division as follows:

Ray 1: Two IIBr series; that to the left (viewed dorsally) bears outwardly (on the left) a IIIBr 2 series and inwardly (to the right) an undivided arm; both of the undivided arms arising from the IIIBr series have the first syzygy between the second and third brachials, but the (internal) undivided arm arising from the IIBr series has the first syzygy between the third and fourth brachials; the $I I B r$ series to the right bears inwardly (toward the left) an undivided arm, in which the first syzygy is between the third and fourth brachials, and outwardly (toward the right) a IIIBr $5(4+5)$ series, the two derivatives from which have the first syzygy between the second and third brachials. The total number of arms on this ray is six, arranged in 2,1,1,2 order.

Ray 2: Two IIBr 2 series; that to the left bears two undivided arms, in which the first syzygy is between the third and fourth brachials; that to the right 
bears inwardly (to the left) a IIIBr $4(3+4)$ series, both derivatives from which have the first syzygy between the second and third brachials, and outwardly (to the right) an undivided arm in which the first syzygy is between the third and fourth brachials. The total number of arms on this ray is five, arranged in $1,1,2,1$ order.

Ray 3: Two IIBr 2 series; that to the left bears externally (to the left) an undivided arm, in which the first syzygy is between the second and third brachials, and internally (to the right) two IIIBr series, all four derivatives from which have the first syzygy between the second and third brachials; the IIBr series to the right bears two undivided arms, in which the first syzygy is between the second and third brachials. The total number of arms on this ray is seven, arranged in $1,4,1,1$ order.

Ray 4: One of the IIBr series, that to the right, is $4(3+4)$, the other, that to the left, 2 ; the IIBr $4(3+4)$ series bears two IIIBr $3(2+3)$ series; in the four derivatives from these the first syzygy is between the second and third brachials in all cases except on the innermost (farthest to the right) arm where it is between the fifteenth and sixteenth brachials; the IIBr 2 series bears two IIIBr 2 series; of these, the inner (to the left) bears two IVBr $3(2+3)$ series; the outer (to the right) bears inwardly (to the left) a IVBr $3(2+3)$ series and outwardly an undivided arm. In all the derivatives from this IIBr 2 series the first syzygy is between the second and third brachials. The total number of arms on this ray is 11 , arranged in $2,2,4,3$ order.

Ray 5: Two IIBr 2 series; that to the left bears externally (to the left) an undivided arm and internally (to the right) a $M I M B r 3(2+3)$ series; that to the right bears internally (to the left) an undivided arm and externally (to the right) a IIIBr 2 series, which bears internally (to the left) a IVBr $4(3+4)$ series and externally an undivided arm. All the first syzygies in the arms of this ray are between the second and third brachials. The total number of arms on this ray is seven, arranged in 1, 2, 1, 3 order.

On the arms on which the first syzygy is between the second and third brachials the first brachial always bears a pinnule; but on the arms on which the first syzygy is between the third and fourth brachials the first pinnule is on the second brachial.

In this specimen all but one of the IIBr series are 2, while of the ten IIIBr series present five are 2 , three are $3(2+3)$, one is $4(3+4)$, and one is $5(4+5)$. In the 36 arms the first syzygy is between the second and third brachials in 29 , between the third and fourth in six, and between the fifteenth and sixteenth in one.

Tabulation of the postradial series of this aberrant individual gives the following:

\begin{tabular}{|c|c|c|c|}
\hline$x^{2}+2=0$ & $\begin{array}{l}\text { In the arm } \\
\text { division. }\end{array}$ & In the arms. & Tot3l. \\
\hline 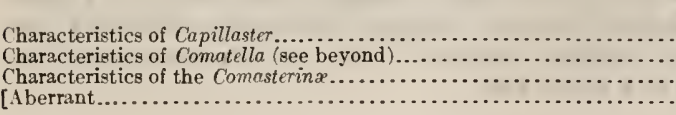 & $\begin{array}{r}\text { Per cent. } \\
38 \\
54 \\
6 \\
2\end{array}$ & $\begin{array}{r}\text { Per cent. } \\
75 \\
6 \\
17 \\
2\end{array}$ & $\begin{array}{r}\text { Per cent. } \\
56.5 \\
30.0 \\
11.5 \\
2.0]\end{array}$ \\
\hline
\end{tabular}


Comatella, Neocomatella, and Palrocumatella.

In the genera Comatella (figs. 152, 154, 156, 174, pp. 83, 89), Neocomatella, and Palaocomatella a curious condition occurs. Typically only the outer derivative from each axillary bears a division series, the inner remaining undivided. Careful examination shows that on these inner undivided branches the first two brachials are always united by syzygy, while the following brachials are united by muscular articlation. Thus following the last axillary we find on the inner side an arm which begins with a syzygial pair and on the outer an arm beginning with a pair of ossicles united by synarthry (often replaced by a syzygy) followed by a pair united by syzygy.

The only possible interpretation of this condition is that, considering only the outer derivatives from each axillary, there occurs the structure normal for species in which the division series are all of two elements; but considering the inner derivatives from the same axillaries, the division series themselves act also as the first brachial pair of each of the arms, which therefore appear to begin with a syzygial pair.

Thus while in Capillaster and Nemaster normally the first element of the pair of ossicles immediately succeeding the $I I B r$ and all following axillaries is suppressed, and sometimes both elements are wanting, in Comatella, Neocomatella, and Palcoocomatella normally both the elements of the pair of ossicles immediately succeeding the IIBr and all following axillaries are suppressed on the inner derivative, though both are present on the outer.

In the species of Comatula with more than 10 arms (figs. 121, p. 79, and 1020, pl. 8) the arm division appears to be similar to that of Comatella.

There is in the British Museum a curious example of Capillaster multiradiata, unfortunately without data, in which three of the IIBr series are 2, the other two being $4(3+4)$; each of the latter bears a IIIBr $3(2+3)$ series; the IIBr 2 series may be immediately followed by a syzygial pair (the normal third and fourth brachials), or they may give rise to undivided arms in which the first syzygy is between the second and third brachials.

Thus this specimen presents the characteristic features of the arm division of Comatella combined with those of the arm division of Capillaster.

\section{Distal arm division.}

In Metacrinus (figs. 161, 162, p. 83) the first brachial pair as defined in the preceding pages immediately follows the radials as in the Pentametrocrinidx and in Atopocrinus, but beyond this, at increasingly long intervals, the arms divide many times.

This type of arm division does not occur regularly in any of the recent comatulids, but is found as a not uncommon sporadic variant in many of the Oligophreata, and rarely in the Macrophreata, instances being recorded in Tropiometra picta (fig. 173, p. 89), where it is not unusual, Dichrometra döderleini (fig. 1027, pl. 11), Catoptometra ophiura, Antedon bifida, and Thaumatocrinus, sp., in the last occurring twice in a single arm. 


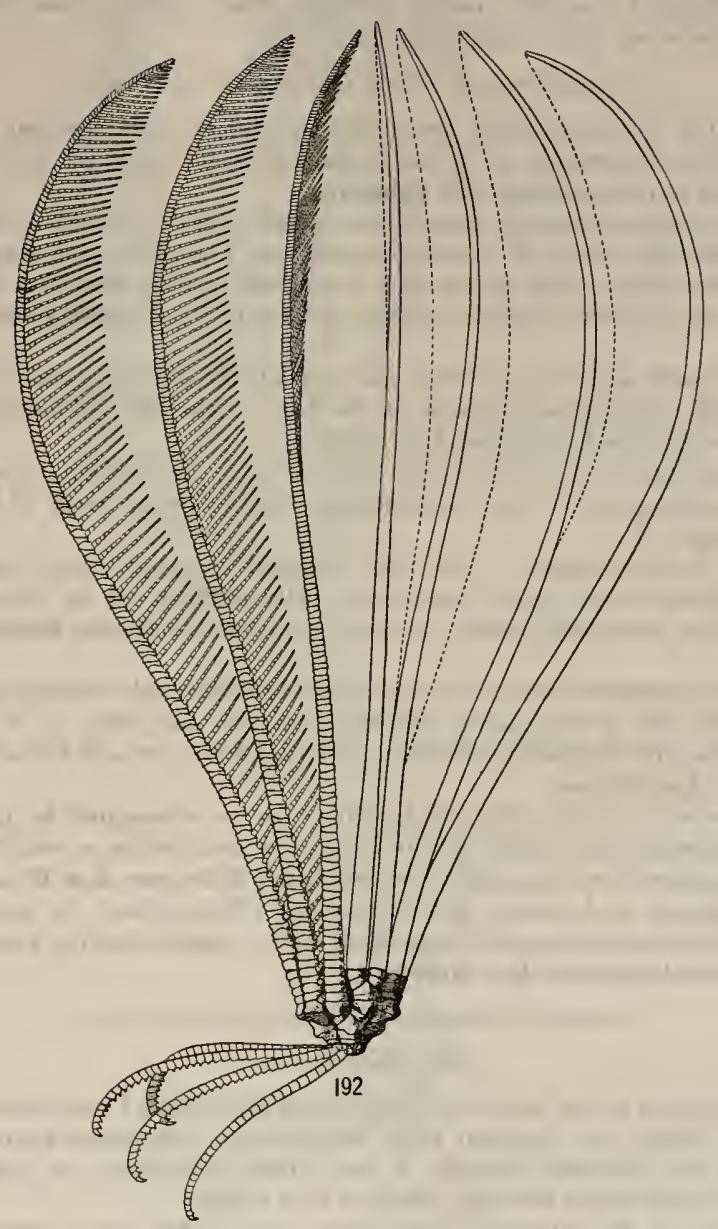

FIo. 192.-LATERAL VIEW OF TYPE SPECMEN OF AMPHIMETRA SCHLEOELIT. 
As will be explained later, each pinnule is in origin an atrophied arm, and arm branching of this type merely indicates that a pinnule has more or less completely reverted to its original intent.

Nomenclature of the different types of post-radial structure.

When the postradial series are undivided and the first brachial pair immediately follows the radials, as in the Pentametrocrinidæ and in Atopocrinus, the arms are said to possess Simple Arm Structure.

All the 10-armed species, except those included in the genus Thaumatocrinus, together with the species of Promachocrinus and Eudiocrinus, in which the first brachial pair at the base of the free undivided arm is preceded by a single reduplication of itself (the $\mathrm{IBr}$ series), are said to have Simple Interpolated Arm Division.

Species with more than 10 arms and with all the division series 2 or $4(3+4)$ and the first brachial pair present at the base of the free undivided arms are said to have Multiple Interpolated Arm Division.

This multiple interpolated arm division may be Primary, where all the division series are 2, or it may be Secondary, where more or fewer of the division series are $4(3+4)$.

When the first element of the first brachial pairs and their reduplications is absent from all the pairs beyond the $\mathrm{IIBr}$ axillary, as in Capillaster and Nemaster, the postradial series are said to possess Defective Interpolated Arm Division.

When the extemal arms on each axillary arise through multiple interpolated division, but the internal arms lack the first brachial pairs, as in Comatella, Neocomatella, and Palceocomatella, the postradial series are said to have Compound Interpolated Arm Division.

Metacrinus, in which the first brachial pair is represented by the first two ossicles following the radials, but in which the arm divides several times distal to it at irregular intervals, is said to possess Simple Extraneous Arm Division.

Such genera as Isocrinus and Pentacrinus (Extracrinus), in which the first or first two division series are interpolated, but all those following extraneous, are said to possess Heterotypic Arm Division.

ADOLESCENT AUTOTOMY AND TEE REDUPLICATION OF THE ARMS.

Young of the Comatulids.

In the young of the species of Eudiocrinus and of the Pentametrocrinidæ the arms from their first inception grow continuously and uninterruptedly during the life of the individual, though in the adults the addition of new brachials, which takes place at the arm tips, proceeds very slowly.

Likewise, in the 10-armed species the arms, forking soon after their first appearance, continue to grow uninterruptedly throughout the life of the individual.

In all the comatulids the arms almost from the very first exhibit all the essential characters of the arms of the adults, and the only change that takes 
MONOGRAPH OF THE EXISTING CRINOIDS.

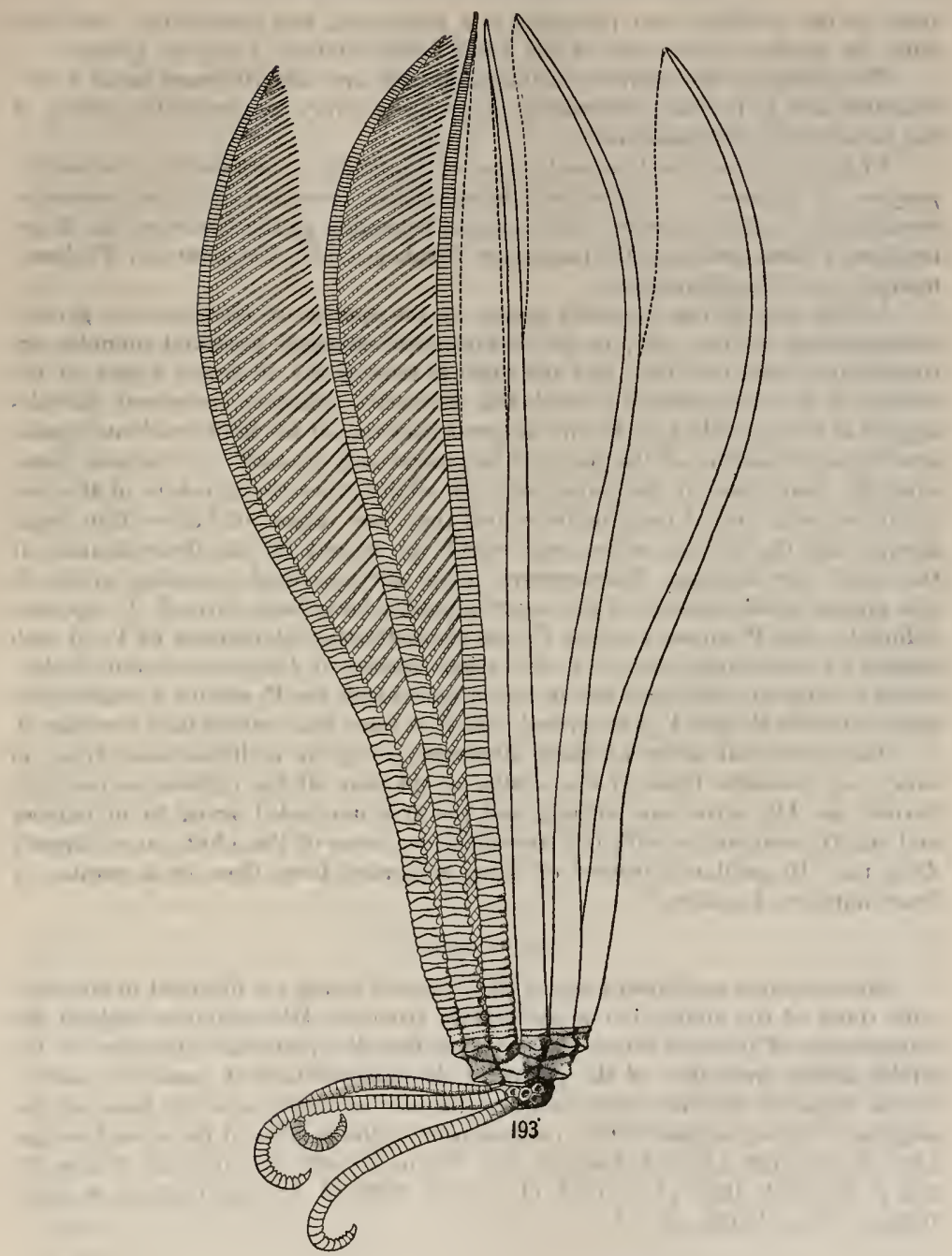

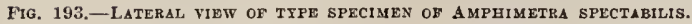


place in the brachials and pinnulars is a shortening and broadening, combined with the gradual appearance of the adult ornamentation if any be present.

The young of the multibrachiate comatulids are also 10-armed until a considerable size is reached, structurally agreeing in every way with the young of the permanently 10 -armed forms.

I have examined the 10-armed young of Capillaster multiradiata, Comanthus pinguis, C. japonica, C. parvicirra, Himerometra martensi, and Stephanometra monacantha, and of numerous other species belonging to the Comasteridæ, Zygometridæ, Himerometridæ, Mariametridæ, Colobometridæ, Calometridæ, Thalassometridæ, and Charitometridæ.

In the case of the 10-armed young of the species of Himerometra generic determination is very easy, as the characteristic enlarged proximal pinnules are conspicuous from the first; and the same is true of the 10-armed young of the species of Stephanometra, in which the distinctive spiniform proximal pinnules appear at a very early age; but in the great majority of the multibrachiate species specific determination of the young is in general only possible by inference, based upon the association of the young with the adults, since the structure of the free undivided arms and of the pinnules which they bear varies but little within broad groups, and the division series upon which we depend for the determination of the adults are lacking. Furthermore, as in the proximal pinnules, which do not appear until several of the outer pinnules have been formed, $P_{1}$ appears before $P_{2}$, and $P_{2}$ appears before $P_{3}$, the characteristic enlargement of $P_{2}$ in such types as Lamprometra and of $\mathrm{P}_{3}$ in various species of Heterometra and Dichrometra is naturally relatively late in becoming evident, for $\mathrm{P}_{1}$ attains a considerable growth before $P_{2}$ and $P_{3}$ are formed, and it is some time before they overtake it.

The postradial series of these 10-armed young of multibrachiate types in every way resemble those of the adults, except that all the division series lying beyond the IBr series are lacking, and the free undivided arms, 10 in number and strictly comparable with the free undivided arms of the adults, arise directly from the IBr axillaries instead of being separated from them by a greater or lesser number of ossicles.

Interpolated division series.

Since the free undivided arms of the 10 -armed young are identical in structure with those of the adults, but arise directly from the $\mathrm{IBr}$ axillaries without the intervention of division series, it is evident that the postradial structure of the adults differs from that of the young in the interpolation of numerous ossicles in the form of division series between the $\mathrm{IBr}$ axillaries and the bases of the original $10 \mathrm{arms}$, together with a reduplication in the number of the arms (see figs. $140,142,144,146,149,151,153,155,157,159$, p. $83 ; 166,167,168,170,172$, p. 86 ; 174 , p. $89 ; 1015,1016$, pl. 6 ; 1018, pl. 7 ; 1019, 1020, pl. $8 ; 1021-1023$, pl. $9 ; 1024$ 1026, pl. 10; and 1029, pl. 11). 
The original 10 arms are composed of numerous brachials and terminate in a growing point, which continually adds new brachials, while in the adults there are never more than four, and usually only two, segments in the second and following division series. Obviously, therefore, the second and following division series can not be formed by the branching of the growing point.

This leaves two possibilities-the proximal pinnules may transform into arms, or the original 10 arms may break off at the base, and from the stumps division series bearing new arms similar to those lost may arise.

Pinnules have never been observed to transform into arms. It is true that they may sometimes be replaced by arms, but in that case the supernumerary arm is a true arm from its very first inception.

If the first pinnule did transform into an arm, thereby forming a division series of two ossicles, the original first two brachials, it would necessitate the formation upon it of an ambulacral groove with the lappets, tentacles, nerves, and correlated structures, the conversion of the first brachial syzygy into a synarthry, the transformation of the muscular articulation between the fifth and sixth brachials into a syzygy, a radial change in the structure of the first inner pinnule, now become the first outer pinnule of the inner arm, including the loss of the ambulacral organs, and a radical change in the disposition of the syzygies throughout the arm, as the syzygies are always farther apart and more irregularly disposed in multibrachiate than in 10-armed species, or in 10-armed young. Similar and even more extensive changes would be necessitated by the development of the first inner pinnule into an arm to form a division series of four elements. Such changes are morphologically impossible; and moreover they could not occur without being readily traceable.

We are therefore compelled to accept the alternative hypothesis that the original arms are cast off and from the stumps entirely new division series and arms grow out to replace them.

It has been frequently observed in several different species normally or ordinarily 10-armed that if one arm be lost at the base, a pair of arms will regenerate from an axillary growing out from the stump, and that these arms will eventually become exactly like the others except for the somewhat greater intervals between the syzygies and the slightly shorter brachials.

Very exceptional in Antedon bifida, and, so far as we know, never occurring in $A$. mediterranea or in $A$. adriatica, and reported but once or twice among all the other macrophreate species, the tendency to develop additional arms after basal fracture may be traced through easy stages in the Thalassometridæ, Charitometridæ. Calometrida, Himerometridee, or Colobometridx, the percentage of frequency of cases rising, species by species, until we find forms in which one or more IIBr series are invariably found; and similarly there is no break in the chain between species having ordinarily from 10 to 15 arms and those having from 15 to 20 or 30. Indeed. certain individual species may cover almost this entire range, though 


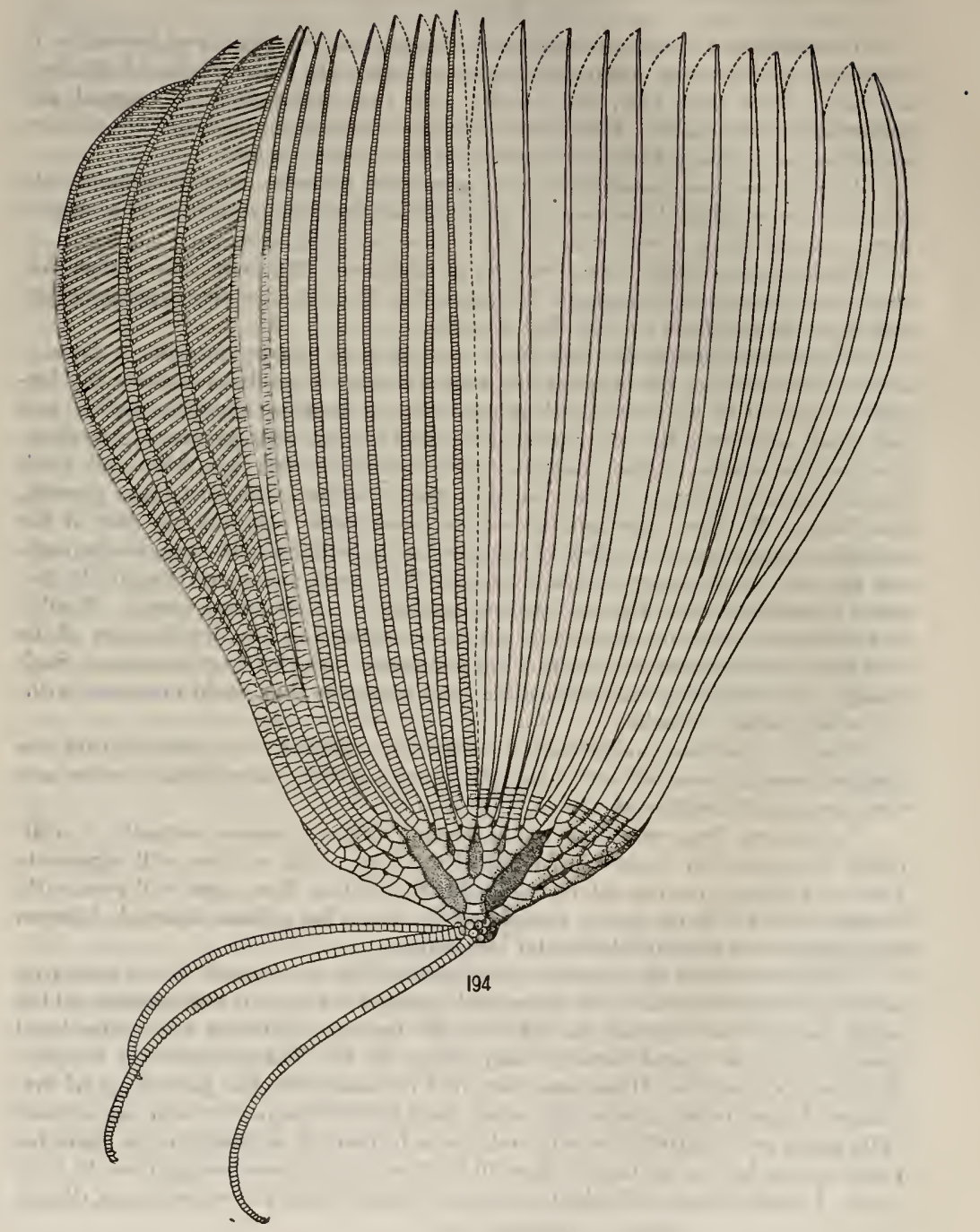

Fig, 194.-Lateral view of sfecimen of Pontometra andersoni from Singafore. 
most forms are definitely and rather narrowly limited. From the 30-armed species it is but a step to those with $40 \mathrm{arms}$, and so on up to the highest limit, nearly 200.

The smaller arm numbers, up to 12 or 14 , have long been conceded to be the result of fracture and subsequent reparation. Since there is a continuous line of species possessing all the intermediate arm numbers from 10 to about 200, the conclusion, in the absence of evidence to the contrary, is logical that all the arm numbers above 10 result from fracture and subsequent repair by division series and paired or further multiplied arms, instead of by single arms resembling the one lost.

I have examined a series of specimens of species of Crinometra including practically every stage from the 10-armed young to the (usually) 30-armed adult, and all of them were increasing the number of their arms by fracture and subsequent reparation. Similar complete series have been studied in Capillaster multiradiata, and in Comanthus parvicirra, and very numerous instances of intermediate stages have come to my notice in other species distributed in almost all of the multibrachiate genera, so that I have no hesitation whatever in making the unqualified statement that any increase in the number of arms over 10 is exclusively brought about by the casting off of one or more of the original 10 arms of the young and the regeneration in its place of an axillary bearing two arms or further division series and arms.

In many species, including all of those which never develop division series further than the second, the original arm, which is usually lost at the brachial synarthry, more rarely at the first brachial syzygy, is replaced by an axillary bearing two arms only. This is the most primitive type of interpolated multibrachiate condition and is only a slight step in advance of the more or less accidental assumption of additional arms, as seen in Antedon bifida-a rare latent tendency become common and of regular occurrence.

In the species which have more than 20 arms after the casting off of each of the original 10 arms an axillary is formed on the stump from which immediately grow, by so-called multiplicative regeneration, additional division series to the full number, followed by free undivided arms to a maximum number of nearly 20 . Thus, no matter how large the number of arms in the adult may be, autotomy never normally occurs but once on each of the derivatives from the IBr series.

The ossicle formed on the stump of a lost arm is always an axillary, and it is joined to the stump by the type of articulation which originally united the stump to the succeeding ossicle. Thus if the original arm was discarded at the synarthry between the first and second brachials, as it most commonly is, the resulting division series will be composed of two elements united by synarthry; but if it be discarded at the syzygy between the third and fourth brachials, the resulting division series will be of four elements, of which the two outer are united by syzygy-that is, $4(3+4)$. 
As the number of arms increases, adolescent autotomy, by acceleration of development, becomes a more and more fixed and fundamental character and

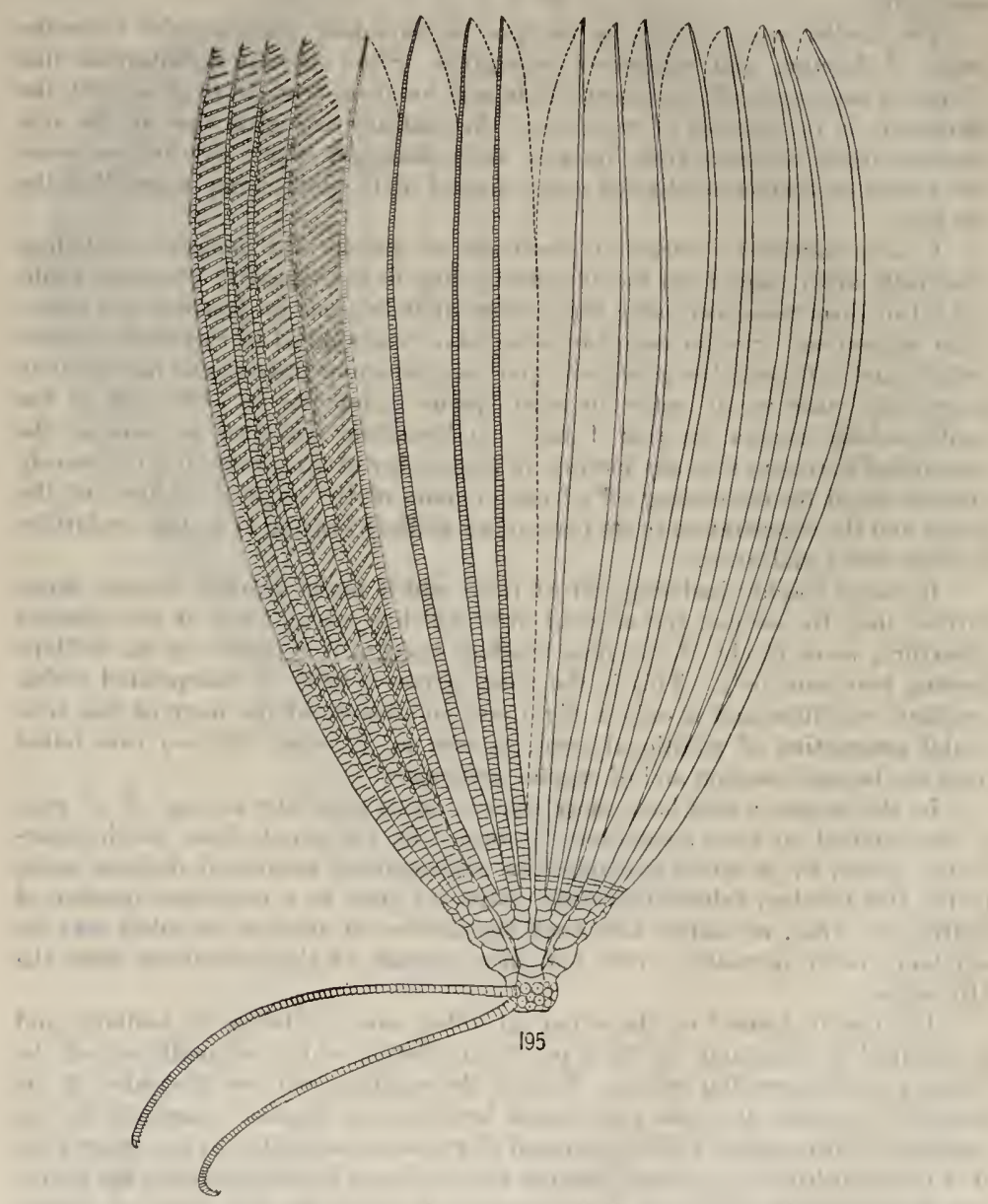

FIG. 195. - LateraL VIEW OF TYPE SPECIMEX OF OXYMETRA FIXSCHII

takes place at progressively younger stages. 'Thus whereas in the case of species with less than 15 arms the adult size is reached before the loss of any of the 
original 10 arms, in species with 20 arms autotomy occurs when the original 10 arms are not much more than three-quarters of the length of the adult arms, and in species with more than 40 arms much earlier. Thus in the species with comparatively few arms the arms of the adults are often shorter than the arms of the fully grown 10-armed young, and they may even be considerably shorter, both absolutely and in proportion to the other dimensions of the animal. As the arms increase in number the animals progressively decrease in the relative maximum size of the 10-armed young, and hence the arms of these 10-armed young become absolutely shorter than those of the adults, the difference increasing proportionately with the increase in the number of the arms. But, relatively, the arms of the 10-armed young are always much longer than those of the adults; and the greater the number of arms in the adults the shorter do they become in reference to the diameter of the disk, and the more do they differ in that relation from the arms of the 10-armed young.

The casting of of the arms in the 10-armed young of the multibrachiate species does not occur simultaneously on all the rays, nor do the two arms of a single ray drop off at the same time. The original arms are lost one by one, and the adult arms are produced successively as the original arms fall off. Thus a young multibrachiate comatulid passing from the 10 -armed to the adult condition always exhibits great diversity in the size of the newly formed division series and arms. some being nearly or quite fully grown, while others are only just beginning to form. I have not been able to ascertain the order in which the arms are lost, or whether they are cast off in any regular order at all, as material in regenerating stages has not yet been collected in sufficient quantity to enable any opinion to be formed on the subject.

The method of the reduplication of the arms in the multibrachiate comatulids by the peculiar and economically wasteful process of discarding the juvenile arms at the brachial synarthry or at the first brachial syzygy, and subsequently regenerating from the stump an axillary with sometimes additional division series bearing two or more arms, each of which is in erery way like the one which they replace, was worked out by the present author as given in detail here. But I afterwards found that Wilhelm Minckert in 1905 had arrived at exactly the same conclusions by a somewhat different process of reasoning. P. H. Carpenter on more than one occasion seems to have felt the possibility of the existence of such a process, but he was never sure enough of his ground to permit himself to express the idea in so many words; and it remained for Minckert, working on the Blake material previously reviewed in part by Carpenter, first to show how the reduplication of the arms in the comatulids is brought about.

Phylogenetic sequence of the arms on each ray.

A very conspicuous characteristic of Lamprometra protectus and Pontiometra andersoni (figs. $275-277$, p. 213), well illustrated also in rarious other multibrachiate species, is that the proximal pinnules on the outer side of the outer arms on each postradial series exhibit the features distinctive of the species to a markedly 
greater degree than do the pinnules on the inner arms, which are of a more generalized type.

Since the specialized specific characters are most pronounced on the onter arms on each $\mathrm{IIBr}$ series, which thereby depart most widely from the primitive type, it is a logical assumption that these outer arms represent a phylogenetical adrance over the inner arms. It has already been mentioned that they commonly bear an additional axillary.

Further evidence of the advance in development of the outer arms over the inner is found in the curions Comatula etheridgei (part 1, fig. 78, p. 131), which may possibly be the young of $C$. rotalaria. In this species the outer arms arising from each $\mathrm{IIBr}$ axillary are always much smaller than the inner and always

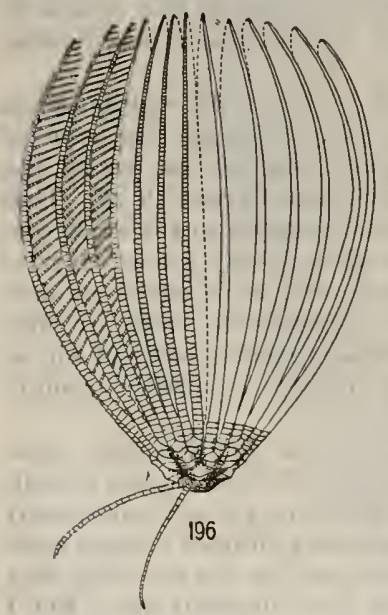

Fig. 196. TATPRAT VIEW OF TYPE SPECIMEN OF MARIAMEMRA TUEERCULATA. show evidence of undergoing rapid growth. Thus in this form the outer arms are ontogenetically of later development than the inner arms; and it may be assumed that, maturing at a much later period, they will exhibit any features characteristic of the species in a more perfected form than the inner arms.

Therefore, in 20-armed species with four arms on each postradial series the evidence seems to show that the two onter arms are more advanced than the two inner (figs. 176, 177, p. 89).

In Lamprometra protectus and in Pontiometra andersoni, when 40 arms are present, eight on each postradial series, it is noticeable that, whereas the proximal pinnules on the outer side of the outermost arms are the most developed, those on the outer side of the innermost derivative from each $\mathrm{IIBr}$ series are much more developed than the arms between these and the outermost arms (the intermediate 30 -armed stage is shown in fig. 178, p. 89).

Tracing the relationship still further, it is easily ascertained that while the phylogenetic status of the arms on postradial series with four ultimate branches (the number 1 representing the most perfected type) is

$$
1: 2:: 2: 1
$$

and on postradial series with eight ultimate branches

$$
1: 3:: 4: 2::: 2: 4:: 3: 1,
$$

on postradial series with 16 arms it is

$$
1: 5:: 7: 3::: 4: 8:: 6: 2:::: 2: 6:: 8: 4::: 3: 7:: 5: 1 \text {, }
$$

each group of four arms tending to act as an independent unit. 
In Heterometra and Craspedometra the phylogenetic sequence of the arms appears to be reversed, and this coincides with the frequent occurrence in these types of additional division series on the inner derivatives from each $\mathrm{IIBr}$ series.

While each of the arms in a comatulid is an exact counterpart of another arm on the same ray, and the arms are therefore paired appendages in the strictest sense of the word, they are not paired, except for the two arising from the $\mathrm{IBr}$ series, with the arms on the same axillaries.

Ontogenetical, phylogenetical, and morphological sequence of the first brochial pairs and their reduplications.

The simplest arm structure found among the comatulids occurs in the genera Thaumatocrinus, Pentametrocrinus, and Atopocrinus, in which the first brachial pair immediately follows the radials and the succeeding brachials are arranged in a linear series.

Thongh this arm structure is theoretically the simplest, it is probably not the most primitive, for in no other genera of the Articulata does it recur, though many of these genera are undeniably more primitive than Thaumatocrinus, Pentametrocrinus, and Atopocrinus in all other ways. We have here apparently a good example of simplification through specialization.

The most primitive arm structure is probably that of the 10 -armed comatulids, or more properly of those species in which a $\mathrm{IBr}$ series is present, which is characteristic not only of the majority of all the Articulata but also of the young of all those which are multibrachiate when adult. The fundamental significance of the presence of the $\mathrm{IBr}$ series is further emphasized by the frequency of its occurrence in the fossil types not represented in the recent seas, especially in the Flexibilia.

From the standpoint of the crinoids as

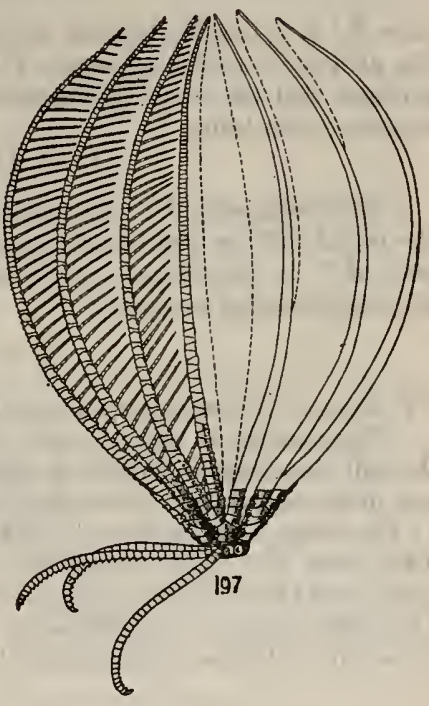

Fig. 197.-LATERAL VIEW OF TYPE SPECIMEN OB MARIAMETRA MARGARITIFERA.

a whole, or of the Articulata as a whole, the occurrence of additional division series of itself represents no phylogenetical advance, whatever may be its significance within limited groups; the presence of one division series is as fundamental as the presence of many. But the presence of additional division series is correlated with the extreme atrophy of the calyx plates and the consequent relative increase in the size of the visceral mass, both of which have an important phylogenetical bearing. 
In a species having five division series, all interpolated, there are five repetitions of the first brachial pair, plus the first braclial pair itself, making six homologous pairs of ossicles between the radials and the free arms from the third brachial onward. 'These may be numbered I, II, III, IV, V, and VI, I representing the $\mathrm{IBr}$ series and $V I$ the first brachial pair.

Ontogenetically these appear in the order I, VI, II, III, IV, V, $V I^{2}, V I^{2}$ being the first brachial pair at the base of the adult free undivided arm, which is an exact reduplication of $V I$ at the base of the discarded larval arm.

If the simplest type of arm structure were also the most primitive the phylogenetical sequence of the pairs would be

$$
\text { II, I, II, III, IV, V, VI'2, }
$$

since $V I$ is invariably present, whether the others are present or not. But from the all but invariable presence of $I$ in addition to $V I$ in the crinoid arm it is probable that the actual phylogenetical sequence is the same as the ontogenetical sequence, both being

$$
\text { I, VI, II, III, IV, V, } V I^{2} \text {. }
$$

Morphologically VI is always present. With the appearance of a gap between the radial and the arm base as a result of the shrinking of the calyx the appearance of $\mathrm{V}$ is necessitated, and subsequently also of IV, III, II, and I, so that the morphological sequence is

$$
V I, \mathrm{~V}, \mathrm{IV}, \mathrm{III}, \mathrm{II}, \mathrm{I} \text {, }
$$

$V I^{2}$, being of the same morphological value as $V I$, not appearing.

The number of arms on each ray which would result from the presence of the full complement of division series-a rare condition beyond the IIIBr series and quite exceptional beyond the IIIBr series-is, 0 (no division series present), 1; IBr series, 2; IIBr series, 4; IIIBr series, 8; IVBr series, $16 ; \mathrm{VBr}$ series, 32; $\mathrm{VBr}$ series, $64 ; \mathrm{VIIBr}$ series, 128 ; 5-rayed comatulids with these series as just given would have the following numbers of arms: 0 (no division series present), 5 ; $\mathrm{IBr}$ series present, $10 ; \mathrm{IIBr}$ series, $20 ; \mathrm{IIIBr}$ series, 40; IVBr series, $\mathrm{S} 0 ; \mathrm{VBr}$ series, 160 ; VIBr series, 320 ; and VIIBr series, 640 .

BRACHIALS OF THE FREE U NDIVIDED ARM BEYOND THE FIRST PAIR.

In the free undivided arms of the comatulids the first two brachials, which together, as previously explained, form a single unit, are immediately followed, excepting only in the Pentametrocrinidx (fig 126, p. 79) and in Atopocrinus (part 1, fig. 227, p. 245), by a second pair of much shorter brachials invariably united by syzygy, just as the first two are united by synarthry (fig. 128, p. 79) ; then comes, except in the Atelecrinidæ, a series of short wedge-shaped brachials which are commonly about twice as wide as the median length; after usually between the ninth to the twelfth the brachials typically become triangular and about as long as broad (fig. 233, p. 193), after the end of the proximal third or 
fourth of the arm gradually and slowly becoming wedge-shaped again, as a result of decreasing obliquity of their ends, and slowly increasing in proportionate, though not in actual, length, correlatively with their gradual decrease in diameter, so that the terminal brachials are much longer than broad, more or less strongly constricted centrally, with their ends almost or quite at right angles to the longitudinal axis of the arm.

The distal edges of the brachials following the first syzygial pair are more or less produced and are commonly bordered with spines, which are usually very fine, but which may become much elongated. On the proximal wedge-shaped brachials this production of the distal edges stands out at right angles to the longitudinal axis of the arm, and if very prominent it may be accompanied by a similar, though lesser, production of the proximal edges. As the brachials become elongated the latter, if present, disappears, and the produced distal edges gradually lean more and more toward the arm tips, so that they overlap more or less the bases of the succeeding brachials (fig. 1140 , pl. 22).

Usually the dorsal surface of these brachials is smooth, but in certain species of Thalassometridæ, and very rarely in other types, they may carry numerous fine spines. On the wedge-

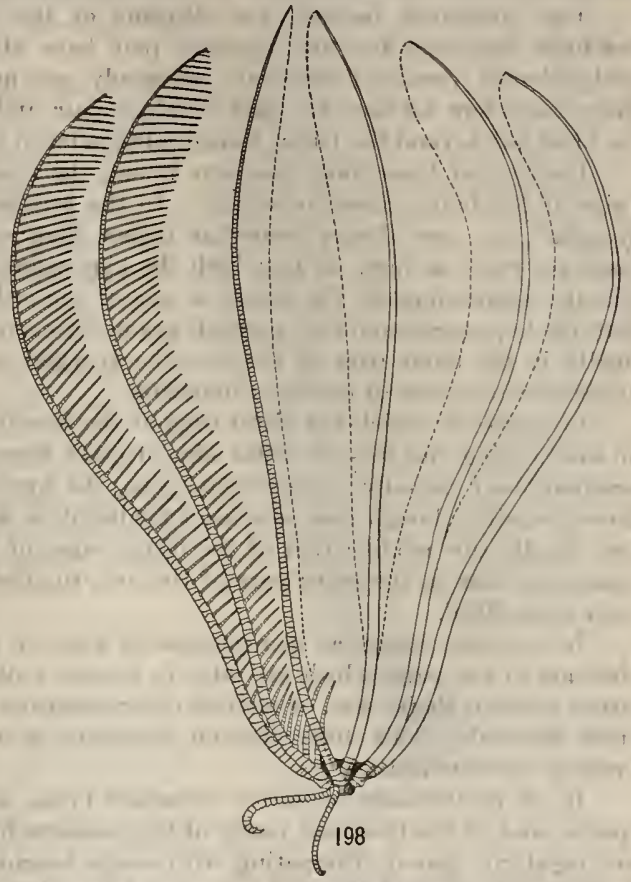

lig. 198. - Lateral view of specimen of Petasometra clak.e. shaped proximal brachials these spines are thickly massed in a broad band and show no definite arrangement, but as the brachials elongate the broad band gradually resolves itself into a triangle, of which the base is the dorsal portion of the distal borders of the brachials and the apex lies in the mid-dorsal line near or at the middle of the proximal border, while the spines themselves gradually come to arrange themselves in rows parallel to the longitudinal axis of the arm. 
In a number of species, especially in the Ptilometrinæ, the brachials carry in the mid-dorsal line a prominent raised keel. On the proximal wedge-shaped brachials this keel is of uniform height, but as the brachials increase in length the distal outer portion becomes higher and higher and the proximal portion lower and lower, so that a high triangular overlapping spine results, the base of which coincides with the mid-dorsal line of the brachial which bears it, while the apex lies more or less beyond the level of the proximal end of the succeeding brachial.

The differences between the elements of the first brachial pair and the brachials following the first syzygial pair have already been considered. The wedge-shaped proximal brachials commonly are more or less intermediate in their characters between the first brachial pair and the first syzygial pair and the brachials beyond the latter, though always much more like the distal brachials.

Distributed throughout the arm among the brachials of the usual type are pairs of brachials united by syzygy. In the proximal portion of the arm these syzygial pairs are always somewhat higher than single brachials, and in some cases are twice as high, so that both the hypozygals and the epizygals are individually approximately the equals in size of the ordinary brachials; but distally both the hypozygals and the epizygals gradually decrease in relative height, so that finally in the outer part of the arm the syzygial pairs come to have quite the appearance and size of ordinary brachials.

In species in which the distal edge of the brachials is strongly produced into an overlapping and spinous distal edge or other form of eversion, or in which the brachials bear dorsally a prominent spine, the hypozygals of the syzygial pairs show a similar though less prominent modification at the line of syzygial union: but distally this modification of the distal edges of the hypozygal gradually decreases, so that in the outer part of the arm the distal edge of the hypozygal is quite unmodified.

In the very young, as in regenerating arms or at the growing arm tips, the elements of the pairs which are later to become united by syzygy are in no way, either through shape, size, or method of articulation, to be differentiated from the other brachials. This differentiation is effected at a comparatively late stage of brachial development.

In all of the more primitive comatulid types, in nearly all of the 10-armed species, and in the 10-armed young of the multibrachiate forms, the syzygial pairs are regularly spaced, alternating with single brachials or, usually, separated by from two to four of them, the number being definite for each species. In the proximal portion of the arm the first syzygy is between the third and fourth brachials, the second between the ninth and tenth, and the third between the fourteenth and fifteenth, or, much less commonly, between the fifteenth and sixteenth (fig. 1018, pl. 7). In the outer part of the arm the number of brachials of the ordinary type between successive syzygial pairs is more or less correlated with the size of the species, very small species commonly having the syzygial pairs separated by single brachials, larger species having them separated by two or three brachials, and the largest species having three or four brachials between the syzygial pairs. 
Three somewhat anomalous departures from the usual type of brachial structure deserve to be noticed here.

In Atelecrinus (part 1, figs. 123, p. 192, and 124, 125, p. 193) and in Atopocrinus (part 1, fig. 227, p. 245) the series of wedge-shaped or more or less oblong brachials which typically interrenes between the first syzygial pair and the triangular brachials beyond the second syzygy is absent, and the brachials assume the triangular form immediately beyond the second.

In the Pentametrocrinidae (part 1, figs. $113, \mathrm{p} \mathrm{181}, 119, \mathrm{p} .185$ ) and in Atopocrinus the first syzygial pair is separated from the first brachial pair by a single brachial.

Both of these departures from the normal type of brachial structure are probably correlated with the excessive length and consequently very rapid growth of the arms.

In most of the species of Crossometra, Perissometra, and Pachylometra the eleventh, twelfth, or thirteenth brachial is usually sharply differentiated from the brachials preceding and succeeding by being regularly oblong with its proximal and distal articular faces parallel to each other; the transverse ridges on these articular faces, however, alternate as usual.

BEACHIAL OF THE ARMS OF THE MULTIBRACHIATE SPECIES.

In the multibrachiate comatulids (figs. 241, 243, p. 197, 244-252, p. 199 and 253-261, p. 205) the free undivided arms differ from those of the 10-armed species (figs. 236-240 [also 242], p. 197) and the 10-armed young of the multibrachiate types in being composed of shorter brachials which have the ends less oblique and are consequently

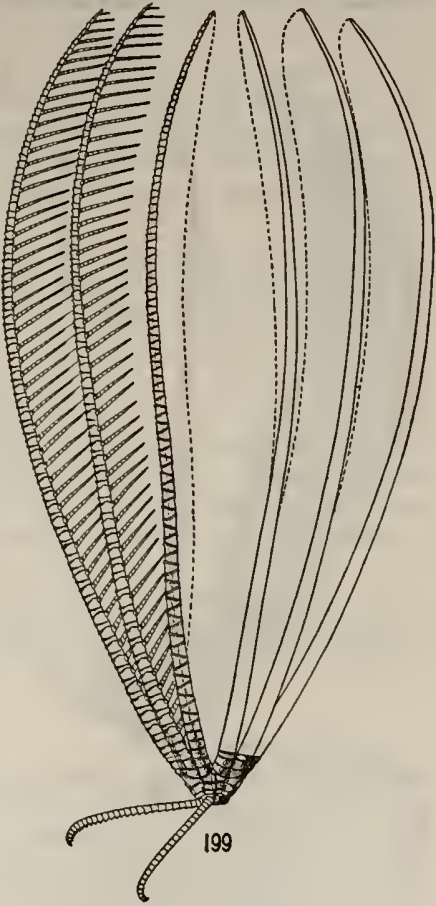

Fig. 199.-Lateral view of specisen of COTYLOMETRA ORNATA. wedge-shaped instead of triangular, and in having the syzygial pairs less numerous and less regularly distributed.

Speaking broadly, it may be said that a species with 20 arms has the brachials shorter than one with $10 \mathrm{arms}$, and wedge-shaped instead of triangular; a species with 40 arms has the brachials still shorter and less obliquely wedge-shaped; and a species with more than 60 arms has this character still more pronounced. But while all the multibrachiate species have the brachials shorter and more wedge- 
slraped than 10 -armed forms, the shape of the brachials is not always strictly proportionate to the number of the arms.

The chief exceptions to the broad generalization that the lurger the number of arms the sliorter and more wedge-sliaped the brachials are the following:

Capillaster multiradiata (fig. 261. p. 205) rarely has more than 20 arms, yet the brachials are extremely short and discoidal, quite as short as, and frequently shorter

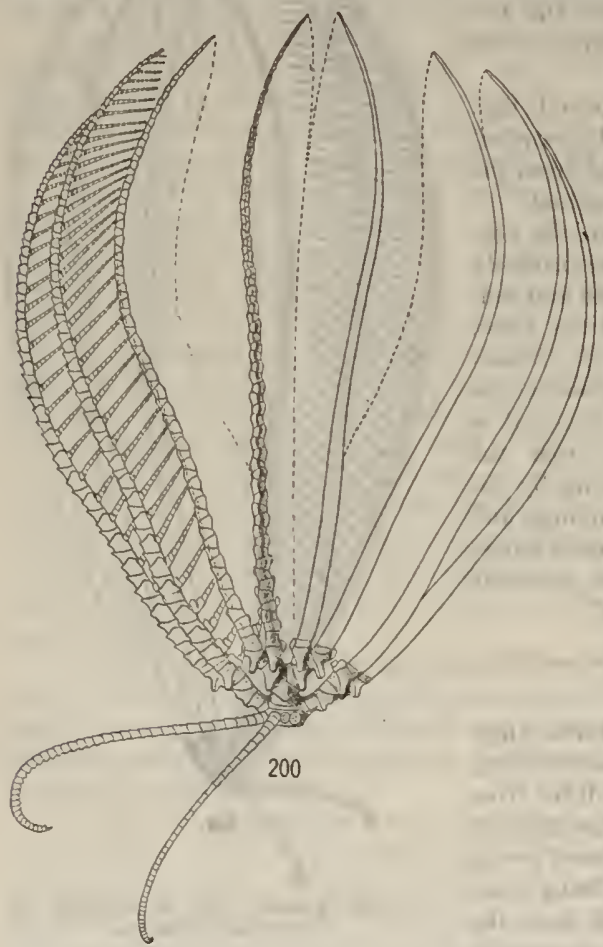

Fig. 200,-LATERAL viEW OF SPECIMEN OF NeOMETba diANa. than, those of the larger $C$. sentosa (fig. 258, p. 205), in which the arms are much more numerous: but individual variants occur in which the brachials are of the shape normal for 20 armed species.

On the other hand, the species of Nemaster (fig. 243, p. 197) and Neocomutella have the brachials rather long for multibrachiate species.

In the species of the 10armed genus $A$ mphimetra (fig. 259, p. 205) the brachials are extremely short and narrowly oblong in dorsal view, in this agreeing with the braclials of several species of the closely allied genus IIeterometra, in which there are fewer than 20 arms.

A striking characteristic of many of the species of Heterometra is the irregularity of the number of arms on the different rays, indicating a marked instability in the arm division. Apparently in correlation with this, individuals are frequently met with in which the formation of additional arms is taking place after the full size has been reached, indicating an exceptionally strong latent tendency toward increase in the number of arms. As has been mentioned, there is commonly an additional axillary on the inner hranches from each $1 \mathrm{IBr}$ series. $\quad P_{3}$ is the longest, and is usually best developed on the inner arms. All of these features, as well as the very short brachials, appear to suggest that these species are descended from others in which the arm number was much greater and the arm structure approached that seen in the genus IIimerometra (fig. 260, p. 205). 
Heterometra philiberti, which has very numerous arms with very short brachials and all the division series except the first $4(3+4)$, and II. crenulata, which also has very numerous arms composed of rery short brachials, possibly approach more or less closely the type originally characteristic of the genus. But most of the species of Heterometra, like those of Craspedometra (part 1, fig. 85, p. 139), Himerometra and Homalometra, fall within the broad generalization.

Thysanometra tenelloides, though having only $10 \mathrm{arms}$, has the brachials very short and wedge-shaped proximally, becoming narrowly oblong in dorsal riew distally. The syzygial pairs, however, are distributed as in normal 10-armed types.

In the rery large species of the Heliometrinæ and in broad-armed species of the Comasteridæ (figs. 242 , p. 197 , and 256. p. 205) the brachials show a tendency to shorten and to approach the type of brachial typically found in species with IIBr series.

In arms arising from a $\mathrm{IIBr}$ or later division series the syzygial pairs are less frequent than in arms arising from the $\mathrm{IBr}$ series; the first syzygial pair, between the third and fourth brachials, is always present, the second is usually absent, the third is more or less variable in position, and the distal are separated by from four to six or seven or more brachials; often, indeed, they may be separated by long intervals, and sometimes they may be almost completely lacking. Thus in a specimen of Cenometra bella at hand, while the first syzygrial pair is in all cases present. there may be no others in the arm. If there be a second it is composed of the forty-second and forty-third brachials (twice), forty-third and forty-fourth, fortyfourth and forty-fifth, forty-eighth and forty-ninth, fifty-fifth and fifty-sixth, or ninety-first and ninety-second.

In this connection it is interesting to note that in the Pentametrocrinidæ and in Atelecrinus the distal intersyzygial interval is greater than that usual for 10 -armed species, and also less regular, being from one to six brachials, usually from two to five.

ARM TIPS.

The comatulid arm ordinarily ends in a growing tip which is slowly adding new brachials, together with the accompanying pinnules (fig. 285, p. 221). The terminal 12 or 15 pinnules, therefore, are progressively less and less mature and decrease gradually in length, the outermost being represented merely by a bud. In the adults the rate of growth of the arm is exceedingly slow, and the same is true of the terminal pinnules, which retain their relative proportions after all growth has practically ceased.

In the species of Calometridæ and Ptilonetrinæ (part 1, fig. 46, p. \$1), especially well illustrated in the latter, the arm ends abruptly with half a dozen very short crescentic brachials, this abortive tip being recurved and more or less concealed between the outer pinnules. The terminal pinnules, like the terminal brachials, decrease very rapidly in length, so that the subterminal pinnules exceed them and when the pinnules are closed together reach several millimeters beyond the arm tip giving the arm the appearance of having been broken off. A greater or lesser approach to this condition is seen in the Tropiometridæ (fig. 291. p. 221) 
and in the species of those genera of Thalassometrinæ in which the arms are relatively short, as for instance Stenometra and Daidalometra.

The abruptness of the distal termination of the arms seems to bear a more or less definite relation to their relative length, and to have no other significance. Species with very long and slender arms have the arm tips tapering very slowly and the pinnules decreasing in length very gradually, but in species with short and robust arms the arms terminate very abruptly and the terminal pinnules decrease in length very rapidly. A considerable difference in this respect is noticeable between Antedon adriatica and A. petasus within the same genus.

Even in the Ptilometrinæ and Calometridæ where the abruptness of the termination of the arms reaches an extreme it is a character assumed at a relatively late stage and is never indicated in the 10-armed young, or in the young of 10-armed species before they are at least half grown.

The posterior arms of the Comasteridæ when ungrooved are peculiar in ending definitely in an axillary ossicle which bears two distal pinnules, one on either side (fig. 1034, pl. 12, and part 1, fig. 4i, p. 81).

PINXELE.

Gencral features.

The pinnules of the comatulids are of three types, each type occupying a definite location on the arm and being, in its perfected form, entirely distinct from the other two (figs. 281,282, p. 215 , and part 1, fig. 1, p. 60). The first type is usually somewhat sharply differentiated from the second, though in many of the higher forms there is more or less intergradation. The second type always changes more or less gradually over into the third.

These three types are:

(1) The Oral or Proximal Pinnules; these occur on the first two to twelve brachials (figs. 262-273, p. 207; 274, 277-280, p. 213; figs. 281-287, p. 215), and their function is to serve as tactile organs (fig. $2 \pi$, p. 213), or to protect the disk (figs. $2 \pi 0,2 \pi 1,2 \pi 3$, p. $20 \pi)$.

(2) The Genital or Middle Pinnules; these follow the oral pinnules and bear the gonads (figs. 281282 p. 215).

(3) The Distal Pinnules; these occupy the outer part of the arm and serve chiefly as food collecting organs (figs. 281, 282, p. 215).

In life the oral pinnules, when flexible, are bent forward and downward, so that they form a sensitive network over the disk (fig. 1044, pl. 12). If rigid they extend inward and more or less upward so that the disk is roofed over by a strong network from which sharp points protrude. The oral pinnules on each arm are always parallel to each other, and only move in a plane parallel to the dorsorentral plane of the arm.

The lower genital pinnules on either side of the arm are in parallel planes and extend outward more or less at right angles to the arm with their distal portion usually curved broadly upward toward the arm tip, but the succeeding genital pinnules begin to lean outward, and this step by step increases until the 
outer genital pinnules, like the distal pinnules, lie horizontally in a plane at right angles to the dorsoventral plane of the arm (fig. 1071, pl. 16).

The genital and distal pinnules can be folded inward until they almost or quite meet and then laid back along the arm so that they form a covering over the soft ventral surface.

Pinnules always occur on the opposite sides of succeeding brachials, so that they alternate regularly all along the arm (fig. 1030, pl. 12). They never occur on the hypozygals of syzygial or of synarthrial pairs, nor upon axillaries.

Usually the pinnules taper gradually, slowly, and evenly from the base to the tip, but in certain species in which the adambulacral plating is highly developed, as in the species of Ptilometrinæ and Calometridæ, they may end abruptly with a few small segments much as the arms do in the same types (figs. 351-593, pp. 235-303).

In viewing a single arm of almost any 10-armed species with the pinnules extended, the elongate oral pinnules are seen to be very conspicuous, and the change from these to the short lower genital pinnules is very abrupt. 'The following genital pinnules slowly increase in length until the lower distal pinnules are reached, after which the same length is usually maintained until near the end

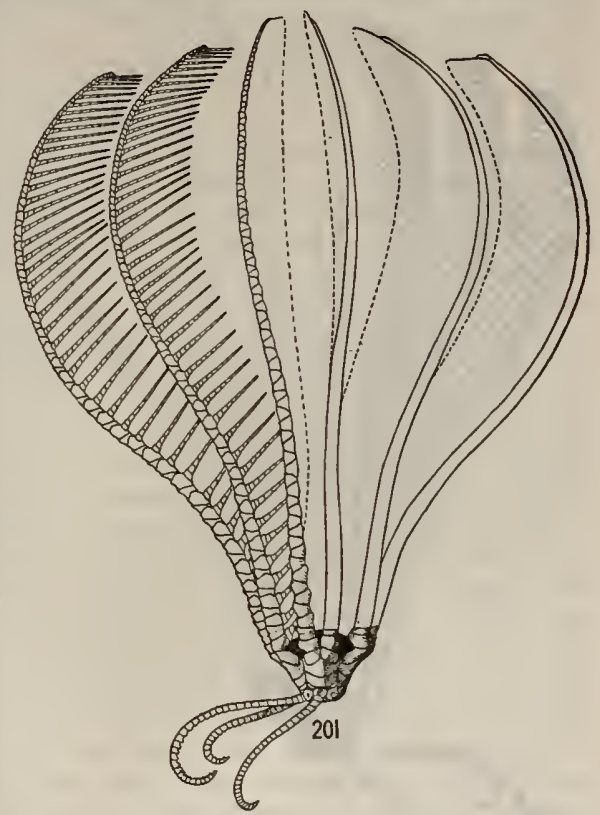
of the arm, when the length decreases with more or less rapidity, so that the distal end of the arm is more or less broadly rounded. The slenderness and delicacy of the pinnules and their rery considerable number give the arms much the appearance of delicate feathers (figs. 262-287, pp. 207, 213. 215).

As a general rule, the pinnules of the oligophreate species (figs. 262-280, pp. $207,213 ; 283-285$, p. 215$)$ are shorter and stouter than those of the species of the Macrophreata (figs. 281, 282, 286, p. 215).

Proportionately with the increase in the number of arms the length of the pinnules decreases, so that in the highly multibrachiate forms they are usually relatively very short (figs. $270-273$, p. $207 ; 274-277$, p. 213). 
In the Ptilometrinæ and in the Calometridx, as well as in the short-armed genera of the Thalassometrinæ, the arms end very abruptly with sharply recurved tips, and the terminal pinnules decrease in length very rapidly, so that the subterminal pinnules extend for some distance beyond them (figs. 277, p. $213 ; 285$, p. 215 ; and part 1 , fig. 46 , p. 81 ). Thus when the arm is extended the tip shows a broad V-shaped gap, with a blunted apex resting upon the subterminal brachials.

The first two segments of the middle and outer pinuules, and often also of

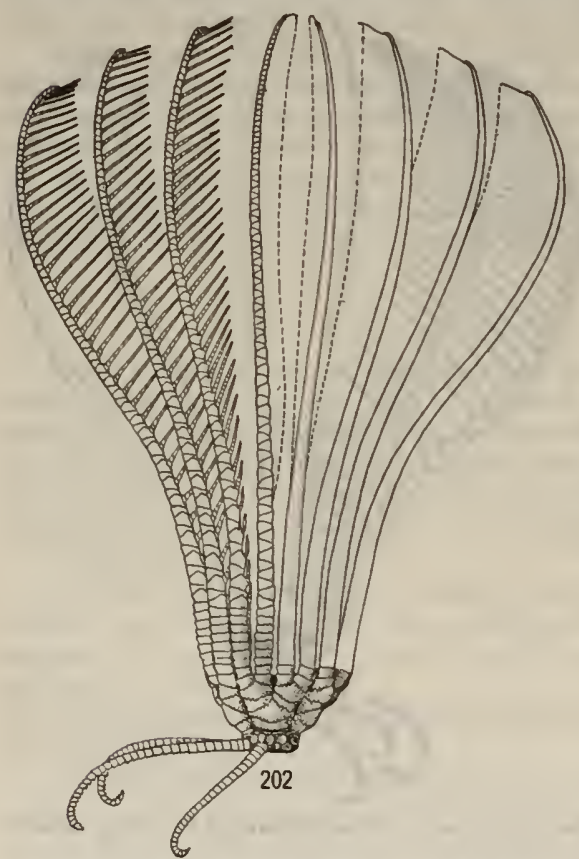

Fig. 202.-Lateral view of specimen of Pectinometr. CARDECM. the proximal pinnules, are always shorter than those following (figs. 1059,1063 , pl. 14). The first is usually between two and three times as broad as long and more or less crescentic in outline; the second is trapezoidal, usually about as long as the proximal (greater) width.

It is at the well-developed articulation between these two ossicles that the flexion and extension of the pinnules takes place. In some forms, more especially in the Oligophreata, a considerable amount of motion may be possible between the more distal pinnulars, but usually these articulations are semirigid, and in certain types, as the Ptilometrinæ, Calometridx, and many of the 'Thalassometrinæ and Charitometridæ, quite rigid. Motion between the pinmulars following the second slowly increases in extent toward the pinnule tip, and the last four to six or more segments are always movable even if the rest of the pinnule be rigid.

The first two pinnule segments are subject to but very slight variation in form, and their size in comparison with the brachials which bear them is always approximately the same. 'Therefore if the pinnules as a whole are very slender, as in most of the Macrophreata, they appear disproportionately large (fig. 1063, pl. 14), not because they have actually increased in size but merely because they have retained their normal and original dimensions while the diameter of the segments following has decreased. 
If the third and following pinnulars have strongly projecting or spinous distal ends or a spinous dorsal surface, or if they are greatly elongated, or greatly attenuated, or very short, or even if they are sharply triangular with a knifelike or spinous dorsal keel, the first two pinnule segments always remain practically unchanged. Their correlation is not with the succeeding pinnulars, but with the brachials, and therefore any variation in them is quite independent of the conditions in the other segments.

The third and following pinnulars gradually increase in length, at the same time gaining in individuality, and the pinnule finally terminates in a definite tip (fig. 345, p. 229). As in the case of the brachials, and especially of the cirri, when the outer pinnules are greatly elongated their ends tend to become swollen so that they often develop greatly expanded articulations.

The distal ends and the dorsal surface of the first two pinnule segments are always smooth, and the same may be true in regard to all the other segments. Almost always, however, the distal edge of the third and following segments is more or less everted, overlapping the bases of the succeeding segments, and finely spinous (fig. 325, p. 227). This character is least marked on the third segment, and gradually increases in prominence distally, as a rule coincidently with the development of fine spinelets on the dorsal surface of the segments. The extent of the occurrence of spines on the distal ends and on the dorsal surface of the pinnule segments (excepting usually those of the oral pinnules) is strictly correlated with the exactly similar development of spines on the distal edges and on the dorsal surface of the brachials, so that species with smooth arms have smooth pinnules, and species with spinous brachials have spinous pinnule segments. The spinosity of the segments of the oral pinnules is correlated with the condition of the division series and first brachial pair, and not with the condition of the outer brachials.

The two to four terminal pinnule segments are always armed dorsally with from two to six or eight or more recurved hooks (figs. 351-593, pp. 235-303), and part 1 , figs. $48-52$, p. 81 ), no matter how smooth the rest of the pinnule may be. These reach a maximum development in the Comasteridæ, especially in the subfamily Comasterinæ (figs. 351-363, p. 235, 361-371, p. 237, 372-385, p. 243, 387-389, 397, p. $245,414-421$, p. 255,422 , p. 257 , and part 1 , figs. 51,52, p. 81 ), and give to many of the species in that family, as is well illustrated by Comanthus samoana, and by many of the species of Comaster, a characteristically rough or dry feeling.

The stiffening of the pinnules, as seen in the oral pinnules of very many oligophreate species (figs. 270,271, 273, p. 207), and in all the pinnules in the Calometridæ and Ptilometrinæ (figs. 280, p. 213, and 285, p. 215), and in most of the Thalassometrinæ (figs. 283, 284, p. 215) and Charitometridæ, comes about through the reduction of the bevel on either side of the transverse ridge of the articulations which limits the possible motion. In spinelike pinnules, such as the oral pinnules of Stephanometra (fig. 273, p. 207), the two halves of the joint face on either side of the median ridge lie in the same plane, thus rendering the pinnule rigid, as all intersegmental motion is prevented. Conversely the enormous flexibility seen in the oral pinnules of the Comasteride and Heliometrinæ (figs. 544-546, p. 289), and 
of Coccometra and Thysanometra, results from the shortness of the many component segments, combined with the very strong bevel of their articular faces on either side of the fulcral ridge, these two features causing the pinnulars to appear hexagonal in dorsal view or, if they are very short, rhombic.

In many of the species of Comasteridre the pinnules on the arms arising from the posterior rays, and often also on more or fewer of the arms arising from the other rays, lack the ambulacral groores and associated structures (fig. 1037, pl. 12).

This is also true of the genital pinnules on all of the arms in certain species of Charitometridø (figs. 1055, 1057, 1058, pl. 14).

A curious condition occurs in Comatulella brachiolata (pl. 50, fig. 1332). All of the arms possess ambulacral grooves, but in the proximal portion of the arms single pinnules, or groups of two or sometimes of three, occur without grooves, and in the outer part of the arms occasional grooveless pinnules are found which are at once recognizable because of their greater stoutness. These grooveless pinnules are capable of being coiled dorsally, and they are commonly found wrapped about the organism to which the animal is clinging, quite after the manner of cirri.

The pinnules of the macrophreate species are always cylindrical, and circular in section or slightly flattened and more or less elliptical; but among the oligophreate forms there is always a tendency to develop a longitudinal ridge along the outer surface just distal to the median line. In the Calometridæ (figs. 336, 339, p. 229), Thalassometridø (figs. $337,338,343,344,350$, p. 229 ), and Charitometridæ all the pinnules are affected and have assumed a strongly prismatic form and triangular cross section (fig. 659 , p. 329 , and part 1 , fig. 54, p. 81 ), with a sharp median ridge which may be more or less serrate. In the Tropiometridæ the oral and genital pinnules are more or less prismatic, but not the distal, while in the other families only the oral pinnules are modified, and these as a rule only slightly, showing a tendency to develop long processes or spines on the distal ends of the segments at the angles of the prism (fig. 315, p. 227), a ridge on the earlier pinnulars (figs. 26i. 268 , p. 207), or, in the Comasteridx, a terminal comb formed by the elongation of one or both of the basal angles of the prism (figs. 591-657, pp. 309-327, and part 1, figs. 56-58, p. 83 , and 59,60, p. 85$)$.

In the comatulids with 10 or more arms in which one or more division series are present, and in those forms with undivided arms in which there are no IBr series, the pinnules are arranged in pairs beginning with the first, so that the character of the pinnule on the second brachial is repeated in the first pinnule on the other side of the arm, the character of the pinnule next above the first on the outer side of the arm is repeated in the second pinnule on the inner side of the arm, and so on. With the gradual loss of individuality in the genital pinnules this paired arrangement becomes less evident, and there is no trace of it whatever in the distal portion of the arm where exactly similar pinnules follow each other alternatingly to the arm tip.

In the genus Eudiocrinus, in which there are but five arms, though IBr series are present, the first pinnule takes the place of the additional arm in the 10-armed forms (part 1, fig. 83, p. 136). The next pinnule, on the other side of the arm, is the first pinnule of the 10 -armed species; but this pin- 
nule always agrees with the pinnule on the $\mathrm{IBr}_{2}$ in character, just as the pinnules on the second element in division series of $4(3+4)$ always agree with the first

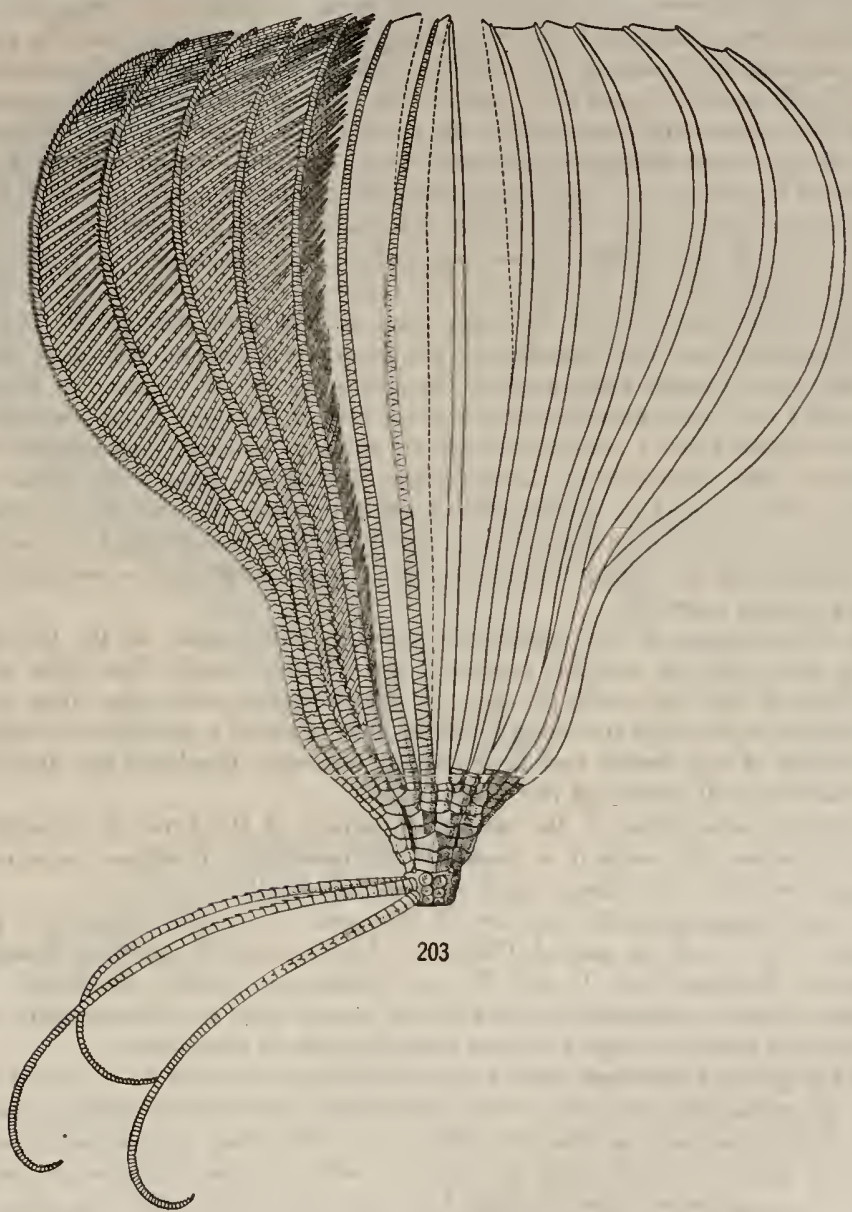

F1g. 203.-Lateral view of specimen of Ptriometra trichopoda from "Albathoss" Station 5179.

pinnules of the free undivided arms. The following pinnule, however, just above the pinnule on the $\mathrm{IBr}_{2}$, is always very different, and its characters are repeated 
on the next pinnule on the opposite side of the arm, the pinnule corresponding to $\mathrm{P}_{2}$ in other forms. Thus the arrangement of the pinnule pairs in the genus Eudiocrinus is just the reverse of what it is in the other comatulids, $P$, being unique in its structure when compared with the other pinnules succecding, and the pinnule pairs consisting of $P_{a}$ and $P_{2}, P_{b}$ and $P_{s}, P_{c}$ and $P_{b}$, etc., instcad of consisting of $\mathrm{P}_{1}$ and $\mathrm{P}_{a}, \mathrm{P}_{2}$ and $\mathrm{P}_{b}, \mathrm{P}_{3}$ and $\mathrm{P}_{c}, \mathrm{P}_{4}$ and $\mathrm{P}_{d}$, etc. But if we disregard the arm structure of Eudiocrinus and consider only tle pinnules, we see an arrangement identical with that on the free undivided arms of other types, for $P_{c}$ agrees with $P_{1}, P_{q}$ with $P_{2}, P_{b}$ with $P_{3}$, and so on. Thus the pinnulation in Eudiocrinus is that of a normal undivided arm and is quite independent of the unique arm structure.

In many of the multibrachiate comatulids, well illustrated in Pontiometra andersoni (figs. 275-277 p. 213) and in Lamprometra protectus, the proximal pinnules on the outer side of the outer arms arising from each radial are much more developed than the pinnules on the inner arms and on the inner side of the same arms, though their general characteristics are the same. In 20-armed species only the lower pinnules on the outer side of the outer arms are enlarged, but in 40-armed types a similar, though not quite so marked, enlargement of the pinnules on the outer side of the innermost derivatives from each of the IIBr series also occurs, and in species with a great number of arms the pinnules on the outer side of the outer arms of each group of four are enlarged, this enlargement diminishing in degree toward the inner part of the ray according to the scheme given on page 124 .

In the ontogeny of the comatulids pinnules first appear at the tip of the growing arm after the arm has reached a considerable length (figs. 1204, pl. 33; 1207,1210 , pl. $34 ; 1217-1219$, pl. 35). $P_{1}$ is not formed until after from two to half a dozen or more of the outer pinnules have reached a considerable size, and the pinnules of the fourth and four or five following brachials not until after $P_{1}$ is relatively well dereloped (fig. 1220, pl. 36).

Deficient pinnulation in the proximal portion of the arms is characteristic of many species. In some it is constant and invariable, in others more or less inconstant, while in still others it only occurs sporadically.

In the Comasteridæ the species of the genus Comatilia (figs. 183, p. 98, and 264. p. 207) lack the second, third, and fourth pairs of pinnules, though the pinnules of the first pair, $\mathrm{P}_{1}$ and $\mathrm{P}_{a}$, are present and highly developed. This condition is quite comparable to that of the young after the development of $P_{a}$, and may have arisen through a sudden arrest in pinnule formation.

In the genus Atelecrinus there are no pinnules on the first 10 or 12 brachials. In this genus the arms are very closely appressed, and the formation of pinnules on the lower brachials is thus prevented. In the allied Atopocrinus (part 1, fig. 227 , p. 245). in which there are only five arms, all the pinnules are present.

In Thaumatocrimus (part 1, figs. $115,116,118$, p. 183) the first pinnule is always on the second postradial ossicle, but in nearly all the species of the closely related Pentametrocrinus (part 1, figs. 120, p. 187, 121, p. 189; exception, fig. 119, p. 185) the lowest pinnule is on the fifth brachial; that is, on the epizygal of the first syzygial pair, the normal first pinnule being absent. 
In Balanometra of the Zenometrinæ and in Hypalometra (fig. 297, p. 221) of the Perometrinæ $P_{1}$ and $P_{a}$ are absent. In both these genera the arm bases

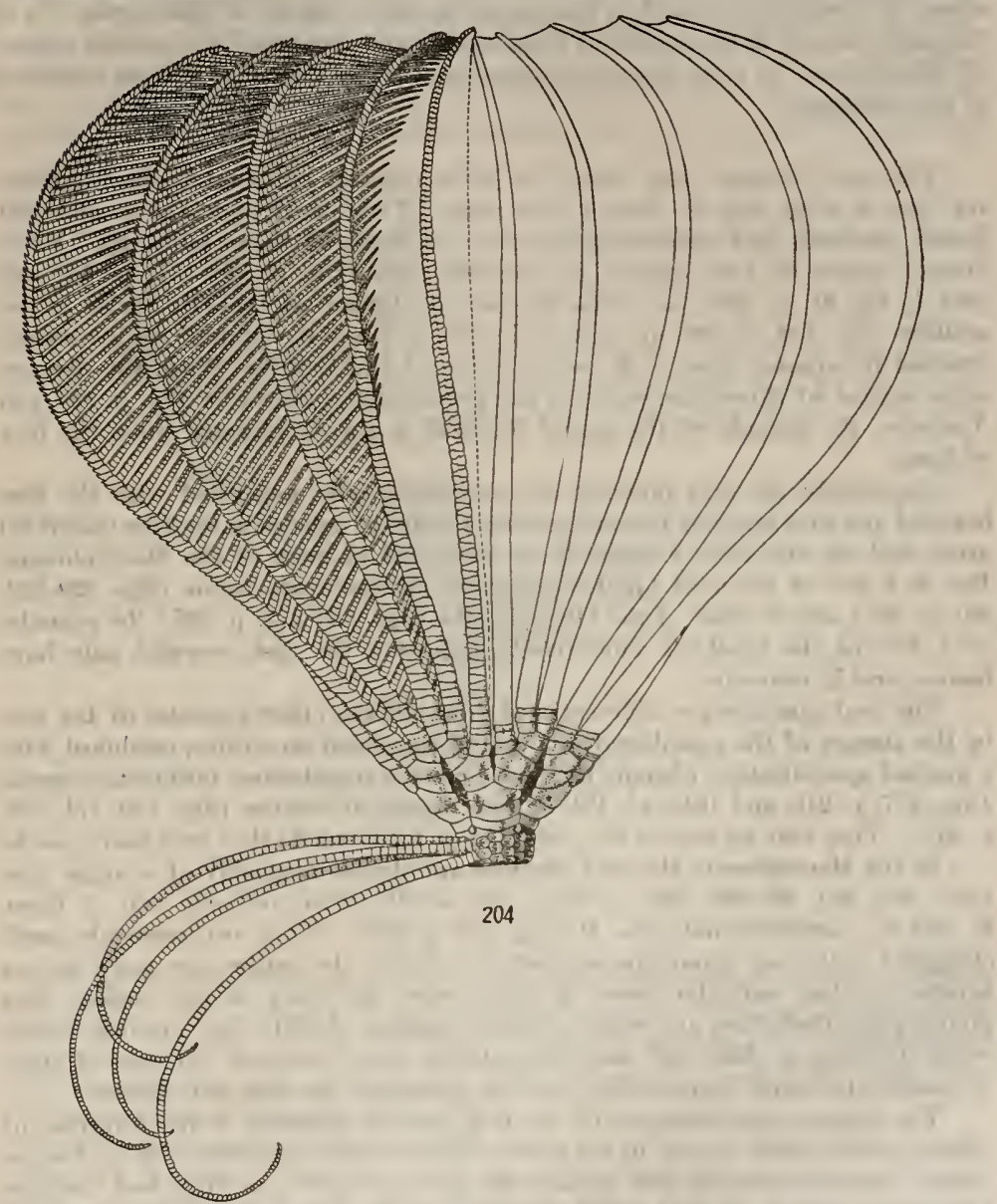

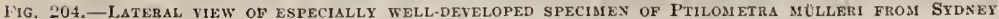
NEW SOUTH WaLes.

are very closely pressed against each other. In the outer arms arising from IIIBr axillaries in Cyllometra $\mathrm{P}_{1}$ and $\mathrm{P}_{a}$ are absent, as also on the inner arms in Epimetra. Both of these genera belong to the Colobometridi. 
In Erythrometra of the Perometrinæ and in Cyllometra, Colobometra, Prometra, and Decametra of the Colobometridæ $\mathrm{P}_{a}$ is always absent. It is always absent in Perometra diomedea, but not in the other species of that genus. It is frequently absent in the species of Cotylometra and occasionally in certain species of Oligometra. In most cases its absence seems to be related to a close crowding of the arm bases.

Oral or proximal pinnules.

The oral pinnules vary from 1 to 12 in number, but most commonly there are from 2 to 6 ; that is, from 1 to 3 pairs. They occur upon the second and fourth brachials and sometimes upon one or more of those following. When division series of four ossicles are present (figs. 123, p. $79 ; 171$, p. 86; and part 1, fig. 81, p. 134), or when the second element of the $\mathrm{IBr}$ series is not axillary (fig. 189, p. 109, an part 1, fig. 83, p. 136), the pinnule of the second brachial is repeated upon each reduplication of this ossicle. When the division series consist of three ossicles, as in the genera Capillaster (fig. 181, p. 94) and Nemaster, the pinnule of the second brachial is always repeated upon the first of these.

Apparently the oral pinnules are morphologically associated with the first brachial and first syzygial (second brachial) pairs of ossicles in the free undivided arms. and we find them exclusively so associated in most of the Macrophreata. But in a few of the most highly specialized macrophreate forms (figs. 292-294, 301, p. 221) and in most of the Oligophreata (figs. 268-273, p. 207) the pinnules of a few of the brachials immediately following the first syzygial pair have become oral in character.

The oral pinnules are differentiated from all the other pinnules of the arm by the absence of the ambulacral groove and associated structures, combined with a marked specialization whereby they have become transformed into tactile organs (figs. 277, p. 213, and 1044, pl. 12), or into organs of defense (figs. 270, 271, 273, p. 207). They take no part in the collection of food, nor do they ever bear gonads.

In the Macrophreata the oral pinnules are almost invariably of a single type (figs. 289,290,292-296, 298, p. 221), and usually there are only two of them, $\mathrm{P}_{1}$ and $\mathrm{P}_{a}$, sometimes only one, $\mathrm{P}_{1}$ (fig. 289, p. 221). They are commonly much elongated with very numerous segments, of which the earlier are more or less beveled on their articular faces, in dorsal view cut away at the corners, thus giving great flexibility, and serve as tactile organs. In life they are bent downward, forming a close and sensitive network orer the disk. If one of them be touched the arms immediately curl up, protecting the disk still further.

The extreme specialization of the first pair of pinnules in the direction of purely tactile organs is seen in the genera Hathrometra (fig. 289, p. 221), Trichometra, Compsometra (fig. 296, p. 221, and part 1, fig. 107, p. 173), and Antedon (figs. 1040, 1044, pl. 12, and part 1, figs. 103, p. 165; 104, p. 167; 105, p. 169; and 106, p. 171), as well as in the oligophreate genus Pontiometra. In these genera they are from two to eight times as long as the following pinnules and exceedingly flexible, with from 20 to nearly 100 segments. Essentially the same conditions 
are found in Leptometra (fig. 370, p. 237), though here two pinnule pairs are involved instead of only one.

In the Pentametrocrinidæ (fig. 286, p. 215, and part 1, fig. 113, p. 181; 119, p. $185 ; 120$, p. 187 ; and 121 , p. 189), Thysanometrinæ (figs. 282, p. 215 , and 378 , p. 243), and Heliometrinæ (figs. 292-294, p. 221) all the pinnules are much elongated, and the oral pinnules, including the first pair only in the Pentametrocrinidæ and Thysanometrinæ, but the first two to six pairs in the Heliometrinæ,

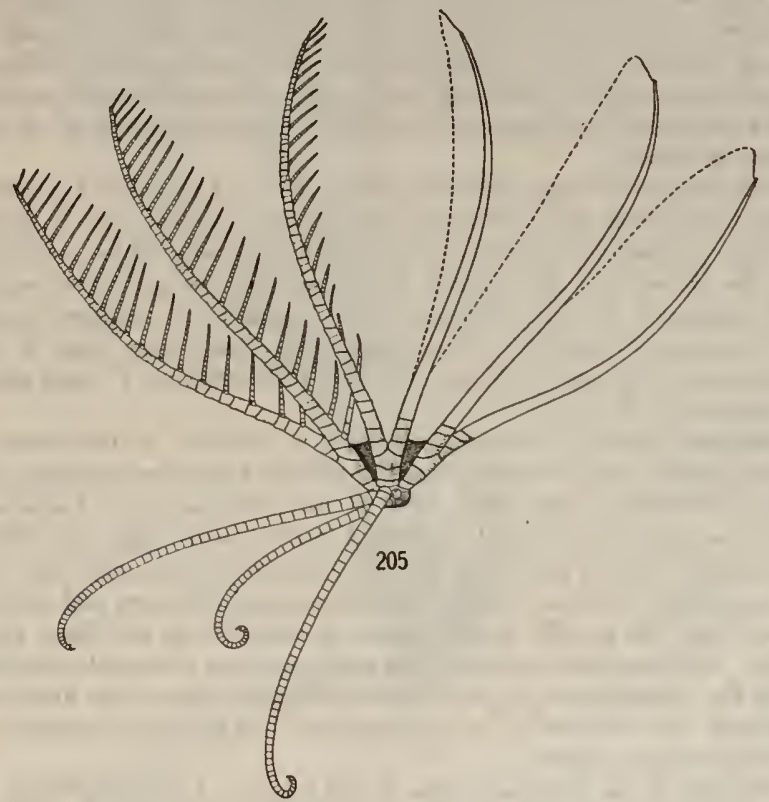

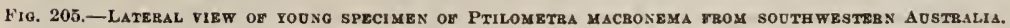

are but little, when at all, longer than those following. They are composed of very short segments, with the corners so cut away that they appear hexagonal in lateral view, and are exceedingly flexible, contrasting strongly in this respect with the less mobile succeeding pinnules.

In the species of the genera Perometra (fig. 319, p. 227), Erythrometra, Toxometra, Eumetra, Iridometra (fig. 301, p. 221), Andrometra, and Dorometra the pinnules of the first pair are tactile in character, though shorter than usual, but the pinnules of the second and sometimes also of the third pair are much enlarged and stiffened, in life projecting outward over the disk and forming a 
close spiny covering above it in addition to the sensitive network of flexible tactilc pinnules just beneath.

There are no oral pinnules in the genera Atclecrinus and Hypalometra (fig. 297, p. 221). In most of the species of Pentametrocrinus $P_{1}$ is absent.

In the species of Bathymctra the oral pinnules are greatly reduced.

Whereas in the Macrophreata the tactile function of the oral pinnules is predominant and there is usually only a single pair present, in the Oligophreata the protective function is predominant, commonly combined with the tactile in various ways, and there arc usually two or thrce pairs present, and may be as many as eight.

The oral pinnules of the Comasteridæe are vcry curiously specialized. They are long and slender, very flexible, at least in the outer portion, and are composed of from 20 to 60 (usually of between 30 and 40 ) segments, most or all of which are about as long as broad.

The terminal 6 to 30 (most commonly from 15 to 20) segments have their distal outer margin produced into a thin calcareous plate, curved slightly inward and basally constricted, being shaped like an arrowhead or spade, which is usually about as high as the diameter of the segment which bears it, but sometimes considerably higher. Occasionally the inner margin of the segments is produced in the same way, as in the genus Nemaster. These plates collectively form what is known as the terminal comb (figs. 594-65T. pp. 309-327, 1072-1082, pl. 17, and part 1, figs. 56-58. p. 83, and 59,60, p. 85 ).

The tcrminal comb in its perfected form is confined to the spccies of the family Comasteridæ, but a somerliat similar though much less developed structure is found in Florometra (figs. 1053, 1054, pl. 13), Solanometra, Anthometra and Promachocrinus, and is occasionally indicated in Heliometra (figs. 545, 546, p. 289).

The terminal comb is primarily restricted to the oral pinnules, but sometimes extends for a greater or lesser distance onto the genital pinnules, and in the species of Comaster (fig. 263, p. 20 7 ) is even found at intervals on the distal pinnules to the arm tip. In these cases, however, it is only upon the proximal pinnules that it is found in the highest state of development; farther out on the arm fewer and fewer segments are involved in its composition, and the teeth become as a rule gradually less and less perfect.

The function of the terminal combs is not known. Long ago Péron observed that the arms are frequently bent inward toward the disk, and this observation led Lamarck to suppose that the food of the comatulids was captured by the distal pinnules and conveyed by them to the opening in the middle of the large conical elevation on the disk, which he supposed was the mouth. Some years ago I suggested that as myzostomes and other parasites are extremely rare upon the arms of the comasterids, this action may be for the purpose of bringing the outer portions of the arms and the outer pinnules within reach of the terminal combs on the proximal pinnules and by means of the latter removing foreign objects from them. Dr. H. I. Clark has also noticed that the arms of the comasterids more or less constantly, but irregularly, bend inward toward the mouth, the tips just brushing the disk and arm bases, but he supposes this is done "to prevent the ciliated grooves from becoming clogged up." 
Comblike structures of independent origin are of frequent occurrence and wide distribution in the animal kingdom. The closest parallel to the combs in

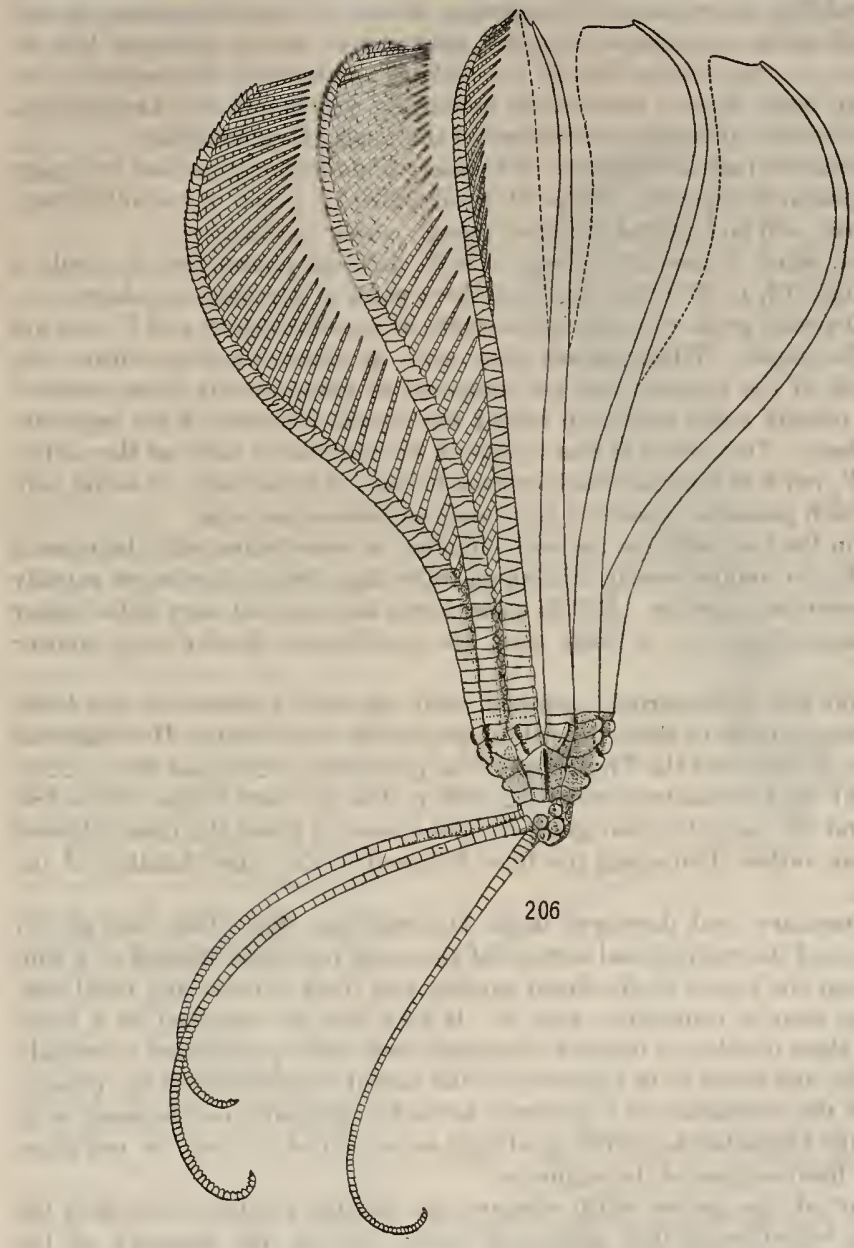

Fig. 206.-LAteral View OF TyPe sfecimen of Asterometra Mirifica.

the Comasteridx is probably to be found in the pectinate pedicellariæ of certain starfishes of the family Benthopectinidx, while the individual teeth are closely 
simulated by the teeth in the pedicellarix of many echinoids and a few starfishes. But there is no reason to assume a direct gcnetic connection between these structures. A comblike arrangement of processes occurs in certain worms, on the mandibles and other appendages of many crustaceans, on the posterior legs of certain spiders, on the anterior legs of the male of the fruit-fly (Drosophila), on the antennæ of many insects, particularly among the Coleoptera and Lepidoptera, and on the middle toe of certain goatsuckers of the family Caprimulgidæ.

On the undivided arms the species of Comastcridæ commonly possess two pairs of true oral pinnules (figs. 262,265, p. 207 ), succeeded by a pair of pinnules intermediate between oral and genital pinnules, though nearer the former.

Comatilia, which is the only comaterid with deficient pinnulation, has only a single pair (fig. 264, p. 207) ; but the next three pairs of pinnules are absent.

In the 10-armed genus Comatonia the combs are confined to $\mathbf{P}_{1}$ and $\mathbf{P}_{a}$ and are not always developed. When present they arise at about, or even within, the proximal third of the pinnule, and are composed of exceptionally large rounded teeth, which usually much cxceed in height the lateral diameter of the segments which bear them. This genus is also unique in having one or more of the earlier segments of $P_{1}$ twice as long as broad, or cven longer. Furthermore, it is the only comasterid which possesses numerous large and conspicuous sacculi.

Usually in the Comasteridæ the oral pinnules, in correlation with their much greater length, are stouter basally than those following, though they taper rapidly and soon become very slender. But in some forms they are but very little longer than thosc succeeding, and in these they are much more slender with shorter segments.

Except for the characteristic terminal comb the oral pinnules of the Comasteridæ are comparable to those of such macrophreate types as the Heliometrinæ (figs. 292-294, p. 221) and the Thysanometrinæ (figs. 282, p. 215, and 298, p. 221), and to those of the Pentametrocrinidæ (fig. 286, p. 215, and part 1, figs. 119, p. 185, 120 , p. 187 , and 121, p. 189 ) ; their general develop,ment is along the lines followed in these groups rather than along the lines followed in the other families of the Oligophreata.

The rudimentary comb developed in the Heliometrinæ (figs. 1053, 1054, pl. 13) is a production of the entire distal surface of the outer pinnulars instead of a thin outgrowth from one border of the distal surface, and there is never any basal constriction to be seen in connection with it. It may best be described as a blunt carination of these ossicles, in its most developed form more pronounced externally than internally, and seems to be the result of the lateral compression of the pinnule tip instead of the expression of a tendency toward a prismatic development as is the comb of the Comasteridæ, which is always accompanied by more or less excavation of the distal surface of the segments.

Almost all of the species which compose the families treated above have the oral pinnules transformed into organs of touch. Among the majority of the species of the Himerometridæ (figs. 268, 269, p. 207), Stephanometridæ (fig. 310. p. 223), Mariametridæ (figs. 312, 313, p. 223) Colobometridæ (figs. 274, 278, p. 213), and Calometridæ (figs. 314,320, p. $22 \overline{7}$, and 311, p. 223), while the first pair is thus 
specialized and has become very slender, delicate, and flexible, with numerous segments, the second, and usually also one or two additional pairs, has become greatly enlarged, swollen, and stiffened, either flagellate distally or ending in a sharp spine. These enlarged and stiffened pinnules point diagonally upward and form a rigid and more or less spinous protective covering over the disk, beneath which is the network formed by the slender tactile pinnules.

This arrangement reaches its greatest perfection in the genus Cenometra (figs. 274, 278, p. 213) and especially in such species of Stephanometra as $S$. monacantha (fig. 310, p. 223) or S. spicata. The same condition is found in the species of Amphimetra (fig. 309, p. 223), Heterometra (figs. 268, 269, p. 207), Craspedometra, Mariametra, Dichrometra (fig. 313, p. 223), Liparometra, Lamprometra (fig. 312 , p. 223), Cyllometra, Oligometra (fig. 315, p. 227 ), and Decametra, though in these genera the pinnules of the second and following pairs have delicate and flagellate instead of sharply pointed tips.

The extreme of the development of the oral pinnules in the direction of protective organs is found in Himerometra (figs. $270-272$, p. 207 , and 326 , p. 227 ), in such species of Stephanometra as $S$. echinus (fig. 273, p. 207, S. tenuipinna, and $S$. oxyacantha, in Analcidometra, Oligometrides, and Austrometra (fig. 324, p. 227), and in Colobometra diadema (fig.

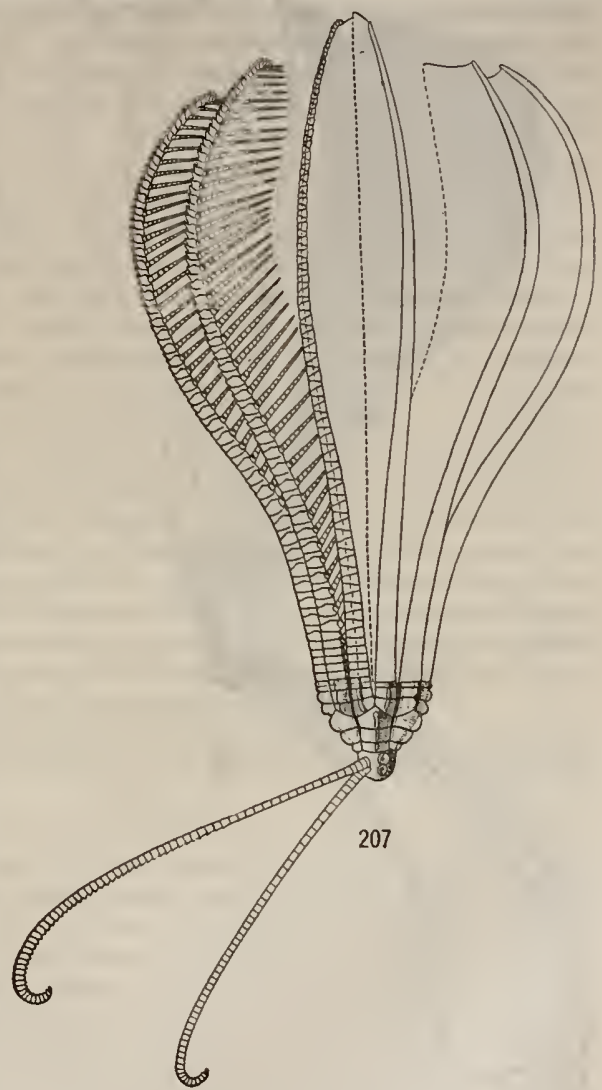

Fig. 207.-Lateral view of speciMen of Asterometra MIIIEICA.

325, p. 227 ). In these forms the first pair of pinnules is of the same stiffened and spine-like nature as the following, and there are no tactile pinnules at all.

On the other hand, some species, as Liparometra articulata and Lamprometra gyges (fig. 312, p. 223), have the pinnules of the second and third pairs so slender that, though somewhat stiffened, they are scarcely more than tactile organs. 
Whereas the extreme of slenderness in the oral pinnules is seen in the Antedonidx, in such genera as Trichometra and I1athrometra (fig. 289, p. 221), the maximum stoutness is found in Himerometra (figs. 270, p. 207, and 326, p. 227),

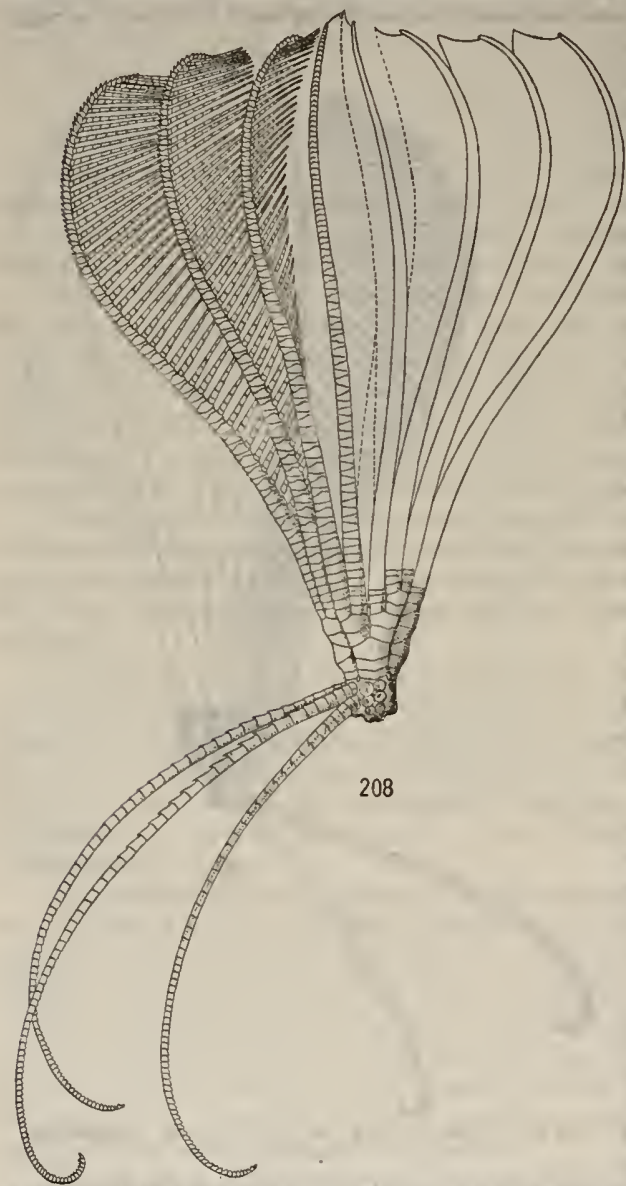

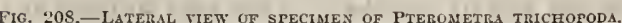

'I'he large species of the genus $Z$ ygometra have oral pinnules corresponding very closely with those of the species of IIimerometra; but the pinnules taper distally to a more slender tip than is usually found in that genus, though such a tip occurs in II. persica (fig. 272, p. 207) and in $H$. bartschi. In $C_{t l}$ toptometra the structure of the proximal pinnules is very similar to that of the proximal pinnules of the species of Comasteridx, though there are no terminal combs. In Eudiocrimus (figs. 190, p. $111 ; 191$, p. 112 ; and part 1 , figs. 83. p. 136, and 84, p. 137) the oral pinnules are very stout and sharply prismatic, recalling $\mathrm{P}_{2}$ in certain of the Thalassometrinæ.

In the genus Pontiometra (fig. $27 \pi$. p. 213), belonging to the Mariametridæ, $\mathrm{P}_{1}$ is, strictly speaking, the only oral pinnule. It is nearly eight times as long as the following pinnules on the same side of the arm, very slender, with about 50 segments. $\mathrm{P}_{a}$ is small, like $P_{2}$.

The species of Colobometrida collectively are in their proximal pinnule strueture strictly comparable to the species of the Himerometridæ, Stephanometridæ, and Mariametridæ taken together, but the distal ends of the segments in these pinnules are as a rule considerably more spinous than is the case in these other families. In the species of Oliogometrides, A ustrometra, and Analcido- 
metra the proximal pinnules are comparable to those of such species of Stephanometra as $S$. echinus or $S$. tenuipinna, though they are proportionately somewhat longer and stouter. In Oligometra serripinna (fig. 315, p. 227) and in 0. carpenteri the oral pinnules are strictly comparable to those of Heterometra crenulata, and the segments of the second or second and third pairs have the same broad processes on their prismatic ridges. In Oligometra japonica and in O. caledonice the lower pinnules are comparable to those of Amphimetra spectabilis or $A$. discoidea (fig. 309, p. 223). Cenometra (figs. 274, 278, p. 213) has essentially the same proximal pinnule structure as Stephanometra monacantha (fig. 310, p. 223), but $\mathrm{P}_{2}$ is usually much stouter and more as in Himerometra. In the species of the genus Colobometra we find a close parallel to the species of the genus Stephanometra (see figs. 273, p. 207 , and 325, p. 227). Most of the species have $P_{1}$ delicate, many jointed and flexible, and from one to six of the following pinnules on either side greatly enlarged, stiffened and spine-like, composed of segments with exceedingly spinous distal ends. Except for this last feature, characteristic of the Colobometridæ, these species are comparable to the large species of Stephanometra, while those with fewer enlarged pinnules are comparable to S. spicata, $S$. monacantha, or $S$. indica. One species, $C$. diadema (fig. 325, p. 227), has $P_{1}$ of the same character as $\mathrm{P}_{2}$, thus being similar to Stephanometra tenuipinna or to $S$. echinus. But all the species of the genus Colobometra are peculiar in lacking $\mathrm{P}_{a}$, though this pinnule commonly reappears on regenerated arms. The oral pinnules of Cyllometra, Decametra, and Prometra may best be compared with those of the species of Lamprometra (fig. 312, p. 223) or Dichrometra (fig. 313, p. 223) from which they differ only in having a greater or lesser development of spines on the distal bor'ders of their component segments. In some forms, as in Decumetra studeri, $\mathrm{H}_{2}$ is only slightly enlarged, while in others, as in Cyllometra manca or $C$. albopurpurea, $\mathrm{l}^{\prime}$, and also $\mathrm{P}_{3}$ are very considerably modified.

In the Tropiometridæ (figs. 279, p. 213, and 308, p. 223) the oral pinnules differ but very little in size or in character from those succeeding, which in this family are much longer than usual.

In the Calometridæ (figs. 311, p. 223, and 314,320 p. 227) the proximal pinnules resemble those of certain species of Colobometra most nearly, but $\mathrm{P}_{1}$ is much more delicate and is composed of numerous very small rounded segments, and the following pinnules, which may or may not be elongated, are sharply prismatic. The first two segments of the earlier pinnules, especially of the first, are flattened and greatly enlarged with broad dorsal processes, this modification, universal throughout the family, not being found carried to such an extreme elsewhere.

There are two types of differentiation of the oral pinnules in the Thalassometridæ. In the genera Ptilometra (figs. 280, p. 213, and 316, p. 227), Pterometra, and Asterometra (fig. 285, p. 215), in which all the pinnules are stiff and spinelike, and the arm bases are so closely crowded against each other that there is no need for any special adaptation of the proximal for protective or for tactile purposes, $P_{1}$ is similar to the succeeding pinnules, but much smaller, and $P_{2}$ is usually also smaller than $P_{3}$. We see here indications of the course possibly followed in 
Atelecrinus, in which genus all of the earlier pinnules are absent. In the remaining genera (figs. 283,284, p. 215 , and $317,318,321-323$, p. 227) $P_{1}$ is always more or less, and typically enormously, enlarged, and much longer than the succeeding pinnules, but in the distal half it tapers, usually rather suddenly, to a slender and delicate tip. $P_{a}$ is very rarely and $P_{2}$ never similarly modified. This combination of defensive and tactile functions is similar to that seen in $P_{2}$ and some of the following pinnules in such genera as Craspedometra, Mariametra, Dichrometra, Lamprometra, Heterometra, Amphimetra, and Decametra, but in the Thalassometrinæ alone does it occur on $P_{1}$ to which pinnule it is in this group confined.

In the Charitometridæ (figs. 302, 306, p. 223) $P_{1}$ and $P_{2}$ are very slender with numerous short segments, and are usually slightly shorter than the succeeding pinnules, while $P_{1}$ is slightly shorter than $P_{2}$. They form typical tactile pinnules of the type common to most of the oligophreate genera in which tactile pinnules occur, the only difference being that the earlier segments are slightly enlarged, and their outer edges are sometimes more or less flattened as a result of the close compression of the arm bases. Thus in the Charitometridæ two pairs of slender oligophreate tactile pinnules are found instead of only one, as in other forms, a condition finding a parallel in the macrophreate genus Leptometra (fig. 290, p. 221).

The pinnules in the Macrophreata, oral as well as middle and distal, are usually cylindrical, in section aproximately circular except for the notch indicating the groove accompanying the ambulacral structures; but they may be somewhat flattened, as in Psathyrometra (fig. 295, p. 221) and Zenometra, the section then becoming more or less oval or elliptical. Such a condition, however, is mostly confined to the lower pinnules.

In the Oligophreata the oral pinnules are invariably primatic, at least in part, and this condition may extend to all the pinnules, as in the Calometridx (figs. 334 , p. 227 , and 336,339 , p. 229), Thalassometridæ (figs. 332, p. 227, and 337, $338,343,344,350$, p. 229 ), and Charitometridæ, or to the middle pinnules but not the distal, as in the Tropiometridæ. In the Comasteridæ this feature is generally observable in the segments forming the terminal comb, and sometimes it extends inward nearly or quite to the pinnule base. In the species of Zygometridæe and Himerometridæ there is usually to be seen on the enlarged lower pinnules a prominent ridge just distal to the dorsal median line which is especially prominent on the basal segments. This ridge is especially evident in Craspedometra, in certain species of Heterometra (figs. 268, 269, p. 207), and particularly in Eudiocrinus (fig. 267, p. 207). In the Mariametridæ and Stephanometridæ. as in the Colobometridx, it is more or less obsolete, though a trace of it may usually be detected on the third segment. In Heterometra crenulata, $H$. producta, Oligometra serripinna (fig. 315, p. 227 ), and $O$. carpenteri, in which strong lateral processes are found on the pinnulars, these are composed either of the produced ventral edges of the pinnulars or of a great development of the dorsal ridge (sometimes of only the distal part) and usually of both. In the species of Colobometridæ having fringes of spines on the distal borders of the pinnule segments 
these spines are longest at the ventral distal corners of the pinnulars, and where the longitudinal ridge meets the distal border.

In the Oligophreata there is sometimes to be observed a curious correlation between the size of, and the number of segments in, the oral pinnules and the cirri. Comanthus pinguis and $C$. bennetti are both remarkable for the enormous size of the oral pinnules as well as for the great size, stoutness, and number of segments in the cirri, while in the allied C. solaster, O. trichopetra, C. samoana, etc., both the oral pinnules and the cirri are small and slender with comparatively few component ossicles.

The systematic value of the oral pinnules varies very greatly in the different groups. They present reliable diagnostic characters for distinguishing the families Thalassometridæ, Charitometridæ, Comasteridæ, Calometridæ, and Stephanometridæ, and the subfamilies Ptilometrinæ, Thalassometrinæ, and Heliometrinæ, and in combination with the middle pinnules the family Tropiometridæ. In these groups they are of relatively slight value for the differentiation of genera, and of still less for the differentiation of species. In the remaining families and subfamilies in which they occur in widely different forms their importance for the determination of genera and often of species is very great.

\section{Middle or genital pinnules.}

Immediately following the oral pinnules there are usually from one to three pairs of pinnules which are more or less intermediate in character between the oral

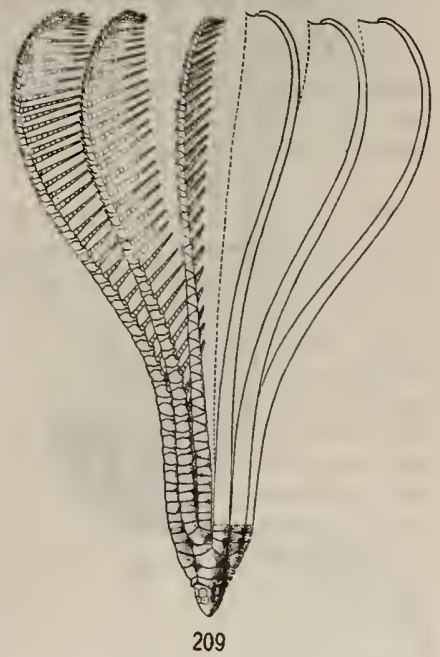
and the genital pinnules, lacking well- Fig. 209.-LATERAL view of TTPE SPECimen of developed gonads and having a calcareous ASTEROMETRA LEPIDA.

structure indicative of the former, though much more generalized, but possessing ambulacral grooves and nerves, lappets, and tentacles like the latter.

As a rule there are two or three pairs (figs. 272, 273, p. 207) of these intermediate pinnules in oligophreate species, and one (fig. 281, p. 215) or none (fig. 282, p. 215) in the macrophreate forms. In the Macrophreata in most cases they resemble exactly the genital pinnules, but bear a smaller gonad or none at all; usually in the Oligophreata and in the very large macrophreate species, such as the species of Heliometrinæ (figs. 293, 294, p. 221), they are intermediate in length and structure between the two types. 
In the transitional pinnules the characteristics of the genital pinnules first appear at the distal end and rapidly extend inwarl toward the base.

These intermediate pinnules are followed by from 3 to 35 or more pinnule pairs (usually from 10 to 20 ) upon which the perfected gonads are developed (figs. 281, 282, p. 215). The first commonly bears a relatively small gonad, but on the second and following this rapidly increases and soon reaches its full size. After the middle, or the proximal two-thirds, of this pinnule series the gonads com-

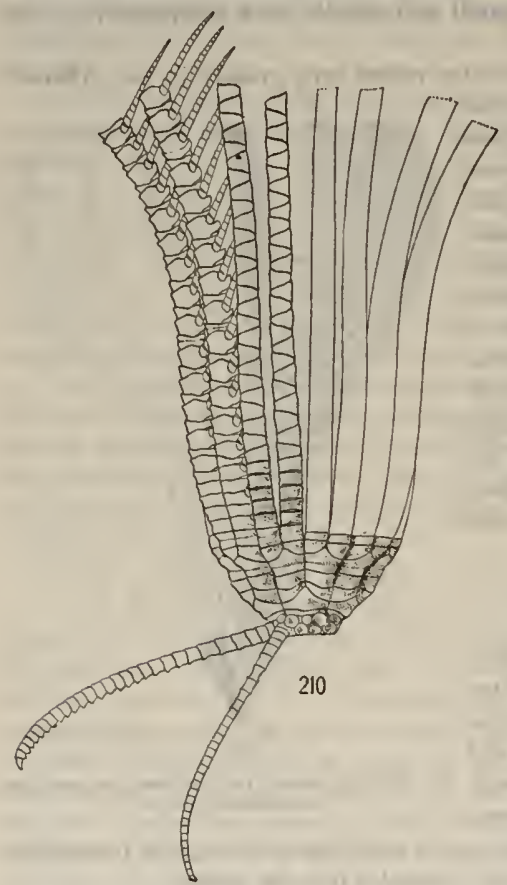

Fig. 210.- Lateral, viet of speciages of ChotaloMETRA FLAVA. monly begin gradually to decrease in size, finally disappearing altogether.

The gonads arise on the third segment and extend outward for a variable distance over from 2 to 20 (usually orer from $\breve{5}$ to 10$)$ segments. They are of two distinct types, each of which has a more or less definite range (1) a short abruptly rounded type (figs. 281,282, p. 215 ) occurring in almost all of the species of the Macrophreata, in the majority of the Charitometridæ, and in certain of the small 10-armed species of Comasteridx, and (2) a long fusiform type, found in the Tropiometridx, most of the 'Thalassometridx, and in large individuals of large species in certain macrophreate genera. Both types are found in the Heliometrinæ, though the second is greatly predominant, and both types are found in Antedon bifida and $A$. petasus, though only the sccond in Antedon mediterranea and $A$. adriaticn.

The genital pinnules are, with but few exceptions, shorter than the oral pinnules, and usually very much shorter. The first four or five pairs are of equal, or nearly equal, length; on the following the length slowly and gradually increases, coincident with the decrease in the size of the gonad, until the outer genital pinnules merge imperceptibly into the distal pinnules. 'I'he transition from the middle to the distal type of pinnule begins first at the distal end and works gradually inward toward the base.

Ordinarily the genital pinnules (figs. 262-287, pp. 207-215, 302, 303, 307, 310, p. $223 ; 324,325,32 i-335$, p. 227 ; and $336-341$, p. 229$)$ are moderately slender and taper very slowly until near the tip. They are much more nearly uniform through- 
out the group than are the oral pinnules, though much less uniform than the distal pinnules. The first two segments are short, the first trapezoidal with the longest side outward and about twice as broad as long, the second trapezoidal with the base inward, joined to the longest side of the first, and about of the same length. The first segment is often more or less enlarged in the earlier genital pinnules, indicating an abrupt decrease in the size of the pinnule as a whole which has not yet affected the basal segments to the same extent that it has affected the others. Farther out the second segment gradually becomes longer, abont twice as long as broad at the base, as in the distal pinnules. The third segment as a rule is squarish, the following very gradually becoming longer and elongating rather rapidly in the distal portion. In the Macrophreata the relative length of the component segments is much greater than it is in the Oligophreata.

In the Macrophreata there is very rarely any special differentiation of the segments of the genital pinnules for the protection of the gonads; they are merely slightly broader than those of the distal pinnules; but in the genera Notocrinus and Isometra (fig. 1239, pl. 38), both from the antarctic, the third-sixth segments are much broadened.

In the Oligophreata the segments of the genital pinnules are almost always slightly broadened from the third outward, though usually not so much so as to alter their general symmetry. This is well seen in the Comasteridæ (figs. 262, 265, p. 207) and in the Thalassometridæ (figs. 332, p. 227, and 336-338, p. 229). In a few groups there is a very marked modification of the genital pinuules. In the genus Comatula (figs. 18t, p. 100, and 262, p. 207) the third and following segments are very short, much broader than long, though the pinnules as a whole are not especially widened. In the Charitometrida (figs. 302-306, p. 223, and 1055, $105 \pi$. $1058,1061, \mathrm{pl} .14)$, to a much less extent in the Calometridæ, and in one genus each in the Thalassometridæ (Horceometra [fig. 321, p. 227]) and Colobometridæ (Avetrometra [figs. 340,341, p. 229]), the third segment is abruptly widened and the fourth even more so; this widening may continue for one or two, or eren lalf a dozen more segments, and then cease abruptly, or it may gradually taper away distally, disappearing toward the tip of the pinnule. The first condition is well illustrated by Pocilometra (figs. 1057, 1058, pl. 14), IIorceometra (fig. 321, p. 227). and Strotometra (figs. 230-232, pp. 118-192), and the second by Crinometra (figs. 302-306, p. 223), Crossometra, Perissometra (fig. 1055, pl. 14), Pachylometra, Glyptometra, Chlorometra, Chondrometra, the genera of the family Calometridx, and Austrometra (figs. 340,341, p. 229). It is worthy of note that abrupt expansion of the segments of the genital pinnules is confined to 10 -armed species. The broadening of the pinnulars results in the formation of a roof over the entire dorsal surface of the gonads, which protects them from injury.

P. H. Carpenter first noticed that the grooveless condition, which is typically and usually limited to the oral pinuules,'sometimes exists on whole arms and on all the pinnules borne by them in many species of Comasteridæ (part 1, fig. 45, $b$, p. 79). Even in the arms which arise from the anterior or oral side of the disk the ambulacral groove does not give off regular branches to the pinnules borne by the 
fourth and succeeding brachials, but a variable number of these earlier pinnules, sometimes only three or four, sometimes as many as forty, resemble in this respect the oral pinnules (part 1, fig. 45, a, p. 79), their ventral surface being convex and devoid of any ciliated epithelium or subepithelial band, while their water vessel is simple without any lateral extensions to respiratory leaves and tentacles. In these oral arms, however, branches of the ambulacral groove enter the pinnules sooner

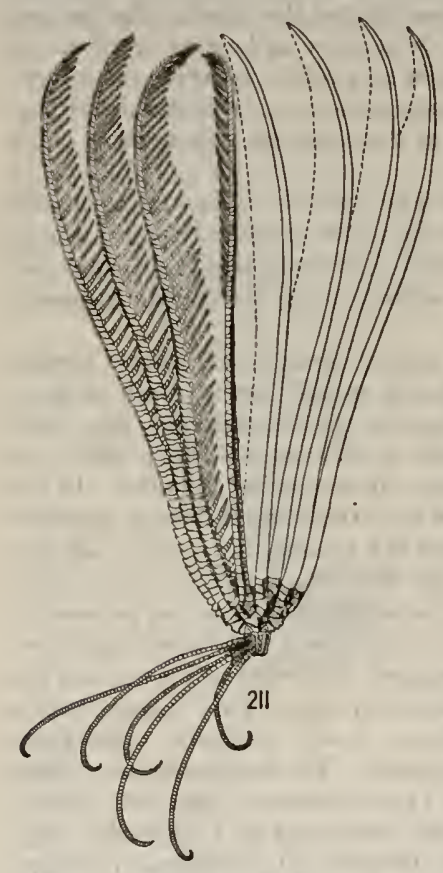

EIG. 211.-LATERAL VIEF OF SPECIMEN OF STENo METRA DIADEMA. or later so that the terminal pinnules are always provided with a distinct tentacular apparatus, while the floor of their median groove is of the usual character, consisting of a ciliated epithelium and a subepithelial fibrillar band.

Carpenter also noticed that in those comasterids which possess ungrooved posterior arms the gonads upon the pinnules borne by them are usually far more developed than those upon the anterior arms; not only are there more fertile pinnules, though the total number of pinnules may not be more than half that of an anterior arm, but the portions of the glands within these pinnules also attain a greater size than in the anterior arms, the basal and median pinnules of the latter being usually less swollen than the corresponding pinnules of a posterior arm.

Carpenter found that this ungrooved condition of the lower pinnules may also occur on all of the arms of some of the endocyclic forms and that it is especially renarkable in types like Pacilometra accha (fig. 1058, pl. 14) and Perissometra angusticalyx (fig. 1055, pl. 14), which have a strongly plated ventral perisome. The ambulacral grooves of all the arms and of the later pinnules are well protected by plates, but they do not extend onto (about) the first 20 pinnules which bear the large gonads, though the latter are protected by a very close and regular pavement of anambulacral plates. In other species, however, which have equally well-plated pinnules, such as Aglaometra incerta (fig. 1062, pl. 14), the ambulacra extend over their rentral surface in the usual way.

While in almost all cases the genital pinnules are shorter than the more slender distal pinnules, this is not always true. In the family Tropiometridæ (fig. 279, p. 213) the genital pinnules are rather stout and very long, longer than the distal pinnules, which are unusually short. In the Ptilometrinæ (figs. 280, 
p. 213 , and 285, p. 215 ) also the genital pinnules are more or less longer than the distal. In the 'Thalassometrinæ and Charitometridæ, and in highly multibrachiate types, the genital and distal pinnules are usually of approximately the same length.

In a single comatulid. Isometra vivipara, the genital pinnules of the female differ from those of the male. In those of the female (fig. 1238, 1240, pl. 38) the third and fourth segments are enormously widened, chiefly on the distal side, to cover the brood chamber. On the proximal portion of the arm the fifth segment also is slightly widened. Toward the end of the series of genital pinnules the broadening of the segments diminishes, first the fifth, then the fourth segment assuming the normal form, the third only remaining broad. A corresponding development takes place in the growing young, small specimens having only the third segment of the lowest geuital pinnules widened, while the outer genital pinnules show no widening of any of their segments.

The male genital pinnules (fig. 1239, pl. 38) also broadened, though not so much as the female. Here the broadening begins on the third segment. which is the widest, and continues, gradually diminishing, to about the middle of the pinnule. It is developed to about the same degree on both the proximal and distal sides.

The segments of the geni-

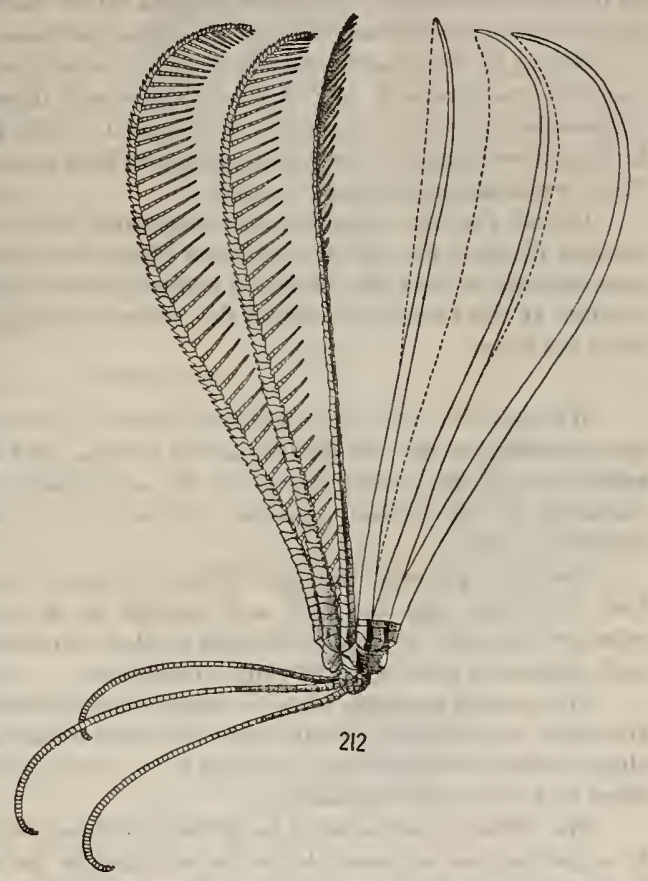
tal pinnules, except for those

which are broadened, are fairly slender and smooth, the distal having only a slight derelopment of spines on their distal borders. The articulations are not swollen.

The number of segments in the genital pinnules varies from 5 or 6 to about 25 ; the usual number is between 10 and 15 .

The gradual transformation of the genital into the distal pinnules is not distributed uniformly among the segments of succeeding pinnules. It commences at the distal end and gradually extends downward toward the base, after the 
same manner that the transition from the oral to the genital pinnules takes place. The first indication is an elongation of the distal segments and an increase in their number, due partly to the addition of new segments and partly to the withdrawal of the gonad toward the base of the pinnule, which leaves the outer segments free. The segments supporting the gonads are not altered until the gonads are withdrawn from them. In the outermost genital pinnules, therefore, where the gonad rests only upon the third and fourth segments, these are exactly as in the preceding pinnules, even though all of the segments beyond them are of the elongate type characteristic of the distal pinnules.

Owing to their comparatively uniforin structure in all comatulids the genital pinnules are generally of but slight systematic importance. They are useful in differentiating genera or species in groups in which they are more or less swollen to form a corering for the gonads, or where they are much elongated, but otherwise their systematic significance is small.

In life the lower genital pinnules stand up in planes parallel to the plane passing through the dorsoventral axis of the arm, but farther out they gradually lean outward so that the outermost genital pinnules are normally in a plane almost or quite at right angles to that of the earlier ones and extend horizontally outward from the arms.

\section{Distal pinnules.}

Whereas the oral pinnules vary widely in the amount and nature of their specialization in the various comatulid groups, and often to a very considerable extent among the several species of the same group, there is comparatively little variation in the genital pinnules and very much less in the distal (figs. 339 . 342-350, p. 229).

The oral pinnules are specialized as organs of touch or of defense, or as both combined, and the kind and amount of specialization varies according to whether the calyx is broad and open or closed and compressed, and in accordance with numerous other more obscure correlations.

The genital pinnules serve to contain the genital products and have the same functions everywhere. Their degree of differentiation is therefore comparatively slight, being almost entirely confined to a variation in the lateral diameter of the third and following segments.

The distal pinnules serve to gather the food particles, a function which may to a great extent or lesser degree be assumed by the more distal genital pinnules. In all groups the interception and capture of food particles involve similar mechanical and physiological problems, requiring a maximum of length combined with a maximum of exposed ambulacral surface; and the fulfillment of these two conditions, both of the utmost importance in the economy of the animals, necessarily leaves but very little scope for variation from a general type, and thus it is that the distal pinnules are very nearly uniform throughout all the comatulid groups.

The oral pinnules stand up parallel to the dorsoventral plane of the arm. distally bending forward more or less over the disk, more rarely outward toward 
the longitudinal axis of the arm. Their component segments either are fitted closely end to end, or the more proximal, sometimes all, have their angles cut away, admitting of motion in a plane parallel to the dorsoventral plane of the arm: there is no provision for lateral motion. The earlier genital pinnules stand up like the oral pinnules, those of the two sides of the arm being parallel with each other, and the distal ends are always more or less curved outward toward the arm tips. Going outward along the arm the later genital pinnules are seen gradually to bend laterally outward, this being correlated with the gradual development of a lenticular space between the first and second segments by which it is chiefly accommodated. As the genital pinnules begin to assume the character of distal pinnules their recumbency increases until the distal pinnules are reached. These latter extend outward horizontally at right angles to the dorsoventral plane of the arm.

Typically the distal pinnules consist of about 20 segments. though there may be as many as 30. They are almost always longer than, usually from half again to twice as long as, the genital pinnules, and as a rule equal the longest oral pinnules in length. They are extremely slender and delicate; the first segment is trapezoidal, the longest side outward, or more or less crescentic, about twice as broad

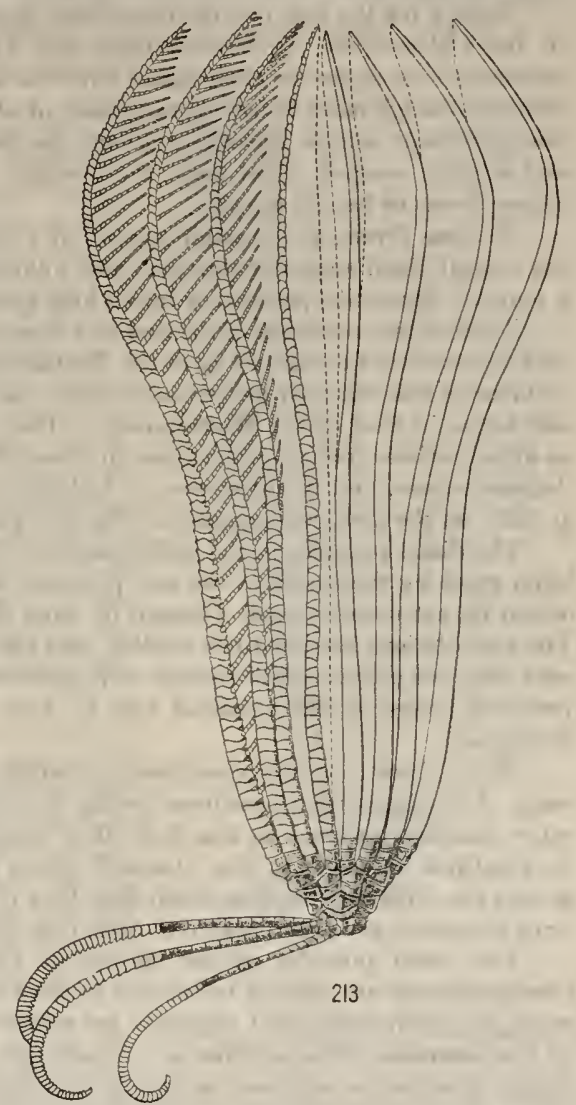

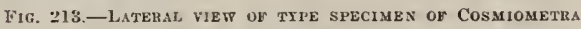
CRASSICIRRA.

as long; the second is trapezoidal, the longest side inward (directed proximally), about twice as long as the first, or about twice as long as the proximal width; the third segment is squarish, or somewhat longer than broad, and the next two or three increase rapidly in length, the outer being from two to four times as long as broad terminally. usually with more or less swollen and slightly overlapping 
distal edges; the last segment is short, without ambulacral structures, and is armed dorsally with several recurved teeth, and the preceding one to three or more segments may be more or less similar to it.

Except for the first two the component segments may be sharply prismatic, as in the Calometridæ, Thalassometridæ, and Charitometridæ, or they may bear numerous long spines on their distal borders-a feature most conspicuous in Colobometra, though more or less characteristic of all groups. Typically, however, they are cylindrical, almost smooth, and very slender, with straight ventrolateral edges and slightly everted distal ends, the eversion of the latter slowly increasing in degree from the base to the tip.

In some forms, as in certain species of Comissia, Comatula, and Colobometra, the ventral distal angles of the third and following segments may be produced into a rounded flange-like process, or into a long spine.

There is less variation in the first two segments than in those succeeding. They may be somewhat elongated as in the Pentametrocrinidæ, and they may appear to be more or less enlarged in species in which the pinnules are exceedingly long and slender, as in most of the Macrophreata. They never bear carinate processes, such as are sometimes found, for example, in Comatella (fig. 1041, pl. 12), Comatula, and Leptonemaster, and in the species of Calometridæ (figs. 311, p. 223, and 314, 320, p. 227), on the first two segments of the oral and lower genital pinnules.

The distal pinnules in the multibrachiate comasterids are comparatively short, never reaching the length of the oral pinnules, and are composed of short segments which do not usually reach a length of more than twice the width, even distally. The articulations are but little swollen, and the dorsal surface is more or less covered with fine spines, which become more prominent toward the distal border. The recurved hooks on the terminal two to four outermost segments are strongly developed.

While there is a very considerable average difference between the distal pinnules of the large multibrachiate species of Comasteride and those of species of other families-so much so that individual comasterid distal pinnules may at once be identified as such-in the 10-armed young and in the 10-armed and smaller species the difference becomes much less; thus the distal pinnules of Leptonemaster or of Comatilia have comparatively little that is distinctive about them.

The distal pinnules of the species of Calometridæ, Thalassometridæ, and Charitometridæ are sharply triangular in cross section from the third segment outward, and their component segments are relatively short as in most of the species of Comasteridæ. The pinnules as a whole are always relatively, and often absolutely, short, as is well seen in the multibraciate genera, especially in the genus Crinometra, so that they do not exceed the genital pinnules in length, and are considerably less than the oral pinnules. In Parametra and in certain of the Charitometridæe with very long arms the characteristic features of the distal pinnules may become more or less obsolete at the arm tips, where the pinnules approach very closely the usual slender elongate cylindrical type.

There is very little difference in the distal pinnules of the remaining families, and what difference there is is mostly correlative. For instance, if the arms are 
smooth the distal pinnules will be smooth, but if the brachials possess overlapping and spinous distal ends, then the distal ends of the third and following pinnulars will also be armed with spines. If there are $10 \mathrm{arms}$ the pinnules will be relatively long, with proportionately long component segments; but if the number of the arms be more than 10 the pinnules become proportionately shorter and the length of the component segments becomes proportionately less and less.

As a general rule the species with 10 arms only have longer distal pinnules than multibrachiate species, and the relative length of the pinnules decreases in direct correlation with the increase in the number of arms.

It may be said also that the species of the Macrophreata possess longer distal pinnules, composed of longer segments, than those of the Oligophreata, though, taking the 10-armed species of these two groups as a whole, the difference is not great. The assumption of a prismatic form as seen in the Calometridæ, Thalossometridæ, and Charitometridæ is accompanied by a more or less marked shortening of the pinnule, which again becomes elongated whenever, as in certain species of the Charitometridæ, the prismatic character becomes more or less obso. lescent.

Among the species of the Macrophreata there is little deviation in the character of the distal pinnules from a common type; they are always greatly elongated, cylindrical, exceedingly slender, with expanded articulations. As the two basal segments are not affected by any change in the outer segments, they appear unusually large or laterally swollen and contrast strongly with the slender segments succeeding.

The systematic importance of the distal pinnules is very slight. In general they

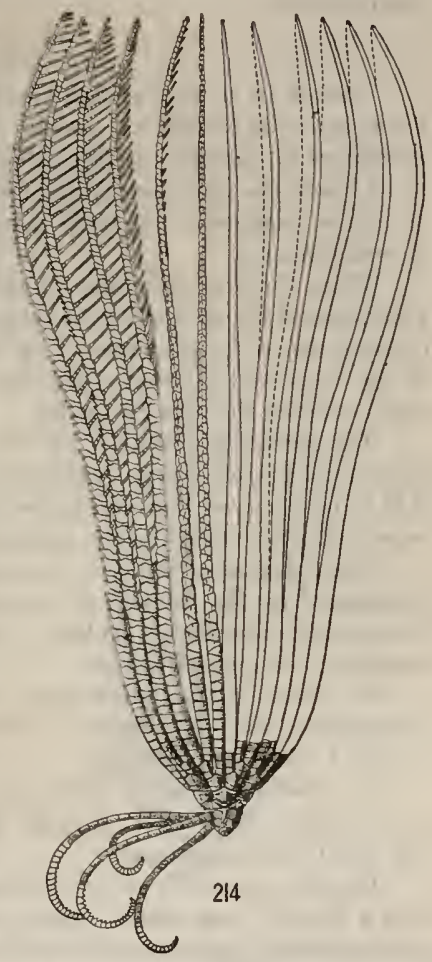

Fig. 214.-LATERAL. view OF TYYE aPECIMEN OF CosmIOMETRA DELICATA. are not consulted except to ascertain the presence or absence of side and covering plates, which is rather more readily determined upon them than upon the other pinnules; but the characters in the earlier pinnules, brachials, arm bases, and cirri always correlated with the presence of an ambulacral plating, are so marked that after a little experience one never refers to the distal pirnules to determine this point. In the Comasteridæ they are very spinous dorsally and therefore diagnostic, but here, because of the prominence of the terminal combs present on the 
oral pinnules and the usually excentric mouth, their assistance is not needed. In other groups also there are certain features by which, after prolonged study, the distal pinnules of any genus may be almost with certainty identified, though such identification is attended with considerable risk, and owing to the greater reliance which can be placed on other structures examination of the distal pinnules is rarely needed.

\section{Pinnules and cirri.}

Though in no way related morphologically both the pinnules and the cirri are linear series of cylindrical ossicles united end to end, and as such they have many characters in common, and are subject to a limited extent to the same variations.

In both the pinnules and the cirri the greater part of the possible interarticular motion is localized in the basal portion, often almost entirely between the first and second segments.

When the oral and outer pinnules differ widely the characters common to the pinnules and the cirri unite the latter with the oral pinnules and the pinnules of the division series, for the reason that they arise from the projection of the characters of the calyx and division series upon them, and the projection of these characters does not reach the distal pinnules.

The proximal pinnules, like the proximal cirri, are typically longer than the others and possess tactile functions (part 1, figs. 310,311, p. 269). In both cases it is to be observed that elongation and added sensitireness is characteristic of the organs situated nearest to the central capsule of the dorsal nervous system.

The function of the cirri is to serve as prehensile organs. The same function is assumed by the grooveless pinnules distributed at intervals along the arms in Comatulella brachiolata (plate 1, fig. 1332), which are capable of being coiled dorsally to an unusual extent.

In certain types, particularly in the species of Prometra, Colobometra, and Oligometra, there is a marked correlation between the number of ossicles in the cirri and in the oral pinnules.

In other types, as in certain species of Heterometra, the development of the dorsal ridge on the oral pinnules is correlated with the amount of carination of the distal cirrus segments.

On the pinnulars, as on the cirrals, the distal dorsal edge is often produced into a frill of long spines; in both sets of structures these spines are never found on the first two segments, but begin on the third and gradually increase in prominence outwardly; in both also this projection from the dorsal surface is at first limited to the distal edge, but distally gradually moves inward.

The growth of the pinnules and of the cirri takes place in exactly the same manner, and in both the terminal ossicle is well formed before the one or more preceding have acquired their full length.

The cirri end in a strong spine, while one or more strong spines are developed on the dorsal surface of the last pinnular. On the antepenultimate segment in both structures one or more spines are developed, and spines of diminishing size may occur for some distance toward the base on the preceding ossicles. 
Cirri have never been observed to branch, but branching is not infrequent in the pinnules. Whenever it occurs it is confined to the first two segments and is usually on the second (figs. 1066, 1067, pl. 15).

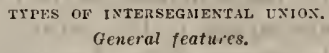

The intersegmental unions in the crinoids are of two types, differentiated by the presence or absence of muscles. Morphologically, the difference between these two types is of no great importance, and primarily all of the unions are non-muscular.

The non-muscular unions occur between the calyx plates, the elements of the pairs in the division series and the first two brachial pairs, and at intervals throughout the arms.

The muscular articulations include the majority of the unions between the brachials, and the articulations at either end of the pairs of ossicles forming the first two brachial pairs and the division series, including the articulation on the distal end of the radials.

All of the plates composing the external skeleton of the crinoids: perisomic plates, pinnulars, brachials, calyx plates, columnals, and cirrals originate in exactly the same way in a uniform layer of mesodermic tissue.

Where they are widely separated, as in the case of poorly developed side and covering plates, there is no modification of the tissues between them.

If they are near together but very rudimentary they are

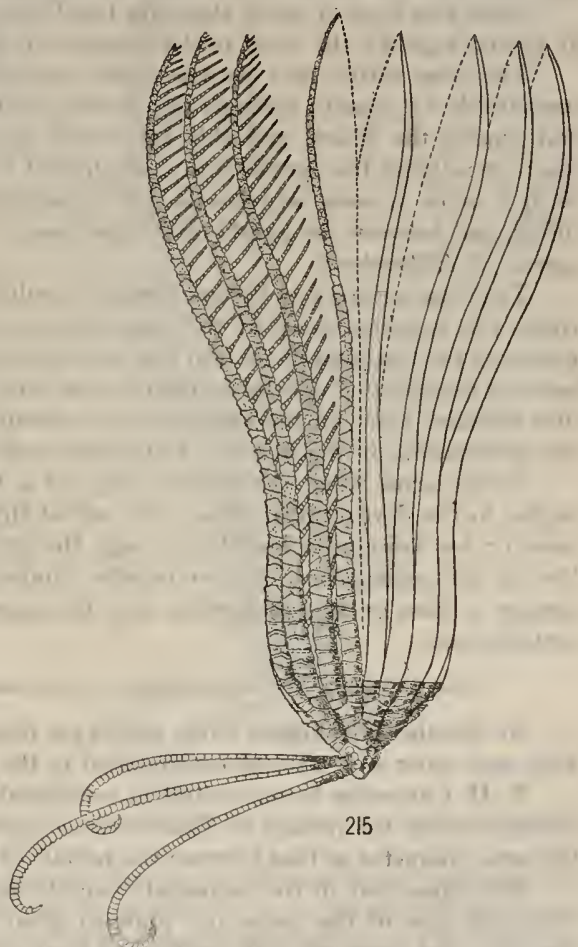

Fig. 215.-Lateral view OF THPE SPEciMen of Cos MiONEtra ASTER.

commonly more or less united by strands of connective tissue. Covering plates are commonly united to the corresponding side plates in this way.

When they are rery close together they are firmly united by parallel ligaments, the ends of which form loops within their substance. The apposed surfaces of ossicles thus united may be smooth, as in the case of the unions between 
the radials and between the radials and the centrodorsal in the comatulids, and also in the brachial and stem syzygies in the pentacrinites, or they may develop more or less numerous irregularly meandering to regularly radiating ridges, as in the unions between the calyx plates in many of the Flexibilia, and in the brachial syzygies and so-called pseudosyzygies in the comatulid arms. A slight amount of motion is usually possible between plates thus united. This type of union is, when movable, known as the loose suture, and when almost or quite immovable as the close suture. In the arms and in the column it is known as the syzygy.

From this type of union there are two lines of departure-one in the direction of greater rigidity, the other in the direction of greater flexibility.

The close suture may become quite immovable and the ossicles united by it inseparable by caustic through the development of a calcareous deposit between and among the fibers, and this calcareous deposit may become so dense as to result in welding the ossicles into a single unit in which no suture lines are visible. Such a union is seen between the infrabasals and the centrodorsal in the comatulids, and between the basals in Bathycrinus, Ilycrinus, Rhizocrinus, and certain species of Ptilocrinus.

The loose suture may become flexible, resulting in the development of a fulcral ridge, the beveling away of the joint faces on either side of it, and the segregation of the ligament fibers into two bundles, as is seen in the so-called synarthries between the pairs of ossicles in the division series and between the elements of the first brachial pairs, in the articulations between the pinnulars and cirrals, and in the articulations in the so-called bourgueticrinoid type of column.

In the arms when the fulcral ridge of a flexible articulation runs at right angles to the dorsoventral plane the ventral ligament bundle is divided into two more or less triangular bundles through the intrusion in the median dorsoventral line of the articulation of two muscle bundles of extra-articular origin which occupy a more or less triangular area the apex of which reaches nearly to the central canal.

Union of radials with each other and with centrodorsal, and wnion of calyx plates.

No detailed histological study has as yet been made of the union of the radials with each other and with the centrodorsal in the comatulids.

P. H. Carpenter has described in considerable detail the characteristies of the suture between the radials in Endoxocrinus wyvillethomsoni, which he states is of the same character as that between the radials of the comatulids.

He writes that in the immediate neighborhood of their apposed lateral faces there are none of the nuclei nor pigment granules which are embedded so abundantly in the more internal portions of their protoplasmic ground substance, and the threads of the plexus of which it is composed become excessively attenuated and disposed with great regularity almost parallel with one another. At the same time the meshes of this organic plexus become greatly elongated in the intervals between the parallel threads or fibers which are connected with one another by very delicate fibrils passing in the form of loops from one fiber to another. These loops are simply the expression of the ends of elongated meshes 
of the protoplasmic plexus forming the organic basis of the skeleton. In the neighborhood of each of the two apposed surfaces the fibrous elements of this plexus assume the character of closely placed parallel connective tissue fibers with no pigment granules nor nuclei embedded in them, but staining deeply with picrocarmine, while the normal protoplasmic basis of the inner part of the calcareous segments is but little affected by this reagent. These fibers pass from the organic basis of one segment into that of the next adjacent so that the two are firmly united, and the superficial denser layer of calcareous tissue is deposited around their ends. The superficial layer of calcareous reticulation which occupies the small intervals between the ends of the fibers thus becomes extremely close and compact, but the central portion of the fibrous tissue does not calcify, remaining as a thin layer of fibrous substance between the two apposed surfaces.

Carpenter, like his father, and all students of the recent crinoids until very recently, believed that the organic or protoplasmic base of the skeleton was continuous from one ossicle to another, but between them became modified into connective tissue strands. Reichen-

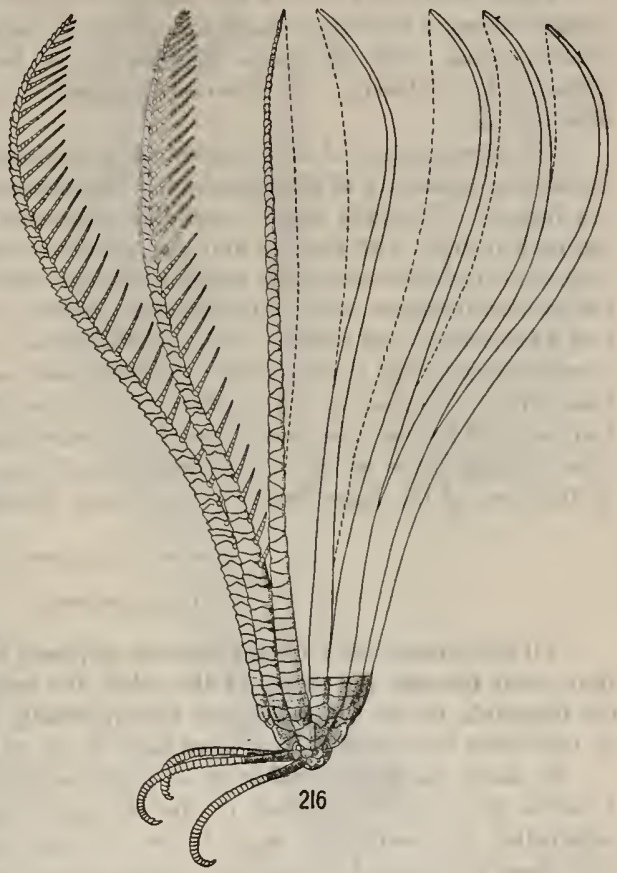

Fig. 216.-Lateral view of specimen of Lissometra alboflava. sperger was the first to show that the ligaments of the brachial articulations are entirely distinct from the organic ground substance of the plates and are formed exclusively of closely packed bundles of fibrillæ the ends of which take the shape of loops within the calcareous substance of the ossicles. From Carpenter's mention of loops, apparently identical with the loops described by Reichensperger, it would appear that the union between the radials is probably identical in character with the ligamentous portion of the unions between the brachials.

The union between the radial circlet and the centrodorsal is of the same nature as that between the individual radials, but it is not quite so close, so that 
the centrodorsal separates from the radials more readily than they do from each other:

The fusion between the infrabasals and the centrodorsal in the comatulids has never been studied, but apparently the coalescence is complete, for the centrodorsal of the adults never shows any evidence of being other than a single element.

From what we know of the stalked crinoids we are safe in saying that in almost all cases the calyx plates are united in the same manner as the radials of Endoxocrinus. But all stages may be traced between the purely ligamentous union and a soldering by calcareous deposit so close that no suture lines are discoverable.

The development of the synostosis or anchylosis is probably due to a gradually increasing continuity of the mesodermic lime depositing layers in which the ossicles are formed. Normally there is complete discontinuity between the sectors including each ossicle; with the less and less complete differentiation of this mesodermic layer into definite sectors the amount of deposition of calcareous matter between the ossicles increases until in those forms, as the species of Ilycrinus, Bathycrinus, and Rhizocrinus, and certain species of Ptilocrinus, in which the mesodermic layer over the basal ring is practically uninterrupted, an almost uniformly continuous basal ring is formed in which there is no trace whatever of interbasal sutures. Carried still farther, the continuity of the mesodermic layer becomes complete, and thus a single plate which is the equivalent of two primitive plates is formed, as in the case of the large basal in Iyocrinus, Thalassocrinus, and Gephyrocrinus.

NON-MUSCUIAR LNLOS,

General remarks.

All the nonmuscular unions between adjacent ossicles in the crinoids, whether they occur between the plates of the calyx, the radials, the columnals, the cirrals, the brachials, or the pinnulars, are fundamentally identical in nature, and so far as they have been studied they have been shown to be histologically the same.

In many fossil types little or no differentiation of these unions according to location can be detected, but in the elongated and slender appendages of the comatulids they ordinarily occur in two distinct forms, one in which the apposed joint faces are marked with numerous radiating ridges, and the other in which they are traversed by a median ridge separating two ligament masses of usually equal size, as in the synarthries between the paired ossicles in the division series and in the arm bases and in the articulations between the pinnulars, cirrals, and larval columnals.

In the pentacrinites, which with the comatulids form a single well circumscribed group, the apposed faces of two ossicles united by syzygy, both in the arms and in the column, are smooth and unmodified, like the apposed surfaces of two adjacent radials. This indicates that the radiating ridges characteristic of the syzygial faces of the brachials in the arms of the comatulids can not be of any particular phylogenetic significance. 
In the proximal portion of the postradial series in certain large comatulids, especially in the genera Comaster and Comatula, there is a well-marked tendency for the synarthries to lose their normal joint face sculpture and either to become nearly plane through the almost complete suppression of the median dorsoventral ridge (part 1 , fig. 36, p. 75 ) or to acquire irregularly meandering or concentric ridges similar to those seeu between the plates in many of the Flexibilia (part 1, figs. $37,38$. p. 75$)$.

In the articulations between the cirri and the centrodorsal the articular surfaces are plane, or. very rarely, scalloped at the periphery. Only in the Atelecrinidie is a transverse ridge with deep ligament fossæ on either side dereloped.

In the ontogeny of the comatulids, while the characteristics of the brachial synarthries are evident from the first appearance of the ossicles on either side, the articulations between brachials ultimately to become united by syzygy do not begin to develop? the radiating ridges until those brachials have acquired most of the features of the fully formed arm segments.

Since the syzygial joint face: are smooth and unmodified throughout life in the pentacrinites. and in the comatulids do not derelop radiating ridges until a very late stage either in the growing young or in regener-

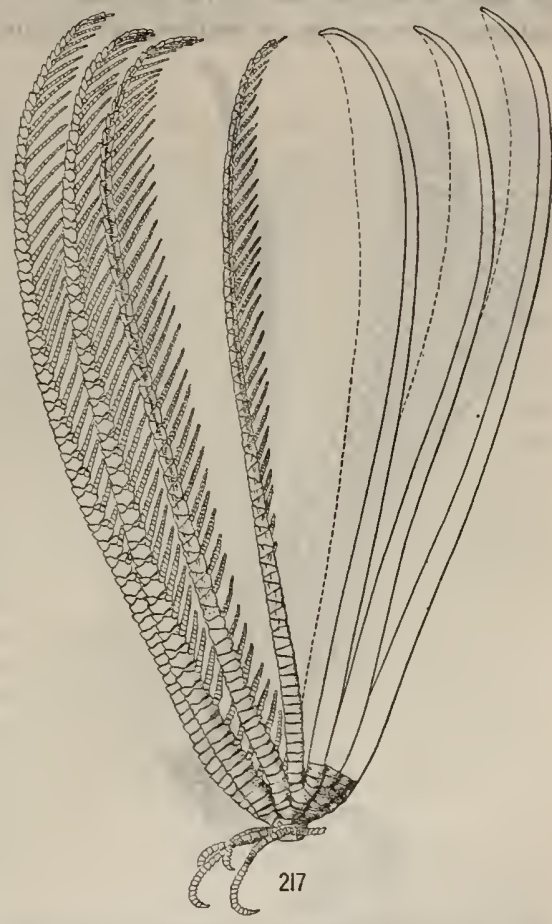

Fig, 217.-Lateral vietw of spectuen of Parametra orion, ating arms, we appear to be justified in assuming that the brachial syzygies are fundamentally unions of smooth surfaces comparable to the unions between the calyx plates or radials which, as the latter do frequently in many types, in the comatulids have dereloped ridges that instead of remaining irregular and meandering hare become straight and regularly radiating to meet the equal stresses exerted in all the radii on a circular joint face.

The occasional transformation of the syuarthries in Comaster and Comatula into articulations indistinguishable from true syzygies (part 1. figs. $37-40$, p. 75 ), 
which are connected by all intermediate stages with articulations in which the joint faces are marked with irregularly meandering or more or less interrupted concentric ridges indicates that there is no fundamental difference between the synarthries (figs. 1084, pl. 18; 1099, 1103, 1107, pl. 19, and 1123, 1127, 1131, 1135, pl. 21) and the syzygies (figs. 1089, 1094, pl. 18) and that both are precisely of the same nature as the sutures between the calyx plates in which the apposed surfaces of the ossicles are marked with irregular lines, while at the same time the

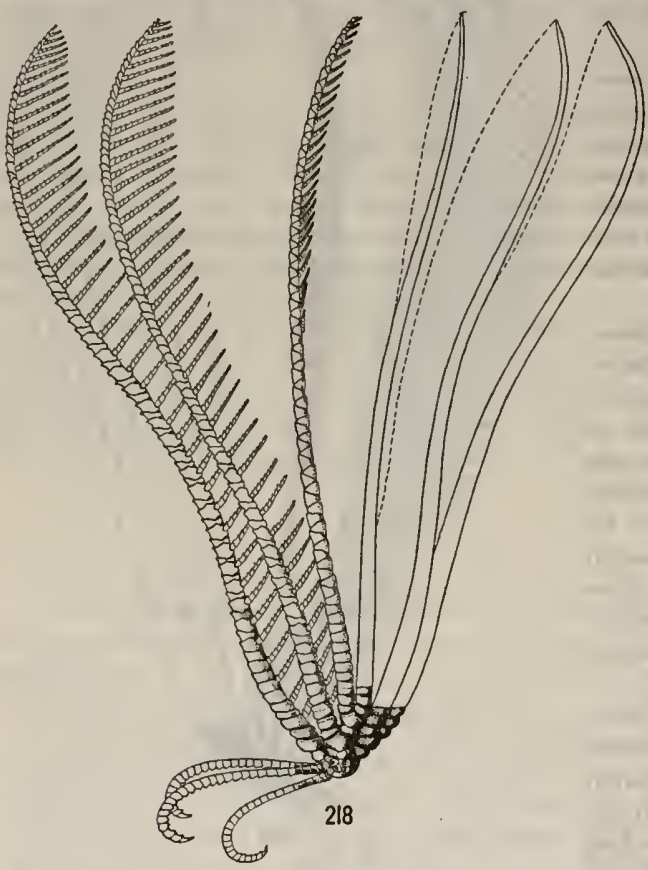

Fig. 218, - Lateral view of type specimen of Parametra fishert. synarthry, through the cryptosynarthry in which the joint face sculpture is obsolescent, grades imperceptibly into the type of articular union between two plane surfaces as seen between the radials.

As a rule, the proportion of nonmuscular to muscular interbrachial articulations in the crinoid arm decreases with increasing specialization.

Thus in the arms of IIolopus, the most specialized of the recent crinoids, there are no nonmuscular articulations.

In the arms of the comatulids and pentacrinites, the next most highly specialized groups, the number of nonmuscular articulations is usually between one-fourth and one-sixth that of the muscular articulations, and may be even less than one-

tenth. Only in one or two of the smallest comatulids are the nonmuscular articulations almost as numerous as the muscular. Furthermore, in these two groups secondary arms developed to replace arms lost and the arms of multibrachiate species which replace the ten arms of the young always have fewer nonmuscular articulations than the primary arms which are replaced, and the arms of the 10armed young.

In the Bourgueticrinidæ the number of nonmuscular and muscular articulations is approximately equal. 
In the genera Thalassocrinus (part 1, fig. 145, p. 209) and Gephyrocrinus of the Plicatocrinidæ there are about as many nonmuscular as muscular articulations, but in the genus Hyocrinus there are two nonmuscular articulation to one muscular.

As exceptions to this rule we find the genera Phrynocrinus (part 1, fig. 2, p. 61), Ptilocrinus (part 1, fig. 144, p. 207), and Calamocrinus, in the arms of which nonmuscular articulations are relatively infrequent, and Proiscrinus (part 1, fig. 128 , p. 199), in which there are none beyond the synarthry in the first brachial pair.

srzYGr.

Scattered at more or less regular intervals throughout the comatulid arm are pairs of brachials very closely united by an articulation consisting of ligament fibers only. The apposed faces of the brachials so united show, running to a more or less broad raised rim about the central canal, prominent radiating ridges of unusually dense and compact calcareous structure with furrows between them, which on the two adjoining articular faces correspond in position (figs. 1089, 1096, pl. 18, and part 1, fig. 34, p. 71). Externally two brachials so united appear as a single brachial, usually slightly longer than those on either side, crossed by a fine white line at right angles to the longitudinal axis of the arm (fig. 1092, pl. 18), which under magnification appears dotted, the dots representing the ends of the little blind canals beetween the apposed ridges of the two joint surfaces. The ligaments binding together two brachials united in this way are identical in character with the ligaments in the muscular articulations, in the synarthries, in the articulations between the pinnulars and cirrals, and between the radials, but are much shorter. The fibers are very numerous and closely packed along the apposed ridges, but more scattered in the furrows between them.

Such an articulation is known as a syzygy (part 1, figs. 6 , p. 63,30 , p. 71 ), and two brachials united by syzygy form a syzygial pair (figs. 1090-1092, pl. 18).

The number of radiating ridges on the apposed faces of a syzygial articulation varies from 5 in Atopocrinus sibogce (part 1, fig. 227, p. 245) to at least 50 in Amphimetra discoidea, but is usually between 15 and 40 . It appears to be to a certain extent proportionate to the size of the articular face, and is greater in the Oligophreata than in the Macrophreata.

Generally speaking the ridges are straight, and run from the periphery of the joint face toward the central canal; many of them are short, running for a greater or lesser distance inward and tapering to a slender point which may lie anywhere between the periphery and the central canal, while others coalesce with a neighboring ridge, the two continuing as a single ridge to the canal.

It not infrequently happens in the outer part of the arms that an especially large and broad ridge runs in the median line from the canal to the middle of the dorsal border of the joint face, or two or three noticeably straight, strong, and prominent ridges may be developed here. When this occurs the remaining ridges are commonly more or less undeveloped, terminating at some distance from the rim about the central canal, so that we see an approach to the synarthrial type of articulation. 
While in the comatulids the radiating furrows and ridges are always very distinct, in the closely allied pentacrinites they do not occur, and at most the joint face is indistinctly scalloped or beaded about the periphery. In the pentacrinites also the surface of the joint face, which in the comatulids is perfectly flat, is undulating.

The joint faces of the syzygies in Atopocrinus siboga are so extraordinary as to deserve special notice.

Laterally and dorsally the central canal is bounded by a high ridge of moderate

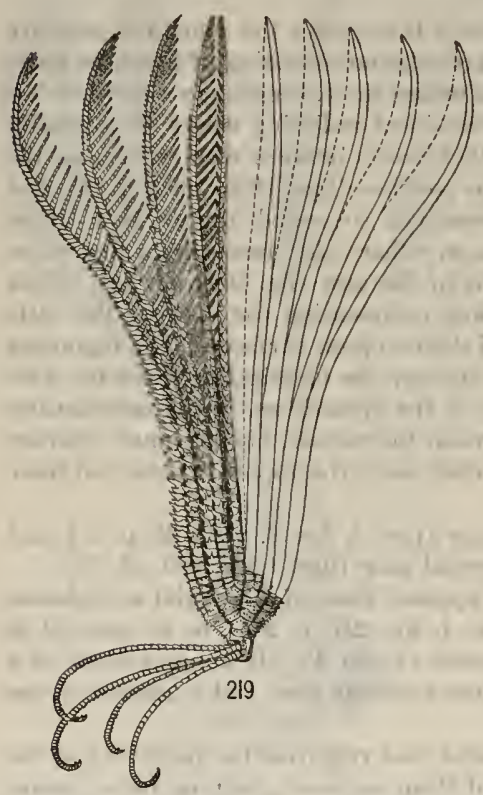

Flg. 219.-LATERAL VIEW OF \$PECIMEN OF STYLONETRA SPINIEERA. width; from this ridge there extends to the dorsal margin of the joint face in the dorsoventral line another ridge which at first is about as broad as the ridge from which it springs, but outwardly gradually broadens slightly; two similar ridges extend outward, one from either end of the laterodorsal ridge about the central canal, making with the median ridge an angle of about $45^{\circ}$, or about a right angle with cach other. Just beyond these lateral ridges, entirely unconnected with the ridge about the central canal, separated from the lateral ridges by a ligament space about the same in shape and size as the two lateral ridges, are two more ridges, slightly broader than the others; each has a very narrow fan-shaped space beyond it. Beyond these two ligament spaces, the distal borders of which are approximately at right angles to the dorsoventral axis of the joint face, are two large obsolete muscular fossæ, which are about as high as the distance between their proximal border and the dorsal edge of the joint face; these are roundedtriangular in shape; inwardly each rises somewhat, forming two parallel, very inconspicuous, low, and well rounded ridges, which are interiorly separated by a shallow rounded groove which becomes more accentuated just beyond the central canal, where it separates the inner ends of the inner pair of ridges; the inner ends of the ligament spaces just beyond these ridges are bounded by the ridges bordering the muscular fossa interiorly. There is a deep intermuscular notch the sides of which make an angle of from $60^{\circ}$ to $90^{\circ}$ with each other. The ridges on the syzygial faces are high, and consequently the ligament fibers are long, appearing in dorsal view almost or quite as long as those of the neighboring dorsal ligaments. 
The outer or distal element of a syzygial pair, which bears on its distal border a muscular articulation and a pinnule socket, is called an epizygal, and the proximal element, carrying on its outer end only the syzygial joint face, is known as a hypozygal.

Syzygies occur in the postradial series at more or less regular intervals from the tip of the arm down to the third and fourth brachials, which together always form the first syzygial pair. If division series be present consisting of four or of three ossicles the two outermost always form a syzygial pair, which, as has already been explained, is in reality a reduplication of the first syzygial pair of the free arms.

There are very few exceptions to this rule. In the Zygometridæ a syzygy replaces the synarthry normally found between the elements of the $\mathrm{IBr}$ series, but the following division series, when present, are of the usual type and the first two brachials are united by synarthry. In Comatella and Neocomatella, and sometimes in Comatula, on the free arms arising from the outer side of the axillaries, the first four ossicles are usually united in two syzygial pairs. In most of the species of the genus Comaster all of the division series except the second consist of two ossicles united by syzygy, and the second consists of two syzygial pairs; but the IIBr series are sometimes $4(3+4)$, and in one species all of the division series are of the usual type.

The details of the distribution of the brachial syzygies have already been discussed (see p. 128, last paragraph, and p. 131, middle).

There is a very considerable difference in the readiness with which comatulids belonging to different groups lose their arms, and the relative brittleness of the brachial syzygies is always correlated with the brittleness of the syzygies between the first cirrus segments and the centrodorsal, and with the tenacity of the unions between the radials. As the arms of the species of Macrophreata are always more brittle than those of the species of Oligophreata, their cirri more easily detached, and their radials more readily dissociated, a possible correlation is observable between the brittleness of the animal as a whole and the size of the central nervous organ.

The cirri and the arms are always in the same degree fragile. In a species which loses its arms very readily the cirri are also found to be readily lost; but in a species in which the arms are rarely broken the cirri will be found also to be unusually tough.

The only exceptions to this interesting correlation occur in the species of the comasterid genera Comaster, Comatella, and Neocomatella, in which one or more of the synarthries in the proximal portion of the post-radial series are replaced by peculiarly brittle syzygies.

Another point of agreement between the arms and the cirri is that, whereas in the multibrachiate species the 10 larval arms are frequently discarded at the first brachial syzygy, in most forms during growth the oldest cirri, nearest the tip of the centrodorsal, are continuously discarded at the syzygy joining the cirri to the centrodorsal.

142140-21-Bull. $82-13$ 


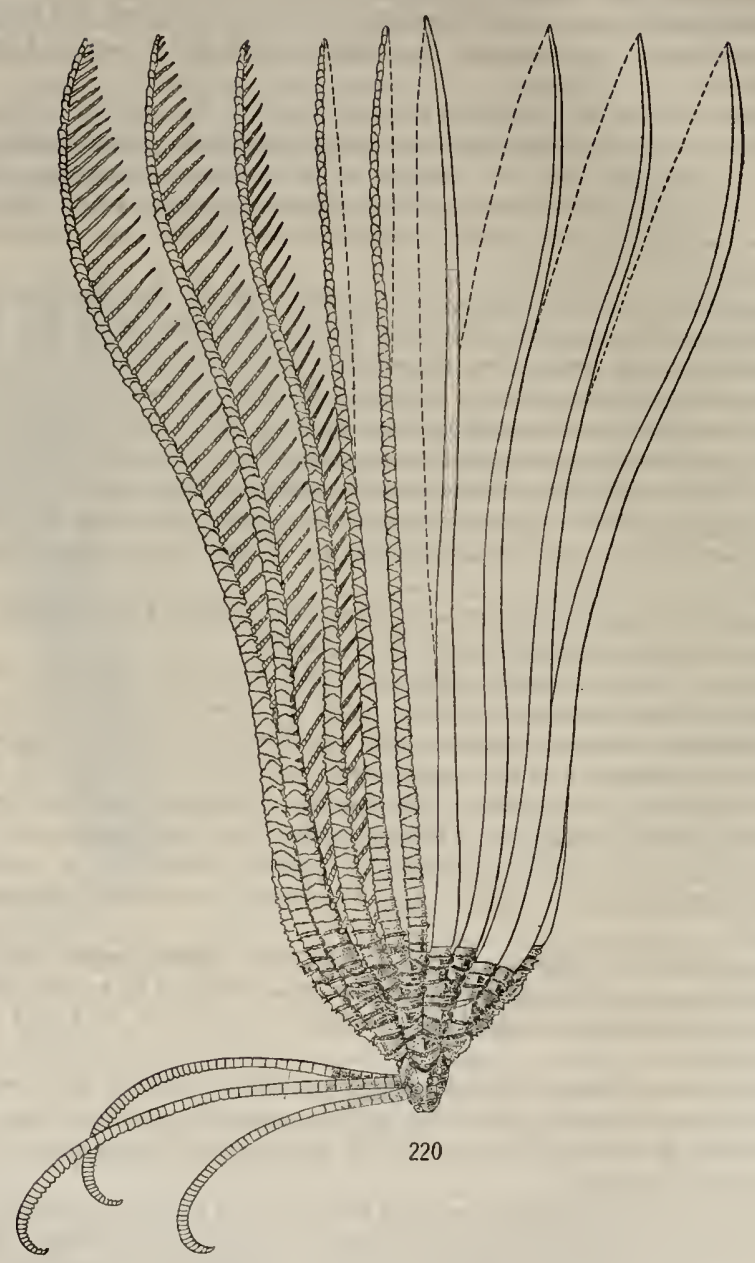

Fig. 220.-Lateral view of type specimen of Oceanometra gigantea. 
In all of the genera of the Comasteridæ, excepting those in which syzygies oceur in place of one or more of the synarthries, the arms and cirri are unusually tough, so that almost or quite perfect specimens are relatively easy to secure: even the minute Comatilia from great depths is but rarely mutilated, and the same is true of the slender and delicate Leptonemaster.

As in the comasterid genera Comaster, Comatella, and Neocomatella, the species of all the genera of $\mathrm{Zygometrida} \mathrm{in} \mathrm{which} \mathrm{the} \mathrm{disk} \mathrm{is} \mathrm{small} \mathrm{are} \mathrm{especially} \mathrm{liable} \mathrm{to}$ fracture of the arms at the most proximal syzygy, which in these genera replaces the synarthry between the elements of the IBr series; but the species with large disks are not so brittle. In this family, and in the Himerometridæ and Colobometridæ, the tendency of the arms to break at the first brachial syzygy as a rule does not appear to be so strong as in the Mariametridæe and Stephanometridæ.

It is somewhat difficult satisfactorily to compare the species of the Thalassometridæ with those of the preceding families because of the much rougher treatment necessary in capturing them, owing to the ordinarily greater depth of their habitat, where they are usually found among stones and coral. Generally speaking, they seem to be peculiarly tough, as tough as the species of Comasteridæ with, as in that family, a few curious exceptions. The species of Ptilometrinæ, with the single exception of the species of Tropiometridx, are perhaps the least brittle of any of the comatulids, and it is astonishing to see how the individuals will stand the roughest sort of treatment in the dredge and yet remain whole; on the other hand, the species of Stenometra, Daidalometra, and Stiremetra are extremely brittle, and it is almost impossible to obtain anything like satisfactory specimens of any species of either of these two genera. All of the other genera of the Thalassometrinæ are tough, though this is not quite so marked as in the Ptilometrinæ.

The species of Calometrida and Charitometridæa are all very tough, on the whole resembling those of the Ptilometrinæ and Tropiometridæ.

As a result of the toughness of the species of these groups the cirri are sometimes torn apart at a greater or lesser distance from the base and the outer portion regenerated. I have observed such partial regeneration of the cirri in Ptilometra, Pterometra, Asterometra, Tropiometra (part 1, fig. 319, p. 275), Crinometra, Pachylometra, and Glyptometra, and in some of the genera of the Calometridæ. Outside of these genera it has only been reported in Promachocrinus, and as a result of artificial mutilation in Antedon.

In the Macrophreata there is a very considerable diversity in the rea diness with which the arms and cirri are lost, but the species as a whole are far more brittle than the species of Oligophreata. A curious difference between the two is that whereas in the Oligophreata brachial fracture usually occurs at the first syzygy, in the Macrophreata it quite as frequently. or even more commonly, occurs at the second or third syzygy, or even farther out on the arm.

The toughest of all the forms in the Macrophre:ta are the species of the genera of Perometrinæ and Antedoninæ, which in this respect, as in others, approach the species of the Oligophreata. All of the genera in these two subfamilies are about equally tough. 
The species of Zenometrinæ, Pentametrocrinidæ, and Atclecrinidæ are extremely brittle, so brittle indeed that in many the cirri and the arm tips are quite unknown. In these three groups it is especially noticeable that the arms are rarely lost at the first syzygy, but almost always at the second or third or beyond.

The species of Bathymetrinæ are mostly very brittle, and in many of them the cirri and the outer portions of the arms have never been seen. Trichometra and Thaumatometra stand rather apart from the other genera in being much less subject to mutilation during capture. In the case of Triohometra this relative toughness has almost the value of a generic character in serving to differentiate the species from those of the very closely related but extremely brittle Hathrometra.

The species of the genera of Heliometrinæ, though very large, are decidedly brittle, and good specimens are almost impossible to secure. The species of Solanometra seem to be rather less fragile than their allies.

The species of the genera Thysanometra and Coccometra, included in the Thysanometrinæ, are rather less brittle than most macrophreate types.

In the Arctic and north Atlantic oceans species of Heliometra and of Hathrometra are often dredged together, and when this occurs Heliometra is seen to be much less fragile than the smaller Hathrometra. In the Olkhotsk and Japanese seas Heliometra and Thaumatometra occur together and are often intermingled in the dredge, and here the small Thaumatometra is found to be much less fragile than the larger Heliometra.

The tendency of the comatulids to cast off their appendages, pinnules, arms, and cirri, when taken from the water or otherwise placed under unfavorable surroundings, renders them very difficult to preserve satisfactorily. But I have found that self-mutilation can largely be prevented by quickly lifting the animals and plunging them at once into very strong alcohol or very hot water. If one attempts to kill them slowly in the usual way, in weak alcohol or in fresh water, they are certain to disintegrate into small fragments.

Long ago the Japanese fishermen discovered the high commercial value of the "bird's foot" (Metacrinus rotundus) in the European market, and they soon found that "birds' feet" could be preserved without the loss of their arms if when they were brought to the surface the arms were brought together and bound in place with a strip of cloth. This in most cases prevents the creatures from breaking off the arms, as they are certain to do if allowed to bend them outward and downward toward the stem.

Almost all the students of the comatulids except Sars have considered the syzygies as loous minoris resistentio where fracture of the arm automatically takes place when the arm is seized, as the result of some special weakness.

My experience with living comatulids and with preserved specimens has led me to agree with Sars; the syzygies under ordinary circumstances are at least as strong as the muscular articulations, as anyone may prove for himself by breaking up crinoid arms; and those who have separated the brachials of a crinoid arm by means of caustic have always found that the syzygies are by no means regions of lessened resistance, for they are as a rule the last joints to come apart, and often 


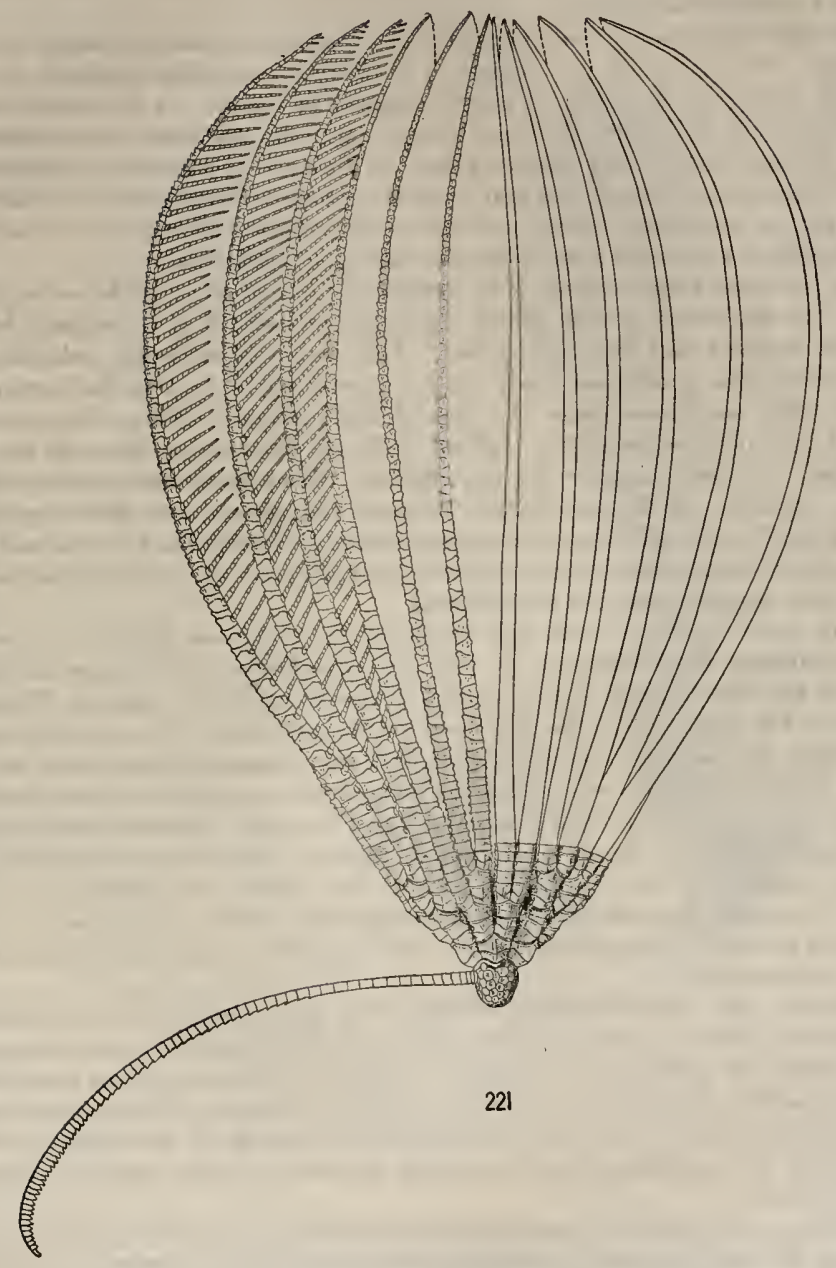

Fig, 221.-Lateral view of type specimen of OCeanometra Maga. 
all the other articulations will have separated yet some force is still necessary to break asunder the syzygies.

In life it is certainly true that fracture of an arm almost invariably occurs at a syzygy. If an aninal be exposed to unfavorable conditions, placed in warm or fresh water, or very often if merely exposed to the air, all the arms are commonly cast off at the first brachial syzygy, and the detached arms continue to break up into smaller and smaller pieces by fracture at succeeding syzygies.

Reichensperger has shown that syzygial unions are innervated in exactly the same way as muscular unions, and this would seem to indicate that fracture at the syzygies is a voluntary act under the control of the animal.

In the more brittle types, as in Antedon, if one of the cirri be seized firmly, or if it be cut across, it will almost invariably be cast off at the syzygy between its first segment and the centrodorsal. This action is evidently voluntary.

Unfarorable conditions when not severe enough to lead to the breaking up of the arms sometimes cause the loss of the pinnules. When this occurs the genital pinnules are the first to fall off, followed by more or fewer of the distal pinnules. The oral pinnules are not affected. When the pinnules break off they always separate at the articulation between the second and third segmentsthat is, at the first articulation composed entirely of very short fibers, and therefore strictly comparable to the brachial syzygies and the syzygies between the first cirrus segments and the centrodorsal.

The term "syzygy" was first employed by Johannes Mïller for the type of articulation first described in 1825 by Lansdowne Guilding, who believed that all the articulations in the comatulid arm were of this nature. The application of the term has in the past been somewhat broad. Two brachials united by syzygy and forming a syzygial pair have been commonly considered as but a single brachial, which was called by synecdoche a syzygy. Thus Carpenter repeatedly speaks of the "third brachial" as a "syzygy," or says "first syzygy in the third brachial." Another meaning is given to the word by Pourtalès, who, besides speaking of the "syzygium in the third joint," also calls, in the distal part of the arm, the interval between two syzygial unions a syzygium. Thus he describes the arms of a comatulid as having "syzygia composed of three, or seldom four, articulations."

Müller and Carpenter believed that when two brachials become united by syzygy the lower (hypozygal) entirely loses its individuality, and the syzygial pair, usually in general size and shape as well as in its pinnulation resembling a single brachial, should then be treated as a single brachial. But Carpenter made an exception to this in the case of the $\mathrm{IBr}$ series which in the comatulids he always considered as consisting of two separate elements whether they be united by syzygy or not.

Bather was the first to appreciate the necessity of a more consistent interpretation of the conditions, and he strongly urged that the term "syzygy" be employed solely to designate a syzygial union, and that the two elements of the syzygial pair be considered, as they morphologically are, separate units. In this eminently 
logical stand he was later strongly supported by Minckert, and the term has now universally come to be restricted as he suggested.

Bather believes, with Carpenter, that a syzygy is an oblique muscular articulation which has become peculiarly specialized, the proximal ossicle during this process having lost its pinnule and much of its individuality. But it is obvious that if this were the case the proximal and distal articulations of the syzygial pairs would be parallel, and both strongly oblique in the same direction, for the course taken by oblique muscular articulations across the arm always alternates at succeeding articulations, and if one of these articulations were transformed into a syzygy and thus made horizontal the articulations on either side of it, with both of which it alternates in position and which would become the proximal and distal articulations of the resultant syzygial pair, would of necessity be parallel with each other, a condition never found. Moreover, the pinnules always alternate in position on either side of the arm; if an oblique muscular articulation were transformed into a syzygy and the pinnule on the brachial the distal border of which was formed

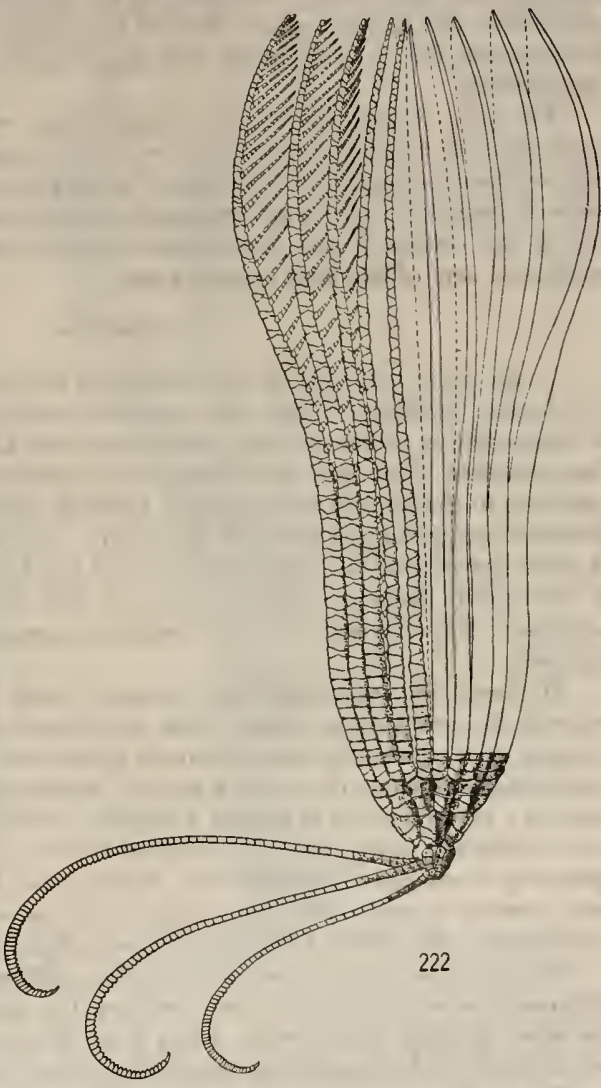
by that articulation lost, the Fig. 222.-Lateral View of TYPE SPEcisen of Oceanometba pinnules on either side of the AXNAXDALEI.

syzygy (the pinnule on the distal end of the syzygial pair and that on the distal end of the brachial preceding it) would come to lie on the same side of the arm, and thus all along the arm at every syzygial pair two pinnules would be found on the same side of the arm, a condition which never occurs. 
Chadwick supposes that a primitive single brachial may develop a transverse fracture plane which eventually becomes a syzygy, just as the peculiarly weakened joints in the legs of crabs are developed, the similarity of which to crinoidal syzygies was first called attention to by Bather in 1895. Although by this explanation the morphological effect of the syzygy upon the arm structure would be accounted for, it is definitely and emphatically negatived by the ontogeny of the brachials.

The only explanation of the syzygial pairs which accounts for all of their many peculiar features is that they are strictly homologous with the first brachial pairs of the arms, and with the pairs of ossicles in the division series, and represent pairs of ossicles in every way comparable to these which have remained unmodified during the course of the development of the immensely elongated and highly specialized arm of the later crinoid types.

\section{Pseudosyzygy.}

In the great majority of the comatulids the first syzygy is between the third and fourth brachials of the free undivided arms, or between the reduplications of these ossicles in the division series when the latter are composed of three or four elements. But in a few types one or more of the synarthries which occur proximal to the normal first syzygial pair are replaced by more or less perfectly developed syzygies (part 1, figs. 37-40, p. 75). On account of the anomalous position of these syzygies in the comatulid arm and the fact that usually they differ more or less widely from the distal syzygies in the direction of the synarthries they have been differentiated from the brachial syzygies under the name of pseudosyzygies.

It should be emphasized that in reality there is no morphological difference between the syzygies as found from the second brachial pair onward and the syzygies that replace the more proximal synarthries. The latter show all possible intergradations from the perfect syzygy indistinguishable from that in the free arms to a syzygy which is merely a slightly modified synarthry. In other words, the transition in these proximal syzygies between the true syzygy and the typical synarthry is complete and unbroken, showing that there is no fundamental difference between syzygies and synarthries and that all the postradial nonmuscular articulations are really homologous morphologically as they are histologically.

The proximal syzygy reaches its greatest perfection in the species of the family Zygometridæ, where it occurs only between the elements of the IBr series, all of the other division series being either 2 or $4(3+4)$ as usual and the first two brachials of the free undivided arms being united by synarthry.

In the Zygometridæ the proximal syzygy is quite indistinguishable from a brachial syzygy excepting only in a single small 10-armed species, Zygometra pristina, in which the outer part of the articular faces for about one-half of the distance from the periphery to the rim of the central canal is marked with radiating ridges, the remainder of their surface being smooth and flat except for the low and narrow median synarthrial ridge. 
Only in the species of Zygometridæ do we find the proximal syzygies confined to the articulation between the elements of the IBr series, and only in this group do they occur in all the species.

In the species of the genus Comaster, excepting in $C$. multifida and $C$. taviana in which they are entirely absent, the proximal syzygies reach a high state of perfection. In the articulation between the ossicles of the $\mathrm{IBr}$ series in $C$. fruticosus (part 1, fig. 37 , p. 75 ) the central canal is surrounded by a well-marked rim from which a more or less broad median ridge runs to the middle of the ventral border of the joint face; between the rim and the middle of the dorsal border of the joint face are half a dozen or so small narrow ridges of which the two central usually cover the entire distance while the others radiate, more or less irregularly, outward from the central canal toward the dorsal and dorsolateral border. The outer half of the joint face is marked by usually three or four more or less prominent concentric ridges; between this outer concentrically arranged portion and the rim about the central canal the surface of the joint face is thickly set with blunt points and tubercles and short or interrupted ridges of various lengths which may be arranged more or less concentrically or more or less radially, or may have no particular arrangement. Sometimes these inner structures may become almost or quite obsolete, so that the joint faces have almost

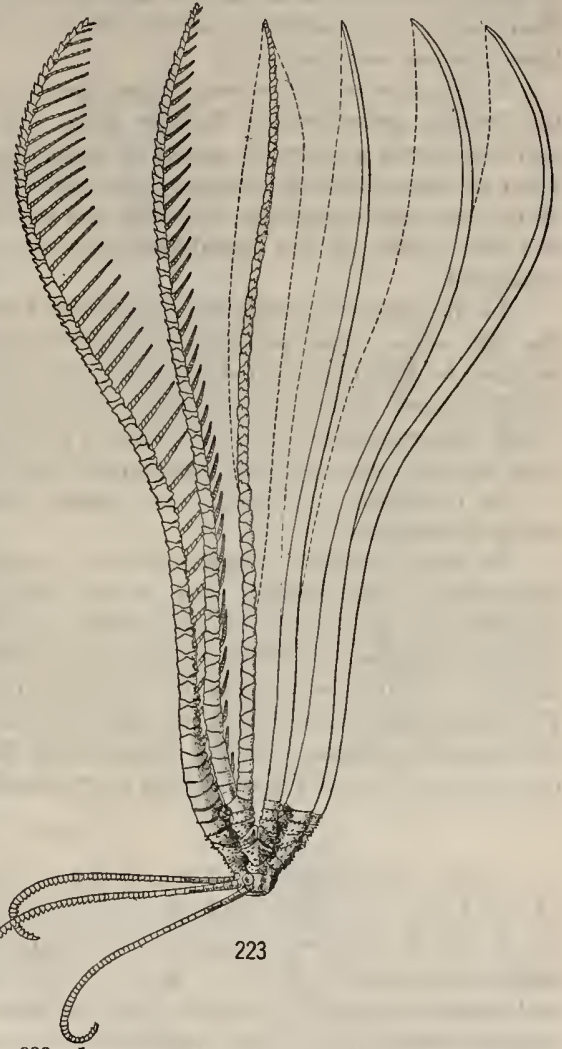

Fig. 223.-Lateral view of type specimen of Thalassometra HAWAIIENSIS. the appearance of a typical synarthry; again, they may be very prominent with a generally radial arrangement, so that except for the broad concentric outer border the joint face resembles that of a typical syzygy.

Carpenter described the syzygy between the elements of the IBr series in Comaster novaguinere and states that while in all the recent comatulids the 
apposed faces of the two portions of a syzygial union are marked by a series of slightly elevated ridges with alternating furrows which radiate from the opening of the central canal toward the dorsal margin of the joint face, in Comaster novaguinece these ridges are frequently not perfectly continuous but are broken up into a row of little elevations, squarish or oblong in shape, and arranged with their longer axes radiating outward from the central canal; on some joint faces these are not very numerous.

In the species of Comaster other than the two mentioned the elements of all the division series beyond the $\mathrm{IBr}$ series and the first two brachials of the free undivided arms are always united by syzygy, and these syzygies range all the way from an almost typical synarthry to a quite typical syzygy (part 1, fig. 40, p. 75) With very rare exceptions, however, the median ridge between the central canal and the middle of the dorsal border of the joint face is always more or less developed.

In the genus Comatula the synarthries between the elements of the $\mathrm{IBr}$ series, the IBr series (when present), and the first two hrachials are almost invariably replaced by highly perfected syzygies (part 1 , fig. 39, p. 75). But in the so-called slender-armed variety of Comatula solaris, $C$. pectinata, and $C$. purpurea, in which the arms are not swollen basally, the synarthries are retained, though their joint face sculpture is much less marked than usual (part 1, fig. 36, p. 75).

In Comactinia, which is very closely related to Comatula, the synarthries remain unmodified.

In the so-called bourgueticrinoid (synarthrial) articulations between the columnals in Bathycrinus and in the rery young pentacrinites (observed in Isocrinus and in Comastrocrinus), there is a tendency for the median ridge to break up into a number of smaller ridges which radiate outward from the central canal so that a joint face is formed which is, to all intents and purposes, a syzygy. This articulation, which is quite comparable to the proximal syzygy in the arins of the comatulids, becomes in the pentacrinites the characteristic stem joint in which the apposed faces of the columnals show complicated petaloid figures.

Synarthry.

In the brachial synarthrial articulations (figs. 1084, pl. 18; 1099, 1103, 1107, pl. $19 ; 1123,1127,1131,1135$, pl. 21 ; and part 1 , figs. 6, p. $63 ; 10$, p. 65 ; and 30 . 33 , p. 71) the apposed joint faces are transversely oval and are divided in the median dorsoventral line by a more or less broad ridge running from the dorsal and rentral borders to the rim about the central canal, so that the two ligament masses occupy each a large semicircular or semielliptical area on either side of the dorsoventral line.

With the brachial synarthries the articulations in the column of the larval comatulids, which consist of two ligament masses, one on either side of a median ridge coinciding with the longer axis of the joint face, as well as the similar articulations between the cirrals and the pinnulars from the second outward, are in all ways homologous (part 1, fig. 139, $b$, p. 205). 
In a dorsal view of a postradial series of ossicles synarthries may be at once distinguished by their straight course across the arm taken in connection with the appearance of the point of contact between the two ossicles (representing the ends of the longitudinal ridges on the two joint faces) exactly in the median dorsal line (fig. 668 , p. 329 ; the two elements of each of the three pairs of ossicles represented are united by synarthry).

Synarthries only occur between the two elements of the first brachial pair and their more proximal reduplications; that is to say. the two elements of each of the division series consisting of two ossicles, and the first two elements of division series consisting of four ossicles.

Some or all of the synarthries in the postradial series in certain species may be replaced by syzygies (see p. 174), though the converse is not true.

The term synarthry was first proposed by Minckert to cover all interbrachial articulations except syzygies. The synarthry as here understood was originally called bifascial articulation by Carpenter. The word synarthry is preferable to the term bifascial articulation on account of its euphemism and brevity; it is also conveniently close to the word syzygy to suggest a relationship. It has seemed permissible, therefore, to adopt the word synarthry from Minckert, but at the same time to redefine it so as to include within its meaning a single definite type of articulation.

$$
\text { Cryptosynarthry. }
$$

In the slender-armed varieties of Comatula solaris, C. pectinata, and $C$. purpurea, where the synar-

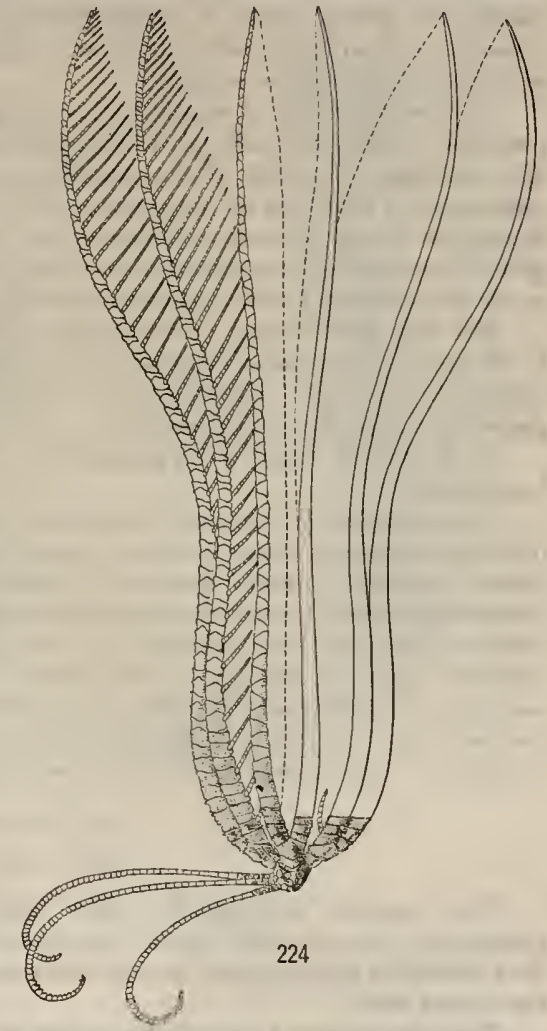

F1G. 224,-Lateral VIEW OF TXPE SPEClMeN OF ThalasSOMETRA PUBESCENS.

thries persist instead of giving place to syzygies, as in the broad-armed varieties of the same species, the apposed surfaces of the ossicles become almost plane; but a close examination reveals a faintly marked median ridge, on either side of which are the two large but very shallow and almost obsolete ligament fossæ. The borders of the ligament fossæ, ordinarily narrow rims, are here 
very broad, but the median ridge is no wider than usual (part 1, fig. 36, p. 75; this is only a moderately developed example). Thus a small synarthrial articulation occupies the center of a large flat joint face. As the ligament bundles, on account of the broadening of the rim about them, and its close contact all around with the rim of the adjacent ossicle, are not visible exteriorly, and the close union has eliminated the beveling conmonly characteristic of synarthrial articulations, causing the line of union to appear perfectly uniform and straight, the cryptosynarthry appears externally merely as a very fine line and is only with difficulty to be distinguished from a syzygy.

This peculiar type of synarthry, in which the true synarthrial joint face occupies only a relatively small part of the entire joint surface, appears to be the result of a cessation of growth of the synarthry at some time considerably before the attainment of adult size by the animal so that, after the synarthry stops increasing in size, the further increase in the size of the joint face as a whole is effected by the gradual broadening of the borders of the ligament fossæ, which effectually masks, so far as the external view is concerned, the synarthrial nature of the union.

For this peculiar type of synarthry, which is characteristic of certain forms in the genus Comatula and appears to be clearly differentiated from the ordinary synarthry and easily distiuguishable even by external examination, I have suggested the name of cryptosynarthry.

It is evident that the cryptosynarthry is not very far removed from the loose suture.

Large specimens of species belonging to other genera of the Comasteridæ often have the synarthrial unions so close as scarcely to be recognizable as such externally; indeed Carpenter himself described Actinometra notata as having "syzygies" between the elements of the division series and placed it next to Comatula rotalaria, when in reality it is identical with his Actinometra stelligera, belonging in a totally different "group"; but with a little practice there will never be any danger of confusing the true synarthry and the cryptosynarthry. Where the latter is present the two elements united by it appear as a single ossicle, just as do two ossicles united by syzygy. This is never the case with two elements united by a true synarthry.

MESCULAR ARTICULATIONS.

General remarks.

The muscular articulations differ from the nonmuscular articulations in possessing a pair of muscle bundles attached to their ventral borders and extending for a greater or lesser distance inward along the median line of the joint face toward the central canal.

The first muscular articulation unites the radial to the proximal element of the $\mathrm{IBr}$ series (figs. 1, p. 6, 1118, pl. 20), and subsequently muscular articulations occur between the pairs of ossicles in the division series and between all the brachials in the free undivided arms except those nnited in syzygial pairs (part 1, fig. 6, p. 63 ; fig. 30, p. 71 ). 
Muscular articulations are of two types-one in which the fulcral ridge runs across the joint face at right angles to the dorsoventral plane and the two halves of the rentral portion of the joint face on either side of the median line are alike and symmetrical, known as the straight muscular articulation (part 1, fig. 31, p. 71), and one in which the fulcral ridge is strongly diagonal, so that the two portions of the ventral surface on either side of the median line are very different in size and shape, and there is a pinnule socket on the ventrolateral border of the larger ventral division, known as the oblique muscular articulation (part 1, fig. 32, p. 71). The distal ends of axillary ossicles bear two muscular articulations side by side, the apposed borders of which are more or less cut away (figs. 1102, 1101, pl. 19, and 1128,1186, pl. 21). In character these are commonly intermediate between straight and oblique muscular articulations. In reality they should be considered in the same light as single oblique muscular articulations, for all gradations occur between two similar articulations side by side on the distal end of an ossicle through stages in which one of these gradually diminishes in size to the single articulation bearing a cirrus socket on its onter border.

Viewed from the dorsal side the straight muscular articulation passes directly across the arm at right angles to its longitudinal axis (note the articulation between the radial and $\mathrm{IBr}_{1}$ iu any figure), while the oblique muscular articulation is always more or less oblique, succeeding articulations alternating in direction, with the pin-

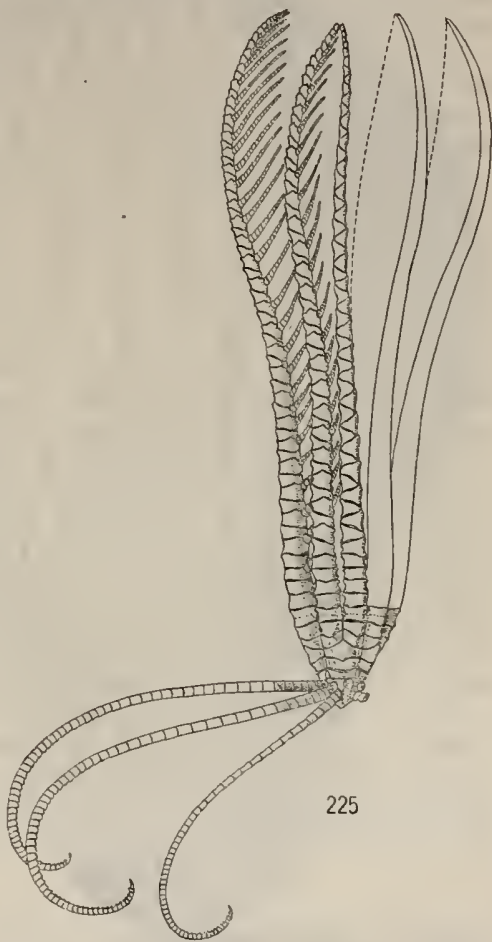

Fig. 225.-LAteral VIEW Ob tTPE sPecimen OH AglaoMETRA EUPEDATA.

nule socket just below the more distal end (part 1, fig. 1, p. 60; all the articulations shown in the two central arms except just at the base are oblique muscular).

The only straight muscular articulation is that between the radial and the $\mathrm{IBr}_{1}$. The other muscular articulations are all of the oblique type, and always double.

The muscular articulations of the free undivided arms do not vary greatly in the different groups, but those toward the arm bases, in the division series, and especially on the distal ends of the radials, become progressively more and more 
differentiated, assuming definite group characters, which are based upon the proportionate reduction in the size of the muscles (figs. 1-115, pp. 6-67, 950-1007, pls. 1-4).

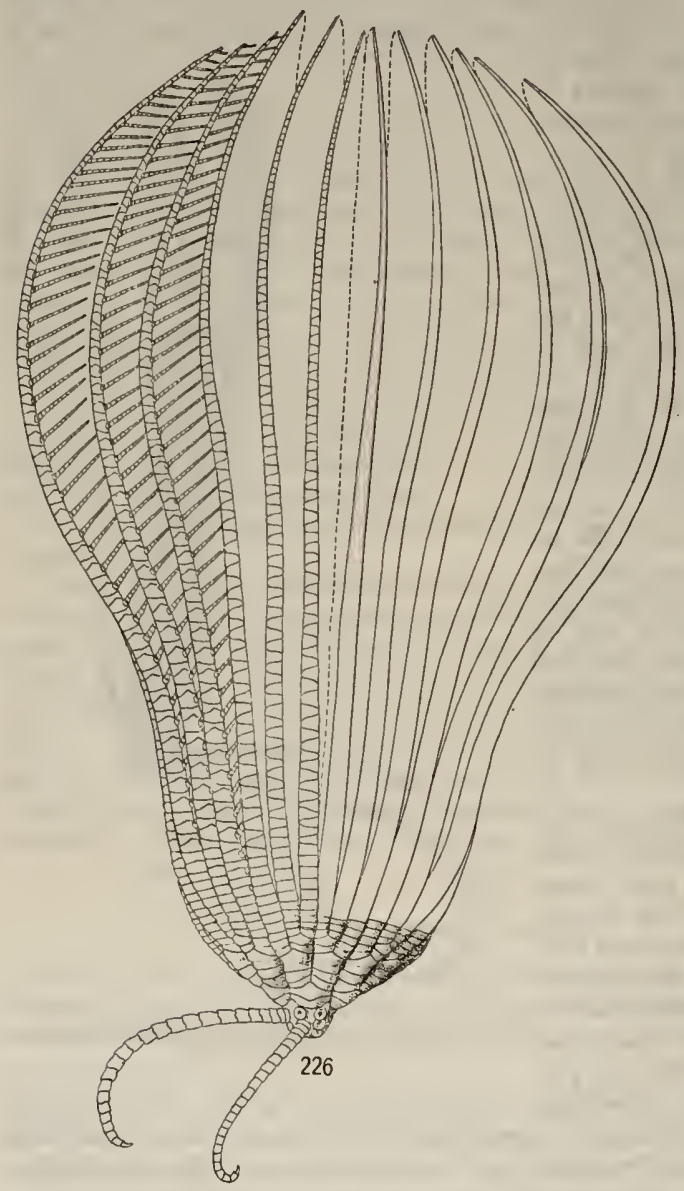

1ig. 226,- Lateral view of specimen of Crossometra helies.

In the straight muscular articulation on the distal face of the radials uniting the radials with the $\mathrm{IBr}_{1}$ there is a complete intergradation from types with enormously developed muscles, as in Pentametrocrinus (figs. 114, p. 67, and 1006, pl. 4 ), to types in which the muscles are almost entirely lost, as in Himerometra martensi (fig. 41, p. 26), and even quite absent, as in Pontiometra andersoni (fig. 51, p. 33).

In these last we $h$ ave an articulation comparable with the synarthry, but with the fulcral ridge at right angles to the median dorsoventral line instead of coinciding with it, and with a broad furrow reaching from the middle of the ventral border nearly to the central canal representing the incompletely closed channel through which the central nerve cord has reached its final position, which is the homologue of the similar channel seen in the brachial syzygies. In Pontiometra the fulcral ridge is in process of disintegration, and in this type we appear to see a further step in the direction of the syzygy. 
Through such forms as Himerometra and Pontiometra we appear to find a complete intergradation between the muscular and the nonmuscular articulations.

It is noticeable that the highest development of the muscles on the radials occurs on the 5 and 10 armed species, while the last is found in the highly multibrachiate types, and this might be supposed to indicate that the gradual loss of the muscles was correlated with progressive specialization and therefore that the primitive form was the type in which the muscles are developed to the highest degree. But highly developed muscular articulations giving great flexibility to the arms characterize comatulids with rery greatly elongated arms the very numerous brachials of which, particularly the distal, are to the highest degree developed and specialized as uniserial elements of an attenuated appendage, and their appearance is first at or near the arm tips from which they gradually extend themselves toward the basal portion of the arms. In the highly multibrachiate species in which the number of division series is large and the visceral mass extends beyond them to the base of the free undivided arms the plates of the division series become broadened and thin as they are in those fossil forms in which they are incorporated in the body wall, and in their mode of union as in their outer attributes revert to a more primitive type. We appear to be justified, therefore, in considering the type of muscular articulation on the distal end of the radials in Himerometra and Pontiometra as more primitive, by correlative reversion, than that on the distal ends of the radials in Pentametrocrinus.

The more or less complete loss of the muscles in the proximal muscular articulations in multibrachiate comatulids, culminating in their entire absence in Pontiometra andersoni, suggests that the muscles are a purely secondary feature of these unions. The invariable occurrence of a pair of large ligament masses ventral to the fulcral ridge, which gradually decrease in size as the muscles increase, also indicates that the brachial articulations are only secondarily muscular, for in a union primarily muscular we should expect to find only muscles on one side of the fulcral ridge and only ligaments on the other, a condition toward which the articulations between the comatulid brachials are evidently tending.

The numerous successive pairs of muscles between the brachials in the crinoid arms probably represent collectively a single pair of longitudinal muscles comparable with the radial longitudinal muscles of the holothurians or the Echinothuridæ.

$$
\text { Straight muscular articulations. }
$$

The straight muscular articulations have already been described in detail in the section dealing with the articular faces of the radials (pp. 1-77).

Oblique muscular articulations.

While in the straight muscular articulations the transverse ridge traverses the joint face at right angles to its dorsoventral plane, the two interarticular ligament and muscular fossæ being similar and of equal size, and viewed dorsally (exteriorly) the joint face is seen to cross the arm at right angles to the longitudinal axis, in the oblique muscular articulation (figs. 1083. pl. 18; 1110, pl. 20; 
and part 1 , fig. 32, p. 71) the course of the transverse ridge is oblique, normally making an angle of about $45^{\circ}$ with the dorsoventral plane of the joint face, the

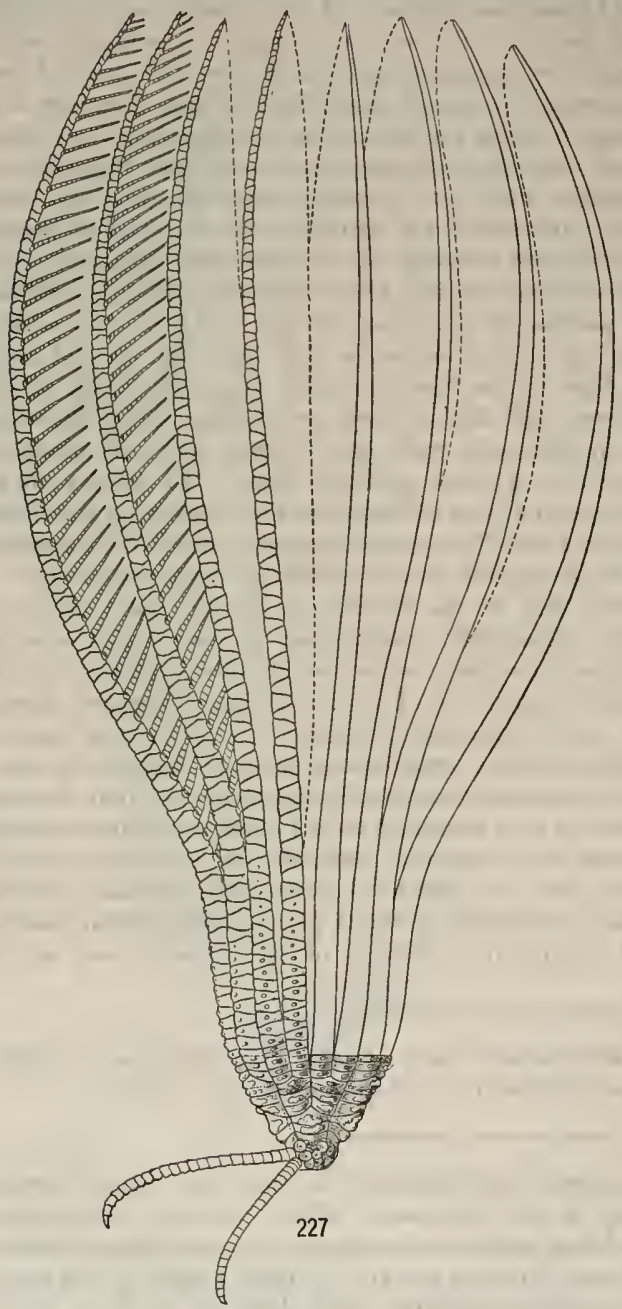

Fig. 227.-Lateral view of specimen of Perissometra selene. interarticular ligament and the muscular fosse on one side of the median line consequently being crowded and those on the opposite side correspondingly extended, and viewed dorsally the joint face is seen to cross the arm at more or less of an angle (typically about $45^{\circ}$ ) to the longitudinal axis.

In an external dorsal view of a postradial series of ossicles a straight muscular articulation may usually be at once distinguished by its straight course across the arm and by having the two points of contact marking the ends of the apposed fulcral ridges equidistant from the median dorsal line. An oblique muscular articulation, on the other hand, runs diagonally across the arms, most commonly at an angle of from $30^{\circ}$ to $45^{\circ}$, and the two points of contact are one dorsolateral, the other ventrolateral (part 1, fig. 30 , p. 71).

Two oblique muscular articulations following each other are always reversed, and this alternation is the invariable rule. If the fulcral ridge of one oblique muscular articulation crosses the joint face from a left ventrolateral to a right dorsolateral position, the 
pinnule socket being in the right muscular fossa, the transverse ridge of the next succeeding (or next preceding) oblique muscular articulation will be found always to cross the joint face from a left dorsolateral to a right ventrolateral position, and the pinnule socket will be found always in the left muscular fossa. The fulcral ridges of succeeding oblique muscular articulations make an angle with each other typically of approximately $90^{\circ}$. This alternation in the direction of the fulcral ridges accounts for the marvelous flexibility of the crinoid arm.

The straight muscular articulation admits of motion only in the dorsoventral plane. The alternation in the direction of the fulcral ridges of the oblique muscular articulations admits of motion, collectively, in any direction; but the arm can not be rotated. Synarthries admit of motion in the plane at right angles to the dorsorentral plane, but the scope of synarthrial motion is always very limited. Syzygies admit of no motion whatever.

While the straight muscular articulation is invariably single, oblique muscular articulations are always double. Except in Eudiocrinus, Atopocrinus, and the Pentametrocrinidx, the first oblique muscular articulation always occurs in the form of two similar articulations situated side by side on the distal end of the second postradial ossicle (fig. 1102. pl. 19), and several of those immediately following may be developed in the same way. The first oblique muscular articulation of the free undivided arm consists of the articulation uniting the second with the third brachial, plus a large and well-developed pinnule socket, and the following articulations are similar except that the pinnule socket rapidly diminishes in size and perfection.

In the recent comatulids the two articular faces on the distal end of each axillary are always exactly alike, but in the genus Metacrinus the axillaries beyond the first always hare one of the two articular faces and the arms arising therefrom larger than the other, and the difference is sometimes very marked. In the closely related genus Pentacrinus (fossil only) the discrepancy in the size of the two faces becomes much more marked, so that in each postradial series there are commonly four main arm trunks giving off ramules at fairly regular intervals.

The condition normal in Metacrinus and Peniacrinus occurs sporadically in the comatulids, and it is not unusual, especially in Tropiometra picta (figs. 173, p. 89 , and 1027, pl. 11), to find a specimen in which one of the distal pinnules has been replaced by a more or less perfectly developed arm. Replacement of a pinnule by an arm is much more common, however, on the second postaxillary ossicle than distally. In Comatula etheridgei (part 1, fig. 78, p. 131) this ossicle normally bears arms which are only a fraction of the length of the normal inner arms, but in most cases the supplementary arm is of full size.

It occasionally happens that an axillary bears two pinnules instead of two arms, replacement of an arm by a pinnule occurring as well as the conrerse.

Since axillaries bear arms of all degrees of diversity in size from two exactly similar arms to an arm and an insignificant ramule. and any pinnule may be replaced by an arm or any arm by a pinnule, it seems logical to assume that pinnules, interchangeable with arms, are but dwarfed arms themselves derived through

142140-21-Bull. 82- 14 
ramules, and that their present status of pinnules has been due to the rapid increase in the perfection of the arm, extending from the base outward, in the direction of a linear series of supporting ossicles.

In species of a number of comatulid genera one or more of the proximal pinnules are normally or occasionally absent, though except for the lack of a pinnule socket the accompanying muscular articulations are of the usual character. This occurs in the genera Comatilia, Petasometra, Cyllometra, Decametra, Oligometra, Cotylometra, Colobometra, Prometra, Balanometra, Perometra, Erythrometra, Hypalometra, Ateleorinus, Thaumatocrinus, and Pentametrocrinus. Usually the second (first inner) pinnule, $\mathrm{P}_{a}$, is missing, as in Petrisometra, Cyllometra, Deca-

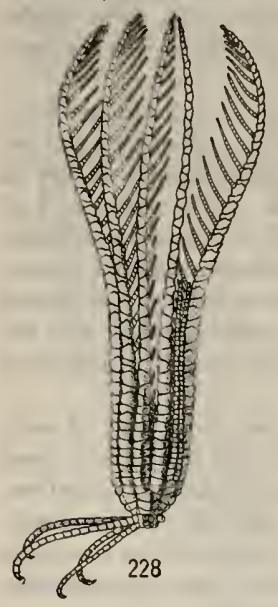

Fig. 228,-Lateral Viet of TYPE SPECIMEN OF CHLOTOMETRA GARRETTIANA. metra, Oligometra (very rare), Cotylometra (not usual), Colobometra, Prometra, Perometra (one species), and Erythrometra, sometimes accompanied by the first (outer) pinnule, $P_{2}$, as in the outer arms arising from a IIIBr series in Cyllometra, in Balanometra, and in Hypalometra; in Atelecrinus there are no pinnules on the first 10 or 12 brachials; the second, third, and fourth pinnule pairs fail to derclop in Comatilia (fig. 183, p. 98), and $\mathbf{P}_{a}, \mathbf{P}_{2}$ and $\mathrm{P}_{b}$ in "Antedon" impinnata, and in the Pentametrocrinidæ $P_{1}$ is frequently absent.

That this is a more or less anomalous state of affairs is shown by the fact that these genera have widely different affinities, the related forms in all cases having the normal pinnulation, by the more or less constant presence of one or more of the missing pinnules on one or more of the arms, and by the common reappearance of some or all of the absent pinnules on regenerated arms. When pinnules ordinarily absent in these genera are present they are commonly, but by no means always, small and weak and more or less imperfect.

In most cases it is clear that the absence of the pinuules is the result of the crowding of the arm bases, whereby no room remains for their development. In Comatilia and in "Antedon" impinnata the absence of pinnules seems to be due to arrested development.

In the Macrophreata great elasticity and a wide range of movement prevail throughout life at all of the muscular articulations and at the synarthries, even though the species may reach an enormous size. The largest species or individuals are but little less pliant than the smallest, or than the young.

In the Oligophreata, though the young exhibit the same elasticity and range of movement as the young of the Macrophreata, and the smaller species are little, if any, more restricted in their motion, the adults of the larger species as a rule lose a large part of their original power of novement proximally, becoming stiffened and more or less inert. This stiffening of the proximal articulations appears to be correlated with size and number of atms rather than with species, and always begins at the base of the calyx, gradually extending outward during development. 
In many species of this group, as, for instance, Comanthus solaster, though the young are as slender and as active as a young antedonid, the adults have the proximal portion of their postradial series so closely united that it becomes difficult to trace the sutures and all possibility of intersegmental motion is lost.

\section{ARTICULATIONS OF THE PINNULES.}

The articulations between the pinnulars and between the first pinnular and the brachials have not as yet been studied in detail.

Viewed from the exterior it is seen that the fulcral ridge of the articulation between the brachial and the first pinnular (figs. 1083, 1085, 1090, 1095, 1096, pl. 18) is roughly parallel to the transverse ridge on the adjacent brachial articulation; the fulcral ridge of the articulation between the second and third pinnulars crosses that of the articulation preceding at an angle of about $45^{\circ}$, while the fulcral ridges of all the succeeding articulations run dorsoventrally (fig. 659, p. 329, and part 1, fig. 54, p. 81 ).

The two basal articulations show, in certain types, sufficient resemblance to muscular articulations to remove all doubt in regard to their homologies, while in others they are reduced almost to the status of the brachial synarthries. The articulation between the second and third pinnulars and all following articulations resemble the brachial synarthries, except that, in some if not most species, there is a small muscle bundle just within each ventrolateral angle.

Describing the articulations between the pinnulars in Antedon bifida W. B. Carpenter wrote that the articular faces of the segments are formed on nearly the same plan as those of the segments of the dorsal cirri, the opening of the central canal, by which every segment is traversed, being surrounded by a slightly elevated ring, sometimes extended into a transverse ridge, and a depression being left by the beveling away of the surface in both directions that serves for the lodgment of interarticular ligaments. But besides these depressions there is in each of the basal segments, at least of well-developed pinnules, a small but deep notch in the ventral margin of each articular surface (fig. 1090, pl. 18), but deeper in the distal, and this lodges a minute muscle, by the action of which the pinnules can be so flexed that those of the two sides of the arm are brought toward each other, the converse movement of extension being cffected, as in the arms, by the elastic ligaments when the muscles are relaxed.

P. H. Carpenter stated that each pinnule has a muscular attachment to the brachial which bears it, while in the large tropical oligophreate species the lower segments are united by muscles instead of by liganient or suture only.

The pinnule articulations of II imerometra martensi, based upon the study of a large specimen from Singaporc, may be described as follows:

The articulation between the second brachial and $P_{1}$ : The joint face is somewhat broader than high and is shaped like the joint face on the distal end of the radials. The fulcral ridge passes across the joint face approximately at right angles to the longitudinal axis of the arm. The dorsal ligament fossa is deeply excavated and is more broadly rounded inwardly than outwardly; a promi- 
nent and deep ligament pit excises a portion of the fulcrai ridge just beneath the large circular central canal. Beyond (distal to) the fulcral ridge the joint face is divided into two portions, an inner and an outer, of which the latter is somewhat broader than the former, by a narrow intermuscular ridge which does not reach quite to the distal edge of the joint face. The proximal half of the area beyond the fulcral ridge is raised into a broad platform nearly on a level

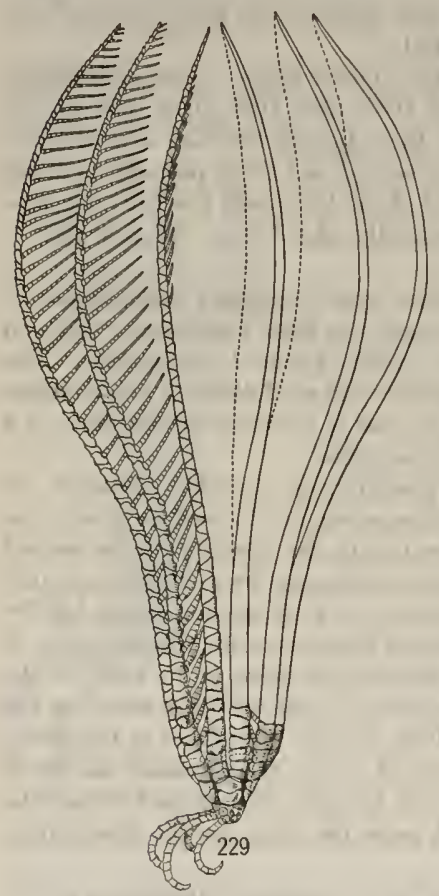

Fig. 229.-LATERAL VIEW OF TYPE SPECIMEN of Pacilometra scalaris. with the summit of the fulcral ridge; the distal half is rather deeply excavated. This excaration is especially prominent on the inner side, in the form of a right angled triangle, of which the right angle is over and just to the inner side of the middle of the central canal, the hypotenuse opposite is slightly convex, and the angle just inside the middle of the distal border of the joint face is produced in the form of a very narrow but deep groove along the distal border of the outer half of the joint face to the outer distal corner. This fossa, very large and triangular on the inner half of the joint face, but on the outer half reduced to a narrow band along the distal border, contains muscle fibers. On the outer portion of the joint face beyond the fulcral ridge the excavation is not so deep. Here it takes the form of a right-angled triangle. of which the right angle, sharply rounded off, lies at the distal outer corner of the joint face, the two adjacent sides are about the same length, and the hypothenuse, running from above the central canal just beyond the middle to the outer end of the fulcral ridge. is concave, but more or less indefinite. This fossa, less deep than that on the inner side of the joint face, lodges a large interarticular ligament. On the outer side this articulation resembles very closely that on the distal end of the radial, but on the inner. side the dorsal ligament fossa is more broadly rounded, and the narrowly linear muscular fossa running along the distal border of the joint face expands into a large triangular fossa occupying almost the entire inner side beyond the fulcral ridge.

'The articulation between the first and second segments of $P_{1}$ : This is a fairly typical oblique muscular articulation. The fulcral ridge, which, as usual, is very prominent, is nearly parallel to the longitudinal axis of the arm, but the distal end is slightly nearer that axis than the proximal. Outside the fulcral ridge is 
a large dorsal ligament fossa, which is somewhat more broadly rounded distally than proximally; a small but deep dorsal ligament pit cuts into the fulcral ridge just beneath the central canal, which is large and transversely oval. About the central canal is a broad raised area on all sides sinking gradually into the excavation of the interarticular ligament fossæ, which is continued as a narrow band of diminishing height to apices at the outer ends of the fulcral ridge. Inside the fulcral ridge the proximal half of the joint face is half again as high as the distal, and is evenly and broadly rounded outwardly, while the latter, running in a slightly convex line from the distal end of the fulcral ridge to the inner distal angle, makes there a rather sharply rounded turn. A broad intermuscular furrow with parallel sides runs to the rim about the central canal. In the proximal half the interarticular ligament fossa is triangular, the distal border sloping inward and downward and making an angle of about $30^{\circ}$ with the fulcral ridge, and the approximately semicircular portion of the joint face beyond is occupied by a large muscular fossa of about two-thirds its area. In the distal half the distal border of the interarticular ligament fossa is roughly parallel with the fulcral ridge, though bending outward is a very broad curve in its inner half, and the muscular fossa is more or less boomerang shaped with a short and narrow inner limb coming to a point at the inner end of the intermuscular furrow, and a broad slowly tapering outer limb. The muscular fossæ, though well differentiated, appear to contain very few muscle fibers.

The articulation between the second and third segments of $P_{1}$ : The articular surface is semicircular outwardly, and inwardly composed of two semicircles meeting in a deep, narrow incision in the median line. The surface is moderately excavated, with a broad median fulcral ridge which runs from the incision between the two semicircular halves of the inner border to a point just proximal to the middle of the dorsal border, including the central canal just beyond the proximal third.

The articulation between the third and fourth segments of $P_{1}$ : The articular surface, of the same shape as that of the preceding articulation, is almost plane, but the inner portion is very slightly depressed and shows a rather broad and ill-defined ridge of denser tissue, appearing opaquely white against a darker background, which crosses the joint face from the middle of the ventral border to a point considerably proximal to the middle of the dorsal border, including the central canal at the end of its ventral third.

The articulation between the distal segments of $P_{1}$ : There is a broad dorsoventral fulcral ridge, and near the ventral outer corners on either side a small deep approximately circular pit which lodges a small but compact and conspicuous muscle bundle. This pair of muscles continues to the pinnule tip.

The articulation between the outer brachials and the distal pinnules: The dorsal ligament fossa is deeply excavated with a deep and prominent ligament pit excising the fulcral ridge and separated from the large transversely oval central canal by a very narrow septum; in the distal portion of the articular face there is a large, deep, undivided muscular fossa which, in the form of a 
narrow triangle, extends from a base coinciding with the inner side of the joint face to an attenuated point at the outer distal angle. The greater part of the outer lialf of the joint face beyond the central canal is occupied by an unpaired interarticular ligament fossa.

The articulation between the first and second segments of the distal pinnules: This is essentially the same as the corresponding articulation in $P_{1}$.

The articulation between the sixth and seventh segment of the distal pinnules: The dorsal border of the joint face is evenly convex; the ventral border is concave; the two ventral angles are well rounded. There is the usual broad median

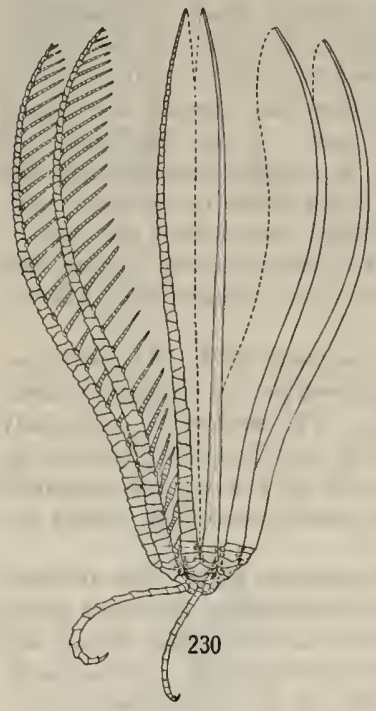

Fig. 230.-LAteral View of specidex of STrotometra PRIAMUS. fulcral ridge. Occupying two pumpkin-seed shaped areas, of which the rounded ends coincide with the rounded ventrolateral angles of the joint face and the sides converge inwardly to a point a little more than half way to the median line and slightly beyond the level of the central canal, are two large and deep muscular fosse lodging a conspicuous pair of muscle bundles.

Similar paired muscle bundles appear to occur at all of the articulations of the distal pinnules beyond that between the first two segments. ARTICULATIONS OF THE CIRIT.

The articulation between the first cirrus segment and the centrodorsal is usually plane, but the periphery of the joint face may be crenulate, or low ridges may extend inward for a short distance toward the central canal. In the Atelecrinide transverse fulcral ridges with deep fossæe on either side occur, which resemble those at the articulations between the columnals in the larval stem, and there are sometimes traces of transverse ridges in other types. In its usual form this articulation is syzygial, like that between the centrodorsal and the topmost columnal.

As noticed by W. B. Carpenter, each of the cirrals in Antedon bifida is perforated by an axial canal (part 1, plate 13, fig. 587) of about one-fifth of its diameter, around which is a raised articular surface. In the oral (rentral) and aboral (dorsal) sides of this projection there are two depressions lodging the connecting ligaments. In the basal segments (part 1, plate 13, fig 587, 6 ) the canal with its surrounding raised area is central, and the ventral and dorsal depressions are of equal size or nearly so; but in the terminal segments (part 1, plate 13, fig. 587, $a$ ) the canal and the articular surface are nearer the ventral side and the ligament fossa is both larger and deeper on the dorsal.

The terminal claw is attached to the last segment by a plane surface so closely that it is incapable of independent movement. 
There seems to be no difference of importance between the articulations of the cirri in different types.

ANALYSIS OF AMBULACRAL OSSICLES.

The arm as a whole.-In studying the crinoid arm it must continually be borne in mind that this structure is not a true appendage, but a local evagination of the body wall, and that all of the brachials-that is to say, the ambulacral ossicles-are invariably formed in the body wall between the radials and the mouth.

In the "cystid stage" the arms first appear as low hump-like evaginations in the intersegmental (radial) angles-mere bulges in the body wall. At this stage it is perfectly obvious that any plates formed above the radials are formed between them and the mouth, on the lower slope of a swelling over the top of which is the mouth. As the arms elongate this fundamental relationship becomes obscured but remains unchanged. No matter how long and slender the arms may become, or how many times they may be divided, they are always reducible to an evagination of the body wall at the line of union between two of the original body segments and between the dorsal and ventral surfaces which, though becoming enormously elongated and extraordinarily attenuated, still retains its primitive relation to the ventral circumoral structures by pulling out into itself ventrally loops or linear extensions from their intersegmental (radial) angles, and still retains its primitive relation to the skeleton forming dorsal surface by the formation of a series of dorsal ossicles extending for its entire length.

Since this is so it is evident that the connection between the dorsal and the ventral surface of a crinoid in the radial regions is always along the dorsal side of the arm to the tip, around the tip, and down the rentral side to the mouth, and never across the base of the arm, as it would be in the case of a true appendage.

Thus it is obvious that in reality all the brachials are formed between the radials and the mouth just as strictly as if the region between the radials and the mouth were a plane surface instead of being at the border line between the dorsal and ventral surfaces where they are together abruptly evaginated in the form of an enormously elongated process.

The arm in detail.-The specialization of the crinoid arm has been along the lines of progressively increasing length, correlated with progressively increasing perfection as a uniform linear series of ossicles.

With the formation of the primary swelling the shape of the circumoral structures becomes more definitely pentagonal, and as the arm forms the angles of the pentagon become drawn out into it as radial processes from the circumoral rings. This radial elongation of the angles of the body is slow at first, slow enough to permit the brachial ossicles to associate themselves in pairs, but gradually increases in rapidity until they are formed as a linear series of exactly similar elements.

In the comatulid arm, which is the most highly specialized arm found among the crinoids, traces of the course by which the distal perfection of the arm has been evolved are still to be seen. 
In the 10-armed comatulids there is a very appreciable difference between the arms as far as the second or third syzygial pair (brachials $9+10$ or $14+15$ ) and beyond that point (see figs. 220 , p. $168 ; 221$, p. 171 ; and 222, p. 173 ). The characteristic features of the first pair of brachials have already been discussed. Between the first and second syzygial pairs the brachials are short, usually about twice as broad as long and more or less oblong or wedge-shaped; beyond the second syzygial pair they become triangular, about as long as broad, distally elongate wedge-shaped, and terminally much elongated with their ends more or less at right angles with the longitudinal axis of the arm.

There is a corresponding difference in the pinnules. The two lowest pinnulesthe first $\left(\mathrm{P}_{1}\right)$ on the outer side of the distal element of the first brachial pair, the second $\left(\mathrm{P}_{a}\right)$ on the inner side of the distal element of the second brachial (first syzygial) pair-are typically much longer, stouter, and better developed than those succeeding, and the articulations between their segments, especially between the first and second, approach more or less closely the muscular articulations between the brachials. Following these to the second or third syzygial pair there is a series of pinnules which are short and more or less rudimentary, after which the pinnules become greatly elongated and extremely slender.

All the evidence seems to indicate that in the comatulid arm there is a marked increase in the rate of growth after the second syzygy, which reaches its full effect at or shortly after the third syzygial pair.

The following facts appear to show that this is the case: The brachials become much longer. The pinnules become much longer, with greatly elongated segments On the brachials before the second syzygial pair the produced and spiny distal edges, when developed, stand up at right angles to the longitudinal axis of the arm, and are duplicated on the proximal edges; but beyond the second syzygial pair the production of the proximal edges of the brachials entirely disappears, and that of the distal edges becomes accentuated and leans gradually distally, overlapping the base of the succeeding brachials. In species in which all the brachials are strongly carinate the keels on the earlier wedge-shaped brachials are of uniform height from end to end ; as the brachials become elongated the keels transform, by the sinking of the proximal and the rising of the distal portion, into a triangular overlapping spine, of which the base coincides with the mid-dorsal line of the brachial. In species in which the dorsal surface of the brachial bears numerous very fine spines those on the proximal wedge-shaped brachials are without definite arrangement and occupy a broad median band with parallel sides; on the elongate brachials following they occupy a triangle, of which the base is the distal dorsal edge and the apex lies at the middle of the proximal edge, and are arranged in longitudinal rows. Beyond the second the two elements of the syzygial pairs become united at an earlier stage, so that the hypozygal loses its individuality and the pair as a whole becomes similar to a normal brachial.

In the secondary arms of the multibrachiate species, which replace the 10 primary arms, the structure is much more uniform than in the arms of the 10-armed species, or in the arms of their own 10-armed young. There is a greater uniformity in the shape of the brachials, all of which are typically wedge-shaped, and the 
series of short oblong proximal brachials is very rarely to be distinguished from those following. All the pinnules beyond the oral are of practically the same length and very similar, and all arise at the same stage in the formation of the brachial which bears them. The syzygial pairs are less frequent and much more widely separated, and may even be almost entirely lacking; the long interval between the first and second syzygial pairs so conspicuous in 10-armed species is not evident.

During development the first pinnules to appear are always the lowest of the elongated distal types and the next the oral pinnules; the intermediate pinnules on the wedge-shaped proximal brachials are the last formed. In Antedon the oral pinnules appear soon after the first formation of the distal pinnules, but in II athrometra many of the distal pinnules are present before the oral pinnules are formed.

The comatulids and the Flexibilia Impinnata.-The comatulid arm proximal to the second syzygy is characterized by (1) the short oblong or wedge-shaped brachials, (2) the absence of syzygies beyond the first syzygial pair (the intersyzygial interval between the first and second syzygial pairs is the longest on the arm), and (3) the absence of pinnules until after the brachials are completely formed.

The developing comatulid at the stage when the arms have developed as far as the hypozygal of the second syzygial pair, just beyond which the first pinnules appear (see figs. 1208, 1214, pl. 34, and $121 \bar{i}, \mathrm{pl} .35$ ), presents the following features: (1) The brachials are oblong, with their ends at right angles to the longitudinal axis of the arm; (2) all the brachial articulations are of the same nature; (3) arm flexure is effected by the contraction of a ventral muscular band continuous

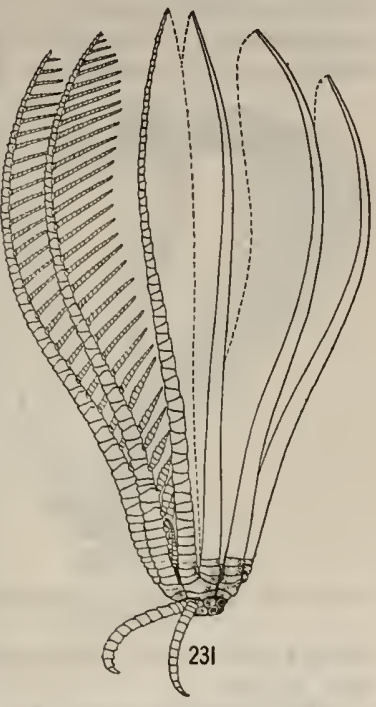

Fig. 231.-Lateral view of spectaren of STROTOMETRA PARVIPINNA. with that about the mouth, there being no interbrachial muscles; $(4)$ there are no pinnules; (5) the orals are well developed; $(6)$ the radianal has just been excluded from the radial circlet, and the two posterior radials are not yet in contact; (7) there are commonly five interradials; $(8)$ the basals are large, forming a complete and conspicuous circlet; and (9) the topmost columnal has increased in size.

In the young comatulid before the appearance of the first pinnules and the cirri there is no difficulty in recognizing a fairly typical representative of the Flexibilia Impinnata.

From this stage onward the course of development of the comatulid suddenly changes: (1) Arm growth increases in rapidity; (2) pinnules develop on the distal- 
most brachials, later on the two proximal brachial pairs, and subsequently on the intermediate brachials; (3) the brachials become much longer; $(4)$ the ends of the brachials become very oblique; (5) the ventral muscle band, a radial continuation of the circumoral muscle band, vanishes and is superseded by a series of paired interbrachial muscles; (6) the articulations betwcen the brachials, up to this time uniform loose sutures, become differentiated into synarthries between the first and second brachials, syzygies between the third and fourth and ninth and tenth brachials, and at regular intervals between the subsequent brachials, and muscular articulations clsewhere; (7) the orals disappear; (8) the radianal disappears; (9) the interradials disappear; (10) the basals withdraw into the interior and become metamorphosed into an internal scptum ventral to the chambered organ; (11) the radials become recumbent and form a closely knit radial pentagon to the exclusion

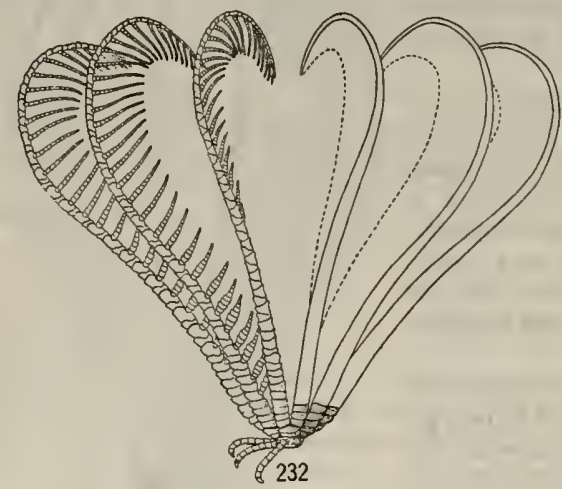

Fig. 232.-Lateral View OF Sieciaen of StrotoMetra HEPBCRNIANA. of all the other calyx plates; (12) the topmost columnal increases enormously in size, spreads itself over the outer surface of the radials and, now become the centrodorsal, gives rise to numerous cirri; and (13) the larval column is discarded beneath the topmost columnal.

Thus by a sudden and profound altcration in the course of development of the arms, pinnules, calyx, and column commencing just as the elements of the second syzygial pair of brachials are forming the pentacrinoid of the comatulids changes from a fairly representative member of the Flexibilia Impinnata into a young comatulid (compare figs. 1217 and 1219 , pl. 35).

The oblong proximal brachials, the relatively undeveloped genital pinnules, and the unusually large interval between the first and second brachial syzygies in the arms of the comatulids are therefore all remnants of the ancestral structure as seen in the Flexibilia Impinnata, and the true comatulid brachial structure is not developed until after the second or third brachial syzygy. Since the secondary arms of multibrachiate types are not developed until after the young have become true comatulids, these arms are true comatulid arms throughout, the brachials being all wedge-shaped without special differentiation of the proximal, and the pinnules being all of about the same length and structure and developed in regular sequence.

The arms of the Atelecrinide and Pentametrocrinida.-In Atelecrinus (part 1, figs. 123 , p. 192, and 124, 125, p. 193) and in Atopocrinus (part 1, fig. 227, p. 215) 
MONOGRAPH OF THE EXISTING CRINOIDS.

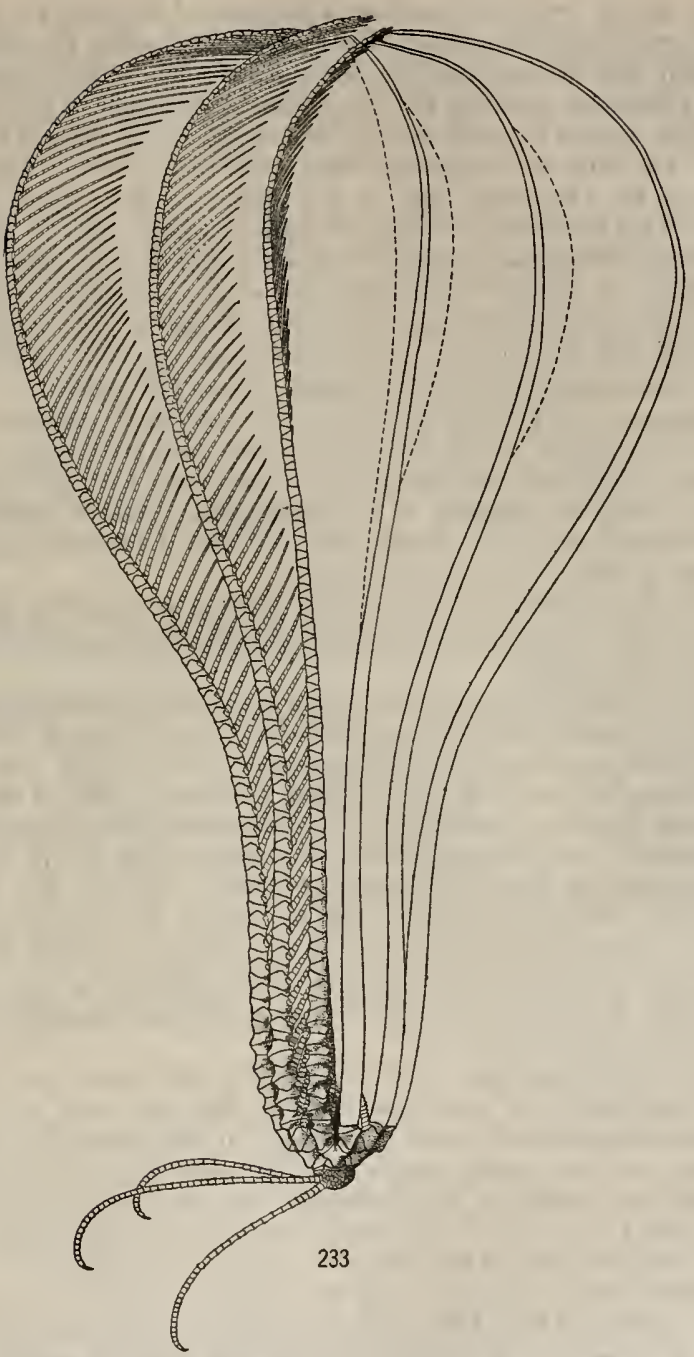

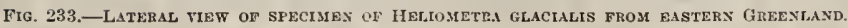


there are no oblong proximal brachials at the base of the arm, all the brachials beyond the second being triangular. The arms in Atelecrinus are unusually long, and apparently they assume from the first the attributes of true comatulid arms, at least the triangular brachials and the regular distribution of the syzygies, not passing through a stage in which they are comparable to the arms of the Flexibilia Impinnata. The arms of Atopocrinus have never been observed, but, except for the absence of the IBr series, they do not appear to differ from the arms of Atelecrinus. This acceleration of the development of the arms in Atelecrinus is correlated with a retardation of the development of the pinnules before the twelfth brachial, which are always suppressed, and with a retardation of the metamorphosis of the basals, which remain visible externally. In Atopocrinus it is correlated with the insertion of a supernumerary brachial between the first brachial and first syzygial pairs and the absence of the IBr series.

In Thaumatocrinus (part 1, fig. 113, p. 181) and in Pentametrocrinus (part 1 , figs. 119, p. $185 ; 120$, p. 187 ; and 121, p. 189) the arms are greatly elongated, as in Atelecrinus. This excess of arm growth is correlated with the absence of the IBr series and with the insertion of a supernumerary brachial between the first and second brachial pairs as in Atopocrinus, and with the frequent absence of $P_{1}$, suggesting the condition found in Atelecrinus.

In all of these genern the intersyzygial interval is unusually long, and aỉ of the syzygies are evenly spaced, agreeing with the high state of spccialization of the arms in other ways.

Pinnules.-In the form and number of the component segments and in the type of articulation between them the oral pinnules of such types as Analcidometra and Himerometra, and to a slightly lesser degree Antedon, show a striking similarity to the arms of certain of the Flexibilia Impinnata, while at the same time they are equally similar to the arms of the pentacrinoid before the appearance of the first pinnules. The correspondence is so complete that we are probably safe in considering them as strictly comparable structures (compare figs. 270 and 271 , p. 207 , and 1207,1208 , and 1210, pl. 34 ; also figs. 273 , p. 207, and 1214, pl. 34).

The oral pinnules therefore are arm branches which have failed to assume the adult character, but instead have remained in the condition of the main arm at the time of their first appearance; that is to say, they are Flexibilia arms borne upon a comatulid arm trunk.

We have already seen that in 20 -armed species the outer arms arising from each IIBr series bear more specialized pinnules than the inner, which indicates that they are phylogenetically more developed; in other words, of later phylogenetic origin. In most types, though the outer arms are more developed than the inner, they are developed simultaneously with the latter; but in Comatula etheridgei (part 1, fig. 78, p. 131) they actually appear much later and never reach more than a fraction of their length. The first oral pinnule $\left(P_{1}\right)$ develops upon the ossicle which in species with the division series of two ossicles each becomes the axillary of the IIBr series and which in Comatula etheridgei bears the short arm exteriorly. In 20-armed species this ossicle is, together with the larval arm beyond it, thrown off and a new element is regenerated bearing two 
arms, of which the outer is more highly developed than the inner. At the time this occurs the larva is already a perfect comatulid, and therefore the two new arms are of the perfected comatulid type. The origin of $P_{1}$ appears to be identical with that of the short outer arms of Comatula etheridgei, with this difference, that at the tine the oral pinnule appears the pentacrinoid arms are still in the Flexibilia stage.

The very slender distal pinnules are composed of segments which, except for the first two, are greatly elongated, and they bear no resemblance whatever to the distal portion of the arms. They are true comatulid pinnules, correlated with the true comatulid type of arm. At the same time they are obviously of exactly the same nature as the oral pinnules, and it is noticeable that their first two segments always maintain the same size relationship with the brachials as do those of the latter, no matter how slender they may become.

The genital pinnules are transitional between the oral and the distal pinnules. They appear after the oral pinnules and are at first greatly reduced replicas of them, but soon the distal segments elongate, and this modification gradually extends itself basally, so that they merge imperceptibly into the pinnules of the distal type.

Thus while the enormously elongated comatulid arm has developed along lines characteristic of and more or less peculiar to the comatulids, the arm branches have remained permanently in the state of supplementary arms of the Flexibilia type, from which they differ only in their greater slenderness. This explains the curious uniformity in the number of pinnule segments throughout the comatulids as a whole. At the Flexibilia stage the arms of the pentacrinoid larvæ consist of about 15 brachials, and most pinnules have between 15 and 20 segments.

The view that pinnules are dwarfed arm branched or ramules is quite correct, but in the comatulids it must be bornc in mind that these dwarfed arm branches belong to the ancestral type of arm and not to the perfected comatulid arm type.

That the pinnules are in reality modified arms is shown by the more or less frequent replacement of a pinnule by an arm, or the reverse, and the occasional bifurcation of a pinnule on the second segment, which then becomes axillary.

In the ontogeny of the comatulids pinnules first appear at the tip of the larval arm after the first 12 to 15 brachials have been formed. $P_{1}$ does not appear until from one to half a dozen or more pairs of distal pinnules are present, and the intermediate pinnules appear from the most proximal of the distal pinnules one by one downward to the oral pinnules after the arm has assumed more or less the true comatulid character, and after $P_{1}$ is well grown.

In certain types, as Comatilia iridometriformis (fig. 183, p. 98) and "Antedon" impinnata, the pinnules between the most proximal distal and the oral never appear at all, while in many others the last of these, $P_{n}$, is never found except upon regenerated arms. In Metacrinus (fig. 287, p. 215), Hypalocrinus, and Comastrocrinus (part 1, fig. 126, p. 195) the pinnules toward the arm tip suddenly become greatly reduced and finally disappear altogether, so that the terminal portion of the arm is strictly comparable to arms of the ancestral Flexibilia type. 
The type of oral pinnule seen in Analcidometra, Himerometra, and Antedon, and directly comparable to the Flexibilia arm, is relatively rare, for almost everywhere specialization in the form of increased slenderness has occurred, combined in a few types, as in IIeliometra, with a considerable addition to the number of component ossicles.

In many forms, especially among multibrachiate types, the perfection of the comatulid arm as such has resulted in the loss of the sharp line of demarcation between the proximal and the basal portions of the arms, with the result that two or more pairs of oral pinnules occur, of which the second or third may be more highly developed than the earlier.

In Antedon (fig. 1040, pl. 12) the oral pinnules appear when only one or two pairs of distal pinnules have formed, and in this genus they remain fairly close to the type of structure characteristic of the Flexibilia arm. In Hathrometra many distal pinnules are present when the oral pinnules first are seen, and in this genus they have assumed certain of the characteristics of distal pinnules (fig. 289, p. 221). It may be that the less the difference between the oral pinnules and the arms of the Flexibilia the earlier do the former appear in the ontogeny.

The present modification of the oral pinnules into tactile or protective organs does not indicate that the pinnules originally were of this nature. In the phylogeny of the comatulids the functions of the Flexibilia arm as a whole have become segregated and localized and distributed in such a way that the distal pinnules are now merely food-collecting organs, the middle pinnules are concerned almost exclusively with the development of the sexual products, and the oral pinnules are tactile or protect the disk.

Division series, and pairing of the ossicles in the ambulacral series.-The multibrachiate comatulids are always 10 -armed until a considerabie size is reached, when the 10 original arms are cast off at the articulation between the first and second brachials (more rarely between the third and fourth) and from the stumps axillaries surmounted by new arms arise. At the time of the fracture the dividing line between the dorsal and the ventral surface of the visceral mass passes over the distal border of the second brachial; but before the regeneration of the new arms the visceral mass has so increased in size that the stumps are a considerable distance from this border. The region between the distal edge of what in the primary arms was the second brachial and the new junction of the dorsal and ventral surfaces of the visceral mass is spanned by plates exactly resembling those of the IBr series, which similarly lie entirely in the unmodified dorsal wall of the visceral mass; that is, plates arranged in pairs (or pairs of pairs), of which the more distal element is axillary, and the two elements are united by a nonmuscular articulation.

When the junction between the dorsal and ventral surfaces is reached this type of plate formation ceases, and arms are produced which in every essential detail reproduce the arms lost.

Thus the loss of an arm in the 10-armed young of the multibrachiate types is made good by the reproduction of several similar arms, which are separated from the original first brachial by a new series of ossicles which are reduplications of the 


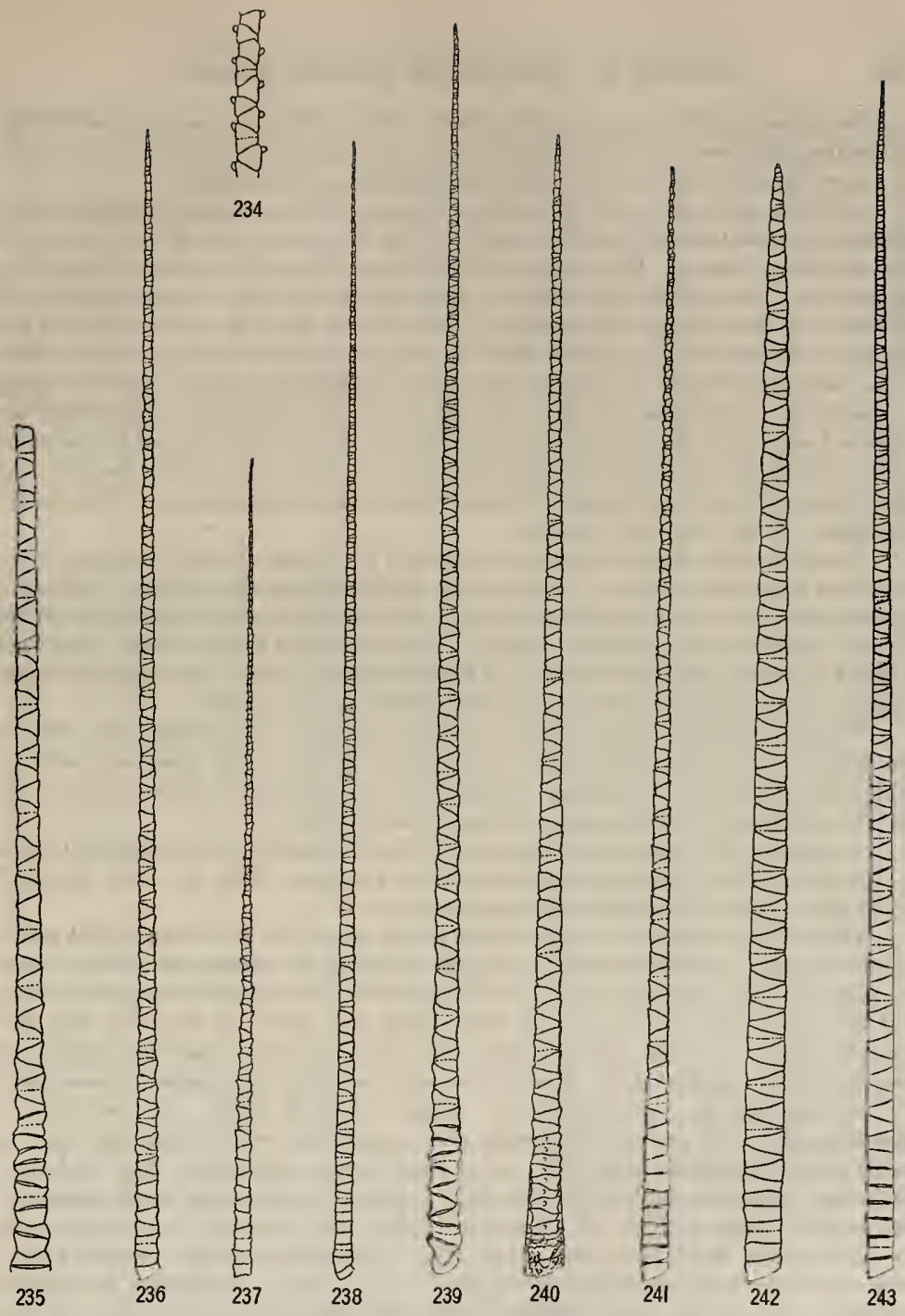

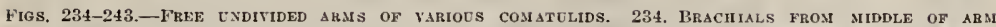

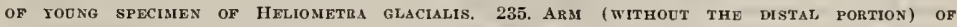
Pentametrocrinos tuberculatus. 236. Ara of Leftonemaster venustis. 23t, Arm of Comatila ibidometriformis. 238. Ara of Antedon petases, 239. Ara of Helometra glacialis. 240. Arm of Calyptometra laterals. 241. Alm of fectivojetra flatopumperfa. 242. Arm of CoMissia lotkeni. 243. Arm of Nemaster iowensis. 
ossicles preceding the original first brachial. The net result is, no essential change in the free arms beyond the first brachials, but the interpolation of numerous ossicles of a more primitive type between the first brachials and the radials.

Addition to the plates in the ambulacral series of the comatulids usually takes place at the distal end of the arm-that is, as has been explained, at the oral end of the ambulacral series. But in the multibrachiate forms it is evident that, when opportunity offers, addition to their number also occurs close to the aboral end of the series, as in the other echinoderms. Furthermore, while the distal brachials are entirely different from any plates found in other echinoderm groups, narrow, elongate, deep, more or less cylindrical structures uniserially arranged and developing consecutively, each better adapted than the last to the function of supporting the slender body extension, the interpolated plates at the arm base are all of the same type, develop into similar pairs, are always as primitive, broad, short, shallow, and platelike as the first two formed after the radials, and resemble more or less closely the plates of the other echinoderms.

Stated in other words, the plates of the very highly specialized free arms are in the form of a linear series of more or less cylindrical ossicles, which is without a counterpart in the other echinoderm groups; but whenever an opportunity is offered for the formation of ambulacral plates on the unmodified body wall the plates are formed in pairs, become broadened and flattened, and in other ways approach more nearly the type in general common to the echinoderins as a class.

The plates of the division series, therefore, furnish a connecting link between the brachials of the free arms and the ambulacral plates of the other echinoderms, which are formed in a double row in the body wall, differing from the latter chiefly in being arranged in tandem pairs instead of side by side.

An apparently fundamental attribute of all the ossicles in the ambulacral series of the comatulids, excepting only those of the pinnules, which are truly uniserial structures, is their invariable occurrence in pairs.

This paired condition is very evident in the basal part of the postradial series, where not only do all the plates up to and including the outermost axillary occur in pairs, the two components of which are united by nonmuscular articulation, but the distal element of each of these pairs also bears on its distal end two exactly similar ossicles side by side. The division series therefore consist of ossicles paired longitudinally, of which the outer carries ossicles paired transversely.

At the arm tip new elements are always added in pairs. At first the two members of a pair are exactly similar and suggest the two ossicles following an axillary in the division series, but one of these grows much faster than its fellow, becoming a new brachial, while the other, lagging far behınd in its development, becomes the basal segment of a pinnule. Thus every brachial is fundamentally an axillary and bears two arms one of which is of the perfected comatulid type, while the other never develops beyond the Flexibilia type. Sometimes two ossicles appear at the arm tip, one in advance of the other instead of side by side. In this case the two never develop to full size but unite by a close nonmuscular articulation and form a syzygial pair. These syzygial pairs are homologous with the pairs 

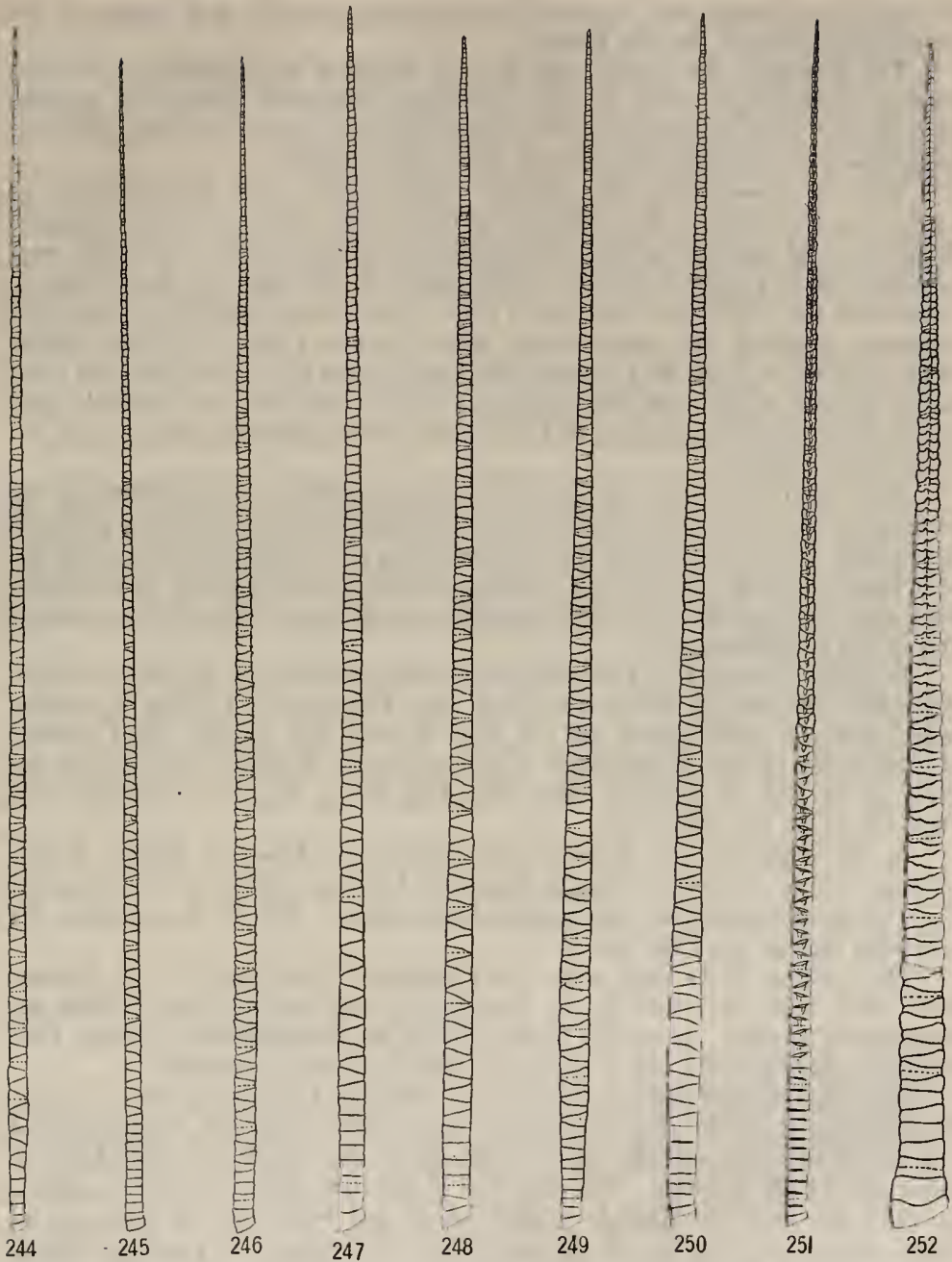

Figs. 244-252.-Free undivided arms of various conatulids, 244. Abi of Comaster parvus. 245. Arm of Pachylometra distincta. 246. Arm of Comantherla imbricata. 247. Ara of mariametra subcarinata, 248. Arm of Colianthus pinguis. 249. Arat of Comatula rotalaria. 250. Arm of ladiprometra protectus. 251. Arm of Parametra orion. 252. Ara of Ptilometra mulleai. 
in the division series and represent the projection into the arm proper of the longitudinal pairs of the arm bases.

The growth of the crinoid arm may be described as consisting of the formation of continuous series of pairs of similar ambulacral plates, the elements of each pair lying side by side; one of these develops rapidly and soon gives rise to another pair, while the other slowly grows into a pinnule.

Thus it appears that the comatulid brachials are each fundamentally an axillary, comparable to the axillaries in the division series, and the elongated linear series of brachials in the free arms is in reality a series of axillaries, each of which bears a pinnule and the continuation of the arm (another axillary). Whereas in the division series successive pairs of ossicles, one distal to the other, are produced, of which the outer element always carries a pair of exactly similar elements, both of which may develop into arms, or one into an arm and the other into a pinnule, in the arms the longitudinally arranged pairs are relatively rare, and in the transverse pairs one of the elements always develops into an arm, the other into a pinnule.

Since the free arms of the Flexibilia are represented in their entiety by the pinnules of the comatulids, and the comatulid brachials are in reality axillaries comparable to the axillaries in the division series, the comatulid arm is composed of a linear series of ossicles, each homologous with the last axillary in the Flexibilia and each bearing on one side a similar ossicle and on the other a complete arm of the Flexibilia type.

In certain species this arrangement has been carried over into the perfected comatulid arm, and we find arising from each IBr axillary a series of division series, each of which bears on one side an arm and on the other another division series, so that a long series of ossicles results, of which every second one gives off an arm on alternate sides (figs. 148, 150, p. 83) or on the same side (figs. 156, p. 83, and 134, p. 79).

In the echinoids and starfishes the ambulacral plates are always in two columns, which are always sharply separated from each other in the midradial lines which represent the intersegmental boundaries. But in the crinoids the midradial regions carry the arms.

The position of the anus, water pores (especially when only five in number, as in the young comatulids and in Rhizocrinus), and primary nerve trunks, all interradially situated, shows that in the crinoids the intersegmental dividing lines fall in the middle of the radial areas as in the echinoids and starfishes.

The chief characteristic of the series of ambulacral ossicles in the crinoids is the doubling of all the elements, usually transversely across the mid-ambulacral line, sometimes longitudinally, and the pairing of the ambulacral appendages on either side of the mid-line. This doubling is especially evident in those crinoids in which the arms are biserial-a condition toward which there is a greater or lesser amount of reversion in the comatulid arm beyond the proximal oblong brachials, where the following brachials for a variable distance are triangular.

In the comatulids only the pinnules show no indication whatever of a doubling of their component segments. The pinnules represent the arms of the Flexibilia. 
These arms are similarly uniserial but are developed upon axillaries, and therefore always paired, lying on one side or other of the median line, never in the middle. In the same way at the stage when the arms of the pentacrinoid are equivalent to the arms of the Flexibilia they are always two in number and lie one on either side of the mid-ambulacral line. In the posterior arms of certain of the Comasteridæ the terminal brachial is an axillary bearing two similar pinnules side by side (fig. 1034 , pl. 12 , and part 1, fig. 47 , p. 81 ).

Viewed in the light of the conditions found in the echinoids and starfishes this doubling of the elements in the ambulacral series in the crinoids is easily explained as the retention of the fundamentally biserial character of the echinodermal ambulacral plates.

The comatulid arms are elongate structures developed in the midradial line from two columns of plates, one situated on either side of it, which have combined themselves in such a way as to form a secondarily uniserial branched appendage.

Nonmuscular articulations. - The nonmuscular articulations are strictly comparable with the situres between the calyx plates and between the radials, and occur only between elements which originate as longitudinal pairs, as in the arm and column, or as longitudinal series of exactly similar ossicles, as in the pinnules and cirri. Ossicles originating as transverse pairs are always united to the preceding ossicle by muscular articulation. But while the elements of transverse pairs are united to the preceding ossicle by muscular articulations, the elements of each pair immediately following an axillary are commonly more or less bound together by suture. In each species all of the transverse pairs of ossicles immediately following the outer axillaries are united to approximately the same extent as those immediately following the $\mathrm{IBr}$ axillary, and in different specimens of the same species, where there is considerable variation in the latter, there is a similar correlated variation in the former. Increase in size or in the number of the arms induces a broadening of the $\mathrm{IBr}_{1}$ and a closer lateral union, and the same feature is projected upon all the transverse pairs immediately following axillaries farther out in the postradial series. As a general rule the $\mathrm{IBr}_{1}$ are united for a slightly greater proportion of their interior length than the $I I B r_{1}$, and the $\mathrm{IBBr}_{1}$ than the $\mathrm{IIBB}_{1}$, and so on, so that there is a very gradual lessening of the completeness of this internal union distally. The graduation is commonly so slight as to be barely appreciable, except in those species with a very large number of arms.

In the pentacrinoid larvæ of the comatulids before the appearance of the first pinnules all the articulations, both of the column and of the arms, are nonmuscular. Specialization in the comatulid arm is in the direction of the gradual elimination of the nonmuscular articulations, which are replaced by unions of the muscular type.

Up to and including the first syzygial pair of the free undivided arms all the ossicles beyond the radials are united in pairs by nonmuscular articulations, synarthries between the two ossicles immediately following each axillary, and syzygies between the outer pair in the division series in which two pairs are dereloped. 
The first syzygial pair is composed of the third and fourth brachials, the second of the ninth and tenth, and the third of the fourteenth and fifteenth, more rarely of the seventeenth and eighteenth. Beyond this point syzygial pairs occur regularly separated by one, two, three, or four, most commonly two or three, single brachials, the number being more or less directly correlated with the size of the species.

The long interval between the first and second syzygial pairs is a heritage from the ancestral Flexibilia arm, and is correlated with the retarded development of the pinnules borne by the intermediate brachials.

In the secondary arms of the multibrachiate species the brachials become more uniform and more wedge-shaped, with less oblique ends, the pinnules become more uniform and stouter, the syzygial pairs become much less frequent and more widely spaced, and the articulations between the pinnulars take on more and more the character of true muscular articulations.

In the Atelecrinidæ and Pentametrocrinidæ, in which the arms are unusually long and very highly developed, the syzygial pairs are more widely spaced than in the arms of ordinary 10-armed types, and, excepting only in Atelecrinus, the first syzygial pair is separated from the distal element of the first brachial pair by an interpolated ossicle.

In the distal part of the arms as the brachials become more and more perfected in the direction of a linear series of ossicles the two elements of the syzygial pairs become less and less individualized, each pair taking on more and more the characteristics of a single normal brachial.

Radials. - The radials have always been considered as true calyx plates, and the radial circlet has, therefore, been assumed to be quite as much an integral part of the crinoid calyx as the circlet of basals or of infrabasals.

The radials have the following characteristics of true calyx plates:

In very many types they form, in the shape of a broad closed ring resembling the basal ring, an integral part of the cup in which the visceral mass is lodged.

Alternating with the basals, they are usually interlocked with them in the same way that they are interlocked with the infrabasals.

The size of the radials often bears roughly the same proportion to the size of the basals as the size of the latter does to that of the infrabasals.

The arms often arise as slender free appendages from the middle of the distal border of the radials, while the latter are incorporated in the wall of the capsule inclosing the visceral mass.

That these characteristics are not fundamental attributes of the radials is evident from the following facts:

Very frequently the radials do not form a closed ring, but are separated from each other by interradials, which are particularly likely to occur in the posterior interradius. They may become, as in the comatulids and pentacrinites, so altered as to cease to function as an integral part of the body wall, serving merely as bases upon which the arms are developed; furthermore, a variable number, often large, of the postradial plates may become incorporated in the body wall. 
They are, especially the right posterior, sometimes separated from the basals by infraradials.

In the Articulata as a whole and in certain sections of other groups the size of the radials is correlated with that of the basal portion of the postradial series and bears no relation whatever to that of the basals and infrabasals; this is well illustrated in the comatulids and pentacrinites.

The arms tend to arise as slender appendages from the edge of the disk, no matter whether the plate situated there is a radial or one of the plates of a subsequent division series; unless they happen to lie at the edge of the disk the size of the radials agrees with that of the following postradial ossicles, and not with that of the preceding plates.

From this it is clear that the only invariable attribute of the radials is their connection with the postradial series of ossicles.

The origin of the radials as we know it in the comatulids indicates no relationship whatever with the orals, basals, and infrabasals, but a most intimate connection with the arms.

The radials do not appear until the orals, basals, and infrabasals, which arise simultaneously at a very early period, have attained their perfected form and proportions.

The first traces of the radials are found when the swellings indicating the budding arms first appear and the ventral ambilacral structures have begun to extend toward them.

Carpenter noticed that the radials, like the basals and orals, commence as expanded cribriform films, while the endogenous additions by which they are subsequently thickened are cribriform like those of the basals, and not fasciculated like those of the primibrachs, which originate as imperfect rings, which soon become filled up with lengthening fasciculated tissue, just as is the case with the columnals and later brachials.

This is probably correlated with the fact that the radials are broader than the succeeding plates and without further significance.

Structurally the radials are always related to the following ossicle in exactly the same way that all the axillaries are related to the ossicles immediately following, and in certain types, as, for example, Arachnocrinus bulbosus (part 1, pl. 16, fig. $595)$, there is an unmistakable agreement in form between the radials and the axillaries.

The orientation of the five primary nerve trunks, which are interradial, the position of the water pores, which are interradial, and the location of the anus, which always lies in the posterior interradius, show that in the larva the five segments of the body are the regions covered by the orals and the basals, and that the radials are intersegmental plates.

Radianal.-In the pentacrinoid young of the comatulids the radianal plate is always found, is invariably well developed, and is always closely associated with the right posterior radial, usually at first occupying a position beneath its left lower angle from which it moves upward and outward, passing around the entire left side of the radial and out onto the disk. 
Its identification in the pentacrinoids has been delayed by the fact that in Antedon it does not appear until relatively late, when it occupies a position between the two posterior radials, the left side of the right posterior radial being cut away to accommodate it.

In this genus its position is essentially that of the so-called anal $x$ in the fossil forms with which it has been confused. But its relation to the right posterior radial is that of the radianal and not that of anal $x$, it moves outward from the radial circlet exactly as does the radianal in other types, and anal $x$, though greatly reduced, is usually also present.

In Promachocrinus (see pp. 530-557) and in certain other types the radianal is formed before the first appearance of the radials, so that following the so-called prebrachial or cystid stage a stage occurs in which the radianal is the only radially situated plate in the calyx; but almost immediately the right posterior radial appears as an exactly similar plate situated just to the right of it and in the same transverse plane. During subsequent growth the radianal moves upward and toward the left until it is nearly over the apex of the posterior basal, when, by the approximation of the two posterior radials beneath it, it is shoved directly outward onto the disk and disappears.

The radianal in Antedon is not formed until a stage in the general development is reached equivalent to that in which in Promachocrinus the radianal has reached a position near the apex of the posterior basal.

In the comatulids until the final extrusion of the radianal from the radial circlet the centers of the radianal and of the right posterior radial always lie in the same transverse plane, the radianal moving upward and outward as the radial increases in size; but on account of the shape of the radial the radianal often appears to lie more or less beneath its lower left-hand border.

In the Flexibilia there is the following diversity in the occurrence of the radianal :

The following genera are without a radianal: Mespilocrinus, Calpiocrinus, Harmocrinus, Nipterocrinus, Lithocrinus, Metichthyocrinus, Synaptocrinus, Euryocrinus, Amphicrinus, Dactylocrinus, Synerocrinus, Wachsmuthicrinus, Parichthyocrinus.

The radianal may be situated obliquely above the right posterior radial, pushed upward on the right shoulder of the elongated posterior basal, in Forbesiocrinus, Eutaxocrinus, Taxocrinus, Onychocrinus-in the last three being the first plate of the tube series, usually larger than those following.

The radianal is rhombic and situated obliquely below the right posterior radial in Lecanocrinus, Cholocrinus, Pycnosaccus, Gnorimocrinus.

The radianal is obliquely below the right posterior radial, usually between the basals, in Sagenocrinus.

The radianal is more or less beneath the right posterior radial, but above the line of basals, in Anisocrinus.

The radianal is beneath the right posterior radial and between the basals in Homalocrinus. 

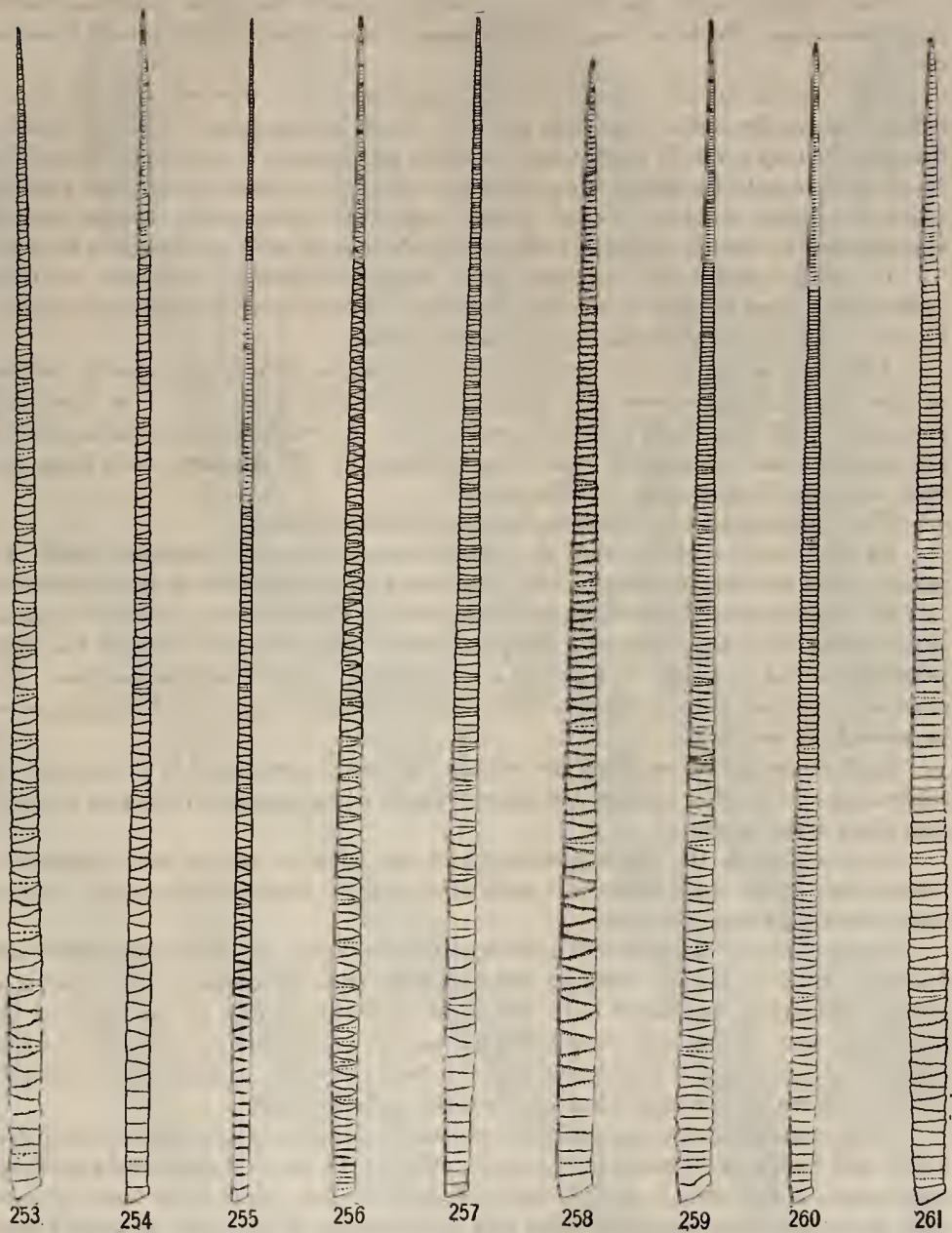

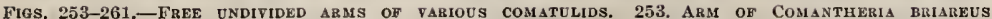
254. Aris of Cenometra unicornis. 255. Arm of Pontiometra andersoni. 256. Arm of Comatula 80laris. 257. ARM of Comatella nigra, 258, ARM of Capiliaster sentosa. 259. ARM OF AMPHIMetra discoidea. 260. ARM OF Himerometra magnipinNa, 261. AzM of Capillaster multiradiata. 
The radianal is in the form of a radial beneath the right posterior radial in Temnocrinus, Meristocrinus, Ichthyocrinus, Clidochirus, Cleistocrinus, Protaxocrinus.

Thus while in the comatulids the radianal moves upward and is shoved outward from the radial ring onto the disk where it disappears, in the Flexibilia, though this may occur in those types in which no radianal is present in the adults, there is an equally marked tendency for the radianal to retain its original position while the right posterior radial grows around it, culminating in the tandem arrangement of these two plates, both equally developed, with the radial in advance.

In certain genera of Fistulata, as in some Larviformia, one, two, or three radials may have a large infraradial beneath it, while in others the radianal may be very much larger than the right posterior radial.

Although occurring in a great number of diverse forms, and usually reduced in size, the radianal shows two outstanding characteristics: (1) It is invariably associated with the right posterior radial, and its reduplications (infraradials) are equally closely associated with other radials, and (2) whenever it is large and well developed it resembles a radial itself.

This Iatter feature is illustrated by the following cases:

At first in Promachocrinus the radianal and the right posterior radial are exactly alike and situated side by side, forming a transverse pair of similar ossicles.

In Temnocrinus, Meristocrinus, Ichthyocrinus, Clidochirus, and Protaxocrinus, the radianal is in the form of a supplementary radial situated beneath the right posterior radial and with it forming a longitudinal pair of similar ossicles. The same arrangement also occurs in certain genera of Larviformia and Fistulata, often on more than one ray.

In Hybocrinus the radianal lies within the radial circlet and is practically the equivalent of the other radials, but bears a small right posterior radial on its truncate right distal angle.

In Baerocrinus the right posterior and the anterior radials are replaced by infraradials (the equivalents of radianals) which resemble the other radials except that they bear no arms.

Since whenever the radianal is sufficiently developed to exhibit any distinctive features at all it always exhibits the characteristics of radials, and since it is always intimately associated with the right posterior radial, in the light of the conditions seen in the very young Promachocrinus, and in Temnocrinus, Meristocrinus, Ichthyocrinus, Clidochirus, and Protrxocrinus, the assumption is justified that it is in reality the equivalent of the right posterior radial.

In the comatulids the gradual and eventually complete elimination of the infrabasals and basals as elements of the wall inclosing the visceral mass and the disapappearance of the orals, a morphological transformation which runs hand in hand with the extraordinary prolongation and development of the arms, is easily traced in the ontogeny, and among the fossil forms we find evidence supporting the belief that phylogenetic advance has in general been along similar lines, involving a reduction in the number and size of the calyx plates correlated with an increase in the length and size of the arms. 
MIONOGRAPH OF THE EXISTING CRINOIDS.

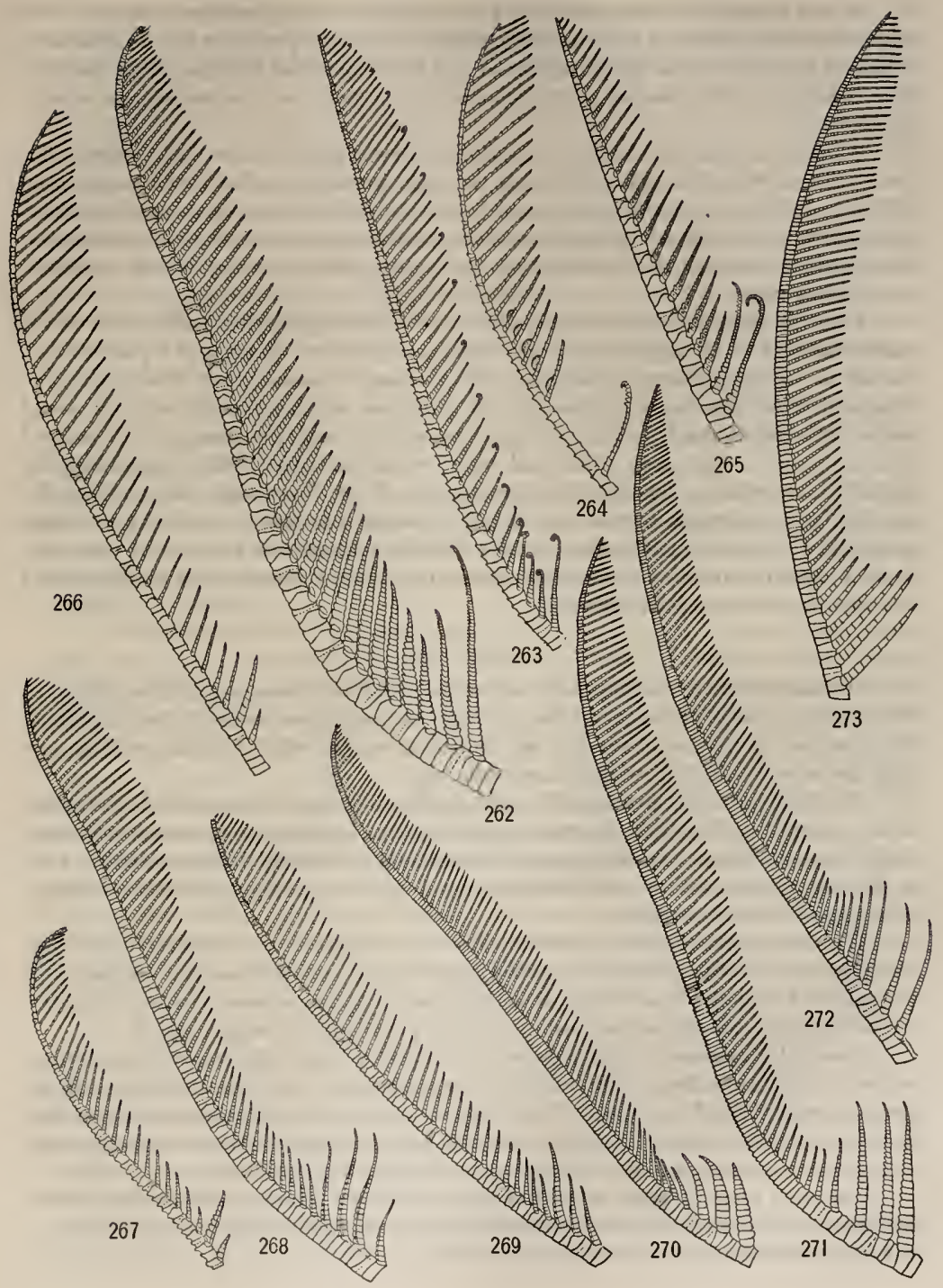

Figs. 262-273.-ARMs and pinNoles of variods comatulids. 262. Conatlua solaris. 263. Comister taviana. 264. CoMatila iridometriformis. 265, A posterion ari or Cosiatula micraster, shuWing the spherodes. 266. Eudrocrinus variegates. 267. Eudiocrtnus serripina. 268. HeteroMETRA COMPTA. 269. HETERoMEtra sinoulahis. 270. HIMEROMETRA ROBUSTIPINNA. 271. HisibroHETRA MAONIPINNA, 272. HIMUROMETRA persica. 273. STHPHANOMETRA ECHINUS. 
It has already been suggested that the relation of the posterior portion of the digestive tube to the anal area, and especially to the right posterior ray, is such as to result in the retardation in this region of any developmental changes along the lines of a reduction in the number of the elements in the calyx and its consequent simplification.

Thus if the radianal really is, as seems at least possible, the first element of a pair of exactly similar plates of which the right posterior radial is the second, and if this condition was originally found in all the radial areas, it is easy to understand why in the crinoids as we know them, both fossil and recent, the radianal has been greatly reduced and confined to the right posterior radial region or eliminated altogether.

If at the stage in which the radianal and the right posterior radial, both of the same size and to all appearances just alike, are present, this pair of plates is assumed to be reduplicated in all the radial areas, an assumption which is by no means without justification, there would result an organism from which a broad series of echinodermal homologies conld be worked out; for from such a pair of plates in each radial area additional pairs would be added either proximally or distally, according to whether the development of the body took place proximally or distally in reference to the zone or belt in which they occur; and if we add the possibility of larval development in the crinoids without the rupture of the vestibule, a logical connection between the recent types, the Camerata, the blastoids, and the cystids becomes easily traceable.

ORNAMFATATION.

Ornamentation is the exponent of, or the resultant from, a superabundance of vitality or excess of ontogenetic energy over the immediate needs of the individual. It is limited in its manifestations by considerations of vital economy, which as a rule operate to confine it within narrow bounds.

The fixed habit of the crinoids would appear to be conducive to the development of ornamentation, but their enormous specialization, intimately connected with their body form, and their curiously specialized method of feeding, have resulted in such a delicate adjustment to their environment that only a slight departure from a generalized type is possible.

The ornamentation of the recent crinoids is confined to comparatively slight modifications of the edges or exposed surfaces of the ossicles and much of it, though undoubtedly ornamental in origin, has come to possess a secondarily economic function exactly as has happened in the case of many other animals.

Comatulid ornamentation appears to be (exclusive of the very distinct interarticular ornamentation) divisible into three general types, one including all the productions of the free edges of the ossicles, another the lateral compression and carination of the median line of the ossicles, and the third the general modification of the exposed surfaces; but all three types intergrade more or less.

The first type appears to be the most primitive and appears earliest in the ontogeny, while the last is the most specialized and is the latest to become evident; it is only found in highly specialized genera. 
In practically all species of comatulids the distal dorsal border of the brachials is more or less produced outward over the base of the succeeding segments (figs. $1059, \mathrm{pl} .14$, and $1070, \mathrm{pl} .15$ ), and at the same time is more or less spinous or sharply dentate. This character appears in the young not long after the beginning of the free existence. It is primarily the result of the cessation in the longitudinal growth of the ossicles, due to the development of the articular faces and the fixation of the organic matter in a more or less stable form before the deposition of calcareous matter has ceased-an expression on a small and limited scale of the well-recognized fact that skeletal structures continue to develop after the other structures have reached maturity - the further calcareous deposition taking place at the only point possible, the free distal edge of the ossicle bordering the dorsal ligament fossa.

As a rule the production of the distal edge of the brachials is not evident proximal to the fourth brachial of the free undivided arm, gradually increasing in intensity from that point outward, but diminishing again near the tip.

The distal edges of the pinnulars, except the first two, are almost always produced and spinous, like the distal edges of the brachials, and this feature increases from the base of the pinnules outward.

In the cirri spinous distal edges on the segments are not common. They occur in the species of the genus Colobometra and in a few of the species of Thalassometra, where they are developed on the basal segments and extend outward in diminishing intensity onto the fixed proximal segments. They never occur on the mobile outer cirrals.

In the Macrophreata the production of the distal dorsal edges of the brachials and of the pinnule segments is always very slight, though always present, at least distally. It is sometimes reduced to a row of fine spinelets, which are scarcely visible even under a good glass. In the Oligophreata it is always pronounced and is often carried to extremes, as in the Comasteridœ, especially in the species of Comaster and in certain species of Comanthus, in most of the species in the Zygometridæ, in many of those of the Himerometridæ, Mariametridæ, Charitometridæ, and Thalassometrinæ, and particularly in the genus Colobometra.

This produced distal dorsal edge of the ossicles is always serrate for the reason that all free calcareous borders of crinoid ossicles increase by sending out more or less slender and tapering teeth, as is well seen in the development of the orals. With further growth the interstices between these teeth may become more or less filled up, resulting in a comparatively smooth edge, and this appears to take place in certain species of such genera as Himerometra and Zygometra.

In a few species, such as Strotometra ornatissima (part 1, figs. 101, 102, p. 163), Perissometra patula, Charitometra basicurva, Eudiocrinus ornatus (fig. 190, p. 111), Heterometra crenulata, and Heterometra aspera, the distal border of the earlier wedge-shaped or oblong brachials is abruptly turned outward, forming a conspicuous ridge across the arm. This reaches a maximum in Strotometra ornatissima and is well illustrated in Charitometra basicurva and in E'udiocrinus ornatus, but in the other species it is only slightly marked.

In most comatulids the lateral edge of the ossicles is smooth and straight, but occasionally it becomes produced, wholly or in part. Such a production of these 
lateral edges gives rise to thin flange-like borders, which are usually ventrolateral, in this case assisting to support the visceral mass, more rarely dorsolateral. These are usually widest at the point of maximum growth activity (the distal corners) and may be wholly or chiefly confined to this location.

In general, this type of ornamentation is confined to the first brachial pairs and their reduplications, or to the first two pinnule segments, but it is oceasionally developed on all the brachials and pinnulars.

In the Macrophreata production of the ventrolateral border of the ossicles is very rare, but it is seen in the Atlantic species of Antedon and in species of Eumetra and Iridometra and one or two other related genera. It does not occur in the Comasteridæ, Zygometridæ, Himerometridæ, Thalassometridæ, Charitometridæ, or Mariametridæ. In certain species of the genera Stephanometra (figs. 125, 130, p. 79), Cenometra (fig. 122, p. 79, and part 1, fig. 87, p. 143), Colobometra, Cyllometra, Decametra, Oligometra, and Cotylometra, as well as in some forms of certain species of Lamprometra, it is usually strongly developed, taking the form of broad, thin, rounded processes, usually more or less confined to the distal half of the ossicles and not occurring beyond the second brachial of the free undivided arms. In the Calometridæ a similar condition is found, but the lateral processes are more extensive and arise from a greater part of the lateral borders of the segments. They often are in apposition laterally, so that the lateral portion of the visceral mass is completely inclosed in a calcareous casing.

The edges of these lateral processes, though very thin, are ordinarily entire and smooth, for the deposition of calcareous matter in the crinoids in other directions than that of rapid directive growth always leaves a clean, smooth edge such as is seen on the posterior borders of the orals as contrasted with the opposite growing angles; but in a few forms, such as Cotylometra ornata, and the species of Pectinometra, they are regularly serrate or coarsely denticulate always, however, with a smooth margin to the minor processes.

In very many of the genera which have the arm bases flattened against each other, especially those in which the IIBr series are $4(3+4)$, the whole lateral border of the ossicles appears to have been pushed outward so that the ossicles are sharply flattened laterally, yet when viewed dorsally appear to be strongly convex dorsally with narrow, produced, and flattened borders. This is characteristic of the species of Amphimetra, Heterometra, and Craspedometra of the Himerometridæ, of Crinometra, Crossometra, Perissometra, Pachylometra, and Glyptometra of the Charitometridx, of certain species of Thalassometra, and is seen in a few species of Dichrometra, Liparometra, Lamprometra, and Mariametra of the Mariametridæ. In Glyptometra the dorsolateral edges of the segments are sometimes everted and stand out as a thin interradial keel.

In Prcilometra (figs. 118, 132, p. 79, and 229, p. 186), which has the division series and arm bases close together but not quite in apposition, the dorsolateral border of the ossicles has become produced, resulting in a uniform thin flange-like border about the edges of the segments of the elements of the IBr series and of the first brachial pairs. 
The ventrolateral edges of the pinnule segments are less frequently produced than are those of the earlier brachials. Such production, resembling that of the elements of the division series and of the first brachial pairs in Stephanometra, is found in Colobometra and in Comatula, while in Comissia the distal ventral angle of the pinnulars is produced into a long sharp spine, most marked in $C$. peregrina. In a few cases the dorsal outer border of the outer pinnulars may be more or less extravagantly produced, standing up high above the general distal profile of the pinnule. This is characteristic of the Comactiniinæ, especially of the genus Comactinia, and is equally well marked in some of the Comasterinæ, most noticeably in Comaster belli. In the genus Nemaster of the Capillasterinæ it also occurs, but is confined to the oral pinnules, not extending for a greater or lesser distance along the genital pinnules as in the other forms.

Occasionally ouly the first two pinnule segments are modified. In certain species of the genera Nemaster, Comatella (fig. 1041, pl. 12), Comatula, and Leptonemaster, and in all the species of the Calometrida, the two basal pinnule segments bear a high, thin, rounded, dorsal keel. This modification is usually confined to the lower genital pinnules, not occurring, or being but slightly evident, upon the oral pinnules; in Leptonemaster and in the species of Calometridæ, however, it is most noticeable on $\mathrm{P}_{1}$, rapidly diminishing in intensity distally.

In most of the species of Himerometridæ, Mariametridæ, Stephanometridæ, Zygometridæ, and Colobometridæ the segments of the lower pinnules following the first two are more or less, sometimes very, strongly carinate.

All of the species of the Oligophreata exhibit more or less tendency toward a styliform or prismatic shape in their pinnules which is occasionally reflected in their cirri. This is seen in the rhombic section of the cirri in Pectinometra acanthaster, and in the rounded triangular section of the cirri in certain of the Colobometridæ; in Pterometra (fig. 208, p. 146) the central profile of the cirri has become more or less sharpened, in the mid-ventral line being produced into a long, sharp, ventral spine.

In the pinnules whenever the tendency toward a prismatic condition is very strong any production of the dorsal distal edge becomes localized and shows itself at the ventrolateral angles and in the mid-dorsal line. This is best shown in the lower pinnules of such species as Oligometra serripinna (fig. 315, p. 227) or $O$. carpenteri, and in Heterometra crenulata and $H$. producta; in a somewhat different aspect it is evidenced in the terminal combs of the species of Comasteridæ. It is traceable in most of the Oligophreata.

Next in frequency to the production of the free edges of the ossicles comes the development of fine spines over more or less of the dorsal surface. There are two distinct varieties of this type of ornamentation.

When developed beyond the first brachial pair the projection of the distal edge of the brachials and the spinosity of the dorsal surface appear to have a certain connection, for the development of a spinous dorsal surface always begins at the distal edge of the segments and slowly spreads proximally. In a few species, as in Cosmiometra aster (fig. 215, p. 159) and in some species of Oceanometra (figs. 
220-222, pp. 168-173) and Thalassometra, the dorsal spinelets are arranged in regular longitudinal lines, but usually, as in the Comasteridæ, they are studded thickly over the dorsal surface, at first small and fine, but becoming larger and coarser distally. In certain of the Thalassometridæ, as in the genus Asterometra, there is a tendency for these spines, when developed on the pinnulars, to become segregated aloug the crest of the dorsal ridge.

In the Comasteridæ all the postradial elements beyond the first brachial pair are thickly covered with small spines, and this character is of such constancy as to be of considerable diagnostic value, so that single brachials or pinnulars may usually be determined as of species of that family by it alone. In the other groups it is rarely well developed, and when present it is commonly confined to the brachials, and usually to the outer half of their dorsal side, not occurring, or being but imperfectly developed upon, the pinnulars and the proximal half of the brachials. It is most prominent in species with prismatic pinnules.

The spinosity of the elements of the first brachial pairs, of the elements of the division series, and of the radials, is apparently of an entirely different type and is of very great systematic significance. Whereas the spinelets on the surface of the outer brachials and of the pinnulars are directed anteriorly and are much better developed on the outer part of the segments than on the inner, those on the proximal ossicles and on the radials are erect, distributed uniformly over the plates or forming borders around the edges of the dorsal surface which are of the same width proximally as distally and are composed of spinelets of equal size.

In the genera Oceanometra (figs. 220-222, pp. 168-173), Thalassometra (figs. 223, 224, pp. 175, 177), Stylometra (fig. 219, p. 166), Sarametra (part 1, fig. 109, p. 175 ), and Zenometra the radials, division series, and lower brachials are always covered with fine spines, these furnishing valid generic and specific characters of the highest importance. Typically these spines are uniformly developed all over the dorsal surface of the ossicles, but in certain species they are much larger along the borders. In the genus Crinometra (figs. 678-683, p. 338) the radials, division series, and first brachial pairs are usually thickly covered with small spines or tubercles of various sizes. These may be arranged in horizontal rows, as in C. gemmata (fig. 679, p. 338 ), or may be quite without arrangement; they may be entirely and well separated, or confluent.

The species of Mariametra (figs. 196, p. 124, 197, p. 125, and 684, p. 338) also have spinous radials, division series, and first brachial pairs, but the center of the ossicles is always snooth and obscurely carinate, the keel being sometimes more or less tubercular. A similar condition also occurs in certain species of Cosmiometra and of Crinometra.

Like the development of spinosity on the dorsal surface of the postradial ossicles, the development of a median dorsal carination appears to be divisible into two types, each quite distinct from the other, though both often occurring together, and both reaching their maximum in the same groups. In one type only the outer brachials are affected, from the first or second syzygial pair onward (more rarely only the distal brachials), and in the second only the division series and first 


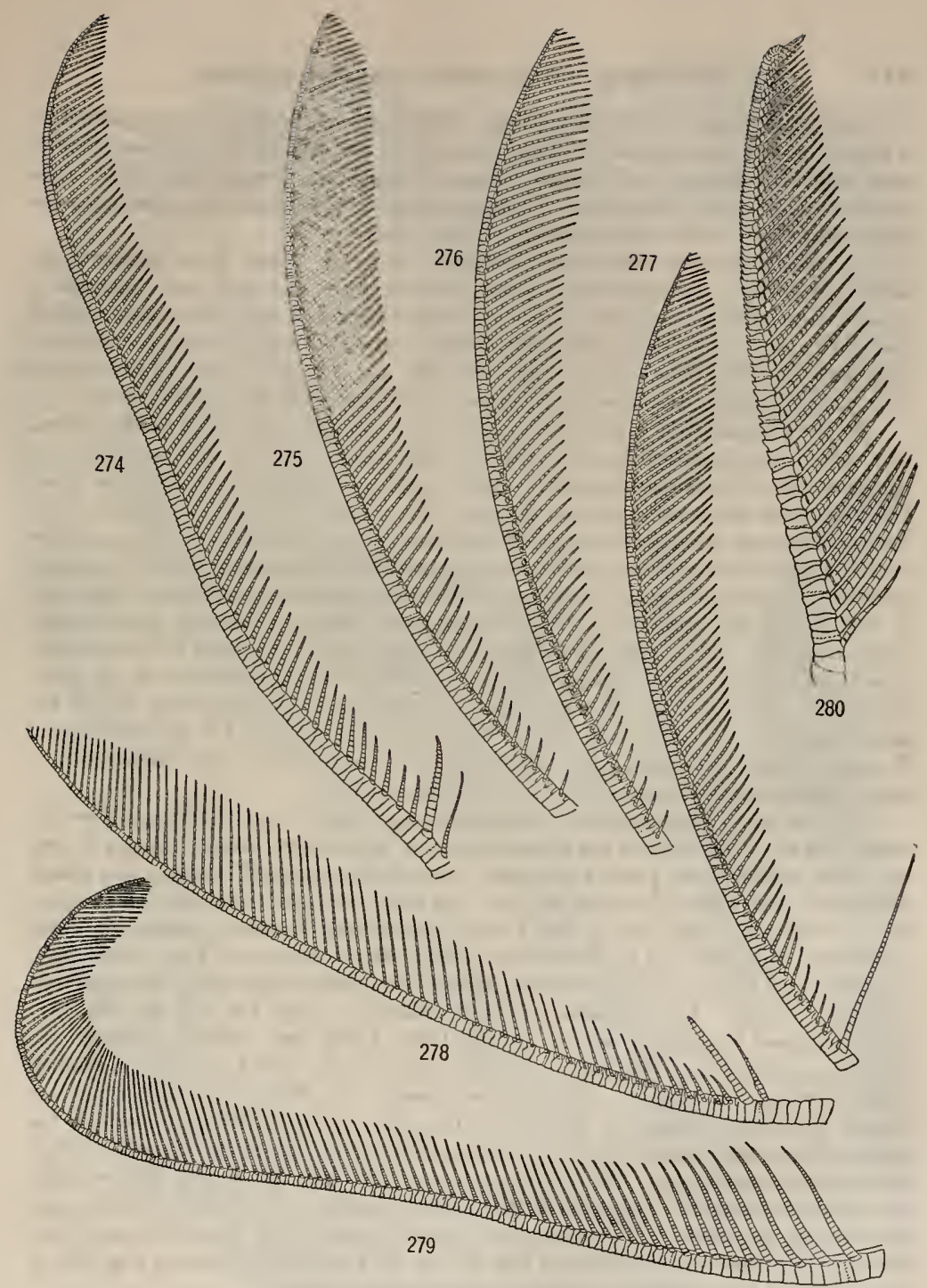

Ftgs, 274-280,-Arms and pinnules of various comatulids, 274. Cenometra denicornis. 275, PinNULES ON INNER SIDE OF OUTERMOST ARM BOBNE BY POST-RADIAL SERIES OF PONTIOMETRA ANDERSONI,

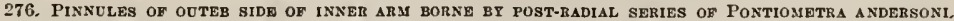
277. PINNULES OF OUTER SIDE OF ODTERMOST ARM BORNE BY POST-RADIAL SERIES OF PONTIOMIETRA ANDER-

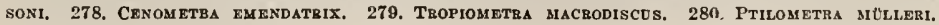


brachial pairs, together with the radials. The first type is always accompanied by a strong lateral compression of the brachials, and the carination has a tendency to lean anteriorly, taking the form of a more or less broad overlapping spine. The second type is, on the other hand, accompanied by a considerable broadening of the plates affected, and the carination is perfectly erect.

Carination of the distal brachials does not occur unless those segments are smooth dorsally; but carination of the division series and first two brachials is almost invariably accompanied, as in Crinometra (figs. 678,680,683, p. 338), Mariametra (fig. 684, p. 338), Glyptometra, Perissometra (fig. 658, p. 329), Cotylometra (fig. 199, p. 129), Occanometra (figs. 220-222, pp. 168-173), and Thalassometra (fig. 224, p. 177), by a spinous or tubercular modification of the dorsal surface.

In the Comasteridæ a very thin, narrow, low, and inconspicuous median elevation which can be detected only with difficulty occurs more or less constantly on the brachials of certain species of Comatula, and in Comatonia a few of the lower brachials have the central portion elevated into a blunt keel with a spinous crest. Except for these cases neither type of carination is ever found in the Comasteridæ other than as a rare variant, nor in the Zygometridæ, Himerometridæ, or Stephanometridx. Proximal carination occurs in all the species of Mariametra (figs. 196, p. 124,197 , p. 125 , and 684 , p. 338 ), though never found in those of Dichrometra, Oxymetra (fig. 195, p. 122), or Pontiometra (fig. 194, p. 120), and in Cotylometra ornata (fig. 199, p. 129), though not in C. gracilicirra nor elsewhere in the Colobometridæ. In the Tropiometridæe distal carination is characteristic of all the smaller species of Tropiometra (fig. 173, p. 89), but is not found in the two largest. It occurs in all of the species of Calometridæ, in one genus of which there is also a very slight proximal carination in a few of the species.

It is in the Thalassometridæ that both types attain their maximum development. In the Ptilometrinæ the distal carination is excessive, though usually it does not occur on the lower part of the arm; but certain species of Asterometra (those allied to A. longicirra [figs. 206, 207, pp. 143, 145]) and of Pterometra (those allied to $P$ t. trichopoda [fig. 208, p. 146]) may possess very strongly marked proximal carination, this reaching its maximum in some of the species of the former (figs. 206,207 , pp. 143, 145), though entirely absent from others (fig. 209, p. 149, and part 1, fig. 94, p. 155). In Stiremetra and in Cosmiometra (figs. 213, 214, pp. 155, 157) only proximal carination occurs, in the latter being only faintly evident. In Stylometra (fig. 219, p. 166, and part 1, fig. 35, p. 73) only distal carination is found, here, however, reaching its greatest development. In Parametra both types are found, the distal, except in one species (fig. 218, p. 164), strongly marked, the proximal scarcely noticeable. In Thalassometra both types are found, though never in the same species. In Oceanometra gigantea (fig. 220, p. 168) the proximal carination is curiously restricted to the second element of the first brachial pairs and to their morphological reduplications, never occurring on any of the other segments. The species of Stenometra (fig. 211, p. 152) and Daidalometra (fig. 212, p. 153) have all the postradial ossicles very strongly carinate. 


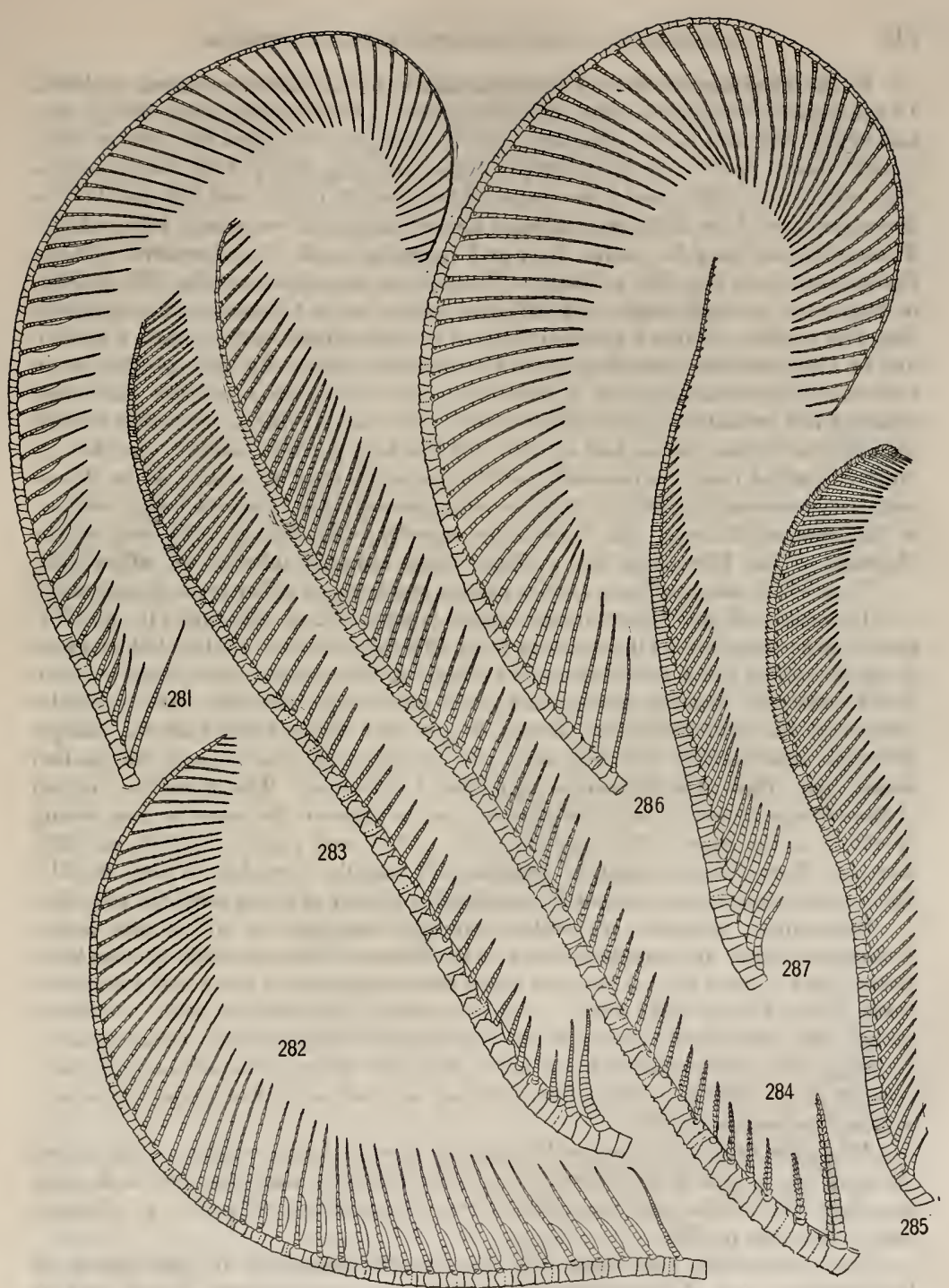

Figs. 281-287. - Arms and pinnules of various comatulids. 281. Antedon petasus. 282, Thysanometra tenelloides. 283. Crotalojetra rustica. 284. Oceanometra gigantea. 285. Astenometra aacropoda, 286. Pextametrocrinus varians, 287. Metacrinus acutus. 
In the Charitometridæ no true carination is found, either proximal or distal. In the genera Crossometra (figs. 673,675, p. 335), Perissometra (figs. 658, p. 329, and 670 , p. 335, and part 1, fig. 100, p. 162), Pachylometra (figs. 671, 672, p. 335), Chondrometra (part 1, fig. 99, p. 160), Chlorometra (fig. 228, p. 184), Calyptometra (figs. 676,677, p. 338), and Crinometra (figs. 678-683, p. 338, and 674, p. 335) the dorsal surface of the division series and lower brachials is commonly tuberculated. These tubercles may be coarse, low, and irregular as in Chondrometra robusta, Perissometra lata (fig. 658, p. 329), or Crossometra investigatoris (fig. 673, p. 335), or they may be small, high, and subequal in size as in Crinometra margaritacea (fig. 683, p. 338). Often a generally rugose or tuberculated surface bears a median line of high rounded tubercles, as in Perissometra selene (fig. 227, p. 182) or in Crinometra concinna (fig. 678 , p. 338 ), or a more or less sharp median carination standing out prominently as in Glyptometra tuberosa. In these genera the median line of the division series and of the first brachial pairs is usually occupied by larger tubercles than the remainder of the dorsal surface, or it may, as in Mariametra subcarinata (fig. 684, p. 338), be quite smooth, the tubercles being confined to the interradial areas. In Aglaomctra eupedata (fig. 225, p. 179) each of the elements of the $\mathrm{IBr}$ series has a single large rounded tubercle on either side.

None of the macrophreate species possess any trace of either type of carination.

In certain of the Macrophreata (part 1, figs. 112, p. 179, and 110, p. 176), much more rarely in the Oligophreata (figs. 192, 193, 200, pp. 115, 117, 130, and part 1 , fig. 86, p. 141), the articular fulcral ridges of the apposed joint faces are produced outward, forming strong and very prominent tubercles. The tubercles formed at the synarthries are always larger than those formed at the oblique muscular articulations, and they are more prominent as they occupy the median dorsal line; these are known as synarthrial tubercles. The tubercles formed at the oblique muscular articulations only occur between the more or less oblong brachials at the base of the arm (fig. 233, p. 193, and part 1, fig. 121, p. 189); they are from four to eight in number and rapidly diminish in size distally. Their prominence is not necessarily correlated with that of the synarthrial tubercles.

Synarthrial tubercles are rather strongly developed in all of the larger Antedonidæ; they are very prominent in the Zenometrinæ, especially in Psathyrometra (part 1, fig. 110, p. 176), and reach their maximum in the genus Perometra (part 1, fig. 112, p. 179) and in Neometra diana (fig. 200, p. 130). Curiously enough, they are equally large in the oligophreate Amphimetra ensifer (part 1, fig. 86, p. 141) and well developed in A. discoidea, though obsolete or quite nonexistent in all the other oligophreate forms, as well as in the Atelecrinidæ and in the Pentametrocrinidæ.

When the articular tubercles between the proximal arm ossicles are developed the arm base is said to be tubercular. As the tubercles alternate with each other on either side of the arm the effect is very characteristic (fig. 233, p. 193, and part 1, fig. 121, p. 189).

Such tubercular arm bases are characteristic especially of the species of Heliometrinæ and Pentametrocrinidæ among the macrophreate forms, and of 
Heterometra crenulata and $H$. philiberti among the oligophreate. They are found, rather less developed, in Perometra (part 1, fig. 112, p. 179), Asterometra (fig. 209, p. 149, and part 1, fig. 94, p. 155), and Ptilometra, and in certain other of the larger and stouter species of many other genera.

In many oligophreate species specimens are often found with a white or very light mediodorsal line along the division series and the arms, this line being usually bordered on either side by a narrower dark or black line. Very frequently this line resembles a mediodorsal carination so closely as to be with difficulty distinguished from it, and the confusion is increased by the fact that both the line and the carination very often, as in certain species of Comatula, occur together. Such a dorsal stripe is invariably found in the species of the genera Eudiocrinus and Cotylometra and usually in the species of Colobometra and Pterometra. It is very common in all of the species of Comatula and in many of those of Comanthus and Comanthina, as well as in various species of Cyllometra and Pontiometra, and in Oligometra serripinna.

A somewhat less common condition is a narrow black mediodorsal line. Such a line is seen in Coccometra nigrolineata, in Mariametra margaritifera, and in many of the species of Comaster, in all of which it is fairly constant. Only in Mariametra margaritifera, however, does it cover a median carination.

The ornamentation of the proximal ossicles by the development of spines or tubercles on the dorsal surface or by the development of spines along their borders indicates a primitive type and is characteristic of the young of many species, of which the adults are almost or quite unornamented. Thus in Heliometra glacialis the elements of the division series and the lower brachials of the young have very spinous borders which are entirely lost later in life, while in many of the species of Thalassometra the young have an excessive development of spines on the borders of all the proximal ossicles, which in the adults are nearly, or even quite, smooth.

Thus by a study of this type of ornamentation we are able to judge more or less accurately of the comparative phylogenetic importance of many genera and species and are able to appreciate the fact that the extremely ornate species of such genera is the West Indian Crinometra and Stylometra are really more primitive than the corresponding species of the closely related, but far less ornate, species of the East Indian genera Crossometra, Perissometra, Monachometra, Pachylometra, and Cosmiometra; and also that the spinous or tuberculous species of such genera as Flyptometra, Parametra, Cosmiometra, and Thalassometra occurring in the central East Indian region are more primitive than the much less spinous or tuberculous species of the same or closely allied genera occurring in southern Japan, the Hawaiian Islands, New Zealand, or the Lesser Sunda Islands. Similarly, it is evident that the species belonging to the genera characteristic of the Antarctic region, all of which are noticeable for the development of spines or keels on their ossicles, are more primitive than the species of the genera characteristic of the Arctic region, all of which are smooth, though spinous when young. 
PERISOMIC PLATES.

The perisomic plates as usually understood are the plates developed within, and entirely confined to, the integument of the ventral surface. They vary very considerably in size in different species, and even in different parts of the same individual. Though in general their shape and manner of occurrence is fairly uniform, it is sometimes quite fortuitous; usually they are quite irregular, but in places where the integument is more or less modified or assumes a special form, as along the raised borders of the disk ambulacra or in the so-called lappets fringing the sides of the ambulacral grooves of the arms and pinnules, the included calcareous deposits are cast or molded during formation into definite shapes. This is especially noticeable in the case of the covering, or side and covering, plates which occur along the brachial and pinnule ambulacra forming such a characteristic feature in the Calometridæ, Thalassometridæ, Charitometridæ, and (covering plates only) certain genera of the Capillasterinæ.

Originally the body of the crinoid was entirely inclosed within a calcareous capsule consisting of a central plate (commonly represented by a stem), three alternating rows of calyx plates of which the last bore processes on their outer borders, and a circlet of five apical plates (orals) about the pole opposite the central plate the individual elements of which agree in orientation with the elements of the middle row of calyx plates. Such a condition is seen in the pentacrinoid young of the comatulids after the formation of the arms.

Development from this type has been through the reduction of the calyx plates row by row and the resorption of the orals, so that a progressively increasing part of the body wall of the animal was left unprotected by the original covering.

In most of the comatulids this process has been carried so far (part 1, fig. 74, p. 127) that the representatives of the original calyx plates now merely form a small button beneath the center of the visceral mass, which rests mainly on the arm bases, with its entire ventral and much of its lateral and dorsal surface exposed.

As the original calyx plates withdraw, leaving areas of unprotected perisome, new skeletal elements in the form of minute spicules appear in the latter, which may persist as spicules of various shapes and sizes, or may develop into more or less perfected plates.

The first vestiges of the calyx plates (fig. 1200, pl. 31) are in all ways similar to the spicules in the perisome, but while the latter ordinarily do not develop, or develop irregularly, the former grow very rapidly and regularly into definite calcareous structures (figs. 1200, 1197, 1196, pl. 31). The fact that the perisomic spicules sometimes develop rapidly and regularly into very definite and highly complicated plates, as in the case of the side plates on the pinnules of the species of Calometridæ (figs. 835-842, p. 405), Thalassometridæ (figs. 859-866, p. 419), and Charitometridæ (fig. 816, p. 385), shows that there is no tangible fundamental difference between the primary and the perisomic plates. .

The perisomic plates, ontogenetically similar to the primary plates, and wherever this is possible running the same developmental course, must therefore be 
regarded as an exactly similar body covering the development of which is induced by the atrophy or cessation of development of the primary plates. The reason that the perisomic plates are very rarely so perfected as the primary plates is probably to be found in the much greater general mobility of the areas where they are formed, which tends to separate the mesodermic lime depositing cells into small groups, thus inducing the formation of a great number of individual spicules, instead of allowing these cells to lie in broad areas and thus permitting a few spicules to develop into large plates.

If this is so, then the perisomic plates represent phylogenetically the most primitive type, and we are led to the hypothesis that the original covering of the crinoid body essentially resembled that of the holothurians (figs. 782 , p. 366, and $790-792,796$, p. 372 ), and that this covering developed into a complete calcareous investment comparable to that of the echinoids; in the later types wherever and whenever the latter is suppressed the former immediately reappears.

Woodland states that in the disk of Antedon bifida, which he studied at Plymouth, the majority of the spicules lie toward the inner side of the soft integument and are of two kinds, the imperforate thin "glasplättchen " of comparatively wide diameter and concentrically marked, and the ordinary perforated plates which, however, often assume a very irregular shape and occasionally become mere branching structures. All transitions are to be found between the "glasplättchen" and the ordinary perforated plates; the former, however, are much more common and exist in great numbers. The imperforate plates each originate as a spherical granule contained within a single cell; this granule gradually becomes larger and early assumes the plate-like form. Thus there is no rod or triradiate stage in the growth of these plates, and the plate is never of the perforate type. The nucleus of the original mother scleroblast divides at an early stage of growth of the spicules, and the number of nuclei present at different stages of growth (a score or more on fully developed plates) is strictly proportionate to the size attained by the spicule. These large, thin, squamous spicules of Antedon exist in great numbers. They are very easily decalcified in virtue of their extreme thinness. The dark granules so common in the scleroblasts of many Cucumariidæ are also present in the scleroblasts of Antedon.

P. H. Carpenter noted that the margins of the ambulacra of the disk, arms, and pinnules of the comatulids are rarely, if ever, perfectly free from any traces of calcareous structures, which may take the form of simple short spicules almost entirely limited to the marginal leaflets, or may be forked and branching spicules of various shapes and sizes.

The spicules in the ventral integument of Comactinia echinoptera were long ago figured by Carus.

Present within the integument in all of the comatulid groups the perisomic spicules are often, as in Antedon moditerranea and in the Macrophreata generally, of small size and quite invisible exteriorly. When this is the case the species is said to have an "unplated" disk. They may, howcver, become enlarged and stand out from the integument as calcareous plates or nodules of various sizes and shapes, 
either isolated or in groups, as seen in Antedon petasus (fig. 747, p. 349) and in Comatula solaris. In many cases they are so frequent as to form a more or less solid plating all over the surface of the disk, as is seen in the Zygometridæ (figs. 1155-1157, pl. 25), Thalassometridæ, and Charitometridæ (figs. 1159-1161, pl. 26), and especially in the Calometridæ (figs. 735-737, p. 349). When this occurs the disk is said to be "plated."

In the young comatulids and in the later pentacrinoids there are, so far as we know, no périsomic plates other than those bordering the ambulacral grooves which appear almost simultaneously with the latter.

In the young of Comactinia meridionalis, and probably also of other comasterids, large thin fenestrated plates forming an uninterrupted layer appear in the integument during the later pentacrinoid stages, when there are as yet only five cirri, the orals have scarcely commenced to undergo resorption, the mouth is central, and the digestive tube makes but a single coil. As the orals are resorbed these plates also gradually disappear from the ventral surface of the disk, persisting, however, until considerably later in the lateral perisome between the arms. Some time after the complete elimination of these plates the perisomic plates of the usual type appear.

The plating on the disk of the young of Thaumatocrinus renovatus (part 1, fig. 117, p. 183), as described and figured by P. H. Carpenter, is probably of the same nature.

These plates are probably to be interpreted as homologous with the plates covering the disk in certain palæozoic types, those in the laterodorsal interbrachial regions (part 1, fig. 412, p. 317), which are larger, more solid, and more perfectly formed, being the representatives of the interradials and interbrachials. They exist only so long as the narrow perisomic areas between the outer borders of the orals and the radial circlet are held taut and inflexible by the surrounding plates. When with the resorption of the orals and the retreat of the basals these areas increase in size and movements of the external surface due to the movements of the internal organs take place they soon disappear.

They are thus in reality primary plates of the disk-that is to say, plates which have reached the maximum development possible under the mechanical limitations imposed by slight general perisomic movement. Their successors, the so-called perisomic plates of the disk, as a result of the great increase in the mobility of the surface of the disk during the growth of the animal, usually remain at a much earlier derelopmental stage.

The persistence of the plates in the interbrachial areas is due to the fact that amplitude of motion here increases very much more slowly than on the disk and is always very limited.

Comaster belli, $C$. novreguinea, $C$. multifida, and Comanthina schlegelii often have the interradial portions of the lateral perisome, as well as the spaces between the division series and arm bases, completely covered with a solid pavement of plates by which the various primary elements are closely cemented together. These plates are sometimes so developed that each of them appears strongly 


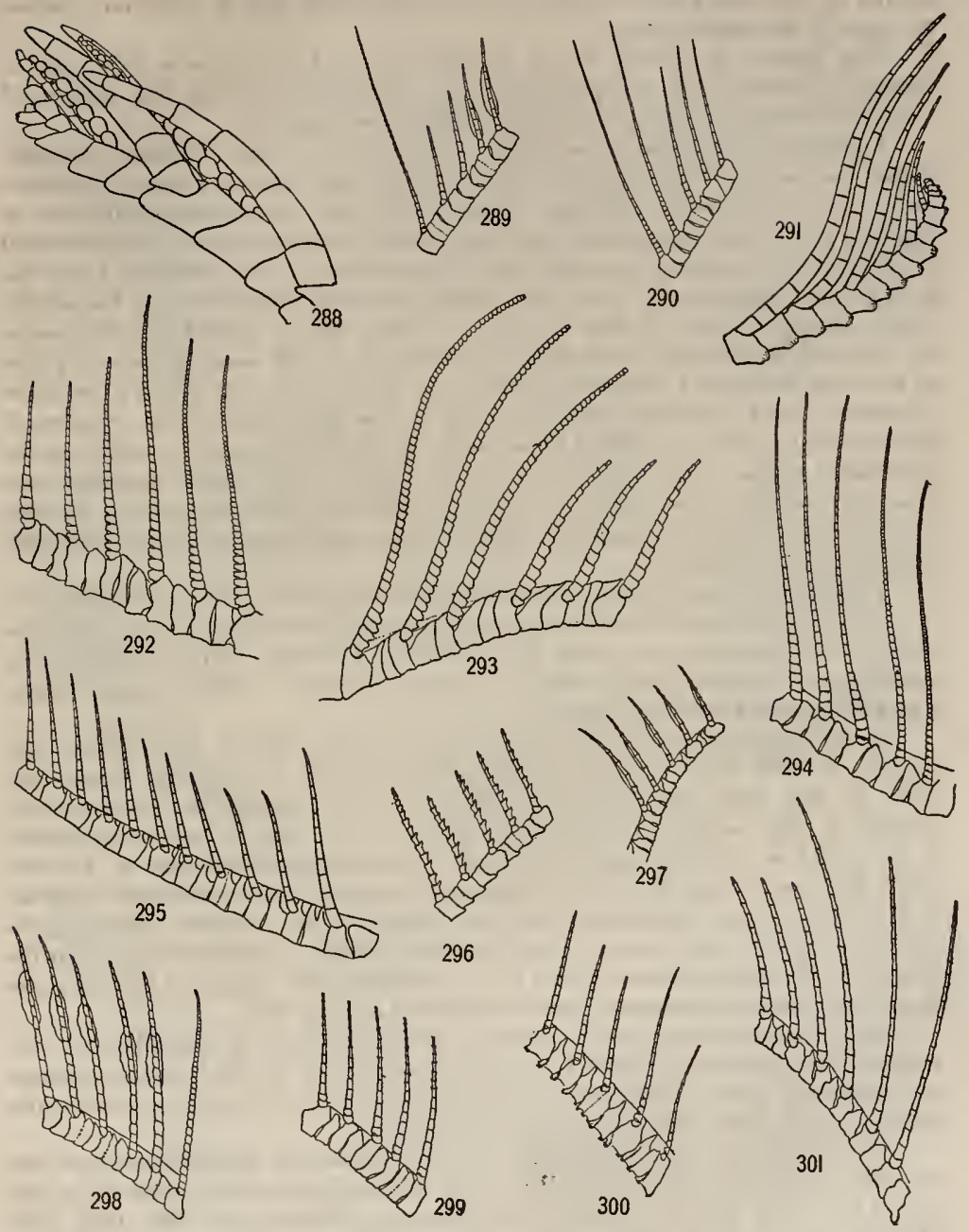

Figs, 288-301.-Arm tips and proxisal pinndles of variods coaratolids. 288. Aga tip of Pocilonetra scalabis, 289. Proximal pinndegs of Hathrometra tenella, 290. Proxialal pinndeles of Lepto-

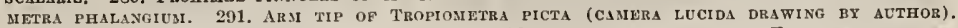
292. Proximal pinndeles of Florometra laodice. 293. Proximal pinneles of Flobometra marim. 294. Proximal pinndees of Florometra asperriaia. 295. Proximal pinndegs of Psathyrometra erythrizon. 296. Proximal pindeles or Compsometra sereata. 297, Lowest pinndees of Hypalo-

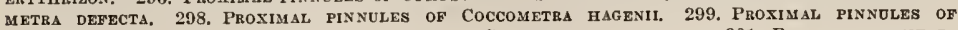
Prometra owstoni. 300. Proximal pinndles of Saradietra triserialis. 301. Proximal pinndles OF IRIDOMETRA ADRESTINE. 
convex on the outer surface, just as do the plates often seen in a similar position in many of the fossil species.

This plating is always, so far as known, found in Comaster belli, almost always in Comanthina schlegelii, but only occasionally in the two species of Comaster, where, however, it reaches its highest development.

I previously regarded these plates as the sum of all the calcareous particles within the portion of the perisome affected, which have become cemented together into a uniform granular calcareous sheet, which, with the consequent increase in rigidity, always maintained sutures along definite lines determined by mechanical considerations dependent upon the surface movements of the interradial and the interbrachial integument. There is no doubt that these plates are very frequently, if not usually, formed in this way, for all stages can be traced in such species as Comanthina schlegelii; but since the discovery of the large perisomic plates in the very young of Comactinia meridionalis (part 1, fig. 412, p. 317) and their persistance until comparatively late in life in the lateral interradial perisome it has seemed possible to consider these plates in Comanthina and Comaster as the interradial plates of the very young, which, instead of becoming resorbed, have been retained and have increased in size correlatively with the general increase in size of the animal, although the plates on the rentral surface of the disk have long since disappeared.

These plates usually have a very definite arrangement. At the proximal end of the series, between the distal ends of, or just above, the radials, there is a single more or less rhombic plate which is followed by a double column of alternating subhexagonal plates; rarely there are some additional, usually small, plates inserted between these two columns.

In the Atlantic species of the genus Antedon (figs. 1018, pl. 7 , and 1145, 1146, pl. 23), as well as in Comatilia iridometriformis and a few other forms (fig. 1143 , pl. 23), there are found close down upon the radials in the interradial portion of the perisome several small plates which may be so closely united as to appear as a single interradial plate. Thomson supposed that in Antedon bifida these are derived from the five minute interradial plates sometimes observed in the very young, representing the last restiges of the complete juvenile perisomic plating just described in Comactinia meridionalis. He did not trace out the process of derivation, however, and P. H. Carpenter has suggested that they are in reality secondary perisomic plates originating in later life.

The perisomic plates on the ventral surface of the disk are ordinarily distinguishable from those in the lateral interradial areas by the common presence of perforating water pores, but Carpenter found that these pores are occasionally present in the plates occupying the interradial areas.

P. H. Carpenter first noticed that in those comatulids which have short and rounded gonads and plated ambulacra the enlarged part of the pinnule is protected by a very strongly developed anambulacral plating (figs. 1055, 1057, 1058, 1062, pl. 14), which is much more regular and closely set than that of the disk and arm bases. Resting upon the four or five middle segments of the short 


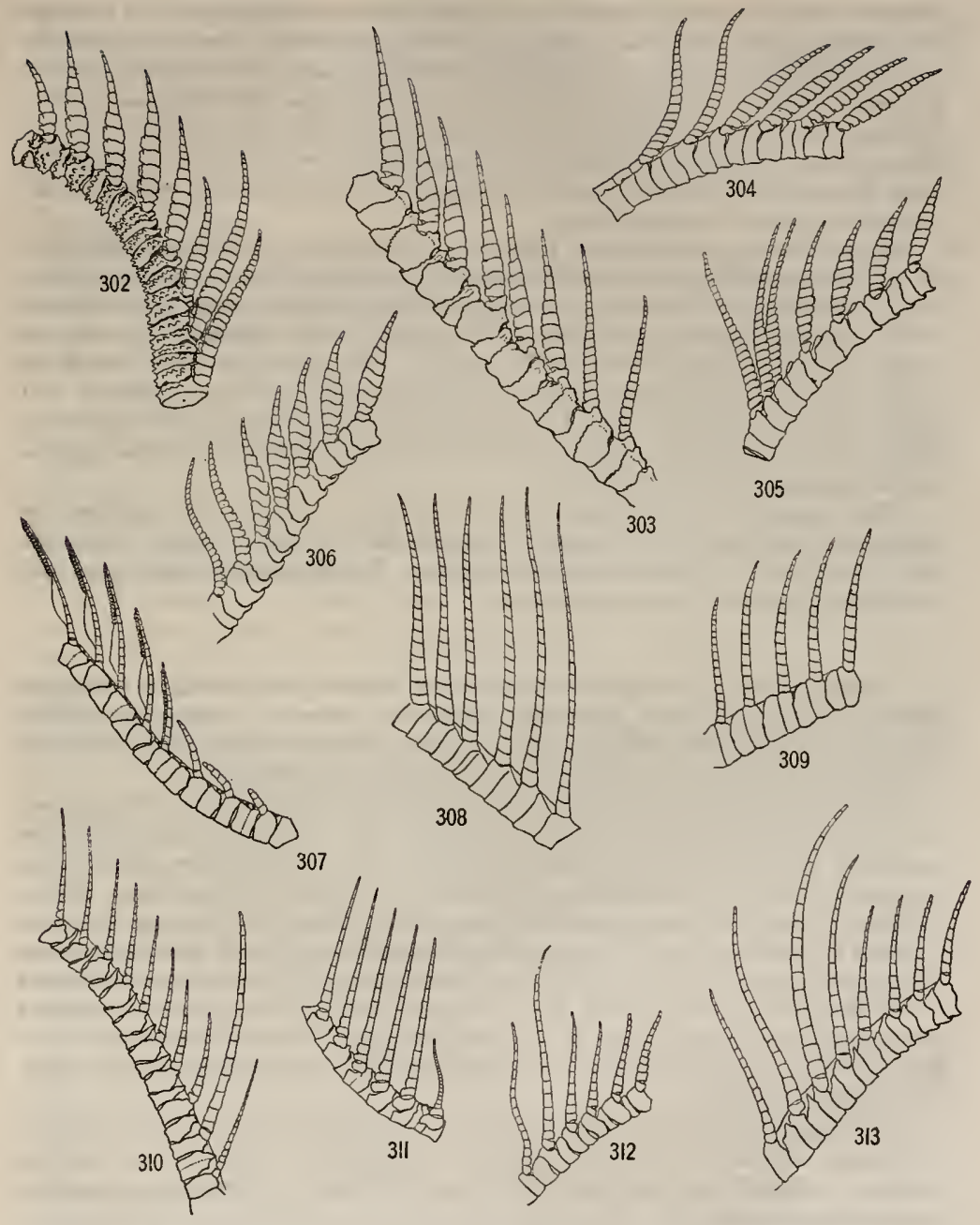

Figs. 302-313. - Proximal pinneles of various comatulios. 302. Crinometha concinna. 303. Calyptometra lateralis. 304. Crinometra imbeicata. 205. Proximal portion of arm of Crinometra

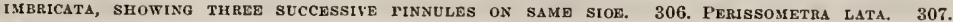

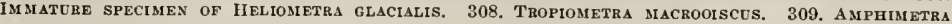

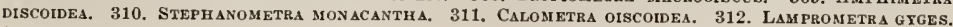
313. Dichrometra oüderLeini. 
pinnules there is a double row of large plates which are rectangular at the base but somewhat more irregular in shape at their upper ends. There are generally five or six plates in each row, but those of the two sides liave no fixed relative positions, sometimes corresponding exactly and sometimes alternating as exactly. These are best developed in Pecilometra (figs. 1057, 1058, 1061, pl. 14). In the other genera of the Charitometridæe they are smaller and much more irregular, while those of the two sides may be separated by the ambulacrum with its welldeveloped side and covering plates.

In Pecilometra, and in such forms as Perissometra angusticalyx (fig. 1055, pl. 14), these swollen genital pinnules receive no branches from the brachial ambulacra, resembling in this respect the corresponding pinnules in many of the Comasteridæ, and the anambulacral plates covering the gonads consequently meet one another in the midventral line of the pinnule. The sacculi, however, which lie at the sides of the ambulacra, may extend onto these grooveless pinnules and occupy small holes between the large protecting plates, while on the outer segments of the pinnules, beyond the gonads, the sacculi occupy the median groove on the upper surface of the skeleton.

The presence of this plating over the gonads is not, as was supposed by Carpenter, confined to those species in which the side and covering plates are highly developed, but it may occur in any group. It is frequently highly developed in Heliometra and in Pentametrocrinus.

Plating of the disk.

Under ordinary examination the disk may appear quite naked, or it may be more or less covered with calcareous nodules or plates of various sizes which sometimes form a solid pavement over it. The presence or absence of a calcareous plating is of considerable importance from a systematic standpoint.

Strictly speaking, the disk always contains limy deposits, even though they may be invisible exteriorly and microscopic in size. In certain species they are present in the form of very minute spicules and imperforate plates and are confined to the sides of the ambulacral grooves, but usually they are more or less uniformly distributed throughout the integument of the disk showing, however, a strong tendency to become segregated, or at least most strongly developed, along the ambulacra and in the middle of the interambulacral areas, especially dorsal to the periphery of the ventral face. Almost invariably the calcareous deposits are more numerous and larger in the anal area than elsewhere, especially about the base of or on the anal tube, and frequently this is the only part of the disk where they are visible.

Speaking broadly, it may be said that among the macrophreate forms the disk is without noticeable calcareous deposits, while they are usually more or less evident in oligophreate species. There are, however, very numerous exceptions to this generalization.

Except for the side and covering plates the perisomic plates are usually confined to the disk, or at most do not extend beyond the outermost division 
series. Among the Thalassometridæ, however, there are several species in which the entire ventral brachial perisome is plated far out on the arms, more or less irregular plates being present between the ventral processes of adjacent brachials, and between the brachials and the side and covering plates.

As a rule, if the disk is well plated side and covering plates are also strongly developed, but there are several interesting exceptions to this, for instance in the families Zygometridæ, Himerometridæ, Mariametridæ, Colobometridæ, and Pentametrocrinidæ.

Completely plated disks are always entire, and always approach, as nearly as possible, a spherical form (figs. 734-737, p. 349). Partially plated disks, like naked disks, may assume any form.

No one has ever studied the disk in Atelecrinus (figs. 1163, 1164, pl. 26); it contains no deposits visible to the naked eye.

In the species of Pentametrocrinidæ no calcareous deposits are visible except in Pentametrocrinus semperi (fig. 1158, pl. 25) and in $P$. atlanticus, in which the disk is well covered with a pavement of small rounded plates. In the young of Thaumatocrinus renovatus (part 1, fig. 117, p. 183) the perisome between the interradials and the orals is completely covered with plates, as in the young of Comatilia iridometriformis (part 1, pl. 2, fig. 529) and of Comactinia meridionalis, but as in these comasterids these plates appear to be resorbed.

In the species of the family Antedonidæ the disk is naked except in three genera. In the curious genus Erythrometra (figs. 666, 667, p. 329) the disk is usually naked on the ventral surface, but the lateral interradial areas bear two or three columns of rounded interradial perisomic plates which are not in contact either with each other or with the adjacent plates of the primary series, and there are usually additional plates between the first two brachials of the arms of each pair. Antedon bifida possesses a naked disk, but very frequently there are small clusters of perisomic plates in the lateral interradial (interprimibrachial) spaces just above the sutures between the radials, which collectively appear as single interradial plates (figs. 1145,1146, pl. 23), while in Antedon petasus (fig. 747, p. 349 ), and in the genus Mastigometra (fig. 750, p. 349 ), in addition to these comparatively large scattered calcareous nodules are often found on the ventral surface of the disk in the interradial areas, more particularly in the anal area. Antedon mediterranea and $A$. adriatica (fig. 757 , p. 349 ) have the entire perisome usually without visible deposits.

In the families Thalassometridæ (figs. $738-745$, p. 349) and Charitometridæ (figs. 746, p. 349, and 1159-1161, pl. 26) the disk is usually well protected by small approximately uniform more or less rounded plates, the sides of the ambulacral grooves being always furnished with a double row of smaller irregular plates set very close together. While frequently in these families the plates in the interambulacral areas form a solid pavement which, indeed, often extends outward all along the perisome of the arms, they are commonly somewhat isolated from each other and, in some cases, may be widely scattered. The plating found in the Charitometridæ is as a rule rather more highly developed than that found in the 
Thalassometridæ, where the interambulacral areas of the disk commonly contain well-separated and often widely scattered plates. It is in the latter family, however, that the most perfect plating of the brachial perisome occurs. In Stylometra (fig. 743, p. 349 ) the perisomic plates are more or less conical and have a spinous appearance, a condition which is carried even further in Precilometra (fig. 1161, pl. 26), though here the pointed ends are not so sharp.

The Calometridæ (figs. 734-737, p. 349) possess the most substantial plating found in the recent crinoids, the plates being large and firmly united with each other, so that the visceral mass is inclosed in a solid inflexible dome. This plating is characteristic of the family and is developed at a very early age. It causes the visceral mass to present a globular appearance which, on account of the rigidity of the structure, is not affected by shrinkage in alcohol, so that a detached disk of any of the species of this family is recognizable at sight. The calcareous plating of the disk in the Calometridæ is quite superficial, and it is firmly attached to the subjacent soft structures only along the ambulacra, so that shrinkage on preserration merely causes the formation of cavities below the interambulacral areas of the plated vault without in any way altering the external shape. In certain species the dorsal angles of the lateral perisome just above the sutures between the radials are protected by plates which are rather smaller than those on the ventral surface, and each of these plates rises into a sharp conical protuberance (fig. 736, p. 349) like the plates in Stylometra (fig. 743 , p. 349, though rather more regular in form.

In the disks of the species of the family Tropiometridæ (figs. 729-733, p. 346) no plating is ever visible.

The disks of the species of Colobometridæ (figs. 727, 728, p. 346) are usually unplated, but in Colobometra diadema (fig. 728, p. 346) a complete pavement is found, the interambulacral plates being especially large, while in $C$. vepretum (fig. 727, p. 346) there may be plates abont the base of the anal tube.

In the genera $Z$ ygometra (figs. 710,711, p. 346, and $1155-1157$, pl. 25) and Eudiocrinus (fig. 712 , p. 346 ) the disk is completely plated, much as in the Calometridæ (figs. 734-737, p. 349), though the plates are less closely united and usually somewhat smaller. In Catoptometra the plating is fairly complete, but is usually more or less undeveloped in the interambulacral areas.

Many, if not most, of the species belonging to the family Comasteridæ (figs. $685-709$, p. $341,1142,1144,1147,1148$, pl. $23,1149-1153$, pl. 24,1154, pl. 25 , and 1165 , pl. 26) develop large scattered irregularly rounded calcareous concretions in the interambulacral areas, more particularly in the anal area ; but, contrary to what is usually the case, these are commonly unaccompanied by prominent plates along the sides of the disk ambulacra. Occasionally these concretions become so abundant on and about the base of the anal tube as to form a fairly complete covering, though as a rule they are sparsely distributed.

In the Mariametridæ (figs. $719-725$, p. 346) there is no plating visible on the disk except in the genus Mariametra (figs. 721-723, p. 346). In this genus the disk is strongly plated and may be entirely covered by a pavement of small plates. The disk in Pontiometra (figs. 724,725, p. 346) appears naked, and for systematic 


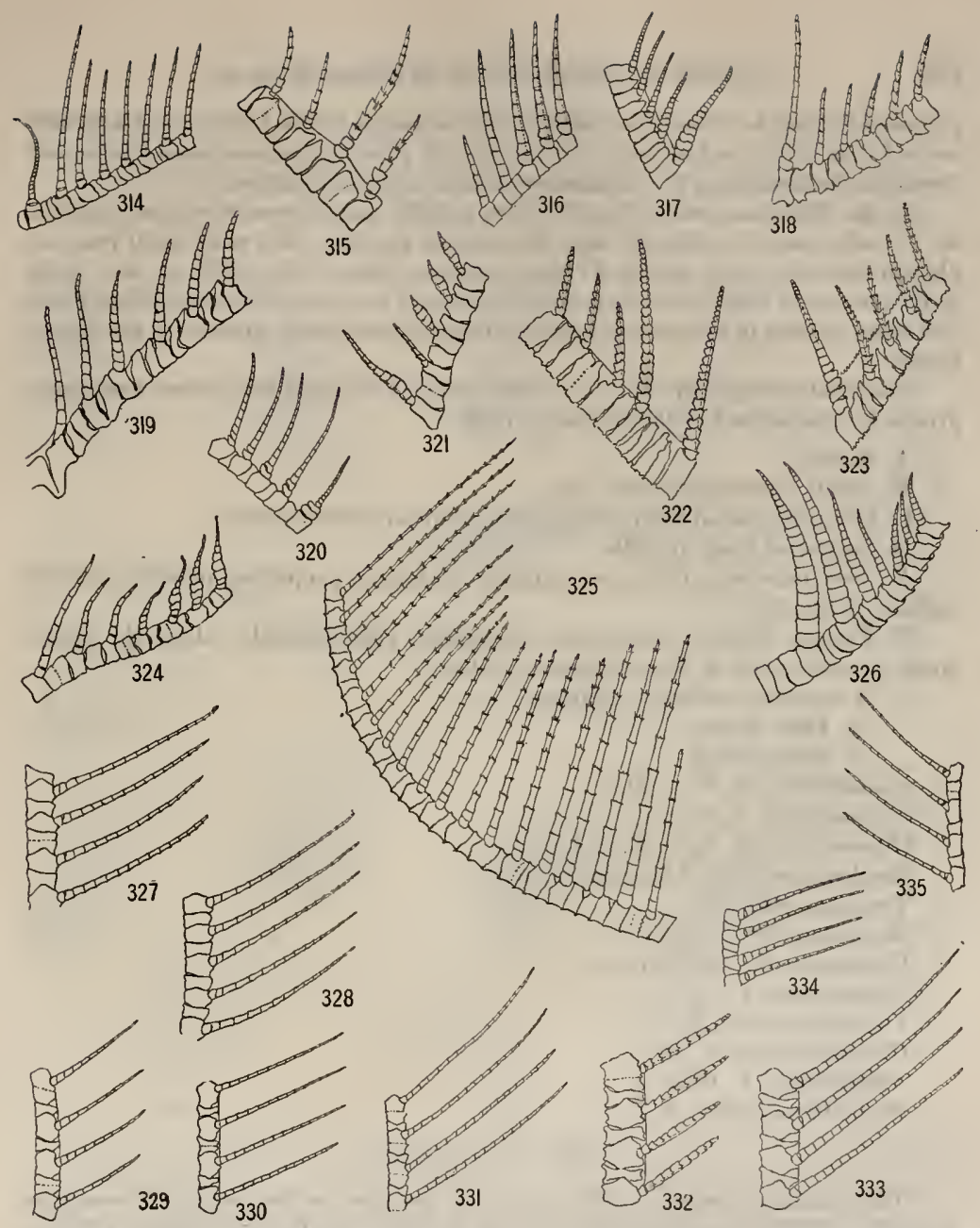

Figs. 314-335.-Proximal and middle pinnules of various comatulids, 314. Proximal pinnules of Neometra multicolor. 315. Proximal pinnules of Oligometra serripinva (AFTer Chadick). 316. Proximal pinneles of Ptilometra mullers. 317. Proximal pinnules of thalassometra pubescens. 318. Proximal pinneles of Strlometra spinifera. 319. Proximat pinneles of probometra diomedex. 320. Proximal pinnules of Calometra callista, 321. Proximal pinneles of

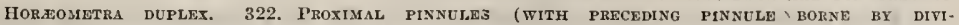
sion series) of Oceanometra gigantel. 323. Proxishal pingules of thalassometra villosa. 324. Proximal pinneles of Austrometra thetidis. 325. Proximal pinnules of Coloiometra diadeala. 326. Proximal pinnules of Himerometra martensi. 327. Middel pinneles of Prometra owstoni. 328. Middin pinvules of Iridometra adrestine. 329. Lowen middle pinxeles of

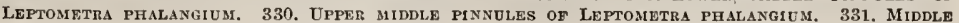
Pinnules of Coccometra hagenit. 332. Middle pinnules of Oceanometra gigantea. 333. Middle pinnules of Florometra asperrima. 334. Middle pinveles of Calometra callista. 335. Middi. PINALLES OF COMPSOMETRA SERRATA. 
purposes it must be classed as naked; but it is rough to the touch, and Carpenter noticed that when touched with acid the disk of Pontiometra andersoni effervesced strongly, demonstrating the abundance of lime in its composition.

In the Himerometridæ (figs. 713-718, p. 346) certain species of Amphimetra, as $A$. ensifer and $A$. schlegelii, have the cutis of the disk filled with small rounded plates resembling those seen in Pentametrocrinus semperi (fig. 1158, pl. 25), while in Himerometra (figs. $713-715$, p. 346) larger and more scattered concretions much like those present in certain comasterids are sometimes found situated in the deeper layers.

The relationships between the several types of disk and the various systematic groups is summarized in the following table:

A. Naked.

B. Small interradial plates only.

C. Complete dorsal interradial plating, but no ventral plates.

D. Scattered thick nodules.

E. Very numerous, thin, noncontiguous plates, not projecting above the general surface of the disk.

F. Larger, thicker, conspicuous, projecting, and, especially along the ambulacral grooves, more or less contiguous plates.

G. A complete perisomic plating.

a. Disk entire.

b. Disk incised.

Comasteridæ, A, B, C, D, $a$.

Zygometridæ, F, G, $a, b$.

Himerometridæ, A, D, E, $a, b$.

Stephanometridæ; Atelecrinidæ, A, $b$.

Tropiometridæ, A, $a$.

Mariametridæ, A, F, G, $b$.

Colobometridx, A, F, G, $a, b$.

Calometridæ, G, $a$.

Thalassometridæ, $\mathrm{F}, b$.

Charitometridæ, F, G, $b$.

Antedonidæ, A, B, D, a.

Pentametrocrinidæ, A, E, $b$.

Side and covering plates.

The perisomic skeleton of the arms and pinnules in the comatulids was first noticed in 1866 in Antedon bifida (pl. 50, fig. 1335) by W. B. Carpenter; in this species, however, it disappears before the adult stage is reached.

In 1868 Michael Sars described the characteristic rods in the ambulacral lappets of Hathrometra sarsii (fig. 1174, pl. 27).

In a semipopular article published in $1880 \mathrm{P}$. H. Carpenter figured highly developed side and covering plates comparable to those of the pentacrinites which he had found in a new comatulid (subsequently called accla) dredged by the 
Challenger. In 1881 he described similar plates in Stylometra spinifera, and in 1884 in Thalassometra lusitanica.

In his memoir on the stalked crinoids of the Challenger expedition published in 1884 Carpenter wrote that the margins of the ambulacra of the disk, arms,

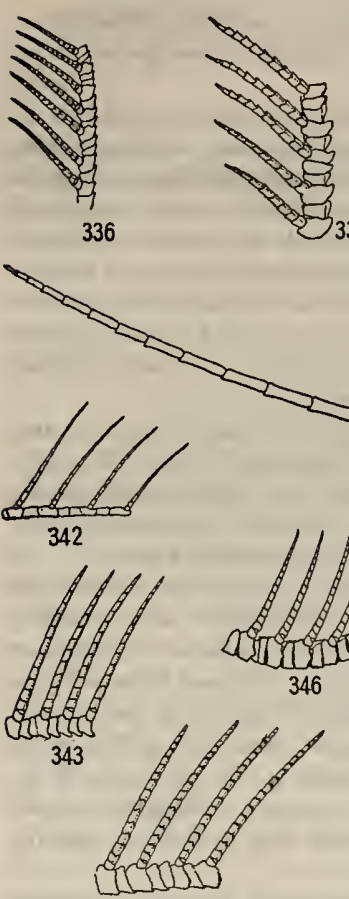

344
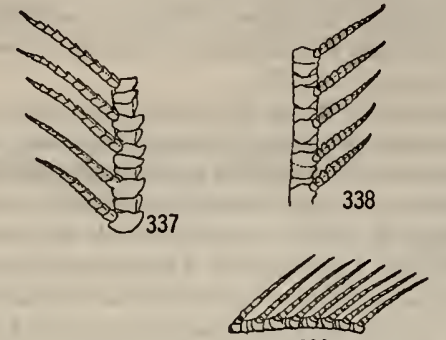

339

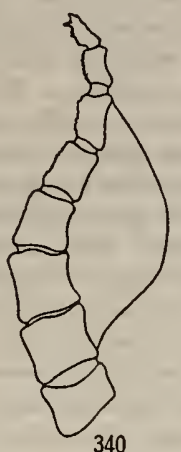

340

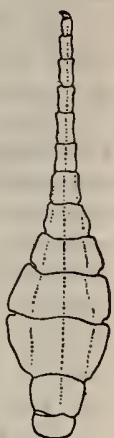

341

345
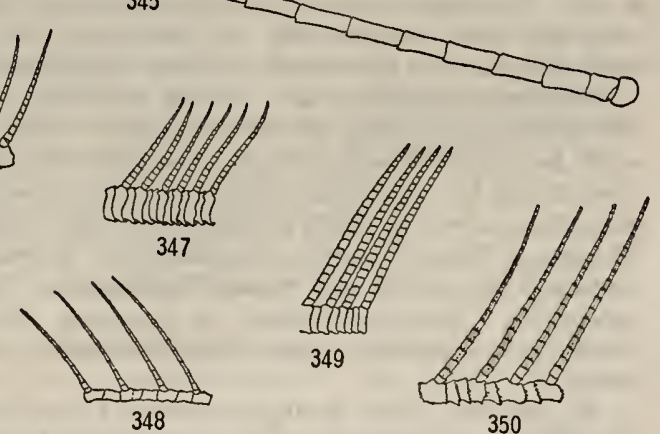

350

Fros. 336-350,-Pinndles of variods comatulids, 336. Midde pinneles of Neometra multicolor. 337. MIDDLe PINNules of Strlometra spinifera. 338. MiddLe PiNNules of Thalassometra pUbescens. 339. Distal pinNules of Neometra multicolor, 340. ABout thi Ninth PINNULE Oy Austrometra thetidis. 341. Dorsal view of gBnital pinnule of austrometra thetidis. 342. Distal pinnules of Compsometra serrata. 343. Distal pinneles of Ptilometra mulleri. 344. Distal pinntles of Ochanodetra gieantea, 345. Distal pinNule of heliometra olacialts. 346. Distal pinNules of LaMprometra gyges. 347. Distal pinnules of Himbiometra martensi. 348. Distal pinnules of Prosietra owstoni. 349. Distal pinnules of Amphimetra discoldDa. 350. Distal pinNUleg OF ThalassometBa villosa.

and pinnules are rarely, if ever, perfectly free from any traces of calcareous structures; they may take the form of simple short spicules, which are almost entirely limited to the marginal lappets, or they may be forked and branching spicules or rounded cribriform plates of variable size which are movable and 
can be everted or closed down over the grooves. At the same time he figured the highly developed side and covering plates in Pocilometra acoela (fig. 1169, pl. 27), Perissometra angusticalyx, Aglaometra incerta (fig. 1166, pl. 27), Pachylometra incequalis (fig. 1168, pl. 27), and Charitometra basicurva (fig. 1167, pl. 27), species collected by the Challenger and described in 1888.

In 1886 Carpenter found highly developed side and covering plates in an arctic species which he called Antedon barentsi, and which since has proved to be an inconstant variation of Heliometra glacialis.

In his memoir on the comatulids of the Challenger expedition published in 1888 Carpenter used the occurrence of highly developed side and covering plates as the chief criterion for systematic differentiation in the multibrachiate endocyclic types and as a secondary character of the highest importance in the 10-armed endocyclic forms. But, excepting in those species in which they are very highly developed, belonging to the families Calometridæ, Thalassometridæ, and Charitometridæ, he does not mention the ambulacral armament at all, and even in them his figures and descriptions appear to have been based upon dried material, there being no evidence that he ever isolated and studied the plates. Carpenter denied the existence of an ambulacral skeleton in the Comasteridæ.

Dr. Clemens Hartlaub in 1895 described in detail and figured the side and covering plates in a new species of Thalassometra, Th. agassizii (figs. 1171, 1172, pl. 27). The figure, drawn from material trented with hot caustic potash, shows large side plates parallel with the borders of the pinnulars, alternating with small side plates at right angles to these which bear the covering plates.

Hartlaub suggested a new division of the species of the genus Antedon as then understood, placing all the forms with "plated ambulacra" in one series, which he called Series I, and all those with "unplated ambulacra" in another series, Series II. But in his Series I he puts Carpenter's "Elegans Group" (the genus $Z$ ygometra), in which the ambulacra are "unplated" and also Carpenter's "Basicurva Group," which, as outlined by Carpenter, contains species with "unplated" as well as with "plated" ambulacra. Similarly, in lis Series II he includes the "Eschrichti Group" of Carpenter (Heliometra, Solanometra, and Florometra) containing species which occasionally have the ambulacra heavily plated.

In 1902, Mr. Frank Springer described a new comasterid, Nemaster iowensis, from Florida, in which the ambulacra are bordered with highly developed covering plates, a feature not hitherto noticed in the family.

Dr. Th. Mortensen in 1903 described and figured large and well-formed ambulacral plates in a specimen of Heliometra glacialis from East Greenland, as well as the ambulacral rods of Hathrometra prolixa. In 1910 he described and figured another type of ambulacral rod in IIathrometra prolixa, as well as the spicules in the tentacles; and in 1918 he described the side and covering plates and the spicules in the tentacles in Notocrinus virilis (figs. 1329, 1330, pl. 49) and Isometra vivipara (figs. 1328, 1331, pl. 49) and determined the complete absence of both types of deposits in Thaumatometra nutrix.

The description of the ambulacral armature and of the spiculation of the tentacles in a representative series of comatulids follows: 


\section{Family COMASTERIDA.}

Comatella nigra.-Excepting for a superficial layer of very numerous and very minute spicules no calcareous deposits could be detected in the thick ventral perisome.

No calcareous bodies were found in the tentacles.

Comatella stelligera.-The conditions are the same as in the preceding species.

Comatella maculata.-The conditions are the same as in the two preceding species.

Neocomatella pulchella (figs. 782 , p. 366 , and 792, p. 372 ).-Toward the distal end of the outer pinnules where they are most developed the calcareous deposits in the perisome of the pinnules are in the form of very thin and delicate calcareous films, one to each of the ambulacral lappets, very irregular in outline and considerably elongated at right angles to the pinnulars. The deposits usually, however, consist of a series of very slender and irregular forked or branched rods, in general lying at right angles to the edge of the pinnulars, intermingled with spicules, forming a layer of irregular spicules and rods. In the proximal two-thirds of the pinnules this layer is composed mainly of branched spicules more or less evenly spaced and with no definite orientation, forming an interrupted reticulation, but distally the spicules gradually give way to evenly spaced rods, two or three to a pinnular and at right angles to their borders.

Small spicules are present in the tentacles.

Neocomatella alata.-Toward the distal end of the outer pinnules, where they are most developed, the calcareous deposits are in the form of very thin and delicate calcareous films, very irregular in shape, rather large, somewhat longer at right angles to the pinnules than broad at the widest part. The deposits are usually reduced to a series of slender, irregular, branched or forked rods intermingled with spicules, forming an interrupted reticulation in the perisome of the pinnule which in their distal third gradually transforms into a series of more regular and evenly spaced rods at right angles to the pinnulars.

The tentacles contain irregular spicules and occasionally long and very narrow cribriform films.

Capillaster sentosa.-Except for numerous minute superficial spicules the ventral perisome of the arms and pinnules appears to be without calcareous deposits.

No spicules were detected in the tentacles.

Capillaster multiradiata.-Toward the ends of the distal pinnules the apices of the ambulacral lappets contain small calcareous films which may be continued downward toward the pinnulars in the form of very narrow extensions; the lateral perisome of the pinnules contains more or less regularly spaced rods standing at right angles to the borders of the pinnulars. In most pinnules no calcareous deposits could be found.

There appear to be no spicules in the tentacles.

Capillaster coccodistoma.-I was not able to find any calcareous deposits in the brachial or pinnular perisome of this species.

142140-21-Bull. 82-17 
There appear to be no deposits in the tentacles.

Nemaster grandis.-Each ambulacral lappet contains a large and conspicuous plate, very thin and delicate, triangular in shape with the outer apex rounded and somewhat produced. There are about three of these to a pinnular.

Nemaster iowensis.-Each ambulacral lappet contains a large and conspicuous triangular plate, there being about three of these to a pinnular.

It was in this species that an ambulacral skeleton was first noticed in the family Comasteridæ. The deposits were described and figured by Mr. Frank Springer in 1903.

Nemaster mubiginosa (fig. 781, p. 366).-Each ambulacral lappet contains a very thin and delicate conspicuous large, rounded, triangular plate, of which there are about three to a pinnular.

Nemaster discoidea.-I have been unable to detect any calcareous deposits in the brachial or pinnular perisome of this species.

Comissia peregrina.-There appear to be no calcareous deposits in the brachial or pinnular perisome of this species.

Comissia littkeni.-The lateral perisome of the pinnules in this species is almost naked, containing merely a few very slender and inconspicuous usually widely scattered spicules.

The spicules in the tentacles are very highly developed, forming a continuous layer along the outer side, reaching nearly to their tips.

Commisia littoralis.-The lateral perisome of the pinnules and the ambulacral lappets contain a great number of scattered minute spicules which become longer in the latter. In lateral view these spicules are seen to form bands from the lappets to the border of the pinnulars, where they intermingle with another band of very minute spicules running along the latter.

There are no spicules in the tentacles.

Leptonemaster venustus (fig. 783, p. 366).-In the lateral perisome of the pinnules are slender, very delicate, and more or less irregular, sometimes branched, rods, evenly spaced, lying at right angles to the border of the pinnulars, sometimes in groups of two or three, about three (or three groups) to a pinnular. Occasionally these become more numerous, forming a very loose and rudimentary narrow crescentic meshwork about the distal border of the marginal lappets.

The spicules in the tentacles are unusually abundant and often form along the distal side a continuous meshwork reaching nearly to the tip.

Comatonia cristata (fig. 790, p. 372).-The lateral perisome of the pinnules contains a series of straight and simple very slender rods leaning slightly distally, usually four to a pinnular, between the bases of which are the large and conspicuous sacculi.

The tentacles contain numerous extremely slender spicules, which may form a continuous layer along the outer side nearly or quite to the tip.

Comatilia iridometriformis (figs. 803-805, p. 378; see also figs. 763,764 , p. 353) - Large, conspicuous, and well-formed plates are present. five to each two pinnulars. These are considerably higher than the lateral diameter of the pin- 
nulars, extend outward and slightly distally, and are somewhat more than twice as long as broad and strongly constricted centrally, so that they appear as two similar circles joined by a broad neck. Their reticulation is very fine, and the borders are regular, though unfinished.

The integument over the genital glands contains irregular plates and spicules of various sizes, which are not in contact with each other.

The tentacles contain numerous spicules in the proximal portion.

Comatula rotalaria.-Along the ambulacral grooves, with their rounded ends filling the inner ends of the ambulacral lappets and their pointed ends toward the pinnulars, is a series of thin, but well and definitely formed, pumpkin-seed shaped plates, about four to each pinnular; between these and the pinnulars the lateral perisome of the pinnules is occupied by a very loose irregular network of long and slender spicules, which may toward the distal end of the pinnules broaden into irregular films several meshes wide; at the distal end of the pinnules the pumpkinseed shaped plates reach downward to the pinnulars.

Comatula solaris.-The ambulacral lappets are occupied by thin and filmy, but large and very definite, pumpkin-seed shaped plates, of which there are about four to a pinnular; between each of these and the pinnulars is a very narrow and irregular side plate standing at right angles to the pinnulars, on the outer end of which the point of the covering plate rests, which is sometimes resolved into a more or less loose mass of spicules.

Comatula pectinata.- In the middle of the free portion of each of the ambulacral lappets is a small plate with unfinished borders, composed of from 6 to 12 hexagonal meshes. The lateral perisome of the pinnules between the ambulacral lappets and the pinnulars contains only minute spicules.

In the tentacles spicules are very rare or entirely absent.

Comactinia meridionalis.-The ambulacral lappets in a specimen from Y ucatan are occupied by extremely thin and filmy plates, which may be of considerable size, though always irregular, completely filling them, or may be narrowed to a long, narrow, calcareous band from one to three meshes wide standing at right angles to the pinnulars.

In a specimen from South Carolina the ambulacral lappets contain a small group of spicules, which at the most form one or two meshes; between each of these and the border of the pinnulars is another, usually smaller, group of spicules; in some cases the two together may form merely a straight or irregular line or band of scattered spicules reaching from the lappet to the pinnulars.

There appear to be no deposits in the tentacles.

Comatulides australis.-There are no deposits in the ventral perisome of the pinnules, and none in the tentacles.

Comaster novoguinea.-The lateral perisome of the pinnules contains numerous large straight or branched spicules, which may form a continuous closely-set row along the margins of the pinnulars, with which they make a right angle, may form a loose spiculiferous band which is continued into the lappets, or may be collected in little groups, two or three groups to a pinnular. 
The tentacles contain a conspicuous and continuous layer of spicules along their outer side, which reaches nearly to the tips.

Comaster minimus.-There appear to be no calcareous depsits in the ventral perisome of the pinnules.

There appear to be few or no spicules in the tentacles.

Comaster multibrachiata.-The ambulacral lappets may contain very small plates, with unfinished edges, composed of from 6 to 12 meshes, which may be rounded or more or less irregularly elongated toward the pinnulars; but usually perisomic deposits appear to be absent.

The perisome of the nontentacular pinnules contains numerous small rounded plates, and quantities of minute rods and spicules.

The tentacles contain a very conspicuous layer of spicules, which are at first branched, later becoming simple and distally minute, which continues along the outer side nearly to the tips.

Comaster fruticosus.-The lateral perisome of the pinnules contains irregular rods at right angles to the pinnulars, three to each, or is quite without deposits.

The tentacles contain a continuous layer of small spicules which at first are branched, later becoming simple and distally very minute, which extends along their outer side nearly to the tips; on account of the almost or quite complete absence of other deposits these tentacular deposits are very conspicuous.

Comaster distincta-There appear to be no deposits in the lateral and ventral perisome of the pinnules.

The genital glands are completely covered by large thin filmy plates.

The tentacles contain a continuous layer of spicules, at first branched, later becoming simple, and then minute, which reaches nearly to their tips.

Comaster parvus.-The lateral perisome of the pinnules contains small and widely scattered spicules.

The tentacles contain a continuous layer of spicules, which runs along their outer sides nearly to their tips.

Comaster taviana.-Beyond a few widely scattered and inconspicuous spicules along the borders of the pinnulars the perisome of the pinnules appears to be without deposits.

A continuous band of very small spicules runs along the outer side of the tentacles almost to their tips.

Comaster delicata.-On some pinnules the lateral perisome contains evenly spaced spicules, usually standing at right angles to the pinnulars, but for the most part the perisome is without calcareous deposits.

On their outer side the tentacles contain a continuous layer of very small spicules, which reaches nearly to their tips.

Comantheria briareus.-There appear to be no deposits in the ventral perisome of the pinnules.

A few of the tentacles, in the terminal pinnules and in the distal part of the others, contain spicules near their bases.

Comantheria polyonemis.-There appear to be no deposits in the ventral perisome of the pinnules. 


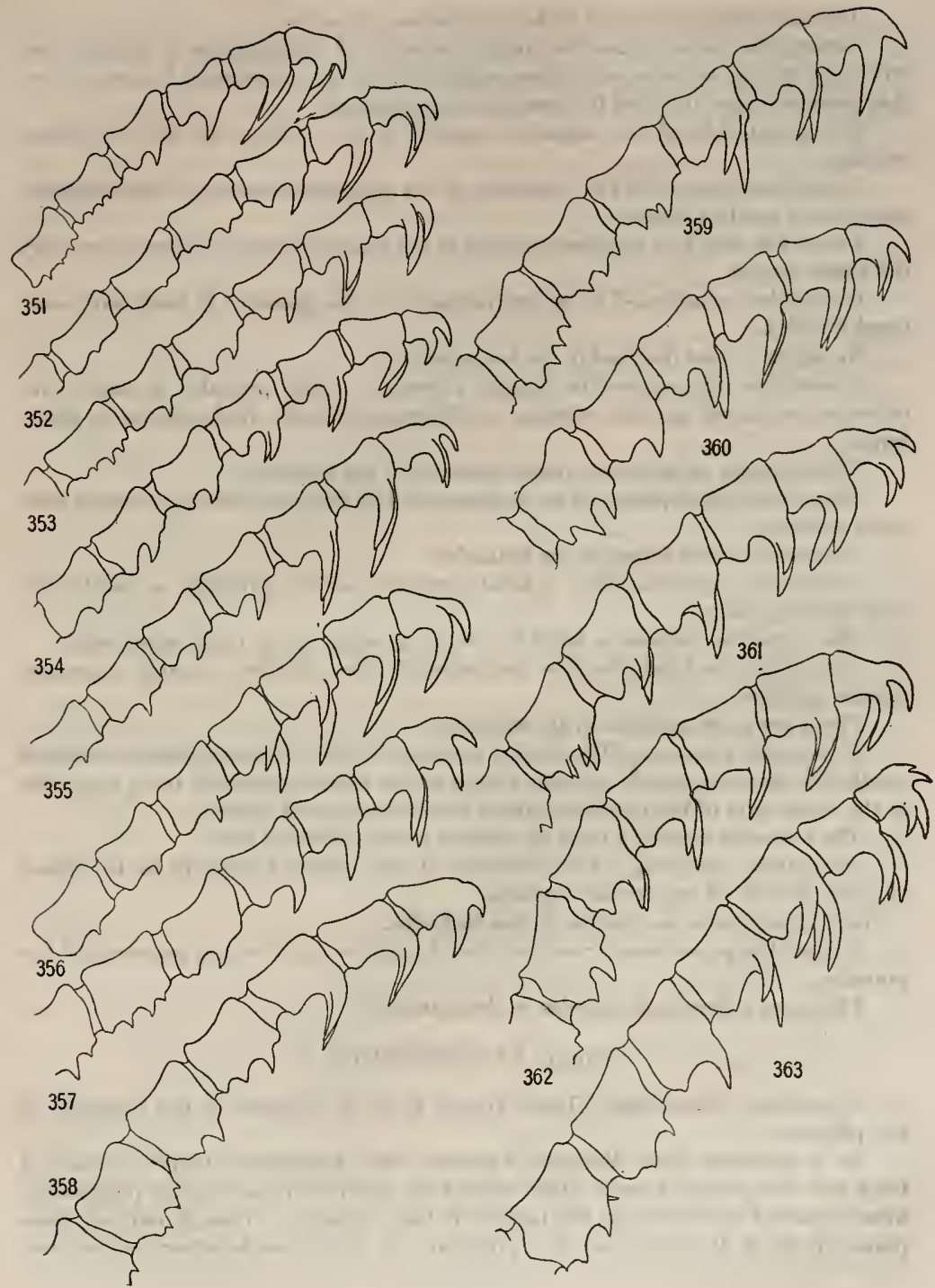

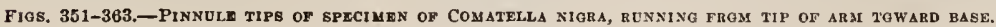


The tentacles appear to be without calcareous deposits.

Comanthina schlegelii.-The lateral perisome of the pinnules is thickly beset with very minute spicules, which are continued into the ambulacral lappets, where they become larger and tend to form loose aggregations.

The distal side of the tentacles contains a thin continuous line of minute spicules.

Comanthus pinguis.--The perisome of the pinnules contains a few scattered, mostly very small, spicules.

I have not been able to detect spicules in the tentacles, which, however, are very thick and opaque.

Conanthus solaster.-The lateral perisome of the pinnules is beset with scattered spicules.

No deposits were detected in the tentacles.

Comanthus japonica.-The lateral perisome of the pinnules is beset with numerous scattered spicules varying, in different pinnules, from minute to fairly large.

There appear to be no calcareous deposits in the tentacles.

Comanthus trichoptera.-The perisome of the pinnules contains minute scattered spicules.

No spicules were found in the tentacles.

Comanthus benhami.-The lateral perisome of the pinnules is beset with very small spicules.

The tentacles contain a band of small spicules along their outer side.

Comanthus wahlbergii.-The perisome of the pinnules contains numerous minute spicules.

There are a few spicules in the tentacles.

Comanthus samoana.-The lateral perisome of the pinnules contains scattered needle-like spicules, mostly at right angles to the pinnulars, which may, especially in the distal part of the pinnules, extend into the marginal lappets.

The tentacles contain a band of spicules along the distal side.

Comanthus annulata. - The perisome of the pinnules appears to be almost or quite devoid of calcareous deposits.

There appear to be no spicules in the tentacles.

Comanthus parvicirra.-Small scattered spicules occur in the perisome of the pinnules.

There are a few small spicules in the tentacles.

\section{Family ZYGOMETRIDAE.}

Zygometra microdiscus.-There appear to be no deposits in the perisome of the pinnules.

In a specimen from Western Australia each ambulacral lappet contains a thick and conspicuous narrow plate which runs downward and slightly proximally, often tapering somewhat, to the border of the pinnulars. Though narrow, these plates, of which there are four to a pinnular, are quite close together, so that they 


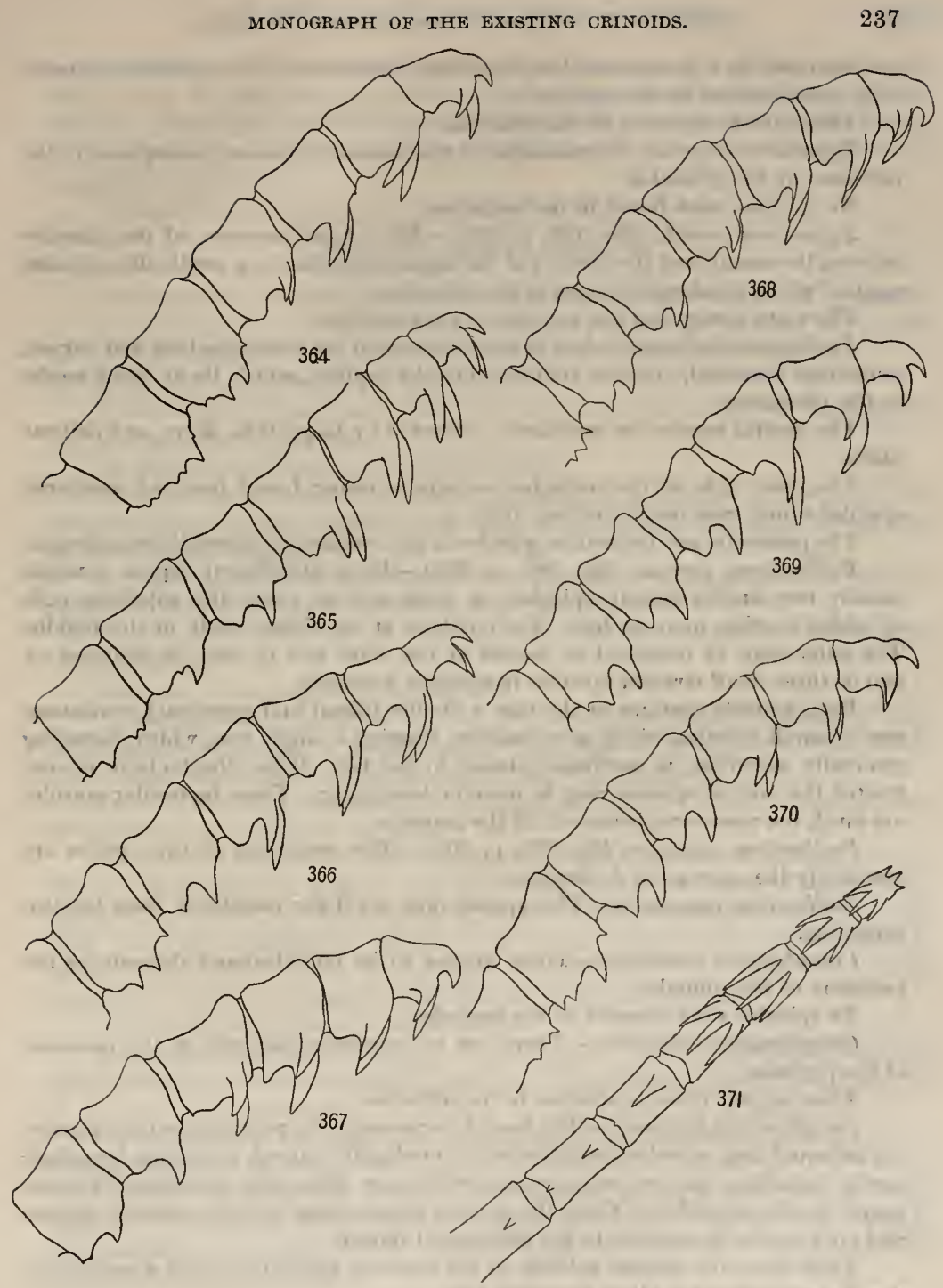

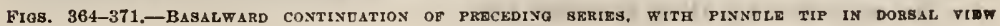
(FiG. 371). 
are separated by a space much less than their own width. This condition appears to be very unusual in this species.

There are no spicules in the tentacles.

Zygometra elegans.-Examination of two specimens showed no doposits in the perisome of the pinnules.

No spicules were found in the tentacles.

Zygometra comata (fig. 779, p. 366).-The lateral perisome of the pinnules between the sacculi and the borders of the lappets contains long needle-like spicules, most of which lie at right angles to the pinnulars.

There are a very few fine spicules in the tentacles.

Eudiocrinus indivisus.-Just beyond the sacculi are numerous long and curved, sometimes branched, spicules running into the lappets, which lie at right angles to the pinnulars.

The genital organs are completely protected by large, thin, filmy, and delicate plates.

The outer side of the tentacles contains a rather broad band of interlaced spicules which runs nearly to their tips.

The perisomic and tentacular spicules in this species are unusually conspicuous.

Eudiocrinus junceus (fig. 788, p. 366).-Each ambulacral lappet contains usually two similar smooth spicules, an outer and an inner, the adjoining ends of which overlap more or less. Each is bent at an obtuse angle in the middle. The outer may be branched or forked at the outer end or may be replaced by two or three small straight spicules irregularly arranged.

Each tentacle contains at the base a double (distal and proximal) continuous row of small spicules, which soon coalesce, forming a single row, which, becoming gradually narrower, is continued almost to the tip. When the tentacle is contracted this row of spicules may be more or less zigzag. These tentacular spicules are much the most conspicuous of all the deposits.

Eudiocrinus pinnatus (fig. 787 , p. 366).-The conditions in this species are essentially the same as in $E$. junceus.

Eudiocrinus venustulus.-This species does not differ essentially from the two preceding.

Catoptometra magnifica.-There appear to be no calcareous deposits in the perisome of the pinnules.

No spicules were detected in the tentacles.

Catoptometra rubrofava.-There are no calcareous deposits in the perisome of the pinnules.

There appear to be no spicules in the tentacles.

Catoptometra hartlaubi.-The lateral perisome of the pinnules contains numerous subequal long spicules, usually straight or slightly curred, sometimes branched, rarely including one or two meshes, which run from the ambulacral lappets nearly to the pinnulars. Over the genital glands these spicules become shorter and are practically confined to the ambulacral lappets.

There are a few slender spicules in the tentacles which may form a continuous row for some distance along the outer side. 
Catoptometra ophiura.-Each ambulacral lappet contains a single long spicule, which from its inner end curves very gradually toward the distal end of the pinnule. These spicules, which extend from the outer border of the lappets nearly to the pinnulars, running near the proximal borders of the sacculi, are usually roughened at each end.

No deposits were found in the perisome over the genital organs.

\section{Family HIMEROMETRID无.}

Himerometra martensi.-At the end of the outer pinnules there are occasionally to be found slender, straight spicules extending from the lappets inward to between the sacculi. Except for these there are no perisomic deposits.

There are no spicules in the tentacles.

Himerometra magnipinna.-There appear to be no calcareous deposits in the perisome of the pinnules.

No deposits could be found in the tentacles.

Himerometra bartschi.-The lateral perisome of the pinnules contains a row of closely placed rough spicules which stand at right angles to the pinnulars, two or three to each lappet.

In their proximal portion the tentacles have a very fine continuous band of spicules both on their proximal and on their distal sides.

Himerometra robustipinna.-There are no calcareous deposits in the perisome of the pinnules.

There are no deposits in the tentacles.

Craspedometra acuticirra.-Each of the ambulacral lappets contains a very small rudimentary plate of usually two or three meshes, rarely more, from which a continuous line of spicules runs downward toward the sacculi.

Each of the tentacles contains in its basal half two very fine continuous lines of spicules, a proximal and a distal.

Heterometra crenulata.-Each ambulacral lappet contains a relatively large, but extremely delicate, multiradiate spicule with from four to six (usually five) more or less curved branches radiating from a more or less complete hexagonal cell. The lateral perisome contains large and prominent spicules, usually two beneath each lappet, which, in general at right angles to the pinnulars, diverge proximally, so that a K-shaped or lambda-shaped figure is formed.

No deposits were found in the tentacles.

Heterometra savignii.-Near its tip each lappet usually contains a straight, less commonly forked or branched, more or less roughened spicule lying parallel to the edge of the pinnular.

Each tentacle in its basal third or half contains a proximal and a distal fine continuous line of spicules.

Heterometra philiberti._Each of the ambulacral lappets contains a small spicule, which is sometimes straight, but usually with four or five radiating branches and sometimes a central cell. The perisome between the row of sacculi and the pinnulars is without deposits. 
The tentacles contain two, a proximal and a distal, very narrow and delicate lines of spicules, which run to the end of the basal half or two-thirds. In a lateral view of the pinnule these appear as a closely set row of very narrow triangles with open distal apices.

Heterometra quinduplicava.-Each ambulacral lappet usually contains one or two extremely slender spicules, which usually extend, at right angles to the pinnulars, to near the sacculi; but there may be a branched spicule, or a net of one or two meshes.

The tentacles contain a continuous line of extremely slender spicules.

Heterometra bengalensis (fig. 796, p. 372).-Each ambulacral lappet contains a small spicule, which is Z-shaped, forked, multiradiate, or containing one or two meshes; if elongated, the elongation is parallel to the edge of the pinnulars; between each of these and the pinnulars there is usually a slender, straight spicule, at right angles to the pinnulars.

In their proximal half the tentacles contain two slender, continuous lines of spicules, one along the distal, the other along the proximal border.

Heterometra compta.-Near their tips the ambulacral lappets contain very minute calcareous reticulations of one, two, or three meshes. The perisome between the sacculi and the pinnules is unplated.

The tentacles contain two narrow lines of spicules. one distal and one proximal, which extend to about the end of their proximal half.

Heterometra pulchra.-The tips of the ambulacral lappets contain minute forked, branched, or multiradiate spicules. Beneath these are long, more or less irregular spicules, usually one over each sacculus. These lie at right angles to the pinnulars, and are sometimes forked or paired, or gathered into small groups.

There appear to be no spicules in the tentacles.

Heterometra reynaudii.-Near their tips the ambulacral lappets contain small spicules, which may be straight and parallel to the pinnulars, forked, or multiradiate. There are no deposits between the sacculi and the pinnulars.

Each tentacle contains a distal and a proximal fine continuous line of spicules, which runs for about half of its length.

Heterometra quinduplicava.-Near their tips the ambulacral lappets usually contain forked or branched spicules, which lie parallel with the pinnulars; sometimes these spicules are multiradiate, and sometimes they form one or two meshes; occasionally the lappets contain several long spicules lying at various angles. There may be other elongate spicules between these and the row of sacculi.

The tentacles contain two conspicuous fine lines of spicules, a distal and a proximal, which run for about half their length.

Homalometra denticulata.-Each ambulacral lappet contains a very slender branched, triradiate or quadriradiate spicule lying parallel to the edge of the pinnulars; below this is a long straight spicule reaching nearly to the border of the pinnulars; in addition to the latter the lateral perisome of the pinnules contains a series of long spicules, the majority of which lie at right angles to the edge of the 
pinnulars or lean slightly distally, forming a wide meshed irregular and interrupted reticulation.

There are no spicules in the tentacles.

Amphimetra spectabilis.-There are no calcareous deposits in the perisome of the pinnules.

There appear to be no deposits in the tentacles.

Amphimetra discoidea (fig. 791, p. 372).-Each ambulacral lappet contains a long but very narrow, very delicate plate, with unfinished borders, which lies at right angles to the pinnulars. These are sometimes reduced to extremely narrow plates, or even to straight roughened rods, just within the distal border of the lappets. In the distal portion of the pinnules these may become broader and more rounded.

The perisome between the line of sacculi and the pinnulars contains a series of irregular filmy longitudinally elongate plates of various sizes, sometimes quite large and sometimes of only one or two meshes, which form an interrupted line just beneath the line of sacculi; sometimes these form a broad continuous double band. and occasionally they are much reduced in size and widely scattered over the perisome.

The presence of spicules in the tentacles could not be determined.

Amphimetra parilis.-Each of the ambulacral lappets contains usually three long very slender spicules, the two outer, running along the sides, slightly curved, the distal much more than the proximal, and curving toward each other outwardly, the other more irregular, and sometimes forked; in a lateral view of the pinnule these appear as a rather closely set row of long spicules distally curved in opposite directions, reaching downward nearly to the sacculi. Sometimes these spicules may branch inwardly and these branches overlap, forming a narrow and long plate within the lappet; in this case minute rounded plates alternating with them are found between their bases over the spaces between the sacculi.

The perisome over the genital glands is without calcareous deposits.

The tentacles have a rather broad continuous layer of small spicules along the distal side.

Amphimetra papuensis.-Each of the ambulacral lappets contains a single straight roughened rod, which leans slightly distally.

The perisome between the sacculi and the pinnulars contains at intervals delicate filmy plates of from 6 to 15 meshes, which are usually more or less elongated in the direction parallel to the edges of the pinnulars.

There appear to be no deposits in the tentacles.

\section{Family STEPHANOMETRIDE.}

Stephanometra monacantha.-The perisome of the pinnules is without deposits. There are no deposits in the tentacles.

Stephanometra echinus.-The perisome of the pinnules contains only extremely minute scattered spicules.

The tentacles contain inconspicuous proximal and distal lines of spicules. 


\section{Family MARIAMETRID E.}

Pontiometra andersoni (fig. 798, p. 372).-In the lateral perisome of the pinnules is a continuous row of conspicuous plates, trapezoidal in shape, with the angles rounded, their distal sides being nearly half again as long as their proximal; a thickened ridge traverses the plates diagonally from the produced distal outer to the proximal inner angle; the distal border of each plate overlaps the proximal border of the following. On some pinnules these plates are reduced to a row of diagonally placed narrow triangles, which may be so narrowed as to almost resemble rods. Though forming a very conspicuous band, these plates are only of moderate size, their height in lateral view being about one-third the diameter of the pinnulars.

Beyond the apex of each of these is a very minute plate of from 6 to 12 meshes, which is elongated in a direction at right angles to the pinnulars.

The perisome between the sacculi and the brachials is without deposits.

No deposits were found in the tentacles.

Oxymetra finschii.-In one specimen, a cotype, no deposits were found in the perisome of the pinnules.

In another the lateral perisome of the pinnules contains a row of moderately long straight spicules, one near each sacculus, extending outward and slightly distalward from between the sacculi.

In the first the tentacles were quite without deposits; in the second there were occasionally a few spicules along the distal side in the proximal portion.

Oxymetra aranea.-Near the tip of the lappets is a minute forked or branched or multiradiate spicule, which may inclose a single cell; between these and the row of sacculi there may be single very slender straight spicules extending outward and slightly distally in reference to the pinnulars. On many pinnules the perisome of the pinnules appears to be quite without deposits.

The perisome between the row of sacculi and the pinnulars is almost completely covered by large irregular filmy plates.

In about their proximal third the tentacles contain two very fine continuous lines of spicules, a proximal and a distal.

Dichrometra citiata.-Each ambulacral lappet contains two long straight or slightly converging spicules, which extend downward nearly to the row of sacculi.

Each tentacle contains, running along the distal side for about two-third of the distance to the tip, a broad band of small matted spicules.

Dichrometra flagellata.-There are no deposits in the perisome of the pinnules.

There are no deposits in the tentacles.

Dichrometra döderleini.-Each of the ambulacral lappets contains a long curved spicule, with the convexity distally, which runs near the distal border down to near the row of sacculi. Rarely there may be one or two additional spicules irregularly placed.

Occasionally the tentacles contain a few very small spicules.

Mariametra subcarinata.-The perisome of the pinnules contains a few widely scattered irregular minute spicules. 

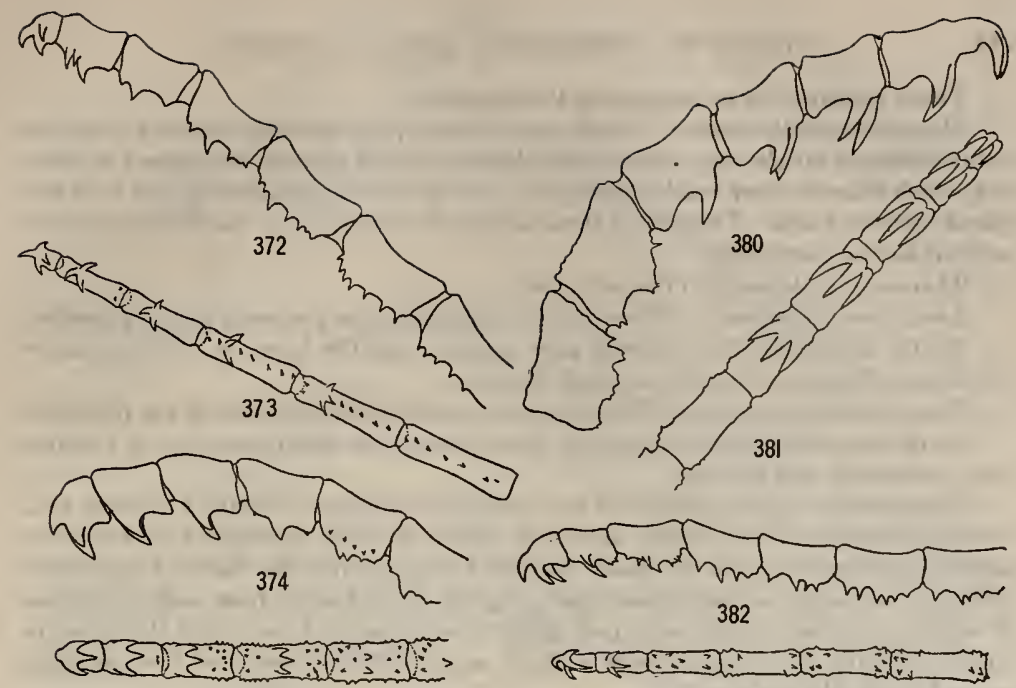

375

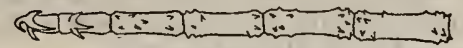

383
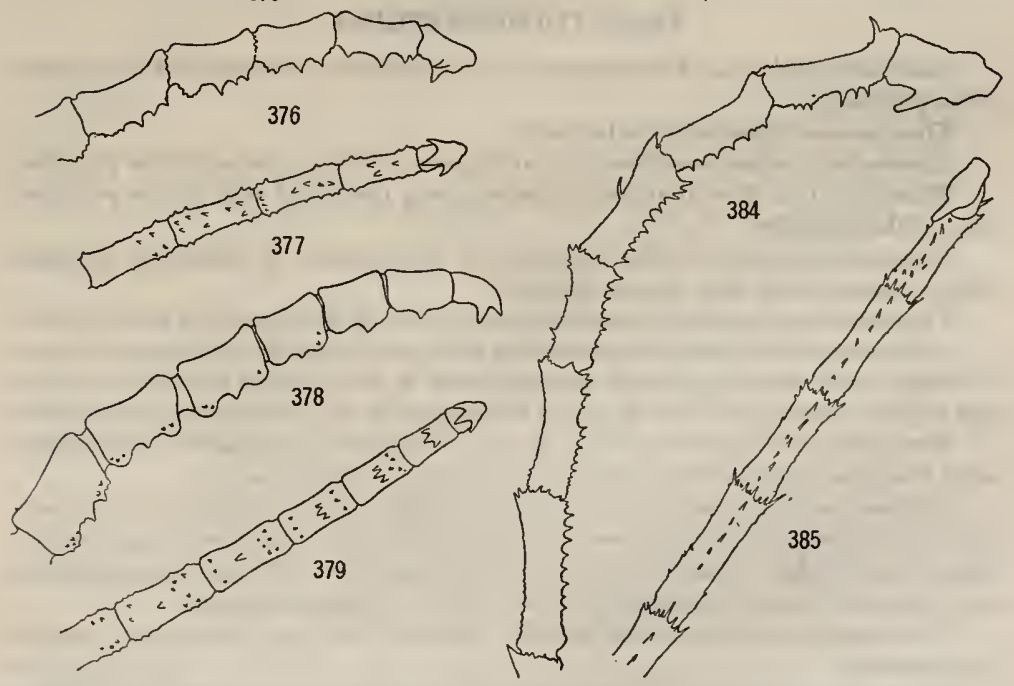

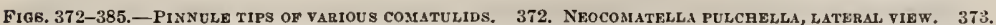
SaMe, doksal view. 374. Capillaster sentosa, lateral View. 375. Same, dobsal view. 376. Capillaster sminsa, latreal view. 377. SAME, doBsal View. 378. Capillaster multiradiata, lateral view. 379. SAME, dorsal view. 380. Nemaster iowensis, lateral view. 381. SaMe, DORSAL view. 382. Nemaster rUbiginosa, lateral view 383. Saie, dorsal view. 384. NeMasteb Discoidea, LATERAL VTEW. 385. SAME, DORSAL VIEW. 
There appear to be no spicules in the tentacles.

Mariametra delicatissima.-Each ambulacral lappet contains, running along its distal border, a single very slender and slightly curved spicule, roughened at each end, which extends downward almost to the line of sacculi, terminating just over the spaces between them. Frequently these are much reduced, and sometimes they are only evident as short rods.

There are no deposits in the tentacles.

Lamprometra palmata.-There are no spicules in the perisome of the pinnules.

On the distal side the tentacles may contain near the base one or two minute spicules, or they may be quite without deposits.

Lamprometra protectus.-There are no deposits in the perisome of the pinnules.

At the base the tentacles contain a conspicuous thin continuous row of spicules both proximally and distally.

Lamprometra gyges.-Each of the ambulacral lappets contains a slender rod, usually slightly curved, rarely branched, which extends downward to near the sacculi, terminating above the spaces between them; between the bases of these rods there are commonly two other short rods, slightly curved away from each other, one of which, proximal to the main rod, slightly overlaps its base, while the other is directed distally and, making only a slight angle with the border of the pinnular, passes beneath the main rod.

\section{Family COLOBOMETRID $巴$.}

Cenometra delicata.-There appear to be no calcareous deposits in the perisome of the pinnules.

There are no deposits in the tentacles.

Cenometra herdmani.-There are no deposits in the perisome of the pinnules.

There is a thin line of minute spicules along the distal side of the proximal third of the tentacles.

Cenometra unicornis.-The perisome of the pinnules is naked, or contains widely scattered and very minute spicules.

The tentacles occasionally contain a few spicules on the distal side near the base.

Cyllometra disciformis.-Occasionally there are found in the lappets spicules or straight rods which are almost perpendicular to the edges of the pinnulars, but lean slightly distally; usually there are no deposits in the perisome of the pinnules.

Along the proximal third or half of their distal side the tentacles contain a few small irregular spicules, which usually do not form a continuous row.

Cyllometra albopurpurea (figs. 776-778, p. 366).-Each ambulacral lappet contains an extremely fine, straight rod, reaching nearly to the line of sacculi, extending outward and slightly distally in reference to the pinnulars. On some pinnules these may be reduced to a minute spicule, or they may be altogether absent.

Occasionally minute spicules may be found on the distal side of the base of the tentacles.

Decametra taprobanes.-Each ambulacral lappet contains a single very slender straight rod, which may be forked at the tip, directed outward and slightly distal- 


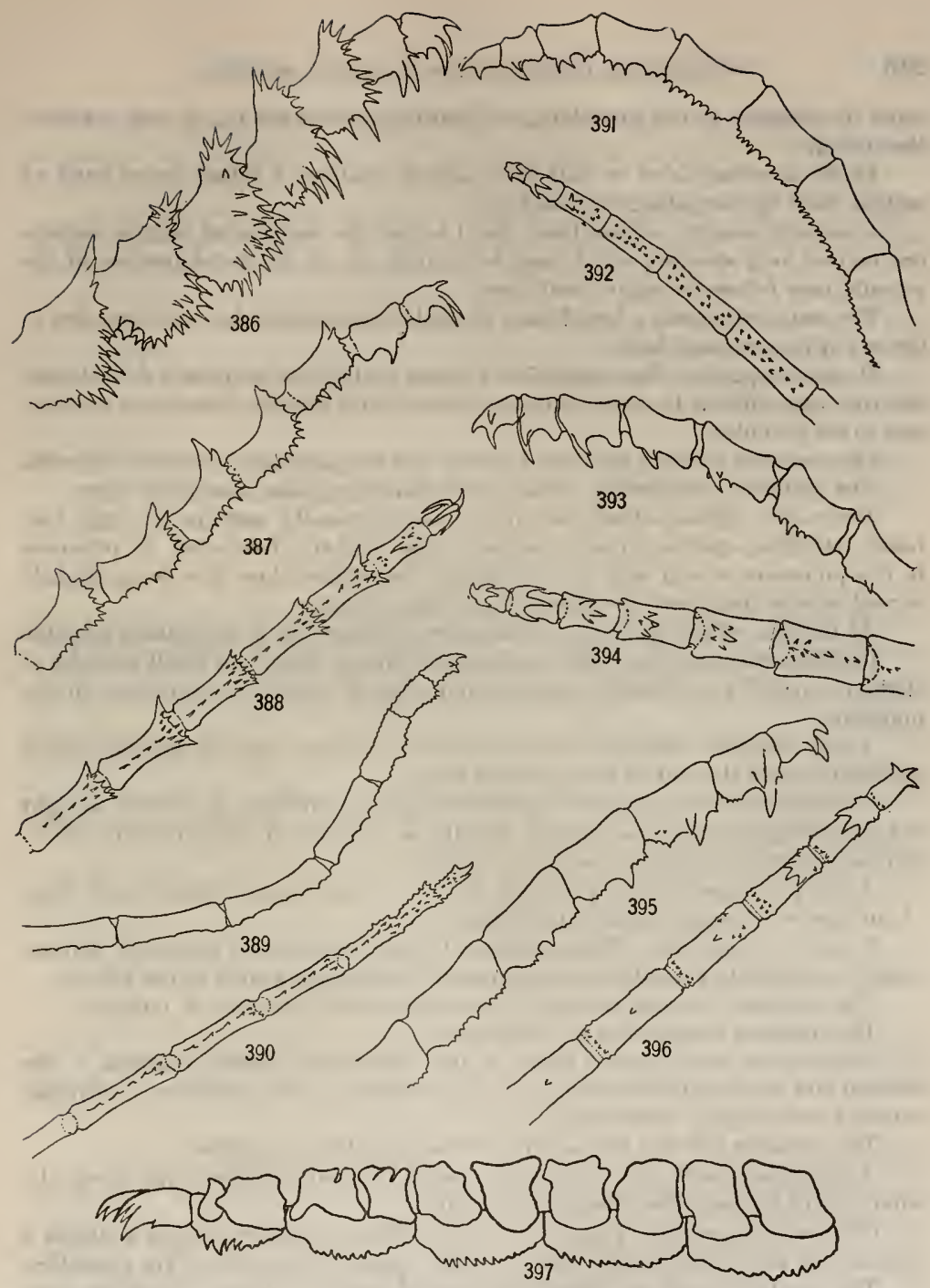

Fios. 386-397,-Pinnule tips of variods comatulids, 386. Comanthus pinouis, lateral view. 387.

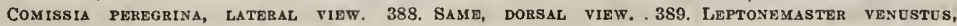
lateral View. 390. SAME, DOBSAL viEw. 391. Comatela rotalaria, lateral view. 392, SaMe, dorsal view. 393. Comatela solaris, lateral view. 394. Same, dorsal view. 395. Comatdla PBCTINATA, FROM ANTERIOR ARM, LATERAL VIEW. 396. SAME, DORSAL V1EW. 397. COMATILIA IRIDOMETRIFORMIS, WITH COVERING PLATES (DRATINO BY AUTHOR). 
ward in reference to the pinnulars, and reaching downward to, or even between, the sacculi.

In its proximal third or half each tentacle contains a rather broad band of matted small spicules along the distal side.

Decametra mylitta.- Near their distal border the ambulacral lappets contain one or two long spicules, which may be straight or, in the distal portion of the pinnule, may follow the outer distal curve.

The tentacles contain a broad band of thickly matted spicules, which reaches to the end of the proximal half.

Decametra parva.--Each ambulacral lappet contains an extremely delicate and fine rod, very difficult to detect, directed outward and slightly distalward in reference to the pinnulars.

The perisome between the line of sacculi and the pinnulars is without deposits.

The tentacles occasionally contain very minute spicules near their bases.

Decametra tigrina.--Each ambulacral lappet usually contains a single fine, nearly straight, spicule, directed outward and slightly distalward in reference to the pinnulars, which may be very short. Sometimes there is a long, slightly curved spicule along both the proximal and distal borders.

At the base of the tentacles on the outer side there are a few minute spicules.

Colobometra vepretum.-Each ambulacral lappet contains a small straight or slightly crooked rod directed outward and slightly distally in reference to the pinnulars.

Along the outer side the tentacles contain a median band of spicules, which reaches to about the end of the proximal half.

Colobometra discolor.-Each ambulacral lappet contains a narrow straight rod, extending outward and slightly distally in reference to the pinnulars, which reaches downward nearly to the line of sacculi.

Along the outer side each tentacle contains a continuous, rather broad, band of spicules which reaches nearly to its tip.

Prometra chadwicki.-Each ambulacral lappet contains an extremely delicate straight or slightly curved rod, which reached downward nearly to the sacculi.

The perisome between the line of sacculi and the pinnulars is unplated.

The tentacles contain few or no spicules.

Cotylometra gracilicirra.-Each of the ambulacral lappets contains a fine straight rod reaching to the sacculi, which, in reference to the pinnulars, is directed outward and slightly distalward.

The perisome between the sacculi and the pinnulars is unplated.

A continuous and very conspicuous band of small spicules runs along the outer side of the tentacles almost to their tips.

Oligometrides adeona (fig. 793, p. 372).-Each ambulacral lappet contains a very slender needle-like spicule, lying at right angles to the border of the pinnulars.

The genital glands are completely covered by filmy plates, which are very large along the line of sacculi, becoming small along the borders of the pinnulars. 
The proximal portion of the tentacles contains a dense mass of spicules, which appears as a thick roughened rod extending outward to a height equal to about as much again as the height of the sacculi.

Oligometra carpenteri.-Each ambulacral lappet contains a very slender, straight, needle-like spicule extending outward and slightly distalward in reference to the pinnulars. There are no other deposits.

There are no deposits in the tentacles.

Oligometra serripinna (fig. 780, p. 366).-Each lappet usually contains a long, but extremely fine, spicule situated along the distal border and curved in conformity with it, or straight; more rarely there are several scattered long spicules.

At their bases the tentacles contain a few very delicate spicules along the outer side.

In another specimen no deposits were found in the perisome of the pinnules.

Each tentacle contained at the base two short and very narrow lines of minute spicules, a distal and a proximal.

\section{Family TROPIOMETRIDE.}

Tropiometra macrodiscus (fig. 797, p. 372).-Each ambulacral lappet contains a minute rudimentary plate, usually of two or three meshes, but sometimes, toward the end of the pinnules, becoming of appreciable size and consisting of from 15 to 20 or more meshes. When this is the case the plate is more or less oval and elongated in a direction perpendicular to the edge of the pinnulars, and beneath it, lying between the sacculi, is another similar but smaller plate. When the covering plate is very rudimentary the lateral perisome of the pinnules may contain very minute scattered spicules, or may be entirely naked.

The perisome over the genital glands contains very abundant minute, rounded plates and spicules which are especially numerous in parallel rows at right angles to the border of the pinnulars, about one to each sacculus.

Spicules are very few, or altogether absent, in the tentacles.

Tropiometra afra.-Each ambulacral lappet contains a small rudimentary plate of usually from two to five meshes.

Along the sides of the pinnulars is a series of plates, usually roughly triangular in shape, elongated perpendicularly to the pinnulars, not quite in contact basally, the distal ends of which pass between, or partially around, the sacculi. There is one of these beneath each covering plate.

There appear to be no deposits in the tentacles.

Tropiometra carinata.-The major portion of the ambulacral lappets is usually occupied by relatively large, very thin, irregular plates with rather coarse meshes and irregular borders, the inner proximal corners of which are produced downward and usually come into contact with the plates beneath. These may be reduced to a single cell with radiating rods, or even to a very slender and delicate rod, usually straight, sometimes irregular or forked, at right angles to the pinnulars, opposite the spaces between the sacculi.

142140-21-Bull. $82-18$ 
Along the sides of the pinnules, near the pinnulars, there is usually a continuous band of the squarish plates, about three to each pinnular, the distal outer corners of which are broadly cut away by the sacculi. Sometimes these are reduced to triangular plates with their outer apices between the sacculi, or to very small, rounded plates between the sacculi. When the covering plates are well developed they may resemble them, but they are somewhat larger, with a very irregular outline, and usually slightly higher than broad.

The perisome over the genital glands is covered with a continuous layer of large and delicate, more or less irregular plates.

There are no spicules in the tentacles.

Tropiometra picta.-Toward the distal ends of the outer pinnules there is in the outer portion of eacl ambulacral lappet a short median rod, which may be forked, or a minute irregular plate of one or two meshes. A second small specimen showed similar deposits.

There are no plates or spicules in the lateral perisome of the pinnules.

There appear to be no spicules in the tentacles.

Tropiometra indica.-Each ambulacral lappet contains a usually straight or very slightly curved, rarely forked, rod with roughened ends, which lies at right angles to the pinnulars.

Other than these, the perisome of the pinnules contains no deposits.

Spicules are extremely rare or altogether absent in the tentacles.

\section{Family CALOMETRIDÆ.}

Neometra alecto (figs. $835-837$, p. 405).-Along the sides of the pinnules and immediately adjoining the pinnulars is a continuous row of side plates, from five to seven to each pinnular.

These are of very peculiar and characteristic shape. The base of each slightly overlaps the base of the one distal to it. On the distal side, just beyond the base, there is a deep semicircular excavation reaching inward for about one-third the length of the plate as measured along the base. On the proximal side there is a similar but shallower excavation. Between these excavations the plate is reduced to about half the basal length. When the plates are in their normal position the excavations of adjacent plates together form circular holes through which the distal third or half of the sacculi protrude. The distal lateral excavation is bordered outwardly by a narrow arm rounded distally, which, making a slight angle with the pinnular, reaches a point almost but not quite directly over the distal end of the base where it adjoins the succeeding plate. Beyond this narrow arm limiting the distal excavation outwardly the plate leans proximally at an angle of about $45^{\circ}$, so that the outer portion beyond the lateral excavations may be said to consist of a narrow distal arm over the deep distal excavation, making an angle of usually less than $45^{\circ}$ with the base, and a very much broader proximal portion, making an angle with the base of about $45^{\circ}$. This latter terminates in a straight line perpendicular to the pinnular directly over the proximal end of the base where it adjoins the narrow distal extension of the plate just proximal 
to it, which overlaps it slightly. The outer surface of the side plates is not all in the same plane. The basal portion adjoining the pinnular, which is narrowly oval with broadly rounded ends and in maximum width about equal to the distal proximal extension, is turned inward toward the pinnular; but, while all of the basal portion lies in the same longitudinal plane, the two outer extensions are directed slightly inward, each making a small angle with the longitudinal plane of the basal portion so as to considerably increase the size of the apertures through which the sacculi protrude. In some cases, where the basal portion is unusually large, the lower portion is bent inward abruptly and lies on the inner side of the pinnular. On the outer border of the plate in the deep, rounded notch between the narrow distal and broad proximal extensions lies a small but conspicuous oval plate which almost completely fills the concavity. On the inner surface of each side plate are two prominent and usually high ridges. One of these, the smaller, runs along the under side of the narrow distal process to its base and then, decreasing in height, curves downward and runs perpendicularly to the proximal edge of the plate; frequently this ridge is not developed beyond the base of the distal process. The other, much higher, runs perpendicularly outward from the base, gradually decreasing in height, just touching the deepest portion of the proximal excavation and traversing the outer proximal extension.

The covering plates, which are very large and conspicuous, very fine in texture with finished edges, are almost circular, slightly flattened at the base where they adjoin the side plates. They lie on the outer side of the broad proximal extension of the side plates and are attached by means of a ligamentous articulation to the end of the long and straight ridge just described.

The perisome over the genital glands is completely inclosed by large filmy plates.

In addition to the plates described, the ventral perisome on the sides of the ambulacral groove contains occasional rather large multiradiate spicules, which for the most part look like spiny balls.

There are no spicules in the tentacles.

Neometra acanthaster.-The perisomic plates resemble those of $N$. alecto.

Neometra conaminis (fig. 838, p. 405).-The perisomic plates do not differ essentially from those of $N$. alecto.

Neometra gorgonia (figs. 839-842, p. 405).-The conditions are the same as in N. alecto.

Calometra callista.-There is no tangible difference between the perisome plates of this species and those of Neometra alecto.

Calometra discoidea.-The perisomic plates resemble those of Neometra alecto.

Gephyrometra propinqua.-The conditions in this species resemble those in Neometra alecto, but the small plate in the notch between the distal process and the broad proximal process is much reduced, being very minute, or in the form of an elongate spicule parallel with the pinnulars.

Pectinometra carduum.-The conditions in this form are essentially as in $\mathrm{Neo}$ metra alecto; the narrow distal process is more slender and curves outward toward 


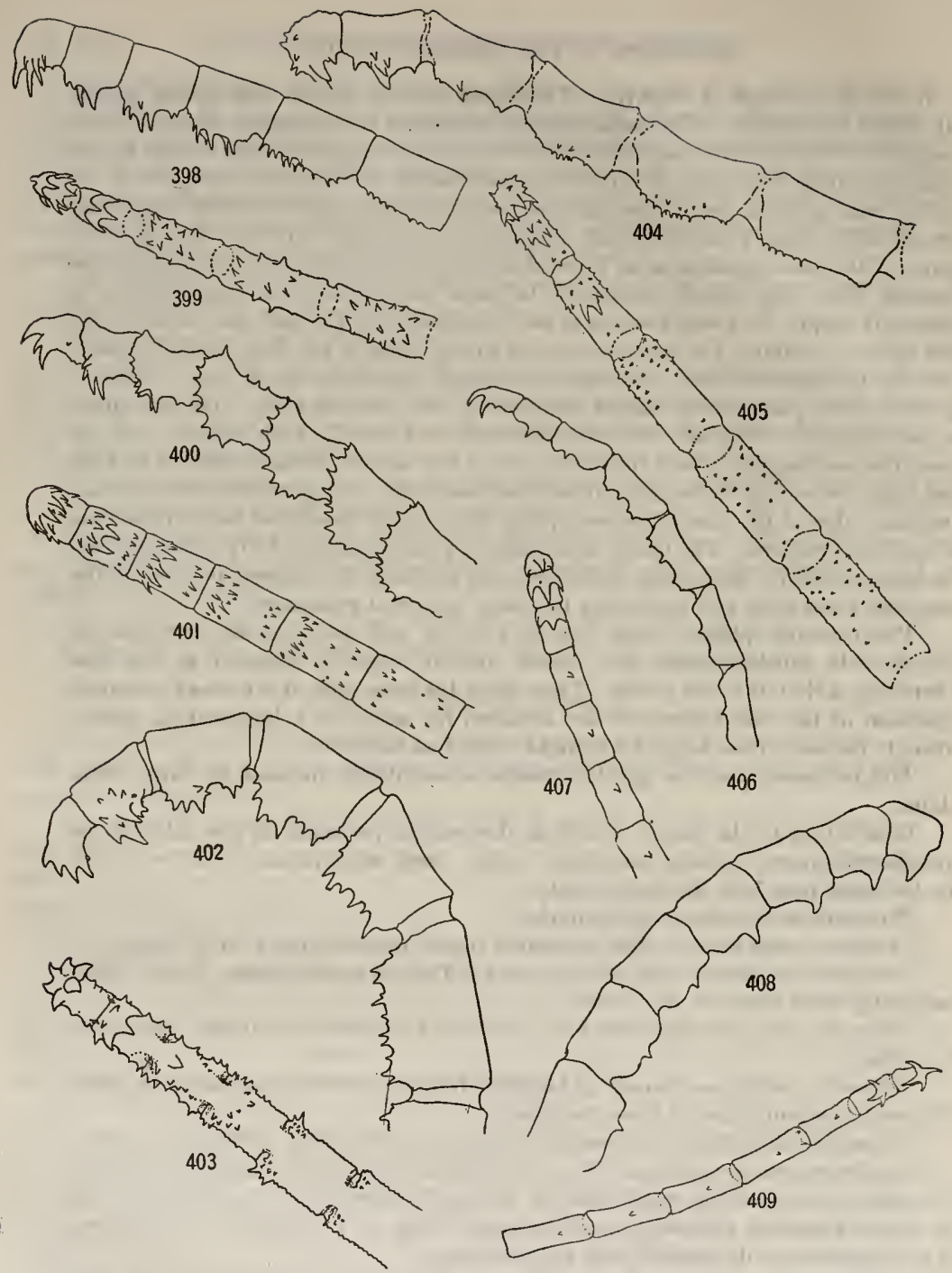

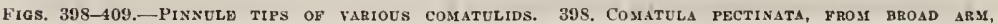

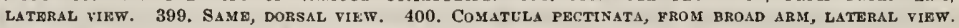
401. SAME, Dorsal view. 402. CoMatula pectiNata, From broad ary, lateral view. 403. Same,

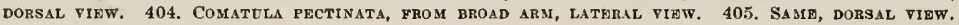
406. Comatula purpurea, lateral, view, 407. Same, dorsal view. 40S. Comatela perptera, LATERAL VIEW. 409. SAME, DORSAL VIEW. 
the ambulacral groove. The outer part of the side plates is strongly incurved toward the median line of the pinnule; the small plate between the distal and proximal processes lies in a semicircular area bounded proximally by a blunt angle on the outer side of the broad proximal process. duum.

Pectinometra flavopurpurea.-The perisomic plates resemble those of $P$. car-

Family THALASSOMETRIDE.

Ptilometra macronema (figs. 857,858, p. 412).-In lateral view the outline of the side plates is almost square, the distal and proximal edges, which are parallel, leaning slightly distally; about a third of the distal edge is cut away in a semicircular excision which is just above the middle, so that the outer distal corner, which is slightly produced and overlaps the outer proximal angle of the succeeding plate, is narrower and more pointed than the broadly rounded lower distal corner; the corresponding notch on the proximal border of the plate is much less deep. The sacculi are relatively small, and sometimes absent, in which case the distal and proximal borders of the plates are straight, and the former overlap slightly the proximal borders of the succeeding plates.

From this simple type of side plate there is derived a more specialized type which in all essentials resembles the side plates of the Calometridæ. On the distal half of the outer border a curved incision makes its appearance, so that the outer distal portion of the plate becomes restricted to a narrow process directed outward at a small angle to the pinnulars, and slightly curved outward. The proximal half of this outer edge, proximal to the curved incision, is straight and supports the covering plate.

On the inner side the surface of the distal process is thickened into a prominent keel. Tangent to the incision on the proximal border a strong rib runs across the whole side of the plate perpendicular to the base, which is produced downward in the form of a long, straight spine lying within the groove of the pinnular.

There is no small plate or spicule in the excision on the outer edge of the side plates such as is found in the Calometridæ.

The structure of the plates is much coarser than in the Calometridæ.

The covering plates, which are attached to the outer end of the long straight rib on the inner side of the side plates, are relatively slightly smaller than those of the Calometridæ, and almost circular in outline, though frequently slightly elongated in the direction of the chief axis.

Ptilometra mülleri.-The side and covering plates in this species do not differ essentially from those in Pt. macronema.

Asterometra anthus.-In direct lateral view the side plates are seen to have the outer and inner sides, which are parallel, slightly longer than the proximal and distal sides, which are also parallel; the distal edge of each overlaps slightly the proximal edge of the succeeding; the outer border is very slightly depressed in the middle; from the proximal inner angle, which may be slightly produced proximally, a broad process, in width equal to about one-third the length of the inner border, extends inward and slightly distally over the inner surface of the pinnular for a 
distance somewhat greater than its own length; this process may originate from the border of the side plate, but usually arises from just within the border, which projects over it like a shelf. In a transverse section of a pinnule the side plates are seen to be strongly and evenly curved, the convexity being outward. In a ventral view of the pinnule the outer edges of the side plates, toward the ambulacral groove, are seen to be cut away by a semicircular incision, and the distal and proximal angles are broadly rounded off so that the semicircular incision is bordered by two converging plates resembling the horns of a crescent, of which the proximal extends farther inward toward the middle of the pinnule than the distal; in the border of the semicircular incision proximal to the middle is an obtusely angular process, which disturbs the symmetry of its contour. The sacculi, which are easily seen in cleared specimens through the side plates, reach the surface through the semicircular incision of the outer borders-ventrally, therefore, instead of laterally, as in Ptilometra. On the inside of the side plates are two prominent ridges, which are parallel and perpendicular to the proximal border; one of these runs midway between the center and the proximal, the other midway between the center and the distal edge. The former is the higher, bearing the covering plate on its outer end, its inner end terminating against the process which extends over the inner side of the pinnular.

The covering plates are very broadly oval or somewhat kidney-shaped, broader than long.

Asterometra macropeda (figs. 812-815, p. 385).-The side and covering plates in this species do not differ essentially from those of $A$. anthus; but the process from the base of the side plates which runs over the inner surface of the pinnule is broader and trapezoidal with its free inner edge, which is parallel with the base of the side plate, longest.

Asterometra cristata.-The conditions in this species do not differ essentially from those in $A$. anthus.

Pterometra magnipeda.-The side and covering plates in this species resemble those in Asterometra anthus.

Pterometra splendida.-The side and covering plates of this species resemble those of Asterometra anthus, but the structure is much coarser.

Pterometra pulcherrima.-The perisomic plates are essentially like those of Asterometra anthus.

Pterometra trichopoda.-The side and covering plates resemble those of Asterometra anthus.

The perisome over the genital glands is completely covered by large filmy plates.

Cosmiometra crassicirra (figs. 843-848, p. 405).- In the plane parallel with the dorsoventral plane of the pinnule the side plates are very strongly convex, so that when the pinnule is viewed ventrally they appear as a row of half cylinders with the convexity outward. In lateral view the main body of the plate is about as high as broad; the base upon which this portion rests is very narrow, and in contact with the bases of the adjacent plates; the sides are throughout their whole length regu- 
larly concave, forming broad lenticular gaps between adjacent plates. The distal outer angles are produced into long narrow horns, which curve toward the ambulacral groove and slightly outward, and which, though very narrow in lateral view, extend inward for some distance across the pinnule. The proximal outer angles are produced into a broad process rounded at the end, which makes an angle of about $45^{\circ}$ with the pinnular and is bent inward under the distal horn-like process of the preceding plate. In the middle of the distal border, at the base of the proximal broad process, is an angular projection, forming approximately a right angle. The side plates are extremely delicate, though everywhere with definite edges. They bear no ridges on the inner side, and have no basal extension over the inner surface of the pinnulars.

The moderately large, almost circular, covering plates are articulated to the distal side of the proximal process.

Toward the base of the pinnules the side plates become lower and lower, finally becoming reduced to very narrow horizontal plates and later disappearing altogether; at the same time the covering plates become reduced, though much more gradually, finally occurring only as irregular calcareous films in the marginal lappets.

There are no calcareous deposits in the tentacles.

An intermediate stage in the reduction of the side plates shows them reduced to somewhat irregular broad crescents with blunted ends, curving proximally, with the circular covering plates just beyond the outer edge of the outer horn, alternating with straight rods of the same height leaning slightly distally, which represent the distal horn-like process and the distal edge.

The sacculi are situated between the side plates.

Cosmiometra delicata.-The side and covering plates essentially resemble those of $C$. crassicirra, but the texture of the side plates appears to be much finer. The proximal outer angle of the side plates is not so much produced as in $C$. crassicirra, and is not more conspicuous than the median outer angle; the chord of the reentrant arc between these two is almost parallel to the base, and in this concavity the covering plate rests. As in C. crassicirra, the notch between the narrow distal process and the median angle gradually deepens until the distal portion separates off in the form, in lateral view, of a rod. leaving the proximal portion in the form of a broad crescent with the covering plate on the inner (concave) side of its proximal end.

Stylometra spinifera. -The side and covering plates are of the same general type as those of Cosmiometra. The side plates are just in contact basally, higher than broad, with slightly concave sides, which leave between them long lenticular gaps for the reception of the sacculi, which outwardly narrow gradually but basally a re abruptly rounded off against the appressed bases of two adjacent plates. The outer edge shows a proximal outer angle and an obtuse median angle with an obtusely angular incision between them. The distal angle is produced into a thin, horn-like process, which, however, is broad transversely, curving distally and upward, the angular notch between this and the median angle being much deeper than that between the median and the proximal angles; whereas the base of the 
plate as viewed from the inside of the pinnular forms approximately a quarter of a circle, the outer edge as viewed ventrally is almost a right angle, the apex of this angle coinciding with the apex of the notch between the proximal extension, which, viewed laterally, appears to be very narrow, but viewed ventrally is seen to be quite deep, and the median angle.

The covering plates, which are circular with the outer half of their circumference bordered with long spines, are attached to the outer side of the proximal angle.

Toward the base of the pinnules the side plates degenerate, the distal portion gradually separating off and appearing as a straight rod directed outward and slightly distally, and the remaining portion gradually becoming an irregular calcareous film which grows smaller and smaller until it disappears.

Relatively large covering plates with unfinished edges are found in the lappets after the side plates have become very minute.

Stenometra quinquecostata.-In their simplest form the side plates are squarish in lateral view; the proximal edge is usually straight, sometimes with the median third slightly concave; the lateral edges are slightly incurved, the distal overlapping the proximal of the succeeding plate; the outer proximal corner is broadly rounded; the outer distal corner is rather sharply rounded; in the middle of the distal edge is a broadly rounded angle the distal point of which is on the same level as the outer points of the rounded proximal and distal angles from which it is separated by shallow rounded incisions, that on the distal side being deeper than that on the proximal. Toward the distal end of the pinnule this form becomes slightly modified by a deepening of the notch between the median angle on the outer border and the distal process, which becomes longer and narrower, and a deepening of the concavity of the distal lateral border.

The same modification takes place toward the base of the pinnule, where it is carried farther, so that both the proximal and the distal sides become strongly concave and the distal process becomes very long and thin. At the base of the pinnules the side plates become lower and lower and finally disappear; the covering plates, though they become smaller, persist to the junction with the arm. In direct ventral view the outer edges of the side plates are seen to be curved in such a way that they form about a quarter of a circle; in dorsal view the lower edges are parenthesis shaped with the convexity outward. The distal edge of the side plates is thickened beneath the insertion of the covering plates, and in the distal process.

The almost circular covering plates are attached to the outer border of the side plates just within the proximal outer angle.

The perisome between the side plates and the pinnulars is completely incased by large and filmy plates.

There are no deposits in the tentacles.

Stenometra cristata (figs. $820-822$, p. 392).-The side and covering plates in this species resemble those of $S$. quinquecostata.

Stenometra diadema.-The side and covering plates are essentially like those of S. quinquecostata. 


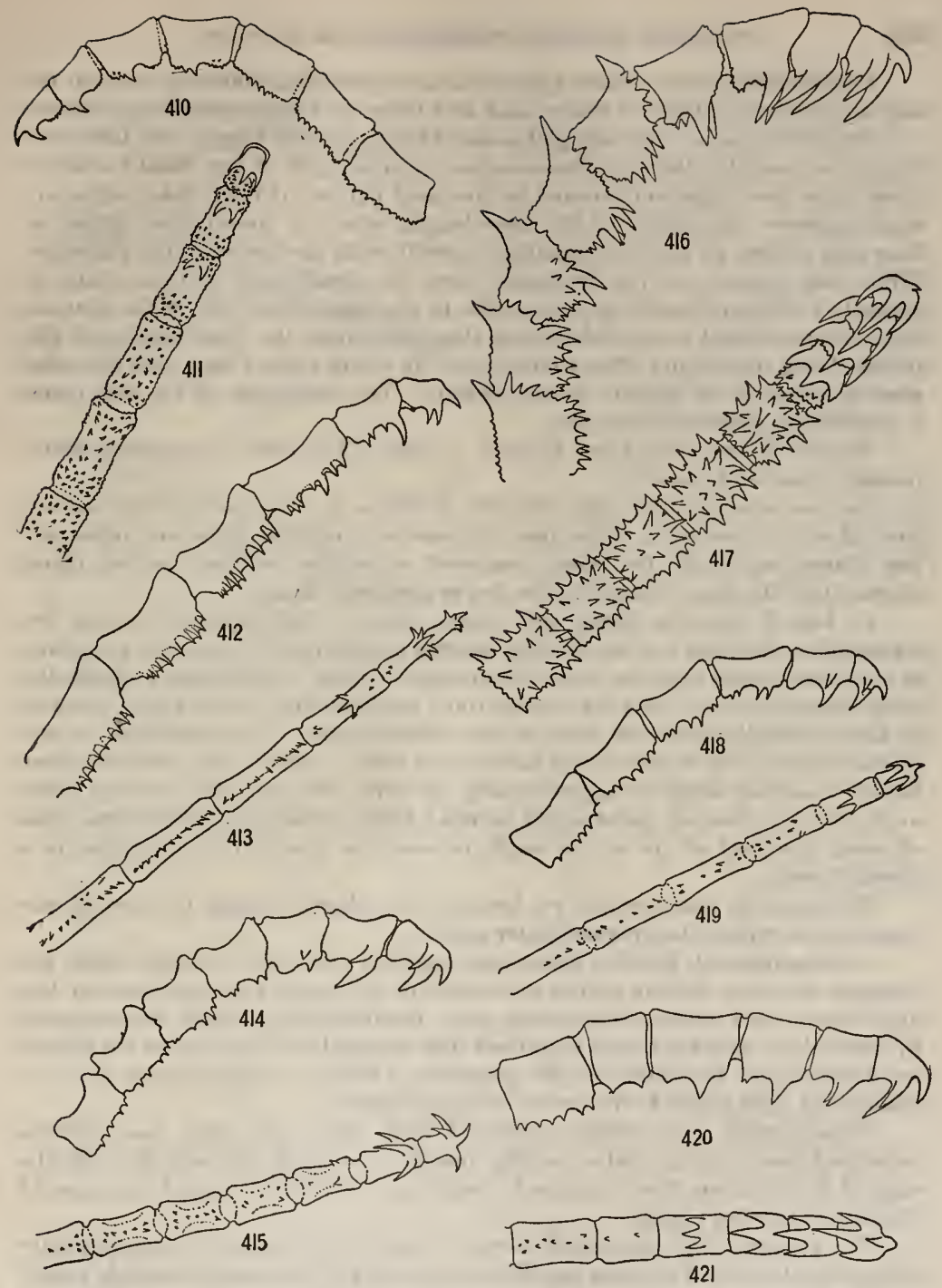

Figs. 410-421.-Pinnole tips of variods comatulids, 410. Comatula micrastfr, latgral view. 411. Same, dorsal view. 412. Comactinia echinoptera, lateral view. 413. Sajie, dorsal view. 414. Comaster MUltibrachiata, lateral View. 415. SaMn, Dorsal view, 416. Comaster MULTibrachiata, Lateral, view. 417. Same, dorsal vibw. 418. Comaster distincta, lateral view. 419. SAME, doRsal yiew. 420. Comaster belli, lateral Vieif. 421. SAME, dorsal view. 
Daidalometra hana.-There appears to be no essential difference between the side and covering plates of this species and those of Stenometra quinquecostata.

Parametra orion.-The side plates are of two types; the larger, with the covering plates, resemble those of Oceanometra gigantea; just at the distal border of these large side plates, and covered by the vasal portion of their distal edges, are much narrower side plates of the same length, which in lateral view appear as long rods making an angle of something over $60^{\circ}$ with the border of the pinnulars. While they appear rod like in lateral view, the distal third of these plates is abruptly produced inward, at right angles to the longitudinal axis of the pinnule, for a distance equal to somewhat more than the length, the distal border of this process being convex and often a semicircle. In direct ventral view, this expanded portion is seen to be slightly convex distally. The basal edge of the side plates is parenthesis shaped in end view.

Parametra granulata (figs. 874-878. p. 435).-The side and covering plates resemble those of $P$. orion.

Oceanometra gigantea (figs. 859-866, p. 419).-In this species there are two rows of side and covering plates, one, composed of much the larger and more perfect plates, superficial, the other, composed of smaller and less perfect plates alternating with these, situated in the deeper perisomic layers.

In lateral view the larger side plates, those of the superficial series, are trapezoidal; the distal border, which is straight and perpendicular to the pinnulars, is somewhat longer than the base; the proximal border is half again as long; the outer border is convex, with the median third produced and its outer edge concave, so that it usually takes the form of two obtuse angles. The inner half of the plates is plane, but in their outer halves they twist in such a way that the outer border makes an angle of approximately $45^{\circ}$ witl the base, the proximal outer angle, which is more or less strongly rounded, being inward; on the proximal side at about the level of the obtuse angle between the distal and outer sides is a rounded notch.

The covering plates, which are broadly oval, slightly longer than broad, are attached just within the proximal outer angle.

Alternating with the side plates just described and deeply sunken within the perisome are large definite groups of spicules of all shapes and sizes, more or less agglutinated and sometimes becoming very irregular plates, which are separated by intervals of somewhat more than their own longitudinal diameter, or the diameter parallel with the border of the pinnulars, which is usually greater than the diameter at right angles to the border of the pinnulars.

Beyond these, and entirely separated from them, are much more definite sausage-shaped covering plates, leaning distally at an angle of about $60^{\circ}$ with the edge of the pinnulars, their outer ends reaching to, or slightly beyond, the bases of the larger covering plates.

The perisome over the genital glands is completely inclosed by longitudinally elongate plates, which decrease rapidly in size from the pinnulars to the side plates.

The tentacles may contain extremely minute deposits, especially toward their tips. 


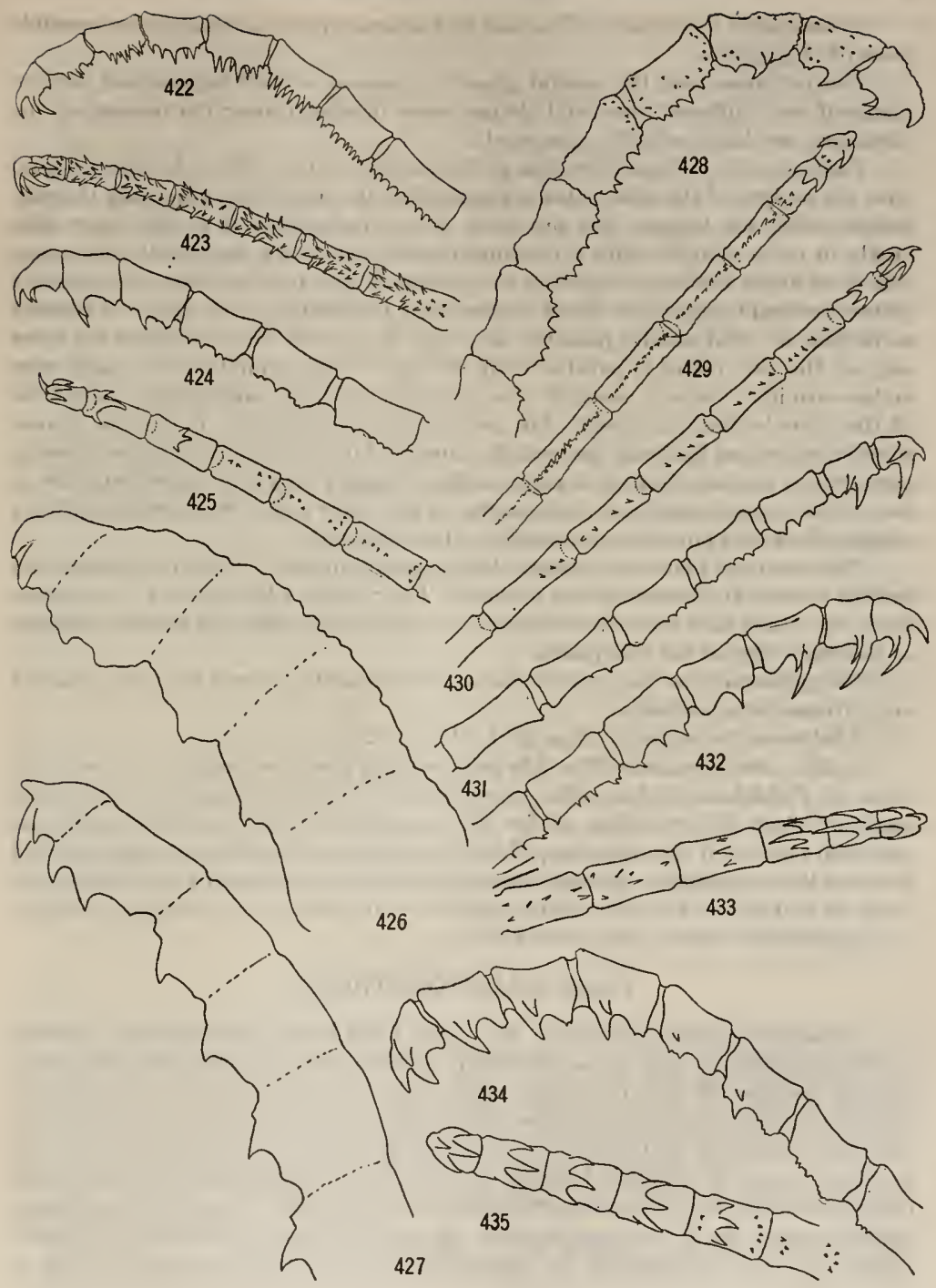

Figs, 422-435,-Pinnele tips of variods comatulids. 422. Comaster parves, lateral view. 423.

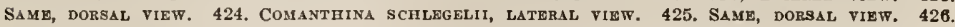
COMANTHUA BENNETTI, LATERAL VIEW (FROM SPECIMEN PRESERVED IN FORMALIN). 427. SAME. 428.

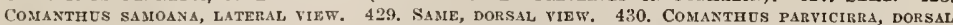
view. 431. Sade, lateral view. 432, Comanthos parviciria, lateral view. 433. Same, dorsal view. 434. Comanthes parvicirra, latebal view. 435. Saste, dorsal view. 
Oceanometra annandalei.-The side and covering plates in this species resemble those of 0. gigantea.

The perisome over the genital glands is incased in well-formed and definite plates of very different sizes and shapes, some of which, near the borders of the pinnulars, are longitudinally elongated.

Thalassometra villosa (figs. 823 , p. 392 , and 879,880, p. 435).-In direct lateral view the outline of the side plates is trapezoidal, the inner side, adjoining the pinnulars, being the longest; the proximal side is perpendicular to the inner side, nearly or quite straight, with a prominent notch just below the middle; the outer side is of about the same length as the proximal, and has the form of a broadly obtuse reentrant angle; the distal border leans proximally at an angle of slightly more than $45^{\circ}$, and usually joins the inner side in a broad curve; whereas the inner edge of the side plates is parallel with the edge of the pinnulars, the outer edge makes with it an angle of about $45^{\circ}$, the proximal end being much nearer the middle of the pinnule than the distal. On the slanting outer border of the side plates, slightly more than half way between the inner and outer ends, is a narrow covering plate, which projects from it at right angles in lateral view, and in ventral view is seen to be approximately at right angles to the outer edge; it is articulated to a slightly thickened portion of the border of the side plate.

The covering plates are shaped like a pumpkin seed, with the pointed end inward toward the center of the pinnule. Their lower edge shows a very obtuse angle, by which they are articulated to the middle of the obtusely angular excision of the outer edge of the side plates.

The perisome over the genital glands is completely covered by thin plates of very diverse form and size.

Thalassometra agassizii (figs. 1171, 1172, pl. 27).

Aglaometra eupedata.-The side and covering plates resemble in all essentials those of Daidalometra hana; the thin proximal process is turned inward at an angle of about $45^{\circ}$, reaching as far as the midline of the covering plate; the proximal portion of the side plate, which bears the covering plate, is turned inward at about the same angle. In both cases the torsion is in the outer two-thirds of the plate, so that in this part the central portion of the plate is very convex exteriorly.

Aglaometra incerta (fig. 1166, pl. 27).

\section{Family CHARITOMETRIDAE.}

Crossometra helius (fig. 867, p. 419).-In direct lateral view the major portion of the side plates is seen to be practically square, with the proximal outer angle broadly rounded off and the distal outer angle, at the base of the process to be described, raised into a slight obtuse angle; the distal outer corner is produced distally and outwardly in the form of a narrow curved horn; the outer half of the proximal border is produced laterally and slightly outwardly for a distance about equal to two-thirds of the transverse diameter of the plate. Large and prominent saceuli occupy the broad gaps between the apposed outer processes of adjacent plates. Viewed from beneath the inner ends of the side plates are seen to carry at 
either end a stout process of the same thickness as the edge of the plate itself, which extends inward, at right angles to the edge of the plate, for a distance equal to about two-thirds the length of the latter. The figure presented by the inner end of the plate as seen in end view is thus three sides of an oblong; the area included between the edge of the plate and the inward extensions may be three sides of a square, but is usually more or less rounded, sometimes about three-quarters of a circle. In direct ventral view the side plates appear semicircular, with the proximal inner end of the semicircle produced in a broad process which touches the distal inner end of the semicircle formed by the preceding plate.

The covering plates, which are almost circular, or slightly longer than broad, and flattened at the base, are attached to the proximal outer process halfway between its tip and the slight angle marking its junction with the main body of the plate.

There are no deposits in the tentacles.

Perissometra selene (figs. 817,818 , p. 385 , and 819 , p. 392).-The side and cover ing plates resemble essentially those of Crossometra hetius. The distal process on the side plates is much thicker at the base, and the angle on the outer border at the base of the broad proximal process is much more developed. Within the semicircular notch, as the plates are viewed from an angle of $45^{\circ}$ to the dorsoventral plane of the pinnule, between the posterior process and the median angle there is a very small irregular plate, often of only two or three meshes. Toward the base of the pinnule, alternating with the bases of the side plates and lying deeper in the perisome, are irregular plates of considerable size with ragged edges representing a second, deep, row of side plates. On the proximal side of the first two pinnulars normal side plates, much reduced in size, alternate with side plates without covering plates in the form of equilateral triangles which reach to the level of the bases of the covering plates on the normal side plates. The normal side plates and the covering plates which they bear rapidly increase in size and after the third or fourth the secondary side plates pass deeper into the perisome and become rudimentary, persisting to the fifth pinnular.

The covering plates are nearly circular and less flattened than those of Crossometra helius.

Perissometra patula.-The side and covering plates do not differ essentially from those of Crossometra helius, but they are coarser in texture, and the side plates have ragged borders.

Perissometra lata.-In lateral view the side plates, which are of the same structure as in related species, appear more nearly rhombic, as they are very close together and the large proximal outer processes of each are covered by the distal processes of the following; the notch in the distal border is very small and often very shallow. The concavity between the distal outer process and the median angle of the outer edge contains a very small more or less irregular plate.

On their lower side the covering plates bear a low keel in their proximal third which runs somewhat diagonally.

Pachylometra distincta (figs. 831-834, p. 405, and 856, p. 412).-While the structure of the side plates is the same as in Crossometra helius they are very low and 
broad, the width at the base being almost or quite twice the median height to the apex of the angle on the outer edge just above the middle of the base; the proximal process is large and broad; it extends outward for a distance equal to from onehalf to two-thirds of the length of the base; the inner half of its proximal border is concave, the outer half convex; the edge from the proximal outer corner to the median angle of the outer edge is slightly concave, and to the middle of this edge the covering plate is attached; between the median angle and the distal corner the outer edge of the plate is deeply concave, having the form of a semicircle; in lateral view the distal outer angle is produced in the form of a hook; its extremity is expanded, this expansion showing in lateral view as a right angle midway between the base and the point.

The covering plates are very broadly rounded, as broad or as slightly broader than long, with the proximal edge in the form of a broadly obtuse angle, and the inner angle, between the base and the broadly curved side toward the middle of the pinnule, sharper and less rounded than the onter.

Pachylometra incoqualis (fig. 1168, pl. 27).

Chondrometra robusta.-The side and covering plates are essentially as in Perissometra lata; the notch between the distal outer process of the side plates and the median notch on the distal border is occupied by a small plate.

Calyptometra lateralis (figs. 868-871, p. 425).-The side and covering plates do not differ essentially from those of Perissometra patula. In their proximal third the covering plates bear a median keel, placed somewhat diagonally, which is high and triangular, the base of the triangle touching and perpendicular to the proximal edge.

On the underside of the ventral perisome of the pinnules is a continuous series of large irregular plates forming a continuous broad band.

Glyptometra tuberosa (fig. 816, p. 385).-The side and covering plates are essentially the same as those of Pachylometra distincta, the side plates being very low and broad, twice as broad as high. The side and covering plates are extraordinarily thin and delicate, composed of a thin calcareous film. The side plates are so low that the proximal process curves around to the proximal end of the base; this process is much finer in texture than the rest of the plate.

On the underside of the covering plates in their proximal third is a keel, placed somewhat diagonally; from near the end of this keel on the outer side the outer border of the plate curves about in a circle as far as a point on the inner side directly over the outer corner of the proximal process, whence it is continued in a straight line downward to that angle; the portion of the base which lies on the inner side of the keel, or point of attachment, is perfectly straight, meeting the proximal part of the inner border at right angles over the outer corner of the proximal process; the distal and outer portions of the periphery are fringed with fine but prominent spines. Sometimes this form of covering plate is not developed, the outer side joining the proximal end of the keel on a level with the inner side instead of the distal end; but in this case the inner basal angle is much less rounded than the outer. On the other hand, the parallel sided portion of the plate, between the median keel and 


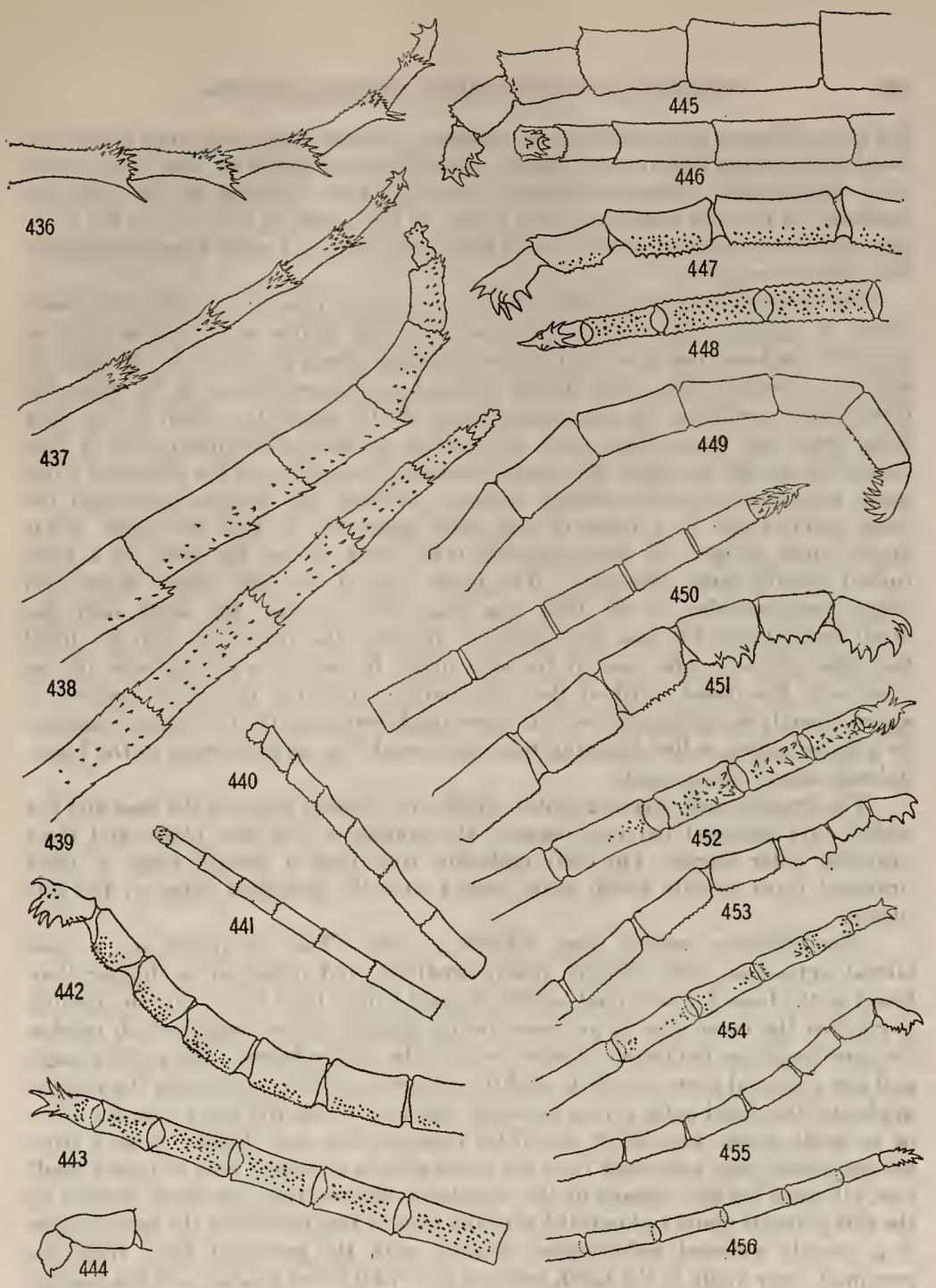

Figs, 436-456.-PinNule mips of variód comatulids, 436. Eudocrinus ornates, lateral view. 437.

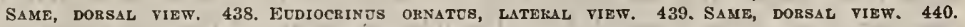
Heterometra gavignit, lateral view. 441. Same, dorsal view. 442. Himeronietra Martansi, lateral view. 443. SAME, dorsal VIEW, 444. Himerometra persica. 445. Hetrómetra Crenulata, lateral view, 446. Same, dorsal view, 447. Heterometra philiberti, lateral view. 448.

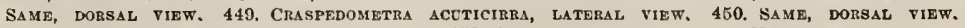

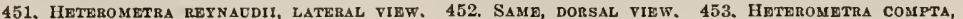
lateral view. 454. SAME, dorsal view. 455. Heterometra singelaris, lateral view. 456. SAME, DORSAL VIEW. 
the inner edge, may be considerably elongated, in some cases occupying about onethird of the entire length of the plate. In the covering plates an area in the shape of a right-angled triangle extending from the edge adjacent to the proximal extension of the side plate to a point as far as the length of this side on the inner edge and thence to the proximal end of the median keel is of much finer texture than the rest of the plate.

Crinometra insculpta.-Both side and covering plates are relatively small, coarse in texture, with unfinished edges. The side plates are about as high as broad at the base; the inner half of the proximal side is excavated in the form of almost a semicircle; the outer half is straight and perpendicular to the base; the distal side is concave, the maximum depth of the concavity, which is not very deep, being just below the center; the median portion of the outer edge is produced into an obtuse angle; the border between this angle and the proximal outer angle is straight or very slightly concave; between this median angle and the outer distal angle is a more or less deep concavity, so that the outer distal angle, which is more or less produced, takes more or less the form of a horn curved distally and outwardly. The inner side of the side plates shows two ridges perpendicular to the base, one near the proximal, the other near the distal border; near the base these suddenly diverge; the distal runs into the distal horn-like process. The base of the side plates is parallel with the edge of the pinnulars; the distal third of the distal edge, embracing the distal process, is approximately at right angles with the proximal two thirds, the two being connected by a broad curve; a line bisecting this angle would be perpendicular to the longitudinal axis of the pinnule.

The broadly oval covering plates, which are broadest between the base and the middle, are attached halfway between the middle of the side plates and their proximal outer angles. On their underside they have a narrow ridge in their proximal third or half which is in contact with the proximal ridge on the side plates.

Monachometra fragilis (figs. $824-830$, p. 399 ).-The side plates are in close lateral apposition with straight inner, proximal, and distal edges, higher than broad at the base, the proximal border slightly longer than the distal; the median portion of the outer edge is produced into a slightly obtuse angle, which reaches the same height as the proximal outer corner; the border between the median angle and the proximal outer corner is slightly concave; the border between the median angle and the distal outer corner is deeply concave, so that the latter is in the form of an acute angle; just below the distal outer process and slightly farther from the excavated outer edge than from the distal edge is a circular hole of rather small size, allowing for the passage of the sacculus to the exterior; the inner portion of the side plates is plane and parallel with the edge of the pinnulars; the outer border is a broadly rounded right-angled triangle, with the proximal limb, from the proximal outer angle to the notch between the distal outer process and the median angle, much longer than the distal; both are inclined to the line of the edge of the pinnulars at an angle of about $45^{\circ}$. The interior surface of the side plates bears two prominent parallel narrow ridges of unusual height; one of these runs fairly 
near the proximal border; this is perfectly straight and perpendicular to the side of the pinnular, running to the attachment of the covering plate; the other is midway between this and the distal border; it runs parallel to the first as far as the hole allowing for the protrusion of the sacculus, about the outer edge of which it turns, running to the distal side of the plate; in a direct ventral view of the plate these two ridges appear as two thin processes of considerable height.

The sides of the covering plates, which are semicircular in their outer half, gradually converge in almost straight lines to the relatively narrow base.

Pecilometra scalaris (figs. $849-855$, p. 412 ; and fig. 1169, pl. 27).-The side plates are broader than high; the outer half of the proximal border is produced in the form of a proximal process with parallel sides, which is directed slightly outward; the outer edge of this process is parallel with the edge of the inner half of the proximal side; the edge connecting the two in lateral view is at an angle of about $135^{\circ}$ with each; on the outer edge directly over the middle of the base is a prominent angle, usually of about $90^{\circ}$; the outer distal corner of the plate is produced in the form of an acute angle of about $45^{\circ}$, which lies at the same height as the outer proximal angle. Between the proximal outer angle and the median angle the outer border forms a reentrant obtuse angle, the apex of which, just proximal to which the covering plate is attached, is from one-fourth to one-third of the distance from the median angle to the proximal outer corner. The outer edge between the median angle and the distal angular process is excavated in the forin of a semicircle. In this excaration is a plate which is unusually well developed, shaped like a thick crescent, with the concave side directed toward the base of the side plate, so that a large oval or circular hole is left between it and the border of the side plate. Between the deepest portion of the excavation between the median angle and the distal outer corner and the middle of the distal border of the side plate, and equidistant from both, is a rather small circular opening, through which the outer portion of a sacculus protrudes. The distal border of the side plates is very slightly and evenly convex; in direct ventral view the edge of the proximal third of the plates is straight and parallel to the base; the remaining portion is excavated in the form of a semicircle; the side plates are slightly convex outwardly in the horizontal as well as in the transverse plane. As a result of this the opening for the sacculus is directed diagonally outward and somewhat distally; the inner edge of the side plates, adjoining the pinnulars, is straight and bears directed inwardly two rather long processes, one just within the distal end, the other midway between this and the proximal end, which are the two high internal ridges seen in end view; on the inner side of the side plates are two relatively high ridges; one of these, arising near the proximal end of the base, runs directly upward perpendicular to the latter to the attachment of the covering plate; the other, halfway between this and the distal border, runs perpendicular to the base as far as the hole for the passage of the sacculus, about the distal side of which it turns, and runs outward to the distal border of the plate. The sacculi occupy the entire region between the ridges on adjacent plates, lying over the sutures between them.

The covering plates are usually slightly longer than broad, broadly oval, broadest at about the middle, with the angle between the flattened base and the 
outer side very broadly rounded, and that between the base and the inner side a right angle, and even sometimes less than a right angle; occasionally the covering plates may be truncated distally, or they may take the form of elongated hexagons.

The tentacles have a rather broad band of interlaced spicules along the distal side.

Chlorometra garrettiana.-The side plates, which are of the usual structure, are as broad at the base as the height to the apex of the median obtuse angle on the distal edge; the notch between the median angle on the outer edge and the distal process is deep and almost semicircular; the notch on the distal side below this distal process is deep, and usually semicircular; the inner proximal angle is slightly produced, so that, viewed laterally, there is a deep concavity between this angle and the base of the broad proximal projection; in ventral view the outer edge of the side plates is a thick semicircle, the proximal end of which extends farther inward than the distal; the inner ends, adjoining the pinnulars, are also thick semicircles; the inner side of the side plates shows two high, broad ridges, one passing along the narrow distal process and usually disappearing at the notch on the distal side, the other running directly downward perpendicular to the base from the attachment of the covering plate as far as the notch on the proximal side, then curving about and running to the proximal inner angle.

The covering plates are broadly rounded, about as long as broad. They are not quite symmetrical, the inner side in its proximal third becoming straight and running downward parallel to the median keel to the rounded right angle between the base and the inner border; the opposite side is a segment of a circle. In some cases the outer half of the covering plate is a semicircle, from which the sides converge in almost straight lines to a short straight base, the outer side being fiatter than the inner.

Strotometra hepburniana (figs. 808-811, p. 385).-The side plates are small and delicate, rather coarse in texture, with somewhat ragged edges. The general structure is as in related species; in lateral view the side plates are roughly oblong, half again as broad as high, the distal border slightly concave, the proximal with a notch in the proximal portion just below the middle, or with the whole proximal half concave; the outer distal angle is slightly produced; the outer proximal angle is slightly produced and broadly rounded; a low obtuse angle occupies the middle of the outer border.

The covering plates are reniform, very broadly rounded, slightly broader than long, the inner point where the inner edge passes over into the base almost a right angle, the outer border curving in a wide semicircle from the distal border to the point of attachment.

Charitometra basicurva (fig. 1167, pl. 27).

\section{Family ANTEDONIDE.}

Antedon petasus (figs. 784-786, p. 366).-Normally each ambulacral lappet contains a short, usually straight, rod which is not longer than the length of the sacculus; these alternate with the sacculi, and their inner ends are just within a 
line drawn tangent to the outer borders of the latter; occasionally these rods are forked at their outer ends; frequently they are absent.

There are no other deposits.

Antedon bifida (fig. $1173, \mathrm{pl} .27$, and pl. 50, fig. 1335).-'There are no calcareous deposits in the perisome of the pinnules, nor in the tentacles.

W. B. Carpenter has noticed that in the very young the perisome of the arms and pinnules contains irregular branching spicules which form a sort of incomplete reticulation for the support of the ambulacral lappets; these subsequently undergo complete resorption so that no trace of them is discoverable in the adults.

Antedon adriatica.-There are no calcareous deposits in the perisome of the pinnules, nor in the tentacles.

Compsometra lovéni.-Each ambulacral lappet contains an extremely slender hair-like short rod, usually slightly bent in the middle, which is tangent to the proximal border of the sacculus.

There are occasional spicules along the outer side of the tentacles.

Compsometra incommoda.-Each of the ambulacral lappets contains a minute short straight rod.

The tentacles contain a broad and conspicuous band of extremely fine spicules along their outer side.

Toxometra paupera (fig. 767, p. 362).-Each ambulacral lappet contains a conspicuous and unusually stout rod, roughened at both ends and bent in the middle at an angle of about $120^{\circ}$, which runs downward to the pinnulars tangent to the distal side of the sacculus.

There are no deposits in the tentacles.

Dorometra parvicirra (fig. 789, p. 366).

Eumetra chambertaini.-Each ambulacral lappet contains two slender calcareous rods; the longer, slightly and evenly curved distally, just crosses the distal edge of the sacculus; the shorter is similar but only about half as long and correspondingly more slender and is tangent to the proximal edge of the sacculus.

There are no deposits in the tentacles.

Iridometra adrestine.-Fach ambulacral lappet contains an excessively slender very slightly curved rod, which in its lower portion is tangent to the proximal side of the sacculus.

There are no deposits in the tentacles.

Iridometra melpomene.-Each lappet contains a slender curved rod, as in I. adrestine.

There are no deposits in the tentacles.

Andrometra psyche.-Each ambulacral lappet contains an excessively slender slightly curved smooth calcareous rod which terminates just above, or just over the outer border of, a sacculus.

There are no deposits in the tentacles.

Thysanometra tenelloides.-From the border of the pinnulars into each of the ambulacral lappets there runs a very narrow but very conspicuous calcareous 

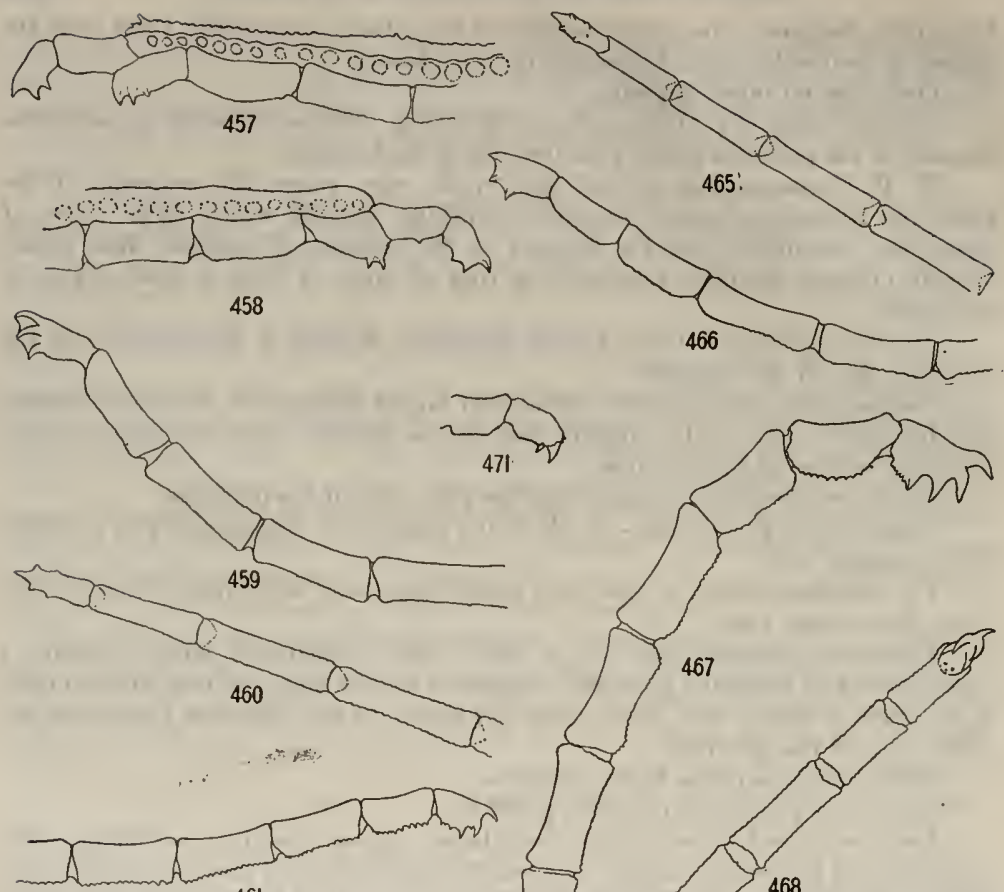

461

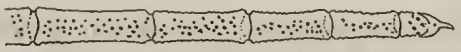

462
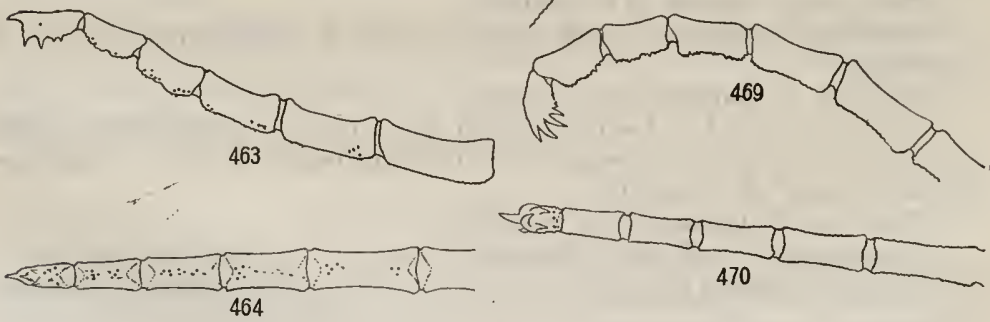

Figs, 457-471. PinNulf tips of various comatolids. 457. Heterometra Bengaligsis, lateral view. 458. SAMv. 459. SaMe. 460. Dorsal view of LaSt. 461. Heterometra bexisalensis, hateral view. 462. SAME, DORSAL VIEW. 463. AMPHIMETRA Discoidea, LATERAL view. 464. SAME, DORSAL VIEW. 465. Stephanometra tenoipina, doRsal view. 466. SaMe, lateral view. 467. StephaNomitra

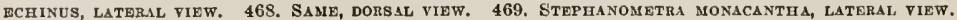
470. Same, dorsal view. 471. ANother specimien from Marshall Islands, lateral fiew. 
band two or three meshes wide, rarely wider, which toward the inner edge of the lappet gradually broadens and forks so that its end is $\mathrm{Y}$-shaped, the proximal arm of the $Y$ being as broad as the original band and making only a slight angle with it, while the distal arm is smaller and narrower, making a considerably greater angle with it; occasionally there is merely a spatulate expansion of the outer end instead of the $\mathrm{Y}$.

There are no deposits in the tentacles.

Coccometra guttata.-Each ambulacral lappet contains a long, uniform, smooth, slender rod, pointed at each end and slightly bent in the middle, which runs from the tip of the lappet to the edge of the pinnulars, each rod tangent to a sacculus on its proximal side.

There are no spicules in the tentacles.

Coccometra nigrolineata.-Each ambulacral lappet contains a long, slender, uniform rod, slightly roughened at the distal end and slightly bent in the middle, which runs, tangent to the proximal side of a sacculus, to the edge of the pinnular.

Coccometra hagenii.-Each of the ambulacral lappets contains an extremely slender straight rod which runs downward tangent to the proximal border of the sacculus. This rod may be so reduced as not to extend beyond the distal edge of the sacculus, or it may even be entirely absent.

There are occasional minute rods in the tentacles, but most of these are without deposits.

Perometra diomedew (fig. 772, p. 362).-Each ambulacral lappet contains a slender, usually straight, rod of medium length which runs downward to the vicinity of the sacculi.

There are no deposits in the tentacles.

Erythrometra australis (fig. 773, p. 362).-Each ambulacral lappet contains a short, rather stout, rod which is slightly swollen and roughened at each end, especially the outer.

There are no deposits in the tentacles.

Erythrometra ruber.- Each ambulacral lappet contains in its outer portion a short straight rod directed outward and distally.

There are no deposits in the tentacles.

Hypalometra defecta (fig. 768, p. 362).-Each ambulacral lappet contains a single long, very slender, conspicuous rod directed outward and distally at an angle of about $60^{\circ}$.

Each tentacle contains a thin line of spicules placed end to end and slightly overlapping which runs nearly to the tip.

There are no deposits in the tentacles.

Nanometra bowersi.-Each ambulacral lappet contains a stout and prominent rod, slightly bent in the middle and slightly roughened at each end.

There are no deposits in the tentacles.

Nanometra clymene-Each ambulacral lappet may contain a short, smooth, bent rod, but these appear to be rare, only occasionally being met with toward the tips of the pinnules. 
Heliometra maxima.-Each ambulacral lappet contains a rather short, stout rod, usually roughened at each end but commonly with the ends expanded and pierced with from one to several holes.

There are no deposits in the tentacles.

Heliometra glacialis.- In a specimen from Greenland each ambulacral lappet contains in its outer portion a rod, usually straight but often with the inner end, more rarely the outer also, broadened and pierced with one or two holes; sometimes the deposit takes the form of a very irregular and rudimentary plate with a few holes of different sizes and shapes.

Between and just outside of the sacculi are other deposits, rods, or extremely irregular rudimentary plates, which are widely separated from each other; these usually occur just below the ends of the rods in the outer ends of the lappets, one or two beneath each rod.

There are no deposits in the tentacles.

In a specimen from the Western Bank the deposits are similar to those in the preeeding but somewhat more developed. The outer portion of the ambulacral lappets usually contains an irregular elongated plate instead of a rod.

There are irregular spicules occasionally to be found in the tentacles.

In certain specimens from the Barents Sea, P. H. Carpenter found extensive calcareous deposits in the perisome of the pinnules.

Mortensen found a similar condition in others from eastern Greenland, in which the plates along the pinnulars resemble those of Promachocrinus kerguelensis or Anthometra adriani, though they are not so well developed. He says that "the covering plates are large, cribrous, of very irregular outline; the lower part is much the larger and may consist of two separate plates lying very closely together; they unite with the neighboring plates and thus form a complete covering on the side of the ambulacral groove, interrupted only by the narrow spaces in which the sacculi are lodged, sacculi and covering plates alternating regularly. The upper part of the covering plate may be more or less separate, forming a very irregular plate, whose adoral side is bent somewhat inward; this part is much smaller than the lower part, the plates being thus widely separated from each other. The connection between the two parts may be represented by a single rod, which forms, however, mostly a more or less extensive network on its aboral, but not on its adoral, side. On the genital pinnulæ there are formed a number of thin, irregular plates covering the widened portion between the joints and the ambulacral plates. When dried these pinnulæ thus show a very distinct irregular plating." He adds that the perisomic plates are not found on the last six or seven pinnulars.

Promachocrinus kerguelensis (fig. 807, p. 378).-Along the sides of the pinnulars is a continuous series of conspicuous plates, the distal border of each overlapping the base of the succeeding. The main portion of these plates is about as high as broad, the distal and proximal edges being for the most part straight and perpendicular to the base, but leaning somewhat distally in the terminal portion of the pinnules. The outer angles are broadly rounded, and the middle half of the outer border is produced into a roughly squarish process with an irregular outer edge, which usually shows a narrow notch near the distal border. In the 


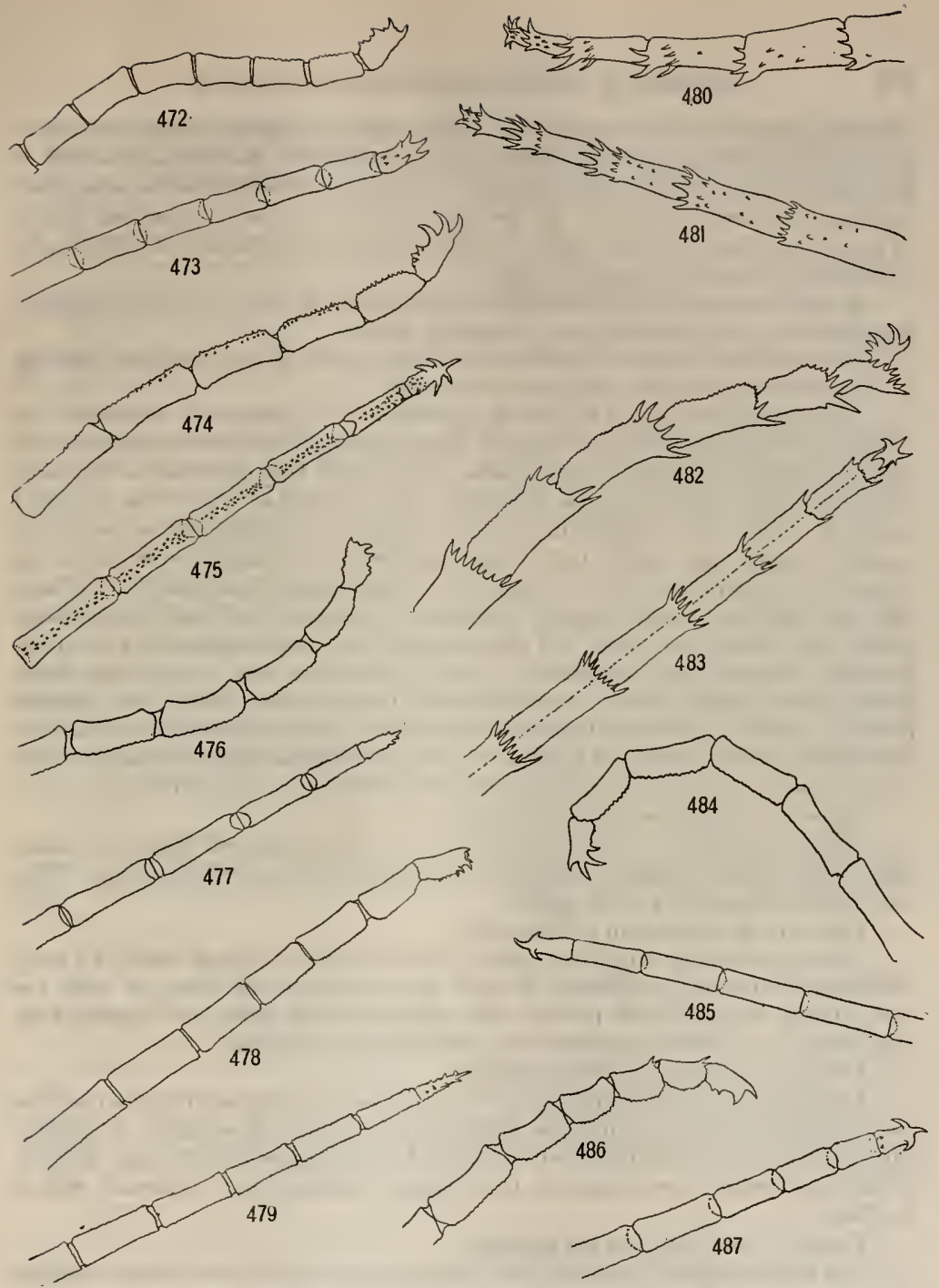

Figs, 472-487.-Pinnule tips of variovs comatulids. 472. Lamprometra protectus, latebal view. 473. SAME, DORSAL VIEW, 474. LAMPROMETRA PALMATA, LATERAL VIEW. 475. SAME, DORSAL VIHW.

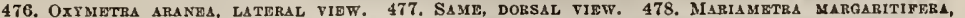
LATERAL View, 479. SAME, doksal view. 480. Colobometra discolor, latral view. 481. Samb, porsal vinw. 482. Coloromitra discolor, lateral view, 483. Samb, dorsal view. 484. DeCa-

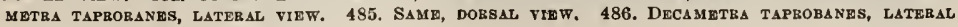
VIEW. 487. SAME, DORSAL VIEW. 
terminal portion of the pinnule this process becomes slightly longer and moves proximally, so that its proximal border is continuous with the proximal border of the main portion of the plate; the notch in the outer border also becomes more constant and more prominent. In the axis parallel with the longitudinal axis of of the pinnule the plates are slightly convex exteriorly; in the axis at right angles to this they are rather strongly curved.

In other specimens this adambulacral armament is seen in various stages of degeneration, and apparently may be entirely absent.

The tentacles contain a conspicuous continuous band of fine interlaced spicules, which runs along the outer side nearly to the tip.

Anthometra adriani.-The lateral perisome of the pinnules is completely inclosed in a continuous series of plates, the distal edges of which overlap the proximal borders of those succeeding; these plates are about as high as broad at the base, becoming higher distally, coarse in texture, with unfinished edges; the proximal border is more or less straight; the distal is usually in the outer half or two-thirds strongly convex; the middle half of the outer edge is abruptly produced in the form of a long process, which at first is not much longer than brond at the base, with the two outer corners broadly rounded, the proximal and distal sides nearly parallel and convex and lying in a plane parallel with the longitudinal axis of the pinnule, but which soon elongates, so that it is about as long as the major basal portion of the plate, moves somewhat nearer the proximal border, and becomes twisted, so that its proximal border is considerably nearer the midline of the pinnule than the distal; when the lappets are closed down these plates completely cover the ambulacral groove interlocking exactly like the fingers on the two hands.

There are no spicules in the tentacles.

Florometra marice.- In the outer portion of each ambulacral lappet is a short rod, usually straight, slightly roughened at the ends, sometimes slightly bent. This rod is often reduced to a mere spicule.

There are no deposits in the tentacles.

Florometra laodice (fig. 770, p. 362).-Each ambulacral lappet contains a long, conspicuous stout rod roughened at each end, especially the outer, or with the ends slightly expanded and pierced with numerous small holes, and slightly bent just before the middle; sometimes these rods are much reduced.

There are no deposits in the tentacles.

Florometra asperrima (figs. 769,771, p. 362 ). - In a specimen from Bering Sea each ambulacral lappet contains a long and very stout rod, straight or slightly curved or bent, of which the inner end is slightly irregular and the outer third is thickly beset with short spines, or, more rarely, expanded and perforated with a few holes.

There are no deposits in the tentacles.

In a specimen from Monterey Bay, California, each ambulacral lappet contains a long and prominent rod, roughened at each end, especially at the outer, very rarely forked, and evenly and rather strongly curved.

There are no spicules in the tentacles. 
Florometra serratissima (figs. 774, p. 362).-Each ambulacral lappet contains a slender rod, which is straight or slightly curved, roughened, rarely forked at the ends, and of moderate length, reaching usually nearly or quite to the underlying sacculus.

There are no deposits in the tentacles.

Florometra magellanica.--Each ambulacral lappet contains a delicate straight rod, short or of moderate length, slightly roughened at the ends.

There are no spicules in the tentacles.

Cyclometra clio.--Each ambulacral lappet contains a slender, rather long rod, which is slightly bent in the middle.

There are no spicules in the tentacles.

Sarametra triserialis (fig. 801, p. 378).--Each ambulacral lappet contains a large and conspicuous fan-shaped plate, with five or six very long, slender spines along the convex outer border. The lower pointed end of this fan is continued downward in the form of a long, straight rod to the edge of the pinnulars.

There are no deposits in the tentacles.

Zenometra columnaris (fig. 800, p. 378).-Each ambulacral lappet contains a very large plate, which is elongate, more than twice as long as broad, slightly constricted in the middle, with rounded ends; the outer border is very wide meshed and bears a number of long spines; the inner end usually bears from two to four long spines, which run to the border of the pinnular, but these may be reduced to one stout spine. In the middle of this plate, lying nearer the distal than the proximal border, is a large oval hole elongated in the same direction as the plate itself, which may communicate with the exterior near its outer end.

There are no deposits in the tentacles.

Psathyrometra borealis.-Each ambulacral lappet contains a long and very narrow band-like plate abruptly bent in the middle, at the base tangent to the distal side of the sacculus, terminating outwardly in from three to five long spines. which are parallel to each other.

There are no deposits in the tentacles.

Psathyrometra fragilis.-The deposits in the perisome of the pinnules resemble those found in $P_{s}$. borealis.

There are no deposits in the tentacles.

Psathyrometra antarctica (fig. 765, p. 362).-Each ambulacral lappet contains a large, stout, and conspicuous smooth rod slightly bulbous and roughened at the outer end which runs downward at an angle of about $60^{\circ}$ to the border of the pinnular, then abruptly turns proximally and runs along the edge of the pinnular to the bent portion of the succeeding rod.

There are no deposits in the tentacles.

Psathyrometra gracillima.-Each ambulacral lappet contains a long and slender, almost straight rod which is roughened at each end, more especially the outer.

There are no deposits in the tentacles.

Eumorphometra concinna (fig. 806, p. 378).--Each ambulacral lappet contains a long, thick, and conspicuous rod, making an angle of nearly $60^{\circ}$ with the border 
of the pinnulars, which is roughened or studded with small projections on its somewhat enlarged outer end, and near the border of the pinnular suddenly expands into a coarse meshed reticulation adjoining a similar reticulation from the adjacent rods.

There are no spicules in the tentacles.

Leptometra celtica (figs. 795,799, p. 372).-The lateral perisome of the pinnules is occupied by a continuous series of large plates, each of which distally overlaps the base of the succeeding. The greatest diameter of these plates is in the middle; the sides of the portion below the middle are strongly concave, curving about the sacculi, the curve being sharpest about the outer border of the sacculi and gradually straightening out toward the base of the plate; in the middle of the outer border of the plate are two prominent narrow projections side by side separated by a narrowly rounded or V-shaped notch. From the base of these projections the outer border forms a rounded obtuse angle which lies about halfway between the bases of the processes and the middle of the distal and proximal sides, where it abruptly passes over into the lateral concavities. Usually on the distal side the side of the distal outer process is carried further basally than on the other, so that the angle on the distal outer border is much more nearly a right angle than that on the proximal outer border; occasionally between the base of the distal outer process and the angle on the outer distal border there is a rounded notch, so that the latter takes the form of a prominent narrow angle directed outwardly; occasionally also the proximal side may run proximally from the tip of the proximal outer process proximally and downward at an angle of $45^{\circ}$ with the edge of the pinnular to a point directly above the middle of the sacculus, when it turns and runs perpendicularly downward. Viewed from the inside of the plate the outer processes are seen to be much thickened; the thickening of the distal process is confined to the process itself, while that of the proximal process is continued for a considerable distance down on the inner face of the plate. The outer third of the plate is curved inward toward the middle of the pinnule.

The tentacles usually contain a few small spicules which may form a group or elongated patch in about their middle.

Leptometra phalangium.-Each ambulacral lappet typically contains a large and conspicuous covering plate which is triangular, higher than broad at the base, with the inner border more or less concave; these are sometimes much reduced in size and irregular in shape, and occasionally occur only as straight rods leaning slightly distally; rarely a side plate is found beneath the covering plate.

The tentacles usually contain a short band of roughened spicules near the middle. Sometimes this band is narrower and much elongated; many of the tentacles are entirely without deposits.

Notocrinus viritis (figs. $1329,1330, \mathrm{pl} .49$ ).-The lateral perisome of the pinnules contains large plates which are usually triangular in shape with rounded angles and mostly about half again as high as broad at the base. Their bases are separated from each other by a space about equal, on the average, to half the basal length. 


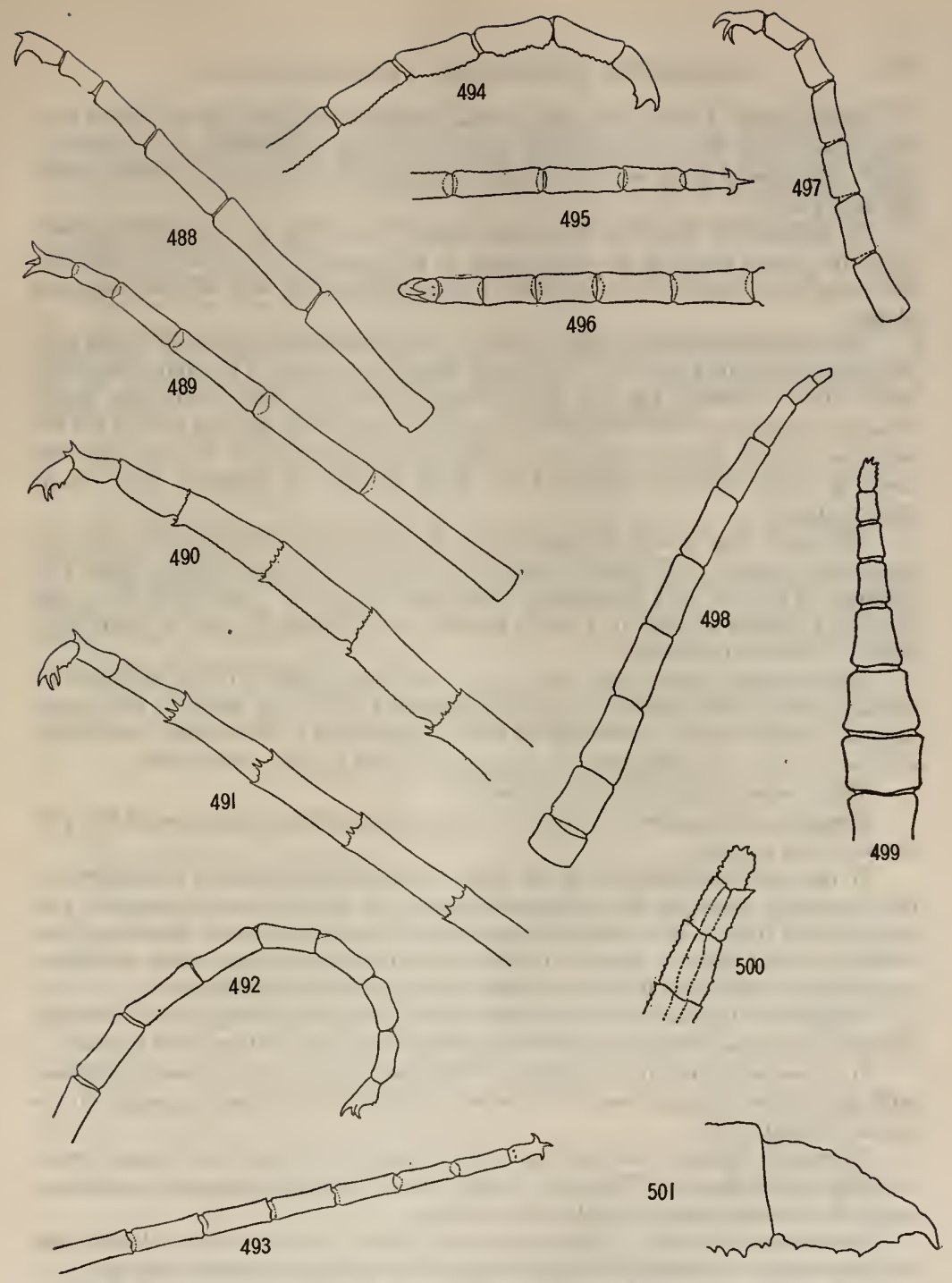

Fios. 488-501,-Pinnele tipg of variods comatulids. 488. Cillometra soluta, lateral view. 489. SAME, DORAal VIEW. 490. Cotylometra ornata, lateral View, 491. SAME, DORSAL view. 492.

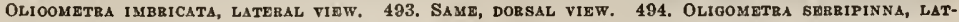
graL vIEW. 495. SAME, DORSAL VIEW. 496. OLIOOMETRA SERRIPINNA, DORSAL viEW. 497. SAME,

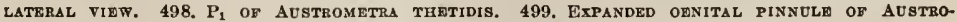
METRA THETIDIS IN DORSAL VIEW. 500. AUSTROSHETRA THETIDIS, TIP OF P IN VENTRAL VIEW. 501. AUSTROMETRA THETIDIS, TIP OF DISTAL PINNULE, LATERAL VIEW. 
Beyond each of these side plates in the ambulacral lappets, but in contact with their outer ends, lies a considerably smaller covering plate which is irregular in shape, but usually more or less elongate, and tapers to the point of contact with the side plate.

In addition to this type Mortensen figured very long and extremely narrow band-like plates standing at right angles to the pinnulars, with beyond them, in the ambulacral lappets, very irregular but usually narrow and elongate covering plates.

Isometra vivipara (figs. 1328, 1331, pl. 49).-Mortensen states that "some thin, irregular fenestrated plates are developed along the borders of the ambulacral furrows. They represent the side and covering plates, the latter being the larger. The side plates are often irregularly arranged, so that it is difficult to find the one corresponding to each covering plate; they may be even totally wanting; also, the covering plates may be reduced to a single spicule, at intervals even totally disappearing."

Mortensen has figured the spicules in the tentacles of this species; they are long and straight, with usually rather numerous short and usually blunt projections. They are very inconstant. Mortensen says that "sometimes there may be quite a bundle of them in a single tentacle of a pinnule, the rest of them being entirely devoid of spicules."

Hathrometra prolixa (figs. $1170, \mathrm{pl} .27$, and 775, p. 362 ).- In the specimen examined each of the ambulacral lappets contains a very long, more or less evenly curved, smooth rod, the outer end of which usually has a few minute projections, or, more rarely, is slightly forked or expanded, with a few perforations.

There were no spicules in the tentacles.

Mortensen has figured two types of plates in the lateral perisome of the pinnules of this species.

In one type the plates are in the form of long, smooth, curved rods, of which the outer end, lying in the ambulacral lappets, is expanded and narrowly fanshaped, with from four to nine perforations and an unfinished and irregular distal border, and the inner is parallel to the border of the pinnular, which it follows proximally to well beneath the recumbent portion of the succeeding rod.

In the other type the rods are thicker, without any broadening of the outer end, abruptly bent in an obtuse angle in the middle, and studded with minute thorns.

In a pentacrinoid larva figured by Mortensen these rods are more irregular, with one or two long processes from about the region of the median angle on the convex (distal) side.

Mortensen figures occasional spicules in the tentacles of the young pentacrinoids of this species. These are in the form of irregular elongated calcareous rods, which bear frequent minute obtuse spines.

Hathrometra tenella.--Each ambulacral lappet contains a very slender and delicate smooth rod, usually slightly curved, and of moderate length or short.

Some of the tentacles contain a thin line of spicules, which runs for a short distance along the outer side. 
Hathrometra sarsii (fig. 1174, pl. 27).-In the lateral perisome of the pinnules of this species Professor Sars found long, slender, slightly curved rods, with the outer ends, in the distal outer portion of the lappets, expanded and pierced with a few holes, and the inner ends, lying much more proximally, adjoining the border of the pinnulars. Similar spicules occur in the brachial perisome from the first appearance of the arms.

Fariometra explicata.-There are no deposits in the perisome of the pinnules. There are no spicules in the tentacles.

Trichometra cubensis (fig. 766, p. 362).-Each ambulacral lappet contains a prominent long smooth rod, bent distally just before or at the middle, the outer end of which bears several short spinules or processes, is slightly forked, or is expanded with a hole surrounded by short irregular processes.

There are no spicules in the tentacles.

Trichometra vexator.-There are no deposits in the perisome of the pinnules. There are no spicules in the tentacles.

Thaumatometra nutrix.-According to Mortensen there are no deposits in the perisome of the pinnules and no spicules in the tentacles.

Thaumatometra tenuis. - In the outer portion of the pinnules each ambulacral lappet contains a long and rather stout rod, bent just before the middle, with the outer quarter roughened, armed with scattered short spinules, or expanded and perforated with several holes.

Along their outer side the tentacles contain a broad and conspicuous band of very fine interlaced spicules, which persists nearly to their tips.

\section{Family PENTAMETROCRINID无.}

Thaumatocrinus rugosus.-There are no deposits in the ambulacral lappets.

The genital glands are covered with large, thin, filmy plates.

There are occasional spicules in the outer side of the tentacles.

Thaumatocrinus boreatis.-On some pinnules each ambulacral lappet contains a long but extremely narrow band-like plate, which reaches nearly to the edge of the pinnulars. On other pinnules the lappets contain a long slightly curved rod, slender and smooth, or thick and roughened throughout its length. Again, there may be at the base of each lappet a very loose calcareous structure, consisting of one or two, rarely of three, very large meshes of different sizes, usually accompanied by a rod in the outer part of the corresponding lappet.

The genital glands are inclosed in a thin calcareous film, consisting of a large meshed reticulation with very slender bars.

There appear to be no spicules in the tentacles.

Pentametrocrinus japonicus.-At the base of each of the ambulacral lappets is a very loose meshwork of from 5 to 12 meshes, which are small near the pinnular and rapidly become larger outwardly and distally, bordered with unfinished meshes. The structure extends outwardly and distally from the point nearest the pinnular, or from a point near the inner border. 


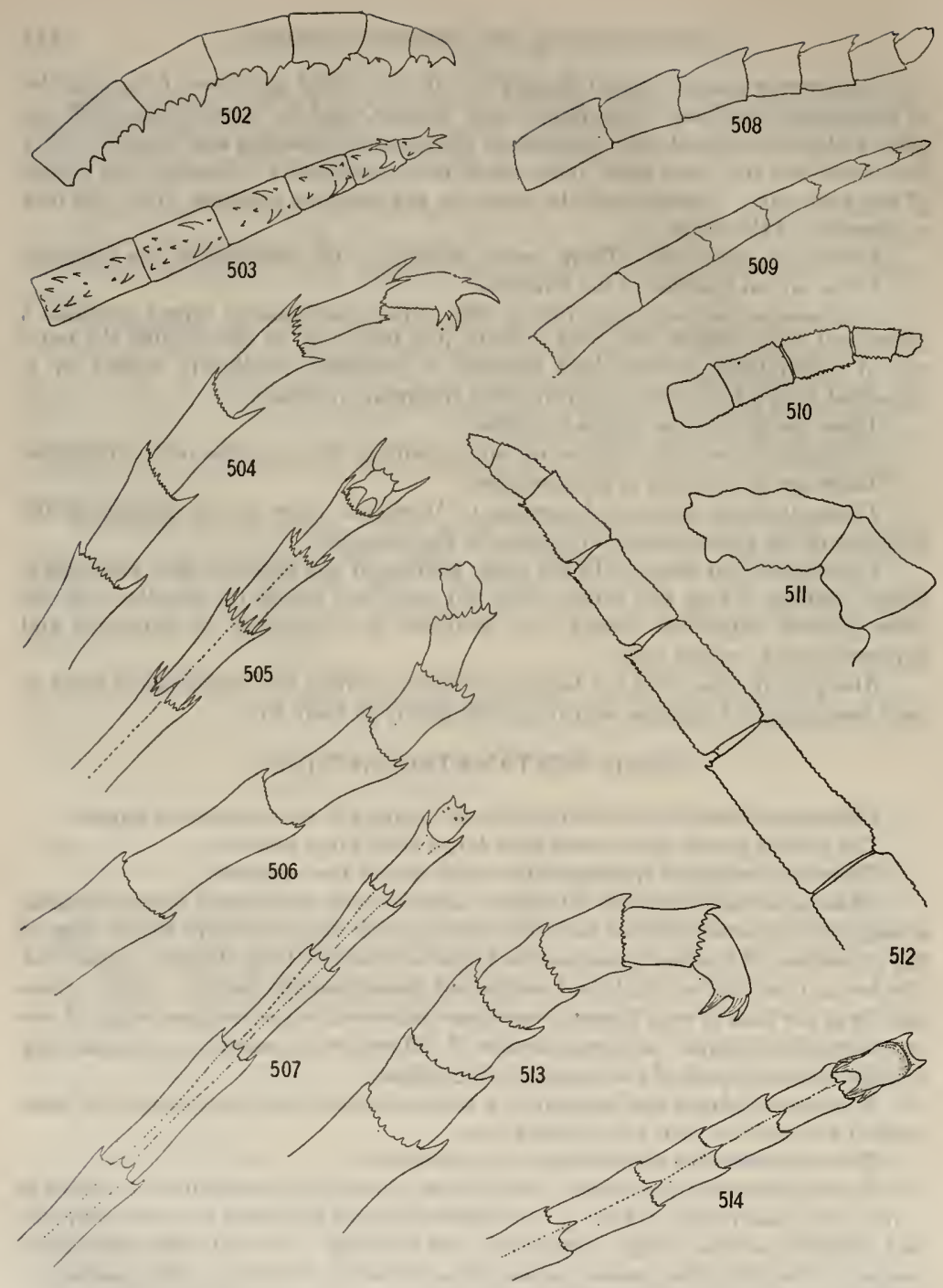

Figs, 502-514.-PinNule tips of various comatulids. 502. Tropiometra carinata, lateral view.

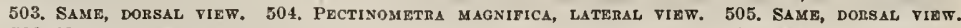

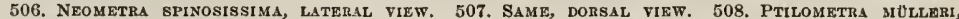

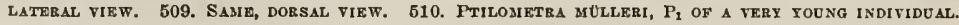

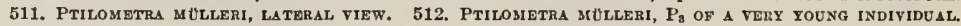
513. PTEROMETRA TRIChOPODA, LATERAL VIEW. 514. SAMK, DORSAL VIEW. 
Within the ambulacral lappets is a long, straight or slightly bent rod, sometimes two, which is studded with scattered short spinelets in the outer portion and with the outer end expanded, forked, branched, or modified in other ways; from the outer portion of the lappet this passes inwardly and proximally, making an angle of about $45^{\circ}$ with the pinnular, along the outer proximal side of the large meshwork first described to the pinnular.

The genital glands are entirely covered by curious scale-like plates of moderate size, subequal, with rounded angles and no reentrant sides, which imbricate outwardly, away from the pinnulars; these plates have excessively tine perforations, and usually appear imperforate.

There are no deposits in the tentacles.

Pentametrocrinus tuberculatus.-The perisomic deposits resemble those of P. japonicus.

Over a swollen genital gland the plates in the perisome, which are entirely separated from each other, appear subequal, all subcircular, with a slightly thickened white spot in the center surrounded by concentric rings of extremely minute perforations.

Pentametrocrinus varians (fig. 802 , p. 378).-At the base of the ambulacral lappet is a large, coarse-meshed plate, with unfinished edges, more or less oval in outline, longer along the longitudinal axis of the piunule than high.

Beyond the proximal outer side of this plate, making an angle of $45^{\circ}$ with the edge of the pinnulars, is a long, stout, and slightly curved rod, which reaches nearly to the edge of the pinnulars, and of which the outer end, over the distal portion of the large plate, bears on its outer side a few short branches, or two or three meshes.

The genital glands are completely incased by a pavement of rather small subequal polygonal plates of very fine texture.

There are no rleposits in the tentacles.

\section{Family ATELECRINIDÆ.}

Atelecrinus sulcatus.-Each ambulacral lappet contains in its outer portion a rather conspicuous elongated triangular plate, with the apex at the distal end of the lappet and the longest side parallel to the ambulacral groove; the shortest (proximal) side makes an angle of about $45^{\circ}$ with the edge of the pinnulars; these plates are widely separated from each other.

There are no deposits in the tentacles.

The occurrence of the several types of adambulacral deposits is shown in the following table:

$a^{2}$. No adambulacral structures; the ventral perisome is either entirely naked, or contains only minute irregularly scattered spicules.

Comatella nigra.

Comatella stelligcra.

Comatella maculata.

Capillaster scntosa.

Capillaster muItiradiata.

Capillaster coccodistoma.
Nemaster rubiginosa.

Nemaster discoidea.

Comissia lütkeni.

Comissia littoralis.

Comatulides australis.

Comaster novagninea. 
Comaster minimus.

Comaster multibrachiata.

Comaster fruticosus.

Comaster distincta.

Comaster parvus.

Comaster taviana.

Comaster delicata.

Comantheria polyenenis.

Comantheria briareus.

Comanthina schlegelii.

Comanthus pinguis.

Comanthus solnster.

Comanthus japonicus.

Comanthus trichoptero.

Comanthus benhami.

Comanthus tahlbergii.

Comanthus samoana.

Comanthus annulata.

Comanthus parvicirra.

Zygometra microdiscus.

Zygometra elegans.

Catoptomctra magnifica.

Himerometra magnipinna.

Himeromctra robustipinna.
Amphimetra spectabilis.

Stephanometra echinus.

Stephanometra monacantha.

Oxymetra finschii.

Oxymetra aranea.

Dichrometra ciliata.

Dichrometra fiogellata.

Mariametra subcarinata.

Lamprometra polmato.

Lamprometra protcctus.

Cenometra unicornis.

Cenometra delicata.

Cenometra herdmoni.

Cullomctra disciformis.

Cyllometra albopurpureo.

oligometra serripinna.

Antedon petasus.

Antedon bifia.

Antedon odriatica.

Promochocrinus kerguelensis.

Fariometra explicata.

Trichometra vexator.

Thaumatometra nutrix.

Thaumatocrinus rugosus.

$a^{2}$. Definite plates present in the ambulacral lappets or in the lateral perisome of the pinnules between them and the pinnulars, or in both situations.

$b^{2}$. Two series of plates or spicules present; a plate or spicule in each ambulacral lappet and another between this and the border of the pinnulars.

$c^{3}$. Plates of both series large, conspicuous and highly developed, the lateral perisome of the pinnules and the ambulacral lappets being completely inclosed by them; plates in the lappets unore or less circular, oval, or reniform; lateral plates with a narrowly produced distal and broad proximal process, and on the Inner side two prominent ridges, the distal curved and usually interrupted, the proximal straight, at right angles to the pinnulars, and earrying the covering plate articulaterl to the outer end.

$d^{2}$. No supplementary side plates present.

$e^{2}$. The saceull do not pierce or notch the side plates.

Ptilometra macronema. Pterometra magnipeda.

Ptilometra müllcri. Pterometra splendida.

Asterometra anthus. Ptcrometra pulcherrima.

Asterometra macropoda. Pterometra trichopodo.

Asterometra cristata.

$e^{2}$. The sacculi rench the exterior through boles in the side plates, or through gaps between them formed by two apposed notehes.

$f^{2}$. The outer portions of the sacculi pass to the exterior through apertures

formed by two rounded notches in the adjoining ends of adjaceut plates.

Neometra alecto.

Neometra acanthoster.

Neometra conaminis.

Neometra gorgonin.

Calometra callista.
Calometra discoidea.

Gephyrometra propinqua.

Pectinometra carduum.

Pectinometra flaropurpurea.

Ptilometra macronemo. 


$\begin{array}{ll}\text { Ptilometra milleri. } & \text { Aglaometra eupedata. } \\ \text { Cosmiometra crassicirra. } & \text { Crossometra helius. } \\ \text { Cosmiometra delicata. } & \text { Perissometra selene. } \\ \text { Stylometra spinifera. } & \text { Perissometra patula. } \\ \text { Stenometra quinquceostata. } & \text { Perissometra lata. } \\ \text { Stenometra cristata. } & \text { Pachylometra distincta. } \\ \text { Stcnometra diadema. } & \text { Chondrometra robusta. } \\ \text { Daidalometra hana. } & \text { Calyptometra lateralis. } \\ \text { Parametra orion. } & \text { Glyptometra tuberosa. } \\ \text { Parametra granulata. } & \text { Crinometra insculpta. } \\ \text { Thalassomctra villosa. } & \text { Ohlorometra garrettiana. }\end{array}$

$f$. The outer portions of the sacculi pass to the exterior through large holes near the proximal borders of the side plates.

Monachometra fragilis.

Pæcilometra 8calaris.

$d^{2}$. Supplementary side plates are present.

$e^{x}$. The supplementary side plates are in the form of elongate triangular, somewhat recurved, plates situated on the outer distal angle of the side plates, to which they appear to be articulated.

\section{Thalassometra villosa.}

$e^{2}$. The supplementary plates are in the form of long boomerang-shaped plates, broader in the outer than in the inner portion, lying in a plane making a relatively small angle with the transverse planes of the pinnule, and situated between the side plates, or just within their distal borders; at the base of the pinnules the supplementary side plates may be divided into a rounded outer and an elongated and less dereloped inner portion, the former appearing as a supplementary covering plate.

Cosmiomctra crassictrra.

Parametra granulata.

Cosmiometra delicatr.

Oceanometra gigantea.

Stylometra spinifera.

Oceanometra annandalei.

Parametra orion.

$c^{2}$. Plates of both series more or less reduced and often rudimentary, the plates of the two series separated from each other.

$d^{2}$. Plates of one or the other series composed of a delicate reticulation.

$e^{3}$. Covering plates composed of a delleate reticulation, or, if more or less spiculiform, lying with the axis partllel to the border of the pinnulars.

$f^{2}$. Side plates forming a continuous series, imbricating distally.

$\boldsymbol{g}^{2}$. Side plates dense, with a strong median ridge.

Pontiometra andersoni.

$g^{2}$. Side plates composed of a thin cribriform film.

Heliometra glacialis.

$f^{2}$. Side plates not in contact.

$g^{1}$. Side plates forming irregular or narrow tringles or bands, with the longer ares at right angles to the pinnulars.

Tropiometra macrodiscus.

Tropiometra afra.

Tropiometra carinata.

Thysanometra tenelloides.
Heliometra glacialis.

promachocrims kerguelensis.

Notocrinus vtrilis.

Isometra vivipara. 
$\eta^{2}$. Slide plates reduced to a spicule, or to a group of spicules.

$\begin{array}{ll}\text { Neocomatella alata. } & \text { Heterometra bengalcnsis. } \\ \text { Nencomatella pulchella. } & \text { Hcterometra compta. } \\ \text { Capillaster multiradiata. } & \text { Hcterometra pulchra. } \\ \text { Comatula rotalaria. } & \text { Heterometra reynaudii. } \\ \text { Comatula solaris. } & \text { Heterometra quinduplicava. } \\ \text { Comatula pectinata. } & \text { Homalometra dcnticulata. } \\ \text { Comactinia meridionalis. } & \text { Amphimetra discoidea. } \\ \text { Comaster multibrachiata. } & \text { Amphimetra parilis. } \\ \text { Craspedometra acuticirra. } & \text { Oxymetra aranea. } \\ \text { Heterometra crenulata. } & \text { Tropiometra macrodiscus. } \\ \text { Heterometra savignii. } & \text { Tropiometra afra. } \\ \text { Heterometra philiberti. } & \text { Tropiometra picta. }\end{array}$

$e^{2}$. Covering plates reduced to struight or curred rods, but side plates composec of a delicate reticulation.

Eumorphometra concinna.

Thaumatocrinus borcalis.

Pentametrocrinus japonicus.

Pentametrocrinus tuberculatus.

$d^{2}$. Both side and rorering plates spieullform.
Neocomatella pulchella.
Eudiocrinus venustulus.
Neocomatella alata.
Himerometra bartscli.
Capillaster multiradiute.
Heterometra quinduplicana.
Nemaster rubiginosa.
Amphimctra parilis.
Leptonemaster venustus.
Lamprometra gyges.
Zygometra comata.
Cyllometra albopurpurea.
Eudiocrinus indivisus.
Decametra mylitta.
Eudiocrinus junceuts.
Eudiocrinus pinnatus.
oligometrides adeona.
Eumctra chamberlaini.

$b^{2}$. Only a single series of plates present.

$c^{3}$. The perisone of the pinnules is completely occupied by a continuous series of large imbricating plates.

Hcliometra glacialis.

Anthometra adriani.

Promachocrinus kerguelensis. Leptometra celtica.

$c^{2}$. The ambulacral lappets contain plates, rods, or spicules, which are entirely independeut of those on either side.

$d^{1}$. Each lappet contains a definite jlate.

$e^{x}$. The plates are strongly convex outwardly, and usually large.

Ncmaster grandis.

Nemaster iocensis.
Nemaster rubiginosa.

Comatilia iridometriformis.

$e^{2}$. The plates are plane. or nearly so.

$f^{1}$. The plates are small, triangular, and confined to the apices of the lappets.

\section{Atelecrinus sulcatus:}

$f^{2}$. The plates are large, and ure continued dowaward almost or quite to the pinnulars.

$g^{1}$. The plates are fan-shaned.

Sarametra triserialis.

$g^{2}$. The plates have approximately parallel sides.

$h^{2}$. The plates are rery brogd, oval in ontline. 
Zenometra colımnaris.

$h^{2}$. The plates are very narrow and band-like.

Psathyromctra borealis.

Thanmatocrinus borealis. Psathyrometra fragilts.

Isometra viviparu.

$d^{2}$. Each lappet contains a single rod or spicule.

$e^{\star}$. The rods or spicules are straight.

Comatonia cristata.

Himerometra martensi.

Mariametra delicatissina.

Cyllometra disciformis.

Cyllometra albopurpurea.

Decametra taprobanes.

Decametra tigrina.

Decametra parva.

Colobometra vepretum.

Colobometra discolor.

Prometra chadwicki.

Cotylometra gracilicirra.

oligometrides adeone.

Oligometra carpenteri.

oligometra serripinna.
Tropiometra picta.

Tropiometra indica.

Antedon petasus.

Compsometra loveni.

Compsometra incommoda.

Erythrometra ruber.

Erythrometra australis.

Heliometra maxima.

Heliometra glacialis.

Florometra maria.

Florometra aspcrima.

Florometra serratissima.

Florometra magellanica.

Psathyrometra gracillima.

$e^{2}$. The rods or spicules are curved or bent.

$f^{\prime}$. The convexlty of the curve is outward and proximal.

Catoptometra hartlaubi.

Catoptometra ophiura.

Amphimetra papuensis.

Oxymetra finschii.

Cyllometra albopurpurea.

Prometra chadwicki.

Antedon petasus.

Compsometra lovéni.

Toxometra paupera.

Iridometra adrestine.

Iridometra melpomene.

Andrometra psyche.

Coccometra nigrolineata.
Coccometra hagenii.

Nanometra clymene.

Florometra maric.

Florometra laodice.

Florometra asperrima.

Florometra scrratissima.

Cyclometra clio.

Trichometra cubensis.

Thaumatocrimus borealis.

Pentametrocrinus tuberculatus.

Pentametrocrinus japonicus.

Pontametrocrinus varians.

$f$. The conrexity of the curve is inward and distal.

Comatonia cristata.

Dichrometra döderleini.

Mariametra delicatissima.

Decametra mylitta.

Oligometra scripinna.

Hypalometra defertr.
Psathyrometra antarctica.

Hathrometra prolixa.

Hathrometra tenella.

Hathrometra sarsii.

Thaumatometra tenuis.

From the preceding analysis it is evident that the relationships between the various types of adambulacral structures and the systematic position of the species is quite similar to the relationships between the latter and the various types of cirri; that is to say, only a small minority of the systematic units have cliaracteristic adambulacral plates. It is interesting to note further that the systematic 
units in which the cirri are most uniform and most distinctive also have the most uniform and distinctive adambulacral plates, and the reverse. In certain groups a single specimen often has two or more types of cirri; similarly, a single specimen has two or more types of adambulacral plates; also, in the case of both structures, most marked in the Heliometrinæ, there may be great variation in different specimens of the same species.

In their relation to calcification the ambulacral lappets of the pinnules and the adjacent lateral perisome show three chief conditions.

In the 203 species examined the ambulacral lappets contained each a single rod or spicule in 65 specimens, representing the following families:
Comasteridæ (very rare).
Colobometrida (majority).
Zygometridæ (rare).
Himerometridæ (rare).
Mariametridæ (rare).
Tropiometridæ (rare).
Antedonidae (majority).
Pentametrocrinidæ (alternative).

In 60 specimens there were no definite ambulacral structures whatever. These were distributed in the following families:

Comasteridæ (great majority).

Zygometridæ (majority).

Himerometridæ (minority).

Stephanometridæ (all).

\author{
Mariametridæ (majority). \\ Colobometridæ (about half). \\ Antedonidæ (Antedon only). \\ Pentametrocrinidæ (one species).
}

In 52 species very highly developed side and covering plates, always of the same general type, were present. These species included all of those examined in the families Calometridæ, Thalassometridæ, Charitometridæ.

In the remaining specimens very diverse conditions were found, which, however, were always traceable to one or other of the two last.

In the families Calometridæ, 'Thalassometridæ, and Charitometridæ the side plates possess certain distinctive features by which the species may be assignec to their proper family.

In the Calometridæ there is a remarkable uniformity of structure throughout the genera and species, but in the other two families there is considerable variation.

In the Thalassometridæ the species of the subfamily Ptilometrinæ and of the genera Stylometra and Oceanometra appear to possess distinctive side and covering plates, while the same is true of the species of Monachometra and Pocilometra in the Charitometridæ; but in the other genera no distinctive features are evident, though certain peculiarities, such as the possession of supplementary side plates, are confined to limited groups of genera.

The side plates of Pontiometra appear to be distinctive; but only one specimen was examined, and it is quite possible that they may be subject to more or less extensive variation.

The Pentametrocrinidæ have a curious combination of a rod and a plate which is diagnostic, though in certain parts of each individual rods alone may be found.

Sarametra possesses a quite unique type of adambulacral plating, which is evidently a modification of the equally unique type found in Zenometra, both of which 


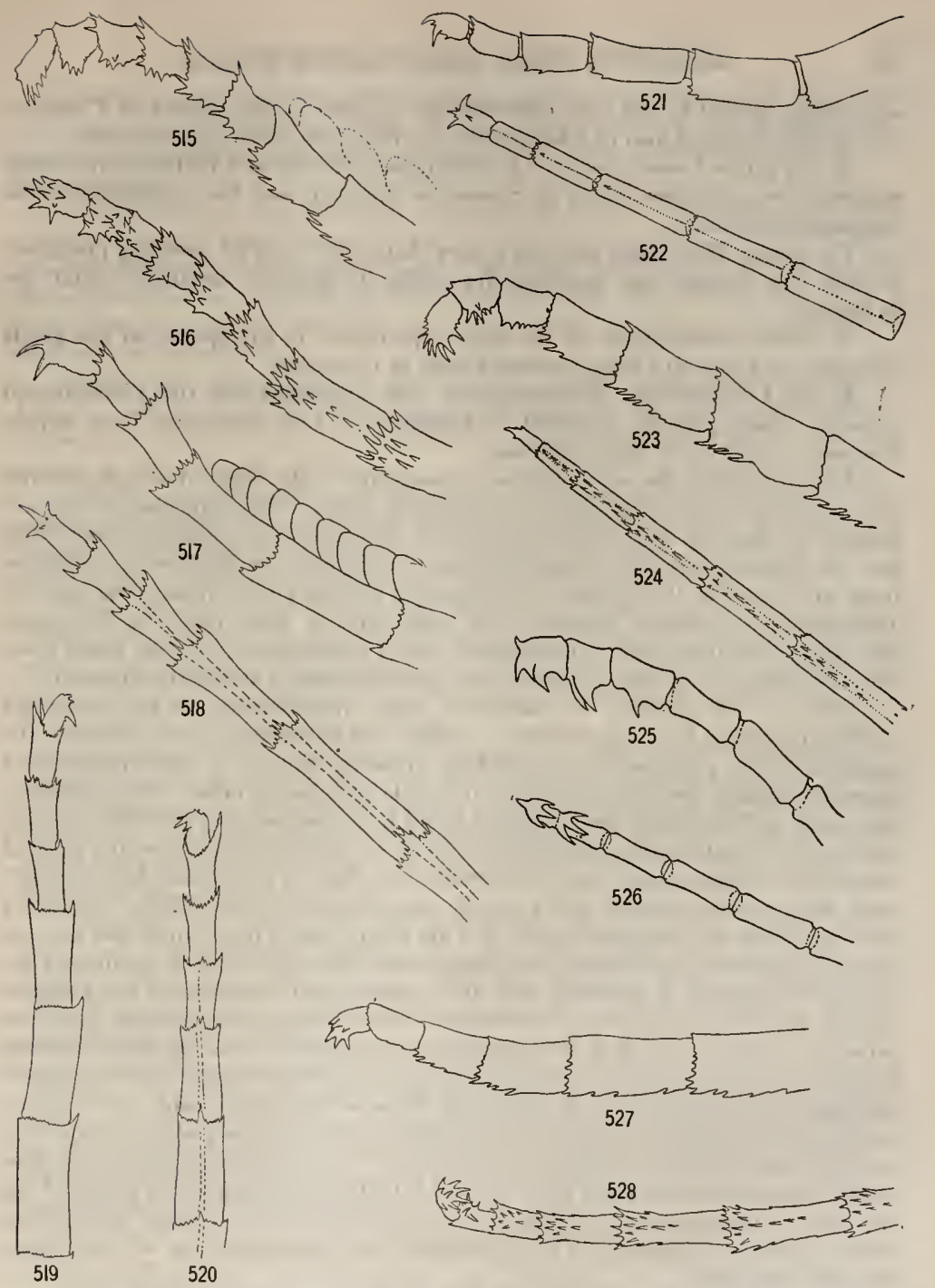

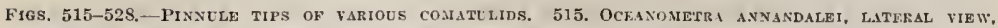

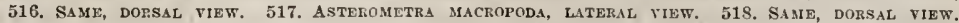
519. ASTERoMETRA MACROPODA, LATERAL VIEW. 520. SAMF, DORSAL VIET. 521. STILOMETRA SPINIFERA, lateral view. 522. Same, dolsal view. 523. Thalassometra attenuata, lateral view. 524. SaMe, dorsal View. 525. Comanthos trichoptera, lateral view. 526. SaMe, dorsal vipw. 527. Thalassometra attendata, Lateral view. 528. SAME, DORSAL view. 
are clearly related to the type characteristic of most of the species of Psathyrometra, and occurring also in Thaumatometra, Isometra, and Thysanometra.

In the genus Eumorphometra a combination of rods and plates occurs which suggests the conditions found in Sarametra inverted, and the conditions in the Pentametrocrinidæ.

The genus Atelecrinus exhibits a very distinctive type of covering plate, but as only one pinnule was available for study its possible variations could not be traced.

A further development of the same type occurs in the species of the genus Nemaster, and in a still more perfected form in Comatilia.

In the Comasteridæ, Himerometridæ, and Tropiometridæ the adambulacral armature, when present, is almost invariably of a very distinctive type, which, however, is alike in all three families.

Most commonly the adambulacral deposits are in the form of simple spicules or rods, which occur either singly or in tandem pairs. These spicules or rods are straight or slightly curved, and measure in Leptonemaster venustus about 0.020 $\mathrm{mm}$.; in Zygometra comata, from $0.015 \mathrm{~mm}$. to $0.025 \mathrm{~mm}$.; in Eudiocrinus pinnatus, from $0.070 \mathrm{~mm}$. to $0.115 \mathrm{~mm}$; in Cyllometra albopurpurea, from $0.002 \mathrm{~mm}$. to $0.090 \mathrm{~mm}$.; in Antedon petasus, from $0.025 \mathrm{~mm}$. to $0.050 \mathrm{~mm}$.; in Perometra diomedece, from $0.025 \mathrm{~mm}$. to $0.060 \mathrm{~mm}$.; and in Hathrometra prolixa, about 0.300 $\mathrm{mm}$. In nearly all of these types they are more frequently absent than present.

Since in the majority of comatulid types, representing all the comatulid families excepting the Atelecrinidæ (of which our knowledge is very limited) the perisome of the pinnules is quite without deposits, contains a vast multitude of extremely minute spicules, or a series of simple spicules, in other words, recapitulates more or less exactly the conditions found in the perisome of the disk of which it is the direct continuation; since the adambulacral deposits never show any trace of ontogenetical degeneration; and since, while all plates of every sort develop originally from minute spicules, and a spicule may increase in size without forming a plate, and there is no evidence, so far as I am aware, that a plate which has once attained phylogenetic significance ever degenerates into a solid rod or spicule, we are apparently justified in assuming that the adambulacral armature of the pinnules consists merely of perisomic (secondary) plates strictly comparable with the perisomic plates of the disk, but localized and modified as the result of physical limitations and mechanical factors, originating as a consequence of the inherent tendency in the crinoids to form calcareous deposits wherever possible, and of independent origin within the group and even within small divisions of the group, with no phylogenetic history whatever behind them. The adambulacral plates are thus merely the continuation upon the arms and pinnules of the perisomic plates of the disk, and in those species in which they are highly specialized forms intermediate between them and the plates of the interpalmar regions may always be found along the disk ambulacra.

The simple spicule may develop in either of two directions: (1) It may simply enlarge and thicken into a stout rod, almost invariably with the outer, or with both, ends swollen and roughened, as in Comatonia cristata, Oligometrides adeono, 
Toxometra paupera, Erythrometra australis, P'sathyrometru antarctica, Florometra asperrima, and Florometra laodice; or (2) it may broaden into a plate, either directly after its first appearance, or after it has taken on more or less of the rodlike character.

An intermediate type is seen in such forms as Florometra serratissima, Florometra asperrima, Hypalometra defecta, Hathrometra protixa, and Trichometra cubensis, where more calcareous matter is deposited on the distal end of the plate than elsewhere, and this is largely laid down in a plane parallel to the surface, so that a broadened and flattened end, often with large incisions or pierced with one or several holes, results.

If this additional deposition is extensive and all in one plane, a fan-shaped form, as seen in Sarametra triserialis, derived through the type found in Pentametrocrinus varians, results; and if both ends are similarly modified, an oval form, as seen in Zenometra columnaris.

After a considerable growth the spicule may fork or branch, so that a large and stout triradiate or branched spicule results; spicules of this type are usually, perhaps always, intermixed with others of simpler form; they are seen well illustrated in Neocomatella pulchella and in Nemaster mubiginosa.

If the branching first occurs when the spicule is smaller, greater complexity is found and one or two complete meshes may be formed, as in Amphimetra discoidea and in Heterometra bengalensis; and if it occurs when the spicule is very small a more or less definite plate with indefinite borders results, as in Pontiometra andersoni and in Tropiometra macrodiscus.

But instead of first undergoing more or less enlargement as a spicule, the original spicule may almost from the start take the course of the spicules which form the bases of the first plates to appear in the larvæ; that is to say, it may almost immediately develop into a fine network, spreading out over the perisomic regions and entirely inclosing them; the cells in this network, however, are never so small as those in the primary plates.

When this occurs the relatire distinctness and mobility of the outer portion of the lappets will determine whether there is a single series of large plates, as in Promachocrinus kerguelensis, or in Comatilia iridometriformis, or whether there are distinct side and corering plates, as in the species of Calometridæ, Thalassometridæ, and Charitometridæ.

Though the side plates in the Calometridæ, Thalassometridæ, and Charitometridæ show great uniformity, and their structure is usually very complicated, there is not the slightest reason for supposing that they are phylogenetically connected with the adambulacral plates of any other groups, or that they are anything else than the result of the secondary calcification of the perisome, which has been influenced by purely local factors.

Each side plate is the external covering of a definite unit, composed of the inner portion of an ambulacral lappet and the associated tentacles and sacculus.

In their most simple form the side plates in these families are low and approximately oblong in shape, with rounded corners, as seen in Asterometra macropoda 
and in Ptilometra mülleri. In the latter they first appear at an extraordinarily late developmental stage.

Increase in the height of the side plates brings them into contact with the sacculi below them, and in their distal portion with the tips of the tentacles which when folded down lie on the outer border of the ambulacral groove beneath or beyond the outer edge of the covering plate, and almost over the sacculus above them. The downward extensions of the plates pass around the superficial portion of the sacculi, which at first come to lie in gaps formed by the excised lower corners of two adjacent plates, and later in holes formed by two apposed rounded notches just below or even at the middle of the borders of two adjacent plates. In some cases the plates may grow entirely around the sacculi, leaving them protruding through more or less circular holes near the proximal border, as in Monachometra fragilis and in Pocilometra scalaris; but in the types in which this occurs all stages may always be found between the isolated perforation and the usual two apposed notches. Even when the sacculus reaches the exterior through a perforation near the proximal border of the side plates the adjoining distal edges of the adjacent side plates are notched, since, as a result of the contour of the side plates and of the position of the sacculi, they come in contact with them.

The uniform outward growth of the side plates is prevented by the tentacle tips, and in each side plate a large semicircular notch is formed in the distal portion of the outer border in which the tentacle tip rests; this leaves a slender curved horn-like process on the distal outer angle between the tentacle tip and the sacculus.

On the inner surface of the plates septa appear more or less inclosing the sacculi which lie over the apposed edges of adjacent plates, and to the outer end of the proximal septum the covering plate is attached.

Whenever sacculi are absent the distal and proximal borders of the side plates promptly reassume their normal form. If a sacculus be absent, but the notches in the ends of the plates present, it indicates that the sacculus has merely discharged its contents and that another will soon form in the same place.

The formation of the supplementary side plates results from the separate calcification of the main proximal portion and the distal border of the lappets. Since the supplementary side plates are formed within the tissue ordinarily inclosing the distal border of the side plates with their accompanying ridge, they are in reality nothing but this distal border which has become detached from the main body of the plate; and, indeed, in certain species the progressive detachment of this portion of the plates may be traced in all its stages.

The cause of this detachment of the distal border of the plate appears to lie in the compensation, by the swinging outward of the side plate, of the interior crowding caused by the unusually deep downward flexion of the covering plates. This lateral movement of the side plates, pivoting on the proximal border, can not be extended to the distal border of the plate the ridges on the inner side of which pass deeply within the tissues of the pinnule; there thus remains a permanently uncalcified strip of perisome between the mobile main portion of the plate and the fixed distal border. 


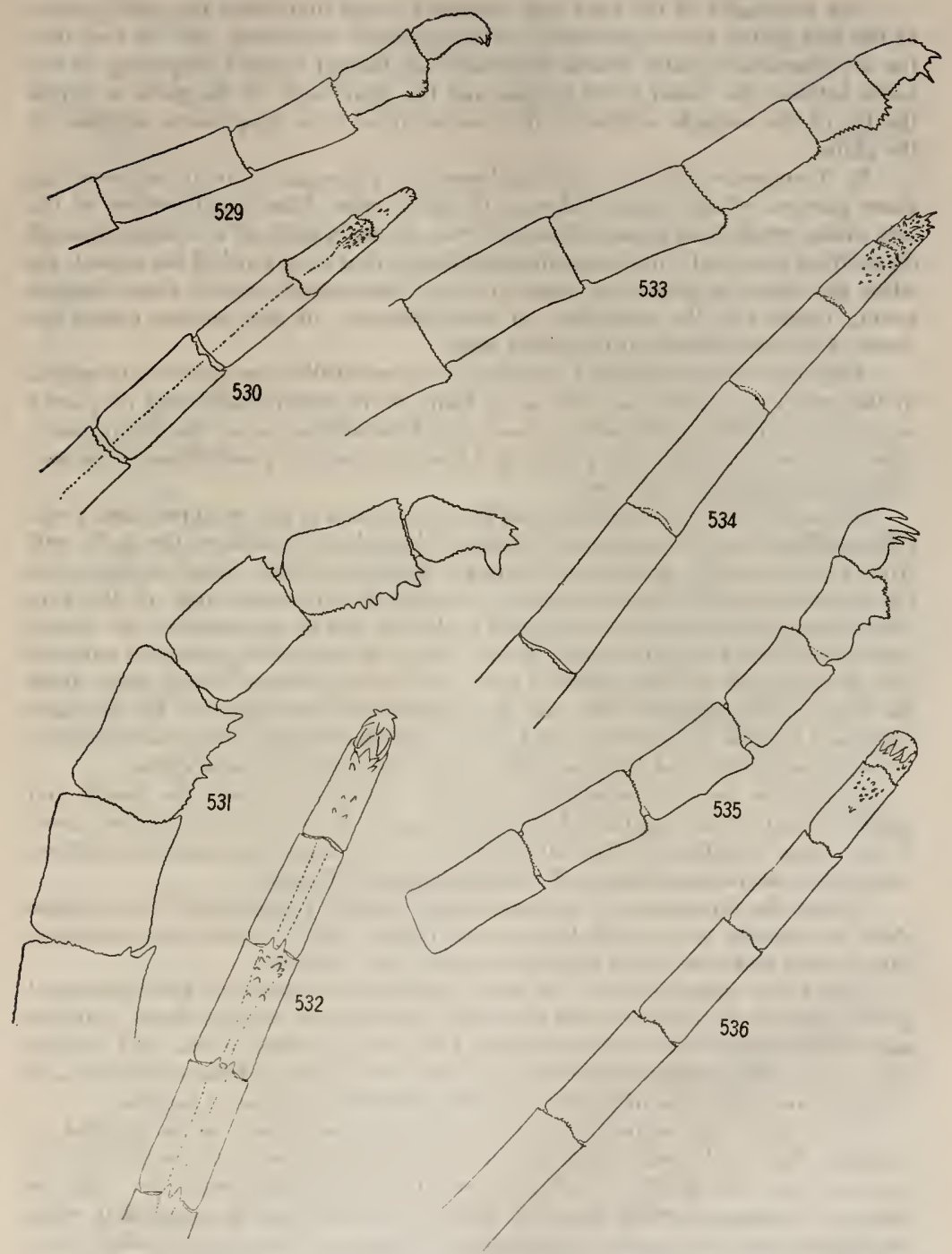

Figs. 529-536.-Pinnule tips of various conatulids, 529. Perissometra selene, haterai, vibw. 530. Same, dorsal view. 531. Crotalometra flava, lathral view. 532. Samb, dorsal view. 533. Perissometra Macilenta, lateral vibw. 534. Same, dorsal view. 535. Cinometra mortmisent, LATERAL VIEW. 536. SAME, DORSAL view. 
Any movement of the kind just described would first affect the outer border of the side plates, thence gradually extending itself downward; and we find that the supplementary plates become separated off, though a rapid deepening of the notch between the distal outer process and the main body of the plate in which the tip of the tentacle ordinarily lies, accompanied by a progressive eversion of the plate.

In Oceanometra gigantea the supplementary plates undoubtedly represent the inner portions of the curved ridge on the inner side of the distal borders of the side plates which have become detached from the main body of the plates through the shifting proximally of the sacculus and the moving downward of the tentacle tip when the covering plates are closed over the ambulacral groove, these changes having resulted in the resorption, or nonappearance, of any portion except the crests of the two sections of the distal ridge.

Although the adambulacral deposits in the comatulids are sporadic in origin, in the group as a whole as well as in many of its subdivisions, and of purely secondary signinicance, without any such direct homologies as we are, for instance, able to trace in the primary plates, still there are certain possibilities to be considered in connection with them.

It has already been explained that the crinoid arm is not an appendage, properly speaking, but an enormously elongated branched eversion of the body wall from a point exactly on the line where the heavily calcified dorsal surface joins the perisomic surface, which carries out within it extensions from all the ring formed structures about the moutl and gullet, as well as an extension, the dorsal nerve cord, from the central nerve mass. The only organs not continued outward into the arms are (1) the digestive tube, (2) the axial organ, which arises from the wall of the digestive tube and is probably the homologue of the so-called notochord in other invertebrates, and (3) the chambered organ, which is intimately connected with the axial organ and lies within the central nervous system.

Within the arm the extensions from the ring systems about the mouth and gullet maintain their original relationships; and as in the calyx the central dorsal nervous mass is isolated in the centrodorsal, so in the arms its extension is isolated within the calcareous substance of the brachials and pinnulars.

Before the formation of the arms we find in the young crinoid five lappets about the mouth, over which they can be closed, each of which has associated with it three tentacles, and at the base on either side a sacculus.

Along the ventral side of the arms and pinnules, bordering the ambulacral groove, just as the lappets about the mouth border upon the peristome, with the same relationships with the extensions of the ring systems as the oral lappets have to the ring systems themselves, and each with a group of three tentacles and a sacculus on either side of the base, we find a continuous series of lappets.

From their size, structure, and relationships we appear to be justified in assuming that the lappets bordering the ambulacral grooves of the arms and pinnules are not only strictly homologous with those about the mouth, but with the latter at the stage at which the arms are first formed; that is to say that while the lappets about the mouth undergo many changes in passing to the adult stage, 


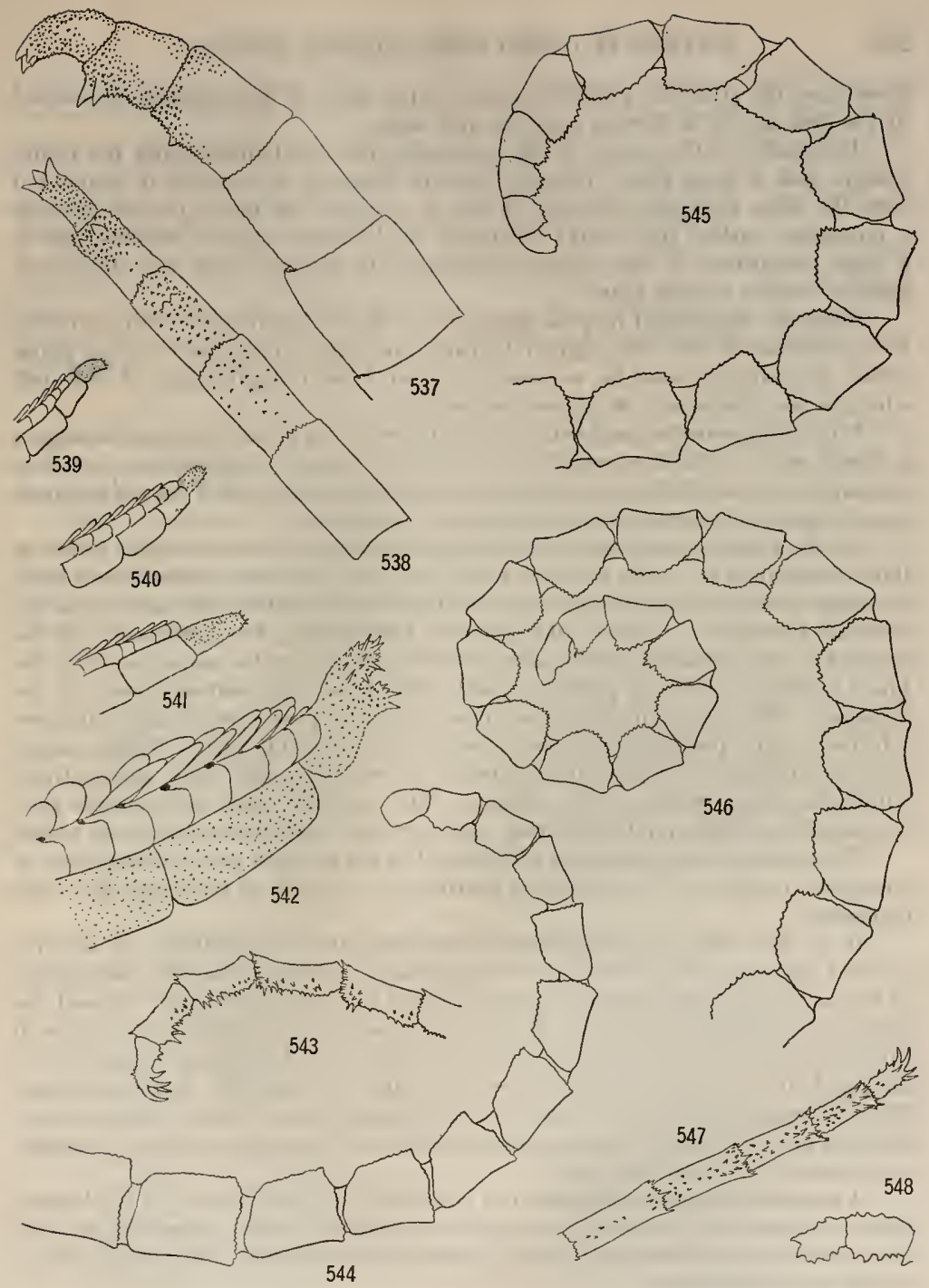

Fros, 537-549,- I'INNele tips of various comatulibs. 537. Crossometra investigatoris, lateral vibw. 538. Same, noksal view. 539. Pfecirometra scalaris, lateral view (drawing by aUthor). 540. SAME (DRAWING RY AUTHOR). 541. SAJIE (DKAWING BY AUTHOR). 542. SAME (DRAWINO BY

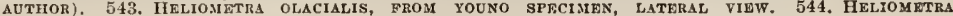
Clacialis, tip of $\mathrm{P}_{1}$. 545. Saie. 546. Saje. 547. Helionintra glacialis, flom a rodng speciaex, DORSAL VIET. 548. HELIOMETRA GLACLALIS, FROM YOUNO SPECIMEN, LATERAL VIEW. 
those upon the arms and pinnules remain at the stage of development represented by the first ones to be formed upon the arm bases.

Invariably in the young of the comatulids the five lappets about the mouth contain each a large plate primarily more or less oval or rounded in shape, but with the edges abruptly upturned in such a way that the major portion presents a triangular outline (the oral); invariably in the recent stalked crinoids, and in a large proportion of the mature comatulids, the lappets along the ambulacral grooves contain similar plates.

Since the ambulacral lappets appear to be clearly homologous with, or rather reduplications of, the five original lappets about the month, the covering plates which they contain must be, to some extent at least, reduplications of the orals which in size, shape, and structure they resemble.

While it appears reasonable to consider the covering plates as at least analogous to larval orals, which they resemble even in their manner of closure, no such close comparison is possible between the side plates and the basals; and yet the two have certain features in common which can not be overlooked.

At the time the orals are at the stage represented by the covering plates in those comatulids in which they are most developed, the basal beneath each bears the same relation to the ring systems about the mouth as the side plates do to the brachial extensions of these ring systems; furthermore, the lower ends of the basals are bent inward over the topmost columnal in just the same way that the lower borders of the side plates are bent inward over the ventral surface of the pinnulars. The basals in the comatulids eventually pass inward and transform into the rosette, protecting the dorsal nerve cords; the side plates develop strong inward extensions, and the distal borders, as we have seen, may pass entirely within the fleshy portion of the pinnule. The orals are much less variable than the basals, and similarly the covering plates are less variable than the side plates.

The interest in the preceding discussion lies not so much in the homologies, or analogies, involved as in the possible bearing on the origin of the basals and orals themselves.

It is clear that the adambulacral structures are reduplications of the five perioral lappets of the larva; it is not improbable, therefore, that the calcification of the ambulacral lappets and the formation of the basals and orals followed the same path. The calcification of the basals and orals must be complete in order to furnish a support for the larval calyx; the ambulacral lappets are supported by the brachials or pinnulars, and there is no such necessity for further support. Thus the calcification of the ambulacral lappets may occur in any form between the most primitive and the most perfected, while only the perfected type is possible in the case of the basals and orals.

A reasonably complete sequence can be traced in the calcification of the lappets from an integument containing multitudes of minute spicules, suggesting those of such ascidians as Didemnum, through enlarged single spicules, which may reach a very large size, to plates.

If the similarity between the adambulacral plates and the basals and orals is more than superficial, the available facts would suggest the following inferences: 
(1) The basals and orals in the early larva are perisomic plates, not having as yet assumed their ultimate status of primary plates; (2) the plates of the crinoid calyx originated as a development from an integunent filled with minute spicules; and (3) the spicules in such an integument may develop individually into specialized forms, such as large spicules, rods, scale-like plates, buttons, or anchors, or through plates of the perisomic type into the typical crinoid plates.

There is an interesting superficial similarity between the side and covering plates in the crinoids and the so-called "snowshoes" developed (from modified feathers) along the sides of the toes of certain grouse in winter (fig. 762, p. 353) to increase the area corered by the feet, and thus to enable them to travel over soft snow.

TENTACLES.

In the details of their anatomical and histological structure the tentacles appear to vary but little in the different groups. There is great diversity, however, in the extent to which calcareous deposits are developed within them.

These calcareous deposits, when present, are always in the form of small spicules, sometimes smooth, straight, or bent, but usually roughened or studded with minute spines and more or less irregular.

The manner of occurrence of these spicules is indicated in the following table: $a^{2}$. No calcareous deposits in the tentacles:

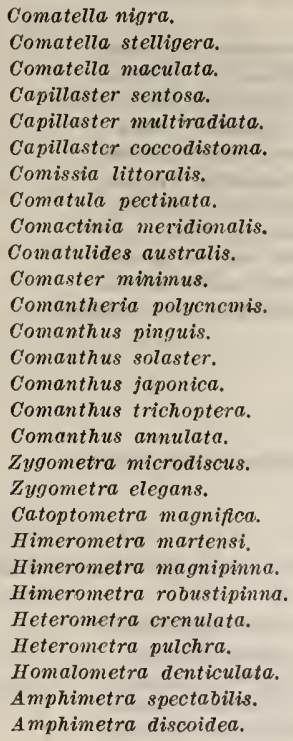

Amphimetra papuensis.

Stephanometra monacantha.

Pontiometra andersomi.

Oxymetra finschii.

Dichrometra fagcllata.

Dichrometra döderleini.

Mariametra subcarinata.

Mariametra delicatissima.

Lamprometra palmata.

Cenometra delicata.

Cenometra unicornis.

Cyllometra albopurpurea.

Decametra parva.

Prometra chadwicki.

Oligometra carpenteri.

Cosmiometra orassicirra.

Tropiometra macrodiscus.

Tropiometra afra.

Tropiometra carinata.

Tropiometra picta.

Tropiometra indica.

Antedon petasus.

Antedon bifida.

Antedon adriatica.

Toxometra paupera.

Eumetra chamberlaini.

Iridometra adrestine.

Iridometra melpomene. 
Andrometra psyche. Thysanometra tenelloides. Coccometra hayenii. Erythrometra ruber. Erythrometra australis. Heliometra maxima. Heliometra glacialis. Anthometra adriani. Florometra maria. Florometra laodice. Florometra asperrima. Florometra serratissima. Florometra magellanica. Cyclometra clio. Sarametra triserialis. Zenometra columnaris.
Psathyrometra borealis. Psathyrometra fragilis. Psathyrometra antarctica. Psathyrometra gracillima. Eumorpliometra concinna. Leptometra celtica. Isometra vivipara. Hathrometra prolixa. Fariometra explicata. Trichometra cubensis. Trichoinetra vexator. Thaumatometra nutrix. Thaumatocrinus borealis. Pentametrocrinus japonicus. Pentanetrocrinus varians.

$a^{2}$. Splcules are present in the tentacles, or the tlp is protected by a more or less developed plate. $b^{2}$. Tlp of the tentacles naked and unprotected.

$c^{2}$. Splcules Irregulariy scattered.

$d^{2}$. Spicules not localized, and few in number.

Neocomatella pulchella.

Neocomatella alata.
Comatula pectinata. Comaster minimus.

$a^{2}$. Spleules more or less definitely locallzed.

$e^{2}$. Splcules confined to the proximal portion of the tentacle.

$f^{1}$. Spicules few in number.

Comantheria uriarcus.

Comanthus voahlbergii. Comanthus parvicirra. Zygometra comata. Catoptometra liartlaubi. Oxymetra finschii. Dichrometra döderleini. Lamprometra palmata. Cenometra unicornis. Cyllometra disciformis. Cyllometra albopurpurea. Decametra tigrina.
Prometra chadwoickt. Oligometra serripinna. Tropiometra macrodiscus. Tropiometra indica. Compsometra lovéni. Coccometra hagenit. Leptometra celtcia. Isometra vivipara. Hathrometra prolixa. Hathrometra tenella.

Thaumatocrinus rugosus.

$f$. Spicules numerous.

Comatilia iridometriformis.

$e^{2}$. Splcules occurring only in the distal portlon of the tentacle.

Oceanometra gigantea.

$c^{2}$. Spleules arranged in broad hands.

$\boldsymbol{d}^{\mathbf{2}}$. A single hroad band of spicules along the outer side of the tentacles, which may reach nearly to the tlp.

Comissia lütkeni.

Leptonemaster vonustus.

Comatonia cristata.

Comaster novaruinea.

Comaster multibrachiata.

Comaster fruticosus.
Comaster distincta.

Comaster parvus.

Comaster taviana.

Conianthus benhami.

Comanthus samoana.

Eudiocrinus indivists. 


$\begin{array}{cl}\text { Catoptometra hartlaubi. } & \text { Colobometra vepretum. } \\ \text { Heterometra quinduplicava. } & \text { Colobometra discolor. } \\ \text { Amphimctra parilis. } & \text { Cotylometra gracilicirra. } \\ \text { Diclirometra ciliata. } & \text { Oligomctridcs adcona. } \\ \text { Cenometra herdmani. } & \text { Compsometra incommoda. } \\ \text { Decametra taprobancs. } & \text { Hypalometra defecta. } \\ \text { Decametra mylitta. } & \text { Promachocrinus kerguelcnsis. } \\ \text { Decametra parva. } & \text { Thaunatometra tenuis. }\end{array}$

$d^{2}$. Two bands of spicules, a proximal and a distal, which finally meet and unite.

Leptonemaster vcnustus.
Comatonia cristata.
Eudiocrinus junceus.
Eudiocrinus pinnatus.
Eudiocrinus venustulus.
Himerometra bartschi.
Craspedomctra acuticirra.
Heteronetra savignii.
Heterometra philibcrti.

Heterometra bengalcnsis.

Hcterometra compta.

Heterometra reynaudii.

Hcterometra quinduplicava.

Stephanometra echinus.

Oxynctra aranea.

Lamprometra protcctus.

oligometra serripinna.

$b^{2}$. Tip of the tentacles protected hy a calcareous cap, button, ring, or rudimentary plate.
Neometra alecto.
Neometra acanthaster.
Neometra conaninis.
Neometra gorgonia.
Calometra callista.
Calometra discoidea.

\author{
Gephyrometra propinqua. \\ Pectinometra carduum. \\ Pcctinometra flavopurpurea. \\ Calyptometra lateralis. \\ Pocilometra scalaris.
}

A detailed examination of the tentacles was made in 172 individuals.

Usually all the tentacles in a given specimen agree morc or less closely in the frequency and character of their deposits, but this is by no means always the case; it frequently happens that deposits, commonly a few spicules, occasionally considerable aggregations, are found in one or two tentacles of a pinnule but are entirely absent in the remainder, while in the Charitometridie the tentacles in which the tip is protected by a more or less developed plate are mostly confined to the base of the pinnules.

When adambulacral deposits are absent, deposits in the tentacles are usually also absent, but this is not always so, for in several species in which there is no trace of adambulacral deposits the spiculation of the tentacles is very highly developed. Though in the Calometridæ, Thalassometridæ, and Charitometridæ the adambulacral deposits are very highly developed, for the most part spicules are few or quite lacking in the tentacles.

In many cases the spicules in the tentacles are far more conspicuous than the adambulacral deposits, which are often difficult to distinguish from the usually enlarged basal spicules of the tentacles.

Of the 172 individuals 87 , or approximately half, distributed in all the groups represented, were found to be without deposits in the tentacles; 28 , representing the Comasteridæ, Zygometridæ, Himerometridæ, Mariametridæ, and Colobometridæ, with a few Antedonidæ, showed numerous spicules in a conspicuous band along the outer side; 23, representing all groups excepting the Stephanometridæ 
(in which there apparently are never ventral deposits of any kind), Calometridæ, Thalassometridæ, and Charitometridæ had a few spicules in the proximal portion; 17, in the Comasteridæ, Zygometridæ, Himerometridæ, and Mariametridæ showed two conspicuous bands, a distal and a proximal, becoming confluent in the outer portion; 11,9 in the Calometridæ and 2 in the Charitometridæ, had the tip protected by a more or less developed plate, and usually spicules in the outer portion; 4, all belonging to the Comasteridæ, had a few scattered spicules; 1 , belonging to the Comasteridæ, had numerous scattered spicules in the proximal portion; and 1 , belonging to the Thalassometridæ, had scattered spicules in the distal portion, but no terminal deposit.

SUBAMBULACRAL PLATES.

P. H. Carpenter noticed that deep ambulacral grooves with strongly plated sides are met with on the disk of Comatula solaris. In this species the disk may be nearly naked, or plated very completely. The whole of the large interambulacral area in which the anal tube is situated is usually covered with more or less scaly plates which become stouter and more granular in the neighborhood of the subcentral anal tube. The sides of the deep ambulacral grooves are bounded by numerous smaller plates without any definite arrangement; but they are strictly limited to the disk, not extending onto the arms. Much of this plating extends beneath the water vessels of the disk, and a similar plating is found in a similar position in the arms, taking the form of more or less regular plates, though with no definite arrangement, being practically only a portion of the general calcareous plating beneath the upper surface of the disk; this corresponds to what Müller called the subambulacral plating in Isocrinus.

In Comatula rotalaria the large anal area is often beset with numerous irregular plates many of which bear nodules of variable size. They are smaller on the base and sides of the anal tube, and there are few or none in the small interambulacral spaces between the edge of the disk and the marginal ambulacra, which are themselves devoid of supporting plates.

TISCERAL SKELETON.

P. H. Carpenter employed the term "visceral skeleton" to denote the numerous spicules and networks of calcareous matter which occur more or less plentifully in the bands of connective tissue that traverse the visceral mass of the comatulids.

He noted that the simple spicules and thin networks of calcareous matter which occur in the less heavily plated disks are especially abundant in the visceral layer of the peritoneum. This is well seen in thosc crinoids in which there is but little connection between this visceral layer and the parietal layer lining the interior of the cup, so that the visceral mass is readily detached from the calyx. Unlike that which lines the cup, the oral perisome is usually very closely adherent to the visceral mass and can not be separated from it without some trouble. The peritoneal covering of the latter also contains limy deposits, so that sections through the upper part of the disk show two layers of plates and spicules. The upper one is in the perisome itself and belongs to the anambulacral system, while the lower belongs to the upper surface of the visceral mass. AIl of the recent crinoids have more or less 


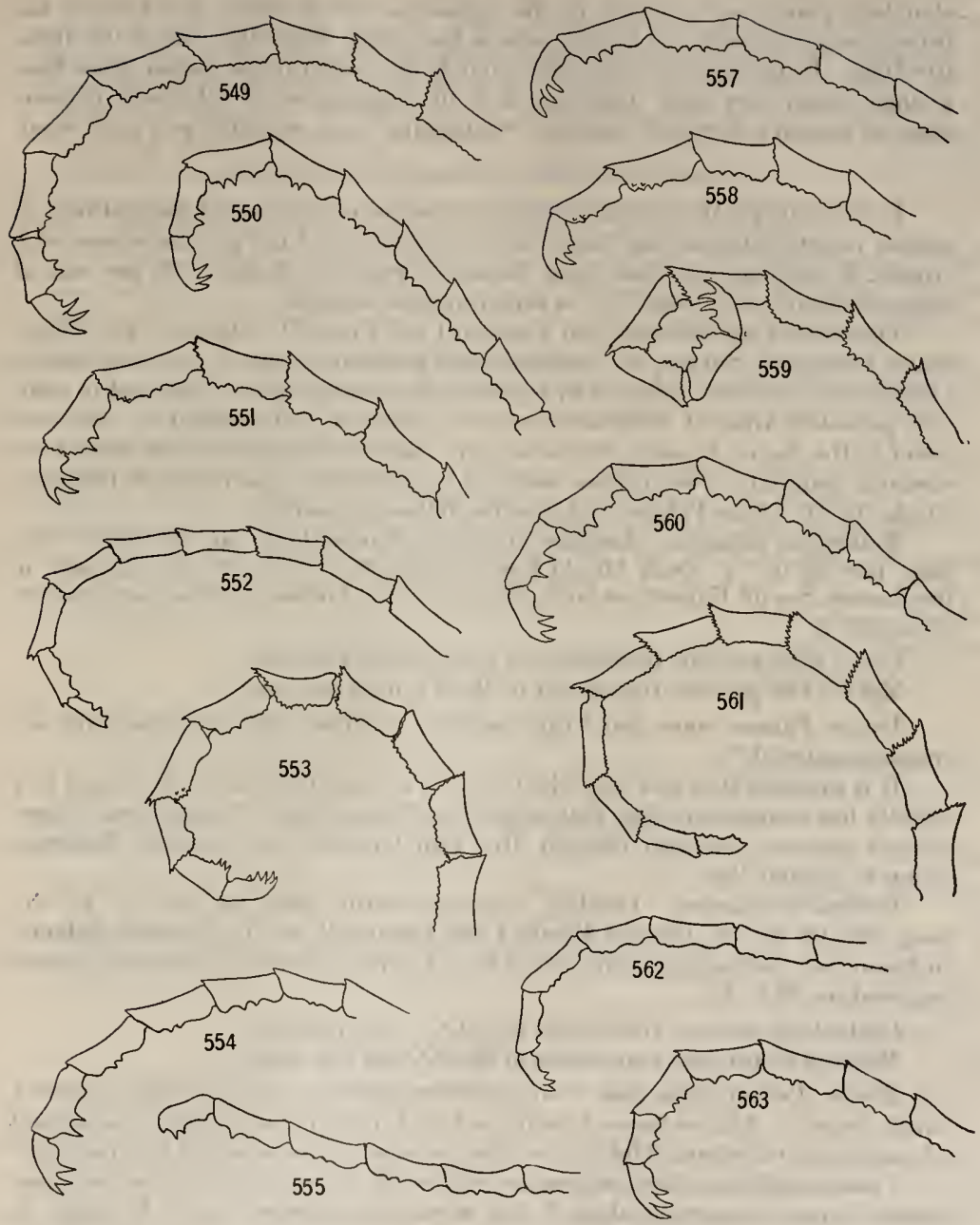

S.

Figs. 549-564.-PinNule mips of ANTedon birida, 564 in doRsal view, others in lateral view. $142140-21-$ Bull. S2— 21 
abundant plates and spicules in the connective tissue which lies beneath the peristome and supports the lip, and also in that which unites the coils of the digestive tube. In the regular endocyclic crinoids this organ makes rather more than a single round turn upon itself, and it is the aggregation of calcareous deposits upon its central side which forms the "columella," once regarded as a sand canal.

INORGANIC CONSTITEENTS OF SKFLFTON OF HFCENT CRINOHU.

In $1906 \mathrm{Mr}$. H. W. Nichols published a number of analyses of the skeletons of marine invertebrates, among them one of the skeleton of the pinnulate arms of a crinoid, Metacrinus rotundus, from Japan, in which he found 11.72 per cent of magnesium carbonate $\left(\mathrm{MgCO}_{3}\right)-\mathrm{a}$ rather unusual amount.

This incited my curiosity, and I sent to Prof. Frank W. Clarke, of the United States Geological Survey, for analysis some pinnulate arms of the same species (Metacrinus rotundus) collected by myself in the Eastern Sea in 1906, and in addition pinnulate arms of Heliometra maxima, which I had dredged in very cold water in the Sea of Japan in the same year. Both specimens were air dried from alcoholic material. The analyses were made, under the supervision of Professor Clarke, by Dr. Chase Palmer, and gave the following results:

Metacrinus rotundus.-Locality, Albatross Station 4934 ; lat. $30^{\circ} 58^{\prime} 30^{\prime \prime} \mathrm{N}$., long, $130^{\circ} 32^{\prime} 00^{\prime \prime} \mathrm{E}$. (Sata Misaki Light bearing N. $77.5^{\circ}$ E., 7 miles distant), in the Eastern Sea off Kagoshima Gulf; depth, 103-152 fathoms; bottom temperature, about $56^{\circ} \mathrm{F}$.

$\mathrm{CaO}=49.95$ per cent (equivalent to $\mathrm{CaCO}_{3} 89.19$ per cent).

$\mathrm{MgO}=4.89$ per cent (equivalent to $\mathrm{MgCO}_{3} 10.29$ per cent).

Doctor Palmer notes that "this specimen is white and quite free from extraneous material."

It is probable that this individual lived at a somewhat greater depth and in a slightly less temperature than that studied by Nichols, which I assume was a commercial specimen obtained through Mr. Alan Owston from Japanese fishermen living at Sagami Bay.

Heliometra maxima.-Locality, Albatross Station 4986 ; lat. $43^{\circ} 01^{\prime} 40^{\prime \prime} \mathrm{N}$, long. $140^{\circ} 22^{\prime} 40^{\prime \prime} \mathrm{E}$. (Benkei Mizaki Light bearing N. $35^{\circ} \mathrm{E}$., 15 miles distant), in Iwani Bay, northeastern part of the Sea of Japan; depth, 172 fathoms; bottom temperature, $33.9^{\circ} \mathrm{F}$.

$\mathrm{CaO}=40.03$ per cent (equivalent to $\mathrm{CaCO}_{3} 71.48$ per cent).

$\mathrm{MgO}=2.68$ per cent (equivalent to $\mathrm{MgCO}_{3} 5.61$ per cent).

Doctor Palmer adds that "this specimen contains much foreign material, chiefly organic. On the basis of purity as found in the other specimen, the content of magnesium carbonate $\left(\mathrm{MgCO}_{3}\right)$ in this specimen may be accepted as 7 per cent."

I commented upon these analyses as follows: Heliometra maxima "is the largest crinoid known, measuring about 3 feet across its extended arms. It might be supposed that the comparative openness of its skeleton was due to this very large size, as a result of the deposition of inorganic matter not keeping pace with the rapid increase in bodily size. It is noticeable, however, that the crinoids of the deep seas and from the colder regions have more delicate and more open skeletons 
than those from comparatively shallow water in the tropics, and it therefore seems most probable that cold has the effect of retarding the deposition of inorganic matter by the animals to a far greater degree than it retards the general body development. Probably in the deep-water forms the enormous pressure under which the animals live also tends in various ways to make the deposition of inorganic matter more difficult; but the fact that among the crinoids the skeletal conditions found in the inhabitants of the deep sea are to almost or quite the same degree repeated or continued in those of the polar regions points to the conclusion that the chief factor involved is temperature rather than pressure."

The great discrepancy in the proportion of magnesium in the skeletons of these two crinoids, one from relatively warm and one from very cold water, aroused Professor Clarke's interest, and he suggested the advisability of more extended investigations. I sent him the following material:

Capillaster multiradiata.-Philippine Islands, 1.3 miles from Joló Light, Joló (lat. $6^{\circ} 04^{\prime} 25^{\prime \prime} \mathrm{N}$., long. $120^{\circ} 58^{\prime} 30^{\prime \prime}$ E.) ; depth, 36 meters; no temperature record (Albatross Station 5137).

Zygometra microdiscus.-Aru Islands, anchorage off Pulu Jedan (Pearl Banks); depth, 13 meters; no temperature record (Siboga Station 273).

Catoptometra ophiura-Philippine Islands, North Balabac Strait, 15.5 miles from Balabac Light (lat. $8^{\circ} 06^{\prime} 40^{\prime \prime}$ N., long. $117^{\circ} 18^{\prime} 45^{\prime \prime}$ E.) ; depth, 104 meters; no temperature record (Albatross Station 5036).

Heterometra quinduplicava.-Philippine Islands, 3.3 miles from Tinakta Island, Tawi Tawi group, Sulu (Joló) Archipelago (lat. $5^{\circ} 12^{\prime} 30^{\prime \prime} \mathrm{N}$., long. $119^{\circ}$ $55^{\prime} 50^{\prime \prime}$ E.) ; depth, 32 meters; no temperature record (Albatross Station 5157 ).

Tropiometra picta.-Rio de Janeiro, Brazil.

Ptilometra mülleri-Sydney, New South Wales.

Parametra granulata.-Philippine Islands, between Negros and Siquijor, 11.8 miles from A po Island (lat. $9^{\circ} 15^{\prime} 45^{\prime \prime} \mathrm{N}$., long. $123^{\circ} 22^{\prime} 00^{\prime \prime}$ E.) ; depth, 502 meters; temperature, $11.95^{\circ} \mathrm{C}$. (Albatross Station 5536).

Perissometra patula.-Philippine Islands, North Balabac Strait, 15.5 miles from Balabac Light (lat. $8^{\circ} 06^{\prime} 40^{\prime \prime}$ N., long. $117^{\circ} 18^{\prime} 45^{\prime \prime}$ E.) ; depth, 104 meters; no temperature record (Albatross Station 5036).

Chondrometra rugosa.-Lesser Sunda Islands, near Rotti (lat. $10^{\circ} 39^{\prime} \mathrm{S}$., long. $123^{\circ} 40^{\prime}$ E.) ; depth, 520 meters; no temperature record (Siboga Station 297).

Crinometra concinna.-Northern coast of Cuba (lat. $23^{\circ} 10^{\prime} 35^{\prime \prime} \mathrm{N}$., long. $82^{\circ}$ $20^{\prime} 24^{\prime \prime}$ W.) ; depth, 59 meters; temperature, $26.17^{\circ}$ C. (Albatross Station 2324).

Promachocrinus kerguelensis.-Shores of the Antarctic Continent, in the vicinity of Gaussberg (approximately lat. $67^{\circ} \mathrm{S}$., long. $90^{\circ}$ E.) ; depth, 350-400 meters; temperature, $-1.85^{\circ} \mathrm{C}$.; salinity, 3.3 per cent (Gauss).

Florometra asperrima.-Coast of Washington (lat. $47^{\circ} 29^{\prime} 30^{\prime \prime}$ N., long. $125^{\circ}$ $43^{\prime} 00^{\prime \prime}$ W.) ; depth, 1,145 meters; temperature, $3.28^{\circ}$ C. (Albatross Station 3070).

Anthometra adriani.-Shores of the Antarctic Continent, in the vicinity of Gaussberg (approximately lat. $67^{\circ} \mathrm{S}$., long. $90^{\circ} \mathrm{E}$.) ; depth, 350-400 meters; temperature, $-1.85^{\circ} \mathrm{C}$.; salinity, 3.3 per cent (Gauss). 

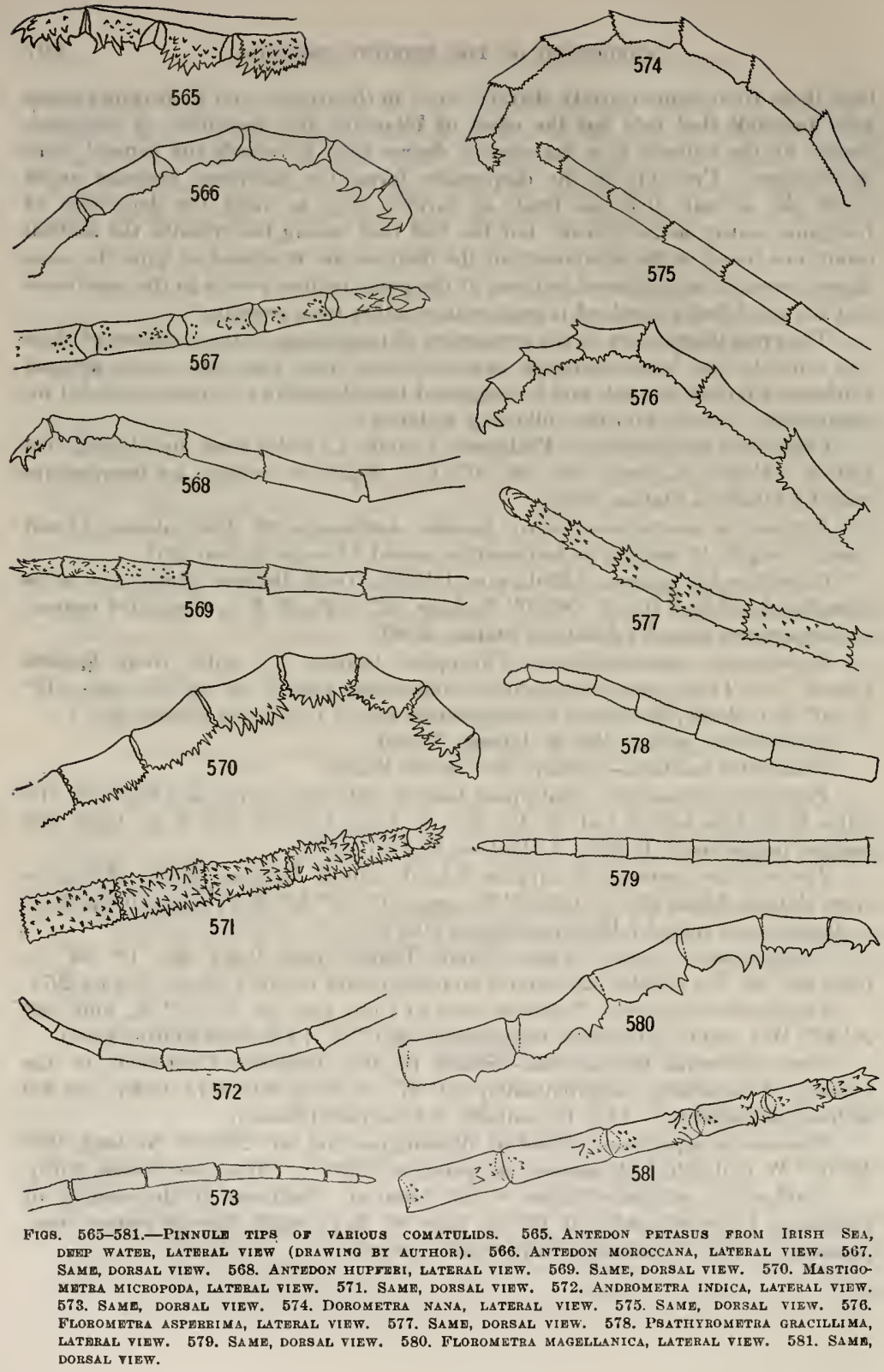

579 
Hathrometra tenella.-Off Marthas Vineyard, Massachusetts (lat. $39^{\circ} 56^{\prime} \mathrm{N}$., long. $69^{\circ} 24^{\prime}$ W.) ; depth, 329 meters; temperature, about $7.8^{\circ}$ C. (Fish Hawk Station 1033).

Psathyrometra fragilis.-Yezo Strait, Japan (lat. $44^{\circ} 05^{\prime}$ N., long. $145^{\circ} 30^{\prime}$ E) ; depth, 540-959 meters; temperature, 1.61 ${ }^{\circ}$ C. (Albatross Station 5032). Pentametrocrinus japonicus. - Southern Japan, 34.5 miles off Omai Saki Light (lat. $34^{\circ} 04^{\prime} 20^{\prime \prime} \mathrm{N}$., long. $137^{\circ} 57^{\prime} 30^{\prime \prime}$ E.) ; depth, 1,123 meters; temperature, $3.39^{\circ}$ C. (Albatross Station 5083).

Hypalocrinus naresianus.-Philippine Islands, 3.4 miles off Cagayan Island, Joló Sea (lat. $9^{\circ} 37^{\prime} 05^{\prime \prime}$ N., long. $121^{\circ} 12^{\prime} 37^{\prime \prime}$ E.) ; depth, 612 meters; temperature, $10.22^{\circ}$ C. (Albatross Station 5424).

Endoxocrinus parra.-Off Habana, Cuba.

Isocrinus decorus.-Off Habana, Cuba.

Bythocrinus robustus.-Gulf of Mexico, southeast of Pensacola (lat. $28^{\circ} 38^{\prime}$ $30^{\prime \prime} \mathrm{N}$., long. $85^{\circ} 52^{\prime} 30^{\prime \prime} \mathrm{W}$.) ; depth, 255 meters; no temperature record.

Ptilocrinus pinnatus.-Off the Queen Charlotte Islands, British Columbia (lat. $52^{\circ} 39^{\prime} 30^{\prime \prime} \mathrm{N}$., long. $132^{\circ} 38^{\prime} 00^{\prime \prime}$ W.) ; depth, 2,858 meters; temperature, $1.83^{\circ}$ C. (Albatross Station 3342 ).

In the following table the actual analyses are given.

The symbol " $\mathrm{R}_{2} \mathrm{O}_{3}$ " represents the sum of ferric oxide and alumina.

The "loss on ignition" covers carbon dioxide, water, and organic matter, the last being often very high.

Table of actual analyses.

\begin{tabular}{|c|c|c|c|c|c|c|c|}
\hline - & $\mathrm{SiO}_{2}$ & $\mathrm{R}_{2} \mathrm{O}_{3}$ & $\mathrm{MgO}$ & $\mathrm{CaO}$ & $\mathrm{P}_{2} \mathrm{O}_{6}$ & $\begin{array}{l}\text { Loss on } \\
\text { ignition. }\end{array}$ & $\begin{array}{c}\mathrm{CO}_{3} \\
\text { needed to } \\
\text { satisfy } \\
\text { the bases. }\end{array}$ \\
\hline Capillaster multiradiata................. & 0.16 & 0.62 & 4.77 & 38.12 & Trace. & 54.61 & 35.19 \\
\hline Zygometra microdiscus............... & .04 & .48 & 4. 92 & 37.19 & 0.17 & 55.05 & 34.47 \\
\hline Catoptometra ophiura... & .04 & .79 & 4.64 & 40.75 & .33 & 51.80 & 36.81 \\
\hline Heterometra quinduplicava............. & .15 & .19 & 5.13 & 42.77 & .11 & 50.28 & 39.17 \\
\hline Tropiometra picta........... & .02 & .35 & 4.51 & 39.57 & .10 & 53. 64 & 36.05 \\
\hline Ptilometra mülleri....... & .17 & .19 & 4.17 & 38.91 & .17 & 54.61 & 34.90 \\
\hline Parametra granulata... & .40 & .50 & 4.48 & 41. 79 & Trace. & 51.44 & 37.77 \\
\hline Perissometra patula... & .12 & .63 & 4.94 & 41.34 & .43 & 51.36 & 37.51 \\
\hline Chondrometra rugosa.. & .05 & .23 & 3. & 42.72 & Trace. & 51.69 & 37.95 \\
\hline . & .04 & .25 & 4.75 & 41.78 & Trace. & 50.33 & 38.00 \\
\hline Promachocrinus kerguelensis...... & .02 & .45 & 3.02 & 40.68 & Trace. & 54.53 & 35.18 \\
\hline ctra asperrima........... & .04 & .39 & 3. & 40.37 & .21 & 53.75 & 35.48 \\
\hline tra adriani... & .23 & .37 & 3.2 & 42.49 & Trace. & 52.22 & 37.08 \\
\hline tra tenella...... & 3.17 & .31 & 2.49 & 26.12 & .23 & 65.25 & 22.73 \\
\hline Psathyrometra fragilis.......... & 1.11 & 1.01 & 3. 12 & 34.20 & Trace? & 60.04 & 31.37 \\
\hline ctrominus janonime & .37 & .71 & 3. & 38.50 & .40 & 55.25 & 34.01 \\
\hline Hyрат & .07 & .09 & 4.44 & 45.86 & Trace. & 48. 32 & 41.27 \\
\hline Endoxocrinus parræ (arms)..... & .15 & .26 & 5.04 & 43.41 & Trace. & 50.00 & 39.65 \\
\hline Endoxocrinus parræ (column)... & .04 & .20 & 5.09 & 45.42 & Trace. & 48.58 & 41.29 \\
\hline Isocrinus decorus (arms). . & .09 & .19 & 4.70 & 42.77 & Trace? & 50.59 & 38.71 \\
\hline s column & .03 & .07 & 5. & 45.67 & Trace. & 47.54 & 40.40 \\
\hline 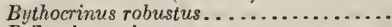 & .40 & .31 & 4. 56 & 47.08 & Trace. & 47.17 & 41.93 \\
\hline Ptilocrinus pinnatus.................. & 1.64 & 1.07 & 3.08 & 40.65 & .11 & 51.45 & 35.23 \\
\hline
\end{tabular}


Professor Clarke says that "in order to make these analyses more instructive it is necessary to recalculate them into such form as to show the composition of the true crinoid skeleton-that is, to eliminate the highly variable organic matter of the original specimens. On doing this, and recalculating to 100 per cent, we find that they assume the following form":

Table of revised annlyses.

\begin{tabular}{|c|c|c|c|c|c|}
\hline & $\mathrm{BiO}_{2}$ & $\mathrm{R}, \mathrm{O}_{2}$ & $\mathrm{MgCO}_{2}$ & $\mathrm{CaCO}_{2}$ & $\mathrm{Cas}_{\mathrm{s}} \mathrm{P}, \mathrm{O}$, \\
\hline apillaster multiradiata.. & 0.21 & 0.78 & 12.69 & 86.32 & Trace. \\
\hline Zygon & .05 & .62 & 13. 37 & 5.48 & 0.48 \\
\hline Catopt & .05 & .95 & 11.68 & & .86 \\
\hline Heleto & .24 & .22 & 12. & & .27 \\
\hline Tropi & .02 & .43 & 11. & & .27 \\
\hline & .21 & .24 & 11.13 & 87.94 & .48 \\
\hline Param & .47 & .59 & 11.08 & & Trace. \\
\hline & .14 & .74 & 12. 20 & & 1.11 \\
\hline & .06 & .27 & 9.8 & & Trace. \\
\hline & .05 & .30 & 11.69 & & Trace. \\
\hline Prom & .02 & .57 & 7.8 & 91.55 & Trace. \\
\hline Floron & .05 & .48 & 9.44 & 89.45 & .58 \\
\hline Antho & .28 & .44 & 8.23 & 91.05 & Trace. \\
\hline Heliom & & & 17.28 & & \\
\hline Hathr & 5.73 & .56 & 9.36 & & \\
\hline & 1.57 & 1.41 & & & Trace? \\
\hline Penta & .48 & .91 & 10.15 & 87.34 & 1.12 \\
\hline Metac & & & 10.34 & & \\
\hline & .08 & .10 & 10.16 & & Trace. \\
\hline & .17 & .29 & 11.9 & & Trace. \\
\hline & .04 & .21 & 11.0 & & Trace. \\
\hline Isocri & .10 & .21 & 11.42 & 88. & Trace? \\
\hline & .03 & .08 & 11. & & Trace. \\
\hline & .42 & .33 & 10.09 & & Trace. \\
\hline Ptilocrinus pinnatus... & 2.01 & 1.31 & 7.91 & 88.48 & .29 \\
\hline
\end{tabular}

1 Reealculated from the figures given above.

Professor Clarke notes that from the figures it is perfectly clear that the proportion of magnesium carbonate in the crinoid skeleton is in some way dependent on the temperature of the habitat, being least in the crinoids occurring in very cold water and, increasing with extraordinary regularity, greatest in those found in the tropical littoral.

At first Professor Clarke supposed that the peculiar relation between the temperature of the habitat and the composition of the skeleton might possibly be due to a difference in the form of the most abundant carbonate-the less stable aragonite in the warm-water forms, and calcite in the crinoids from colder regions. But tests by Meigen's reaction proved that the organisms were all calcitic, and so this supposition had to be abandoned.

In considering the composition of the crinoid skeleton it should be borne in mind that the structure is always entirely internal, protected from the surrounding water by living tissue, so that whatever alteration it may undergo after its original deposition can not be influenced except very indirectly by the water in which the animal lives. 
It is interesting to note that the compactness of the crinoid skeleton increases in direct proportion to the percentage of magnesia in its composition.

Professor Clarke remarks that the proportion of magnesia given for Hathrometra tenclla is probably too low, for the specimen as analyzed contained over 6 per cent of silica and sesquioxides-evident impurities due to adherent mud from which the delicate structure could not be wholly freed. If these are rejected, the magnesium carbonate $\left(\mathrm{MgCO}_{3}\right)$ is raised from 9.36 to 10 per cent, which gives the crinoid a better and more probable rating.

This line of investigation was subsequently extended by Professor Clarke to include all the echinoderm groups, and of the echinoderms as a whole he says:

From the evidence now available it seems almost certain that the inorganic constituents of any echinoderm will have the composition of a moderately magnesian limestone. There may be exceptions, but none has as yet been found. The three tables, for crinolds, sea urchins, and starfishes [including ophiurans], all tell the same story, and with remarkable unanimity. Furthermore, the proportion of magnesium carbonate appears to be a function of temperature, the organisms from warm reglons being richer in it than the cold-water forms. The exceptions to this rule are apparent rather than real; for cold or warm currents and varying depths of water account for all seeming Irregularitles. The sea urchins seem to be a little poorer in magnesia than either of the other groups, but the analyses are fewer and therefore less conclusive. Sillca and sesquioxides are probably altogether extraneous, although it is possible that smali quantities of them may really belong to the urganisms. In phosphate of lime the starfishes are richest, and all the specimens analyzed contain it in small amounts. Whether It is an essential constituent or not is uncertain. As shown by Meigen's reaction, all the echinoderms studied are calcitic, and no evidence of aragonite in them was found.

The temperature regularity shown by the analyses offers an interesting biological problem with which we can not undertake to cope. It is not due to differences of composition in the solid matter of sea water, for that is practically uniform all the world over. In all the great oceans, and even in minor bodies of water like the Mediterranean, the Baltic, and the Black Sea, the proportion of magnesia to lime is very neariy if not actually constant. In gaseous contents, and especially in carbon dioxide, the waters vary, the gases belng more soluble in cold than in warm water. Whether this fact has any relation to the phenomenon under discussion we can not attempt to say. We can only report the facts and leave their biological discussion to others.

On the geological bearing of the evidence now before us it is easy to speculate; but here great caution is needed. It would be unwlse to assume that magnesian sediments are more abundantly deposited in warm than in cold cllmates, and so to derelop a system of what might be called palæoclimatology. Against such an attempt there are two obvious reasons. First, the sediments are only in small part derived from echlnoderm remalns. Other agencies are more important in the formation of marine limestones. Secondly, a dense population, so to speak, of cold-water organisms may deposit much more magnesia than a sparse population of warm-water forms. The data now in hand, with all their suggestiveness, are too few to warrant any far-reaching generalizations. It is our Intentlon to carry the lnvestigation still further studying other marine invertebrates by the same methods as those which we have followed here.

More recently Professor Clarke, in connection with Dr. R. M. Kamm, has published an analysis of a specimen of Tropiometra picta collected at Pigeon Point, Tobago, in shallow water, of which the temperature was about $28^{\circ} \mathrm{C}$. The analysis follows:

\begin{tabular}{ccrrrr}
$\mathrm{SiO}_{3}$ & $(\mathrm{Al}, \mathrm{Fe})_{2} \mathrm{O}_{3}$ & $\mathrm{MgCO}_{3}$ & $\mathrm{CaCO}_{3}$ & $\mathrm{Ca}_{3} \mathrm{P}_{2} \mathrm{O}_{4}$ & \multicolumn{1}{c}{$\mathrm{CaSO}$} \\
0.54 & 0.51 & 13.74 & 83.13 & 0.64 & $1.44=100.00$
\end{tabular}


DisE.

P. H. Carpenter employed two different methods in distinguishing the radial and interradial parts of a crinoid. The ray opposite the anal area he frequently designated as the anterior, while the other four he called right anterior, right posterior, left posterior, and left anterior, respectively; but he also used a system of lettering in which, viewing the animal from the ventral side, the anterior ray was called ray $A$, the right anterior ray $B$, the right posterior ray $C$, the left posterior ray $\mathrm{D}$, and the left anterior ray $\mathrm{E}$. According to this terminology the anal area would be known as interradius $C-D$, while the two derivatives from each radial in 10-armed types might be differentiated, as he suggests, as $A_{1}$ and $A_{2}$, $B_{1}$ and $B_{2}$, etc. This system of marking the topography of the disk has a number of advantages over that preceding, and will be employed in the succeeding pages.

As was first noticed by $\mathrm{P}$. H. Carpenter, the ventral perisome varies considerably in thickness in the different groups. Generally speaking, that of the macrophreate forms is thin and delicate, and the ambulacral grooves are but slightly raised above it. In the oligophreate types the perisome of the disk is much thicker and more opaque, and the ambulacral grooves are more or less elevated above the general surface.

In the endocyclic comatulids the mouth is usually situated very near (just anterior to) the center of the disk (figs. 710-728, p. 346), especially in species in which the disk is deeply incised (figs. 713-727, p. 346); but frequently it occupies a more anterior position, having moved outward along radius $\mathrm{A}$. This is most noticeable in large species, or in large specimens of smaller species, which have no incisions in the interbrachial margin of the disk, and is particularly noticeable in the large species of Heliometrinæ, and in Tropiometra (fig. 731, p. 346). It is rare, however, for the mouth to be further removed from the center of the disk than half the distance between the center and the base of ray $A$, and uncommon for it to be even so much displaced. In the two most primitive endocyclic families, the Pentametrocrinidæ (figs. 758,759 , p. 353 , and 1158, pl. 25) and the Atelecrinidæ (figs. $1163,1164, \mathrm{pl} .26$ ), the mouth is almost exactly in the center, but it appears never to occupy quite this position in any of the other groups.

From the mouth there radiate outward across the disk five equal ambulacral grooves, which branch dichotomously just before the arm bases are reached (part 1, figs. 15, 16, 18,19, p. 67), and farther out branch again with each division of the post-radial series (part 1, fig. 17, p. 67). Ordinarily the branching of the ambulacral grooves upon the disk takes place near the margin, and all the primary ambulacral groove trunks are of equal length; this is especially true in the Macrophreata (figs. 747-757, p. 349), but in certain genera belonging to the Oligophreata, more especially in Tropiometra (figs. 729-733, p. 346) and in Ptilometra (figs. 739741, p. 349), the division of the primary groove trunks is irregular both in different individuals and on the different rays of the same individual, sometimes occurring at the peristome, so that, instead of the single primary trunks, two secondary trunks are given off side by side. 

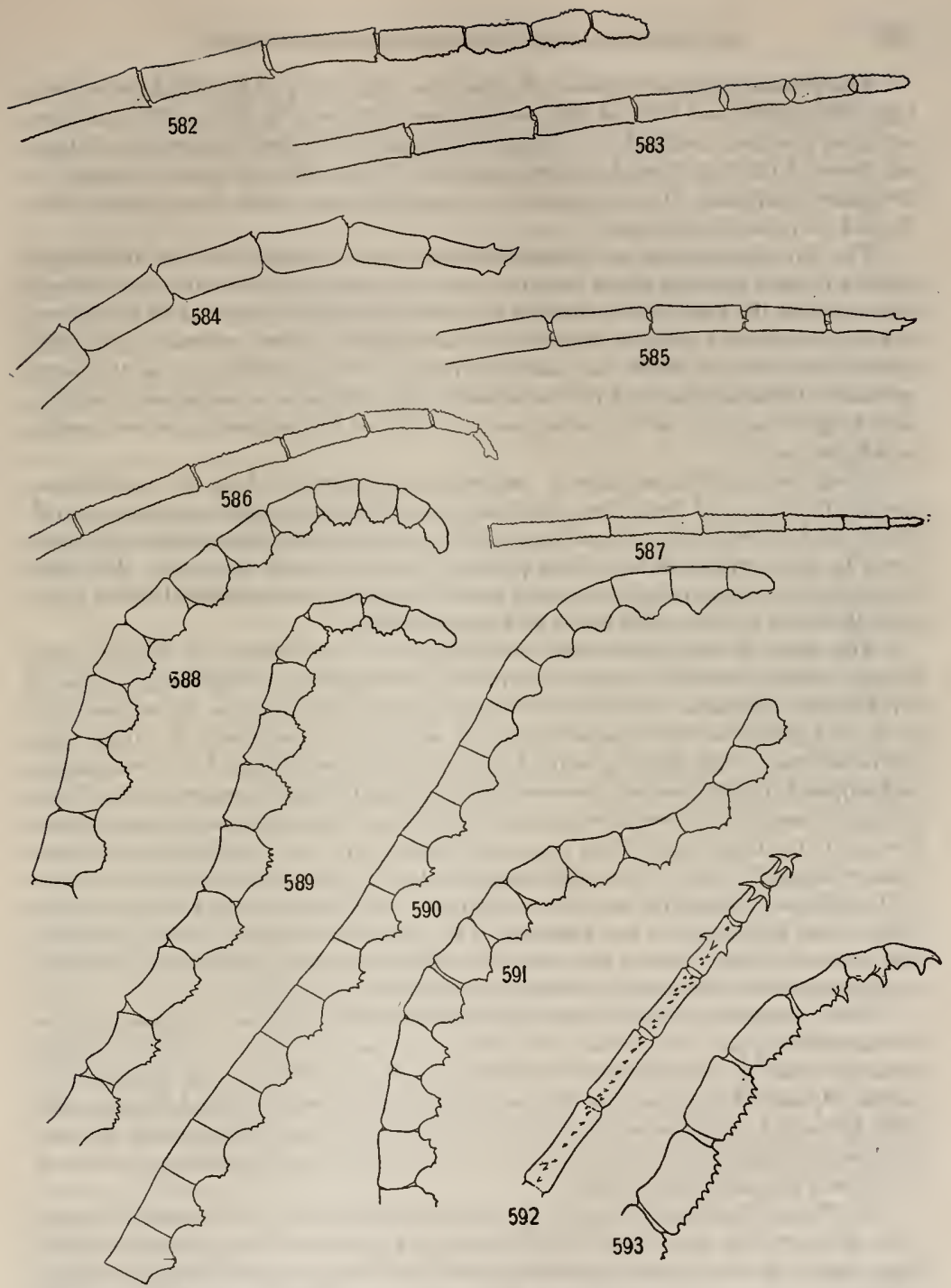

Figs. 582-593.-PinNule tifg of variods comatulids, 582. Leptometra celtica, lateral view. 583. SAME, DORSAL view, 584. HATHROMETra prolixa, lateral view. 585. SAME, dorsal VIEW. 586.

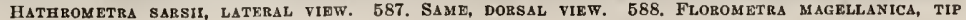
of $P_{1}$. 589. Same. 590. Florometra perplexa, tip of $P_{1}$. 591. Florometra magellanica, tip OF $P_{1}$. 592. Comatilia iridometriformis, dorsal view, 593. SaMn, lateral view. 
The primary groove trunks of Eudiocrinus (fig. 712, p. 346), Pentametocrinus (figs. 758, p. 353 , and 1158, pl. 25), and Thaumatocrinus (fig. 759, p. 353) continue out upon the arms undivided. On the disk those of the first two are equidistant, but those of the last, though entirely separated from each other, are arranged in five pairs, indicating the five primary radial divisions, which have become subdivided to form the 10 rays.

The five interpalmer or interambulacral areas delimited by the ambulacral grooves in their passage across the disk are usually nearly of the same size, though that in which the anal tube is situated is commonly slightly larger than the others, and the ambulacral grooves bounding it are slightly bowed outward. In large species, however, in which the mouth is more or less excentric, as in the large species of Heliometrinæ and in Tropiometra, the anal area is sometimes considerably larger than any of the others and is bounded by noticeably convex ambulacral grooves.

From the disk the ambulacral grooves extend outward along the ventral surface of the arms, and from these brachial extensions lateral branches are given off, which reach nearly to the tip of each of the pinnules, with the exception of those borne by the division series (when present) and the lowest brachials. The floor of the grooves is composed of ciliated epithelium with a subepithelial nerve band, beneath which lie the radial blood and water vessels.

The sides of the groores are not straight, but are scalloped, showing continuous series of minute valvules or lappets, the crescentic or respiratory leaves of Sir Wyville Thomson. At the base of each lappet, and to some extent protected by it, is a group of three tentacles, one of which, the most distal, is larger than the other two. This trifid group of tentacles and the cavity of the respiratory leaf adjacent to them receive a common branch from the radial water vessel. These groups of tentacles alternate on the opposite sides of the ambulacral grooves from the base to the tip of each of the arms and pinnules, and are distributed in the same manner along the sides of the ambulacra of the disk, though here they are not so well developed, especially near the peristome, where every lateral branch of the water vessel supplies only one tentacle. The lappets at the sides of the groove are also far less distinct than on the arms, the edges of the folds of perisome bounding the grooves being only faintly marked by an indistinct wavy line.

P. H. Carpenter noticed that the conditions described above in many of the Comasteridæ apply only to the arms of the two anterior radii, $\mathrm{A}$ and $\mathrm{B}$, and to more or fewer of the antero-lateral arms, $\mathrm{C}_{1}$ and $\mathrm{E}_{2}$. The arms of the posterior radius, $\mathrm{D}$, and of the posterior divisions of the lateral radii, $\mathrm{C}_{2}$ and $\mathrm{E}_{1}$, are often entirely devoid of tentacles, and in many of them the ventral perisome not only exhibits no ambulacral groove (fig. 1037, pl. 12), but is, on the contrary, convex, as in the oral pinnules of Antedon.

In Comanthus parvicirra, as in all comasterids with an interradial mouth (figs. 685, 689,691, p. 341 and $1149-1153$, pl. 24), the anal area is bounded by two large aboral groove trunks which start from the posterior angles of the peristome and form a horseshoe-shaped curve the limbs of which are unequal in size. The smaller right limb is formed by the right lateral ambulacrum, $\mathrm{C}$, while the larger 
left limb represents the posterior ambulacrum, D, combined with part or the whole of the left lateral ambulacrum, E. In neither of these limbs are the tentacular groups and crescentic leaves so well developed as they are in the two anterior ambulacra. After the branches to the two antero-lateral primary arms, $\mathrm{C}_{1}$ and $\mathrm{E}_{2}$ have been given off, or sometimes even sooner, the tentacles at the sides of the two aboral groove trunks become more and more insignificant and finally disappear altogether, while the position of the crescentic leaves is only indicated by a very faint wavy line at the edge of each groove. In small specimens with but few arms the grooves of the posterior and postero-lateral arms, D, $\mathrm{C}_{2}$, and $\mathrm{E}_{1}$ may remain in this condition; but in larger specimens with many arms all traces of the lappets disappear, and the two edges of the groove meet and unite so as to produce a condition in which the ventral surface of the arms and pinnules is convex and does not show the least trace of a groove of any description. The position of the point at which the two folds of perisome bounding the sides of the original ambulacral groove meet and unite varies extremely. The fusion may, though rarely, take place on the disk (figs. 692, 693,699, 700, p. 341, and 1150, 1151, 1153, pl. 24); sometimes it is at the base of the arms, and sometimes not till near their middle or terminal portions. In any case, however, the fusion whenever it occurs is so complete that all trace of the original ambulacral groove is entirely obliterated.

The position of the mouth in the Comasteridæ is subject to great variation. Exceptionally it is central or nearly so; this is invariably the case in Comatilia (fig. 687, p. 341), Comatonia, and Microcomatula, and occurs frequently in Leptonemaster (fig. 877, p. 435), Comaster (especially in the smaller species) (figs. 697, 698 , p. 341), and Comissia, and not uncommonly in Capillaster multiradiata (fig. 1147 , pl. 23; compare with fig. 1148). Usually, howerer, it is marginal or submarginal, this position being especially emphasized in the Comactiniince (figs. 688-693, p. 341, and 1149, pl. 24) and in Comanthus (figs. 700, 701, p. 341, 1152, pl. 24, and 1154, pl. 25).

When the mouth is marginal or submarginal it varies from a strictly radial position immediately opposite the center of ray A (figs. 690,692, p. 341) to an interradial position in the middle of the interradius A-B (figs. 689, 691, 699, 701 , p. 341) ; generally speaking, the mouth in 10 -armed species is radial in position, while in multibrachiate forms it is more commonly interradial, though in each species specimens may occasionally be found in which it is quite radial (figs. 691, 692, p. 341).

The explanation of the interradial position of the mouth may be the following: The ambulacral grooves of necessity divide many times in the multibrachiate types upon the disk as the latter reaches above the last arm division. Economy calls for a maximum concentration of the food particles at the lips, and the fewer the grooves reaching the mouth the greater the concentration will be. It is essential, therefore, that the mouth shall be the focus of the minimum number of food grooves each of which will carry food in the condition of maximum concentration, and each of which will carry approximately the same amount of food. The many coils of the digestive tube force the anterior portion of the organ, and with it the mouth, to a marginal position so close to the edge of the disk that, were it to 
remain in the radial line, the ambulacra from the numerous subdivisions of the anterior ray could not possibly join before reaching it. The shifting of the mouth to the right appears to be an effort to minimize the number of groove trunks reaching it and to equalize the amount of food delivered by each.

The shifting of the mouth into the interradius $A-B$ and never into the interradius $\mathrm{A}-\mathrm{E}$ is probably connected with the coiling of the digestive tube.

In the early stages and until a considerable time after the resorption of the orals the mouth is central. It first migrates anteriorly along the line of radius $A$ to a position near the base of the anterior arm and later moves to the right. In the adults it may occupy a position anywhere along this course between the center of the disk and the middle of the border of interradius $A-B$.

P. H. Carpenter notes that in the Comasteridæ the mouth occupies the center of the peristome (fig. 687, p. 341) and is bounded by two lips-a large anterior and a smaller posterior (fig. 1154, pl. 25)-so that its opening is very inconspicuous and usually so much extended in a direction transverse to the antero-posterior diameter of the disk that it presents the appearance of a simple slit. The circumoral portion of the peristome, the peristome proper, is a more or less oval depression in the ventral perisome of the disk which completely surrounds the oral opening and gives off the ambulacral grooves. Beneath this depression lies the water vascular ring, which gives off a trunk under each of the grooves radiating from it. The number and distribution of these are very variable and primarily depend upon the way in which the grooves divide so as to give rise to the trunks corresponding to the 10 primary arms. As a general rule, the two ambulacra corresponding to the radii $\mathrm{D}$ and $\mathrm{E}$ unite into one large posterior trunk from which the branches are distributed to the various arms into which these radii divide. In other cases the left lateral ambulacrum, E, leaves the peristome alone, while in others it is partially united with the posterior ambulacrum, D, its anterior division, $\mathrm{E}_{2}$, leaving the peristome by a separate trunk, while its posterior division, $\mathrm{E}_{1}$, unites with the posterior ambulacrum. As a general rule, the right lateral ambulacrum, C, leaves the peristome alone and supplies the arms of the corresponding radius, but occasionally it is seen to unite with the posterior division, $\mathrm{B}_{2}$, of the right anterior ambulacrum, $B$. The mode of division of the two anterior ambulacra $(\mathrm{A}$ and $\mathrm{B})$ is excessively variable; as a general rule, there are no principal trunks corresponding to the two radii $A$ and $B$, and the primary divisions $A_{1}, A_{2}$, $B_{1}$, and $B_{2}$ originate directly at the peristome (fig. 690, p. 341 ). In the specimens with but few arms, however, each pair may be united for a longer or shorter distance, as in Antedon. Not infrequently the posterior divisions $\mathrm{A}_{1}$ and $\mathrm{B}_{2}$ of these two anterior ambulacra unite for a longer or shorter distance with the two large aboral groove trunks to form an open horseshoe-shaped curve bounding the anal area. The position of the anal tube in this area, and also in regard to the whole surface of the disk, varies somewhat with the position of the mouth; it is rarely, if ever, absolutely central. Its appearance differs very much according as it is full or empty; sometimes its aperture is so completely closed as to be scarcely discernible though the tube below is widely distended, and sometimes the aperture 
is patent, with its edges everted and crenulate, and the tube leading to it quite shrunk and flaccid.

In the species of Comasteridæ in which the mouth is interradial the main ambulacral trunk which passes to the left from it is considerably longer than that which passes to the right (fig. $685, \mathrm{p}$. 341 ), as a natural result of the displacement of the mouth. A line passing through the mouth and the anal tube passes also through the center of the left posterior ray (part 1, fig. 26, p. 69), though this ray is supplied entirely from the left ambulacral trunk. If this line be taken as representing the antero-posterior axis the left groove trunk is seen to pass to all the arms of the left side, and thence onward to all the arms of the posterior ray, half of which lie on the right side, while the right groove trunk passes only a part of the way down the right side. The former thus supplies three rays and the latter two. But almost invariably when this occurs the ambulacra of the posterior arm are suppressed (part 1, fig. 27, p. 69), so that in reality each of the primary trunks supplies two rays. When the mouth is radial it is in line with the anal tube and the center of the posterior interradius (part 1, fig. 25, p. 69), and in this case each of the groove trunks supplies two rays, the anterior ray being furnished with grooves which lead directly to it from the mouth as in Antedon.

Among the species of Comasteridæ in which the mouth is radial and the two lateral groove trunks therefore of equal size, as in Comatula rotalaria (fig. 688, p. 341), the metamorphosis of the two posterior rays, by which the ambulacra, epithelial nerves, and associated structures are lost, takes place at an equal rate; but when the mouth is interradial, as is usually the case in multibrachiate species, the left posterior ray, which is farthest from the mouth, is always affected first and to the greatest extent (figs. 700,699, p. 341). Very many cases are met with in which this is the only ray to be affected, so that a peculiarly complicated symmetry has resulted, in which the right anterior interradius (including the mouth) is anterior, and the reduced and modified left posterior ray is posterior, the plane of the bilateral symmetry superposed upon the fundamental pentamerous symmetry thus having been shifted $36^{\circ}$ from the normal in which radius $\mathbf{A}$ is anterior and the opposite interradius posterior (part 1, figs. 25-28, p. 69). With the atrophy and metamorphosis of the left posterior ray and the disappearance of its ambulacral structures this becomes an isolated ray with similar interradial areas on either side, each of which is bounded on the further side by a ray supplied with ambulacral grooves derived from a trunk coming from the mouth which is of the same length as the trunk on the opposite side of the disk. Since the anal tube in either case is approximately central, so far as the structures of the disk and rays are concerned, this symmetry, when developed, is just as perfect a bilateral symmetry as the normal in which ray $\mathrm{A}$ lies in the antero-posterior axis.

The relation of the ambulacral grooves to the brachials varies greatly in the different genera and species. Carpenter noted that the middle line of the upper surface of each segment of the brachial skeleton is occupied by a groove of variable width and depth which is bordered on each side by the more or less prominent 
muscle plates of the successive brachials, and the vascular structures which are partly contained in it are continued from one brachial to another between the two large muscle bundles which unite them. In the Oligophreata and in very large species of the Macrophreata this arm groove merely lodges the lowest part of the cœliac canal, while the genital cord, with the water vascular and blood vascular tubes and the ambulacral epithelium are all situated above the arm groove and separated from it by a variable amount of intervening perisome, so that little more than half the vertical height of the arm is due to its dorsal skeleton. In the majority of the Macrophreata, however, a great part, sometimes even the whole, of the soft parts of the arm are lodged within the groove on the upper surface of the skeleton, and there is no substantial ventral perisome in the ordinary sense of the word, or it is reduced to a mere film, sometimes thinly plated, which covers up the muscular bundles.

The outline of the disk may be approximately circular or pentagonal (figs. 712, p. 346, and $747-752$, p. 349), in which case the disk is said to be entire, or there may be more or less deep reentrants in the interradial areas (figs. 713-724, p. 346), when the disk is said to be incised.

In one family, the Pentametrocrinidæ, the disk is very strongly stellate (figs. 758,759 , p. 353 , and 1158 , pl. 25 ), due to the extraordinary extension over the proximal portion of the arms.

Incision of the disk reaches its extreme in the families Himerometridæ (figs. 713-718, p. 346), Stephanometridæ (fig. 726, p. 346), and Mariametridæ (figs. 719725 , p. 346 , and part 1 , fig. 17 , p. 67), in the genera Zygometra (figs. 710, 711, p. 346 , and $1155-1157, \mathrm{pl} .25$ ) and Catoptometra of the Zygometridæ, and in the genera Cenometra (part 1, fig. 16, p. 67), Cyllometra and Epimetra of the Colobometridæ, and is marked in the Thalassometrinæ (figs. 743, 745, p. 349) and in the Charitometridæ (figs. 746, p. 349, and 1159-1161, pl. 26).

The disk is most nearly circular in outline in the Calometridæ (figs. 734-73i. p. 349 , and part 1, fig. 19, p. 67), in many of the Antedoninæ (figs. 750, 756, p. 349), and in the genus Eudiocrinus (fig. 712, p. 346) of the Zygometridæ, in which it is almost globular in form, and it is very strongly rounded in the other subfamilies of the Antedonidæ (figs. $747-757$, p. 349), in the Tropiometridæ (figs. 729-733, p. 346, and part 1, fig. 15, p. 67), and in the Ptilometrinæ (figs. 738-742, p. 349).

The interradial borders are slightly incised in the Comasteridæ (figs. 685-709, p. $341 ; 1144,1147,1148$, pl. $23 ; 1149-1153$, pl. 24 ; and 1154, pl. 25), the Colobometrid» (figs. 727,728 , p. 346), excepting the genera C'enometra, Cyllometra, and Epimetra, and the Atelecrinidæ (figs. 1163, 1164, pl. 26).

Thus while between the shape of the disk and the systematic position of the comatulids there is but slight correlation, between it and the number of arms there is a much more definite connection, for, broadly speaking, the larger the number of arms the deeper are the reentrants between the five arm groups; but it should be emphasized that even here the correspondence is only approximate, and we find a notable exception in the Comasteridæ.

The ventral surface of the disk may be (1) quite naked (though calcareous deposits are always present in the cutis) (figs. 748, 749, 751, 752, 754-757, p. 349), 


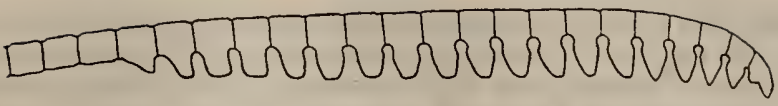

594

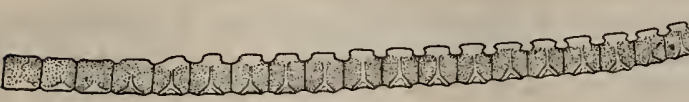
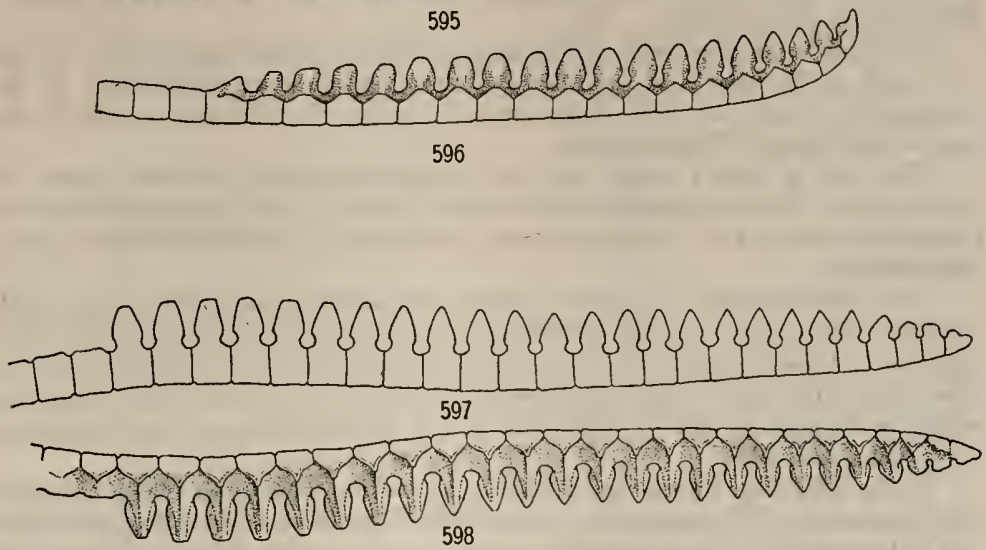

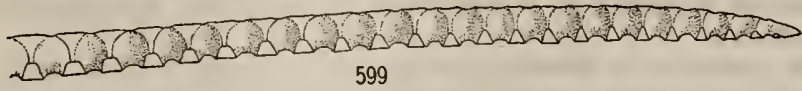
599

600

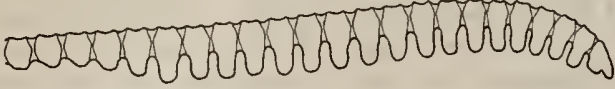

601

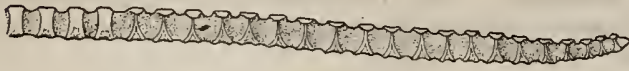

602

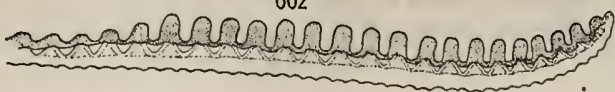

Figs. 594-602.-Terminal combs of variods comasterids. 594. Comatella nigra, external view. 595.

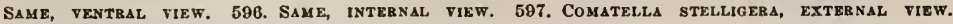
598. S.ME, INTERNAL VIEW, 599. SAME, VENTRAL VIET. 600. NEOCOMAFELLA FLLCiFLA, RXTERNAL viEw. 601. SAME, ventBal VIEW. 602. SAME, iNTERN.4L VIEW. 
(2) studded with a few large rounded isolated concretions, mostly in the anal area (figs. 741, 743, 747, 750, 753, p. 349), (3) thickly beset with very numerous subequal rounded plates of moderate size which are usually more or less in contact (figs. $738,744,746$, p. 349 ), or (4) almost completely, or quite, incased in a pavement of larger and thinner polygonal plates (figs. 734-737, p. 349).

The disk is quite naked in most of the Comasteridæ, in the Himerometridæ and Stephanometridæ, in most of the Mariametridæ, most of the Colobometridæ, most of the Antedonidæ, and most of the Pentametrocrinidæ, and in the Tropiometridæ and Atelecrinidæ.

The disk is studded with a few large rounded isolated concretions, for the most part in the anal area, in many of the Comasteridx (particularly in the Comactiniinæ), and in a few of the larger species of Antedoninæ (chiefly in the genera Antedon and Mastigometra).

The disk is thickly beset with very numerous subequal rounded plates of moderate size, which are usually more or less in contact, in the Thalassometridæ and Charitometridæ, and in Pentametrocrinus semperi and P. atlanticus of the Pentametrocrinidæ.

The disk is entirely inclosed in a solid vault of large polygonal plates, which separates very easily from the underlying structures, in Eudiocrinus of the Zygometridæ, Colobometra diadema of the Colobometridæ, and in the Calometridæ; the same type of plating, though less perfect and with the plates not always in contact, occurs in Zygometra and Catoptometra of the Zygometridæ, and in Mariametra of the Mariametridx.

In the following families the disk is always of the same type: Himerometridæ, Stephanometridæ, Tropiometridæ, Atelecrinidæ, Thalassometridæ, Charitometridæ, and Calometridæ; while the following include species having the disk of two types: Comasteridæ, Zygometridæ, Mariametridæ, Colobometridæ, Antedonidæ, and Pentametrocrinidæ.

The occurrence of different types of disks in related forms is emphasized by species in the following genera: Colobometra, Antedon, Mastigometra, and Pentametrocrinus; and different types of disks are even found in different individuals of species in the genera Comatula, Antedon, and Mastigometra.

The plating of the disks of the species of Calometridæ is quite characteristic, and detached disks of these species (fig. 736, p. 349) can at once be assigned to the family; but this is the only family in which this is the case. The disks of the species of Thalassometridæ and Charitometridæ present features not otherwise known in the comatulids, but those of the different species in the two families show only average differences. Disks of the species of Eudiocrinus are readily recognizable, more because of the very narrow torn areas than on account of the character of the plating.

In the remaining comatulid families and genera overlapping and intergradation of the disk characters occur to such an extent that no general statements can be made, though in many types certain features other than the plating, or combinations of characters, are diagnostic. For instance, the disks of the species of Promacho- 


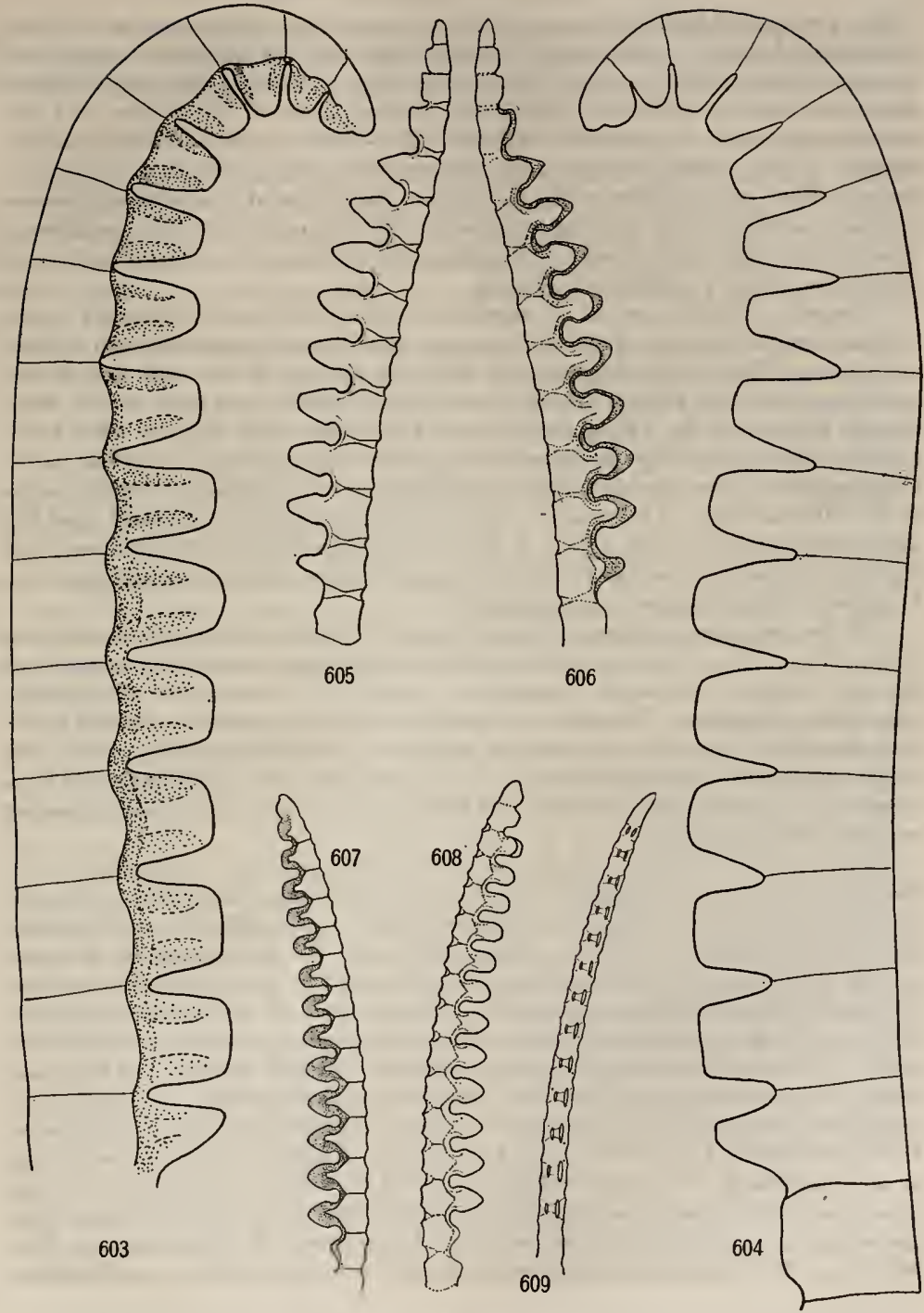

I'igs, 603-609.-Terminal combs of various comasterids, 603, Nenaster iowensis, internal view.

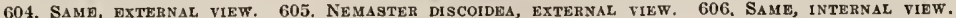
607. Nemaster Bubiginosa, internal view. 608. SAME, external view. 609. SAME, ventral view. $142140-21-$ Bull. $82-22$ 
crinus are easily identified because of the 10 rays; those of the species of Thaumatocrinus because of the deeply stellate shape and 10 undivided ambulacral grooves; those of the species of Pentametrocrinus because of the deeply stellate shape and the five undivided ambulacral grooves; those of the species of Comasteridæ because of the absence of sacculi; those of the species of Himerometridæ because of the incised borders and numerous irregularly-branched ambulacral grooves; those of the Zygometridæ (other than the species of Eudiocrinus) because of the character of the plating, combined with the many-branched ambulacral grooves; and those of the species of Tropiometridx because of the irregular division of the five primary ambulacral grooves.

There is a limited amount of correlation between the extent of plating on the disk and the development of side and covering plates along the brachial and pinnule ambulacra. Thus in the Calometrida both the plating of the disk and of the ambulacra reach the highest degree of perfection, and the next most perfect stage of each is found in the Thlassometridæ and Charitometridæ. On the other hand, covering plates are highly developed in the genera Nemaster and Comatitia in the Capillasterinæ (Comasteridæ), and both side and covering plates in certain species in the Heliometrinæ (Antedonidæ), in all of which the disks are naked; and the disk is more or less heavily plated in the Zygometridæ, Colobometra diadcma, and Pcntametrocrinus semperi and $P$. atlanticus, in which no side or covering plates can be detected without minute examination.

In the very young postpentacrinoid stages of Thaumutocrinus ronovatus (part 1. fig. 117, p. 183) and of Comactinia meridionalis the disk between the margin and the outer borders of the orals is completely covered by a pavement of small plates. which later disappear. These do not appear to have any connection with the plates just described, but seem to be the last vestige of a complete plating of the disk which occurred in the ancestral types. It is curious that such a plating has not been observed in the developing Antedon, but the stage at which it occurs has not as yet received much attention.

In certain of the larger species in the Comasteridæ, most conspicuously developed in Comaster multifida, C. belli, $C$.novreguinere, and Comanthina schlegelii, in Erythrometra, in Mastigometra, invariably in Antedon dübenii and 1. moroccana, and frequently in $A$. bifida, interradials occur. In the comasterids these are usually in the form of two, sometimes with a more or less developed third, columns of large polygonal plates resting upon a single plate in the interradial angle. They may be supplemented by similar plates between the branches of the division series. In Comanthina schlegelii they are almost invariably present, and large and solid; in the other species they are sometimes extraordinarily developed, each individual plate having a conrex outer surface, and very frequently quite absent. In the dereloping Comactivia it has been noticed that the early complete plating of the integument of the disk persists longest in the lateral interradial areas, and it is quite possible that these interradials as seen in the large comasterids arise from the retention and enlargement of these larval structures. In Erythrometra (figs. 666,667, p. 329) the interradials take the form of several columns of small isolated 
plates in the lateral interradial perisome. In Mastigometra and Antedon (figs. $1018, \mathrm{pl} .7$, and $1145,1146, \mathrm{pl} .23$ ) they occur as a small rounded group of from half a dozen to a dozen plates in the interradial angles between the $\mathrm{IBr}_{1}$.

ORGANIC BASE OF THE SKELETON.

In general, the organic base of the skeleton forms a network of more or less narrow meshes, between which the calcareous portions of the skeleton lie. Sometimes the spaces in this network are quite uniform, as in the calyx of Isocrinus decoms, but often wider and narrower, elliptical, and circular meshes are found indiscriminately in close proximity, as in the arms of Antedon. They are always sharply outlined.

The network is composed of the processes of star-shaped cells with at least two branches which lie most commonly at the nodes, though present in other places.

In the organic base of the skeleton two types of cells can be differentiated. The cells of the first type are spherical or somewhat elongate with dark nuclei surrounded by a small quantity of plasma. These cells give off processes in the shape of fine fibrillæ which branch extensively, often forming an irregular entanglement with the fibrillæ of the neighboring cells.

The cells of the second type probably have to do with the deposition of the calcareous material. In the resting stage in the older skeletal structures they are of very characteristic form, ovoid or almost spherical, with a usually elliptical nucleus which lies close to the cell border, mostly at the more pointed pole. They occur everywhere where calcified connective tissue is present, or is in process of formation.

In the regenerating arm where skeletal elements occur there are found spherical mesenchyme cells which divide actively and possess a large nucleus with a prominent nucleolus. As these cells increase in size the nucleus becomes somewhat smaller and stains so deeply that no details are visible in it. At the same time there appear in the cell plasma granules of the same color as the nuclens which, apparently consisting of chromatin, collect in larger or smaller masses. Immediately a small resicle may form. which increases in size and occupies a large portion of the cell, though usually there appear in these cells a great number of resicles of different sizes, but always spherical. In older developmental stages the nucleus is only rarely to be found and is of more or less indefinite form.

Like the preceding, these cells appear to be concerned with the construction of the calcareous elements. It is noticeable that the larger vesicles within them show much similarity to the vesicles in the chambered organ.

The calcareous substance in the ossicles of the arms and pinnules often projects in the form of ncedle-like points through the epidermis. In Heliometra glacialis these extruding points may be as long as $0.02 \mathrm{~mm}$.

CONNECTIVE TISSER.

In the crinoids most of the connective tissue is found within and about the skeletal elements. This connective tissue has already been described. 
In the wall of the end gut the connection of the fibrillæ with the cells is easily seen. In the gelatinous ground substance, which appears more or less finely granular, lie spindle and star shaped cells, the processes froin which radiate in all directions through it, uniting with the processes of other cells at various places. When the fibrillæ run parallel to each other the tissue acquires, if they are suffciently numerous, a cartilaginons consistency, as is more or less evident in the inner layers of the cutis. Amœeboid cells of all shapes are present and are often more or less grouped.

In the arms of Meliometra glacialis there are found cells $0.01 \mathrm{~mm}$. in diameter which show one or several processes, or may be more or less spherical. A spherical nucleus $0.002 \mathrm{~mm}$. in diameter lies in the granular cytoplasm.

In Antedon the cell substance does not stain, but a reticulation can be made out in the meshes of which lies the deeply stained nucleus. About the dorsal portion of the mesodermal nervous system these cells are abundant.

In Neoccmatella pulchella on the dorsal and lateral surfaces of the arms and also beneath the epithelium of the anal tube prominent cell clusters appear in the form of more or less egg-shaped structures. These cell groups, each consisting of five or more cells, occur immediately beneath the external epithelium. The individual cells are bladder like, consisting of a thin membrane in which the cell substance is inclosed. The cells are filled with a watery transparent fluid which is not stainable. A spherical nucleus lies more or less centrally, surrounded by a small amount of plasma, which, in the form of pseudopodia-like threads, stretches to the wall, holding the nucleus in place. The walls of occasional cells are often strongly pleated.

Such cell groups are a prominent feature of the walls of the pinnules in all the species of Comasteridæ which have been studied, but they have never been found in any endocyclic form.

It has been supposed that their function is to antagonize the ventral muscles. PLGMENT.

Pigment cells, containing free pigment granules, are abundant elements in the mesoderm of the cutis and occur also widely distributed throughout the body.

vISCERAL MASS.

In Antedon the body wall of the visceral mass is everywhere uniform except at the ambulacral furrows, beneath which the water vessels and other organs lie. In mature animals the thickness of this wall is at the most $0.1 \mathrm{~mm}$.

It is composed of four layers: (1) The general body epithelium, composed of a single layer of cells; (2) the cutis; (3) the connective tissue layer; and (4) the epithelial lining of the body cavity.

The external epithelium has secreted no cuticle, and is scarcely to be differentiated from the connective tissue layer. The small size of the component cells often renders them difficult to demonstrate. There are no cell borders, but the presence of nuclei lying closely together in an irregular layer indicates the presence of an epithelium. 
In Neocomatella pulchella the form of this epithelium is more easily seen. The cells, the borders of which can rarely be determined, are approximately cubical, and their position is indicated by their dark-colored nuclei.

In Antedon mediterranea, Tropiometra carinata, and Neocomatella pulchellaapparently in all comatulids-the connective tissue layer is divisible into two strata, of which the more superficial is composed of a loose union of fibers running in every direction, while the deeper, bordering the cœlomic epithelium, shows a cartilaginous consistency. In this connective tissue layer are nerve branches, which run parallel with the surface, from which nervules proceed to the epithelium. It is traversed by the water pores, which lead into the body cavity.

The ambulacral grooves lead from the pinnules to the arms, down the center of the ventral surface of each arm, and across the disk, converging at the mouth, about which they unite to form a ring-like area. They are bordered on either side by lappets and tentacles.

The epithelium lining these grooves is greatly thickened. The constituent supporting and sense cells, as well as the nerve fibrillar layer, have already been described.

Below this epithelium there is found in many species a schizocœle cavity, and always a water vessel which leads out from a ring canal about the mouth.

As the body cavity between the wall of the intestinal canal and the body wall is traversed in all directions by connective tissue strands, it is often scarcely recognizable as such, and in some places the distinction between the body wall and the connective tissue strands can hardly be made out. But all the subdivisions into which the body cavity is broken up are lined with enterocoele epithelium.

BODY CAVITY.

In the recent crinoids the development of mesenteries, bands, and septa traversing the body cavity and serving to hold the internal organs in place has been carried to such an extreme that the body cavity as a whole lias vanished, and there is only to be found a system of intercommunicating canals, which collectively are the remnant of the original body cavity.

In Isocrinus decorus the body cavity within the calyx has entirely disappeared.

In Neocomatella pulchella, as in all the large species of the Comasteridæ, the number of these bands and septa is very great, so that the body cavity is enormously subdivided. These bands, of all sizes, form a maze of fibrous branches on all sides: and are attached some to the intestinal wall, others to the body wall.

Pigment and calcareous concretions occur in the bands, and in the species of the genus Antedon, though rarely, sacculi.

These bands are covered (that is to say, the remnants of the body cavity are lined) with a very fine epithelium of flattened cells the oval nuclei of which stand out prominently in the flattened cell body. Within the bands themselves are found wandering cells lying in the gelatinous ground substance between spindle and starshaped cells.

A cross section of an arm shows a continuation of the body cavity as at first three canals, a dorsal and two ventral or subtentacular canals, which are separated 
from each other by a septum within which runs the canal containing the genital rachis.

At the base of the arm somewhat different conditions are found. A section through the first brachial shows the ventral canal without a median septum, while the septum between it and the dorsal canal is much thickened and is traversed by a large number of intercommunicating cavities, of which one contains the genital cord. Passing outward along the arm these last mentioned cavities decrease gradually in number until finally only the genital canal is left.

The dorsal canal in Antedon mediterranea is much broalened in places, while in the vicinity of the interbrachial musculature it expands dorsally so as to frequently come, furrow-like, within a short distance of the dorsal nerve cord. Similar swellings are also found in Heliometra glacialis, but in this species are more complicated in structure, the cells of the dorsal furrows being thickened and bearing long cilia. Septa often appear, which cut off this ciliated furrow from the remaining portion of the brachial extension of the body cavity, and as often vanish, so that all the cavities in the arms (with the exception of the water vessels and the small subneural schizocæle canal) are intercommunicating.

In Heliometra glacialis the epithelium lining all these cavities presents a very varying aspect. It reaches its greatest development in the ciliated grooves. In the section lying dorsally its cells are smaller and more flattened, while in the intercommunicating canals, between the dorsal and ventral canals, it is composed of flattened cells without cilia.

It is from the sections of the dorsal canal furnished with ciliated grooves that the dorsal canals of the pinnules, which bear the ciliated sacks, arise.

$$
\text { ALIMENTART CANAL. }
$$

P. H. Carpenter observed that both in Antedon and in Heliometra the gullet runs downward and backward, trending slightly to the left. When it has reached the bottom of the visceral mass the intestine turns to the right and coils around its anterior side until it has reached the hinder part of the disk behind the commencement of the first coil where it turns upward and slightly forward, to end in the anal tube. The descending portion of the fore-gut is comparatively short, and the coiled intestine into which it passes lies spread out on the upper surface of the radials, so that there is no general dilatation of the gut at the bottom of the cup as in the pentacrinoid.

He found that in the majority of the Comasteridæ the digestive tube proceeds directly downward to a point somewhat behind and to the left of the center of the disk, and then commences to wind. Its direction, as in the endocyclic species, follows the hands of the clock when seen from the ventral side, but there are four coils instead of one. The first coil occupied the extreme edge of the lowest part of the disk, and consequently passes in front of the mouth so as to appear beneath it in longitudinal section. The second coil passes immediately behind it and is followed by two more in an ever-narowing but ascending spiral which terminates in the more or less central anal tube, which is often some little distance in front 
MONOGRAPH OF THE EXISTING CRINOIDS.
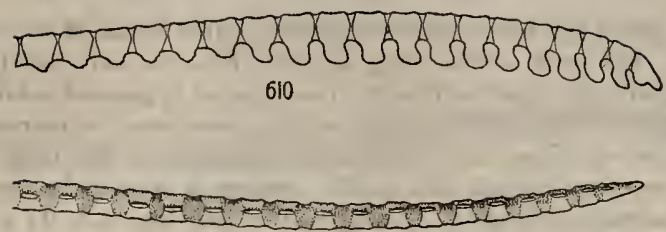

6li
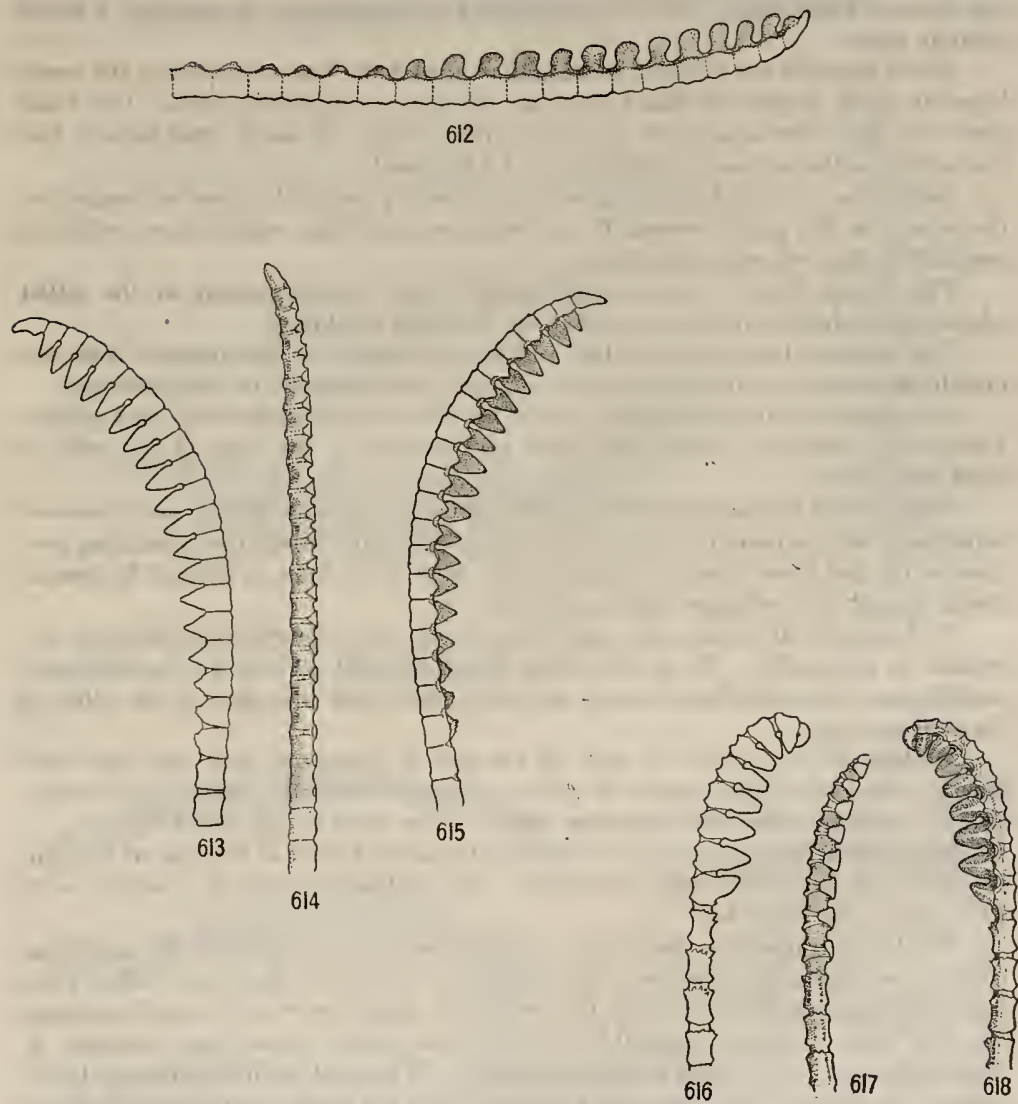

Figs 610-618.-Trranal cosibs of variots cojasterids. 610. Callelaster sentosa, exterval view. 611. SaMie, ventral VieW, 612. Same, internal view. 613. Capillaster multiradiata, external VIEW, 614. SAME, VENTRAL viEw, 615. SAME, INTERNAL ViEw. 616. COMATILIA iRIDOMETRIFORMIS, EXTERNAL VIEW, 617. SAME, VENTBAL VIEW. 618. SAME, INTERNAL VIEN. 
of the point where the lowest part of the long gullet turns off to enter the great exterior coil. The walls of this long digestive tube are but slightly plicated.

Histologically the digestive tube has been studied in greatest detail by Hamann.

The epithelial lining of the gullet, which passes over uninterruptedly at the mouth and anal openings into the general epithelium of the body wall, and on longitudinal sections through the mouth opening is seen to be continuous with that of the ambulacral furrows, is composed of hair-like cells $0.1 \mathrm{~mm}$. in length, of which the nuclei lie inwardly, toward the middle, or even at the bases. Eggshaped gland cells $0.1 \mathrm{~mm}$. long, the contents of which remain unstained, lie toward the lumen of the tube, while at the base of the epithelium there runs a nerve fibrillar layer.

When the cells are isolated it is easily seen that the fibers traversing the nerve layer at right angles are basal processes from the supporting cells. The basal processes from the other cells are much finer, break off easily, and behave like the nerve fibrillæ between which they can be followed.

Below the epithelial layer there is a scarcely perceptible layer of connective tissue, and in the gullet beyond this a well-developed ring muscle layer which is overlaid by the cœlomic epithelium.

The muscle layer is only recognizable in the commencement of the gullet where the epithelium passes over from the disk into the lumen.

The nervous layer becomes less and less noticeable as the distance from the mouth increases, and in the hind-gut can not with certainty be demonstrated.

Excepting within the anal tube, the cells of the whole alimentary tract glisten. There is no cuticular lining. The cilia are attached to the ends of the cells by short foot pieces.

While about the commencement of the gullet the muscle fibrillæ are in several layers and form a more or less well-developed sphincter, about the remaining portions of the gut there is only a single layer, which in Antedon is difficult to demonstrate, though in the larger types easily seen.

In longitudinal section the anal tube is seen to be a cylinder, more or less swollen in the middle. In its formation the body wall, as well as the gut itself, participates, the epithelium of each section passing over into that of the other at the anal opening.

Within the anal tube the wall of the gut is connected with the body wall through connective tissue cords or septa at regular intervals. These have collectively a definite order and structure which is the same in all comatulids.

The wall of the rectum is composed of the same layers as the rest of the gut, but these are here differently developed. The epithelial lining is provided with cilia only in the lower half.

While the connective tissue layer increases in thickness distally, the epithelial layer correspondingly decreases, and in the terminal section in no way differs from the epithelium of the body wall into which it passes over at the anal opening, like the latter merging insensibly into the connective tissue layer beneath it. Gland cells are here present in large numbers. If the gut is fully extended longitudinal plications or folds are seen to extend from the anal opening about halfway 


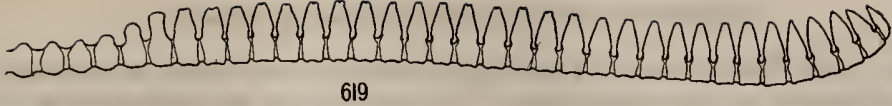

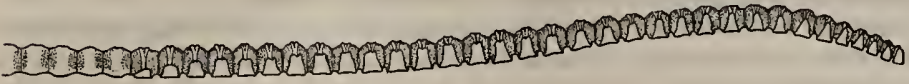

620

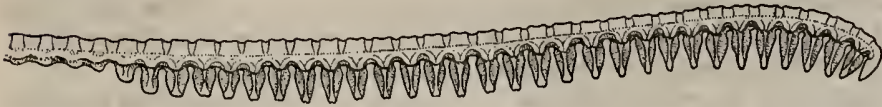

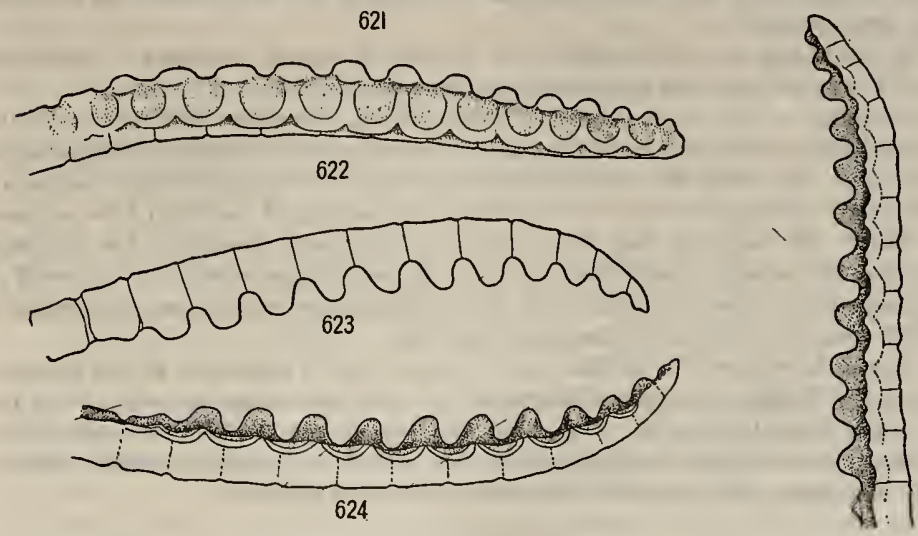

625
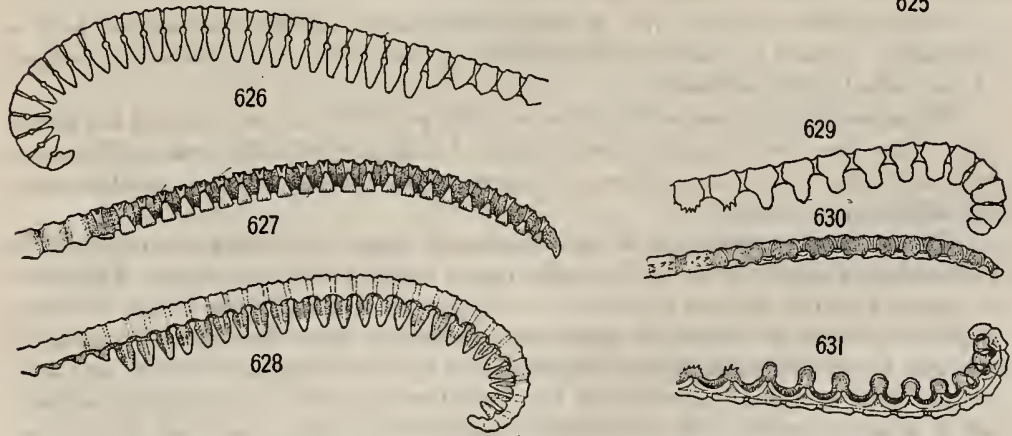

Figs, 619-631, - TrRminal combs of various cosisterids. 619. Comatula solaris, external view. 620. SAME, ventral vinw. 621. SAME, internal view. 622. Comatula purpurea, ventral vibw. 623. Same, external view, 624. Same, internal view. 625. Sadie. 626. Comatula micraster, exTERNAL viEw. 627. SAME, veNTRAL viEw, 628. SAME, inTERNAL view. 629. Comatula rotalakia, EXternal viEW. 630. SaME, Ventral VIEW. 631. SAME, internal view. 
to the base. The connective tissue layer, about $0.1 \mathrm{~mm}$. thick, is composed of spindle-shaped and star-shaped cells. In Antedon there is no calcification. The muscular layer is developed in the form of a strong splineter.

The cords which establish the union between the gut and the body wall within the anal tube are composed of connective tissue which outwardly passes into the cutis and inwardly into the connective tissue layer lying in the gut wall just beyond the ring muscle.

Nerve branches proceed from the mesodermal oral nervous system and from the lateral nerves of the water vessels and enter the connective tissue layer of the anal tube, innervating partly the skin and partly the musculature.

The histological structure of the gut is the same in all the comatulids in which it has been studied.

In the young of Antedon bifida Sir Wyville Thomson described a "primitive liver" which has not been mentioned by subsequent writers.

Speaking of the adult Antedon bifida, W. B. Carpenter states that in the thickened disk which surrounds the mouth, formed at the junction of the perisome of the oral disk with the wall of the alimentary canal, he detected a series of cæcal tubuli opening into the commencement or esophageal portion of the alimentary canal. He suggests that these may have a salivary function. He also suggests that the peculiar gland-like character of the plicated portion of the wall of the inner side of the horizontal coil of the alimentary canal seems to render it probable that it performs the function of a liver.

Doctor Mortensen found that in Notocrinus virilis the walls of the intestine are greatly folded, a complete labyrinth of folds appearing on removal of the skin of the ventral side of the disk. The folds are not confined to the ventral side, although most strongly developed there. A reticulate connective tissue, containing no calcareous deposits, fills the interstices between the folds.

CHAMBERED ORGAN.

The chambered organ lies in the central cavity of the centrodorsal and is completely incased by the nerve fibrillæ which collectively form the central organ of the dorsal nervous system.

Hamann, studying especially Neocomatella pulchella, has worked out the structure of the chambered organ in great detail. He finds it to be the same in Neocomatella pulchella, Comatula rotalaria, Comanthus parvicirra, Antedon mediterranea, and Heliometra glacialis.

In the dorsoventral axis of the chambered organ there runs a cord which is a dorsalward continuation of the axial organ lying within the calyx. This cord is attached to the wall of the chambered organ by five radiating bands or septa, which thus form five separate chambers. Ventrally, these five chambers contract and run as narrow tubes close along the axial cord, soon ending blindly, and connecting bridges appear between the five radial mesenteries; dorsally the chambers are in communication with the central vessels of the cirri into which derivatives from the five septa run as flattened median partitions. The cirrus vessels are given off only in the five meridians, though nsually in several rows. Toward the center 
of the dorsal portion of the chambered organ cirrus vessels are found which run through the centrodorsal and end blindly within the epithelium; these are the last traces of cirri which have become obsolete and have been discarded. The median partition in each cirrus ressel is of the same structure as the septa of the chambered organ, with which it is continuous. It consists of a thinner connective tissue sheet covered on both sides with epithelium, and does not contain muscle fibers.

The cavities of the chambered organ are lined with an epithelium which is continuous with and similar to that covering the radiating connective tissue septal, and which is also produced into the cirrus ressels. This epithelium is composed of uniform closely crowded cells $0.005 \mathrm{~mm}$. to $0.004 \mathrm{~mm}$. high with decply staining nuclei and without cilia, which form a continuous layer.

Perrier noticed in the cavities of the chambered organ a great number of free elements, very regularly spherical and staining only very faintly. He never found these bodics outside of the cliambered organ.

Reichensperger in his studies on Isocrinus noticed these bodies and later made a detailed investigation of them in several species of comatulids.

In all parts of the chambered organ, and only within that structure, large and small spherical bodies occur which show a decided partiality for certain stains. 'The small particles are composed of a fine friable substance; the larger are covered with the same material, some with a very thin, others with a thicker stratum.

These spherical bodies are hollow spheres, of which the largest measure from $6 \mu$ to $10 \mu$ in diameter. They were found in all the species examined.

Reichensperger was not able to determine the place of origin of these spheres but suggests that they may possibly be formed by the moderately high epithelium of the chambered organ, for on this epithelium lie most of the smaller bodies, as well as those which are more thickly enveloped in organic substance. He did not, however, observe actual origin from the epithelium, or any alteration within its cells which would suggest such an origin. The minuteness of the elements involved rendered determination of this point difficult.

These bodies were found in the following material:

Five Isocrinus decorus, whole chambers with numerous little spheres.

Two Comanthus bennetti, whole chambers with numerous little spheres.

One Comasterid, species undetermined, the same.

Six Antedon mediterranea, the same.

Of three specimens of Antedon mediterranea which were regenerating whole arms one possessed a very few little spheres, the two others none at all, but instead there appeared in the chambered organ a network of a strongly stained substance resembling that enveloping the spheres.

Reichensperger suggests that these spheres may serve to contain a reserve supply of limestone in a more or less concentrated solution for use in the reparation of the skeleton.

The chambered organ, together with the canals which lead into the cirri, in the very young animal is in communication with the body cavity, of which it is an integral part, but from which it later becomes entirely cut off. 
AXIAL ORGAN.

The axial cord which traverses the chambered organ emerges from it ventrally and continues as an irregular cord-like structure into the calicular body cavity, running upward between the coils of the digestive tube and ending blindly in the vicinity of the mouth. It does not lie in the center of the calyx, but on one side.

The axial organ is covered on all sides with colomic epithelium composed of squarish or more flattened cells. A cross section through it shows a series of chambers lying in a common connective tissue, which is distinct from the cœlomic epithelium. The nearer the sections studied lie to the ventral surface of the animal the more numerous are the cavities, some of which are cut across, others longitudinally.

Toward the middle of the organ the diameter and the number of the chambers increases, from that point onward gradually diminishing again. Longitudinal sections show that these chambers give rise to short, blind, lateral branches, the greater part of which run longitudinally. Single chambers may branch out together from the main mass, causing the organ, originally in a single line, to break up into several lines. These branches are also covered with cœlomic epithelium.

The individual chambers are lined with an epithelium about $0.04 \mathrm{~mm}$. in height composed of closely crowded cylindrical cells showing granular contents, and with the circular vesicular nuclei lying at their bases. The lumen of the chambers is sometimes wide and sometimes narrow, and is often filled with a coagulable clear fluid.

The connective substance in which all these chambers lie is made up of clear ground substance which shows no calcification, and spindle or star shaped cells the processes of which are irregularly intertwined.

The circumference of this organ decreases toward the ventral side, and the last chambers end blindly. The dorsal end dwindles away, and is continued as the axial cord of the chambered organ. Sections through this end portion show that the number of the chambers has become very small and decreases dorsally. The chambers are very narrow and possess an epithelial lining which differs from that in the chambers lying within the body cavity, being composed of lower, almost flattened, or cubical cells.

The last four or five narrow little canals end blindly. The cirrus vessels are not processes from these canals, but arise from the chambered organ.

According to Hamann the axial organ is a closed capsule ensheathed by fibrous connective tissue. The inclosed vesicles, which have no connection with the exterior, are shorter or longer tubes, sometimes flask shaped, sometimes club shaped and partially branched.

Hamann noticed that blood lacunæ may be traced into the immediate vicinity of the axial organ, and that they appear narrowly to connect with it on the ventral end. The blood from these lacunæ can not enter the lumina of the cavities, but can at the most enter the connective tissue of the organ, where, however, Hamann has not been able to observe it. 


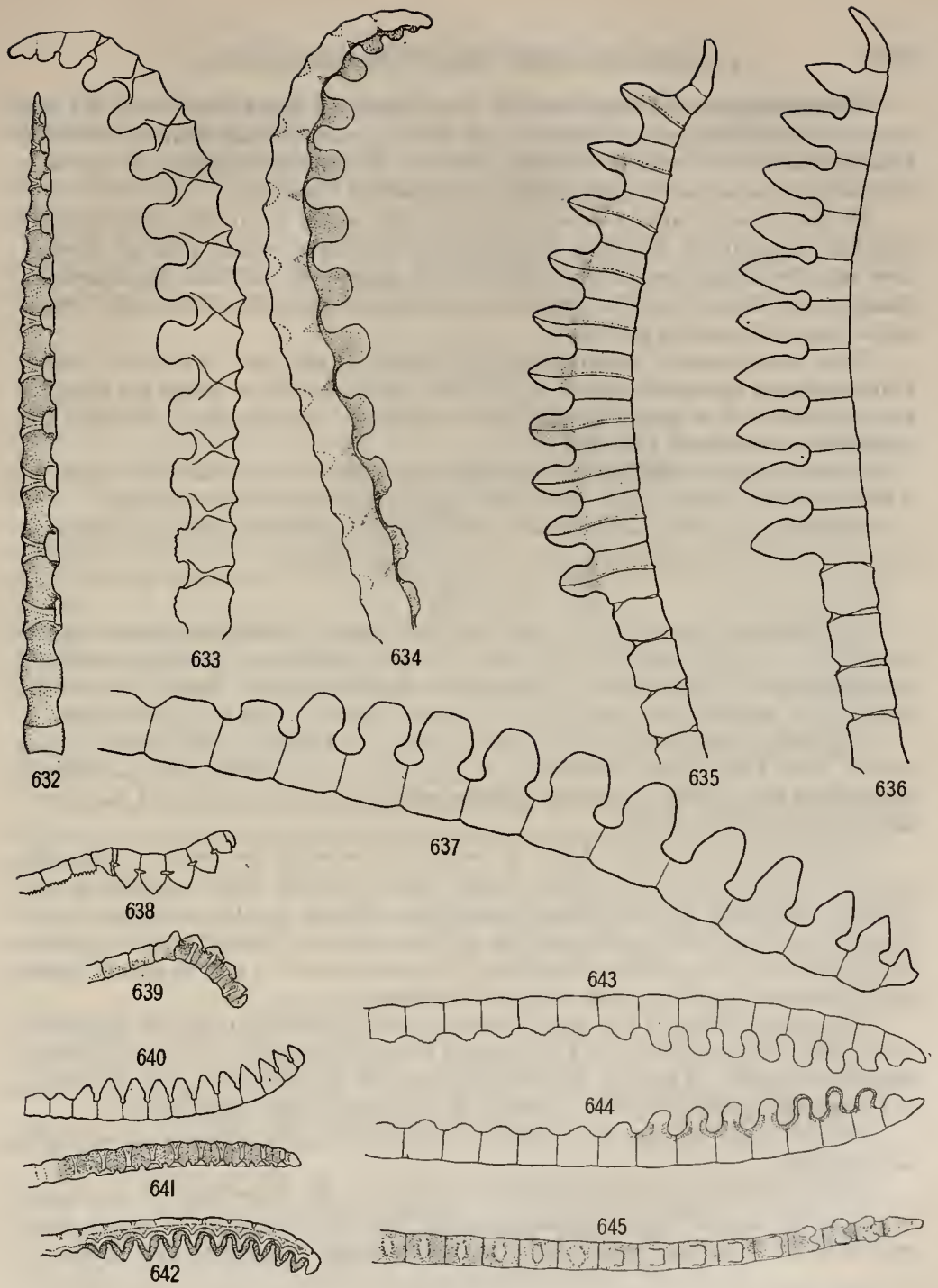

Figs. 632-645.-Teiranal combs of various comasterids, 632. Comactinia echinoptera, ventral view, 633. Same, external view. 634. Same, internal view, 635. CoMaster parvus, internal view. 636. Same, external view. 637. Comaster belli, external view. 638. Comaster distincta, distal COMB, EXTER NaL view. 639. SAME, INTERNAL view, 640. CoMASTER Distincta, proxisial COMB, exter Nal view. 641. Same, ventral view, 642. Same, internal view, 643, Comanthina schlegeli1. external view. 644. Sadie, internal view. 645. Same, ventral view. 
Reichensperger reinvestigated the axial organ in great detail but did not succeed in elucidating its relation to the other organs further than to convince himself that it is in intimate relation with the blood lacunar system, as had been assumed by Ludwig and more recently reaffirmed by Chadwick.

He found many times places where the blood ressels apparently enter directly into the organ itself, the thin epithelium of the blood vessels passing directly over into the thicker epithelium of the axial organ. In addition, he sometimes found in the blood vascular system the products of the cells of the axial organ, in the slape of rounded granules.

That these rounded granules are the product of the cells of the axial organ Reichensperger believes is shown by the fact that in the places where the granules lie the cells have a markedly glandular character. Among other features, the cytoplasm shows small vacuoles.

Chadwick noted that at the breeding season the cells of the axial organ in Antedon bifida loosen from their basal membrane and become amoboid.

Reichensperger was not able to confirm this in Antedon mediterranea, although he was at Naples during the height of the breeding season.

TENTRAL ORGAN.

The central organ of the dorsal nerrous system, sometimes known as the central capsule, is composed of a mass of nerve fibrillø, in general concentric in arrangement, which entirely envelops the clumbered organ except for a small area at the ventral pole where its axis passes ventrally into the axial organ.

From the dorsal portion of the central organ, involving all of the nerve fibrillar layers, arise radially the envelopes of parallel nerve fibrillæ which ensheath throughout their whole course the tubular extensions of the cavities of the chambered organ into the cirri.

Above these, with their bases in contact all around the central organ, are given off the five large and stout primary nerve branches which, narrowing and passing diagonally upward, almost immediately divide, the two resultant halves of each diverging widely and merging with the similarly diverging halves of the two adjacent to form, within the radials, the secondary nerve trunks which become the dorsal nerve cords, or axial cords, of the arms.

The inner fibrillæ of the central organ, which lie directly upon the chambered organ, run concentrically, this arrangement being interrupted only at the bases of the cirrus vessels. Those of the cortical layer are for the most part concentric, but their arrangement is rery irregular at the bases of the cirrus nerves.

The fibrillæ of the five nerve masses which form the five primary nerve trunks are parallel.

Large ganglion cells are especially numerous on the dorsal side of the central organ at the base of the cirrus nerves, and where the five primary nerves arise, and these still further interrupt the normal concentric course of the fibrillw.

clrkt's NETrEs.

Each of the tubular vessels which run from the chambered organ into the cirri is incased all along its course by an investment of parallel nerve fibrille 
which forms a stout envelope all about it, being of greater thickness than the diameter of the vessel itself.

In cross section ganglion cells are seen which are mostly bipolar and lie either peripherally or scattered between the fibrillæ; they are arranged in definite groups.

Within each cirrus segment, as within each brachial and pinnular, four nervules are given off from the main stem at opposite corners; these innervate the ligaments between the segments and the outer layers of the segments themselves.

BRACHIAL NERVES,

Nerves of the division series.

Each half of the five primary interradial nerve stems, which divide immediately upon leaving the central organ, joins within the calcareous substance of the radial the adjacent half of the neighboring primary stem to form one of the five secondary interradial nerve stems. Very shortly after this union the five secondary nerve stems are connected all around the calyx by an intraradial commissure, which is pentagonal in form.

From the radials the secondary nerve stem passes as a single cord through the $\mathrm{IBr}_{1}$; but on entering the $\mathrm{IBr}_{2}$ (axillary) it divides into a right and left branch, these two branches running to the center of the right and left distal faces of the axillary. Just before leaving the axillary the two branches are connected by a transverse commissural band of fibrilla and by a chiasma formed by two obliquely placed bands which cross one another and, joining the opposite branches at the ends of the transverse commissure, furnish additional communication between the right and left branches.

Every subsequent division series reduplicates the conditions found in the $\mathrm{IBr}$ series, and every subsequent axillary contains a similar transverse commissure and chiasma.

The branches of the secondary nerve stems leave the axillaries as single cords and, gradually decreasing in size distally, pass along the dorsal side of the undivided arms in tubular channels perforating the brachials as the axial nerve cords of the arms.

Finer structure of the brachial nerves.

The nerve cords which emanate from the central organ are throughout their whole length solid and approximately circular in section. In Antedon mediterranea the diameter of the primary nerve stems is $0.2 \mathrm{~mm}$., that of the two derivatives of each of these which unite to form the axial cord of the arms $0.1 \mathrm{~mm}$., and that of the branches forming the chiasma $0.02 \mathrm{~mm}$.

The fibrillæ of the dorsal nerves are exceptionally fine and run everywhere parallel to each other and closely appressed. The short bundles of fibrille which form the chiasma in the $\mathrm{IBr}_{2}$ (axillary) pass each other in the center, almost at a right angle, without intermingling.

About the periphery the nerve cords are studded with large, mostly multipolar, ganglion cells; these are abundant dorsally, forming a sort of peripheral capping, and occur irregularly in the central portion. 
Small bipolar cells are also present, uniformly distributed.

Though large multipolar cells are abundant at the ends of the commissures, there are few ganglion cells in the chiasmas.

In glycerine the nerve fibrillæ appear finely granulated and possess strong refractive power. Generally speaking, they are uniform in thickness, about 0.001 $\mathrm{mm}$. in cross section.

Two entirely distinct kinds of ganglion cells are found among these nerve fibrillæ, small bipolar cells $0.003 \mathrm{~mm}$. long irregularly distributed between the fibers, and larger, mostly multipolar, cells which are either spindle shaped (bipolar) or very irregular. The size of the latter is difficult to give, for the cell body may be much elongated; according to Hamann, they vary between $0.007 \mathrm{~mm}$. and $0.02 \mathrm{~mm}$. Reichensperger says that, including their processes, they vary from $36 \mu$ by $10 \mu$ to $65 \mu$ by $10 \mu$. Their vesicular necleus is oval and almost always shows a prominent nuclear body and a fine, more or less diffused, network of chromatin threads. The cytoplasm stains very deeply and appears granulated, the granulations being traceable to the extreme ends of the processes.

While the smaller ganglion cells are scattered everywhere in great numbers, the larger, less numerous, chiefly lie on the surface of the fibrillar bundles, being especially abundant about the base of the lateral nerve branches, particularly at the chiasma which is formed at the commencement of each pinnule nerve. In the arms they may pass deeply into the nerve cord and there form a longitudinal band which often makes the cord appear as if divided into two halves by a median septum.

The processes of the ganglion cells ramify and penetrate the fibrillar bundles.

Branching of the axtal cord in the arms.

In the middle of each brachial there is a swelling of the axial nerve cord, and from this swelling four stout nerve branches arise with laterally and dorsally a few weaker additional branches between them.

The individual nerve branches leaving the mid-brachial swelling in part penetrate far into the interior of the nerve mass of the central cord, and they are bound together at the base by commissures.

Of the four chief nerve branches the two dorsal penetrate the calcified substance of the brachials and reach the epithelium; the two ventral pass to the interbrachial muscles, the ventral epithelium, and the pinnules.

Hamann has worked out in Heliometra glacialis the ramifications of the two dorsal nerve branches. Shortly after their origin these divide dichotomously, and each of the resultant twigs divides in the same way. This process continues until each nerve presents the appearance of a widely branched tree of which the trunks are the original dorsal nerve branches and of which the outermost twigs, composed each of a few fibrillæ, enter the body epithelium.

The ultimate divisions of these dorsal nerve branches, composed of small bundles of nerve fibrillæ, lead to specialized groups of epithelial cells. The cylindrical or more or less flattened epithelial cells in these groups are more crowded than usual, so that the nuclei appear more numerous. They taper toward their 

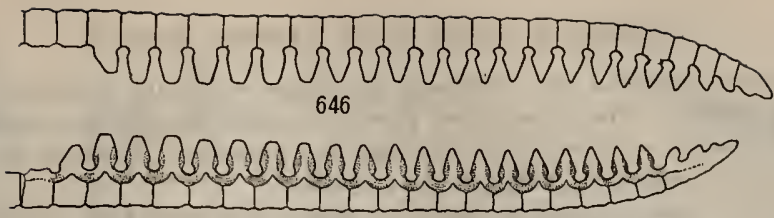

647

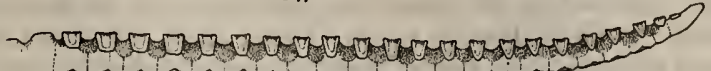

648
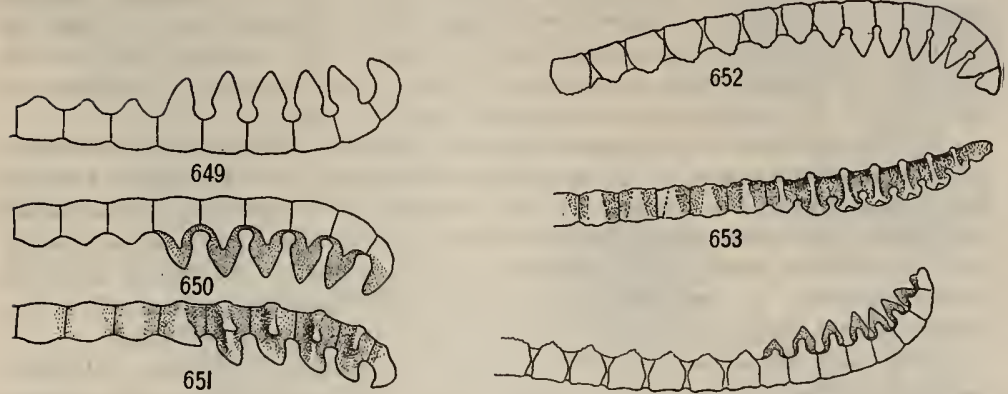

653

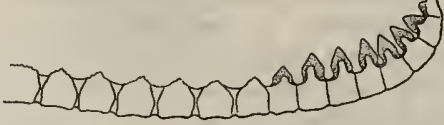

654
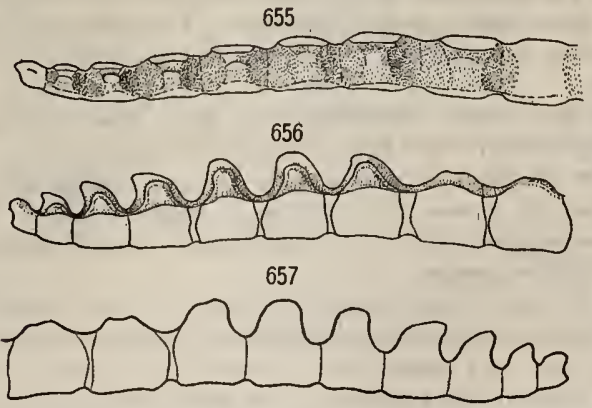

Figs. 646-657.-Terminal conis of variovs comasterids, 646. Comanthus trichoptera, External viEw, 647. SAME, INTERAL VIEW, 648. SAME, veNTRAL viEw, 649. COMANTHUS SAMOANA, EXTERNAL

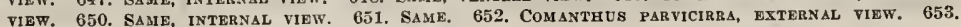

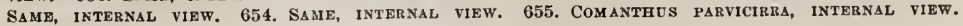
656. SAME, INTERNAL VIEW. 657. SAME, EXTERNAL VIEW. $142140-21-$ Bull. $82-23$ 
bases and are produced into extremely fine fibers which are in connection with the nerve fibrillæ. These specialized groups of epithelial cells are found on the dorsal and lateral surfaces of the brachials and pinnulars. Hamann found them most easily demonstrated in Heliometra glacialis.

The two ventral branches ramify in exactly the same way. One of them, alternately the right and the left, enters the pinnule, in which its course and its subdivision exactly duplicate that of the axial cord itself within the arm. After very numerous divisions these ventral branches resolve themselves into fine twigs, some of which reach the body epithelium, in the ambulacral lappets and on the ventral portion of the arm generally, while others, radiating out brush-like into single fibrillæ, enter the ventral interbrachial muscles.

In Heliometra glacialis Hamann found in the portion of the axial cord traversing the muscular articulations between each pair of brachials ganglia composed of a number of unipolar cells, each with a globular body $0.01 \mathrm{~mm}$. by $0.02 \mathrm{~mm}$. in size containing a clear resicular nucleus with a nuclear body, which taper into a strong process penetrating the nerve mass in which it radiates out like a brush. The ganglia have not been described in Antedon.

In those portions of the calcareous ground substance which border immediately upon the ligament masses of the muscular articulations, the articulations between the cirrus segments, the syzygies and the synarthries lie numbers of the so-called pear-shaped cells which give off at the small end often several processes pentrating far into the fiber mass. The cytoplasm, including that of the finest divisions of the processes, is very finely granulated. Reichensperger suggests that the occurrence and strong staining of these granules recalls Nissle's bodies.

These pear-shaped cells were first described as ganglia by Perrier. His successors either doubted their nerrous nature or failed to ascribe to them any definite function until very recently Reichensperger, studying the question anew, was able to confirm Perrier's interpretation of them.

According to Reichensperger the only difference between these cells and the ganglion cells of the axial cord lies in their stronger microchemical reaction, and perhaps also in their more branched processes. The latter are also more or less isolated, while these are massed, lying generally in pairs on the bows of the dorsal ligaments.

In Antedon they recede somewhat from these bows, and the nerve twigs therefore lie finely divided below them instead of above.

The processes of the pear-shaped cells are not united with cells, but run between the ligament masses and surround single bundles. The connection between these pear-shaped cells and the axial nerve cord of the arms was worked out in detail by Reichensperger.

Just within the anterior and posterior border of each brachial there run out from the axial cord nerve branches comparable to the nerve branches in the middle of each brachial, but very much finer. These divide almost immediately and, ramifying in a plane at right angles to the axial cord, resolve themselves into extremely fine fibrillar bundles, which unite with the terminal layer of pearshaped cells. In a normal adult but few ganglion cells are found at the base 

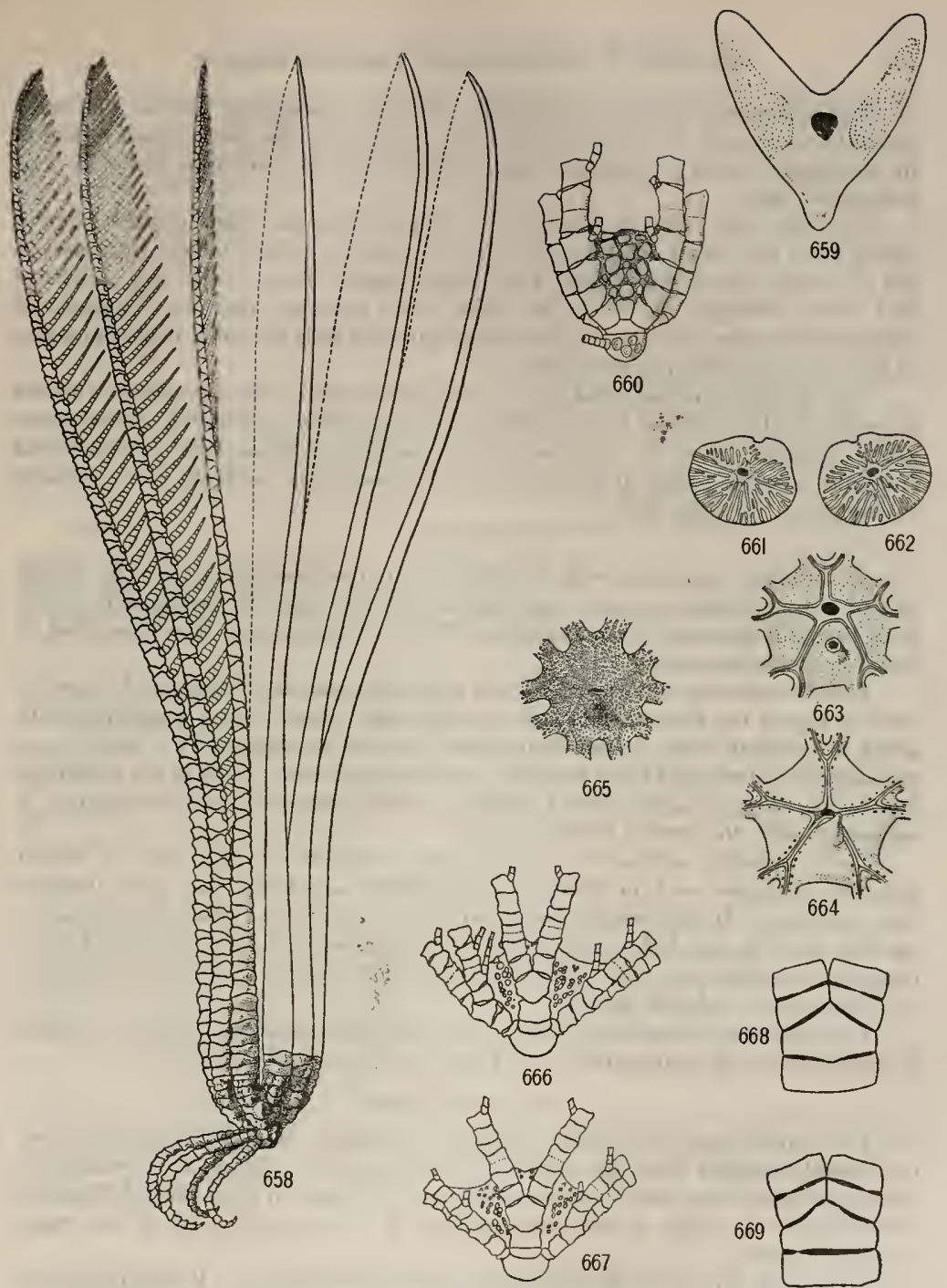

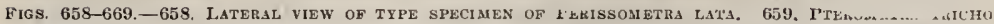

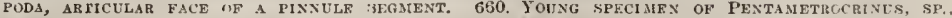
SHOWING INTERERACHIAL PERISOMIC PLATES, 6fit. I'SEUDOSXZXGIAL ARTICULAR SURACE OY DISTAL END OF FIRST BRACHIAL OF SPECIMIEN OF COMATUla PURPLREA, 662. AdJOINiNg PROXIMAi, SLRFACE OF SDCOND BRACHIAL, 663, UNPLATED DISK OF ANTEDONID, 664, UNPLATED DISK OF ANTEDONID, SHOWING SACCUl, 665. PLATED DISK OF THALASsometrid. 666. Proximal portion of ERTthrometra REBER, SHOWING INTERBRACHIAL, PERISOMIC PLATES, 667. SAME. 668. DIVISION SERIES OF TWO OSSI. CLES, AND TWO FIRST BRACHIAL PAIRS; TWO ELEMENTS OF DACH OF TIREE PAIRS ARE UNITED BY SYNARTHRT, WHILE ARTICULATIONS AT EITHER END OF EACE PAIR ARE MUSCULAR. 669. AXILLART IN ExTRANEOES ARA DIVISION; ALL ARTICULATIONS SHOWN ARE OBLIQUE MUSCULAR. 
of these branches from the axial cord. In the regenerating animal the nerve elements are mostly in continuity with the processes of the pear-shaped cells, but in the normal adult it appears more as if the fibrillæ ran upon the cells and surrounded them.

In Heliometra glacialis Hamann was able to trace the single unpaired nerves which unite the dorsal axial cord of the arm with the paired longitudinal nerves, one of which runs on either side of the water vessel. These nerves run undivided in a nearly straight line. Like the other nerve branches, they are composed of parallel unbranched fibrillæ the multipolar ganglion cells of which lie peripherally or more or less within the nerve mass.

The structure of the axial cord of the arms and of its derivatives appears to be practically identical in Comatella nigra, Comanthus parvicirra, Tropiometra picta, Antedon bifida, A. mediterranea, A. adriatica, Heliometra glacialis, and Isocrinus decorus. Most of the finer work has been done on Heliometra glacialis on account of its large size.

WANDERING CELLS.

In intimate connection with the elements of the mesodermal nerrous system and of extreme importance in regeneration are the large wandering cells, which were first differentiated from ganglion cells by Hamann, and later described in detail by Reichensperger.

These wandering cells are very much more numerous in Antedon and Isocrinus than in any of the Comasteridx. In Antedon they often form a complete sheath about the central organ in the centrodorsal, as well as about all the nerve cords radiating therefrom and their branches, occurring as isolated cells to the outermost fine twigs. They also are found, though usually somewhat less abundantly, in connection with the ventral nerve cords.

The wandering cells occur in every conceivable form; they may be almost spherical, elongate oval, or elongate to wormlike; sometimes they have three or four processes. In the resting condition their contents are either homogeneous, or they show in the feebly stained cytoplasm masses of fine darker and lighter irregular granules and rods. The nucleus is not very large, stains moderately, and almost never exhibits details.

The size of the wandering cells can be only approximately given; according to the amount of elongation they vary from $34 \mu$ by $2 \mu$ to $52 \mu$ by $1.5 \mu$.

TENTRAL NERVOUS SYSTEM.

The ventral nervous system, which is intimately connected with the dorsal but entirely distinct from the epithelial nervous system, centers in a pentagonal circumoral nerve ring, oval in section and about $0.03 \mathrm{~mm}$. in dorsoventral diameter, which lies in the cutis on the same level as the circumoral canal of the water vascular system.

This nerve ring gives off a very large number of branches. Radiating inward are branches leading to and entering the tentacles; ontwardly on either side of the radial water tubes there runs a longitudinal branch, $0.02 \mathrm{~mm}$. in diameter, and 
this pair of branches divides and enters the arms, subsequently dividing in such a way that a similar pair of nerve cords is always found in the ventral perisome above the water vessel which trarerses each arm and pinnule. In addition to these, Hamann usually found branches, commonly two, between each two radial water vessels leading outward and ramifying into the skin in every direction as far as the border of the disk and giving off strong nervules which ramify in the connective tissue of the mesenteries, bands, and septa traversing the body cavity, where they are met with everywhere. Derivatives from this circumoral pentagon innervate the epithelium of the madreporic or calicular pores.

From the two ventral nerve cords accompanying the water vessel of the arins and pinnules arise a number of fine branches which run to the musculature of the water vessels and their ramifications in the tentacles, and a branch which runs along the connective tissue of each tentacle to its tip. The sense papillæ of the tentacles are innervated by branches from this ventral nervous system, the fibrillæ from the epithelial nerve plexus being only of secondary importance.

Throughout the length of the arms and pinnules an intimate connection is maintained between this system of paired ventral cords and the axial cord of the dorsal portion, the latter sending out in the middle of each brachial at the point of origin of the pinnule nerve and opposite it connectives which unite it alternately with the right and left cords of the ventral system; the length of these connectives in Antedon mediterranea is $0.82 \mathrm{~mm}$; furthermore, the peripheral branches of the two systems are in union with each other.

These nerres and their branches are all compact and solid in their structure, like those of the dorsal nervous system. Large bipolar and multipolar ganglion cells resembling those of the dorsal nervous system occur, for the most part lying peripherally, with some scattered through the fibrillar mass, especially along the two main branches in the arms.

INNERVATION OF THE TENTACLES.

The epithelium on the side of the tentacles toward the ambulacral groove is greatly thickened, equaling in thickness that of the ambulacral groove itself. According to Hamann, its height in Heliometra glacialis is $0.08 \mathrm{~mm}$. It is composed of epithelial sense cells intermixed with supporting cells.

This epithelium, together with its papillæ, is innervated by a lateral branch from the epithelial nerve of the adjacent ambulacral groove, which can be traced nearly to the tip of the tentacle.

The epithelium on the outer side of the tentacle is innervated by a lateral branch from the adjaccnt longitudinal cord of the ventral nervous system, which may be followed to the tentacle tip.

NEURILEMMA.

In Heliometra and in Antedon the only structure which might possibly be interpreted as a neurilemma is the uncalcified connective tissue layer about the axial nerve cord of the arms in which wandering cells occur here and there in 
large numbers. The branches arising from the axial cord appear never to possess a sheath of any kind.

In Tropiometra carinata (or picta) Hamann found that a very different condition obtains. While in Antedon it is only with certain reservations that we can speak of a connective tissue sheath about the nerve stems, Tropiometra possesses a very thick and dense neurilemma which is best developed about the cirrus nerves and least developed on the periphery of the central organ.

In a cross section of a cirrus nerve the larger part is occupied by the neurilemma, the smaller by the nerre itself, from which alone the nerve branches are seen to arise.

The neurilemma is composed of two different portions; for the most part it is made up of fibers and cells lying very close together in the ground substance. This fibrous part is separated from the nerve fibrillæ by a membranous sheath which incloses the fibrille and extends outward into the fibrous portion as a network. The neurilemma is sometimes sharply differentiated from the ground substance of the ossicles, and sometimes passes directly into it.

About the axial cords of the arms the neurilemma forms only a thin sheath, but it passes directly through these cords as a longitudinal dorsoventral partition.

The nerve branches given off from the axial cords are inclosed in a neurilemma for only a short distance, and their branches are quite unsheathed.

The structure of the neurilemma about the axial cords is the same as that of the neurilemma about the cirrus nerves, but the former is never so highly or perfectly developed as the latter.

It is possible that the extraordinary toughness of the species of this genus, as contrasted with the brittleness of the species of the Antedonidre, and the consequent relative infrequency of regeneration processes, may in part account for the presence of a strongly developed neurilemma, or rather that the necessity for frequent reparation of lost parts in Antedon and Heliometra may have resulted in the reduction of the neurilemma in those forms. The great reduction in size of the chambered organ in Tropiometra as compared with Heliometra may possibly be correlated with the high state of development of the neurilemma in the former.

EPITHELAL NERVES.

The epithelial nerves are composed of a continuous layer of nerve fibrillæ, which, truly epithelial in position, run between and at right angles to processes from certain of the columnar epithelial cells forming the floor of the ambulacral grooves of the disk, arms, and pinnules, sending out branches to the tentacles and converging with the ambulacra to the mouth, thence passing inward under the epithelium of the esophagus and of the digestive tube and, rapidly diminishing in importance, following the further course of the latter as a very slightly developed fibrillar layer.

No true circumoral ring is formed by this nervous system, for all the fibrillæ converging from the ambulacral grooves maintain their original relative direction so that about the mouth a funnel-shaped nerve sheet is formed, composed of 
parallel fibrillæ passing downward along the sides of the funnel instead of passing concentrically around it.

Wherever, as on the oral pinnules and distal extensions of the arms and pinnules in Heliometra glacialis and other types, on the genital pinnules of certain of the Charitometridx, and on whole arms, and even whole post-radial series in certain of the Comasteridæ, the tentacles and ambulacral epithelium are absent, the epithelial nerves are also absent.

The fibrillæ composing the epithelial nerres are exactly like the fibrillæ of the dorsal and ventral nerrous systems, and may be at once differentiated from the connective tissue elements by their strong refractive power. Scattered among them are multipolar and bipolar ganglion cells of which the cytoplasm is often scarcely perceptible.

The connective tissue lamella described by Ludwig and others between this nerve layer and the epithelium of the ambulacral groores appears to be the processes of the supporting cells.

P. H. Carpenter beliered that the epithelial nerve band was united with a fibrillar plexus from the axial cords which he traced into the connective tissue of the perisome forming the ventral surface of the disk; but at present the opinion is that there is no connection between the epithelial and either division of the inesodermal nervous systems.

The epithelial nerres appear to be identical in all the comatulids which up to the present have been studied.

PHYSIOLOGY OF THF CRINOIDAL dERVOUS SYSTEM.

In order to determine the functions of the different portions of the nerrous system of the comatulids a considerable amount of experimental work has been done by W. B. Carpenter, Perrier, Jickeli, and A. Milnes Marshall, especially by the first and last.

The results of this work have been thus summarized by Professor Marshall:

All parts of the surface of the animal are sensitive, but in very unequal degrees. Irritation of the dorsal surface of the calyx causes only slight morements of the arms, unless the irritation is severe or prolonged. Irritation of the dorsal or lateral surfaces of the arms, where the integument is very thin, causes flexion of the arms, with extension of the pinnules close to the irritated spot. The response is usually prompt, but the movement is only slight. Prolonged or more violent irritation causes exaggeration of the morement, together with approximation of the adjacent arms toward the irritated arm as though to remove the source of irritation, and in some cases active movement of the whole animal in a direction away from the irritated arm.

Irritation of the ventral surface of the disk between the ambulacral grooves causes movements of the arms, but not nearly sucl active morements as when the oral pinnules are touched.

The epithelium of the ambulacral grooves is extraordinarily and exceptionally sensitive, and the response to stimuli is very definite. The slightest irritation 
causes instantaneous movement of the four or five pairs of pinnules immediately adjacent to the irritated spot, the pinnules being folded alongside the ambulacral groove so as to close it in and grasp the needle or other source of irritation. If the stimulus be continued the arm is actively flexed and the adjacent arms applied to it as though to remove the source of irritation. The communication between the sensitive surface of an arm or pinnule and the motor mechanism of all the arms is not effected by the epithelial band, and is not affected by its destruction. Experiments yield identical results in eviscerated and unmutilated individuals. Marshall believes that the epithelial nerves form a special part of the nervous system connected with the ambulacral epithelium and the water vessels.

Irritation of a pinnule causes, according to the degree and duration of the stimulation, movement of the pinnule, movement of the whole arm, approximation of the adjacent arms to the affected one, or active movement of the whole animal away from the source of irritation.

Irritation of the oral pinnules causes immediate and very active flexion of all the arms, resulting in closing them in over the disk.

Irritation of the central organ, whether mechanical or chemical, causes strong flexion of all the arms, which persists as long as the stimulation is continued. Dr. W. B. Carpenter found that sudden and consentaneous flexion of the arms follows irritation of the central organ from the oral surface, while Professor Marshall found that swimming movements quite as often result. The latter believes that the slight difference may be accounted for by the oral pinnules being accidentally irritated in some of the experiments, for if these be clipped off swimming movements of the arms almost invariably follow irritation of the central capsule from above.

Mechanical or chemical stimulation of the axial cord in the stump of an amputated arm causes violent and repeated flexion of all the arms; stimulation applied to other parts of the cut end produce but very little effect. Destruction of the axial cord causes the arm beyond that point to coil spirally and to remain so coiled regardless of the movements of the rest of the arm or of the animal. Stimulation of the distal portion of an arm in which the axial cord has been destroyed causes active movements of the irritated arm as far as the injury, but no movement whatever either of the proximal portion of the injured arm or of any of the other arms. The epithelial nerves under the ambulacral grooves, however, continue to respond to stimuli in a perfectly normal manner. If the axial cord be divided in two places, stimulation between the two wounds causes movements of that part of the arm only.

Thus the axial cord furnishes the sole afferent communication, as well as the sole motor communication, betwcen the arms and the central organ, and between different parts of the same arm. Destruction for some distance of the soft parts of the ventral surface of an arm does not affect, either in eviscerated or in unmutilated individuals, the movements of the animal on either side of the destroyed portion.

The central organ is in direct physiological communication with the muscles of the arms, and experiments yield identical results whether performed on evis- 

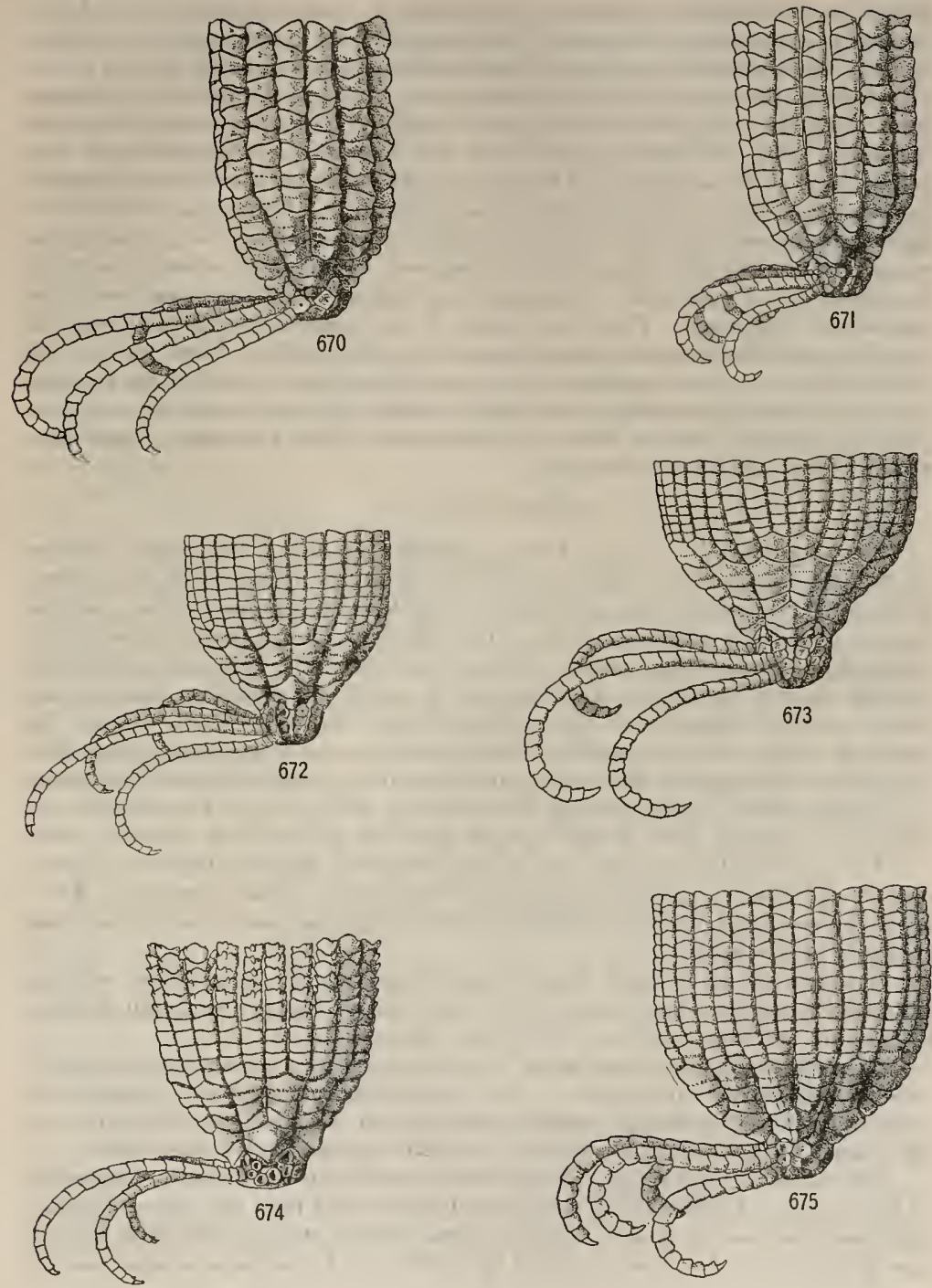

Figs, 670-675.-Proximal portion of various species of Charitometride. 670. Perissometra alaci lenta. 671. PAChylometra levigata, 672. Pachylometra distincta. 673. Crossometra investigatoris. 674. Crinometra imbricata. 675. Crossometra septentrionalis. 
cerated or unmutilated specimens, proving that the epithelial nerve plexus forms no part of the central mechanism. The removal of the central organ completely destroys the coordinating mechanism between the arms as tested by (1) the power of executing the normal swimming movements, and (2) the power of righting itself when inverted, both of these powers being permanently destroyed by the operation. But the central capsule does not form the sole physiological connection between the axial cords of the several arms, for experiments show a physiological connection through the intraradial commissure. Destruction of the pentagonal commissure as well as of the central organ destroys the physiological connection between the arm pairs, but does not disturb the connection between the two arms of each pair. Eviscerated individuals yield the same results as unmutilated specimens. From the results of his experiments Marshall was led to believe that the transverse commissure in the IBr axillary furnishes the real physiological connection between the two arms of each pair, and that the chiasma (the two crossed intraaxillary connectives between the axial cords of each arm pair) is connected with the alternating movements of the two arms of each pair which occur in the act of swimming.

INTERBRACHIAL MTSCLES.

The interbrachial muscles of the comatulids appear on the ventral surface of the arms from the radials outward as yellow or lighter or darker brown bundles of fibers which form, according to their location, narrowly oblong, wedgeshaped, irregularly elliptical, more or less rhombic, or semicircular masses with the longer axis extending, usually more or less diagonally, quite across the arm, and the shorter, parallel to the direction of the fibers, stretching between the narrow ventral extensions of the brachials which form the muscle plates. In species in which, as in the smaller Antedonidæ, the ventral perisome is thin and more or less transparent, the muscle bundles, owing to their relatively dark color, are nsually easily visible through it: in others, as the larger Comasteridæ, in which the perisome is thick and opaque, they are hidden from external view.

The individual fibers are more or less band-like, usually elliptical in cross section, and are arranged in groups with their broader sides in contact. They are easily separated, and the myofibrillar bundles of which each fiber is composed are easily broken apart.

Bosshard found in fresh teased preparations and in longitudinal sections through the ventral arm muscle of Antedon smooth fibers, fibers with distinct longitudinal striping, and fibers with double diagonal striping.

Reichensperger found that, after being subjected to a somewhat complicated staining process, the sarcoplasma of the muscle fiber (the isotropic substance of Bosshard) shows a yellow or reddish coloring, and wound about it spirally are the sharply outlined dark threads of contractile substance, the myofibrillæ.

The course of these spiral threads differs according to the state of contraction of the muscles. If the fiber is very strongly contracted they run almost parallel transversely across the muscle, though a state of such strong contraction is very rare in Antedon and was not observed by Bosshard. In the same muscle mass he 
found smooth longitudinally striped fibers and double diagonal striped fibers mixed. The double diagonal striping he interpreted as a contraction phenomenon, for on arm sections in which the fibers were stretched he found only fibers uniformly longitudinally striped, while on sections of arms very strongly flexed ventrally he found almost exclusively fibers with a strong diagonal striping, those most flexed having the fibers with the closest spirals. In contrast to Bosshard, Reichensperger was never able to find the smooth type of fiber.

Reichensperger states that the anisotropic substance of the fibers (composing the dark lines) forms only a single spiral system; the appearance of a crowded double diagonal striping is due to the striping on both sides of the fiber being visible at the same time. The dark stripes appear to be present only in the outermost layer of the muscle fibers.

A part from the spiral bands the muscle fibers in longitudinal section appear homogeneous, without a cortical layer or similar structure.

In a cross section through a muscle fiber, which gives a circular or more or less elliptical figure, numerous muscle ribs are seen, which appear as more or less elongate wedge-shaped or triangular areas with the smaller ends or apices directed toward the center. The number of these ridges is seldom very high, mostly under 20, and never exceeding 25. They are embedded in sarcoplasma and are separated by moderately large spaces. If the muscle is relaxed the central clear space is moderately extensive; in contraction the form of the individual ribs becomes markedly triangular, and they elongate inward so that the central space becomes small, and in a state of especially strong contraction almost disappears.

The ribs consist of a matrix in which the myofibrillæ lie enbedded, mostly in two, rarely in three rows, in general along the edges, the median portion remaining free.

Bosshard describes the nucleus of the the muscle fiber as situated on the side, externally, and as being long and elliptical, commonly surrounded by a somewhat lighter granular zone over which the sarcolemma, not always easily visible, extends. The sarcolemma is often somewhat raised in the region of the nucleus, while over the remainder of the fiber it clings closely to the contractile substance.

Hamann believes that not one but several nuclei belong to each fiber. $\mathrm{He}$ describes them as elongate-oval in form and as lying at approximately equal intervals on the outer surface. He says that in Ileliometra glacialis these nuclei are very large; in Antedon mediterranea they are slimmer and smaller; in the latter the longest fibers in a state of weak contraction are $0.5 \mathrm{~mm}$., the nuclei being $0.04 \mathrm{~mm}$. in length.

Reichensperger says that the single nucleus occupies a position on the border of the clear central area within the fiber.

On the insertions of the fibers compact plates are developed in which no details can be made out. These adapt themselves to the contour of the meshes in which lie the skeletal parts. From the more intensive staining of these plates and of the adjacent ligamentous portion of the fibers it appears almost as if a special substance was secreted to form the attachment. 

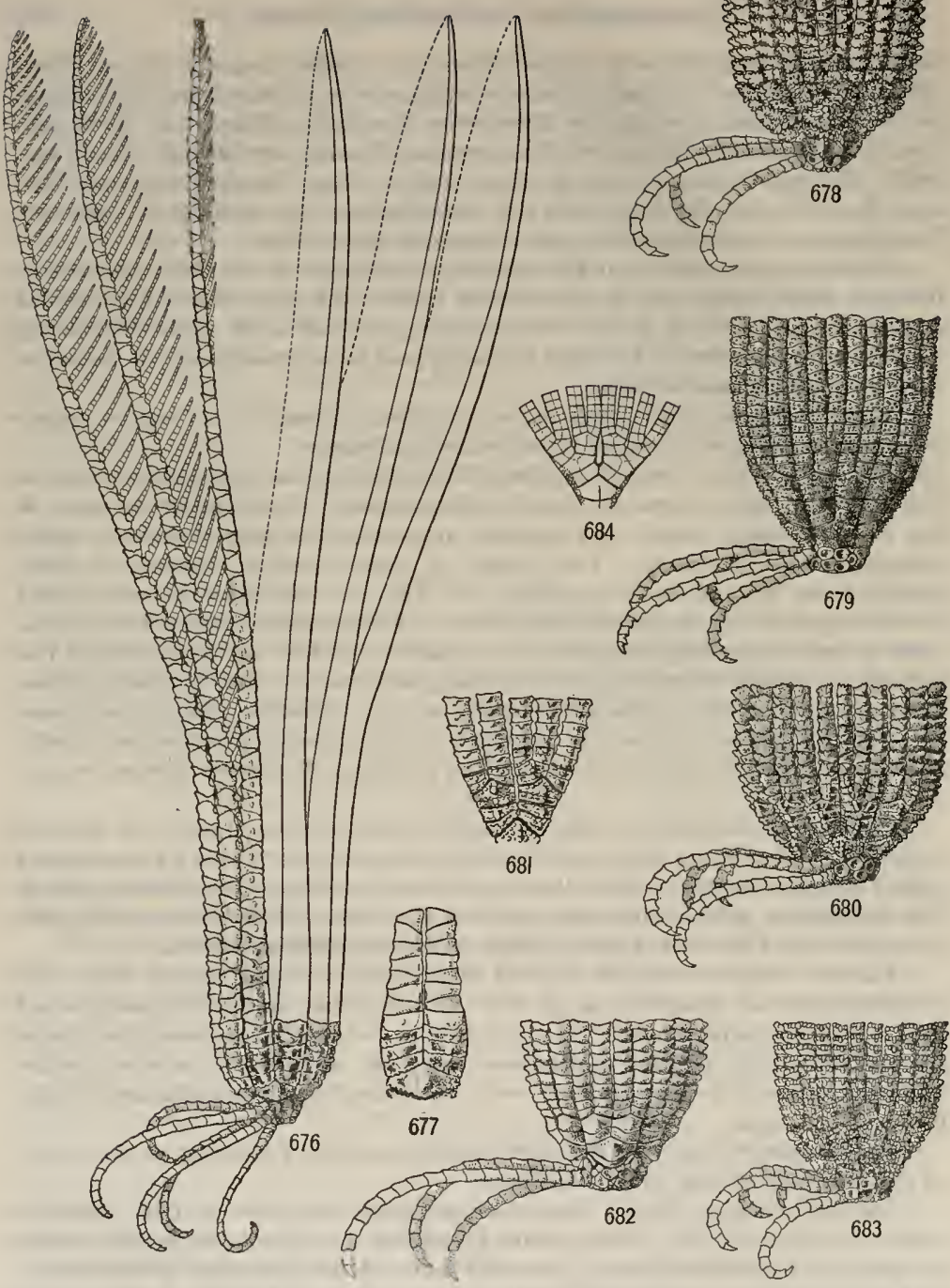

Fios, 676-684.-Ornamentation of various comatulids. 676. Lateral view of Calyptometri lateralis. 67t. Base of arm parr of Caliptometra lateralis. 678. Promial portion of Crisometra CONCINAa, 679. Proximal portion of Crinometra gemMata. 680. Proximal pontion of CriNometra insculpta, 681. Proximal gortion of post-radial series of youno specimen of Crinometra insculpta, 692. Proximal portion of Crinometra pulchra. 683. Proximal portion of Crinometra araroaritacea. 684. Proximal portion of postradial series of Makiametra subcarinata. 
In the ground substance of the skeleton adjacent to the attaching plates of the muscle fibers Reichensperger found peculiar crescentic or semicircular cells with large. deeply staining nuclei, which give off from the two ends complicated ramifying processes running fiber-like in various directions, some of which accompany the muscle fibers for a short distance.

Reichensperger believes that these may be specially differentiated connective tissue elements which aid in strengthening the part to which the muscles are attached. They have nothing to do with the innervation of the musculature, which is accomplished by a ventral branch from the axial cord that in the form of extremely fine twigs penetrates the muscle bundle from the side and runs up on the fibers.

Muscle fibers similar to those just described occur in Isocrinus and in the Comasteridæ.

$$
\text { EPITHELIAL MUSCLES. }
$$

In the walls of all the water vessels very numerous muscle fibers are found, most of which run parallel to the axis of the vessels, a few traversing the lumen. These are connected with the epithelial cells lining the water vascular canals.

The true epithelial cells are cubical; but connected with each of them and running longitudinally along the wall of the canals or across the lumen is a short spindle-shaped muscle fiber, terminally pointed, which in Antedon mediterranea measures from $0.02 \mathrm{~mm}$. to $0.03 \mathrm{~mm}$. in length, but scarcely half of that if strongly contracted.

LIGAMENTS.

The so-called ligaments uniting the pinnulars and cirrals, occupying the interarticular and dorsal ligament fossæ of the muscular articulations, as well as the paired fossæ of the synarthries, binding the syzygial surfaces together, and in the stalked crinoids uniting the columnals, are all of the same nature. In the muscular articulations a differentiation has usually been made betiveen the ligaments occupying the interarticular ligament fossæ and the ligament pit in the dorsal ligament fossa, and those of the rest of the dorsal ligament mass; but this division can not be maintained histologically.

In life the dorsal ligament mass is white and glistening, and the interarticular ligament masses in reflected light are bluish with a marked mother-of-pearl luster.

The interarticular ligament masses are much tougher than the others, and resist the action of caustic longest.

The fibers of the dorsal ligament are almost always bowed outward, away from the axis of the arm.

In the interarticular ligaments the individual fibers are much more slender and noticeably shorter than those in the dorsal ligament. Stout and slender fibers are here intermingled so that a felt-like appearance is produced.

Jickeli was the first to indicate that the so-called ligaments between the cirrals are not of a purely elastic nature. He had noticed that the cirri are capable of active movement. 
Perrier refers to the ligament masses as true muscle, calling them hyaline muscles in contrast to the brown ventral muscles which he designates as refractive muscles.

Hamann and Reichensperger followed Perrier, while Bosshard reverted to the earlier conceptions of $\boldsymbol{J}$. Mïller and the Carpenters, who considered the ligaments as merely elastic tissue.

The detailed structure of the ligaments is most readily understood when taken up in connection with their derelopment. As this has only been worked out in regenerating pinnules and arm tips the discussion of this part of the subject will be reserved for the section on regencration (p. 429).

There is no connection whatever between the fibrillie of the ligaments and the organic base of the skeleton.

The rich innervation of the ligament masses, as well as the difference in staining properties, show conclusively that they are not of a connective tissuc nature. Reichensperger believes that this innerration should be interpreted as showing that the ligament masses, especially of the syzygies, which are composed of ligaments alone, are predetermined foci for autotomy.

Often, especially when the ventral musculature is fully extended, remarkable wave-like figures appear in longitudinal sections through the dorsal ligament mass which distantly resemble the so-called contraction knots in smooth muscle cells. The staining of the knots approaches that of true muscles, while the intermediate regions take the usual stain of the dorsal ligament.

There is a slight difference between the staining properties of the interarticular ligament masses and the fibers in the pit just beneath the center of the transverse ridge in the dorsal ligament fossa, and those of the dorsal ligament bundles and the ligament bundles of the synarthries and syzygies, and in these places the ligament bundles are more closely packed together, but no other difference between the ligaments of these regions can be found.

Microscopically it is seen that the syzygies usually tear apart across the middle of the fibers and seldom in the region of the loops. Apparently as a result of stimulation of the nerves a sudden over-contraction of the fibers occurs, and these part more or less in the center.

Autotomy takes place very quietly, without convulsive movements. Reichensperger doubts that, as has been suggested, autotomy can follow mechanically from a rolling up of the arms.

Autotomy is frequent at the synarthries between the elements of the $\mathrm{IBr}$ series, as well as between the first two brachials.

At muscular articulations it is in the highest degree exceptional. When it occurs the dorsal ligament first tears across, and later the ventral muscles are ripped apart. The broken surface presents a confused mass of ligaments and muscles, and regeneration is somewhat less prompt than after fracture at a syzygy

The ligaments in the Comasteridæ and in Isocrinus are identical with those in Antedon. 


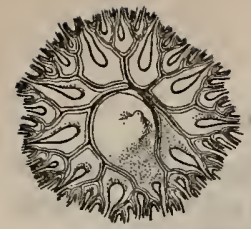

685

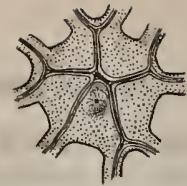

686

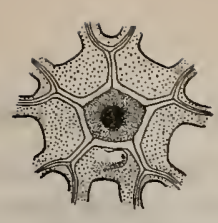

687

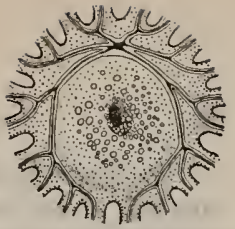

688

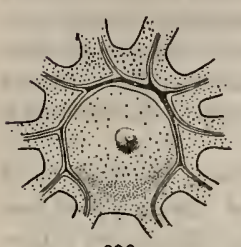

689

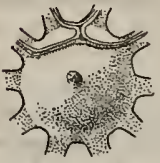

693

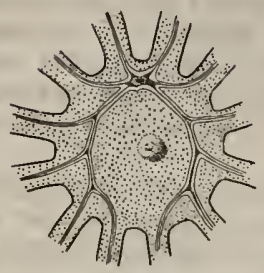

690

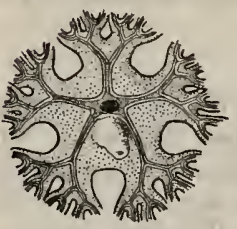

697

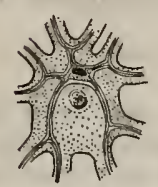

694

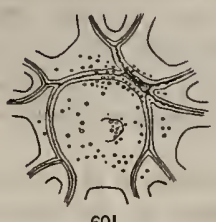

691

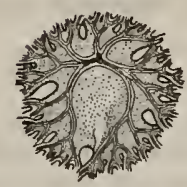

695

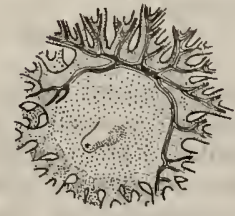

699
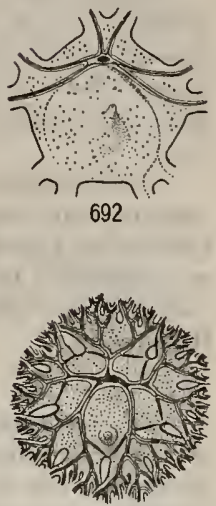

696

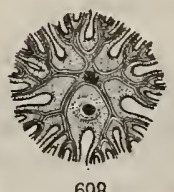

698

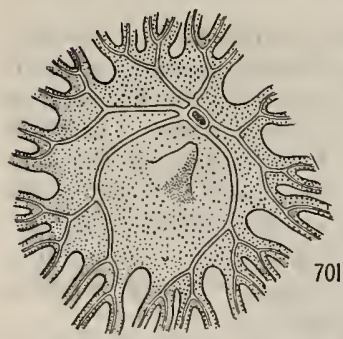

\section{踏}

702

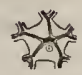

703

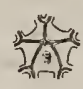

704

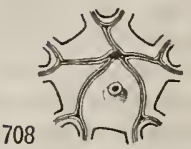

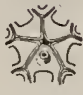

$70 \overline{5}$

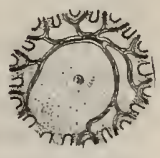

700

Figs, 685-709,-Disks of Various comasterids, 685. Capillaster sentosa. 686. NiNe-ARMED SpECiMEN of Leptonedaster venustus. 687. Comatila iridometriformis. 688. Young individual of Coma. tUla rotalaria, 689, Comatula pectinata, 690, TWelve-armed specimen of Comatula peCtinata. 691. TYPE SPECIMEN OF COMACTINIA ECHINOPTERA. 69:. AXOTHER SPFCIMEN OF COMACTINIA ECHINOP-

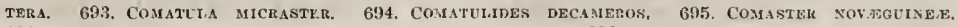
696. Comaster Multibrachiata, 697. Comaster parvus, 698. Comaster serrata, 699, Coman-

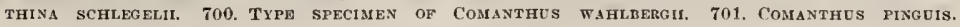
702. YOUNG SPECIMEN OF COMACTINIA MERIDIONALIS WITH ARMS 10 Ma. LONG. 703. YOUNG SPECIMEN of Comactinia meridionalis with arms 12 mis, Long. 704. Young speciaien of Comactinia MERIDIONALIS WITH ARMS 14 MM. LONG. 705. YOUNG SPECIMEN OF COMACTINIA MERIDIONALIS WITH ARMS 17 MM. LONG. 706. YOUNG SPECIMEN OF COMACTINIA MERIDIONALIS WITH ARMS 20 MiM, LONG.

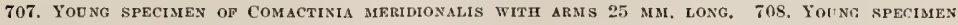
OP COMACTINIA MERIDIONALIS WITH ARMS 30 Ma. LONG. 709. YOUNG SPECIMEN OF COMACTINIA MERIDIONALIS WITH ARMS 4 M MA. LONG. 
The structure of the ligaments in the columnal syzygies in Isocrinus is identicul with that of the brachial syzygies, though here the ligaments are shortened to a minimum and the various elements are more difficult to demonstrate.

In the column of Isocrinus the pear shaped ganglion cells occur in only limited numbers, except at the syzygies. The ligaments of the internodes mostly run through several columnals and are very deeply embedded in the calcareous substance. Between the syzygies the column is very tough, and broken surfaces always show fragments of the adjacent ossicles. Only at the syzygies does a smooth break occur.

Reichensperger comes to the conclusion that the fiber bundles of the dorsal and interarticular ligaments in the muscular articulations, and of the syzygies and synarthries, possess primitive muscular attributes and are to be interpreted rather as a primitive type of muscle than as pure connective tissue. But, as he says, additional investigation, especially along physiological lines, is needed to settle the question.

LigAMENTS IN THE CIRRI.

The movements of the cirri have been mentioned by many observers, and it is clear that the ligaments uniting their segments must be capable of independent movement; but they agree in every respect with those in the dorsal and interarticular ligament bundles of the muscular articulations, and with those in the syzygies and synarthries.

WATER-VASCULAR SYSTEM.

The water-vascular system consists of a ring canal about the mouth, running beneath the ambulacral depression, and vessels radiating from this which run out under each ambulacral groove, following its course onto the arms and pinnules.

Attached to the ring canal is a row of little tubes which open into the body cavity, and which collectively are the equivalent of the so-called stone canal of the other echinoderms.

A madreporite comparable to that of the starfishes was described in Antedon mediterranea by Delle Chiaje, but it turned out to be a convex parasitic worm of the genus Myzostomum. Communication between the body cavity and the exterior is maintained by a variable number of pore canals, or calyx pores. Carpenter notes that the early pentacrinoid larva has but one of these, situated in the same interradius as the fore gut; in the later stages of pentacrinoid life and in the young Antedon just free from the larval column there are five, one in each interradius: while in the adult $A$ ntedon bifida there are about 30 in each interradius. and in Heliometra glacialis the number becomes still larger. Ludwig estimates that there are 1,500 in the ordinary adult Antedon mediterranea.

The calyx pores occur on the oral surface of the disk and on the lateral surface of the arms as far as the second brachial. Except in the immediate neighborhood of the mouth they are less abundant in the anal interradius than elsewhere, and though they sometimes occur on the sides of the disk they never extend far down toward the dorsal side. When the disk is plated the pores may 
be scattered singly in individual plates, or they may be grouped, several to a single plate.

Carpenter has noticed that in the Comasteridæ the calyx pores are generally situated in the immediate neighborhood of the ambulacra, and the greater part of the disk which is occupied by the large anal interradius is almost entirely free from them. They are not necessarily limited to the disk, for they may also be found on the lower parts of the arms and also on the proximal pinnules. In both cases they open near the genital canal. In a ferw cases Carpenter found calyx pores on the middle and later pinnules of the arms; these open into the genital canal of the pinnule, according to Carpenter, close to the point where it arises from that of the arm.

The calyx pores are the external openings of minute canals which are lined with columnar epithelium, and expand almost immediately into ampulla-like enlargements, which traverse the body wall as wider canals of uniform width, leading into the outer chambers of the restricted body cavity. The epithelial lining is composed of closeiy crowded ciliated cells which have deeply stained oval nuclei. These cells are $0.01 \mathrm{~mm}$. high, and bear cilia $0.02 \mathrm{~mm}$. in length, which in Antedon mediterranea entirely fill the lumen of the ampulla-like swelling, the latter being $0.06 \mathrm{~mm}$. in diameter. In life the cilia beat inwardly, according to W. B. Carpenter. At the inner end of the calyx pores the ciliated epithelium passes gradually over into a low flat pavement epithelium, which again transforms into the epithelium lining the body cavity. On the oral side of the disk the inner end of the canal often bends at an obtuse angle, so that the canal does not traverse the body wall perpendicularly. There are no calyx pores on the arms beyond the second brachial. On the arms the pore canals open into the genital canal or into the cavities around it and in communication with it, which are extensions of the body cavity.

The radial vessels of the water-vascular system, which nnderlie the ambulacral grooves of the disk in the comatulids, arise from the angles of the pentagonal dorsoventrally flattened water-vascular ring as single trunks situated beneath the median line of the ambulacra. In addition to these five main radial branches the circumoral water-vascular ring gives off small branches to the oral tentacles.

In Isocrinus decomes and in Endoxocrinus wyvillethomsoni there is a radial extension of the labial plexus of the blood-rascular system in this position, and the two trunks which ultimately unite to form the single water vessel of the ambulacrum are thus kept separate for a considerable distance, $1.5 \mathrm{~mm}$. or more, from the edge of the peristome; that is to say, the circumoral water-vascular ring is markedly stellate, instead of simply pentagonal, as in the comatulids.

Neither the oral ring nor the radial water vessels have any ampullæ connected with them, though, as suggested by Ludwig, these are perhaps represented by the small lateral pouches of the radial vessels which are opposite the tentacular branches and are crossed by muscle threads, while the function of the ampullæ may be also in part performed by the muscle threads which cross the lumen of the water tubes everywhere. 
P. H. Carpenter noted that the presence of tentacular branches from the water vessels is invariably correlated with the presence of an ambulacral groove on the ventral surface of the arms and pinnules. If this remains undeveloped not only are the ambulacral epithelium, nerves, and blood vessels absent, but, since there are no tentacles, the water vessels are simple tubes without lateral extensions.

This condition may occur in a majority of the arms and the corresponding portions of the disk in many of the species of the Comasteridx, in a variable number of the lower pinnules in certain of the Comasteridæ and Charitometridæ, and is found in the proximal pinnules of most comatulid types.

On the other hand, P. H. Carpenter noticed that in Metacrinus the ambulacral grooves, and with them the water vessels of the large basal pinnules, may arise directly from the primary ambulacra of the disk, or even from the peristome itself.

In a cross section of an arm one sees in the floor of the ambulacral groove the high epithelium of thread-like cells, between the basal processes of which run the epithelial nerve fibrillæ; beneath this epithelium with its nerve fibrillar layer lies a thin connective tissue layer in which a schizocole cavity can be made out: and just below this lies the water ressel, giving off at intervals to right and left smaller vessels to the tentacles. The water vessel often lies so closely to the schizocnele cavity in the connective tissue layer just above it that the partition separating them appears merely as a thin membrane of firm consistency. The water vessel and the overlying structures maintain the same relationships on the disk.

The water vessels are lined with a low epithelium composed of cubical cells. Each cell of the external layer under the epithelial ncrve is prolonged into a muscle fiber which runs parallel to the axis of the vessel, and is therefore an epithelial muscle cell.

These epithelial muscle cells have been found by Hamann in Comatula rotalaria, Comanthus parvicirra, Tropiometra picta, Antedon mediterranea, and Isocrinus decorus. In Antedon mediterranea the height of these cells is $0.003 \mathrm{~mm}$., in the tentacles $0.004 \mathrm{~mm}$. They bear no cilia.

An exceedingly fine membrane ensheathes the water ressels.

The humen of all the water vessels is traversed by muscle fibers, and there are also longitudinal muscle fibers attached to the epithelial cells.

The canals which open into the chambers of the body cavity from the circumoral canal are in Antedon mediterranca $0.002 \mathrm{~mm}$. in diameter. They are circular in cross section and are composed of three layers, a layer of ciliated epithelium lining the inner cavity, a thinner connective tissue layer, and an external epithelium, which at the openings passes over into the ciliated epithelium. The inner layer is composed of cells the nuclei of which are elongated oval in form; they possess so little cytoplasm that in a section the layer appears as a ciosely crowded layer of nuclei. The length of these canals in Antedon mediterraneu is $0.2 \mathrm{~mm}$.

At their free ends these canals are almost always bent; their mouths are funnelshaped, and the same in Tropiometra picta as in Antedon mediterranea. The cilia are always very finely preserved. The thin connective tissue layer in their walls shows no trace of calcification. 
Carpenter notes that in a large comatnlid like Heliometra glacialis these canals may be found depending from the bases of the radial ressels beneath the middle line of the ambulacrum in the first two or three sections beyond the edge of the peristome.

In Isocrinus and Endoxocrinus the middle line of the ambulacrum near the peristome is occupied by the blood vascular plexus, which has a water vessel on either side of it, and the water tubes extend outward in a radial direction as long as the water vessels remain double. They may extend for a distance of more than $3.5 \mathrm{~mm}$. from the peristome. They coil around, as it were, the subambulacral plates to open below into the upper part of the circumvisceral cœlome. When, however, the radial extensions of the labial plexus gradually thin out and the two lateral water vessels unite into a single median trunk, the water tubes become less numerous and are only found in the first two or three sections beyond the point of union. They are thus really in the same position as in the comatulids, if we consider the double water vessels as expressing extensions of the water vascular ring in the direction of the rays.

BLOOD-YASCTLAR SYSTEM.

The blood-vascular system of the crinoids is very highly developed, though the blood vessels themselves are nothing more than intercommunicating cavities or gaps in the connective tissue of the mesenteries, bands, and cords, which in all directions traverse the body cavity. Since the individual bands and cords have for the most part a small diameter, while the cavities in their connective tissue in which the blood circulates may be extraordinarily expanded, the former are sometimes reduced to the condition of a thin sheath inclosing the blood lacunæ.

On a series of horizontal sections through the calyx a more or less regular column of recurring lacunæ may be made out. In Antedon mediterranea above the approximate middle of the calyx there appear large lacunæ, $0.1 \mathrm{~mm}$. in diameter, which are concentrically arranged abont the axial organ, between this and the outer coil of the digestive tube. In the upper part of the calyx there are equal sized lacunæ, concentrically arranged, which give off large branches irregularly on all sides. Surrounding the esophagus there lies a mass of very small lacunæ.

The lacunæ of the bands and cords of the body cavity are in communication with others in the wall of the digestive tube. The bands and cords themselves pass over into the wall of the intestine, their connective tissue layer as well as their epithelial investment merging into that of the gut wall.

The lacunæ of the body cavity are not continued into the arms. The so-called radial vessels in the arms, according to. Hamann, are not blood lacunæ and are not connected with the blood lacunar system.

A connection between the blood lacunæ and the axial (glandular) organ is present in that the connective tissue wall of the latter is continued into the cords and bands in which the blood circulates.

All these blood lacunæ have the same structure. A section through a mesentery containing a bloor ressel shows externally the cœlomic epithelim which 


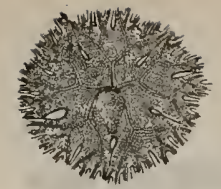

710

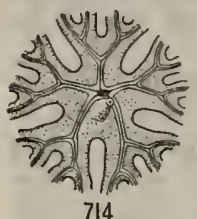

714

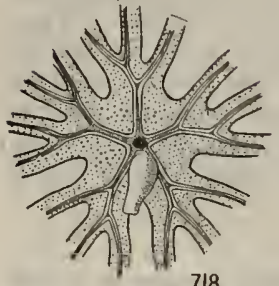

718

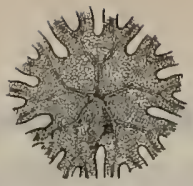

711

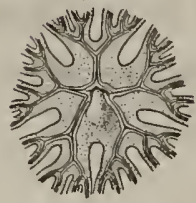

715

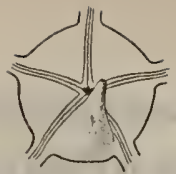

712

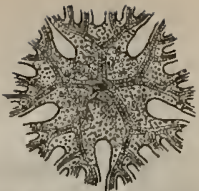

713

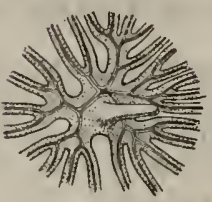

716

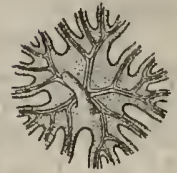

717

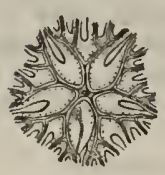

719

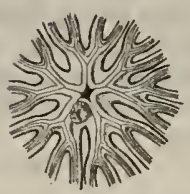

720

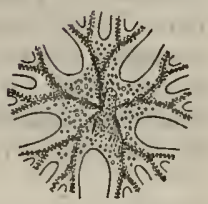

721

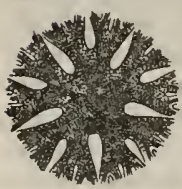

722

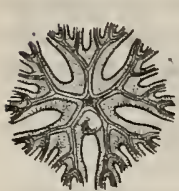

726

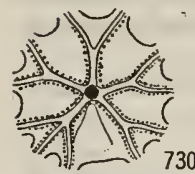

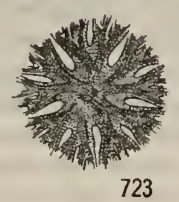

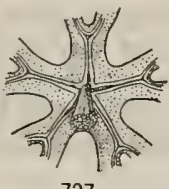

727

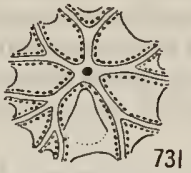

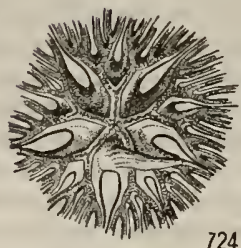

724
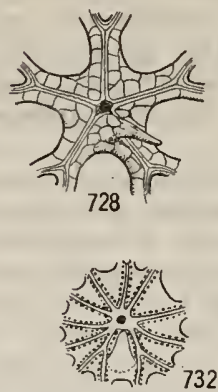

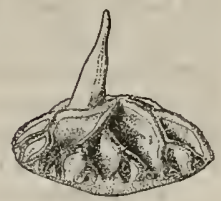

725

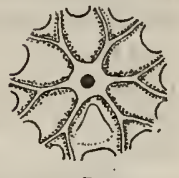

729

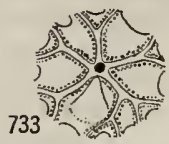

Figs. 710-733.-Disks of vahious comatulios. 710. ZYgometra meEgans, 711, Zrgometha Comata.

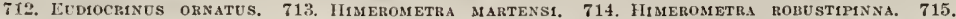

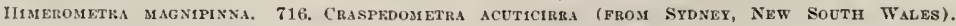

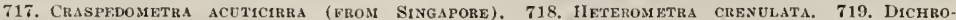
Metra flagkllata. 720. Lamprometra plotectes. 721. Marimetra MargarifFeka. 722. Mariametra sebcarinata. 723. Same. 724. Pontiometra andersoni. 725. Saje, detached, lateral view. 726. Stephanometra monacantha. 727. Colobometra vepretum. 728. Colobometra dadema. 729.

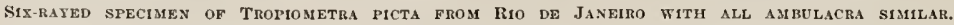
730. SAME, WITH ADDITIONAL RAY INSERTED BEHIND LEFT POSTEMOR. 731. SAME. 732. SAME, WITH B1LATERALLY SYMMETRICAL DiSK. 733. SAME, W1TH ADDITIONAL RAY INSERTED BEHIND RighT POSTERIOR, 
incloses all the organs in the body cavity, and within this a connective tissue layer of variable thickness in which cells with fibers may appear. There is no true endothelium. Though in Heliometra glacialis the connective tissue cells bordering the humen may be fiattened here and there, such cells never form the entire lining.

The contents of the blood ressels consist of a finely granulated coagulable fluid which rarely shows cells. It is difficult to demonstrate the existence of this fluid in the connective tissue layer of the digestive tube, since the latter is always but very slightly dereloped.

Sea water has access to the various subdivisions of the body cavity through the calyx pores, but is entirely exchnded from the blood-vascular system; the latter has no connection whatever with the water-vascular system.

The blood-vascular system of Ileliometra, Isocrinus. and such species of the Comasteridæ as have been studied is exactly like that of Antedon.

LABIAL PLEXUS AND SPONGY ORGAY.

P. H. Carpenter termed that part of the blood vascular system, composed of very small lacunæ, which lies about the esophagus the labial plexus. Vogt and Perrier described this labial plexus as spongy tissue with branched vessels.

In Promachocrinus kerguelensis, Heliometra glacialis, and Solanometra antarctica Carpenter found that a portion of the labial plexus between the mouth and the anal tube differs very considerably in structure from the rest of this organ. The limits of this portion appeared so well defined, and it differed so much from the remainder of the labial plexus, that Carpenter proposed to designate it by the name of spongy organ. As described by Carpenter, the spongy organ lies between the mouth and anus on the left or "eastern" side of the esophagus and therefore is slightly nearer to the left posterior than to the right posterior ambulacrum. In its most fully developed condition, only found between the month and anus, the spongy organ is a somewhat egg-shaped mass, consisting almost entirely of a delicate network of connective tissue with more or less open meshes. The latter are rather wider in Promachocrinus than in any other crinoid which Carpenter examined. The trabeculæ forming its outer portion are much more delicate than those nearer the surface, and Carpenter was unable to find that they possessed any epithelial covering. The surface of the organ is more compact, with larger trabeculæ and generaly smaller meshes which are lined with epithelial cells, being, in fact, the ends of those blood vessels forming the labial plexus which are connected with the spongy organ mostly, if not entirely, on its ventral side.

Carpenter notes that the spongy organ of Heliometra glacialis is more compact than that of Promachocrinus, but is similarly situated in the space left by the incomplete adhesion of the risceral and parietal layers of the peritoneum, being suspended in this space by threads of connective tissue. It is practically the direct backward continuation of the labial plexus at the eastern angle of the mouth, where it is much more largely developed than on the opposite side. The relatively thick epithelial walls of the vessels gradually disappear as they enter the spongy organ, while the latter in turn passes insensibly backwards into the plexus of 
ressels in the upper surface of the visceral mass from which are derived both the intervisceral vessels and the genital vessels of the two posterior ambulacra.

Hamann considers the differentiation of the labial plexus and the spongy organ from the remaining portions of the blood vascular system impracticable and unnecessary.

$$
\text { SCHizocale CaVitiEs. }
$$

In the crinoids beneath the ambulacral groove of the arms and pinnules and just below the epithelial nerves there runs a slitlike canal which may, though very rarely, be made out as traversing the disk and forming a ring around the mouth.

In Antedon mediterranea Hamann found that this schizocœle canal runs out into the arms as a constant structure. It may be closed here and there through the contraction of the musculature of the water vessels in the ambulacral groove, for just as soon as the water ressels become narrowed through the action of the transverse muscle fibers the schizocœle canal vanishes. When the water vessels are thus contracted the epithelium of the ambulacral grooves is not so much arched as normally, forming instead, as seen in cross section, a straight line. The schizocœle canal may also be closed by the movements of the arms.

In Antedon mediterranea the longitudinal schizocole canal of the arms appears in cross section as an oral cavity of small size, $0.04 \mathrm{~mm}$. to $0.09 \mathrm{~mm}$. in diameter according to Reichensperger, and on well-preserved sections of the pinnules as well as of the arms it can regularly be made out.

In Heliometra glacialis it has a diameter of $0.1 \mathrm{~mm}$. It is slitlike to circular in cross section, according to the state of contraction of the musculature of the water vessels.

In large species like the latter the schizocole canal, according to Hamann, shows an endothelium of flattened cells $0.01 \mathrm{~mm}$. in height, the nuclei of which project into the lumen, making it evident that the cavity can not be an accidental gap in the connective tissue layer beneath the epithelial nerve, but must be instead a true and permanent carity.

Reichensperger, however, was unable to convince himself of the existence of the lining of flattened cells described by Hamann.

P. H. Carpenter notes that the schizocœle canals are large in Heliometra glacialis and in Comatella nigra. In the latter they are sometimes triangular in section with the apex pointing downward, so as to be received into a strongly marked concavity in the upper edge of the water vessel; but in Heliometra glacialis and in most other types their section is more or less lenticular, though sometimes triangular with the apex projecting upward toward the epithelial layer above, and so rendering the ambulacral nerve thinner in the middle line than in its more lateral portions. He further remarks that the cellular lining of these radial canals is much more delicate than that of the intervisceral blood ressels and is not ensy to make out.

Ludwig found that the schizocœle canals in the arms of Heliometra glacialis are sometimes divided into two parts by a vertical septum which has a distinctly cellular covering. 

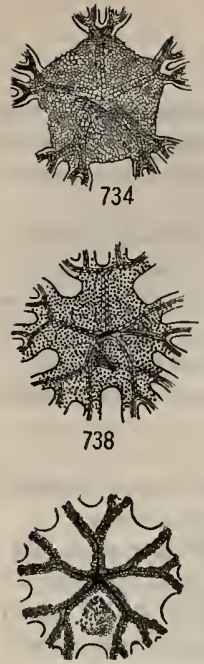

742

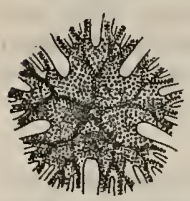

746
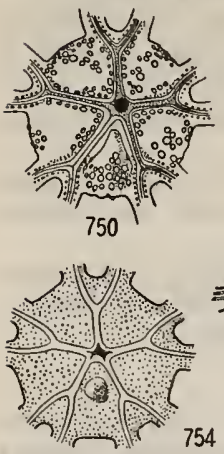
754
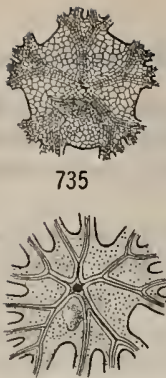

739
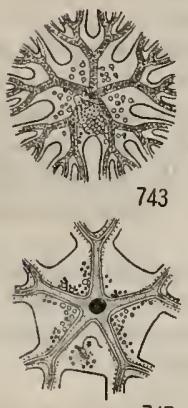

747

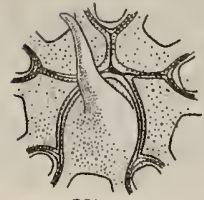

751

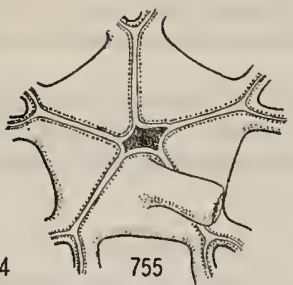

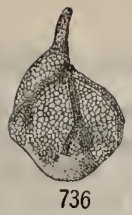

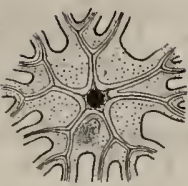

740

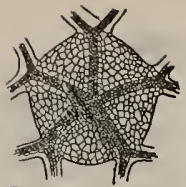

737

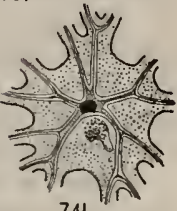

741
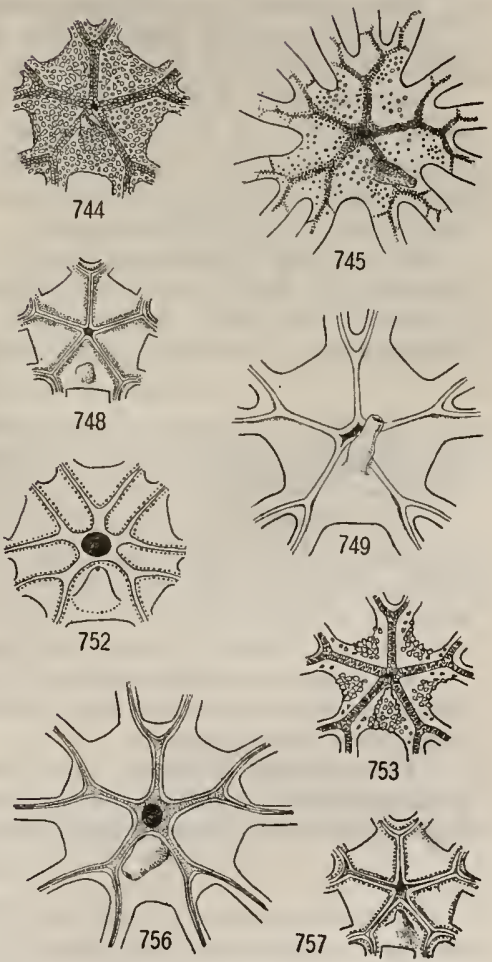

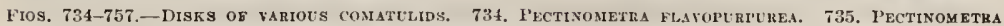

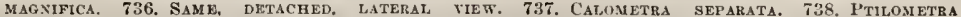
MElLLERI, WELL PLATED. 739. SAME, UNTLATED, 740. SAME. 741. SA KE, WITH FEW FLATES ON BASE OF AXAL TUBE. 742. SAME, WITH PLATES ON ANAL TUBE A.T ALONG AMBVIACRA. T43. STYLOMETRA spinifera. 744. Daidalometra arachnoides. 745. Paramptra orion. 746. Crinometra margaRITACEA. 747. ANTEDON PETASUs. 748. ANTEDON BIFIDA. 749. HATHROMETRA TENella. 750. MasTIGOMETRA FLAGELLIFERA. 751. JOROMETRA NANA. 752. THYSANOMFTrA TENELLOIDES. 753. ERYTHRO-

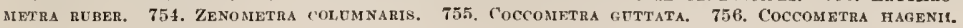
757. AXTEDON ADRIATICA. 
Carpenter not infrequently found in the disk of the same species that the lumen of the canal may be crossed in various directions by delicate threads, with nuclei in them, which resemble the nucleated muscle threads in the water vessels, but are much finer and less refractile.

Hamann believes that the canal in which the genital tube lies may possibly be a schizocœle canal. It is lined with a flattened endothelium, the cells of which in size and appearance resemble connective tissue cells. This endothelium is only feebly developed and may be partially deficient. In any case, the cells are to be differentiated markedly from the cells which line the canals of the arms.

Ludwig and P. H. Carpenter considered the schizocoele canals of the arms the radial canals of the blood-vasculir system.

Perrier denied their existence altogether.

Hamann says that these cavities are not connected with the blood lacunar system, and are usually filled with a clear fluid like that of the body cavity.

Reichensperger at first considered the schizocœle canals as blood vessels, following Ludwig and P. H. Carpenter. Later he admitted that the contents of these cavities indicate that they undoubtedly perform the functions of blood lacunæ, since no other cavities of the arms contain so many lymph cells, which are inclosed in typical blood channels.

He now considers that, although on account of their origin and form, and on account of the absence of a uniform endothelium, they can not be considered as normal blood vessels, the schizocoele canals are in reality blood vessels derived through what are primarily schizocele structures.

CILIATED EPITHELIUM OF THI aMBULACRAL gROOVES.

The ciliated epithelium of the ambulacral grooves is composed of two kinds of cells, epithelial sense cells, and supporting cells, the former in the majority. Both types bear cilia which are attached to the slender cell body by foot pieces.

The epithelial sense cells are fine and almost hairlike. The spindle-shaped cell body, inclosing an elongate-oval nucleus which shows a distinct network, is produced outward into a fine process of variable length on which a cilium stands; inwardly it is produced into a fine extension, sometimes swollen here and there, which may be followed into the nerve layer.

The supporting cells, possessing also elongate-oval nuclei which appear to stain less deeply than those of the sense cells, are produced interiorly into stout hyaline, strongly refractile processes.

The epithelium lining the depression about the mouth opening is a continuation of the epithelium of the ambulacral grooves and is composed of the same elements. Near the ends of the arms and pinnules this epithelium disappears.

CILIATED SACKS.

Under the name of ciliated sacks Ludwig described in the dorsal wall of the extension of the body cavity into the pinnules sacklike invaginations grouped in each pinnule segment which are lined with ciliated epithelium.

Hamann studied these structures in detail in Comatula solaris, Comanthus parvicirra, Antedon mediterranea, Heliometra glacialis, and Isocrinus decomus. 
In sagittal sections of the extension of the body cavity into the pinnules the circular openings of these sacks are visible, surrounded by a swollen border. Sometimes these openings are large, sometimes contracted; in the latter case the organ has a spherical appearance.

In Heliometra glacialis a structureless membrane separates the sacks from the surrounding connective tissue. The epithelium lining the organ consists of high cells which become flattened at the bottom of the sack and do not bear cilia. In the upper part and about the opening the epithelium is greatly thickened, the cells becoming more or less filiform with the oval nuclei, which lie in a swollen area, sometimes nearer the base, sometimes nearer the summit. The long cilia are attached to the cells by short foot pieces.

In Comanthus parvicirra Hamann found these organs mostly in the form of closed sacks, $0.05 \mathrm{~mm}$. long and $0.04 \mathrm{~mm}$. broad. Their structure was essentially the same as in Heliometra glacialis, but at the bottom there were lower cells and on the sides and about the opening longer ciliated cells.

In Isocrinus decorus they also form closed sacks.

In Antedon mediterranea they occur in large numbers. They have the same structure as in Heliometra glacialis, but the ciliated cells run deeper into the cavity, which beyond them is lined with cubical cells without cilia.

These organs Hamann found to be best developed in Comatula solaris. In this species they lie closely massed in rows so that on a cross section through a pinnule eight or more are cut through.

The ciliated sacks serve to impart motion to the fluid of the body cavity.

A MBULACHAL MUCUS CELLS.

In 1902 K. C. Schneider first described in Antedon mucus-producing cells, which he found scattered between the supporting and sense cells of the ambulacral epithelium.

These were subsequently studied by Reichensperger, who found them everywhere present in the ambulacral grooves of the disk, as well as in those of the arms and pinnules, not only of Antedon mediterranea but of Isocrinus and of such of the Comasteridæ as he examined as well.

SACCULI,

Figs. 1317-1321, pl. 46.

The sacculi are small, spherical bodies, easily visible under a hand lens. ranged in an evenly spaced continuous row along either side of the ambulacral grooves of the disk, arms, and pinnules. In the genus Antedon, and probably also in other types, they occur in the walls of the digestive tube. P. H. Carpenter found them in the lowest part of the cup of a larva with five cirrus stumps, just above the chambered organ; but in other species he notes that they are either entirely absent, or are invariably limited to the immediate neighborhood of the water ressels.

In life the sacculi are colorless, but in preserred specimens they are, as a rule, conspicuous as blackish, dark red, greenish, purplish, or yellow dots. 
Carpenter has noted that in those species in which the ambulacra are plated the sacculi are lodged between the successive side plates, the anterior edges of which are notched for their reception, while they occupy small pits in the large plates which cover the genital pinnules.

In general, it may be said that sacculi are more abundant in slallow than in deep water species, and they are of more uniform occurrence in the Macrophreata than in the Oligophreata. They appenr to be absent from the species of the family Comastericlæ, excepting only Comatonia cristatc.

Bury thus describes the structure of the sacculi. Each sacculus is a spherical body bounded by a thin membrane in which are embedded a few flattened nuclei. The interior of the splere is more or less filled with a number of pyriform sacks, each of which is, in its turn, filled with highly refractive spherules and is bounded by a membrane continued at its inner end into a long thread which joins the wall of the sacculus.

The refractive spherules have, at any rate in some cases, a definite arrangement around a central carity. The spherules, which are spherical when isolated, are evidently much compressed within the sacks.

The greater part of the sacculus is enbedded in the tissues, but at one point its cavity is only separated from the exterior by its limiting membrane, which here does not exhibit any nuclei.

During life the sacculus has a swollen appearance, and its free margin frequently bulges out toward the exterior; this is due to the presence of a quantity of mucus between the pyriform sacks and the wall of the sacculus and, if a living pinnule be placed on a slide with a drop of water, this water becomes charged with mucus, thongh whether this is due to a continuous secretion or to injury Bury was unable to say. But any rough treatment of the pinnule leads to the escape not only of increased quantities of mucus but also of many of the spherule-bearing sacks. In spite of this it is rare to find in sections a sacculus freely open to the exterior, and therefore Bury supposes that there is some means of rapidly mending the ruptured membrane.

According to Reichensperger's observations the matter extruded by the rupture of the sacculi in the living animal consists exclusively of granules in clusters which, as noted by Perrier, much resemble the egg clusters. There is no mucus associated with them at any time--a fact which is made clear by the entire absence of a reaction to mucus stains.

The sacculi of the disk, arms, and pinnules discharge their contents freely into the surrounding medium; those which lie in the wall of the gut, especially at the posterior end, for the most part discharge into the gut: After the periodical rupture of the wall of the sacculus and the sudden extrusion of the granular contents the healing of the wound resembles the healing of the orifice in the pinnule wall throngh which the eggs are extruded. In most cases in the normal Antedon after the discharge of the contents the capsule of the sacculus quickly shrivels, apparently under pressure from the surrounding tissues and from the immediate regeneration of the torn epithelium. Reichensperger was unable to find out what becomes of the remains of the capsule. In the place of the spent sacculus, or in the immediate 
proximity. mesenchyme cells become prominent, and the formation of a new sacculus is begun.

The first sacculi, five in number, appear in the Antedon larva shortly before the breaking through of the vestibulum.
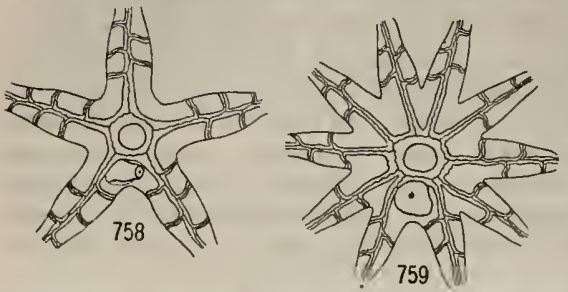
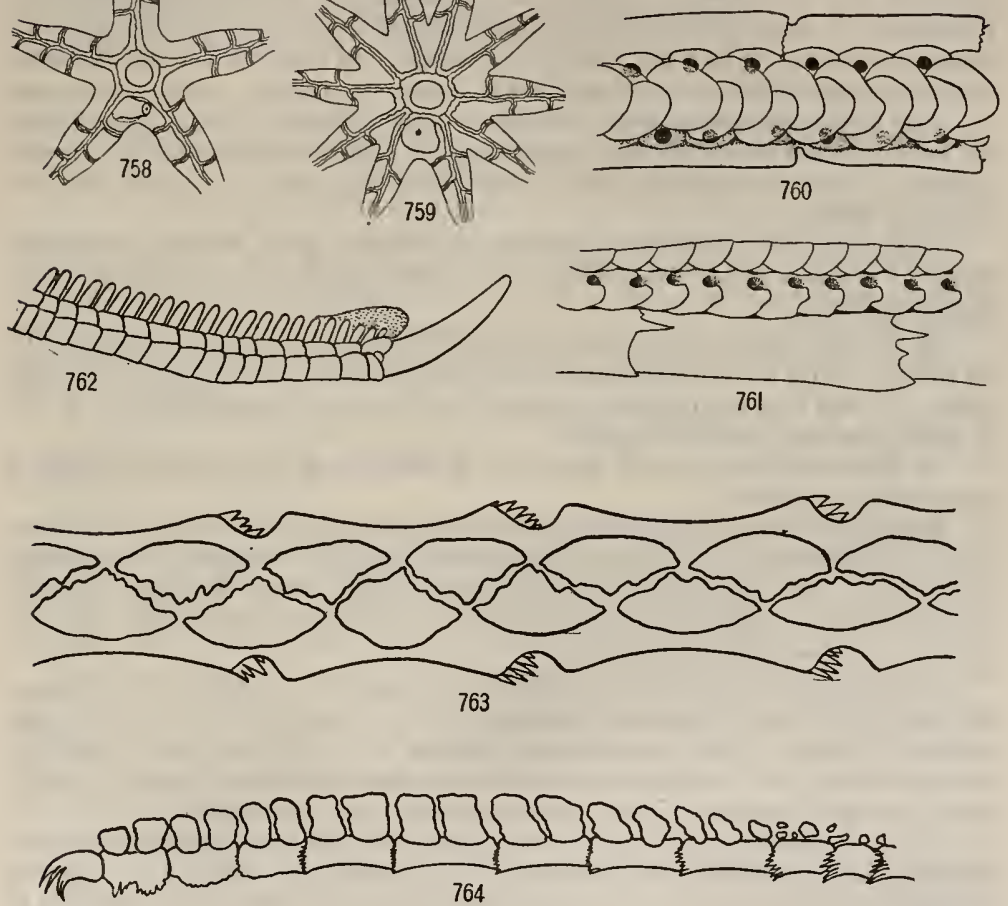

Figs, 758-764,-758. Disk of Pentametrocrinus varians. 759. Disk of 'Thaumatometra horealis. 760. Ventral view of portion of PINNUle of PhBissometba selene, showino coverino flates CLOSED DOWN OVER AMBULACRAL GROOVE. 761. LATERAL VIEW OF PORTION OF DRIED PINNULE OF NEOMETRA SPINOSISSIMA, SHOWINo COVERINo PLATES CLOSED DOWN OVER AMBULACRAL GROOYE. 762. TOE OF OROUSE (BONASA UMBELLATA), SHOWINO SCUTES DEVELOPED IN WINTER WHICH ARE SIMILAR TO Coverino plates (DRAWING by aUthor). 763. Ventral VIET OF PORTION OF DRIED PINNULE OF CONATILIA IRIDOMIETRIFORMIS, SHOWING COVERING PLATES (DRAWINO BY AUTHOR). 764. LATERAL VIEW

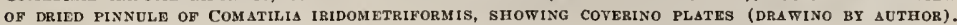

In describing the formation of a sacculus Reichensperger says that a limited number of mesenchyme cells assemble, usually forming a small spherical cell mass. These cells possess a circular nucleus with prominent nuclear bodies. The small 
sphere which they form eularges through the growth of the cells in such a way that a free space remains in the interior. By its growth the saceulus is shoved near the periphery and often eauses a small external swelling. Reichensperger did not observe at this stage any special epithelium as described by Seeliger.

With the enlargement of the sphere the nuclei become more indistinct and a nuclear body is no longer recognizable. At the same time fine vesicles appear. The cells have now become enlarged and elongated, so that they are somewhat tongue-like in shape, with the broad bases crowded together and the more slender distal ends projecting into the lumen of the sphere. In these slender and elongated portions of the cells the larger granules are found, and further increase in number.

At a later stage certain cells everywhere on the periphery, chiefly lying toward the outer side, are seen to produce no granules, but to become narrower and laterally broader. These close together into a thin broad ring about the larger cells, encapsuling them.

At the time of the commencement of the building of the terminal thread the nuclei of the cells is moderately large, and in the cytoplasm can be differentiated thread-like cords.

In the fully developed sacculus the granules appear as if packed together and lie clearly within the cell membrane, which is produced into a thread-like twisted point. At first they are regularly spherical, but they later become flattened on two or more sides and somewhat angled.

At different developmental stages the granules show the widest variation in their reaction to stains.

Speaking of the variability in the number of sacculi in different species Reichensperger says that in an apparently undescribed species of "Antedon" the saceuli occupy by far the largest place in sections of the arms. They lie closely together, separated only by a thin connective tissue layer, and are of considerable size, displacing the other organs of the arm.

Reichensperger is undecided whether the vacuolar cell eomplex which Hamann first described in the Comasteridæ represents in that family the sacculi of the other comatulid groups. Their corresponding position in the disk and in the arms appears to indicate it. In many sections also it appears as if they opened to the exterior through the rupture of their wall in the same way as the sacculi.

P. H. Carpenter says that in some species of the Comasteridæ individual vesicular bodies resembling the elements of the sacculi are scattered through the ventral perisome, but they are not regularly arranged in groups along the sides of the ambulacra.

No less than 11 more or less widely different functions lave been ascribed to the sacculi. In chronological order they have been considered as-

(1) Excretory organs, secreting a reddish fluid, especially at the period of sexual maturity (Dujardin and Heusinger).

(2) Ovaries (Forbes).

(3) Excretory organs (Perrier, Ludwig, Chadwick, and Reichensperger in his more recent contributions). 
(4) Calcareous glands (Wyville Thomson).

(5) Sense organs (W. B. Carpenter).

(6) Symbiotic algæ; Zoöxanthellæ (Vogt and Y'ung).

(7) Slime glands (Bury).

(8) Glands producing an amorphous secretion (Hamann).

(9) Stores of reserve material (Cuénot).

(10) Cement glands (Seeliger).

(11) Defence organs (Reichensperger in his earlier work).

At the present time they are interpreted as excretory organs.

TENTACLE PAPJLL.

The tentacle papillæ consist of four or five elongated epithelial cells, with the nuclei in the basal portion, each terminating in a fine sense hair.

At the base of each papilla lie usually five, exceptionally six. irregularly pearshaped single-celled glands, in which a nucleus is usually visible, the extremely fine ducts of which, shightly broadened at the mouth, run out longitudinally between the processes of the elongated epithelial cells. According to Reichensperger, these gland cells measure in Antedon mediterranea $0.006 \mathrm{~mm}$. to $0.008 \mathrm{~mm}$. by 0.002 $\mathrm{mm}$. to $0.003 \mathrm{~mm}$.; the lehgth of the ducts varies according to the state of contraction of the papillæ.

Longitudinally through the center of each papilla there runs an axial muscle fiber bearing a prominent nucleus, which is produced inwardly into the epithelial muscle layer of the tentacle.

Though the relative size varies, the structure of the tentacle papillæ is the same in Isocrinus and in the Comasteridæ as in Antedon, and in these types also five is the usual number of gland cells present about their bases.

The structure of the tentacle papillæ has been interpreted in a number of different ways, giving rise to a considerable amount of controversy.

Wyville Thomson described them as hollow, their lumen in communication with that of the tentacle. He noticed that they are arranged in three or four irregular longitudinal rows on each tentacke, and that they are extensible, when extended appearing uniform and structureless, when contracted showing three or four annular groores.

Perrier denied the existence of a median cavity in the papillæ in connection with that of the tentacles, and described in its place a glistening muscle fiber which is produced into the second layer of the tentacle wall. On eacl of the three terminal lappets he noticed an extremely fine, stiff hair, which he said disappeared after death.

Ludwig described the wall of the papillæ as uniform and structureless. Denying the presence of a central muscle fiber, he considered that the median axis was occupied by a longitudinal canal, which broadens out in the epithelial layer of the tentacle into a spherical cavity which is entirely cut off from the lumen of the tentacle. He comments upon the extraordinary extensibility of the papillæ, which in IIeliometra glacialis measure when extended $0.063 \mathrm{~mm}$. in length by 
$0.0045 \mathrm{~mm}$. in thickness, but which are only $0.008 \mathrm{~mm}$. long when contracted. Ludwig believed that the terminal hairs described by Perrier were nothing but secretion products.

Cuénot confirmed the existence of the axial muscle fiber noticed by Perrier and discovered its nucleus.

Jickeli described the papillæ as composed of the extensions of three or four epithelial cells with nuclei at their base, the distal ends of each carrying a fine sense hair. He noted the existence of a slowly waving flagellum projecting between the three or four terminal sense hairs, which he considered a prolongation of the median fiber described by Perrier.

Miss Irene Sterzinger noticed mucus at the tip of the tentacles, but was not able to demonstrate its occurrence in the papille.

Reichensperger, whose description of the papillæe is given above, found that the waving terminal flagellum described by Jickeli is merely an optical effect due to the secretion from the gland cells escaping into the water.

Perrier, Möbius, and Götte considered the papillæ as sense, or tactile, organs; Ludwig, with great diffidence, suggests that they may be single-celled glandular organs; Jickeli denied the presence of a secretion in the papilla and described them as purely sense organs; Miss Sterzinger suggested that the mucus glands in the tentacles may be connected with the procuring of food.

Reichensperger noticed that the secretion of the glands at the base of the papillæ differs markedly from that of the epithelial gland cells, and from that of the cement-secreting cells, and is not of a purely mucoid nature. He believes that the papille are defence organs, analogous to the nettle cells of actinians. When the terminal hairs are touched the papillæ contract, pouring out their secretion into the water. This secretion is of such a nature that by it large animals are prevented from reaching the soft parts of the animal, while small organisms, small crustaceans and the like, are benumbed or killed, and subsequently carried by the cilia of the ambulacral epithelium to the mouth.

DORSAL GLANDS.

On the dorsal side of the calyx, on the sides of the arms and pinnules, and also beneath the epithelium of the anal tube in Neocomatella pulchella, Hamann found more or less egg-shaped cell groups. These groups, each composed of five or more individual cells, occur directly below the epithelial layer. The single cells are vesicular, possessing a thin membrane inclosing the clear, watery fluid which does not stain; a spherical nucleus is visible lying more or less centrally surrounded by a small amount of cytoplasm which is stretched out pseudopodia-like to the cell walls and holds the nucleus in position. When isolated the walls of these cells are often much folded.

Similar cell groups were found in the walls of the pinnules in all the comas. terids studied by Hamann, but they were not met with in any endocyclic species. 
BRACHIAL AND PINNULE CYSTS OE ANTEDON.

Figs. $1305-1305, \mathrm{pl}, 44$.

In $1885 \mathrm{P}$. H. Carpenter called attention to peculiar swellings which he very firequently observed on the pinnules, and less commonly on the arms, of Antedon. From their appearance Carpenter thought that possibly they were caused by myzostomes, and for that reason he sent a number of them to Prof. Ludwig von Graff for examination.

The latter found that the malformations of the pinnules are extraordinarily numerous and occur on specimens of the several species of Antedon from the most diverse localities. Sometimes they are hardly noticeable thickenings of a single segment, or of two, less frequently of three, sometimes larger spherical dilatations toward the adambulacral side. Somewhat rarely dilatations occur which are really only pits surrounded by a thickened wall. On the other hand, there are not infrequently two or three such swellings on the same pinnule, and on a single arm of an example of Antedon bifida from Milford ron Graff counted 7 of the malformations, and in all 14 characteristic swellings on one individual.

The arm swellings are less numerous. On a specimen collected near Gibraltar by the Vettor Pisani three distinct deformities occur in close approximation. The very slight swelling of the arm extends over two segments and is tolerably uniform on either side. Von Graff observed, however, one-sided conical swellings of the brachials, sometimes combined with an enlargement of the basal segment of the attached pinnules.

Von Graff opened 14 of these malformations under a lens, and, after decalcification, cut longitudinal sections of thein, but in no case did he find a myzostome or any other encysted organism; instead, both in the various pinnule deformities and in the arm swellings, he found a rounded brown foreign body which was apparently the cause of the deformity, though he was not able to determine anything definitely as to its nature or origin.

The diameter of one of these spheres, from a pinnule swelling of an Antedon bifida from Cumbræ, was $0.3 \mathrm{~mm}$. Its substance was distinctly divisible into a strongly refracting cortical layer and an opaque granular internal mass. The former was radially divided into cell-like portions, and had quite the appearance of cylinder epithelium both in optical section and on surface view; there was not, however, any sharp boundary between the outer layer and the central mass. The whole had thus the appearance of a superficially segmented ovum.

These bodies sometimes lie in the center of the swollen segment in the calcareous substance, or near the integument, or even embedded in the latter. In sections they are seen to be surrounded by a noncalcified tissue uniformly stained by carmine. When the body lies just below the integument the tissue is connected with the latter.

The sections sherl no light upon the nature of the included body. In a figure given by von Graff of one of the spheres which had a diameter of $0.26 \mathrm{~mm}$. the cortical substance appears in part roughly divided, and in the central mass also 
there are fine lines which suggest a similar division. When the contents are compressed they fall into clumps like yolk segments.

A smaller swelling contained a single body with a diameter of $0.058 \mathrm{~mm}$. in which no structure could be detected, and the distinction between cortical and central mass was less obvious. On the other hand, in three bodies which were contained in a larger swelling on the same pinnule, and which mensured from $0.10 \mathrm{~mm}$. to $0.12 \mathrm{~mm}$. in diameter, the structure described was already indicated.

Since none of the stained preparations exhibited any trace of nuclei, von Graff concluded that they could not be ova.

GENITAL CORD.

Between the three extensions of the body cavity into the arms, the dorsal canal, and the two ventral canals, there lies, in the thickened partition, a longitudinal cavity, the genital canal, and in this lies the genital tube, which surrounds the genital cord. From the arms the genital tube passes into the disk, where it runs in a carity communicating with the other divisions of the body cavity, and forms an irregular pentagon lying between the ventral integument and the digestive tube.

In the disk the genital canal has a lesser diameter than in the arms, measuring only $0.02 \mathrm{~mm}$., while the genital cord is $0.01 \mathrm{~mm}$. thick; the latter is circular in cross section.

Ludwig described the lumen of the genital tube as a blood ressel, but Hamann found no eridence for this view.

The genital cord lies on the wall of the genital tube. It is composed of large cells, which usually entirely fill the lumen of the tube. These are the primitive germ cells from which in the pinnules arise the eggs and sperm.

The cells within the genital cord are amoboid, and often lie so thickly together that their borders become unrecognizable. In Ileliometrc glacialis they measure $0.08 \mathrm{~mm}$. in diameter. They contain prominent large circular nuclei and have a finely granulated cytoplasm.

The nuclei of the cells of the outer epithelial layer of the genital tube lie so closely together than the cytoplasm is almost entirely obscured. The tube wall beneath this epithelial layer consists, according to Ludwig, of longitudinal fibers. and at intervals there are ring-muscle fibers. Hamann also found a thin layer of connectire tissue. Within this is an epithelial lining, which extends over the genital cord.

The genital tube is attached to the wall of the genital canal by spindleshaped cells.

The structure of the genital cord and of the genital tube is the same throughout their course.

No connection between the genital cords and the axial organ has been conclusively demonstrated.

CEMENT SECRETLNG CELLS.

In addition to the mucus-secreting cells of the ambulacral epithelium Schneider found other cells, which he described as mucus-secreting, very sparingly distributed in the epithelium of the ventral perisome. 
These have been described in much greater detail by heichensperger.

Reichensperger found these cells only in gravid females, in the region where the eggs are extruded from the pinnules. He was quite unable to find them in males, and could detect only traces of them in unripe females. They do not appear to occur in Isocrinus nor in any of the Comasteridæ.

The cement cells are almost exclusively confined to the ventral side of the pinnules, occurring in a broad longitudinal band. In all probability they are profoundly modified epithelial cells.

As a rule they are elongate oval, on the average $0.012 \mathrm{~mm}$. long by $0.00 t \mathrm{~mm}$. in greatest breadth. The nucleus, which is small and often difficult to demonstrate, lies near the base.

The eggs of Antedon, on coming to maturity, break through the pinnule wall on the ventral side; after fertilization they are held fast to the outer side of the pinnule until the ciliated larvæ have developed.

On both sides of the rents in the body epithelium through which the eggs are extruded are numerous cement cells. As the eggs advance these cells empty almost their entire contents on them, which, as a thick, half-solidified gummy mass, clings to the egg case, roughened by numerous minute spinelets, and fastens the egg to the outer pinnule wall. About the eggs can be commonly seen long threads of the hardened secretion. This secretion must be only very slightly soluble in water, or it must entirely harden, for after the escape of the ciliated larva a part or even all of the egg case often remains for a considerable time on the pinnules.

GENITAL PORES OF THE MALF.

- Prof. William S. Marshall has described the genital pores of the male Antedon mediterranea. While working with a series of sections of a male pinnule he noticed a number of pores passing almost completely through the pinnule wall, whieh upon further examination were found to be present in a number of pinnules on each arm of the two specimens examined. As many as four pores were found on a single pinnule, they having, however, no very definite position other than being in the neighborhood of the sacculi.

From the specimens studied he.was led to believe that these pores are present in ripe pinnules, and that through them the spermatozoa are expelled.

At these points the genital cord grows toward, and partially through, the wall of the pinnule. The fully developed and developing spermatozoa show a longitudinal linear arrangement, which is broken wherever one of the genital pores is developed, and at this point they pass outward to fill the pore, undoubtedly remaining within it until its rupture, when they are expelled into the water.

P. H. Carpenter has described the pores of the male in Pcecilometra accela and in Perissometra angusticalyx. In these species the fertile part of the gonad is short, thick, and rounded. It only extends over four or five of the enlarged and broadened pinnule segments, and is protected by a tolerably regular pavement of plates. At about the middle of its length one or two small conical projections rise from it toward the ventral surface of the pinnule. Carpenter does not think that, as a rule, there is more than one to each pinnule. 
SPERMATOGENESIS AND THE SPERMATOZOA.

Prof. George W. Field gives the following account of the spermatogenesis and of the spermatozoa of Antedon mediterranca. For descriptive purposes he divided the mature spermatozoan into the following parts:

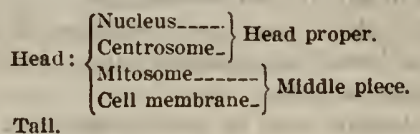

The nucleus of the spermatozoa of Antedon mediterranea measures in longitudinal diameter $3.3 \mu$ and in transverse diameter $1.3 \mu$; the centrosome is $0.66 \mu$ in diameter, and the mitosome is $1.3 \mu$.

The nuclei of the spermatogones in the outer zone, as seen in a section of the testis, usually alone of all the cells show nucleoli.

Considering the amount of cytoplasm the nucleus is relatively large. It very soon begins the process by which it will ultimately give rise to the spermatozoa. It is divided by mitosis and forms the nuclei of two spermatocytes. The number of chromosomes into which the nuclein of the spermatogone collects seems to be from 28 to 36 ; in the spermatocyte, from 16 to 18 . The attempt to count with exactness such small and numerous bodies so closely crowded together is well nigh fruitless.

The dividing nucleus is seen plainly to be made up of several substances, as for example, nuclein, the caryoplasma, and another substance which has the appearance of minute granules; these evidently form the mitotic spindle. A centrosome is also present.

The nucleus of each spermatocyte has the same constituent parts as that of the spermatogone. It divides by mitosis and forms the nuclei of two spermatids. The nucleus of each spermatid contains eight or nine chromosomes and caryoplasma. Within the nucleus there seems to be no sign of the granules which formed the nuclear spindle, but these granules and the centrosome are now very distinctly seen to be in the cytoplasm. It should be noted that each of these mitoses are reducing divisions.

With the spermatid begin those changes in the shape and constitution of the nucleus which are connected with the specialized form of the spermatozoon. The nucleus gradually changes from spherical to conical. There seems to be a change in the constitution of the nucleus. The chromosomes (usually 9, sometimes 8) can be demonstrated in the spermatids and in certain of the spermatozoa, probably the immature ones. But in others the nucleus remains homogeneous under the same reagents and conditions which demonstrate the chromosomes in the others. These spermatozoa with the homogeneous nuclei are the most active, and most frequently penetrate into the ovum. In sections of fertilized eggs the nucleus of the spermatozoon when in the outer zone of the cytoplasm of the ovum is small, dense and homogeneous; on the other hand, the nucleus which has traveled for some distance toward the female pronucleus is considerably larger and shows 
eight or nine chromosomes surrounded by a lightly staining caryoplasma. Hence it is probable either that the chromosomes in the nucleus of the spermatozoon dissolve in the caryoplasma and form a denser homogeneous mass preparatory to penetrating the membranes and more compacted outer cytoplasmic laver of the ovum, or else the caryoplasma is extruded and the nucleus of the mature spermatozoon consists very largely or even solely of chromosomes (nuclein) closely packed together.

There is a very considerable reduction in the size of the nucleus in changing from that of the spermatid to that of the spermatozoon, and correspondingly an increase in size, with a reappearance and wider separation of the same number of chromosomes, after the spermatozoon in the fertilization process has passed the peripheral denser portion of the cytoplasm of the ovum. The question is, whether this change in the nucleus is merely one of density; that is, does the nucleus of the mature spermatozoon consist of the same quantity of nuclein and caryoplasma but with the nuclein dissolved in the caryoplasma, or does the caryoplasma as a liquid portion pass into the cytoplasm before the spermatozoon becomes fully mature, and after the spermatozoon has entered the cytoplasm of the egg is the caryoplasma restored from the cytoplasm of the egg?

On account of the very evident alterations in size of the nucleus one is inclined toward the latter alternative. It seems to be a pretty good case for proving that an interchange of substance goes on between the nucleus and the cytoplasm, and that in this instance at least the substance which passes through the nuclear membrane is the caryoplasma, a liquid protoplasm. If this is the case it makes strongly for the view that the nuclein is the essential part, for in this case most of the male caryoplasma passes out into the cytoplasm of the male cell, and the caryoplasma is replaced by liquid from the cytoplasm of a female cell.

In Antedon the nucleus is comparatively small; in the anterior surface, usually at the very apex, there is a depression into which the centrosome fits.

Field has never seen a centrosome in the spermatogones in the outer zonethat is, next to the germinal epithelium. He first succeeded in finding it in the dividing spermatogones. At first it seemed to be within the nuclear membrane, but observation on this point was very difficult, and he is by no means positive in regard to the place or manner of first appearance.

Field never saw in the spermatogone the actual division of the centrosomes, but it is probable that it occurs preparatory to the mitotic division. With the disappearance of the nuclear membrane the centrosomes are seen to have the usual position at the poles of the nuclear spindle.

This spindle seems to be formed of those violet staining granules which are present in the nucleus before the disappearance of the nuclear membrane. These granules remain in close proximity to the chromosomes, the cytoplasm being entirely free from them previous to the final division which gives rise to those cells, the spermatids, which will become the spermatozoa.

After the division of the nucleus of the spermatocyte into the two spermatid nuclei, and before the division of the cytoplasm has taken place, those granules 
362

BULLETIN 82, UNITED STATES NATIONAL MUSEUM.
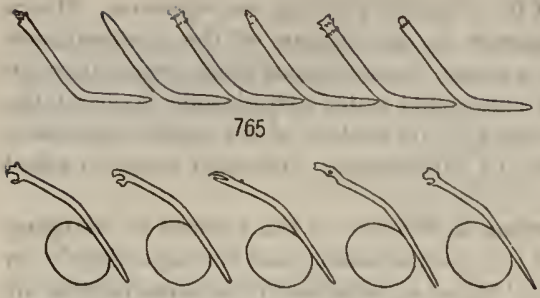

766
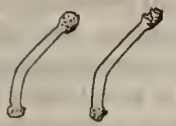

767
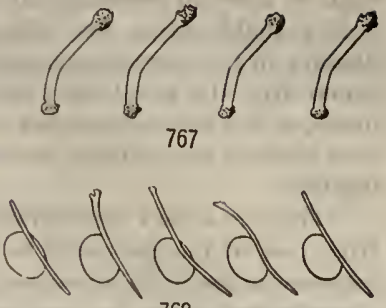

768

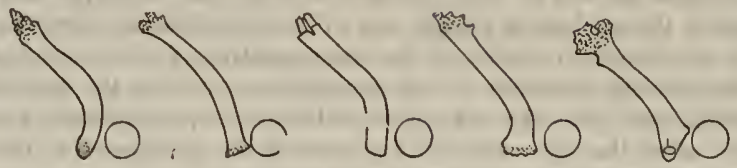

769

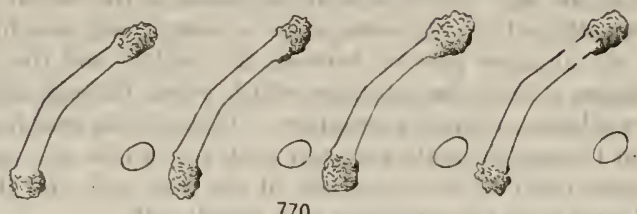

770

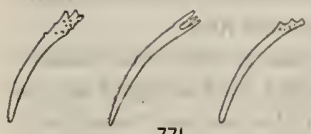

771
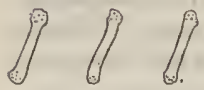

773

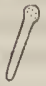

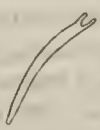

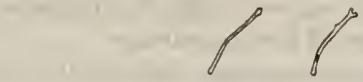

$\int$

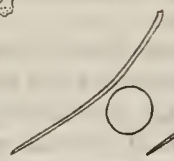

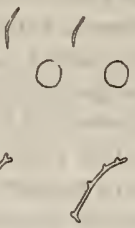

774

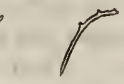

772

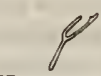


which composed the spindle fibers are seen scattered through the cytoplasm; the nuclei themselves, rounded up and with a nuclear membrane, are free from the granules. In the cytoplasm also, close beside each nucleus, remains one of the centrosomes which took part in the division of the cell.

According to Field, the probable history of the centrosomes is as follows: The original centrosome appears first in the spermatogone and is of intranuclear origin. Field can not say that the centrosome is not present in the spermatogones while they are still close to the germinal epithelium, but lie has never seen it previous to the disappearance of the nucleolus, and when first seen it seems to be within the nuclear membrane.

In the spermatogone it divides into two, which participate in the mitotic division resulting in two spermatocytes.

With each spermatocyte nucleus there is left one centrosome, which is onehalf of the original centrosome of the spermatogone. Initiatory to the mitotic division of the spermatocytes, this centrosome divides into two which come to lie at the poles of the spindle. With the completion of this mitosis each spermatid contains one centrosome. Thus from the original centrosome of the spermatogone four centrǫsomes have been derived, and each of these four centrosomes comes to be placed at the apex of the head of a spermatozoon, and in the fecundation process enters the ovum with the nucleus of the spermatozoon and takes part in the subsequent fertilization.

When the nuclear membrane is formed around the nucleus of the spermatid the centrosome is not included, but is left outside in the cytoplasm. This fact either points to the probability that the centrosome is extranuclear in the spermatogone, or else that for some reason the condition in the spermatogone varies from that in the spermatid. If the latter is true, a possible explanation for this difference may be found in the fact that with the spermatid the series of mitotic divisions is completed, and that subsequently the constituent parts of the cell will undergo an extreme modification.

With the formation of the tail it first begins to be possible to say which part of the spermatid will be the anterior point of the spermatozoon. The centrosome, which hitherto apparently has had no special position with reference to the nucleus, now comes to lie close beside it, and usually directly opposite the point where the tail is forming. With the diminution of the cytoplasm around the nucleus the centrosome comes to lie in a depression in the nucleus, but remains entirely outside of the nuclear membrane. This condition is probably brought about mechanically by the pressure of the tightly drawn cell membrane which invests the spermatozoon, pushing the unyielding refringent centrosome into the wall of the nucleus.

The sperm centrosome is the centrosome of the spermatid and of the previous cell generations, and it continues in company with the nucleus of the spermatozoon until the completion of the process of fertilization.

As soon as it has passed the denser outer layer of the cytoplasm of the egg it draws farther away from the nucleus and the characteristic radiations appear in the cytoplasm. It no longer directly precedes the nucleus, but comes to lie at one side. 
The very small granules visible in the nucleus before the disappearance of the nuclear membrane, and which later become the fibers of the mitotic spindle, have already been referred to, as well as the fact that after the division of the spermatocyte into the spermatids these granules, which were the mitotic spindle of the spermatogone and spermatocyte, are no longer included within the nuclear membrane, but are scattered through the cytoplasm. With the beginning of these changes which mark the transformation of the spermatid into the spermatozoon these granules gradually fuse into larger and larger bodies until they come to form in the cytoplasm a small number (from 6 to 8 ) of refringent spheres. These finally fuse into a single spherical mass-the mitosome.

The mitosome apparently may at first take any position whatever in the cytoplasm, but with the formation of the tail and the consequent diminution of the cytoplasm in the head of the spermatozoon the mitosome soon becomes pressed upon by the cell membrane and is gradually drawn into the place of least resistance-that is, between the nucleus and the beginning of the tail, its normal position in the mature spermatozoon, where it forms the so-called "middle-piece."

The tail is a round flagellum $0.2 \mu$ to $0.3 \mu$. in diameter, formed from the cytoplasm of the spermatid. Soon after the mitotic division of a spermatocyte into two spermatids the cytoplasm of the spermatid begins to form a bulging which increases into a large projection like an enormous blunt pseudopodium; the cytoplasm continues to push or flow into this projection, and so it becomes elongated and flask shaped, the body of the flask consisting of a large drop of cytoplasm which is connected with the cytoplasm proper by a narrow neck. The continued lengthening of the tail takes place with the elongation and diminution in the diameter of the neck, together with a diminution in the size of the drop of cytoplasm at the tip, as well as by a diminution of the cytoplasm which has hitherto remained around the nucleus and the mitosome in the cell proper.

The tail then is the cytoplasm of the spermatid which has become modified in a very special way. It is possible that its violent motions in the water are expressions of some molecular change which the sea water brings about in the protoplasm of the tail, for Field has noticed that spermatozoa when first removed from the testis into sea water lie motionless. After a short time a slight motion begins, which after a few minutes increases to the normal rapid motion.

It seems most probable that the tail is in direct continuation with the cell membrane which surrounds the spermatozoon. The cell membrane being morphologically but the external slightly changed cytoplasm, probably differs very little. morphologically not at all, from the tail, and these two-the tail and the cell membrane-probably pass insensibly into one another. The mode of development would seem to prove this.

A delicate cell membrane surrounds the head of the spermatozoon, inclosing the nucleus, centrosome, and mitosome. This membrane is best seen in cases where from some mechanical cause a slight separation has taken place between the nucleus and the mitosome, this membrane in that event being stretched but still unbroken. It may also be seen stretching over the centrosome in cases where the 
centrosome has been crowded out of the socket in the anterior end of the nucleus. Field regards this membrane as the original cell membrane which has persisted from the spermatid.

GENITAL ORGANS OF ISOMETRA VIVIPARA.

The female genital organs of Isometra vivipara have been described by Dr. K. A. Andersson, and to Andersson's description Dr. Th. Mortensen has added a few supplementary observations.

A cross section through a fully developed female pinnule of this species in the region covered by the expanded third to fifth pinnulars (to which region the development of the ovary and of the accessory structures is confined) shows two striking peculiarities: On the distal side a deep and narrow pocket with a short and narrow slit-like opening situated close to the ambulacral groove shows the presence of a brooding chamber or marsupium, which is separated from the ovary by a very thin membrane containing no calcareous deposits, and in the center of the ovary there is a special cavity for the reception and conservation of the spermatozoa-a receptaculum seminis.

Except for a small canal occasionally narrowing to a small slit, which extends throughout its entire length, the ovary is an almost solid structure. This canal represents the genital tube of other crinoids, but, instead of being filled with eggs, it contains a variable number of spermatozoa and evidently functions as a receptaculum seminis. It is provided with longitudinal evaginations which extend in between the eggs, so that on a cross section it appears as an irregular or star-shaped figure in the middle of the ovary. It reaches the outer border of the latter only in a very limited area, where the ovarial wall is thinnest, between the ovary and the marsupium, being here separated from the latter only by a single layer of cells.

The wall of the receptaculum seminis is composed of a single layer of cells, which forms the germinal epithelium.

In young ovaries, or in slightly developed portions (as, for instance, the proximal portion) of mature ovaries, some of the cells of the germinal epithelial layer are seen to be larger than the others and to be provided with large nuclei. These cells, which arise from the outer wall of the receptaculum seminis (representing the genital tube of other crinoids), are small egg cells.

In young ovaries many of the cells in the germinal epithelium are in process of division; between these are smaller cells, which sometimes are provided with long processes, which are not egg cells; in fully developed ovaries these cells are greatly in excess and the egg cells are rery few.

Beyond the layer of cells just described is a thick layer of connective tissue, in which the large eggs are embedded, and between the ovary and the genital sinus is a thin layer of pavement epithelium. There is no genital cavity, as in Antedon, Heliometra, Tropiometra, and the other comatulids which have been studied.

As the egg cells increase in size they migrate, not into the carity of the genital tube (which in this case has become the receptaculum seminis), as in other forms, but into its wall, into which they gradually sink deeper and deeper. They never entirely sever their connection with this cell layer. 
O'O'O'O'O'OOO'

${ }^{2} 0_{1} O_{1} O_{1} O^{\prime} O$ $\begin{array}{llllll}1 & 1 & 1 & 1 & 1\end{array}$

200000

777

$\mathbb{R} / \mathbb{R} / \mathbb{R} 778$
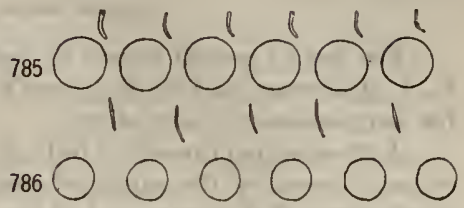

$1111,11,11$

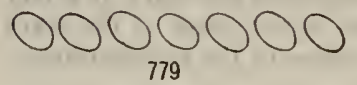

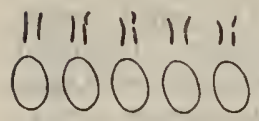

780

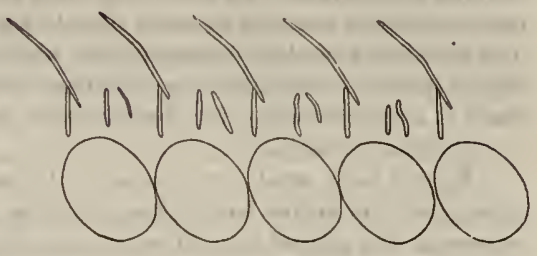

787

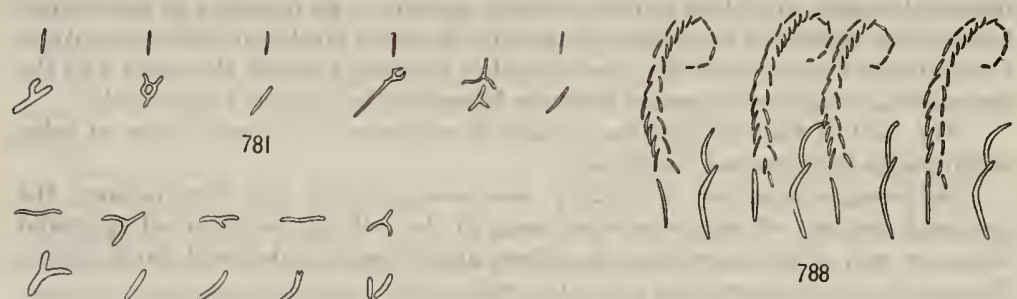

782

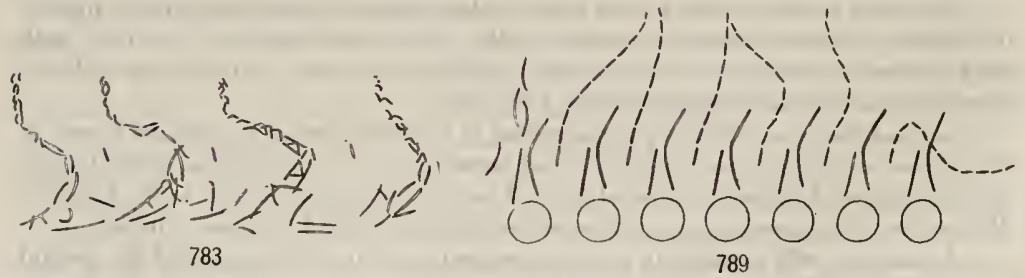

Figs. 776-789.-Adaibulacral deposits of various comatulids (drawings Bi aethor). 776. CilloMETRA ALBOPURPUREA. 777. SAME. 778. SAMF. 779. ZYGOMETRA COMATA. 780. OLIGOMETRA SERRIPINNA. 781. NFMASTER TIHIGINOSA FROM LAHL, BPAZIL. 78\%. NwOCOMATELLA PULCHJLLA. 783. LEPtonemaster ventestes, 784. ANTEdon petasus. 785. Same. 786. SAME, 7St. Eudiocrinus pin-

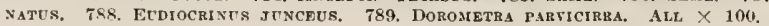


All the eggs, the small as well as the large, are in contact with the receptaculum seminis through a small opening, by means of which the spermatozoa are able to reach them.

In the mature ovary the ripe eggs occupy the major portion. In size they are about the same as those of Antedon adriatica or $A$. mediterranea, being $0.3 \mathrm{~mm}$. in diameter; but an accurate statement of their size is difficult to give, for as a result of pressure on all sides they are usually oval or irregular in shape.

The eggs are inclosed in a thin membrane and enveloped in a follicular epithelium with a small opening on the spot where it adjoins the receptaculum seminis. Andersson believes that the cells of this follicle arise from the connective tissue cells immediately adjacent to the egg.

In strong contrast to most comatulids, in which a large number of eggs are matured at one time and extruded simultaneously, the ovary of Isometra vivipara never contains more than a few mature eggs, with others in all stages of development.

As the eggs become ripe they are fertilized and extruded one by one into the marsupium. Thus the marsupium contains most commonly three, and never more than five, embryos in different stages of development. Entry into the marsupium appears to be by means of slits torn in the wall by the pressure of the egg.

In confirmation of Andersson, Mortensen states that the fertilization probably occurs within the ovary. He did not succeed in finding any fertilized eggs still lying within the ovary, but, on the other hand, he found no unfertilized egers within the marsupium.

GENITAL OBgANS OF NOTUCRINUS viniLis.

Figs, 1349-1352, pl. 55.

In Notocrinus viritis, as described by Dr. Th. Mortensen, the genital organs lie almost wholly on the arms.

The testes are enormously developed, forming two alternating rows of conspicuous white bodies, closely appressed along the median line of the arm, which appears considerably swelled. They are about $4 \mathrm{~mm}$. long and look like small beans.

On their distal side, in the angle between the pinnule and the arm, there is a small pore, through which the spermatozoa escape.

The testes occur from $\mathrm{P}_{3}$ to $\mathrm{P}_{14}$.

Mortensen suggests that the large size of the testes may be accounted for by the fact that the spermatozoa have to find their way to the eggs in the marsupium through its small opening, which involves considerable difficulty.

The ovaries, which are much smaller than the testes, about $2 \mathrm{~mm}$. in length, are similarly situated on the arms at the bases of the pinnules, but are not in contact along the median line. They occur from $P_{3}$ to about $P_{12}$, or a little farther out in very large specimens. As in the case of the testes, there is no definite outer limit, they merely diminishing gradually in size to the twelfth or fourteenth brachials, beyond which point they may be continued in rudimentary form. They are generally slightly concave distally, where they abut upon the marsupium. 
Mortensen believes that the eggs must break through the wall separating the ovary from the marsupium. He could not determine definitely whether or not a true opening exists, though in one instance this seemed to be the case.

MARSUriUn.

In Notocrinus virilis (pl. 55, fig. 1351), according to Dr. Th. orMtensen, the formation of the marsupium may be studied in the younger specimens.

The first stage is a fairly deep invagination of the skin, widened at the bottom. Further development consists simply of a widening of the sack, which ultimately covers the whole distal side of the ovary.

At first its lumen is rather narrow, but with the development of the embryos it widens very considerably, so that it comes to occupy a considerably larger space than the ovary.

The walls of the marsupium are at first strongly ciliated, especially in the middle of the bottom, where the epithelium is distinctly thickened.

In the fully developed marsupium this thickening has disappeared, and the ciliation also appears to have been lost.

The opening of the marsupium remains unaltered, a deep, narrow pore with a thick ciliated epithelium. This pore is situated on a fairly distinct papilla, which stands on a low elevation like a small mammary gland.

Since in the males the pore is not elevated, they are easily distinguished from the females.

In Thaumatometra nutrix (figs. 1232-1237, pl. 38) the marsupium is a pocketlike groove on either side of the genital pinnules. A section through a genital pinnule shows the empty marsupium as a deep, narrow-sided fold, the opening being a very narrow slit. On the pinnules which carry large pentacrinoids the marsupium is widely opened.

In Isometra vivipara (fig. 1238, pl. 38), as described by Dr. K. A. Anderson, the marsupium is always on the distal side of the ovary, from which it is separated by a thin partition.

When fully developed it is very large and contains numerous larvæ in different developmental stages. It occupies the region supported by the third, fourth, and fifth pinnule segments, and to accommodate it these segments are expanded distally, the third and fourth very considerably and the fifth slightly, giving the pinnules a very asymmetrical appearance.

The opening through which the fully developed larræ escape is slitlike, situated on the ventral side near the ambulacral groove.

In specimens which are not sexually mature the pinnules lack the marsupium and are symmetrically developed. As the eggs begin to grow some small invaginations appear on the ventral side of the pinnules, one of which soon becomes larger than the others and forms the rudiment of the marsupium. As the eggs become larger this invagination increases in extent until the marsupium is fully formed. 


\section{SEXUAL DIFFERENTIATION.}

As in the other echinoderms, differentiation of the sexes is very rare in the crinoids, where it only occurs in those species in which the larvæ undergo their development within a brooding cavity or marsupium.

In Notocrinus virilis (figs. 1349-1352, pl. 55) the genital organs lie almost entirely upon the arms, and the sexes are readily distinguished by an examination of their ventral surface. In the males the enormous testes, which look like small white beans, form two alternating closely appressed rows along the arms, while in the females the ovaries, which are about half the size of the testes, are similarly situated but are only half as large and are not in contact in the median line; the marsupia when fully developed cover the entire distal side of the ovary.

In Thaumatometra nutrix (figs. 1232-123i, pl. 38), as in Notocrinus viritis, there appears to be no sexual differentiation in the calcareous structures. The females are readily distinguished from the males, however, by the marsupia, which occur in the form of deep pocket-like grooves on either side indifferently of the genital pinnules.

In Isometra vivipara (figs. 1238-1240, pl. 38) the genital pinnules of the females have the third and fourth segments enormously expanded distally and the fifth slightly expanded, serving as a protection for the ovaries and the marsupium. The genital pinnules of the males and of the immature females have the third-sixth segments slightly and symmetrically expanded.

Besides these three comatulids, only 5 or 6 other echinoderms exhibit sexual dimorphism.

In one or two of the spatangoids the lateral petals of the female are much broader and deeper than those of the male and serve as brood chambers, and in Anochanus there is a highly developed brood pouch.

One of the clypeastroids has the female with the abactinal area deeply depressed to form a horseshoe-shaped brood chamber, which is not found in the male.

In one of the holothurians the female has a peculiar brood chamber developed in the dorsal integument.

In one of the ophiurans the male has five arms, while the female has from six to eight.

None of the asteroids are known to exhibit sexual dimorphism.

All of the sexually dimorphic echinoderms are from the antarctic or subantarctic seas except Anochanus, which was described from China.

\section{SPAWNING SEASON.}

COMATRLLA NIGRA.

A specimen of this species taken near Joló (Sulu), Philippine Islands, on February 14, 1908, has the eggs apparently ready for extrusion.

\section{COMISSIA SPANOSCHISTUM.}

According to Dr. H. L. Clark, specimens of this species with the genital pinnules immensely swollen with the reproductive cells were taken in March and A pril, 1914, by the Australian fisheries steamer Endeavour. 
In his description Doctor Clark confused this species with Comanthus tasmanice, and it is not quite clear whether the latter was also found breeding at that time or not.

\section{COMISSIA LITTORALIS.}

Anchorage off the Kawio and Kamboling Islands, Karkarolong group: On July 22-23, 1899, the Siboga dredged a specimen of this species in 23-31 meters which had seren young pentacrinoids attached to the cirri.

\section{COMACTINIA MERIDIONALIS.}

Yucatan: On January 30, 1855, the Albatross dredged in 21 fathoms off Yucatan numerous small specimens of this species which bore, attached to the cirri, a very large number of pentacrinoids of all ages from the prebrachial stage onward.

\section{COMAXTHUS JAPONICA.}

Professor Ijima wrote, in a letter to Mr. Frank Springer, that this species attains sexual maturity at about the same time as Tropiometra macrodiscusthat is to say, in September.

Since the summer of $1917 \mathrm{Mr}$. Furusawa has endeavored, under his direction, to secure the larvæ and pentacrinoids of this form, but so far witlout result, although the gonads seemed to be ripe, or nearly so.

Experiments in artificial fertilization with artificially liberated sexual products all failed.

A number of living individuals were kept in a pond and examined from time to time. On October 1 there occurred a violent typhoon, and since that day not a single individual with ripe sexual products has been found, either among those in captivity or among those freshly taken from the sea. It is certain that the typhoon caused the discharge of the sexual products.

A year later, on February 25, 1919, Professor Ijima wrote to Mr. Springer that scores of Comanthus japonica had been kept alive at the Misaki Marine Station and continually watched to determine the spawning season, old individuals being from time to time replaced by animals freshly caught. It was found that they lived best in a boat-shaped live car containing seaweed and bamboo twigs for the larvæ to fix upon, moored in the open water in front of the laboratory.

During August many females were found with their pinnules swollen and containing nearly full-grown ova, but no ripe males were found.

On October $14 \mathrm{Mr}$. K. Aoka, the collector at the station, discovered for the first time some fully mature examples. Artificial fertilization was at once resorted to. On October $15 \mathrm{Mr}$. Aoki reported finding larvæ inclosed in the vitelline membrane; on the 16th they escaped from the membrane and began to swim about; on the 17 th they all attached themselres to the sides of the jars. On the 27 th they were dying off rapidly, although the water had been changed every day, and apparently all derelopment had ceased. A fresh supply of adult animals were obtained, but these were found to be no longer ripe. 
It appears, therefore, that sexual maturity is reached at about the middle of October, and that the discharge of the sexual products takes place very quickly.

In the case of Tropiometra macrodiscus Mr. Aoki found that the period of sexual maturity had passed at the end of October.

$$
\text { COMANTHUS ANNULATA. }
$$

Dr. L. E. Griffin reports that in a specimen of this species captured at Port Galera, Mindoro, Philippines, on May 20, 1912, spermatozoa were being given off from near the base of the pinnules.

\section{CATOITOMETRA OPHITRA.}

In a specimen dredged in North Balabac Strait, Philippine Islands, at a depth of 58 fathoms, on January 5, 1909, the ovaries contained well-developed eggs.

\section{AMPHIMETRA SIRCTABILIS.}

The ovaries of a specimen taken in Limborres Cove, Manila Bay, Philippine Islands, on February 8, 1909, contained well-developed eggs.

\section{AMPHIMETRA PARILIS.}

Eggs of considerable size were found in the ovaries of a specimen dredged near Siasi, in the Sulu (Joló) Archipelago. Philippine Islands, at a depth of 21 fathoms, on February 16, 1908.

\section{CENOMETRA DELICATA.}

A specinen dredged in the Gulf of Dávao, Philippine Islands, in 23 fathoms, on May 18, 1908, has eggs of considerable size in the ovaries.

TROP'LMETRA MACRODISCUS.

Mr. Furusawa, under the direction of Professor Ijima, prepared a large series of the embryos of this species for Mr. Frank Springer.

The mother animal from which these embryos were obtained discharged the eggs on September 10, 1917.

\section{TROPIONETRA PICTA.}

Doctor Mortensen found this species spawning at Tobago during his visit to the island, from March 23 to April 23, 1916.

\section{CALY PTOMETRA IATERALIS.}

A specimen dredged near Niihau, Hawaiian Islands, at a depth of 319-451 fathoms, on August 12,1902, had eggs of considerable size in the ovaries.

\section{ANTEDON BIFIDA.}

Orkneys: Busch first found larvæ in the Orkneys in the last days of July.

Arran, Scotland: Sir Wyville Thomson says that on the island of Arran the spawning season commences at the end of May or the beginning of June. 

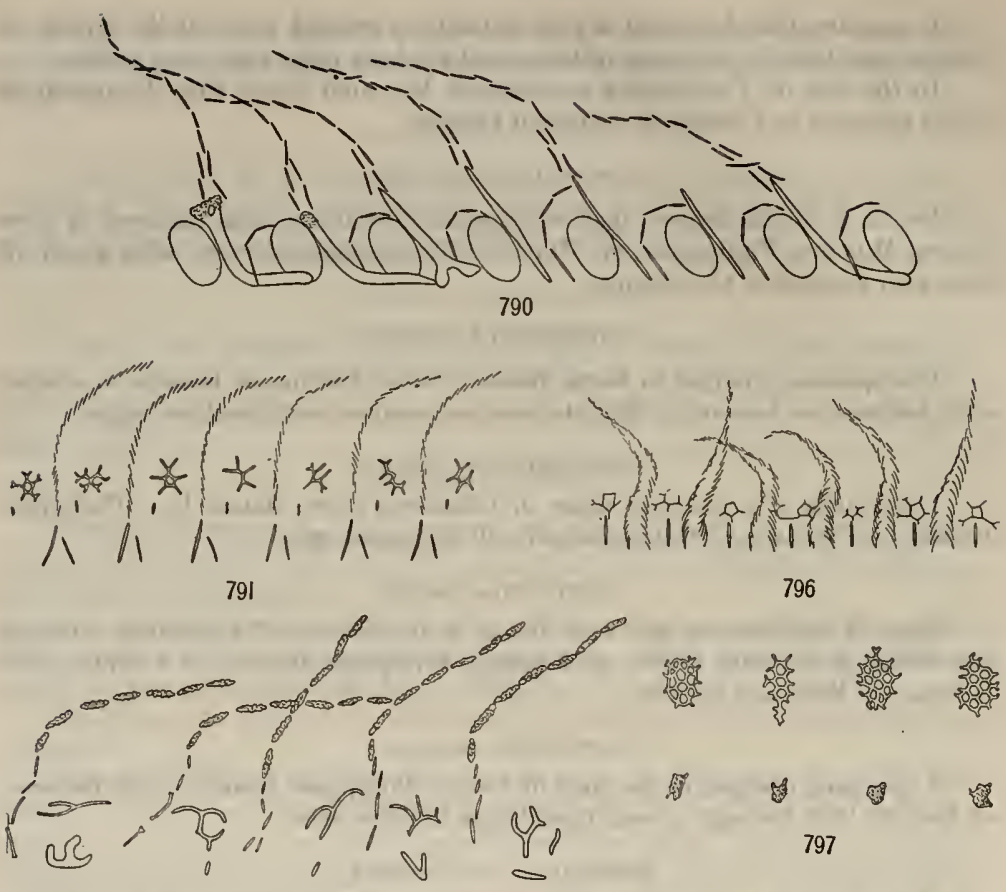

792

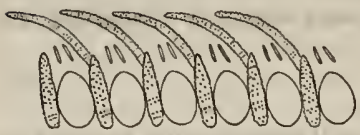

793

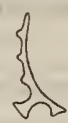

794

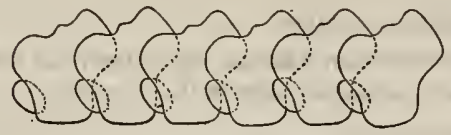

795

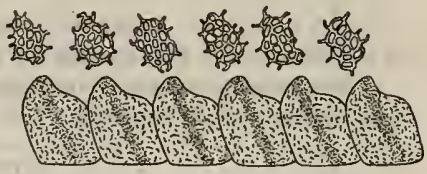

798

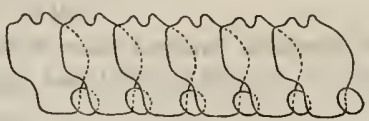

799

Figs, 790-799,-ADaAbelacral deposits of variods comatolids (DRawings by author). 790. CoMatonia

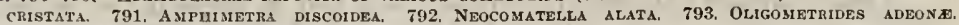
794. SAME, FROM NEAR BASE OF PINNULE. 795. L.EPTOMETRA CELTICA, 796. HETELOMETRA BENGALENSIS. 797. Tropiometra Macrodisces. 798. Pontiometra andersoni, 799. Leptojetra celtica, AlL $\times 100$. 
Millport on the Clyde: Dendy found that at Millport on the Clyde the height of the breeding season appeared to be in July.

Southern Ireland: According to J. V. Thompson the eggs are found on the Irish coast first in July.

\section{ANTEDON MFDITERRANEA.}

Naples: Götte gives March as the spawning season. Schmidtlein says that this species breeds in the spring.

Lo Bianco states that this species reproduces throughout the entire year, and that the months in which individuals with eggs and larvæ are met with in greatest abundance are November, December, February, and April.

Villafranca: According to Barrois the breeding season is April. He also states that the first breeding period can be followed by a second and even a third, an assertion partially confirmed by Seeliger's observations on Antedon adriatica.

Toulon: The breeding season is April, according to Barrois, as at Villafranca.

\section{ANTEDON ADRIATICA.}

Trieste: At Trieste Seeliger found that the chief spawning period commenced in the last days of May and continued until he left at the end of June. At all times it was easy to find a number of individuals with embryos, and toward the end of his visit he found females which had undoubtedly liberated larvæ.

The first sexually mature individual he found on April 25-a female which bore on the pinnules a few embryos, proving on closer examination to be gastrulæ.

It may be that there is more than one breeding period at Trieste, for Seeliger often found embryo-bearing females with nearly ripe eggs in the ovaries.

\section{COMPSOMETRA LONÉNI.}

Whitelegge states that at Port Jackson, New South Wales, the pentacrinoids of this species are often found attached to seaweeds in August and September.

\section{COCCONETRA NIGROLINEATA.}

The ovaries of a specimen taken off Habana, Cuba, in January, 1885, contained eggs apparently ready for extrusion.

\section{COCCOMETRA HAGFNII.}

Eggs apparently ready for extrusion were found in the ovaries of a specimen dredged near Key West, Florida, in 122 fathoms, on February 26, 1902.

PSATIIYROMETRA FRAGILIS.

In a specimen of this species dredged in Yezo Strait, northern Japan, in 300-533 fathoms, on September 30, 1906, the ovaries contained eggs apparently ready for extrusion.

\section{LEPTOMETKA PHALANGIUM.}

Lo Bianco states that at Naples mature eggs are found on the pinnules of this species in January, and that young occur on the cirri of the adults in June and September. 


\section{HATH ROMFTRA SARSH.}

Professor Sars gives the period of sexual maturity in the Lofoten Islands as June. He found the youngest prebrachial stage at the beginning of July.

\section{PENTAMETROCRINUS TUBERCULATUS.}

The ovaries of a specimen dredged off southern Japan on October 13, 1896, in 169 fathoms, contained well-dereloped eggs.

\section{PENTAMETROCRINUS JAPONICUS.}

Well-developed egrgs were found in the ovaries of a specimen dredged off southern Japan on August 23, 1906.

\section{PENTAMETROCRINUS VARIANS.}

Eggs apparently of full size were found in the ovaries of specimens dredged off southern Japan between August 13 and October 20, 1906.

The species which have been found spawning in the different months are as follows:

January : Comactinia meridionalis, Catoptometra ophiura, Antedon mediterranea, Coccometra nigrolineata, Leptometra phalangium.

February: Comatella nigra, Amphimetra spectabilis, Amphimetra parilis, * Antedon mediterranea, Coccometra hagenii.

March: Comissa spanoschistum, Tropiometra picta, Antedon mediterranea.

April: Comissia spanoschistum, Tropiometra picta, *Antedon mediterranea.

May: Cenometra delicata, Antedon bifida, Antedon mediterranea. Antedon adriatica.

June: Antedon bifida, Antedon mediterranea, Antedon adriatica, Hathrometra sarsii.

July : Comissia littoralis, Antedon bifida, Antedon mediterranea.

August: Calyptometra lateralis, Antedon mediterranea, Compsometra lovéni, Pentametrocrinus japonicus, Pentametrocrinus varians.

September: Comanthus japonica, Tropiometra macrodiscus, Antedon mediterranea, Compsometra lovéni, Psathyrometra fragitis, Pentametrocrinus varians.

October: Comanthus japonica, Antedon mediterranea, Pentametrocrinus tuberculatus, Pentametrocrinus varians.

November: *Antedon mediterranea.

December: *Antcdon mediterranea.

In the case of Antedon mediterranea the asterisk $\left({ }^{*}\right)$ indicates the months in which the greatest number of egg-bearing females are found.

In regard to two species, Antedon bifida and Hathrometra sarsii, there seems to be a definite breeding season in the late spring and early summer, from May to July. Both these species live in the northenstern Atlantic, on consts where the water undergoes considerable seasonal change in temperature and in plankton content, and the definiteness of the spawning period is probably connected with this seasonal change. 
It may be that the spawning season of Compsometra lovéni, of southeastern Australia, is circumscribed in the saine way.

But for the remaining species, other than Antedon mediterranea, we have no data upon which to base deductions of any kind; judging from the known conditions in Antedon mediterranea and in Leptometra phalangium we might suggest that probably comatulids spawn individually throughout the year, breeding examples being rather more common at certain times, dependent upon local causes as well as upon seasonal changes, than at others.

COPULATION.

Jickeli described what he believed to be a case of copulation in Antedon mediterranea, but no other investigator has confirmed his observations, which appear to have been based upon close association of the animals as a result of lack of oxygen or some other unfavorable condition.

More recently both K. A. Andersson and Th. Mortensen have assumed the occurrence of copulation in Isometra vivipara to account for the otherwise apparently inexplicable transfer of the sperm from the male to the receptaculum seminis of the female.

PASSAGE OF THE SPERMATOZOA TNTO THE RECEPTACULUM SEMINIS IN ISOMETRA VIVIPARA.

In Isometra vivipara the spermatozoa apparently first enter the marsupium, thence passing through the very thin wall between the marsupium and the receptaculum seminis, for in several cases Andersson found spermatozoa not only in the dorsal portion of the marsupium, but also in small interstices in the connective tissue of the wall itself, evidently on their way to the receptaculum seminis.

It is easy to see, therefore, why the receptaculum seminis extends to the outer border of the ovary and is separated from the marsupium by only a thin layer of cells composed of the ovarial wall and the adjacent wall of the marsupium, here completely fused into a thin partition.

DEVELOPMENT OF THE EGGS.

So far as we know it is normally only within the pinnules of the crinoids that the sexual products come to maturity, though our information is not as yet sufficient to enable us to speak with absolute certainty.

The fertile intrapinnular portions of the genital cords vary considerably in shape; in such types as Preilometra, Strotometra, and the genera of the Pentametrocrinidæ they are short, thick, and rounded; they sometimes terminate in rounded ends, and are sometimes continued as slender cords through two or three pinnulars. In Heliometra and other genera they are long, fusiform, and relatively inconspicuous. Both the short rounded type and the long fusiform type occur in the genus Antedon.

Professor Semper found that the ovaries of Comanthus parvicirra are not attached to the genital cord by their ends in the usual way. A backward process is given off at the point where the short branch of the sterile genital cord expands into the fertile portion, lying within the ventral perisome of the arm on the $142140-21-$ Bull. $82-26$ 
proximal side of the pinnule attaclıment. This is as fertile as the rest of the cord within the pinnule, so that the whole structure appears to be attached to the genital cord at some little distance from its end. It descends into the arm almost to the brachial genital cord, the lateral branches of which are quite short. Thus in most sections of the arms an ovary is to be seen on either side of the central genital cord.

P. H. Carpenter, quoting Semper's observation, notes that the same condition occurs in Comanthina schlegelii, and from an examination of the ventral perisome of the arms suspects that it is tolerably common in the larger tropical comatulids.

In one specimen of Antedon lifila Carpenter found a small but well-developed ovary occupying the position of the genital cord beneath the left posterior ambulacrum of the disk. The first traces of it appeared in the sections which pass through the hinder part of the spongy organ, and it extends outward to the point where the primary ambulacral groove divides into the two which proceed to the arms. It contained the nuclei of half a dozen ova in various stages of development, some with a germinal spot and some without.

Carpenter found a still larger and more fully developed ovary in the disk of one of the three specimens of Neocomatella pulchella which he sectioned. It commenced close to the peristome and extended outward beneath the left anterior ambulacrum nearly to its bifurcation, lying close down upon the upper surface of the digestive tube and molded to the plications of its wall.

In Tropiometra picta Carpenter met with detached portions of ovaries containing more or less fully developed ova in various parts of the body cavity, in the spaces of the connective tissue network forming the lip, in the intervisceral portion of the body cavity between the two parts of the coiled digestive tube, and in the subtentacular canals between the genital plexus and the water vessels.

In some sections through the arm of an unknown species belonging to the Pentacrinitidæ, which had been cut for Sir Wyville Thomson, Carpenter found an ovary occupying the position where the undereloped genital cord is normally found. He himself cut sections of the arms of all the more common species of that family, but in none of them found any trace of such a condition.

Sperry found in sections through the division series of Metacrinus rotundus a well-developed functional orary in the IIIBr series, which occupied a large part of the ventral side of the arm. The genital cord remained distinct nearly all the way, merging in but one spot into the ovary and soon reappearing to give off a branch to the succeeding pinnule. The branches of the genital cord running into the pinnules were much larger than the main strand.

In sections through the calyx of another specimen of Metacrinus rotundus Sperry found a small ovary lying in the body cavity surrounded by loose connective tissue.

In Holopus Carpenter found ovaries in the lower part of the arms.

In the sexually mature comatulid the primitive germ cells of the genital cord in the pinnules have by their development expanded the genital tube to such an extraordinary extent that it usually entirely fills the genital canal. On the periphery of the nearly solid mass filling the genital tube lie the developing eggs, while the ripe eggs lie in the center. At a later stage the contents of the genital 
tube are entirely solid, consisting of large egg cells which show germinal vesicles. Here and there on the periphery lie small, younger egg cells, while undeveloped cells, possibly primitive germ cells which have failed to mature, lie between them.

An outer epithelium composed of flattened cells which ensheathes the entire solid cylindrical ovarial structure can always be made out.

GROWTI CF THE OÖCrTE.

Prof. Gilbert C. Chubb has made a detailed study of the growth of the oöcyte in Antedon bifida, his material having been obtained at Plymouth, England. The following account is taken from his memoir on the subject published in 1906:

In the maturing ovary the growing oöcytes form a more or less solid mass of cells between which oögonia are still present in considerable numbers. The only constant feature in the arrangement of the germ cells consists in the invariably peripheral position of the still growing oöcyte. As there is no germinal epithelium, the new generations of oöcytes being derived from the scattered oögonia, there must either be an active peripheral migration of the oöcyte prior to the commencement of its growth, or else only those oöcytes which happen already to possess this position ever commence the latter process. The fact that this position should be maintained during the "growth" period of the egg, and that it should be frequently lost while yolk formation is still in progress, is of great interest in connection with the question of the relation of yolk formation; that is, the actual appearance of the definitive yolk spherules, to the general cell metabolism. In the more mature individuals the scattered oögonia are only rarely found in mitosis, while in the mature pinnules these abortive oögonia have undergone considerable degenerative changes.

When freely floating the oögonia are amœeboid in form, but when closely packed their outline is not always distinguishable. The nucleus is approximately spherical and measures from $3 \mu$ to $5 \mu$ in cliameter. There is a well-marked nuclear membrane, and the chromatin is in the form of irregular and deeply staining masses at the nodal points of a clearly defined linin reticulum. In many nuclei the meshes of this reticulum are so large that the greater part of the chromatin forms a series of peripheral masses on the nuclear membrane, while the remainder is massed around the nucleolus, the linin being reduced to a few strands radiating out from the surface of the nucleolus to the peripherally placed chromatin masses. There is a single nucleolus ranging from $1 \mu$ to nearly $2 \mu$ in size and apparently always peripheral in position. It appears as a pale brown or yellow perfectly regular and sharply defined spherule surrounded by the deeply staining chromatin. In some cases, especially in the rery immature pinnules, there are not only two nucleoli, but the nucleus itself is distinctly double.

In the dividing oögonia the nucleus measures $5 \mu$ to $6 \mu$ and the cell body $7 \mu$ to $8 \mu$, thus showing a considerable increase in size over that of the resting oögonia. A split spireme thread is formed, and this enters a synapsis stage, becoming aggregated around the nucleolus on one side of the nucleus. During this process the thread shortens and thickens, so that the longitudinal split usually entirely dis- 

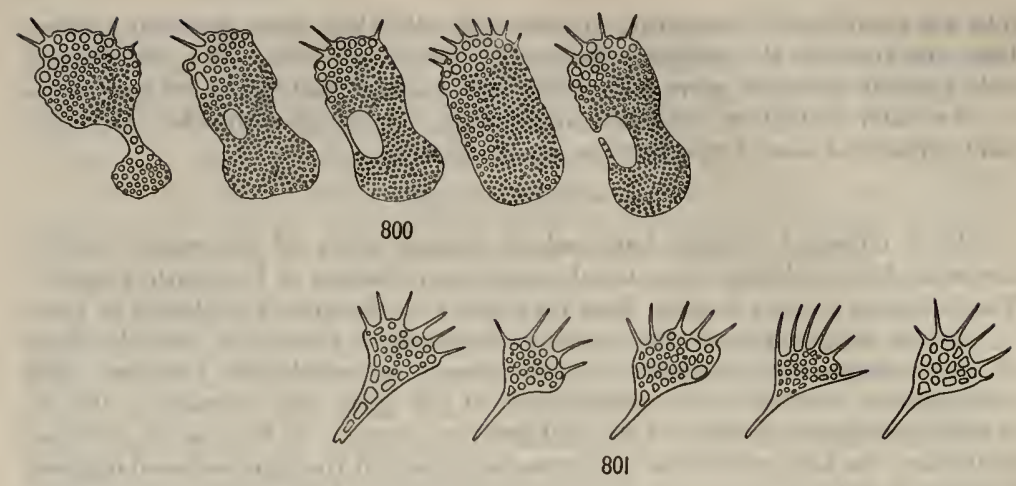

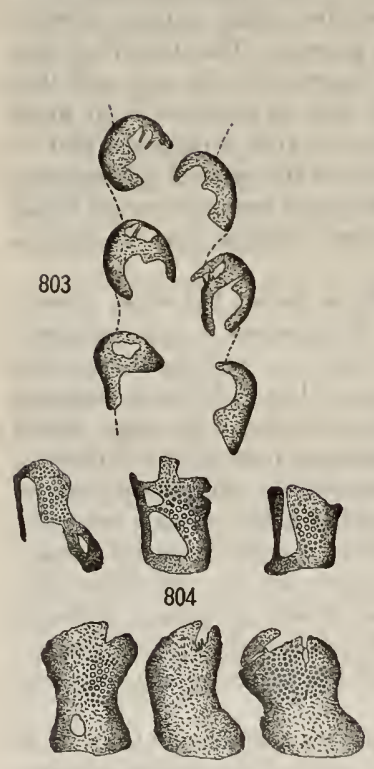

805
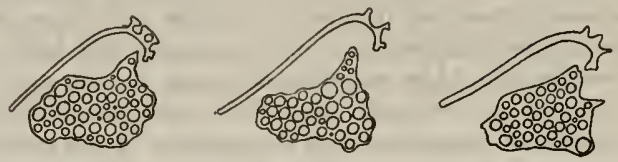

802

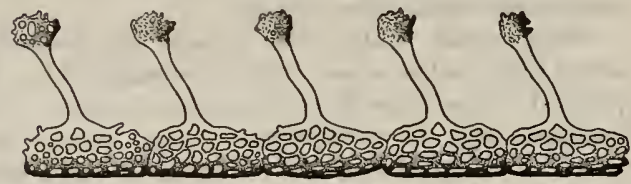

806

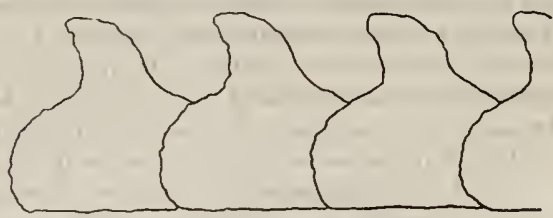

807

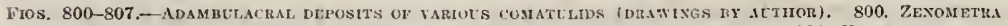

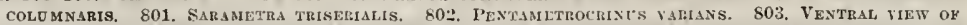

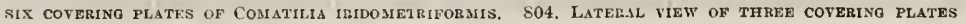
of Comatilis iridometriformis. 805. Same. 806. Eumorphometra concinna. 807. Promachocrindos kergotenis. ALL $\times 100$. 
appears, but the thread character of the chromatin is always evident. In the resolution of the synapsis the nucleolus is seen to be still present, of normal size, deeply stained, and sharply spherical, while the chromatin appears to radiate out from it onto the nuclear membrane in the form of (apparently) eight deeply stained and homogeneous strands. The latter lose their apparent connection with the nucleolus and, without further segmentation, give rise to the (apparently) eight $U$-shaped chromosomes which leave the nuclear membrane and aggregate together in the center of the nucleus to form the equatorial plate. From this stage onward it is not possible to detect the nucleolus, nor is there any trace of this structure in the completed spindle.

In spite of the large number of oögonia found in active mitosis, Professor Chubb never saw the anaphase stages of these oögonial divisions, and he was therefore unable to trace the actual formation of the oöcyte.

In what appears, however, to be the stage immediately succeeding the completion of the last oögonial division, the young oöcyte possesses a distinct nuclear membrane inclosing a spherical mass measuring $5 \mu$ in diameter in the center of which the nucleolus is suspended by a faintly stained linin reticulum. The nucleolus measures $1.25 \mu$ in diameter and is, after most fixing reagents, deeply stained; as in the oögonia, it is surrounded by a layer of chromatin. In the oöcyte, however, though the whole of the chromatin present is massed around the nucleolus, it forms a layer too thin to affect appreciably the spherical form of the latter.

The absence of anaphase stages has made it impossible to determine the part taken by the massive chromosomes of the oögonium in the formation of the nucleus of the oöcyte, and therefore also the mode of origin of the nucleolus. But having regard to the behavior of the nucleolus in the ooggonium-the rarity with which it is seen during the formation of the equatorial plate and its invariable abscnce in the completed spindle-it seems fairly certain that this structure arises in the oöcyte as a new formation is not genetically related to that of the oögonium.

The invariably central position of the rapidly growing nucleolus of the young oöcyte conclusively shows that the peripheral position of this structure in the relatively quiescent oögonium can not have any significance as denoting an extranuclear origin for this structure.

The young oöcyte grows rapidly, and with the growth of the cell body there is a corresponding growth of the nucleus and nucleolus. Early in this process the nuclear reticulum, at first faintly stained, commences to stain more deeply. This increase in the staining capacity of the nuclear reticulum proceeds from the nucleolus outward, and though the nuclear reticulum can, with suitable illumination, be seen really to extend from the nucleolus out to the nuclear membrane, the process gives it the appearance of consisting of longer or shorter, more or less deeply staining threads, radiating out from the surface of the nucleolus. Sooner or later the basophile reaction has extended over the whole of the nuclear reticulum. Soon after this the strands lose their connection with the surface of the nucleolus and with the nuclear membrane and become irregularly scattered over the nucleus, an arrangement which is maintained throughout the remaining 
history of the oöcyte, the irregularly scattered chromatin strands showing no further spatial relation either to the nucleolus or to the nuclear membrane.

As the chromatin threads lose their radial arrangement they become more deeply stained and sharply defined, and now for the first time bear distinct, though as yet small, deeply stained spherules. Often the strands appear to be composed solely of these minute spherules. Sometimes, however, appearances suggest that the latter are really arranged on a fine, deeply stained, and apparently homogeneous axial thread the zigzag and branched character of which gives to the chromatin strands a "mossy" or "filagree" appearance. During the period preceding the commencement of yolk formation, and thus during the progressive increase in the basophile reaction of the cytoplasm, the chromatin is always relatively small in quantity and is often very faintly stained. As yolk formation progresses, however, both the quantity and the staining capacity of the chromatin greatly increase, and at the same time the spherules on the chromatin threads grow in size until, in the adult egg, they may equal the spherules of the yolk.

The staining capacity of these chromatin spherules and the size they ultimately attain varies considerably in different individuals and is also to some extent dependent on the mode of fixation, and in material fixed solely with sublimate solution there is no trace of either chromatin or chromatin spherules. On the completion of yolk formation the condition of the chromatin remains unchanged as long as the egg remains in the pinnule.

In the younger oöcytes the nucleolus, which is at this stage invariably central in position, is homogeneous in appearance and, after most fixing reagents, deeply basophile. As growth proceeds, however, this uniform staining reaction is lost, the nucleolus showing a tendency to part with the basic stain during extraction. This destaining is always from within outward and may, with moderate extraction, be so extensive as to include the whole nucleolus. Usually, however, there is a considerable cortical region which tenaciously retains the basic stain. The readiness with which this destaining takes place is mainly determined by the condition of the nucleolus itself at the moment of fixation and is independent of the age of the egg; eggs of the same age and in the same ovary differ greatly in this respect.

The more faintly staining internal region of the nucleolus is never spherical in form, and its size, though mainly due to the condition of the nucleolus itself, is partly determined by the extent of extraction the slide has undergone; moreover, its contents are distinctly acidophile, far more so than is the caryolymph. It is evident, therefore, that the faintly staining area of the nucleolus is not of the nature of a vacuole.

True vacuoles, spherical in form and with clear, unstained contents, do, however, occur in the nucleolus. Their occurrence, like that of the destained area, is quite inconstant, for they are sometimes present, sometimes absent, at all stages of the egg's growth, though they are far more rarely met with in the earlier than in later stages. They are always much smaller than the faintly staining area. and although they may be present throughout the whole body of the nucleolus when this is deeply basophile, they are almost or entirely confined to the periphery when a considerable destained area is present. 
The nucleolar vacuoles, even when they reach a considerable size, never cause the slightest projection on the surface of the nucleolus, nor has Professor Chubb ever seen any other indication that they discharge their contents to the exterior. The appearance of the faintly staining region, on the other hand, is frequently such as to suggest that a discharge from it into the caryolymph is taking place. Thus, wherever the faintly staining area comes to the surface it causes a slight but distinct projection. In no case, however, do appearances ever suggest that the acidophile substance of the faintly staining area is itself discharged.

In the adult egg an extensive faintly staining area is always present, and its form and position almost invariably suggest that a discharge is taking place from it-a suggestion which is greatly intensified by the almost invariable presence in the caryolymph of deeply stained spherules so placed as to appear as if recently discharged as a stream from that region of the nucleolar surface to which the faintly staining area most closely approaches. Occasionally the faintly staining area approaches the surface of the nucleolus at more than one point; in such cases it is common to find spherules in the caryolymph in relation to each such point. It is only rarely that such spherules are found in the nucleus which do not show this spatial relation to the nucleous; and when such spherules do occur they are always more or less isolated in position and few in number.

The mode of origin of these spherules as a discharge from the faintly staining area of the nucleolus, which their arrangement irresistibly suggests, is still further indicated by the appearance presented by the nuclei figured by Professor Chubb. In each of these a spherule, similar to those in the caryolymph, is seen in the center, not of the destained area, but of one of the racuoles in the cortical region. Another figure shows a deeply basophile spherule identical with those in the caryolymph immediately outside the faintly staining area of the nucleolus, but lying in a vacuole within the substance of the cortical region and, by reason of its intensely basophile character, standing in striking contrast to it.

These spherules, like the substance of the nucleolus itself, are equally well fixed with all reagents and, like, the cortical substance of the nucleolus, are, nearly always deeply stained. Their staining reactions, however, do not exactly correspond with those of the cortical substance, for when, as frequently happens in the older eggs after Hermann fixation, the cortical substance of the nucleolus is destained to a faint brown, the discharged spherules in the same egg are usually deeply basophile. In size these nucleolar spherules often equal the peripheral spherules, with which they also agree in showing a much greater range of variation than do the yolk spheres proper.

Similar spherules, presenting the appearance of having been recently discharged from the nucleolus, are also occasionally, though much more rarely, to be found in the growing oöcyte.

The fact that this appearance of a discharge of spherules from the nucleolus should be so rarely seen in the growing oöcyte admits of very simple explanation. In the growing egg the intermittent discharges must be separated from one another by a considerable interval, while the time occupied by the actual discharge must be very brief. The chances, therefore, against the moment of discharge coinciding 
with that of fixation are very great. In the adult egg, on the other hand, the great frequency with which the discharge is seen can not be explained as due to its more frequent occurrence, for this would indicate a degree of activity on the part of the nucleolus at this stage for which there is no particle of evidence; the completion of yolk formation is accompanied by the complete cessation of all nucleolar activity and growth, the nucleolus remaining of the same size and retaining the same appearance as long as the egg remains in the pinnule.

Professor Chubb states that there appear to him to be only two possible explanations: Either the discharge so frequently seen in the adult egg represents the last which occurred during the waning activity of the nucleolus, and which has since remained unclianged, or, and he thinks this the more probable explanation, the discharge in the adult egg is caused by the contraction of the nucleolus at the moment of fixation, the activity of the nucleolus during the closing period of the egg's growth being insufficient to provide the necessary pressure for a normal discharge of the gradually accumulating material. He has, however, never seen the appearance of a discharge of spherules from the nucleolus of the still growing oöcyte after yolk formation has commenced, and he is unable to do more than to suggest that this restriction of the contracting influence of the fixing reagent to the nucleolus of the adult egg may be due to a change in the physical properties of the cortical layers of the nucleolus after the activity of the latter structure has ceased.

The occurrence of discharged nucleolar spherules in the young oöcyte long before there is any obvious indication of the formation of spherules on the chromatin threads, their almost invariable spatial relation to the destained area of the nucleolus, and their uniform beharior, irrespective of the nature of the fixing reagent, distinguish these spherules sufficiently clearly from those on the chromatin threads. The fact that the nucleolar spherules are less frequently met with in later than in earlier stages indicates that they do not accumulate as such within the nucleus. Equally certain is it that they do not dissolve in the caryolymph, for there is never, at any period, any trace of nucleolar spherules in course of dissolution in the nucleus, although if such a process occurred it would necessarily occupy some time. There remains, therefore, as the only possible fate for the discharged nucleolar spherules, an immediate passage to the cytoplasm.

In addition to the persistence in the caryolymph of the last nucleolar discharge, the completion of yolk formation is marked by another phenomenon in connection with the nucleolus, namely, the gradual formation, on the surface of this structure, of one or more lens-shaped accumulations.

As its first appearance this accumulation is extremely thin, tapering away imperceptibly at its edge on the nucleolar surface. It gradually increases in size, becoming more and more hemispherical as it does so, until it may equal more than one-third the total bulk of the nucleolus. Its staining affinity generally resembles that of the destained area of the nucleolus, being usually weakly basophile but showing considerable affinity for the acid stain. The substance of the accumulation is always homogeneous in its staining reactions; it never shows a destained area, and it is never vacuolated. The absence of any connection between nucleolar 
activity and the formation of the accumulation is indicated by the complete absence of any spatial relation between this structure and either the discharged spherules in the nucleus or the destained area within the nucleolus. Moreover, the simultaneous appearance of the accumulation and completion of yolk formation is also accompanied by a complete cessation of the growth of the nucleolus, a growth which. as already noted, shows at earlier stages a remarkably constant relation to that of the egg. The inactivity of the nucleolus during the formation of the accunulation is further shown by the fact that nucleoli with a large amount of this accumulated material on their surface and, therefore, presumably fixed some considerable time after the completion of yolk formation, do not appear to possess less of the basophile cortical substance than do those in which the accumulation is absent.

The approximately spherical form of the nucleolus and its steady growth, irrespective of the facility with which it parts with the basic stain, indicate that the whole of the nucleolus is formed of a ground substance continuous alike through the basophile and acidophile regions. The fact that the occasional departures from the spherical form are invariably produced by that portion of the nucleolar surface in contact with the destained area, together with the fact that it is from this region the nucleolar discharge invariably takes place, indicate that the capacity for tenaciously retaining the basic stain is accompanied by a considerably firmer consistency of this portion of the nucleolar substance. As the loss of this reaction proceeds from within outward the ontermost lavers of the deeply basophile cortex must possess a considerably firmer cousistency than those lying further inward. This condition readily explains the entire absence of any indication of a discharge taking place directly to the exterior from the racuoles in the cortical region, however peripherally they may be placed, and lends support to the assumption that the vacuoles discharge instead into the more fluid substance of the faintly staining area, an assumption which is still further suggested by the periodical discharge taking place from the latter.

The products of the activity of the nucleolus, the formation of which is accompanied by the appearance of vacuoles in the basophile region and the loss of this basophile reaction, accumulate, therefore, within the nucleolus, the internal pressure of which at the same time steadily increases. When this internal pressure reaches a certain point the firmer cortex of the nucleolus is ruptured at the point of least resistance-that is, at that point on its surface to which the more fluid faintly staining area happens to approach most closely. When this rupture of the cortex occurs the accumulated products of nucleolar activity, partly in the form of a clear fluid, partly as basophile spherulcs, are discharged from all parts of the nucleolus through the less resisting, more faintly staining, internal region to the exterior.

The accumulation of products of nucleolar activity which must be present within the nucleolus prior to its discharge is not very evident. The fluid portion is probably contained within the frequently numerous vacuoles in the cortical region of the nucleolus. Only rarely, however, are spherules similar to those discharged to be seen within the nucleolus. This is to be expected, for the spherular form of the discharged material is as much due to the fluid character of the surrounding 
caryolymph as to the physical consistency of the discharged material itself, and when this is formed within the nucleolus it is surrounded by the relatively firm nucleolar substance and does not, therefore, assume the spherular form. In all those rare cases in which Professor Chubb saw spherules within the nucleolus similar to those outside they were each contained within a vacuole and were, therefore, here also surrounded by a fluid medium.

In the great majority of cases we should expect the basophile substance resulting from the nucleolar activity to form an irregular zone on the inner side of the as yet unaltered cortical region, between this and the faintly staining area, and only to assume a spherular form as it is discharged into the more fluid caryolymph. There is some evidence to slow that this is the actual mode of accumulation of the substance of the future spherules.

The extent of the faintly staining area shows no gradual increase in size with the growth of the egg, eggs of the same age and in the same pinnule possessing nucleoli sometimes deeply stained and sometimes greatly destained, even in the same section. On the other hand, the growth in bulk of the nucleolus does proceed perfectly steadily, and shows a striking correlation with the growth of the egg. It is evident, therefore, that while the faintly staining ground substance of the nucleolus steadily increases in bulk, the amount of basophile substance present in the nucleolus fluctuates greatly, sometimes gaining, sometimes losing, on the nucleolar activity.

Since it is only in the earlier stages of its growth that the nucleolus shows any spatial relation to the chromatin, and only very exceptionally at any period shows any relation to the nuclear membrane, it follows that the caryolymph must be the immediate source for both these nucleolar substances.

This source for the basophile substance is very clearly indicated by the appearance often seen in material in which the nucleolus readily parts with the basic stain. the faintly stained nucleolus being studded all over with minute basophile areas, each flush with the nucleolar surface externally, and projecting irregularly into the faintly stained ground substance of the nucleolus internally. This appearance would seem to suggest that the basophile substance enters the nucleolus by diffusion through the nucleolar surface. Osmotic diffusion through the surface layers of the nucleolus is also suggested by the mechanism of discharge already described.

The caryolymph as the immediate source for the ground substance of the nucleolus is convincingly shown by the formation of the nucleolar accumulation on the completion of yolk formation, for, as we have seen, this accumulation not only strongly resembles the faintly staining area of the nucleolus in its staining reactions, but its formation synchronizes with the cessation of growth on the part of the nucleolus. It is impossible, therefore, to avoid the conclusion that this accumulation represents material to which the steady increase in size of the nucleolus was formerly due, and which, now that the nucleolar activity has ceased, can no longer be incorporated in the body of the nucleolus.

According to Professor Chubb the formation of the nucleolar accumulations on the cessation of nucleolar activity would seem to suggest that, in so far as this 

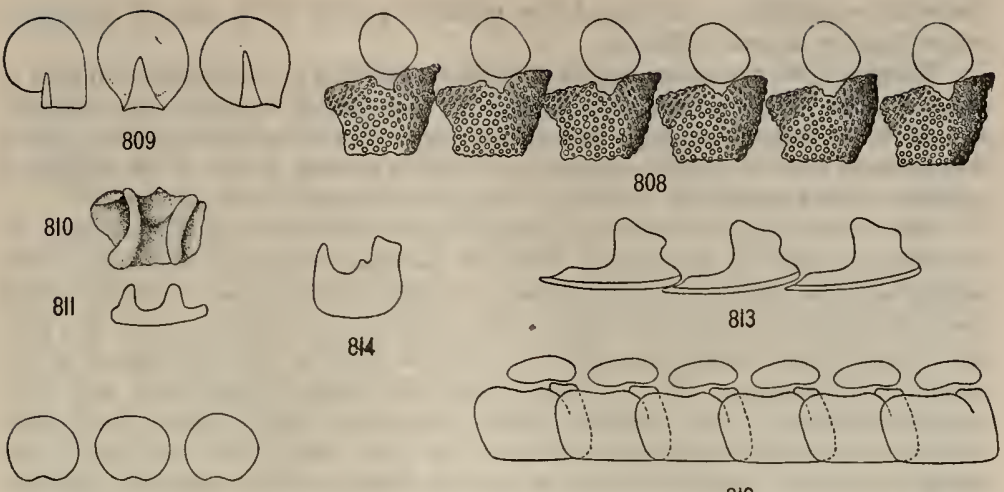

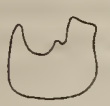

814

$8: 5$

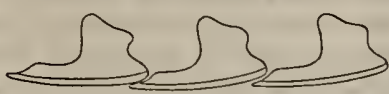

813

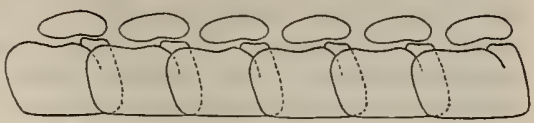

812
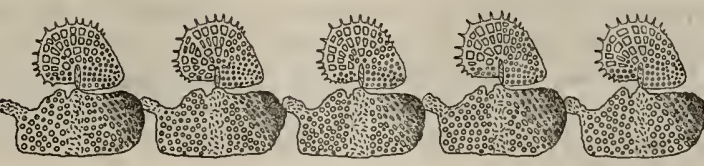

816

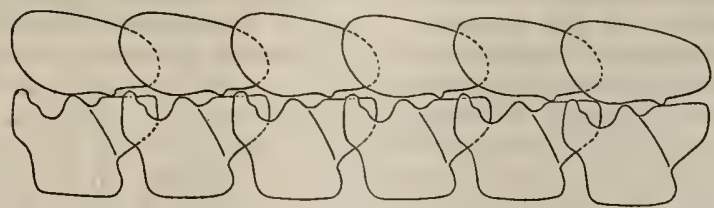

817

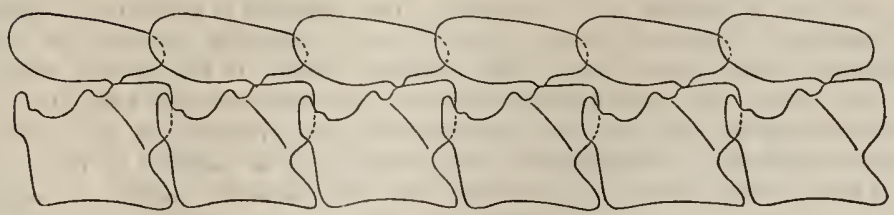

818

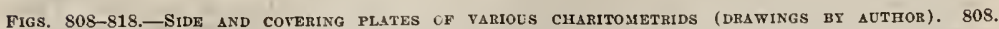
STROTOMETRA hEPBURIANA. 809. SAME, THRE COVERING PLATES TIEWED FROM INTERIOR. 810. SAME, INTERIOR VIHW OF SIDI PLATE. 811. SAME, DORSAL VIEW OF SIDE PLATE. 812. ASTEROMETRA MACROPUDA. 813. Same, dorsal ends of three side plates. S14. Same, ventral view of side plate. 815. SaMe, three covering plates. 816. Glyptometra tuberosa. 817. Perissometra shlenh. S18. Samp. ALL $\times 100$. 
nucleolar constituent is conccrned, the mode of growth is by passive deposition rather than by osmotic diffusion.

There are two points concerning the young nucleolus to which attention may be directed: The first concerns its position. In the resting oögonium the nucleolus appears to be always peripheral in position, whereas in the actively growing oöcyte it is for some time invariably central-a fact which scarcely points to the peripheral position of the nucleolus as denoting a cytoplasmic origin for this structure.

The second point concerns the close relation which the young nucleolus invariably shows to the chromatin. Both the peripherally placed nucleolus of the resting oögonia and the centrally placed nucleolus of the actively growing oöcyte are surrounded by a portion at least of the chromatin. In the oögonium this relation is maintained until preparation for mitosis leads to the withdrawal of the perinuclear chromatin. In the young oöcyte the gradual subdivision and more equal distribution of the chromatin which accompanies the increasing metabolism of the growing cell more speedily leads to the same result. The fact that in the young oöcyte, at a stage which can be but very little removed from the anaphase stages of the preceding oögonial division, there should already be a relatively large nucleolus surrounded by a thin layer representing the whole of the chromatin of the cell emphasizes the importance of this relation between the nucleolus and the chromatin. It is evident, however, that though this arrangement may facilitate, it can not be essential to, the formation of the nucleolar substance, for in the growing oöcyte the nucleolus more than trebles its diameter after it has lost all direct relation with the chromatin.

On the other hand, the later behavior of the nucleolus in the ö̈cyte of Antedon offers considerable evidence of a highly suggestive character relative to the significance of this structure in the cell metabolism. One of the most striking morphological features which the nucleolus invariably presents is its spherical, or approximately spherical, form-a form in which the minimuin surface area is associated with maximum bulk. In this respect the nucleolus offers an instructive contrast to the chromatin, where it is an obvious endeavor to assume a form with as great a superficial area as possible. It is impossible not to conclude that this difference between the nucleolus and chromatin indicates the nature of the difference in their physiological significance; that while the chromatin is active, and probably selectively so, taking what it requires from the caryolymph, the nucleolus, at least in so far as getting fresh material is concerned, is passive, the nucleolar constituents being deposited on, or diffusing through, its surface without any effort on the part of the nucleolus itself. It has already been seen that the further changes which the nucleolar substance undergo take place most actively within the interior of the nucleolus and give no indication that a reaction between the nucleolar substance and the caryolymph is essential to the process.

Although the immediate source for both the nucleolar constituents must be the caryolymph, yet their very different behavior when nucleolar activity ceases would seem to indicate their derivation from distinct ultimate sources. There are three possible sources for these nucleolar constituents, namely, the chromatin, 
the cytoplasm, and the nutritive plasma of the parent organism by which the egg is bathed.

Apart from the improbability of the nutritive plasma, as we understand it, exercising a selective action in depositing food material onto the nucleolus, this source for the ground substance of the nucleolus is excluded by the remarkably constant relation which the size of the nucleolus always shows to the stage of the egg's growth, a relation very difficult to explain if the nucleolus passively receives the bulk of its substance directly from a source outside the cell. On the other hand, the cytoplasm is equally excluded as a source for the ground substance of the nucleolus, for this substance continues to be deposited on the surface of the nucleolus after the completion of yolk formation, at a time, therefore, when practically the whole of the cytoplasm has been converted into metabolically inactive yolk spherules. There remains, therefore, only the chromatin as the source for the ground substance of the nucleolus, a source already indicated by the intimate relation this structure shows to the nucleolus in the young oöcyte, in which the as yet relatively inactive metabolism permits of a massed arrangement of the chromatin.

The origin of the basophile constituent of the nucleolus presents more difficulty. There is reason to believe that the activity of the chromatin is continued for some time at least after the simultaneous completion of yolk formation and cessation of nucleolar activity. The only structure, therefore, which in its beharior shows a direct temporal relation to the cessation of nucleolar activity is the cytoplasm. On the completion of yolk formation there is not only an abrupt cessation of nucleolar activity, but there is also a sudden failure in the supply of the basophile nucleolar constituent, a fact which certainly points to the cytoplasm as the source for this substance.

It is not, however, only the completion of yolk formation but also the complete cessation, of all cytoplasmic activity, which coincides with the termination of nucleolar activity. 'The production of the basophile nucleolar substance shows no relation to the commencement of yolk formation, but is produced continuously throughout the growth of the egg. This substance must be the result, therefore, not of yolk formation itself but of a much more fundamental vital process of the cytoplasm, a conchusion which is supported by the fact that we already have, in the peripheral spherules presently to be described, an obvious by-product of the actual process of yolk formation.

That the nucleolus deals with the waste products of cytoplasmic activity rather than with the nutritive material in the caryolymph is also indicated by the ultimate fate of the discharged material described below.

The nucleolus of Antedon would thus appear to be derived from the chromatin and to function as the excretory organ of the cell, the waste products of cytoplasmic activity undergoing their final clianges within its substance and being discharged, now, presumably, inert and harmless, into the cytoplasm, where they slowly dissolve.

It has been shown that throughout the growth of the oöcyte the nucleolus periodically discharges dceply basophile spherules into the caryolymph. It has 
also been shown that, as there is no accumulation of these spherules in the nucleus, nor any sign of their absorption, either by the caryolymph or by the chromatin, it is probable, from evidence provided by the nucleus alone, that these spherules pass at once into the cytoplasm.

Basophile spherules commence to appear in the cytoplasm even before the chromatin has lost its radial relation to the nucleolus, and they occur in increasing numbers as growth proceeds until the formation of the definitive yolk nucleus in eggs with a nucleolus of from $7 \mu$ to $8 \mu$ in diameter. The spherules are found with all fixing reagents, and are always deeply basophile, even after prolonged extraction. The individual spherules are sharply defined and vary in size from $0.5 \mu$ to $1.5 \mu$, or even occasionally $2 \mu$. 'They do not increase in size with the grow th of the egg, the few spherules first to appear in the young oöcyte being as large as the more numerous spherules at later stages, and very small spherules are rare at any stage. The spherules are only occasionally found isolated in the cytoplasm; far more usually they are associated together in sinall clusters of from three to six, irregularly disposed around the nucleus and lying either in actual contact with the nuclear membrane or at some little distance from it. They are seldom, however, found far from the nucleus, and are rarely, if ever, found peripheral in position. The spherules of any one cluster vary in size within the limits already noted, and it is rare to find a group consisting solely of very small spherules.

It has already been noted that, compared with the period intervening between successive discharges, the time actually occupied by the spherules in passing from the nucleolus into the cytoplasm must be very brief, and that this is ample explanation for the rarity with which this process is seen. The few instances in which the passage outward has coincided with the moment of fixation in the still growing oöcyte have already been referred to in considering the behavior of the nucleolus.

In addition to the spatial relation which the nucleolar spherules are frequently seen to bear to those in the cytoplasm, the nucleolar origin of the latter is also indicated by their arrangement in the cytoplasm. It is difficult on any other supposition to account for their arrangement in small groups, irregularly scattered around the nucleus; and this arrangement, together with the fact that they are never found in a peripheral position, and that there are, at this stage of the egg's growth, no cells in relation to the egg's periphery, exclude the possibility of an extracellular origin. The fact that the spherules are of much the same size in the youngest as in the older oöcytes and that groups of very small spherules are rarely, if ever, seen, exclude both a cytoplasmic origin and a mode of origin by diffusion through the nuclear membrane.

It should also be noted that the groups in the cytoplasm show no relation to the distal ends of the radially arranged chromatin strands. and moreover continue to appear after this arrangement of the chromatin has been lost.

The basophile spherules, therefore, which are discharged at intervals in batches from the nucleolus, pass at once into the cytoplasm, and in the young oöcyte form scattered groups around the nucleus. 
In the young oöcyte the nucleolar spherules in the cytoplasm increase in number with every discharge from the nucleolus, but otherwise remain unchanged. The cytoplasm also at this period shows no other change than a considerable increase in bulk and a very slight increase in basophile staining reaction. Sooner or later, however, and alawys by the time the nucleolus measures $8 \mu$, in eggs, therefore, of from $20 \mu$ to $30 \mu$ in diameter, a portion of the hitherto uniformly staining cytoplasn commences to retain the basic stain. This more deeply staining region of the cytoplasm is at first extremely irregular and diffuse in character and nearly always stands in relation to some, at least, of the groups of nucleolar spherules, and the appearance thus presented strongly suggests that a diffusion is taling place of the deeply staining substance of the nucleolar spherules onto the surrounding cytoplasm. During this diffusion the sharply marked and deeply stained nucleolar spherules become more and more scarce, and at the same time the more deeply staining region of the cytoplasm gradually loses its irregular and scattered condition, becoming instead compact and regular, and assumes the form of a faintly staining but clearly defined concavo-convex, lens-shaped body, closely applied to, though never in actual contact with, the surface of the spherical nucleus and measuring 25 $y_{\text {. to }} 30 \mu$. in diameter and from $8 \mu$ to $10 \mu$ in tichkness. This is the definitive yolk nucleus.

That the more deeply staining area of the cytoplasm, and consequently also the definitive yolk nucleus, does not arise by a simple aggregation of the nucleolar spherules is shown by the difference in staining reaction of the yolk nucleus and of the nucleolar spherules. Professor Chubb gives a figure representing an egg fixed in sublimate showing two groups of nucleolar spherules which have only just come into relation with the stainable area; their deeply basophile character and sharp outline offer a striking contrast to the somewhat diffuse and less deeply stained spherules of the more deeply staining cytoplasmic area. This contrast was still more striking with material fixed with other reagents; thus with Hermann, or with acetic bichromate, the nucleolar spherules are, as with the sublimate, deeply stained and clearly defined, while the texture of the yolk-nuclear area, like that of the rest of the cytoplasm with these reagents, is finely granuloreticular in character, only differing from the surrounding cytoplasm in its greater affinity for the basic stain.

Although the accumulated nucleolar spherules in the cytoplasm greatly diminish in number during the formation of the yolk nucleus, and may even be entirely absent on the completion of this process, they nevertheless are still occasionally to be seen in eggs in which a definitive yolk nucleus is present. The rapid increase in staining capacity shown by the yolk nucleus soon after its appearance, and which is described below, is in all probability to be explained by this incorporation of additional nucleolar spherules. At later stages, as the nucleolar discharges become more and more infrequent, spherules in the cytoplasm are more rarely met with, and are never found in contact with the yolk nucleus after this has lost its intensely basophile character, although even in the adult egg groups of partially dissolved nucleolar spherules are occasionally to be seen embedded in the yolks. 
When the stainable area first assumes the regular form of the definitive yolk nucleus it is, as already noted, much less deeply basophile than the original nucleolar spherules from which it has been derived. This faintly staining condition of the yolk nucleus does not last long, and in eggs very slightly, if at all, larger, the yolk nucleus is as deeply stained as the original spherules. Accompanying this increase in staining capacity on the part of the yolk nucleus there is a corresponding, though slower and much less strongly marked, increase in the basophile reaction of the cytoplasm.

That the basophile reaction of the yolk nucleus is, in the main at least, due to other causes than those determining the corresponding reaction of the cytoplasm has already been suggested by the mode of origin of the yolk nucleus. It is still further indicated by considerable differences in this staining reaction in these two regions of the cytoplasm; for not only does the yolk nucleus stain deeply before there is any basophile reaction on the part of the general cytoplasm, but the basophile reaction of the yolk nucleus is only very slightly influenced by the character of the fixing reagent, while that of the cytoplasm varies greatly, and with some reagents-for instance, acetic bichromate-may be entirely absent. Moreover, even in material in which the basophile reaction of the cytoplasm is most marked, extraction always greatly destains the latter without appreciably affecting the appearance of the yolk nucleus.

As the yolk nucleus acquires its deeply basophile character it moves away from the surface of the nucleus, becoming rounder and shorter as it does so, and assumes a position midway between the nucleus and the egg periphery. At this stage the yolk nucleus and, after sublimate fixation, the cytoplasm also, has reached its maximum basophile reaction. Yolk formation now commences, and very soon after this, while yolk formation is still only faintly indicated, the yolk nucleus assumes a peripheral position close to, though not as a rule in actual contact with, the egg periphery. At the same time it loses its regular form and rounded contour, acquiring instead a form roughly determined by the nature of the egg periphery and a somewhat irregular outline. At this period, and while yolk formation is as yet mainly confined to the egg periphery, the yolk nucleus shows a considerable increase in size and accompanying loss of staining capacity. As yolk formation proceeds, the yolk nucleus retains its peripheral position and appears to spread out over the ever-increasing surface of the egg, becoming considerably thinner as it does so, always, however, covering the same proportional area of the egg periphery.

Neither during its disappearance nor during the earlier stages of yolk formation does the yolk nucleus ever show the slightest indication of undergoing a granular disintegration. Its outline, though never showing the even character it presented prior to the commencement of yolk formation, is never so irregular as to be indefinite, and as soon as the loss of staining capacity has proceeded sufficiently far it is seen that the structure of the yolk nucleus in all respects resembles that of the surrounding yolk, the only difference being the ever-decreasing basophile reaction, and it is evident that yolk formation has proceeded in the region of the cytoplasm constituting the yolk nucleus exactly as in other regions 
of the cell. During its actual disappearance the yolk nucleus is frequently represented by several detached areas, but in all such cases these regions are so placed with reference to each other as to indicate that they are not detached fragments, but persisting regions of the original yolk nucleus, the unequal disappearance of the last traces of the basophile reaction having led to their isolation. Very shortly after this stage the yolk nucleus disappears from view altogether, and no trace of it is ever to be seen on the completion of yolk formation.

In the above description of the behavior of the yolk nucleus no mention has been made of a peculiar feature in connection with this structure which is of very frequent occurrence. After most fixing reagents the yolk nucleus is accompanied, usually on its outer side, by a clear space in the cytoplasm. On the first appearance of the definitive yolk nucleus, while this is still faintly staining, this space is absent, the cytoplasm in the immediate neighborlıod of the yolk nucleus in no way differing from the rest. This condition is maintained throughout the subsequent history of the yolk nuclens in material fixed solely in a saturated solution of sublinate, but after most other fixing reagents a clear area appears on the outer side of the yolk nucleus and grows step by step as the latter increases in staining capacity, and only finally disappears shortly before the disappearance of the yolk nucleus itself, slowly decreasing in extent as the latter loses in staining capacity. In the later stages the clear space, like the yolk nucleus itself, is less regular in form, and though usually or mainly on the outer suface of the yolk nucleus, may occasionally completely surround it, or even be confined to its inner side, though this latter condition is rarely seen.

The gradual growth of the clear space, hand in hand with the increase in basophility of the yolk nucleus, and its disappearance with the decline of this reaction-that is, its coincidence with the period of apparent greatest activity of the yolk nucleus-seems at first sight to suggest that the clear area stands in some direct physiological relation to the activity of the yolk nucleus, and represents an accumulation of noncoagulable fluid in the living egg. There are, however, several difficulties in the way of such an interpretation.

In the first place, the space is entirely absent in sublimate fixed material, though present in material taken from the same individual, but fixed with an acid reagent. The absence of the clear space in sublimate material can not be due to the great coagulating power of this reagent having coagulated the fluid accumulation, for not only would such a well-marked segregation of material so different in constitution from the rest of the cytoplasm show some difference in staining capacity from the latter, a difference of which there is no trace, but there is frequently in this material no room for such an accimulation on the outside of the yolk nucleus.

The clear space, therefore, is wholly unrepresented in sublimate material, and its presence in other material must be an artifact due to shrinkage during fixation. Indirectly the absence of the clear space in sublimate material is due to the greater capacity of this reagent for fixing simple proteids in the absence of a free acid; for the coagnlation of these waste or metaplastic substances with which the yolk nucleus and general cytoplasm are loaded prevents the shrinkage 


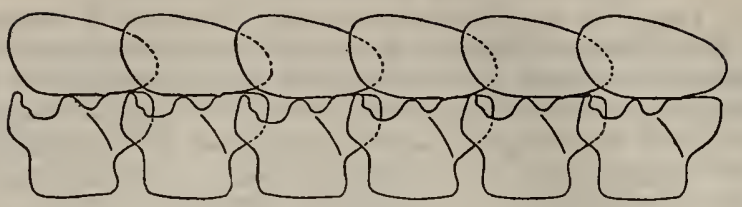

819

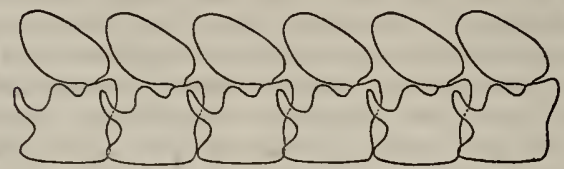

820
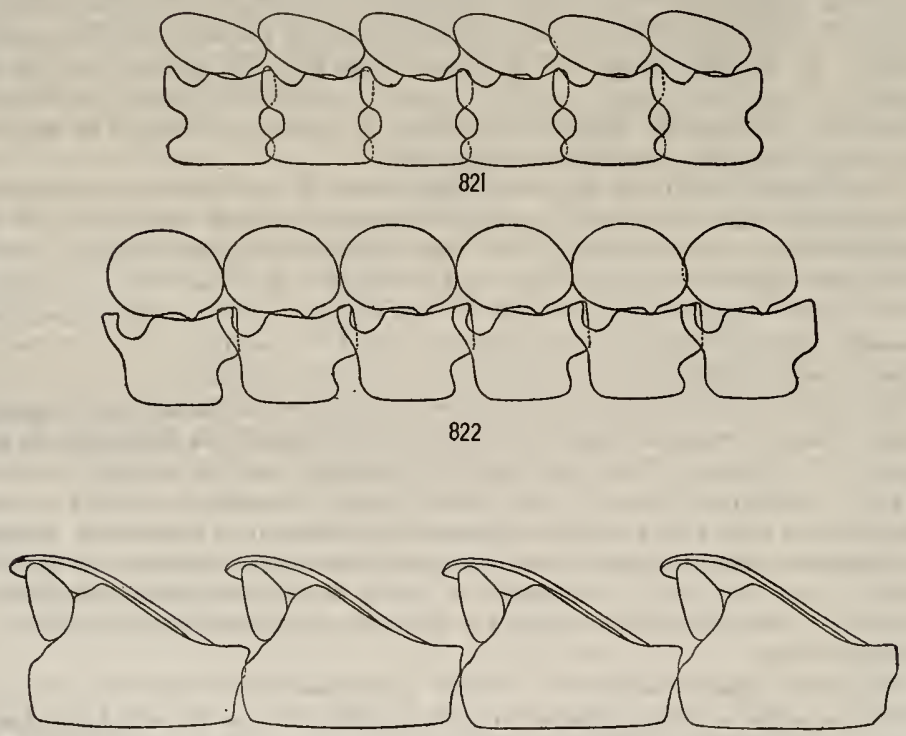

823

Figs. 819-823,-Side and covering plates of variods comatulids (DRAwings By aUthor). 819. Perissometra selene. 820. Sthnometra cristata. 821. Same. 822. Same. 823. Thalassometra VILLOSA. ALL $\times 100$. 
which produces this space in other material. That this is the explanation of the absence of the clear space in sublimate material is very clearly shown by the fact that even in acid-fixed material there is no clear space accompanying the yolk nucleus when this structure is faintly stained, and when it is, therefore, presumably less heavily loaded with noncoagulable material.

In the. second place, both the clear space and the yolk nucleus of the older oöcytes have lost the regular form they possessed in earlier stages, and it is then frequently seen that the outline of the clear space corresponds exactly with that of the yolk nucleus, a correspondence which can only be explained by supposing that the two surfaces were originally in contact and have been separated by shrinkage and is wholly incompatible with the supposition that the space is caused by an accumulation of fluid material in the living egg. This interpretation of the space as a split due to shrinkage is also supported by the presence, on the surface of the yolk nucleus facing the space, of numerous frayed strands of cytoplasm. The extensive changes in the form and size of the yolk nucleus make it impossible to ascertain by direct measurements, on acid-fixed and sublimatefixed material from the same individual, to what extent the shrinkage of the yolk nucleus is responsible for the clear space; but the fact that there is no great difference in size between yolk nuclei in oöcytes of about the same age, the one accompanied, the other unaccompanied, by a clear space, shows that this contraction can not be a very extensive one, and an explanation other than the condition of the yolk nucleus must be found for the very large clear space often present. The explanation is given by two figures in Professor Chubb's paper which clearly show that the contraction of the egg cytoplasm as a whole may often be largely responsible for augmenting the size of the clear area. In one the yolk nucleus is accompanied by a clear space of a size, and in this particular case of a shape, wholly inconsistent with the assumption that it is due entirely, or even mainly, to the contraction of the yolk nucleus. In the other the general contraction of the cytoplasm has occurred on the side of the egg remote from the yolk nucleus and shows that the clear area as seen in the first is due to the combined contraction of both yolk nucleus and cytoplasm.

The clear space which often accompanies the yolk nucleus, usually on its outer side, is therefore an artifact and is due to the shrinkage which results from the inability of the acid-fixing reagent to coagulate the waste and metaplastic substances with which the yolk nucleus and general cytoplasm are loaded. When the yolk nucleus is faintly stained, as on its first appearance and shortly before its disappearance, at times, therefore, when it is less heavily loaded with these substances, it is unaccompanied by a clear space in any material.

It is not necessary to assume for the yolk nucleus an active participation in the cell metabolism in order to explain the changes in form and position which this structure undergoes during yolk formation, for these changes are perfectly in accord with the assumption that they are entirely passive in character and due to the gradual change in the physical consistency of the cytoplasm which precedes 
yolk formation and to the great growth of the cytoplasm by which this latter process is accompanied.

The progressively increasing basophile reaction of the cytoplasm which precedes yolk formation is due to the gradual loading of the cytoplasm with material supplied by the chromatin and passed out from the nucleus by diffusion through the nuclear membrane, the material so supplied being subsequently utilized in yolk fornation. It is not unreasonable to suppose that this progressive change in the chemical constitution of the cytoplasm is accompanied also by a progressive change in its physical consistency, a change resulting either in an increased or decreased viscosity. The assumption that the change is in the direction of a more fluid consistency is the one which seems most easily correlated with the changes in the yolk immediately to be described.

In the young egg the nucleolar spherules lie stationary and unchanged, slowly accumulating in the faintly staining cytoplasm, the viscid nature of which is indicated by the arrangement of the spherules in small clusters, each representing a discharge from the nucleolus, and each having penetrated only a little way into the cytoplasm. With the appearance of the basophile reaction and, as Professor Chubb assumes, more fluid consistency of the cytoplasm, the nucleolar spherules can no longer retain their original character, and the substance of which they are composed diffuses onto the surrounding cytoplasm. At first the areas of the cytoplasm so affected are scattered and diffuse in character. Gradnally, however, they come together and assume a form in contact with the nucleus, which is entirely in agreement with the assumption that capillary laws constitute the sole morphogenic factor, the presence of the substance of the nucleolar spherules having so modified the physical character, and hence also the surface tension, of the region of the cytoplasm which bears it, as to give it a physical individuality of its own.

By the continued change in the physical consistency of the cytoplasm which accompanies the increase in its basophile reaction, and by the yet further addition of nucleolar substance to the yolk nucleus, the difference in surface tension between these two regions of the cytoplasm is still further augmented, and the yolk nucleus, leaving the surface of the nucleus, assumes a more compact and rounded form midway between the nucleus and the egg periphery, often, indeed, being almost in contact with both.

Yolk formation now commences, and as this progresses the coarsely alveolar structure it produces causes the cytoplasm to lose much of its original semifluid consistency. Capillary forces are therefore no longer able to exert the influence they formerly possessed in maintaining the regular shape of the yolk nucleus, and the smooth contour of the latter gives place to a somewhat irregular outline.

During the actual process of yolk formation there is a rapid and very considerable increase in the bulk of the cytoplasm, the diameter of the egg being often more than quadrupled during the process. As the yolk nucleus represents an area of the cytoplasm only differing from the rest by being infiltrated with the substance of the nucleolar spherules, it also should show an increase in bulk corresponding to that of the whole egg. This increase in the size of the yolk nucleus 
does actually occur in the earlier stages of yolk formation, but at a later stage it is masked by the great extension and thinning out of this structure at the egg periphery. If the expansion of the cytoplasm during yolk formation were due to the equal and simultaneous expansion of all its parts, then the form and position of the yolk nucleus toward the close of yolk formation should be approximately similar to that seen in earlier stages, and some other cause than the simple increase in bulk of the cytoplasm would have to be found in order to account for the peripheral position and attenuated form which this structure invariably shows at this stage. But the increase in bulk of the cytoplasm-in other words, yolk formation-as has already been shown, is not uniform all over the cytoplasm, but, apart from its first commencement, proceeds from without inward. The increase in bulk thus caused in the peripheral layers of the cytoplasm, being unaccompanied by any great increase in the superficial area of the egg, since the expansion is confined for the present solely to the peripheral layers, results in a considerable increase in thickness and only a slight superficial extension of this portion of the yolk. It is at this stage that the yolk nucleus shows the increase in size already referred to. At a later stage, however, when yolk formation is general all over the interior of the egg, there is a very considerable increase in the size of the egg as a whole, but the peripheral layers of the yolk, having finished their expansion, can only keep pace with this increase in the superficial area of the egg by superficial extension. In the yolk nucleus we have a region of the yolk in which these changes can be actually observed, the thinning out and superficial extension which this structure shows being merely that to which the whole of the peripheral portion of the cytoplasm is at this period subjected. As we should expect from this process, the yolk nucleus approximately covers the same proportional area of the egg surface at all stages of yolk formation.

There only remains to be explained why the yolk nucleus should always lie at the periphery of the cell at the commencement of yolk formation, for it is evident that it is primarily to this position that the changes in the form described above are due. The assumption, however, that the outward migration of the yolk nucleus at the commencement of yolk formation is also passive and due to general changes in the surrounding cytoplasm does not offer much difficulty. During yolk formation we have a constant migration to the periphery of granules or droplets arising in the body of the cytoplasm. As it is impossible to assume that this outward migration is due to the activity of the droplets themselves it must be concluded that there are forces in operation in the egg during yolk formation which tend to send formed bodies to the periphery. These forces may be of the nature of centrifugal diffusion currents, or, as perhaps is more probable, are simply the result of an effort on the part of the still metabolically active cytoplasm to remain in touch with the nucleus. In either case the presence of the nucleolar substance on the yolk-nuclear area would serve to bring this structure under the influence of such forces, though the fact that the yolk nucleus is itself, in part, composed of ordinary cytoplasm would considerably weaken their action. This would explain why the yolk nucleus, though always more or less peripheral in position during yolk formation, is never quite so; it never competes with the 
peripheral spherules of the yolk already referred to and yet to be described for a position in actual contact with the vitelline membrane.

Thus the absence of any participation by the yolk nucleus of Antedon in the cell metabolism is indicated both by the origin of this structure as a region of the cytoplasm onto which has diffused a portion only of the material intermittently discharged from the nucleolus throughout the growth of the oöcyte, and by the fact that its subsequent behavior can be entirely explained as due to the influence on a semifluid mass of the varying physical conditions obtaining in the cell.

The entirely fortuitous manner in which the yolk nucleus arises in Antedon offers a ready explanation of a hitherto puzzling fact, that though this structure is of constant occurrence in those forms in which it occurs at all, it is nevertheless frequently entirely absent in closely allied species. For it is obvious that very slight changes in the constitution of the yolk, or in the mode of its formation, might suffice to remove the conditions under which the diffusion described above could alone take place.

In the young oöcyte, previous to the formation of the definitive yolk nucleus, the cytoplasm is faintly acidophile, showing little or no tendency to retain the basic stain. At about the time of the appearance of the definitive yolk nucleus, however, the cytoplasm commences to show a distinct basophile reaction which steadily increases in intensity as the oöcyte grows, until yolk formation commences. The basophile reaction of the cytoplasm, therefore, first becomes marked in eggs of from $30 \mu$ to $40 \mu$ in diameter, in which the nucleolus measures about $8 \mu$, and in which the yolk nucleus is already deeply basophile. The reaction reaches its maximum in eggs of from $50 \mu$ to $60 \mu$ in diameter, in which the nucleolus measures $9 \mu$ to $10 \mu$, and gradually disappears as yolk formation progresses.

Unlike the yolk nucleus, the basophile reaction of which shows but little variation with different fixing reagents, the staining capacity of the cytoplasm varies greatly according to the fixing agent employed. The reaction is most marked in material fixed with a saturated solution of sublimate, the cytoplasm often being, with moderate differentiation, so deeply stained as to almost obscure the black yolk nucleus; greater differentiation will, however, always greatly destain the cytoplasm without appreciably affecting the appearance of the yolk nucleus.

After fixation with sublimate and acetic, the reaction of the cytoplasm is very similar, though slightly less intense, to that seen after sublimate fixation. In Hermann material, however, it is much weaker than with either of the above reagents, the eggs at the commencement of yolk formation staining a faint blue, but the yolk nucleus, though not so intensely stained as after sublimate fixation, is still deeply basophile. In material fixed with bichromate and acetic there is no indication whatever of a basophile staining reaction of the cytoplasm at the commencement of yolk formation, the eggs at this period actually staining more faintly than at any other time, but the yolk nucleus stains as intensely as in sublimate material.

The interest attaching to this variation in the staining capacity of the cytoplasm, according to the nature of the fixing reagent employed, as emphasizing the distinct nature of the causes determining this reaction on the part of the yolk 
nucleus and cytoplasm, respectively, has already been noted. This variation is also of interest in another connection. The progressively increasing staining capacity of the cytoplasm which preceded yolk formation may be assumed to be due to the gradual accumulation in the cytoplasm of material destined to be utilized later in the formation of the definite yolk spherules. The variation in the staining capacity of the cytoplasm in the fixed material would depend on the capacity of the reagent employed to fix these metaplastic substances. They are, as we should expect, well fixed in sublimate material, and almost as well fixed in sublimate acetic material. In acetic bichromate material, on the other hand, they appear to remain wholly unfixed and are washed out of the cell subsequent to fixation.

This varying action of the fixing reagent is accompanied not only by a corresponding variation in the staining capacity of the fixed cytoplasm, but also in its structural appearance. Thus in sublimate material, in which the basophile reaction is most strongly marked, the cytoplasm has the appearance of being composed of indefinite, closely packed, and in the earlier stages faintly staining, spherules. In material fixed with an acid reagent, on the other hand, the texture of the cytoplasm is that of a more or less open, fine, and deeply stained reticulum the strands of which are, however, so fine that the cytoplasm as a whole does not appear deeply stained. This reticular structure of the cytoplasm is found equally in material fixed with acetic bichromate, with which reagent the basophile reaction is almost, if not entirely, wanting. Such a behavior of the cytoplasm would seem to suggest that the reticulum shown after fixation with an acid reagent represents the living protoplasm of the original cytoplasm, from which the more or less unfixed metaplastic substances have been washed out subsequent to fixation.

In the adult egg the yolk consists of closely crowded spherules of two kindsthe yolk spherules proper, constituting the greater bulk of the cytoplasm, and the spherules which Professor Chubb calls the peripheral spherules, forming only a thin layer at the periphery of the egg.

The yolk spherules proper average from $1 \mu$ to $1.5 \mu$ in diameter and are always quite spherical in form. After fixation with sublimate or sublimate acetic they remain unstained by the hæmatoxylin and appear pale yellow in color and refringent. After fixation with acetic bichromate, on the other hand, the yolk spherules are deeply basophile, prolonged extraction only serving to destain their extreme peripheral portions. After fixation with Hermann's fluid, the spherules remain unstained, are nonrefringent, and vary in color from a pale yellow to a dark brown or even black. This coloration is due to the osmic acid in the fixing reagent and is entirely independent of staining or extraction, a fact which. together with their varying and irregular distribution, serves sharply to distinguish them from the peripheral spherules.

The peripheral spherules form a thin layer immediately within the vitelline membrane. The surface of the adult egg, and with it the inner surface of the egg membrane, is, in fixed material, almost invariably thrown into fine wrinkles, the peripheral granules being collected in the ridges so produced. In the younger 
eggs this surface wrinkling is absent, and here the peripheral spherules form an even layer.

The peripheral spherules of the adult egg differ from those of the rest of the yolk both in their size and in their staining reactions. Their size, though averaging that of the yolk spherules, shows a considerably greater range of variation, spherules measuring as much as $3 \mu$ across being occasionally met with. Their staining reaction, unlike that of the yolk spherules, shows no relation whatever to the mode of fixation, the spherules, after all reagents, being intensely stained with iron hæmatoxylin. This staining reaction shows a further peculiarity, for in all cases very slight differentiation is sufficient to destain these spherules totally, and the ease with which this takes place is irrespective both of the nature of the fixing reagent and the duration of its action. In sublimate, or sublimate acetic, material with moderate extraction the deeply stained peripheral spherules offer a striking contrast to the unstained yolk. With slightly greater extraction, insufficient, however, appreciably to affect the appearance of the other cell elements, the peripheral spherules are entirely destained, and they then appear as faintly yellow spherules of about the same size as the yolk spherules, but, unlike these, nonrefringent. In acetic bichromate material the peripheral layer can still be detected, though the strongly basophile character of the yolk spherules after the use of this reagent renders it much less conspicuous. Here again, however, slight differentiation, to an extent which has no appreciable effect on the appearance of the yolk, suffices totally to destain the peripheral spherules, which then form a relatively clear region between the deeply stained yolk and the egg membrane.

In Hermann material the peripheral spherules, when destained, can not be distinguished from the faintly yellow and nonrefringent yolk spherules; but with less differentiation they form with these as striking a contrast as in sublimate or sublimate acetic material. Occasionally, however, in the Hermann material, this contrast between the peripheral spherules and those of the rest of the yolk is more or less obscured by the arrangement of the more deeply colored yolk spherules. The destaining of the peripheral spherules is so sudden that, unless differentiation is carried out under the microscope, it is rare to obtain slides in which the peripheral layer is only partially destained. When, however, such a slide is obtained, it is seen that nearly all the still visible spherules are as large and as deeply stained as in less extracted slides, though present in far fewer numbers. Only here and there will a sphernle have been caught in the act of destaining, and then it is seen that, even in the case of the individual spherule, there is no gradual transition from an unstained to a deeply stained condition, for a part of the spherule still remains as deeply stained as before. while the rest, usually one side or the periphery, rarely the center, is already completely destained. There is no evidence, in the destaining of the peripheral layer during differentiation, that the more or less peripheral position of the spherules in any way influences the ease with which they part with the basic stain.

That the behavior of the peripheral spherules is not due merely to their peripheral position is also indicated by the fact that in the adult egg they are never so closely crowded as totally to exclude the ordinary yolk spherules from 


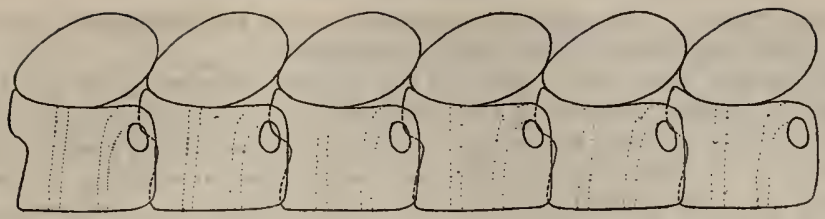

824
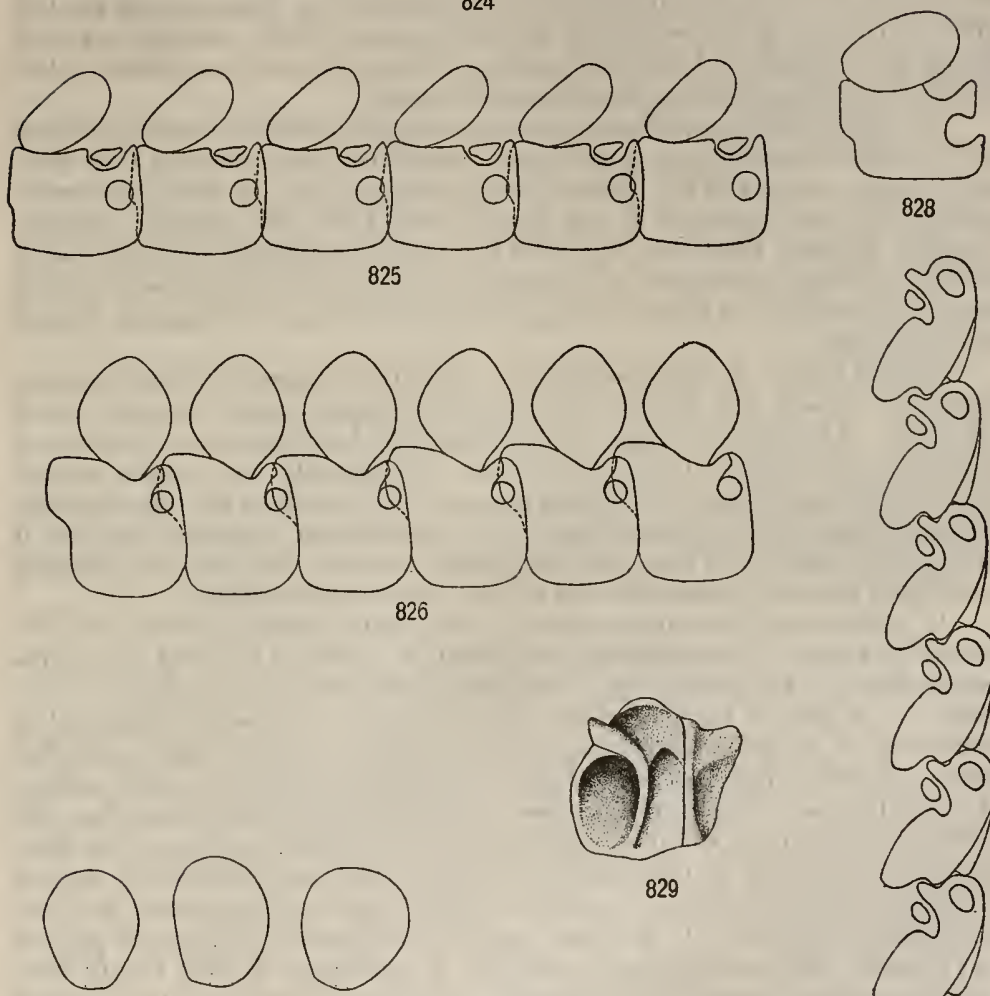

829

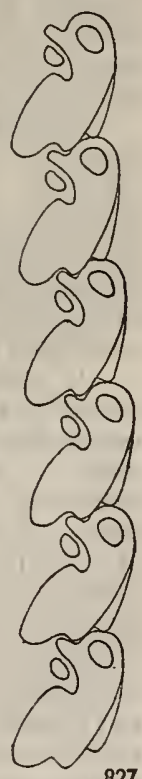

830

Figs. 824-830. - Side AND covering plaths of MoNachomftra Fragilis (DrawiNgs by aUthor). 824. Six

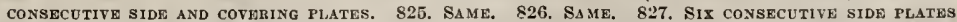
IN VENTRA. VIEW. 828. SiDE AND COVERING PLATE FROAI BASE OF A PINNULE, SHOWING ROUNDED INCISION INSTMAD OF PERFORATION, 829. INTERIOR VILF OF SIDE PLATE. S30. THREe COVERING PLATES VIETED FROM INTERIOR. ALL $\times 100$. 
this region, ordinary yolk spherules occurring among the peripheral spherules right up to the inner surface of the vitelline membrane.

It is therefore clear, from a study of the evidence afforded by the adult exg alone, that the peculiar behavior of the peripheral layer of spherules is not of the nature of a fixation artifact, nor in any way due to the peripheral position which they occupy; it is, instead, evident that they must differ considerably in constitution from the yolk spherules. Nor is there any evidence that a conversion of the one into the other is taking place, a conclusion fully in harmony with the fact that the number of the peripheral spherules remains fairly constant, not only during the closing period of yolk formation, but also after the completion of this process for as long as the egg remains in the pinnule.

The vacuolated a reas indicating commencing yolk formation remain unstained after all fixing reagents, and in sublimate or sublimate acetic material they stand out in strong contract to the intensely basophile cytoplasm. In acetic bichromate material the yolk spherules do not acquire their (with this reagent) intensely basophile character until some time after their first appearance. With Hermann's fluid the vacuoles in the areas of commencing yolk formation can be seen on their very first appearance as faintly yellow spherules standing out well against the pale blue cytoplasm.

Isolated groups of yolk spherules, of a size equaling those of the adult egg, are frequently present long before yolk formation becomes general over the whole cytoplasm. These isolated areas of precocious yolk formation show, however, no constant spatial relation to any of the other cell elements, and as soon as yolk formation becomes general this process proceeds most rapidly at the cell periphery, and as it extends from without inward the interspherular substance, and with it the basophile reaction of the cytoplasm, slowly disappear, the last traces forming a faint and irregular perinuclear area of ever decreasing dimensions.

In addition to this complete absence of any spatial relation between the yolk nucleus and areas of commencing yolk formation, it should be noted that in the earlier stages of this process the yolk nucleus still retains its regular form and shows as yet none of the appearances which have been previously interpreted as indications of its granular disintegration. Moreover, in later stages yolk formation proceeds within the body of the yolk nucleus exactly as in other regions of the cytoplasm. The only difference which the yolk nucleus shows from the surrounding cytoplasm consists in the more intense staining reaction of the interspherular protoplasm in this region, a reaction which renders the yolk nucleus visible long after all tendency to retain the basic stain has disappeared from the surrounding cytoplasm. In the later stages of yolk formation the faintly stained and irregular yolk nucleus exactly resembles in appearance the still faintly basophile perinuclear region of the cytoplasm, and in many cases only its peripheral position serves to distinguish it from the latter region.

As soon as yolk formation becomes general, the peripheral spherules make their appearance. As always, they are intensely basophile, but at this early stage they are extremely minute in size, far smaller than the yolk spherules, and are scattered sparsely over the body of the cell. At a slightly later stage the spherules 
are more numerous and show a considerable increase in size, though very small spherules are still abundant, and there is now a thin but distinct peripheral layer, formed mainly of the larger spherules, which lies immediately on the inner side of the vitelline membrane. From this time onward, as yolk formation progresses, the peripheral spherules continue to increase both in size and in number, not only in the body of the cell but also at the egg periphery.

As yolk formation approaches completion the spherulcs scattered over the cytoplasm decrease rapidly in number, though without showing any other change, and by the time the process is completed have almost or entirely disappeared from the body of the cell. At the same time, the peripheral layer increases considerably in depth and density until, on the completion of yolk formation, it presents the appearance Professor Chubb has already described in the preceding section and which is maintained for as long as the egg remains in the pinnule.

The behavior of the peripheral spherules just described clearly indicates that they arise in the cytoplasm during yolk formation as a by-product of this process, and gradually accumulate at the surface of the cell. They have thus nothing to do with the discharged nucleolar spherules which, in the adult egg. they so frequently resemble, and their very different behavior with fixing reagents, especially with sublimate solution, serves to distinguish them from the often contemporaneously appearing chromatin spherules. The entire absence of any spatial relation on the part of the peripheral spherules to the yolk nucleus, together with the behavior already described for this structure, equally exclude the latter as a possible source for these spherules. The frequency with which spherules, often described as originating by the granular disintegration of the yolk nucleus, have been made to take an active part in determining yolk formation necessitates considerable emphasis being laid on the mode of origin and fate of the peripheral spherules in Antedon.

Professor Chubb pointed out, when considering the significance of the nucleolus, that one of the reasons for excluding the raw food material dissolved in the caryolymph from the category of possible immediate sources for the nucleolar constituents was the strict correlation the size of this structure invariably shows with the phase of the egg's growth, a correlation very difficult to understand, in the absence of any indication of a reaction between the nucleolus and the caryolymph, if the growth of the nucleolus is due to the passive deposition on its surface of substance derived directly from a source outside the cell. When, however, we come to consider the behavior of the chromatin, we find that this structure, unlike the nucleolus, does show a very obvious endeavor, which is indicated by its subdivision and equal distribution, to increase the facilities for rcaction with the surrounding caryolymph. This behavior must indicate not merely that the chromatin depends, for the material on which it works, on substances dissolved in the caryolymph, for so does the nucleolus, but that these substances are not deposited, as such, on the chromatin, but have instead to undergo their initial changes under the direct influence of this cell structure while they are still dissolved in the caryolymph. In other words, the chromatin obtains its food material by active incorporation, whereas the nucleolus grows by passive deposition. The obvious source for the 
food material of the chromatin, which thus, unlike that of the nucleolus, shows so little relation to the requirements of particular cell structures, is the nutritive and oxygenated plasma of the parent organism which enters the tissues of the ovary from the surrounding sinus. In this connection the invariably superficial position in the ovary of the growing oöcyte at the time when this activity of the chromatin is at its maximum should be noted.

Professor Chubb has already given reasons for assuming the passage of substance from the chromatin to the nucleolus; he believes there is also evidence for assuming the passage of substance fron the chromatin to the cytoplasm. During the early growth of the oöcyte, prior to yolk formation, the cytoplasm is not only increasing in quantity but is also steadily accumulating material to be subsequently utilized in yolk formation, this accumulation being indicated by the progressively increasing basophile reaction of the cytoplasm. During this period the chromatin, from being massed around the nucleolus, has become finely subdivided, and has, at the same time, lost much of its affinity for the basic stain. With the commencement of yolk formation, on the other liand, the chromatin shows a progressively increasing staining capacity, and at the same time deeply staining droplets appear on the threads and gradually increase in number and sizc. Professor Chubb interprets the faintly stained condition of the chromatin prior to the commencement of yolk formation as due to the avidity with which the cytoplasm at this stage takes up the products of the chromatin activity. The caryolymph is thus always unsaturated and absorbs this material as fast as the chromatin can produce it. With the commencement of the probably automatic changes in the cytoplasm by which this accumulated material is converted into the definitive yolk spherules, there is, as we should expect, a marked diminution in the avidity with which the cytoplasm absorbs the products of chromatin activity. The chromatin, however, continues, for a time at least, to produce them in as great a quantity as before, but the caryolymph, being now saturated, no longer removes them, and they therefore slowly accumulate on the chromatin threads, causing both the deeper staining of the latter and the formation of the chromatin spherules.

Up to the commencement of yolk formation the nucleus, like the nucleolus, increases steadily in size step by step with the growth of the cytoplasm, the ratio of their diameters remaining almost, if not quite, constant. Thus the nucleus is usually a little over a half, the nucleolus a little under a quarter, the diameter of the egg. The following measurements show this relation at different periods of the egg's growth prior to yolk formation, the figure given for each stage being the mean of a considerable number of closely approximating measurements:

\begin{tabular}{|c|r|r|}
\hline Nucleol11s. & Nucleus. & \multicolumn{1}{c|}{ Cell. } \\
\cline { 1 - 2 }$\mu$ & $\mu$ & \multicolumn{1}{|c|}{} \\
2.5 & 6.5 & 10 \\
3.5 & 10.0 & 18 \\
5.0 & 14.0 & 20 \\
7.0 & 18.0 & 30 \\
8.0 & 20.0 & $30-40$ \\
9.5 & 25.0 & 45 \\
\hline
\end{tabular}


With the commencement of yolk formation, however, this correlation in growth ceases and the cell body grows or, to speak more correctly, expands at a much faster rate than do the other cell structures, so that on the completion of yolk formation the nucleolus measures abont $17 \mu$, the nucleus $50 \mu$, while the cell body measures fully $160 \mu$. The following figures represent typical measurements during the progress of yolk formation; they were obtained in the same way as those just given for earlier stages, the mean being taken of a large number of closely approximating measurements for each stage. It should be noted, however, in considering these figures, that although the nucleolus continues to increase in size perfectly steadily during yolk formation, a corresponding behavior could not satisfactorily be determined for the nucleus, the irregular form of the latter at this period quite precluding accurate measurement. The figures for the nucleus, therefore, are only approximately correct.

\begin{tabular}{|r|r|r|}
\hline Nucleolus. & Nucleus. & \multicolumn{1}{|c|}{ Cell. } \\
\cline { 2 - 3 }${ }^{\mu}$ & ${ }^{\mu}$ & \multicolumn{1}{|c}{} \\
12 & $35-40$ & $50-80$ \\
15 & 40 & 135 \\
17 & 50 & 160 \\
\hline
\end{tabular}

In Heliometra glacialis, though the eggs are larger, exactly the same relative proportions for the nucleolus, nucleus, and cell body are found.

Professor Chubb states that one of the most striking features of the young oöcyte is the extreme regularity of its spherical nucleus. With no fixing reagent did he ever find this structure in early stages to show the slightest tendency to assume an irregular form. In striking contrast to this behavior of the nucleus in the younger oöcytes, this structure in later stages is almost always more or less irregular in form, and in some material is markedly so. This irregularity coincides with the period during which the cytoplasm is deeply basophile, becoming more and more pronounced the deeper the cytoplasm stains, and gradually passing away as this staining capacity of the cytoplasm is lost during yolk formation, the nucleus never, however, regaining the regular spherical form characteristic of the earlier stages. The irregularity of the nucleus thus coincides not with the actual process of yolk formation but with the basophile staining reaction of the cytoplasm.

There are several facts which show that for Antedon this irregularity is a result of the action of the fixing reagent. In the first place, the nuclear irregularity shows no spatial relation whatever either to the other cell structures, to commencing yolk formation, or to the position of the nucleus in the cell. In the second place, it is only in radial section that the nuclear irregularity presents the appearance of pseudopodia; in tangential sections these nuclear processes are found invariably to resolve themselves into a coarse wrinkling of the nuclear membrane. Finally, the artificial nature of the nuclear irregularity is strongly indicated by the variable behavior of the nucleus with varying fixation. Only in material fixed with sublimate is the irregularity of the nucleus invariably well inarked. With other 
reagents the irregularity may be much less marked, or even entirely absent; and this is true even of material taken from one and the same individual.

Although the nuclear irregularity is thus seen to be dependent upon the action of the fixing reagent, yet the striking temporal relation which this irregularity shows to the condition of the cytoplasm, and thus to the egg's growth, indicates that its occurrence is also dependent, in part at least, upon a physiological condition of the egg peculiar to this period. The fact that the nuclear irregularity is always well marked in material fixed in sublimate solution alone, while it is much less marked, or even entirely absent, when the fixing reagent employed contains a free acid, would seem at first sight to suggest that the nuclear irregularity may be due to the slow action or penetration of the fixing reagent. This suggestion, however, entirely fails to explain the cause of the direct temporal relation between the nuclear irregularity and the stage of the egg's growth as indicated by the condition of the cytoplasm. For not only is the egg, at the stage marked by the greatest nuclear irregularity and cytoplasmic staining capacity, invariably at the surface of the ovary, and therefore in a position to be most quickly reached by the fixing reagent, but the younger eggs, in which the nucleus is perfectly spherical, are usually in the interior of the ovary, either floating freely, or tightly packed between the larger eggs. Moreover, eggs at this early stage are occasionally found at the surface of the ovary, yet their nuclei are no less regularly spherical. In the same way the form of the nucleus in adult, or nearly adult, eggs shows no relation whatever to the position of the egg relative to the surface of the ovary. The position of the egg in the pinnule, and thus also the facility offered for rapid penetration by the fixing reagent, can not, therefore, be a factor in determining the irregularity of the nucleus.

The cytoplasm is the only cell constituent to the condition of which the nuclear irregularity shows any definite relation, and here Professor Chubb believes is the true cause of the nuclear irregularity seen in fixed material.

In the younger oöcytes the spherical form of the nucleus is determined by the osmotic interchange taking place between the nutritive plasma of the ovary on the one hand, and the caryolymph within the nucleus of the oöcyte on the other. As the egg grows there is a gradual accumulation of metoplastic material in the cytoplasm, the presence of which must very greatly increase the osmotic intensity at the cell wall while producing a corresponding decrease in the osmotic intensity at the nuclear membrane. The nucleus, therefore, no longer possesses the same powerful tendency to retain a spherical shape, and although it is possible, indeed probable, that the actual deviations from this spherical form in life are slight, they may obviously be greatly intensified by the action of the fixing reagent in coagulating the cytoplasm.

As yolk formation progresses the cytoplasm gradually loses its fluid character, for although the yolk spherules are themselves as fluid as the original food-laden cytoplasm, yet the conversion from a fine to a coarse alveolar structure is necessarily accompanied by a firmer consistency of the alveolar mass as a whole. The nucleus, therefore, is no longer free to assume a markedly irregular form during fixation, or, to put it in another way, the firmer consistency of the coarsely alveolar 


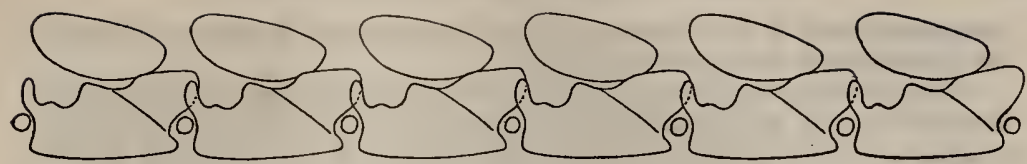

831
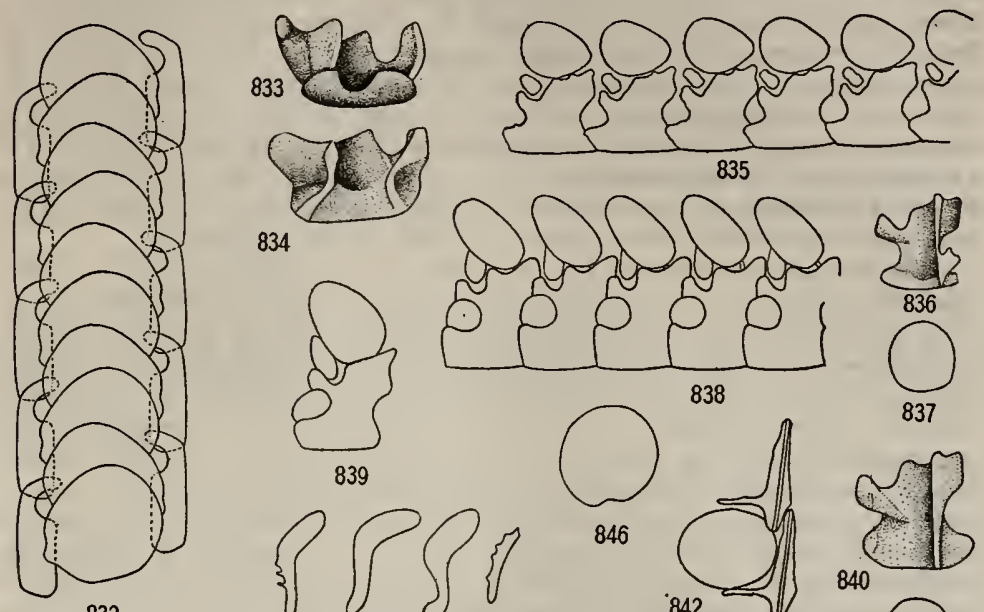

835

834
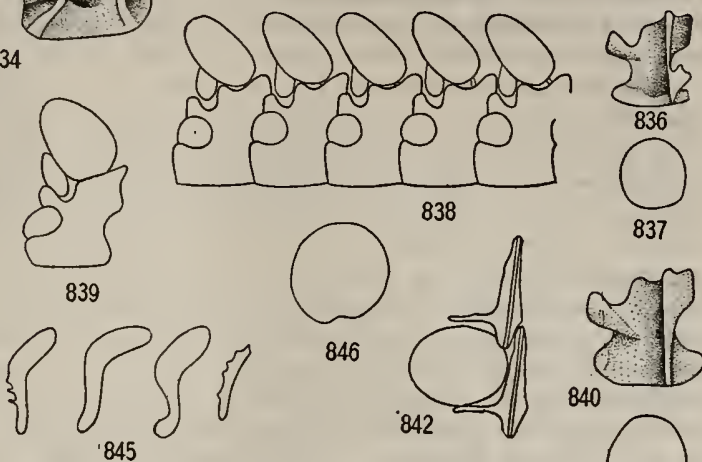

832

'845
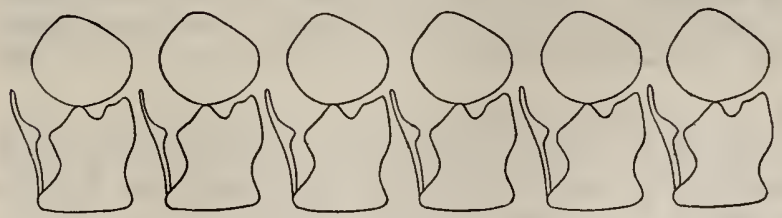

843
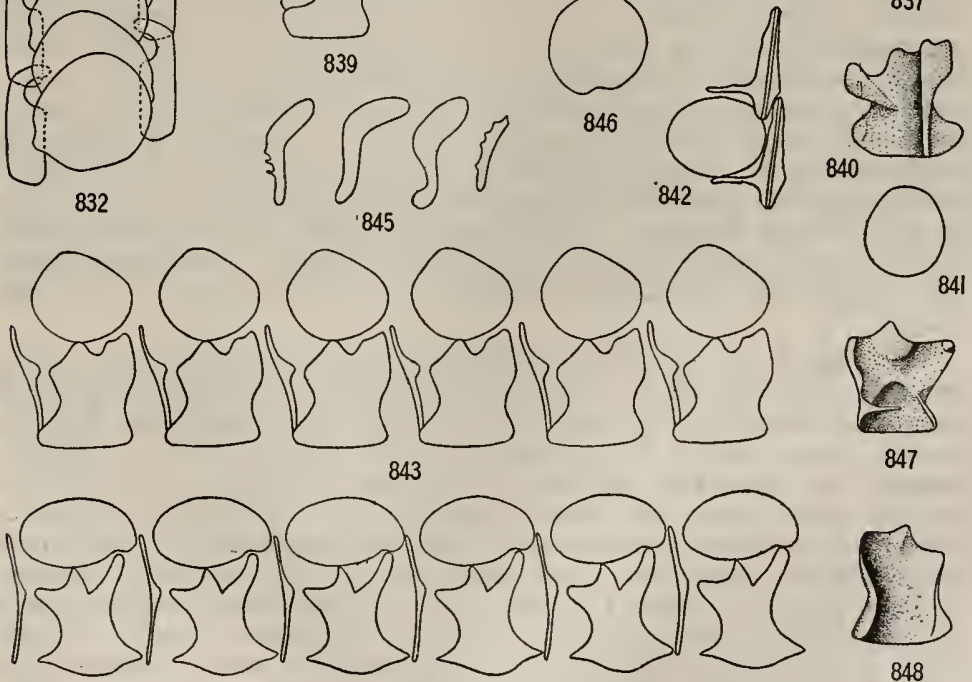

844

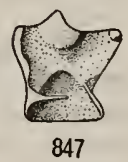

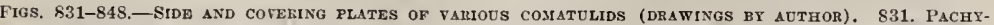
LOMETBA DISTINCTA. S32. TENTRAL VIEW OF POITION OF PINNULE OF SAME, SHOWING SIDE AND COVERING

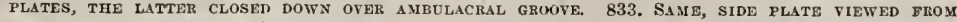

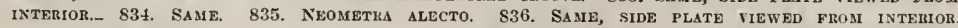
837. Same, ottline of cotering plate. 838. Neonetra conaminis. 839. Neometra gorgonia, side

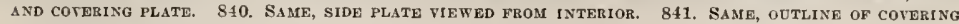
PLATE, 842. SAME, TWG SIDF PI.ATgS IN DORS.IL (END) VIEW, WITH I SACCULUS BETWFEN THEM. 843. Cosmiometra crassicirra. 844. SAME. 845. SAME, isolated supplementari side plates. 846. Same, outline of coterino plate. 847. Sade, side plate viewed frodi iNterior. 848, Same, All $\times 100$. 
cytoplasm results in less movement of the latter during fixation and therefore less disturbance in the form of the nucleus.

The existence of a distinct nuclear membrane has been frequently accepted as incompatible with the discharge of spherules as such from the nuclens into the cytoplasm, and the partial or complete disappearance of this membrane las been interpreted as indicating an increased reaction between the nucleus and the cytoplasm. As Professor Chubb's conclusions for 1ntedon assume the discharge of formed spherules into the cytoplasm, though a distinct nuclear membrane be present, and as his interpretation of the cell processes takes no note of the condition of the nuclear membrane, he finds it necessary to offer some explanation of the latter structure which shall not necessitate the assumption that the existence of a clearly defined nuclear membrane in any way interferes with an active reaction between the nucleus and the cytoplasm, or that it possesses in the living egg the firm consistency which it often appears to possess in fixed material.

The nuclear membrane is always present in the oöcyte of Antedon. Only when the nucleus is very irregular in form does the nuclear membrane appear to be interrupted. The partial disappearance of the limiting membrane in these nuclei is, howerer, always directly associated with the irregularities in the nuclear outline and is, according to the belief of Professor Chubb, due to the nuclear membrane of these points being cut in a very oblique direction, a natural result of the wrinkled form of the nucleus. This suggestion receires considerable support from the appearance of tangential sections of the nucleus, in which it can be readily seen that the nuclear membrane is perfectly well marked on any part of the nuclear outline which does not quickly change its position in neighboring sections of the series, but is invisible in those regions of the outline which do quickly alter their position in adjacent sections, and which thus show that they are cut extremely obliquely. The frequency with which this local disappearance of the nuclear membrane has been described as associated with nuclear irregularity suggests that the above explanation will be found to apply to these other cases also.

Although we may therefore assume that the nuclear membrane is always present at all stages of the oöcyte's growth, it nevertheless varies greatly in appearance according to the nature of the fixing reagent employed. It is, for example, always difficult to see after the nse of sublimate, while in Hermann material, and indeed after the use of all reagents containing a free acid, it is not only quite distinct, but usually deeply stained. It is thus seen that the behavior of the nuclear membrane shows a striking parallelism with that already described for the cytoplasm. Those reagents which give a well-fixed cytoplasmic reticulum give also a distinct nuclear membrane, while those reagents, such as sublimate, after the use of which the cytoplasmic reticulum is alsent or masked by the metaplastic substances, give a nuclear membrane which is indistinct and often difficult to detect. When there is a distinct cytoplasmic reticulum, as for instance, after the use of Hermann's fluid, the nuclear membrane appears to be continuous with the strands of the latter. Professor Chubb thinks that this behavior indicates that the nuclear membrane consists of a layer of the living 
protoplasm free from the metaplasic substances with which the rest of the cytoplasm is loaded. The formation of such a layer of hyaline protoplasm at the junction of the cytoplasm with the caryolymph is to be explained as due to physical causes and is comparable with the hyaline layer of Amœba.

Such a conception of the nuclear membrane not only allows its formation to be readily explained as due to physical causes, but also offers a ready explanation of the ease with which this structure can be absorbed and reformed at different periods in many cells. Moreover, it would certainly seem that the living protoplasm of the cell is the most natural material of which the membrane. through which all solutions must diffuse before entering the nucleus, would be composed.

There are two very characteristic features in which the germinal vesicle differs from the nucleus of actively secreting somatic cells; these are $(a)$ the relative paucity and fine subdivision of its chromatin, and $(b)$ its large size and (at all events usually) spherical form.

Professor Chubb believes himself able to offer an explanation of both these features of the germinal vesicle which will be in complete harmony with the interpretations and conclusions to which he has been led as a result of the study of the oöcyte of Antedon, and which will, moreover, bring the behavior of the latter into line with that, not only of somatic gland cells, but also of abortive ova functioning as nurse cells.

It is generally assumed that the chromatin of the germ cell constitutes the main, if not the only, carrier of specific characters. If this assumption be accepted, then it is not unreasonable to suppose that this consideration must place a very considerable limitation on the adaptive changes which the chromatin may undergo during the increase of the cell activity which accompanies the process of growth and yolk secretion. The somatic gland cell, on the other hand, as also the abortive egg or nurse cell, are not destined to give rise to a long line of descendents; still less are they responsible for the unimpaired preservation of the specific characters of the race. Their chromatin, therefore, is free from the limitations which Professor Chubb has assumed to exist in the case of the oöcyte, and is thus capable of very considerable adaptation to the requirements of the cell's activity. We thus find that, while the nucleus of the gland cell and nurse cell speedily becomes richly chromatic as the cell activity increases, that of the egg remains relatively poor in chromatin.

If such a limitation to the growth of the chromatin in the oöcyte does exist, then we have a ready explanation of the fine subdivision and equal distribution of this material so frequently found in the germinal vesicle which will permit of our following Rückert in interpreting this condition as correlated with intense nuclear activity; although it is absent in the equally active nuclei of gland and nurse cells. For it is obvious that this limitation will necessitate what chromatin there is being used to the greatest possible advantage, and no clearer indication of such an economical utilization of the chromatin could be offered than a fine subdivision and equal distribution of this material.

Professor Chubb has suggested that the spherical form of the germinal vesicle is due to the latter constituting an active osmotic system, and that the occasional 
deviation from this form which is seen in fixed material is an artifact, due to the action of the fixing reagent at a time when the osmotic intensity has been considerably lessened by changes in the cytoplasm. The large size of the germinal vesicle is to be explained as due to the same cause as that which brought about the fine subdivision of the chromatin, namely, the limited growth allowed to this material in the germ cell. For it is obvious that there arc two ways of enabling a small amount of chromatin to perform readily the utmost possible amount of work. One of these is the great increase in surface area which is brought about by extreme subdivision, whereby the facilities for reaction with the caryolymph are greatly augmented; the other is the increase, both in quantity and in nutritive value, of the caryolymph itself, which is brought about by an increase in the surface area of the nuclear membrane through which diffusion takes place, the size of the germinal vesicle being determined when equilibrium is established between the rate of diffusion of nutritive substances through the nuclear membrane on the one hand, and the requirements of the chromatin on the other.

RIPENING OF THE EGGS.

Hamann has studied in detail the ripening of the eggs in Heliometra glacialis.

As soon as the eggs have reached their full size they move into the central cavity of the swollen portion of the genital tube, and often fill it entirely up. They have a diameter of $0.3 \mathrm{~mm}$.

These eggs have lost their germinal vesicles, having in place of them a large spherical nucleus of homogeneous appearance $0.01 \mathrm{~nm}$. in diameter. The vitelline membrane stands out prominently. On the periphery there lie two polar bodies, of which the second is oval in shape and shows many chromatin granules; it lies on the periphery with its longer axis at right angles to the cell wall.

EXTRESTON OF THB EGOS.

Fig. 1175, pl. 28.

There are no female genital openings in the crinoids. As the eggs approach maturity a small hemispherical swelling appears on the ventral side of the gravid pinnule, which is noticeable on account of its whitish color. This is due to the bulging outward of the wall of the genital tube containing the eggs, which pushes against the previously somewhat sunken median portion of the ventral wall of the pinnule. As the pressure increases the wall of the genital tube is forced more and more outward into the pinnule wall, which finally opens and, the wall of the genital tube tearing, the eggs are liberated through relatively small slits.

During this process the egg case is formed about the egg cell.

After the extrusion of the eggs the rent in the pinnule wall is closed, the wall of the genital tube is withdrawn, and a rapid healing and regeneration takes place in the pinnule wall, which is accompanied by accelerated cell proliferation.

In Thaumatometra nutrix the eggs, which are only about $0.15 \mathrm{~mm}$. in diameter, when ripe pass through the wall of the pinnule into the marsupium, where fertilization takes place. 
In Isometra vivipara the same thing occurs, but in this case the eggs have previously been fertilized, this process taking place in the ovary itself.

NGG CASE.

The whole surface of an egg extracted from the ovary just before the normal time of extrusion (that is, after the formation of the swelling indicating the position of the subsequent rupture of the pinnule wall) is covered with a dark meshwork, the open spaces in which are closely set and regularly spaced circular areas. In Antedon mediterranea, the eggs of which at this stage are about $0.3 \mathrm{~mm}$. in diameter, these circular areas have a diameter of approximately $0.022 \mathrm{~mm}$., and there are from 16 to 20 of them about any equator.

This meshwork lies neither on the outer surface of the transparent egg case, which is entirely smooth, nor in its substance. The egg case bears on its inner surface, immediately contiguous to the egg cell, peglike processes with broadly rounded tips which project into the substance of the egg cell, and it is these pegs seen in optical section which form the circular areas in the meshwork when the egg is viewed from the exterior, the dark portion of the meshwork representing the spaces between the processes where the dark yolk comes nearer the outer surface. The yolk carries on its surface pit-like depressions, in which the peg-like processes of the egg case fit.

After the egg has been exposed for a short time to the action of sea water the pegs on the inner surface of the egg case become gradually lower and lower, and the cavities between them shallower and shallower, until finally the inner surface of the egg case smooths itself entirely out and the egg case becomes a spherical shell, everywhere uniformly thick. Simultaneously the surface of the yolk becomes smoother and smoother, until at last it shows no trace whatever of the pits into which the pegs originally projected.

A section of the egg case at an intermediate stage shows the border between it and the egg cell as a crenulate line which gradually straightens out so that finally both the inner and the outer borders form concentric circles. It is to be noted that as the pegs on the inner surface of the egg case disappear the thickness of the case between the pegs increases.

The smoothing out of the inner surface of the egg case appears to begin very soon after the eggs are laid in sea water, for the intermediate stage just described is reached at the furthest in 10 minutes.

If the egg is so treated so that the yolk contracts and shrinks away from the inner surface of the egg case the former almost entirely obliterates the pittings on its surface, while the peg-like processes on the inner surface of the latter are not in any way affected.

Reichensperger was able to comfirm the preceding observations of Ludwig, and he found further that as the peg-like processes on the inner surface of the egg case decreased in size the outer surface developed very much smaller finepointed processes, so that the fully matured egg is covered with fine prickles. 
In Isometra vivipara the eggs are inclosed in a thin membrane, which to a greater or lesser degree, but never entirely, has the appearance of a fine network.

In Tropiometra picta the fertilization membrane is finely sculptured and closely beset with small spines.

EGGS.

Seeliger states that the eggs of Antedon adriatica just extruded and fixed in sublimate-acetic acid average $0.25 \mathrm{~mm}$. in diameter, individual eggs reaching $0.30 \mathrm{~mm}$.

On account of the abundance of yolk material the eggs are very opaque, so that only the earliest cleavage stages can be studied in the living object.

The eggs of different animals differ in size, transparency, and color, but with trifling variations all the eggs of any one individual are alike.

Usually the eggs are yellowish or light reddish, though often quite white. When white they are almost always entirely opaque.

Bury says that the eggs of Antedon mediterranea are $0.30 \mathrm{~mm}$. in diameter. Wyville Thomson gives the diameter of the eggs of Antedon bifida when fully grown as $0.50 \mathrm{~mm}$.

BEGHNERATION.

The power of regeneration is most highly developed in the comatulids, pentacrinites, and bourgueticrinites, and least in the Plicatocrinidæ and, so far as we know, in the Holopodidæ.

In the pentacrinites it is very common in Metacrinus, nearly as common in Isocrinus, less noticeable in Endoxocrinus, and rare in Comastrocrinus and Hypalocrinus.

This is not the result of a greater inherent ability to regenerate in Metacrinus and Isocrinus, but arises from the fact that they run up into the shallowest water, for the proportion of regenerated individuals decreases rapidly with depth, regardless of species.

Among the comatulids regeneration is very common in all littoral species, but with increasing depth becomes less and less frequent.

Broadly speaking, it appears to occur to a much greater extent in the Macrophreata than in the Oligophreata, though partially regenerated cirri have been mostly recorded in the latter.

It is quite possible that this is connected with the larger chambered organ of the Macrophreata; and it is also possible that it is the small size of the chambered organ which to a large degree limits the extension of the pentacrinites and such comatulids as the Thalassometrinæ and the Charitometridæ toward the surface, since as a result of wave action breakage is most common in the littoral, and without a large chambered organ a crinoid, unless unusually tough, could not repair its injuries with sufficient rapidity to survive.

Minckert divides arm regeneration into the following types:

(a) Reproductive regeneration, resulting in a simple replacement of the lost part. 
(b) Augmentative regeneration, resulting in an increase in the number of arms. 1. Duplicative regeneration, resulting in the formation of an axillary from which two arms arise in the place of a single undivided series of brachials.

2. Multiplicative regeneration, resulting in the formation of two or more axillaries each followed by two series of ossicles in the place of a single undivided series of brachials.

(c) Reductive regeneration, resulting in the replacement of a lost axillary by a single arm.

Minckert noted that among the comatulids studied by him from 75 per cent to 90 per cent of the fractures in the arms were at the syzygies.

In specimens of Isocrinus Reichensperger found regenerating buds in the following situations: Seventeen on the distal ends of hypozygals, 10 on the distal ends of $\mathrm{IBr}_{1}, 7$ on the distal ends of radials, and 2 on the distal ends of outer brachials.

Thus in Isocrinus as brought up in the dredge 75 per cent of the brachial fractures are at nonmuscular articulations ( 47 per cent at the syzygies and 28 per cent at the synarthries). After the syzygies and synarthries fracture is most common on the distal ends of the radials.

If an arm be broken off at the radials, necessarily a portion of the disk comes away with it. This regenerates first, and for a considerable time shows no trace of ambulacral grooves, which first appear after the new arm has reached an appreciable size.

Perrier observed that Antedon mediterranea does not thrive in direct sunlight. When the light becomes strong the animals roll up their arms, and if the exposure is too prolonged, or is repeated too often, the arms are cast off. Minckert, bearing in mind the fact that the majority of the multibrachiate species live within the zone above the 400 -meter line, suggests that possibly it is the influence of the sunlight which induces the young to cast their arms in adolescent autotomy. It is more probable, however, that the arms break off as a natural result of growth changes.

Total loss of the pinnules is relatively rare, but these organs are commonly broken off at the base, or lose their distal portion. This is particularly true of the long oral pinnules when they are stiffened, as in the Stephanometridæ. It sometimes happens that a lost pinnule will regenerate a more or less rudimentary arm.

In types with very prominent disks, which habitually live with the arms widely extended, such as the species of Calometridæ, Zygometridæ, and Antedoninæ, individuals are frequently dredged in which the original disks have been lost and a new disk is in process of formation. In all the species of Calometridæ, and in the species of the genera Eudiocrinus and Catoptometra in the Zygometridæ, eviscerated specimens are usually in the majority, while numerous cast-off disks are found in the bottom of the dredge. Though the first species of Eudiocrinus was described in 1868 , it was not until the last 10 years that the character 


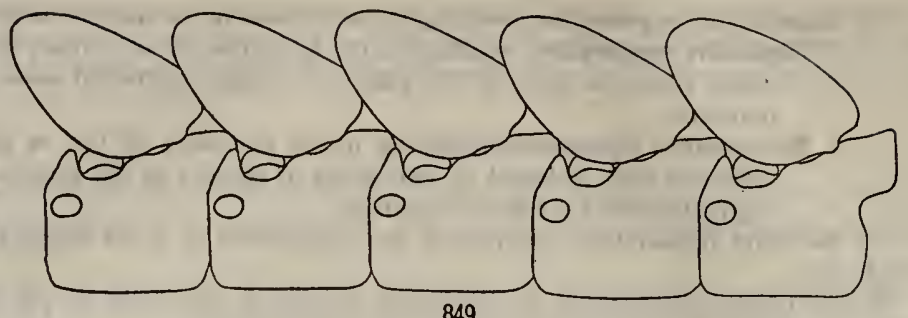

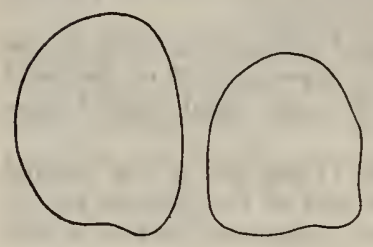

850
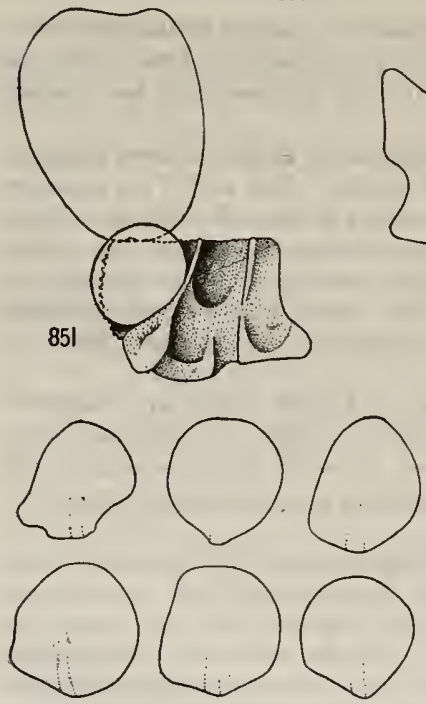

856

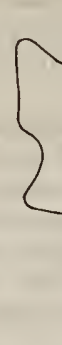

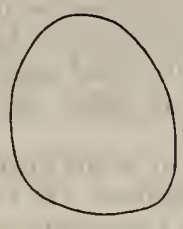

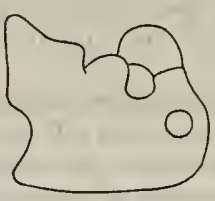

852
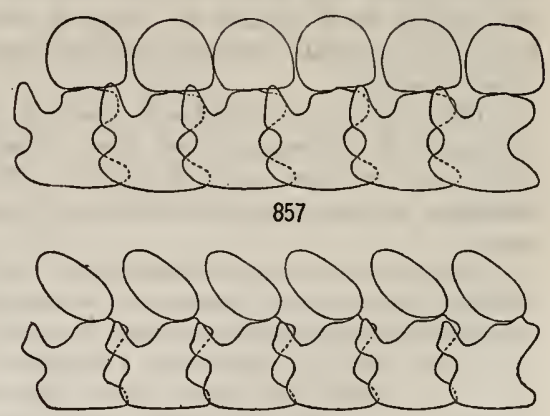

858

Figs, 849-858. - Sidf and covering plates of various comatulids (drawings Bx author). S49. Pogcilo.

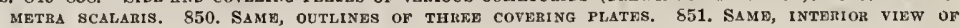
SIDE PLATE, WITH OUTLINE OF ATTACHED COVERING PLATW AND OF gACCULUS. 852. SAME, ISOLATED SIDE PLATE, 853. SAME, SKELETON OF TENTACLE. 854. SAME, TERMINAL CAP OF TENTACLE IN END VIEW, 855. SAME, THRMINAL CAPS OF TWO TENTACLES iN LATERAL VIDW. 856. PACHYLOABTRA DIS. tincta, outlines of six covering plates. 857. Ptilometra macronema. 858. Same. All $\times$ 100. 
of the disk was known. The first notice of a species of Zygometra, also published in 1868, was based upon a detached disk, which was described as a recent cystid, while the type species was called microdiscus on account of the original specimen possessing a disk only half grown.

In types in which the arm bases make a relatively small angle with the dorsoventral axis, and therefore inclose the visceral mass on all sides except the ventral, as in the Thalassometridæ, Charitometridæ, and Atelecrinidæ, loss of the disk rarely, if ever, occurs, and no cases of regeneration of the disk have been recorded. It appears to be extremely rare in the remaining families.

Spontaneous evisceration has never been proved in any species.

Individuals with one, or even two, radials regenerated have been noted in Ptilometra mülleri, Antedon bifida, and A. mediterranea, and in a few other species. Loss of a radial can only come about through a serious accident.

Regeneration of the cirri occurs throughout the comatulids but is not so common as the regeneration of the arms and pinnules. In the macrophreate types the cirri, which are very fragile and often deciduous, are usually (but not always) lost in their entiety, and total regeneration supervenes. In the oligophreate types, in which the whole animal is usually less fragile than in the Macrophreata, the cirri are commonly broken off at some distance from the base, and the distal portion regenerates, though loss of the entire cirrus and total regeneration also occurs. Partial loss of a cirrus is common in the species of Tropiometra, and is not rare in the species of Charitometridre and of Ptilometra. Elsewhere it is of more or less casual occurrence. In certain species of Thalassometridæ with long conical centrodorsals the earlier cirri are cast off and replaced by short, irregular, rounded-conical spines with their tips crowned with spinelets.

In total regeneration of the cirri, as described by Minckert and seen in species of Crinometra, a small peg-like process appears on the cirrus socket in the central canal. As this increases in size segmentation makes its appearance, and it becomes divided into a number of narrow rings which in the proximal portion soon become short cylinders though remaining ringlike distally where the new segments are formed.

Regarding Antedon bifida at Roscoff, Perrier writes that nothing is commoner than to find arms which are in process of regeneration. The animals do not break up spontaneously, and they are not even as fragile as many ophiurans of much larger size; but the movements of the waves, their habit of entangling themselves with each other and with the branches of the seaweeds among which they live, as well as the actions of the animals living in the same habitat, cause a considerable amount of mutilation.

The mutilation is not of long duration, for the lost parts very soon regenerate. At the end of a few days a white digitation appears on the stump, and the lost member, pinnule or arm, soon is replaced.

On August 9 Perrier removed the extremity of an arm of a carmine Antedon which had been kept in a basin for eight hours. Near it was a vermilion Antedon with all the arms but three cut off more or less near the base and in process of 
regeneration. Each of the stumps was surmounted by a small digitiform process. white in color.

On August 14 he reexamined the carmine Antedon and found that a digitiform process $1 \mathrm{~mm}$. long had already formed, resembling those of the vermilion Antedon.

The next day he examined carefully the regenerated arms of the latter. At the base of each of the digitiform processes a pair of long pinnules had already formed, and beyond them were numerous young pinnules in various stages.

Perrier believes that 8 or 10 weeks should suffice for the complete regeneration of an arm.

POSSIBLE FXTENT OF REGENERATION.

As a result of his studies at Naples Przibram found that Antedon mediterranea $(a)$ is able to regenerate an excised fifth, comprising an arm pair, the corresponding part of the disk, and parts of the centrodorsal and cirri; $(b)$ entirely halved examples can regenerate the lacking two arm pairs and single arm; $(c)$ a fifth of an animal can regenerate at least an arm pair (during which process the cirri fall off $) ;(d)$ before these operations the disk can be removed without hindering the regeneration, and will itself always regenerate (whether after regeneration the anal tube occupies the same interradius as before has not been determined); (e) after the removal of the disk the floor of the calyx may be completely scraped without hindering the regeneration of the disk; $(f)$ if all the arm pairs are cut away close to the base these, together with the disk which is cast off after the amputation of the two arm pairs, will immediately regenerate; $(g)$ if all the arm pairs are cut away in such a way that only the centrodorsal and the cirri are left, these die without regenerating; $(h)$ on the contrary, an arm pair can regenerate at least another rudimentary arm pair, though it is questionable whether or not a small piece of the calyx is necessary; $(i)$ single arms regenerate nothing; $(j)$ single pieces of the calyx regenerate nothing; $(k)$ if the cirri are all cut away they will not regenerate, at least in the time in which the other regenerations are completed; $(l)$ if the cirri together with the distal part of the centrodorsal are cut away the open wound heals over, but no regencration occurs, at least in the time in which the other regenerations are completed; $(m)$ if the disk is lost it at once regenerates; $(n)$ if the centrodorsal with the cirri be removed and the central nervous system be entirely destroyed the animal in a short time dies, even though the parts remaining if separated possess the power of regeneration to a greater or lesser degree; $(o)$ if after the removal of the disk the central nervous system is destroyed the animal dies.

Przibram notes that the negative results are perhaps subject to future correction, especially since they are based upon relatively few experiments.

It is interesting that the destruction of the central nervous systcm causes death if the animal be left entire, while separated parts remain alive and will to a greater or lesser degree regenerate.

Detached disks or portions of disks will not regenerate, though they remain alive for several days. 
The regenerative powers of the disk are summarized by Przibram as follows:

Regeneration of an anal tube cut away proceeds regularly and the functioning of the new anus can be observed after one month. Regenerative power, therefore, is not lacking in the disk, and its incapacity when detached to exist or to regenerate may be ascribed to the absence of sufficient ectodermal parts, and especially to the absence of a sufficiently large portion of the ectodermal nervous system.

A disk half detached grows again entirely onto the calyx.

The following methods are employed to hinder the immediate return of the disk to its original position: The detached half was cut away; the calyx lining under the loosened half was removed; a strip of gummed paper was inserted under the loosened half; and the oral pinnules, in the normal condition held above the disk, were inserted under the detached portion.

In the two last cases the disks were cast off ; in the first two they grew completely on again, and since subsequently the disk were not always orientated according to the orientation of the arms, it is to be assumed that the disks themselves have assisted the regeneration to a certain degree.

Disks can be transplanted from one animal to another if the original orientation is preserved. If not cast off the disks grow fast in their new position in about a week.

Transplantation of the disk has no effect upon the color of regenerating arm tips, which remain of the same color as before the disks were exchanged. ${ }^{\circ}$ In these experiments caution is necessary, for regenerating arm tips of a yellow specimen are sometimes red, and in the case of transplantation of the disk it would be easy to ascribe this to the influence of a new red disk.

Reichensperger carried out experiments along the same lines. He cut off the arms of five specimens at the radials without injuring the latter. In all cases the disk was immediately thrown off. After four months two of the specimens had regenerated five arms, from $1.1 \mathrm{~mm}$. to $1.3 \mathrm{~mm}$. in length; the other three were dead. If during the amputation the radials are injured no regeneration will occur.

When the central capsule of armless specimens was injured with a fine pin no regeneration took place; but in two of the three specimens in which four or five brachials were preserved regeneration set in in spite of the injury to the central organ.

If after the removal of the arms the dorsal cord in the radials be injured, regeneration never occurs, even if the $\mathrm{IBr}_{1}$ be preserved.

Reichensperger believes that his investigations appear to confirm the existence of a regenerative zone at the base of the arms, and concludes that a certain minimum of the substance of the dorsal nervous system, and especially of the wandering cells, must be present uninjured to give rise to regeneration.

Reichensperger found that single arms would regenerate nothing, and that arm pairs regenerated only if attached to a part of the calyx which contains a fragment of the central organ; but in the latter case if the distal brachials be removed or the arms otherwise injured no regeneration occurs.

In the arms regeneration takes place with equal facility at all points, on the distal end of any brachial, or on any fractured surface within the substance of any 
brachial. The articular facets of the nonmuscular articulations are especially fitted for regeneration only because they are especially adapted for autotomy.

On December 15 Reichensperger removed all the cirri from eight specimens; on January 17 the first signs of regeneration were visible; on February 20 three showed large regenerating buds, and two additional had buds still further advanced; on March 7 from five to seven cirri on each animal had attained about onethird of the normal size. 'The remaining three animals, though still living, showed no trace of regeneration on March 7 .

Regeneration of the cirri, though it occurs, proceeds with extreme slowness.

Reichensperger met with only 11 cases of partial regeneration of the cirri in Antedon mediterranea. Minckert records one in Tropiometra picta, and P. H. Carpenter one in Tropiometra carinata (?picta).

In 2 of the 11 cases noticed by Reichensperger, regeneration took place after fracture from natural causes, once from the third and once from the seventh segment. In the other 9 the fracture was artificial, and in these 8 regenerated from the end of an ossicle, and 1 from a cut through the middle. About 170 cirri were used in the experiments, but most of the stumps were cast off by autotomy.

\section{INELUENCE OF DIFEERENT FACTORS ON REGENERATION.}

Reichensperger confirms previous investigators when he says that the more unimportant the lost parts are the slower, in general, is the regeneration; the larger the portion removed the quicker and stronger will regeneration set in.

So far as it is possible to estimate, a regenerating arm with a $\mathrm{IBr}_{1}$ as a base grows about twice as rapidly as one arising from one of the distal brachials.

If on one animal all the arms are cut away at about the tenth brachial, and on another animal of equal vigor only one or two, in general the regenerating buds on the animal deprived of all its arms will reach a length of $0.7 \mathrm{~mm}$. to $0.8 \mathrm{~mm}$. when those on the other are at the most $0.4 \mathrm{~mm}$. or $0.5 \mathrm{~mm}$. long.

During a stay of over five months' duration at Naples Reichensperger was not able to determine any exhaustion of the powers of regeneration in the arms of Antedon mediterranea.

In three vigorous animals he broke off individual arms at the syzygy between the third and fourth brachials, at intervals of from 8 to 10 days. They always regenerated with almost equal perfection and speed. In two cases the experiment was carried out 12 times on the same animal, and in one case 14 times. There is no difficulty in inducing regenerating buds of the second, third, and even fourth order in any location.

The assimilation of food can play only a slight part in influencing regenerative processes. There is practically no difference in the rapidity of the regeneration between animals with and without disks. Specimens which are in process of regenerating extensive portions of the arms rarely show the visceral mass extended with food; in fact, it is shown by sections through the visceral mass of rapidly regenerating animals that the alimentary tract is almost always empty. 
There is no perceptible difference in the speed of regeneration between animals in water with an abundant supply of food and animals in water with a minimum of food.

There is also no difference in the speed of regeneration between animals with fully developed sexual products and those from which the sexual products have been given off. If several weeks before sexual maturity large portions of the arms be cut away regeneration takes place on an injured arm in conjunction with the undisturbed maturation of the sexual products. The pinnules remaining on the proximal portion of an amputated arm develop the sexual products simultaneously with those on uninjured arms. Thus the maturation of the sexual products is not affected by regenerative processes, and the material intended for the former is not diverted to the latter.

COLOR OF REGENERATING PARTS.

In the crinoids as a whole regenerating parts are usually yellow, more rarely whitish or pink, and much lighter than the remaining portions of the animal. This is especially evident in dark-colored types in which the contrast between the original and the new structures is often strongly marked. But in the lighter colored species exceptions are frequent, and in Antedon red regenerating buds on yellow arms or brown on whitish specimens are commonly met with.

The specimens of Isocrinus and Metacrinus are often quite white in color when alive, and if dark the color quickly changes or entirely disappears in alcohol. In preserved material regenerating parts as a rule are lighter than the rest of the specimen, though often indistinguishable. In the latter case it is quite possible that the color may have been different in life.

VISCERAL MASS.

It is well known that in many of the comatulids the visceral mass is more or less readily lost and is soon regenerated without any apparent inconvenience.

The facility with which this occurs varies greatly in different groups. In the Comasteridæ it appears to be very exceptional. Only very few specimens without disks have come under my notice, and in these the disks were evidently lost as a result of very rough methods of capture. No case of a regenerated disk in this family is known.

In the Zygometridæ, on the other hand, the loss of the visceral mass is a very frequent occurrence, both under natural conditions and as a result of capture. Indeed, so easily is the disk lost that it is as yet unknown in several of the species of Catoptometra and Eudiocrinus, and in one of the species of Zygometra. The detached disk of a species of the last-named genus served as the type specimen of Lovén's Hyponome sarsii, described as a recent cystidean, while another species, microdiscus, was so named because of its small disk, which in the type specimen is in the early stages of regeneration.

In the Himerometridæ loss of the disk occurs, but is extremely rare.

In those species of Mariametridie which have narrow and well-separated division series, such as the species of Pontiometra and Liparometra and a few 
other forms in the remaining genera, the disk is sometimes lost, though, speaking generally, in this family loss of the disk is very unusual.

In the species of Stephanometridæ individuals in which the disk has been lost are not uncommon.

The species of Colobometridæ all lose their disks rather easily, especially the 10 -armed species and the species of Cenometra. In one of the species of this genus which is known from only two specimens, $C$. emendatrix, the disk has not been observed except in the early stages of regeneration.

The Tropiometrida are extraordinarily tough, and in this family loss of the disk, as well as loss of any other part of the body, is rare.

In the Calometridæ, especially in the genus Neometra, the attacliment of the visceral mass is peculiarly weak, it being more frequently lost even than in the Zygometridæ.

Among the species of Thalassometridæ and Charitometridæ loss of the disk is as a rule very exceptional, since in these families, as a result of the compression of the division series and arm bases, it is entirely inclosed both dorsally and laterally. The only genus in which the disk is frequently lost is Strotometra, which is characterized by the absence of the protective approximation of the division series.

Loss of the disk is common in the subfamily Antedoninæ, in which the division series are narrow and in life are extended almost at right angles to the dorsoventral axis; but in the other macrophreate types it is very rare, and quite unknown in the Atelecrinidæ and Pentametrocrinidæ.

As a general rule, it may be stated that comatulids having well separated rays, a convex disk, and a patent habit lose their visceral mass readily, especially if it be plated; but those with the rays and division series in close contact or with the ventral surface of the disk normally flat or more or less concave lose their visceral mass seldom, or not at all.

Prof. Arthur Dendy has made a special study of the regeneration of the visceral mass in Antedon bifida, his observations having been carried out at Millport on the Clyde.

It was first noticed in 1592 by Fabius Columna that the visceral mass of Antedon mediterranea was readily separated from the rest of the animal. Dr. W. B. Carpenter remarked the same thing in Antedon bifida at Oban, while the naturalists of the Challenger expedition often noticed it in various other forms. Prof. A. Milnes Marshall had observed its frequent occurrence in Antedon mediterranea at Naples, and had found that it was easily brought about by artificial means. He also observed that after evisceration regeneration promptly began, and he collected a series of specimens for the further study of the process which he turned over to Professor Dendy, and it is upon these that part of the latter's studies are based.

Dendy noticed that the concave surface of the calyx is lined with a thin layer of connective tissue, on which the visceral mass rests and to which it is very closely attached. 


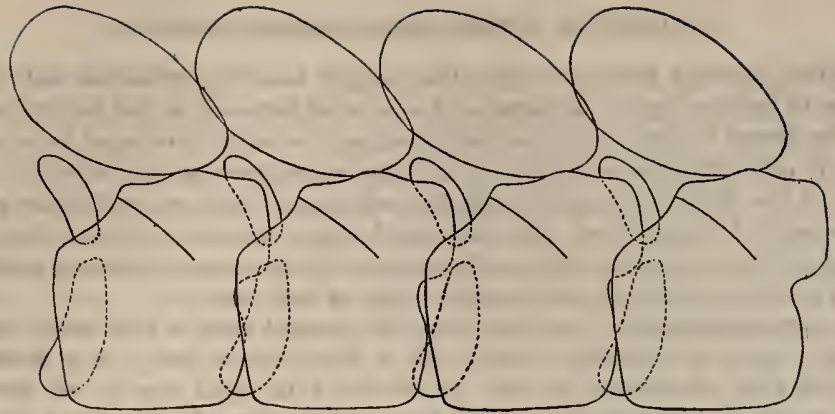

859

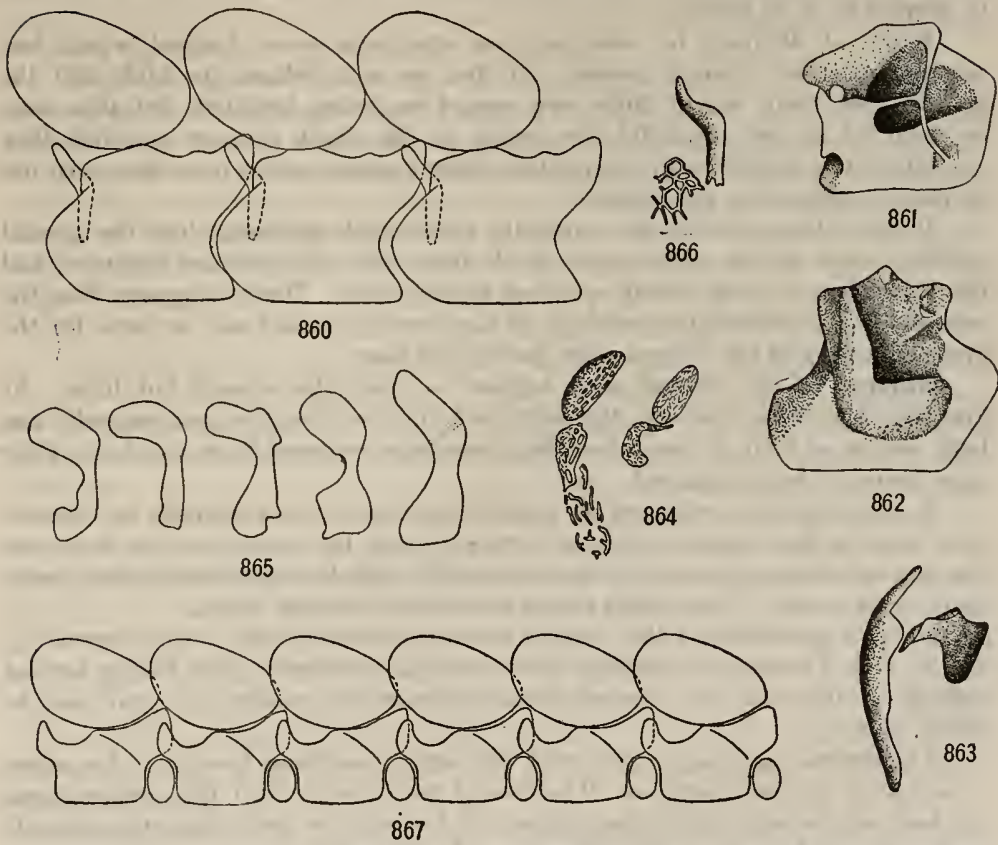

FIOS. 859-867.-SidE AND COVERINO PLATES OF VARIOUS COMATULIDS (DRAWINGS BY AUTHOR). 859. OCEANOMETRA GIGANTRA; OUTLINE OF LOWER HALF OF SUPPLEMENTARY SIDE PLATES REPRESENTS BOUNDARIES OF MASS OF SPICULES (SEF FIG. 864). 860. SIME; SUPFlEMENTARY SIDE PLATES ART NOT DIVIDED.

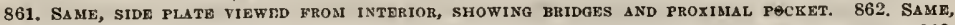
SIDE PLATE FIEWED FroN INTERIOR, nORSOIENTRAL RIDGE BROADENED TO FORM DEeP POCKET. 863. SAME, VeNTRAL VIEW OF SIDE PLATE WITH DETACHED DISTAL PORTION. 864. SAMF, ISOLATED SUPPLE-

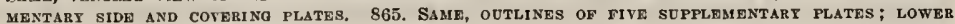
HALVES ARE COMPOSED OF FEW VERY LAROE RETICUlations, S66. SaMe, isolated SUPplementaRT PLATE. 867. Crossometra helis. ALL $\times 100$. 
When removed from the calyx the visceral mass is a roundish ball from a quarter to half an inch in diameter and somewhat flattened on the ventral surface.

The dorsal surface, which normally rests on the calyx, is covered by a compact layer of connective tissue which has a silky appearance on the outside. In the center of the dorsal surface is a minute perforation which serves for the passage of the central plexus from the chambered organ into the visceral mass. The ventral surface is covered with epidermis overlying connective tissue, continuous with a similar covering on the ventral surface of each arm.

In some specimens of Antedon bifida the visceral mass is very easily removed from the calyx by pushing it aside with a blunt needle, but it is a noteworthy fact that this evisceration can not be effected with equal ease in all cases, for while in some specimens the visceral mass comes away almost with a touch, in others it adheres firmly to the calyx and can not be brought away at all except by tearing it all to pieces.

While at Millport he observed that specimens were dredged which had already lost their visceral masses. At first he was inclined to think that the animals cast them out of their own accord on being irritated, but this must be regarded as very doubtful, for owing to the slight manner in which they are generally attached to the calyx, the visceral masses might have been torn out by rough treatment in the dredge.

It was observed that the naturally eviscerated specimens had the genital products more or less undeveloped, while those with the pinnules distended had the visceral mass more firmly attached to the calyx. Dendy supposes that the necessity for uninterrupted nutrition at the breeding period may account for the greater tenacity of the visceral mass during this time.

Removal of the visceral mass appears to affect the animals but little. At first they fold their arms over the calyx, but this condition does not generally last long, and in an hour or two, when they have once recovered from the shock, their vigor seems to be unimpaired.

It is evident that evisceration involves tearing of the epidermis and dermis in a more or less regular circle all around where the arms join the disk, and that the ambulacral grooves and nerves, together with the ambulacral vessels, must also be torn across. The central plexus must also be broken across.

Isolated specimens of the visceral mass of Antedon bifida were observed by Sir Wyville Thomson to perform slow creeping movements, but Dendy noticed nothing of the sort; the visceral masses appeared to remain quite still and to slowly decay.

The central capsule, together with the nerves radiating from it to the arms, is uninjured by the operation. The line of tear along which the oral perisome has been separated from the integument of the arms is very distinctly marked; each ambulacral groove is torn sharply and suddenly across, generally at about the level of the base of the oral pinnules.

Between any two adjacent arms or pairs of arms is a tightly stretched translucent membrane bounded by a free incurred edge which marks the line of tear interradially and radially. These membranes form an important part of the floor 
of the visceral basin and assist in supporting the visceral mass. It will be seen that the line of tear forms the edge of the visceral basin. This edge does not maintain an even curvature all the way around but is deeply notched. There are 10 of these notches or bays, one between the two arms of every pair, and one between each two adjacent arm pairs, the latter being a good deal the deeper.

The floor of the visceral basin is lined with an exceedingly thin transparent membrane of connective tissue through which the muscles between the calcareous ossicles are very distinctly visible. The degree of distinctness with which these muscles are visible beneath the overlying regenerating tissues forms, during the earliest stages, a good indication of the amount of regeneration which has taken place.

By comparing sections of an uninjured specimen and sections of an isolated visceral mass it is found that the separation of the visceral mass takes place between two layers of connective tissue, one lining the visceral cavity, the other covering the aboral surface of the visceral mass.

Forty-three hours after evisceration specimens of Antedon bifida exhibit a thickening of the connective tissue lining of the floor of the visceral basin. The interarticular muscles are much less distinct, though still plainly visible. The thickening is more marked around the edges of the injured area than in the center, so that the muscles between the radials and $\mathrm{IB}_{\mathbf{r}_{1}}$ are much more distinctly visible than those between the second primibachs and the $\mathrm{IBr}_{1}$. In one specimen of this stage Dendy found the outer circle of muscles nearly hidden by the ingrowing mass of connective tissue. The line of tear along which the visceral mass has been separated from the calyx no longer appears sharp and distinct.

At two days the new growth of connective tissue, which had commenced at 43 hours, has proceeded farther. The muscles on the floor of the visceral basin are all completely hidden by the newly formed tissues. The line of tear is marked by the sudden stopping of the lappets and pigment spots along the borders of the ambulacral grooves. In sections it is seen that the surface of the regenerating cushion of tissue is covered by a thin, deeply staining layer, which is apparently formed by the arching over and ingrowth of the edges of the injured area. This layer is formed of two parts-an upper, which is probably epidermal, and a lower dermal. The deeper connective tissue layer is continuous with strands of the same substance which have grown out from the floor of the visceral basin. In the center, above the chambered organ, the superficial layer of this regenerating visceral mass is still incomplete, so that on looking at it from above two or three little holes are visible in the center leading down to the chambered organ. The regenerated cushion of tissue is still very thin, averaging in thickness only about half a millimeter.

Regeneration, then, appears to commence in two chief ways-(1) by a series of outgrowths from the thin layer of connective tissue which forms the floor of the visceral basin, and (2) by an ingrowth of connective tissue and epidermis from the edges of the injured area forming a roof to the visceral basin.

At the next stage the new visceral mass is seen to have grown and has thickened considerably. The openings leading down to the chambered organ are now 
closed over. In the center of the regenerating visceral mass is a small opaque papilla, probably due to the thickening of the epidermis preparatory to the formation of a mouth, but unfortunately Dendy's sections were not sufficiently well preserved to decide the point.

Sections show that regeneration has proceeded as far as the formation of a cushion of loose connective tissue, much thicker than at two days, and covered by the deeply staining epidermic layer before mentioned. The growth of connective tissue is especially strong underneath the point where the mouth is subsequently to be found, so that we have here a pillar of denser connective tissue reaching from the top of the rosette to the roof of the visceral basin and thickest just beneath the epidermal layer.

The central plexus is very well shown; but in these sections and in those of later date there is no means of telling how much of it, if any, has regenerated and how much was left after evisceration.

The ambulacral system has begun to regenerate, as is shown by the presence of new ambulacral pores. On examining one of these more closely it is seen to be vesicular, lined with columnar epithelium and opening to the outside; no internal opening is yet visible.

Another specimen supposedly, like the preceding, of three days' growth, is much more advanced, the mouth and alimentary canal being present. In other respects it is similar. In the center of the visceral mass is a depression; the epidermis covering the depressed area is thickened, and in the center is a small mouth leading obliquely downward into a feebly developed alimentary canal. The alimentary canal has already the characteristic form found in normal specimens, taking one turn in a horizontal plane and ending in an interradial anus. The most remarkable feature about it is the rudimentary condition of its walls. In histological characters the walls of the alimentary canal are almost indistinguishable from the roof of the visceral basin, and to all appearances have been formed by an invagination of this roof.

The roof of the visceral basin is composed of two layers-externally a thin layer of minute, rounded, deeply staining cells, which are probably epidermal, and beneath this a thicker layer of connective tissue cells, which stain less deeply.

In the floor of the central depression already mentioned the epidermal cells show a slight tendency to become columnar. The walls of the alimentary canal are composed of exactly the same two layers-a layer of more deeply staining cells which corresponds to the epidermal layer of the roof, but is now, of course, on the inside, and outside this a layer of connective tissue. The cells of the inner layer show a tendency to become columnar, and this layer is more distinct than the epidermal layer of the roof. The lumen of the alimentary canal is very small and its walls are very thin and but slightly folded. There is no trace of an anal cone; the anus itself is represented by a minute perforation in the roof of the visceral basin. The walls of the last part of the intestine just before reaching the anus are quite indistinguishable from this roof. There is no decisive evidence as to the manner in which the alimentary canal is formed; but there appears to Dendy to be a strong probability in favor of the view that it is formed by invagination, the 
inner glandular layer of its walls being formed from invaginated epidermis, and the outer connective tissue layer from the underlying dermis.

At five days the condition is about the same; the alimentary canal is very small and almost solid, the inner layer of its walls being composed of minute deeply staining nucleated cells, more or less rounded in shape and showing a slight tendency to become columnar in places, and being histologically indistinguishable from the tissue covering the general surface of the disk. Here, again, the alimentary canal appears to have been formed by invagination, accompanied by rapid proliferation of the cells of the epidermis. In the specimen described this proliferation has formed a thick mass of minute cells projecting on the surface at one side of the mouth. No anal cone is yet visible. The terminal portion of the intestine touches the roof of the visceral mass, but no definite opening was found. No ambulacral nerves or canals are as yet visible around the mouth. A number of new ambulacral pores have been formed, apparently by invagination; the epithelium lining them is at first not distinctly columnar.

At nine days the boundaries of the ambulacral grooves are seen to have met and formed a pentagon around the mouth. They inclose a slightly depressed area, with the mouth in the center, and appear as thickish white ridges, in some places notched, showing where lappets are beginning to regenerate.

Dendy believes that the ambulacral grooves are, from the first commencement of regeneration, left as areas along which the thickening of the regenerating tissue is not so great as elsewhere. This thickening takes place centripetally in five distinct areas, one in each interradius. As these grow inward the ambulacral grooves and the central depression around the mouth are left as less thickened portions. The mouth is oval, runs obliquely downward, and is now for the first time distinctly bounded.

The beginning of the anal cone is visible as a small conical papilla placed interradially. In sections the alimentary canal is seen to be fairly well developed; it contains food refuse, indicating that its use has begun.

The epidermis covering the depressed areas around the mouth is now composed of columnar nucleated cells and passes gradually into the inner lining of the esophagus, the cells of which are still more columnar.

The walls of the stomach are also composed of the usual two layers-an inner layer of columnar nucleated cells and an outer layer of connective tissue. This outer layer is connected with the loose connective tissue filling the body cavity. In the specimen described the cells forming the inner wall of the alimentry canal have become columnar right up to the anus. The anus is very minute and is situated on the top of a small papilla. The columnal cells lining the cavity of the anus are very small and pass gradually into the epidermal cells covering the rudimentary anal zone; the epidermal layer at this point is thickened. In the region of the stomach the walls of the alimentary canal are beginning to become folded, especially on the axial side, and on this side also the glandular layer is thicker.

In another specimen of this age, which appears not to have advanced quite so far in regeneration, the alimentary canal, as it approaches the anus, narrows very much. Its inner wall, which in the first part of its course is composed of the usual 142140-21-Bull. $82-29$ 
columnar cells, here consists of a layer of very minute cells, such as line the whole of the canal at an earlier date, and identical with the cells corering the general surface of the disk. In thickness this inner layer is very irregular, and the cells composing it appear to be rapidly proliferating. At its extreme end they block up the lumen of the canal so that the latter appears solid and the end of the canal fuses indistinguishably with the layer of similar cells covering the general surface of the disk. At the point of fusion there is a thick mass of these minute round cells forming a little elevation on the surface of the disk. This indicates the position of the future anal cone. Dendy was unable to find a distinct anal opening in the specimen. He believes that the facts support the view that the alimentary canal is formed by invagination from the oral end.

At 12 days no great advance has been made on the condition presented by a nine days' specimen. In one specimen the pentagon around the mouth, formed by the lips of the ambulacral grooves, has become notched into lappets all the way around, and in sections the alimentary canal is seen to have become very considerably complicated and folded upon itself. In sections of another specimen of this age the ambulacral epithelium and canals can be traced across the disk very nearly to the lip of the mouth; they present the same features as in the normal specimens; thus the canals exhibit the transverse muscle fibers found in ordinary specimens. The anal cone is still very small.

At 19 days little advance is to be noted except in the further growth of the anal cone, which is now fairly well developed. Sections show a large body cavity in the anal cone, surrounding the terminal portion of the intestine, which latter is attached to the body wall by strands of connective tissue.

In sections of a specimen of 21 days a blind diverticulum is visible, given off from the alimentary canal at the junction of the stomach with the esophagus, as described by Ludwig in the normal animal. There is little to distinguish a regenerated specimen of this date from a normal adult excepting the smaller size of the visceral mass and the want of pigment upon it.

The 43-hour stage is described from specinens of Antedon bifida taken at Millport on the Clyde, the other stages from specimens of A. mediterranea from Naples.

Dendy suggests that, as the crinoids can have no possible power of food selection, the facility of regeneration of the visceral mass may be an acquired provision for the rejection of poisonous or obnoxious food which has found its way into the alimentary canal.

DETAILS OF ARM REgENERATION.

The histological details of arm regeneration have been studied by Perrier, and more recently by Reichensperger. The former in 1872 recorded the outward appearances of regenerated parts, and the inner structure, so far as it could be made out in stained and cleared specimens, while the latter worked along the most modern lines.

Closure of the wound and degeneration of the cell elements.-Immediately after the fracture a certain amount of fluid escapes from the water vessel and from the 

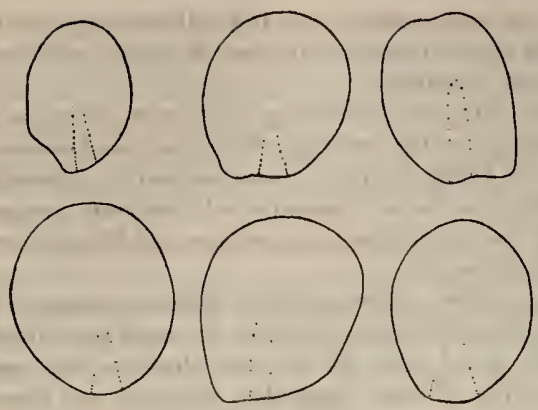

868

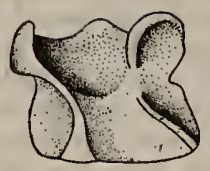

872

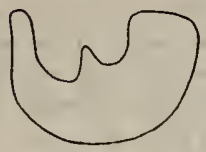

873

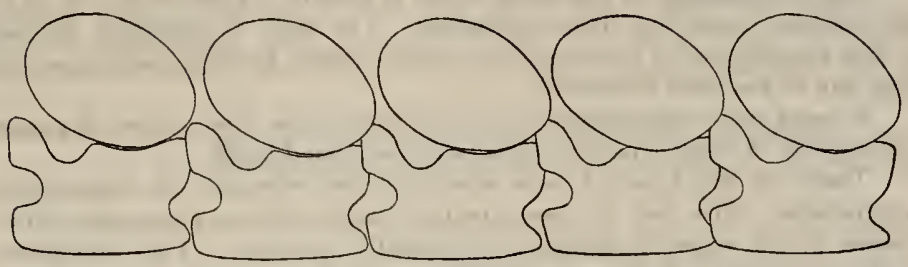

869

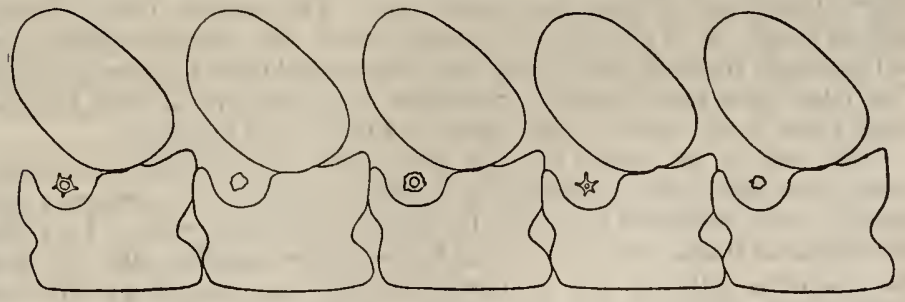

870
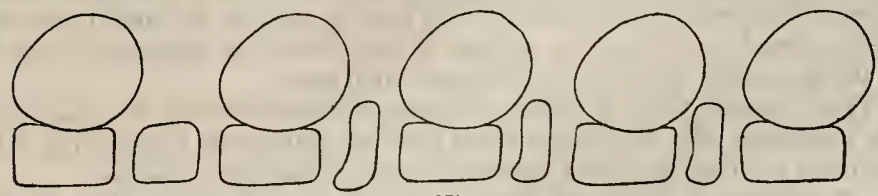

871

Figs. 868-873.- Side and covering plates of Calyptometra lateralis (dhawings by author). 868. Ottlines of six covering plates. 869. Five side aNd covering plates. 870. Samb. 871. SAME, FRON BASE OF PINNDLE OTER GENITAL GLAND, SHOWING SHPPLEMENTARY SIDE PLATES WITHOUT COTERing plates, 872. Side Plate, viewed From interior. 873. Side plate vigwed veNthalli. ALL $\times 100$. 


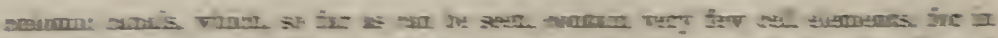

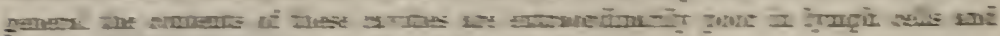

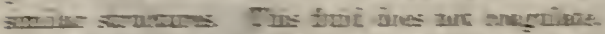

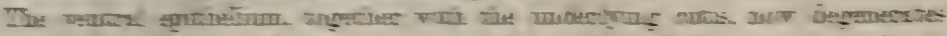

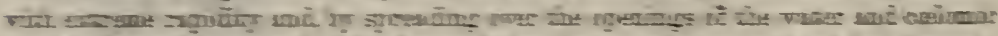

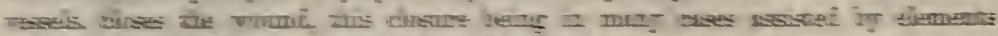

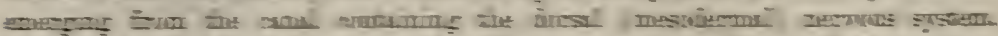

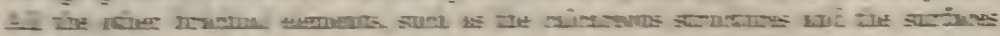

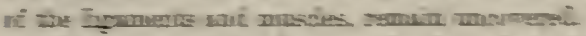

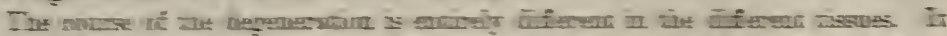

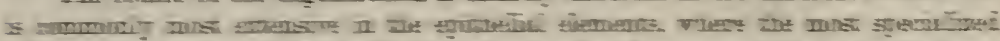

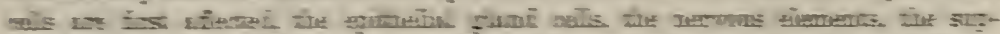

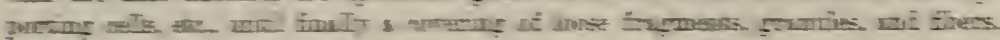

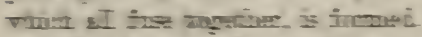

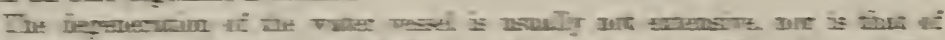

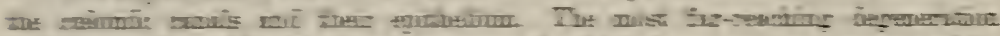

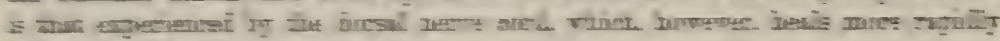

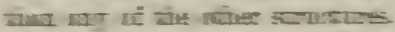

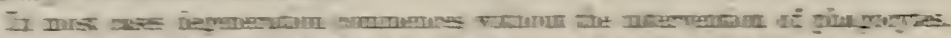

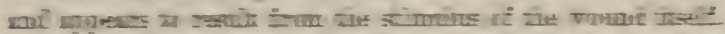

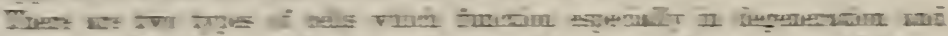

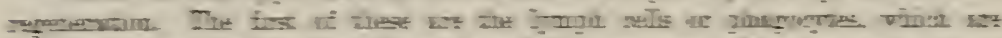

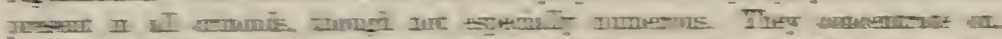

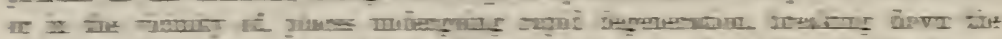

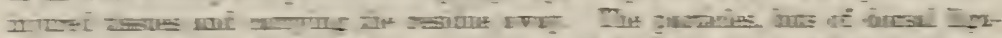

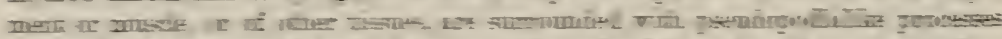

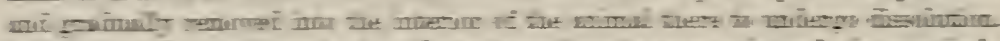

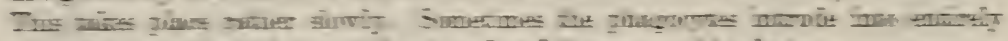

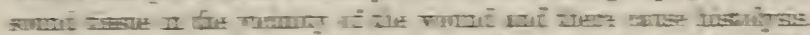

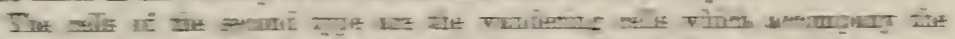

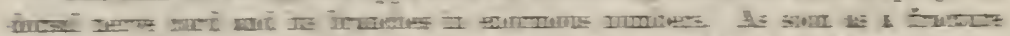

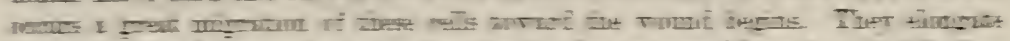

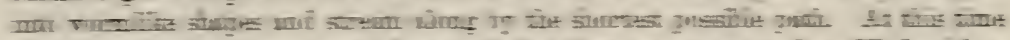

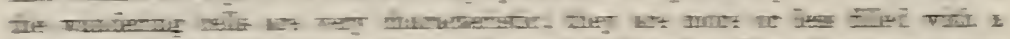

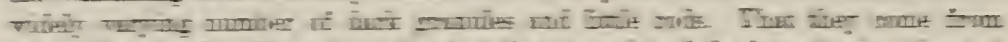

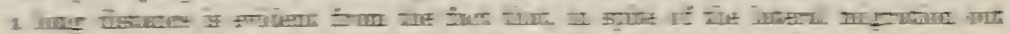

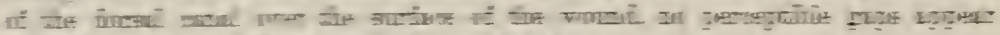

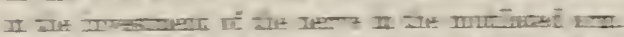

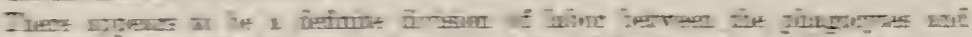

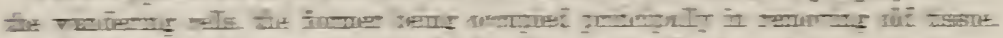

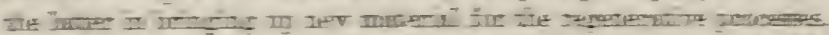

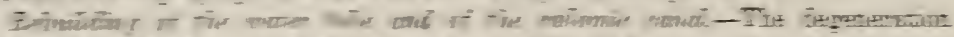

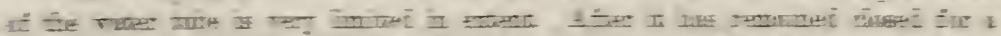

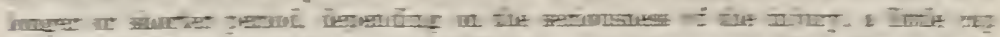

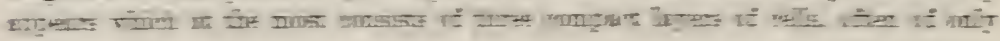




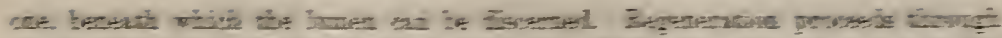

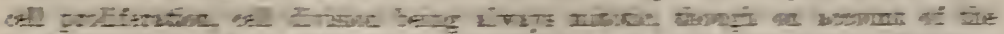

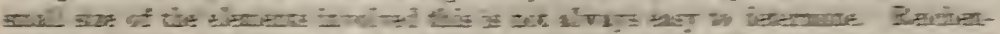

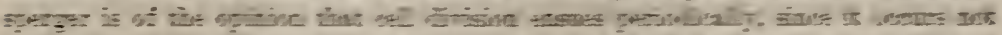

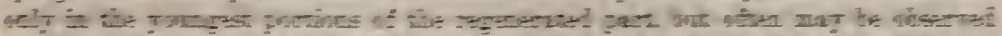

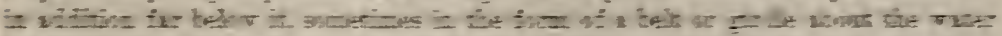
The

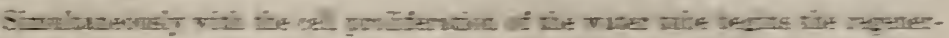

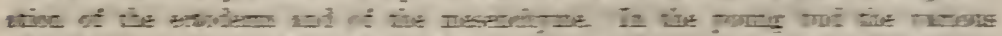

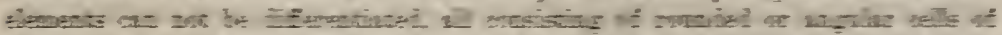

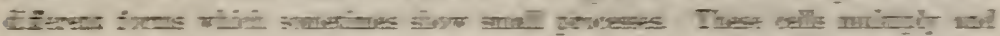

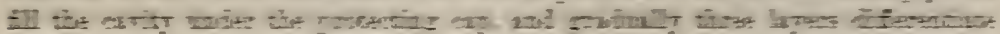

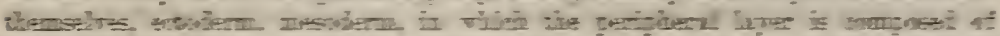

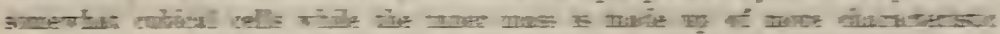

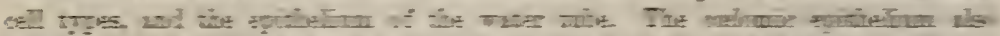

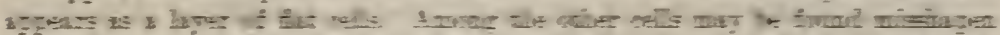

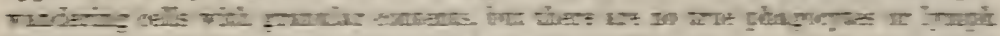
ec?

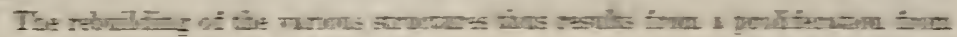

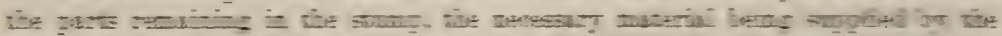

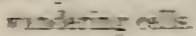

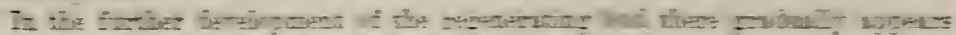
1. Iu

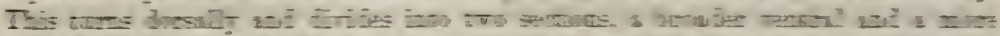

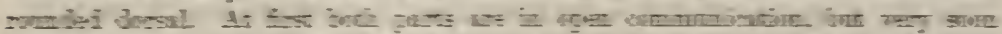

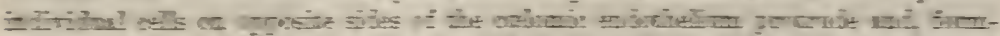

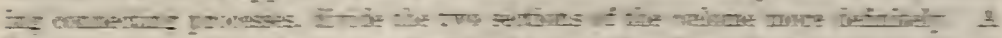

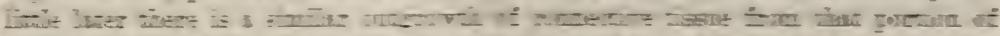

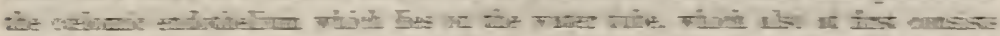

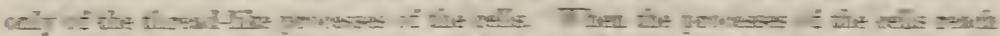

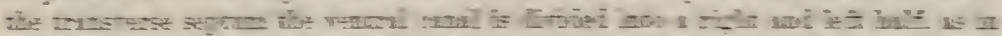

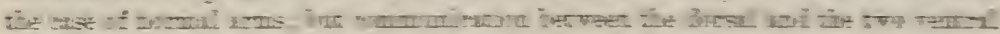

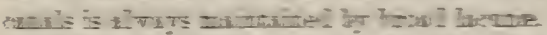

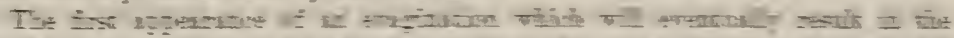

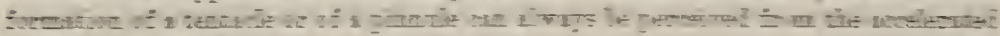

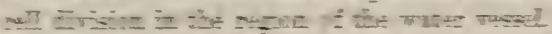

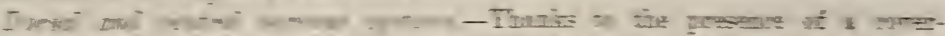

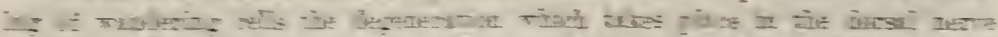

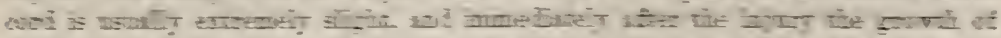

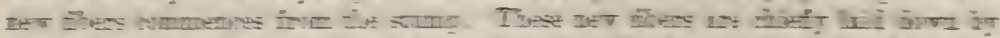

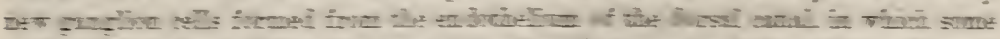

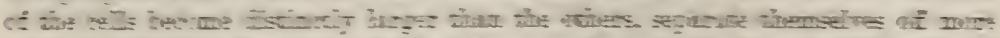

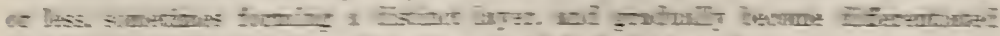

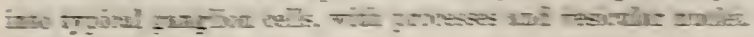


In the regenerating arm the nerve fibers at first lie directly upon the endothelium of the dorsal canal, and it is some time before the lateral ingrowth of connective tissue and the development of the calcareous substance of the ossicles forces them away from the dorsal canal and into their normal position.

Subsequent growth of the dorsal nerve cord proceeds normally. It is ensheathed by wandering cells, and ganglion cells can be made out along its course. At four points the latter occur in considerable numbers, and in these regions the cord thickens and becomes drawn out into branches which lead to the ends of the dorsal ligaments, and which, in combination with the ganglion cells previously described, which at first are somewhat elongated and possess numerons processes which later unite with the nerve fibers, innervate the dorsal ligament.

The rebuilding of the ventral portion of the mesodermal nervous system, which runs on either side of the water tube, follows a course parallel to that of the dorsal portion of the same nervous system, but lags behind the regeneration of the other brachial elements.

The two ventral nerve cords are formed from the endothelium of the water vessel by a proliferation of cells into the connective tissue, which results in a thickening of the walls on either side, and from the elements of these thickened walls ganglion cells are differentiated; in other words, they arise exactly as the dorsal nerve cord.

Reichensperger found that the destruction of the dorsal nerve in the stump of a mutilated arm usually induces autotomy beyond the injured region; but if this does not occur regeneration is retarded for about 10 days, suggesting that it is necessary for the nerve to regenerate before a general rebuilding can take place. From this he assumes that it is the dorsal nerve cord which plays the most important part in regeneration. It is possible, however, that the retardation of regeneration under these conditions results rather from the effect on the wandering cells than from the damage to the nerve itself.

It is probable that in the larvæ the development of the mesodermal nervous system will be found to follow the lines indicated by Reichensperger in regenerating pinnules and arm tips, for in regeneration the ectodermal nerves follow the same course as in ontogeny.

Since it has been demonstrated that in the young larræ the ectoderm so completely fuses with the mesoderm that no dividing line can be found between them, the idea suggests itself that the so-called mesodermal nervous system in reality owes its origin to cells primarily ectodermal which have passed downward into the mesodermal tissues.

During the early stages of regeneration the cells in the connective tissue become more and more noticeably differentiated, and the epithelial cells with their supporting processes become more and more distinct from those of the underlying cutis. Correlatively the evagination of the tentacles from the water tube begins, which is accompanied by a parallel extension of the connective tissue and epithelium of the arm on the ventral side. A process similar to that which has taken place in the endothelium of the dorsal canal now occurs in the single-layered epithelium of the ambulacral groove. Several layers of cells are formed which 
undergo wide differentiation. First, moving out from the innermost portions, ganglion cells appear, though only in relatively small numbers, followed by supporting cells, and later, when the tentacles have entirely regenerated, epithelial gland cells are formed. The schizocoele cavity appears rather early. The cilia are rather later in making their appearance.

Reichensperger believes that the rebuilding of the epithelial nerve layer for the most part can be traced back to the outgrowth of the original nerves, but that the newly formed ganglion cells also assist in the reconstruction to some extent.

Genital cord.-The genital cord undergoes extensive degeneration. In individuals not sexually mature it shrivels and disintegrates as far as the branch given off to the preceding pinnule, though in sexually ripe animals the degeneration is much less far reaching. In both cases regeneration proceeds in the same way, proceeding exclusively from the unchanged portion and progressing rapidly once it has set in.

First a bud is formed from the approximate walls of the genital canal and genital tube, to which the genital cord apparently also contributes. This bud penetrates the very loose connective tissue which separates the divisions of the brachial cœlome, and its various elements become reassorted.

Differentiation of the elements in the genital cord occur very early, numerous cells becoming converted into germ cells.

Muscles and ligaments. - In well-advanced regenerating buds the first indication of the formation of the muscles and ligaments consists in the accumulation of mesenchyme cells in certain definite regions. The muscle cells make their appearance somewhat later than those of the dorsal ligament, and at first are only with difficulty distinguishable from the latter.

The dorsal ligament cells are oval and somewhat elongated, with a finely dotted plasma and a moderately large nucleus, containing usually several large and many small nuclear bodies. They collect at the ends of the ossicles and move toward the dorsal nerve cord, in the immediate vicinity of which the oldest cells are found.

The cells now elongate, and fine fibers can be made out. Whether these fibers are internal, or whether the cell rests upon them, has not been definitely determined.

When the formation of the fiber bundle is completed the cells are entirely different in appearance. The nucleus stains so intensively that no details can be distinguished. The amount of the now homogeneous cytoplasm gradually diminishes until it is present only as a thin clear film about the nucleus. From the cells more and more fine fibrils are produced which in the middle lie closely together, but at either end become spread out brush-like and, gradually turning toward each other within the meshwork of the skeletal pieces, finally meet, producing regular bows or loops. These loops lie usually in several or numerous rows, and the farther they are from the middle of the fiber bundle the more isolated are the fibers and the more difficult it becomes to differentiate them.

Often, especially in the earlier stages, only the fibers of a single bundle join to form a loop, but later the fibers of neighboring bundles become knotted together. 
Each fiber bundle, and not each individual fiber, possesses a nucleus, and, though the individual fibers of each bundle are more or less widely separated at the ends, they are all closely packed together in the middle.

The muscles arise from elements which are quite similar to those from which the dorsal ligaments are formed. The primitive muscle cells are somewhat larger than the primitive ligament cells, and their plasma appears streaked rather than dotted. The nuclei possess a single prominent nucleolus. Before such cells are further differentiated a mitotic division almost always occurs, preceded by a darkening of the nucleus and a disappearance of the nucleolus.

After this division, which takes a normal course, the two daughter cells, which usually lie close together, become curiously altered. The nucleus becomes larger and shows two nucleoli, and the cell plasma becomes drawn out toward the two ends. Soon the cell becomes still more elongated and pointerl at the ends, the nucleus becomes oval, and in place of the two nuclear bodies only a single larger one is found. At this stage the formation of the first fibrillæ occurs.

In the next stage the number of the fibrilla has greatly increased, and the young muscle fiber forms a twisted band. Whether this twist has any connection with the subsequent spiral striping has not been determined.

Each individual fiber terminates in a distinct dark point on the calcareous ground substance, but whether it comes into actual contact with the calcareous matter is not known.

In the growing fiber a special type of granulation is visible in the sarcoplasma; the nucleus is elongated and shows a small vesicle, with nuclear bodies. On the insertions compact plates have developed, in which the individual fibers can not be distinguished. These plates accommodate themselves to the contour of the meshes in which lie the skeletal parts. From the more intensive staining of the plates and of the adjacent ligamentous portion of the fibers it appears almost as if the attachment was brought abont by a specially secreted substance.

Minckert has pointed out that in the ontogeny of Antedon the brachials for some time after their appearance do not differ in form, and also that all are united in the same way.

Regenerating brachials show the same thing, and for some time it is impossible to decide whether a given articulation will eventually become a muscular or a nonmuscular articulation.

Skeletal structures.-The rebuilding of the skeleton commences in the earliest stages and proceeds very rapidly.

In 1 socrinus the regeneration of the calcareous structures is more rapid and more complete than in Antedon, and in Antedon mediterranea it is more rapid in animals taken from the sea than in those kept in captivity.

DETAILS OF THE REGENERATIOX OF THE CIRRI.

The regeneration of the cirri, total or partial, proceeds along the same lines as the regeneration of the arms.

The closure of the wound takes place much less actively and is less extensive than is the case in the arms, and fewer connective tissue elements and wandering cells are involved. 
In the case of partial loss the wound sometimes simply heals over with no restitution of the missing part. 'This occurs frequently in the terminal portion of very long cirri, such as those of the species of Ptilometrinæ. More commonly, however, there forms in the course of a few days a small bud, apparently consisting of ectoderm and mesenchyme elements which can not be differentiated. Later an epithelium of more or less cubical cells appears. Meanwhile, with the usual cell proliferation and active cell division, the endothelium of the cirrus canal and of the enveloping nerve sheath begins to regenerate, and there is formed, projecting into the bud, a hollow finger-like cap over the end of the canal. Immediately there appear the beginnings of the skeletal structures in the form of a fine spicule which gradually enlarges into a fenestrated plate.

As in the case of the arms, the chief stimulus for the growth of the regenerating bud appears to come from the nerve, about the periphery of which rapid cell formation takes place.

While in old cirri the band of connective tissue which divides the cirrus vessel into two halves appears more or less solid, in the regenerating buds it is clearly composed of two bands, which form a sort of canal. Reichensperger considers it probable that a nourishing fluid passes along this canal and out of its open end to the actively proliferating cells. It may be a blood vessel, since it is connected with the connective tissue of the axial organ, which certainly contains blood vessels.

\section{EMBRYOLOGY AND DEVELOPMENT.}

The embryology and development of four closely related species of comatulids-Antedon bifida of the Atlantic coasts of France and England, Antedon mediterranea of the Mediterranean, Antedon adriatica of the Adriatic, and Antedon moroccana of the northern coasts of Africa-have been studied by a number of able investigators, and the chief features are now relatively well understood.

The latest and most exhaustive work has been done upon Antedon adriatica, and this, monographic in scope, includes a comparative account of the conclusions reached on every point by all the previous authors.

The major part of the investigations have been carried out on Antedon mcditerranea, and upon the embryology and development of this type we have two most excellent treatises, besides numerous scattered notes.

Antedon moroccana has served as the basis for very detailed studies, but the results have been somewhat obscured by the fact that it was not differentiated from Antedon bifida and A. mediterranea, both of which were under consideration at the same time.

All of the pioneer work was based upon Antedon bifida, but since the middle sixties this particularly interesting species has received no attention, thanks to the greater a vailability of material of the Mediterranean forms.

The first step in the study of the development of recent crinoids may be said to have been taken by John Vaughan Thompson, who in 1827 published an elaborate memoir upon a supposedly new small stalked crinoid which he had discovered in the Cove of Cork, Ireland, and which he called Pentacrinus europæus. This 
discovery of a stalked crinoid in European waters aroused very considerable interest and was widely noticed. Subsequent study of these small creatures showed that instead of being adult pentacrinites they are in reality only the young of the common comatulid of the Irish consts, Antedon bifida-a discovery which Thompson announced in 1835 .

Thompson found that the ova are developed in conceptacles formed by the thickening of the membranous expansion within each of the first 15 or 20 pairs of pinnules beyond the oral pair, and that the ova make their exit through a round hole in the fascial side of each conceptaculum, "still, however, adhering together in a roundish cluster of about a hundred each."

In the same year Dujardin also noticed the development of ova in the pinnules and their escape through apertures formed in the integument in Antedon mediterranea at Toulon.

In spite of the seemingly conclusive accounts of Thompson and Dujardin, Edward Forbes in 1841 stated that spermatozoa only are found in the swollen pinnules and mistook the sacculi for ovaries. From original observations made in Dublin Bay he confirmed the identity of Pentacrinus europaus with Antedon bifida, in regard to which Dujardin was somewhat doubtful.

The existence of a free-swimming larval stage in the comatulids had not as yet been demonstrated. In 1851 Wilhelm Busch, a pupil of Johannes Müller, published an account of such a larva which he had found during a visit to England and Scotland, but he did not succeed in tracing its development. Incidentally the larva he describes and figures, which resembles to a striking degree a holothurian pupa, is abnormal, representing a rather frequent type of precocious development.

In 1863 Professor Allman published a memoir upon a prebrachial stage in the development of the stalked larva of Antedon bifida, his material consisting of a single specimen which he had obtained on the coast of South Devon.

Two years later Sir C. Wyville Thomson published an excellent account of the early stages of Antedon bifida, which was supplemented in the following year by the masterly work of Dr. W. B. Carpenter upon the later developmental stages of the same species.

In 1873 Prof. Edmond Perrier published a short paper which marks his entry into a field where later he was to achieve so much distinction, and in 1876 Götte published the results of his studies on the comparative embryology of Antedon mediterranea. In the next few years Professors Hubert Ludwig and Elias Metschnikoff made notable contributions to the developmental history of the same species, though from the anatomical rather than from the embryological standpoint.

In the eighties original investigation and philosophical consideration of the derelopment of Antedon were undertaken with renewed vigor, the former because the many new refinements of technique had made more accurate work possible, the latter as a result of the wonderful wealth of fossil forms recently discovered. During this decade Perrier made numerous original contributions to the subject, culminating in his exhaustive and elaborate monographic survey of the field based mainly upon Antedon moroccana and A. bifida, which was published in 1886. Professor Jules Barrois, in addition to some short papers, published an excellent 
comprehensive treatise dealing with the young of Antedon mediterranea; Wachsmuth and Springer dealt with the development of the crinoids from the fralæontological side; Sladen considered the comparative embryology of all the echinoderms; while Vogt and Yung gave the results of some original observations and made some remarks upon the possible interpretation of certain structures. The two Challenger volumes by P. H. Carpenter, together with his numerous short papers, and the memoirs of Henry Bury on the development of Antedon mediterranea and on the comparative development of the echinoderms call for special mention. Basing their opinion upon the orientation of the interradial angles of the centrodorsal and its significance in the light of their well-known law, Wachsmuth and Springer in $\mathbf{1 8 8 5}$ had arrived at the conclusion that Antedon is in reality a dicyclic genus and had suggested that, though no infrabasals had ever been found, these plates might eventually prove to be present in the young. P. H. Carpenter had subjected the law of Wachsmuth and Springer to very spirited criticism and had brought forward what appeared to him to be insuperable objections to it. He was especially emphatic in his denial of the possibility of the occurrence of infrabasals in Antedon. It remained for Bury finally to settle the question by his discovery of infrabasals in this genus.

The only comprehensive work published since the appearance of Bury's paper is that of Dr. Oswald Seeliger on the early stages of Antedon adriatica. In this the segmentation of the ovum and the development of the embryo and larva up to and including the so-called prebrachial stage are treated in minute detail. Detailed explanations of the differences between his results and those of previous investigators add much to the value of the memoir.

The development of Antedon adriatica may be summarized as follows:

CLEAYAGE.

The first division always begins shortly after 8 o'clock in the morning. It appears as a shallow furrow on the animal pole, which gradually extends to the opposite pole, at first superficial, later sinking deeply into the mass of the egg.

For a time the two blastomeres appear to be united at the vegetative pole by a narrow bridge of protoplasm, but this eventually gives way, leaving two equally large well circumscribed cells mutnally adherent through a circular area.

In well-prepared material the nuclei of the two blastomeres can always be made out, lying nearer the animal than the regetative pole; but the large amount of yoke sometimes makes this more or less difficult.

In most cases two little bodies can be seen between the cells, which are probably polar bodies.

Because of the fact that the embryo very soon acquires a monaxial structure, in which the plane of the first cleavage can no longer be determined, it has not been definitely proved whether or not the two first blastomeres correspond to the two body halves of the bilateral larra. The chief axis through the animal and regetative poles, however, can be traced through all the stages, and it is not difficult to prove that it corresponds to the major axis of the larva. 
Twenty minutes after the inception of the first division a part of the eggs have already divided into the four-cell stage, the remainder soon following. The second division runs meridionally like the first, and at right angles to it, so that four cells of equal size are formed with between them a free canal running along the axis passing through the animal and regetative poles, the first beginnings of the cleavage cavity. Each of the four cells thus rests upon the two neighboring cells, but not upon the opposite cell.

At the funnel-like opening of the central canal at the animal pole one, or even two, polar bodies may often be observed.

The third cleavage plane runs parallel to the equator, though not equatorially, for it lies nearer the animal than the vegetative pole and thus divides the embryo into four smaller and four larger cells, which are directly superimposed.

As in succeeding stages the cleavage carity is now smaller at the animal pole, where it is surrounded by the smaller cells, than at the regetative pole, where it appears between the larger cells.

The embryo is now quadrilateral; but a definite relation between these quadrants and the body regions in the later embryo has not been determined.

The next division first begins at the animal pole and divides the four small cells into eight of approximately equal size. The division of these four cells is usually not everywhere entirely syuchronous.

As a rule the furrows first appear on the four vegetative cells after all four of the animal cells are entirely divided; as in the case of the cells at the animal pole, the division of the vegetative cells is not always synchronous.

As a result of these divisions the inner borders of the eight cells of the animal pole retreat a little from the major axis, so that the cleavage cavity becomes wider, while at the regetative pole no change takes place.

The following division runs equatorially and divides the eight smaller cells at the animal pole into 16 of approximately equal size. The embryo is thus composed of 24 cells, arranged in three superposed zones.

After the division of the animal cells is completed, indeed often while it is still in progress, the newly formed blastomeres rearrange themselves in such a way as to bring about the complete closure of the orifice at the animal pole. This is accomplished rather quickly, often before the end of the 2t-cell stage; before the completion of the 32-cell stage the orifice is invariable closed.

This rearrangement of the cells at the animal pole does not always take place in exactly the same way. Sometimes one of the small cells moves out of the ring surrounding the opening more or less completely into the line of the major axis, while again all eight of the cells about the opening may move toward each other in such a way as to close it. The examination of a large number of embryos at this stage shows very diverse conditions at the animal pole, making it clear that the rearrangement of the cells is brought about in various ways.

The 32-cell stage following arises from the 24-cell stage through the appearance of furrows, parallel to the equator, which divide the eight vegetative cells. These furrows do not always appear simultaneously on all the cells, and they are not equidistant between the equator and the pole, but slightly nearer the former, so 
MONOGRAPH OF THE EXISTING CRINOIDS.

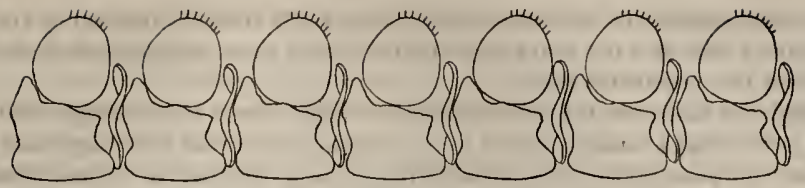

874
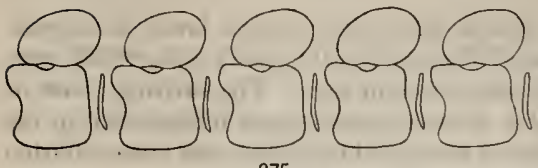

875

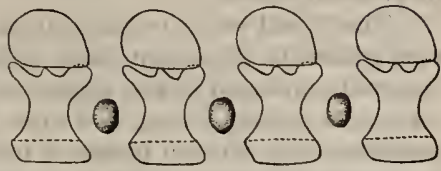

876

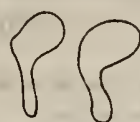

877

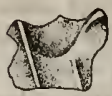

878

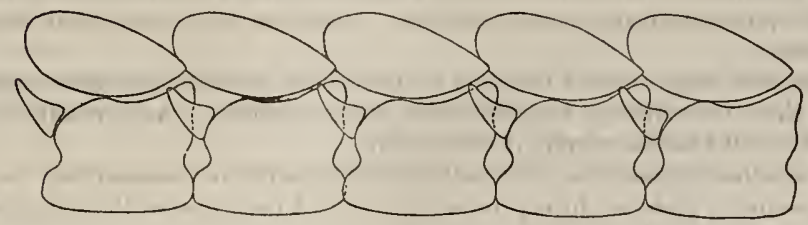

879

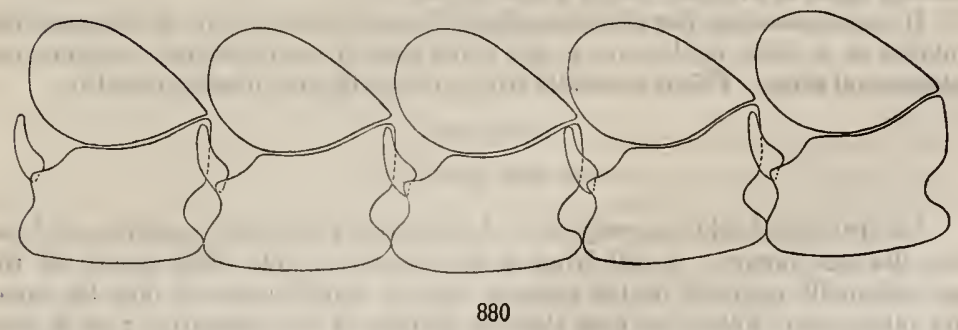

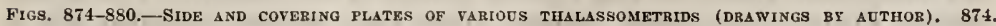
Parajetra granteata. S75. Same, 876. Same, three sacceli shown. 877. Same, two supple-

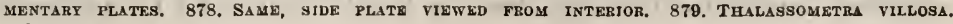
880. SAME. 
that the eight vegetative cells are divided into eight smaller, bordering the lower tier of animal cells and not markedly different from them in size, and eight larger. surrounding the vegetative pole.

Though the orifice at the animal pole is always closed at this stage, that at the opposite pole always remains open; but a certain amount of rearrangement of the cells about the pore takes place which, though very diverse in its manifestations, always tends to narrow the opening, causing it to appear slit-like and forecasting its eventual closure.

The 48-cell stage, resulting in an almost perfectly spherical larva, in appearance a blastula, is brought about by the division of the 16 animal cells, which were originally arranged in two superposed zones of eight each. The shifting about of these cells before, during, and after this division causes great irregularity in the position of the division planes of many of the individual cells; but these division planes can all be traced back to an originally meridional position.

At this stage a rearrangement of the eight vegetative cells immediately surrounding the apical orifice takes place, which results in its complete closure, and also causes a slight flattening of the vegetative pole.

The ensuing division of the vegetative cells gives rise to a 64-cell blastula, in which the regetative cells are noticeably larger than the others.

As a result of the crowded conditions under which the embryos exist when attached to the pinnules of the mother, combined with the nechanical weakness of a 64-cell blastula, the larvæ at this stage almost invariably depart slightly from the perfectly spherical form, usually showing a more or less pronounced flattening on one side.

From this stage onward the cells do not divide with the previous regularity, some of them outstripping the remainder in development. As a result of this a regular 128-cell blastula rarely, if ever, occurs.

As in other echinoderms, the cells of the blastula on commencing to divide tend to assume a globular form; toward the end of the division the daughter cells again transform into longer prismatic cells.

After division the chromatin content of the daughter nuclei is diminished, increasing again at the inception of a new division.

It is an interesting fact that throughout the greater part of the development the embryos on a single mother are at any given time at approximately the same developmental stage. This is especially true in the early part of embryonal life.

GASTRUTATION.

Figs. 1315,1316, pl. 46.

Gastrulation begins scarcely seven hours after the initial appearance of the first cleavage furrow. A cell lying at the vegetative pole sinks inward on the spot originally occupied by the cleavage pore; a neighboring cell does the same, and others soon follow, so that there is formed at the vegetative pole a very narrow, shallow, and slitlike furrow, which later becomes elongated and is sometimes interrupted here and there, in length about equal to one-fourth of 
the circumference of the embryo, from the borders of which the invagination of the entoderm takes place.

The monaxial blastula has thus become a bilateral gastrula.

The inner cavity is, as in the preceding and succeeding stages, filled with an albuminous substance.

Both the ectoderm and entoderm cells are more or less prismatic in shape, and in both series the cells are arranged in a single layer.

The nuclei of the ectoderm cells lie in their outer halves, often very near the periphery. In the entoderm cells they occur mostly in the middle. In the cells which, as a result of the abrupt folding. are more or less pyramidal in sliape, they lie in the broad cell end, whether this is toward the lumen of the primitive gut or toward the primary body cavity.

Among the prismatic cells there are in the ectoderm a number of globular cells situated exteriorly and excluded from the primitive body cavity by the arching together of the neighboring prismatic cells beneath them. These are ectoderm cells undergoing division.

The number of cells in the blastula continues to increase. The elements of the single-layered ectoderm become relatively higher and narrower, while those of the entoderm appear by contrast more rounded. The lumen bounded by the latter always retains the form of an elongate very narrow fissure.

While at the time of the first formation of the blastopore the gastrula was bilaterally symmetrical, this is no longer true, for the invagination of entoderm cells takes place with slightly greater rapidity on one side than on the other, and the blastopore, now more or less constricted in the middle, where the invagination is deepest, is placed somewhat diagonally. There is considerable variation in the form of the blastopore as well as in that of the primitive gut.

During the entire course of the first night the embryo continues in the gastrula stage. The cells increase in number, and mesenchyme formation begins in the entoderm.

The blastopore now has the form of a narrow crescent the concave side of which corresponds, within the embryo, to the side toward which the entire mass of invaginated cells bends orer. That is to say, within the gastrula there is a more extensive free body carity on the side of the primitive gut corresponding to the convexity of the blastopore than on the other.

As in the preceding stage, there is considerable variability in the form of the blastopore and of the primitive gut.

It is possible with a reasonable degree of correctness to indicate the orientation of the 16-hour gastrula in terms of the free-swimming larva. The side toward which the primitive gut leans will become the ventral. As the blastopore is posterior the right and left sides are also determined.

In some cases embryos of older stages are found in which the anterior (innermost) end of the primitive gut is turned toward the dorsal instead of toward the ventral side, later reversing its position. It is thus evident that the side toward which the gut leans at this stage is not necessarily the ventral side. 
Only with a similar reservation can the ventral side of the 10-hour embryo be inferred from that of the 16-hour stage, for in intermediate stages the gut often appears straight, so that the surface toward which it inclines at first is not necessarily that to which it will eventually be curved.

When preparing to divide the ectoderm cells contract and, withdrawing to the exterior of the cell layer, there form large globular cells widely excluded from the primitive body cavity by the meeting of the adjacent prismatic cells beneath them. On sections these neighboring prismatic cells show more or less extensive incisions corresponding in outline to the outline of the globular cell. After division, which occurs in the usual way, the daughter cells elongate and push their way down between the surrounding prismatic cells until their inner ends reach the primitive body cavity, becoming in the process indistinguishable from these. In sagittal sections of the ectoderm which show the prismatic cells as five or six sided polygons their nuclei are sometimes seen undergoing division, so that it may be inferred that it is not always necessary for the ectoderm cells to assume the globular form preparatory to division.

The entoderm cells differ from those of the ectoderm in their shorter and more rounded form. But among the relatively short and rounded cells there are numerous more slender prismatic cells of the same length as the others which possess two nuclei, resulting from the division of a mother nucleus, one of which lies toward the gut lumen, the other toward the body cavity. The appearance of these two nuclei is followed by the division of the cell body in such a way that one of the daughter cells borders the gut lumen, the other the body cavity.

These daughter cells bordering the body cavity are first found at the blind end of the primitive gut and represent the mother cells of the mesenchyme.

Between the typical entoderm cells there are others of approximately equal height, which toward the body cavity are swollen into a very thick, rounded base, and toward the gut lumen are drawn out to a fine point.

The several-layered condition of the entoderm, which leads to the formation of the mesenchyme, appears to result not only from the division of the entoderm cells parallel to the surface as just described, but also from the formation and subsequent liberation of these top-shaped elements.

All stages between the cells just emerging from the entoderm and the typical mesenchyme cells can be found. The process reaching in between the entoderm cells shortens and finally is entirely withdrawn, while at the same time the cell severs all connection with the entoderm.

The typical mesenchyme cells, which in the primitive body cavity lie abundantly on the entoderm, are strongly rounded and invariably show a nucleus. They undergo division individually and independently.

In the 19-hour embryo, as a result of continued cell division, the ectoderm cells have become shorter and the whole ectoderm layer therefore thinner. As the embryo has increased not at all or only insignificantly in size, additional ectoderm cells must have forced themselves through the blastopore opening, since the primitive gut sack has become more extensive, reaching quite across the primitive body cavity to the animal pole; indeed, in a cross section through the blastopore a 
funnel-shaped opening is seen, at the base of which lies the very narrow (crescentic) slit representing the blastopore opening of the preceding stage.

At this stage the cells recently invaginated differ somewhat from those earlier pressed inward, but later an equalization of the differences occurs and a uniform entoderm results, from which mesoderm cells are usually given off as freely in the immediate vicinity of the blastopore as elsewhere, though frequently only from a circumscribed region at the blind end of the primitive gut.

During the succeeding hours the formation of mesenchyme continues, while at the blastopore invagination still occurs, though now only to a limited extent.

In these processes numerous cases of individual variation can be observed, not only in embryos of different animals, but also in those of the same pinnule of the same animal. The shape and form of the blastopore especially raries, it being frequently elliptical, and sometimes very small and almost circular.

The increasing thinness of the ectoderm layer and the decreasing size of its constituent cells is explained by the loss of material through the extensive invagination of the entoderm and the formation of the mesenchyme.

The bilateral condition of the embryo has now become strikingly disturbed, for it is always to be observed that the left side of the end of the primitive gut lies nearer the ectoderm than the right, and that as a consequence mesenchyme cells are more numerous on the right side of the primitive gut than on the left.

$$
\text { CLOSURE OF THE BLASTOPORE. }
$$

In the stage last described ( 24 to 26 hours) the blastopore was perceptibly narrowed. This process continues, and 36 hours after the inception of cell division practically all of the embryos have the blastopore closed and the primitive gut in the form of an isolated sack.

The embryo is now, as in the preceding stage, approximately spherical; its diameter has become somewhat larger than that of the egg, measuring $0.27 \mathrm{~mm}$.

In the cases where the blastopore in young embryos exists as a narrow slit the closure takes place in two different ways, beginning either at or between the ends. If the closure begins toward the middle of the blastopore and does not advance with exactly the same speed on both sides, the last trace of the blastopore does not lie precisely in the major axis.

The line of closure can be demonstrated in the ectoderm for a considerable time as a channel-like shallow depression, which is indicated by the small size of the bordering ectoderm cells and by a slight indentation. This furrow persists for a long time after the detachment of the entoderm.

When once the adjacent cells have become the same as the other ectoderm cells the furrow vanishes. The smoothing out of this furrow follows the same course as the original closure of the blastopore. At the last only a socket-like cavity can be detected over the place where the blastopore was, and soon even this disappears.

-Meanwhile the primitive gut has assumed the form of a constricted sack and from the presence of the groove over the location of the original blastopore it is possible to determine that this constriction has taken place in the direction of the major axis.

$142140-21-$ Bull. $82-30$ 
Histologically essentially the same conditions are found as in the preceding stage, but all of the cells have become smaller as a result of the continued division. In the ectoderm the traveling of the nuclei toward the inner ends of the cells has made progress. On the outer side of the ectoderm, between the long narrow prismatic cells, lie the globular cells in process of division.

The entoderm cells are of very different shapes and lengths; some of them, lying on the lateral borders, exceed considerably the longest ectoderm cells. Laterally and posteriorly the primitive gut is composed of a single layer of cells, and is sharply differentiated from the body eavity. While in this region only isolated cells sporadically leave the entolermal epithelium to become mesenchyme cells, this process continues very actively and uninterruptedly over the anterior end of the gut.

The mesoderm cells, which now fill the major portion of the body cavity, are mostly more or less spherical in shape, with the nuclei either resting or undergoing division.

In a slightly more adranced stage mesoderm cells have pushed themselves in between the posterior portion of the primitive gut and the ectodermal Iayer, and the furrow which indicated the course of the blastopore has disappeared save for a slight indication in two or three sections.

In other embryos of this same age the conrse of the original blastopore can no longer be made out on the spherical body wall, though its location may readily be determined through the close approximation of the now detached primitive gut to the ectodermal wall.

Often at this stage the two crossed axes can not with certainty be determined, in which case the embryo again exhibits an almost monaxial structure which is disturbed only by the slight displacement of the gut sack ventrally and toward the left. In numerous embryos, however, the detached primitive gut remains in the transverse axis and the blastopore slit is somewhat more elongated and persistent, so that bilaterality is demonstrable. Both types are found side by side on the same mother, and it may be that the first condition is a more advanced stage of the second.

DIVISION OF THE PRIMITIVE GUT INTO MESENTERON, PERTTONEAL SACK, AND PRIMARY HYDROCELE.

During the second night the division of the primitive gut into two sections begins. This is effected through the appearance of a groove encircling the gut sack at right angles to the major axis of the embryo, which presses the cells inward before it, forming a sphincter-like constriction. As the cells are pressed inward the communication between the two sections of the gut becomes more and more restricted until finally it is entirely interrupted. The last trace of this intercommunication always lies in, or very near, the chief axis.

The two sections of the primitive gut always differ in size, though this difference is subject to individual variation and is often very slight. The anterior section is the larger, later becoming the mesenteron and hydrocele, while the smaller hinder section gives rise to the colome.

Only at the very first appearance of the groove do the lumina of the two portions of the gut appear similar, in sections cut across the chief axis as a series of 
circles of different diameters, and in sections cut parallel to this axis as a pair of ellipses, with the longer axes parallel.

The more the separation of the two sections progresses the more strongly comes out the contras: between them. First the posterior section becomes more and more strongly compressed dorsoventrally, and laterally elongated parallel to the blastopore slit, so that it assumes an almost tubular form. The anterior section then extends itself ventrally and dorsally partially around the tube-like posterior portion, so that in section the lumen of the former appears as a narrow crescent stretching dorsally and ventrally just beyond the broadly elliptical lumen of the latter, which runs from right to left.

At this stage there is no clearly marked bilateral structure which can be followed with certainty through all the following changes to the fixed pentacrinoid. The major axis, equivalent to the longitudinal axis, can be determined in the earliest division stages. The tube-like posterior section of the primitive gut runs from right to left. The rentral and dorsal sides are at first almost identical, except that on the ventral the entodermal sack reaches nearer the ectoderm than on the other. In the same way the right and left sides are never exactly the same. Very soon, when the dorsal and rentral sacks become differentiated, symmetry of the bilateral type becomes again established.

During the division of the primitive gut the region from which the mesenchyme cells are given off becomes more restricted and finally reduced to a small area of the anterior wall of the upper entoderm sack in the immediate neighborhood of the major axis, mesenchyme cells at other places appearing only sporadically. It is therefore to be assumed that the mesoderm cells which push in between the ectoderm and the posterior sack have arisen through the division of those earlier formed.

The form and size of the cells in the three germ layers, which were already differentiated in the 26-hour embryo, hare meanwhile become appreciably altered. All the cells have increased in number and decreased in size, and their yolk elements have diminished and in part been already entirely consumed.

In the ectoderm there are found, as in the earlier stages, globular elements in process of division among the high prisnatic cells, the nuclei of which lie now in the inner ends. But with the migration of the nuclei into the inner ends of the cells the distribution of these globular elements undergoes a change, for they are now not confined to the outer portion of the ectoderm but occur, though in small numbers, also on the inner surface toward the body cavity.

The walls of the coelomic (posterior) sack, like those of all the epithelial structures of the embryo, are of one layer of cells, but the shape of the individual cells varies considerably. Here again appear the globular cells representing the prismatic cells in process of division, though cell reduplication also occurs by the direct division of the prismatic cells themselves.

In the anterior sack the differences in form of the individual cells are more considerable than in the posterior. Here also cell division occurs both directly 
and through the intermediary of globular cells. From the anterior end of this sack mesenchyme cells continue to arise.

When the mesenchyme cells are abundant many of them, through mutual pressure, appear polyliedral. The difference in the chromatin content of the nucleus in the resting stage and at various steps during mitosis is especially striking.

The relative paucity of chromatin in the nuclei in the resting stage lying in a plasma always rich in yolk renders them very difficult to see, and this is possibly the reason for the numerous figures of mesenchyme cells without nuclei which have been published.

In the entoderm cells also a change in the amount of chromatin in the nuclei can be detected at different times, though the differences are less considerable than in the mesenchyme cells. In the ectoderm cells, on the contrary, the amount of chromatin appears to be constant at all times.

In the following stage the posterior cœlomic sack becomes more and more elongated laterally, somewhat constricted centrally, and broadened at the two ends.

The anterior section of the primitive gut has continued its growth about the posterior section, which, with its recurved ends, it now incloses.

In almost all of the embryos the ectoderm of the ventral side has now become somewhat thicker than that of the dorsal, though frequently this first occurs somewhat later. This broad zone of higher ectodermal cells on the ventral side indicates the position of the subsequent vestibular invagination.

Histologically the conditions at this stage are essentially the same as in the preceding.

Slightly more developed embryos show the ectoderm becoming locally differentiated, so that in longitudinal sections there can be distinguished four transverse bands and a terminal ring in which the nuclei are more lightly colored and lie more closely together than elsewhere. At this time these zones are broader than the intermediate zones (though later the reverse is true) and are somewhat irregular, of varying breadth and in places only slightly differentiated from the neighboring region. The sharp differentiation of the ciliated bands from the remainder of the ectoderm is first noticeable at about the sixtieth hour.

The cœlomic sack has now become more constricted centrally, while the two ends have become swollen anteriorly, so that two rather extensive lateral pockets are formed which are connected by a minute canal. Since their growth has been especially dorsalward they appear here much less widely separated than ventrally. In a median section the canal connecting them shows a thick wall with a very small lumen. Histologically the structure is essentially the same as in the preceding stage.

The two median processes of the anterior sack, which lie dorsally and ventrally, above and below the canal uniting the cœlomic pockets, have curved themselves around this last until their blind ends lie behind it.

The more extensive central portion of the anterior sack lies closely appressed to the canal uniting the two ccelomic sacks. Its walls are everywhere composed 
of one layer of cells. In some embryos a few mesenchyme cells are given off in the immediate vicinity of the major axis, while in others this process has already ceased.

From this central portion ventrally there stretches an extensive process, the hydrocœle, which at first maintains a broad connection with the remaining parts of the anterior sack.

The beginnings of the parietal canal can often, though not always, be determined at this stage. It first shows itself as a small evagination of the anterior wall of the mesentero-hydrocœle sack lying anterior to the union hetween the two colomic pockets on the border of the positions of the gut and water vessel.

While in the cases described both sections of the primitive gut are entirely cut off from each other, equally old and almost equally organized embryos can be found in which a union between the cœlomic and mesentero-hydrocoele portions is demonstrable near the major axis.

The primitive body cavity is now entirely filled with mesenchyme cells, which have greatly increased in number. Most of them are approximately spherical, but many are pear-shaped, while others exhibit a tendency to send out processes and to become star-shaped. The varying amount of chromatin in the nuclei of these cells is readily demonstrable.

FORJATION OF CTLIATED BANDS, LARVAL NERTOTS STSTEM, AND ALTERITION IN POSITION OF INTERNAL ORGANS (60 To St HOURs).

During the third night very inportant changes take place in the embryos, though the developmental advances are no longer as completely synchronous as in the younger stages. Only in rare cases now does one find all the embryos on a single mother at an equivalent developmental plane; usually the variations exhibited are considerable. Thus on the fourth day there are found, in immediate proximity to the older stages, others which have lagged behind 12 or 14 hours, so that it is possible to study in the embryos from a single mother all the changes which have taken place during the night.

Externally the embryos of this age are without exception characterized by an elongation along the chief axis, and by five transverse ciliated bands, of which the foremost is interrupted in the rentral median line. The average length is now $0.30 \mathrm{~mm}$.

The four posterior ciliated rings encircle the embryo like the bands of a cask, but they no longer run quite parallel to each other. As a result of the appearance of the vestibular invagination in the median plane ventrally the third band is arched posteriorly, and the second is, to a somewhat greater degree, arched anteriorly. The further the invagination extends the more the mid-ventral portions of these two bows are displaced.

Just before the displacement of the mid-ventral portion of the second and third ciliated bands the entire ventral side of the embryo appears thickened and a little flattened. Most of the cells are exceptionally long prismatic cells, which extend uninterruptedly from the primary body cavity to the outer surface. Their nuclei 
are somewhat larger than those of the cells of the ciliated bands, and in carmine and hæmatoxylin stain more deeply. On the rest of the ectodermal wall the contrast between the ciliated bands and the intermediate zones is always more pronounced.

In the region of the first band there occurs a very active nuclear division, with which the division of the cell bodies does not keep pace. As a result of this there are usually found in a single cell body several nuclei, small but relatively rich in chromatin, in different phases of division or in the resting stage. In the intermediate zone the nuclei remain in the resting stage without undergoing further division, and for that reason are relatively less numerous. They are also poorer in chromatin, and in some no chromatin whatever can be demonstrated. These nuclei without chromatin are very difficult to find.

At the apex of the embryo, at the anterior end of the major axis, a small flat cavity, the apical pit, appears. In this region the ectoderm is thickened and composed of several layers. The apical pit often can be demonstrated in embryos of from 40 to 50 hours, while it may be absent in others of equal age and equally developed in other respects.

The cells of the apical pit form the ciliated tuft of the free-swimming larva which later becomes so prominent. They do not all give rise to eilia, however, for a part of them migrate out of the epithelial layer and move deeper into the body. This process is not confined to the cells of the apical pit, but occurs also in the adjacent regions.

The ectodermal elements are here now cut off from the more deeply lying structures by a membrane just within which is a layer of fine fibrillæ, apparently nerve fibrillæ of ectodermal origin. Within these fibrillæ, resting upon the ends of the prismatic cells, are pear-shaped cells possessing several processes. Apart from their position they are differentiated from the mesolerm cells through containing less yolk and having more finely pointed processes. These are evidently ganglion cells of ectodermal origin.

At first the fibrillæ and the ganglion cells, indicating the embryonal nervous system, are limited to the immediate vicinity of the apical pit, but later these extend themselves further and further outward over the anterior end of the embryo and along the ventral side.

Some time after the appearance of the apical pit there appears just behind it in the median ventral line a second almost circular flattening in the ectoderm, which at first is very small. This deepens rapidly into a groove, which for a time usually remains very small, but in many cases soon becomes very considerable. During the later embryonal stages it continually broadens and eventually forms the region of attachment of the free-swimming larva.

The foremost ciliated band is ventrally interrupted by this fixation plane.

In the thickened ventral surface there appears at about the eightieth hour (earlier than the fixation plane), in the median line between the second and third ciliated rings, an invagination which quickly becomes more extensive-the restibular groove. The anterior portion of this, which displaces anteriorly the second ciliated band, is more depressed than the posterior, which lies near, or against, the 
third band. The depth of this invagination varies greatly and is often very considerable.

The internal organization now shows very important changes. The two celomic sacks, which in the preceding stage were united by a fine tube, have now become entirely separated from each other. A knob-like swelling on the median wall of the right cœlome, which persists for some time, is the last remnant of this connection.

Simultaneously with the thinning of the walls the two sacs increase in size and become pocket-like, with the inner and outer walls lying very near each other, so that the lumina are very narrow.

The right sack has extended itself dorsally almost around the entire body cavity and has reached over on the dorsal side somewhat to the left; also it has grown considerably anteriorly, where it now covers the gut.

The left sack has extended itself less far anteriorly, and in its anterior part is much less widened ventrally, so that it lies on the dorsal wall of the hydrocole, pushing to the right with its dorsal margin and thus forming a sort of mesentery. It has extended especially posteriorly and there surrounds the gut, meeting the posterior border of the right sack.

Thus the mesentery on the dorsal side runs almost in the median plane, though a little to the left; posteriorly the nearer it approaches the ventral side the more it shifts to the right. It forms approximately a half circle. which opens upward and ventrally, since on the ventral side the ventral corners of the two cœlomic sacks are at this stage very widely separated from each other (through an angle of about $90^{\circ}$ ), and also anteriorly approach the edges only in the dorsal region.

As from the beginning, the colomic walls are single layered, but the cells have now become perceptibly smaller and lower.

While these alterations in the colomic sacks have been taking place the two sections of the mesentero-hydrocœle have become completely separated.

The primitive hydrocœle is somewhat constricted dorso-ventrally and lies closely on the thickened ectoderm wall, almost entirely on the left side of the embryo, toward which side all the internal organs are more or less displaced.

Dorsally it extends almost as far as the gut itself, to the posterior end of the left cœlome; anteriorly it reaches over the gut and covers it in its central part. This anterior dorsal portion of the primary hydrocœle becomes differentiated as a tubular structure, which runs almost parallel to the ventral surface from right to left, but in the center of the embryo crosses the chief axis not quite at right angles; this is the parietal canal.

Histologically the wall of the primary hydrocœle is throughout a single-layered epithelium of cylindrical cells of which the prominent nuclei lie near the inner border.

During the separation of the parietal canal the histological contrast between this and the secondary hydrocœle sack becomes progressively more and more marked; the former is composed always of smaller, at first cubical and later more flattened cells, while in the latter the form of the cells appears not to be essentially altered. 
The parietal canal is enlarged in such a way that its walls, without increasing perceptibly in mass, continually become thinner.

The beginnings of the definitive gut develop from the two median dorsally and ventrally running horus of the anterior sack and from the central section in so far as it is not concerned in the formation of the hydrocœle and the parietal canal. With the dissolution of the union between the two coclomic sacks the two vertical entodermic processes unite, first anteriorly and later also posteriorly.

During these changes the gut in different individuals shows striking variations in the thickness of the walls and in the extent and form of the lumen which can not be explained as part of a continuous developmental series.

Cross sections show the gut predominently triangular with the base of the triangle parallel to the hydrocele sack and the apex dorsal, lying between the two cœlomic sacks of the mesentery. It does not rum exactly in the major axis, nor parallel to it, for its anterior end is displaced toward the left and its posterior usually a little toward the right.

The walls are composed of cylindrical or cubical cells, among which on the outer side are occasionally seen globular cells in process of division.

It is certain that the parietal canal and the water vessel intercommunicate after they have severed their connection with the definitive gut. The last point of union witl the gut is at the region of the connection between the two, so that they might be considered as two evaginations of unequal size from the anterior gut section extending dorsally and ventrally from it, while the two ccelomic sacks might be considered as right and left evaginations of the posterior end of the gut, near the blastopore.

It might be said that in the primitive gut (archenteron) after its closure there can be differentiated three divisions-a posterior (lying near the blastopore), a middle, and an anterior. The posterior has already been separated off and divided before the anterior appears. The middle remains single and forms the definitive gut. The anterior and posterior each divide into two parts; the latter gives rise to the right and left cœlomic sacks, the former ventrally to the hydrocole and dorsally to the parietal canal.

The mesenchyme filling the primitive body cavity is now composed of more numerous but smaller elements, rounded or star shaped, with short processes. The more or less gelatinous albuminous substance which in the younger stages filled the body cavity has been almost entirely consumed by the mesoderm cells.

In the crinoids the division of the archenteron is as follows:

Archenteron: $\left\{\begin{array}{l}\text { peritoneal sac } \\ \text { (at hinder end) } \\ \text { mesentero-hydrocœele }\end{array} \quad\left\{\begin{array}{l}\text { right cœlome. } \\ \text { left cœlome. } \\ \text { mesenteron. } \\ \text { prlmitive hydrocœle sac }\end{array}\left\{\begin{array}{l}\text { definitive hydrocœle. } \\ \text { parletal canal. }\end{array}\right.\right.\right.$

In the other echinoderms:

Archenteron $\left\{\begin{array}{l}\text { mesenteron. } \\ \text { one or two vaso-perltoneal sacs (at anterior end) }\left\{\begin{array}{l}\text { perltoneal sac. } \\ \text { hydrocoele sac. }\end{array}\right.\end{array}\right.$ 
LAST PERIOD OF embeyonal deVelopment; formation of calcakeous sKeleton (84 to 120 hocrs).

During the fifth day the embryo escapes from the egg membrane and becomes a free-swimming larva. It is now elongated in the direction of the major axis and has reached a length of about $0.40 \mathrm{~mm}$. As a result of the advance of the vestibular furrow the general form has become beanlike.

Up to the time of the appearance of the calcareous skeleton the inner organs remain essentially as just described, but the walls are composed of smaller cells, and the lumina are more extensive.

Owing to the exceptional opaqueness of the living object it is necessary to study the skeleton in preserved material.

In embryos of 100 hours there are already present five orals, five basals, and from three to five infrabasals in the calyx, and about 11 calcareous elements in the columin.

It appears that in the embryos of animals kept in aquaria for some time before the extrusion of the eggs the calcareous structures are less extensively developed, smaller and thinner, and at the same time very much more variable, than is the case in embryos from mothers living freely in the sea.

The calcareous plates are often quite irregularly developed in animals of exactly the same age, and the individual plates of the same series in the same animal often show considerable differences.

Each of the five basals, like each of the five orals, is approximately equidistant from those on either sidc, except that in each series the distance between the two outermost is greater than the distance between any two of the others. Thus it is that the basals and orals have usually been described as lying in horseshoeshaped bands, open ventrally, surrounding the major axis. If it is borne in mind that the planes of the two horseshoes are strongly oblique, so that the open sides lie much more anteriorly than the closed ends, and that the left arms of the horseshoes in each case reach farther antcriorly than the right, the relative positions of the plates in these two series are fairly well indicated.

At this stage the individual basals and orals do not lie exactly behind each other, for the basals are slightly more displaced dorsally than the orals. Frequently this displacement is such as to bring the first basal almost or quite in line with the second oral.

The left basal $\left(b_{1}\right)$ lies farther anteriorly than the right $\left(b_{5}\right)$ and the left oral $\left(o_{1}\right)$ in the same way lies farther forward than the right $\left(o_{5}\right)$. Usually, the right basal lies farther anteriorly than the left oral.

The plates in these two series lying farthest posteriorly are those in the median plane dorsally, the third oral and the third basal.

While the first and fifth basals lie in the region delimited by the third ciliated ring, usually just proximal or just distal to it, the third basal lies under the fourth ring. In the same way while the first and fifth orals lie under the fourth ring, the third lies under the fifth. 
Although the position of the plates as just described appears to be the normal, many variations occur.

Bury believed that the orals are formed in the vicinity of the left, the basals about the right cœlomic sack; but Seeliger found that the first basal without exception appears so far forward that it lies entirely outside the region of the right colome, and that the first oral appears without any reference to the left colome, on the contrary reaching with its dorsal and anterior branches far within the region of the right cœlomic sack; and there are other displacements which seem not to harmonize with Bury's conclusions.

But it is significant that at the time of the appearance of the calyx pieces the two colomic sacks have already abandoned their original position, and that the orals and the basals are formed not in a different antimere of the bilateral embryo, but both in the same antimere. In their horseshoelike arrangement about the chief axis their relations are similar to the relations of two metameres.

Seeliger finds that the calyx plates at first are always separated from the ectoderm by two or three layers of mesenchyme cells, rarely by only a single layer. Later they move nearer the surfacc, and their needlelike processes may then be easily demonstrated within the ectoderm.

Originally the meshwork of the calyx plates, which is finer than that shown by Thomson in Antedon bifida, lies all in a single plane and does not repeat the curvature of the surface of that portion of the body under which the plates lie. Commonly the basals and orals are about equally large, but the plates of either series may be larger than those of the other. The course and the thickness of the bars of the meshwork may vary in different ways.

Each plate begins in the same way. Two small calcareous needles appear from which soon branches are given off at an angle of $120^{\circ}$ that quickly increase in length, join with similar branches to form again a single bar, and then repeat the process. Later the original bars of the meshwork thicken, the spaces between them become smaller, and the whole aspect of the plate becomes more sievelike. In larre raised in an aquarium the increase in the thickness of the plates is slower than in larvæ from mothers taken from the sea.

Seeliger was unable to find a case where two or more originally separated calyx plates later became merged into a single element.

Anterior to the basals, deeper and nearer the central axis, lie the extremely small beginnings of the infrabasals. In some specimens Seeliger was able to find only three or four, more rarely only two; but he believes that five is the true number, and that in these specimens the whole number had not yet been formed. However, in some cases he found three infrabasals arranged as described by Bury.

The usual arrangement of the five infrabasals is in the form of a horseshoe open ventrally stretching over the dorsal half of the embryo. The two lateral infrabasals, right and left, lie quite near each other, and this naturally suggests that the two larger lateral infrabasals described by Bury have arisen through the coalescence of two originally separate points of origin.

The first trace of a calcareous deposit Seeliger found to be in a cavity in a group of mesenchyme cells, mostly pear-shaped, with readily recognizable globular 
nuclei, lying on one of the cells which stood out from the rest on account of the somewhat larger nucleus lying near the cell wall from which the calcareous particle appeared to have been secreted by a sort of cuticular extrusion. As the calcareous particle becomes larger progressively more and more cells take part in the deposition of lime about its edges as well as over its surface.

In the middle of the anterior portion of the embryonal body between the second and third ciliated bands lie the rudiments of the columnals. They are closely placed one behind the other in a single slightly curved row the concave side of which is directed ventrally.

The foremost element of the row. the terminal stem plate, lies near the base of the restibular invagination. In some cases, if the curve of the series of columnals is especially strong, the plane of this plate is almost parallel to the major axis, though usually it makes an acute angle with it. The most posterior stem plate lies within the circlet of the infrabasals, displaced a little corsally.

It this stage, as well as at the following stages, the number of the columuals is variable; very commonly it is 11 , but there may be 13 . If a considerable number be present new columnals form always at the posterior end of the series and are never intercalated.

The form of the individual columnals is very variable. Seeliger gives three figures of different stages. The first shows a minute calcareous crescent, of which the concave side is directed ventrally. In the second the ends of the somewhat larger crescent have become swollen and a brond straight-edged process has appeared centrally. In the third each angle of this straight-edged process has been produced into a radial spine, the swollen ends of the crescent as seen in the last stage have become produced into radial spines, and the horns of the crescent have become still further produced, so that the concavity now is almost semicircular. In this same series the more anterior columnals were markedly larger, and had already extended so far ventrally that the concave side formed threequarters of the circumference of a circle. The radial processes on the convex side had become more numerous and had begun to fork at the point.

If a large number of columnals be present new ones are formed always at the posterior end of the series, and new plates may appear through intercalation between the last two, between the penultimate and the preceding, or between the third and fourth from the last; they probably never appear further anteriorly.

In embryos of this age the formation of new plates between others already existing is rendered possible by the existence of two or more layers of mesenchyme cells between them. Usually the columnals lie so closely together that only a single layer of mesenchyme cells lies between, which of necessity is occupied with the increase of those plates.

The terminal stem plate is the most extensive of all the calcareous structures of the embryo, and is probably the first to appear, although this has not as yet been determined with certainty. It resembles the calyx plates much more than it does the other columnals, for it is in the shape of a rather extensive meshwork which shows no trace of having been derived from a primitive crescent. 
FREE-SWIMMING LARVA.

Five days after the first cleavage the embryo ruptures the inclosing membrane and escapes as a free-swimming larra. The length of this free-swimming life varies extraordinarily, even in the different individuals of the same brood; some attach themselves after a few hours and immediately proceed to further development, while others, somewhat larger though with only insignificantly altered structure, are to be met with still free swimming after a lapse of as much as 108 hours. Even at 60 hours the larvæe which immediately became fixed have the body divided into stalk and calyx, and possess 15 tentasles projecting into the closed vestibule.

When just liberated the larre are almost invariably about $0.40 \mathrm{~mm}$. long. If they remain free swimming for a considerable time they may reach at the end of the second or third day a length of $0.45 \mathrm{~mm}$. to $0.48 \mathrm{~mm}$., or in some cases even $0.50 \mathrm{~mm}$.

The larvæ usually swim with the anterior pole forward; only exceptionally, as for instance when they strike an obstacle, is the direction reversed. Occasionally a rotation about the major axis may be observed.

\section{Ectoderm.}

During the later embryonal stages the ectoderm has undergone important changes, and is quite different from that of the 75 to 80 hour stage.

Anteriorly the entire rentral part is deeply sunken so that, with its elongate form, the larva now appears distinctly bean-shaped.

The five ciliated bands are sharply differentiated from the much broadened intermediate zones, and over the deepened apical depression a large tuft of cilia las formed.

The attachment pit has also deepened, and appears much more sharply differentiated from the neighboring regions.

Ectodermal epithelium, ciliated bands, and intermediate areas.-The course of the ciliated bands is in general as in the younger stages.

The foremost band surrounds the apical pit with its tuft of cilia. On the ventral side it is interrupted by the more or less circular attachment pit into the ciliated borders of which its ends pass over.

The second bow is entire; in the median line ventrally it is arched forward slightly and passes between the attachment groove and the vestibular invagination. Dorsally in the median plane it is arched forward somewhat, though not so much as on the ventral side. Its course varies more or less in details in different individuals.

The third band is far displaced posteriorly in the nedian line ventrally by the extension of the restibular groove, about the posterior angle of which it runs. Later, as the vestibular groove is further extended posteriorly, it cuts across this third band, which sinks into it and takes part in its formation. This third band, thanks to the broad ventral posterior sweep and to its slightly diagonal course along the sides of the embryo, is the longest of all. 
The first three bands lie anterior to the internal organs over the region from which later the stalk is formed. The third approximately indicates the dividing line between the stem and calyx of the fixed larva. The fourth band surrounds the posterior body region over the internal organs, and does not present any marked irregularities. The fifth surrounds the posterior pole of the body beyond the internal organs.

In the ciliated regions the epithelium is thickened and arched outward, except dorsally in the median line where it is more flattened; inwardly toward the body cavity a feeble concavity may underlie the external more marked convexity.

The cells are high prisms, pyramids, or spindles of extremely small diameter, which extend from the exterior to the body cavity. On the outer side they bear a glistening investment over a cuticle-like edging, striped at right angles to the surface.

The cilia are deeply inserted in the outer part of the cell body. The nuclei, especially in hæmatoxylin, stain very quickly and intensively. They are markedly smaller than the nuclei of the cells in the intermediate zone and have greatly increased in number by division during the preceding derelopment period. Since frequently a new nuclear division intervenes before the cell body has completed a previous division, several nuclei can easily be found in a single cell.

The nuclei of neighboring cells lie at different heights, but mostly near the middle or in the inner cell half.

Structurally closely related to the slightly protruding type of ciliated band just described is another, which differs in that it does not rise above the general body surface, but instead is somewhat depressed below it so that it forms a shallow furrow. This occurs on the dorsal surface of the larvæ in the median line, and sometimes elsewhere.

The glistening cells here appear as extraordinarily attenuated pyramids, the bases of which are toward the body cavity, while the cilia are attached to the apices. Each cell apparently carries a single cilium.

The four zones bounded by the ciliated bands and the posterior ring are composed of considerably larger cells which lack the glistening character; in end view these are irregular polygons mostly six, sometimes five sided. The nuclei are larger than those of the glistening cells, but much less easily stainable, and lie mostly in the middle or near the inner end, very seldom toward the outer end. In some no chromatin granules can be demonstrated, and it is possible the chromatin may entirely disappear. Sometimes there are two nuclei in an undivided cell body.

Among the normally formed ectodermal cells there appear in later embryonal life certain other elements. These may be described as club-shaped cells containing a nucleus and colored deep yellow: the broader end is outward, and not only reaches the surface but sometimes projects beyond it.

After preservation in alcohol and staining in hæmatoxylin these structures stand out intensively, and it is then easily seen that the coloration comes from variously formed inclusions in the cells which lie at different heights, sometimes 
in the inner cell end near the nucleus, sometimes on the outer side in part extruded from the cell. These inclusions appear to be products of the cells in which they lie, and the cells appear to be ectodermal gland cells. The function of the cells and of their secretion is unknown.

During the free-swimming larval period the cells excrete externally a fine cuticular membrane, and between them a clear homogeneous transparent glasslike intermediate substance appears, first at the outer cell ends, later advancing gradually inward. Simultaneously the nuclei move into the inner ends of the cells and their chromatin content again increases.

Very soon after the commencement of the secretion of the intermediate substance the cells begin to withdraw from the surface, becoming club-shaped, and occasionally almost spherical, and lying at the base of the ectoderm between the protoplasmic bodies of the other cells which still reach to the outer membrane, but which are no longer throughout parallel to each other.

To what extent the shortening of the cells is related to the secretion of the intermediate substance is not clear, but the rounded cells have lost in volume, while among the elongated cells many can be seen which are about as large as in the first few hours of free existence.

Toward the body cavity the border of the ectodermal layer is no longer so well defined as in the younger stages, for the club-shaped and rounded cells project more or less inwardly; but in spite of this and of the fact that the formation of the intermediate substance gives the ectodern a certain similarity to connective tissue. especially in later stages, no doubt can at any time exist during the free-swimning period as to whether a giren cell belongs to the ectoderm or to the mesoderm.

Apical pit and nervous system.-During the free-swimming larval period the apical pit and the subjacent nervous layer reaches its highest derelopment, only to dwindle and disappear soon after fixation.

In the preceding stage individual ectodermal cells had migrated to a position beneath the ectoderm where, separated from the body cavity by a membrane, they had changed their form and a fine fibrous layer had appeared.

Little by little the number of these subepithelial cells increases, chiefly through the inward migration of new ectoderm cells, but also by division. They become markedly shorter, and send out one, two, or three processes. They become rounded when about to divide. These are evidently bi- or multipolar ganglion cells.

The size of the cell body is variable, between $0.005 \mathrm{~mm}$. and $0.006 \mathrm{~mm}$. measured without the processes, which may be of various lengths.

The cells lie on the fiber layer, between it and the ectoderm; a few of them force themselves deeper and become entirely surrounded by the fibers.

The fiber layer has become very considerable under the apical pit, and extends thence outward over the anterior end of the larva, becoming gradually finer toyard the periphery and disappearing at the second ciliated bands. Only individual fibers proceed further posteriorly along the sides to supply the posterior ciliated bands. 
Only in the most anterior portion of the larva does the membrane mentioned above separate the nervous elements sharply from the body cavity; farther posteriorly it becomes less and less prominent during the later larval existence, while at the same time connective tissue fibers appear.

In the center of the nervous apparatus directly under the apical pit there lie on the fiber layer very numerous irregular ganglion cells arranged in several layers. Laterally and farther posteriorly they become progressively less and less common, and over the finer fiber strands none occur.

Prominent on account of their size and constant in their course are two nerve cords which arise from the central fiber layer under the attachment pit and run right and left along the ventral side of the larva in the angles formed through the vestibular invagination. In cross section they appear triangular, with the smaller side toward the body cavity and the two longer toward the inner side of the ectoderm, and the lateral wall of the vestibule. Posteriorly both become progressively finer; they probably reach the fourth ciliated band.

In the anterior portion isolated ganglion cells lie on the side toward the body wall, but in the posterior portion these seem not to occur, and here only detached ectoderm cells are found which have only partially withdrawn from the ectodermal layer. These latter consequently resemble those in the apical pit at a younger stage which are in process of moving to a subepithelial position as a preliminary to transformation into ganglion cells. But in the posterior region of the two ventral nerve cords the cells do not complete the transformation into ganglion cells, since before sufficient time has elapsed for this the degeneration of the whole nervous apparatus supervenes.

During the later embryonal period the cells which remain in the epithelial layer of the apical pit have become markedly altered, and, like the cells in the ciliated bands, have greatly increased in number. They are now slender wandlike cells, which possess a deeply stained usually elongate nucleus situated near their inner end. In the central portion, where they are longest, they are from 0.025 $\mathrm{mm}$. to $0.030 \mathrm{~mm}$. in length, decreasing thence toward the border so that their deeply stained nuclei in longitudinal sections through the region form an arcshaped band with the coneavity toward the exterior. On their outer ends they carry the long cilia which are deeply embedded in the cuticular cell ends, causing the latter to appear longitudinally striper. Just under this longitudinally striped zone there is a narrow band of deeply stained cytoplasm.

On the basis of differences in the inner ends two sorts of cells can be differentiated in the apical pit. One type has a clublike swollen or truncated end; these are shorter than the others and lie irregularly distributed among them; their nuclei lie quite near their inner ends. These appear to be supporting cells. The second type tapers off into an exceptionally fine and long process which extends between the ganglion cells in the fibrous layer. These are to be interpreted as sense cells having to do especially with taste, since from the reactions of the larvæ a certain amount of the ability to taste is to be inferred. 
It is probable (though not proved) that only the true sense cells carry cilia.

Attachment disk and vestibular invagination.-The attachment disk, first demonstrable at a considerably younger stage, now appears elongated and deepened. Within its compass in the fully formed embryo the prismatic cells show a fine ciliation, but the cilia are markedly shorter than those of the apical pit. Later the cells divide and become wandlike, but they never become so fine as those of the apical pit. No subepithelial ganglion cells are formed here, and apparently there are no sense cells. Such ganglion cells as occur are confined to the border zone and appear to have arisen through the division of the ganglion cells originating from the ectoderm of the apical pit.

The nuclei of the cells in the attachment pit are mostly somewhat larger and more elongated than those in the sense cells, and in hæmatoxylin stain a little less deeply. They lie at different heights in the inner half of the cell, only occasionally in the outer half.

Sometimes the cells at the base of the pit are very long, almost a third again as long as the sense cells in the apical pit.

Just before and during the fixation of the larva the glandular character of this region becomes more and more marked; the cilia disappear, the cells become mostly somewhat shorter and thicker and give off exteriorly a layer of homogeneous secretion, which accomplishes the fixation.

In the larva just liberated the vestibular invagination extends over the greater part of the ventral side. As in the younger stages, it is deepest anteriorly, becoming shallower posteriorly where it is bounded by the anterior border of the third ciliated band. Very soon the ventral median portion of the third band becomes involved in the extending invagination, which reaches to the fourth bow.

The cells of the vestibular floor are long and almost wand-shaped, and their nuclei lie at different heights, though in the anterior median portion almost exclusively in the inner end near the body cavity, from which, as from the mesenchyme cells, these cells are sharply cut off.

On their outer ends the cells carry cilia which are embedded in a cuticlelike layer, so that the section shows a certain similarity to a section through the ciliated rings.

The whole invaginated region is lined with a single layer of cells. Such cells as do not reach across the entire thickness have probably just arisen through division and hare not as yet reached their ultimate length.

Because of the enlargement of the surface which this portion of the ectoderm wall undergoes, active cell division must occur. In the posterior part of the beginnings of the vestibule, where at first only a slight flattening is found, the ectoderm is noticeably thickened and shows numerous dividing cells. Later the median portion sinks in, and this posterior part assumes the character of the more anterior sections.

If the larva remains free swimming for more than 24 hours important changes occur in the vestibular invagination. If it attaches itself immediately these processes take place in the fixed stage after the disappearance of the ciliated bands. 
On the second day the edges of the vestibular invagination approach each other and finally grow together in the posterior portion, this union of the two sides gradually extending anteriorly until an extensive tubular structure is formed which opens to the exterior on the ventral side through a constantly decreasing opening behind the second ciliated band.

The vestibule never appears to become entirely closed during the free-swimming period, but only after fixation.

The vestibular tube later extends under the fourth ciliated band, but whether this is an extension of the open furrow or of the closed tube itself has not been determined. If concerned at all, the fourth ring can only play a small part in the formation of the restibule.

Occasionally, in addition to the normal closure from the posterior end, the sides of the anterior portion also grow together, though this only takes place to a limited degree.

In the still open anterior portion the vestibule shows in section essentially the same features as in the younger larvæ, except that it has become somewhat deeper and has increased in size proportionate with the increase in size of the entire larva.

Farther posteriorly, where the closure is already completed, the vestibule appears tubular, strongly compressed dorso-ventrally. The lumen is very narrow, the walls very thick, especially dorso-laterally; they are thinnest along the floor of the groove.

At the end of the free-swimming larval period the ciliation of the vestibular invagination disappears. The cilia appear to persist longest in the anterior portion in two narrow lateral zones running near the border in which the cells are richer in plasma than elsewhere. In these zones the cell borders can not be differentiated throughout. The nuclei lie in the cell end toward the body cavity, which is richer in plasma than the other. while outwardly the plasma appears netlike, inclosing a homogeneous substance.

In preparations treated with absolute alcohol the intermediate substance retains hæmatoxylin stain to a remarkable degree, and in such sections it appears in the form of intensively colored club-shaped figures.

In the portion of the vestibule already closed into a tube the wall is essentially single layered. The lateral cells are of considerable length and carry the nuclei at different heights. Even when the cilia have disappeared, the cuticle-like cell border can be demonstrated.

Intestinal Canal.

Of all the internal organs the intestinal canal undergoes probably the least change during the later embryonal and free-swimming period.

As last described it was an entirely isolated sacklike structure surrounded by the two colome pockets and the beginnings of the water vessel. At no place does it come in contact with the ectodermal body wall, from which it is entirely excluded by the surrounding organs.

142140-21-Bull. 82- 31 
With the growth of the whole body the digestive apparatus becomes extended; its walls become appreciably thinner, and its form alters in a remarkable way. It becomes elongated in the direction of the major axis and at the same time somewhat compressed dorso-ventrally. But sometimes it is enlarged dorso-ventrally, as well as elongated in the direction of the major axis, so as to appear more or less baloonlike. As this is the usual form in the young attached animal, this may be considered as premature development.

Normally the dorsal wall is rather strongly convex, while the ventral wall is concave, and in the concavity of the latter lies the water vessel.

The dorsal wall is thick and is composed of a single layer of high prismatic cells, of which the nuclei lie near the lumen. The ventral wall for the most part is composed of a single layer of approximately cubical or low-prismatic cells which carry the nuclei mostly in the inner half.

Anteriorly the intestinal canal tapers rather abruptly and ends against the parietal canal and the most anterior end of the right cœlomic sack.

In rare cases there are found within the lumen in larvæ just liberated a few intrusive cells. Later these cells occur very extensively.

Generally speaking, the relations as just described are only slightly altered during a free-swimming period of two or three days.

The gut swells out on all sides, eventually becoming globular, and as the concavity of the ventral wall decreases individual cells detach themselves from the wall and pass into the lumen. But this process is of limited extent, for at the most Seeliger counted only 20 such cells in the oldest free-swimming larva, while in many the gut lumen was entirely empty.

In the most advanced larva there appears approximately in the middle of the ventral wall a small evagination directed toward the ectoderm. This elongates through the center of the water vascular ring, this space being occupied merely by a few mesenchyme cells. An extensire proliferation of ectoderm cells from the lower side of the vestibular invagination grows out to meet it, though it is usually later in the fixed larra, after the vestibule has entirely closed, that the two unite.

The dividing line between the ectodermic and mesodermic layers can be demonstrated for a long time. and thus the esophagus is clearly seen to be a purely ectodermal structure.

Cxlome and Chambered Organ.

The shifting about of the two cœlomic pockets originally lying right and left, which began during the embryonal period, becomes much further advanced in the free-swimming larva.

The right colomic sack has passed around the entire dorsal side of the intestinal canal, posteriorly having almost entirely moved into a dorsal position, and has permitted a process from the left sack to take part in bordering the gut on the right side. Further anteriorly, however, it elongates on the right side of the intestinal mass, covering the gut and water vessel, widely ventralward to the 
immediate vicinity of the vestibular invagination. Its foremost end extends out somewhat over the gut and reaches the transverse branches of the parietal canal.

The walls are single layered throughout; that appressed to the gut is somewhat thicker than the opposite, though always markedly thinner than the gut wall, and is composed of cubical or low-prismatic cells, which for the most part carry their nuclei near the coelome lumen. In the dorsal wall there are already found in many places pavement cells, which, however, are always sharply differentiated from the mesenchyme cells.

In cross section the lumen appears almost sickle-shaped, since the dorsal and ventral walls have moved considerably nearer to each other, and both are strongly concave toward the gut.

The course followed by the left colomic sack is somewhat more difficult to determine than that followed by the right. Anteriorly, it nerer reaches so far as the other, extending only slightly beyond the fourth ciliated band, while it terminates on the obliquely running end pieces of the parietal canal. From the left it grows out over the whole broadened posterior side of the intestinal canal and water tube, and stretches over their right side, where it extends itself anteriorly. This encroachment on the right side in larvæ just liberated is emphasized in very different ways. In the posterior ventral portion of the gut and water vessel it of necessity must remain closely circumseribed, but its anterior extension varies. Sometimes it is merely a small tip which is found at the right of the gut; again, it extends farther forward, especially on the right side of the water ressel, and sometimes it reaches anteriorly as far ventrally as on the left side; that is to say, far over the region of the fourth ciliated ring.

But the ventral side of the water vascular system remains uncovered by the left colomic sack almost throughout its entire extent. Only at the hindmost end can the latter be seen extending over a small area of its ventral side.

The lumen of the left colomic sack, like that of the right, is narrowed to a slit.

Histologically its walls differ very strikingly, for they are throughout thinner, and are composed of a single layered parement epitheliun; only in the portion joining the right colomic sack, the mesentery, are the cells somewhat higher and prismatic.

In larvæ just liberated the plane of contact between the two cœlomic sacks appears horseshoe-shaped in section, the horseshoe being open anteriorly.

During the several days of free-swimming larval life important changes occur in the colomic sacks.

The right, after entirely growing about the gut dorsally in the anterior part. has passed over a little onto its left side: but the border of the right sack always lies nearer the ventral side than that of the left. The anterior end no longer covers anteriorly the entire intestinal canal, while the parietal canal moves more ventrally.

On the anterior side of the gut it grows in toward the ventral side, and laterally anteriorly in two pockets separated from each other. These pockets come 
into contact over the gut near the median plane and there form a sort of mesentery, which later is of significance as the vertical mesentery of the right cœlome.

Histologically the only change to be noticed is the thinning of the cœlome wall running parallel to the enlargement. On most places there is a moderately fine pavement epithelium. In the mesentery and on the ventral wall of the left diverticulum (adjacent to the parietal canal) larger prismatic or cubical cells are present.

From the anterior wall of the two diverticula, as well as farther dorsally on the place of division, there arise five tube-like evaginations, which indicate the beginnings of the chambered organ. At their place of origin they are broadened out, ampulla-like; anteriorly the lumen narrows very rapidly and soon entirely disappears, so that they show merely cord-like structures, which extend very far anteriorly into the region circumscribed by the second ciliated ring. All five tubes surround the major axis of the embryo and, passing the rudimentary columnals at right angles to their planes, reach the terminal stem plate. When the rudiments of the columnals are horseshoe-shaped they surround the chambered organ and its extensions dorsally and laterally. In the fixed larva, when the two ends of the horseshoes have joined and the plates have become circular elements with a large hole in the center, the chambered organ lies in the channel thus formed.

In cross section the five tubes appear arranged on the periphery of a circle; mesenchyme cells appear not to occur between them. Just at their origin the diameter of the circle is relatively broad, and the individual tubes are large with an extensive lumen; farther anteriorly the cords into which they are drawn out lie nearer together.

Seeliger numbers the tubes from 1 to 5,1 being the one arising ventrally from the left point of the right cœlome, 2 the one just dorsal to it, and 5 the one at the ventral end of the right sack.

Histologically each part of the chambered organ is a single-layered tube formed of pyramidal or cubical cells, the nuclei of which almost always lie in the middle or in the outer ends. There appears to be no ciliation of the lumen. Toward the anterior end of the animal where there is no lumen the cells become longer, almost spindle-shaped. They may be differentiated from the surrounding mesenchyme cells by the closer crowding and by the somewhat more intensive staining of the nuclei.

Certain changes have taken place in the left cœlomic sack. On both sides it has extended farther anteriorly, especially on the right, and this right branch now ends at the same level as the left, slightly behind the anterior end of the gut.

Neither the anterior side of the gut and hydrocole nor the ventral side of the latter are covered by the left colomic sack, of which the walls anteriorly as well as ventrally are some distance away from the walls of the others.

Anteriorly on the ventral side the beginnings of the vestibule lie between the side pieces of the parietal canal. The horseshoe-like form of this canal has become nore marked. The two side pieces have become quite equal and no longer lie ventral to the right cœlome throughout their entire extent. The right lies nearer 
the ventral side and entirely covers this side of the hydrocoele, which is only partially done by the left.

As in the preceding stages the wall of the colome is composed throughout of one layer of cells, which becomes very thin on the portions adjacent to the gut, where it is sometimes reduced to a fine pavement epithelium. Of all the cells those in the mesentery are the highest.

\section{Hydrocale and Parietal Canal.}

Toward the end of the embryonal period the commencement of the hydrocole closes itself off from the parietal canal and bends itself about in such a way that in cross section it appears horshoe-shaped with the right branch somewhat larger than the left. This right branch develops rapidly at the expense of the left, which finally reaches much less far posteriorly than previously. So much does the right branch enlarge that posteriorly it reaches as far toward the left as the other, causing the opening of the horseshoe to appear displaced toward the left, where it is covered in part by the anterior end of the left colome.

At this stage five knob-like evaginations directed toward the ventral side appear on the hydrocœle, from each of which later three tentacle vessels arise. It has not been definitely determined whether these evaginations are simultaneous, or whether, if not, there is any definite regularity in their appearance. In any case they appear very suddenly and almost simultaneously, for of larvæ of the same age a short time after their liberation some show none and some show all five already formed.

Numbers 1 and 5 , at the two extremities of the sack, are commonly more advanced than the others, and it is not improbable that they are formed first. Number 4 appears to be in early stages the least developed.

The peculiar horseshoe-shaped form taken by the hydrocœle indicates that it can readily become closed into a ringlike form; but the formation of a closed water vascular ring first occurs at a considerably later stage.

The walls are everywhere composed of a single layer of cells which are prismatic or pyramidal in form and of approximately equal height, as in the gut. Their nuclei lie throughout in the inner ends of the cells, near the lumen.

In the older free-swimming larvæ the opening of the horseshoe becornes directed toward the anterior and left, turning about an angle of more than $90^{\circ}$ anticlockwise. The two ends of the hydrocœle have now closely approached each other, and the five primary evaginations have become considerably more extensive. The walls are still of a single layer of cells, but on the side toward the gut they are markedly thinner and are there for the most part composed of almost cubical cells.

It is in the older free-swimming larvæ that the first beginnings of the primary stone canal can be recognized. It shows itself as a short process from the (originally) left blind end of the horseshoe-shaped hydroccele running dorsally and toward the left and inserting itself between the anterior end of the gut and the parietal canal, ending blindly on the right cœlomic sack. At this stage there is no longer an opening into the parietal canal. 
During the last of the embryonal period and the free-swimming larval existence the parietal canal undergoes important changes. It soon closes off entirely from the hydrocoele and becomes a tubular structure running dorsally from it, while in the free-swimming larva its major part comes to lie directly in front of it. The left end grows posteriorly and lies at the left of the hydrocoele and gut, reaching the ectodermal body wall just before the fourth ciliated band, eventually opening outward here through the pore.

In the young larva the pore lies between the two branches of the hydrocole, betreen the places where the first and fifth evaginations will arise.

The formation of the pore often occurs in the final embryonal period, and the opening is always clearly visible in larva of a few hour's age. There is sometimes a slight infolding of the body wall in the immediate vicinity of the pore, hut again the small-celled terminal portion of the parietal canal may extend into the body wall as if it had bored its way through it. In any case, the part taken by the ectoderm in the formation of the end piece at the pore is very small.

At its first appearance the pore lies to the left of the median plane, distant from it about one-sixth of the circumference of the larva. Later the distance increases somewhat.

At the pore the lumen of the canal is very small, but it broadens rapidly inward and anteriorly, going over into the transversely running major portion, which is very differently developed in different individuals. In somewhat more developed stages in which the anterior gut end is more rounded it becomes more extensive, and at the same time part of the earlier ascending branch retains a more transverse course.

At the place where these two sectors pass over into each other there is to be noticed in quite young larvæ a short hornhike process, directed toward the right and posteriorly, which lies in the angle between the anterior end of the gut and the left hydrocœle. This process, which later disappears, appears to be the last remnant of the original connection between the parietal canal and the hydrocole sack.

The last section of the parietal canal is the anterior process. This arises from the transverse portion ventrally near the median plane and runs forward, a little toward the left, extending to before the second ciliated ring under the attachment pit. Anteriorly the lumen becomes progressively narrower, finally disappearing entirely, though in some cases the foremost end swells into a knoblike structure with a prominent lumen.

The posterior end, representing the position of the transverse section, lies very near the base of the restibular invagination, though not directly upon it. Farther forward the tube approaches it and clings to it, so that the whole process is feebly curved in the form of a bow with the concave side directed ventrally. This anterior process is a very striking structure.

The wall of the parietal canal is composed of a single layer of cells througlout; it is markedly thinner than in the 75-hour embryo (the stage in which it was last described), though everywhere clearly demonstrable and sharply differentiated from the other tissues. The cells are cubical or slightly flattened, some- 
what higher in the middle section, somewhat smaller in the terminal. During the free-swimming larval period it undergoes no important changes.

With the closing off of the vestibular invagination all of the internal organs are displaced toward the dorsal side, and at the same time the distance of the pore from the median plane has reached about one-fifth of the circumference of the larva.

As a consequence of the changes in the hydrocole as just described the pore no longer lies at the level of the region between the first and second primary evaginations. The ascending branch shows a tube of considerable length which rises more steeply anteriorly than was earlier the case. The hindmost end, terminally broadened out ampullalike, lies embedded in the ectodermal body wall.

Especially extensive is the transverse portion; on all median longitudinal sections it is met with cut across as a thin-walled structure with a wide lumen, rounded or somewhat flattened dorsally, placed before the gut and hydrocele ventral to the former and directly over the latter.

In the old larvæ the condition of the anterior process varies. In some cases it can be demonstrated, but in most it has entirely disappeared, apparently having been withdrawn into the transverse branch. There is no evidence that it has degenerated and that its constituent cells have become mesenchyme cells, as has been supposed.

The walls of the canal, except in the hindmost section, have become thinner, most markedly in the transverse sector, which for the greater part is lined with pavement epithelium, though toward the dorsal side where it borders on the right colome the cells are somewhat higher and richer in plasma. Seeliger believes that the pore and the outermost end piece are ciliated.

\section{Mest nehyme.}

Most of the mesenchyme cells which are not occupied in the formation of the calcareous skeletal elements are now assuming the form of connective tissue cells, while some are transforming into muscle cells.

The connective tissue cells occur in all possible forms in varying sizes. In the youngest larvæ they are predominently rounded or provided with small processes posteriorly and along the major axis anteriorly, while peripherally star-shaped and spindle-shaped cells are common. In older larvæ, generally speaking, the size of the mesenchyme cells decreases somewhat.

Apparently in the living animal the cells are able, through amœboid movements, to alter their form quickly and in the most diverse ways.

In the lateral portions of the anterior section the processes of the star-shaped cells become progressively more and more extended and begin to unite with each other, so that there appears in sections, cut at a later stage through the column, a very loose connective tissue layer made up of branched fibers under the ectoderm, while toward the middle rounded cells, placed much closer together, form the calcareous elements of the column. On the ventral side in the merlian plane these 
skeletal-forming mesenchyme cells reach the ectodermal vestibular invagination, there being no connective tissue layer between.

In addition to the rounded and star-shaped cells elongated strongly refractive cells stand out prominently, which appear to be muscle fibers in process of formation. They appear to have no definite arrangement but run in various directions. In later stages they appear to become still morc elongated fibers, mostly passing quite through the loose connective tissue layer, which bear on the side a plasmatic cell body containing the nucleus.

In addition to the muscular fibrillæ there occur rather prominent, mostly undulating, smooth fibers traversing the connective tissue which show neither a nucleus nor a superposed cell body. These are probably elastic fibers, thongh possibly only simple connective tissue fibrillæ.

The fact that larræ of this age are able to alter their form to a considerable degree shows the existence of functional muscle fibers.

By far the greater part of the mesenchyme cells in the posterior portion of the animal, which later becomes the calyx, and in the central portion of the anterior section, are occupied in the formation of the calcareous plates of the calyx and column.

In the last stage described all of the calcareous elements were laid down except a few columnals which appear later intercalated between those at the calical end of the column. During a large part of the free-swimming period there ensues only an enlargement of the individual plates and insignificant alterations in their relative positions.

Their form and size vary exceedingly in different individuals. In many they have developed only slightly, while in other larvæ the columnals have become considerably enlarged and are no longer crescentic, but have assumed the form of closed rings, though this usually first takes place in the fixed stage.

The orals and basals of the left side ( 1 and 2 ), which at first were situated more anteriorly than those of the right, have moved posteriorly, so that they are now on the same plane as these; but the ventral orals and basals always lie farther anteriorly than the dorsal, and the planes in which the orals and basals lie are approximately at right angles to the water vascular ring.

The infrabasals lie at the same height as the basals but more centrally, so that they are covered by them. They are disposed in a horseshoe open ventrally and toward the left.

The calcareous rudiments of the columnals have moved farther from each other, and the terminal stem plate thus approaches the base of the attachment pit to which it lies nearly or quite parallel.

The relation between the mesenchyme cells and the plates which they form can best be determined on longitudinal sections through the anterior part of the larva. Such sections show the invariable existence of two layers of strongly rounded mesenchyme cells between each two columnals. Beyond these, outside of the compass of the calcareous plates. similar cells lie closely appressed to each other, which later will take part in the enlargement of the plates and in the formation of their peripheral processes. 
ATTACHMENT OF LARVA AND ITS TRANSFORMATION INTO STALKED FORM.

DESCRIPTION OF LARVA OP TO FIFTH DAT AFTER ESCAPE FROM EGG MEMBRANE.

After a free-swimming existence lasting usually for only a few hours, more rarely for two or three days, the larva attaches itself by means of the attachment disk at the anterior end.

In an aquarium this may be observed very readily, for the larvæ will attach themselves to almost anything, to the glass walls, to stones, to shells, and to various parts of seaweeds; but they seem to avoid attaching themselves in places where the water is agitated.

It is easy to preserve the larvæ together with the vegetable support to which they are attached, when the base can easily be cut in sections and the details of the attachment made clear.

After fixation development progresses in different individuals at very different rates, so that no general statement can be made as to the exact time when any given process takes place. The difference, indeed, may be so great that it is possible to find among larvæ 110 hours old many which have not passed the 48-hour stage.

This is in strong contract to the extraordinarily synchronous way in which the earlier development takes place in the embryos of the same brood.

As a result of the position of the attachment pit on the ventral side of the anterior end of the body the young larva at first lies with its entire ventral side almost in contact with the object to which it is attached. Simultaneously with the differentiation of the body into calyx and column the larva elongates and raises itself to a position with the major axis at right angles to the plane of its support.

The erect attitude is, as a rule, first attained when the roof of the vestibule has broken through, the tentacles have become extremely mobile structures of considerable length, and the stalked larva appears capable of the independent assimilation of nutriment.

Directly after the attachment, when the vestibule is still on the ventral side, the indications of radial structure are restricted to the five evaginations of the hydrocœle ring, the beginnings of the chambered organ, and the basals and orals, though none of these have attained their ultimate position.

But during the changes about to be described the pentamerous structure becomes dominant, although the original median plane can always be determined.

In the early fixed larva a cross section shows the bilateral symmetry disturbed only by the parietal canal, which is confined to the left side, and by the pore.

The vestibule first shows a radial structure when it has moved entirely onto the free posterior end, while in the section of the calyx adjoining the column there is even then no indication of a radial arrangement.

The rays in the stalked larva are indicated by Seeliger with the numbers $\mathrm{I}-\mathrm{V}$ : Ray $\mathrm{V}$ stands in the median plane of the bilateral larva ventrally; that is to say, the plane in which the last trace of the vestibular invagination has dis- 
appeared. To the left of ray $\mathrm{V}$ is ray $\mathrm{I}$, and to the right ray IV. The left dorsal ray is ray II, and the right dorsal ray ray III.

Thus the pore lies between radii I and V, but very near the former.

The five primary hydrocnele evaginations coincide with the radii I-V.

ECTODERM.

The ciliated bands disappear immediately after the fixation of the larva, and the ectodermal epithelium shows a uniform structure throughout. The first (most anterior) incomplete band is the first to go, followed a few hours later by all the others. The disappearance of the first band may even occur before fixation. Occasionally free larre are found lying on the bottom of the containers which have lost all of the ciliated bands. But it is possible that these larvæ are incapable of further development, and in general it is correct to consider the disappearance of the cilia as the result of attachment.

It has already been mentioned how in the intermediate zones of the older freeswimming larva the cells begin to secrete a homogeneous hyaline substance while their protoplasmic content decreases in volume so that the epithelial layer appears loose. After fixation the same process takes place in the ciliated bands, so that very soon their borders are no longer demonstrable.

When this process has been completed the whole ectoderm is composed of detached spindle-shaped cells, considerably elongated, which for the most part stand at right angles to the surface, in section reseinbling somewhat the palisades of a wooden fence. In addition there are found other types of cells, some of pyramidlike shape with broadly expanded bases turned either outward or inward and long drawn out apices, and others more rounderl, almost spherical.

The spindle-shaped forms predominate in the anterior section of the column, while the rounded forms are more commonly met with in the region of the hydrocœle ring. In the middle of the cells are the nuclei, which are sometimes seen in process of division.

In general cell division in the ectoderm is rare at this stage, and an appreciable enlargement of the number of cells no longer occurs. It is possible that with the increase in the intermediate substance in the ectoderm the cell borders entirely disappear.

Some of the ectoderm cells have withdrawn from the surface and have assumed a subepithelial position, a process the eommencement of which may be observed in the older free-swimming larvæ. In addition to these cells, which have passed out of the ectoderm in their entiety, there are others, originally subepithelial in position, which have arisen through the division of ectoderm cells parallel to the body surface instead of at right angles to it.

In the free-swimming larva the ectodermal body epithelium is everywhere sharply defined, and nowhere can there be a doubt whether a given element belongs to the ectoderm or to the mesenchyme. But soon after attachment the relation between the ectoderm and the inner elements undergoes an important change. Simultaneously with the inward migration of numerous ectoderm cells, and the giving off from them of processes directed into the body cavity, individual star- 
shaped mesenchyme cells increase the length of their processes, which then unite with those of the ectoderm cells. When it is considered that individual ectoderm elements of varied form pass down beneath the processes of the others, and that individual mesenchyme cells pass upward to the same level, it is obvious that a sharp line of denarcation between the ectoderm and mesoderm can no longer be drawn, and that in regard to numerous cells it is impossible to determine the layer from which they have arisen.

In many cases Seeliger found the histological character of the ectoderm at the posterior end of the body, where it forms the closed roof of the vestibule, somewhat different from that covering the remaining portions of the body surface.

Under the sharply defined exterual layer is a layer of plasma containing numerous nuclei; cell borders are only to be madc out raguely in a few places. Toward the body cavity a few pinlike plasmatic processes extend, and between them are a few subepithelial ectoderm cells which are united with the superficial cells by broad plasmatic bridges.

The central portion of the flattened ectoderm wall of the vestibule has already approached the outer body wall, indicating the position of the later rupture. In younger larræ this region is often one of especial thickness, including an abundant connective tissue which later is in part resorbed.

Immediately after the attachment the whole region of the apical pit undergoes the same alterations as the rest of the ectodermal epithelium, and becomes in every way similar to it. The tuft of cilia vanishes; with the appearance of the intermediate substance the sense and supporting cells lose their characteristic forms, and the ganglion cells also can no longer be recognized as such. The thick layer of nerve fibrillæ disappears, and the membrane separating it from the body carity is no longer demonstrable. There is no further trace of the longitudinal nerve cords running on either side of the restibular invagination.

After fixation the region of the attachment pit quickly broadens to a disklike structure, which in the older larvæ may acquire a very considerable circumference. Over the surface of this disk there is a thin layer of a viscous secretion arising from the gland cells which accomplishes the fixation. The surface itself is quite smooth, without processes which might penetrate a foreign substance.

The terminal stem plate has now moved down directly on to the place of attachment, and in some places is coveered only by a single, sometimes very thin, layer of cells. Some of these cells stretch out coarser or finer processes through the holes in the plate. The nuclei can be easily recognized in the granular plasma; they show the chromatin in varying amounts and arranged in different ways.

VESTIBULE.

Normally very soon after fixation, but exceptionally at the end of a long freeswimming period, the vestibular invagination becomes entirely closed off from the ectodermal epithelium. 'This process takes place very quickly, within a few hours. 
At first the vestibule extends over the entire ventral side, and encroaches slightly on the posterior end. Later it migrates posteriorly until it leaves the ventral side and becomes confined to the posterior end, which it entirely covers.

When the anterior portion of the vestibule is still open the various walls of the posterior closed part are seen to be very differently constituted. The whole basal wall is extraordinarily thickened and lies close down upon the water vessel so that the tentacular evaginations force themselves into it. The side of the vestibular wall turned toward the lumen is entirely smooth, and of the tentacles there is nothing to be seen.

Through the center of the as yet unclosed hydrocole ring a solid process runs toward the gut to which it is attached. This represents the place on which in the free-swimming larva a peglike process is formed on the primitive gut.

As a rule after the closure of the restibule the ectodermal portion can be differentiated histologically from the entodermal.

In the anterior part of the basal wall the nuclei lie almost exclusively very close to the body carity; posteriorly they become more numerous, and not only are not restricted to the innermost portion of the cells, but occur as far as the middle, and occasionally in the outer halves.

Seeliger was not able to demonstrate cell borders. Toward the posterior end the basal wall gives the impression of a multinuclear plastic plasma mass, and very often here a lighter middle zone can be differentiated between two darker bordering zones. While in the latter the plasma usually appears granulated, in the clearer portion the general impression is that of a fibrillar structure.

The zones show individual variation in extent as well as in position, and in many cases are quite lacking. In that event the whole base is composed of a uniform finely granulated plasma. Since sections of the ciliated bands as well as of the intermediate areas are involved in the formation of the restibule, it is perhaps possible that the differences are traceable to this.

In addition to the nuclei, which are quite typical and generally poor in chromatin, there are very numerous (in the light zone much less frequent) smaller rounded bodies which stain very intensively in hæmatoxylin and retain the stain as tenaciously as the chromatin of the nuclei. Bury believed these to be phagocytes. Seeliger at first considered them chromatin granules from degenerated nuclei, but later supposed them to be bodies arising in the plasma which were later consumed.

In the hinder part the lumen of the closed restibule is crescentic in section, with the concare side turned inwardly; in the anterior portion it is elliptical, with the longer axis transverse.

In the cuticular layer bordering the restibular carity a radial striping can no longer be demonstrated.

From the floor of the restibule outward the walls decrease rapidly in thickness, and in the median plane rentrally the lumen is separated from the exterior only by a very fine layer of cells. This ventral wall is of only a single layer; in the mid-zone it is composed of cubical and flat parement cells, which laterally become gradually higher while at the same time their borders become indistinct. 
Corresponding to the transrersely elliptical cross section of the restibule, the ventral side of the larva in the posterior portion is slightly flattened. Just over the restibule the cell layer is especially thin, and in the median line there are no mesenchyme cells beneath the ectoderm. Thus the two borders of the rentral side of the larræ stand out prominently on cross section, and one is easily tempted to find in this eridence of the inception of the radial structure, though as a matter of fact the future radii do not lie along these prominent borders, and originate quite independently of them.

In the next stage the restibule has mored entirely within the calyx section of the larva and has extended itself out orer the greater part of the posterior end. The rentral (outer) wall has become markedly thinner and shows a frail parement epithelium. It is entirely distinct from the mesenchyme.

The hydrocele ring has become noticeably wider, and an extensive, though shallow, proliferation from the floor of the restibule now entirely fills the central space where earlier only a short peglike process was present.

Throughout the whole floor the nuclei lie in several superposed layers, but only in a few places can cell borders be demonstrated, and these almost nerer can be followed through its entire thickness.

In the succeeding stage the restibule mores completely onto the posterior end of the animal. It no longer extends orer the hydrocœle ring ventrally, while dorsally it is already beginning to grow over the evaginations from the water ressel-the beginnings of the tentacles.

The central proliferation extending through the water rascular ring has enlarged noticeably, while it has grown anteriorly to before the hydrocœle, its adrance being parallel to the posterior withdrawal of the end of the restibule. As this proliferation has migrated anteriorly with the gut, and in the meantime has completely broken through, it is clear that the esophagus, passing through the floor of the restibule and the livdrocœle ring, is ectodermal in origin, uniting itself with the stomach by means of the peglike process of the latter.

In the funnel-shaped esophagus, which is histologically very different from the gut. cell borders can again be demonstrated through the entire thickness. In spite of the apparent arrangement of the nuclei in sereral layers there can be shown to be a single-lasered epithelium of very high, slender prismatic cells the nuclei of which lie near the middle, though in neighboring cells at different heights.

The tentacle evaginations from the hydrocole are already visible in the cavity of the restibule.

The restibule, having become more and more extensire, now includes the entire posterior end of the calyx section. Its outer wall is cup shaped, the posterior end (the base of the cup) rounded pentagonal, the anterior border (the lip of the cup) where it goes over into the tentacle inrestment with at first rery strongly rounded angles and broader than the flattened posterior end.

The lining is composed of parement epithelium and lies closely upon the ectoderm larer, from which it is separated by sparse mesenchyme tissue.

On the basal surface important alterations have taken place. The fire eraginations from the hydrocoele, at a time when they are scarcely perceptible within 
the cavity of the vestibule, each divide themselves into three parts. Thus are formed 15 tentacles which grow rapidly to cylindrical processes and receive an ectodermal investment from the base of the restibule.

Simultaneously with the migration of the vestibule the hydrocoele ring has assumed a position almost exactly at right angles to the major axis. It has become noticeably wider, but still remains narrower than the diameter of the anterior (basal) vestibular border, so that the tentacles rise directly within the latter.

The arrangement of the tentacles in five groups of three each corresponds to the radial structure of the adult. The five central tentacles lie in radii $I-V$ and farther outwardly than the others, since they occupy the rounded angles of the pentagon. The groups of tentacles are separated in the interradial planes. As yet the insertions of the tentacles are not quite in the same plane, so that in a transverse section they are cut through at different heights.

The ectoderm of the tentacles is composed throughout of rather high cylindrical cells disposed in a single layer. On the inner side it is somewhat higher than elsewhere, and here, since the nuclei lie at different heights in adjoining cells, it often appears to be arranged in several layers.

On sections through the bases of the tentacle groups the ectoderm on the inner side of the three tentacles appears fused together, that on the outer wall being well defined.

In slightly older larvæ the esophagus is composed of elongated, alnost wandshaped cells, most of which have the nuclei in the middle.

In a somewhat more advanced stage the number of tentacles has risen to 25 , for two interradial tentacles have formed between each of the groups of three. These are noticeably shorter than the others and are united at the base by a bridgelike elevation of the vestibule wall. Though similarly arising from the hydrocœele, they are situated more toward the central axis of the animal than the other tentacles, so that they stand on the periphery of a circle of smaller diameter. Their structure is identical with that of the older tentacles.

Before the rupture of the vestibule the tentacles grow to a considerable length, their ends bending inward under the roof of the vestibule toward the center. In part the extension of the tentacles takes place at the expense of their diameter, which becomes progressively less and less.

INTESTINAL CANAL.

Soon after fixation the gut appears much extended and balloon-like, a little flattened toward the hydrocole, and through the center of the latter connected with the vestibule.

In the older free-swimming larvæ individual entoderm cells can be seen to detach themselves from approximately the center of the epithelial lining of the fiattened wall and to enter the lumen, though usually this process first takes place in the fixed larva. Apparently none of these cells are given off from the dorsal wall. In the nourishing juices in the cavity of the gut these cells multiply with 
extreme rapidity, becoming continually smaller. Only in the first stages can indirect nuclear division be clearly recognized.

Sections through animals in which the gut is completely filled show that the wall of the gut itself has no definite cell boundaries, and inwardly passes imperceptibly into the yolklike interior mass. But along the walls of the gut the nuclei, in the resting stage and mostly very poor in chromatin, are visible. These are very clearly differentiated from the elements of the inner mass, which are exceptionally small, strongly stained, and arise from the nuclei of the cells which have passed into the gut lumen, by their relatively large size, the possession of a distinct outer membrane, and the always rounded shape. Apparently in the breaking down of the cells within the gut lumen the chromatin substance within the nuclei breaks in pieces and becomes irregularly divided, giving rise to the strongly colored specks abundant within the central mass. In addition to these specks, probably nuclear fragments, there are others, larger, with strongly stained inclusions. These may be looked upon as products of the plasma itself, though this is not certain. Later these disappear also.

A completely broken-down yolklike mass is not always formed within the gut lumen. In many cases, probably when relatively few entoderm cells have entered, one sees mostly separated cell fragments with relatively little yolklike material. But the ultimate fate of the cell mass, entire resorption through the wall of the gut, is the same in all cases.

Though the entry of entoderm cells into the gut lumen probably is never entirely stopped, in some cases it is very greatly reduced, and then from the single layered epithelium of the gut there appear protoplasmic pseudopodia-like processes extending inward on which isolated cells lie.

Later the cell borders again make their appearance and the gut wall appears as an epithelium of cylindrical cells of which the nuclei lie near the outer ends.

It can now be seen that a part of the elements of the inner mass has been taken up by the walls of the gut, while more is about to follow. The distinctness of the elements filling the lumen from those composing the gut epithelium can be determined with greater clearness. The former advance to the outer cell ends of the latter and become gradually absorbed so that finally only chromatin bodies are to be seen, which likewise finally disappcar. The nuclei of the gut epithelium are easily differentiated from the elements within the gut lunen since they exhibit all the characteristics of resting nuclei.

Immediately after the attachment the entire gut appears extended and balloonlike, but very soon the ventral side becomes concave in such a way that the chief mass of the gut lies on the originally left side near radii I and II, while a smaller part, appearing as a hornlike process of the other, occupies the right side, its blind end being ventrally on the right between radii IV and V.

The union with the vestibule takes place through the esophagus on the left side ventrally between radii $\mathrm{I}$ and $\mathrm{V}$.

The difference between these two portions of the gut becomes more and more pronounced. The one lying to the left and dorsally again assumes a more or less 
spherical form and becomes the stomach, while the other, resting on this with a broad base, becomes a horizontal tube tapering to its blind end and forming the blind gut. This latter quickly elongates, growing from right to left on the ventral side, until at about the one hundredth hour it has reached approximately the radius $V$. It runs in the now horizontal mesentery between the originally left (oral) and right (aboral) cœlome in such a way that it only borders the oral cœlome with its posterior edge, while it protrudes into the aboral so that in section it appears laterally and anteriorly surrounded by it.

For a long time the gut, clear to the blind end, is filled with the mass of disintegrated cells.

CCELOME AND ITS DFRIVATIVES (AXIAL AND CHAMBERED ORGANS).

The alterations which take place in the two cœlomic pockets focus in changes in position which are determined by the progress in the formation of the vestibule and the intrusion of the closed vestibule into the hinder end of the larva.

The turning about of the mesentery separating the two sections of the colome takes place according to the same plan as that of the floor of the vestibule, so that it passes over from the vertical to the horizontal plane and comes to lie at right angles to the major axis.

A longitudinal section through a 28-hour larva, just attached, shows the coelomic sack only slightly altered. The mesentery has the shape of a horseshoe and lies with both its side pieces, which are not quite the same, extending anteriorly and somewhat ventrally, almost parallel with the floor of the vestibule.

A cross section of a larva in which the vestibule is entirely closed cut on the plane passing through the anterior end of the hydrocole shows similar relationships; but the right cœlome has become more noticeably extended and on the right side entirely covers the anterior tip of the left outwardly and reaches as far as the vestibule. It also broadens out ventrally, inserting itself between the grut and the tip of the left colome, which advances toward the median line to intrude itself between the hydrocœle and gut.

On the other hand, the right side piece of the left cœlome extends itself on the ventral side considerably farther toward the median line than does the left, through which the circumstance, especially emphasized later, is already indicated that the opening of the horseshoe does not lie in the median plane of radius $\mathrm{V}$, but is displaced toward the left.

As the mesentery gradually acquires a horizontal position the last-mentioned processes take on a greater and greater significance. Sections cut parallel to the major axis illustrate this.

A section lying near the median plane shows the left colome cut through dorsally and posteriorly between the gut and hydrocœle, which have now become considerably separated. In this space the left cœlome has extended itself as far inward as the union between the gut and the floor of the vestibule.

The sections to the right and left of this show that the left colome lies entirely between the gut and hydrocœle. The horseshoe-shaped form in cross 
section has become narrowly elongate with indentations in which the horizontal part of the parietal canal, the stone canal, and the esophagus lie.

Later the horizontal position is entirely attained, and the left cœlome, which by the older authors is now known as the oral coclome, surrounds the esophagus, the broad ring being interrupted only on the ventral side. It is now no longer an entirely distinct cavity, for it has become united with the right cœlomic sack.

During all these changes the wall remains of one layer of cells, but owing to its great extension this cell layer has become a fine pavement epithelium, which, however, can always be clearly differentiated from the mesenchyme.

On the sides forming the ventral (vertical) mesentery, where the circumesophageal ring is interrupted, the cells are, especially in younger stages, somewhat higher and richer in plasma, and here an epithelium of cylindrical cells may be found.

The changes in the right coelomic sack are much more complicated.

This has extended itself ventrally, and anterior to the middle beyond the tip of the left coelome it has pressed forward on the right side almost as far as the median plane, from which on the left side it is separated only by a branch of the parietal canal.

The foremost end of the sack from which the chambered organ arises shows in section a peculiar horseshoelike figure arising from a deep fold proceeding inward from the ventral side between radii IV and $V$ which is directed dorsally and a little toward the left. This place represents that on which, in the freeswimming larva, there have already appeared two diverticula from the right cœlome, of which the median partition walls remain uniterl to form a vertical mesentery; only in the torsion of the internal organs it has become a little advanced ventrally.

In this vertical septum the cells on the left side are considerably thicker than on other places, where they form a fine pavement epithelium. There is no trace of a fusion of the cells with those of the mesenchyme.

The chambered organ is essentially as previously described; between the evaginations 1 and 5 lies the deep furrow corresponding to the anterior end of the vertical mesentery. As before, the most anterior ends are drawn out cordlike through the circular openings in the columnals as far as the terminal stem plate. In these cords cell borders are no longer recognizable; the nuclei, which stain fairly well, are elongated longitudinally.

As the wall of the restibule, the hydrocole and the left colome become more and more horizontal, the parietal canal on the ventral side becomes shoved more and more posteriorly, so that it no longer lies on the ventral side of the gut, but of the esophagus.

Correlatively the right cœlome extends outward over the ventral side of the gut, pushing anteriorly as well as posteriorly, and the vertical mesentery becomes more and more elongated posteriorly.

The two blind ends have grown out from right and left to the median plane, without as yet having united. The right tip lies over the left, the latter remaining closely appressed to the gut.

142140-21-Pull. 82- 32 
In this way the vertical mesentery has been formed in the compass of the right coelome, and the ventral mesentery lies a little to the right of the median plane, between radii IV and V. Toward the foremost end it approaches the median plane more closely and passes over directly into the wall of the furrow described above.

The vertical mesentery posteriorly does not run dorso-ventrally, but obliquely, more or less parallel to a line joining the outer ends of radii IV and V. There is, however, much individual variation regarding its direction as well as its length. Anteriorly it becomes longer and more nearly parallel to the median plane, since here the right extremity of the left no longer covers it.

During these changes the place of origin of the chambered organ remains at the anterior end, moving only slightly anteriorly. The individual chambers are usually very easy to recognize; through the thinning of their walls their lumina have become more extensive.

At this stage the so-called axial organ first makes its appearance. At about the twenty-eighth hour there is to be seen a simple thickening of the left wall of the vertical mesentery directly behind the place on which the chambered organ appears. This thickening consists in an increase in height of the epithelial cells. Nuclear divisions parallel to the surface of the epithelium can be observed which later bring about the several-layered condition of this region. A small cell group pushes itself out and advances between the bases of the two ventral tubes of the chambered organ. This is the most anterior end of the axial organ.

In somewhat later stages the axial organ without exception lies near the vertical mesentery in the left extremity of the right cœlome. It shows itself first as a thickening of the wall of the mesentery jutting out into the cœlome. The nuclei of its cells resemble those in the cells of the remaining portions of the cœlome wall.

Somewhat later it has doubled in length, and has come to lie entirely on the mesentery. Anteriorly, toward the column, it has only united with the left wall of the mesentery for a short distance, but posteriorly the union is more extensive.

The nuclei of the constituent cells are now not all alike, for some have become larger and vesicular, and are surrounded by a thicker plasma zone.

Posteriorly the thickening in the left wall of the mesentery gradually flattens itself out before it reaches the hinder border of the cœlome wall.

Anteriorly where the axial organ lies entirely separate between the two walls of the vertical mesentery it can be followed as far as the calyx border. Since here it appears in section in the form of a dorsally directed fold, it is evident that it goes still further anteriorly and enters the column between the ventral processes of the chambered organ.

After the restibule has completed its migration to the posterior end of the animal and the oral colome has become horizontal the changes in the right or aboral cœlome cease for a time.

On the ventral side it has extended outward over the stomach and the posterior gut section, and also incloses the greater part of the esophagus. Between radius 4 and radius 5 it has grown far posteriorly, and there on some places corers 
the left colome exteriorly, although this also in the same region extends further posteriorly than elsewhere.

In the individual the form of the body cavity is determined through the progressive development of the intestinal canal; with the exception of the posterior side on which lies the oral colome this remains entirely inclosed in the epithelium of the right cœlome.

When the stomach and gut are excessively extended by an anusually large inner mass, the outer and inner cœlomic layers are closely pressed against each other, and there is no body eavity to be seen. On the dorsal side this is frequently observed; but ventrally there always persists a more or less extensive space between the stomach and lateral extension of the gut where the originally left tip lies. This part of the right cœlome grows posteriorly independently so that it appears on cross sections as a blind sack closed on all sides.

The hinder section of the gut lies on the border of the oral colome in the vertical mesentery, and so as a result of its enlargement the two layers of the latter become spread apart, retaining their former close association only anteriorly. It further comes about that the place of union between the gut and stomach gradually narrows dorso-ventrally, and thus the blind end of the aboral colome lying in this corner shores itself further dorsally. So the gut remains in spite of its increased length covered on all sides by cœelomic epithelium.

The region between esophagus, stomach, and middle gut is where the horizontal mesentery vanishes, and both parts of the cuelome unite.

It is the right ventral tip of the oral ccelome which breaks through into the left portion of the aboral. The opening appears first at the ventral end near the median plane and extends thence dorsalward toward the right.

First the two layers of epithelium grow together; later in the center of this region an extraordinarily fine slitlike cavity is formed, which widens rapidly, while along its borders the two layers become completely fused, passing uninterruptedly over into each other. Since before the union the walls of the two cavities were histologically similar, it is now impossible to discover at what point the union took place except on a circumscribed region on the inner side where, at least at first, the extension of the axial organ characterizes the right cœlome.

At this stage the axial organ occupics the entire extent of the ventral side of the inner wall of the aboral cœlomc. In the most anterior part, near the chambered organ, it lies as a solid cord of cells on the vertical mesentery. Further posteriorly it becomes more prominent, standing out as a pleatlike thickening lying on the gut. At the posterior end is the youngest developmental stage. There is no evidence that mesenchyme cells take part in its formation.

Under high magnification it can be easily seen how the flat cœlomic epithelinm juts out into the body cavity and the cells involved become richer in plasma and divide, so that a several layered swelling results among the cells of which there very soon appears a differentiation of the nuclei, some rapidly increasing in size and becoming vesicular. 
In individual larvæ soon after the first formation of the axial organ strikingly large vesicular nuclei appear which have quite the aspect of germ vesicles. They surround themselves with an especially thick plasma zone, and their bulk appears so considerable in contrast to that of neighboring cells that they give the impression of young egg cells.

Seeliger believes it is possible that this condition may indicate the animals later to become females.

The axial organ does not run in an absolutely straight line; clinging to the curve of the stomach and esophagus, it is more or less sausage-shaped. The posterior end lies on the border of the oral and aboral coclome, while the anterior proceeds into the column where it becomes extremely difficult to follow.

At the end of the gut the axial organ bends toward the major axis and enters the stem at the place on which in younger stages the ventral furrow in the foremost end of the coelome was present, between the first and fifth tubes of the chambered organ.

In the description of the origin of the chambered organ it has been mentioned that mesenchyme cells accumulate on the evaginations of the colome in order to take part in the formation of the cords running through the column, and the same possibility is present here.

On the other hand, it is conceivable that the walls of the chambered organ on the sides toward the axis might through proliferation form a central string which subsequently united itself with the axial organ of the calyx.

Finally the axial organ of the calyx, which already in the early stages enters the chambered organ as an isolated cord, may quite independently enlarge and elongate posteriorly throughout the entire column.

In the oldest larvæ of this stage the formation of trabeculæ begins in the aboral cœlome. In isolated instances single cells raise themselves up at right angles to the plane of the epithelial wall, their broad bases dovetailed in among the other cells, their onter ends projecting far into the body cavity. In these cells the nucleus is usually displaced toward the middle. This process has taken place much more extensively in the hydrocœle.

IITDROCOLE.

Like the vestibule, the hydrocole ring, at first placed parallel to the major axis of the body, gradually turns through an angle of $90^{\circ}$ until it comes to rest practically at right angles to this axis under the now transverse floor of the vestibule. In this migration it maintains throughout the same relations with the latter.

The break in the continuity of the ring lies between radii $\mathrm{I}$ and $\mathrm{V}$; that is to say, in the same interradius as the pore.

The hydrocole is embedded in the thick basal wall of the restibule. As it passes from a longitudinal to a transverse position the more extensive becomes the proliferation of cells from the vestibule floor, which will eventually form the esophagus. 
A lumen is always demonstrable in the hydrocole, though it is frequently much narrowed dorso-ventrally.

During the turning the five broad evaginations of the hydrocœle ring alter their form, becoming narrower radially, and appearing as elongate lappetlike structures. At the same time their distal ends, emberded in the floor of the vestibule, begin to divide into three points, so that now 15 processes are present. These are the beginnings of the 15 hydrocœle tentacles, but at first they are only of inconsiderable length, and are entirely concealed in the vestibular wall.

The way in which the left cœlome inserts itself between the gut and hydrocole ring, bordering the anterior wall of the latter, which earlier was directed dorsally, has already been noticed.

Histologically the wall of the hydrocœle is a single-layered cylindrical or cubical epithelium of considerable thickness. Except in the ring, where the lumen is most extensive, the walls are usually thicker than the diameter of the central canal.

As a result of the strong curvature of the walls the latter appear very commonly in sections to be made up of several layers, chiefly for the reason that the nuclei are not everywhere at the same height.

After the hydrocole ring has attained a horizontal position it remains open for a long time between radii $I$ and $V$, the interradius in which the horseshoeshaped oral cœlome is also open.

Between the five primary evaginations the ring is almost circular in section, but near the latter it passes to an oval form, elongated parallel to the major axis.

The originally high cylindrical cells of the wall become lower and lower, and shortly before the rupture of the vestibule they have transformed into low, in part pavement, cells which are somewhat swollen in the middle, where they carry the nuclei. This process continuing, a fine pavement epithelium is formed, which becomes somewhat thicker on the inner side of the ring. Very noticeable are elongated, often thread-shaped cells, which are always to be found in larvæ of this age traversing the lumen of the canal and running radially between the outer and inner walls, to which they stand usually, though not always, at right angles.

Rather early, usually on the third day, individual cells in the hydrocœle canal and its processes raise themselves up and project freely into the lumen, in the same way as similar cells in the cœlome. Usually these appear on the thicker inner wall, but occasionally on the outer.

At first the cell rests entirely in the epithelium of the wall and is only distinguishable from the neighboring cells through its spherical or pear-shaped form; but very quickly the free end elongates and passes entirely across the lumen to the opposite wall.

The nuclei of these cells often remain at the base at the same height as the nuclei of the neighboring cells, although the cell itself has passed entirely across the lumen. But very commonly the original nuclei at the base divide and the daughter nuclei assume a position more or less near the middle of the lumen. Sometimes 
also there is no nuclear division, but the original nucleus moves outward from the base into the middle of the filament.

Before the formation of these trabeculæ begins the rudiments of the first 15 hydrocœle tentacles increase considerably in size and appear within the vestibule as small elevations. Scarcely have they reached an appreciable height when the 10 interradial tentacles appear at the base of each of the five original evaginations. There thus arise from each primary evagination five tentacles, three central, larger and older, and two lateral, one on either side, as yet rudimentary. The central tentacle in each group lies in the midradial plane. While the extensions of the hydrocole forming the 15 older tentacles are parallel to the major axis of the body, those giving rise to the 10 interradial tentacles lean inward toward that axis.

All the tentacles are tubes composed of a single layer of epithelium ensheathed in the ectoderm of the vestibule. The lumen is very narrow, narrower than the diameter of the walls, and in the outer ends usually is not demonstrable on account of the two walls being pressed together.

The borders of the cells in the tentacle walls are not always visible. When they can be seen the cells in a cross section of the tentacle appear as a truncated pyramid with the base outward, in a longitudinal section as a prism or cube.

In the older free-swimming larva the commencement of the stone canal can be recognized as a pointed process on the right (originally left) end of the hydrocoele ring. After the assumption by the latter of a position at right angles to the major axis it still occupies the same place, between radii $I$ and $V$, arising from the wall of the ring toward the oral colome. It has become a short S-shaped canal showing little individual variation, which lies entirely in the compass of the oral colome, between its two side branches. From its point of origin on the hydrocole ring it turis toward the left and anteriorly, then ventrally and toward the right. For a long time its end remains closed, though thrust against the left inner wall of the parietal canal. The opening of the blind end into the parietal canal usually takes place on the fourth day.

The walls of the stone canal are composed throughout of relatively high cells with centrally situated nuclei, exhibiting the histological features which in previous stages had characterized the walls of the hydrocœle ring itself, and which recur in the budding tentacles. As in these, the lumen is in most cases of considerably less diameter than the walls.

In the part lying near the hydrocole ring a broadening of the lumen anteriorly and toward the left usually occurs, which directly before the entrance into the parietal canal may expand into an ampullalike swelling. Here Seeliger found in some cases that the border of the lumen was cross striped, though he was unable to determine the presence of cilia.

parietal canal.

The changes in the parietal canal during the early part of the attached existence are closely connected with those in the vestibule and hydrocœle. 
On its first appearance in the embryo it is dorsal in relation to the hydrocoele; in the free-swimming larva it has become displaced in such a way that its chief piece lies on the ventral side anterior to the hydrocole; in the stalked larva it moves posteriorly in the same degree as the vestibule and hydrocole and comes to lie horizontally always, however, maintaining its primitive relations with the adjacent organs.

The long anterior vertically running branch is very early withdrawn; it becomes shorter and shorter, loses its tubular shape, and appears as a pointed appendage of the transverse chief piece. This latter proceeds outwardly against the originally ventral side after the vestibule end has been entirely withdrawn.

While in the beginning its anterior end stretched to the end of the gut, and in the free-swimming larva lay before it, nothing further is to be seen of it in this region.

Posteriorly as well as anteriorly it is considerably compressed dorsoventrally and appears no longer as a transverse tube but as a sacklike structure which is somewhat longer in the major axis than in the transverse axis.

It appears to have increased in extent relatively much less than the other organs.

Since the chief part of the parietal canal has moved further posteriorly it has approached the plane of the pore, although always somewhat anterior to it. The ascending branch becomes more and more, though never quite, horizontal. The end piece runs approximately crosswise. While the outer end bends abruptly and opens outwardly through the pore, the inner end passes insensibly into the parietal cavity. The pore lies near a sacculus, a little ventral to radius I.

Histologically only the portion of the end piece adjoining the pore differs from the conditions found in the parietal cavity, which is lined throughout with a pavement epithelium at this stage everywhere demonstrable and nowhere showing a fusion with the mesenchyme cells. Further toward the oral side, about the stone canal, the cells are mostly a little thicker and the epithelial character of the wall is more easily apparent. The extreme end, which makes an obtuse angle with the remaining portion and breaks through the ectoderm layer of the body wall, consists of rather higher cells. Although the lumen is more extensive than in the adjoining transverse canal, its diameter as a rule is less than that of the wall. In cross sections the end piece and its lumen are circular. On the inner side the cells bear a cuticlelike lining finely striped transversely and bearing cilia.

MHSENCHYMF.

Calcareous skeleton.-As long as the vestibular invagination remains on the ventral side in the embryo, and in the free-swimming larva, the five basals and five orals lie in two horseshoes, of which the two arms are rather widely separated ventrally. When the vestibule has finally assumed its appointed place on the posterior end of the body the two series have rearranged themselves in two pentagonal systems at right angles to the major axis, directly superposed. 
The individual plates are not quite parallel to the major axis, for the oral ends of the orals and the aboral ends of the basals mark the sides of smaller pentagons than those outlined by the approximated edges of the same plates. These plates therefore appear arranged in a five-sided double pyramid truncated at both apices.

The relation of the calcareous pieces to the internal organs has also undergone a change.

While the basals entirely surround the aboral cœlome the orals have migrated out of the compass of the oral cœlome, so that this now lies between the two systems.

The pore lies between the aboral ends (bases) of the first and second orals, later becoming surrounded by the outermost processes of the first oral plates.

The five orals stretch over the open vestibule anteriorly and are movable; the five lappets in which they lie can be turned outward or inward, in the latter case closing the vestibular entrance.

The basals and orals are now so placed that the first basal and first oral, directly superposed, lie in the interradius bounded by radii $I$ and $V$, and the fifth in the interradius bounded by radii V and IV.

The basals lie beneath the ectodermal layer, and almost on the parietal layer of the aboral cœlome.

A weak layer of ectoderm, composed of mostly spindle-shaped cells standing at right angles to the surface, also covers the orals. Apparently with the increasing thickness of the orals all the mesenchyme cells of this region are drawn into their compass to contribute to the calcareous secretion, or possibly to form loose connective tissue filling the spaces in the calcareous meshwork.

The individual plates increase in area through the formation of rods along their borders which fork and join with the neighboring rods; and also the whole meshwork thickens so that the spaces, at first broad, become narrower, and their polygonal form rounds itself off more and more until the plates finally acquire a sievelike appearance.

The orals and basals do not always grow at the same rate; sometimes one series, sometimes the other, is more extensively developed; but very often also the difference is negligible.

The infrabasals, five or four, very rarely three, in number, are disposed, not quite regularly spaced, in a circle of relatively small diameter about, or just beyond, the oral (posterior) end of the proximal columnal. They are obliquely placed in such a way that their aboral ends lie nearer the major axis than the oral. But the grade of the obliquity varies in different individuals, as well as in the different plates in the same series. They always, however, lie more horizontally than the basals.

In the younger stages the individual plates in this series are usually of very different sizes. In the rare cases where there are three only the central one is very small and the two lateral very large, suggesting the possibility that the latter have each arisen through the fusion of two originally separate beginnings. 
The infrabasals eventually become fused to the proximal (most posterior) columnal, which is cup shaped, with a considerable central cavity for the reception of the chambered organ. Their anterior borders now reach to the aboral ends of the basals, which they begin to overlap.

In a 110-hour larva the centrodorsal was similarly formed, but somewhat more extensive; it measured from $160 \mu$ to $180 \mu$ in diameter, and was composed of a somewhat finer meshwork than the basals. The suture between the infrabasals could no longer be recognized, but as the outermost border showed four low and broad projections it is probable that there originally had been four.

The number of the skeletal elements in the column may be as high as 17 or 18 , including the centrodorsal and the terminal stem plate, though in many cases it is three or four under this number. The distance between them gradually decreases toward the calyx. In the vicinity of the infrabasals they lie quite closely together, and in younger larvæ the proximal end of the series is in part overlapped by the aboral ends of the latter.

As from the first the terminal stem plate considerably exceeds all the other columnals in size, and now lies entirely in the disklike broadening of the attached end of the body.

The progressive decrease in the size of the following pieces becomes gradually less and less marked, but for a long time very small plates, apparently newly formed, lie just beneath the calyx, the last of these eventually fusing with the infrabasals to form the centrodorsal. When this occurs the number of columnals has risen to at the most 19 .

Meanwliile the columnals have become greatly altered. Those lying at the aboral end outstrip the others in their derelopment, though the latter gradually overtake them so that finally all are essentially similar. But the thickness of the individual columnals decreases toward the calyx up to the last stage studied by Seeliger.

In the younger fixed stage the crescentic form of the plates occurs only at the oral end. The crescents are open ventrally, and the regularly curved inner borders are smooth. From the outer borders single and dichotomously branched processes arise, of which those in the dorsal median line are the most developed, the others gradually decreasing in size toward the horns of the crescents. These last gradually grow together until they meet and a plate is formed which shows a large circular opening displaced excentrically toward the ventral side. Meanwhile an active growtl of the calcareous processes takes place all about the periphery, which is still a considerable distance from the ectoderm of the stem, while peglike processes arise abundantly on the meshwork parallel to the longitudinal axis of the stem and at right angles to the plane of the columnals. These peglike processes, which occur very numerously even on the borders of the plates, grow very rapidly. They are mostly somewhat longer and thicker centrally than peripherally, though toward the center of the plate small ones may be found. In cross section they appear as glistening circular or oval structures forming an irregular broad band of dots. 
A more developed columnal shows a sieve-formed plate with a circular central opening, through which pass the extensions of the axial organ and of the chambered organ, which in several places reach the outermost wall of the stem, where they are covered only by a membrane instead of being overlaid with cells. The longitudinal processes have become considerably longer and stronger, and at different heights cross branches bind them together. With the growth of these processes the plates become separated, and elongation of the column results.

Although these longitudinal processes often overlap those of the neighboring columnals, fusion never occurs between them.

Sacculi-From 24 to 48 hours before the opening of the calyx the sacculi first make their appearance, one in each of the five angles of the calyx.

Each sacculus originates from a small cluster of mesenchyme cells, which forms on the outer side of the ring canal at the base of the middle tentacle of each group. In cross sections through the larva they appear elongate, with the inner side lying closely upon a longer or shorter extent of the hydrocœle wall. These clusters number from 8 to 12 cells, and they can be differentiated from the neighboring mesenchyme tissue of the body wall only through the closer approximation of the cells. From the hydrocœle, vestibule, and oral cœlome they are sharply and clearly differentiated.

When the required number of cells have assembled no further additions are received from the mesenchyme, and the organ develops entirely from the circumscribed cell cluster.

At this stage the rounded form of the constituent cells results in the presence of a small gap between them, but there is no true lumen.

Later the sacculus becomes somewhat enlarged, showing a definite wall composed of a single layer of cells which are somewhat larger on the side toward the hydrocoele than outwardly, a definite lumen, and a few cells lying within the lumen and resting on the cells of the outer wall, some of which doubtless arose through the intrusion of the cells of the outer wall into the lumen. But whether some of these inner cells are derived from such of the cells in the original cluster as from the first have occupied a more central position, or whether at one stage all of the cells formed a continuous and even one-layered wall from which they have passed inward, has not been definitely determined.

At this stage all the cells are rich in plasma and show prominent nuclei, which are somewhat larger than those in the mesenchyme cells. They stain more strongly than the neighboring cells of the body wall.

Before the rupture of the vestibule the inner cells have become considerably more numerous. Nuclear division commonly occurs in the cells of the outer wall in which the spindles are mostly approximately at right angles to the surface of the sacculus, which appears to indicate that cell division will take place parallel to this surface.

In cross section the sacculus now appears as a strongly colored, well-circumscribed cell cluster, the elements of which, mostly rounded, are of different sizes 
and show between them remnants of the earlier lumen. Already some of the inner cells appear about to disintegrate.

Seeliger found that the sacculi on the pinnules in course of formation on a regenerating arm tip develop exactly as the first sacculi of the larvæ.

Connective tissue.-The remaining mesenchyme cells of the larva, which take part neither in the construction of the calcareous plates nor in the formation of the sacculi, are collectively considered as composing the connective tissue.

No sharp line can be drawn between these cells and those which lay down the calcareous framework, as it is impossible to determine which of the cells and cell groups within the interstices of the plates serve exclusively as connective tissue for the occupation of the spaces, and which serve only in secreting lime. It is possible that, in general, the more rounded mesenchyme cells may possess the latter function; but, on the other hand, it is also possible that the branched or spindle-shaped cells between the calcareous trelliswork in the column may exercise both functions.

As already explained, the mesenchyme cells lying under the ectodermal epithelium merge with it and form a more or less uniform tissue in which the two original layers are no longer to be distinguished. Only from their position can it be inferred that the cells situated more deeply originate from the mesenchyme, and that the outer, which are often spindle shaped and placed at right angles to the surface, belong to the ectoderm.

As the plates become more and more extensive the deeper layers of mesencliyme cells gradually disappear to sink into the interstices of the calcareous skeleton and apparently also to take part in the enlargement of its various elements.

Thus in the calyx of the older larvæ the much-thickened calcareous plates are in general covered only by a layer of ectoderm cells, mostly placed at right angles to the surface, all of the subepithelial cells being inclosed within the calcareous framework. Only in the radial planes between the plates does the body wall preserve its original appearance. In the stem only over the tapered ends of the masses of longitudinal bars arising in each direction from the primitive rings and between the individual columnals is the original character of the body wall retained.

In the mesenchyme of the column connective tissue fibers are also found, which in part may be traced back to the structures already noticed in the freeswimming larvæ, and in part are of later origin.

The fate of the fibers is the free-swimming larvæ interpreted as muscular has not been determined; it is possible that they have broken down. No muscle fibers have ever been demonstrated in the young attached larva, though possibly they exist but have not been differentiated from other connective tissue elements. If any occur they could only be individual fibers, for the later musculature arises quite independently. 


\section{STALKED LARVA AFTER RUPTURE OF VESTIBUIE, UP TO APPEARANCE OF RUDIMENTS OF ARMS.}

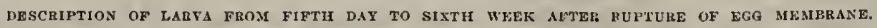

In its general form the larva is now characterized by the sharper differentiation of the five-rayed calyx and the considerably elongated stem. In the calyx the restibule has broken through, showing the 25 tentacles in five groups of 5 each surrounding the mouth.

At the time of the rupture of the vestibule (the fifth day) the larvæ have reached a length of about $1.25 \mathrm{~mm}$. Five weeks after the liberation of the embryo the larvæ measure from the terminal stem plate to the outermost tips of the tentacles $3.25 \mathrm{~mm}$; ; about $2.50 \mathrm{~mm}$. of this is included in the column. Average measurements are difficult to give, as the calyx can change its form to the most extraordinary degree.

\section{ECTODRRM.}

Ectoderm of body wall.-While up to this time the pore formed the only connection between the interior of the larva and the surrounding fluid, two new ones now appear, through the rupture of the wall of the vestibule, and later through the formation of the anus.

In the stage last described the portion of the wall of the body covering the vestibule had become considerably thinner. It becomes more and more flattened and then sunken and funnel-like in the center, where the outer cuticular layer on a very limited region merges with the pavement epithelium of the vestibular roof, and a perforation appears. This rapidly enlarges to an elongate rounded opening, which is large enough to permit the passage of the longest tentacle.

Occasionally in conjunction with these processes a partial dissolution of mesenchyme cells can be noted, the resultant fluid being absorbed by the neighboring tissues.

In older larvæ, of from 8 to 10 days, the opening into the vestibule has become considerably altered. From the original central aperture five radial excisions run outward between the five oral plates, so that the vestibular roof is divided into five lappets. These excisions gradually extend to the neighborhood of the hydrocœle ring, and the five lappets thus become the five triangular flaps containing the five triangular oral plates so well known in the "prebrachial " or "cystid" stage.

These five flaps are highly mobile; they may be turned inward, covering the vestibule and the tentacles, or opened widely outward so that the whole calyx appears disklike. This movement is rendered possible by a special musculature in the hydrocoele wall, in the ring canal as well as in the tentacles.

Histologically the ectoderm has undergone only inconsiderable changes. The protoplasmic cell bodies are somewhat more reduced than previously, the intermediate substance, on the other hand, being somewhat more extensive. About many nuclei the plasma is restricted to an extraordinarily thin layer, which is either stretched out threadlike or spindlelike at right angles to the surface, or 
radiates out in several very fine pseudopodialike processes. In other cases the plasma has become more extensive, though similar in form. The branched processes of different cells may unite with each other and thus form a plasmatic net traversing the sievelike calyx plates.

Apparently not all the nuclei of the ectoderm cells remain in the living state. In addition to such as show the typical form of the resting stage there are found others which clearly are beginning to dissolve. In the deeper layers it can not be determined with certainty whether these originally belonged to the outer layer or to the mesenchyme.

The degenerative changes are exhibited in different ways. Sometimes there is a shriveling of the nucleus and a decrease in the amount of chromatin; the nuclei appear small and pale with an indefinite contour, the chromatin granules being either absent entirely or appearing as irregular isolated peripheral specks. On the other hand, here and there strikingly large nuclei are to be seen, likewise feebly stained and without chromatin granules or chromosomes, but containing racuoles or accessory inclissions and always surrounded with a very small amount of plasnia.

There is a possibility that these degenerative changes are not entirely normal, since they occur only in individual instances and are not by any means general; but at all events an increase in the number of nuclei through division at this stage is most unusual.

As during this period the surface area of the body is considerably increased it necessarily follows that the cells become more and more separated, and at the same time nuclear division becomes less and less frequent.

In the living larva individual cells of a yellow color stand out prominently in the body wall and, less frequently, in the ectoderm of the tentacles. Except for the color these resemble in every way the colorless cells, but on being treated with reagents they seem to shrivel more readily, and they lose their spindlelike shape more easily than the others.

It is possible, though not proved, that these are identical with the yellow cells of the free-swimming larva. They lack the protruding club-shaped processes so characteristic of the others.

In the column also the histological relationships of the ectoderm are only slightly different from those in the preceding stage. A cross section through the portion of the stem adjacent to the calyx shows a number of spindle-shaped and threadlike cells, lying more or less at right angles to the surface, with some starshaped cells distributed among them. There is no sharp demarcation between ectoderm and mesenchyme. The whole external surface is covered with a transparent glassy cuticle, which at the base may reach a considerable thickness.

Vestibular lining and nervous system.-At the end of the developmental period just described there could be differentiated on the ectodermal vestibular wall three sections-(1) a posterior and outer, showing a pavement epithelium; (2) the anterior basal wall, which goes over into the esophagus; and (3) the outer covering of the tentacles, which develops from the border zone of the basal region. 
At the time of the appearance of the five radial excisions soon after the rupture of the vestibule the pavement epithelium of the inner side of the five flaps containing the orals can always be demonstrated as such; but gradually it transforms itself into a cuticlelike membrane without nuclei. Whether the nuclei bccome simply absorbed, or whether they retreat to the deeper layers of the body wall, has not been determined. The latter, however, is more probable, since before a homogeneous cuticlelike membrane is formed there is on many places a complete fusion of the ectodermal pavement epithelium with the mesenchyme, whereby the nuclei of the ectodcrm cells, with the extremely attenuated plasma surrounding them, become united with a proccss from a mesenchyme cell. On the other hand, the inner investment of the orals in the oldest larve of this stage sometimes shows a pavement epithelium passing over uninterruptedly into a membrane devoid of nuclei, which must have arisen from the transformation of such an epithelium.

Whether in still older larvæ the inner side of the orals is covered exclusively by a membrane Seeliger could not determine from lack of proper material; but it is not improbable that the transformation of the original pavement epithelium is carried through to its logical conclusion.

Inwardly the parement epithelium passes over into the outer wall of the tentacles, and between these into the floor of the vestibule, where an entirely different histological structure has now arisen. Outwardly, on the border of the oral flaps, it goes over directly into the cuticle formed from the ectoderm of the outer body wall.

The basal wall of the vestibule, which extends out between the tentacle bases and leads into the esophagus, decreases considerably in thickness toward the outer border of the calical cavity, at the same time here spreading itself over a broader surface. On account of this the nuclei, previously lying in several layers, become rearranged in such a way that they now lie approximately in a single layer. This condition is most marked about the borders, so that the hydrocoele ring is now covered on its inner side with a very fine pavement epithelium, which, at first running vertically, bends about the aboral border of the hydrocœle ring into the horizontal oral disk, simultaneously gradually altering its histological nature.

The component cells are outwardly cubical, becoming in the vicinity of the mouth high prisms bearing on their outer ends cilia which appear embedded in a clear cuticular border.

Immediately about the mouth the epithelium resembles that of the esophagus. into which it passes over without a definite line of demarcation. According to the state of contraction this transition zone is sonictimes drawn into the funnelshaped invagination as an esophageal wall, and at other times spread out horizontally as circumoral disk epithelium. Thus, in contrast to the aboral side of the larva, the oral side preserves the epithelial character of the ectoderm.

It is the epithelium of this transition zone, designated by Barrois as the intratentacular area, or secondary vestibule, which latcr spreads out over the entire ventral side of the disk and also throughout the ambulacral region of the 
arms and pinnules, everywhere preserving in all essentials its original histological characteristics.

In some of his oldest larvæ Seeliger saw the cylindrical epithelium of the disk extend unmodified to the water vascular ring without passing through a broad intermediate zone, by which the gradual transformation to the pavement epithelium is brought about, as is commonly the case. He assumes that this results from the extension of the epithelium through an increase in the plasma content of the cells, whereby they are changed from the strongly flattened to the prismatic type resembling the form of the ancestor cells at the time the vestibule was still closed.

There is no connection whatever between the nervous system of the freeswimming larva and the nerve ring of the stalked larva which develops into the ectodermal (ventral) nerrous system of the adult. The latter first appears in the fourth week, a long time after the rupture of the vestibule, as a derivative from the ectoderm of the original vestibular invagination on the region where the epithelium of the disk passes over into that of the tentacles. In longitudinal sections this region is very early noticeable on account of the relatively high ectoderm cells which show closely crowded nuclei, contrasting strongly with the pavement epithelum on either side.

The nerve ring lies close down on the hydrocole ring which, as will be noticed subsequently, is remarkable for the extremely strong ring muscular fibrillø. When these contract they press upon the nerve ring, and its borders stand out less sharply. When the calyx is opened out the two structures are separated by an intermediate space.

At the first appearance of the nervous system the ectoderm of the region where it is found is composed of a single layer of cells which either have no definite borders at all, or show them only in their outer ends. Inwardly, toward the ring muscle of the hydrocole, the cell ends pass over into a substance which retains the stain rather more tenaciously than the outer part and appears fibrillar, with coarse ring fibrillæ running parallel to the surface which appear in cross section as coarse grains. The nuclei, rich in chromatin, are very prominent; they lie in the outer ends of the cells, though not all at the same level. Here and there one may be seen undergoing division. There is no doubt that the ring fibrillæ, which are nerve fibrillæ, as well as the intermediate substance in which they are embedded, have been formed from the basal part of the ectoderm cells. The appearance of the nerve ring is not simultaneous throughout its entire extent; it seems to form on several places simultaneously, gradually growing into a closed ring. But there is a possibility that the apparently nerveless intermediate zone may possess a very fine ring nerve not demonstrable on preserved material.

In larvæ five weeks old the development of the nerve ring is somewhat further advanced. Over the now larger nerve fibrillar layer the ectodermal epithelium is now no longer one layered, for a number of cells have detached themselves and assumed a subepithelial position, in part lying with their outer ends between the bases of the epithelial cells, in part already entirely isolated from 
them. Like the fibrillæ these cells, which eventually will become ganglion cells, do not appear simultaneously throughout the whole extent of the ring.

At this stage cordlike processes from the nerve ring extend toward the bases of the tentacles, where in the single-layered ectoderm a few fibrillæ can be detected in the inner ends of the cells. These can not, as a rule, be followed farther into the tentacles, though preparations consisting of the whole animal sometimes show a fibrous cord running closely beneath the ectoderm which is probably nervous.

In the free-swimming larva, besides the nerve layer beneath the apical pit, there are two lateral nerve stems which run along either side of the vestibular groove. It could very well be that, as a result of these changes in the vestibule, these might come to occupy the same position as the later nerve ring. But apparently no such transformation occurs, the nervous system of the free-swimming larva disappearing in its entiety.

\section{ECTODERM OF THE TENTACLES.}

At the close of the developmental period last described there were 25 tentacles, each corered with a similar ectodermal epithelium.

After the rupture of the vestibule the tentacles enlarge very rapidly and become movable to the highest degree.

In the oldest larvæ, up to the time of the appearance of the rudiments of the arms, the first 15 tentacles are immediately distinguishable in size and structure from the 10 interradial. The former were called by Sir Wyville Thomson the "extensile tentacles," the central one being the "azygous tentacle," and the latter the "nonextensile tentacles."

The number of interradial tentacles does not remain limited to 10 but increases through the appearance of new tentacles interradially between those already formed indiscriminately in the several radii. Occasionally new tentacles appear between the larger radial tentacles also. The highest number of tentacles observed by Seeliger at this stage was 29,4 accessory tentacles having arisen. As previously, the 15 older tentacles stand farther from the center of the animal than the 10 smaller and the accessory.

While the 15 older tentacles are entirely independent of each other throughout their entire length, being only in contact at the base, the two interradial tentacles in each interradius are united across the interradial planes by an ectodermal fold, whereby the independent mobility of each is inhibited.

These folds reach from the bases of the tentacles to somewhat beyond their middle. On their distal border they appear considerably thickened, so that on preparations made of the entire animal at first only this thickened edge is seen, stretching rafter-like between the two tentacles. But on sections it is easy to see that this is an ectodermal fold of which the inner wall passes over laterally into the tentacles and basally into the periphery of the oral disk at the place beneath which the nerve ring lies, while the outer, more strongly flattened, curls around into the inner wall of the oral flaps and is laterally produced into the ectodermal epithelium of the tentacles. 
Between the body wall and the two layers of the fold there is seen in cross section a roughly quadrangular space, traversed only by a few plasmatic processes.

These folds persisted in the most developed larva examined by Seeliger.

Younger larvæ, at the end of the second week, give the explanation of the origin of this union. In these it can be easily seen that the common origin of each pair of interradial tentacles is enveloped at the base by a common ectodermal sheath, from which the two points arise. The same condition is found at the base of each group of radial tentacles, but here the common basal ectodermal mantle is not enlarged, becoming instead eventually divided to the very roots of the tentacles.

Simultaneously with the spreading out of the ectoderm of the 15 radial tentacles over an enlarged surface, there takes place within it marked histological changes during which the original uniformity of the cells disappears.

A cross section through a radial tentacle of an 11-day larva shows the nuclei gathering into groups, the groups being separated by small intermediate zones, in which nuclei are sparsely distributed or are entirely absent.

In the regions where the nuclei are grouped, indicating the places of origin of the papillx, the ectoderm is thickened and elevated, protruding in the form of a peg, which appears hyaline and almost homogeneous and is composed of the metamorphosed outer ends of the protoplasmic cell bodies. Cell borders can not be determined either in the outer part or in the thickened basal section.

The nuclei are often seen in process of division. Sometimes a small nucleus can be seen in the distal cuticular tip of the structure. Whether this is natural, or artificialy induced. has not been determined, but at all events in the fully formed papille nuclei occur only in the basal part.

The papillæ, as becomes increasingly more evident in later stages, are arranged in four somewhat irregular longitudinal rows. Those situated basally are less advanced in development than the distal.

In larvæ four or five weeks old the papillæ have reached the perfected form and resemble in all essentials those of the ambulacral regions of the adult animals.

The tentacles themselves have become rather long, very active organs, which taper slightly toward the distal end where they are more densely covered with papillæ than at the base, so much so, indeed, that the bases of these are everywhere in mutual contact, and the epithelium therefore appears uniformly beset with nuclei, without intermediate zones. Here the papillæ are especially well developed, measuring at their bases more than one-third of the circumference of the tentacles, which is here considerably reduced. Since their arrangement in longitudinal rows, though more or less disturbed, persists to the tip, they have become considerably displaced by crowding. Thus on a cross section relatively few are cut across, but farther basalward, toward the middle of the tentacle and beyond, the arrangement of the papillæ in four longitudinal lines is clearly marked, even though the four in each circumtentacular ring do not always stand at precisely the same height, and at the same time they become more isolated, with increasingly extensive areas of thin clear ectoderm without nuclei between them.

$142140-21-$ Bull. $82-33$ 
Only exceptionally does a nucleus occur in the intermediate zone which has not been drawn into the bases of the papillæ; such a nucleus causes a slight swelling in the thin intermediate layer.

According to the state of contraction the nucleated bases of the papillæ sometimes project slightly into the underlying hydrocœle wall, and sometimes form an arch bowed outward from it.

The number of the nuclei assembled in the base of the papillæ is not constant. In the central portion of the older tentacles it varies between 20 and 30 , the number of the nuclei, as well as the area of the base of the papillæ, having increased over what it was in the younger stages. The nuclei are almost, always arranged in a circular or oval disk, and differ somewhat among themselves in size as well as in chromatin content. Though most of them are in the resting stage, individual nuclei can always be found in course of division.

From the base of the tentacle there rises a homogeneous glassy cylindrical structure which in extreme cases measures $36 \mu$. in length, though often it is considerably shortened, and thicker. The tip is expanded, three or four cornered, and from each of the corners there projects a fine hairlike process with sometimes an additional one in the middle. The insertions of these hairs stain with especial facility, and they appear to possess broadened ends sunken into the end of the papilla. The axis is traversed by a fine glistening thread, the outer end of which passes over into the deeply colored end of the median hair, the inner end broadening out, attaching itself to a nucleus of the papilla base, and merging with the plasma of the cell body. In younger stages, when this axial fiber is first formed, it appears to grow outward from the base to the tip.

In the basal section of the 15 tentacles the papillæ gradually become smaller, and finally disappear entirely, the aggregations of nuclei becoming less and less clearly defined.

On the base of the tentacles in the immediate vicinity of the nerve ring the ectoderm of the inner and lateral walls is always similar and more or less flattened. On the contrary, the outer basal wall passes over gradually into the outer body wall of the calyx, into the inner basal ectoderm of the five mouth flaps containing the orals. The true ectodermal epithelium of the tentacles does not extend so far basalward on the outer side as on the inner, for on the former the hydrocœle of the tentacle at the base is covered by the lateral portion of the mouth flaps. Thus it comes about that whenever the tentacle bases are turned inward the mouth flaps and the included oral plates necessarily close down.

Histologically the structure of the ectoderm of the interradial tentacles is somewhat anomalous. The conditions are essentially those found in the large tentacles when they were approximately of the same length. Papillæ, smaller than those of the larger tentacles and more or less conical in shape, cover the surfaces toward the larger tentacles of the same parameres, elsewhere occurring only above the fold uniting the two. In the distal portion these papillæ are longer than in the basal, where they finally become reduced to small swellings. They are more crowded than on the large tentacles, and the intermediate zones 
between them are much less extensive. At their bases the nuclei lie at different heights. In the more developed an axial fiber can always be clearly seen, though the presence of bristles on their outer ends has not been determined. In the proximal basal portion, in the region of the fold, a low epithelium passes over by an abrupt curve, into that of the inner wall of the mouth flaps. The sides of the two tentacles which face each other have the same structure as the connecting fold.

$$
\text { iNTESTINAL CaNaL. }
$$

Although the intestinal canal is without a special muscular investment its component parts are nevertheless able to alter their relationships with each other somewhat, and the esophagus especially can change its form to a considerable degree.

This is rendered possible through the musculature of the hydrocele, and is thus connected with the contraction of the entire calyx and of the oral disk.

The mouth opening is usually oval, like the cross section of the esophagus, and lies a little excentrically in the interradial area delimited by radii $I$ and $V$, rather closer to the former. Correlatively the esophagus occupies a position which, in reference to the major axis of the bilateral larva, is toward the left. In the vicinity of the mouth the esophagus is broader than elsewhere, and here its right side extends for some distance over the median plane into the originally right antimere.

The esophagus is more or less sacklike in form. Its longer axis is not quite parallel to the transverse axis of the animal, but is approximately parallel with a line joining the distal ends of radii $I$ and III, or IV and V. It is compressed in the direction of radius II.

Thus it comes about that the wall adjoining the stomach is somewhat concave and the outer wall is convex, so that a cross section appears somewhat crescentic, this being especially emphasized in the lumen. When contracted the lumen may become narrowed to a slitlike canal, but on the other hand it sometimes appears of considerable size.

Sometimes, as a result of changes in the calyx, the aboral end of the esophagus becomes more or less closed off from the stomach, while at other times they appear broadly connected.

Histologically the wall of the esophagus resembles the epithelium of the oral disk. In the older larvæ the cells become relatively high, appearing almost wandshaped, and traverse the entire thickness of the wall. This one layered condition often can be very clearly recognized in the outer part of the wall toward the posterior portion of the gut when it is extended more than usual. Under these conditions the nuclei are arranged in a single regular row, in all the cells being at the same height. The inner wall toward the stomach is often strongly folded and thickened, so that the nuclei come to lie in several layers. Under normal conditions of contraction the nuclei are not always at the same height, but lie indifferently in the middle or in the outer ends of the cells. On very thin sections or in teased 
preparations there is no difficulty in determining that the cells extend throughout the entire thickness of the wall.

On the ends bordering the lumen the cells bear fine cilia the broadened ends of which, embedded in the cell plasma, cause the cells to appear striped. The ciliation is extremely delicate and easily destroyed. It has not been determined whether each cell carries one or more than one cilium.

The union between the esophagus and the stomach sometimes appears suffciently broad to permit of demonstration on several sections, and again may be so constricted that the two cavities appear entirely unconnected.

The stomach is in the form of an extensive and thick-walled sack, which however, is not sharply differentiated from the hind gut. In the earlier stages of this period its lumen is usually almost entirely empty, or is occupied only by slight remnants of the disintegrated cell material which previously filled it. As this disappears little by little the inner contour of the stomach wall again becomes clearly defined. In the later stages the stomach is very often filled with partially digested remains of food derived from foreign bodies.

When the stomacl is filled by food masses the sharp inner contour of the walls in connection with the process of digestion again disappears, and the inner ends of the cells become very irregular as a result of the extrusion of pseudopodialike processes.

In cross sections of the larva the strong convexity of the stomach wall toward the originally dorsal side close to which it runs and the contour of which it follows is very striking, especially in contrast to the opposite side, which is straight and runs approximately in the median transverse plane.

At the oral end the stomach is considerably extended in a direction at right angles to radius V. Aborally it contracts very quickly, appearing there of very irregular form.

The stomach wall is composed throughout of a single layer of cells, which are larger than those in the esophagus. Since the cells increase and decrease regularly in height, the surface bordering the lumen appears in sections waved or scalloped, these waves or scallops being much more marked in some individuals than in others.

Approximately in radius I, where, on a cross section of the animal, the dorsolateral wall of the stomach passes abruptly over into the inner wall, a moderately deep channel bordered with especially small cells runs from the oral to the aboral end.

The cells of the stomach wall, in spite of the difference in their lengths, are all of the same structure, prismatic, carrying the nuclei in their outer ends toward the colome. These nuclei are larger than those in the cells of the esophagus, but stain somewhat less intensively in hæmatoxylin. When the stomach is empty the ciliated inner ends of the cells are clearly seen, each cell apparently bearing a single cilium with a deeply colored root sunken into the outer end. Under the plasmatic bordering layer is a narrow clear zone in which the plasma appears frothy and includes clear rounded vacuoles which are possibly filled with digestive 
fluid secreted from the cells themselves. Very often this clear zone is of considerable width.

When the stomach is filled with food the inner ends of the cells lose their distinct borders, and the cell plasma appears to merge into the included mass.

The hind gut, representing the hind gut on the originally right side of the stomach, arises gradually from the posterior end of the latter, so that no sharp dividing line between te two can be drawn. Such a dividing line would lie in the interradius bounded by radii III and IV.

The hind gut tapers quickly to a tube, which, as in younger stages, runs in the horizontal mesentery close to the body wall, passes through the interradius IV-V in a broad curve, and, extending somewhat beyond the original median line, opens to the exterior through the anus, which is situated more or less near radius $V$, though always in the interradial space V-I. Seen from the oral side of the larva the turning of the gut is clockwise.

The wall of the hind gut is composed of a single layer of cells. In the proximal part the cells resemble those of the stomach wall. Farther posteriorly they usually become lower, and the differentiation of the inner ends described for the cells of the stomach wall can no longer be made out. Thus in the younger stages the walls here may be closely pressed against each other, so that the lumen entirely disappears. Usually no cell borders can be distinguished, though the nuclei lie fairly regularly distributed near the outer walls. In a few cases, however, cross sections through the end gut show clearly high prismatic cells, the nuclei of which lie in the outer ends, while from the inner ends pseudopodialike processes radiate which form with those of the adjacent cells a reticular structure. In the cases where no cell borders can be demonstrated similar pseudopodialike structures are found, but here the network appears to be more coarsely developed, often filling the entire lumen. It is possible that this is the effect of preservation, and that in the living object the cells are ciliated, like those of the stomach.

According to Perrier the anus is bordered with large cilia-an observation partially confirmed by Seeliger.

The distalmost end of the gut is of exclusively entodermal origin. The ectodermal invagination observed in numerous cases in the formation of the anus, by which an ectodermal rectum is formed, appears to be of later origin, occurring after the anus has moved from its lateral position on the side of the calyx to the definitive position.

COFOME AND ITS DERIVATIVES.

At the end of the last developmental period the two cœlome pockets had already reached their definitive position, and their further alterations are relatively unimportant.

These alterations consist in a progressive advance in the dissolution of the mesentery, so that the originally separate sections become more and more broadly united, and finally can no longer be clearly differentiated.

The wall of the oral colome is now composed of an extremely delicate pavement epithelium which can everywhere be clearly demonstrated as such, though 
in many cases it has become intimately united with the aboral wall of the hydrocœle ring and with the body wall.

Since the ventral ends of the colome pockets are still considerably separated from each other, a typical mesentery is not found in the early fixed stages. But when as a result of the dissolution of the horizontal mesentery the right end has broken through, this increases very rapidly and comes into contact with the left blind end of the oral cœlome. The wall of the latter and that of the united oral and aboral cœlome lie closely together and form the vertical mesentery of the oral cœlome in which the stone canal runs. This mesentery runs from the margin of the esophagus directed approximately toward radius $\mathbf{I}$ into the interradial space $\mathrm{I}-\mathrm{V}$, but always reaches the body wall near radius $\mathrm{I}$.

The inner wall of the aboral cœlome enveloping the gut and the axial organ can always be clearly recognized as a distinct pa vement epithelium, but the outer wall (the parietal layer) in various places merges so intimately with the body wall that over much of its extent it is no longer demonstrable as an independent layer.

The vertical mesentery is no longer preserved as an entity. First it atrophies in its central portion, and then begins to disintegrate into individual disconnected cords which traverse the body cavity longitudinally and more or less diagonally.

Meanwhile the dissolution of the horizontal mesentery has made progress. In longitudinal sections it appears as a thin lamella, including nuclei in which the two layers from the union of which it has arisen are no longer everywhere demonstrable. The entire central part, extending between the esophagus, stomach, and gut, has disintegrated into trabeculæ.

In addition to these trabeculæ, arising from the remains of the mesentery, many others form independently from the cœlome wall. This process first began in the preceding stage, but now the trabeculæ appear in much greater numbers and reach a greater length. Often an entire trabecula is composed simply of a single metamorphosed cell, though commonly several take part in its formation.

With the advancement of the dissolution of the mesentery the whole colome takes on more and more the character of a single cavity, which is lined with an inner layer (the visceral layer) inclosing the internal organs and an outer layer (the parietal layer), which here and there is fused with the body wall.

By the remnants of the vertical mesentery of the lower cœlome and the lamellæ of the horizontal mesentery the body cavity is now separated into entirely distinct chambers, which are traversed by trabeculæ in part derived from the mesentery and in part of independent origin.

CFAMBERED ORGAN.

$A_{\mathrm{s}}$ in the preceding stage the chambered organ is composed of five ampullalike swellings and five processes from these extending into the stem.

The former are encompassed by a wall composed of a pavement epithelium made up of a single layer of cells; but the thickness of the wall, as well as the form of the swellings and the size of the lumina, is more or less variable. These 
rudiments of the chambered organ lie close down upon the cœlomic wall, though there seems never to be a connection between the two cavities. Often the five chambers do not lie in the same transverse plane, but it is not difficult to find individuals in which this is the case.

Since in this region a section through the calyx now shows the pentamerous structure strongly marked, it is easy to see that the chambers are radial in position, a fact not previously clearly brought out.

Regarding the question in what way the original evaginations which appeared in the free-swimming larva have moved into radial positions, it is evident in sections cut farther orally that the vertical mesentery is in interradius IV-V, and correspondingly the chamber lying in radius $\mathrm{V}$ can be traced back to that evagination which originally appeared on the left side ventrally and was designated as evagination 1. From this it is easy to see that the original evaginations 2, 3, 4 , and 5 are now the chambers lying in radii I, II, III, and IV.

The extensions of the chambered organ traverse the stem as cords of cells in which the cross section shows no lumen, and indeed the individuality of the cords themselves is lost a short distance from the calyx.

In longitudinal view the component cells are seen to be elongate and spindleshaped, with distinct nuclei, joined together end to end. The ends of adjacent cells are so intimately united that the cell borders are not recognizable, and the impression given is that of a continuous plasmatic cord bearing more or less regularly spaced nuclei. A similar developmental stage can be commonly observed in the formation of the muscle fiber lines, but whether the further developmental course of the two is the same is uncertain.

\section{AXIAL ORGAN.}

Soon after the opening of the vestibule the axial organ becomes detached from the whole oral part of the fold of the visceral layer through the thickening of which it has arisen, and appears as an isolated cord of cells.

This cord very quickly becomes hollowed out into a tube of which the lumen at first is always narrower than the thickness of the walls. The latter consist of a single-layered epithelium, though cell borders can not always be differentiated in the thick mass of plasma. The structure appears to be in course of active growth, for the nuclei are commonly seen in process of division. The resting nuclei are larger than those of the colomic wall.

The fold of the visceral layer enveloping the axial organ is composed of a more or less strongly flattened epithelium, which in the middle section always lies closely on the tube. In the oldest larvæ of this period the axial organ on the side toward the gut is accompanied by a number of longitudinal muscle fibers which are formed from the fold of the visceral layer on the side toward the axial organ. These fibers also are found in the esophageal section of the fold, and in a short section lying on the gut.

Toward the oral side the axial organ has become extended as far as the oral disk and into the vicinity of the oral cœlome, where it approaches the border of 
the esophagus facing the posterior end of the gut. $A_{\mathrm{S}}$ in the central section it is here also enveloped by a fold of the coelome wall, which in the outermost part, however, is less closely connected with it, so that the axial organ is immediately surrounded by a small space, which can be traced back to the primitive body cavity, and has no connection with the true cœlome. On the oral side this cavity ends under the ectodermal oral disk, to the inner wall of which the fold of the colomic wall enveloping the axial organ is attached, after broadening out like a funnel. Aborally it disappears, since the axial organ entirely fills the cavity.

Toward the aboral end the axial organ, as already described, passes into the vertical mesentery of the aboral cœlome, traverses the central space which is inclosed by the chambered organ, and finally loses itself between the cordlike processes of the latter. How far it extends into the stem has not been determined.

Sometimes in the oldest larræ of this period the aboral part of the axial organ almost from the entrance into the chambered organ appears merely as a cell cord without a central lumen.

In its short course in the vertical mesentery it possesses in some cases a special sheath which appears as a fine parement epithelium.

In the portion of the axial organ lying at the outermost end of the colome the conditions are as they were in the oral portion at its first appearance.

HYDROCGLE.

In this stage the hydrocœle ring usually becomes entirely closed by the growing together of the two blind ends in the interradius I-V. The septum composed of a double thickness of parement epithelium representing the apposition of the two blind ends ruptures in various places and finally disintegrates into a number of trabeculæ. But among larvæ of five weeks individuals may still be found in which the two layered septum still persists.

The lumen is rather extensive. Its shape in cross section varies according to the state of contraction, but apparently it is usually broader in the direction parallel to the major axis than in the transverse plane.

The wall is everywhere composed of a single layer of high cells, which become larger in a zone running under the nerve ring. Along this zone ring fibrillæ appear which surround the whole hydrocœle ring and form a sort of sphincter. They lie on the outer side of the hydrocœle wall and in cross sections are evident as strongly refractive elongate or peg-shaped bodies. In longitudinal view the fibrillæ are seen to be cross-striped, and the nuclei appear in general to be arranged in longitudinal rows.

In some of the oldest larvæ the ring fibrillæ occur not only on the region lying on the nerve ring, but also on the entire inner wall and on a part of the aboral wall, where, however, they are very delicate and not entirely regular, not accompanying the entire canal in an unbroken layer, but forming a more or less complete investment of longer or shorter ring fibers.

These muscular fibrillæ arise from the hydrocœle wall, and not from mesenchyme cells. 
The trabeculæ traversing the ring canal and connecting the inner and outer walls have increased considerably in numbers. In each a nucleus is found, usually in the middle; frequently two or more occur in a single trabecula. In the younger stages these have no special fibrillar structure, and in cross section are rounded or quadrilateral, somewhat flattened, or bandlike. The last is the most common in the older stages, in which the broad side is usually, but not always, parallel to the oral wall.

When the trabeculæ contract they become more cylindrical. On the border the cross section shows a prominent stripe which on strong magnification resolves itself into a number of fibrillæ running closely side by side. These fibrillæ are usually from two to four in number, often only one, in a few cases five. They appear usually entirely structureless, but sometimes finely granulated; cross striping has not been proved. At the end of the trabeculæ the fibrillæ appear to be somewhat thicker than in the middle. They enter the hydrocele wall and end with it.

In the larvæ in which the septum in the hydrocœle ring still persists the origin of the stone canal from the blind end lying to the right in interradius V-I can be very clearly made out. It forms a V-shaped loop, of which the two arms are bent in a different way, so that the whole canal can never be seen at one time on a thin section. It runs in the vertical mesentery of the oral cœlome and opens on its border against the horizontal mesentery in the parietal canal. This branch often runs quite horizontally and is directed outwardly and toward radius I, while the part joining the hydrocœle ring runs more vertically.

In its structure the primary stone canal of the larva entirely resembles the numerous canals of the adults. It is a thick-walled tube, of which the diameter of the lumen in the older larvæ somewhat exceeds the thickness of the walls, and is composed of a single layer of moderately high prismatic or truncated pyramid cells, the nuclei of which are large and stain strongly. In the terminal section the cells in the wall toward the parietal canal are somewhat lower, often cubical. From the mesenchyme tissue the canal is sharply differentiated. In the lumen a striped border zone can often be demonstrated, suggesting ciliation.

From the preceding description it is evident that the stone canal is formed rather late as an independent evagination of the hydrocœle ring which leads into the parietal canal and at no time opens freely to the exterior.

The hydrocole cavities of the tentacles consist of single-layered sacks, with broad lumina, which taper toward the distal end, lying directly beneath the ectoderm. In the 15 large tentacles the separation of the individual sacks has advanced to the hydrocole ring, so that each of these tentacles now arises from that ring quite independently of the other two.

In the hydrocœle of the tentacles there are now no muscular trabeculæ, though these were present in the original evagination. The walls are composed of a flat epithelium in which the nuclei, lying on the inner side, are somewhat larger but less easily stained than those of the ectoderm cells. At the distal end the cells are somewhat thicker and richer in plasma, and further extension of the sack, correlated with the lengthening of the tentacle, appears to take place here. 
On the outer side the epithelium has everywhere given rise to parallel longitudinal fibrillæ, which in cross section appear as strongly refractive bodies, and viewed longitudinally appear cross-striped. Toward the root the fibrillæ extend to the hydrocœle ring. On the inner side the fibrillæ are here considerably coarser than on the outer, and their distalmost ends stretch over a part of the ring musculature of the hydrocœle ring, running between it and the ectoderm. On the thinner outer wall the fibrillæ become finer basally, and some (but not all) of them continue as extremely fine fibers, to the oral part of the outer wall of the ring canal. Seeliger was unable to recognize cross striping in the ends of these fibrillæ.

The structure of the hydrocœle cavity of the small interradial tentacles is essentially the same. At their bases, however, the outer muscular fibrillæ are especially well developed, and can be followed somewhat farther aborally than those of the inner side. The hydrocœle of these tentacles is connected with the hydrocele ring by a common base, over which only the outer fibrillæ pass.

There are no ring fibrillæ in the tentacles.

PARINTAL CANAL.

During this period the parietal canal undergoes no important changes; but the contrast in the histological structure of the two sections becomes more and more emphasized.

The terminal section is tubular, and is composed of a cubical or fairly high prismatic epithelium, which is probably ciliated. As in earlier stages it runs transversely, and its inner end is depressed more or less steeply toward the aboral and originally right side, reaching about to the vertical mesentery of the right cœlome, where it passes over, the walls gradually becoming thinner, into the parietal cavity. The outermost portion of the terminal section turns outwardly at a sharp angle to open as a pore near radius $I$, and always in the interradius V-I, where the anus also lies.

The pore varies in form and width and appears to be able to expand and to contract. Since special muscles are absent, the changes in the shape of the pore must be connected with the changes in the entire calyx.

The end of the canal immediately adjacent to the pore is ciliated, and in some places longitudinal striping can be recognized in the ends of the large cells. If any ectoderm cells at all are involved in its formation they can only be very few in number and at most can only form the outer border.

The inner section of the parietal canal, the parietal cavity, shows considerable differences in regard to its form as well as in regard to the histological structure of its walls. Generally speaking, it stretches in a peglike blind extension more or less far toward the aboral pole, lying closely upon the parietal layer of the aboral coelome. Into the broader portion the stone canal opens.

Sometimes in old larvæ the wall can be demonstrated as a distinct pavement epithelium, especially in the aboral end piece; again it becomes fused with the 
tissue of the body wall surrounding the parietal canal, so that it loses its individuality. The latter seems to be its ultimate fate in all the larvæ.

In young larvæ the inner wall of the parietal cavity is always separated from the coelomic epithelium by mesenchyme. Little by little this is withdrawn, and both walls gradually grow together into a single lamella.

This lamella separating the cœlomic cavity and the parietal canal at first is composed of two pavement epithelia, which can be differentiated in many larvæ, though in others there is only a thin partition with embedded nuclei to be seen, which finally breaks down, so that the parietal cavity becomes merely a diverticulum of the colomic cavity. The intercommunication of these cavities appears to become established in different larvæ at widely different ages.

The number of stone canals and pore openings through the calyx increases considerably in the subsequent development. At the time of the separation from the larval column five stone canals are present which open outwardly through five pores as in the adult of the species of Rhizocrinus. Later the stone canals, as well as the calyx pores, increase in number, without further correlation. As Ludwig states that there are at least 30 stone canals in each interradius (in Antedon mediterranea), while the number of calyx pores is approximately 1,500 , it necessarily follows that the later efferent vessels from the hydrocole can not be formed in the same way as the first.

As the result of muscular action the larva assume very different forms, and apparently the volume of the body changes also. This is probably the result of changes in the volume of the water in the intestinal canal, which is open to the exterior through the mouth, though partly due to the variation in the water content of the parietal cavity, which opens to the exterior through the pore.

\section{MESENCHYME.}

Sacculi-After the rupture of the vestibule the first five sacculi enlarge rapidly, becoming spherical or egg-shaped hodies, causing humplike swellings in the cuticle, from which they are no longer separated by intermediate cells.

Correlatively with the increase in size the structure of the sacculus changes. An epithelial cortical layer separates itself from the inner mass and rapidly becomes flattened, forming a membranelike pavement epithelium in which flattened nuclei can be clearly made out inclosing the inner mass like a capsule. There is no fusion between this and the surrounding mesenchyme. Often the inner side of the capsule is composed of cells richer in plasma than elsewhere; such a condition probably represents an intermediate developmental stage in which the flattening has not yet been entirely completed.

The cells which fill the capsule, originally showing the nucleus and cell body clearly differentiated, after increasing by division become rapidly altered. The form becomes rounded, and they unite in numerous groups, each of which is composed of a number of individual elements, from two, three, or four to a dozen or more. The size and form of each group varies with the number of 
included elements. The smaller are usually egg shaped, the larger like bunches of grapes. In the same sacculus the most diverse types are seen side by side.

In the living object the individual elements of each little group are colorless homogeneous, and strongly refractive. They stain readily and uniformly and oräinarily show neither nuclei nor chromatin grains. But under special treatment most of the elements can be recognized as true cells.

Roughly in the center the nucleus, including a few chromatin grains, can be differentiated. It is large and vesicular, surrounded by the scant protoplasmic mass of the cell body, which, when the elements are closely crowded, are convex only on the free side, the other sides being flattened against each other and polyhedral. Very commonly, however, a definite nucleus can not be made out, and there are only to be seen chromatin grains apparently lying freely in the cytoplasm. The amount of chromatin is variable in the different elements; sometimes there is a considerable quantity, and again so little that its demonstration is difficult.

In a somewhat more advanced stage the cell clusters have become elongated and the constituent cells spherical. Between the larger clusters lie a few smaller irregular groups. There appears to be no definite arrangement of the large groups, although the majority lie with the curved base on the cortical pavement epithelium and the point centrally. Seeliger in a few cases saw clearly the filiform hyaline process at the pointed end of the cell clusters, though it was shorter than in the adults and never reached the wall of the sacculus. No enveloping membrane was discerned.

By the isolation of the individual elements of a cluster it is made plain that in spite of the absence of an inclosing membrane these cling rather closely together. They are not all the same in structure. Relatively few can be shown to be complete cells with a cell body and a small nucleus containing a few chromatin granules. Most of the nuclei contain no chromatin. Within some of the cells is a clear vesicular body, usually placed excentrically, which is perhaps the remains of the nucleus, or perhaps the beginnings of a vacuole. This last type may represent the ultimate development.

In the oldest larra of this period five new sacculi are formed between the original five and the oral surface. They do not develop at the same rate, with the result that a single larva shows several different derelopmental stages in the different radii. The separation of the original cluster of mesenchyme cells into a peripheral and a central part in these sacculi occurs much earlier than in the first five.

Conncetive tissue.-As in the period preceding the mesenchyme cells form in connection with the elements of the outer layers in the body wall a uniform tissue, in which only the most superficial cells, mostly spindle-shaped and standing more or less at right angles to the surface, can with certainty be traced back to the cctoderm, while the deeper cells, bordering directly upon the hydrocœle or the parietal layer of the cœlome, undoubtedly originated from the mesenchyme. In the intermediate layer no separation of the cells according to their origin is 
possible. All the cells are connected by protoplasmic processes and, as in younger stages, lie in a homogeneous intercellular mass.

In the middle and deeper layers of the body wall the cell forms are extraordinarily diverse. They may be strongly rounded, star shaped, branched, or spindle shaped, with pointed or gabled ends, each type being indiscriminately distributed. Some, scattered and running in various directions, give the impression of muscle fibers, but whether they are in reality contractile elements has not been definitely determined. The musculature of the hydrocœle suffices to explain the movements in the larval calyx.

In the column the mesenchyme shows approximately the same structure as in the stage preceding. With the extraordinary elongation of the columnals the importance of the connective tissue has diminished.

Between each two columnals a layer of closely packed mesenchyme cells, spindle shaped, with the strongly stained nuclei in the thickened central portion, is found. Whether or not these cells are attached to the ends of the calcareous segments has not been determined.

The other mesenchyme cells of the column lie within the fascicles as a mass of weak and pliant connective tissue, and are concerned with the formation of the calcareous portion of the columnals. If any of the cells function purely as connective tissue it is not evident from their structure, since all of the mesenchyme cells appear essentially the same. For the most part the cell bodies are elongated in the direction of the major axis and are united through their branched ends. The nuclei are sharply delimited. Within the calcareous substance cell borders are very difficult to recognize, so that the nuclei appear to lie in a plasmatic reticulum.

The axial canal, passing through the central portion of all the columnals, is now entirely occupied by the process from the axial organ, and the five processes from the chambered organ surrounding it. The cord formed of these six structures is covered by mesenchyme cells only in the region of the articulations.

Dorsal nervous system.-At the junction between the calyx and the column, about the chambered organ there is a considerable aggregation of mesenchyme cells which does not take part in the formation of the calyx plates. They resemble the usual connective tissue cells and are mostly rounded, with numerous starshaped, and some spindle-shaped. These cells eventually form the dorsal (mesodermal) nervous system the central organ of which surrounds the chambered organ.

\section{ANTEDON MEDITEIRANEA.}

Figs. 1182-1185, pl. 2\&, 1190, pl. 29, and 1194, pl. 30.

Very detailed studies have been made on the embryology and development of this species by Bury at Naples, and by Barrois at Villafranca, his material coming from Villafranca and especially from Toulon.

Both investigators found that all the embryos, not merely on the same mother but on all the individuals from the same locality, brought in on the same day are in the same developmental stage. 
In the 32-cell stage Barrois found the embryo to consist of eight larger cells about the vegetative pole and 24 smaller cells, as Seeliger describes it in A. adriatica. Bury makes no mention of a difference in the size of the cells.

Bury notes that the first cleavage furrow makes its appearance soon after midday, probably at least three hours after fertilization. Subsequent divisions occur at intervals of about an hour.

The formation of the blastosphere is not completed until fuliy 12 hours after the first cleavage.

Gastrulation begins about 20 hours after fertilization ( 17 hours after the appearance of the first cleavage furrow); the blastopore attains its greatest dimensions about the middle of the second day, and closes completely about 40 hours after fertilization.

Apparently no cilia are developed until after the closure of the blastopore. Early on the third day the embryo is covered with a uniform coating of cilia.

By the fourth day the embryo has nearly lost its pink color and has become white or faintly yellow. It has also become somewhat more elongated and, though still ciliated all over, the body surface has begun to show distinct ciliated bards.

By the fifth day the embryo has acquired almost all the external features of the completely developed free-swimming larva. The general color is usually yellowish brown, but this color is confined to the nonciliated portions, so that the ciliated bands and the two ventral depressions (also ciliated), which are white, are very clearly defined, their degree of distinctness varying with the amount of pigment developed elsewhere. The greatly elongated cilia of the anterior tuft also spring from a nonpigmented area.

Besides the yellowish brown cells the nonciliated areas also contain a number of the "yellow cells." By reflected light, if much pigment is developed elsewhere, these cells are very inconspicuous; but when teased out and viewed by transmitted light they appear bright green, while the other ectoderm cells, in which but little pigment is present, appear colorless.

Bury found that in almost all cases the ciliated tuft is directed forward; indeed, out of hundreds of larvæ examined he never saw one swim in the opposite direction, except when it encountered an obstacle, in which case it would reverse its motion for a short distance always, however, resuming before long its original course. The fact that when at rest the cilia all curve toward the anterior end is probably connected with this mode of swimming.

The first rudiments of the skeleton make their appearance early on the sixth day. Bury could discover no indication that the terminal stem plate, basals, and orals are developed in any particular order, though he considers it probable that all of them are developed before the columnals.

Early on the seventh day the infrabasals make their appearance at the posterior end of the series of columnals. They are three (rarely four or five) in number, and in form resemble small basals, though they are developed at a much deeper level than these plates, and are usually nearer the posterior end of the 
body than the two ventral basals. These three infrabasals are at first equal in size, but after a while two of them begin to grow more rapidly than the third, eventually attaining to about double its size.

At a later stage the inner border of each becomes smooth and concave, and they then range themselves in a circle around the chambered organ, just above the topmost columnal. The arrangement of the plates is still the same as in the earlier stage. Somewhat later they fuse with one another and with the topmost columnal so as to form one large plate. Though the sutures of the infrabasals still persist, the plates themselves have grown out into five angles which are radial in position, fitting in between the bases of the basal plates. While the dorsal infrabasal produces only one angle, each of the other two grows out into two angles, this fact strongly suggesting that each of these larger infrabasals represent a pair of coalesced plates, and that the primitive arrangement would be the possession of five radial infrabasals. At a slightly later stage the sutures disappear, though the groove separating the infrabasal series from the topmost columnal persists for some time.

Thus in reality the topmost columnal only forms the lower half of the centrodorsal, the upper half being formed by the infrabasals.

Bury records that the larvæ showed a singular want of discrimination in their choice of positions for fixation; besides numbers which perished from attaching themselves to objects too small to support them, some attached themselves to the pinnules of the parent, where they never managed to adhere very long, and others to their own cast-off ritelline membranes, which were soon eaten up by bacteria and infusoria.

The ease with which the vitelline membrane can be broken is subject to considerable variation. Some whole broods are set free with ease on the fourth day; but in most broods the majority are not set free until the seventh day, and a considerable number are unable to free themselves even on the ninth or tenth days, long after the majority of the larva have become fixed. Such prisoners, when at length liberated, are seldom able to fix themselves, and if they do they usually exhibit considerable abnormalities of form and either grow into monstrous shapes or remain perfectly spherical. Some of the last Bury liberated as late as the eleventh day, and though they had lost the two ventral depressions, they still retained some of their cilia in active motion.

Bury writes that the reason of so much variation in the consistency of the vitelline membrane, leading so often to considerable loss of life, is not easy to see, but it may possibly be connected with the varying conditions to which these animals are exposed. Thus if the membrane were always of the same strength a sudden storm might set all the larvæ free at too early a stage of development, and so deprive them of the protection afforded by the pinnules of the parent, while if the membrane were strong enough to resist a storm, a continued calm might leave a greater number unable ever to free themselves than at present occurs.

The first changes which occur after fixation are principally histological, and it is not for some hours that the general internal anatomy alters much. The 
ectoderm soon loses its distinctness from the mesoderm, the ciliated bands degenerate, and histolysis, setting inward from the ectoderm, rapidly spreads to all the tissues, and results in the obliteration of almost all the previously existing histological differentiation. The details of this histolysis are extremely difficult to follow, and both in its mode and degree of action and in the relative times at which it affects different organs it appears to vary considerably.

Bury notes that the number of columnals in the free-swimming larva is variable, but by the time the larva fixes itself from 13 to 15 are usually present, and this number is maintained throughout the pentacrinoid stage.

Prof. A. Russo, taking exception to Seeliger's interpretation of the conditions in Antedon adriatica, states that the parietal sac is from the beginning in communication with the stone canal, and that at first, as in all the echinoderms, it alone communicates with the exterior, opening on the back of the larva near the fourth ciliated band. In the course of development this primitive opening is obliterated, so that in the fixed larva a few days old the madreporic system is composed of an internal sand canal which carries at its extremity, turned inwardly, a vesicle which is the parietal sack. Communication between this system and the exterior is reëstablished later, when the column has become elongated and the oral valves have formed. It comes about through a secondary and independent formation from the true water vascular system-that is, by means of a canal of ectodermic origin which ultimately opens into the parietal sack.

Russo noticed that below the point which corresponds to the opening of the secondary ectodermal canal leading into the parietal sack a primitive gonad is formed, which after a short time atrophies.

\section{ANTEDON BIFIDA.}

Figs. 1176-1181, pl. 28, 1186-1189, pl, 29, 1191-1193, pl. 30, 1195, pl. 31, 1201-1203, pl. 32, 1204-1206, pl. 33.

Our knowledge of the embryology of Antedon bifida is based upon the work of Busch (1849, 1851), Sir C. Wyville Thomson (1865), and Prof. W. B. Carpenter (1866), all of which was done before the inception of modern methods of technique. The results of their studies, therefore, are not strictly comparable with the elaborately detailed investigations of Seeliger, who was able to avail himself of all the latest refinements. But certain important features stand out which are not dependent upon differences in methods.

According to Sir Wyville Thomson the eggs of this species when fully grown measure about $0.5 \mathrm{~mm}$. in diameter.

The formation of the polar bodies may be very easily followed. A very distinct globule about half the diameter of the germinal vescicle, with an obscure nucleus, passes out of the egg. In all cases in which Thomson observed it, it was accompanied by two or three minute rounded granular masses. During the earlier stages of segmentation the polar bodies remain perfectly distinct, but toward the beginning of gastrulation it becomes difficult to differentiate them from the cells of the embryo. 
Thomson says that the free-swimming larvæ are from $1.5 \mathrm{~mm}$. to $2 \mathrm{~mm}$. in length. The larvæ found by Busch in the Orkneys were somewhat smaller than those of Antedon adriatica.

Thomson notes that the cilia do not vibrate with the regular rhythmical lashing of ordinary cilia, but seem to move more independently, their motion regulating the rapidity and direction of the movements of the animal in the water. The anterior tuft of long cilia is in perpetual vibratile motion.

The larva swims with either extremity in advance indifferently. It swims rapidly with a peculiar swinging semirotary motion.

When resting the ventral surface is downward.

The spicules forming the rudiments of the calcareous plates are at first blunt: irregular cylinders, but shortly they fork at either end and, finally, by repeatedly dichotomizing and anastomosing, they form delicate plates of calcareous network.

W. B. Carpenter observed that the nature of the objects to which the larvæ attach themselves varies with the locality. In Lamlash Bay, Arran, he never found them on anything but the fronds of Laminaria, to which the adults habitually cling, or on bryozoans or Spirorbis growirg on these. But at Ilfracombe, where Laminaria is much less abundant, but where on the contrary Salicornaria grows in great luxuriance in the habitat of Antedon, the pentacrinoid larva are found living on it. In the Bay of Cork $\mathrm{Mr}$. J. V. Thompson found the larvæ attached to the various species of Sertularia and Flustracea which occur in the deeper parts of the Cove, in from eight to ten fathoms. Mr. Wiliam Thompson (of Belfast) found them attached to Delesseria sanguinea. Usually the larvæ are widely distributed over the surface of the object to which they are attached, but sometimes a group of several, showing different stages in development, may be met with. Doctor Carpenter had one specimen showing more than 70 pentacrinoids, all nearly in the same stage of development, attached to the surface of a patch of Membranipora which was encrusting a frond of Laminaria; and another, given him by Sir Wyville Thomson, in which 35 pentacrinoids in the "prebrachial stage" are so closely crowded that the discoidal bases of their columns have come into mutual contact and have acquired a polygonal form. These latter were bred in an aquarium. Similar clusters were found by Thomson attached to the inner surface of a dead valve of Modiola modiolus.

In pentacrinoid larvæ somewhat older than the oldest examined by Seeliger Doctor Carpenter found beginning immediately within the mouth a series of irregularly lobed glandular masses, pale yellowish brown in color, projecting into the cavity of the stomach and curving in an irregular spiral down to the bottom of the cup. These glandular folds are richly clothed with long vibratile cilia. The merest film of sarcode separates their secretion from the stomach cavity. The slightest touch, even of a hair, ruptures them and causes the effusion of a multitude of minute granules. some colorless and transparent and others of a yellow or brownish hue. Carpenter believes that from their position and color there can be little doubt that these lobes form a rudimentary lever. They appear very early in the pentacrinoid, coloring the lower portions of its body in the $142140-21-$ Bull. $82-34$ 
earlier stages of its growth within the free-swimming larva. They increase constantly in volume during its later stages, and with but little change of character make up a large portion of the visceral mass in the adult.

In the pentacrinoid toward the end of the "prebrachial stage" the rapid enlargement of the body causes five diamond-shaped spaces to appear at the points where the upturned angles of two oral plates adjoin the truncated upper angles of two adjacent basals. In these spaces cylindrical spicules appear which soon become club shaped, dichotomize, branch, and anastomose into delicate netlike superficial plates, irregularly oval in shape, slightly produced superiorly, their upper narrower portions resting beneath and supporting the gradually. extending sarcode projections which are terminated by the azygous tentacles. The equatorial portion of the body, the band between the upper edges of the basals and the lower edges of the orals, now rapidly expands. The five young arms extend outward, their bases carrying out with them a zone of sarcode which gives the central portion of the body a great additional width. The oral plates maintain their original position, so that they are now completely separated from the basals by this intervening equatorial band, and are left, a circlet of five separate plates each inclosed in its sarcode lobe, on the center of the upper surface surrounding the mouth and inclosing the 10 interradial ("nonextensile") tentacles only The radial plates begin to thicken, especially toward the upper margin, and this thickening is produced by the growth beneath the cribriform superficial calcareous film of a longitudinal mass of tissue of the same character as that which forms the cylindrical axis of the columnals. On the lower surface of each arm, in linear series immediately above the radials, two spicules, horseshoe shaped with the opening abore, appear almost simultaneously and become quickly filled up with elongating sheaves of longitudinal trellis work. These extend along beneath the extending arms, and indicate the $\mathrm{IBr}_{1}$ and the $\mathrm{IBr}_{2}$ (axillaries).

The upper surface of the arms now becomes grooved by the development on either side of the central vessel of a series of delicate crescentic leaves. These leaves are hollow, communicating by special apertures with the radial vessel and filled with fluid from it. At the base of each of the leaves there is a pair of tentacles forming a group with the leaf, and along with it communicating with the vessel. One of these tentacles (the distal) is somewhat larger than the other. They are both slightly club shaped. the club-shaped extremity fringed on either side with conical papillæ. They are nonextensile, and resemblc in every way the 10 nonextensile (interradial) tentacles early developed from the oral ring. $\Lambda$ group consisting of a crescentic leaf and two nonextensile tentacles lies immediately at the base of each extensile tentacle, and a little lower down the arm. Minute spicules, some of them simple or key shaped and others expanding into a cribriform film, appear in the superficial sarcode layer along the back or edges of the arms; and usually at the base of each of the tentacles, irregularly embedded in the sarcode substance, there is a sacculus.

A little later the end of the arm shows a tendency to bifurcate, and two half rings, with their inclosed sheaves of calcified tissue, give the first indication of the first two brachials. 
At this stage the arm is free from the base of the $\mathrm{IBr}_{1}$; later the visceral sack extends to the bifurcation, and the whole of the $\mathrm{IBr}$ series becomes included in the cup and disk.

The azygous (median unpaired) tentacles go no farther than the bifurcation. They remain for some time in the center between the two divisions of the arm, while secondary branches from the radial canal run on in the brachial grooves.

About the period of the development of the $\mathrm{IBr}_{1}$ a forked spicule makes its appearance in one of the interradial spaces between the upper portions of two of the radials. This gradually extends in the usual way until it becomes developed into a superficial rounded cribriform plate.

Simultaneously with the appearance of this radianal plate a cæcal process, like the finger of a glove, rises from one side of the stomach toward the plate. The plate increases in size, becomes inclosed in a little flattened tubercle of sarcode and, maintaining its upright position, passes slightly outward, leaving a space on the edge of the disk between itself and the base of the oral plate immediately within it. Toward this space the cecal intestinal process directs itself. It rises up through it in the form of an elongated tubular closed papilla. The summit of the papilla is finally absorbed, and a patent anal opening is formed.

The azygous tentacles remain persistent for some time in the angles between the two first brachial segments, and finally become absorbed and disappear.

Regarding the later development of the arms W. B. Carpenter says that at the beginning of the free stage the first primibracis begin to show a modification of their originally nearly cylindrical form, being somewhat widened out at their lower end, so as to form two articular surfaces which are not, however, directly opposite those of the radials, but slope away from them, so that, while in close proximity with them on the dorsal face, where they are connected by ligaments, they are separated by a considerable interval on the ventral side, where muscle intervenes-an arrangement which gives to the muscle fibers the length required for their efficient contraction. The upper end, however, is simply rounded off, presenting no proper articular surface, and it is connected with the base of the second primibrach by ligaments only. Although the dorsal surface of the first primibrach is everywhere convex, its ventral face still shows a deep groove along its median line; this, however, is separated by a distinct layer of calcareous network from the axial canal beneath it, which opens at its lower end between the articular surfaces and at its upper in the center of its rounded termination.

$\mathrm{The} \mathrm{IBr}_{2}$ (axillaries) at the commencement of the free stage show, like the $\mathrm{IBr}_{1}$, only a slight departure from the original simple type, their lower portion being incompletely cylindrical, while the upper is somewhat expanded laterally to form a pair of articular surfaces, which look obliquely toward either side and are separated by a projecting median ridge. The lower extremity is rounded off so as to resemble the upper end of the first primibrach and, like it, shows the orifice of the axial canal in its center, while each of the articular surfaces at its upper end shows a similar perforation which is the orifice: of one of the two branches into which the axial canal bifurcates in the interior of the segment for 
the supply of the two arms borne by it. The dorsal face of this segment is everywhere irregularly convex, but the ventral face has a deep depression in its center, the bottom of which almost reaches the axial canal.

The alteration which the form of the $\mathrm{IBr}_{1}$ undergoes in the progress to maturity is even greater than that of the radial, for while they increase but little in the direction of their original length they undergo a great augmentation both in breadth and in depth, their proximal face attaining an equality in both dimensions with the distal face of the radial to which they are articulated, and the distal face coming to present a similarly expanded surface to the proximal face of the $\mathrm{IBr}_{2}$ in place of the mere convexity in which the then cylindrical segment terminated at an early period. This change in the proportion of the several dimensions of these plates begins to show itself very soon after the termination of pentacrinoid life and, as in the case of the radials, there takes place concurrently with their increase in size a gradual development of the prominences that give attachment to muscles and ligaments, with a deepening of the cavities that lie between them, as well as a progressive enlargement of the central canal.

The change in form which the $\mathrm{IBr}_{2}$ undergo concurrently with their great increase in size is scarcely less considerable than that of the $\mathrm{IBr}_{1}$, and the same tendency is manifested to lateral and vertical augmentation rather than to increase in radial length. The proximal face of the plate, which is apposed to the distal face of the $\mathrm{IBr}_{1}$, rapidly increases both in width and depth, and comes like it to present an expanded surface the ventral and dorsal margins of which form the bases of triangles formed by the ventral and dorsal faces respectively. The entire sides of these triangles now form the margins of those lateral surfaces for the articulation of the first brachials, which in the earlier period were merely a pair of facets somewhat inclined to each other on the distal extremity of the segment; and these lateral articular faces, as they increase in proportional dimensions, come also to present prominences and fossa similar to those that are characteristic of the distal faces of the radials, which they nearly equal in size as well as resemble in appearance. The central canal, with the branches into which it bifurcates, is progressively enlarged by the internal resorption of its wall as in the preceding cases.

In the later stages of pentacrinoid life the elements of the $\mathrm{IBr}$ series exhibit an increase in all their dimensions without much departure from their original form.

Each of the arms is terminated by a growing point of condensed sarcode in which new brachials successively originate, a cribriform calcareous film being first formed on the dorsal face and an ingrowth of fasciculated calcareous tissue then taking place in such a manner as in the first instance to leave a deep groove on the ventral face which is afterwards converted into a canal by the closing over of its margins so that a transverse section at first resembles a horseshoe rather than a ring.

As the skeleton of the arms increases in length the vascular structures are prolonged, and new groups of tentacles are developed from the extensions, each 
of these consisting, as before, of a leaflike expansion with three tentacles procecding from its base, of which one is much more extensile than the other two.

The sarcodic substance which unites the pieces of the skeleton now begins to show a delicate fibrous texture at their adjacent extremities, but no separate fibers are as yet to be distinguished.

During the later stages of pentacrinoid life the arms continue to increase in length, both by the addition of new segments distally and by the growth of those previously formed, and it is when they have attained the length of about 0.08 inch and consist of about 12 segments that we see the first indication of the development of pinnules. This shows itself at the growing extremity, which now presents a bifurcation, the two rami being in the first instance almost equal, and each tumified at its extremity by an accumulation of sarcode.

One of these rami grows faster than the other and soon assumes a direction continuous with that of the axis of the arm, from which the other diverges at an acute angle, so that the former comes to be the proper extension of the arm, while the latter takes on the form of a pinnule. Soon, however, the growing point again subdivides, two branches being formed, as previously, and while one of these becomes a continuation of the arm the other is soon to be distinguished as a pinnule given off from it on the side opposite to that of the first formed pinnule.

Thus the formation of the first pair of pinnules takes place in such a manner that the extremity of the arm presents in the first instance an appearance of bifurcation, and then of trifurcation.

The new segments henceforth added to the extremities of the arms are all pinnulate, the pinnules (the skeleton of which consists at this stage of six or eight simple cylindrical segments) being developed alternately from one side and the other, and being furnished with extensions of the tentaculiferous apparatus of the arms.

Owing to the thickness and opacity of the cumulus of condensed sarcode in which they originate, Carpenter was not able to speak with positiveness as to the mode of formation of their calcareous skeleton, but he believes it to take place rather after the manner of the ossicles of the column and dorsal cirri than after that of the segments of the division series and arms; that is, to commence with a complete ring which extends itself into a hollow cylinder rather than by a cribriform plate which wraps itself, so to speak, around the extension of the sarcodic axis. It is remarkable that the basal portions of the arms, which had been developed previous to the first appearance of the terminal pinnules, remain destitute of these appendages to the end of the pentacrinoid stage, except in the case of the second segment, from which, on each arm, an oral pinnule is developed.

The connection of the brachials by distinct fibrous tissue is now clearly discernible, but this tissue corresponds rather with the ligamentous than with the muscular tissue of the adult Antedon.

At the beginning of the free stage the segments which form the skeleton of the free arms depart even less than the primibrachs from the simple type of conformation which they present at their first developinent, being still obviously 
composed of the original cribiform plate, which constitutes their convex dorsal surface, with an ingrowth of fasciculated tissue which closes over the axial canal and gives to the ventral aspect a flattened surface with a median groove. This ingrowth is most abundant toward the extremities, where also the meshes of the reticulation are smaller, so that these parts have a more solid character than the rest.

We now begin to see that alternate inclination to one side and the other which is so marked a feature in the articular extremities of the segments of the adult, and we also notice that while these extremities are in close contact with one another in the dorsal aspect, except where a small depression exists in each for attachment of the articular ligament, the articular surfaces of the ventral face slope away from each other so as to leave a considerable space for the lodgment of the two muscular bundles which are now conspicuously interposed between each pair of segments in the basal part of the arms, with certain exceptions. These exceptions correspond to those which present themselves in the adult, though the peculiarities of conformation which mark them are as yet but little pronounced. Thus the adjacent extremities of the first and second brachials present nearly the same aspect on their ventral as on their dorsal face, no beveling being seen on the articular surfaces of either, and they are connected by ligament only, no muscular fibers being here distinguishable. Again, the adjacent articular surfaces of the third and fourth brachials come into yet closer contact, not even a connecting ligament being interposed, and the line of their junction being transverse instead of oblique. This prefigures the peculiar syzygial union which shows itself between these and other pairs of segments in the adult. Toward the extremities of the arms we find the segments even more cylindrical, except where lateral processes are given off for the articulation of the pinnules, and the terminal faces are simply apposed to each other transversely without either the alternate obliquity or the beveled articular surfaces of the basal segments, and precisely the same rudimental condition of the segments presents itself, as that which has been already described as showing itself at an earlier period in their basal segments. Thus we may trace in one and the same arm sereral successive stages of development of the pieces of its skeleton, the most advanced proximal segments showing adumbrations of their adult peculiarities, though not as yet departing in any considerable degree from their simple primitive type.

Besides the brachials there are commonly found in the perisome of condensed sarcode of the arms irregular branching spicules, which, like the orals, subsequently undergo complete resorption so that no trace of them is discoverable in the adult.

The sacculi, which are quite colorless in life, after death are immediately and strongly stained by the pigment liberated from the perisome.

The total number of segments in the fully developed pentacrinoid column is subject to a considerable amount of rariation. There may be as many as 24 , or as few as 16 . The average may be considered as about 20 .

The total length of the fully grown pentacrinoid from the base of the column to the extremities of the arms when these are folded together may be about 0.7 
inch, that of the column alone being about 0.25 inch; when the arms are fully expanded the diameter of their circle is about 0.5 inch.

In Antedon bifida no anterior ciliated ring has been mentioned by Busch, Thomson, or Carpenter. It is not unlikely, therefore, that it is absent in this species.

No observer has ever reported the presence of infrabasals, though Thomson's examination was sufficiently thorough to enable him to detect the extremely minute calcareous cylinders representing the first beginnings of the other calcareous plates.

\section{ANTEDON MOROCCANA.}

Perrier's studies on the embryology and development of Antedon were based upon larvæ of Antedon moroccana sent to him by Prof. Camille Viguier from Algiers, though he mentions, in passing, isolated observations on pentacrinoids of Antedon bifida collected by himself at Roscoff.

So far as can be seen from Perrier's description the development of Antedon moroccana does not differ essentially from that of $A$, adriatica as given by Seeliger.

Perrier appears to have been the first to notice that all the young of a given mother are in the same developmental stage.

The youngest fixed larva which he observed measured $0.21 \mathrm{~mm}$. in length and $0.13 \mathrm{~mm}$. in breadth.

Perrier makes no mention of infrabasals, and it is quite possible that they are absent from the young of this species, as well as from the young of the closely related $A$. bifida, occurring only in the more primitive $A$. adriatica (five) and A. mediterranea (three).

\section{COMACTINLA MERIDIONALIS.}

In connection with Mr. Frank Springer's monograph on the Crinoidea Flexibilia his assistant, Dr. Herrick E. Wilson, made a study of the development of the digestive tube in the pentacrinoid larvæ of Comactinia meridionalis.

$\mathrm{He}$ found that in the early prebrachial stage the alimentary canal consists of a mouth, surrounded by a narrow lip from which the oral tentacles spring; a short, broad, funnel-shaped esophagus; a horizontal portion distended transversely, resembling the human stomach, into the larger end of which the esophagus opens; and a slender intestine ending blindly which originates at the smaller left end of the stomach, makes a half turn, and coils dextrally around it.

This simple alimentary system is loosely suspended in the cœlome by threads and lamellæ of connective tissue, and is in contact with the inner wall of the cup only at the mouth and at the posterior end.

The intestine in its development has coiled dextrally around the stomach, then turned obliquely upward toward the posterior interray, the upward turning having commenced near the middle of the anterior border of the right posterior basal, and ending in this stage with the formation of the anus slightly to the right of the posterior interradial plane, on a level with the distal margins of the incipient radials. 
The upward turn of the intestine, which appears in the posterior interray of Antedon shortly after the appearance of the radianal, in this species does not come to lie in the posterior interradius until a very much later stage in development.

As the cup expands laterally and vertically the intestine also expands, but, growing more rapidly than the calyx, soon fills the body cavity.

The radianal, formed previous to and just below the anus, is parallel to the intestine at that point, and evidently very firmly attached to it, as is shown by its subsequent migration.

The upward growth of the cup and the concomitant dextral growth of the intestine carry the radianal and the arms upward and into the plane of the posterior interradial, which, by reason of the retirement of the oral distalward, is the path of least resistance.

When the portion of the intestine to which the radianal is attached comes to lie in a vertical position along the plane of the posterior interray the radianal is completely withdrawn from the radial and rests equally upon the truncated distolateral margins of the posterior radials.

Its migration follows the upward and dextral growth of the intestine, which does not bend sharply upward along the posterior interray. The radianal for a considerable time holds closely to the right posterior radial, thus causing inhibition of its lateral growth and its peculiar asymetrical development.

\section{TROPIOMETRA MACRODISCUS.}

A large series of embryos of this species, collected by Mr. Furusawa, were sent by Professor Ijima to Mr. Frank Springer.

Eggs preserved from 1 to 2 hours after fertilization, which are purplish pink in color, show the cleavage stages.

The stages between 18 and 96 hours ( 4 days), yellowish in color, are freeswimming larvæ. stages.

The embryos of from 5 to 48 days, fading into colorless, show the earlier fixed

\section{TROPIOMETRA PICTA.}

At Tobago Doctor Mortensen found that the embryo of this species, which has the same shape as the larva of Antedon, swims very actively for a period of about three days, when it attaches itself; but if no suitable place of attachment is found it may continue its free-swimming life, and in some cases it was found not to attach itself until it was 8 days old.

The eggs of Tropiometra picta are extruded freely into the water instead of being attached to the pinnules as in the case of Antedon.

ISOMETRA VIVIPARA.

Dr. Th. Mortensen writes that the larve of this species are enveloped in the egg membrane until they are ready to leave the marsupium. They have welldeveloped ciliated bands. This leads Mortensen to believe that the free-swimming 
stage is not entirely lacking, though it is probably very short, only long enough to enable them to traverse the distance between the marsupium and the tips of the cirri upturned between the arms to which they attach themselves.

Dr. K. A. Andersson states that the development of the embryos of this species in all essentials agrees with that of the embryos of Antedon.

The immigration of the entoderm cells into the lumen of the gut begins much earlier than in interdon, for it has already commenced when the invagination of the vestibule begins, and long before the development of the embryo is completed the gut is crammed with them, and its wall is quite without definite cell borders, passing uninterruptedly over into the inner mass, which is very rich in yolk.

In contrast to the usual conditions the vestibular invagination is deepest at the anterior end, and its closure begins there.

In two cases Andersson found larvæ in which the posterior end had coalesced with the wall of the marsupium which separates it from the genital sinus. He suggests that possibly this is to assure better nutrition of the embryos; but Mortensen says that this condition, which he was unable to confirm, must be decidedly abnormal, and that it can lave nothing to do with the nutrition of the embryos.

When fully developed, in which condition they resemble the corresponding stages of Antedon, the larvæ leave the marsupium through its slitlike opening. After their escape they apparently attach themselves immediately to the cirri without passing through a true free-swimming stage.

Since the arms as well as the cirri are movable, Andersson suggests that such iarvæ as are intercepted by the arms or pinnules are transferred to the cirri.

\section{NOTOCRINUS VIRILIS.}

In this species, according to Doctor Mortensen, the eggs are from $0.2 \mathrm{~mm}$. to $0.3 \mathrm{~mm}$. in diameter.

As a number of ripe or nearly ripe eggs are found at the same time in the ovary, while there are generally only one or two, rarely three embryos in each marsupium, Mortensen believes that some of the eggs do not develop, but are dissolved and possibly serve as nourishment for the embryos. In some cases he found a yellow, coarsely granulated substance in the marsupia, without embryos, which had the appearance of eggs in process of disintegration.

The embryos were found to be all at very nearly the same stage of development. They are considerably larger than the embryos of any other crinoid, being nearly $2 \mathrm{~mm}$. in length. They possess no ciliated bands, and thus must be incapable of swimming.

\section{ABNORMAL EMBRYOS AND LARVE.}

Seeliger found that in some cases the first cleavage furrow divides the egg into two cells, which are more or less markedly different in size. The second furrow first divides the smaller, later the larger. The four-cell stage thus differs from the normal in consisting of two larger and two smaller cells instead of being composed of four of equal size. The third furrow is at right angles to the 
first and divides the four cells in such a way as to produce four larger and four smaller daughter cells. In appearance the embryo now agrees entirely with the normal eight-cell stage; but it has arisen through the appearance of what is normally the third cleavage furrow in advance of the first and second.

Among perfectly formed blastulæ of eight and a quarter hours Seeliger found an embryo of very extraordinary structure. Its markedly elongated form called attention to it at once. Further examination showed a very large number of cells and two gastrulalike invaginations, the two blastopores being slitlike and almost at right angles to each other, at the blind ends of which a number of mesenchyme cells had been given off. Apart from the double invagination, development had progressed twice as fast as normally, for the embryo had reached a stage similar to that of embryos of 16 to 17 hours. Seeliger suggests that the condition of this embryo may be explained through double fertilization.

On very many embryos of between 13 and 17 hours Seeliger found, usually directly opposite the blastopore, though sometimes nearer it, a second invagination just like the first, which extended inward as far as the blind end of the primitive gut, in some cases even pushing this out of position. This second invagination did not give rise to mesenchyme cells. The embryos themselves were of the usual spherical form. At the 24 -hour stage this second invagination had invariably disappeared, and from that point onward the embryos developed normally to free-swimming larvæ.

Among 60-hour embryos of normal form Seeliger found a number which were remarkable in that they possessed external tentacles, thus resembling that described by Busch, except that the tentacles were shorter and stiffer. Some retained the ciliated bands and swam about freely in the water, while others, which had already lost the cilia, were picked up from the bottom of the vessel. The intestinal canal was much more extensive than in the normal individuals and was entirely filled with a mass of cells undergoing dissolution. The left coelomic sack was here the one which was asymmetrically developed. The branch uniting the two horseshoe-shaped side pieces in the posterior section ventrally had pushed itself in between the gut and hydrocœle. The most striking point of departure from the normal was the possession of ventral tentacles. The vestibular invagination here appeared as a shallow groove, on both borders of which the tentacles arose as peglike structures. The hydrocœle had not yet closed into a complete ring; on its ventral side there arose five groups of three evaginations each, of different lengths; the longest of these filled the ectodermal tentacle evaginations, while the shorter at most produced exteriorly insignificant nipplelike elevations between the tentacles. The ectodermal covering of the evaginations of the hydrocole is composed of a single layer of cells, prismatic in form, with the nuclei near the middle or in the outer half.

Others of equal age, in which the ciliated bands had disappeared, had the gut extended and balloonlike, but without the included mass of disintegrating cells; into the lumen at various places pseudopodialike processes extended. It was only on the ventral side, in the immediate vicinity of the vestibular groove, that the 
ectoderm appeared as an epithelium sharply marked off interiorly; elsewhere it was so intimately united with the mesenchyme that the two together formed a uniform tissue. The celomic sacs showed no noteworthy deviations from the normal. On the ventral side there were nine tentacles which showed the same structure as those in the larvæ just described. These nine tentacles represented the three posterior groups of evaginations from the hydrocole, the two anterior groups being so slightly developed that the body surface on the left side appeared entirely smooth, while that on the right side showed such small projections that they could not appropriately be referred to as tentacles. Larræ such as these appear to be incapable of further derelopment.

Sir Wyville Thomson noticed that when the ova are liberally supplied with fresh sea water and placed in a warm temperature the later stages of larval growth are, as it were, hurried over, so that the free larvæ scarcely attain their perfect form before being distorted by the growing crinoid. In other instances, in colder seasons and in a less favorable medium, the larvæ reach a much higher degree of independent derelopment and retain for a longer period the larval form.

W. B. Carpenter remarked that the embryos when losing the power of locomotion were frequently seen floating in such a manner that the incipient discoidal base spread itself out (often in a stellate form) on the surface of the water, while the column and body of the rudimentary pentacrinoid hung downward from this; and it sometimes happened that by the approximation of a number of individuals in the same condition the stellate extensions of the disks became mutually adherent.

In a 48-hour larva Seeliger found six basal instead of the normal five; two of the six were considerably smaller than the other four, and evidently together represented the normal fifth.

\section{THE PENTACRINOID YOUNG.}

\section{COMISSIA LITTORALIS.}

On one of the specimens of this species collected by the naturalists of the Siboga on a reef near the anchorage off the Kawio and Kamboling Islands, Karkaralong group, on July $22-23,1899$, there were a number of pentacrinoids attached to the cirri. The smallest of these has apparently just attained the erect position. The others resemble very closely the pentacrinoids of Comactinia meridionalis.

One of them measures $2.2 \mathrm{~mm}$. in total length, the crown being $0.6 \mathrm{~mm}$. long.

The stem is composed of 13 columnals of which the first four are very short and lenticular, the fifth nearly twice as long as broad, the sixth longer, and the seventh and eighth the longest, nearly four times as long as broad.

The terminal stem plate is circular.

The radials are about the same size as the basals, approximately square with rounded angles, just in apposition laterally. The $\mathrm{IBr}_{1}$ and $\mathrm{IBr}_{2}$, which are extraordinarily narrow, are present.

The radianal lies on the left distal edge of the right posterior radial, which is broadly cut away for its reception, though its left lateral angle almost reaches the right lateral angle of the left posterior radial; the radianal reaches about to the posterior interradial suture, and distally to just beyond the base of the $\mathrm{IBr}_{1}$. 
The orals are rather narrow, with the tips somewhat produced; the proximal border is approximately hemispherical, and the sides converge to a rounded tip; the central portion is very slightly depressed.

The most developed specimen measures $3.5 \mathrm{~mm}$. in total length, the crown being $0.7 \mathrm{~mm}$. long.

The stem is composed of 17 columnals and a terminal stem plate.

The first five columnals are very short and lenticular, the sixth slightly longer than broad, the seventh longer than the sixth, and the eighth the longest, nearly four times as long as broad; the following very slowly decrease in length distally; the columnals are cylindrical, with only slight traces of terminal enlargement.

The terminal stem plate is slightly lobate.

The basals are much reduced in size.

The radials are unusually large, approximately square with rounded angles, and are in contact laterally through the slightly truncated lateral angles.

The large and conspicuous radianal, which is very broadly oval, almost circular, reaches nearly to the middle of the $\mathrm{IBr}_{2}$ distally and to the left as far as half way between the posterior interradial suture and the base of the left posterior $\mathrm{IBr}_{1}$; the left distal edge of the right posterior radial is cut away in a broad curve beneath it from the base of the $\mathrm{IBr}_{2}$ to its junction with the left posterior radial.

On the distal border of the radial circlet in each of the interradial angles there lies a rhombic interradial which distally reaches to the level of the base of the $\mathrm{IBr}_{1}$; the posterior interradial (anal $x$ ) is displaced to the left by the radianal, so that it spans the distance between that plate and the left posterior $\mathrm{IBr}_{1}$.

About three brachials are present, they and the $\mathrm{IBr}_{2}$ being accompanied by extremely narrow and delicate covering plates.

The IBr series and the brachials are unusually slender.

COMISSIA HARTMEYERI.

On the cirri of the eight specimens of this species collected at Erg Tor, Gulf of Suez, by Dr. Robert Hartmeyer, were a number of pentacrinoids.

COMANTHUS WAHLBERGI.

On a specimen of this species in the British Museum from the Cape of Good Hope I found attached to the cirri 13 pentacrinoids.

The columnals in these pentacrinoids number 17 .

COMACTINIA MERTDIONALIS.

Fig. 941, p. 519, and part 1, figs. $408,411,412$, p. 317 ; and pl. 4, fig. 548 .

After the discovery of the pentacrinoids of the species of the genus Antedon the stalked larvæ of Comactinia meridonalis were the next to be reported. During the residence of Prof. Louis Agassiz at Charleston, South Carolina, he collected some specimens of this species on the cirri of which were growing pentacrinoid 
young in various stages of development. In their "Seaside Studies," published in 1865, his son, Mr. A lexander Agassiz, and Mrs. Elizabeth Cary Agassiz mentioned this species for the first time and gave a rough sketch of the pentacrinoids. Though the specimens still exist in the Museum of Comparative Zoölogy at Cambridge, they have never been described.

On January 30,1885 , the Albatross dredged in 21 fathoms off the coast of Yucatan a large number of the young of this species, to the cirri of which many pentacrinoids were attached. Several years ago I examined these specimens superficially, making notes of the more striking features, and laid them aside for future study.

When Mr. Frank Springer was completing his monograph on the Crinoidea Flexibilia I suggested to him that he take the material and study it in connection with his work on the group. This he did, and with the assistance of Dr. Herrick E. Wilson he prepared a description of these pentacrinoids which is so comprehensive and so detailed that all that is necessary here is to give a résumé of their results.

None of us, and none of those to whom we have shown the specimens, have been able to detect any trace of infrabasals in this form.

There were in all 200 specimens of the larvæ, which were found clinging to the cirri of a number of young individuals. The crowns of the larger ones, the stems of which pass upward between the arms of the foster parent, appear on the ventral side of the latter as a circlet of closed or opened buds lying close down upon the proximal pinnules.

These larvæ show almost every stage from that of a nearly closed cup of basals and orals, with faint incipient radials and a long tapering column, through the development of anal, radial, interradial, and perisomic structures, arms, pinnules, and cirri, to the stages characterized by the diminution and ultimate resorption of the orals and interradials, and the loss of the column.

The very small pentacrinoids measuring from $0.31 \mathrm{~mm}$. to $1.85 \mathrm{~mm}$. in the liameter of the calyx were attached to the cirri of the foster parent by the usual form of primitive terminal stem plate.

The youngest larvæ show a calyx composed almost exclusively of basals and orals, the latter closed and standing quite erect, and a column with the segments increasing in length distally.

Very small patches of calcareous reticulation consisting of a few spicules, which are the beginnings of the radials, have appeared in the rhombic spaces between the corners of the basals and orals; but in one of these spaces the radial is wanting, and in its place there is a somewhat larger plate similar in composition to the others, which is attached to the anal end of the intestine, nor plainly visible on the outer side of the calyx. This plate is the radianal, which now lies in the position corresponding to that which the radials occupy in the other areas, at the base of the area to be occupied by the right posterior ray.

The calcareous reticulation is so thin and translucent that by transmitted light the complete alimentary system is plainly visible. It consists of the esophagus, 
stomach, and dextrally coiled intestine. The closure of the orals has compressed the mouth of the esophagus so that its margin appears crenulate or folded.

There are two specimens in which this stage is distinctly shown. In the second the orals, while of the same relative size as in the one just described, are slightly parted, and the oral tentacles project between their summits, but have not yet branched. As in the first, the radial of the right posterior ray has not appeared, but its place is occupied by the radianal attached to the gut. Although the projecting tentacles make this specimen appear the more advanced, the radianal is smaller than in the other one. The difference is due to the slight opening of the orals, which stretches the mouth so that its border is without wrinkles.

In the next stage represented the right posterior radial has appeared, and beneath it to the left is the rapidly enlarging radianal attached to the gut, which is still visible through the thin reticulate plates of the body wall just below the anal opening. The disparity in size between the two plates is important, as tending to confirm the antecedent appearance of the radianal and its status as an independent element. The anal pore is here very distinct, and the intimate attachment of the plate to the gut just below the opening is evident.

In the following stage the radials have notably increased in size, and above them at the base of the tentacles may be seen two small disconnected plates which are the beginnings of the $I B r_{1}$ and $I B r_{2}$. The radianal is enlarged to a lesser degree, and it lies to the left of the radial, which now begins to curve around it toward the middle of the posterior basal. The gut has become concealed behind the radianal except at the opening, which is visible at the apex of that plate.

In the next stage the radials have enlarged until they almost come into lateral contact, except posteriorly. The elements of the $\mathrm{IBr}$ series have thickened and become connected with the radial and with each other, the $\mathrm{IBr}_{2}$ being an axilliary and covering the base of the tentacles, now three in number. The basals and orals have become relatively smaller, owing to the superior growth of the radials. The radianal is approximately on a level with the radial to the right of it, indenting its left side and still touching the sloping shoulders of the posterior basal. In the triangular spaces between the radials and orals small plates have appeared, formed in the same manner as the other calyx plates, which are readily recognized as interradials. The orals now exhibit rather distinct pores distally.

In the following stages the radials increase in size until they greatly exceed the basals, which now form a low and nearly horizontal base. The interradials are pushed upward through the meeting of the radials below them and increase in number from one to five or six, in the posterior interradial area passing over into the plates of the heavily plated integument which is extended upward into a large conical protuberance now definitely constituting the anal tube. The gut has continued to extend itself upward until its opening is now at the apex of the conical projection rising far above the orals, which by the multiplication of interbrachial plates are now being more and more separated from the dorsal cup and are becoming relatively reduced in size. The radials have met and have formed a closed ring. The arms have appeared, and rudimentary cirri have appeared upon the proximal columnal. All the elements of the complete skeleton 
are now represented, with the exception of the pinnules. The orals form a low pyramid, at the apex of which is the mouth. They have been reduced by relatively one-third from their former size and have become separated from the radials by the extension of a band of interradial plates, which tend gradually to pass over into the perisomic plates. The tegmen thus is now approximately comparable to that of Holopus, Ptilocrinus, and the young of Thaumatocrinus renovatus as described by $\mathrm{P}$. H. Carpenter.

From this point onward the resorption of the orals proceeds rapidly, and concurrently there is seen a progressively increasing differentiation between the interradials and the ventral integument, the perisomic plates of which become gradually resorbed. This resorption also involves the radianal, which has now been left far behind by the protruding anal tube and is actually as well as relatively diminished in size. The same relative decrease is true of all the dorsal elements of the calyx, which have leaned outward, approaching more and more a horizontal position, so that now they collectively serve merely as a shallow saucer for the support of the visceral mass.

The pentacrinoid is now almost ready to discard its column, the cirri having developed to a length of 7 or 8 segments, with strong terminal claws. Pinnules of considerable size have appeared. The ventral perisome, still further expanded, is now studded with a multitude of indefinite plates from which the interradials are well differentiated, though reduced in number and evidently in process of resorption. The ambulacral grooves have appeared, traversing the disk from the arms to the mouth and passing in between the orals, which are now reduced to very small triangular plates. The anal tube has become still more conspicuous, and rises high above the general level of the disk. The radianal is now entirely above the radial circlet and no longer forms a part of the dorsal cup. The perisome at this stage is covered with a sort of velvety coating in which the numerous small plates are difficult to distinguish, and it is evidently on the verge of transformation into the granular skin of the adult stage, from which all plates ventrally situated, including interradials and radianal, have been completely resorbed. The radianal, after being left far behind by the posterior end of the gut as the latter is carried upward with the anal tube, is resorbed, together with the interradial plates from which in the later stages it scarcely differs. The basals become transformed into a rosette, just as do the basals of Antedon.

According to Mr. Springer the outstanding differences in the development of this type from that of Antedon lie in the position, size, and much greater sweep of migration of the radianal and in the prominence of the anal tube. both attesting the great importance of the movements of the posterior portion of the intestinal canal in inducing, or retarding, changes in the form and in the composition of the calyx.

\section{COMASTERID PENTACRINOIDS.}

At station 3809 , off Honolulu, Hawaiian Islands, in 51 to 125 fathoms, the Albatross dredged a number of pentacrinoids, some of which were attached to a cirrus probably of a species of Comactiniinæ. 
These pentacrinoids, which have about 14 columnals, are in general similar to the pentacrinoids of Comactinia meridionalis.

No species of Comasteridæ has heretofore been reported from the Hawaiian Islands.

\section{?LAMI'ROMETRA, SP.}

A very interesting pentacrinoid collected by the Danish consul at Singapore, Mr. Svend Gad, in 1907, can not with certainty be assigned to any one of the numerous species of comatulids inhabiting that locality.

The column, with the distal portion missing, consists of 33 columnals, including centrodorsal.

The centrodorsal is relatively high, its length being approximately equal to that of the third and fourtlı columnals combined, or about three times that of either of the two immediately following. In its distal third it suddenly broadens, so that this portion extends outward beyond the parallel sides of the more proximal portion like the flange on a car wheel, its outer border reaching to a point almost directly beneath the distal border of the first cirrus segment when the cirri are straightened out. The diameter of the distal third of the centrodorsal is about one-tliird greater than that of the proximal two-thirds.

The second columnal is short and discoidal, about four times as broad as long, and is equal in breadth to the proximal two-thirds of the centrodorsal. The third is very slightly longer, and very slightly less broad. The fourth is a short cylinder, about equal in width to the third, and about twice as broad as long. The fifth is about one-third longer than broad and slightly constricted centrally. 'The sixth is twice as long as broad, with a more prominent median constriction and a narrow median raised girdle which shows a rouneded profile. The next is similar, but longer. The following are cylindrical, with somewhat abruptly enlarged ends, and without a median girdle; they increase slowly in length to the eighteenth and following, which are about four and one-half times as long as the median diameter. In the distal third of the column as preserved its diameter decreases very gradually, so that the last segment is only about two-thirds as long as and half as broad as the eighteenth.

There are four cirri present, which are of different lengths, radial in position, directed upward and lying close to the sides of the calyx. The longest of these reaches to just beyond the articulation between the $\mathrm{IBr}_{1}$ and $\mathrm{IBr}_{2}$. It is composed of nine segments and a long slender and slightly curved terminal claw which is almost as long as the two preceding segments combined; the first segment is about as long as broad, the next is about one-third longer than broad, the following six, which are slightly less in diameter than those preceding, are about as long as broad, the antepenultimate is slightly longer than broad, and the penultimate is about as long as broad. The last differs from the preceding in being triangular instead of quadrilateral in side view, the proximal border sweeping in a broad curve from its junction with the ventral border to the dorsal base of the terminal claw; the angle formed between the ventral and the distal borders is 
a right angle; that between the distal border and the oblique curved proximal border is well rounded, and projects slightly beyond the base of the terminal claw. The cirrus segments are not constricted centrally, and there are no signs of dorsal processes. Another cirrus with nine segments and a terminal claw reaches to the distal two-thirds of the $\mathrm{IBr}_{1}$; a third with eight segments and a terminal claw reaches to the middle of the $\mathrm{IBr}_{1}$; and the fourth, with about eight short segments and a terminal claw, reaches to the distal end of the radial in the median line. The fifth cirrus is lacking. The longest cirrus is the left anterior, and the shortest the right posterior.

From the character of the cirri the identification of this pentacrinoid with any of the comatulids inhabiting the vicinity of Singapore, with the exception of Comatula solaris, C. pectinata, Heterometra quinduplicava, Stephanometra spicata, S. monacantha, and Lamprometra protectus, would appear to be excluded.

Judging from what little we know of the pentacrinoids of the species of Comasteridx the length and slenderness of the column and the relatively large number of columnals would seem to indicate that this specimen can not be the young either of Comatula solaris or of $C$. pectinata.

The sides of the calyx to the distal borders of the radials are approximately straight, and diverge from the centrodorsal at an angle of nearly $90^{\circ}$.

The presence of infrabasals can not be determined; but at this stage, if present, they would probably be united with and concealed by the centrodorsal.

The basals are very prominent and are about equal in length to the radials.

The latter are broadly united all around the calyx, their apposed sides being of about the same length as those of the basals.

The radianal is very large and conspicuous and is entirely excluded from the radial circlet, though the radials subjacent are still separated by a long and very narrow V; its base, semicircular in outline, runs along the distal third of the lateral borders of the radials and entirely spans the distance between the bases of the $\mathrm{IBr}_{1}$ on either side. The lateral borders are slightly convex, the right more so than the left, and converge slightly so that the distal edge, which is almost straight and horizontal and is on a level with the articulation between the elements of the $\mathrm{IBr}$ series, is only about two-thirds as long as the base. The reticulation in a transversely oval area coterminous with the proximal border and extending distally for about one-third the length of the plate is much finer than elsewhere. The distal border is more or less rough and denticulate. The plate exhibits no evidence of resorption.

Except for the radianal there are no plates in the interradial areas between the orals and the circlet of radials. On the basis of our present knowledge this would seem to indicate that this specimen can not belong to any of the species of Comasteridæ.

The orals are about as long as the radianal, but narrower, with a less regular outline. They appear to be deeply dentate distally and deeply depressed in the middle. It is not possible to determine these features satisfactorily, as they are more or less concealed by the arm bases. 
The $I B r_{1}$ and $I B r_{2}$ are about equal in length, very narrow, and of the usual shape. The width of the base of the $\mathrm{IBr}_{1}$ is about half that of the distal border of the radial.

The arms consist of about 17 brachials, each with an ambulacral lappet, a group of tentacles, and a sacculus. Very long slender pinnules are developed on the eleventh or twelfth and following brachials.

The total length is about $13 \mathrm{~mm}$; the crown (with the arms) measures $3 \mathrm{~mm}$.

So far as we are able to judge, this pentacrinoid is the young of Heterometra quinduplicava, Stephanometra spicata, S. monacantha, or Lamprometra protectus. As the last is by far the commonest of the four, it is probably to this species that the pentacrinoid should be referred.

TROPIOMETRA PICTA.

During a visit to the island of Tobago, British West Indies, in March and April, 1916, Dr. Th. Mortensen obtained a large series of the larvæ of this species. He writes me that he hopes to complete his report upon them in the near future.

So hardy were these little pentacrinoids that Doctor Mortensen was able to bring a number of them living to New York.

\section{PTILOMETRA MÜLLERI.}

Figs. 939 , p. 549 , and $1229,1229,1230$, pl. 37.

In February, 1898, the Australian steamer Thetis dredged off Manning River, New South Wales, in 22 fathoms, a large number of pentacrinoids of this species which were attached to the pinnules of young individuals.

This is the only case yet recorded of the attachment of pentacrinoids to the pinnules and not to the cirri of larger specimens. Attachment to partially grown individuals in preference to adults is duplicated in the case of the pentacrinoids of Comactinia meridionalis from Yucatan.

Dr. H. L. Clark has described these pentacrinoids. He says:

The youngest stage observed has a short, rather fleshy stalk, with a large attaching disk at one end and the somewhat ellipsoidal body at the other. At this stage the joints of the stalk appear as more or less discoidai plates, whife the body wall contains 10 large plates-5 orals and 5 basals. No radiai plates are visible.

In a specimen a trifle older the radials have arisen in the space bounded by two oral and two basal plates, and the stem joints are not so discoidal.

At a still later stage the radials are conspicuous, though the orals and basals are equally prominent, the first costal $\left[\mathrm{IBr}_{1}\right]$ and the costaf axillary [ $\left.\mathrm{IBr}_{2}\right]$ appear as rather elongated plates, and the arms consist of two or three joints; the stem, which is relatively far more slender than at the eariier stage, consists of 10-12 joints, of which the middle ones are longer than wide and are encircled at the mid-zone by a conspicuous ridge, a possible indication of a circle of cirri in some ancestral form. A similar ridge occurs on the stem joints of Metacrinus cingulatus (and other species of the genus), where it appears to be purely ornamental. ${ }^{1}$

1 The conspicuous ridge encircling the columnals at the mid-zone is, of course, the outer edge of the primitlve medlan anuulus, and has no relation whatever to the ridges on the coinmnals of Metacrinus. Cirri are formed on the onter ends of canais which, extending from the central organ outward, pierce the secondary deposit of calcareous suhstance in the nodals or in the centrodorsal. It would he quite impossibie for them to occur on the periphery of the median annulus. 
The older stages have the stem and attaching disk of approximately the sane actual slze as earlier, and therefore relatively much smaller. The stem joints have lost the encircling ridge and are practically smooth; the basals are relatively small, but the orals are still conspicuous; the cirri have begun to appear on the margin of the centrodorsal; they have a variable number of jolnts, of course, and are very erect, parallel with the arms; the latter have elongated and the brachlals are well defined. No syzygies are to be found, but the third and fourth plates appear to be somewhat closer together than the others.

One of the figures given by Wright in illustrating the type of Kallispongia archeri, described by him as a new genus and species of sponge, probably represents a pentacrinoid of this species.

Three pentacrinoids of this species at hand from off Manning River, New South Wales, in 22 fathoms, are extremely young, the ends of the crescents from which the columnals are built up apparently having just joined on the ventral side.

The short and very stout column consists of 10-12 columnals, which are little more than the primitive annuli, and a broad ring-shaped terminal stem plate nearly three times the diameter of the column which occupies the center of a large fleshy disk.

At the top of the stem there is very clearly to be seen a circlet of rounded infrabasals, apparently five in number, which are quite distinct both from the topmost columnal and from the basals.

The basals have very broadly rounded angles.

The orals are rather narrow; with the distal portion rather strongly incurved. Their edges are not everted nor modified in any way.

\section{CROTALOMETRA PORRECTA.}

Figs. $1207-1209$, pl, 34 .

On April 3, 1876, near Ascension Island (lat. $7^{\circ} 54^{\prime} 20^{\prime \prime}$ S., long. $14^{\circ} 28^{\prime}$ $20^{\prime \prime}$ W.) the Challenger dredged in 420 fathoms three pentacrinoids, which Carpenter deternined as belonging to Thalassometra multispina, for the reason that this was the only 10-armed species found at this station. But the fact that the pentacrinoids had 10 arms only is no evidence that they are not the young of a multibrachiate species, since increase in the number of arms does not occur until long after the larval column has been discarded. This, however, Carpenter did not know.

I am inclined to regard these pentacrinoids as the young of Crotalometra porrecta for the following reasons:

Carpenter says that "they are relatively much larger and inore robust than the corresponding stages of any other species which I have seen, with the exception of "Heliometra glacialis. Now Thalassometra multispina is a rather small species, with arms only $50 \mathrm{~mm}$. long, and it is unlikely that it would be characterized by exceptionally stout larve. while Crotalomotra porrecta is a large aud massive type, with arms $150 \mathrm{~mm}$. long, and would naturally be supposed to have larvæ more comparable in size to those of Heliometra glacialis. 
Carpenter states that "the spines of the cirri are present from the first, but those on the calyx, arms, and pinnules do not appear till after the pentacrinoid stage." This indicates that the ossicles of these pentacrinoids are smooth. But so far as we know the development of spines in the comatulids is always much more marked in the very young than in the adults, the spinosity becoming less and less conspicuous and often disappearing altogether in later life. As these pentacrinoids bear no spines it is almost certain that the species of which they are the young is also devoid of spines.

The extraordinary stout cirri are obviously more like those of Crotalometra porrecta than like those of Thalassometra multispina. Bearing in mind that the relative length of the cirrus segments always decreases with age, it is evident that it would be difficult to derive the long segmented cirri of Thalassometra multispina from the relatively short segmented cirri of these pentacrinoids, while the cirri of Crotalometra porrecta are very easily derived from them by the simple addition of segments distally, plus the shortening of the segments which always accompanies increase in size.

Thus there seems to me to be no doubt that these pentacrinoids are the young of Crotalometra porrecta and not of Thalassometra multispina, as supposed by Carpenter.

As noted by Carpenter, the youngest of these pentacrinoids is remarkable for the shortness of the column, which has only 14 segments, including the centrodorsal, and terminates in a large and expanded terminal stem plate. His figure shows a pentacrinoid $7.5 \mathrm{~mm}$. long, the crown measuring $3.5 \mathrm{~mm}$. and the column $4 \mathrm{~mm}$.

The centrodorsal is a thin plate but little larger than the columnals below it, and the rudiments of three radial cirri have appeared upon it, the position of the other two being indicated by imperfect sockets. There are three similar very short discoidal segments beneath the centrodorsal, and the longest columnals (the seventh-ninth from the centrodorsal) are scarcely more than twice as long as broad.

The basals are very short, while the radials have almost attained the perfected form. The elements of the $\mathrm{IBr}$ series are so broad as to be just in lateral contact when the arms are closed. There are 12 or 13 brachials, but no pinnules. Very large and conspicuous covering plates, which are supported by imperfect side plates, are present.

In the next stage, in which the crown is $5.8 \mathrm{~mm}$. long, the first pinnules have appeared on the eleventh or twelfth brachials and are provided with large covering and side plates. The five radial cirri which were first formed are well developed, so far as can be judged from their basal segments, which are all that remain, while there are one or two slight indications of the second whorl of cirri, the positions of which alternate with those of the first. The centrodorsal has increased considerably in thickness, as have also the segments below it, which have similar reentering angles, just as is the case in the infranodals in the column of the pentacrinites.

In the oldest larva the basals are concealed by the centrodorsal, which has now reached a considerable size, with the second whorl of cirri well developed and even traces of a third, while there is only one discoidal segment below it. 


\section{GLYPTOMETRA TOBEROSA.}

Fig. 1211, pl. 34 .

On January 25, 1875, while in the Philippine Archipelago off Panglao and Siquijor (lat. $9^{\circ} 26^{\prime} \mathrm{N}$., long. $123^{\circ} 45^{\prime}$ E.) the Challenger dredged in 375 fathoms a single young pentacrinoid, which Carpenter identified as belonging to Glyptometra tuberosa, captured at the same station.

The total length of the pentacrinoid is $6 \mathrm{~mm}$., of which the column represents about $4.2 \mathrm{~mm}$.

There are 13 columnals, including the centrodorsal but not the terminal stem plate. Only the centrodorsal and the segment immediately below it are broader than long. The eighth-ninth, which are the longest, are greatly elongated. There are no indications of cirri.

The calyx is conical and rather narrow, the sides diverging, in approximately a straight line, from the centrodorsal at an angle of about $60^{\circ}$.

The basals and radials are of about the same height, and their lateral borders are united for about the same distance.

The $I B r_{1}$ and $I B r_{2}$ are elongated and very narrow. The $\mathrm{IBr}_{1}$ occupies the median third of the radial. There are about six brachials, which carry large and conspicuous covering plates.

The larva is a trifle more robust than the corresponding stage in Antedon bifida.

ANTEDON PETASU8.

Fig. 1355, pl. 56.

In January, 1910, Doctor Mortensen found attached to a Balanus on a valve of a Pecten maximum at Kristineberg, Fiskebäckskil, Sweden, a single pentacrinoid of Antedon petasus.

The crown of this specimen measures $2 \mathrm{~mm}$. and the column about $4 \mathrm{~mm}$. in length. Both the first pinnules and the cirri are present, having apparently arisen contemporaneously.

The column consists of 27 segments, of which the 9 proximal are short, and the 2 nearest the calyx conspicuously broader than the others. The fully formed columnals are hourglass-shaped, widened at the ends in the usual way, the long axes of the articular surfaces of each at right angles to each other. There is no trace of the median annulus. They are rather short, $0.3 \mathrm{~mm}$. long by $0.1 \mathrm{~mm}$. wide. Distally the columnals become gradually shorter. The terminal stem plate is only slightly lobed.

There are no infrabasals. This I can confirm personally, for Doctor Mortensen was so kind as to allow me to study the specimen in his laboratory at Copenhagen.

The calyx exhibits no distinctive characters.

The orals resemble those of Antedon bifida.

The first pinnules are on the eleventh or twelfth brachials.

The cirri are radial in position. 


\section{ANTEDON BIFIDA.}

Figs. 1191-1193, pl. $30 ; 1195$, pl. 31 ; 1201-1203, pl. 32 ; and 1201-1206, pl. 33 .

The pentacrinoids of this species in their later stages have already been described, and the earlier stages are considered in the section dealing with embryology and development (p. 502). It will be sufficient here to recall the following facts:

The total length of the fully grown pentacrinoids from the base of the column to the extremities of the arms when these are folded together is 0.7 inch; the column alone measures $0.25 \mathrm{inch}$; when the arms are fully expanded the diameter of their circle is about $0.5 \mathrm{inch}$.

There appear to be no infrabasals.

The columnals number $16-27$, averaging about 20 .

Prof. Michael Sars, who described the pentacrinoid of IIathrometra sarsii, was never able to secure pentacrinoids of Antedon petasus with which to compare them, but through friends he obtained 17 specimens of the pentacrinoids of Antedon bifida from Belfast, Ireland, and from the Firth of Clyde, of which he gave a description for purposes of comparison with the pentacrinoids of $I$. sarsii.

The most developed of these pentacrinoids of Antedon bifida was $10 \mathrm{~mm}$. long; the column, composed of 16 segments, measured $4.25 \mathrm{~mm}$. In three other's of approximately the same size the stem was composed of 16,21 , and 27 segments In one of these three, of which the length was also $10 \mathrm{~mm}$., and in which the column was relatively longer than in the others, being nearly $8 \mathrm{~mm}$. long and consisting of 27 segments, the crown, which scarcely exceeded $2 \mathrm{~mm}$. in length, was only slightly developed, the arms being without pinnules and the centrodorsal without cirri.

The specimens in which the arms are the most developed and possess two or three pairs of pinnules near the distal extremity have the centrodorsal with $5, \tau$, or 9 cirri of different sizes; in one it bears a little tubercle, indicating the beginnings of a tenth cirrus.

The five primary cirri are, as stated by W. B. Carpenter, situated interradially.

$P_{1}$ begins to develop when the rest of the arm has only two or three pairs of pinnules near its distal end.

In one of the largest individuals the periphery of the terminal stem plate shows some very short digitiform prolongations as in the pentacrinoid of IIathrometra sarsii.

While in the case of Antedon bifida very often several pentacrinoids may grow so closely together that they appear to arise from a common base, this never happens in $\Pi$. sarsii.

Professor Sars thus summarizes the difference between the pentacrinoids of Antedon bifida and those of Hathrometra sarsii.

Though when adult Hathrometra sarsii is no larger than Antedon bifida its pentacrinoid young is very much larger, being from three to four times as long. The column is relatively much longer, but the arms are shorter. 
The column of the pentacrinoids of $H$. sarsii is composed of usually about 40 (in some cases as many as 44 , or even 49 ) segments. In $A$. bifida the number varies between 16 and 27 , a veraging about 20 .

The terminal stem plate in $H$. sarsii is provided with long digitiform prolongations. In $A$. bifida it is circular or lobate and only very rarely shows short and broad processes. Sars suggests that the characteristics of the terminal stem plate of $H$. sarsii are necessitated by the large size of the larvæ.

At the time of detachment from the larval column $H$. sarsii is much farther advanced than $A$. bifida. There is a much greater number of pinnules, which occur all along the arm, and the centrodorsal bears a very much larger number of cirri.

H. sarsii breaks away from the larval column from the end of March to May, while A. bifida becomes detached between the middle of August and the middle of September.

Sars' youngest pentacrinoids were taken at the beginning of July and his oldest in March, April, and May, together with young free living individuals which evidently had just become detached, and which were no larger nor in any way more developed than the oldest of the pentacrinoids. Some of them were even less developed than the latter.

Sars found eggs in the pinnules of $H$. sarsii in June. Assuming that the sexual products are developed in the early summer and at no other season (which, however. is not established), it would seem that the development of the pentacrinoids of this species takes place much more slowly than that of the pentacrinoids of Antedon, occupying almost an entire year.

Regarding the pentacrinoids of Antedon bifida, J. V. Thompson says that they possess the power of bending or inclining the column freely in every direction, and, what is more remarkable, of twisting it up into a short spiral, and that with a considerable degree of vivacity - a kind of movement that has not been noticed except in Vorticella. He speaks of the arms as at one time spreading outward like the petals of a flower, at another rolled inward like an expanding bud.

Allman said that his specimen, in the "prebrachial stage," was very irritable, and on the slightest annoyance the tentacles were suddenly withdrawn and the valvelike plates of the pyramidal roof instantly closed down over them. In this retracted state it might remain for a long time, wearying the patience of the observer, who might have to wait for hours together before he could again obtain a satisfactory display of its structure.

J. V. Thompson stated that from observations repeatedly made he thought it most probable that the comatulids attain their full growth in one vear, so as to be in a condition to propagate their kind the summer following that of their birth.

At that time (viz.. May and June) these full-grown individuals have the membraneous expansion inside each of the pinnæ considerably extended, at least as far as the fifteenth or twentieth pair. These, which are the matrices or conceptacula, at length show themselres distended with the ova which in July, and even earlier, make their exit through a round 
aperture on the fascial side of each conceptaculum, still, however, adhering together in a roundish cluster of about 100 each, by means of the extension and connection of their umbilical cords. By what means these ova are dispersed, or how they become attached to the stems and branches of corallines, remain to be discovered; but it is strongly to be suspected that the animal is gifted with the power of placing them in appropriate situations; otherwise we should find them indiscriminately on fuci, shells, stones, etc., which does not appear to be the case.

He also remarked that the great abundance of comatulids in the places they inhabit is not to be wondered at when we are aware how exceedingly prolific they are; thus each arm may be estimated to bear 30 fruitful conceptacles, each producing about 100 ova, and, as there are 10 such, this gives 30,000 as the amount of ova produced by a single individual.

According to J. V. Thompson and Sir Wyville Thomson, the casting off of the stalk takes place not before the middle of August and usually not later than the middle of September. Since Sir Wyville determined the maturity of the eggs as occurring at the end of May or the beginning of June, the duration of the stalked life is from two and a half to four months.

W. B. Carpenter states that the larvæ detach themselves from the stalk after a developmental period of from five to six months. When detached they are far from mature, acquiring maturity at the earliest in the following summer. He says that the full-sized animals are probably several years old.

Sir Wyville Thomson noticed that the larvæ sometimes remain free swimming for many days, and Busch kept larvæ for a considerable time without their becoming attached.

\section{ANTEDON MIOROCCANA.}

Though the pentacrinoids of this species have been studied in great detail by Perrier, as he did not distinguish between this form and Antedon bifida and A. mediterranea it is impossible to say to which of the three his remarks apply. I saw many of these pentacrinoids from Algiers in the Paris Museum, but I had no time to study them in detail.

Perrier writes that the larvæ of the comatulids live during the greater part of their development either adhering to the pinnules of the mother or fixed to submerged bodies, such as algæ, bryozoans, hydroids, the tubes of annelids, etc. This may refer in part to the young of $A$. moroccana, since the young of none of the other species of Antedon have as yet been found upon the parent.

\section{ANTRDON MEDITERRANEA.}

Figs. 1337-1340, pl, 51.

Chadwick's account (1907) of the development of Antedon bifida and his figures are based upon this species, his material having come from Naples.

The pentacrinoids of Antedon mediterranea agree in almost all particulars with those of Antedon bifida, but they appear to be slightly less robust, with slightly longer columnals.

There are usually three infrabasals.

The columnals number 13-15. 
Bury gives the length of the free-swimming larval life as about 12 hours.

Barrois states that the enbryo usually remains inclosed in its membrane and attached to the pinnule of the parent until the sixth or seventh day, and that the majority are not freed until the seventh day, though in this respect they are subject to considerable variations. Elsewhere he says that the duration of the development of the larvæ is seven days of 24 hours each.

He also noticed that many larvæ continued for a considerable time without fixation and then underwent abnormal development.

\section{ANTEDON ADRIATICA.}

The pentacrinoids of this species are almost identical with those of Antedon mediterranea.

There are usually five infrabasals.

The columnals number $13-18$.

COMPSOMETRA SERRATA.

While staying at Misaki, Japan, Doctor Mortensen was so fortunate as to obtain a large series of the pentacrinoids of this species, upon which he is now working.

Up to the time of Mortensen's visit to Japan Compsometra serrata was known from only two specimens, both taken in the same dredge haul by Mr. Alan Owston.

\section{COMPSOMETRA LOVÉNI.}

Part 1, fig. 410, p. 317.

There are at hand, attached to a small piece of seaweed from Port Jackson, New South Wales, four very young pentacrinoids of this species, in none of which the radial structures have as yet appeared.

The length of the most developed is $2 \mathrm{~mm}$.

The column is composed of 14 columnals, with in all cases an irregularly lobate terminal stem plate, which is rather large. The first four columnals are very short, lenticular, the first the shortest. The following increase in length to the seventh-eleventh, which are about three times as long as broad, with the median annulus very prominent; the distalmost become shorter again.

The basal cup is broader than high, with the profile strongly rounded.

The orals are about as long as the basals, with the distal portion strongly incurved. In the proximal half the sides are parallel; in the distal half the outline is semicircular. The central portion, a triangular region with the proximal border as a base, is depressed, the lateral areas beyond curving rather strongly outward.

In the smallest specimen the orals, which are narrow, are only slightly depressed in the middle, the eversion of the sides having only begun.

Judging from the figures given by Wright of his new genus and species of sponge, Kallispongia archeri, it was based chiefly upon a pentacrinoid of this species. 


\section{LEPTOMETRA CELTICA.}

Fig. 1212, pl. 34 .

P. H. Carpenter recorded that the Porcupine, dredging in 220 fathoms off Cape Mondego, Portugal, in 1870, yielded a single larva of this species in which the radials have not as yet appeared. He noted that it did not differ in any important respect from the corresponding stage in the larva of Antedon bifida, but the column is a trifle less robust as compared with the size of the head, and the five sacculi, which are so constant in the Antedon larva (one between the bases of every two oral plates) do not appear to be present.

The figure shows 13 columnals, a circular terminal stem plate, and oráls with considerable more eversion of the lateral edges than occurs in Antedon.

LEPTOMETRA PHALANGIUJ.

Lo Bianco states that the pentacrinoid young of this species are found on the cirri of the adults in June and September at Naples. There is no further reference to them.

\section{ISOMETRA ITVTPARA.}

Both K. A. Andersson and Th. Mortensen have published notices of the pentacrinoids of this species; neither has described them in detail, though the latter will do so shortly.

Among 11 sexually mature females examined by him, Andersson found 7 with stalked young on the cirri.

The cirri to which the young are attached are more developed than the others, consisting of usually 34 or 35 , seldom of as few as 31 , segments, and are directed upward between the arms, while the other cirri, curving downward as usual, are composed of only 27-29 segments.

The young are always attached near the tips of these longer erect cirri, and always within a sector from $2 \mathrm{~mm}$. to $3 \mathrm{~mm}$. in length.

One female carried no fewer than 99 young distributed on 8 cirri, which bore $30,24,17,12,9,4,2$, and 1, respectively. Another had 40 young distributed on 6 cirri. All the stages between the oldest and larvæ just attached are represented.

The largest pentacrinoids present are $15 \mathrm{~mm}$. long, the crown being $4 \mathrm{~mm}$. in length. The pinnules are in process of formation, but no cirri have as yet appeared. The terminal stem plate is in the form of a disk which is wrapped about the cirrus.

Some of the small pentacrinoids are on the stems of the larger ones.

HELIOMETRA GLACIALIS.

Figs. 1215, pl. 34, 1226, pl. 37, and 1354, pl. 56.

Doctor Danielssen records that the Norwegian North Sea Expedition secured a pentacrinoid of this species in latitude $80^{\circ} 03^{\prime} \mathrm{N}$., longitude $8^{\circ} 28^{\prime} \mathrm{E}$., at a depth of 260 fathoms, on August 14, 1878. 
While at Bergen I examined sereral additional pentacrinoids secured by the same expedition but not recorded in the published results. Two of these, one of which is mounted on a slide, were taken on August 6,1876 , in latitude $64^{\circ} 36^{\prime} \mathrm{N}$., longitude $10^{\circ} 22^{\prime} \mathrm{E}$, at a depth of 299 fathoms. There is no trace of cirri, and, so far as can be determined, infrabasals appear to be absent.

Another was dredged at Station 74 in August, 1876, at a depth of 612 fathoms. There are about a dozen cirri, a pair, side by side, in each radial area, and one or two additional.

'Two, one of which is mounted on a slide, were found on July 22, 1878, at latitude $74^{\circ} 54^{\prime} \mathrm{N}$., longitude $14^{\circ} 53^{\prime} \mathrm{E}$., in 658 fathoms. One of these is rather stout in all its parts. There are 5 cirri, the largest with 15 segments. The columnals are about 40 in number. In the distal portion of the column radicular cirri and extra attachments are present, as described by Sars in Hathrometra sarsii.

The arms of a pentacrinoid of this species at a stage when three or four pinnules are present show large side and covering plates, as described by Mortensen.

The Danish steamer Dijmphna secured a single pentacrinoid of this species in the Kara Sea (fig. 1226, pl. 37) which measured $21 \mathrm{~mm}$. in length, the crown being $\tau \mathrm{mm}$. and the column $14 \mathrm{~mm}$. long.

The column consisted of 37 segments and terminated in a strongly digitiform terminal stem plate, recalling the same structure in Hathrometra sarsii. The proximal columnals are short and discoidal. In the figure four are shown of this type, including the centrodorsal, which decrease rather rapidly in diameter. The following 12 are markedly swollen, especially the first six of these, their sides being strongly convex in lateral view. In the distal six the swelling is confined to a median zone, which appears as a narrow transverse band in lateral view. The succeeding six are approximately cylindrical, or slightly broadened at the ends. On the following six the sides are markedly concave in lateral view. Most of the segments are provided with fairly regular parallel rows of small protuberances, the regular arrangement of which is interrupted at the median transverse zone and at the ends of the segments, which have concave sides. The oldest (distalmost) columnals are quite without a regular arrangement of the small protuberances. and the narrow median zone, representing the primitive annulns, has disappeared.

The basals are still evident.

According to the figure given by Levinsen five cirri, which reach to the first brachials, are present.

On the distal portion of the arms a number of pinnules are present, the lowest being on the thirteenth or fourteenth brachials.

Doctor Mortensen has described two pentacrinoids of Heliometra glacialis from Spitzbergen, one of which is in the Zoological Institute of Ipsala and the other in the Stockholm Museum.

In the specimen at Stockholm (pl. 56, fig. 1354) the first pinnules and the cirri have appeared. The crown is $5 \mathrm{~mm}$. in length, and the column, in which 35 segments remain, but from which probably about 10 of the distal are lacking, is $20 \mathrm{~mm}$. 
The calyx agrees with that of Hathrometra sarsii in the corresponding stage, the $\mathrm{IBr}$ series having become rather broad and the orals having become widely separated from the radials.

The orals are of the same shape as those of Hathrometra prolixa.

There are no infrabasals.

The cirri are radial in position and evidently have appeared serially.

The first pinnules appear on the twelfth or thirteenth brachials.

The three proximal columnals are conspicuously wider than the rest. These and the two following are quite short. In the sixth the portion below the median annulus has begun to lengthen, the length of the columnals increasing from this point distally. The median annulus is very conspicuous in the more proximal segments, these being distinctly wider in the middle than at the ends. In the fully formed segments where the ends are expanded the median portion is still somewhat prominent.

In the specimen at Upsala, which is attached to a cirrus, the pinnules have not yet ap peared. The calyx measures $2 \mathrm{~mm}$. and the column $5 \mathrm{~mm}$. in length.

The orals are still in contact with the radials and are of the same shape as those of Hathrometra prolixa.

The proximal columnals are only slightly broader than those beyond.

Mortensen notes that the length of the column is so different from that of the other specimen and from that in the specimen recorded by Levinsen (which had a column $14 \mathrm{~mm}$. long) that it seems scarcely credible that it could reach a simlar length in a corresponding stage.

Dr. K. A. Andersson states that one of the specimens subsequently described by Doctor Mortensen was found attached to the cirri of an adult.

PROMACHOCRINUS KERGUELENGIS.

Figs. $881-937$, p). 533, 538, 541, 545, 549.

A large series of the pentacrinoids of Promachocrinus kerguelensis is at hand, which forms part of the crinoidal material collected by the naturalists of the German South Polar Expedition in the vicinity of Gaussberg in 1902-03.

The pentacrinoids brought back by the Gauss were captured at all seasons of the year. The dates on which the various developmental stages were found are as follows:

Least developed specimens, with no radial structures: February 7,8 ; November $9,22,24$.

Specimens showing the development of radial structures: January 12, 28; February 7, 15; December 26.

Specimens with the radials showing considerable growth: April 14.

Specimens with $\mathrm{IBr}_{1}$ just appearing: November 9.

Specimens with the radials not quite in contact: January 12; August 12.

Specimens with the radials just in contact: January 28; February 7,8 ; A pril 17; June 25; July 31; November 9. 
Specimens with the radials about two-thirds as large as the basals: April 10. Specimens with the radials nearly as large as the basals: September 1; November 9 .

Specimens with the radials just in contact in the posterior interradius: January 12, September 1, November 9.

Specimens with 12 brachials: June 25.

Specimens showing the first appearance of interradials: September 1.

Specimens with the interradials half as large as the radials; January 30 , November 9 .

A specimen nearly ready to discard the column: June 14.

Expressing the same facts in another way, on the following dates the developmental stages listed were found:

January 12: (1) Specimens showing the beginnings of the radial structures; (2) with the radials not quite in contact; and (3) with the radials just uniting across the posterior interradius.

January 28: (1) Specimens showing the beginnings of the radial structures, and (2) with the radials just in contact.

January 30: (1) Specimens with the interradials half as large as the radials.

February $7:$ (1) Specimens with the radial structures as yet undeveloped: (2) showing the beginnings of the radial structures; and (3) with the radials just in contact.

February 8: (1) Specimens with the radial structures as yet undeveloped, and (2) with the radials just in contact.

February 15: (1) Specimens showing the beginnings of the radial structures. basals.

April 10: (1) Specimens with the radials about two-thirds as large as the

April 14: (1) Specimens with the radials showing considerable growth.

April 17: (1) Specimens with the radials just in contact.

June 14: (1) An apparently fully grown pentacrinoid.

June 25: (1) Specimens with the radials just in contact, and (2) a specimen with 12 brachials.

July $31:$ (1) Specimens with the radials just in contact.

August 12: (1) Specimens with the radials not quite in contact.

September 1: (1) Specimens with the radials nearly as large as the basals, (2) with the radials just uniting across the posterior interradius, and (3) showing the first appearance of interradials.

November 9: (1) Specimens with the radial structures as yet undeveloped; (2) with the radials not quite in contact; (3) with the radials just in contact; (4) with the radials nearly as large as the basals; (5) with radials just uniting across the posterior interradius; and (6) with the interradials half as large as the radials.

November 22: (1) Specimens with the radial structures as yet undeveloped. November 24: (1) Specimens with the radial structures as yet undeveloped. December 26: (1) Specimens showing the beginnings of the radial structures. 
According to the preceding datil, we appear to be justified in concluding that Promachocrinus kerguelensis spawns in the spring and reaches the end of the cystid or prebrachial stage (indicated by the incipient and actual fornation of radial structures) in November-February-that is to say, in midsummer. Although. so far as I am aware, no quantitative information is available, this season, being the season of maximum illumination, must be the season of the maximum abundance of the diatom flora and of the associated floras and faunas.

By April the radials show considerable growth, and in the following November the $\mathrm{IBr}_{1}$ appear.

One year after the first appearance of the radial structures the radials form a complete circlet about the calyx, except in the posterior interradius, where the two posterior radials are separated by the radianal. They are found almost in contact in August-January and just in contact in November-July.

In April of the second year the radials are about two-thirds as large as the basals, and in the following September-November they have become nearly as large as the basals.

The end of the second year finds the two posterior radials coming into contact beneath the radianal, which occurs in September-January.

By the following June, two years and a half after the completion of the cystid stage, in the middle of the second winter of its existence, the pentacrinoid, judging from a comparison between the most developed individuals and the smallest free living specimens, is fully grown and ready to discard the larval column.

The following examples of the pentacrinoid stage of Promachocrinus kerguelensis have been studied:

No. 1 (fig. 881, p. 533) : Dredged on November 9, 1902, at a depth of 385 meters.

Total length (distal portion of column missing) $1.1 \mathrm{~mm}$. length of crown, $0.3 \mathrm{~mm}$.

The stem as preserved consists of seven columnals, of which the first is twice as broad as long, with a projecting narrow girdle about the proximal margin; the second is about as long as broad, with a similar prominent projecting girdle near the proximal margin; the third is somewhat longer than broad, with a narrow girdle just proximal to the middle; and the fourth and fifth are about twice as long as broad, with a median girdle; the two distalmost columnals are crushed.

Prominent infrabasals appear to be present.

The basals form a deep cup with slightly and regularly convex sides, which is slightly higher than broad.

The orals are about as high as the basals; their sides in the proximal half are parallel, and the profile of the distal half, which is bent inward, is semicircular, with a narrow median notch; bounded by lines running from the apex of this notch to the proximal angles is a triangular area which is more or less flattened from which the distal and lateral portions of the orals are bent outward at a considerable angle.

No. 2 (fig. 882, p. 533) : Dredged on Norember 9. 1902, at a depth of 385 meters.

Total length (distal portion of column missing), $2.3 \mathrm{~mm}$.: length of crown. $0.3 \mathrm{~mm}$. 


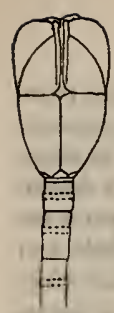

881

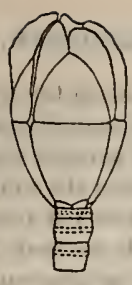

882

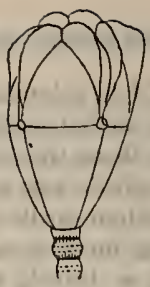

883

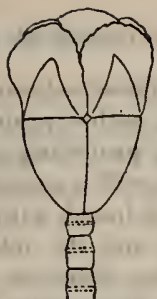

885

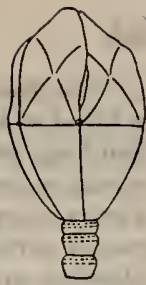

886

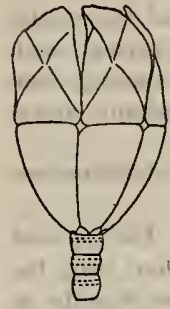

887

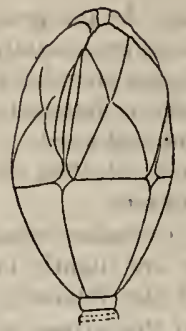

888

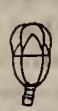

884
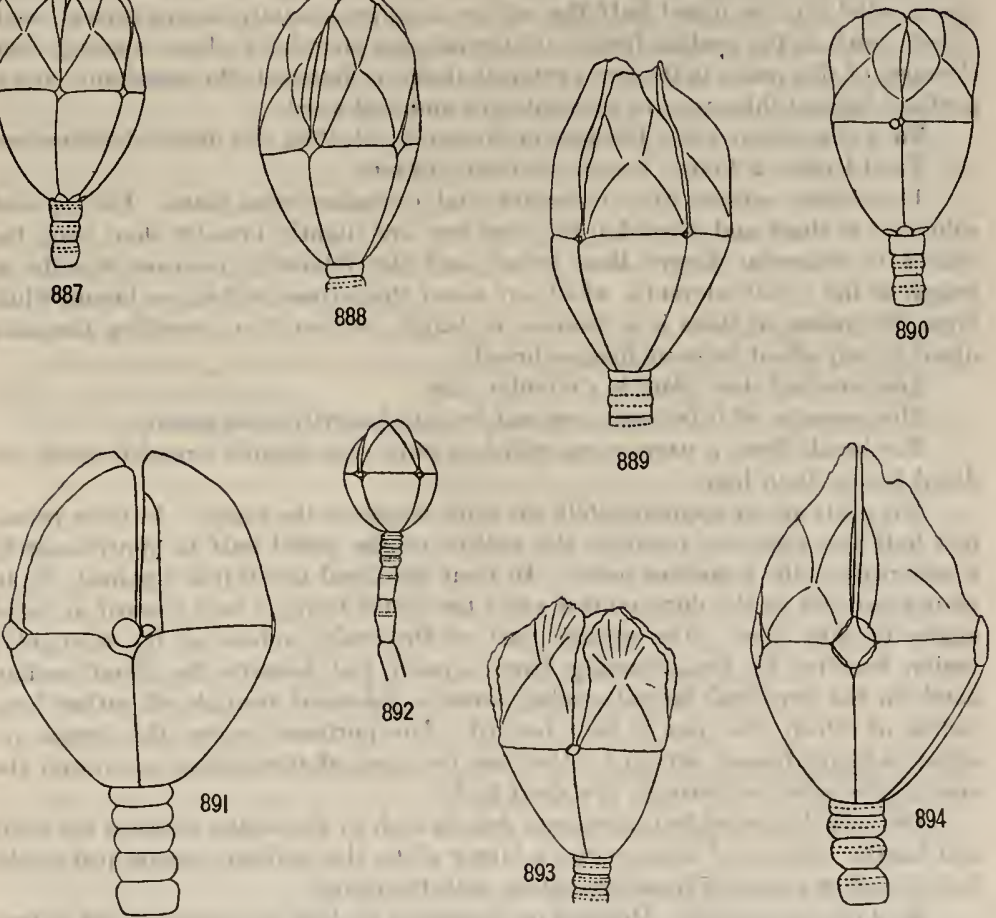

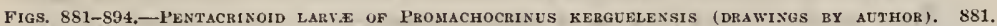
SPECIMEN DESCRIBED AS No. 1. 882. SPECIMEN DESCRIBED AS No. 2. 883. SPECIMEN DESCRIBED AS No. 3. 884. SPECIMEN DESCIIBED AS No. 4. S85. SPECIMEN DISCRIBED AS No. 5. 886. SPECIMEN

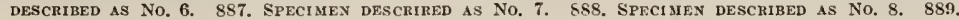
SPECIMEN DESCRIBED AS No. 9.890 . SPLC1MEN DESCrILted AS No. 11. 891. SPECIMEN DESCRIBED AS

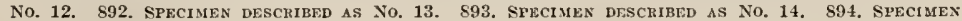
DESCRIBED AS No. 16. 
The stem as preserved consists of 14 columnals, of which the first is over twice as broad as long, with a projecting median girdle; the second is slightly broader than long, with a projecting girdle about the proximal border; the third is about as long as broad, with a projecting girdle just proximal to the middle; the fourth is twice as long as broad, with a median girdle which does not project beyond the general surface; and the following increase in length so that the eighth and following are four times as long as broad, with a conspicuous median ring. Except for the earlier columnals, which have a projecting girdle, the stem segments are all cylindrical without a central construction or swollen ends.

There are five prominent infrabasals.

The basals form a deep cup about as broad distally as high, the sides of which become almost parallel in the outer portion.

The orals are about as long as the basals. In the proximal half their sides are parallel; in the distal half the outline is approximately hemispherical, with a deep notch in the median line; a triangular a rea bounded by lines running from the apex of this notch to the two proximal angles is flattened; the distal and lateral portions beyond this area are bent outward and backward.

No. 3 (fig. 883, p. 533) : Dredged on November 24, 1902, at a depth of 385 meters.

Total length, $2.2 \mathrm{~mm}$; length of crown, $0.3 \mathrm{~mm}$.

The column consists of 15 columnals and a terminal stem plate. The topmost columnal is short and discoidal, the next two are slightly broader than long, the fourth is somewhat longer than broad, and the following increase rapidly in length to the eighth-eleventh, which are about three times as long as broad, while from this point on there is a decrease in length, so that that preceding the most distal is only about twice as long as broad.

The terminal stem plate is a circular disk.

The presence of infrabasals can not be satisfactorily determined.

The basals form a narrow cup which is only very slightly broader across the distal border than high.

The orals are of approximately the same length as the basals. In their proximal half the sides are parallel; the outline of the distal half is approximately a semicircle, with a median notch. In their proximal two-thirds the orals lie in planes parallel to the dorsoventral axis; the distal third is bent inward at right angles to this plane. The greater part of the orals, embracing the triangular region bounded by lines running from a point just beneath the distal median notch to the proximal lateral angles, forms a spherical triangle of rather long radius of which the apex is bent inward. The portions beyond this region on either side are turned outward. Between the apex of the median notch and the apex of the spherical triangle is a short keel.

The radials are evident as minute dots in each of the angles between the orals and basals. In one of these angles a larger plate, the radianal, occurs just to the left of and on the same transverse plane with the radial.

No. 4 (fig. 884, p. 533) : Dredged on November 22, 1902, at a depth of 385 meters.

Total length (distal portion of column missing), $1.7 \mathrm{~mm}$; length of calyx. $0.3 \mathrm{~mm}$. 
The column, of which the distal part is missing, contains 16 columnals. The first two are very thin, the following gradually increasing in length to the eighth, which, with the following, is about twice as long as broad. All of the columnals show a median annulus, which, though very conspicuous and projecting outward for some distance on the earlier, becomes inconspicuous after the ninth or tenth.

There are five prominent rounded infrabasals.

The basals, of the same height as the orals, form a deep and narrow cup, which is about as broad as high. In the outer half of this cup the sides are nearly parallel; in the proximal half they curve regularly and rather rapidly inward to the top of the column.

The orals are, broadly speaking, shaped like those of Hathrometra prolixa; in a lateral view of the calyx the distal and lateral profiles of the orals collectively are straight for about half their length, uniting with each other in a broad regular curve; in other words, the orals show an oblong figure, broader than long, with the two outer angles broadly rounded off. In the proximal half of each oral the sides are parallel; the profile of the outer half in direct view is semicircular. A triangular median portion extending from the proximal border as a base to a point about two-thirds of the distance from the base to the tip in the median line as the opposite apex is depressed, taking the form of a spherical triangle. With this portion the remainder makes a slight angle. The median distal region is broadly rounded, neither carinate nor flattened, so that the orals when closed together leave a relatively large stellate opening between their apices.

There are no radial structures.

No. 5 (fig. 885 , p. 533) : Dredged on February 7, 1903, at a depth of 350 meters.

This specimen resembles the preceding, and sinilarly there is no notcl in the distal border of the orals.

No. 6 (fig. 886, p. 533) : Dredged on January 28, 1903, at a depth of 380 meters.

Total length, $2.3 \mathrm{~mm}$.; length of crown, $0.3 \mathrm{~mm}$.

The column consists of 16 columnals and a terminal stein plate; the topinost columnal is very short and discoidal, the following increasing in length to the sixth, which is about as long as broad, and, the seventh, which is about twice as long as broad, still further increasing to the ninth-eleventh, which are about six times as long as broad, and from that point decreasing in length distally. A narrow median girdle is visible in all the columnals and projects strongly in the first six; in the seventh it passes about the end of the proximal third.

The terminal stem plate is regularly and broadly pentalobate.

Infrabasals of considerable size appear to be present.

The basal ring is of moderate proportions, half again as broad distally as high.

Five minute radials appear to be present.

$J$ ust to the left of and on the same level as one of these is a much larger plate, the radianal.

The orals have approximately parallel sides in the proximal half; in the distal half they are bent inward, and the sides converge to a rounded distal angle. Each is roughly divided into three triangular and one rhombic areas. Bounded 
by lines running from the middle of the median line, which is depressed, to each of the proximal lateral angles, is a triangular area which follows the contour of the body; a rhombic area bounded by the distal border and by lines from the outer third of the lateral borders to the depressed point midway between the tip and the base is nearly plane; laterally in the proximal two-thirds there are two triangular areas, the obtuse apices of which lie on the depressed point midway between the tip and the base, which are bent outward in such a way that their outer borders, between the proximal lateral angles of the orals and the lateral angles of the distal rhombic area, form a broad curve.

No. 7 (fig. 887, p. 533 ) : Dredged on February $\tau, 1903$, at a depth of 350 meters.

Total length (distal portion of column missing), $1.5 \mathrm{~mm}$; length of crown, $0.3 \mathrm{~mm}$.

The column as preserved consists of seven segments, of which the first is short and discoidal, and the following increase in length to the fourth, which is about as long as broad, the fifth, which is three times as long as broad, with a narrow projecting girdle about the end of the proximal third, and the sixth and seventh, which are about six times as long as broad.

There appear to be five prominent rounded infrabasals.

The basals form a deep cup, with slightly convex sides, which is not quite half again as broad as high.

No radial structures could be detected.

The orals have parallel sides in the proximal half; in the distal half the sides converge rapidly to the rounded apex. A triangular area, of which the proximal border forms the base and the central point on the median line from the base to the tip the apex, is flattened; a rhombic area, including the distal portion and converging to a proximal apex at the central point in the median line between the base and the tip is moderately concave exteriorly; the two narrowly triangular lateral areas remaining are bent outward and backward.

No. 8 (fig. 888, p. 533) : Dredged pn February 8, 1903, in 350 meters.

This specimen does not differ essentially from the preceding.

No. 9 (fig. 889, p. 533) : Dredged on February 8, 1903, in 350 meters.

Total length (distal portion of column missing), $4 \mathrm{~mm}$.; length of crown, $0.7 \mathrm{~mm}$.

The distal portion of the column is missing. There remain 21 columnals, of which the first four are short, though of progressively increasing length, more than twice as broad as long, with a prominent projecting median girdle; the fifth is about as long as broad, with a projecting girdle in its proximal portion; the sixth is nearly three times as long as broad, with a prominent girdle about the end of the proximal third; and the following, which have no girdle, gradually increase in length to the eleventh-fifteenth, which are between five and six times as long as broad, while the following become gradually shorter again, so that the last three remaining are scarcely three times as long as broad. The column is of the same diameter throughout, and the columnals, except those with a girdle, are simple cylinders without a median construction or swollen ends.

There appear to be five well-developed infrabasals. 
The basals, which are not quite so long as the orals, form a cup which is relatively high, slightly broader than long, with slightly convex sides.

A minute radial is present in each of the angles between the basals and the orals, and in one of these angles a much larger plate-the radianal-has developed just to the left of and in the same plane with the radial.

The orals are peculiar in having the distal angles somewhat produced, broadened, and flattened. An area having a surface which is approximately a spherical triangle reaches from the entire proximal border as a base to an apex which lies in the median line halfway between the base and the tip, and follows the contour of the body. From this portion the lateral regions, which form narrow triangles with the apices at the proximal lateral angles, bend outward at a slight angle, distally adjoining the narrowly fan-shaped anterior process, of which the apex touches the apex of the spherical triangle just described, and the rounded side opposite forms the distal border, which is itself slightly bent backward, its plane making a slight angle with the plane upon which the spherical triangle rests. The basals, therefore, show essentially the same characteristics as those of Hathrometra prolixa, but the angle which the lateral portions make with the depressed central portion is not nearly so great, and the tip, instead of being carinate in such a way that when the orals are closed the five keels come into mutual contact for their entire length, is flattened and elongate fan-shaped.

No. 10: Dredged on June 16, 1902, in 385 meters.

A badly broken specimen in the stage just before the appearance of the radial structures.

No. 11 (fig. 890, p. 533) : Dredged on February 7, 1903, at a depth of 350 meters.

Total length (distal portion of column missing), $2 \mathrm{~mm}$; length of crown, $0.3 \mathrm{~mm}$.

There are 10 columnals in the remaining portion of the column.

Rounded infrabasals appear to be present.

The basals form a deep cup slightly broader than long.

A small rounded plate - the radianal-is present in one of the angles between the basals and orals, situated just to the left of the plane dividing them.

In their proximal half the lateral borders of the orals are parallel; in the distal half they converge to the broadly rounded tip; the lateral borders are turned outward, and the distal apex is slightly produced.

No. 12 (fig. 891, p. 533) : Dredged on February 15, 1903, at a depth of 400 meters

Total length (distal portion of column missing), $2.2 \mathrm{~mm}$; length of crown. $0.6 \mathrm{~mm}$.

There are nine columnals remaining, of which the first four are short and discoidal and the following rapidly become elongated, so that the ninth is about four times as long as broad.

Infrabasals appear to be present.

The basals form a broarl well-rounded cup, which is much broader than high.

The radials are small, but well defined, rhombic plates lying in the angles between the basals and the orals. 

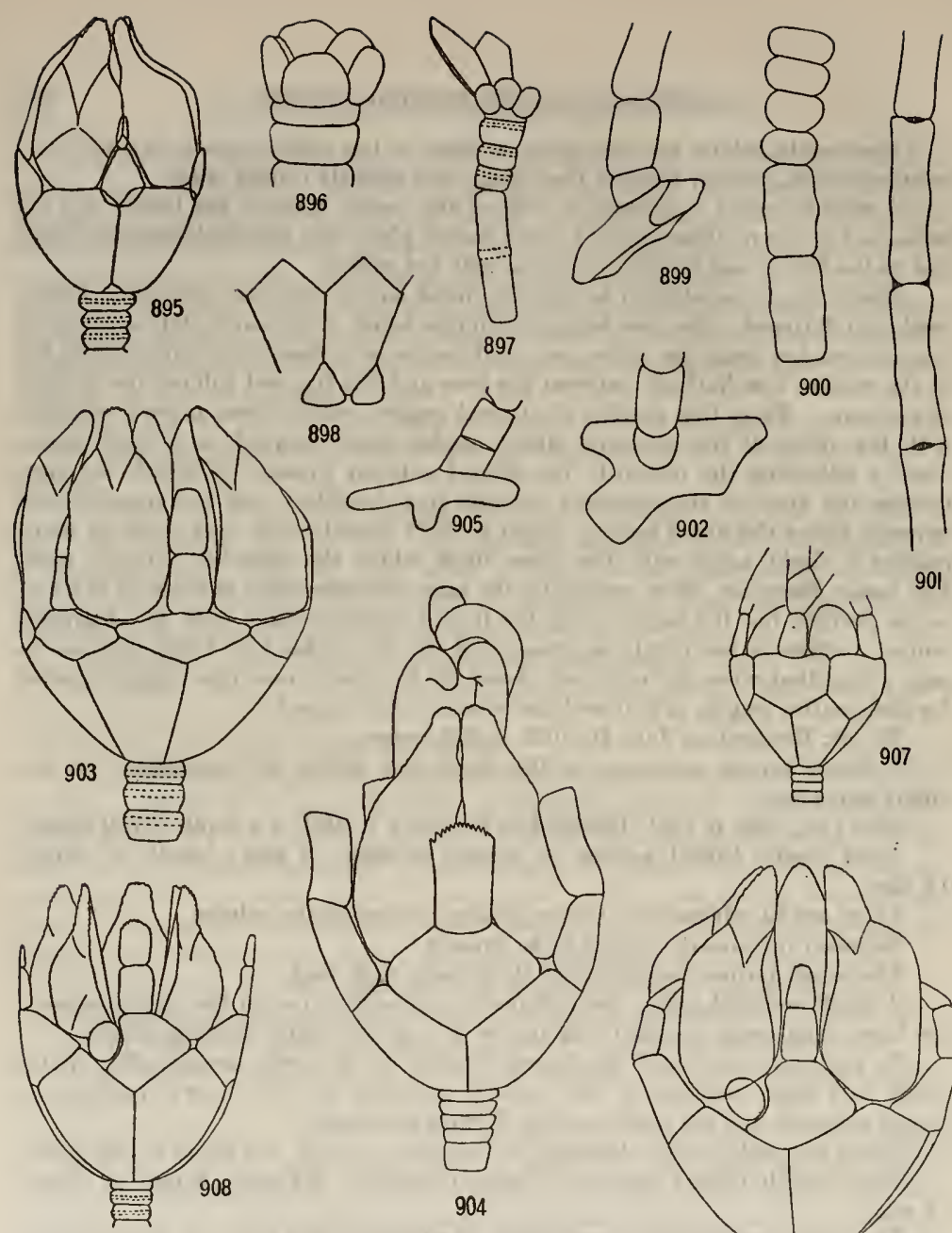

904

906
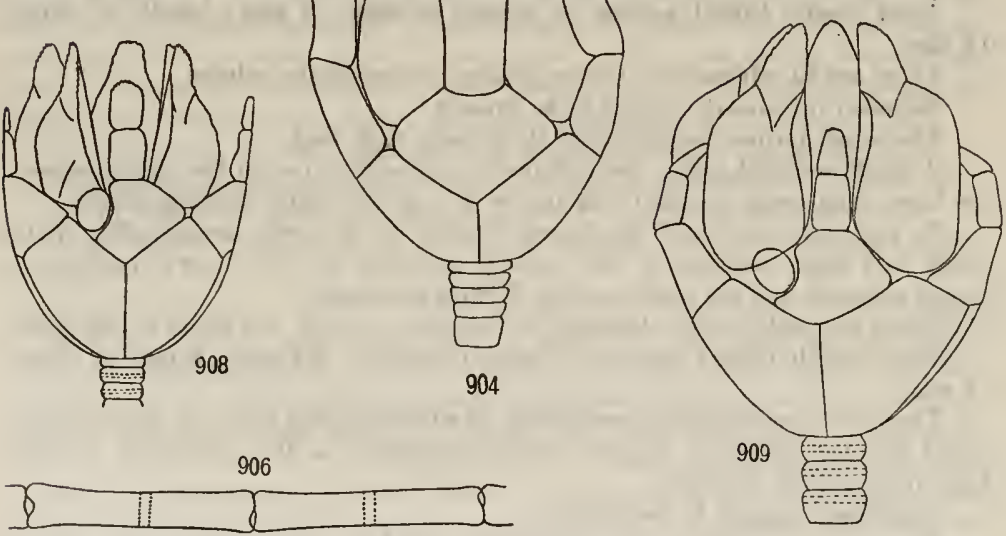

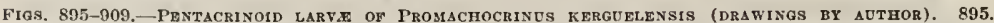
SPECIMEN DESCBIBED AS No. 17. 896. INFRABASALS AND TOFMOST COLUMNALS OF SPECIMEN DESCRIBED AS No, 18. 897. TWO BASALS, THRER INFRABASALS, AND TOPMOST COLUMNALS OF SPECIMEN DESCRIBED

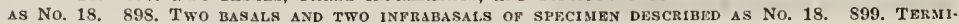

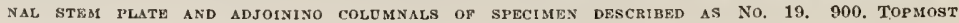
COLUMNALS OF SAME SPECIMEN, 901. FULLF DUVELOPED COLUMNALS OF SIME SPECIMEN. 902, ANOTHER VIEW OF TERMINAL STEM FLATE OF SAME SPECIMEN. 903. SPECIMEN DESCRIBID AS No. 20.

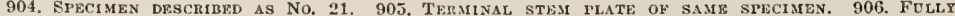
DEVRLOPE COLEMNALS OF SAME SPECIMIN. 907. SPECIMEN DESCRIBED AS No. 22. 908. SPECIMnN DESCRIBED $\triangle \mathrm{S}$ No. 23. 909. SPECIMEN DESCBIBED $A S$ No. 24. 
Just to the left of the smallest radial is the much larger oval radianal, to make room for which the right distal angle of the posterior basal is cut away. Distally and to the left the radianal overlaps the right proximal angle of the posterior oral.

The orals are rather broad, their sides converging rather rapidly in the distal half to the rounded apex. A triangular area extending from a point about two-thirds of the distance from the base to the tip in the median line as an apex to the two proximal angles, so that the proximal border serves as a base, is depressed. The portion anterior to this region is exteriorly broadly concave; the lateral portion of the orals is turned outward. Thus the orals of this specimen, instead of being of the form most characteristic of this species (as illustrated in Nos. 6, 7, 8, 9, and 11) tend to approach the form characteristic of the orals of Hathrometra prolixa.

No. 13 (fig. 892, p. 533) : Dredged on December 26,1902, at a depth of 385 meters.

One specimen resembling the preceding but with the orals, though much broader, essentially like those of No. 2 .

No. 14 (fig. 893, p. 533) : Dredged on January 12, 1903, in 380 meters.

Total length (distal portion of column missing), $1.3 \mathrm{~mm}$.; length of crown, $0.4 \mathrm{~mm}$.

The fragment of the column attached to the crown consists of 7 segments.

There appear to be five infrabasals of considerable size.

The basals form a cup with slightly convex sides which is half again as broad as high.

The minute beginnings of radials have appeared in the angles between the basals and the orals; to the left of one of the radials is the larger radianal.

The orals are rather broad; their sides are approximately parallel in the proximal half, in the distal half curving broadly inward and converging to a rounded apex. A triangular portion reaching from the proximal border to the middle of the median line is more or less flattened and depressed; the distal portion, including the tip and forming a rhombic area the proximal angle of which coincides with the distal apex of the proximal triangle, is also flattened; the lateral portions not included in these two areas are bent outward (backward).

No. 15: Dredged on December 26, 1902, at a depth of 385 meters.

Total length, $7.8 \mathrm{~mm}$.; length of crown, $0.7 \mathrm{~mm}$.

The column consists of 26 columnals and a terminal stem plate. The first three columnals are short and discoidal, with an evenly and sharply rounded lateral profile. The fourth is half again as broad as long, with a narrow projecting girdle just under the proximal border. The following rapidly increase in length to the eighth, which is about three times as long as broad, and the thirteenth-sixteenth, which are about five times as long as broad. The remainder gradually decrease in length. A narrow median girdle is evident on all the segments; on the earlier it projects beyond the general surface and is very conspicuous, but after the eighth it becomes inconspicuous. Except for the proximal, the columnals are regularly cylindrical without expanded ends.

The terminal stem plate is slightly lobate. 
There appear to be five rather large infrabasals.

The basals form a broad cup, which is rather more than half again as broad as high, with almost straight sides.

The radials are rhombic plates of medium size, covering the angles between the basals and the orals.

Just to the left of one of the radials, in a space formed by the excavation of the right distal angle of the posterior basal, the right proximal angle of the posterior oral, and the left side of the radial, lies the oval radianal.

The sides of the orals, which are not so large as the basals, converge slightly in the proximal half, and more rapidly in the distal half; a triangular area extending from the proximal border as a base to a point on the median line midway between the base and the tip as an apex is depressed; the tip, which projects somewhat, is flattened; the sides are bent backward (outward).

No. 16 (fig. 894, p. 533) : Dredged on April 14, 1902, in 385 meters.

Total length (distal portion of column missing), $1.7 \mathrm{~mm}$; ; length of calyx, $0.8 \mathrm{~mm}$.

The fragment of the column attached to the calyx consists of 10 columnals, of which the first is short and discoidal, the following increase in length to the fourth, which is slightly broader than long, the fifth, which is slightly longer than broad, and the sixth, which is twice as long as broad; and the last four are about half again as long as broad.

There appear to be five infrabasals of moderate size.

The basals form a long cup with almost straight sides which is about half again as broad distally as long.

The radials are roundedly rhombic plates of considerable size.

Just to the left of one of the radials is an oval plate of similar size-the radianal-situated well beyond the line of division between the posterior and the right posterior basals and orals, over which the adjacent radial lies, and noticeable on account of its very fine reticulation. The right-hand portion of the distal edge of the posterior basal is cut away for its reception.

The orals are of about the same length as the basals, approximately longtriangular in outline, tapering to a rounded tip armed with prominent spines. The proximal portion, comprising a triangular area extending from a point which lies between one-third and one-half of the distance between the base and the tip as an apex to the two proximal lateral angles, is flattened; a rhombic area, including the tip and reaching proximally nearly to the apex of the triangular area just mentioned, is also flattened. The long-triangular areas bounded inwardly by these areas are bent outward and backward.

No. 17 (fig. 895, p. 538) : Dredged on November 9, 1902, in 385 meters.

Total length (distal portion of column missing), $5 \mathrm{~mm}$; length of calyx, $0.7 \mathrm{~mm}$.

The portion of the column remaining consists of 16 columnals, of which the first five are very short and discoidal, though of gradually increasing length, more than twice as broad as long, with a prominent projecting girdle, and the follow- 

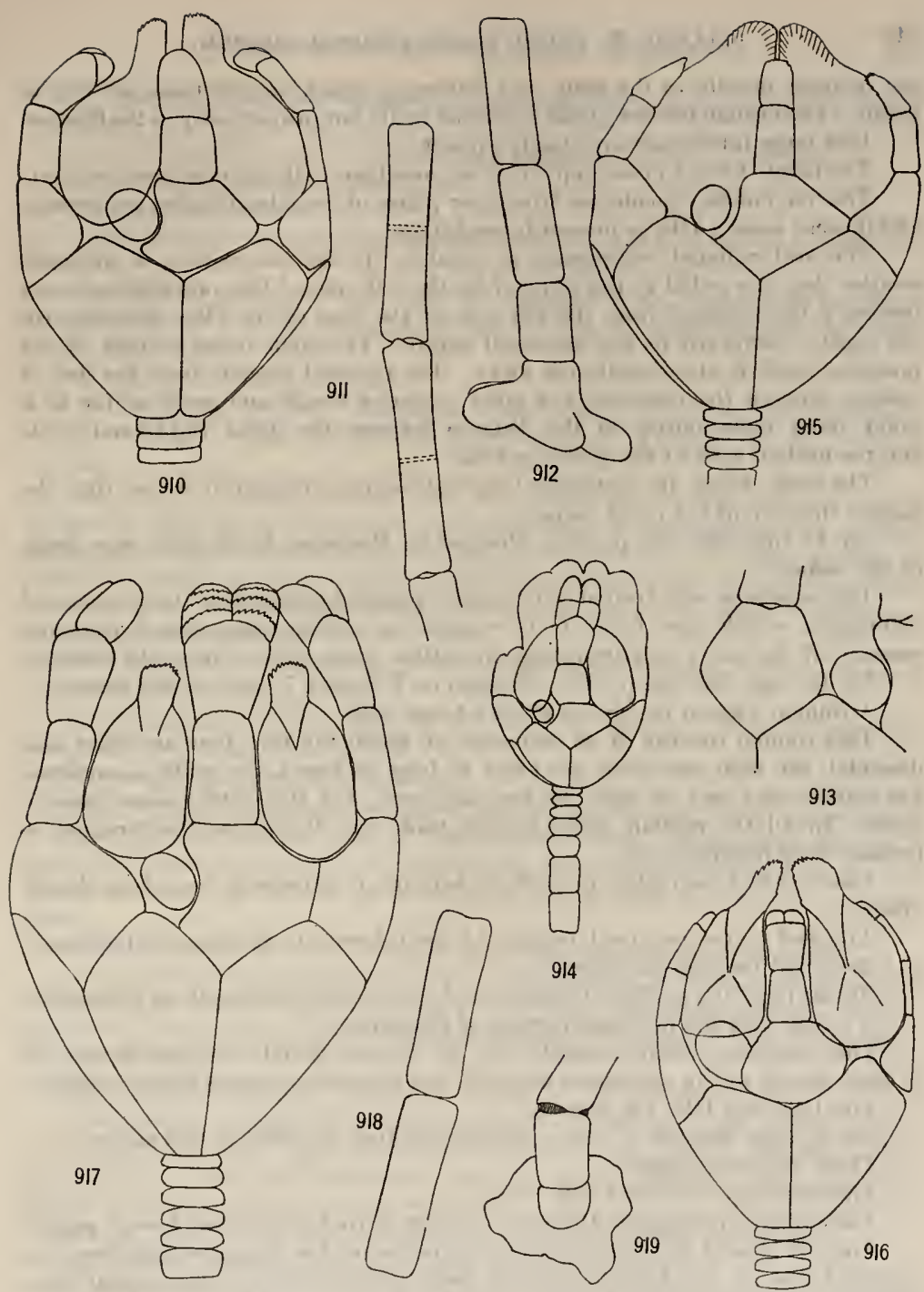

913

914

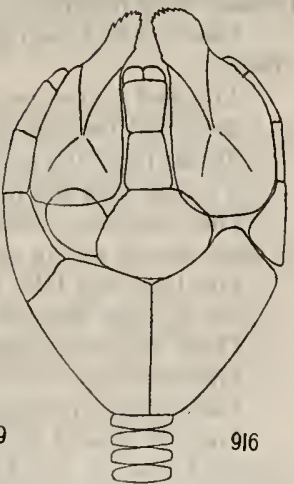

figs. 910-919.- Pextacrinoid larva on Prohlchocrinus kerguelexsis (Drawisgs by author). 910. SPECiMex described as No, 25. 911. Fully developed columals from sami specimen. 912. TERMINAL STEM T'LATE AND ALJOINING COLOMNALS OF SAME SPECIMEN. 913. RADIANAL AND ADJACENT PLATES OF SPECIMEN DESCribed AS No. 26. 914. Specianen Described AS No. 27. 915. Specimey described as No. 28. 916. Sppeidien describlid as No. 29. 917. Speciamen descrired as No. 30.

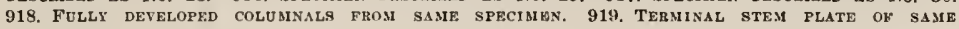
SPECIMEN. 
ing increase rapidly to the tenth and following, which are six times as long as broad. The median narrow girdle is distinct in all, but projects only in the first six.

Five large infrabasals are clearly present.

The basals form a broad cup which is more than half again as broad as high.

The five radials, rhombic or triangular plates of considerable size, are present, and in some cases a $\mathrm{IBr}_{1}$ is present beyond them.

The oval radianal, conspicuous as usual by its fine reticulation, is not much smaller than the radial to the right of it; the left side of this radial is cut away beyond a line running from the left side of the base of the $\mathrm{IBr}_{1}$ obliquely (to the right) downward to the interbasal suture. The right distal margin of the posterior basal is also slightly cut away. The radianal extends from the line of contact between the posterior and right posterior basals and orals as far as a point about three-fourths of the distance between the distal right-hand angle and the median apex of the posterior basal.

The orals, which are unusually long and narrow, are slightly longer than the basals; they are of the usual shape.

No. 18 (figs. 896-898, p. 538) : Dredged on December 19-23, 1902, at a depth of 385 meters.

This specimen was treated with caustic potash to determine the presence of infrabasals, which were found to be rounded in outline when viewed from the exterior of the calyx and triangular in outline when viewed from the interior.

No. 19 (figs. 899-902, p. 538) : Dredged on February 7 , 1903, in 350 meters.

A column without the crown, about $5.5 \mathrm{~mm}$. long.

This column consists of 22 segments, of which the first four are short and discoidal, the fifth and sixth are twice as long as broad, the ninth-seventeenth are between five and six times as long as broad, and the distal become shorter again. In all the median girdle can be made out, though in the terminal it becomes very inconspicuous. lobate.

The terminal stem plate is much broken, but it appears to have been deeply

Attached to the proximal portion of the column are portions of the basals and five small rounded infrabasals.

No. 20 (fig. 903, p. 538) : Dredged on July 31, 1902, at a depth of 385 meters. A crown with the proximal portion of the column.

This specimen closely resembles No. 28 , but the radials are only about half as long, though just in apposition laterally, and the orals are more pointed distally.

The $\mathrm{IBr}_{1}$ and $\mathrm{IBr}_{2}$ are present.

No. 21 (figs. 904-906, p. 538) : Dredged on June 25, 1902, in 385 meters.

There are 28 columnals.

The basal cup is low and very broad.

The radials are large and rhombic, almost in contact by their lateral angles.

The left side of the right posterior radial, beyond a line extending from the left-hand base of the $\mathrm{IBr}_{1}$ to a point about midway between the central apex and the right-hand border of the posterior basal, is occupied by the oval radianal.

Beyond the $\mathrm{IBr}_{2}$ about four brachials are present. 
The borders of the terminal stem plate are produced into five long digitiform processes.

No. 22 (fig. 907, p. 538) : Dredged on September 1, 1902, in 385 meters.

Total length, approximately $22 \mathrm{~mm}$.

There are 40 columnals.

The borders of the terminal stem plate are produced into five long digitiform processes.

The radials, which are very broadly in contact laterally and have an almost straight horizontal distal border, are about as long in the midradial line as the interbasal sutures.

The orals are short and broad.

No. 23 (fig. 908, p. 538) : Dredged on January 28, 1903, at a depth of 350 meters.

Total length (distal portion of column missing), $4.3 \mathrm{~mm}$.; length of calyx, $0.7 \mathrm{~mm}$.

The portion of the column which is attached to the calyx consists of 14 columnals, of which the first 6 are very short and the following rapidly increase in length, so that the twelfth and following are more than six times as long as broad. A median girdle is evident on all, and on the first six projects beyond the general surface. The elongated segments are cylindrical without a central construction or enlarged ends.

The basals form a broad strongly rounded cup which is half again as broad across its distal margin as high.

The radials are rhombic, broader than long, in contact by their lateral angles except in the posterior interradius.

There appear to be five infrabasals.

The radianal occupies its original position, in that its center is practically on the same level as the center of the adjacent radial. This radial (the right posterior) has the left side cut away beyond a concave line running from the left side of the base of the $\mathrm{IBr}_{1}$ to the middle of the right distal border of the posterior basal.

The $\mathrm{IBr}_{1}$ and $\mathrm{IBr}_{2}$ are developed, but there are as yet no brachials.

The orals are large, with the proximal triangular flattened area, the distal rhombic more or less flattened area. and the everted lateral regions as previously described. Their tips, which are spinous, extend considerably beyond the distal borders of the $\mathrm{IBr}_{2}$.

No. 24 (fig. 909. p. 538) : Dredged on July 31, 1902, in 385 meters.

This specimen in all essentials resembles the preceding. The $\mathrm{IBr}_{1}$ and $\mathrm{IBr}_{2}$ are present; the radials have not quite come into lateral contact; the excision of the left side of the right posterior radial for the reception of the radianal is not quite so extensive as in the preceding.

No. 25 (figs. 910-912, p. 541) : Dredged on April 17, 1902, in 385 meters.

Total length, $9.4 \mathrm{~mm}$. : length of calyx, about $0.8 \mathrm{~mm}$.

The column consists of 28 columnals and the terminal stem plate. The first six columnals are short and discoidal, the following rapidly increasing in length 
to the eleventh, which is twice as long as broad, and the seventeenth, which is about six times as long as broad. The last four gradually decrease in length, so that the one just preceding the terminal stem plate is not quite twice as long as broad. The elongated columnals are cylindrical, with only a slight suggestion of enlargement of the ends.

The terminal stem plate, attached to the stem of a lydroid, consists of four prominent well-rounded lobes of different sizes.

Between the bases of the basals are small triangular processes, which are probably the distal angles of the infrabasals.

The basals are large and broad, the distal diameter of the basal cup being nearly twice as great as its height.

The radials are rhombic, broad, almost in contact laterally.

The prominent oval radianal rests on the right distal border of the posterior basal. Its right-hand edge is directly beneath the left lower corner of the $\mathrm{IBr}_{1}$, and its left-hand edge is almost directly over the distal angle of the posterior basal. For its reception the left side of the right posterior radial is cut away beyond a strongly concave line from just beneath the lower left-hand corner of the $\mathrm{IBr}_{1}$ to the middle of the right distal face of the posterior basal.

The $\mathrm{IBr}_{1}$ and $\mathrm{IBr}_{2}$ and rudiments of the first brachials are present.

The orals are very large, with their characteristic sliape much accentuated.

No. 26 (fig. 913, p. 541): Dredged on August 12, 1902, in 385 meters.

The crown is about $1.5 \mathrm{~mm}$. in length.

The radials have not as yet come into lateral contact, being separated by a space from one-half to quite as wide as the base of the $\mathrm{IBr}_{1}$.

The left side of the right posterior radial is cut away beyond a concave line from the left-hand base of the $\mathrm{IBr}_{1}$ to about the middle of the right distal border of the posterior basal.

The oval radianal lies in the area formed by the cutting away of the left side of the right posterior radial, and extends as far as the line parallel with the dorsoventral axis which passes through the apex of the posterior basal.

No. 27 (fig. 914, p. 541) : Dredged on February 8, 1903, in 350 meters.

The portion of the column attached to the calyx consists of seven columnals. of which the first is very thin and discoidal; the second is thicker and lenticular; the third and fourth similar, but progressively thicker; the fifth cylindrical, twice as broad as long, with a broad, rough, raised girdle about its proximal half; the sixth half again as long as broad, with a similar girdle just proximal to the middle; and the seventh is twice as long as broad with a median girdle.

The radials are just in contact laterally by the tips of their lateral angles.

The radianal, which is thickened and lenticular, has been shoved outward by the growth of the lower left side of the right posterior radial until it has come to lie just to the right of and above the apex of the posterior basal.

There are four brachials present. The $\mathrm{IBr}_{2}$ and the brachials are bordered with large filmy covering plates.

The orals are scoop shaped, deeply depressed in the middle. Their tips are on a level with the distal borders of the $\mathrm{IBr}_{2}$. 


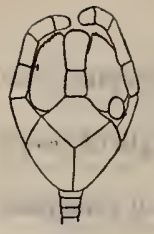

920
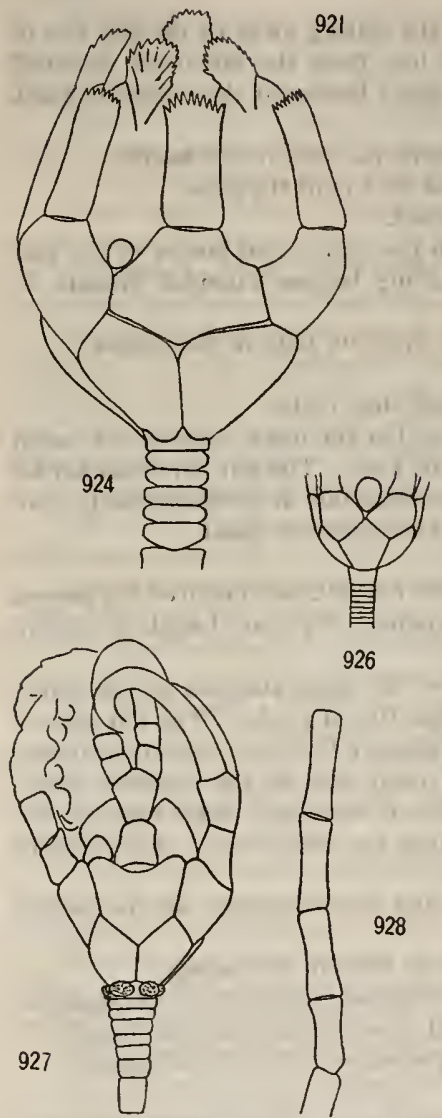

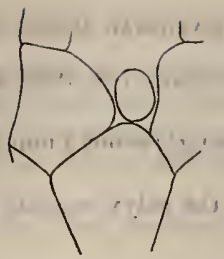

921

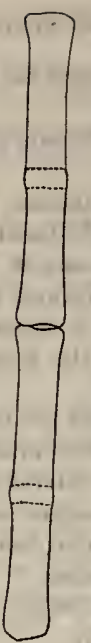

923

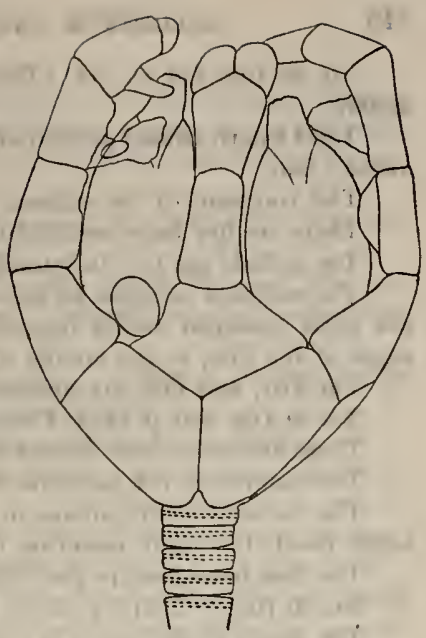

922

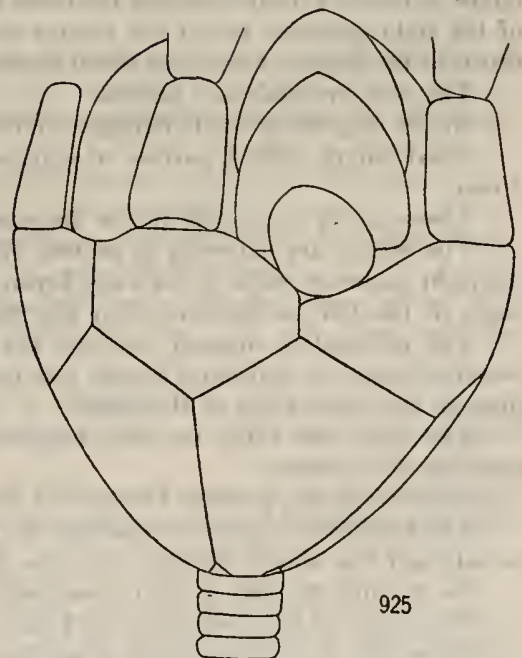

Figs, 920-928,-Pentacrinoid harva of Promachocainús kerguelensis (drawings by atthor). 920.

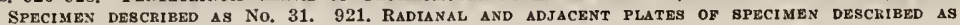
No. 32. 922. SPECiMen descuibed as No. 33. 923. Fulli developed Colu inals of same specimen. 924. SPECIMDN DESCRIBED AS No. 34. 925. SPECIMEN DESCRIBed AS No. 35. 926. SPECIMEN DeSCRIBED AS No. 36. 927. SPECIMEN DEscribed AS No. 38. 928. 23nD-27th COLUMNALS OF SAME SPECI MEN. 

meters.

No. 28 (fig. 915, p. 541) : Dredged on February 7-8, 1903, at a depth of 350

Total length (distal portion of column missing), about $5 \mathrm{~mm}$; length of crown, about $1 \mathrm{~mm}$.

The fragment of the column attached to the calyx consists of 19 columnals. There are five large rounded infrabasals.

The radials are just in lateral contact.

The radianal occupies an area formed by the cutting away of the left side of the right posterior radial beyond a concave line from the left-hand proximal angle of the $I B r_{1}$ to the middle of the right distal border of the posterior basal.

The $I B r_{1}$ and $I B r_{2}$ are present.

No. 29 (fig. 916, p. 541): Dredged on January 12, 1903, in 380 meters.

There are seven short discoidal columnals at the top of the stem.

The radials are not yet quite in lateral contact.

The radianal is still almost in contact with the right distal border of the posterior basal, the right posterior radial not having become extended beneath it.

The first brachials are just forming.

No. 30 (figs. 917-919, p. 541) : Dredged on April 10, 1902, in 385 meters.

The length of the crown is $1 \mathrm{~mm}$.

There are 22 columnals and a lobate terminal stem plate.

The radials are broadly in contact laterally, but the distal edge of the radial circlet is deeply concave between the bases of the $\mathrm{IBr}_{1}$. The left proximal border of the right posterior radial has become extended so that it occupies nearly twothirds of the length of the right distal border of the posterior basal.

The first brachials are present.

No. 31 (fig. 920, p. 545) : Dredged on November 9, 1902, at a depth of 385 meters.

Total length (distal portion of column missing), $3.2 \mathrm{~mm}$; length of crown, $1 \mathrm{~mm}$.

There are 12 columnals in the fragment of the stem attached to the calyx.

The radials are narrowly in contact by their lateral angles. The left side of the right posterior radial is cut away beyond a concave line from the left proximal angle of the $\mathrm{IBr}_{1}$ to the middle of the right distal edge of the posterior basal.

The radianal is situated over the left half of the right distal edge of the posterior basal, its left-liand border just touching the dorsoventral plane passing through the distal angle of the basal.

The $I B r_{1}$ and $I B r_{2}$, the first brachials, and the rudiments of the second brachials are present.

No. 32 (fig. 921, p. 545) : Dredged on June 25, 1902, in 385 meters.

The radianal occupies a relatively narrow region between the two posterior radials and lies almost directly orer the distal apex of the posterior basal.

No. 33 (figs. 922, 923, p. 545) : Dredged on February 8, 1903, in 350 meters.

The length of the crown is about $1 \mathrm{~mm}$.

There are 22 columnals and a terminal stem plate. The longest columnals nre somewhat over eight times as long as broad, with a median girdle. 
The radials are just in contact laterally.

The radianal, though still large and conspicuous, has been shoved upward and outward through the growth of the lower left-hand corner of the right posterior radial outward along the distal right side of the posterior basal nearly to the apex.

The $\mathrm{IBr}_{1}, \mathrm{IBr}_{2}$, first brachials, and rudiments of the second brachials are present.

Delicate, irregular, cribiform films along the sides of the $\mathrm{IBr}_{1}$ and $\mathrm{IBr}_{2}$ and of the first brachials, increasing in size to those bordering the last named, are the beginnings of covering plates.

There is a pair of sacculi at the base of the $\mathrm{IBr}_{1}$, another at the base of the first brachials, and a third at the base of the second brachials.

No. 34 (fig. 924, p. 545) : Dredged on November 9, 1902, in 385 meters.

Total length (distal portion of column missing), about $5 \mathrm{~mm}$; length of crown, about $0.6 \mathrm{~mm}$.

The basals are only very slightly convex and collectively form a very broad cup which is rather more than twice as broad distally as high.

The radials, which are about as long as the basals, are broadly in contact laterally. The distal border of the radial circlet shows deep, regularly rounded concavities between the bases of the $\mathrm{IBr}_{1}$.

The radianal, apparently much reduced in size, lies over the suture between the two posterior basals; the left side of the right posterior basal has become almost symmetrical with the right.

The $\mathrm{IBr}_{1}$, which are about as long as the radials, are present, but beyond their distal border the arms have been lost.

The orals, the tips of which extend for some distance beyond the distal ends of the $\mathrm{IBr}_{1}$, are of the usual shape.

No. 35 (fig. 925, p. 545) : Dredged on September 1, 1902, in 385 meters.

A specimen resembling the preceding in all essentials.

No. 36 (fig. 926 , p. 545) : Dredged on January 12, 1903, at a depth of 380 meters.

Total length, about $10 \mathrm{~mm}$; length of crown, about $2.6 \mathrm{~mm}$.

The stem is composed of 32 columnals and a terminal stem plate. The proximal columnal is elongated, about twice as broad as long, but as yet shows no evidence of broadening.

The terminal stem plate, attached to the stem of a hydroid colony, is very deeply stellate, so much so that it bears a striking resemblance to a specimen of Henricia sanguinolenta.

The radials are in contact laterally for a distance equal to about half that of the apposed borders of the basals. The posterior radials have just come into contact beneath the radianal.

There are eight or nine brachials present.

No. 37 : Dredged on December 31, 1902, in 385 meters.

There are 26 columnals and a terminal stem plate, which, as in the preceding, is produced into five long, slender, fingerlike processes. 
The radials, which are about half again as broad as the median length, are united for a distance about equal to two-thirds of that of the apposed sides of the basals.

The radianal is entirely excluded from the radial circlet.

There are about five brachials.

No. 38 (figs. 927,928 , p. 545) : Dredged on June 25, 1902, in 385 meters.

The crown is about $3 \mathrm{~mm}$. long.

There are 29 columnals, the distal portion of the stem being lost. The topmost columnal has become slightly thicker than those following and has broadened, the addition of new material being mainly in the interradial regions, which are also thickened more than the radial regions, so that in end view it would appear as a pentagon with broadly rounded angles. This seems to be in preparation for the formation of the five plates described in connection with the oldest pentacrinoid (No. 43). The next five segments, which are thin and discoidal, gradually decrease in diameter; the next is slightly over twice as broad as long; the following half again as long as broad; and the succeeding twice as long as broad. The articulation between the two last and between all those following is of the bourgueticrinoid type, the long axes of the ellipses on the two ends of each colummal crossing each other at right angles. The earlier elongated columnals have flattened ends, so that they appear as long trapezoids in lateral view, but the later gradually increase in diameter toward each end. The columnals increase in length to the twenty-third and following, which are between four and five times as long as broad; the last four or five in the column as preserved decrease again.

The basals form a relatively low ring.

The radials form a ring which is about the same height as that formed by the basals. Their lateral edges, by which they are in contact with each other, are about as long as those of the basals. Their distal borders are gently concave for the reception of the bases of the $\mathrm{IBr}_{1}$, which occupy one-half of the total length, and their distal lateral angles are somewhat produced and broadly rounded.

The radianal, which has not undergone appreciable reduction in size, is situated on the distal border of the radial ring. It adjoins the left side of the base of the right posterior radial, reaching thence to just beyond the posterior interradial suture.

There are no traces of interradials.

The arms consist of about 12 brachials, each with a pair of sacculi and large covering plates.

No resorption of the orals appears to have taken place, but they are relatively much smaller than previously, and their bases are separated from the distal borders of the radials by a considerable area of naked perisome.

No. 39 (figs. 929, 930, p. 549) : Dredged on December 31, 1902, in 385 meters.

The proximal portion of a column, showing the interradial enlargement of the proximal columnal.

No. 40 (figs. 931-933, p. 549) : Dredged on September 1, 1902, in 385 meters. 


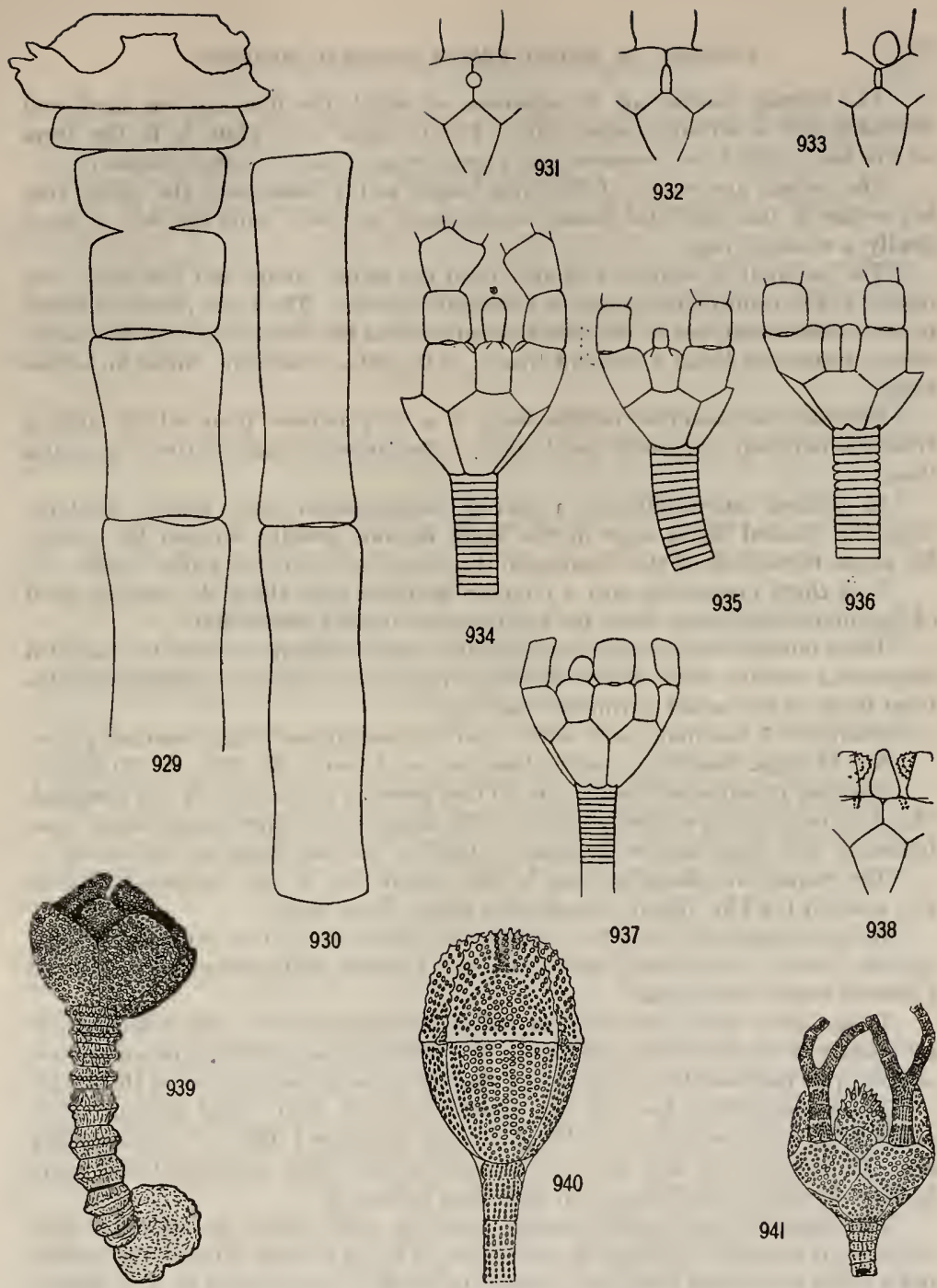

Figs. 929-941.-Pentacrinoid Laryzi of variods comatulids. 929. Pronachocrindes kerguelensis, TOPMOST COLUMNALS OF SPFCIMEN DESCRIBED AS No. 39. 930. FULLT DEVELOPED COLUMNALS OF SAME

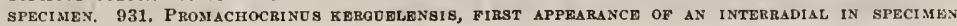
DESCRIRED As No. 40. 932. SAME SPECIMEN, ANUTHER INTERRADIAL. 933. SAME SPECIMEN, POS tertor intrridal. 934. Promachockinds kfrodglensis, specinen described as No. 41, Showing WELE DEVELOPED INTERrADIAL FOLLOWED BT TWO PLATES. 935. SAME SPECIMEN, SHOWING ANOTHEB INTERRADIOS. 036. SAME SPECIMEN, SHOWING TWO INTERRADIALS SIDE BY SIDE. 937. PROSACHOCRINLS KFRGUELENSIS, SPECIMEN DESCRIBED AS No. 42. 938. ANTHOMETRA ADRIANi, POSTERIOR INTERradies. 939. Ptilonetra mUlleri, dried pentacrinoid 1 as. long. (All preceding drawines by ATthor). 940. Hathromftra prolixa, 941. Comactinia meridionalis, showing interkadial. 
The column consists of 40 segments, of which the first six are short and discoidal, and a terminal stem plate. The terminal stem plate is in the form of five long digitiform processes and resembles an Henricia sanguinolenta.

The radials are nearly of the same height as the basals, and the radial ring is peculiar in that its distal border, as the calyx is viewed from the side, is practically a straight line.

The radianal is entirely excluded from the radial circlet and lies above and mostly to the right of the posterior interradial suture. The right posterior radial is now symmetrical, but in the posterior interradius the distal border of the radial circlet, instead of being a straight line as in the other interradii, forms an obtuse angle.

Between the posterior radials there is a very narrow plate which, arising from the narrowly truncated distal apex of the posterior basal, entirely separates them.

In another interradial area a narrow wedge-shaped plate, arising similarly from the blunted distal apex of the basal, extends distally between the radials for about two-thirds of the distance to the distal border of the radial circlet.

In a third interradial area a circular inclusion over about the median third of the interradial suture shows the beginning of another interradial.

These interradials, growing very rapidly, come eventually to form the so-called interradial radials, from which division series arise which are indistinguishable from those on the radial (primary) radials.

There are 7 brachials, each with a pair of sacculi and large covering plates.

No. 41 (figs. 934-936, p. 549) : Dredged on January 30, 1903, in 380 meters.

The first 12 columnals (which are all that remain) are very short and discoidal. The first two are very closely united. The topmost is rather longer than those following and bears narrow processes extending into the bases of the basals.

The radials are about as long in the median line as the interbasal sutures. The bases of the $\mathrm{IBr}_{1}$ occupy almost their entire distal border.

In one interradial area the radials are separated by two interradials, side by side, similar in size and shape, the two together being about equivalent to a normal single interradial.

In the other four intcradii the radials are separated by interradials which are about two-thirds as broad and about two-thirds as long as the adjacent radials, resting upon the broadly truncated and slightly concave distal angles of the basals.

These interradials bear on the middle third of their distal margin interradial $I B r_{1}$ which exactly resemble the radial (primary) $\mathrm{IBr}_{1}$ of corresponding size. From their size and shape it is probable that these interradial $\mathrm{IBr}_{1}$ were followed by interradial $\mathrm{IBr}_{2}$ which have been broken off.

The radianal, easily distinguished from the other plates by its much finer structure, is evidently undergoing resorption, as it has become narrow and leaflike, and a small calcareous plate just beyond its distal border appears to be a portion which has become separated from the main mass.

There were probably six or eight brachials following the radial $\mathrm{IBr}$ series. 
No. 42 (fig. 937, p. 549) : Dredged on November 9, 1902, at a depth of 385 meters. Total length, $25 \mathrm{~mm}$.

There are 53 columnals and a terminal stem plate.

The 10 proximal columnals are very short and discoidal; the longest are about six times as long as broad, with slightly enlarged ends.

The terminal stem plate is rounded, with two blunt digitiform processes.

There is as yet no trace of the formation of the centrodorsal. The middle of the proximal border of each basal, which overhangs the proximal columnals, shows a prominent notch.

Between the radials, which have become relatively narrow and are now no wider than the $\mathrm{IBr}_{1}$ which they bear, are large and prominent interradials which are about two-thirds as long and about two-thirds as broad as the radials on either side of them and rest upon the broadly truncated distal angles of the basals.

The radianal, reduced in size, is entirely excluded from the radial circlet and lies just beyond the posterior interradial, in contact with rather more than the right half of its distal border, and in contact with the left-hand border of the $\mathrm{IBr}_{1}$ borne by the right posterior radial.

The $\mathrm{IBr}_{2}$ are more or less squarish in shape, and of the same width as the radials which bear them. The $\mathrm{IBr}_{2}$ are shield shaped, distally as broad as the $\mathrm{IBr}_{1}$.

There were probably four or five brachials beyond the $\mathrm{IBr}_{2}$.

No. 43 : Dredged on June 14, 1902, in 180 fathoms.

Total length (distal portion of column missing), $65 \mathrm{~mm}$.; length of crown, $12.5 \mathrm{~mm}$.

As preserved the column, with the centrodorsal, consists of 65 segments.

The centrodorsal is rounded conical, as in fully grown specimens, with the tip truncated, and about as high as broad. It bears three irregular rows of large cirrus sockets, of which the lowest are radial in position, the middle interradial, and the proximal, nearest the periphery of the centrodorsal, again radial.

The columnal immediately beneath the centrodorsal is discoidal, seven or eight times as broad as long, with the sides as seen in profile sloping inward and downward. Its diameter is slightly greater than that of the centrodorsal at its base and apparently at least twice as great as that of the truncated tip.

On its proximal side it bears about the periphery five conspicuous triangular plates which are just in contact laterally, and proximally extend upward between the bases of the lowest cirri, reaching a height equal to nearly or quite twice the length of the underlying columnal. The texture of these plates and of the underlying columnal is very coarse, much coarser than that of any of the elements of the crown. The inner surface, which is very uneven, slopes inward and downward, but how far they extend inward it is impossible to determine. As these plates arise from the outer edge of the columnal bearing them and lean slightly outward, they extend rery considerably beyond the converging sides of the distal portion of the centrodorsal, so that the latter is seen to rest upon the central portion of a rosette formed of five wedges triangular in section, tapering inwardly, and placed side by side. 
These five plates, if they are in reality as they appear five separate units, probably have resulted from the unequal and exclusively interradial growth of the outer portions of the columnal immediately following the centrodorsal.

The columnal following that beneath the five plates just described is discoidal, about two-thirds of its diameter and about two-thirds of its length, with the sides slightly converging distally. The next is similar and of the same length, but very slightly less in diameter and with parallel sides. The following is about twice as long, and the next, to which it appears to be united by a bourgeticrinoid articulation instead of by more or less uniformly distributed ligaments, longer still. From this point onward the length of the columnals slowly increases, the twenty-fifth and following being between three and three and one-half times as long as broad. In the outer half of the column as preserved the ends of the segments become rather prominent and the lateral profile evenly concave.

There are 15 cirri present; the longest of these-those of the middle interradial row, reach to the base of the seventh brachial and are composed of 14 or 15 segments, of which the first is twice as broad as long, the second is slightly broader than long, the third is nearly twice as long as broad, the next two are slightly over twice as long as broad, and the remainder are about half again as long as broad as the base. In the second-fifth segments the outer portion increases slightly in diameter in lateral view, and the distal dorsal border is armed with numerous prominent spines. Beyond this point the segments become more compressed laterally, and the increase in diameter in lateral view is uniform from the base to the distal encl, which dorsally is armed with prominent spines. On the antepenultimate segment there is a fine serrate middorsal carination, and on the last a small sharp terminal opposing spine. The terminal claw is slender, moderately curved, and slightly longer than the segment which bears it.

The radial cirri about the tip of the centrodorsal, alternating with the five plates, which are the oldest, reach to the base of the third brachial and consist of 12 segments. They resemble those just described.

The interradial peripheral cirri, which are the youngest, are as yet rudimentary, and do not quite reach the distal border of the $\mathrm{IBr}_{2}$.

The basals form a complete, though low, ring about the calyx. Beneath the convex proximal border of the radial radials the lateral portions of the basals are very narrow; interradially, where their distal angles are broadly truncated by the proximal borders of the interradial radials, they are about $t w i c e$ as high.

The radial radials have almost attained the perfected form, though the articular face is still rather narrow, falling considerably short of reaching the lateral borders. Their distal edges bear numerous rather short conical spines arranged in a narrow band.

The interradial radials, of which the distal ends are at the same height as those of the radial radials, are only about half as broad as the latter, and reach proximally for only about two-thirds of the distance, where they abut against the truncated distal angles of the basals.

The radial arms are very long and well developed. All of them have lost the tips. The longest consists of 22 brachials; when perfect it probably had 
about 30. Except for being much elongated, the brachials have attained approximately the perfected form. The dorsal surface of the first 8 or 10 brachials is thickly beset with fine spines, and the distal border is armed with much longer spines. This latter character persists and becomes accentuated distally. The syzygies are distinguishable from the muscular articulations, but the brachials on either side of them have not become appreciably shortened. Very large and conspicuous rounded covering plates, between which are the large and conspicuous dark brown sacculi, border the ambulacral grooves on either side. There are five sacculi and covering plates for each three brachials.

Long and slender pinnules are developed from the twelfth or thirteenth brachials onward, and the pinnule on the second brachial $\left(P_{1}\right)$ is present. The pinnules do not differ essentially from those of the adult, but the component segments are much more elongated. The third-fifth segments bear seven very large and conspicuous covering plates, which considerably exceed in height the lateral diameter of the segments bearing them. Large dark-brown sacculi occur between the covering plates.

The interradial arms are as yet very small and rudimentary, with the tips turned inward. They reach only to the distal border of the first brachial.

The character of the disk can not be made out, as it is hidden by the arms; but orals appear still to be present.

The essential features in the development of the pentacrinoids of Promachocrinus kerguelensis may be summarized as follows:

Column.-Broadly speaking, the column is similar to that of the species of Hathrometra and Heliometra. It reaches a great length and is composed, when fully grown, of more than 65 segments, of which a usually considerable but very variable number of the proximal are short and discoidal; but the increase in diameter of these toward the calyx is never very marked.

The interesting feature in regard to the column is the occurrence just beneath the centrodorsal of either a rosette of five wedge-shaped plates or a single plate sharply divided into five sections, in the middle of which the tapered point of the centrodorsal rests. The right rounded outer ends of these plates or sections of a plate are interradial in position.

Notches in the middle of the proximal borders of the basals in many specimens in which the centrodorsal has not as yet developed, which are evidently to accommodate the interradial processes just described and which indicate that the columnal immediately beneath the basals is the one which is later found beneath the centrodorsal, suggest that the centrodorsal is not formed from the lateral enlargement and thickening of the most proximal columnal as in Antedon, but that it originates as a very small circular plate, entirely excluded from external view, situated between the center of the basal ring and the topmost columnal, and that this plate increases in diameter only through the addition of broader and broader layers between itself and the basal ring, so that it assumes from the first the form of an inverted cone the base of which is applied to the basal ring, while the slightly truncated tip rests in the middle of the rolumnal beneath it. 
The growth of the topmost columnal as seen in this species apparently is not the preliminary stage of its transformation into a centrodorsal, but instead indicates its transformation into a deep cup, within which, concealed from external view, the centrodorsal is developed. At a relatively late stage, when the centrodorsal has attained considerable size, the basal ring becomes lifted off of the pentalobate cup into which the topmost columnal (as seen in external view) has been transformed, and the centrodorsal, hitherto concealed, becomes visible.

The structure of the centrodorsal as seen in the largest specimen is much finer than that of the columnals immediately beneath it, indicating a much slower development. It most certainly could not have arisen from a plate resembling the preceding columnals.

The occurrence of a proximale smaller and of less diameter than the preceding columnals, which it is necessary to assume in explaining the origin of the centrodorsal in Promachocrinus, is not at all unusual. In recent types such a proximale is found, for example, in Rhizocrinus and in Calamocrinus.

Terminal stem plate.-The terminal stem plate of the pentacrinoid of Promachocrinus is at first a circular disk. This soon becomes broadly pentalobate, and the five lobes gradually extend themselves into five long tapering fingerlike processes, so that in its perfected form the terminal stem plate resembles nothing so much as a specimen of Henricia sanguinolenta.

Infrabasals. - It is very difficult to determine the presence or absence of infrabasals with certainty. There appear, however, to be five of equal size, forning a circlet just above the topmost columnal.

In the earlier stages the lower border of the basal ring shows five rounded or more or less pointed notches situated on the interbasal sutures; these represent infrabasals. Later these disappear, and five notches are formed, each of which occupies the middle of the lower border of a basal. These notches accommodate the processes arising from the distal growth of the interradial portions of the topmost columnal.

Basals.-The basal cup in Promachocrinus is at first noticeable on account of its height and narrowness, being about as long as broad distally. It subsequently expands very rapidly, and in the later stages it becomes unusually broad.

Radianal.-The radianal seems to be the first of the radially situated plates to put in an appearance, and from the evidence at hand we are justified in assuming that it is of considerable size at the time the right posterior radial is first formed.

At first these two plates lie side by side at exactly the same level, the radianal, which is situated on the right-hand end of the very narrow perisomic strip separating the posterior oral from the posterior basal, being accommodated by the cutting away of the distal right-hand corner of the latter.

The radianal increases in size very slowly and always shows a much finer structure than the other plates.

The right posterior radial, growing much more rapidly than the radianal, is at first only able to develop on its right side, the development of the left side being prevented by the presence of the radianal. 
At about the stage when the radianal and the right posterior radial are equal in size (two similar plates situated side by side, one, of coarser structure, situated on the line of division between the basals and the orals, the other, of finer structure, lying just to the left of it) the radianal begins to migrate to the left. At the same time, as a result of the growth of the radials, the distal lateral angles of the basals become more and more broadly cut away until the basals, instead of being bounded distally by a straight edge, are bounded by two distal edges which meet in the middle at an obtuse angle. Thus the course taken by the radianal in its migration toward the left along the distal border of the posterior basal, at first horizontal, soon becomes diagonally upward toward the apex of the basal. Meanwhile the right posterior radial is rapidly increasing in size. As a result of the upward, as well as outward, course taken by the radianal, the center of the latter remains on the same level with that of the right posterior radial (the excision of the latter being bounded by a more or less deeply concave line, with the chord more or less vertical) until the left side of the radianal touches or extends slightly beyond the dorsoventral plane, passing through the apex of the posterior basal-that is to say, until about the time of the formation of the first brachials.

From this time onward the course of the radianal is almost directly upward and outward, the proximal left corner of the right posterior radial rapidly extending itself along the distal right border of the posterior basal until it reaches the median distal apex, where it meets the right side of the left posterior radial and completely excludes the radianal from the calyx.

After its exclusion from the calyx the radianal lies for some time almost or quite directly over the posterior interradial suture before it disappears.

Radials.-Beyond the relatively late union of the two posterior radials beneath the radianal, the radials of Promachocrinus in their development do not differ from those of previously known types.

Interradials.-Interradials have been described in the young of Antedon bifida and of Comactinia meridionalis, but in these species they are always formed beyond the distal margin of the radial circlet, and are erentually resorbed.

Similarly in Promachocrinus the interradials do not appear until after the circlet of radials is complete; but in this type they are formed not beyond the radials but between them, apparently first on the apices of the basals, thence rapidly extending themselves, as very narrow plates, anteriorly until they entirely separate the radials. Broadening rapidly, while at the same time the radials cease their lateral extension and become relatively narrower, they gradually assume all the characters of the true radials, and on the middle of their distal border a small plate appears, soon followed by another, and the latter by two more side by side, until we recognize the beginnings of the interradial arms.

These interradial arms, which first appear before the formation of the centrodorsal and the disintegration of the orals, increase in size very rapidly, but they do not attain the size of the radial arms until the animal is almost fully grown.

An extraordinary fact in regard to this species is that the interradials do not always develop, or only the one in the posterior interradius develops, so that a 
large percentage of the recently detached young have only the 10 radial, or the 10 radial and 2 (posterior) interradial arms. Since all of the fully grown specimens recorded have 20 arms, it would appear that these 10 or 12 armed young never reach full size.

Brachials.-The brachials do not differ appreciably from those in the young of other species.

Covering plates.-Each brachial as soon as it appears is accompanied by a pair of large, though thin, covering plates, composed of a large and irregular main portion (side plate) and a smaller incompletely differentiated distal portion (covering plate proper).

These covering plates not only accompany all the brachials but are also found on either side of the $\mathrm{IBr}_{2}$ (axillaries) and even sometimes on either side of the $\mathrm{IBr}_{1}$, where, however, they are much reduced in size.

Pinnules.-The first pinnules appear, apparently about the time of the appearance of the first cirri, on the twelfth or thirteenth brachials, and are soon followed by the pinnule on the second brachial. All of the pinnules from their first inception resemble more or less closely the perfected form.

On the distal pinnules the third-fifth segments bear seven very large and conspicuous covering plates, which in height considerably exceed the lateral diameter of the plates bearing them.

Orals.-The orals of Promachocrinus are probably at first, as is usually the case, spherical triangles. But sometime before the appearance of the radial structures the original plan of the orals is suddenly changed, and the extension of their free lateral borders takes place at an abrupt angle to the surface of the plate as first laid down in such a way that further growth is in planes which include the dorsoventral axis of the animal. Each oral thus consists of a spherical triangle with abruptly upturned edges gradually tapering to a point at the proximal lateral angles, the upturned borders of the two outer sides being separated by a deep and narrow notch, the point of which rests upon the distal apex of the original spherical triangle.

At about the time of the first formation of the radial structures this plan of growth changes. The notch between the everted lateral extensions becomes filled with a new calcareous reticulation, which, growing more rapidly than the lateral extensions, gradually comes to form a produced narrowly rounded tip to the oral, this new growth as a whole eventually becoming rhombic in shape, either flat or gently concave (as viewed from the exterior), the rounded anterior angle of the figure forming the distal angle of the oral, while the proximal sharp angle, which rests upon the distal apex of the original primitive oral, represents the filling in of the original notch, now greatly increased in size through the continued extension of the lateral borders.

As the same time these lateral borders, originally formed in planes including the dorsoventral axis of the animal, have become curved inward in order always to maintain the connection with the growing, more or less flattened, distal rhombic area, so that now in lateral view their edges are seen to make a broad curve from the proximal angle of the basal to the outer angle of the rhombic area. 
This form of oral, in greater or lesser perfection, is very characteristic of this species and persists up to the time of the disappearance of these plates.

Speaking of the larvæ of Promachocrinus kerguelensis, which I loaned him for study in connection with his work on the Crinoidea Flexibilia, Mr. Frank Springer writes that the origin and development of the radianal as shown in Comactinia is paralleled in this species.

The series studied by him begins with the prebrachial stage, in which the radials have just appeared as small dots, but, contrary to what is the case in the youngest Comactinia, all of them are present, though that of the right posterior ray is smaller than the others and much smaller than the radianal to the left of it.

Mr. Springer thinks it probable, as I have suggested, that the radianal actually develops before any of the radials are formed.

In the succeeding stages the radianal does not increase to the relative size to which it attains in Comactinia, but it runs a similar course until it is lifted out from the ring of radials by the growth of the anal tube and the interradial spaces have been occupied by the interradial radials characteristic of this genus.

\section{ANTHOMIETRA ADRIANI.}

Fig. 93S, p. 549 .

Among the numerous pentacrinoids brought home by the Gauss were two evidently belonging to Anthometra adriani. The characters of these are as follows:

No. 1: Dredged on September 27, 1902, in 385 meters

The seven columnals immediately following the calyx are short and discoidal, progressively decreasing slightly in diameter distally. The topmost columnal is slightly longer than that just below it, to which it is very closely joined.

Broadly speaking, the calyx and columnals resemble those of Promachocrinus kerguetensis at the same developmental stage. In profile the sides of the calyx are nearly straight, diverging from the topmost columnal at an angle of somewhat less than $90^{\circ}$.

The basals are large and conspicuous. The left distal side of the posterior basal is half again as long as the right distal side.

The radials, which are broadly in apposition laterally, are about as long in the median line as the interbasal sutures. On the distal borders of the radials just below the proximal angles of the $\mathrm{IBr}_{\mathrm{x}}$ on either side there are a few conspicuous more or less webbed spines.

The radianal is unusually long and narrow. From a base extending from the proximal left corner of the $\mathrm{IBr}_{1}$ on the right posterior radial to halfway between the posterior interradial suture and the base of the $\mathrm{IBr}_{1}$ on the left posterior radial it extends diagonally upward, gradually narrowing, to a position just over the interradial suture (in the mid-interradial line), where it ends in a blunt, rounded point on a level with the distal end of the $\mathrm{IBr}_{1}$. 
On the distal half of the sides of the $\mathrm{IBr}_{1}$ are a number of long webbed spines which form broadly rounded spinous lateral extensions of the narrow distal end, increasing its width to more than that of the base.

The lateral angles of the $\mathrm{IBr}_{2}$ are more or less spinous.

All of the brachials have the distal border armed with more or less everted and prominent spincs, and each bears a pair of sacculi, but no covering plates.

No pinnules are as yet developed.

The bases of the orals, which appear to resemble those of Promachocrinus, are separated from the distal border of the radial circlet by a broad unplated strip of perisome equal in breadth to about half the height of the $\mathrm{IBr}_{1}$.

No. 2: Dredged on June 25, 1902, at a depth of 385 meters.

The column consists of 32 columnals, including the centrodorsal, and distally carries a portion of the terminal stem plate.

The centrodorsal is discoidal, four or five times as broad as high and slightly swollen in the interradial areas, over which there are small rounded notches in the proximal border of each basal.

The following columnal is nearly as large and about two-thirds as high and is similarly swollen interradially. The third and fourth from the calyx are of the same size, each about half as high as the centrodorsal, and slightly swollen interradially; the next three are short and discoidal, rather abruptly less in diameter than the preceding. The following increase rapidly in length to the seventeenth-twenty-first, which are the longest, about five times as long as broad, then decrease gradually to the one adjoining the terminal stem plate, which is about as long as broad. The elongated columnals are of the bourgueticrinoid type with swollen ends which become prominent in the distal half.

Two rudimentary cirri reaching to the lateral angles of the basals and the base of a third are present. They are radial in position.

In profile the sides of the calyx to the distal border of the radial circlet are nearly straight, and diverge from the centrodorsal at approximately a right angle.

The basals are of moderate length and offer no peculiarities. except that in the posterior the left distal side is about twice as long as the right.

The radials are well developed. In the median line they are about as long as the interbasal sutures, and the large articular face occupies about three-quarters of their distal border. Just below the proximal angles of the $\mathrm{IBr}_{1}$ on either side conspicuous spines are developed.

The radianal, which is long and narrow, resembles that described in the other specimen.

The sides of the $\mathrm{IBr}_{1}$ converge distally, so that the distal end is about half as broad as the proximal; but in the distal half the borders are armed with long and prominent more or less webbed spines which are longest at the distal angles; including these spines the $\mathrm{IBr}_{1}$ are slightly broader distally than proximally, with broadly rounded distal angles.

The $\mathrm{IBr}_{2}$ are shield shaped, distally as wide as the distal ends of the $\mathrm{IBr}_{1}$, including the spines, proximally converging to a rounded point, with spinous lateral angles. 
There are about 20 brachials, which have prominently spinous distal borders. Each brachial bears a pair of sacculi, but there are no covering plates.

On at least two arms there is a rudimentary pinnule on the fourteenth brachial.

The orals, which resemble those of Promachocrinus but are more delicate, more nearly flat, and much more spinous distally, are separated from the distal border of the radial circlet by a naked strip of perisome about equal in width to half the length of the $\mathrm{IBr}_{1}$.

FLOROMETRA SERRATISSIJIA.

During a visit to Puget Sound Dr. Th. Mortensen was so fortunate as to secure a considerable series of the pentacrinoids of this species, which he intends to describe in the near future.

\section{HATHROMETRA PROLIXA.}

Figs. 1213 , pl. 34 ; 940 , p. 549 , and 1227 , pl. 37 ; pl. 56 , fig. 1353 ; and part 1 , fig. 409 , p. 317 , pl. 3 , fig. $532,535,538$, pl. 4 , figs. 542,544 , and pl. 6, figs. 559-564.

On the cirri of specimens of Hathrometra prolixa dredged by the Danmark off northeastern Greenland, in 304 meters, on July 22, 1908, Dr. Th. Mortensen found numerous pentacrinoid larvæ representing several developmental stages.

As a rule, these occurred on about the middle of the longer peripheral cirri, sometimes two together; more rarely they were found on the shorter distal cirri.

The youngest specimen was only $1.4 \mathrm{~mm}$. long, the length of the column being $1 \mathrm{~mm}$. and that of the calyx $0.4 \mathrm{~mm}$. It possessed about 10 columnals, of which the central were the longest, $0.15 \mathrm{~mm}$. in length by $0.05 \mathrm{~mm}$. in breadth, with the primitive median annulus very distinct and somewhat raised. The terminal stem plate was circular.

In another, which measured $2.5 \mathrm{~mm}$. in total length, the column being $2 \mathrm{~mm}$. and the calyx $0.5 \mathrm{~mm}$. long, there were 15 columnals, of which the three proximal were quite short, but not broader than the succeeding. In the fourth columnal the portion distal to the primitive annulus was somewhat elongated, the proximal part remaining short. The following columnals were elongated, cylindrical, but with the median annulus distinct, the longest measuring $0.25 \mathrm{~mm}$. in length and 0.05 $\mathrm{mm}$. in breadth. The terminal three or four were somewhat shorter. The terminal stem plate was small and slightly lobed.

The basals were slightly convex, trapezoidal with straight edges, the upper border being finely undulated, corresponding to the lower border of the adjacent oral. The proximal portion consisted of an irregular meshwork, while the distal was quite regular in structure, the holes in the mesh work being arranged in straight lines. Mortensen notes that this indicates that the proximal portion represents the plate in its original size, the regular distal portion representing additional growth, and as additional evidence for this view he notes that the regular distal portion becomes more extensive with age. The same feature was observed in the orals.

The most searching investigation failed to disclose the presence of infrabasals. I can confirm this statement, for at the time Doctor Mortensen was studying these pentacrinoids I was in Copenhagen, and we both went over the material together. 
The orals are triangular, the proximal portion in the shape of a spherical triangle, along the two free sides of which the borders are abruptly everted, the eversion increasing in amount to the apex and standing everywhere in planes including the dorsoventral axis.

Similar eversion of the free borders of the orals was described in Antedon bifida by Dr. W. B. Carpenter, but it is not nearly so extensive as in this species.

Along the base of the triangle, where the oral adjoins the corresponding basal, there is a narrow belt of regularly arranged holes representing the zone of new growth. It is much narrower than the same zone in the basals.

Five sacculi are present.

In the next stage, characterized by the presence of the radials, the length is from $6 \mathrm{~mm}$. to $8 \mathrm{~mm}$., of which the column occupies from $5 \mathrm{~mm}$. to $7 \mathrm{~mm}$. and the calyx $0.7 \mathrm{~mm}$. to $0.8 \mathrm{~mm}$.

The number of the columnals is 22-24. The longest, the eighth-fourteenth, are cylindrical, with the median annulus distinct, though scarcely prominent, and measure $0.05 \mathrm{~mm}$. by $0.005 \mathrm{~mm}$. The distal columnals are somewhat shorter, and the three or four proximal quite short, only slightly wider than those succeeding. The terminal stem plate is distinctly lobed.

The radials are represented by small rhomboid plates lying in the angles where the basals and orals meet, the corners of these plates being truncated for their reception.

The basals have increased considerably in length through addition to their distal borders. There has been some addition to the proximal edges of the orals, and their everted margins have increased considerably in height.

The tentacles contain irregular elongated calcareous rods.

$A$ specimen in which the rudiment of the $\mathrm{IBr}_{1}$ has appeared shows the beginnings of the radianal. The right posterior radial is displaced to the right so that it lies almost entirely on the right posterior basal. Adjoining it just to the left and resting on the posterior basal is the radianal. In area the radianal is somewhat more than one-third the area of the adjacent radial, and its distal half overlaps the base of the posterior oral when the latter is closed over the disk.

In the stage in which the $I B r_{1}$ and $I B r_{2}$ are developed the length is $8.5 \mathrm{~mm}$., the calyx being from 0.7 to $0.8 \mathrm{~mm}$. long.

There are 25 columnals, of which the longest are $0.5 \mathrm{~mm}$. long and from 0.06 $\mathrm{mm}$. to $0.07 \mathrm{~mm}$. wide, somewhat thicker than in the preceding stage and slightly thickened at the ends. The lobes of the terminal stem plate have become slightly more pronounced.

In one of the specimens the $\mathrm{IBr}_{1}$ and $\mathrm{IBr}_{2}$ are small and similar; in another they have become considerably differentiated.

In the latter the $\mathrm{IBr}_{1}$ is still narrow and slender, though somewhat widened at the proximal end, where it adjoins the now distinctly pentagonal radial. The $\mathrm{IBr}_{2}$ (axillary) has widened, and on its outer borders the first brachials have just appeared.

The basals have increased considerably in length through addition distally, and the radials have nearly come into mutual contact beyond them. 
The upturned edges of the orals have increased considerably in height.

The anal plate is distinct.

In the stage characterized by the presence of the first brachials the pentacrinoids are from $13 \mathrm{~mm}$. to $15 \mathrm{~mm}$. long, the calyx measuring from $1.5 \mathrm{~mm}$. to $2 \mathrm{~mm}$.

There are 33-35 columnals of which the longest are $0.6 \mathrm{~mm}$. by $0.1 \mathrm{~mm}$. The proximal six or seven are short, but not broader than the succeeding. The central are cylindrical, without distinct traces of the median annulus, and with slightly broadened ends, which are elliptical in end view, the axes of the ellipses on the two ends of each columnal being at right angles to each other. The articular faces resemble those figured by Sars in Hathrometra sarsii, but the fulcral ridge is not so strongly serrate. The distal columnals gradually become shorter, the most distal being only about half as long as wide. The terminal stem plate is rather large and coarsely lobed.

The radials have formed a completely closed circle, and their apposed lateral edges are of considerable length. They are somewhat thickened at the point where the $\mathrm{IBr}_{1}$ are attached.

The $\mathrm{IBr}_{1}$ and $\mathrm{IBr}_{2}$ are still long and narrow.

The basals now end distally in an angle beneath the interradial sutures and thus have become pentagonal.

The radianal is still distinct.

The orals still retain their characteristic shape and still reach the edge of the disk.

The brachials resemble those of $H$. sarsii at the corresponding stage.

Side plates, somewhat more branched than those found in the pinnules of the adults, have appeared.

Fischer recorded two pentacrinoids of this species, which, attached to a Rhynchonella, were dredged at the Austro-Hungarian polar station at Jan Mayen. One of these was sent to P. H. Carpenter, who published a figure of it.

The broken column with 26 segments was $14 \mathrm{~mm}$. long; the crown, with the arms broken at the distal end of the eighth brachials, was $4 \mathrm{~mm}$. long.

The longest of the five cirri reached almost to the first brachials.

In the Challenger report Carpenter figured (under the specific name tenella) a pentacrinoid of this species.

He gives no measurements, but the figure shows a pentacrinoid about $18 \mathrm{~mm}$. long, of which the column, consisting of 23 segments with a considerable part of the distal portion missing, is $12.7 \mathrm{~mm}$. long.

There is only one cirrus, which reaches to the level of the $\mathrm{IBr}_{2}$.

The column is attached by a slight calcareous expansion at about the thirtyfifth segment (not shown in the figure) to one of the rays of a Rhabdammina abyssomum, and it then passes on to form two other spreading attachments, with radicular branches sprouting from them over a portion of a tubular hydroid.

Six or eight long pinnules are developed on each arm, the lowest being on the ninth, tenth, and twelfth brachials.

Two pentacrinoids which were dredged by the Porcupine in the "cold area" of the Faroe Channel P. H. Carpenter referred to this form. 
In one of these there is no trace of cirri, the anal plate separates two of the radials, and there are two short brachials.

There are five discoidal segments at the top of the broken column, which is much more robust than that of the corresponding stage of Antedon bifida, while the crown, which is $1.1 \mathrm{~mm}$. in length, is nearly twice as large as that of Antedon bifida.

The orals, which rest directly on the radials, were compared by Carpenter to those of Hyocrinus, having a deep median groove, which is more marked than in that type, with the lateral borders folded over somewhat strongly. This character is more pronounced than in the larva of Antedon bifida.

Carpenter notes that this pentacrinoid, which, like the succeeding, was determined as belonging to Hathrometra prolixa by a process of elimination, resembles the larva of $H$. sarsii in the great height of the basals but differs from it altogether in the unusual shortness and width of the radials and $\mathrm{IBr}$ series.

In the second larva the column, which is broken about $20 \mathrm{~mm}$. from the calyx, forms an attachment to a hydroid tube at about its thirtieth segment, and is continued downward for half a dozen segments further.

There are six discoidal segments below the rudimentary centrodorsal, which bears the sockets of five short cirri, only one of which remains, reaching to the distal border of the basals, which collectively make up about half the height of the cup.

The $\mathrm{IBr}_{1}$ and $\mathrm{IBr}_{2}$ (axillaries) are well developed, as are also the arms, which are broken at about the tenth brachial or earlier; but even under these circumstances the crown has a length of $4 \mathrm{~mm}$.

A slightly bifid plate having a somewhat worn appearance stands up in one of the interradii of the disk. Carpenter states that it may be one of the orals. but is more inclined to regard it as the radianal.

A striking feature of this very robust larva is the large development of the arms before the appearance of the cirri. The radials and brachials are larger than those of a recently detached Antedon bifida.

The brachial ambulacra of this larva are protected by relatively large plates not unlike those in certain forms in the genus Leptometra, though the armature of the ambulacra in the adult $I$. prolixa consists of quite simple carcareous rods.

This difference, as stated by Carpenter, may perhaps be explained by an absorption of the perisomatic skeleton of the pentacrinoid, such as seems to take place in certain forms of Antedon.

In addition to many of the specimens described by Doctor Mortensen I have personally examined the following:

East of Jan Meyen (lat. $72^{\circ} 05^{\prime}$ N., long. $0^{\circ} 36^{\prime}$ W.), 96 fathoms; taken on July 24, 1891.

A well-developed example in a poor state of preservation.

East of Iceland (lat. $65^{\circ} 00^{\prime} \mathrm{N}$., long. $11^{\circ} 16^{\prime}$ W.), 310 fathoms.

The radials are in contact laterally through the rather broadly truncated lateral angles.

Northeast of Iceland (lat. $67^{\circ} 53^{\prime} \mathrm{N}$., long. $10^{\circ} 19^{\prime}$ W.), 1,010 fathoms. 
Total length (distal portion of column missing), $3.0 \mathrm{~mm}$; length of calyx, about $0.8 \mathrm{~mm}$.

The stem fragment attached to the calyx consists of 12 columnals, of which the first four are very short and discoidal, the fifth is half again as long as broad, the sixth is twice as long as broad, and the tenth and following are about five times as long as broad.

The radials are rhombic plates of moderate size.

\section{HATHROMETRA TENELLA.}

A pentacrinoid of this species was figured by Verrill, who, however, gave no description of it, nor did he indicate where or at what depth it was dredged.

The figure shows a specimen $22.5 \mathrm{~mm}$. in length, the crown being $4 \mathrm{~mm}$. long.

There are 28 columnals, of which the topmost six are very short and discoidal, decreasing slightly in diameter. Those in the distal half of the column are shown as five or six times as long as broad, with slightly enlarged ends. Though the object of attachment is drawn, no terminal stem plate is shown, and many of the earlier elongated columnals are drawn as two, the median annulus having been mistaken for the border between two.

The distance across the distal part of the radial circlet is equal to about twice the distance between the distal portion of the radial circlet and the topmost columnal. The sides of the calyx are rather strongly convex.

The radials in the middle line are about as long as the interbasal sutures. The distal edge of the radial circlet as seen in lateral view is straight.

The bases of the $\mathrm{IBr}_{1}$ occupy about half of the distal edge of the radials.

Nine brachials are shown. No pinnules are developed.

On September 12,1884 , the Albatross dredged a nearly or quite fully grown pentacrinoid off Cape Hatteras in 243 fathoms.

The total length is about $17 \mathrm{~mm}$., the crown measuring about $6 \mathrm{~mm}$.

There are 29 columnals and the terminal stem plate and centrodorsal.

The centrodorsal is apparently a low truncated cone; the columnal immediately following the centrodorsal is very thin and platelike, rather strongly pentalobate, the interradial portions being produced laterally as broadly rounded extensions, suggesting the conditions found in Promachocrinus; the next segment is less in diameter, slightly thicker, the proximal border produced and rounded pentagonal with the angles interradial, the sides converging strongly distally. These two columnals are very closely united, apparently by a stem syzygy. The following columnal is less in diameter than the preceding and longer, being four or five times as broad as long, united both to the preceding and to the succeeding by the bourgueticrinoid type of articulation. The fourth columnal from the centrodorsal decreases rapidly in diameter distally, and is about as long as its distal breadth, with a roughened girdle about the proximal border. The fifth is about twice as long as broad, with a roughened, very slightly raised, broad median girdle. The following increase in length to the eighth, which, with the following, is about three times as long as broad. After the 
ninth, which, like the preceding, is cylindrical, the segments begin to show a median constriction and swollen ends; in the distal half of the column this feature becomes very strongly marked.

The terminal stem plate, which is attached to a small bivalve, is produced into three long bifurcated digitiform processes and a broad irregular digitiform mass, which occupies nearly one-half of its circumference.

The lowest cirri, about the apex of the centrodorsal, are composed of 10 segments. They are radial in position and reach about to the second brachial. Beyond these there is an irregular band of cirri, of which the lowest resemble the apical and the uppermost, which are the longest cirri present, reach to the ninth brachial or slightly beyond, and are composed of 11 or 12 segments. About the proximal edge of the centrodorsal in the interradial angles are some rudimentary cirri.

The crown resembles that of the youngest free-living examples. The distal angles of the $\mathrm{IBr}_{1}$, the lateral angles of the $\mathrm{IBr}_{2}$, and the distal edges of the brachials are armed with prominent spines.

All the pinnules are present.

A specimen dredged by the Albatross on August 22, 1884, between Cape Hatteras and Nantucket, in 428 fathoms, is badly mutilated, most of the arms and column and all of the cirri being lost.

Apparently it is in the same stage as the one just described.

The centrodorsal is low conical, its truncated tip resting in the center of the very thin columnal following, which is somewhat broader than the base of the centrodorsal and pentalobate, the lobes being directed interradially.

\section{HATHROMFTRA SARSII.}

Figs. 1216-1225, pls. 35 , 36 ; and part 1 , figs. 407,413 , p. 317 ; pl. 2, fig. 530 , and pl. 3 , firs. 534, 536, $537,539-542$.

In 1856 Prof. Michael Sars communicated to the congress of Scandinavian naturalists assembled at Christiania a brief account of the pentacrinoid young of Hathrometra sarsii.

Later he obtained 32 arditional pentacrinoids in different stages of development, which he described in great detail in 1868. Thirty-one of these pentacrinoids were dredged by his son, Prof. George Ossian Sars, at different localities in the Lofoten Islands, between 100 and 300 fathoms, at various times between the beginning of March and the middle of July, and one was secured by himself in March at Manger, near Bergen, at a depth of 50 fathoms.

The youngest specimen was captured at the beginning of July at Brettesnaes in the Lofoten Islands, at a depth of 100 to 200 fathoms. It was attached to the stalk of a Rhabdopleura mirabilis growing on the column of a Rhizocrinus lofotensis.

The total length was $4 \mathrm{~mm}$., the column measuring $3.5 \mathrm{~mm}$., and the calyx a little less than $0.5 \mathrm{~mm}$.

In the stem there were 18 columnals, of which the two or three proximal were almost spherical, or rather lenticular, being slightly compressed along the axis of 
the column. These were also a little broader or thicker than those following, which were cylindrical, becoming more and more elongate toward the middle of the column, where they were from six to seven times as long as broad. Toward the distal end of the column the segments became shorter again. With the exception of the two or three proximal columnals and of the distalmost, all showed a narrow median transverse line, sometimes slightly elevated, denoting the primitive annulus. The distal end of the terminal segment spreads out into a little hyaline disk, almost circular, which is attached by its lower face to the foreign body. This disk is almost entirely composed of a fine calcareous network, a continuation of that of the segment itself, irregular and lobed in outline.

The crown is composed entirely of the basals and orals, no trace of the radials having appeared, and no infrabasals having been identified.

The straight distal border of the basals is not quite equal to their length; the two lateral borders converge, so that the proximal border is very short.

The orals are of about the same size as the basals.

All the plates of both series are composed of the ordinary calcareous network, moderately regular, and pierced with little rounded perforations, which on the rounded (distal) tips of the orals is furnished with minute but prominent conical points.

Another specimen, taken at the same time and place as the preceding, was attached to the stem of a dead individual, much older, of the same species, which, in its turn, was attached to a branch of a Crisia denticulata. Although this example was no larger than the preceding, being $4 \mathrm{~mm}$. in total length, with the crown $0.5 \mathrm{~mm}$. long, it was a little more developed.

The column was composed of 19 segments, of which the four or five uppermost were more strongly compressed longitudinally than were the corresponding elements in the preceding, being in lateral view twice as broad as long. The following were cylindrical and became progressively longer and longer, so that at the middle of the stem they were five or six times as long as broad; here they were somewhat constricted centrally and thickened at the two ends, and at the same time a little narrower than those above and those below. The latter gradually decrease somewhat in length.

The end of the distalmost columnal expands into a little disk with a convex surface, from the periphery of which there arise four short, thick, digitiform prolongations, which extend over the surface of the object of attachment (in this case a columnal of a larger individual) and partially inclose it. The disk and its prolongations are composed of a fine calcareous network like that of the columnals but less regular.

In Antedon the terminal stem plate is a circular or slightly lobed disk instead of a digitiform structure as in this species.

Between each pair of orals and basals there has been formed a radial, the radials thus separating these plates heretofore united by their bases.

The basals appear a little smaller than at the preceding stage, and now their distal border, previously straight, forms in the center, on account of the intercalated radials, an obtuse angle. 
The five radials, almost as high as broad and hexagonal in shape, are already so large that they are almost in contact with each other at the lower extremity of their lateral borders, which are separated from those of their neighbors by a narrow vertical fissure.

On the distal straight border of each of the radials there has appeared a $\mathrm{IBr}_{1}$, which is elongated and as high as, though scarcely half as broad as, the radial.

The orals are in the same condition as in the preceding stage.

In one of the interradial spaces, at the level of two of the radials and between them, a small plate, oval in shape, with the longer axis parallel with the stem, which with its proximal border touches the distal angle of a basal and distally overlaps the proximal border of an oral, has appeared. This is the radianal.

Three specimens, taken at the same place, time, and depth as the two preceding, are at a more advanced stage. One of these was attached to the tube of a Pectinaria hyperborea, and the two others to the stalk of a Cellularia ternata var. gracilis.

The length of these specimens is $10 \mathrm{~mm}$.

In one of them the column is composed of 27 , in the other of 29 segments. The five proximal columnals are strongly compressed along the axis of the stem, the others being as in the preceding stages.

The crown, which is $0.75 \mathrm{~mm}$. long, shows many changes.

The radials are all united by their lateral borders. On the distal border of the $\mathrm{IBr}_{1}$, which is still very narrow, there has developed a $\mathrm{IBr}_{2}$ (axillary) which is of about the same height and width as the $\mathrm{IBr}_{1}$, and beyond it the two arms are in course of development.

The elements of the $\mathrm{IBr}$ series are very narrow and are very widely separated from their neighbors.

The arms are $0.75 \mathrm{~mm}$. long, directed upward, or sometimes more divergent, with the ends pointed and slightly bent inward, and are composed of as yet only six segments which are longer than broad, and already comparable to those of the adult in which, however, they are broader than long, especially in the proximal portion of the arms.

The dorsal portion of the brachials, of which the distal border overlaps slightly the proximal border of the brachial succeeding and is armed with minute conical points, is deep, semicylindrical, and composed of a calcareous network crowded with little rounded meshes. The two lateral portions are very thin and membranous, and the distal part of their border turned inward, or ventrally, forms a rounded flap. In the fully grown pentacrinoid and in the adult the ventral border of each brachial has two or three similar flaps.

Each of these flaps is supported by a long and slender calcareous rod or spicule situated within it, usually somewhat $\mathbf{S}$ shaped, which is directed obliquely upward and inward, and of which the end, situated near the ventral border of the segment, is a little enlarged and pierced with a larger or smaller number of small round holes. The opposite end, situated near the dorsal calcareous network, is pointed, or sometimes bifurcated. 
In free-living individuals 1.5 inches in length the same structure, composed of one or two spicules, still persists in each of the ambulacral lappets, and they are found in the pinnules of adult individuals of Antedon petasus from 3 to 4 inches in length, although here they are much reduced.

These spicules also occur in the pinnules, at least in those of the distal half of the arms, of the adult $H$. sarsii.

Along the ventral groove of the arms there are two rows of tentacles and two rows of colored vesicles (sacculi). As yet there is only one pair of these for each brachial, though in the adult there are many, usually three pairs.

The tentacles are cylindrical, with very slight equally spaced constrictions, or feebly annulated, and are furnished with minute tactile papillæ which are slender, cylindrical, and rounded at the ends.

The sacculi, situated on the outer side of the tentacles, are spherical, and opaque reddish yellow or reddish brown as in the adults. In life, however, they are colorless. On the disk there is a pair of them above the base of the $\mathrm{IBr}_{1}$.

There were four specimens taken at the beginning of March at the Guldbrand Islands, in 100 fathoms, and at Skraaven, in the Lofoten Islands, in 300 fathoms, two of which were attached to the stem of a Rhabdopleura mirabilis, the two others being affixed to the tests of rhizopods.

The largest of these has a total length of $20 \mathrm{~mm}$., of which the crown (including the arms) occupies $4 \mathrm{~mm}$. The column is composed of 38 segments. The three others are slightly smaller, from $13 \mathrm{~mm}$. to $16 \mathrm{~mm}$. in length.

As a result of the development of the digestive organs and of the soft ventral disk which covers them the calyx has become greatly enlarged, and the oral plates, now separated as a consequence of this increase in size from the much enlarged and much further developed radials, are still fairly large but seem from this time onward to become more and more reduced and rudimentary.

The form of the radials has changed considerably. The distal border, previously short and straight, has become very broad and concave to receive the base of the $\mathrm{IBr}_{1}$, which similarly has broadened. On the distal border of the radial circlet there are now to be seen five rounded-triangular interradial angles with rounded apices which project distally on the lines of the interradial sutures, and are slightly bent inwardly.

The $\mathrm{IBr}_{2}$, similarly enlarged, is almost as broad and high as the $\mathrm{IBr}_{1}$. The arms, considerably elongated, are each now composed of 14 or 15 brachials. In the largest specimen, though not in the others, the arms are bifurcated at the tip. Examining these more closely, it is found that this is in reality the first formation of the pinnules. The pinnules are still very short and filiform, being at the base about half the thickness of the arm and gradually tapering distally. They are composed of a few indefinite segments, of which the two lowest already show sacculi, which, however, are much smaller than those on the arm itself.

A pentacrinoid in a more advanced stage of development, taken in the middle of April at Skraaven in 300 fathoms, is $21 \mathrm{~mm}$. long, the crown (with the arms) measuring $4 \mathrm{~mm}$.

$142140-21-$ Bull. $82-38$ 
The column, composed of 49 segments, forms in its distal half a pronounced S-shaped curve. It is attached not only, as in most cases, by the terminal stem plate but also at two higher places, to a foreign body, a Rhabdammina abyssicola.

In another specimen at the same developmental stage there arise from the terminal stem plate some digitiform prolongations, of which two are bifurcated one or more times.

In a third, belonging to the following stage, the discoidal enlargement representing the terminal stem plate is of irregular form and incloses some sponge spicules; a few other segments in the distal portion of the column may also give rise to tubercular or digitiform processes by which they are attached to foreign objects.

The three proximal columnals have become much more flattened than previously, almost discoidal - a feature still more accentuated in the next stage.

In one of the interradial areas of the soft ventral disk, which has considerably increased in size, the anal tube has appeared. It already rises high above the surface of the disk and is cylindrical, slightly oval, or pyriform in shape. At its summit a small round dark spot indicates the position of the anus. As in the free stage the anal tube is approximately midway between the mouth and the periphery of the disk, and consequently far from the place first occupied by the primitive radianal.

Just below the base of the anal tube there are found in the skin of the disk two small rounded calcareous plates of which the lower covers with its distal border the proximal border of the upper. The two occur almost in a vertical line, as if they had been drawn out by the anal tube in the course of its development. These calcareous scales seem to be the remains of the original radianal, which as an entity has disappeared.

From the groove between the calyx and the topmost columnal cirri have begun to protrude, and, with them, the centrodorsal, to which they are attached, appears. This plate, still very uarrow or annular, increases very rapidly at the next stage. forming a basin which very soon conceals the basals.

The first cirri are five in number and radially situated. They are directed upward, lying closely upon the interbasal sutures, and are cylindrical, almost straight or slightly curved (following the contour of the surface of the basals), still smooth and unarticulated, with the tip rounded and devoid of a hook or claw. All are about of the same size, and their tips scarcely extend beyond the distal border of the basals.

The radials have not been appreciably altered.

The arms have elongated a little, and are composed of from 18 to 20 brachials. There is only a single pair of pinnules, which are longer than in the previous stage. straight, and pointed at the tips.

In another specimen, not more advanced in other respects, the five primitive cirri have become four or five times as long as in the individual just described, and are composed of seven or eight well-developed segments, of which the terminal is already provided with two claws. 
A third has the five primitive cirri still more developed and composed of 9 or 10 segments. Between two of these cirri and immediately above them there is a sixth filiform cirrus directed upward which has no distinct articular divisions and terminates in a simple conical tip, the claw not having as yet developed. This cirrus, which has appeared later than the others, is interradial; the first five always maintain their original radial position.

The fully developed pentacrinoid stage is represented by seven specimens. Of these, six were taken in March, April, and the beginning of May at Skraaven and at the Guldbrand Islands at the depths already given. They were attached to the tests of different rhizopods, to small shells, etc. The seventh is that taken by Professor Sars himself, in the middle of March, at Manger, near Bergen, in 50 fathoms, which he described in 1856.

The largest complete specimen was attached to a Crisia'denticulata. It measures $28 \mathrm{~mm}$. in total length, the crown (with the arms) being $8 \mathrm{~mm}$. long. The column is composed of 44 segments, which seem generally shorter than in the preceding stages (the longest are almost four times as long as broad), having increased considerably in thickness.

The three proximal columnals are almost discoidal, separated from each other by straight and deep constrictions, and are peculiar in that their surface shows moderately large transverse grooves, irregular, and somewhat sinuous, as if they were composed of thin transverse lamellæ. Professor Sars believes that the loose structure of these segments has to do with the detachment of the pectacrinoid from the column.

In the individual in question the two topmost columnals are the most discoidal, being two or three times as broad as long; the third is a little less broad and the fourth narrows a little toward its lower end, which is not broader than the following segments, which, as usual, are cylindrical and progressively increase in length.

All the elongated columnals show very distinctly (a fact which was difficult to appreciate in the preceding stages on account of the smallness of the object) the same structure as the columnals of Rhizocrinus. The two thickened ends are somewhat compressed laterally, so that the articular faces are more or less elliptical. On the two faces of each columnal this compression takes a direction almost at right angles, so that the longer axis of the ellipse on the distal end crosses that of the ellipse on the proximal end at an oblique angle. The compression alternates at succeeding articulations all along the column.

The articular faces show two similar large rounded fossæ, one on either side of the longer axis. These fossæ are united in the middle by the circular axial canal. The fulcral ridge, interrupted in the middle by the central canal, shows about six very small conical teeth on either side. The fossæ contain a large number of soft parallel fibrillæ, very fine and strong.

Additional cirri have appeared on the centrodorsal, so that there are now nine larger and five smaller. The longer are well developed and are composed of 10 segments, of which the distalmost, as in the free adults, is already furnished with two claws. The five smaller cirri, situated immediately above and between the 
larger in the interradial spaces, are very short, about one-fourth or one-fifth as long as the longest, and are indistinctly articulated, with the tips rounded and without claws.

The disk, with the five ambulacral grooves radiating from the mouth each near the border dividing into two branches which continue onto the corresponding arms, and the anal tube, much larger than at the preceding stage and cylindrical, more or less crenulated at the tip about the anal opening, resembles that of the free-living adult. The five orals hare been completely resorbed.

The $\mathrm{IBr}_{1}$ have increased considerably in size and thus appear shorter than in the preceding stage, being about twice as broad as long. The $\mathrm{IBr}_{2}$ are also somewhat broader, being about as broad as long.

Additional pinnules have developed, five on one side and six on the other of each arm, of which they occupy a little less than the distal half. They have become longer and more developed and are composed of a larger number of segment. The tentacles and sacculi remain as before.

On the lateral ventral border of each brachial are two rounded flaps, each of which contains as a brace a calcareous rod, as previously described.

On the outer side of the second brachial a pinnule is now in process of formation which did not exist at any preceding stage; it is still very short, scarcely longer than the width of the brachial, filiform, unarticulated, rounded at the tip, and without tentacles.

The brachials between the second and the twelfth (in one specimen the tenth) show as yet no trace of pinnules.

Already the sygyzies can be distinctly recognized between the third and fourth and ninth and tenth brachials, as in the adults.

Another specimen $22 \mathrm{~mm}$. long, the crown (with the arms) measuring $6 \mathrm{~mm}$., the column of which is composed of 37 segments, is a little less developed than the last described. The centrodorsal bears only 10 cirri, of which the five largest (the primary cirri, radially situated) are composed of eight segments; the five small cirri are situated immediately above them in the interradial angles. There are as yet only two or three pairs of pinnules on the arms.

A third individual, with the column composed of 34 segments, is $20 \mathrm{~mm}$. long, but incomplete, the 10 arms heing all more or less broken. On two of the arms there remain only the three lowest brachials. From the distal end of the third brachial (the hypozygal of the first syzygial pair) a new arm has arisen which resembles in a striking manner a young shoot grafted on a tree. It is very short and slender, only $2 \mathrm{~mm}$. long, at the base scarcely half as thick as the stump which bears it, tapering toward the tip, which is curved inward. It is composed of 11 or 12 segments and bears no pinnules, though it is already provided with tentacles and with minute sacculi, a pair for each brachial except for the last four or five, on which they are still lacking. The oral pinnule is well developed, consisting of six or seven segments.

The largest and most developed of all the pentacrinoids was that which Professor Sars described in 1856. 
The actual total length of this specimen, from which the tips of the arms and the distal portion of the column are missing, is $30 \mathrm{~mm}$.; the crown (with the arms) as preserved measures $10 \mathrm{~mm}$. Professor Sars estimates that in life the total length must have been a little over $40 \mathrm{~mm}$.

The column as preserved consists of 32 segments, of which the two just below the centrodorsal are discoidal or lamelliform, the third dish-like, and the following, as usual, cylindrical and becoming progressively elongated, being in the middle of the column from three to three and one-half times as long as broad, and swollen at the two ends. The distalmost columnals become somewhat shorter.

The centrodorsal, which, as in the adult, conceals the basals and the radials, bears from 20 to 30 cirri ( 26 in actual count) which are without any definite order.

The cirri midway between the base and the dorsal pole of the centrodorsal are the longest and the most developed, being $5 \mathrm{~mm}$. long and about 0.16 to $0.20 \mathrm{~mm}$. in breadth. Toward the pole the length diminishes to $1.5 \mathrm{~mm}$, and the marginal cirri are even less developed.

The centrodorsal thus resembles that of the adult, in which the cirri are uniformly distributed over the surface, except on the small dorsal pole, and number between 30 and 40 .

The cirri are more or less curved, especially distally, the tip being usually directed downward and slightly inward toward the column. The largest are composed of 13 segments (the number in the adults varies from 13 to 19), which are cylindrical and, excepting those immediately adjoining the centrodorsal, slightly compressed laterally; they already show the elongate form characteristic of those of the adults. The cirrals, especially in the proximal half of the cirri. where they are somewhat more slender than in the distal half, are somewhat constricted centrally; the distal end is a little broader than the proximal, and its finely denticulate dorsal border overlaps slightly the proximal end of the segment following, which gives a somewhat crenulate dorsal profile to the cirrus in lateral view. As in the adult the last segment bears a strong immovable conical pointed terminal claw, which is slightly recurved, at the base of which dorsally is the shorter and less curved, often nearly straight, opposing spine. The smallest cirri, situated about the dorsal pole, are composed of only 7 segments, but in all other respects they agree perfectly with the larger just described. Near the rim of the centrodorsal, one in each of the interradial angles of the calyx, are five cirri which are almost as long and stout as the smallest of the ordinary cirri; they are uniformly cylindrical and smooth throughout, without distinct articulation, but showing very fine transverse annular rings, and their tips are obtusely conical; in other words, they resemble the five primary cirri at an early stage. Exactly comparable cirri are seen also in the same place in the adults apparently throughout life, always few in number and of different sizes, and always occurring between the older cirri and the margin of the centrodorsal.

The $\mathrm{IBr}_{1}$ has become much broader and therefore appears much shorter. The $\mathrm{IBr}_{2}$ (axillary) has become as broad as the $\mathrm{IBr}_{1}$ and has attained its definitive, almost rhomboidal, form. 
The longest remaining portion of the more or less broken arms is $10 \mathrm{~mm}$. long, with a thickness of $0.5 \mathrm{~mm}$. at the base, and of $0.33 \mathrm{~mm}$. at the end, from which it may be inferred that the missing portion had at least the same length. This arm stump, composed of 20 brachials, bears 9 pinnules on one side and 10 pinnules on the other.

At the time of detachment from the larval column the arms of Antedon bifida bear only five pinnules, three on one side and two on the other, and $P_{1}$ is the only pinnule developed in the proximal portion.

The brachials have the same form as in the adults, but they are proportionately longer.

In Antedon bifida at the time of detachment the articulations between the brachials have not as yet become oblique.

Syzygies are present between brachials $3+4,9+10,14+15,18+19$, and $22+23$, just as in the adult. Many of the arms are broken at the first syzygy, and the radial striation of the distal articular face of the third brachial can be easily seen.

The three or four lowest pairs of pinnules are very slender and hairlike. $P_{1}$ is very long, composed of from 12 to 14 segments (in the adults of from 25 to 35 ), without tentacles, and with a few very small scattered sacculi, which, though sometimes arranged in pairs very close to ench other, form, however, only a single row.

The two or three following pinnules are scarcely half as long as $P_{1}$, which in the fully grown animal is often fully three times as long as they are.

Professor Sars finds that in the fully grown Hathrometra sarsii, more or less adult, the two pinnules on either side of the arm which immediately follow $P_{1}$ are similarly very slender, almost hairlike, without tentacles, and in certain cases even without gonads, which, like the tentacles, are not present before the fourth pair of pinnules.

$\mathrm{P}_{5}$ in the same individual has about the same length as the pinnule immediately preceding, but, like the following, it has the usual form, thick at the base and gradually tapering toward the tip. It is composed of 9 segments, and, like all those following, it is provided with tentacles and with sacculi, there being 6 pairs of the latter in two alternating rows. $P_{6}$ has 13 pairs of sacculi. Ordinarily there are on the arms 1 or 2 pairs, and on the pinnules 2 or 3 pairs of sacculi to each segment.

The following pinnules become gradually somewhat longer.

At the end of this stage the perfectly developed pentacrinoid is ready to detach itself from its column and to lead a free existence. All the essential structures of the free adults are present, although many of them are not so numerous as they will become later.

Professor Sars notes that there is, however, reason for believing that at the time of discarding the larval column the pentacrinoids are not always so perfectly developed as the specimen from Manger just described; for from March to June there were dredged among the Lofoten Islands (at the Guldbrand Islands in 100 
to 120 fathoms and at Skraaven in 200 to 300 fathoms) some very small free individuals among a large number of medium size, none of which had the gonads developed on the pinnules.

Of these small specimens the largest, which is complete, has the arms only 14 $\mathrm{mm}$. long, provided with 13 or 14 pairs of pinnules, which occur throughout their entire length from the second brachial outward. The centrodorsal has about 20 cirri.

The smallest, of which the arms are broken in their distal portion, is almost equal in size to the largest of the pentacrinoids already described from the Lofoten Islands, and a little smaller than that from Manger. The remaining portions of the arms are entirely similar to those of the latter, but on the centrodorsal there are only 15 cirri, of which the largest is only composed of 11 segments. This individual has evidently only just been detached from the column.

A third specimen, only very slightly larger than the last, still lacks some pinnules on the lower portion of the arms, though $\mathrm{P}_{1}$, which normally develops before detachment, is present.

Doctor Danielssen records that on June 9, 1876, the Norwegian North Sea Expedition dredged a pentacrinoid of this species in latitude $61^{\circ} 00^{\prime} \mathrm{N}$., longitude $4^{\circ} 49^{\prime}$ E., at a depth of 200 fathoms.

Doctor Mortensen compared directly pentacrinoids of Hathrometra sarsii and H. prolixa. While he did not find any differences of undoubted specific value in the calyx, he found that the columnals of $H$. sarsii differ conspicuously from those of $H$. prolixa in being more robust and more constricted centrally.

In addition to most of the specimens described by Professor Sars and by Doctors Danielssen and Mortensen, $I$ have examined the following:

Off southwestern Norway (lat. $58^{\circ} 32^{\prime} \mathrm{N}$., long. $4^{\circ} 18^{\prime}$ E.), 280 meters; April 30, 1903.

A number of well-developed examples.

Off southeastern Iceland (lat. $64^{\circ} 16^{\prime} \mathrm{N}$., long. $11^{\circ} 04^{\prime}$ W.), 192 fathoms.

There are about 16 columnals, most of which are greatly elongated; the terminal stem plate is slightly lobate; the radials are large, rhombic, just in contact laterally.

South of Iceland (lat. $63^{\circ} 21^{\prime} \mathrm{N}$., long. $16^{\circ} 22^{\prime} \mathrm{W}$.), 500 to 560 meters; May 26, 1905.

Two specimens; the larger has the crown about $10 \mathrm{~mm}$. long and all the pinnules developed, and is apparently ready to discard the column; the broad thin lobate column following the centrodorsal is typically developed; in the smaller the pinnules are developed from the twelfth brachial onward.

Southwest of Iceland (lat. $61^{\circ} 44^{\prime} \mathrm{N}$., long. $27^{\circ} 00^{\prime}$ W.), 485 fathoms.

Total length about $12.5 \mathrm{~mm}$.

The column consists of 35 columnals and a terminal stem plate. The nine topmost columnals are very short and discoidal, very slightly larger in diameter than those succeeding. The following increase in length to the fifteenth or six- 
teenth and following, which are from four to five times as long as broad. Those in the distal half of the stem are constricted centrally, with much swollen ends.

The terminal stem plate is coinposed of two stout tapering radicular cirri, which run out in opposite directions along a sponge spinule and give off more or less developed lateral stumps.

The sides of the calyx are nearly straight and diverge from the topmost columnal at slightly less than a right angle.

The distal border of the radial circlet is abruptly produced between the bases of the $\mathrm{IBr}_{1}$, forming rounded processes, which reach to nearly half their height and entirely occupy the spaces between them.

The radianal, long triangular with rounded angles, spans the distance between the bases of the posterior $\mathrm{IB}_{\mathrm{r}_{2}}$ and, gradually narrowing, extends to a point beyond the base of the $\mathrm{IBr}_{2}$, where it terininates in a broadly rounded apex.

The $\mathrm{IBr}_{1}$ are approximately square, with rounded corners, and occupy more than two-thirds of the distal border of the radials. The $\mathrm{IBr}_{2}$ are of about the same length, broadly shield-shaped with the proximal edges strongly convex, so as to join the center of the distal border of the $1 B r_{1}$ in a very obtuse point.

There were probably 8 or 10 brachials present.

The orals show no indication of resorption.

Southeast of Iceland (lat. $64^{\circ} 16^{\prime} \mathrm{N}$., long. $11^{\circ} 11^{\prime} \mathrm{WV}$ ), 190 fathoms.

Two specimens, both poorly preserved; in one, apparently almost fully grown, there are 26 columnals attached to the calyx, of which the two uppermost (beneath the centrodorsal) are broad and plate-like, very thin, and much broader than those following; the centrodorsal is truncated conical, the tip where it adjoins the columnal just below being not quite half so broad as that columnal. The other had probably 8 or 10 brachials.

West of Iceland (lat. $64^{\circ} 18^{\prime} \mathrm{N}$., long. $27^{\circ} 00^{\prime}$ W.), 295 fathoms.

Total length about $12 \mathrm{~mm}$.

The stem consists of 32 columnals and a broken terminal stem plate. The first eight columnals are short and discoidal; the longest are about four times as long as broad; those beyond the middle of the stem are strongly constricted centrally, with prominent swollen ends.

The sides of the calyx, which diverge at considerably less than a right angle, are straight.

The radials are about as high as the basals; the distal border of the radial circlet is produced interradially into prominent rounded angles.

The radianal is long and narrow, situated on the posterior rounded interradial angle into which the two appressed distal angles of the two posterior radials are produced, spanning the distance between the two posterior $\mathrm{IBr}_{1}$ and reaching anteriorly to somewhat beyond the base of the $\mathrm{IBr}_{2}$.

The $\mathrm{IBr}_{1}$ occupy about two-thirds of the distal edge of the radials.

The orals, which are much depressed centrally, are still in contact with the distal border of the radial circlet. 
TIIAUMATOMETRA NUTRIX.

F'igs, 1232-1237, pl. 38 .

Dr. Th. Mortensen has given a short account, to be followed later by a detailed description, of the young of this curious viviparous species.

When ready to attach themselves the larve do not leave the marsupium, but become affixed to its inner wall, at any point from near the mouth to the bottom, with the calyx and proximal portion of the column protruding through the opening. In this position they remain throughout their whole development until they are ready to detach themselves from the stalk.

In the older stages Mortensen found the distal end of the column, which lacks the terminal stem plate, regularly attached to the second or third pinnular, which is laterally broadened to accommodate it; in one case the column was attached to the articular surface between the third and fourth pinnulars, both of which were broadened.

The young pentacrinoids are very small, but in the course of their development they grow to a very considerable size.

The large pentacrinoids attached to the pinnules of the small mother give the latter a very curious appearance.

Sometimes two pentacrinoids are attached to the same pinnule. In one case these were in about the same stage of development, but in another one was a nearly full grown pentacrinoid with five cirri, while in the other the arms were just beginning to develop. This indicates that an egg may undergo development in the ovary while a pentacrinoid protrudes through the marsupial opening.

From the number of pentacrinoids found it is apparent that generally only one, and rarely two, eggs at a time are developing in the marsupium.

None of the fully grown pentacrinoids have more than one or two arms in place, but the cirri are well preserved and show that at least 10 are developed before the young crinoid detaches itself from the stalk.

Figures given by Mortensen show that at the stage in which one or two brachials beyond the $\mathrm{IBr}_{2}$ (axillaries) are present the column consists of five or six short columnals, without a terminal stem plate.

A large pentacrinoid has the column composed of 10 columnals and a centrodorsal but without a terminal stem plate. The three columnals immediately beneath the centrodorsal are short and discoidal, progressively decreasing in diameter; the next is about as long as broad; the seventh-ninth beyond the centrodorsal are the longest, though they are not more than half again as long as broad.

The centrodorsal as shown bears 7 cirri, 5 of which, radial in position, are large and composed of 10 segments, while the others, interradial in position, are rudimentary.

?THAUMATOMFTRA, SP.

Fig. 1214, pl. 34 .

On October 18, 1873, off Tristan da Cunha (lat. $37^{\circ} 21^{\prime} 00^{\prime \prime}$ S., long. $12^{\circ} 21^{\prime} 30^{\prime \prime}$ W.), in 1,000 fathoms, the C'hallenger dredged three pentacrinoid larvæ, but no corresponding adults. 
The figure given by Carpenter shows a crown $3.5 \mathrm{~mm}$. long, which closely resembles that of the species of Ilathrometra in the corresponding stage. The basals are high and the radials very wide, while the $\mathrm{IBr}_{1}$ and $\mathrm{IBr}_{2}$ are relatively long and narrow, though a considerable number of brachials is developed beyond them. There are no traces of an ambulacral skeleton.

There appear to be six very short discoidal columnals immediately beneath the calyx. From the ninth onward the columnals are greatly elongated, with the median annulus prominent.

The orals, shaped like those of the species of Hathrometra, are relatively small.

There is little doubt that this pentacrinoid is the young of a species of Thaumatometra, an abyssal genus closely related to Hathrometra.

\section{DOUBTFUL SPECLES.}

In 1901 Professor Ijima recorded that a small stalked crinoid was taken from the carapace of a specimen of the giant crab (Macrocheira kaempferi) caught in Sagami Bay.

Wishing if possible to obtain some clue as to what this small stalked crinoid might be I wrote to Prof. H. Matsumoto, of Sendai University (then of the Imperial University at Tokyo), and from him I received the following letter:

I have examined Professor Ifima's crinoid. The unique specimen represents the pentacrinoid stage of a comatulid, which may possibly be a Psathyrometra, though belonging to a species as yet unknown.

Description.-Column $17 \mathrm{~mm}$. long, composed of 32 segments, which are elongated and "dice-box shaped" except for the proximal 6 , which are very short and discoldal.

Cirrl $X$ in number, arranged in two (a radial and an interradial) circlets, $3 \mathrm{~mm}$. long, composed of 10 or 11 segments which are elongated, "dice-box shaped," wider distally than proxlmally. All the clrrus segments are longer than wide, the third-fifth being the longest; the dlstal edges of the segments are produced and overlap the bases of the succeding; there are no dorsal spines; the opposing spine is minute, terminaliy situated; the terminal claw is long and stout. In addition to these 10 clrri there is a very rudimentary one, radially situated.

Basals just visibie, triangular.

Radials well developed, forming a complete ciosed circlet. Their external surfaces are very rough, and there is a row of spines along their dlstal margins.

Elements of the $\mathrm{IBr}$ series narrow and widely separated.

$\mathrm{IBr}_{1}$ narrower distally than proxlmally, the surface very rough, the lateral and distai margins armed with prominent spines. Axillaries rhomboidal, ionger than broad, with very rough surfaces, and with especially prominent spines on the lateral borders and along the distal edges.

Arms, 10 in number, about $10 \mathrm{~mm}$. long; brachials longer than broad, "dice-box shaped," the first four or five with rough surfaces, the spines being especially prominent along the dorsal slde; fifth-fourteenth brachiais with a very prominent spine on the distal border in the median line.

Syzygies occur between the third and fourth, eieventh and twelfth (or ninth and tenth). slxteenth and seventeenth, and twentieth and twenty-first brachials.

$P_{1}$, on the second brachial, as yet rudimentary, $0.7 \mathrm{~mm}$. iong, composed of three or four much elongated segments with rough surfaces. The first and second segments are about twlce as long as broad, "dlce-box shaped"; the third segment is half again as long as hroad; the 
pinnules of the third-thirteenth brachials have not as yet appeared; the pinnule on the fourteenth brachial is $2.5 \mathrm{~mm}$. long and is composed of nine segments, of which the first and second are twice as long as broad, "dice-box shaped," and the third-sixth much elongated, four times as long as broad, with both ends expanded. The distal third of the seventh segnent, as well as of the following segments, has a series of denticles along the ventral median line, forming an arm comb. The ends of all the segments are serrate. The following pinnules are essentially similar.

Color in alcohol, white.

Collected off Adawara, Sagami Bay, on July 30, 1895, by Professor Ijima.

SUMMARY.

As in the case of the adults the pentacrinoids of the comatulids are all formed upon the same general plan, but this plan admits of great variation in details.

Size.-The total length and the length of the crown of the pentacrinoids differs greatly, as is shown by the following table:

Promachocrinus kerguelensis

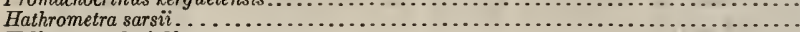

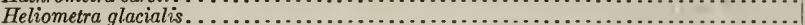

Hathrometra tenella.

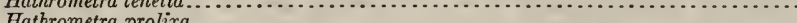

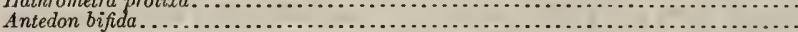

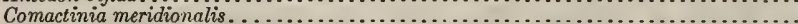

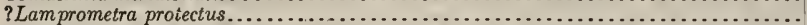

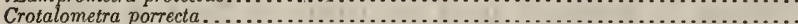

Ptilometra mülleri.

\begin{tabular}{c|c|c}
\hline & $\begin{array}{c}\text { Total } \\
\text { length. }\end{array}$ & Crown. \\
& & \\
& $m m$. & $m m$. \\
$\ldots .$. & 65.0 & 12.5 \\
$\ldots .28$ & $21-25$ & $4-8$ \\
$\ldots .$. & 22.5 & $5-7$ \\
$\ldots .$. & $18+$ & 5.3 \\
$\ldots .$. & 18.0 & 11.0 \\
$\ldots .$. & $13+$ & 10.0 \\
$\ldots .$. & 3.5 & 3.0 \\
& 3.3 & $5.8+$ \\
\hline
\end{tabular}

Whereas the records just given are for pentacrinoids of approximately full size, the following are of pentacrinoids in various younger stages:

Glyptometra tuberosa

Antedon petasus..

Leptometra celtica.

Compsometra lovéni.

\begin{tabular}{r|r}
$\begin{array}{r}\text { Total } \\
\text { length. }\end{array}$ & Crown. \\
\hline$m m$. & $m m$. \\
6.0 & 1.8 \\
6.0 & 2.0 \\
2.7 & \\
2.0 &
\end{tabular}

From these figures it would appear that the length of the fully grown pentacrinoid in the Macrophreata ranges from 18 to $65+\mathrm{mm}$., the range in the Oligophreata being from 3.3 to $15 \mathrm{~mm}$.

Were it not that Crotalometra porrecta is a deep-water type and that Hathrometra tenella occurs in 25 fathoms or less, it might be supposed that the length of the column increased with depth; and were it not that Antedon inhabits water quite as cold as that inhabited by Hathrometra tenella and $H$. sarsii, it would seem that the colder the water the longer the column. 
It must be remembered that in those macrophreate species in which the larvæ develop within a marsupium the column of the pentacrinoids is short, as in the Oligophreata.

The percentage of the total length represented by the crown varies very greatly, as is evident from the following table:

\begin{tabular}{|c|c|c|c|}
\hline & Per cent. & & Per cent. \\
\hline 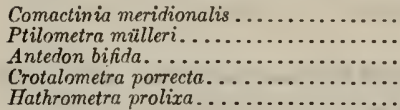 & $\begin{array}{l}\text { 66. } 6 \\
63.6 \\
61.1 \\
46.6 . \\
29.4\end{array}$ & 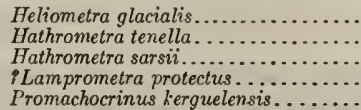 & $\begin{array}{r}23.8-28.0 \\
23.5-26.6 \\
19.0-28.6 \\
23.1 \\
19.2\end{array}$ \\
\hline
\end{tabular}

From these figures it appears that in the Oligophreata the columns of the pentacrinoids are relatively much shorter than in the Macrophreata, ranging from 46.6 to 66.6 per cent of the total length, as against 19.2 to 29.4 per cent in the latter. Of the two exceptions to this generalization (outside of the forms in which the young develop within a marsupium) one, Antedon, is an anomalous type, with many oligophreate features, while the figures for the other, ?Lamprometra protectus, are of doubtful value.

Column.-In all of the comatulid larvæ the stems are of exactly the same type. At the summit there are a few discoidal or lenticular, very short, segments, usually decreasing slowly in diameter, after which the columnals, becoming cylindrical, rapidly increase in length, at about the middle of the stem becoming constricted centrally with expanded ends, the articular faces of which, oval in outline, are at right angles on the two ends of each columnal, and toward the distal end becoming shorter again.

The larval column of the comatulids is the exact counterpart of the very young sections of the pentacrinite stem, if we assume one of the lowest of the pentacrinite nodals to be replaced by the comatulid terminal stem plate, and with the column of Thiolliericrinus. It differs from that of the Bourgueticrinidæ, aside from the development of the proximale into a cirriferous nodal, in lacking the occasional union of the columnals in syzygial pairs. which is so conspicuous a feature of the younger portion of the column in the recent types.

The number of the columnals in the pentacrinoids of the comatulids is as follows :

\begin{tabular}{|c|c|}
\hline & \\
\hline$-40-49$ & \\
\hline $37-45$ & \\
\hline $33-35$ & \\
\hline $33+$ & C'or \\
\hline 32 & \\
\hline $28-30$ & Leptor \\
\hline 27 & Glyptometra tuberosa \\
\hline - & Ptilometra mülleri \\
\hline omanthus wahlbergii & ietra nutrix_. \\
\hline
\end{tabular}


The proportions of the longest columnals vary considerably; in general it may be said that the more numerous the columnals the longer they are. The relation of length to breadth in the longest columnals is shown in the foilowing table :

\begin{tabular}{|c|c|}
\hline $\begin{array}{l}\text { ra tuberosa } \\
\text { tra prolixa }\end{array}$ & Comactinia \\
\hline Promachocrinus kerguelensis _... & $\begin{array}{l}\text { Comactinia meridionalus } \\
\text { Heliometra glacialis }\end{array}$ \\
\hline Anthometra adriani_........... & Compsometra lovéni_.... \\
\hline Hathrometra tenella___. & Antedon petasus._. \\
\hline QLamprometra protectus__. & Crotalometra porrecta \\
\hline Antedon bifida & 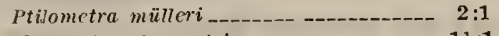 \\
\hline Hathrometra sarsii & Thaumatometra \\
\hline
\end{tabular}

From the figures it appears that, in general, the species belonging to the Macrophreata have more numerous and longer columnals than those belonging to the Oligophreata.

The number of short discoidal or lenticular columnals following the centrodorsal shows considerable diversity, but the available figures are unsatisfactory for comparative purposes.

At first, when the column is increasing very rapidly in length, these columnals are relatively few, usually only 1 or 2 ; just before the formation of the centrodorsal the number of new columnals formed beneath the calyx is continued as before, but the development of these new columnals is greatly retarded; hence at the time of the first appearance of the centrodorsal the number of short discoidal or lenticular columnals at the summit of the column is relatively large. As the centrodorsal grows the short columnals beneath it slowly increase in length, so that at the time the animal is ready to discard the larval column the number of those still discoidal or lenticular is usually reduced to 3,2 , or even 1 .

Most of the following figures are from specimens the exact comparative age of which is unknown:

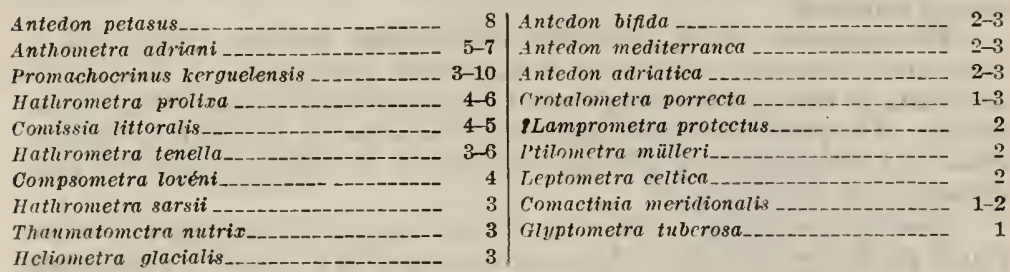

No exact statement is possible, but the indications are that the short discoidal or lenticular columnals are more numerous in the Macrophreata than in the Oligophreata, as would be expected from the longer and more numerously jointed stems of the former. 
The columnal immediately following the centrodorsal is always attached to the latter by a so-called stem syzygy. It may be either of nearly the same or of lesser diameter than the centrodorsal, as in

Comactinia meridionalis.

Comissia littoralis.

PLamprometra protectus.

Ptilometra mülleri.

Crotalometra porrecta.

Glyptometra tuberosa.
Antedon petosus. Antedon bifida. Antedon mediterranea. Antedon adriatica. [?Heliometra glacialis]. Anthometra adriani.

\section{Thaumatometra nutrix.}

or it may be broader than the centrodorsal, as in

Promachocrinus kerguelensis.

Hathrometra prolixa.

Hathrometra tenella. Hathrometra sarsii.

In the species in which the columnal following the centrodorsal is of greater diameter than the centrodorsal it is always more or less strongly lobate, the lobes being directed interradially. It may remain in the condition of a flat pentalobate plate, or the lobes may thicken and form considerable inclusions in the central portion of the lower margins of the basals, appearing like a second circlet of small basals oriented as the first.

In all of these species the centrodorsal is conical, tapering to a more or less sharp point. It appears to arise as a minute calcareous ring between the middle of the basal circlet and the following columnal, which, receiving additions only on its proximal side, gradually takes on the form of a cone and grows to a considerable size before its increasing length finally separates the following columnal from the basals and reveals it as a small cone, with the base upward, connecting the center of the basal ring with the center of the much broader following columnal.

The first cirri are formed as soon as the basals become separated from the second columnal, and this led Professor Sars to state that in Hathrometra sarsii the first cirri arise from a slit between the calyx and the topmost (in reality the second) columnal.

The appearance of the proximale, always firmly attached to the calyx by close suture, indicates the maturity of the column in the group of crinoids, the Articulata, to which all the recent forms belong, with the exception of the Plicatocrinidæ. The proximale may be larger than the following columnals, as in A piocrinus and Bathycrinus, of the same diameter, as in Phrynocrinus, or of lesser diameter, as in Rhizocrinus.

From the contrasting conditions in Bathycrinus and Rhizocrinus it is evident that in the Bourgueticrinidæ we have conditions parallel to those in the comatulids, in some genera the proximale (the homologue of the centrodorsal) being larger, and in others smaller, than the following columnal.

Terminal stem plate.--In the pentacrinoid larvæ of the comatulids the terminal stem plate takes a number of more or less distinct forms. In the very young it is always circular; from this circular type a lobate form develops, and the lobes may elongate into five regular tapering processes, or may develop very irregularly into a group of digitiform extensions which are in reality radicular cirri, and which 
may be supplemented by the appearance of additional radicular cirri on the long axes of some of the immediately preceding columnals and of sporadic attachments elsewhere.

In the different species the development of the terminal stem plate may cease anywhere between the extremes mentioned; but it always follows the same course in every individual, no matter what the species.

The terminal stem plate is absent in Thaumatometra nutrix, in which species the distalmost columnal attaches itself to an expansion of the distal end of a pinnular.

The terminal stem plate is circular or slightly lobate in

Comactinia meridionalis.

Comissia littoralis.

Ptilometra mülleri.

Crotalometra porrecta.

[?Glyptomctra tuberosa].
Antedon petasus. Antedon bifida. Antedon mediterranea. Antedon adriatica. Compsometra lovéni.

Leptometra celtica.

It is deeply stellate with five long tapering extensions in Promachocrinus kerguelensis.

It is strongly digitiform in Hathrometra prolixa and Hathrometra tenella.

It is strongly and irregularly digitiform, more or less completely transformed into radicular cirri, and supplemented by true radicular cirri and extra attachments in Heliometra glacialis and Hathrometra sarsii.

From this it would appear that the development of the terminal stem plate is correlated with the length and slenderness of the column.

Attachment.-The larræ of the comatulids show great diversity in their choice of objects to which to attach themselves. They fall in this respect into two main groups-(1) those which will attach themselves to almost anything, and (2) those which will attach themselves only to large individuals of the same species. These latter again fall into two groups- $(a)$ those which will attach themselves only to the cirri, and $(b)$ those which will attach themselves only to the pinnules.

The pentacrinoids of the following species are found attached to various objects :

Tropiometra macrodiscus.

Tropiometra picta.

Crotalometra porrecta.

Glyptometra tuberosa.

Antedon petasus.

Antedon bifida.

Antedon moroccana.

Antedon mediterranea.

Antedon adriatica.
Compsometra serrata.
Compsometra lovéni.
Leptometra celtica.
* Heliometra glacialis.
Promachocrinus kerguelensis.
Anthometra adriani.
Florometra serratissima.
*Hathrometra prolixa.
Hathrometra tenella.

Hathrometra sarsii.

The two species marked with an asterisk $\left({ }^{*}\right)$ are also found attached to the cirri of larger individuals. 
The objects to which these pentacrinoids attach themselves, or at least upon which they will survive after attachment, are circumscribed by certain economic considerations-(1) a free circulation of pure well aerated water must be assured, and (2) there must be an adequate food supply.

Thus in shallow water mobile arborescent organisms, such as hydroids and bryozoans and seaweeds of all sorts, particularly laminarix, are usually chosen. In an aquarium the larvæ will attach to practically anything, even the glass walls, but in the sea the young of littoral types are only very exceptionally found on dead objects.

Lo Bianco has noticed that in the echinoderm tank at the Stazione Zoologica at Naples the pentacrinoids of Antedon mediterranea, in different stages up to about $7 \mathrm{~mm}$. in length, are almost always found attached to the walls of the aquarium or to old branches of gorgonians and antipatharians; these do not develop further, possibly, he suggests, through lack of nutriment.

In the sea he found pentacrinoids of the same species in all stages up to the fully grown ready to discard the stem on the firmer algæ (Sargassum, Halymeda, and Codium) and on different branched organisms dredged where the crinoid lives.

In deeper water, where the aeration is more uniform and the food supply less subject to local fluctuations, while the arborescent organisms, particularly the hydroids, are still the usual objects of attachment, the pentacrinoids are often found on bivalve molluses, barnacles, and other organisms (there is one record of a pentacrinoid on the carapace of a crab), and on foraminifera, and the spicules and skeletons of dead sponges and other animals.

So far as I am aware no pentacrinoids have ever been found attached to stones. This, however, is probably due to the fact that in water sufficiently pure and with a sufficiently high food content for young crinoids the ocean bottom is more or less completely covered with a growth of other organisms.

The pentacrinoids of the following species are found attached to the cirri of more or less fully grown specimens:

Comissia littoralis.

Comissia hartmeyeri.

Comactinia meridionalis.

Comanthus wahlbergii.
Leptometra phalangium.

* Heliometra glacialis.

* Ilathrometra protixa.

Isometra vivipara.

In the two species marked with an asterisk $\left({ }^{*}\right)$ the pentacrinoids are also found attached to other objects, and their attachment to the cirri of the fully grown appears to be more or less a matter of chance; that is to say, they will attach themselves to any suitable object, whether it be the cirrus of an adult or any other support.

But in the case of the other six attachment to the cirri of larger animals of the same species appears to be the invariable rule, and in these they are attached not to all of the cirri or to any of the cirri indiscriminately, but always to certain of the longest peripheral cirri which are not used for gripping the object to which the foster parent is fixed, but are raised upward toward or between the arms so that the crowns of the pentacrinoids appear on the ventral surface standing up between and above the pinnules. 
In the two following species the pentacrinoids are attached to the pinnules: Ptilometra mülleri. Thaumatometra nutrix.

In Ptilometra mülleri the attachment is by means of a circular terminal stem plate; but in Thaumatometra nutrix, where the embryos are retained within a marsupium and there pass through all the larval stages, there is no terminal stem plate, the distal end of the larval column becoming attached to the expanded distal end of a pinnular.

It is interesting to note that in Ptilometra mülleri all, and in Comactinia meridionalis most, of the pentacrinoids have been found attached not to fully grown specimens of the same species, but to partially grown individuals, apparently as a result of successive swarms of larvæ drifting away from the original parent mass.

Cirri.-The developmental stage at which the cirri first appear varies' considerably.

The first pinnules are formed simultaneously with the brachials which bear them-that is to say, the ninth-twelfth.

The cirri appear before the pinnules in

Comactinia meridionalis.

Ptilometra mülleri.

Crotalometra porrecta.

Antedon bifida.

Antedon mediterranea. Antedon adriatica.

Thaumatometra nutrix.

The cirri appear simultaneously with the pinnules in Antedon petasus.

The cirri appear after the pinnules in

PLamprometra protectus.

Heliometra glacialis.

Promachocrinus kerguelensis.

IIathrometra prolixa.

Hathrometra tenella.

Hathrometra sarsii.

Thus in those species in which the column is long and slender and composed of a relatively large number of segments the cirri are later in making their appearance than in those species in which the column is short and stout and composed of few segments.

The first five cirri to appear are interradial in Antedon bifida.

The first five cirri to be formed are radial in

Comactinia meridionalis.

\$Lamprometra protectus.

Ptilometra mülleri.

Crotalometra porrecta.

Antedon petasus.

Heliometra glacialis.
Promachocrinus kerguelensis.

Anthometra adriani.

Hathrometra prolixa.

Hathrometra tenella.

Hathrometra sarsii.

Thaumatometra nutrix.

The interradial appearance of the first cirri in Antedon bifida, attested both by W. B. Carpenter and M. Sars, is difficult to understand, especially in view of their radial appearance in the closely related $A$. petasus.

As has already been explained, the first cirri to be formed approach nore or less a generalized type, but the later cirri of the pentacrinoids always show all of the essential characteristics of the adults.

The figures for the number of cirri developed at the time of the casting of the column are unsatisfactory, but it appears to vary between 10 or 12 and 20 $142140-21-$ Bull. $82-39$ 
or more. It is largest in the species with conical centrodorsals, the species of Heliometra, Promachocrinus, Anthometra, and Hathrometra, in which also the crown is most developed at the end of the pentacrinoid stage, and in which the length of the larval life appears to be longest.

Infrabasals.-Unless sufficient material is available representing the very early stages, which is very rarely the case, the presence or absence of infrabasals in pentacrinoids is very difficult to determine.

There are five infrabasals in

Ptilometra mülleri.

\section{Promachoorinus kerguelensis.}

Antedon adriatica.

There are three infrabasals in Antedon mediterranea.

There are no infrabasals in

Comactinia meridionalis.

Antedon bifida.

Antedon petasus.

Hathrometra prolixa.

Heliometra glacialis.

The presence or absence of infrabasals has not been definitely determined in Comissia littoralis.

?Lamprometra protectus.

Crotalometra porrecta.

Glyptometra tuberosa.

Hathrometra sarsii.

Compsometra lovéni.

Leptometra celtica.

Anthometra adriani.

Hathrometra tenella.

Judging from the figure given by P. H. Carpenter there would appear to be large infrabasals present in Leptometra celtica; such an interpretation, however, is open to question.

Basals.-The basals exhibit relatively little variation.

In the Oligophreata and in Antedon the basal cup is relatively broad from its first appearance, while in the Macrophreata it is narrower and appears elongated, being about as long as its distal diameter. In the later stages this difference usually disappears.

At first all the basals are of the same size and symmetrical, but in the later stages the left distal border of the posterior basal becomes longer than the right. The difference is usually not marked, but in Anthometra adriani it is very pronounced, the left distal side of this basal being from half again to twice as long as the right.

The condition of the basals at the time of the loss of the column varies greatly, being correlated with the comparative state of development of the crown in other respects. In those species in which separation from the larval stem occurs relatively early when only a few cirri are developed on the centrodorsal the basals are still of considerable size and very noticeable in an external view, while in those species in which the crown is well advanced and numerous cirri and pinnules are developed they are completely concealed by the centrodorsal.

Radials.-The development of the radials follows the same course in all types.

There is a great difference in the relative time at which the two posterior radials come into contact beneath the radianal, but this is dependent upon the development of the latter and is only secondarily an attribute of the radials. 
In the species which as adults have the division series broad and stout, as for example Crotalometra porrecta, the articular facet on the distal border of the radials increases very rapidly in width, correlatively with the increase in width of the $\mathrm{IBr}_{1}$ and $\mathrm{IBr}_{2}$, and occupies almost or quite the entire width of the radial at a relatively early age. In the species in which the division series are narrow and widely separated in the adults the widening of the articular facet takes place very slowly.

Radianal.-The course of development of the radianal, always present in the pentacrinoid young of the comatulids, is the same in all species, but it varies very greatly in the time of its first appearance, and hence in the proportion of the course as a whole which it covers in the different types.

The radianal is the first plate of the radial series to appear in Comactinia meridionalis and in Promachocrinus kerguelensis.

It appears simultaneously with, or possibly slightly before, the right posterior radial in Hathrometra prolixa.

It appears when the radials are almost in contact in Hathrometra sarsii.

It does not appear until the period of the development of the $\mathrm{IBr}_{2}$ in Antedon bifida, Antedon mediterranea, and Antedon adriatica.

It has been observed, but its history is not known, in Comissia littoralis, ?Lamprometra protectus, Antedon petasus, Heliometra glacialis, Anthometra adriani, and Hathrometra tenella.

The only pentacrinoids of the following which have been studied were too young to show it: Compsometra lovéni, Leptometra celtica.

In the description of the pentacrinoids of the following species the radianal was not mentioned: Ptilometra mülleri, Crotalometra porrecta, and Glyptometra tuberosa.

At first the radianal lies in the angle where the posterior and right posterior orals and basals join, just to the left of the right posterior radial plane and mostly below the plane of division between the orals and the basals, being accommodated by a slight cutting away of the right distal angle of the posterior basal.

The right posterior radial, appearing almost immediately after the radianal and just to the right of it in the same transverse plane, grows much more rapidly, and the result of its increase in size is to shove the radianal along the distal edge of the posterior basal to the left, though the presence of the radianal prevents the development of the right posterior radial toward the left, this side being cut away in a broad curve about the right half of the radianal.

As the radials increase in size, as rhombic plates, the lateral distal angles of the basals become more and more broadly cut away until finally the distal borders of the basals, instead of being straight and lying in a plane at right angles to the dorsoventral axis, are resolved into two straight lines running obliquely upward and inward and meeting in the center at an obtuse angle.

With the further growth of the right posterior radial the radianal moves along the right distal edge of the posterior basal, outward (to the left) and at the same time upward, its center remaining on the same transverse plane as the center of 
the right posterior radial, until its left border comes to lie over the median apex of the posterior basal, and therefore near the right lateral angle of the left posterior radial.

From this point the course of the radianal is almost directly upward, and as it passes upward the proximal portion of the right posterior radial rapidly extends itself along the edge of the posterior basal beneath it, finally reaching the right lateral angle of the left posterior radial and entirely excluding the radianal from contact with the posterior basal.

When the posterior radials have become completely joined so that the posterior interradial section of the radial circlet does not differ from the other interradial sections, the radianal is seen to lie upon the surface of the ventral perisomic disk at the base of the anal tube, with the greater part of its area to the right of the posterior interradial suture, and with its posterior (proximal) border usually just in contact with the distal border of the radial circlet.

The radianal may be resorbed in this position, or it may move slightly farther outward.

No matter at what stage the radianal is first formed it always follows the same course, and in those cases in which it appears when the radials are almost in contact, or even after the complete closure of the radial circlet, its behavior is the same as if it had been present before the appearance of the right posterior radial.

The radianal is of much slower growth than the other plates of the crown, and is always distinguished from them by a much finer structure.

Interradials.-The presence of interradials has been determined in the pentacrinoids of four species of comatulids, in which they occur in two very different forms.

Interradials are formed on the distal border of the radial circlet in Comactinia meridionalis, Comissia littoralis, and in Antedon bifida.

In Comactinia meridionalis and in Comissia littoralis they first appear when the radials have almost come into contact, at about the time of the formation of the $\mathrm{IBr}_{1}$, as small plates in the triangular space above the approximated lateral angles of the radials and below the proximal borders of the orals. They grow rapidly into conspicuous rhombic plates the distal borders of which are on a level with the bases of the $\mathrm{IBr}_{1}$.

In Comactinia meridionalis, as the space between the proximal border of the orals and the distal border of the radial circlet increases additional interradials appear, so that there may be as many as five or six, which grade into the perisomic plates of the disk.

The further development of the interradials in Comissia littoralis is not known.

In many of the Comasteridæ (for instance, in Comanthina schlegelii and in certain large species of $C$ omaster) the dorsal interradial areas as far as the edge of the disk are occupied by a solid calcareous plating, which often is of considerable thickness. It is possible that this is a development from the larval interradials which have been retained.

In Antedon bifida the interradials are very rudimentary and not always present; they appear at about the time of the formation of the $\mathrm{IBr}_{2}$ and appar- 
ently are soon resorbed, though it is possible that they develop into the cluster of interradial plates often found between the $\mathrm{IBr}_{1}$ in the adults.

Interradials incorporated in the radial circlet are found in Promachocrinus kerguelensis and similarly in the species of Thaumatocrinus, although the pentacrinoids of this latter genus are not known.

In Promachocrinus the interradials appear first, after the radial circlet has been completely closed for some time, as narrow triangles on the distal apices of the basals. Rapidly extending themselves distally, they soon come to separate the radials as very narrow interradial plates, resting upon the truncated distal angles of the basals, which widen rapidly and from the middle of the distal edge give off a $\mathrm{IBr}_{1}$ and $\mathrm{IBr}_{2}$ followed by brachials, which exactly resemble the same plates following the radials, but are much smaller.

In postpentacrinoid growth these interradials and the arms which they bear grow somewhat more rapidly than the radials and the postradial series beyond them, so that when the full size is reached the animal possesses 10 radials and 20 arms which are indistinguishable one from the other.

There can be no doubt that the five additional radials and the five additional arms of Thaumatocrinus are formed in exactly the same way, and it is likewise probable that in six-rayed specimens of other species the sixth ray (almost invariably inserted behind the left posterior) has the same origin.

It is a very curious fact that in the young of Promachocrinus often no, or only one, interradial is developed, so that five and six rayed specimens are very common, though apparently these never attain full size.

It is not absolutely certain that the interradials of Promachocrinus and of Thaumatocrinus are homologous with those of the young of Comactinia, Comissia, and Antedon; but the so-called anal $x$ in certain fossil types, from which a series of ossicles arises, appears to be a connecting link between them.

Arms.-The arms do not differ appreciably in structure in the different types. Almost from the first, however, the relative slenderness or robustness of the postradial series of the adults is forecasted.

Pinnules.-The pinnules from their first appearance essentially resemble the definitive form.

The distal pinnules, from the ninth to the twelfth or even the fourteenth brachials onward, are the first to appear, followed by the pinnule on the second brachial $\left(\mathrm{P}_{1}\right)$ and, considerably later, by the pinnules on the intervening brachials.

The relation between the development of the pinnules and the development of the cirri has already been discussed.

In some forms, as in Antedon, the pinnule on the second brachial develops when only two or three pairs of distal pinnules are present. In others, as in Hathrometra, it derelops much later.

In the following species all the pinnules are present at the time of detachment from the larval column:

Heliometra glacialis.

Promachocrinus kerguelensis. Mathrometra protixa. Hathrometra tenella.

\section{Hathrometra sarsii.}


But in the following only the pinnules beyond the ninth-twelfth brachial and that on the second brachial are present:

Comactinia meridionalis.

Ptilometra mülleri.
Antedon bifida.

Antedon meditcrranea.

\section{Antedon adriatica.}

Side and covering platcs.-From their first appearance the side plates and covering plates of the pentacrinoids resemble very closely those of the adults.

In Promachocrinus kerguelensis side plates and covering plates accompany the $\mathrm{IBr}_{1}$ and $\mathrm{IBr}_{2}$, as well as the brachials and pinnulars. In Antedon petasus, and probably also in many other species, they accompany the $\mathrm{IBr}_{2}$.

In the pentacrinoids of the following species the side plates and covering plates (usually in the form of side plates with incompletely differentiated covering plates) are large and conspicuous:

Crotalometra porrecta.

Glyptometra tuberosa.

Heliometra glacialis.

Promachocrinus kerguelensis.

They are moderately large in Antedon petasus; they are very rudimentary and delicate, and usually very narrow, consisting of a few rods arranged in a loose meshwork in

Comactinia meridionalis.

Comissia littoralis.
Antedon bifida.

Antedon mediterranea.

Antedon adriatica.

they are reduced to slender rods which may be branched in

Hathrometra prolixa.

Hathrometra sarsii.

they do not occur in Anthometra adriani; and they have not been noticed in Ptilometra mülleri.

Orals.-While the outline of the orals is always triangular, so that when they are closed together they almost or quite conceal the mouth, their surface shows considerable diversity of configuration.

In the very young the orals are always spherical triangles, more or less strongly curved inward in the outer portion.

Subsequent addition to their free lateral borders takes place so rapidly that if the original plan of a spherical triangle were maintained they would soon come to overlap; therefore the edges as they form turn outward more or less abruptly, according to the difference in the increase of the surface of the orals as a whole as compared with the increase in the surface of the disk.

If the growth of the orals is comparatively slow the eversion of the edges makes only a small angle with the surface of the original spherical triangle, as in Comactinia meridionalis; but if it is relatively rapid the new calcareous deposit is abruptly everted, so that it is laid down in planes which include the dorsoventral axis of the animal, as in IIathrometra prolixa. 
As the lateral borders of the orals are extended (this extension always increasing in amount distally) they may maintain contact beyond the distal apex of the original spherical triangle, so that from this apex there gradually arises a rounded or sharp keel, as in Comactinia moridionalis and in Hathrometra prolixa; or the two sides may increase independently in such a way as to leave a narrow notch between them resting on the apex of the spherical triangle, which is eventually filled by a plane or nearly plane deposit which, growing distally into a rounded point, forms a rhombic flattened area between the everted lateral areas and touches with its proximal apex the distal apex of the original spherical triangle.

In the following species the orals appear to be spherical triangles:

\section{Ptilometra mülleri.}

The orals are slightly depressed in a triangular area extending from the proximal border as a base to a point a greater or lesser distance below the tip as an apex in

Comactinia meridionalis.

Comissia littoralis.

Antedon petasus.
Antedon bifida. Antedon mediterranea. Antedon adriatica.

\section{Compsometra lovéni.}

The orals are deeply depressed in the basal triangular portion, with the lateral portions abruptly and strongly everted and meeting over the distal apex of the former in a more or less well-marked keel, in

? Lamprometra protectus.

Leptometra celtica.

Heliometra glacialis. Hathrometra prolixa.

\section{Hathrometra sarsii.}

In a triangular area extending from the proximal border as a base to a point on the median line midway between the base and the tip as an apex, the orals are depressed, a rhombic area including the tip and resting with its proximal apex upon the distal apex of the former is flat or only slightly curved, and the sides are more or less strongly everted in

Promachocrinus kerguelensis. Anthometra adriani.

Though the different type of orals are, when typically developed, very distinct, there is more or less intergradation between them.

Perisomic plating of the disk.-In the pentacrinoids of certain species when, as a result of the rapid increase in the size of the disk, the outer edges of the orals draw away from the radial circlet, exposing a constantly widening ring of perisome, this perisomic ring as fast as it appears is occupied by perisomic plates which form a complete pavement between the outer borders of the orals and the radial circlet; but in most species this area remains unplated. These perisomic plates only appear in species in which interradials are developed, and they represent a distal extension, becoming smaller and more and more irregular, of the interradial series. 
A complete perisomic plating is found in Comactinia meridionalis, Comissia littoralis, and in the recently detached young of Thaumatocrinus renovatus and Pentametrocrinus, sp., while the exposed perisome is unplated in

\&Lamprometra protectus.

Ptilometra mülleri.

Crotalometra porrecta.

Antedon petasus.

Antedon bifida.

Antedon mediterranea.
Antedon adriatica.

Heliometra glacialis.

Promachocrinus kerguelensis.

Anthometra adriani.

Hathrometra prolixa.

Hathrometra tenella.

\section{Hathrometra sarsii.}

In the adults of all of the comatulids the perisome of the disk contains spicules and concretions which are usually quite invisible to the unaided eye, though they sometimes take the form of plates of considerable size, and indeed in the family Calometridæ and in certain species of the genus Eudiocrinus the visceral mass is completely inclosed in a rigid calcareous parement.

There is no evidence that these calcareous deposits are in any way connected with the larval perisomic plating of the disk, which in the four types in which it has been demonstrated completely disappears long before the full size is reached.

Spicules of the tentacles.-Almost from their first appearance the tentacles contain long more or less curved and knobby calcareous rods of various sizes (part 1 , pl. 6 , figs. 559, 563):

\section{HYBRIDS BETWEEN CRINOIDS AND ECHINOIDS.}

Dr. Emil Godlewski, jr., working at the Stazione Zoologica at Naples, fertilized with spermatozoa from Antedon mediterranea the eggs of Echinus microtuberculatus de Blainville, Paracentrotus lividus (Brandt) and Spharechinus granularis A. Agassiz. This was found to be possible when the alkalinity of the sea water was raised by the addition of $0.75-1.25$ c. c. $\frac{\mathrm{n}}{10}$ (caustic soda). In his experiments all precautions were taken in order to avoid the possibility of error through the presence of echinoid spermatozoa and the possibility of parthenogenesis was excluded by control cultures.

Godlewski found that a certain relation must exist between the two types of genital products. As a general rule, a large amount of sperm must be used for a relatively small quantity of eggs.

There is considerable individual difference in the animals used for experimentation. Other things being equal, one gets a very different percentage of fertilized eggs from different animals of the same species.

Not only the genital products of different individuals, but also individual eggs and spermatozoa from the same animal vary in a fixed ion concentration. If eggs and spermatozoa in sea water with a slight addition of caustic soda, 0.25 c. c. $\frac{\mathbf{n}}{10}$ $\mathrm{NaOH}$ (caustic soda) : 100 sea water, are passed through mixtures of increasingly higher alkalinity $-0.50,0.75,1.25$, and 1.50 c. c. 10 caustic soda $\frac{\mathrm{n}}{10}$ : 100 sea water-the percentage of fertilized eggs is considerably raised. 
If the echinoid eggs are allowed to lie a long time in an alkaline solution they become swollen when placed again in sea water, and fertilization, although in a smaller percentage of cases, will take place without further treatment with alkali. In the same way, if the genital capsules of Antedon have been previously exposed to the hydroxyl $(\mathrm{OH})$ ions the spermatozoa can fertilize echinoid eggs in normal sea water. From this the inference is drawn that the hydroxyl $(\mathrm{OH})$ ions exercise an influence on the spermatozoa as well as on the eggs.

Morphological investigation of the several developmental stages shows that the stimulus for the development depends in the first instance on the penetration of the spermatozoa into the egg. The raising of the yolk membrane is clearly perceptible on the fertilized eggs, and examination also-shows that the nucleus of the Antedon sperm unites with that of the echinoid egg.

Cell division proceeds in a manner entirely normal for the type represented by the egg, and the time of the different cleavages coincides with that of the eggs in the pure cultures. But since different eggs are fertilized at different times after the mixture of the eggs and sperm, and therefore commence to develop at slightly different periods, there are found side by side in the same vessè eggs in different cleavage stages.

The blastula stage also can not be differentiated from the blastula of the pure echinoid culture. The blastulæ give rise to cilia at the appointed time and swim nimbly about the vessel.

The further development depends upon the echinoid species from which the eggs are derived.

Of the Spharechinus $\times$ Antedon embryos only a small part reached the gastrula stage, and the commencement of skeletal formation was never detected.

The Paracentrotus $\times$ Antedon hybrids for the most part reached the gastrula stage, and individuals among them reached the pluteus stage.

The largest number of plutei were from the Echinus $\times$ Antedon cross.

During the course of development a halting of the morphogenetic processes is often at times to be observed-first during the blastula stage from the commencement of mesenchyme formation, and later after the termination of gastrulation and before the commencement of the formation of the skeleton. This halting of the developmental processes often lasts for several hours and, especially in the Spharechinus $\times$ Antedon cross, Godlewski often noted an interruption of development lasting for two days. In each of such periods a part of the embryos sink to the bottom, while the remainder develop further.

The percentage of the eggs which reach the pluteus stage is as a rule very small, and depends very much on the individuality of the material. At the most, 5 per cent of the Echinus $\times$ Antedon hybrids develop to the pluteus stage, and usually the proportion was very much less. Often there occurred cases where no eggs developed beyond the stage in which the gastrula shows the commencement of the formation of the three-rayed skeleton.

During the whole development the characters are exclusively those of the mother animal, the only differences between these hybrids and normal echinoids 
being found in the lack of contemporaneousness in the original fertilization and the halting of the developmental processes at definite periods.

The morphological features of the young of the E'chinus male $\times$ Echinus female and the Antedon male $\times$ Echinus female crosses are exactly the same. Mesenchyme formation begins in the blastula stage in contrast to the conditions in Antedon, where there is no primary mesenchyme, and in the grouping of the mesenchyme elements there is no difference between the hybrids and the pure-bred animals.

After the mesenchyme has become divided into two masses, and the archenteron has formed in the manner characteristic of Echinus, the beginnings of the three-rayed skeleton appear. The plutei, which exhibit the arms characteristic of the plutei of Echinus, often live for several days.

It is noticeable that, although there occur periods of arrested development or deviations in the formation of certain organs, similar abnormalities occur in the development of pure-bred Echinus. Godlewski never found a deviation from the normal type of the mother animal which could be considered as resulting from the influence of the male parent.

From these observations it follows that fertilization and the transference of characters are two quite unrelated processes. The spermatozoa can penetrate the egg, and its nucleus can unite with the egg nucleus, but in spite of the union of the nuclei none of the characters of the male parent appear in the morphological structure of the hybrid.

His success in fertilizing echinoid eggs with comatulid spermatozoa led Godlewski to try fertilizing fragments of echinoid eggs from which nuclei were absent with Antedon spermatozoa.

A small percentage of such egg fragments were fertilized. Development began with clearage, which presented the usual type of merogonic echinoid division. Often the eggs died during the cleavage stages, but some developed to blastulæ, and Godlewski obtained four embryos which had reached the gastrula stage, though in none of the four were there any traces of the beginnings of the skeleton.

In none of the embryos was there the slightest trace of any Antedon characters; the development was invariably that of the Echinus embryo.

ASYMMETRY,

In the great majority of the comatulids the body is almost perfectly pentamerous, being composed of five similar sectors. The presence of a small muscular cone in the slightly enlarged posterior interradius, at the summit of which is the posterior opening of the spiral digestive tube, gives the only indication visible externally of a departure from true pentamerous symmetry. Internally the contents of the visceral mass, especially the coiled digestive tube and the excentric axial organ, are unsymmetrical, but the nerves and the skeleton and the more superficial organs centering in ring systems about the mouth are perfectly pentamerous.

In certain types, however, a more or less marked deviation from the characteristic symmetry occurs.

In many of the Comasteridæ the mouth moves anteriorly to a position at the base of the anterior ray, and then to the right to a position between the bases of 
the anterior and the right anterior rays. This migration of the mouth is accompanied by the shoving of all the ambulacral grooves outward to the periphery of the disk, where they form a horseshoe-shaped furrow, the opening of the horseshoe being first between the two posterior rays and later, as a result of the disappearance of the ambulacral grooves from the two posterior rays, between the right and left anterior rays. If the mouth moves to the right the opening of the horseshoe, because of the loss of the ambulacral structures on the opposite (left posterior) ray, is between the left anterior and right posterior rays, and if the suppression of the ambulacral structures is carried to an extreme, between the anterior and right anterior rays.

By these changes the bilateral symmetry on either side of a plane passing through the anterior ray, the mouth, the anal tube, and the middle of the posterior interradius, in most types affecting only the disk, first becomes extended to all the other structures by the dwarfing of the two posterior rays, and then changes over into a bilateral symmetry on either side of a plane passing through the middle of the right anterior interradius, the mouth, the central anal tube, and the atrophied left posterior ray.

Occasionally comatulids are found which are six-rayed, with the additional ray inserted behind the left posterior. This variation is especially common in Tropiometra picta. In two genera, Promachocrinus and Thaumatocrinus, an additional ray is normally inserted to the left of all five rays, so that a 10-rayed animal results; but the basal structures remain pentamerous, so that the basal rays lie under the center of alternate radials.

\section{HABITAT OF THE IITTORAL CRINOIDS,}

Though a detailed discussion of the relation between the recent crinoids as a whole and their physical, chemical, and ecological environment will be reserved until later, it seems advisable here to indicate the conditions under which the numerous littoral species are found along the shores, in order first of all to emphasize the importance of these animals in the littoral fauna of the present day, and secondly to show in what diverse surroundings they exist.

Except on sandy and exposed mudily shores littoral crinoids occur in all possible situations. Their one essential requirement is pure, well-aerated water having a relatively high minimum salt content and well provided with minute plankton organisms; and wherever this condition is met within the range of the littoral species they may be looked for in the water just below the low-tide mark, or in the tide pools; sometimes, even, they occur in situations left bare at low tide.

Along the shores of the Indian Ocean from southeastern Africa, Madagascar, and Mautitius to Suez, India, and the Malay Archipelago, along all the coasts of Australia, especially in the north, and thence northward to Fokien and southern Japan, littoral comatulids of many species are abundant, particularly on reefs and rocky shores, less commonly in sheltered situations and in eelgrass, though their occurrence is commonly more or less local, and they are frequently not to be found in apparently ideal places. 
A few species have been found by shore collectors in New Caledonia, Lord Howe Island, Fiji, Samoa, the Marshall, Gilbert, Pelew, Caroline, Society, and Hawaiian Islands, but throughout Oceania they appear to be relatively rare.

None are known from the Japanese coasts north of Tokyo Bay, from the Asiatic coasts north of Fokien, from the northern or eastern shores of the Pacific, or from New Zealand.

In the Atlantic basin littoral crinoids occur from Scandinavia and Great Britain to the Gulf of Guinea, including the islands off the European and African coasts and the Mediterranean area (but not the Black Sea), and in the west from Florida to southern Brazil. But on the western shores, except for Tropiometra picta, they are extraordinarily rare, there being but six records-one from Bermuda; one from the Tortugas, Florida; one from St. Thomas, Virgin Islands; one from Dominica; and two from Brazil.

Of all the comatulids the preeminently littoral genus is Tropiometra, and wherever this genus occurs, from South Africa to Australia, Oceania, and southern Japan, and from the southern Caribbean to south Brazil and St. Helena, it is commonly found along the shore, often in great abundance. In the western Atlantic, from Tobago, Trinidad, and Venezuela to southern Brazil, it is the only really common littoral form.

A close second to Tropiometra is found in the genus Antedon, ranging from Scandinavia and Great Britain to the Gulf of Guinea, including the offshore islands and the entire Mediterranean basin, and also found from St. Thomas to Brazil, all the species of which occur along the shores, where they are often locally abundant. Only two specimens of the American species are known-one from shore collections at Rio de Janeiro, the other from shore collections at St. Thomas.

In order to emphasize the importance of the comatulids as inhabitants of the present-day littoral the following list is given of the species which have actually been taken by shore collectors. A comparison between this list and a similar list containing the names of the species from any one geological horizon is very instructive.

\section{COMASTERIDE:}

Capillatierine-

Comatella nigra, C. stelligera, C. maculata.

Capillaster macrobrachins, C. scntosa, C. maria, C. clarki, C. multiradiata, C. coccodistoma.

Nenaster ionensis, N. irregularis, N. lincata.

Leptonemaster renustus.

Comissia pectinifer, C. littoralis, C. chaduicki, C. hartmeyeri, C. ignota.

CoMactinina-

Comatulella brachiolata.

Comatula rotalaria, C. cratera, C. solaris, C. pectinata, C. purpurea.

COMASTEBINE-

Comaster belli, C. noxaguince, C. gracilis, C. multifida, C. multibrachiata, C. schönovi.

Comantheria alternans, C. briareus, C. magnifica, C. rotula, C. grandicalyx.

Comanthina sehlegclii.

Comanthus bennetti, C. pinguis, C. japonica, C. solaster, C. trichoptera, C. samoana, C. wahlbergii, C. annulata, C. particirra. 


\section{ZYGOMETRIDA:}

Zygometra microdiscus, Z. clegans, Z. comata, Z. andromeda.

HIMEROMETRIDE:

- Himerometra persica, H. bartschi, H. magnipinna, H. robustipinna, H. martensi.

Craspedometra acuticirra.

Heterometra quinduplicava, $H$. savignii, H. nematodon, H. variipinna, H. producta, $H$. crenulata, H. philiberti, H. fora, $H$. africana, $H$. sehlegclii, H. singularis, H. amboina, $H$. joubini, H. gravieri, H. atcr, H. nadagascarensis, $H$. reynaudi, $H$. aspera, $H$. bengulcnsis, $H$. affines.

Amphimetra spectabilis, A. molleri, A. parilis, A. jacquinoti, A. pinniformis, A. milberti, A. ensifer, A. lavipinna, A. papuensis.

STEPHANOMETRIDA:

Stephanometra echinus, S. tenuipinna, S. spinipinna, S. monacantha, S. indica, S. spicata, S. oxyacantha.

MARIAMETRIDA:

Pontiometra andersomi.

Oxymetra erinacca, 0 . finschii.

Liparometra articulata, $L$, regalis.

Lamprometra protectus, L. palmata, L. gyges.

Dichrometra döderleini, D. bimaculata, D. flagellata, D. afra.

COLOBOMETRIDAS:

Cenonetra bella, C. brunnea, C. emendatrix.

Petasometra clarce.

Cyllometra disciformis.

Decametra tigrina, D. mollis, D. taprobanes, D. arabica, D. lavipinna, D. brevicirra, D. modica.

Colobometra perspinosa, C. vepretum, C. discolor, C. diadema.

Cotylonetra gracilicirra.

oligometra imbricata, 0 . serripinna, o. occidentalis, 0 . chinensis, o. japonica, o. caledonia. oligometrides adeonce.

TROPIONETRIDA:

Tropiometra maorodiscus, T. afra, T. audouini, T. carinata, T. indica, T. encrinus, T. picta.

THALASSOMETRIDAE:

Thalassometbine-

Daidalometra arachnoides.

ANTEDONIDA: :

ANTEDONINE-

Mastigometra flagellifera, M. micropoda, M. pacifica.

Euantedon tahitiensis.

Antedon petasus, A. bifida, A. hupferi, A. moroccana, A. dübenii, A. mediterranea, A. adriatica.

Compsometra lovéni, C. serrata.

Toxometra paupera.

Dorometra mauritiana, D. parvicirra, D. nana.

In addition to these 152 species, specimens of which have actually been captured along the shore line, it is probable that in the future all or most of the following will also be found there.

\section{COMASTERIDE :}

Capillasterina-

Comatella decora.

Capillaster gracilicirra, C. tenuicirra.

Comissia percgrin a, C. lütkeni, C. horridus, C. hispida, C. spinosissima, C. spanoschistun. Comatonia cristata. 


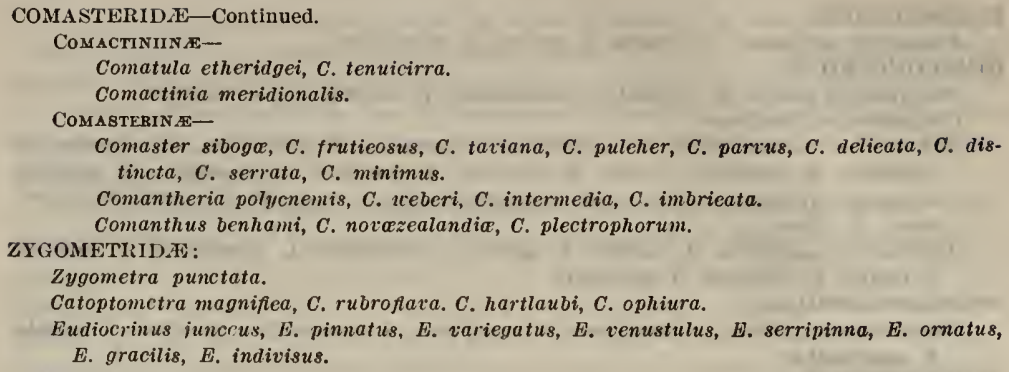

Thus while 152 comatulids are actually known to live along the shore, 93 more undoubtedly also occur there, so that we are justified in assuming 245 littoral species among the forms already described.

Of these 245 species 226 are from the Indo-Pacific region (including northern Australia and Oceania), 8 are from the region between Bermuda and Florida and Brazil, 6 are from the northeastern Atlantic (north of the Gulf of Guinea), and 4 are from southern Australia.

Species found swimming at the surface.-The young of two comatulids, Comanthus parvicirra and Dorometra nana, have been taken swimming at the surface in 
quiet anchorages. It is quite probable that the young of many species display considerable activity for a longer or shorter period between the time the column is discarded and the assumption of the adult habit of life.

Species found between tide marks.-At King (Padaw) Island, in the Mergui archipelago, Dr. John Anderson collected a dozen examples of Amphimetra discoidea, half of them from mud flats exposed at spring tide. at Suez.

Mr. Cyril Crossland found Lamprometra palmata living between tide marks

On the sand flats on the southern side of Friday Island, Torres Strait, at low tide, Dr. H. L. Clark collected a single specimen of Zygometra punctata.

Prof. S. J. Hickson told me that at Macassar he was surprised to see comatulids at low tide clinging to the piling of the wharves above the surface of the water.

Dr. H. L. Clark writes that at Buccoo Bay, Tobago, Tropiometra picta occurs in water from a few inches to several feet in depth at low tide, and that at the lowest tides some individuals are probably out of the water, in part at least, for a short time.

It is only reasonable to suppose that all the species inhabiting coral reefs or other localities where the water is very shallow at low tide are occasionally left dry.

Species found on coral reefs.-The following species have been reported by shore collectors from coral reefs:

Comatella nigra, C. stelligera, $C$. maculata.

Capillaster sentosa, $C$. multiradiata.

Comissia littoralis, C. hartmeyeri, C. ignota.

Comatula pectinata, C. purpurea, C. solaris.

Comaster novkguince.

Comanthus samoana, C. annulata, C. parvicirra.

Stephanometra echinus, S. spicatr, S. monacantha, S. indica.

Liparometra regalis.

Lamprometra protectus, L. gyges, L. palmata.

Dichrometra flagellata, D. afra.

Cyllometra disciformis.

Colobometra perspinosa.

Oligometrides adeonce.

Tropiometra afra, T. carinata, T. indica, T. audouini, T. picta.

Antedon moroccana, $A$. dübenii.

Dorometra nana.

In addition to these the records of capture of a very considerable additional number make it reasonably certain that they were taken on coral reefs.

As a general rule the reef-inhabiting species choose more or less protected situations, living on the lower surfaces of rock masses, in the cavities of the coral heads and sometimes of large sponges, or among the branches of the arborescent corals; but certain species provided with strong stout cirri frequently occur clinging to gorgonians, hydroids, or bryozoans. 
The position of the ventral surface appears to be a matter of complete indifference; it is rarely horizontal, and if so, is as often directed downward as upward.

On the reefs it has been observed that the crinoids usually occupy restricted localities and are not by any means universally present. Thus at Maër Island, Torres Strait, Dr. H. L. Clark found them on different parts of the reef flat; but except for the ubiquitous Comatula purpurea they were virtually confined to the southern and eastern side of the island. They were usually in water not less than 2 or 3 feet deep at low tide, but occasionally when the tide was very low they were in water only a few inches deep.

Comatulids have been reported, in very varying abundance, from a large number of reefs all over the Indo-Pacific region, from southeastern Africa, Madagascar, and Mauritius to the Red Sea, and eastward to northern Australia and Oceania; but they occur in the greatest variety and abundance on the reefs of northern Australia and the Malayan region, including western Oceania.

On the reefs in the Atlantic they are very rare, both on the eastern and western shores, having been recorded from only about a dozen widely separated localities (including St. Helena), in all cases but two (St. Helena and Rio de Janeiro) only once, and in all cases but one only a single species was reported.

In water of a few fathoms' depth along the outer side of the reefs comatulids often occur in very great variety and abundance, and it is in such situations that the large multibrachiate species are found. Thus the littoral reef fauna is, properly speaking, the upper fringe of a much more extensive fauna existing from the shore line down to between 20 and 30 fathoms.

It is understood that the term reef as used above is employed in a somewhat broad sense. In most cases it refers to the "coral" reefs properly speaking, but in a few cases the reefs are of volcanic rock, with a superficial and sparse and often restricted growth of coral.

In many places in the Mediterranean and Adriatic and in a few localities on the Atlantic coast of Europe Anterlon occurs on partially subrerged ledges and along rocky shores which are more or less furnished with a heterogeneous growth of marine organisms.

Occurrence of comatulids among seaweeds. - In certain places on the Atlantic coasts of Europe Antedon bifida occurs in considerable numbers among the roots of rockweed.

Dr. L. E. Griffin reports an unidentified species from Culion, Philippine Islands, as being a very active swimmer and as living among the eelgrass.

At Tobago Dr. H. L. Clark found that the bottom frequented by Tropiometra picta is made up largely of Porites fragments, usually more or less covered by a growth of Corallina and Halimeda; scattered over it there is also a sparse growth of short eelgrass (Zostera). Sometimes the bodies of the animals are more or less completely shaded by a clump of eelgrass or seaweed, but this is not usually the case. Generally the individuals are solitary, but occasionally five or six may be found about a single clump of Porites or of eelgrass. 
Occurrence of comatulids in half submerged caves.-In the Tropics half submerged caves, on account of the protection which they afford against the brilliant glare of the tropical sun, often form extraordinarily rich nurseries for many types of marine organisms, and comatulids have occasionally been found to be abundant in such situations.

Absence of comatulids from rock pools.-It might be expected that rock pools would offer very favorable conditions for comatulid existence, but they are seldom or never found in such situations, preferring always open water.

Occurrence of comatulids beneath stones.-In southeastern Australia and in southern Japan the local species of Compsometra, which are very small, are frequently found beneath stones along the low-tide mark.

In Europe Antedon often occurs similarly, and is very prone to withdraw into deep recesses, where individuals often grow to an unusually large size.

Occurrence of comatulids on piling.-In many East Indian harbors where the water is especially pure comatulids are frequently seen clinging to the piling of the wharves and docks, and to the chains and under sides of buoys.

In some places in the Mediterranean and on the Atlantic coasts of Europe Antedon has been found in similar situations.

Breakwaters.-It has long been known that the seaward side of breakwaters in the Indo-Pacific region and in the Mediterranean basin is a favorite habitat for comatulids, especially of the smaller species. The outer side of a breakwater is quite comparable to the outer side of an exposed ledge or reef.

Occurrence of comatulids on mangrove roots.-The only comatulid which Dr. Th. Mortensen collected in the course of his investigations in Siam, Amphimetra discoidea, was found clinging to mangrove roots.

Occurrence of comatulids on mud.-Comaster novaguinece, Amphimetra discoidea, and A. papuensis have been taken on muddy bottoms in sheltered situations, a very unusual habitat for littoral crinoids.

Possible occurrence of a comatulid on sand.-On the sand flat on the southern side of Friday Island, Torres Strait, Dr. H. L. Clark picked up a specimen of Zygometra punctata. It is not quite clear from his account whether the animal was actually living there, or whether it had been washed up; the latter is more probable.

Occurrence of Antedon bifida at Roscoff.-The best account of the occurrence of Antedon bifida as a strictly littoral animal is that given by Prof. H. de LacazeDuthiers outlining the status of that species at Roscoff as he knew it there.

Describing the locality he writes that the port of Roscoff, situated at the northern extremity of a broad tongue of land which projects northward into the English Channel between the rivers of Morlaix and St. Pol-de-Léon on the east and the Bay of Pouldu on the west, is protected by numberless reefs, bare at low tide, on which the zoologist can collect the most varied animal types. Moreover, the Gulf Stream, which bathes these coasts, gives to these regions a temperature which is in a high degree suited to the development of the animals.

To the north Bass Island, a long strip of land granitic like the other rocks, runs east and west, forming a barrier against the waves of the open sea and pro$142140-21-$ Bull. $82-40$ 
tecting the channel between itself and Roscoff. As a result of these conditions the littoral fauna is here particularly rich.

For two years in succession (in 1868 and 1869) he passed a part of the summer engaged in zoological research in this locality, one of the richest on the French coast.

At low tide when one goes directly northward down from the Roscoff church to the beach one sees ahead large granitic peaks, which, never covered by the sea, form islets even at the highest tides. At the east and at the right are the two Bourguignons, at the west and left Green Island, and more distant in an easterly direction some rocks covered at high tide among which are Meinanet and Rolas.

Between these reefs and in the channel the low tide exposes broad and beautiful fields of eelgrass (Zostera) and sandy areas covered with stones, both of which are inhabited by numerous species of animals, by a great variety of ascidians, both simple and compound, by bryozoans, sertularians, sponges, especially calcareous sponges, echinoderms, synaptas, lucernarians, caryophyllias, numerous actinians, planarians, borlasias, very numerous naked and shell-bearing mollusks, etc., which abundantly compensate the zoologist for the difficulties encountered in searching the shores.

The two zones which the algæ habitually occupy, the higher characterized by Fucus vesiculosus and $F$. serratus and the lower by Laminaria, are at Roscoff sharply separated by Himanthalia lorea, which in this region is used, under the name of fiber, as manure for vegetables. The Himanthalia zone is uncovered at the spring tides, but is not entirely dry except at the lowest water, when the Laminaria below is itself accessible. This description of the local conditions is necessary, for one has no idea of the difficulties attending a zoological reconnaissance over the rocks covered with Himanthalia until one has become entangled in these long bundle of lacerating fronds which conceal the holes among the rocks and slip away so easily from beneath one's feet. Almost nothing can be obtained here, for progress is not only extremely difficult, but becomes even dangerous on account of the numerous tumbles.

In the Laminaria zone the search for animals is at the same time easier and more productive; but the point of especial interest is the presence of this seaweed in the Himanthalia zone and the curious fact that this plant sometimes abandons the deeper levels and rises for a considerable distance toward the high-tide mark.

At the lowest tides the water flowing from the land excavates channels in the sandy patches and in the grassy areas, forming streamlets which are often of considerable size and swiftness. West of Green Island and the Bourguignons these channels are numerous, and it is in them that the seaweed ascends and where the pentacrinoids of Antedon are found abundantly. If in these streamlets at low tide the ramifying roots of the seaweed are detached, the bushiest ones being chosen and pulled out close to the ground, it is almost certain in the months of July and August and in the beginning of September that pentacrinoids will be found.

When the roots of the seaweed are much branched the rootlets by their ramifications form a bushlike growth in the midst of which Antedon bifida is especially 
fond of living. Among these rootlets also ascidians, sponges, sertularians, and bryozoans are so numerous that each root yields quite a collection in itself. Antedon is sometimes present in such quantities that, by wrapping its arms about them it almost by itself alone gives color to the stems, and as it occurs in all possible sizes this seems to be a situation especially suited to its development.

With this thought in mind, Professor de Lacaze-Duthiers undertook a search for the pentacrinoids, and his anticipations were immediately realized; even on the beach itself he was able to collect very fine specimens. But he found it more convenient to carry away the roots covered with Antedons and to search through them in the laboratory with a magnifier under water. In this way he found pentacrinoids of all ages. He kept them alive for some time, and was able to observe their metamorphosis. They cast off the column characteristic of the crinoidal form, became free, and mingled with the adult and adolescent Antedons, from among which it became impossible to distinguish them.

In order to verify the observations of Sir Wyville Thomson and Dr. W. B. Carpenter, MM. Lemire and Myèvre, after having worked a long time in the laboratories of Professor de Lacaze-Duthiers under his direction, both at the Museum of Natural History and at the Sorbonne, on his advice went to Roscoff.

M. Lemire did not leave Roscoff until after the spring tide at the beginning of October, and at that time he was no longer able to find pentacrinoids; already in September their number had appeared to be perceptibly reduced, although a great many Antedons could still be found. M. E. Grube, of Breslau, who had come at the instigation of Professor de Lacaze-Duthiers at the commencement of September and whom he had the pleasure of conducting along the shores not only of Roscoff but also of St. Pol-de-Léon, to which place they made numerous excursions together, was able to confirm this.

Therefore it appears that the pentacrinoids can be found with certainty only in the summer months.

About Roscoff pentacrinoids are very restricted in their occurrence. Prof. de Lacaze-Duthiers in his excursions in the neighborhood of Roscoff, for example to Kainou, a plateau of rocks situated southeast of Sainte Barbe in the river of St. Pol-de-Léon, which is not uncovered except at the lowest tides, to the north of Thizaouson, to the west of the fort of Perharidi and of the Roche du Loup, never found them, although seaweed abounds at almost all these localities. The conditions peculiar to the streamlets sheltered behind Green Island are therefore without doubt the most favorable for the spawning of Antedon and for the development of the young.

Prof. Charles Gravier tells me that the relative abundance of Antedon bifida on the French coasts is subject to great variations; in some years they are very common, while in others they become rare.

Prof. F. J. Bell in his account of the comatulids of the Maldive and Laccadive Islands states that they seem especially to frequent the inner ends of the passages where they embouch into the lagoons. 
LOCOMOTION.

Dr. H. L. Clark made extensive observations on the power of locomotion shown by a number of comatulids which he studied at Maër Island, Torres Strait, and from his account the following is taken almost verbatim:

He says that to speak of the methods of locomotion in crinoids, or even in comatulids, is like speaking of locomotion among birds, in that there is as much difference between different kinds of comatulids as between different kinds of birds, and as birds may either fly or run preponderatingly, so comatulids may either commonly swim or creep.

So far as the species studied at Maër are concerned, the Comasteridæ are creepers, while the other families represented there are swimmers. It was a surprise and disappointment to discover that none of the common comatulids would swim, even in the deep water by the live car, so that it was not possible to make the observations and experiments with reference to the swimming of comatulids which he had planned. When any of the species of the Comasteridæ were placed in the water beside the live car, they invariably sank to the bottom (about 20 feet). In the case of Comatella maculata it was noted that, as a rule, the individual would close the arms orally and vertically over the disk, so that it sank almost like a stone. As soon as it touched bottom the arms were opened out and the animal began to creep. In the other species, however, the arms were not closed up, and so the comatulids floated downward to the bottom much more gradually. With one exception, all efforts to induce swimming movements of the arms in a comasterid completely failed.

In no case when the individual was on the bottom did mechanical stimulation result in any attempt to swim, or in accelerated movements of any kind. Suspending specimens in the water by means of a slender thread gave no results; the arms moved about slowly and with no coordinated effort, and with no resulting locomotion. Several individuals were provided with cork floats so attached as not to interfere with their arm morements, but, with the one exception already referred to, none of them made any effort to swim. The one exception was a small Comatella maculata, which, after wearing the cork float in the live car for 24 hours, was dropped into deep water. It immediately began swimming, but spasmodically and not in the beautifully coordinated manner of a Stephanometra. Apparently these comasterids do not, under normal conditions, swim at all, but could with sufficient effort be taught to do so.

On the other hand, all of the species of the other families of comatulids observed at Maër are good swimmers and do not creep about as the comasterids do. They are usually found at rest on the lower side of rock fragments or on a branch of coral with the arms more or less erect, but sometimes the arms are opened out flat against the rock. They maintain their position by means of the cirri, with which they often cling so tightly that it is difficult to dislodge them without damage. Under no conditions did they seek to escape by swimming, but when once dislodged swimming seemed to be their only means of locomotion. Placed in a basin or a deep bucket of sea water, a very slight mechanical stimulus 
served to set them in motion, and swimming continued for a more or less brief interval, varying greatly with different individuals. It seemed as though the frequent contact with the side of the basin or pail served as a deterrent, and Dr. Clark thinks that they would undoubtedly have gone a greater distance in open water. Nevertheless, it was clear that the individuals observed were "sprinters" and not long-distance swimmers, the movements being more like the flitting of small birds in shrubbery than like long-sustained flight. The gracefulness and beauty of the movements were their most uotable feature, but their rapidity and force were also remarkable.

In the 10 -armed specimens swimming was accomplished by using the arms in sets of five alternately, so that when arms $1,3,5,7$, and 9 were brought up almost vertically over the disk, arms $2,4,6,8$, and 10 struck backward forcibly, with pinnules fully extended, until they nearly met behind the cirri. Only a single stroke was made, but as arms $2,4,6,8$, and 10 were relaxed and drawn in and upward over the disk another stroke was made by the alternate five arms. Of course, the movement was much more rapid than a description indicates, but it decreased in rapidity as the comatulid became fatigued. At the start the strokes were at the rate of perhaps 100 a minute, but they rapidly dropped to much less than that and usually ceased altogether in less than a minute. Each stroke appeared to carry the individual about the length of its own arms, so that an individual with arms $50 \mathrm{~mm}$. long started out at the rate of about 5 meters a minute. But the longest distance any specimen was seen to travel continuously was less than 3 meters.

In the multibrachiate Stephanometridæ and Mariametridæ the movements were very similar, but exceedingly difficult to analyze satisfactorily. The arms seemed to be used in sets of five in rapid succession. That is, supposing the individual had $40 \mathrm{arms}$, the first stroke would be given by arms $1,9,17,25$, and 33 , followed almost immediately by $2,10,18,26$, and 34 , then $3,11,19,27$, and 35 , and so on until the eight sets had been used, when the first set would come into action again. Not so great a part of each arm is used as in the 10-arm species, and the stroke does not carry the arm so far back, but the movements are so rapid and the similarity of the arms to each other is so confusing that it is almost impossible to feel sure that one has made no mistake in the analysis of the method of progression. While the swimming is perhaps just as graceful as that of the 10 -armed species, when contrasted with their movement it is reminiscent of " dogpaddle" swimming as compared with the usual stroke. No satisfactory data were secured regarding the speed of, or distance covered by, the multibrachiate species.

The creeping movements of the Comasteridæ are neither so graceful nor so well coordinated as the swimming movements just discussed. The comasterids usually live in the open spaces aniong branching corals or on the lower side of large fragments of rock or coral, with their arms extended and floating listlessly in the water. More or less constantly, but irregularly, the arms bend inward toward the mouth, the tips just brushing the disk and the arm bases. While these movements may be connected with feeding, it was not possible to determine what 
the connection is. One may perhaps hazard the guess that they keep the ciliated grooves from becoming clogged up.

If the coral is broken away or the rock fragment turned over so that the comatulid is exposed, the animal begins at once to move. In the species with welldeveloped cirri, notably in Tropiometra afra, the position is maintained by means of them, but they apparently do not play any important part in locomotion. One might suppose that they would be of some use either in pulling or pushing, but there never was the least indication of movement on the part of the cirri in any of the species observed. In the species in which cirri are feebly developed or quite wanting the position is maintained by the use of some of the arms. It seemed to be usually the shorter arms that were so used, but under laboratory conditions none of the arms remained still for a long period, and while it would seem quite likely that the shorter arms are constantly used as anchors, evidence on the point is not satisfactory.

Creeping is a rather complex movement, a combined pulling and pushing. Certain arms, usually three or four, but sometimes as many as seven, are stretched out to their full extent and the pinnules of the terminal portion catch hold of any available projections. This attachment is not only by the use of the minute hooks which are found at the tips of the pinnules, but by the remarkably viscid nature of the secretion from the glands in their epithelium. The degree of viscidity varies in the different species, and more or less in individuals. It is least noticeable in Tropiometra afra, and hardly more so in Comatula purpurea. It is most marked in Comatella stelligera and in some individuals of Comanthus annulata. Thanks to this viscidity locomotion is possible even on very smooth surfaces, such as that of an enamel-ware basin. It is, however, difficult on loose sand. Rock surfaces and tightly packed sand are the most satisfactory for permitting the pinnules to function successfully. When the pinnules of the extended arms have taken a hold, or perhaps while they are taking hold, three or more arms on the opposite side of the body are drawn up in a strongly arched position and their widespread tips are closely appressed to the bottom very near the disk. Then when the extended arms, having secured their hold, begin to contract and pull the animal toward the place of attachment, the arched arms begin to straighten out and push the animal in the same direction. The result is a movement more or less marked according to the character of the bottom and the size of the comatulid. The total movement may be from one-eighth to one-quarter of the arm length. The process is continually repeated, and, with very slight resting periods, may be kept up for hours.

Doctor Clark found that, on the whole, Comatella maculata and the adults of Comatula purpurea were the most active, and were rarely at rest in aquaria. A specimen of Comatella maculata with arms about $75 \mathrm{~mm}$. long traveled approximately $85 \mathrm{~mm}$. a minute and continued to go around and around a large basin for several hours. It probably traveled about 40 meters an hour, but on a natural surface, such as the reef would afford, it would be able to do better than that.

In comatulids with approximately equal arms there was no evidence of any orientation, one group of arms being quite as likely to be in advance as another. 
Such individuals altered the direction in which they traveled simply by changing the groups of arms which were to be extended.

In adult Comatula purpurea, in which the anterior arms are very much longer than the dwarfed posterior, observations on the reef, at the live car, and at the laboratory showed that there is more or less definite orientation. Under ordinary conditions the long arms are extended in locomotion, and hence are anterior, while the short arms do the pushing, and hence are posterior. The mouth is at the base of the longer arms, and hence is at the anterior side of the disk.

If locomotion in a given direction were prevented the comatulid never reversed its movement, using the short arms to pull and the long ones to push, but gradually swung itself around until ultimately the long arms were in advance. A considerable number of experiments and observations showed that the mechanism for orientation was not by any means perfectly adjusted, for an individual would often go for some distance with the longest arms at one side, or only partially in front. Nevertheless it was clear that long arms in front, short arms behind, gave the normal method of progression.

Doctor Clark remarks it may be a fair inference that the asymmetrical condition of the arms is the result of selection, since it is possible that long arms would be better for pulling and short stout arms for pushing; but it is no doubt true that there are very diverse interpretations of the matter possible.

Locomotion in all the comatulids observed at Maër, whether swimming or creeping, invariably takes place with the oral surface uppermost. If dropped in deep water with the mouth down they commonly righted themselves before reaching the bottom. If not, or if placed on the bottom with the mouth down, they slowly but surely turned over before attempting to either swim or creep. The process of turning over is essentially the same as in a starfish; that is, a group of arms begins the task and continues gradually lifting up one side until the arms of that side can be bent back far enough over and beyond the aboral surface to secure a hold. Then by their pulling, and the pushing of the arms opposite to them, the disk is righted. The process seems a tedious one and is probably not often necessary in the normal life of comatulids on the reef.

Particularly interesting is the question of how much these comatulids move about under the natural conditions of their life, but no satisfactory evidence on the point was secured.

On one occasion a dozen healthy comatulids of four species were "planted" on a part of the reef where no crinoids were living. Twenty-four hours later they had all disappeared, and no trace of them could be found in the neighborhood. But as there had been a strong wind and much surf during the night they may have been simply swept away.

On another occasion 10 large comatulids were carefully located around the margin of a rock fragment about a meter in diameter. Circumstances, including unfavorable tides, made it impossible to visit the spot again for a week. Then it was found that more or less sand had washed in around the rock, and the comatulids were apparently gone, but again there was doubt what part the surf and strong tidal currents may have played. 
Crinoids dropped beside the live car on reaching the bottom began at once to move away and continued moving, usually in a fairly straight line, until they reached a rock beneath which they could find shelter; but it was not possible to determine their ultimate resting place.

Professor Semper, who while living in the Philippines kept various species of Comasteridæ in his aquaria for weeks together, informed P. H. Carpenter that he never saw the least trace of any irregularity in the alternating movements of their arms when swimming, which would imply that they swam more or less frequently; and the West Indian Comactinia and Nemaster are said occasionally to swim.

Doctor Clark also studied the locomotion of Tropiometra picta at Buccoo Bay, Tobago. He says that, like most of the comatulids hitherto studied, this species is exceedingly sluggish. So far as his observations go, it never swims. Dropped or suspended in deep water, it makes only the most feeble arm movements, and unless artificially prevented it sinks rapidly to the bottom.

When, as a result of some adequate stimulus, it does move, the movement is similar to that of Comanthus; that is, it is accomplished solely by means of the arms, and no particular arms take precedence. In one respect the attitude differs from that of Comanthus, for the body is much more distinctly raised. This is obviously to keep the cirri wholly above the substratum and thus prevent their accidentally catching on it. The movement is always slow and labored and does not continue long. When overturned so that the cirri are uppermost a normal healthy individual invariably rights itself at once, sometimes only very slowly and deliberately but usually without delay. The process is, as in other comatulids, by several arms raising up their side of the body until one or more of them, or some of the neighboring arms, can reach over backwards and secure a hold which will enable them to pull the body over. The cirri play no part whatever in this process, any more than in actual locomotion; they are very inert, move slowly and slightly, and are used only as organs of attachment, a purpose which they serve admirably. The pinnules, even near the tip of the arm, have only weakly hooked tips and are but slightly viscid, and it is consequently difficult for the animal to move or even to right itself except on a rough and rather firm surface.

No individuals were seen moving about under normal conditions, but when placed on a bare sandy bottom they crept steadily to its margin of coralline algæ. Many specimens were planted on the reef flat near the laboratory, and most of these ultimately disappeared, but whether they crept away or were carried off by tidal movements it is impossible to say.

On two occasions during the cruise of the Siboga in the East Indies the 10armed young of Comanthus parvicirra were captured at the surface-once at the anchorage off North Ubian, and once in a plankton haul on the south side of the pearl bank in the Sulu Archipelago. It would appear, therefore, that in this species, as apparently in all comatulids, the young are much more active than the adults, and also that the 10-armed young of multibrachiate types are as good swimmers as the young of the normally 10-armed Antedoninæ. 
While the Albatross was anchored off Sulu a young Dorometra nana of about half the adult size was captured at the surface. It was said to have been swimming entirely by means of its cirri, with the arms widely extended.

John Vaughan Thompson was the first to describe the locomotion of Antedon bifida. He says that in swimming the movements of the arms exactly resemble the alternating stroke given by the medusæ to the liquid element, and has the same effect, causing the animal to raise itself from the bottom and to advance, back foremost, even more rapidly than the medusa. He speaks of Antedon as an animal not only free, but leading the most vagrant life of any of the tribe with which it has hitherto been associated by naturalists, at one time crawling about amongst submarine plants, at others floating to and fro, adhering to thin fragments by means of its dorsal claspers, or even swimming about after the manner of the medusæ.

But of all the naturalists who hare written on these animals Thompson is the only one who considered Antedon as normally active. All of the species of this genus appear to agree in their habits, of which the best account is that given by Dr. W. B. Carpenter, based upon Antedon bifida.

Doctor Carpenter says it is quite true that, as stated by Mr. J. V. Thompson, and confirmed by Prof. Edward Forbes, an Antedon placed freely in water will swim with considerable activity, moving back foremost by advancing five arms at a time, and then the alternative five; in fact, he did not know any animal of which the movements are more graceful than those of the feather-star. But he is quite satisfied from repeated observations that these movements are not habitual to the animal and are to be regarded only in the light of a restless search aftev a new attachment, being kept up no longer than is requisite for obtaining this.

If an Antedon be placed in a large basin of sea water having smooth sides and not containing any object of which the cirri can lay hold, the swimming action may continue (with occasional intermissions) for several hours. But if a rough angular stone, a seaweed, a zoöphyte, a cluster of serpulæ, or anything to which the dorsal cirri can attach themselves, be placed in the basin, the Antedon settles itself upon this, and if the attachment proves suitable the creature seldom changes it.

Doctor Carpenter kept a number of Antedons for several weeks together in the same aquarium without any other animals, and he observed that the places of individuals which he could distinguish by some peculiarity of color were scarcely at all altered during the whole period, the amount of change, in fact, being little more than would have been exhibited by an equal number of actinians. One fine specimen he particularly noted as having firmly attached itself by the grasp of its dorsal cirri to the tube of a Serpula, and this it did not let go during the whole time of its captivity.

Doctor Carpenter says that as regards the ordinary fixedness of its position the condition of the adult Antedon only differs from that of its pentacrinoid larva in that whereas the latter necessarily remains fixed to the spot to which the base 
of its pedicel was originally attached, the former can quit its hold when its attachment is no longer suitable to its requirements, and can move from place to place in search of another. How intimate, moreover, is the fundamental relation between the dorsal cirri of the adult Antedon and the column of its pentacrinoid larva further appears from the fact that the cirri only make their appearance in the later part of the pentacrinoid stage in preparation for that detachment of the crown from the column which thenceforth changes the condition of the animal from the fixed to the free.

Doctor Carpenter summarizes the results of his observations as follows: The life of the adult Antedon is habitually passed (I feel justified in asserting) so nearly in the same degree of fixedness as that of its pentacrinoid larva that it may almost equally be regarded as representing the life of the typical Crinoidea. If the creature erer quits its attachment, save on account of the unsuitableness of its position, it is probably during the period of sexual activity, at which it seems more frequently errant than at any other stage of its life except the earliest.

Mr. Herbert C. Chadwick, who has enjoyed altogether exceptional opportunities for observing Antedon bifida at the Isle of Man, agrees with Carpenter. He says that Antedon is not usually an active animal; by means of its cirri it clings tenaciously to stones, algæ, hydroids, etc., the arins being widely spread horizontally, with the tips more or less flexed toward the disk. When disturbed it swims actively and with strikingly graceful movements, the two arms of each pair being invariably flexed and extended alternately.

He also says that it is often found clinging by means of its cirri to the wicker creels used by fishermen for the capture of lobsters and crabs. The fishermen state that specimens are always more numerous on the creels after stormy weather.

In a letter to Mr. Frank Springer, dated September 6, 1900, Mr. Alexander Agassiz wrote:

I take it you know that Comatulæ are excellent swimmers, striking out with their arms and moving about from point to point in Gorgonia groves. It is not uncommon to see a number swimming in a school among the Gorgonias.

In a letter to Dr. H. L. Clark, Dr. L. E. Griffin, of the Bureau of Science, Manila, said:

I saw in Science that you discovered crinoids swimming at Maër. One I sent you from Oulion was a very active swimmer and lived among the eelgrass. We have often seen them swimming in the Philippine Islands.

In recently captured individuals of Antedon adriatica Reichensperger in rare cases observed a sort of slow progress by means of slow movements of the cirri, assisted by similarly slow movements of the arms. The tracks made by the cirri in fine sand were afterwards clearly visible.

In 1866 Jeffreys mentioned that specimens of Leptometra celtica had been found clinging to the rope of a dredge some distance above the end, and in 1895 Bather suggested that these individuals may have been swimming about and therefore may have attached themselves to the rope as it passed by. 
NOTES ON THE HABITS OF ANTEDON.

Prof. A. Milnes Marshall, who studied Antedon mediterranea at Naples, says that the normal position of the animal is a fixed one, the animal being attached by the cirri to some foreign body and the arms spread out horizontally with their tips slightly flexed. The oral pinnules are bent over the disk, crossing one another above it; the other pinnules are spread out nearly at right angles to the arms. In an aquarium containing a large number of specimens the great majority will be found attached either to the bottom or sides of the tank with the oral surface directed either upward or more or less obliquely; some specimens, however, are almost certain to be found, if there be foreign bodies in suitable positions for attachment, inverted, with the oral surface downward. A comatulid when attached exhibits very little tendency to alter its position, and may remain fixed in the same place for weeks. If detached, either spontaneously or by force, it can, and usually does, swim actively until it reaches a suitable place of rest to which it anchors itself by its cirri. The normal swimming movements, which are peculiarly graceful, consist in strong flexion of the proximal half of the arm, which is raised vertically over the disk, and then extension of the whole arm, the distal half of which is thrown out something like a whiplash. During flexion the pinnules are folded alongside the arm, during extension spread out so as to expose as great a surface as possible. Usually two or three arms are raised simultaneously, sometimes as many as five, but the only rule seems to be that the two arms of each pair are always flexed alternately. When the animal is attached the arms exhibit but very slight movements; they are usually spread widely out, apparently to expose as large a surface as possible. If an animal be detached and placed with the oral surface downward it will right itself almost at once. If the surface on which it is placed be a rough one the righting movement is effected in a few seconds, or almost instantaneously. In a glass vessel it takes longer to perform, though never over two minutes in an active individual.

In regard to the ordinary condition of the arms of Antedon bifida W. B. Carpenter noted that there is much the same variety as is seen among actinians with respect to the expansion of their tentacles. Sometimes the arms and their pinnules are stretched out quite straight to their full length, and almost entirely in the same plane, so as to present an appearance of rigidity, while sometimes, still remaining fully extended, they are more or less closed together so as to give their whole expanse the shape of a funnel more or less deep with the central disk at its bottom. More commonly, however, some of the arms curve either obliquely or toward the ventral surface, and this ventral curvature may be so great that the arm forms a spiral, which reminds the observer of the unfolding frond of a fern. Occasionally all of the arms are seen to be thus coiled, so that the diameter of the animal is reduced to not more than one-third of that which it has when the arms are fully extended. In no instance did Carpenter see the arms more than slightly curved dorsally.

W. B. Carpenter noticed that if one of the middle or outer pinnules of any arm be irritated by the contact of a rod, such irritation merely produces a languid wavy motion of the arm thus acted on, which may extend itself to others if the 
irritation be repeated or prolonged; but if the rod be made to irritate the long basal pinnules all the arms (if the animal be in full vigor) immediately close together with an energy and consentaneousness that are seen in no other movement.

W. B. Carpenter believed that the ordinary pinnules are especially related to the function of respiration, while the oral pinnules are sensory protective organs.

Perrier says that in keeping Antedons alive it is necessary to take care to place in the basins rough bodies or twigs, or floating fragments of seaweed, to which they can attach themselves. If this is not done the individuals will attach themselves to each other and become hopelessly entangled, so that their movements result in mutilation and the consequent mortality may be serious. Moreover, it becomes impossible to remove the dead ones, which become foci of infection.

By taking these precautions and changing the water in his basins carefully morning and evening, Perrier was able to keep at the same time in the same basin about 50 Antedons in good health.

The young pentacrinoid larvæ accustom themselves to captivity quite as well as the adults.

Perrier says that the rolling up of the arms in Antedon bifida is an indication of sickness. When the animal is in good health it is generally expanded, and it does not roll up its arms except momentarily when it is disturbed. It likes occasionally to leave the stem upon which it is seated and to swim about with considerable agility, by means of its arms, which, like graceful oars, alternately strike the liquid.

When a comatnlid has remained with its arms rolled up for some days one may be sure that they will soon drop off. Perrier frequently saw animals, still alive, on which there no longer remained a single arm. Such extensive mutilation soon results in death.

Studying Antedon adriatica in the aquaria of the zoological station at Trieste Seeliger found that the spermatozoa are ejected in such quantities that only a few males are able to becloud a very considerable amount of water. The release of the spermatozoa is immediately followed by the extension of the eggs, which never appear at any other time.

At Naples Bury found that the eggs of Antedon mediterranea are always laid, until late in the season, in the morning, probably not much before 8 o'clock. They are attached in masses to the pinnules by a sticky secretion, which makes it extremely difficult to detach them without injury. Each ovum is about $0.3 \mathrm{~mm}$. in diameter and pink in color, and each is inclosed in a transparent and close-fitting vitelline membrane.

At Trieste Seeliger noted that the extrusion of the genital products of Antedon adriatica always takes place at a very definite hour, about 7 o'clock in the morning.

Perrier remarked that among the comatulids (Antedon moroccana) sent him from Algiers all the embryos on all the pinnules of a given mother were at the same developmental stage.

Barrois visited Toulon for the purpose of obtaining a series of embryos of Antedon mediterranea of all stages. He collected a large number of animals with embryos, and the next day discovered to his surprise that all the embryos 
represented a single stage. A short time afterwards he revisited Toulon, and this time he found that the comatulids all bore embryos at the same stage, which were much less developed than the others.

Observation of some comatulids in live cars at Villafranca showed that it was rarely an opportunity offered to secure an isolated breeding animal, even at the height of the breeding period. Two weeks would pass without any of the animals breeding, but when one extruded its eggs the others generally followed. There were therefore general breeding periods, followed by shorter or longer periods of inactivity, during which none of the animals bred.

At Naples Bury found that often several weeks would elapse without a single fertilized ovum being obtained, and then suddenly several adults would be brought in on the same day, each with a number of eggs on almost every pinnule.

Seeliger found that in Antedon adriatica all the larvæ of a given mother are in the same developmental stage, this being particularly true in the earlier stages, and that usually all of the larvæ are liberated at the same time, about 124 hours (four hours more than five days) after fertilization, no embryos remaining behind undeveloped. But occasionally only a part of the larvæ leave the pinnules, the remainder following little by little until the seventh or even the eighth day, although on the fifth day the stage of development of all the embryos had shown but slight variation.

For Antedon mediterranea Barrois and Bury give the length of embryonal life as seven days. Sir Wyville Thomson records that of Antedon bifida as of from three to four days' duration.

The length of the free-swimming period is subject to much greater variation.

Under unfavorable conditions a female after the breeding period may lose the genital pinnules, parts of the arms, or even entire arms. Normally, however, this self-mutilation never occurs, the female remaining quite intact. This loss of pinnules and arms takes place especially in a deficiency of oxygen.

Sir Wyville Thomson said that the larva possesses all the pecularities of the sarcode organisms among the Protozoa and the lower forms of the celenterates. Its external surface is richly ciliated and if lightly touched with a bristle it moves off rapidly by means of these cilia in a direction opposite to the touch, giving evidence of a high degree of irritability and power of automatic motion without the slightest trace of a special nervous system.

Seeliger found that larvæ of the earlier fixed stages do not react to external irritation, which agrees with his observation that no nervous system can be demonstrated histologically. He notes that the nervous system of the young stalked larva as demonstrated histologically does not suffice to explain its movements under external irritation. Contraction of the calyx results not only from touching the tentacles or disk, where nerve branches can be demonstrated, but also from irritation of the aboral surface and of the stem where no nerve fibers have as yet been found.

Bather in 1894 mentioned "floating colonies" of Antedon bifida. In the following year "Paddy from Cork" criticized Bather's "floating colonies" and stated that this species lives clinging in numbers to stones below the low-tide mark. 
He says also that it swims with medusa-like contractions. Bather immediately replied, calling attention to its gregarious habits and its power of flotation or movement from place to place.

Perrier says that at Roscoff Antedon bifida is easily procured at the spring tides. It inhabits the entire region opposite Isle Verte, between that island and Isle de Bas, as far to the east as to the west. To the eastward Professor de LacazeDuthiers showed them to Perrier in 1870 literally covering the stalks of the seaweeds. In that year Perrier found them also to the west, but less abundant, almost opposite but a little to the left of the black beacon of Per-Roch. In two tides Perrier secured there almost 300 , without counting a quantity of young in all stages of development, including pentacrinoids. Antedon bifida is very abundant only below the Himanthalia lorea zone, attached to seaweeds or to the brown and curled fuci which abound at the lower edge of the seaweed zone.

Perrier records that sometimes individuals of Antedon bifida, almost always of large size and of a very bright carmine, are found under stones which have been turned over in a search for other animals.

Foon.

Duchassaing records that the stomach contents of a specimen of Isocrinus decorus which he fished up in relatively very shallow water at Guadeloupe, French West Indies, consisted only of the remains of small crustaceans.

Bronn, summarizing previous accounts, wrote that the stomach contents of Isocrinus were made up of the remains of small crustaceans, while those of the comatulids consisted of diatoms such as Navicula, Bacillaria, Actinocyclus, and Coscinodiscus, of Tethya, and of many types of entomostraca.

W. B. Carpenter said in 1866 that in the very numerous specimens of Antedon bifida from Arran, of which he examined the contents of the digestive cavity, he never found anything other than microscopic organisms, and the abundance of the horny rays of Peridinium tripos made it evident that in this locality that organism is one of the principal articles of food. But in specimens from other localities he found a more miscellaneous assemblage of alimentary particles, the most commonly recognizable forms being the horny casings of entomostraca or of the larvæ of higher crustaceans.

In his account of Hyponome sarsii (the visceral mass of Zygometra microdiscus) Lovén states that in the ambulacral grooves he found masses consisting of minute crustaceans, larval bivalves, and other remains of food.

In $1876 \mathrm{~W}$. B. Carpenter wrote that the contents of the alimentary canal of Antedon bifida both in the pentacrinoid stage and in the adult consists of minute entomostraca, diatoms, spores of algæ, etc., but especially in his Lamlash specimens of Peridinium tripos, which was usually very abundant in that locality.

He also notes that the contents of the alimentary canals of the various types of existing pentacrinites examined by him are of the same nature.

P. H. Carpenter says that the food of a crinoid is considerably varied in its nature, according to the character of the sea bottom on which it lives. The horny casings of entomostraca and the larvæ of larger crustacea are frequently to 
be found in the digestive tube, together with the frustules of diatoms, spores of algæ, etc. In sections of Bathycrinus, Rhizocrinus, Isocrinus, and Endoxocrinus from deep water the silicious skeletons of radiolarians may be found in considerable abundance and variety. Foraminifera, too, form a staple article of food for these deep-sea species, for he frequently found Globigerina, Biloculina, and other types beneath the covering plates of the food grooves on the arms and pinnules, while the remains of their sarcode bodies occur in the intestines of decalcified specimens.

Seeliger believes that he recognized in the earliest food of the larvæ half digested infusorians and different pelagic larvæ.

Bury found the stomach of the early pentacrinoids so filled with diatoms that the cutting of sections was rendered very difficult.

Dr. Edwin Kirk states that in the case of a number of specimens of Comanthus japonica which he examined the contents of the intestine were almost wholly comminuted animal matter.

At Maër Island, Torres Strait, Dr. H. L. Clark examined the stomach contents of four comatulids (species undetermined). He found that in each case the greater part of the food material was green algæ, chiefly unicellular, though some linear forms (thread algæ) were also noted; a few diatoms were detected, and some foraminifera. In one of the stomachs several radiolarians were seen, in another a piece of a red alga, and in a third some fragments of minute crustaceans.

Doctor Clark also examined the stomach contents of Tropiometra picta at Tobago, which he found to consist of a mixture of vegetable and animal food, the former predominating. The plants were diatoms and unicellular green algæ, with occasional fragments of seaweeds; of animals, crustaceans were most frequently noted, but a few foraminifera were also seen. The crustaceans were minute amphipods, copepods, and crab zoæas.

Dr. Th. Mortensen found that a relatively large percentage of the pentacrinoids of Isometra vivipara have in their stomachs the half-digested, but still perfectly recognizable, remnants of larvæ; he even found very young pentacrinoids with the vestibule recently ruptured and the arms not yet developed with embryos almost as large as themselves in their mouths.

He remarks that, on account of the large number of pentacrinoids found attached in clusters to the tips of the upturned cirri--as many as 99 in one specimen--this danger to the embryos is very real, and probably quite a large number of them perish in that way.

PARASITES AND COMMENSALS.

A very large number of organisms belonging to very diverse groups are found more or less intimately associated with the crinoids. The relation between these types and the crinoid hosts runs by imperceptible gradations all the way from true parasitism, in which the organism feeds directly upon the body tissues or fluids of the host, to the most casual or accidental association.

The animals associated with the crinoids may be grouped as follows:

I. True parasites: Animals which (1) live upon the tissues or body fluids of the crinoids and occur either $(a)$ internally or $(b)$ externally; $(2)$ occur internally, 
though not feeding directly upon the tissues of the host; or (3) while living externally upon the surface of the body and not feeding directly upon the tissues or fluids of the host are more or less permanently fixed in position and cause more or less extensive malformations, sometimes becoming encysted.

1. Animals which live upon the tissues or the body fluids of the crinoids.

(a) Internally:

Undetermined internal worm (?myzostome) in the ovary. Parasitic worm of doubtful aflinities.

(b) Externally:

Laphystiopsis iridometrce.

Sabinella ptilocrinicola.

Parasitic Ostracod.

Collocheres gracilicauda. Sabinella capillastericola.

Stilifer bathymetroe.

Stilifer, spp.

Stylina comatulicola. Sabinella, spp.

Melanella capcnsis.

Melanella, spp.

Hemispeiropsis antedonis.

2. Animals which are internal, though not feeding directly upon the tissues of the host:

Enterognathus comatula.

Holotrichous infusorian.

Certain myzostomes.

3. Animals which, while living externally upon the surface of the body and not feeding directly upon the tissues or fluids of the host, are more or less permanently fixed in position and cause more or less extensive malformations, sometimes becoming encysted.

Many myzostomes.

II. Semiparasitic Commensals: Animals which feed upon minute organisms and have to a greater or lesser extent adopted the habit of sucking up the food particles from the streams flowing down the ambulacral grooves of the crinoid to the mouth, or of temporarily entering the digestive tube and feeding upon the contained matter :

Synalpheus comatularum.

Cirolana lineata.

Synalpheus stimpsonii maldivensis.

Synalpheus carinatus binongcensis.

Synalpheus brucei.

Synalpheus, spp.

Periclimenes commensalis.

Periclimenes cornutus.

Periclimenes ceratophthalmus.

Periclimenes brocketti.

Periclinienes pottsi.

Pontoniopsis comanthi.

Galathea elegans.

Galathea inflata.

Galathea minuta.

Anilocra, sp.

Cyclotelson purpureum.

Undetermined crustacean.

Ophiactis delicata.

Ophiomaza cacaotica.

Ophiomaza cacaotica var. picta.

Ophiomaza obscura.

Ophiomaza cataphracta.

Ophiomaza morens.

Ophiocthiops unicolor.

Ophiocethiops clegans.

Ophiophthirius actinometro.

Ophiosphara insignis.

Polynoë minuta oculata.

Polynoë crinoidicola.

Most myzostomes. 
III. Nonparasitic commensals: Animals which, while usually, or commonly, found living upon or among the crinoids, lead an entirely independent existence, and for the most part are found living under similar relations with other organisms:

Hippolyte, sp.

Scalpellum album.

Scalpellum balanoides.

Scalpellum diceratum.

Scalpellum gonionotum.

Scalpellum pentacrinarum.

Scalpellum weltnerianum.
Scalpellum, spp.

Verruca nitida.

Verruca, spp.

Pachylasma crinoidophilum.

Gemellaria loricata.

Loxosomella antedonis.

Rhabdopleura mirabilis.

\section{Parasitic hydroid.}

IV. Casual associates: Animals which normally occur hiding among, crawling over, or attached to other usually arborescent organisms, from which they may or may not derive nourishment, or which normally occur attaclied to any arailable support, and which occasionally stray among or upon, or attach themselves to, the crinoids but remain otherwise entirely independent of them:

Small fishes.

Many crustaceans.

Certain ascidians.

Astrogomphus vallatus.

Asteroporpa annulata.

Sigsbeia murrhina.

Ophiacantha, spp.

Ophiolebes scorteus.

Ophiocoma, sp.

Ophiopholis mirabilis.

IOphiactis, sp.

Ophiomusium, sp.
Other ophiurans.

Certain pelecypods (Avicula, etc.).

Serpulidæ.

Calycella syringa.

Stegopoma fastigatum.

Cuspidella, sp.

Lafoëa fruticosa.

Other hydroids.

Certain sponges.

Truncatulina lobatula.

Polytrema miniaceum.

Other foraminifera.

As in the case of the other arborescent marine types, and in general among the animals that live by filtering the microplankton from the sea water, the crinoids are chiefly subject to indirect parasitism; that is to say, the creatures depending upon them for their existence appropriate the food particles which the crinoids have collected in the ambulacral grooves, or even which they have swallowed, instead of consuming the tissues or body fluids directly. Of the animals which derive a part or all of their nutriment from the body, or from the efforts, of the crinoids, about 10 per cent are directly parasitic, and about 90 per cent are indirectly parasitic, in varying degrees.

There is a curious and interesting correspondence between the relations of the fixed marine organisms (including the crinoids) and their parasites and commensals and those between parasitic and epiphytic plants and their hosts. The barnacles, most hydroids, polyzoans, etc., correspond very closely to the epiphytic plants, especially those of the families Orchidaceæ and Bromeliaceæ. Rhabdopleura and certain hydroids are quite vine-like in habit, ascending crinoid stems as vines do the trunks of trees. Most parasitic plants appropriate the unelaborated sap of the host and convert it to their own ends; most parasites of the fixed marine organisms in the same way appropriate the concentrated but undigested microplankton in or approaching the stomach of the host. On land most animals are 142140-21-Bull. 82-— 41 
parasitized by animals of an inferior organization; but among the fixed marine animals the parasites for the most part belong to a phylum with a superior organization, and sometimes even to the same phylum (cœlenterates parasitic on cœlenterates, crustaceans parasitic on crustaceans, ophiurans parasitic on crinoids, etc.). The relations between the fixed marine animals and their parasites are thus more nearly the same as those between parasitic flowering plants and their hosts. On land the various animal groups are definitely parasitic or nonparasitic; but many plant families, such as the Scrophulariaceæ, Santalaceæ, etc., and even many single genera, such as Pedicularis, Melampyrum, Gerardia, etc., include both parasitic and nonparasitic species, just as do many families and genera, such as Synalphers, Periclimenes, etc., occurring with the fixed marine animals.

Of the animals which are parasitic on the crinoids, nearly all may be described as casual parasites, for they belong to genera or families other representatives of which are nonparasitic; that is to say, they are merely particular species which have found an easy existence in preying upon the crinoids, though this mode of life has not induced any special modification of their structure.

The three types which are of especial interest are: (1) The gasteropods (Stilifer, Stylina, Sabinella, and Melanella), (2) Enterognathus, and (3) the myzostomes.

The family Melanellidæ, to which Stilifer, Stylina, Sabinella, and Melanella belong, includes species showing all gradations between free-living nonparasitic types and shell-less parasites living entirely within the body of the host. As parasites the Melanellidæ occur only upon the echinoderms, where, however, they are found on species of all the classes. Most of the parasitic forms, including all of those occurring on the crinoids, are characterized by extraordinarily delicate shells. Some of the species are permanently fixed in one position on the body of the host, but others, including all those found upon the crinoids, appear to move about and to bore into different parts of the host. It is not a little curious that, apart from Melanella capensis and Stylina comatulicola, all the species parasitic on the crinoids are always attached to the calyx plates, or to the cirrals, brachials, or pinnulars, instead of to the soft ventral integument.

Enterognathus occurs only in crinoids, but the family to which it belongs is well known as a parasite (or commensal) of the tunicates, most of the species living in the branchial chamber of these animals.

The myzostomes form a group of very highly specialized polychæte annelids and are the chief parasites of the crinoids, to which animals they are almost exclusively confined. On the crinoids they are, with one possible exception, always ectoparasitic, though they may form soft or calcified cysts within which they are almost completely isolated from the outer world. An organism, possibly a myzostome, has been reported by Mortensen in the ovarian cavity of Notocrinus viritis. If this really is a myzostome, which is not unlikely, as similarly endoparasitic species occur in starfishes (Asterias, Stolasterias, and Ceramaster) and astrophytons (Gorgonocephalus eucnemis and G. arcticus), we find in the crinoids (in accordance with Wheeler's classification) five groups of myzostome species, as follows :

I. Wandering species, which move about freely and actively over the body of the host, as Myzostomum cirriferum. 
II. Sedentary species, which rarely, if ever, leave the spot where they have settled, as $M$. parasiticum.

III. Cyst-producing species, which cause the formation of galls or swellings on the disk or arms, as $M$. cysticolum.

IV. Entoparasitic species inhabiting the digestive tract, as $M$. pulvinar.

V. Entoparasitic species living in the ovaries, as Protomyzostoma polynephris.

Thus in the crinoids we find a single group of animals, which, broadly speaking, play the part of the fleas, lice, jiggers and bots, intestinal worms, and flukes combined as we know them among the land vertebrates.

In the vertebrates the blood, with its multitudes of red corpuscles which when destroyed are promptly and continuously renewed, is the logical food of practically all the parasites which do not inhabit the intestinal canal. The dilute blood of the crinoids, without structures corresponding to the red corpuscles, has none of the features which make the blood of the vertebrates such a rich reservoir of concentrated food. But the uncountable myriads of minute organisms flowing continuously downward along the ambulacral grooves and into the mouth form a stream of nutrient fluid in many ways analogous to the vertebrate blood stream, and it is from this source that the myzostomes, as well as most of the other parasites, derive their subsistence.

The species in each group parasitic on the crinoids in those cases in which our information is sufficient to permit us to speak with a reasonable amount of certainty follow bathymetrically and geographically the distribution of the classes to which they belong quite regardless of that of their hosts, and apparently, excepting possibly in the case of Stelechopus, the most primitive of the myzostomes parasitic on the most ancient of the recent crinoids, there is not the slightest correlation between the systematic position of the parasite and that of the crinoid.

The following are known as parasites on crinoids only in the Indo-Pacific region :

Parasitic internal worm.

Laphystiopsis.

Parasitic ostracod.

Sabinella.

Synalpheus.

Periclimenes.

Anilocra.

Cirolana.

Cyclotelson.

Ophiactis.

Ophiomaza

Pontoniopsis.

Ophiocethiops.

Galathea.

Ophiophthirius.

Ophiosphara.

Polynö.

though Laphystiopsis, a parasitic ostracod (on fish), Sabinella, Synalpheus, Periclimenes, Galathea, Anilocra, Cirolana, Ophiactis, and Polynö̈ also occur in the Atlantic.

The following are known as parasites on crinoids only from the Atlantic:

Collocheres.

Stylina.

Hemispeiropsis.

Enterognathus.

Holotrichous infusorian. 
but all of these are small and must be especially searched for; probably all occur in the Indo-Pacific.

From the Antarctic only we know Mortensen's parasitic worm of doubtful affinity; but only Notocrinus viritis offers a suitable habitat for it.

Thus while the myzostomes occur wherever crinoids are found, the majority of the other parasites and commensals on crinoids are confined to the Indo-Pacific region, though many are very closely related to nonparasitic Atlantic species.

The chief reasons for this are probably the absence of a richly developed littoral crinoid fauna in the tropical Atlantic comparable to that in the Indo-Pacific region, and the plating of the ambulacra in most of the tropical Atlantic types, including the littoral species, which renders them unarailable as a source of food to most of the parasitic forms.

Many of the species of myzostomes have a much more extended geographical, bathymetrical, and thermal range than any known crinoid genus, or even family. Thus Myzostomum gigas occurs in the Arctic on Heliometra, and in the tropical littoral in Brazil on Tropiometra; M. cysticolum occurs in the tropical littoral in Brazil on Comactinia, in the Gulf of-Alaska in 159 fathoms on Florometra, in southern Japan on the species of Calometridæ, and on the shores of the Antarctic continent in 500 fathoms on Anthometra; $M$. vastum occurs in the Caribbean Sea on Comactinia, and in southern Japan on Comanthus; M. excisum occurs in Florida on Coccometra, and in Mauritius on "Antedon impinnata"; M. inflator occurs at Barbados on Neocomatella, and at the Kei Islands on Adelometra; M. carinatum occurs in the Caribbean Sea, at Mauritius, and in the Moluccas: M. elegans occurs in Florida and in the Philippines; and $M$. murrayi occurs at the Kermadec and Kei Islands, and at St. Vincent, West Indies. Myzostomum japonicum ranges from 52 to 943 fathoms, and $M$. cornutum from the shore line in the Philippines down to 775 fathoms off southern Japan.

Generally speaking, the range of Synalpheus comatulamum, Galathea elegans, Ophiomaza cacaotica, and the parasitic Polynoë coincides with that of the large East Indian comasterids among which they live.

Laphystiopsis is interesting in being represented by two very closely related species-one from the China Sea, parasitic on comatulids, the other from Norway, possibly parasitic on fish.

Of the gasteropods Stilifer occurs in the Pacific on Bathymetra and in the Atlantic on Bythocrinus, ranging from 237 to 1,772 fathoms; Melanella occurs in South Africa on Annametra, in the West Indies on Crinometra, and off Nova Scotia on Rhizocrinus, ranging from the shore line to at least 218 fathoms; and Sabinella occurs at Ceylon and Singapore, and off the Queen Charlotte Islands, ranging from the tropical littoral to 1,588 fathoms.

It is interesting to note that, with the exception of the myzostomes and the gasteropods, the great majority of the organisms which are directly or indirectly parasitic upon the crinoids are confined to the littoral zone.

The reason for this is probably to be found in the development of side plates and covering plates along the ambulacra of the pinnules, arms, and disk in most 
of the crinoids from intermediate and great depths, which enable the animals to convert the ambulacral grooves into closed tubes, and more or less completely to close the mouth, and prevents the appropriation of the food particles by such types as Synalpheus, Periclimenes, Pontoniopsis, Galathea, Anilocra, Cirolana, Ophiactis, Ophiomaza, Ophiocethiops, Ophiophthirius, Ophiosphara, or Polynö̈.

The myzostomes have developed means of avoiding this difficulty, such as boring into the animal by the side of the ambulacral groove and causing the formation of a cyst in which they live, while the gasteropods bore into the body of the crinoid anywhere and feed upon the tissues.

The larger commensals living on the crinoids are usually striped or banded, and resemble them more or less closely in color, though in many cases the closely related noncommensal species are quite plain. This may or may not be the case with the myzostomes.

In regard to the parasites and commensals of the comatulids there is one curious feature which stands out very prominently-the majority of the records, especially of the larger and more vigorous types, are based upon species of the family Comasteridæ.

The large species belonging to the family Comasteridæ are probably the most highly specialized of all the comatulids. They almost, or even quite, completely lack an adambulacral skeleton; the cirri tend to disappear; the central organ is reduced to a minimum; the radials are reduced to a minimum; the arms in length, size, or number are developed to the maximum, and are extraordinarily tough; the pinnules bear peculiar and highly specialized terminal combs; the digestive tube makes about four complete turns instead of only slightly more than one; and the average size is very large.

In the Comasteridæ, therefore, we have what appears to be an overspecialized group consisting chiefly of giants which are relatively helpless; their ambulacral grooves can not be closed; they can not, to rid themselves of parasites, readily cast off their arms or their disks; and they can not swim away from an infested locality. As a natural result they are attracting to themselves as parasites representatives of many types which are quick to adapt themselves to any advantageous new conditions. If this process is continued much further it will mean the disappearance of the dominant comatulids of the Indo-Pacific and north Australian reefs, and the reduction of the Comasteridæ to small and generalized primitive types resembling such genera as Comatonia, Comatilia, and Comatulides.

The more or less sudden extinction of highly specialized giants has occurred over and over again in past ages, and the incipient disappearance at the present time of such types as the elephants, camels, bison, rhinoceroses, tapirs, and whales, as well as the giant tortoises, sea turtles, and giant lizards, is patently evident.

In these cases man is the aggressor, and the process has in recent years been retarded by the enforcement of restrictive laws. But with the Comasteridæ we see the same thing working out in nature, probably just as it did in past ages, through the convergence of a progressively increasing number of parasitic types upon a relatively helpless group. 
The modern method of distributing the material brought up by the dredge or gathered by shore collectors immediately among the different phyla represented, resulting from the almost complete extinction of the "naturalist" with a broad zoological knowledge and the appearance of the "specialist" interested only in some one circumscribed group, has rendered exceptionally difficult the study of the ecology of the various marine types. One is constantly reading descriptions of new species which are undoubtedly commensals, in which not the slightest reference is made to any host. Any collection of crinoids received from the East Indian region is certain to include not only myzostomes, but also many other commensals preserved with the crinoids, and the liaison between the latter and the animals in the containers with them should never be broken until it is definitely determined whether or not there is an ecological relationship between them.

The development of the study of the commensals found with the crinoids has been largely by a series of short notes casually intercalated in papers dealing with crustaceans, ophiurans, annelids, etc., in which a species is said to have been found upon a comatulid, but there are a few records of commensalism properly identified as such.

In a letter written during the cruise of the Challenger by $\mathbf{R}$. von WillemoesSuhm, one of the Challenger party, to Prof. C. Th. E. ron Siebold, and published by the latter in 1876, Willemoes-Sulm says that in 1874 in the Arafura Sea he once examined 80 specimens of a large comatulid and found on about every tenth one a myzostome, the largest he had ever seen. The myzostomes lay or crawled snake-like on the calyx, but seldom in the ambulacral grooves of the arms. Usually there were two or three large ones, and with them a smaller. All these myzostomes were, like the comatulids themselves, mottled with black and white, and all the other parasites of the comatulids showed the same coloration. The other parasites were-first, ophiurans clinging to the calyx; second, small aphroditaceans; third, amphipods which had bored into the disk; and fourth, an apheid. Including the myzostomes, there were thus five parasites on this very large comatulid.

The large black and white comatulids were probably Zygometra microdiscus or Z. elegans. Carpenter and Potts have suggested that Comatula rotalaria and $C$. solaris were probably the species in question, but neither of these was taken at the station in the Arafura Sea, and neither is ever black and white. The myzostomes were Myzostomum horologium, the ophiurans were Ophiomaza, the aphroditaceans Polynoë, the amphipods probably Laphystiopsis, and the alpheids Synalpheus.

In his account of Alpheus comatularum published in 1882 Prof. William A. Haswell states that they were invariably found clinging to the arms of a species of comatulid to which their markings gare them a general resemblance. Other commensals of these comatulids were Galathea deflexifrons, and an undescribed species of cymothoid, the latter usually ensconcing itself in the alimentary canal of its host, in which it remained buried with the exception of the anterior third of its body.

In his monograph on the stalked crinoids, published in 1884, P. H. Carpenter mentions as internal parasites of the group the suctorial crustacean described by 


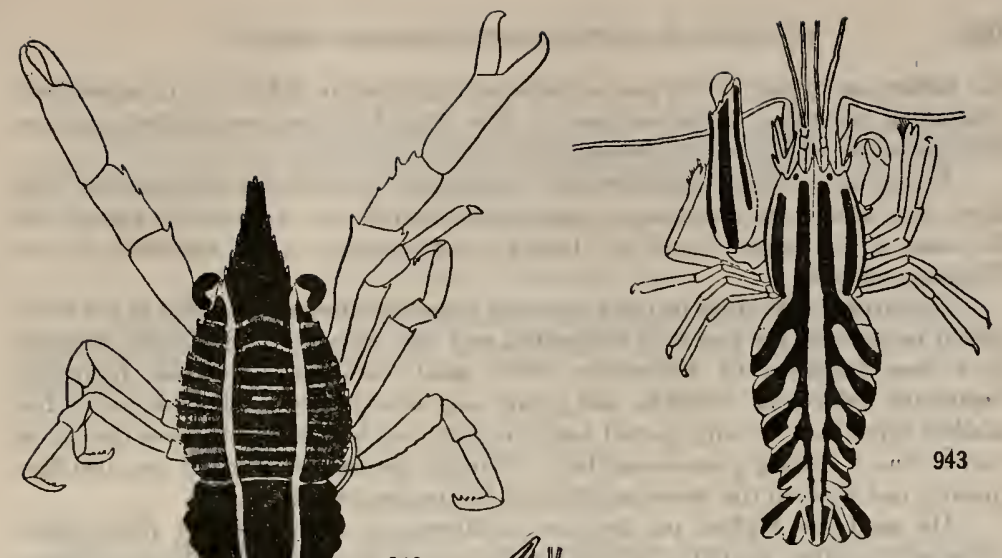

942
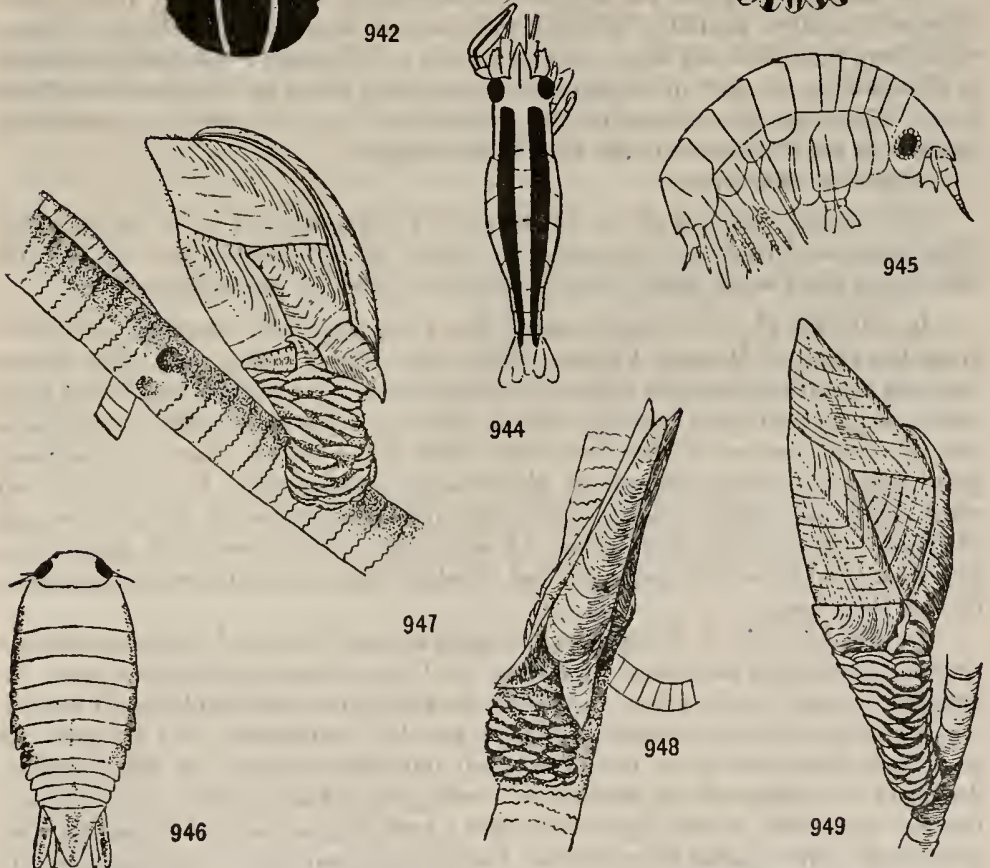

Figs, 942-949,-Parasites and Commensals of Crinoids. 942. Galathda elegans (after potts). 943. Sy nalpheos comatularem (after Potts). 944. Pontoniopsis comanthi (after Potts). 945. Ctclotelson perforeus (After Potts). 946. Crrolana lineata (after PotTs). 947. Scalpellem diceratum (after Pilsbry). 948. Samp (after Pilsbri). 949. Scalpelium pentachinarum (AFTDR PILSBRT). 
his father, an isopod of the genus Anilocra with similar habits, an undetermined crustacean sometimes found encysted in the disk of Heliometra glacialis, and an internal worm which he discovered in Comanthus parvicirra.

Regarding external parasites and commensals he cites the myzostomes, and gives ophiurans, aphroditaceans, amphipods (which he erroneously regards as the same as the isopod found by himself), and alpheids on the authority of von Willemoes-Suhm.

He further states that he has frequently found ophiurans entangled in the cirri, which he regards are probably accidental, and once an ophiuroid pluteus attached to a stem fragment of Metacrinus, while small bivalves, sertularian hydroids, bryozoans, tubicolous annelids, and corals may be attached to the column of the stalked types, not for any special nutritive purpose, but simply because the larvæ had to find a resting place somewhere. Various species of cirripeds are also frequently met with on the stems and cirri of the pentacrinites.

He mentions Stylina on Antedon mediterranea, and says that Rhizocrinus lofotensis is often similarly infested with two or three small shells of Stilifer, which bore comparatively large holes in its calyx. He notes Truncatulina lobatula as abundant on the cirri of certain arctic comatulids which he examined, and Polytrema miniaceum as common on the columns and cirri of certain pentacrinites dredged by the Challenger in the East Indian region.

Alcock in 1902 wrote:

I have already mentioned the sea lily, striped in alternate bands of yellow and purple, on whose fronds simifarly striped crustaceans live without fear of detection; here we found the same sea lily giving secure shelter to sen worms, banded yellow and purple like itself.

In 1904 Mr. H. C. Chadwick stated that a specimen of Comanthus parvicirra from the Gulf of Manaar, Ceylon, which when living was a deep olive brown with the tips of the pinnules yellow, had living upon it an alpheid which was olive brown striped with gray; and in 1908 he recorded a predominantly yellow specimen of Lamprometra palmata from Suez which had a brown commensal polynoid living upon it, and an example of Heterometra savignii from Ul Shubuk which when living was whitish with a violet tinge and with patches of darker color and of yellow, from which were taken 15 ophiurans which lived with their arms twisted around those of the crinoid, and of which the color on the whole resembled that of their host.

In 1915 Lieut. F. A. Potts, who had made a special study of the commensalism between comatulids and other organisms at Torres Strait, published a most interesting memoir on the subject, in which he went into considerable detail regarding the color relations between the hosts and the commensals, and brought out many new facts bearing on their ecological interrelationships. In this paper he described as commensals on comatulids a new genus of amphipods, a new isopod, two new galatheids, a new Synalpheus, and a new Polynö̈, and published detailed notes on the three species of commensal Pontoniidæ discovered by him and recently described by Borradaile. 


\section{TUNICATA.}

Small tunicates, both simple and compound, are occasionally found on the stems and cirri of the pentacrinites; large ones are extremely rare.

\section{ENTEROPNEUSTA.}

\section{RHABDOPLEURA MIRABILIS (SARS).}

This form was found by Sars growing along the column of Rhizocrinus lofotensis; it was originally recorded as a polyzoan under the name of Halilophus mirabilis.

\section{CRUSTACEA.}

DECAPODA MACRURA.

\section{Family ALPHEIDE.}

The family Alpheidæ includes a considerable number of partially and strictly commensal types, among which may be mentioned Arete maruteensis Coutière, which lives among the spines on the oral surface of the large sea urchin Heterocentrotus mamillatus Klein, Arete dorsalis var. indicus Coutière, which Professor Coutière found at Jibuti, French Somaliland, living among the spines on the oral surface of another sea urchin of the same family, Echinometra mathai (de Blainville), the alpheids in both cases resembling the hosts in color, and a number of the species of the genus Synalpheus commensal on gorgonians, Solenocaulon, and comatulids. When these animals are more extensively studied in the field undoubtedly commensalism will prove to be much more frequent than is now supposed.

All of the alpheids commensal on comatulids belong to the genus Synalphers. This genus as now understood includes 63 species and 15 varieties; of these 78 recognized forms only 4 occur on crinoids, 2 of these invariably, so far as known, the other 2 being varieties of species the commensalism of which has not been established.

The genus Synalpheus falls into six well-characterized groups, of which one, the so-called "Comatularum Group:" includes all the forms commensal on crinoids.

The species in the Comatularum Group are the following, those known to be commensal on comatulids being designated by an asterisk $\left({ }^{*}\right)$ :

* Synalpheus comatularum (Haswell) [=S. falcatus Sp. Bate].

Synalpheus stimpsonii stimpsonii de Man.

* Synalpheus stimpsonii maldivensis Coutière.

Synalpheus carinatus carinatus (de Man).

* Synalpheus carinatus binongcensis de Man.

Synalpheus carinatus ubianensis de Man.

Synalpheus amboince (Zehntner).

Synalpheus consobrinus de Man.

Synalpheus odontophorus de Man.

* Synalpheus brucei Potts.

Synalpheus albatrossi Coutière. 
All of these forms are confined to the Indo-Pacific region, and nearly all to the Malayan archipelago; one, S. albatrossi, occurs at Laysan Island, in the Hawaiian group.

Commensalism between an alpheid and a comatulid was first reported in 1876 . During the voyage of the Challenger von Willemoes-Suhm observed, in the Arafura Sea, in 1874, a black and white alpheid living on a mottled black and white comatulid.

In 1882 Prof. William A. Haswell described Alpheus comatularum which had been dredged by the Alert in a few fathoms of water in the Albany Passage, near Cape York, Queensland, and which was invariably found clinging to the arms of a comatulid, to which its color markings gave it a general resemblance.

Mr. E. J. Miers, in the Alert report published in 1884, redescribed Alpheus comatularum in great detail, and cited additional localities. It was again redescribed under the name of Synalpheus falcatus, by Mr. C. Spence Bate in the Challenger report in 1888. His specimens were dredged between Cape York and the Aru Islands in 8 fathoms.

In $1905 \mathrm{M}$. $\mathrm{H}$. Coutière recorded a second case of commensalism between an alpheid and a crinoid, describing Synalpheus stimpsonii var. maldivensis, from the Maldive Islands, which had been found living upon a comatulid resembling it in color. In 1911 Dr. J. G. de Man described Synalphous carinatus var. binongcensis, which had been found on a crinoid, and in 1915 Lieut. F. A. Potts described Synatpheus brucei, commensal on comatulids in Torres Strait, and discusses S. comatularum.

\section{SYNALPHEUS COMATULARUM (HASWELL).}

Fig. 1234, pl. 38.

Lieutenant Potts writes that Synalpheus comatularum is markedly larger than $S$. brucei and is stouter in general appearance; but the resemblance in coloration and habits is so close as to suggest specific identity until the peculiar form of the little chela is noticed.

The individuals were generally seated in pairs on the disk, but when slightly disturbed they immediately dug the hook of this chela into the flesh of the disk, from which it was only dislodged with difficulty; or if the alpheid had left the surface of the disk, the chela was serviceable for clasping the arm of its host. But this instrument is only used for temporary attachment, nor is it usually embedded in the host when the animal is at rest.

Potts notes that there is, in spite of the wonderful similarity in the coloration of this species and of $S$. brucei, one marked difference; that is, the entrance of a white or yellow pigment into the color scheme of this form. He describes a typical example of a light-colored crinoid and its commensal in the following way: The comatulid (Comanthus annulata) had a yellow-green disk, the arms were black with white tips, sometimes with a dash of rusty-red pigment, and the pinnules white, sometimes gray at the side. The underside of the arms was yellow-green and the cirri were white. Both the commensals were light colored and harmonized to a considerable extent with the host. The female had five prominent lines of 
white pigment on the thorax, alternating with brown lines. On the abdomen there was a median white line with a brown line on either side, most of the median space being colorless, and a nonpigmented eye being found on each pleuron. The male showed six lines of brownish-purple pigment on the thorax, the remaining portions being colorless save for some dashes of white pigment. In this case the two partners differed slightly; the female showed well-developed white pigment, and the other pigment was brown; in the male white pigment was almost absent and the pattern was formed by a purple-brown darker than in the female.

Distribution.-Albany Island; Albany Passage; Warrior Reef; reefs north of Mabuiag Island; Prince of Wales Channel; Thursday Island; between Cape York and the Aru Islands; Torres Strait; Singapore; Ceylon.

Depth.-Littoral, and down to 9 fathoms.

SYNALPHEUS STIMPSONIY VAR. MTALDTYENSIS COUTIÈRE.

This form was found on a crinoid which resembled it in color; it was taken at Hulule, Male Atoll, Maldive Islands.

SYNALPHEUS CARINATUS VAR. BINONGCENSIS DE MAN.

One specimen, a female, is the only known example of this form. It was found on a comatulid dredged by the Siboga in 55 meters at the anchorage off Pasir Pandjang, on the west coast of Binongka.

\section{SYNAIPIEUS BRUCEL POTTS.}

Lieutenant Potts' account of this species is as follows:

Comanthus annulatus, with which Synalpheus brucei is usually associated, is very variable in color. It will be sufficient here to say that the coloration varies from a light green mingled with yellow and white to the darkest green or even black. The commensal alpheid is generally black to brownish purple in ground color, but the pigmented dorsum is traversed by longitudinal stripes which are free from pigment. Of these one runs down the middle line from head to tail, there are either two or three on each side of the carapace, and two on the upper surface of the chela. In addition, each abdominal pleuron is traversed by a short oblique pigment-free stripe which may by the encroachment of the pigment become a spot. The relative extent of pigmented and nonpigmented areas is exceedingly variable, and corresponds roughly to the depth of coloration of the host which the alpheid inhabits. Individuals which lodge upon a light green comatulid have only narrow red or purple lines of pigment, the remaining portions being unpigmented; in those which are associated with a dark green or black host the pigment may be extended over the whole of the dorsum.

In the vast majority of cases a pair, male and female, of alpheids is found on each comatulid. In a few cases there appeared to be only a single lodger, but then its small size seemed to show that it was too young to have acquired a mate.

In most cases the pair are similarly colored; rarely, however, there is a difference, and Potts found one case in which one member was marked with very definite 
and fairly wide stripes of dark pigment, while the other was uniformly covered by red pigment.

Potts states that there are two factors in the color variations: One is the character of the pigment, which ranges from a clear red to a purple so deep as to appear black; the second depends on the area of the body covered by the pigment. The first seems to depend very largely on the species of the host. Synalpheus brucei is found, though more rarely, on a second host, Comatula purpurea, in which reddish pigment predominates, and here the crustacean was sometimes observed to show a red pigment covering the whole body, thus matching the host; but sometimes purple and white striped individuals are found on Comatula purpurea.

Among the commensals of Comanthus annulatus also the pigment may be red or red brown; but this is only so in the cases where the colored stripes are narrow; where they are broader the pigment is invariably darker.

Potts gives the chief variations in color as follows: Uniformly red brown in Comatula purpurea; with narrow red stripes in light green varieties of Comanthus annulatus; with purple stripes of uniform dark color in dark green varieties of Comanthus annulatus.

He states that the purple pigment would seem to be either something additional or a more complex product of the red pigment. In the alpheids which were preserved in formalin and glycerin to keep the original color as far as possible the purple was speedily lost, leaving such a red as occurs in the lighter colored forms.

Synalpheus brucei thus exhibits a marked protective resemblance to its host. Against the very light-colored crinoids the almost colorless alpheid is quite inconspicuous. The striped specimens are found upon comatulids in which bars of light and dark pigments alternate, and so they, too, are not easily seen. And lastly, when the dark pigment is uniformly spread over the body of the crinoid, this is also the case with the alpheid.

But though this is often true, there are many cases where the resemblance is by no means close, and the alpheid is rather conspicuous. Potts is inclined to explain these cases by supposing the alpheids to have migrated from some other crinoid at a comparatively recent period. So thickly do the crinoids lie in the crevices of the reef, all conceivable color varieties being herded together without distinction, that it is more than likely that an interchange of commensals should occasionally take place; for Synalpheus, though tending to become a truly sedentary animal, is at times very active, and an excellent swimmer.

Potts suggests that the conditions of commensalism do not allow natural selection to come into play to any marked extent. The commensals are for the most part inclosed by the arms of the crinoid as in a living cage. When the water is calm these arms are relaxed and extended, but on the approach of an intruder they curl up and so protect the soft central disk. It is scarcely to be supposed that even a rapacious fish would take a mouthful of these hard and unsatisfying arms for the sake of the shrimp which lies amongst them. In no case, at least, which Potts saw were the arms of crinoids mutilated. 
In Hippolyte the young larva is at first a colorless creature living at the surface of the sea, and when this is carried inshore it attaches itself to the first seaweed it meets. The skin is in such a sensitive condition that within a week a complete resemblance in color is brought about, whether the seaweed background be red, green, or brown.

Potts believes that the resemblance in coloration between Synalpheus and its host is a similar phenomenon; but it is less perfect because natural selection has not been brought into play to the same extent, if at all, as in Hippolyte, to which the seaweeds offer a holdfast, but not a complete refuge such as the crinoid affords.

In Synalpheus generally both members of a pair are similarly colored. This is a phenomenon which Potts believes may be explained in two different ways: Either mating takes place early, before the pigment pattern has been finally determined and the same factors act equally on both, producing a similar pattern, or else there is assortive mating. Possibly the truth lies in a combination of both explanations; if so, the exceptions where mates are dissimilarly colored are due to the breaking down of the rule of assortive mating, or to the existence of individuals which are not able to assimilate themselves to their background.

With regard to the habits of $S$. brucei, Potts states that it is usual to find the male and female lying side by side on the surface of the disk, but when disturbed they take refuge between the pinnules or on the dorsal surface of the arms. They move about quite freely, but they can guard against forcible detachment by digging the claws of the thoracic legs into the soft flesh of the disk or by clasping the pinnules or arms of the crinoid. The chelæ are less effective for maintaining a hold than the thoracic legs, though it is to be noticed that these can not be said to be specially modified for this purpose. They are provided with two sharp claws, but this provision is also made in cases where the alpheid has no such commensal habits.

When removed from the crinoids they swim about very rapidly, but return as soon as possible to the shelter of the host and cling to it as before.

They exhibit reactions to light and to touch in a very marked manner. Alpheids placed in a glass ressel always cluster together on the side of the vessel away from the light. Besides being negatively heliotropic, they are strongly thigmotropic, for when the finger is introduced into the water it is instantly embraced by the thoracic legs of the alpheid. In the absence of any foreign object the alpheids embrace one another, so that a number left together in a vessel soon look like a mass of swarming bees.

Potts notes that there seems to be a limited faculty for color change. One individual with wide stripes of pigment became lighter toward night, darker again at day. Unfortunately he did not make any extended observations on this point.

SYNALPUETS, SP.

Mr. H. C. Chadwick states that a specimen of Comanthus parvicirra from the Gulf of Manaar, Ceylon, which when living was a deep olive brown with the tips of the pinnules yellow, had living upon it an alpheid which was olive brown striped with gray. 


\section{Family HIPPOLYTIDE.}

HIPIOLYTE, SP.

On one of the harbor buoys at La Hougue, near Cherbourg, Malard found Antedon bifida in immense numbers, literally covering the chain. There were three distinct color types-(1) violet-red, more or less deep; (2) orange yellow, inclining toward saturn red; and (3) alternate white and red with whitish pinnules.

The Hippolyte occurring with them were of the same colors.

\section{Family PONTONIIDE.}

Although the first known species of this family, described as far back as 1829 , is a commensal in bivalves, and many of those subsequently established are commensal on sea urchins, starfishes, ascidians, corals, sponges, and especially in lamellibranchs, it was not until 1902 that any were known to be commensal on comatulids.

In that year Mr. L. A. Borradaile, who had accompanied Prof. J. Stanley Gardiner during his explorations in the Maldive and Laccadive archipelagoes, published an account of cases of commensalism between these prawns and reef-living crinoids.

In 1915 Borradaile described these species, and with them others which had been collected by Lieut. F. A. Potts at Torres Strait; and in the same year Potts published his own notes upon the latter.

An excellent monographic account of the whole family was published by Borradaile in 1917.

Like most of the commmensals living on the comatulids, these prawns subsist on the minute organisms crowded together in the currents of water flowing down the ambulacral grooves toward the mouth.

Borradaile states that in this family the color varies greatly, the animals being striped, spotted, or suffused in very different ways and with very different colors, while the differences between species are often as great between species of the same genus as between those of different genera. In the cases at present known the colors are usually gaudy and conspicuous when the prawns are removed from their proper environment, though in some instances, at least, their coloration harmonizes very strikingly with that of the natural surroundings.

Nothing is known of the color changes which doubtless occur during life, or in regard to the way in which there arises a correspondence between the coloration of the individual and that of its surroundings, or as to the value this may have to the prawn.

The species of this family known to be commensal on comatulids are the following:

PERICLIMENES (PERTCLIMENES) COMMENSALIS BORRADAILE.

This species was described from specimens collected by Lieutenant Potts at Torres Strait and found on Comanthus annulatus. 
PERICLIAIENES (LAONIENES) CORNUTUS BORRADAILE.

This form was described from specimens collected by Prof. J. Stanley Gardiner and Mr. Borradaile at Male Atoll, Maldives, and found on an undetermined comatulid, which was red and brown in color.

PERICLIMENES (LAOMENES) CERATOPHTHALMUS BORRADAILE.

Like the preceding, this species was found by Professor Gardiner and $\mathbf{M r}$. Borradaile on a comatulid at Male Atoll, Maldives.

PERICLIMENES (CUAPETES) BRUCKFTTI BORRADAILE.

Professor Gardiner and Mr. Borradaile found this species at Male Atoll, Maldives, living on a brown comatulid.

PERICLIMENES (CUAPETES) POTTSI BORRADAILE.

The originals of this species were collected at Torres Strait by Lieutenant Potts, who found them living on Comanthus. Potts did not in life distinguish this form from $P$. commensalis, so that probably the following remarks apply to both.

He notes that this shrimp is comparatively common on the comatulids from the Murray Island reef, but only one or two specimens were obtained at Mabuiag. It is a very transparent creature, and though the general coloration, a beautiful purple, harmonizes with the host, there is no distinct arrangement in longitudinal stripes. The low power of the microscope shows that there is a blue pigment contained in very numerous small cells which are regularly disposed over the body; also evenly distributed, but much fewer in number, are cells containing red pigment, which may be spherical or branching. The gut is colored red. The general effect thus is purple.

\section{PONTONIOPSIS COMANTHI BORRADAIIN.}

Fig. 944, p. 621.

Lieutenant Potts, who collected the specimens described by Borradaile, says that this species was found only at Mabuiag on the light-colored varieties of Comanthus annulatus, in which a great deal of green pigment had developed. In general this small crustacean (it is about $8 \mathrm{~mm}$. long) exhibits a striking correspondence with its host. Alternate longitudinal stripes of bright green and black or dark brown occur on the dorsum, and these match the crinoid pinnules, in which green and yellow alternate with dark green or black. There also occurs another variety, in which the green pigment is replaced by yellow and the darker pigment by red or brown. In the specimen figured by Potts, which he states is typical of the species, there were three yellow stripes alternating with two brown stripes of equal width; the chela was yellow, with a brown line. In this case, however, the commensal, living on a crinoid in which green preduminated, was very conspicuous, and Potts supposes that it had developed its pigment in association with another individual of a different color type. 
DECAPODA ANOMURA.

\section{Family GALATHEIDAE.}

In every large collection of comatulids received from the East Indian region small galatheids, usually conspicuously striped longitudinally, are found associated with some of the specimens.

These commensal galatheids have recently been studied in the field by Lieut. F. A. Potts. His observations did not lead him to suppose that the galatheids occur in pairs on each host, as is usually the case in Synalpheus; but the absence of evidence on this point may be due to the fact that they are inclined to leave the host whenever disturbed.

They are not by any means found so commonly on crinoids as are the species of Synalpheus, though Galathea elegans is not infrequent.

There is no special modification for clinging to the crinoids other than the spines on the dactyli of the thoracic legs.

The animals are thigmotropic, and after detachment immediately swim back to the host.

White, in 1817 , listed without description the first of these commensal galatheids to come to light, Galathea elegans, as among the crustaceans in the collections of the British Museum. His specimens, brought home by the Samarang, were from Corregidor, Luzon, and Unsang, Borneo. In the following year, in the account of the voyage of the Samarang, Adam and White figured, but did not describe, the species.

In 1852 Prof. James D. Dana described a new species, $G$. longirostris, which was found on a comatulid dredged at Fiji in 10 fathoms.

In 1882 Prof. William A. Haswell described $G$. deflexifrons, basing his description on a specimen taken by the Alert in Albany Passage, Torres Strait, and stating that it lives on comatulids.

In 1884 Miers placed $G$. deflexifrons in the synonymy of $G$. elegans and recorded, with annotations, various specimens of tho latter taken by the Alert.

Mr. T. Southwell in 1906 recorded three specimens of $G$. longirostris, with the color markings well defined, which were found adhering to individuals of $C$ enometra herdmani taken in the Gulf of Martaban, Ceylon, in shallow water, and at a depth of 7 to 9 fathoms.

In 1913 Dr. Heinrich Balss recorded $G$. longirostris from the Bonin Islands, and doubtfully referred a single male from near Boschu, Sagami Bay, Japan, in 120 meters, to $G$. elegans. Of this latter he says that it apparently occurs on comatulids.

Lieutenant Potts has recently revised the species of galatheids commensal on comatulids, of which he admits three, two of these described by himself from material personally collected at Torres Strait.

GALATHEA ELEGANS ADAM AND WHITE.

Fig. 942 , p. 621 .

According to Potts $G$. longirostris of Dana and $G$. deflexifrons of Haswell are synonyms of this species, which he described in detail, giving a revised diagnosis. 
He notes that all three forms possess a very typical dorsal ornamentation and have a similar color scheme with longitudinal stripes of pigment on the dorsum; from this he concludes that the whole group of related forms are comatulid dwellers, since if not it would be strange that so marked a pattern should occur on a free-living galatheid when it is a character so definitely associated with crinoid commensalism in this and in other groups.

Miers says of this species that no two specimens agree exactly in their markings. In the Bornean specimens collected by the Samarang the stripes are much broader than in the Philippine specimens, from one of which they are wholly absent. In the specimen from Albany Island they are distinguishable only on the anterior part of the postabdomen. The ground color in nearly all is dull red.

Potts notes that the dorsum and limbs are covered with dark pigment, but there are generally pigment-free longitudinal bands of variable width.

Haswell records the color as dark purple, and as yellowish with three narrow longitudinal dark purple bands on the body and one on either side of the chelipeds and ambulatory legs.

Grant and McCulloch state that the color is most variable. Their specimen from Port Curtis when alive was a bright scarlet with a central longitudinal purple band only on the last segment of the abdomen.

Distribution--Recorded from Madagascar, Tuticorin, in the Madras Presidency, India, Gulf of Martaban, Ceylon, Port Molle and Port Curtis, Queensland, Albany Island, Albany Passage, Murray Islands, Holborn Island, and off Mabuiag, Torres Strait, Amboina, Moluccas, New Britain, Singapore, Unsang, Borneo, Corregidor, Luzon, Philippines, Bonin Islands, and Sagami Bay, Japan.

Bathymetrical Range.-Littoral, and down to 120 meters.

GaLATHEA INFLATA POTTS.

Some, or all, of the specimens were found on Comanthus annulatus.

The color of the carapace was dark blue with two fairly broad longitudinal pigment-free bands; others, referred to this species by Potts, were white.

Locality.-Murray Islands, Torres Strait.

Bathymetrical Range.-Littoral.

GAIATHEA MINUTA POTTS.

This species was found on Comanthus annulatus.

The carapace showed alternate longitudinal stripes of white and dark blue of about equal width.

Locality.--Mabuiag Island, Torres Strait.

Depth.-About 4 fathoms.

UNDETERMINED GALATHEID.

Dr. L. E. Griffin reports that on a specimen of Comanthus parvicirra captured at Port Galera, Mindoro, Philippines, which was olive green, becoming proximally yellow with dark brown longitudinal bands and spots, he found 142140-21-Bull. 82- 42 
"crabs" (probably galatheids), with 10 cream-colored bands' on the carapace, a cream-colored median band on the abdomen, several yellow spots on the ventral side, and the chelipeds and walking legs with yellow distal ends.

PRORLEMATICAL DFCAPOD.

Dr. F. A. Bather stated that a decapod has been found in the anal tube of a crinoid. He probably referred to the suctorial crustacean (see p. 640) recorded by W. B. Carpenter.

ISOPODA.

\section{Family CYMOTHOIDEE.}

ANILOCRA, SP.

Pl. 57. fig. 1346.

In 1882 Prof. William A. Haswell mentioned as a commensal of comatulids in the Albany passage, near Cape York, Queensland, an undescribed species of cymothoid, which was usually ensconced in the alimentary canal of the host, in which it remained buried with the exception of the anterior third of its body.

Miers did not refer to this form in the Alert report.

P. H. Carpenter stated in 1884 that he frequently found in the anal tube of Comatula rotalaria and of $C$. solaris from Cape York an isopod of the genus Anilocra which was nearly half an inch long. In 1888 he recorded another specimen of the same species from an example of Zygometra microdiscus dredged by the Challenger in 8 fathoms of water in Torres Strait. He inferred that either as an egg or as a larva it must have been caught in one of the ciliary currents converging on the mouth from the arms and thus have been carried through the digestive tube to the rectum, where it remained.

Beddard did not mention this species in his account of the isopods collected by the Challenger, and I can not find any further references to it in the literature on the group.

W. B. Carpenter described a similar case of commensalism (or parasitism) in Antedon bifida but did not state the group to which the crustacean belonged (see p. 640).

\section{Family CIROLANIDÆ.}

\section{CIROLANA LINEATA POTTS.}

Fig. 946, p. 621.

This species occurs on comatulids, generally on Comanthus annulatus, and was described from specimens collected by Lieutenant Potts himself in Torres Strait.

Potts writes that this species is far from being as sedentary as Synalpheus, which, while very energetic at times, rests for long periods on the disk of the crinoid. While the isopod may make busy excursions on the surface of the 
comatulid, it is often to be seen diving into the gut of the host, where it apparently spends a large part of its time. He believes that it does not feed on the tissues of the crinoid itself but only on the food it finds in the stomach.

$\mathrm{He}$ states further that this case of commensalism is interesting because of the faint but significant response to the color stimuli of the crinoid. In nearly all the species of this genus where the coloration has been noted at all the chromatophores appear to be distributed over the surface so as to form a series of evenly spaced dots or dashes of pigment. The concentration of these into lines and the development of a purplish pigment seem to be the first effects of the commensalism. The insignificant quantitative development of the pigment is probably associated with the very active life of the isopod and its frequent immersion in the gut of the host rather than to any incapacity of the isopod to assume the colors of the environment.

The color is white, except for branding chromatophores carrying a purple pigment and arranged in two lateral stripes and a fainter median line.

AMPHIPODA.

In a letter written to Professor von Siebold and published by him in 1876, R. von Willemoes-Suhm, writing on board the Challenger in July, 1875, during the voyage from Japan to the Hawaiian Islands, mentioned that on some comatulids dredged in the Arafura Sea in the preceding year a parasitic amphipod had been found which had bored into the ventral disk. The specimens appear subsequently to have been mislaid, for there is no mention of them in the C'hallenger monographs.

On examining closely the specimens of Iridometra melpomene dredged by the Albatross at a depth of 88 to 100 fathoms in the China Sea I was surprised to find a number of amphipods more or less buried in the disk, which at once recalled to my mind the note by von Willemoes-Suhm. I turned these specimens over to Mr. Clarence R. Shoemaker, as he was so kind as to draw up a description of them for inclusion in the present volume.

While working at Murray Island, Torres Strait, Lieutenant Potts found a tiny amphipod occurring very often on the darker crinoids, which proved to represent a hitherto unknown genus.

The two amphipods, one parasitic and the other symbiotic, known to be associated with crinoids, are the following:

\section{Family AMPHILOCHIDE.}

CYCLOTELSON PURPUREUM POTTS.

Fig. 945, p. 621 .

This species is symbiotic. Lieutenant Potts found it common on the darker comatulids at Murray Island, Torres Strait. The specimens described were taken from Comanthus annulatus.

The color dorsally is purple. 


\section{Family LAPHYSTIOPSIDÆ.}

Mr. Shoemaker's account of the new amphipod found on Iridometra melpomene follows:

\section{LAPHYSTIOPSIS IRIDOMETRE SHOEMAKER.}

Description of the male.-The eyes are without pigment, but clusters of indistinct visual elements are present under the surface of the convex sides of the head.

The head is broad and flat and produced in front into a horizontal, spatulate, truncated lamella.

The antennæ are proportionately shorter than in L. planifrons Sars. The first and second antennæ do not differ greatly in length; the first has a flagellum of about 12 segments, the second a flagellum of about 10 segments. The first segment of the flagellum of the first antennæ is the longest and is provided with three fascicles of sensory bristles.

The peræon segments are separated from one another by slight transverse depressions. The pleon segments are much deeper than those of the peræon, and the first three are produced posteriorly into a blunt dorsal lobe; the fourth bears a deep saddle-shaped depression.

The mouth parts resemble in all essentials those of $L$. planifrons, but the first segment of the mandibular palp is proportionately longer.

The first four coxal plates are produced anteriorly, and the fifth and sixth are more deeply bilobed than in $L$. planifrons.

The gnathopods and peræopods are all much more robust than those of $L$. planifrons, and the last three are relatively shorter; the third, fourth, and fifth consecutively increase but little in length. The first and second gnathopods are similar in structure, the second slightly the larger. The fourth and fifth segments of the gnathopods are triangular, the sixth is slightly longer than the fifth, and both fifth and sixth are provided on their lower surface with fine setæ and at their distal ends with several longer setæ. The dactyl is strong, well curved, and nearly as long as as the sixth segment; the concave surface is provided with a row of fine setæ, and there are several longer ones near the point.

The first and second peræopods are similar in structure, the second being slightly the larger. The second segments are expanded anteriorly into a broad lobe with evenly curved edges; the third segments are short; the fourth and fifth are produced anteriorly into a broad lobe, directed slightly downward; the sixth increases very suddenly in width, after which the proximal and distal edges are nearly parallel. The dactyl is strong and well curved, about two-thirds as long as the sixth segment. The third, fourth, and fifth perieopods are very much alike in structure; the coxal plate of the third is deeply bilobed; that of the fourth has the anterior lobe deeper than the posterior; and that of the fifth is truncated anteriorly and slightly lobed posteriorly; the second segments of these three peræopods are expanded posteriorly into a broad flat lobe of progressively increasing size, each more expanded and more depressed than the preceding; the third segments are short; the fourth are produced posteriorly into depressed lobes, each longer than the one preceding; the fifth segments are short, and each is produced posteriorly into a 
depressed lobe; the sixth are about as long as the second, progressively increasing slightly in length, each slightly concave anteriorly and increasing very suddenly in width near their upper ends, after which the anterior and posterior edges are nearly parallel. The dactyls are very strong and well curved, and each is about two-thirds the length of the corresponding sixth segment. There are no spines on the sixth segment of the last peræopod, as shown in Sars' figure of L. planifrons.

The uropods are as in $L$. planifrons, but the telson is less oval and more triangular.

The peræon and first three segments of the pleon form an evenly curved arch, while the fourth, fifth, and sixth segments of the pleon are sharply deflected anteriorly and lie between the last three peræopods.

The antennæ lie posteriorly against the peræopods.

In this attitude the animal fits snugly into a hole in the disk of the comatulid in which it is about half buried. It probably attaches itself to the disk by means of the strong hook-like dactyls, and the flesh of the crinoid gradually enveloping it forms the cavity.

The length is $5 \mathrm{~mm}$.

Locality.-China Sea; Albatross Stations 5310 and 5311.

Depth.-88 to 100 fathoms.

Remarks.-The only other species of this genus, L. planifrons Sars, was recorded by Sars from three widely separated localities on the coast of Norway. His specimens were all taken in the dredge. He remarks that the semiparasitic character of the species remains an open question.

It is very interesting to find this second closely allied species parasitic upon comatulids in so distant a locality as the China Sea.

Type.-Cat. No. 49599 , U.S.N.M.

\section{COPEPODA.}

The great majority of the copepods are free living, but a considerable number of them are truly parasitic, living on the juices of fishes, crustaceans, annelids, and other aquatic animals. Another large group is commensal or semiparasitic, living in the cavities of various marine animals, especially in those of the ascidians, both simple and compound. Others occur on the external surface of sponges, sea urchins, and starfishes.

In order that the relation between the copepods parasitic on the crinoids and those occurring upon the other echinoderms may be appreciated, I have given a complete list of the latter, which follows the discussion of the two species known to be associated with the comatulids.

\section{Family ASCOMYZONTIDE:}

COLLOCHERES GRACILICACDA (BRADY).

This species was described in 1880 from Robin Hood Bay, in Yorkshire, in 35 fathoms, by Brady under the name of Cyplopicera gracilicauda. In 1888 it was redescribed by Rosoll, who found it parasitic on Antedon adriatica at Trieste, under the name of Ascomyzon comatula. 
Canu, who proposed the genus Collocheres, determined the identity of Cyplopicera gracilicauda and Ascomyzon comatulo, and recorded it also from the coast of France.

Giesbrecht has reported it, under the name of Clausomyzon gracilicauda, from the Bay of Naples, and G. O. Sars has recorded it from Ris $\phi r$ on the southern coast of Norway.

In depth it ranges from the shore line down to 35 fathoms.

\section{Family ASCIDICOLIDÆ.}

ENTEROGNATHUS COMATULA GIESBRECHT.

This curious copepod was first discovered by Dr. John Beard in the course of his studies at Naples on the development of the myzostomes. It was described in great detail by Dr. W. Giesbrecht in 1901.

This parasite is much commoner in comatulids from a considerable depth than in those from shallow water. On the average there is only about one parasite to a dozen of the latter, and occasionally Giesbrecht found not a single example in about 50. On the other hand, of the Antedons from the Secca di Gajola at least half were parasitized.

There appears to be rarely more than one copepod in a single Antedon, though once Giesbrecht found four in different developmental stages in a specimen from the Secca di Gajola.

The females with egg balls are found throughout the year.

Almost the only color which the mature female shows is the brown of the contents of the intestinal canal. The animals are pale and almost transparent if the fatty tissue is not too richly developed, and the oviduct is not too full of ripe eggs. The eggs are quite opaque and white in reflected light.

The mature free-swimming male is yellowish gray and very slightly transparent. In the head and in the posterior part of the abdomen are some small rusty red globules.

Copepods infesting echinoderms other than crinoids.

Pionodesmodes phormosome Bonnier. From galls on the inside of the test of Hygrosoma petersi (A. Agassiz).

Echinocheres violaceus (Claus). On Paracentrotus lividus (Brandt).

Echinocheres minutus (Claus). On Paracentrotus lividus (Brandt).

Echinocheres globosus Hansen. In swellings on the spines of Arcoosoma gracile (A. Agassiz) and Sperosoma quincunciale de Meijere.

Cancerilla tubulata Giard. On Amphiura squamata Sars.

Philichthys amphiura Hérouard. On Amphiura squamata Sars.

Chrodeumium obesum .(Jungersen). On Asteronyæ lovéni Müller and Troschel.

Arthrochordeumium appendiculosum Stephensen. On Astrocharis gracilis Mortensen.

Astericola clausii Rosoll. On Marthasterias glacialis (O. F. Müller).

Linckiomolgus cceruleus Stebbing. On Linckia lavigata (Linnæus). 


\section{OSTRACODA.}

On a specimen of Metacrinus zonatus dredged by the Albatross at Station 5186, in the Tawi Tawi group, Philippine Archipelago, in 80 fathoms, I found a peculiar parasitic ostracod firmly attached to the column.

\section{CIRRIPEDIA.}

From their mode of life as attached organisms and their fixation to every possible kind of support (they have even been found on the tail feathers of Priofinus cinereus) it is quite to be expected that the barnacles should be found living upon the crinoids; indeed, it is rather surprising that this is not more often the case.

The columns, and especially the cirri, of the pentacrinites frequently support stalked barnacles, and they sometimes occur on the cirri of the larger comatulids of the deeper waters, mostly those of the family Thalassometridæ. There is a record of one attached to a pentacrinite arm. Sessile barnacles have been found only on the pentacrinites and usually occur on the stem, though sometimes on the cirri.

But barnacles are not nearly so abundant, either in number of species or in number of individuals, upon the crinoids as they are upon the urchins, especially upon the dead spines of the cidarids.

There is no evidence that the barnacles attached to the crinoids find in the latter anything more than a convenient object for attachment, such as they would find equally well in a long urchin spine.

Nearly all of the barnacles are inhabitants of relatively shallow water, and Scalpellum is the only genus which is often met with in the deeper portions of the sea, into which it descends to a depth of 2,850 fathoms. This sufficiently explains the fact that most of the barnacles which have been found upon the crinoids belong to this genus.

The pentacrinites of the intermediate depths are the recent crinoids most extensively represented as fossils in the secondary rocks, and the same is true of Scalpellum among the recent barnacles.

None of the Acrothoracica or Apoda have as yet been found in association with the crinoids.

The Rhizocephala are apparently all parasites of malacostracan, and chiefly of decapod, crustaceans, though von Willemoes-Suhm in his notes written on board the Challenger mentions a species which he found in the pouch of a starfish of the genus Hymenaster, where it was possibly introduced by accident, and a Bopymus or Peltogaster from an ophiuran.

The Ascothoracica are known as parasites in corals, antipatharians, and starfishes (Henricia, Hippasteria, and Solaster) but are not known to occur in the crinoids. 
Family LEPADIDE.

\section{Subfamily SCALPELLINE.}

SCALPELLUM ALBUM HOEK.

Scalpellum album was found on a species of Metacrinus taken by the Challenger in 140 fathoms near the Kei Islands. The species of Metacrinus from the station in question were $M$. angulatus, $M$. cingulatus, $M$. nobilis, $M$. tuberosus, and $M .9$ murrayi.

P. H. Carpenter records it on a specimen of Metacrinus varians from off the Meangis Islands in 500 fathoms. As he also found it on a specimen of Metacrinus murrayi of unknown origin, he suspected that possibly the latter came from the same locality.

\section{SCALPELICM BALANOIDES HOEK.}

This species was found attached to an arm of Itctacrinus murrayi which was dredged by the Challenger near the Meangis Islands in 129 fathoms.

It was also found attached to pentacrinites in 500 fathoms off the Meangis Islands. The species dredged here were Mfetacrinus costatus, $M$. moseleyi, $M$. varians, M. wyvillii, M. Imurrayi, Endoxocrinus alternicirrus, and Hypalocrinus naresianus.

\section{SCALPELLUM DICERATUM PILSBRY.}

Figs. 947, 948, p. 621.

Scalpellum diceratum was found on the stems of Isocrinus decorus, dredged by the Albatross in between 33 and 279 fathoms off Habana, Cuba.

\section{SOALPELLUM GONIONOTUM PILSBRY.}

This species was found on the column of a species of Metacrinus dredged by the Albatross in 361 fathoms in the Eastern Sea about 90 miles westsouthwest of the Goto Islands.

\section{SCALPELLUM PENTACRINARUM PILSBRY.}

Fig. 949, p. 621 .

Scalpellum pentacrinarum was found on a cirrus of Isocrinus decorus dredged by the Albatross in between 33 and 279 fathoms off Habana, Cuba.

\section{SCALPELIUM WELTNERIANTM PILSBRY.}

This form was found on a cirrus from a species of Metacrinus dredged by the Albatross in 361 fathoms in the Eastern Sea about 90 miles westsouthwest of Kagoshima Gulf.

\section{SCALPELLUM, SP.}

P. H. Carpenter records the occurrence of a species of Scalpellum on the stem of a Metacrinus interruptus from latitude $10^{\circ} 14^{\prime} \mathrm{N}$., longitude $123^{\circ} 54^{\prime} \mathrm{E}$., in 95 fathoms. 
SCAIPELLUM, SP.

Pl. 53, fig. 1345.

Specimens of Stylometra spinifera taken by the Albatross off Habana, Cuba, in 76 to 157 fathoms, carry barnacles of this genus on the cirri.

Scalpellum is very seldom seen on the cirri of the comatulids, though it is not at all unusual to find it on Stylometra.

\section{Family VERRUCIDEE.}

\section{VERRUCA NITIDA HOEK.}

Figs, 1249, 1250, pl, 39.

Verruca nitida was found on pentacrinites of different genera dredged by the Challenger off the Meangis Islands in 500 fathoms. The pentacrinites taken here were Metacrinus costatus, $M$. moseleyi, M. varians, $M$. wyvillii, $M$. Pmurrayi, Endoxocrinus alternicirrus and Hypalocrinus naresianus.

VERRUCA, SP.

P. H. Carpenter states that in one of the two specimens of Metacrinus cingu- . latus taken by the Challenger off the Kei Islands in 140 fathoms the place of one of the cirrus sockets is occupied by a group of barnacles of this genus.

VERRUCA, SP.

A specimen of Metacrinus nobilis taken by the Challenger off the Kei Islands in 140 fathoms showed a large Verruca covering the whole of one side of a nodal, and also extending onto the columnals above and below it.

\section{VERRUCA, SP.}

Carpenter records several examples of a species of this genus from a specimen of Metacrinus intermuptus taken by the Challenger in lat. $10^{\circ} 14^{\prime} \mathrm{N}$., long. $123^{\circ}$ $54^{\prime}$ E., at a depth of 95 fathoms. They were attached to the cirri.

\section{Family BALANIDAE.}

\section{PACHYLASMA CRINOIDOPHILUM PILBBRY.}

Figs. 1246-1248, pl. 39.

This form was found on the column of a species of Metacrinus dredged by the Albatross in 103 to 152 fathoms in the Eastern Sea, off Kagoshima Gulf.

ORSCURE LARVAL CIRRIPEDE.

P. H. Carpenter states that he found an obscure larval cirripede attached by its ventral margin to a cirrus of a specimen of Metacrinus varians which was dredged by the Challenger in 500 fathoms off the Meangis Islands. 
UNDDTERMINED CRUSTACEANS.

Dr. W. B. Carpenter writes that it is not a little curious that in the specimens of Antedon bifida which, through the kindness of Mr. Charles Stewart, he received from Plymouth Sound, the alimentary canal is frequently almost choked up by the body of a suctorial crustacean with its egg masses.

He says that as this is far too large and powerful an animal to have been drawn into the mouth by the ciliary curlent as an article of food, and as its body rarely shows any indication of having been acted on by the digestive power of the crinoid, he is disposed to think that it is introduced either as an egg or as a larva, and has undergone its development parasitically where it is found.

Encysted in the ventral perisome of the disk of some specimens of Heliometra glacialis which had been cut into sections P. H. Carpenter found the remnants of a parasitic crustacean; but though one or two accomplished zoologists examined the remains he was unable to learn anything about its affinities.

\section{ECHINODERMA.}

OPHIUKOTDE.

Such of the ophiurans as habitually live clinging to arborescent marine organisms, from which they derive their nourishment, usually indirectly through the appropriation of food particles collected by and intended for the host, are occasionally to be found upon the crinoids.

This association, relatively infrequent, appears to be quite fortuitous, excepting only in the case of the species of the genus Ophiomaza; but even these species are occasionally found on other organisms.

The first ophiuran by habit commensal on a crinoid was described in 1867 by Ljungman under the name of Ophiocnemis obscura; its characteristic commensalism was not, however, mentioned.

In 1871 Theodore Lyman established the genus Ophiomaza, describing $O$. cacaotica from Zanzibar.

Speaking of the cirri of the pentacrinites, C. Wyville Thomson wrote in 1873 that they have no true muscles, but that they have, nevertheless, some power of contracting around resisting objects which they touch, and there are often starfishes and other sea animals entangled among them.

In 1874 Lyman referred Ljungman's Ophiocnemis obscura to his genus Ophiomaza. In that year $\mathrm{R}$. von Willemoes-Suhm, then on board the Challenger, noticed on large black and white comatulids dredged in the Arafura Sea some ophiurans which he took to be parasitic, and which were of the same color as the hosts. His observation was published in 1876 and was the first suggestion of commensalism between ophiurans and crinoids.

In $1884 \mathrm{P}$. H. Carpenter remarked that he had frequently found ophiurans entangled in the cirri of the crinoids (it is not quite clear whether of the comatulids or of the pentacrinites, or of both), and once an ophiuran pluteus attached to a stem fragment of a species of Metacrinus; following Thomson, he considers these associations as probably merely accidental. 
In 1884 Bell greatly extended the known range of Ophiomaza cacaotica, recording it from Suez and from Queensland.

In 1888 Brock described as commensals on comatulids Ophiomaza cataphracta from Cape York, and Ophiocethiops unicolor and Ophiosphcera insignis from Amboina. In 1895 Professor Kohler described Ophiocethiops elegans, and in 1898 Ophiomaza morens. In the latter year Prof. Ludwig Döderlein described Ophiophthirius actinometro.

In 1904 Kohler redescribed and revised Brock's species, but without discussing their commensalism.

In 1908 H. C. Chadwick mentioned ophiurans, possibly Ophiomaza cacaotica, but more likely a species of Ophiactis, on comatulids in the Red Sea; and in 1915 Lieut. F. A. Potts published the results of his studies on the commensals living on comatulids in Torres Strait, listing Ophiocoma, sp., Ophiactis, sp. (later described by Dr. H. L. Clark as O. delicata), Ophiomaza cacaotica, O. cacaotica var. picta, and 0. obscura.

\section{Family TRICHASTERIDÆ.}

The species of this family live upon arborescent marine organisms, and many of them are quite active in their movements. Such of the species as live within the range of the pentacrinites are undoubtedly occasionally to be found upon them.

\section{Family GORGONOCEPHALIDF.}

Most, if not all, of the species of this family with undivided, or infrequently divided, arms, and many of those with ramose arms, as Astrocynodus and Astrocaneum, normally live attached to arborescent organisms. Such species as occur in the regions inhabited by the pentacrinites may be expected occasionally to be found upon them.

\section{ASTROGOMPHUS VALLATUS LYMAN.}

This species is not uncommon on specimens of Isocrinus decorus taken off the northern coast of Cuba.

ASTEROPORPA ANNCLAT'A LÜTKEN.

In 1873 Wyville Thomson figured a specimen of Isocrinus asteria to the cirri of which was clinging an individual of this species.

\section{Family HEMIEURYALIDE.}

The remarks under the preceding family heading apply equally to the species of this family. Sigsbeia murrhina Lyman has been found upon the species of Isocrinus in the Caribbean Sea. The similarity in the type of coloration between Sigsbeia lineata Lütken and Mortensen and the echinoderms and crustaceans normally commensal on crinoids is striking. 


\section{Family OPHIACANTHID}

This family is in the same category as the two preceding, the species which normally live attached to arborescent organisms frequently straying on to the pentacrinites and more rarely on to the comatulids; I have seen specimens of various species of Ophiacantha on Metacrinus taken in the Philippines.

OPHIOLERES SCORTEUS LYMAN.

P. H. Carpenter records a specimen of this species which he found entangled in the cirri of a specimen of Eumorphometra hirsuta dredged by the Challenger near Marion Island in 140 fathoms.

\section{Family OPHIOCOMID E.}

The association of ophiurans of this family with crinoids can scarcely be more than accidental though in view of the abundance of both on certain reefs in the East Indian region, and the activity of the former, especially when young, it must be more or less frequent.

OI'IIOCOMA, SP.

Lieutenant Potts states that at Torres Strait he found a young Ophiocoma, too small for accurate determination, on Comanthus annulatus.

\section{Family AMPHIURIDÆ.}

Some of the species in this family, as the species of Ophiactis, are more or less strictly commensal; others, as the species of Ophiopholis, commonly conceal themselves in rootlike growths or cling to arborescent organisms; while others, as the species of Amplizura, Amphipolis, etc., live on or in mud, sometimes burrowing downward for a considerable distance. These last are sometimes phosphorescent.

The species of the first group will naturally sometimes be found on crinoids, and those of the second group will occasionally occur among the cirri of the comatulids and on the stems of the pentacrinites inhabiting the same regions.

OPHIACTIS DELICATA H. L. CLARK.

Lieut. F. A. Potts reported a specimen of an undetermined species of the genus Ophiactis as commensal on comatulids at Torres Strait.

Dr. H. L. Clark described this specimen under the name of Ophiactis delicata.

It was found on an example of Comanthus annulata in 18 fathoms off the southwestern reef at Maër, Murray Islands, Torres Strait.

\section{POPHIACTIS, SP.}

Mr. H. C. Chadwick in 1908 recorded a specimen of Heterometra savignï from U1 Shubuk, on the Red Sea, which, when living, was whitish with a violet tinge and with patches of darker color and of yellow, from which were taken 15 ophiurans that lived with their arms wrapped around those of the crinoid, and of which the color on the whole resembled that of their host. 
The large number of these ophiurans found on a single crinoid appears to indicate that they could not have belonged to any species of Ophiomaza, which normally occur singly, one to each crinoid, and suggests that they represented a species of Ophiactis.

\section{OPIIOPIIOLIS MIRABILIS (DUNCAN).}

A specimen of this species was found coiled tightly about the stem, just under the crown, of a specimen of Metacrinus acutus dredged by the Albatross in the Eastern Sea, off Kagoshima Gulf, in 105 to 152 fathoms.

\section{Family OPHIOTRICHIDE.}

Many, if not most, of the species in this family are more or less strictly commensal in habit. Some, as certain species of Ophiothrix, are normally associated with various aborescent organisms, and occasionally are to be found upon the pentacrinites, and more rarely upon the comatulids; others, as the species of Ophiomaza, are rarely found elsewhere than upon the comatulids.

\section{Opiromaza.}

Ophiomaza is the only genus of ophiurans which has been determined to be normally commensal upon the comatulids. It lives, oral surface downward, upon the disk of the larger species, with the arms wrapped around the dorsal side of the crinoid.

The curiously banded or blotched type of coloration usually found in this genus recalls that of other organisms commensal with the comatulids, and is reminiscent of Sigsbeia lineata Lütken and Mortensen, which is also commensal, though not upon crinoids.

OPHIOMAZA CACAOTICA LYMAN.

P1. 52, fig. 1341.

The commensal ophiuran noted by von Willemoes-Suhm on black and white comatulids from the Arafura Sea was probably this species.

I have found it on Capillaster sentosa from Singapore, and on Heterometra reynaudii from the entrance to Palk Strait, Ceylon, in 6 to 8 fathoms.

Potts states that at Torres Strait he found it commensal on Comanthus annulatus, and that in color it was a uniform black, very deep purple, or brown. One small black specimen was found on a bright red Comatula purpurea.

This ophiuran probably occurs on any comatulid of sufficient size to support it, regardless of species. So far as I have seen there is rarely, if ever, more than one on a single crinoid.

Ophiomaza cacaotica ranges from Zanzibar to Suez and eastward to northern Australia, the Philippine Islands, and the China Sea, but apparently is nowhere abundant. It occurs from the low-tide mark down to nearly 40 fathoms.

Most of the records for the species make no mention of its commensalism. 
of HIOMAZA CACAOTICA VAR. PICTA KGELLR.

This form, which was described merely as a color variety of the preceding, was found among the echinoderms collected by Korotneff in the Sunda Islands, probably at Billiton. Professor Kœhler does not mention the comatulid upon which it occurred.

Lieutenant Potts records it from Torres Strait, on Comanthus annulatus. The individuals were prettily marked with black and white.

OPHIOMAZA OBSCURA (LJUNGMAN).

This species was originally described from Singapore, and I have seen specimens from that locality on Capillaster sentosa. Lieutenant Potts found it on Comanthus annulatus at Maër, Murray Islands, Torres Strait, and says that the specimens were brown, handsomely marked with dull yellow.

OPHIOMAZA CATAPHRACTA (BROCK).

Ophiomaza cataphracta was described from Cape York, Queensland.

OPHIOMAZA MICERENS KOHLER.

This species is known only from Cantores Island, in the Mergui Archipelago. OPHIOATHIOPS UNICOLOR BROCK.

This species was described from Amboina, where Doctor Brock found it living, apparently as a commensal, upon a species of Comasteridæ, which it resembled in color.

\section{OPHIOATIIOPS ELEGANS (KGEHLER).}

This form was described from the Dutch East Indies.

OPHIOPHTHIRIUS ACTINOMIETRE DÖDERLEIN.

Ophiophthirius actinometros was described as a commensal on Comatula solaris from Thursday Island, Queensland.

OPHIOSPIIERA INSIGNIS BROCK.

Doctor Brock found this species at Amboina on one of the Comasteridæ, which it resembled in color.

\section{Family OPHIOLEPIDID $Æ$.}

None of the species of this family can have other than a purely accidental association with crinoids.

$$
\text { OPHIOMUSIUM, SP. }
$$

Attached to the dorsal side of the centrodorsal of a specimen of Perissometra flexilis from near the Kei Islands, in 140 fathoms, P. H. Carpenter found an ophiuran which he believed to belong to the genus Ophiomusium, so far as he was able to make out its characters from a view of the dorsal surface only; but he 
could not refer it to any species of that genus, or to any other of the ophiurans which were obtained by the Challenger. It had a relatively large dorsocentral, five small basals, and five large radials, the outer ends of which were tubercular and fitted in between the two large radial shields, which were also more or less tubercular on their line of junction. The arms extended outward between the cirri of the comatulid and coincided in direction with its rays, while their ends were more or less twisted around the bases of the cirri. The symmetrical arrangement of the large primary plates on the ophiuran disk, together with the position of the arms, gave a very singular appearance to the centrodorsal of the comatulid.

$$
\text { OPHIURAN. }
$$

H. C. Chadwick records that from a specimen of Heterometra savignii taken at Ul Shubuk, Sudanese Red Sea, in nine fathoms which was whitish with a violet tinge, with patches of darker color and of yellow, he took 15 ophiurans which lived with their arms twisted around those of the comatulid, and that the color of these on the whole resembled that of their host.

$$
\text { ophivRan pleteus. }
$$

Dr. P. H. Carpenter mentions finding an ophiuran larva attached by its long pluteus arms to the column fragment of Metacrinus tuberosus which was dredged by the Challenger off the Kei Islands, in 140 fathoms. He considers this association as probably merely accidental.

\section{MOLLUSCA.}

GASTEROPODA.

Professors René Kœhler and Clement Vaney, of the University of Lyons, have recently published a most excellent memoir upon the ectoparasitic gasteropods, nearly all of which occur upon echinoderms.

These parasites fall into four classes. The first comprises species belonging to the family Capulidæ, all included in the genus Thyca; the second is composed of species belonging to the family Melanellidæ, which are distributed in the genera Melanella, Sabinella, Pelseneeria, Mucronalia, Stylina, Stilifer, Megadenus, and Gasterosiphon; the third is represented by the curious Ctenosculum described by Heath; and the fourth by two pyramidellids described by Pelseneer which are parasitic upon the lamellibranchs.

None of the wormlike endoparasitic gasterpods, such as Entoconcha, Enteroxenos, and Entocolax, are known to occur in the crinoids.

Of the echinoderms the starfishes most frequently support ectoparasitic gasterpods, and upon them occur species of the genera Thyca, Melanella, Mucronatia, Stilifer, and Ctenosculum, nearly all of the records being from the East Indian region.

Next to the starfishes the crinoids appear to be the most subject to this form of parasitism, and upon them occur species of the genera Stilifer, Stylina, Sabinella, 
and Melanella; Stylina is known only from the Mediterranean, and Sabinella, as a parasite on crinoids, from Ceylon, Singapore, and the Queen Charlotte Islands; Stilifer and Melanella occur both in the Atlantic and in the Indo-Pacific.

Gasterosiphon, internal and without a shell, though fundamentally an external parasitc, is found in a deep-sea holothurian. Megadenus, truly parasitic, and exhibiting a very marked sexual dimorphism, lives upon the arborescent tentacles of a species of the genus Holothuria in the West Indian region. In another species of the same genus in the East Indian region Melanella has been found attached to the external surface and in the buccal cavity; while in a third species on the coast of Norway a species of $M$ elanella is found in the digestive tube, where, however, it is scarcely more than a commensal.

Several species of Stilifer, and especially of Pelseneeria, have been found upon echinoids, mostly from deep water, both in the Atlantic and in the Pacific, and the genus D/ucronalia has been reported from two ophiurans, Ophiothrix crassispina Kinhler from the Dutch East Indies in 274 meters, and $O$. deposita from the sume region in 310 meters.

We lnow nothing whatever of the habits of the gasterpods occurring on the crinoids; as found they are always very firmly attached to the hosts, but, on the other hand, the frequent presence of perforations in the calyx in addition to those covered by the shells appear to indicate that they are not permanently fixed in one position, but possess the power of changing their location.

In 1868 Count Pourtalès wrote that among the small stalked crinoids dredged in 237-306 fathoms off the Samboes and off Sand Key, Florida, and referred by him to Rourgueticrinus hotessieri (a species of Bythocrinus), he found one which had three small examples of a species of Stilifer adhering to the outside of the calyx, and that small round holes, bored probably by these parasitic molluses, could be seen also in the calices of some of the others.

In 1875 Prof. Ludwig von Graff, who at that time was engaged in his studies upon the Myzostoma, found upon Antedon mediterranea a small gasteropod, which, truly parasitic, is attached to the anal tube or pinnules into which it bores a hole. He called it Stylina comatulicola.

In 1877 Sir Wyville Thomson mentioned two specimens of "Rhizocrinus lofotensis" dredged by the Challenger off Cape Agostinho, Brazil, each of which was infested with several specimens of a species of Stilifer, and in $1884 \mathrm{Dr}$. P. H. Carpenter, evidently having in mind the records of Pourtalès and Thomson, wrote that Rhizocrinus lofotensis is often infested with two or three small shells of Stilifer, which bore comparatively large holes in its calyx.

In 1895 Dr. Clemens Hartlaub figured a parasitic gasteropod attached to an undetermined comatulid, apparently a species of Bathymetra, from the Gulf of Panama. He states that it is related to Stilifer and according to Professor von Martens is apparently a Mucronalia.

On the specimens upon which I based the new species Ptilocrinus pinnatus I found a number of parasitic gasteropods, which Dr. Paul Bartsch described in 1907 under the name of Eulima ptilocrinicola. 
In 1908 Dr. William H. Dall bestowed the name of Stilifer bathymetrce upon the gasteropod figured in 1895 by Hartlaub, and Monterosato referred Bartsch's Eulima ptilocrinicola to his new genus Sabinella.

While studying the crinoids of the Copenhagen Museum I found upon a specimen of Capillaster multiradiata from Singapore a parasitic gasteropod related to the species occurring on Ptilosrinus pinnatus; this Doctor Bartsch named in 1909 Eulima capillastericola.

In 1912 Professors René Kioller and C. Vaney published an extensive memoir upon the ectoparasitic gasteropods, treating in detail those parasitic upon the echinoderms but adding no new information in regard to those occurring upon the crinoids. In the same year I recorded the occurrence of a small species of Eulima on Heterometra reynaudii from Palk Strait, Ceylon, and at the same time stated that I had found the same genus parasitic on Stenometra diadema in southern Japan, the specimens being in the hands of Dr. William H. Dall for description.

On some specimens of Annametra occidentalis from Simon's Bay, Cape of Good Hope, collected by the German South Polar Expedition, I found seven specimens of a new parasitic gasteropod which were described in 1915 by Dr. J. Thiele as Eulima capcnsis. At the same time he referred Bartsch's Eulima capillastericola to Monterosato's genus Sabinella.

In the same year Lieut. F. A. Potts noted that two or three very small gasteropods, apparently parasitic, had been found by him on comatulids at Torres Strait.

$$
\text { STILIFER BATIYYMETRE DALL. }
$$

Pl. 57. tig. 1362 .

Host.-Bathymetra, sp.

Locality.-Vicinity of Malpelo Island, Bay of Panama.

Depth. $-1,772$ fathoms.

STILIFER, SP.

P. H. Carpenter says that Rhizocrinus lofotensis is often infested with two or three small shells of Stilifer which bore comparatively large holes in its calyx.

Carpenter's Rhizocrinus lofotensis included several distinct species, and it is not certain to which form he referred; his note was, however, based at least in part upon the following records:

STILIFER, SP.

Host.-Bythocrinus, sp.

Locality.-Off the Samboes and off Sand Key, Florida.

Depth.-23i, 248, and 306 fathoms.

Remarks.-Anong uumerous specimens of Bythocrinus, sp., from these localities Pourtalès found one with three small Stilifer's adhering to the outside of the calyx, and others with small round holes in the calyx, probably bored by these gasteropods.

142140-21-Bull. 82- 43 
?STILFER, SP.

Host.- "Rhizocrinus lofotensis" (?Bythocrinus, sp.).

Locality.-Off Cape Agostinho, Brazil (lat. $9^{\circ} 10^{\prime}$ S., long. $34^{\circ} 49^{\prime}$ W.).

Depth. -400 fathoms.

Remarks.-Sir Wyville Thomson states that among the special prizes from this station were two specimens of Rhizocrinus lofotensis, each infested by several individuals of a species of Stilifer.

\section{STYLINA COMATULICOIA YON GRAFF.}

Host.-Antedon mediterranea.

Locality.-Naples.

Remarks.-The gasteropods were fastened to the skin of the anal tube or of the pinnules, and after their removal a deep hole was left.

On 175 specimens sent from Naples to Professor von Graff he found eight Stylinas; on one individual 1, attached to the anal tube; on another 1 , attached to a pinnule, and on a third 2,1 on the anal tube and 1 on a pinnule. The other 4 were found detached in the bottom of the container.

An examination of 33 specimens of Antedon adriatica from Trieste yielded no specimens.

S.IBINELLA PTILOCRINICOLA (BARTSCH).

PI. 57, figs. 1356-1361.

Host.-Ptilocrinus pinnatus; on the calyx, which it sometimes distorts.

Locality.-Off the Queen Charlotte Islands, British Columbia.

Depth.-1,588 fathoms.

SABINELILA CAPILTASTERICOLA (BAKTSCH).

Host.-Capillaster multiradiata; on the cirri near their base.

Locality.-Singapore.

Depth.-Littoral.

S.IBINELIA, SP.

Host.-Heterometra reynaudii; on the cirri near their base.

Locality.-Palk Strait, Ceylon.

Depth.-Littoral.

MELANELLA CAPENSIS (THIELE).

Host.-Annametra occidentalis; on the disk.

Locality.-Simon's Bay, Cape of Good Hope.

Depth.-Littoral.

Remarks. - Thiele states that this species resembles $M$. elongata from the coast of France.

\section{MELANELLA, SP.}

Host.-Crinometra, sp.; from a pinnule.

Locality.-Off Habana, Cuba.

Depth.-The genus Crinometra occurs in the Caribbean Sea in water of from 33 to 600 fathoms in depth; it is most common between 100 and 250 fathoms.

Remarks.-This form appears to be near $M$. capensis from South Africa. 
MELANELLA, SP.

Host.-Stenometra diadema; on the cirri.

Locality.-Southern Japan.

Depth.-Stenometra diadema occurs in from 80 to 170 fathoms of water.

MELANELI,A, SP.

Host.-Rhizocrinus verrilli; on the calyx.

Locality.-Off Nova Scotia.

Depth.--218 fathoms.

Remark8. - In bulk the parasite is actually larger than the calyx of the crinoid. There are two perforations in the calyx on the side opposite that on which the gasteropod is attached, but probably made by the same individual.

\section{MEI.ANETLA, SP.}

On a specimen of Coccometra hagenii in the collection of the Museum of Comparative Zoology from the Pourtalès Plateau, in 200 to 225 fathoms, I found an unusually large parasitic Melanella attached to the interradial portion of the disk between the arm bases. Another specimen from the same locality showed a large hole in the same position, apparently made by the same, or a similar, Nelanella.

PARASITIC gasteiropod.

Speaking of the small parasitic gasteropods which he found on comatulids at Torres Strait, Lieutenant Potts says that while one or two were colorless, one individual, which occurred upon a very handsome crinoid striped red-brown and yellow, was very similar in color to its host. The shell was perfectly transparent, but the body was red-brown with distinct yellow spots.

hge Catstefes of a gasteropod.

Mortensen has reported having found the egg capsules of a gasteropod on the cirri of Hathrometro prolixa.

$$
\text { PELECY PODA. }
$$

The young of bivalves are sometimes to be found attached to the cirri and columns of the pentacrinites, much more rarely to the cirri of the comatulids, by their byssus. Such association is nothing more than casual, though it is to be observed almost every time that pentacrinites are brought up in the dredge.

P. H. Carpenter records finding a small Avicula attached to one of the cirri of a specimen of Metacrinus interruptus from lat. $10^{\circ} 14^{\prime} \mathrm{N}$., long. $123^{\circ} 54^{\prime} \mathrm{E}$., in 95 fathoms.

\section{POLYZOA.}

Several polyzoans are of casual occurrence on the crinoids, and a number of species of the family Loxosomatidæ appear to be not at all uncommon as commensals on the cirri of comatulids, especially in the East Indian region. 


\section{Family BICELLARIIDE.}

GEMELLARIA LORICATA.

Mortensen has recorded young colonies of this species on the cirri of Hathrometra prolixa from northeastern Greenland.

\section{Family LOXOSOMATIDÆ.}

\section{LOXOSOMELLA ANTEDONIS MORTENSEN.}

Figs. 1241-1245, pl. 39 .

This species was found by Mortensen on the cirri of Ilathrometra protixa from latitude $77^{\circ} \mathrm{N}$. and longitude $17.5^{\circ} \mathrm{W}$., in 300 meters.

Osburn has recently recorded it from Etah, Foulke Fjord, Greenland, where it occurred on the cirri of Heliometra glacialis.

\section{ANNELIDA POIYCHATIA.}

\section{Family POLYNOIDEs.}

The first notice of a polynoid worm as a commensal on a comatulid was contained in a letter from R. von Willemoes-Suhm to Prof. C. Th. E. von Siebold and published by the latter in 1876. Willemoes-Suhm had observed in the Arafura Sea black and white worms of this type living on a large black and white comatulid.

In $1902 \mathrm{~A}$. Alcock recorded the discovery of a sea worm banded yellow and purple living on a comasterid, which also was banded yellow and purple.

In $1908 \mathrm{H}$. C. Chadwick recorded a predominantly yellow specimen of Lamprometra palmata from Suez which had a brown commensal polynoid living upon it.

Lieut. F. A. Potts described in 1910 a species of Polynoë commensal on comatulids which had been found by Prof. J. Stanley Gardiner in the Maldive Islands, and in 1915 he described a second, which he himself had found at Torres Strait.

\section{POLYNOË CRINOIDICOLA POTTS.}

The original specimens were collected at the following localities: From comatulids at Suvadiva Atoll; at Kolumadulu Atoll; with a crustacean from a comatulid found on the west reef at Hulule, Male Atoll; and from a black comatulid at Miladummadulu Atol; all these atolls are in the Maldive archipelago.

Potts states that the examples from two localities were dark red in color, but others described as commensals on black comatulids are colorless in alcohol, though they were black when alive.

\section{POLYNÖ̈ MINCTA VAR, OCULATA POTTS.}

This worm was found by Lieutenant Potts rather frequently on the darker varieties of Comanthus annulatus at Torres Strait.

The dorsum, with the exception of two longitudinal pigment-free bands, is covered by a dark brown pigment which is insoluble in 70 per cent alcohol. The markings are hidden by the elytra, which are uniformly pigmented. 
Potts found these worms always of a dark, almost black, appearance, and frequenting dark-colored crinoids, and believes that they must be absent from or rare on the lighter-colored hosts.

\section{Family SERPULIDAE.}

The tubes of serpulid worms are very commonly found on the cirri and stems of the pentacrinites, and occasionally on the cirri of the comatulids.

None of the species occurring on the crinoids have been determined, but indefinite references to them are given by Mortensen (cirri of Hathrometra prolixa), Carpenter, and others.

MIZOSTOMIDA.

The Myzostomida, though very highly specialized and aberrant and differing widely in many respects from the other members of the group, belong to the Annelida Polychrta.

The great majority are parasites of crinoids, but a few species occur upon or within starfishes and ophiurans.

Many of the myzostomes wander freely over the body of the host, while others are more sedentary; some are more or less permanently fixed in one position, causing enlargements or malformations of the underlying pinnule or arm; a few attach themselves to the ambulacral surface of the pinnule, the segments of which become larger and more hollowed out, thus forming a canal, while the whole pinnule is wound spirally, forming a chamber in which the parasite lives; certain species bore their way into the interior of a pinnule, which becomes swollen and pear shaped, and others cause insignificant thickenings of the brachials with fissures between them; some species cause the formation of small fusiform oval chambers, arranged longitudinally or transversely and arising from the enlargement of some of the brachials or segments of the division series, while still others form cysts upon the ambulacral surface, sessile or of various forms, or pedunculate or club shaped, which are not produced by the transformation of a brachial or pinnule segment. A few species are true internal parasites, living either in the alimentary canal or in the ovaries.

The body of the myzostome is a more or less circular disk provided on the margin with 10 pairs of digitiform processes. On the ventral side, arranged in two semicircles, are five pairs of nonarticulate parapodia, in the intervals between which, and nearer the margin, are four pairs of suckers. On the end of each of the parapodia is a curved pointed hook supported by a straight rod, which in order to guide the hook is furnished at its extremity with a bent end plate (manubrium) and several smaller hooks. The whole apparatus is capable of extension and retraction by means of a complicated system of muscles radiating outward from a central ventrally placed muscular mass. Close to the anterior end of the ventral surface is the mouth, and close to the posterior end is the aperture of the cloaca. The alimentary canal consists of a muscular pharynx, which can be extruded through the mouth, of an esophagus separated by a valve from 
the stomach, which is itself separated by a circular fold from the terminal portion of the canal, the rectum; from the stomach a number of branched radiating cæca take their origin. Beneath the stomach is the large oblong central nervous system, which gives off anteriorly a commissure surrounding the pharynx. The sexual organs are hermaphroditic. The female organs consist of a number of ovarian cæca, dorsal in position; they open into the cloaca by a central uterine tube. The testes are usually ventral in position, and ramify on either side of the stomach; the cæca unite on either side into a spermatic vesicle, which opens to the exterior between the third parapodium and the margin of the body.

In a few cases the radial arrangement of the body is considerably modified, and it may even be entirely lost, the body becoming greatly lengthened and the parapodia and suckers arranged in two parallel lines; while in Stelechopus not only has the external radial symmetry disappeared, but the muscular septa and the muscles of the parapodia are no longer convergent.

While usually the apertures of the body, as well as the parapodia and suckers, are situated upon the ventral surface, in a few cases the oral and cloacal openings are upon one surface, while the parapodia are upon the other.

Broadly speaking, the myzostomes may be divided into two groups. In one the body is stout and massive and of a solid consistency; the dorsal surface is usually vaulted; as a rule, there are no cirri, or, if present, they are represented by short inconspicuous processes. The ventral surface is bulged outward by the strongly developed muscular mass, and from this central elevation a number of smaller ridges run to the bases of the parapodia, and between them still smaller ridges connect the central elevation with the suckers. On the dorsal surface there are very often seen five pairs of feeble elevations, which mark the position of the base of the hook apparatus, and which may become very much enlarged; sometimes the whole intestine shows itself on the outside in the form of a series of elevated ridges.

In the other the body is thin, flat, membranous, and somewhat transparent, with a more highly transparent marginal border, owing not merely to the lesser development of the muscles, but also to the fact that the ramifications of the intestines and genital organs do not quite extend to the periphery. The greater delicacy of the body in this group is owing to the slighter development of the muscles of the body, especially of the ventral muscular mass; but the presence of a more transparent marginal border is not confined to these forms. This group is also characterized by the possession of long cirri or cirrus-like processes on the margin of the body, of which the number occasionally exceeds 20 .

There are numerous transitional forms which unite these two groups and can witl difficulty be assigned to either. Among these are the very remarkable types distinguished by the possession of two, four, or six fingerlike caudal appendages.

In the cysticolous myzostomes the individuals contained in a single cyst either resemble each other in form and size or are very different. In the latter case each individual is either male or female, and the two sexes are very unlike in appearance, the female being usually from 50 to 100 times as large as the male. 
That these forms are descended from androgynous species, in which the organs of one sex have gradually become abortive, is shown by those types in the females of which there are rudiments of testes but no male generative aperture. These diœcious species are also distinguished by the marginal position of the sexual apertures, both male and female, and by the form of the testes in the males. In a few, which resemble the free-living forms in the possession of 20 long cirri, the testes have the typical ramified form. In all the others they are compact, rounded organs occupying definite areas in the lateral portions of the body.

In those forms in which the individuals inhabiting one cyst are not different in appearance the sexual organs have a different structure. Each individual in this case is androgynous but differs from the free-living androgynous species in that the testis is developed only on one side of the body, and there is but one male genital aperture. In one species there are small remnants of the other testis but no second male aperture. The testis also, as in the diøcious forms, is a small compact gland.

The male and female being found associated in a common cyst and increasing in size witl the growth of the cyst shows that they perforate the brachials or pinnules of their host together. The growth of the cyst is caused by the presence of the parasite. The female deposits her eggs within the cyst, and the young embryos, after they have abandoned the cyst and lost their ciliated coat, associate in pairs and bore their way through the brachials.

In both sexes the sexual development begins with the appearance of testes, but in the female the testes degenerate and disappear entirely, or leave but a minute rudiment, when the ovaries make their appearance.

Wheeler takes exception to von Graff's supposition that the young myzostomes associate in pairs and together take part in forming a cyst. From his studies of Myzostomium parasitieum and $M$. pulvinar, both of which show a distinct tendency to occur in pairs, each consisting of a senior and a junior individual, he is led to believe that, in the case of the cysticolous species, the cyst must be formed by a single individual, and that later a young myzostome, when it abandons its pelagic trochophore stage, must enter through the aperture of the eyst and settle down to a quiet life with the senior individual, and that the latter probably dies at the end of its female stage and, undergoing decomposition, may perhaps serve as food for its still vigorous junior partner, which in turn may become the senior partner of another young myzostome. According to this view, all the cysticolous myzostomes of a given species would not be cyst producing, but only those which, instead of entering the orifice of a preformed cyst in their juvenile stage, happen to settle between the brachials or contrive to work their way into the calcareous skeleton of the crinoid.

In species like $M$. cirriferum and $M$. parasiticum Wheeler recognizes during their development the four following sexual phases:

1. A phase of sexual neutrality, or indifference.

2. A protandric phase, extending from the appearance of the first ripe spermatozoa to the appearance of the first ripe ova (male). 
3. An androgynous or functionally hermaphroditic phase, extending from the appearance of the first ripe ova to the disappearance of the last ripe spermatozoa (hermaphroditic stage).

4. A hysterogynous phase extending from the disappearance of the last spermatozoa to the disappearance of the last ripe ova, an event which is very probably not attained at the time of the animal's death (female).

Wheeler states that in $M$. pulvinar, and probably in many of the cysticolous species which are supposed to be diœcious, the male phase ( $\delta$ ) is very short and terminates before the retarded appearance of the first mature ova, so that this species lacks a functionally hermaphroditic stage (§) corresponding to that of $M$. cirriferum and $M$. parasiticum, and instead there intervenes a period during which the animal grows but does not produce spermatozoa or ova; hence when a number of specimens are examined this sharp separation of the male and female phases in time has superficially the same appearance as the separation in space in gonochoristic forms with dwarf males.

Among the other animals parasitic on crinoids an exactly similar asynchronism and sequence in the ripening of the sexual products occurs in Anilocra.

To determine the relative abundance of $M y z$ stomum glabrum and $M$. cirriferum von Graff examined 323 Antedons from Trieste (adriatica), Pirano (adriatica), Naples (mediterranea), and Messina (mediterranea), and found 123 specimens of $M$. glabrum and over 1,600 of $M$. cirriferum.

The relative abundance of the two species is thus $1: 14$, and on the average there are 5.3 Myzostoma on each Antedon, 4.9 cirriferum, and $0.38 \mathrm{M}$. glabrum; or, each Antedon from the Mediterranean bears on the a verage 4 to $5 M$. cirriferum, and each third Antedon $1 \mathrm{M}$. glabrum. But these averages do not represent the true state of affairs, for fully a third of the Antedons are entirely free from these parasites. Of the 323 examined, not quite two-thirds carried $M$. cirriferum, while scarcely one-fourth carried $M$. glabrum; and while $M$. cirriferum almost always was present in greater numbers than $M$. glabrum, occasionally $M$. glabrum occurred in greater numbers than $M$. cirriferum.

The 123 specimens of $M$. glabrum were taken from 69 Antedons, on which they occurred with the following frequency:
On 39 Antedons, 1.
On 15 Antedons, 2.
On 10 Antedons, 3.
On 3 Antedons, 4 .
On 1 Antedon, 5 .
On 1 Antedon, 7 .

While as a rule there are rarely more than $3 \mathrm{~K}$. glabrum on a single Antedon, there are commonly from 6 to 8 or more $M$. cirriferum, and on a specimen of A. adriatica from Trieste von Graff found no less than 27 of the latter.

On a specimen of Tropiometra macrodiscus collected by Mr. Alan Owston in southern Japan I found 93 rather large myzostomes.

The dorsal surface is sculptured only in the larger species, which are also often distinguished by large elevations and ridges on the surface of the body. This sculpturing, when present, takes various forms; the dorsal surface may be covered by fine folds; the skin may be divided by longitudinal and cross furrows 
into a number of variously sized polygonal areas, minute, or larger, and separated by deeper furrows; or the skin may be covered by a quantity of small tubercles pressed close together or separated by intervals into larger and smaller groups; the tubercles may be of equal size, only diminishing slightly toward the borders, or of very different dimensions; occasionally they become so minute and closely packed that the skin acquires a granular appearance, while on the other hand they are sometimes highly developed and arranged in radial lines.

Von Graff states that the group of species containing the larger and stouter forms displays most variety in color and sculpturing, though only on the dorsal surface, the ventral surface being always of a uniform dull yellow or brown. The species of the second group are nearly all yellow or brown, which are the prevailing colors of the myzostomes, with a somewhat lighter colored margin. The larger forms occasionally exhibit a pattern of two colors on the dorsal surface.

Semper stated that he found Myzostomum glabrum ("tuberculosum"), which is spotted with red and yellow, living only on variegated comatulids, while the uniformly colored $M$. cirriferum he found only on red comatulids, which it matches in color.

Von Willemoes-Suhm recorded the presence, in the Arafura Sea, of black and white spotted myzostomes living upon black and white comatulids.

At Trieste von Graff examined 203 specimens of Antedon adriatica and found black, yellow and whitish myzostomes just as commonly on red individuals as red myzostomes on variegated individuals.

In a special investigation of over 200 comatulids at Murray Islands, Torres Strait, Lieutenant Potts found that blackish, yellow, and white myzostomes were just as frequently to be found on red comatulids as blood-red myzostomes on variegated comatulids.

Lieutenant Potts states that the myzostomes found on the comatulids at the Murray Islands were very numerous and belonged to several species. They are in many cases very brightly colored, and have pronounced color patterns. Generally speaking, there are two types of pattern. In the first, concentric rings of bright and dark pigment alternate; in the second, the dorsal surface is ornamented with radiating ridges, and these are usually free from pigment or very light colored; the ridges are thrown into relief by an edging of a dark pigment, purple or black. The general ground color between the ridges as a rule approaches that of the comatulid upon which the myzostome is found.

One of these was very common on the dark green or black varieties of Comanthus annulatus. The alternate black and nonpigmented rings are in vivid contrast, but the myzostome is thin and the nonpigmented parts are so transparent as to be inconspicuous against the dark ground of the host. This species seems to occur only on the darker crinoids. In another species the same arrangement is found, but much lighter hues prevail, green pigment alternating with very light brown. The colors of the host were not noted.

When the host is very light colored the alternation of darker rings does not occur. On a green variety of Comanthus annulatus a myzostome was found which 
matched it perfectly. The greater part of the body was bright green, but a few white spots represented a broken ring of a lighter color; the edge was relieved by dashes of black pigment, while the cirri were brownish. A very magnificent example of the second type of coloration was found on a green form of Comanthus annulatus. It resembled its host closely and was comparatively inconspicuous. The general color was a bright green; the ridges appeared greenish white, darker at the edges owing to the addition of a granular pigment, and around each there was an intense black line. An allied form was found on darker crinoids. There the ridges were white or yellow, surrounded by a darker line (in one case of purple), and the ground color was brown. Lastly, in one or two forms almost the whole upper surface may be covered by a dark pigment. Thus in one specimen the dorsal surface was a dark green, only relieved by a white line down the middle, while in another it was purple. These occurred on dark comatulids.

Lieutenant Potts concludes that, on the whole, the nyzostomes showed a great color resemblance to their hosts, though striking exceptions occurred, and, even when the color schemes harmonized, protection from human sight, at least, was not always secured.

The first published notice of a myzostome is found in Delle Chiaje's magnificent memoir on the invertebrate animals of the kingdom of Naples, which appeared between 1822 and 1829. Delle Chiaje figured a myzostome on the disk of an Antedon, but he interpreted it not as a parasitic organism, but as a madreporic plate, comparable to the madreporic plates of the starfishes.

Almost simultaneously F. S. Leuckart recognized these animals as peculiar worms occurring on the comatulids, and in 1827 he described several species from the Mediterranean and from the Red Sea.

John Vaughan Thompson. who in 1827 had discovered the pentacrinoid young of Antedon bifida and subsequently had devoted much attention to this animal, naturally had noticed the parasitic myzostomes, and in the paper in which he announced the discovery that his Pentacrinus europaus was nothing more nor less than the young of Antedon bifida, published in 1835, he says of them:

Connected with the natural history of the comatula is that of a nondescript parasite whlch appears to be a complete zoological puzzle, as it is not possible to determine from its flgure and structure to what class it ought to be referred. This little animal is figured * * * much magnified, its natural size not exceeding that of the brendth of the ossicula of the arms of the Comatula; it resembles a flat scale, runs about with considerable vivacity on the arms of the animal, and occasionally protrudes a flexible tubular proboscis ending in a papillary margin. The disk or body is surrounded by 18 or 20 retractile and movable tentacula, and beneath is furnished with five pair of short members, each ending in a hooked claw. Query, is it a perfect animal or a larva, and does it belong to the Crustacea, Annelides, or what?

In connection with his work upon the erinoids, Johannes Müller in 1841 noticed Thompson's parasite and bestowed upon it the name of Cyclocirra thompsonii, at the same time expressing the opinion that Delle Chiaje's madreporic plate was in reality a similar form. He entirely failed to see the connection between these and the species which had been described by Leuckart in his new genus Myzostomum. 
Sven Lovén in 1840 and in 1842 published additional information regarding the myzostomes of Antedon, and in 1858 Semper and also Diesing contributed to the knowledge of the Mediterranean species, both describing several new forms.

In 1875 and 1876 C. Th. E. von Siebold published letters which he had received from R. von Willemoes-Suhm, one of the young naturalists on board the Challenger. In these letters which, having been written on shipboard by a youthful enthusiast, to whom everything was new and interesting, in the midst of the activities of the first great expedition for marine exploration, breathe the spirit of marine investigation to a degree which can never be attained by one who writes in the seclusion of the home from half-forgotten notes taken in the field, various encysting myzostomes are described, diœcious species are recorded, and remarks on the general biology of these animals are included.

The year 1877 saw the completion of Ludwig Graff's (later von Graff) monograph on the genus Myzostomum (emended by him to Myzostoma), in which all that was known about these creatures was included, and in which a considerable number of new forms, largely from the Philippines, were described.

The appearance of this work at once ealled attention to Graff as the leading authority on the myzostomes, and the authorities in charge on the material collected by the numerous British exploring expeditions, actuated by the unselfishness and absence of narrow nationalism which has always characterized the scientific men of Britain, promptly turned over to him all the myzostomes in their possession. Thus between 1883 and 1887 he was enabled to publish reports upon the myzostomes of the Porcupine, Triton, and Challenger expeditions, his two volumes on the last remaining to this day the most voluminous and extensive contributions to the knowledge of the group from the systematic and distributional standpoint.

On the original specimen of Metacrinus rotundus, which had been dredged in Sagami Bay, Japan. by Ludwig Döderlein, P. H. Carpenter found an interesting myzostome, which von Graff described in 1885. In the same year he called attention to certain deformities in fossil crinoids, and suggested that they might have been caused by myzostomes.

In $1885 \mathrm{P}$. H. Carpenter noticed certain cysts in the arms and pinnules of Antedon which he thought were caused by myzostomes, but they were shown by von Graff in 1887 to have a different origin.

In 1886 von Graff described some new myzostomes which were found on the comatulids in the Zoological Museum at Copenhagen; and in $1887 \mathrm{~F}$. von Wagner, one of his students, described a curious new form which he had found associated with Antedon adriatica on the Dalmatian coast.

Up to 1895 all the known myzostomes were parasitic upon the crinoids, and were either free-living or inclosed in cysts which, more or less developed, opened to the exterior. In that year Emil von Marenzeller made known a new type, Myzostomum asterice, which lives as a true endoparasite in certain starfishes.

In 1896 William Morton Wheeler, in a paper primarily on the sexual phases of the myzostomes, described several new species which he had found on pentacrinites in the British Museum. 
In 1902 Hubert Lyman Clark announced the discovery of myzostomes on some ophiurans from southern Japan, and in 1905 Wheeler described a new species entoparasitic in a starfish from southern California.

August Reichensperger described a new species in 1906 from the West Indian Isocrinus decorus.

In 1906 also Hubert Ludwig described an entoparasitic chætopod, Ophiuricola cynips, from a deep-sea ophiuran. While not related to the myzostomes, this animal, nevertheless, is of considerable interest in connection with them.

Several new myzostomes from southern Japan (including those parasitic on ophiurans mentioned by H. L. Clark in 1902), the West Indies, and the Pacific coast of North America were described by Jesse F. McClendon in 1906 and 1907; and in 1908 Rudolf Ritter von Stunmer-Traunfels gave a detailed account of two forms which had been found on the crinoids brought back by the Discovery from the shores of the Antarctic continent.

In 1912 D. Fedotoff described a very extraordinary myzostome, which he called Protomyzostoma polynephris, and which he had found entoparasitic in an astrophyton or basket-fish, Gorgonocephalus eucnemis. Recently he has given a very detailed account of this type, and has announced its discovery in Gorgonocephalus arcticus in the Kara Sea.

In 1915 Charles L. Boulenger described the myzostomes from the comatulids collected by Mr. Cyril Crossland in the Sudanese Red Sea, among which he found one new species.

The anatomy and embryology of the myzostomes have engaged the attention of many able investigators; the life history has been treated by Elias Metschnikoff (1866) and John Beard (1884); the sexual conditions by Beard (1894 and 1898), Wheeler (1894, and especially 1896), and A. F. Coventry (1910); various phases of the embryology by Wheeler $(1895,1896$, and $189 \bar{\top})$, Kostanecki $(189 \bar{\tau}, 1898$, and 1905), and Carazzi (1904); and the general anatomy by Nansen (1885 and 1887), von Wagner (1886), H. Pruho (1892), von Stummer-Traunfels (1903 and 1908), Maidl (1910), G. Retzius (1910), Boulenger (1911 and 1915), and Fedotoff (1914 and especially 1916).

The following list includes all the known species of myzostomes:

MYZOSTOMUAI HOROLOGIUM VON GRAFF.

Occurrence.-Free-living.

Hosts.-According to P. H. Carpenter most probably Comatula rotalaria and Comatula solaris, but more likely Zygometra microdiscus and $Z$ ygometra elegans.

Localities.-Challenger Station 186, Prince of Wales Channel, Torres Strait (lat. $10^{\circ} 30^{\prime}$ S., long. $142^{\circ} 18^{\prime}$ E.), 8 fathoms; and Challenger Station 187, off Booby Island, Torres Strait (lat. $10^{\circ} 36^{\prime}$ S., long. $141^{\circ} 55^{\prime}$ E.), 6 fathoms; probably also Challenger Station 190, in the Arafura Sea (lat. $8^{\circ} 56^{\prime}$ S., long. $136^{\circ} 05^{\prime}$ E.), 49 fathoms.

Remarks.-This appears to be the species mentioned by von Willemoes Suhm as occurring on a large black and white comatulid in the Arafura Sea. 
At Challenger Stations 186, 187, and 190 (the last probably the station referred to by von Willemoes-Suhm) the large species of $Z$ ygometra, $Z$. microdiscus, or $Z$. elegans, were taken, while at the last in addition to Zygometra only Homalometra denticulata was found. These species of $Z$ ygometra occur black and white, while so far as we know Comatula rotalaria and $C$. solaris, in common with all the species in the subfamily to which they belong, are always unicolor, red to brown, deep purple or black, with the dorsal side of the arms sometimes lighter. Apparently the station to which von Willemoes-Suhm referred was Station 190, in 49 fathoms-a depth beyond the known bathymetric range of Comatula rotalaria and of $C$. solaris.

MYZOSTOMUM LONGIPES VON GRAFF.

Occurrence.-Free-living.

Host.-Uncertain.

Locality.-Blake Station 269, off St. Vincent, West Indies, 124 fathoms. MYZOSTOMUM CHINESICUM VON GRAFF.

Occurrence.-Free-living.

Host.-Uncertain.

Locality.-Dredged in the China Sea.

MYZOSTOMUM LABIATUM VON GRAFF.

Occurrence.-Free-living.

Host.-Probably Pachylometra incequalis.

Locality.-Near Kandaru, Fiji (lat. about $19^{\circ} 06^{\prime}$ S., long. about $178^{\circ} 18^{\prime}$ E.). 210,225 , or 610 fathoms.

\section{MYZOSTOMUM ECHINUS VON GRAFF.}

Occurrence.-Free-living.

Hosts.-C'omanthus parvicirra and probably Pachylometra incequalis or Charitometra incisa.

Localities.-Challenger Station 1 14 , near Kandavu, Fiji (latitude about $19^{\circ} 06^{\prime}$ S., longitude about $178^{\circ} 18^{\prime}$ E.), 210, 225, or 610 fathoms; and between Swatow and Formosa (Taiwan) (lat. $23^{\circ} 20^{\prime}$ N., long. $118^{\circ} 30^{\prime}$ E.), 17 fathoms.

Remarks.-Comanthus parvicirra is an exclusively littoral type, while both Pachylometra inaqualis and Charitometra incisa are from deep water. With the two last there were recorded from Challenger Station 174 Comatella stelligera, Comaster novaguinere, Comanthus parvicirra, Stephanometra spicata, and Lamprometra protectus, all littoral species which certainly did not occur with them in life. It is most likely that Myzostomum echinus from Station 174 lived on one of these.

\section{MYZOSTOMUM ALATUM VON GRAFF.}

Occurrence.-Free-living.

Hosts.-Leptometra celtica and L. phalangium.

Localities.-The Minch: The Minch, 60-80 fathoms; off Loch Scavaig, Skye; Porcupine Station 13, 1870, off Cape Mondego, Portugal (lat. $40^{\circ} 16^{\prime} \mathrm{N}$., long. $9^{\circ} 37^{\prime}$ W. ), 220 fathoms; off Carthagena, Spain, 80 fathoms. 
MYZosToßTM COSTATUM F. S. LEUCKART.

Figs. 1255-1262, pl. 40 .

Occurrence.-Free-living.

Hosts.-Comatula solaris, Comanthus parvicirra, Heterometra savignii, PLamprometra palmata, Prometra chadwicki, and ophiurans commensal on Heterometra savignii. Comatula, or Antedon, triqueta Semper, MS., is also given as a host of this species, but this form has never been identified.

Localities.-Red Sea; Tur, near Sinai; Ul Shubuk, 9 fathoms; Suez Bay, 10 fathoms; near Bohol, Philippines.

\section{MXZOSTOMUM PLICATUM VON GRAFF.}

Occurrence.-Free-living.

Host.-Comatella stelligera.

Locality.-Australia.

MYZOSTOMUEA RUBROFASCIATCM VON GRAFF.

Fig. 1263, pl. 40.

Occurrence.-Free-living.

Host.-Uncertain; Boulenger states that his specimens were obtained from an unidentified comatulid.

Localities.-Tur, near Sinai, Red Sea; Forculch Barrier Island, Red Sea. MYZOSTOMUAI PARASITICUM F. 8, LEUCKART.

Synonyms.-Myzostomum glabrum F. S. Leuckart. Myzostomum tuherculosum Semper.

Occurrence.-Free-living; this species is found on the disk in the immediate vicinity of the mouth.

Hosts.-Antedon adriatica, A. mediterranea, A. bifida, and $A$. petasus.

Localities.-Adriatic Sea, at Cattaro; Meditcrranean Sea, at Naples. It is stated to be very common on the disks of the several species of Antedon in all European seas.

MYZOSTOMCM MLAS (LËTIKEN, MS.) VON GRAFF.

Occurrence.-Free-living.

Hosts.-Heliometra glacialis and Tropiometra picta.

Localities.-Barents Sea (lat. $76^{\circ} 51^{\prime}$ N., long. $44^{\circ} 20^{\prime}$ E.), 145 fathoms; Barents Sea (lat. $74^{\circ} 71^{\prime} 0 t^{\prime \prime}$ N., long. $50^{\circ} 23^{\prime}$ E.), 84 fathoms; Porcupine Station 57,1869 , southeast of the Faroë Islands (lat. $60^{\circ} 14^{\prime} \mathrm{N}$.; long. $6^{\circ} 17^{\prime} \mathrm{W}$.), 632 fathoms; Jan Meyen; Pröven, north Greenland, 50 fathoms; Challenger Station 48, Le Have Bank (lat. $43^{\circ} 04^{\prime}$ N., long. $64^{\circ} 05^{\prime}$ W.), 51 fathoms; Bahia, Brazil.

MYZOSTOMUM GLANTEUM NANSEN.

Occurrence.-Free-living.

Host.-Hathrometra prolixa.

Locality.- 
MYZOSTOMUM TESTUDO VON GRAFF.

Occurrence-Free-living.

Host.-Nemaster rubiginosa.

Locality.-Blake Station 285, off Barbados, 13 to 40 fathoms.

MYZOSTOMUM CHELONIUM M'CleNDOX.

Occurrence.-Free-living.

Host.-One or more of the local species of Calometridæ.

Locality.-Southern Japan, Suruga Gulf and Sagami Bay.

MYZOSTOMUM CHELONOIDIUM M'CLENDON.

Occurrence.-Free-living.

Host.-One or more of the local species of Calometridæ.

Locality.-Southern Japan, Suruga Gulf and Sagami Bay.

MYZOSTOMUMI LÜTIKENI VON GRAFF.

Occurrence.-Free-living.

Host.-Comanthus parvicirra.

Locality.-Tonga Islands.

MTZOSTOM UM PALLIDUM VON GRAFF.

Occurrence.-Free-living.

Hosts. - Comatula solaris, Comanthus parvicirra, and an undetermined comatulid referred to "Comatula."

Locality.-Near Bohol, Philippines.

MYZOSTOMUM MARGINATUM VON GRAFF.

Occurrence.-Free-living.

Hosts.-Nemaster iowensis and N. discoidea.

Localities.-Blake Station 155, off Montserrat, 88 fathoms; and Blake Sta. tion 203, off Martinique, 96 fathoms.

MTZOSTOAIUM GRAFFI NANSEN.

Occurrence.-Free-living.

Host.-Hathrometra prolixa.

Locality.-

MYZOSTOMLCMI RREVIIES VON GRAFF.

Occurrence.-Free-living.

Host.-Crinometra, sp.; von Graff states that the host is Antedon poutalesii, but this species has not been determined with certainty.

Locality.-Off Carriacou, Grenadines, 163 fathoms.

MYZOSTOMTM CARI'ENTERI VON GRAFF.

Occurrence.-Free-living.

Host.-Mathrometra prolixa.

Localities.-Triton Station 5, south of the Faroe Islunds (lat. $60^{\circ} 11^{\prime} 25^{\prime \prime}$ and $60^{\circ} 20^{\prime} 15^{\prime \prime}$ N., long. $8^{\circ} 15^{\prime} 00^{\prime \prime}$ and $8^{\circ} 08^{\prime} 00^{\prime \prime}$ W.), 285 to 433 fathoms; off eastern 
Greenland (lat. $77^{\circ} 18.5^{\prime} \mathrm{N}$., long. $18.5^{\prime} \mathrm{W}$.), in 304 meters, and (lat. $76^{\circ} 06^{\prime} \mathrm{N}$, long. $13^{\circ} 26^{\prime} \mathrm{W}$.), in 200 to 250 meters.

$$
\text { MYZOSTOMUM ARLOLATUM YON GRAFF. }
$$

Occurrence.-Free-living.

Hosts.-Comactinia echinoptera and Comactinia meridionalis (recordeid as Actinometra blakei and Actinometra meridionulis var. quadrata.

Localities.-Blake Stations 172, off Guadeloupe, 62 to 100 fathoms; 203, off Martinique, 10 to 27 fathoms; and 278 , of Barbados, 69 fathoms.

$$
\text { MIYZOSTOMUM TRISTE TON GRAFF. }
$$

Occurrence.-Free-living.

Hosts.-Comanthus parvicirra, and undetermined comatulids recorded as "uncertain," and "Comatula, sp., in Ill. Semper collectione No. 6 signata."

Localities.-Near Bohol, Philippines, and Oceania ("Tahiti, Samoa, etc.").

$$
\text { MYZOSTOMUM CORIACEUM YON GRAFF. }
$$

Occurrence.-Free-living.

Host.-Colobometra perspinosa, and "a black Actinometra (n. sp.)."

Localities.-Port Denison, Queensland, 3 to 4 fathoms; Moluccas.

Remarks.-The host of this species was originally recorded as Antedon insignis Bell; later von Grafl stated, on the authority of P. H. Carpenter, that Bell had changed his specific name insignis to lovéni; but insignis-lovéni is the same species that had previously been described by Carpenter under the name perspinosa.

\section{MYZOSTOMTM RADIATTIM VON GRAFF.}

Occurrence.-Free-living.

Host.-A species closely allied to, if not, Comactinia meridionalis.

Locality.-Near Barbados.

$$
\text { MYZOSTOMITM PULYINAR YON GRAFF. }
$$

Occurrence.-Free-living.

IIosts.-Leptometra celtica and L. phalangium.

Localities.-The Ninch, 60 to 80 fathoms; off Loch Scavaig. Skye; Bay of Sorrento (near Naples).

\section{MYZOSTOMLAI CALYCOTYIE VON GRAFF.}

Occurrence.-Free-living.

Host.-Endoxocrinus alternicimus.

Locality.-Challenger Station 214, off the Meangis Islands, 500 fathoms.

MYZOSTOMUM COMPRESSTM YON GRAFF.

Occurrence.-Free-living.

Ilost.-Ilycrinus australis.

Locality.-Challenger Station 146, in the vicinity of the Crozet Islands (lat. $46^{\circ} 46^{\prime}$ S., long. $45^{\circ} 31^{\prime}$ E.), 1,375 fathoms. 


\section{MYZOSTOMUMY BREVICIRRUM VON GRAFT.}

Occurrence.-Free-living.

Host.-Comanthus parvicirra.

Localities.-Between Swatow and Formosa (Taiwan) (lat. $23^{\circ} 20^{\prime}$ N., long. $118^{\circ} 30^{\prime}$ E.), 17 fathoms, and the Tonga Islands.

\section{MYZOSTOMUM PICTUM VON GRAFF.}

Occurrence.-Free-living.

Host.-Probably Stylometra spinifera.

Locality.-Blake Station 157, off Montserrat, West Indies, 120 fathoms.

IIYZOSTOMCM NIGRESCENS VON GRAFF.

Occurrence.-Free-living.

Host.-Comanthus parvicirra.

Locality.-Tokyo Bay, Japan.

MYZOSTOMUMT CIRRIFERUM F. S. IEUCKART.

Synonyms.-Cyclocirra thompsonii I. Müller.

Myzostomum thomsoni Diesing.

Myzostomum schultzeanum Diesing.

Occurrence.-Free-living.

Hosts.-Antedon petasus, A. bifida, A. mediterranea, A. adriatica, and Hath rometra prolixa.

Localities.-Probably cold area, Faroe Channel (Porcupine, 1869); Triton Station 3, on the Faroe Banks (lat. $60^{\circ} 39^{\prime} 30^{\prime \prime}$ ก., long. $9^{\circ} 06^{\prime} 00^{\prime \prime}$ W.), 87 fathoms; Norway; Arendal, Norway; western coast of Sweden; Cattegat; Bressay Sound, Shetland, 5 to 7 fathoms; "northern seas"; Arran, 5 to 10 fathoms; Isle of Man; Oban; Keumaes Bay, north coast of Anglesea; Torquay; Ireland; Naples; Trieste.

Remarks. - This is the species that was mistaken by Delle Chiaje for a madreporic plate. Müller recognized his figure as representing a parasite similar to the one to which attention had already been called by J. V. Thompson, upon which he bestowed the name of Cyclocirra thompsonii.

\section{MYZOSTOMUM CERRIFEROIDIUM M'CLENDON.}

Occurrence.-Free-living.

Hosts.-Crinometra insculpta and Analcidometra armata.

Localities.-Albatross Stations 2752, off St. Vincent, West Indies, 281 fathoms ; 2753 , off St. Vincent, 281 fathoms; and 2146 , near Colon, 34 fathoms.

\section{MYZOSTOMUM CRENATUM VON GRAFT.}

Occurrence,-Free-living.

Host.-Ponactinia meridionalis.

Localities.-Blake Station 203, off Martinique, 10 to 27 fathoms; and Inves. tigator Station near St. Lucia (lat. $13^{\circ} 22^{\prime}$ N., long. $61^{\circ} 07^{\prime}$ W.), 278 fathoms. 


\section{MYZOSTOMUM LONGICIRRUM VON GRAFF.}

Fig. 1265, pl. 41.

Occurrence.-Free-living.

Host.-Comanthus parvicirra.

Locality._Zamboanga, Philippine Islands.

MYZOSTONCM WYILLETHOMSONI VON GRAFF.

Occurrence.-Free-living.

Hosts.-Metacrinus costatus and $M$. angulatus.

Localities.-Challenger Stations 192, near the Kei Islands, 140 fathoms; and 214, off the Meangis Islands, 500 fathoms.

\section{MYZOSTOMUM CIRCINATUAI WHEELER.}

Occurrence.-Free-living.

Host.-Endoxocrinus alternicirrus or Hypalocrinus naresianus.

Locality.-Challenger Station 214, off the Meangis Islands, 500 fathoms.

$$
\text { MYZOSTOMUM VASTUM VON GRAFF. }
$$

Occurrence.-Free-living.

Hosts.-Comactinia echinoptera and Comanthus japonica.

Localities.-Blake Stations 39, 16 miles north of the Jolbos Islands, southwestern part of the Yucatan Bank, 14 fathoms; and 203, off Martinique, 10 to 27 fathoms; and southern Japan.

\section{MYZOSTOMUM AGASSIZII YON GRAFF.}

Occurrence.-Free-living.

Hosts.-Coccometra hagenii and probably Stylometra spinifera.

Localities.-Near Bahia Honda, Cuba, 100 fathoms; Blake Stations 32, on the northern part of the Yucatan Bank, 95 fathoms; 155, off Montserrat, 88 fathoms; and 269 , off St. Vincent, 124 fathoms.

\section{MYZOSTOMUM DUBIUM VON GRAFF.}

Occurrence.-Free-living.

Hosts.-Heterometra crenulata (recorded as Comatula [or Antedon] dubia) and an unidentifiable species recorded as Comatula (or Antedon) triqueta.

Locality.-Near Bohol, Philippines.

\section{MYZOSTOMUM MOEIIANUM VON GRAFF.}

Occurrence.-Free-living.

Host.-Recorded as " Comatula. sp."

Locality-Fouquet Island, southeast of Mauritius, 18 fathoms.

Remarks. - The species collected by Professor Möbius at Fouquet Island were Oligometra occidentalis, Tropiometra carinata, and Dorometra mauritiana. 
Occurrence.-Free-living.

\section{MYZOSTOMUM ELONGATUM VON GRAFF.}

Hosts.-A specimen was found lying loose in a jar with Stephanometra spicata and Lamprometra protectus, and another was taken from an unidentifiable species recorded as Comatula (or Antedon) triqueta.

Localities.-Near Bohol, Philippines; and Challenger Station 174, near Kandavu, Fiji, 210, 225, or 610 fathoms.

Remarks.-There is some mistake in regard to the Challenger station given. The species recorded from it, Stephanometra spicata and Lamprometra protectus, are both littoral and could not have occurred at any of the depths given.

\section{MYZOSTOMUMI VERRUCOSUM VON GRAFF.}

Occurrence.-Free-living.

Host.-An undeterminable species recorded as Comatula (or Antedon) triqueta. Locality.-Near Bohol, Philippines.

Occurrence.-Free-living.

MYZOSTOMUN DENTATUM VON GRAFF.

Hosts.-Heterometra crenulata; another specimen was found lying loose in a jar containing Comatula solaris, Comanthus bennetti, and five endocyclic comatulids.

Localities.-Challenger Station 186, Prince of Wales Channel, Torres Strait, 8 fathoms; and the Moluccas.

\section{MYZOSTOMUM FIMBRIATUM VON GRAFF.}

Occurrence.-Free-living.

Host.-Heliometra glacialis.

Locality.-Challenger Station 48, Le Have Bank (lat. $43^{\circ} 04^{\prime} \mathrm{N}$., long $64^{\circ}$ $\left.05^{\prime} \mathrm{W}\right), 51$ fathoms.

$$
\text { MYZOSTOMUM EXCISUM VON GRAFF. }
$$

Occurrence.-Free-living.

Hosts.-Coccometra hagenii, and a species recorded as Antedon impinnata.

Localities.-Off Alligator Reef, Florida, 96 fathoms; and North Bay, Mauritius, 15 fathoms.

Occurrence.-Free-living.

MYZOSTOMUM IRREGELARE VON GRAFF.

Hosts.-Comactinia echinoperta and $C$. meridionalis.

Localities.-West of Tortugas; "U. S. Coast Survey, 100 fathoms"; Blake Stations 45, northwest of the Tortugas. 101 fathoms; 203, off Martinique, 10 to 27 fathoms; and 249, off Grenada, 262 fathoms.

MYZOSTOMUM CARIBBEANUM VON GRAFF.

Occurrence.-Free-living.

Host.-Uncertain.

Locality.-Caribbean Sea. 
Occurrence.-Free-living.

Host.-Comactinia echinoptera.

Locality.-Blake Station 249, off Grenada, 262 fathoms.

MYZOSTOMUM ORLONGUM VON GRAFF.

Occurrence.-Free-living.

Host.-Probably Comactinia echinoptera.

Locality.-Blake Station 249, off Grenada, 262 fathoms.

MYZOSTOMUM OBLONGUM VON GRAFF.

Occurrence.-Free-living.

Host.-Neocomatella pulchella.

Localities.-Blake Stations 210, off Martinique, 191 fathoms; 224, off St. Vincent, 114 fathoms; and 269, off St. Vincent, 124 fathoms.

MYZOSTOMUII ELEGANS VON GRAFF.

Occurrence.-Free-living.

Hosts.-Comanthus parvicirra, Comactinia meridionalis, and an unidentifiable comatulid recorded as Comatula (or Antedon) triqueta.

Localities,-Near Bohol, Philippines; and off French Reef, Florida.

MYZOSTOMUM ETERMANNI M'CLENDON.

Occurrence.-Free-living.

Host.-Comactinia echinoptcra.

Locality.-Albatross Station 2166, off Habana, Cuba, 196 fathoms.

MIYZOSTONCM ANTENNATUM VON GRAFF.

Occurrence.-Free-living.

Host.-Recorded by von Graff as uncertain; McClendon found it on Comanthus pinguis and on Metacrinus rotundus.

Localities.-Amoy, China, and Suruga Gulf and Sagami Bays, southern Japan.

Remarks.-According to McClendon the following should be considered a synonym of this species:

MYYZOSTOMCM AMBIGUUM VON GRAFF.

Fig. 1266, pl. 41.

Occurrence.-Free-living.

Host.-This species was found lying loose in a jar with Comatula solaris, Comanthus bennetti, and five endocyclic comatulids.

Locality.-Moluccas. 
MONOGRAPH OF THE EXISTING CRINOIDS.

MYZOSTOMUM CORNUTUM. VON GRAFF.

Occurrence.-Free-living.

Hosts. - Thaumatometra cypris, and an undeterminable species recorded as Comatula (or Antedon) triqueta.

Localities.-Challenger Station 236, south of Japan, 775 fathoms; and near Bohol, Philippines.

MYZOSTOMUM BRACHIATUM VON GRAFF.

Occurrence.-Free-living.

Host.-Comatella nigra.

Locality.-Near Bohol, Philippines.

MYZOSTOMUM FISSCM VON GRAFF.

Occurrence.-Free-living.

Hosts.-Uncertain; perhaps Pachylometra incoqualis; another specimen was found loose in a jar with Stephanometra spicata and Lamprometra protectus.

Locality.-Challenger Station 174, near Kandavu, Fiji, 210, 225, or 610 fathoms.

Remarks.-Stephanometra spicata and Lamprometra protectus are both strictly littoral types and could not have occurred at any of the depths given.

MYZOSTOMUM INTERMEDIUM VON GRAFF.

Occurrence.-Free-living.

Host.-Zygometra microdiscus.

Locality.-Challenger Station 187, off Booby Island, Torres Strait, 6 fathoms.

MYZOSTOMUM QUADRIFILUM VON GRAFF.

Occurrence.-Free-living.

Hosts.-Zygometra microdiscus and Heterometra crenulata.

Locality.-Challenger Station 186, Prince of Wales Channel, Torres Strait, 8 fathoms.

\section{MYZOSTOMCM QUADRICAUDATUM VON GRAFF.}

Pl. 52, fig. 1344.

Occurrence.--Free-living.

Host.-Zygometra elegans.

Localities.Challenger Station 190, Arafura Sea, 49 fathoms; and Torres Strait, 10 fathoms, Alert.

MYZOSTOMIIM LOBATUM VON GRAFF.

Occurrence.-Free-living.

Host.-Capillaster multiradiata.

Locality.-Near Bohol, Philippines. 


\section{MYZOSTOMUM FCROATUM VON GRAFF.}

Occurrence-Free-living.

Host.-Found lying loose in a jar containing a black comasterid and several other comatulids.

Locality.-Moluccas.

$$
\text { MYZOSTOMUM BICAUDATUM VON GRAFF. }
$$

Occurrence.-Free-living.

Host.-Comactinia meridionalis.

Locality.-West of the Tortugas, Florida.

IYYZOSTOMIUM FILICAODA VON GRAFF.

Fig. 1264, pl, 41.

Occurrence.-Free-living.

Host.-Coccometra hagenii.

Locality.-Off Sand Key, Florida.

MYZOSTOMIUM FILIFERUM VON GRAFF.

PI. 52, fig. 1343.

Occurrence.-Free-living.

Host.-Heterometra crenulata.

Locality.-Challenger Station 186, Prince of Wales Channel, Torres Strait, 8 fathoms.

MYZOSTOMUAL CARINATUM VON GRAFF.

Occurrence.-Free-living.

Hosts.-Neocomatella alata; another specimen was found on a comatulid recorded as Antedon impinnata; and a third was found loose in a jar containing Comatula solaris, Comanthus bennetti, and five endocyclic comatulids.

Localities.-Blake Station 193, off Martinique, 169 fathoms; North Bay, Mauritius, 15 fathoms; and the Moluccas.

MYZOSTOMUA CORONATUM VON GRAFF.

Occurrence.-Free-living.

Host.-Ilycrinus australis.

Locality.-Challenger Station 146, west of the Crozet Islands (lat. $46^{\circ} 46^{\prime}$ S., long. $45^{\circ} 31^{\prime}$ E.), 1,37 5 fathoms.

MXZOSTOMUM VINCENTINUM REICIIENSPERGER.

Occurrence.-Free-living.

Host.-Isocrinus decorus.

Locality.-Blake Station 269, off St. Vincent, 124 fathoms. 
MYZOSTOMUM FOLIUM VON GRAFF.

Occurrence.-Free-living.

Host.-Cyllometra manca.

Locality.-Challenger Station 192, near the Kei Islands, 140 fathoms.

MYZOSTOMUM MEMBRANACEUAI VON GRAFF.

Occurrence.-Free-living.

Host.-Stephanometra spicata.

Locality.-Challenger Station 208, Philippine Islands (lat. $11^{\circ} 37^{\prime} \mathrm{N}$., long. $123^{\circ} 31^{\prime}$ E.), 18 fathoms.

\section{MYZOSTOMUM BUCCHICHII VON WAGNER.}

Occurrence.-Free-living.

Host.-Antedon adriatica.

Locality.-Near Clemente Island, south of Lesina, Dalmatia.

MYZOSTOMUM CIRRIPEDIUM VON GRAFF.

Occurrence--Free-living.

Host.-Metacrinus rotundus.

Locality._Sagami Bay, southern Japan, 70 fathoms.

\section{MYZOSTOMUMI NANSENI VON GRAFF.}

Occurrence.-Free-living.

Host.-This species was found lying loose in a jar containing a black comasterid and several other comatulids.

Locality.-Moluccas.

\section{MYZOSTOMUM JAPONICUM M"CLENDON.}

Occurrence.-Free-living.

Hosts.-Two ophiurans, both belonging to the family Trichasteridæ, Ophiocreas adipus Lyman, and Astroceras pergamena Lyman.

Localities.-Albatross Stations 3755 , off southern Japan, 52 to 77 fathoms, and 4979, off southern Japan, 943 fathoms.

Remarks.-It is of course possible that these myzostomes are of accidental occurrence on the ophiurans, having crawled onto them from crinoids inhabiting the same localities.

MYZOSTOMLYI SMITHI M'CLENDON.

Occurrence.-Free-living.

Hosts.-One or more of the local species of Calometridæ.

Locality.-Southern Japan, Suruga Gulf and Sagami Bay.

MYZOSTOMUM WHERLER M'CLENDON.

Occurrence.-Free-living.

Host.-Metacrinus rotundus.

Locality.-Southern Japan, Suruga Gulf and Sagami Bay. 


\section{MYZOSTOMUM METACRINI M'CLENDON.}

Occurrence.-Free-living.

Host.-Metacrinus rotundus.

Locality -Southern Japan, Suruga Gulf and Sagami Bay.

$$
\text { MYZostomum CUBANUM M'CLendon. }
$$

Occurrence.-Free-living.

Host.-Uncertain.

Locality.-Albatross Station 2156, off Habana, Cuba, 289 fathoms.

MYZOSTOMUM DEANI M'CL.ENDON.

Occurrence.-Free-living.

Host8.-Florometra serratissina and $F$. perplexa.

Localities.-Albatross Stations 3449, off the state of Washington, 135 fathoms; and 3350, off northern California, 75 fathoms; and off Pacific Grove, California.

\section{MYZOSTOMUM CROSSLANDI BOULENGER.}

Figs. 1251-1253, pl. 40.

Occurrence.-Free-living.

Hosts.-Heterometra savignii, Prometra chadwicki, and an undetermined comatulid.

Localities.-Red Sea; Ul Shubuk, and Suez Bay, in 10 fathoms.

$$
\text { MYZOSTOMUM ANTARCTICUM VON STUMMER-TRACNFEL. }
$$

Occurrence--Free-living.

Host.-Anthometra adriani.

Locality.-Shores of the Antarctic continent, in 124 fathoms; winter quarters of the Discovery.

\section{MYZOSTOMUM ASYMMETRICUM VON GRAFF.}

Fig. 1282. pl. 43.

Occurrence.-Sticking fast to, and enlarging, the pinnules.

Host.-Endoxocrinus alternicirrus.

Locality.-Challenger Station 214, off the Meangis Islands, 500 fathoms.

\section{MYZOSTOMUM PLATYPUS VON GRAFF.}

Figs. 12S6, 1287, pl. 43, and pl. 57, tig. 1363.

Occurrence.-In swellings on the disk. In regard to these swellings $\mathrm{P}$. H. Carpenter wrote to Professor von Graff :

Among six individuals of Actinometra nobilis [Comanthina schlcgelii] from Samboanga I find one with some structures on the clisk that I now recognize as Myzostoma cysts, though I did not know them in $187 \mathrm{~S}$. They seem to have no plating whatever, which is curious. I send you one with the Ifyzostoma inside, which I cut from a corner where the disk was torn; 
and I shall have another part of the disk with a group of cysts drawn by my best artist. They are always close to the ambulacral grooves and most frequently open into them, I suppose in order that the Myzostoma may get hold of some of the food particles which are traveling towards the mouth.

Host.-Comanthina schlegelii.

Localities.-Singapore, and Zamboanga, Philippines.

MYZOSTOMUM PENTACRINI VON GRAFF.

Figs. 1283-1285, pl. 43.

Occurrence.-In swellings on the arms.

Host.-Endoxocrinus alternicirmes.

Locality.-Challenger Station 214, off the Meangis Islands, 500 fathoms.

\section{MYZOSTOMUM CLARKI M'CLENDON.}

Occurrence.-In cysts in the form of an oval enlargement with a pore at either end.

Host.-Metacrinus rotundus.

Localities.-Albatross Station 3741, off southern Japan, 63 to 68 fathoms; and Suruga Gulf and Sagami Bay, southern Japan.

\section{MYZOSTOMUM EREMITA WHEELER.}

Occurrence.-In cysts.

Host.-Metacrinus moseleyi.

Locality.-Challenger Station 214, off the Meangis Islands, 500 fathoms.

\section{MYZOSTOMUM CRYPTOPODIUM WHEELER.}

Occurrence.-In a smooth pea-shaped calcareous cyst.

Host.-Metacrinus intermiptus.

Locality.-Not definitely known.

\section{MYYZOSTOMUM REALI VON GRAFF.}

Figs. 1288-1290, pl. 44.

Occurrence.-In swellings on the arms.

Host.-Perissometra flexilis.

Locality.-Challenger Station 192, near the Kei Islands, 140 fathoms.

\section{MYZOSTOMUM BELLI WHEELER.}

Occurrence.-In hard calcareous galls at the base of the arms.

Host.-Endoxocrinus alternicirmus.

Locality.-Challenger Station 214, off the Meangis Islands, 500 fathoms. 
MIYOSTOMUM DEFORMATOR VON GRAFF.

Figs. $1277-1279$, pl. 43 .

Occurrence.-Within the pinnules, which become swollen and ovoid.

Host.-Endoxocrinus altcrnicirmus.

Locality.-Challenger Station 214, off the Meangis Islands, 500 fathoms.

MYZOSTOMUM CYSTTCOLCM VON GRAFF.

Figs. 1276, pl. 42, and 1293-1297, pl. 44 .

Occurrence.-In independent sessile cysts on the pinnules and on the ambulacral side of the arms.

Hosts.-Comactinia echinoptera, Comactinia meridionalis, and Anthometra adriani.

Localities.-Off Cape Frio, Brazil; Blake Station 249, off Grenada, 262 fathoms; and shores of the Antaretic Continent near Mounts Erebus and Terror, 500 fathoms.

\section{IIYZOSTOMUM CYSTICOLUM VAR. CYSTIHYMENODES M'CLENDON.}

Occurrence.-In uncalcified ovoid cysts protruding from the ambulacral groove of the arms.

\section{Host.-Florometra asperrima.}

Locality.-Off the Trinity. Islands, Gulf of Alaska, 159 fathoms, at Albatros8 Station 2853.

\section{MYYOSTOMUM CYSTICOLUM VAR. ORIENTALE M'CLENDON.}

Occurrence.-Found in a cyst $5 \mathrm{~mm}$. in length with a pore at each end, which contained two individuals, a large one occupying nearly the cavity of the cyst and a small flat one between the larger and the wall of the cyst near one of the pores.

Host.-One or more of the local species of Calometridæ.

Locality.-Southern Japan.

\section{MYZOSTOMUM TENLISPINUM VON GRAFF.}

Figs. 1254 , pl. 40, 1270-1275, pl. 42, and 1298, 1299, 1302-1304, pl. 44.

Occurrence.-In roundish arm cysts.

Hosts.-Pachylometra inxqualis, Perissometra angusticalyx, Charitometra basicurva, and Charitometra incisa.

Localities.-Challenger Stations 170, off the Kermadec Islands, 630 fathoms; 174, near Kandavu, Fiji, 210, 225, or 610 fathoms; and 214, off the Meangis Islands, 500 fathoms.

MYZOSTOMUM WILIEMGESII VON GRAFF.

Figs. 1267-1269, pl. 42, and 1291, 1292, pl. 44 .

Occurrence.-In spiral malformations of the pinnules.

Hosts.-Pachylometra incequalis, Perissometra flexilis, and Charitometra basicurva. 
Localities.-Challenger Stations 170, off the Kermadec Islands, 630 fathoms; 170 , near Kandavu, Fiji, 210, 225, or 610 fathoms; and 192, near the Kei Islands, 140 fathoms.

$$
\text { MYZOSTOMOM INFLA'SOR VON GRAFF. }
$$

Occurrence.-In independent sessile cysts.

Hosts.-Neocomatella pulchella and Adelometra angustiradia.

Localities.-Challenger Station 192, near the Kei Islands, 140 fathoms; and Blake Station 294, off Barbados, 136 fathoms.

\section{MYZOSTOMUMI MCRRAYI VON GRAFF.}

Figs. 1300, 1301, pl. 44.

Occurrence.-In independent stalked cysts.

Hosts.-Horcometra duplex, Stiremetra breviradia, and Adelometra angustiradia.

Localities.-Challenger Stations 170, off the Kermadec Islands, 630 fathoms, and 192, near the Kei Islands, 140 fathoms; and Blake Station 269, off St. Vincent, West Indies, 124 fathoms.

MYZOSTOMUM ASTERLE VON MARENZELLER.

Occurrence.-Endoparasitic, living within the diverticula of the intestinal tract.

Hosts.-Two starfishes, both belonging to the family Asteriidæ, Asterias richardi Perrier and Stolasterias neglecta Perrier.

Locality.-Eastern Mediterranean.

MYYOSTOMUMI FISHERI WHEELER.

Occurrence.-Endoparasitic; one was found in an interradial portion of the colomic cavity.

Host.-A starfish of the family Goniasteridæ, Ceramaster leptoceramus (Fisher).

Locality,-Off Point Loma, near San Diego, California, 376 to 594 fathoms.

$$
\text { MYZOSTOMUM, SP. }
$$

Occurrence.-Free living.

Host.-Amphimetra molleri.

Locality.-Padau Bay, Mergui Archipelago.

$$
\text { MYZOSTOMUM, SP. }
$$

Occurrence.-Free living.

Host.-Charitometra incisa.

Locality.-Challenger Station 170, off the Kermadec Islands, 630 fathoms.

Remarks.-Professor von Graff states that this species shows some resemblance in form, thickness, and translucent marginal zone to $M$. brevipes. 
MYZOSTOMUM, SP.

Occurrence.-Free-living.

Host._Glyptometra tuberosa.

Locality.-Challenger Station 210, off Panglao and Siquijor, Philippines, 375 fathoms.

MYZOSTOMUM, SP.

Occurrence.-Free-living.

Host.-Amphimetra molleri or Zygometra comata.

Locality.-Padau Bay, Mergui Archipelago.

MYZostomUM, SP.

Occurrence.-Free-living.

Host.-Possibly Thaumatometra tenuis; Professor von Graff gives the host as " a small form of Antedon."

Locality.-Vladivostock.

MYZOSTOMUM, SP.

Occurrence.-Free-living.

Host.-"Antcdon, sp."

Locality.-Blake Station 219, off St. Lucia, 151 fathoms.

PROTONIZOSTONA POLYNEPHRIS FEDOTOV.

Occurrence.-Endoparasitic, in the genital organs.

IIosts.-Two ophiurans of the family Gorgonocephalidæ, Gorgonocephalus eucnemis (Müller and Troschel) and $G$.arcticus Leach.

Localities. - Kola Fjord, 100 to 180 meters (in Gorgonocephalus eucnemis); Kara Sea (in $G$. arcticus).

\section{STELECHOPUS HYOCRINI VON GRAFF.}

Occurrence.-Free-living.

Host.-Hyocrinus bethellianus (in the original description given as Hyocrinus bethellianus and Ilycrinus anstralis, but later corrected).

Localities.-Challenger Stations 146, west of the Crozet Islands (lat. $46^{\circ} 46^{\prime}$ S., long. $45^{\circ} 31^{\prime}$ E.), 1,375 fathoms; and 147 , between Marion Island and the Crozets (lat. $46^{\circ} 16^{\prime}$ S., long. $48^{\circ} 27^{\prime}$ E.), 1,600 fathoms.

Dr. L. E. Griffin reports finding undetermined species of myzostomes on specimens of Stephanometra echinus and S. oxyacantha taken at Port Galera, Mindoro, Philippines.

It is an interesting fact that the myzostomes are parasitized by several internal organisms belonging to groups not known to infest their hosts.

Nansen bas described a tapeworm, Tania myzostoma, from Myzostomum grafic. Dr. Brayton H. Ransom writes me that from Nansen's description it is 
not possible to determine the genus to which Tania myzostoma belongs, but that presumably it is the larval stage of a fish tapeworm. Various genera are represented among the tapeworms of fishes, but very little is known of their larval stages.

Wheeler has described a distome, Distoma myzostomatis, from Myzostomum platypus - a curious instance of a trematode parasitic within a myzostome, which itself is parasitic within a crinoid.

Wheeler has also described Amceba myzostomatis, possibly, as he suggests, the young of some gregarine, which he found in great numbers in the body cavity of Myzostomum parasiticum, where it attacks the ova.

The two following cases of parasitism among the ophiurans are of interest in connection with the worm parasites of the crinoids.

Metschnikoff has described a curious worm, Rhopalura, of the family Orthonectidæ, the cysts of which sometimes fill the body cavity of Amphiura squamata Sars and take the place of the ovaries, which disappear.

Ludwig has called attention to an extraordinary polychæte which he called Ophiuricola cynips and which he found in the body of a specimen of Ophioglypha tumulosa Lütken and Mortensen from 2,845 fathoms (5,203 meters).

None of the turbellarians have been found associated with the crinoids, though Anoplodium occurs within or upon holothurians.

\section{UNDETERMINED WORM.}

In some sections of three different specimens of Comanthus parvicirra which had been brought back from the Philippine Islands by Professor Semper, which he prepared while studying at the zoological laboratory of the University of Würzburg, P. H. Carpenter found a peculiar worm.

It was first noticed in the coliac canal of the arms, which it often almost filled, so as to suggest the idea that the egg had been introduced into the body cavity and had developed in that part of it. He subsequently found it in the visceral mass of two other individuals, occupying some of the meshes in the connective tissue network which fills up the intervisceral cœlome.

\section{PARASITE OF DOUBTFUL AFFINITIES.}

In Notocrinus virilis Dr. Th. Mortensen found a small elongate body lying in the cavity of the ovary, which was evidently a parasitic organism. Having been unable to find another specimen of this parasite he did not venture to state definitely what it was, but suggested that it might have been a myzostome.

\section{COLLENTERATA.}

In 1868 Count Pourtalès mentioned that the columns of Bourgueticrinus hotessieri (Bythocrinus, sp.) which he was recording from 237, 248, and 306 fathoms off the Samboes and off Sand Key, Florida, were covered with a thick brown deciduous skin. He later discovered that this supposed skin was a parasitic growth of a hydroid polyp. 
Various hydroids of several different families occur frequently on the stems and cirri of the pentacrinites (pl. 52, fig. 1342), and on the cirri of the comatulids. On the pentacrinites they often form tufts of very considerable size.

Most of the species are merely of fortuitous occurrence, but some are commensal and one or two probably semiparasitic.

There are the following specific records.

\section{Family CAMPANULARIIDA. \\ CALYCELLA SYRINGA LINNAES.}

This species was found by Mortensen on the cirri of Hathrometra protixa, from northeastern Greenland.

STEGOPOMA FASTTGATUM ALDER.

This form occurs on the cirri of Hathrometra prolia a. It was recorded by Mortensen from northeastern Greenland.

CUSPIDELLA, SP.

An undetermined species of Cuspidella was found by Mortensen on the cirri of Hathrometra prolixa, from northeastern Greenland.

\section{Family PERISIPHONIDE.}

\section{LAFOËA FRUTICOSA (SARS).}

Lafoëa fruticosa was found on the cirri of Hathrometra prolixa from northeastern Greenland by Mortensen.

\section{CORALS.}

P. H. Carpenter stated that corals may be attached to the columns of the stalked crinoids. Probably he referred to the white form of Polytrema miniaceum, which is quite coral-like in appearance.

As would be expected, small colonies of hydrocorallines are sometimes found on the older portions of the columns and on the accompanying cirri in the pentacrinites, and, rarely, on the older cirri of the comatulids.

It is rather curious that none of the Actiniaria or sea anemonies have as yet been found upon the crinoids, as certain genera, such as Stephanactis, Amphianthus, and Gephyra, occur very commonly on pennatulids and other arborescent marine organisms.

\section{PORIFERA.}

Small sponges of various kinds are often found attached to the older portions of the stems and to the cirri of the pentacrinites, and sometimes to the older cirri of the comatulids. There is no evidence that their occurrence is other than fortuitous.

\section{UNICELIULAR ORGANISMS.}

The unicellular organisms known to be commensal with, or parasitic upon or within, the echinoderms, are fairly numerous, but only two genera have as yet been 
found associated with the crinoids. 'The most complete account of these organisms is that published by Cuénot in 1891.

The unicellular organisms associated with the echinoderms are the following:

\section{DINOFLAGELLATA.}

\section{Suborder ADINIDA.}

\section{Family PROROCENTRIDÆ.}

PROROCENTRCM MICANS (EHRENBERG).

Perrier was the first to find a species of the genus Prorocentrum in the intestinal tract of Antedon bifida, the announcement of his discovery having been made in 1889.

Cuénot states that when an Antedon is cut into serial sections there are found in some special diverticula of the intestine which never contan food particles a great quantity of these organisms heaped together and almost completely filling the cavities of the diverticula. They are truly parasitic, and are always found in these intestinal diverticula in all specimens examined. They attain a rather considerable size, being up to $80 \mu$ in length, and a large number are always found in process of division. But their parasitism is only temporary, and little by little they escape from the body of the host. Some are always to be seen in the intestine itself among the food particles which have not undergone any alteration.

This species has long been known as a free-living organism.

It is recorded as a parasite from Antedon bifida taken off the Isle of Man, and at Roscoff, Concarneau, and other places on the French Atlantic coast.

It is not known to occur in the Mediterranean species of Antedon, though Cuénot looked for it in A. mediterranea.

PROROCENTREM DENTATCMI STEIN.

PROROCENTRUM ROSTRATCM STEIN.

These species were found by Stein in the intestines of salps, ascidians, and comatulids.

Prorocentrum, sp. Cuénot. Found in the ambulacral grooves of Echinaster sepositus (Lamarck) from Roscoff and Banyuls.

\section{CILIATA.}

\section{Order TRICHOSTOMATA.}

\section{Suborder ASPIROTRICHA.}

\section{Family URONEMID无.}

Uronema echini (Maupas). Found in the intestine of Paracentrotus lividus (Brandt) in the Mediterranean.

Uronema digitiformis (Fabre-Domergue). Found in the mucous on the skin of Marthasterias glacialis (O. F. Mïller). 
Hemispeira asteriasi. Fabre-Domergue. Found on the gills of Marthasterias glacialis (O. F. Müller).

\section{Suborder SPIROTRICHA.}

Section PERITRICHA.

\section{Family LICHNOPHORID $A$.}

Lichnophora auerbachii (Cohn). Found on Cladonema and on varioue worms (Psygnobranchus, Halosydna, Pterosyllis, Pionosyllis, Thysanozoon, etc.), mollusks (Doris, Eolis, etc.) and other invertebrates, and occurring very frequently on echinoderms, in which class it has been recorded from the ambulacral grooves of Astropecten jonstoni (Delle Chiaje), the gills of Asterina gibbosa (Pennant), the body surface of Ophiothrix fragilis (Düben and Koren), and the gills of holothurians.

\section{Family URCEOLARIIDE.}

Trichodina synaptre Cuénot. Found in the cœlomic fluids of Synapta inharens (O. F. Müller), at Roscoff.

\section{HEMISPEIROPSIS ANTEDONIS (CUÉNOT).}

In 1886 Perrier mentioned and figured five specimens of a curious peritrichous infusorian which he had found on Antedon bifida at Roscoff. This was described in 1891 by Cuenot under the name of Trichodina antedonis, and again independently by König in 1894 under the name of Hemispeiropsis comatula.

These infusorians occur on the lower (dorsal) surface of the hosts, between the cirri. They crawl over the integument by means of the lower ciliated crown, and they can also detach themselves entirely, swimming about by means of their large peristomial cilia.

Hemispeiropsis antedonis occurs on Antedon bifida at Roscoff and at St. Waast-la-Hougue, and on Antedon mediterranea in the Mediterranean.

Cyclochata asterisci (Grube). Found on the gills of Asterina gibbosa (Pennant) at Genoa.

Cyclochata ophiothricis (Fabre-Domergue). Found on Ophiothrix fragilis (Düben and Kioren) at Concarneau.

Urceolaria ophiocome Giard. Found on Amphiura squamata (Delle Chiaje) at Wimereaux.

Family VORTICELLIDA.

Vorticella amphiurce Cuénot. Found on Amphiura squamata (Delle Chiaje) at Naples.

Vorticella ophiocome Giard. Found on Amphiura squamata (Delle Chiaje) at Wimereux. Possibly the same as the preceding.

Vorticella, sp. Fabre-Domergue. Found in the stomachic cavity of Ophiacantha sphcerulata (Pennant) at Concarneau. Possibly V. amphiurce. 
Rhabdostyla, sp. Cuénot. Found on the skin and paxillæ of the aboral surface of Astropecten aurantiacus (Linnæus) at Cette.

Rhabdostyla arenaria Cuénot. Found on the skin of Synapta inhorens (O. F. Müller).

Rhabdostyla, sp. Hamann. Found on the skin of a young Asterias rubens (Linnæus) at Kiel.

Cothurniopsis, sp. Cuénot. Found in the ambulacral grooves of Astropecten aurantiacus (Linnæus) at Banyuls-sur-Mer.

\section{SPOROZOA.}

\section{Order GREGARINIDA.}

\section{Suborder MONOCYSTIDEA.}

Syncystis synaptce (Lankester). Found in the colome of Synapta inherens at Margate and Roscoff.

Syncystis mülleri (Giard). Found in the cœlome of Synapta digitata (Montagu) at Trieste.

Syncystis holothurice (Schneider). Found in the cœlome, intestines, and cavities of the arborescent organs in Holothuria tubulosa Gmelin at Nice and Naples.

Lithocystis schneideri Giard. Found in the cœlomic cavity of Echinocardium cordatum (Pennant), E. favescens (O. F. Müller) and Spatangus purpureus O. F. Müller from Wimereux, Dunkirk, Concarneau, le Poulignon, and Marseilles.

\section{FORAMINIFERA.}

Such of the foraminifera as normally attach themselves to foreign objects are occasionally to be found on the columns, and especially on the cirri, of the pentacrinites, and upon the cirri of the comatulids.

Most of these are of purely fortuitous occurrence and do not merit special mention, but two genera, both belonging to the same family, though widely different in appearance, are very commonly associated with the crinoids.

\section{Family ROTALIIDÆ.}

TRUNCATULINA IOBATULA WALKER AND JACOB.

P. H. Carpenter states that this species was abundant on the cirri of the comatulids which were obtained by the Dutch Arctic expedition in the Barents and Kara Seas, and Mortensen records it from the cirri of Hathrometra prolixa from northeastern Greenland.

Allied species are very often seen upon the cirri and stems of the pentacrinites and upon the cirri of the comatulids from all parts of the world.

142140-21-Bull. $82-45$ 
POLYTREMA MINLACEUM (LINNAEUS).

P. H. Carpenter has recorded this species as common on the stems and cirri of the pentacrinites dredged by the Challenger near the Kei Islands in 140 fathoms and off the Meangis Islands in 500 fathoms.

It was similarly abundant on the pentacrinites dredged by the Albatross in the Philippines, usually in the variety alba Carter, and is also found on the pentacrinites in the Caribbean Sea.

It is unusual to find this form on the cirri of the comatulids, though it occurs sporadically (pl. 53, fig. 1346).

The crinoids in association with which parasitic or commensal organisms have been recorded are the following:

COMATELLA NIGRA.

Myzostomum brachiatum.

COMATELLA STELIIGERA.

.Myzostomum echinus.

Myzostomum plicatum.

NeOCOMATELIAA PULChella.

Myzostomum abundans. Myzostomum carinatum.

Myzostomum inflator.

CAPILLASTFR SENTTOSA.

Ophiomaza cacaotica.

Ophiomaza obscura.

CAPIILASTER MULTIRADIATA.

Sabinella capillastericola.

Myzostomum lobatum.

NEMASTER IOWENSIS.

Myzostomum marginatum. .

NEMASTER REBIGINOSA.

Myzostomum testudo.

NEMASTER DISCOIDEA.

Myzostomum marginatum.

COMATULA ROTALARIA.

Anilocra, sp.

?Myzostomum horologium.

Comatula solaris.

Anilocra, sp.

Myzostomum pallidum.

Ophiophthirius actinometre.

? Myzostomum dentatum.

iMyzostomum holorogium.

.Myzostomum ambiguum.

Myzostomum costatum.

Myzostomum carinatum.

COMATULA PTRPUREA.

Synalpheus brucei.

Ophiomaza cacaotica. 
COMACTINIA ECHINOPTERA.

Myzostomum areolatum.

Myzostomum rotundum.

Myzostomum vastum.

Myzostomum irregulare.

9 Myzostomum oblongum.

Myzostomum cysticolum.

Myzostomum evermanni.

CUMACTINIA MERIDIONALIS.

Myzostomum areolatum.

Myzostomum elegans.

$M$ yzostomum radiatum.

Myzostomum bicaudatum.

PMyzostomum crenatum.

Myzostomum cysticolum.

Myzostomum irregulare.

ANNAMETRA OCCIDENTALIS.

Melanella capensis.

\author{
COMARTER NOVEGUINEE.
}

Myzostomum echinus.

COMANTHINA SCHLEGELII.

Myzostomum platypus.

$\$ M$ yzostomum dentatum. COMANTHUS BENNETTI.

9.Myzostomum carinatum.

PMyzostomum ambiguum.

COMANTHUS PINGUIS.

Myzostomum antennatum.

COMANTHUS JAPONICA.

Myzostomum vastum.

\title{
COMANTHET ANNULATA.
}

Synalpheus comatularum.

Synalpheus brucei.

Periclimenes commensalis.

Pontoniopsis comanthi.

Ophiocoma, sp. (young).

Ophiactis delicata.

Ophiomaza cacaotica.

Cirolana lineata.

Ophiomaza picta.

Cyclatelson purpureum.

Ophiomaza obscura.

Polynö minuta oculata.

COMANTHUS, RP. (PROBABLY C. ANNULATA).

Periclimenes pottsi.

Galathea elegans.

Synalpeus, sp.

Internal worm.

Myzostomum echinus.

Myzostomum costatum.

Myzostomum lütieni.

Myzostomum pallidum.
Galathea inflata.

Galathea minuta.

COMANTHUS PARVICIRRA.

Myzostomum triste.

Myzostomum brevicirrum.

Myzostomum nigrescens.

Myzostomum longicirmum.

Myzostomum rlegans. 


\section{ZYGOMETRA MICRODISCUS.}

Anilocra, sp.

?Laphystiopsis, sp.

- Ophiomaza cacaotica.

?Polynoid worm.
शMyzostomum horologium.

Myzostomum intermedium.

Myzostomum quadrifilum.

ZYGOMETRA ELEGANS.

Myzostomum quadricaudatum.

ZYGOMETRA COMATA.

Myzostomum, sp.

HETEROMETRA CRENULATA.

Myzostomum dubium.

Myzostomum dentatum.

Myzostomum filiferum.

Myzostomum quadrifilum.

HETEROMETRA SAVIGNII.

?Ophiactis, sp. Myzostomum costatum. Myzostomum crosslandi.

IIETEROMETRA REYNAUDII.

Ophiomaza cacaotica.

Sabinella, sp.

AMPHIMETRA MOLLERI.

Myzostomum, sp.

Myzostomum, sp.

STEPHANOMETRA SPICATA.

Myzostomum echinus.

:Myzostomum elongatum.

?Myzostomum fissum.

Myzostomum membranaceum.

LAMPROMETRA PROTECTUS.

PMyzostomum echinus. PMyzostomum elongatum. PMyzostomum fissum.

LAMPROMETRA PALMATA.

Polynoid worm.

Myzostomum costatum.

CIILOMETRA MANCA.

Myzostomum folium.

COLOBOMETRA PERSPINOSA.

Myzostomum coriaceum.

PROMETRA CHADITICKI.

Myzostomum costatum.

Myzostomum crosslandi.

ANALCIDOMETRA ARMATA.

Myzostomum cerriferoidum. 
OLIGOMFTRA OCCIDENTALIS.

.Myzostomum mœbianum.

TROPIOMETRA CARINATA.

PMyzostomum mabianum.

Myzostomum gigas.

TROPIOMETRA PICTA.

SOUTHERN JAPANESE SPFCIES OF CALOMETRIDE.

Myzostomum chelonium.

Myzostomum cysticolum orientale.

Myzostomum chelonoidium. Myzostomum smithi.

HORFOMETRA DUPLEX.

Myzostomum murrayi.

STYLOMETRA SPINIFERA.

Scalpellum, sp. Myzostomum pictum. Myzostomum agassizii.

Melanella, sp.

STENOMETRA DIADEMA.

STIREME'TRA BREVIRADIA.

Myzostomum murrayi.

\section{PACHYLOMETRA IN XQQUALIS.}

PMzostomum labiatum.

?Myzostomum fissum.

\$Myzostomum echinus.

Myzostomum tenuispinum.

Myzostomum willemoesii.

PERISSOMETRA AUGUSTICALTX.

Myzostomum tenuispinum.

PEIISSOMETRA FLEXILIS.

Ophiomusium, sp. Myzostomum beardi. Myzostomum willemoesii. GLYPTOMIETA TUBEROSA.

Alyzostomum, sp.

CRINOMETRA INSCULPTA.

Myzostomum cerriferoidum.

Melanella, sp.

CRINOMETRA, SP.

Myzostomum brevipes.

CIIARITOMFTRA BASICURVA.

Myzostomum tenuispinum.

Yyzostomum willemoesii. 
\$M yzostomum echinus. Myzostomum, sp.

Myzostomum tenuispinum. ANTEDON PETASCS.

Myzostomum parasiticum. Myzostomum cirriferum. ANTEION RIFIDA.

Internal suctorial crustacean. Myzostomum parasiticum. Myzostomum cirriferum. Prorocentrum micans.

Uemispeiropsis antedonis.

ANTEDON MEDITERRANE.A.

Enterognathus comatule.

Stylina comatulicola.
Myzostomum parasiticum. Myzostomum cirriferum.

Hemispeiropsis antedonis.

ixTHEON ADRLATICA.

Collocheres gracilicauda. Myzostomum cirriferum. Myzostomum parasiticum. Myzostomum bucchichii.

DOROMETRA MAURITIANA.

Myzostomum moebianum.

IRIOMETRA MELPOMENE.

Laphystiopsis iridometra.

COCCONETRA HAGENII.

Myzostomum agassizii.

Myzostomıum filicauda.

Myzostomum excisum.

NOTOCRI NUS VIRILLIS.

Ovarian worm (?myzostome).

LEPTOMNTIA CELTICA.

Myzostomum alatum.

Myzostomum pulvinar.

LEPTOMETR. PHALANGIUM.

Myzostomum alatum.

Myzostomum pulvinar.

ADELOJHTRA ANGUSTIRADIA.

Myzostomum inflator.

Myzostomum murrayi.

YCMORLHONETLA IIIRSTA.

Ophiolebes scorteus. 
HELIOMETRA GLACIALIS.

Encysted crustaceans in disk.

1 yzostomum gigas.

Myzostomum fimbriatum.

Truncatulina lobatula.

Loxosomella antedonis.

ANTHOMETRA ADRIANI.

Myzostomum antarcticum. $\quad$ Mysostomum cysticolum.

FLOROMIETRA SERRATISSTMA.

Myzostomum deani.

FLOROMETRA PERPIEXA.

Myzostomum deani.

Myzostomum cysticolum cystihymenodes.

hatFroMIETRA P'ROLIXA.

Egg capsules of gasteropod.

Myzostomum carpenteri.

Gemellaria loricata.

Myzostomum cirriferum.

Loxosomella antedonis.

Calycella syringa.

Myzostomum giganteum.

Stegopoma fastigatum.

Myzostomum graff.

Cuspidella, sp.

Lafoëa fruticosa.

Truncatulina lobatula.

THAUMATOMETRA TENUIS.

PMyzostomum, sp.

THAUMATOMETRA CYPRIS.

Myzostomum cornutum.

\section{BATHYMETRA, SP.}

Stilifer (Mucronalia) bathymetra.

"ANTELON IMPINNATA."

Myzostomum excisum.

Myzostomum carinatum.

\section{METACRINUS.}

Scalpellum weltnerianum.

Scalpellum album.

Scalpellum balanoides.

Verruca nitida.

Scalpellum gonionotum.

Pachylasma crinoidophilum.

Ophiacantha, various species.

Metacrixus aceTUs.

Ophiopholis mirabilis.

METACRINUS ANGULATES.

Myzostomum wyvillethomsoni.

Verruca, sp.

Met. CRINCS CINGULATUS. 
METACRINTS COSTATUS.

Myzostomum wyvillethomsoni.

METACRINUS INTERRUPTUS.

Scalpellum, sp.

Verruca, sp.
Avicula, sp.

Myzostomum cryptopodium.

METACRINUS MOSELEY.

Myzostomum eremita.

\title{
METACRINUS MURRAYI.
}

Scalpellum album.

Scalpellum balanoides.

Verruca, sp.

METACRINUS NOBILIS.

METACRINUS MOTUNDUS.

Myzostomum antennatum.

Myzostomum cirripedium.

Myzostomum metacrini.

Myzostomum clarki.

Myzostomum wheeleri.

METACRINUS TUREROSUR.

Ophiuran pluteus.

METACRINES VARIANE.

Larval cirripede.

Parasitic ostracod.

\author{
METACRINUS ZONATUS.
}

ENDOXOCRIYCS ALTERNICIRRUS.

Myzostomum calycotyle.

Myzostomum circinatum.

Myzostomum pentacrini.

Myzostomum asymmetricum. Myzostomum belli. Myzostomum deformator.

IIYPALOCRINUS NARESIANUS.

Myzostomum circinatum.

ISOCRINCS ASTERIA.

Asteroporpa annulata.

ISOCRINUS DECORUS.

Scalpellum diceratum.

Scalpellum pentacrinarum.

Astrogomphus vallatus. Sigsbeia murrhina.

Myzostomum vincentinum.

HICRINUS AUSTRALIS.

Myzostomum compressum.

liyzostomum coronatum. 
BYTHOCRINUS. SP.

Stilifer, sp.

iStilifer, sp.

Melanella, sp.
Parasitic hydroid.

RHIZOCRINUS LOFOTENSIS.

Rhabdopleura mirabilis.

RHIZOCRINUS VERRILLI.

PTILOCRINUS PINNATUS.

Sabinella ptilocrinicola.

HYOCRINUS BETIIELLIANUS.

\section{Stelechopus hyocrini.}

\section{COMMENSALISM OF THE CRINOIDS.}

A number of small comatulids and the young of certain others may be considered as truly commensal, living as they do in the cavities of large sponges and gathering the minute organisms brought to them by the currents flowing into the afferent openings of the host.

Many others habitually cling to gorgonians or withdraw into crevices in corals, where they live symbiotically, but quite independently of the supporting organism.

\section{AVOIDANCE OF CRINOIDS BY FISHES.}

Dr. H. L. Clark states that at Maër Island, Torres Strait, fishes of many species were abundant in the water just outside the reef, and their movements were easily noted. Any object dropped in the water at once attracted their attention and if edible was nibbled at or seized outright.

Comatulids were always noticed, but were never touched either in the water or at the bottom. Fishes, often of large size, always swam toward them, but when within a few inches turned and swam away.

Doctor Clark says that either by sight or some other sense, perhaps stimulated by some exhalation from the comatulids, these animals were recognized as inedible.

Judging from the statements of Reichensperger the crinoids are probably protected by the secretion from the glands at the base of the tentacles.

DEPENDENCE OF COMATULIDS UPON PURE, WELI-AERATED WATER.

Dr. W. B. Carpenter says that there is one point in the habits of Antedon bifida which must be regarded as of considerable importance in the determination of the office of that vast aggregate of tubular tentacula which is borne by the pinnulated arms, namely its close dependence for the maintenance of its life upon pure, well-aerated water. 
When kept with other animals in an aquarium Antedons are among the first to die, and although Carpenter was at first inclined to attribute this to the circumstance of their habitually living under a much greater pressure of water than the littoral animals with which they are associated in such artificial collections, yet he soon came to be satisfied that the real explanation was to be found in their inability to sustain any deficiency in the purity of the medium they inhabit. For by placing them by themselves in small numbers in an adequate supply of water, and by frequently renewing this, he succeeded in keeping the same specimens for several weeks together, and the deficiency in vigor which they showed at the end of that time, manifested in a general flaccidity of the arms and in a disposition to cast off portions of them, appeared quite explicable by the insufficiency of their food supply, made evident by the progressive shrinking of the visceral mass, the ventral surface of which came at last to be concave instead of protuberant.

Moreover, it happened on several occasions that if a dozen spccimens of Antedon were thrown at night into a large basin of water and were left without any means of attachment they were all found dead in the morning, conglomerated at the bottom of the basin, clinging to each other with their dorsal cirri and liaving their arms intertwined in sucl a manner as to suggest the idea that they had died of the asphyxia produced by orercrowding after exhausting themselves in efforts to find a suitable attacliment; while if, in a basin of the samc size and containing the same quantity of water, there were placed with a likc assemblage of specimens a sufficient number of rougl stones to afford them all a basis of attachment, they would be all found in the morning in a state of full expansion, with every appearance of health and vigor.

Regarding the comatulids at Maër Island, Torres Strait, Dr. H. L. Clark says that if a number of specimens were left in a basin, even with a relatively large amount of sea water, they gradually became inactive and after a time perfectly still, and made no response to mechanical stimuli. That they were not dead was indicated by response to chemical stimuli (alcohol and formalin). But if left undisturbed the arms began to break to pieces distally, the process continuing centripetally until only the basal parts of the arms were left attached to the disk. Even then response to stimuli could be induced if the specimens were placed in perfectly fresh sea water. If, however, they were left undisturbed, fragmentation continued until even the basal parts of the arms were completely disintegrated.

There is great individual difference as to the time when amputation of the disk from the calyx takes place. It was very common to have this happen as the first step in disintegration, but in some individuals it was one of the last. Not rarely comatulids shed their disk when first taken from the sea and placed in the pail, but such specimens lived in the live car as well, apparently, as those in which the disk and digestive system were intact.

Doctor Carpenter remarked that the intermixture of a small proportion either of fresh water or of glycerine with the sea water in which Antedon bifida is living is very speedily fatal. 
Experimenting with the common comatulids at Maër Island, Torres Strait, Dr. H. L. Clark was unable to obtain any response to the addition of rain water to the sea water in the aquaria, even when the rain water was poured directly upon the disk of the crinoid.

The transfer of a comatulid from sea water directly to rain water met with marked response and violent movements, but as long as the water in the tank was predominantly salt there was no visible response to the addition of rain water.

Increase in the amount of the salt content seemed to be a matter of equal indifference.

Regarding Tropiometra picta at Buccoo Bay, Tobago, Doctor Clark says that experiments to determine whether Tropiometra is sensitive to changes in the salinity of the water in which it lives gave very interesting results.

Two individuals were placed in an aquarium containing 5 liters of ordinary sea water, and two specimens of similar size and appearance were placed in another aquarium containing 5 liters of 90 per cent sea water (that is, 4.5 liters of sea water with $500 \mathrm{cc}$. of rain water added).

After 12 hours all were normal, and one could not tell from the responses to mechanical stimuli which were in the diluted sea water.

Similar experiments were tried with water only 80 per cent and 75 per cent sea water.

Such water extracted color from the comatulids and after 12 hours was distinctly yellow, yet the animals survived and responded to the transfer to normal sea water by distinct arm movements.

Experiments were then made to see how concentrated a sea water could be survived.

Two specimens, one dark colored and one yellow and purple, survived, with no apparent injury, 12 hours in only 2 liters of water 10 per cent more saline than normal. The brightly colored one was more active after the experiment than the other, which was not what he had expected in view of the greater evaporation in the natural habitat of the dark individual.

A similar experiment with water 20 per cent more saline than normal was tried.

A brightly colored individual was still alive after three hours; it was then transferred to normal sea water and lived overnight.

A dark-colored specimen was still alive after four and a half hours, but although it was then transferred to normal sea water, it failed to revive.

\section{RESPONSE TO LIGHT.}

Perrier, speaking of Antedon Bifida at Roscoff, noted that the animals, while accommodating themselves perfectly to daylight, do not like the direct rays of the sun. When these become strong they roll up their arms, and if the exposure is too prolonged, or if it is repeated too often, the arms are detached one by one and fall to the bottom of the basin, and the animal soon dies. 
At Banyuls-sur-Mer Bohn found that the examples of Antedon mediterranea in the tanks of the aquarium were only very slightly sensitive to light, in this respect acting much like the ophiurans which inhabit sandy bottoms.

Dr. H. L. Clark says that almost the first fact noted with reference to the habits of the comatulids at Maër was that they showed an evident tendency to withdraw from brightly illuminated areas. On overturning a rock fragment on the lower surface of which crinoids were living they at once began to move. Sometimes they withdrew into dark holes or crannies in the rock, but generally the movement was over the surface of the rock to its margin and thence down into the shade of its now lower side. The movement was never spasmodic or hurried, but unless interfered with was very steady and soon accomplished its purpose.

He remarks that it is difficult to see how this invariable habit can be interpreted as anything else than a response to light as a stimulus. Since the rock might be 3 feet under water, no change of temperature could possibly have caused the movement. It is conceivable, however, that the change of position due to the overturning of the rock was the effective stimulus. But the theory that change of position is the determining factor seems to be eliminated by the facts that among the living corals comatulids occur with the oral surface either up, down, or lateral, and that when the coral around them is broken a way with a hammer, exposing them to strong light but not disturbing their position, their movements are also away from the lighted area into the shadow.

Experiments in the laboratory were not altogether satisfactory, so much individual difference was shown. As a rule, if a comatulid was placed in the middle of the tank, one end of which was covered over while the other end was in sunlight, movement to the shaded end almost always was the first result. Often, however, the animal did not remain there, but moved about restlessly, even to the brightly illuminated end. In such cases it is a fair inference that the absence of suitable surface for attachment was the cause of the restlessness.

More consistent results followed when direct sunlight was allowed to fall on comatulids which had been in the shade. With scarcely an exception they moved out of the brightly lighted area. Experiments with artiticial light were entirely negative, presumably because of the weakness of the stimulus, nothing better than an ordinary kerosene lamp being a vailable.

No specific differences were noted with reference to light reactions, all the species watched giving the same results.

Bright sunlight thrown abruptly on a comatulid lying in shadow often produced immediate and sometimes more or less spasmodic closing of the arms over the oral surface of the disk, as though that part of the animal were most sensitive to the stimulus. In confirmation of the view that the disk is more sensitive to light than the arms is the fact that in their natural habitat the crinoids often extended their arms out into the light while the body itself was in heavy shadow. Indeed, all along the southwestern reef, on the brightest days, they were to be seen in such a position. 
Regarding Tropiometra picta as he found it at Buccoo Bay, Tobago, Dr. H. L. Clark says that its remarkable habitat naturally suggested that in its reactions to light it would be positively phototactic.

A tank 6 feet long, a foot wide, and 8 inches deep, having the bottom covered with broken coral and stones, was used for the experiments. It was placed near high-water mark on the beach, in the sun, and two boards, 5 or 6 inches wide, were laid across it, giving shaded areas. One end was made quite dark by covering with a broad piece of board and burying it in the sand.

Numerous individuals of Tropiometra picta were tested in this tank on many different occasions and under diverse conditions of temperature. The results were surprisingly unsatisfactory. No individual showed any decided reaction to light, and none sought the darkness. In most cases, when the specimen was fresh from Buccoo Bay, if placed in a shaded area it remained there; if placed in the sun close to a shaded area it moved into the shade, but if the board were then removed it made no effort to move out of the sun: if placed in the sun some. inches from the shade it remained quietly in the light.

Generally the individuals were placed upside down in the tank, so that the process of righting might serve to initiate movement. But, although they righted themselves promptly, they rarely wandered more than a few inches thereafter. If placed in the tank right side up they were usually content to remain where put, regardless of whether it was in sun or shade.

Experiments were made particularly to see whether the brightly colored specimens from under rocks reacted differently from the dark individuals from Buccoo Bay, but no constant differences could be detected. Brightly colored examples seemed to be a little less hardy and became sluggish and inert in the tank more quickly than the dark ones, but the difference was not striking.

The final conclusion reached, as a result of all the experiments and observations, was that Tropiometra picta at Tobago is slightly negatively phototactic but that other factors in the environment at Buccoo Bay neutralize this tendency almost or quite completely, while on Buccoo Reef it is for some reason strengthened.

While the Albatross was anchored off Sulu a small specimen of Dorometra nana, about half the adult size, was captured which had been attracted to and was swimming about a submerged electric light.

\section{RESPONSE TO HEAT.}

All of the information on this subject we owe to Dr. H. L. Clark, from whose accounts the following is taken:

Observations at Maër Island, Torres Strait.-As ice was not obtainable at Maër, and it was difficult to lower the temperature to any considerable degree, his only experiments with regard to the response of comatulids to temperature changes dealt with the effect of raised temperatures.

An alcohol stove placed under one end of the tank made it possible to raise the water just over the flame several degrees without appreciably affecting the temperature of the other end for nearly an hour. 
The sea water brought from the reef and with which the experiments began had a temperature of $26^{\circ} .6 \mathrm{C}$. The area directly over the stove soon became about a degree warmer than this, while immediately above the flame it rose to $31^{\circ} .7 \mathrm{C}$.

Comatulids placed in the tank at the unheated end began at once to move toward the other end, the whole tank being uniformly illuminated. The passage into the slightly warmer water was not indicated in any way, but whenever the arms extended into the area above $30^{\circ}$ a more or less prompt response and withdrawal followed.

This was shown by all the species tested, but was most noticeable in adult Comatula purpurea, and consequently that species was chiefly used. If an individual were placed in the hot area it immediately moved out, but it did not seek the coolest part of the tank.

At the end of an hour and a half the water in the tank was raised to a minimum of about $29^{\circ}$, and the comatulids were all at rest or moving very languidly. It was interesting to note, however, that transfer from this warm water to the sea water at ordinary temperature $\left(26^{\circ} .6 \mathrm{C}\right.$.) acted as an immediate stimulus, and locomotion was at once renewed. The reverse was also true, comatulids from the normal sea water responding at once with active movements when dropped into the warm water. In the latter case, however, the movements very quickly ceased.

Doctor Clark concludes from these observations that it is evident comatulids are sensitive to comparatively slight changes of temperature, and that for those living at Maër $26^{\circ}$ to $27^{\circ} \mathrm{C}$. is about the optimum. It is not probable that the sea water on the reefs at the Murray Islands ever gets far below that temperature, but it is often much higher, at least on the reef flat itself. It is therefore of great interest to find that at $29^{\circ}$ these comatulids become inactive, and that they withdraw at once, if possible, from $31^{\circ}$.

Evidently, then, a fairly uniform temperature is an essential factor in determining their distribution, and this accounts for their absence from the greater part of the reef flat at Maër, for the water on some parts of this flat, if low tide is near midday, rises far above $31^{\circ}$. It seems probable, too, that the more uniform temperature and the absence at all times of high temperatures in the channel between Maër and Dauer are added reasons why the southwestern reef of Maër has such an abundant comatulid population.

Observations at Tobago. - While it was not feasible to produce really low temperatures, water in the tank fell to $22^{\circ} \mathrm{C}$. during the night. At this temperature T'ropiometra picta showed no signs of discomfort or stimulation. When the water was gradually raised to $33^{\circ}$ or $34^{\circ}$ responses to mechanical stimuli were normal. At $35^{\circ} .5$ two of the four specimens tested were quite unresponsive, but the other two gave normal responses by arm morements. One continued to respond at $36^{\circ} .5$ but at $37^{\circ} .5$ was inert. After a few moments at that temperature the four specimens were placed in normal sea water at $28^{\circ}$, but none recovered.

Individuals taken from water at $25^{\circ}$ and placed in that at $33^{\circ}$ continued to gire responses with the arms. At $34^{\circ}$, however, the arms were quiescent, but the pin- 
nules responded. Complete recovery of these specimens resulted when, after a few moments, they were again placed in water at $28^{\circ}$.

Individuals placed in water at $36^{\circ}$ gave no responses and failed to recover; they became quite rigid.

Doctor Clark remarks that these experiments show that, as compared with the comatulids of Maër Island, Tropiometra picta has a susprisingly large temperature range. This is quite in keeping with their habitat in Buccoo Bay, for while the water there probably never falls below $22^{\circ} \mathrm{C}$., there is no doubt that at the lowest tides it rises in the shallows to $32^{\circ}$, and possibly to $34^{\circ}$. Even should it on rare occasions exceed this figure for a short time the animals would easily survive. Owing to the comatulids' inertness it was impossible to determine the optimum temperature.

In water of $33^{\circ}$ reactions were not consistently different from what they were at $25^{\circ}$. Nevertheless, individuals in water at $33^{\circ}$ assumed a somewhat wilted appearance after a time, which was not the case in water at $28^{\circ}$ and lower.

Healthy individuals gave no response to a sudden change of $2^{\circ}$, but there was generally an evident reaction to an abrupt change of $5^{\circ}$.

\section{RESPONSE TO CHEMICAL STIMUI.}

Dr. H. L. Clark found that the response of the comatulids he studied at Maër Island, Torres Strait, to a strong solution of magnesium sulphate was prompt and violent, so violent as to break off some or all of the arms, and no evidence of cubsequent relaxation was found.

Alcohol poured onto the disk of a crinoid in the tank brought about a very marked response, but the latent period was surprisingly long and the effect of the stimulus soon wore off.

If comatulids were taken from sea water and dropped into alcohol or formalin the response was immediate, and consisted in the extreme flexion of the arms dorsally. Often this would be followed by strong oral or ventral flexion, bringing the arms up vertically over the mouth. This again would be followed by a general relaxation, and later by death and a hardening of the tissues.

Specimens simply thrown into alcohol or formalin or placed in the fluid mouth lown never died in a natural position, the arms being strongly contracted, usually entangled with each other and with the cirri dorsally, but sometimes closed together over the mouth.

Doctor Clark says that owing to the fact that almost without exception the first response is flexion dorsally it is very easy to prepare perfectly expanded specimens.

The animals are lifted from the sea water with the cirri down and plunged abruptly into strong alcohol in a shallow flat dish, care being taken to press the animal down at once to the bottom of the dish. The dorsal flexion causes the arms to lie out flat against the bottom of the dish. The following contraction of the ventral muscles is occasionally strong enough to bring the arms up over the disk and to get them badly entangled, but in the very great majority of cases it is so feeble and so quickly followed by relaxation that a little manipulation of the arms. 
smoothing them down with the fingers and pressing out the curves, results in perfectly expanded specimens.

Only in relatively few cases, and these were individuals which had been in the laboratory for some hours, was the muscular contraction great enough to break off the arm or even cause loss of cirri. These cases are probably to be explained by the susceptibility of these animals to nonaërated sea water-that is, presumably, to carbon dioxide $\left(\mathrm{CO}_{2}\right)$. It was not possible to determine positively whether carbon dioxide was the deleterious substance or not, but there is good reason for that belief, because the comatulids were found only on those parts of the reef where the aeration of the sea water was very well provided for by the surf. Whether carbon dioxide was the factor directly responsible or not, it is beyond question that the comatulids brought to the laboratory were very susceptible to the impurity of the sea water after a few hours in the aquaria.

Speaking of Tropiometra picta as he found it at Buccoo Bay, Tobago, Doctor Clark says that indifference to the amount of carbon dioxide in the water was noticeable, particularly in view of the sensitiveness of the Torres Strait comatulids to that substance.

Two specimens lived over night in only 2 liters of sea water apparently without discomfort, and four or five specimens were often kept over night in aquaria with not more than 6 or 7 liters.

This species responded to a saturated solution of magnesium sulphate in sea water by a complete relaxation of the muscular system. The response was much less complete if the individual had been for some time in a limited amount of sea water; probably the presence of carbon dioxide made the difference.

Response to alcohol and formalin was, as in the case of the Torres Straits comatulids, by flexion of the arms first dorsally and then ventrally. Only exceptionally, and then by individuals which had been long in tank or aquaria, were the arms cast off.

\section{RESPONSE TO MECHANICAL STIMULI.}

Dr. W. B. Carpenter noted that in Antedon bifida if the pinnules other than the oral pinnules of any arm be irritated by the contact of a rod such irritation merely produces a languid wavy motion of the arm thus acted on, which mny extend itself to others if the irritation be repeated or prolonged. But if the rod be made to irritate the long proximal pinnules all the arms, if the animal be in full vigor, immediately close together with an energy and consentaneousness that are seen in no other movement.

Bohn, experimenting with Antedon mediterranea at Banyuls-sur-Mer, found that when either the disk or the cirri are touched, simultaneous movement of the five arms and their branches occurs.

On every stimulation of the disk the arms are raised, forming a sort of dome above it.

On every stimulation of the cirri the arms are lowered.

Thus, as a general rule, there occurs flexion toward the pole touched. The intensity of the reaction is variable. The firmer the attachment of the animal the 
stronger is the reaction. When the animal is not fixed, or when the attachment is precarious, the reaction is always feeble, and slow. Bohn believes that this has to do with variations of sensibility. The tactile sensations of the disk may be inhibited more or less by certain sensations of the cirri.

It may happen that, the comatulid being attached by its cirri, certain arms rest upon a solid surface, while the others float freely in the water. In this case the latter react much more strongly when the disk is stimulated.

Bohn often observed that a series of stimulations at short intervals on the same spot end by having quite a different effect than one or two stimulations on the same place.

Repeated stimulation on the body or on the arms of a comatulid results in undulatory movements of all the arms, not synchronous, until finally the animal swims away.

If a comatulid from which the two arms of the same ray, or two rdjacent arms on neighboring rays, have been removed lies upon a smooth bottom, progression usually takes place in the direction indicated by the missing arms.

If the arms be numbered 1 and $1^{\prime}, 2$ and $2^{\prime}, 3$ and $3^{\prime}, 4$ and $4^{\prime}$, and 5 and $5^{\prime}$, according to the movement of the hands of the clock, and arm 1 be stimulated, the animal generally tends to move in the direction $3^{\prime}$; but if arms 4 and $4^{\prime}$ rest on a rough surface progression may be in the direction $44^{\prime}$; if $4^{\prime}$ and 5 rest on a rough surface progression may be in the direction $4^{\prime}-5$, or at least in a direction between $3^{\prime}$ and 5 . The importance the condition of the surface has in determining the direction of progress is evident.

Speaking of the comatulids which he found at Maër Island, Torres Strait, Dr. H. L. Clark says that mechanical stimuli met with ordinary response under normal conditions. The disk and the pinnules at the bases of the arms seem to be more sensitive to touch than either the middle or terminal part of the arms. The cirri and the whole aboral surface are slow to respond to mechanical stimulation. The response to touching the disk is a closing of the arms over it, and the response to touching the oral surface of an arm is the gradual infolding of that arm.

Mechanical stimulation alone, even a severe pinch of an anterior arm with forceps, seldom caused any change in the direction of locomotion.

The net result of all Doctor Clark's observations was the impression that comatulids are surprisingly callous to mechanical stimuli, and the response is never sudden or hurried.

\section{GEOTROPISM.}

Bohn has found that on an inclined bottom Antedon mediterranea when stimulated tends to move along the line of greatest declivity in the direction opposite to that of the pull of gravity.

EFFECT OF THE RAIN OF CINDERS IN THE BAY OF NAPLES IN APRIL, 1906.

Antedon mediterranea, which in the Bay of Naples is abundant on the bottoms of detritus and in the patches of Posidonia-so abundant, indeed, that thousands ordinarily could be captured with the dredge-almost completely disappeared as a result of the eruption of Vesuvius in April, 1906. 
On the 20th of that month Lo Bianco, dredging off Posilipo at a depth of about 30 meters, took only three specimens, all severely mutilated and dying with the arms almost devoid of pinnules. On the reef at Gajola also Lo Bianco was only able to find a very few specimens.

Lo Bianco states that he can not explain satisfactorily the manner in whicl the cinders caused the deatl of these crinoids. He suggests that the animals, gradually becoming covered by the falling cinders, at last found themselves in an unfavorable environment, and that weakness caused by lunger, combined with the general disturbance caused by the stratum of cinders, induced autotomy, which, becoming more and morc extensive, resulted finally in death.

He was led to this conclusion from having observed that this species, which lives very well in the tanks of the aquarium during the cold season, perishes through gradual progressive fragmentation when the temperature of the water becomes lower or higher than normal.

Antedon mediterranea showed the effect of the rain of cinders at least a week later than the echinoids.

Specimens of Leptometra phalangium dredged on the 7th of May at a depth of about 400 meters, between Capri and Ischia, were in the very best condition; but the cinders which fell here were very few.

\section{EXPERIMENTAI, INVESTIGATION OF THE DORSAI, NEIVOUS SYSTEM.}

In order to convince himself of the nervous nature of the axial cords of the arms and to ascertain the intercorrelation between the nerves of the different arms Dr. W. B. Carpenter carried out a number of experiments, using as his subject Antedon bifida.

Experiment 1.-Taking a large and vigorous specimen he turned the entire visceral mass out of the calyx.

On being replaced in water it executed the usual swimming movements as perfectly as the entire animal would have previously done.

Experiment 2.-From a second specimen, which he took out of the water in the act of swimming, he removed the entire centrodorsal with its contents and appendages, leaving every other part as it was.

On replacing the animal in water all the arms were rigidly straightened out, apparently by the action of the dorsal elastic ligaments which the muscles were now powerless to antagonize.

Experiment 3.-In another lively specimen he divided the soft parts of one of the arms down to the calcareous segment.

On replacing the animal in water all the arms worked as usual, without the slightest disturbance of regularity.

Experiment 4.- He severed the dorsal nerve cord in one arm by the use of nitric acid.

On replacing the animal in water that arm remained rigidlv straightened out, while all the other arms worked as usual.

Experiment 5.-The cntire visceral mass was removed from a specimen in sucl a way as to leave nothing but the calyx with the central capsule and its 
prolongations, and the arms. A needle was then passed down the canal included in the radials so as to irritate the chambered organ.

All the $10 \mathrm{arms}$ then suddenly and consentancously closed up. On the withdrawal of the needle the arms gradually straightened themselves again, and again coiled up as before when the irritation of the ccntral organ was renewed.

Dr. Carl F. Jickeli, working with Antedon adriatica at Trieste, performed some experiments along the same lines as those of Doctor Carpenter. These were as follows:

Experiment 1.--If a freshly amputated arm, or an amputated arm even which has lain a few days in sea water, be scratched with a needle on the ambulacral groove, or its ambulacral groove be subjected to electrical stimulation, no raising of the pinnules can be detected. But as soon as the cavity in the brachial containing the dorsal cord is touched the arm coils up convulsively and the pinnules are set in active motion, even when previously no signs of life could be detected in the arm.

Experiment 8.-If the ambulacral groove be scraped away, or burned away with caustic, reaction call always be obtained to the touch of a needle in the central canal. But if the central canal be burned out with caustic the arm is stretched out stiflly and all further stimulus is in vain.

Experiment 3.-If a detached cirrus be pricked in the central canal, or if the rentral canal be stimulated with an electric current, the cirrus is violently bent and at state of tetanus sets in.

Experiment 4.-If an animal be deprived of the visceral mass and put back into the water, ventral side up, all the arms are rigidly stretched out. If, now, a needle is thrust into the centrodorsal from the ventral side all the arms bend together synchronously, and again sink back into their original position. If a few drops of acid are added to the water the animal immediately begins to swim about with great activity. the movements agreeing entirely with those of uninjured animals.

Prof. A. Milnes Marshall, in confirmation and amplification of Carpenter's results, performed a number of experiments, his subject being Antedon mediterinnea, which he studied at Naples.

Experiment 1.-A large and vigorous specimen was eviscerated without removal from the water. On being released it remained quiescent for about a minute, and then swam about the tank actively and in a perfectly normal manner. After a short time it came to rest on the bottom in a perfectly normal position. Half an hour later, without the slightest disturbance or irritation of any kind, it began spontaneously to swim again, actively and normally. Coming in contact with a piece of stick, it attached itself to it by the dorsal cirri, and remained there for inore than a week.

Experiment 2.-An active spccimen was evisccrated and allowed to come to rest. The ventral surface of one of the arms was then irritated gently with a needle. Active movements both of the irritated arm and of the others resulted. The same 
effect followed irritation of one of the ordinary pinnules, while irritation of the oral pinnules caused immediate and strong flexion of all the arms.

Experiment 3.-An active specimen was eviscerated and allowed to come to rest in the normal position. It was then inverted and placed mouth downward on the bottom of the tank. After a short rest it righted itself in the normal manner, but rather more slowly than usual, the interval between inversion and the completion of the righting being about two and a half minutes.

This experiment was repeated many times with different specimens. Some righted themselves instantaneously, others took a longer or shorter time, but the general average of the times taken by eviscerated specimens to right themselves was about half a minute longer than that of uninjured ones.

Experiment 4.-A specimen was eviscerated and allowed to come to rest. A neerle was then passed from the oral surface down the canal within the radials so as to irritate the central capsule. The result was immediate flexion of the arms, and in many cases active swimming movements of the whole animal.

Experimunt 5.-A specimen was eviscerated and then cut into two parts, one having two pairs of arms and the other three. The central capsule, which was divided and freely exposed by the operation, was then irritated by a needle. The slightest irritation caused very active and violent flexion of the arms.

Experiment 6.-An active uninjured specimen was held under water and the dorsal half of the centrodorsal plate removed by a single snip with a large pair of scissors, so as to expose and partly remove the central capsule. On being released the animal fell to the bottom with the arms very strongly extended, but in about 20 minutes gradually righted itself and assumed the normal position. The exposed central capsule was then irritated, first with a needle and then with strong nitric acid applied by a small brush. The effect of irritation was to cause very strong and spasmodic flexion of the arms, which in the first case ceased on removal of the stimulus, but in the case of the acid persisted for several hours.

Experiment 7.-The centrodorsal of an active specimen was removed with scissors and the central capsule carefully scooped out with a small scalpel. The animal on being released fell to the bottom of the water, where it lay on its side with the arms very strongly extended, remaining in this position for several hours without any attempt to move. If taken from the water and thrown in again the arms moved fairly actively, but there was no attempt at swimming, each arm apparently acting quite independently of the rest. Finally, if placed on its oral surface, it remained there for an indefinite time without making the slightest attempt to right itself.

Experiment 8.-The preceding experiment was repeated on an eviscerated specimen, the results being in all respects the same.

To obtain definite results in these experiments it is necessary to remove completely the central capsule, and this Marshall found could not be effected by simply cutting a way the centrodorsal plate; in addition, the capsule must be either scraped out with a fine scalpel or else destroyed by free painting with strong acid.

Specimens in which the centrodorsal plate has been simply snipped off, though they lose temporarily the power both of swimming and of righting themselves, 
yet regain these more or less completely after an interval of half an hour to an hour. If, however, sufficient care has been taken to destroy entirely the central capsule, the loss of power is absolute and permanent.

Experiment 9.-The centrodorsal plate of an active specimen was removed and the central capsule entirely destroyed; the cavity was also very freely painted with nitric acid, so as to expose and destroy the pentagonal commissure connecting the axial cords at their roots. After being left at rest for an hour the arms were irritated one by one. Each arm responded readily and extensively to the stimulation, but the movement was limited to the arm directly irritated, none of the other arms sharing in it, except sometimes the other arm of the pair to which the irritated arm belonged.

Experiment 10.-Various parts of the surface, both of the disk and of the arms, of active uninjured specimens were irritated, both mechanically and chemically, in order to determine the normal distribution of sensation. All parts of the surface were found to be sensitive, but in very unequal degrees. Irritation of the dorsal surface of the calyx caused only slight movements of the arms, unless the irritation were severe or prolonged.

Irritation of the dorsal or lateral surfaces of the arms, where the layer of integument is very thin, caused flexion of the arms, with extension of pinnules close to the irritated spot. The response was usually ready, but the movement only slight. Prolonged or more violent irritation caused exaggeration of the movement, together with approximation of the adjacent arms toward the irritated $\mathrm{arm}$, as though to remove the source of irritation, and in some cases active movement of the whole animal in a direction away from the irritated arm. Irritation of a pinnule causes, according to the degree and duration of the stimulation, movement of the pinnule, movement of the whole arm, approximation of the adjacent arms to the affected one, or active movement of the whole animal away from the source of irritation. Irritation of the oral pinnules causes, as already noticed, immediate and very active flexion of all the arms, so as to elose in over the disk.

The epithelium of the ambulacral grooves is extremely sensitive, and the results of the stimulation are very definite. The slightest irritation causes instantaneous morement of the four or five pairs of pinnules immediately adjacent to the irritated spot, the pinnules being folded alongside the ambulacral groove so as to close it in and grasp the needle or other source of irritation. If the stimulation be continued the arm is actively flexed and the adjacent arms applied to it and rubbed along the affected part, as though to remove the source of irritation. Finally, irritation of the ventral surface of the disk between the ambulacral grooves causes movements of the arms, but not nearly so active as when the oral pinnules are touched.

Experiment 11.-An active specimen was eviscerated and left for half an hour. The calyx, arms, and pinnules were then successively stimulated, as in the preceding experiment. The results were exactly the same.

Experiment 12.-An active specimen was taken and all the soft parts scraped away with a knife from the ventral surface of one of the arms, the scraped 
portion being about a quarter of an inch in length and 1 inch from the disk. The pinnules were immediately folded closely alongside the wound, and the animal on being released swam activcly away from the injured arm. It soon came to rest in the normal position, and about 6 minutes after the operation the distal end of the injured arm was nipped with the forceps. The distal part of the arm, beyond the injury, was at once flexed actively, the proximal part less actively, and the other arms did not move. After a 20 minutes' interval the distal end of the injured arm was again nipped, when active movement of all the arms at once resulted, the animal moving rapidly away from the source of irritation.

Experiment 13.-A large and vigorous specimen was taken and a quarter of an inch of one of the arms, about an inch from the base, thoroughly scraped with a scalpel all around so as to remove the soft parts as completely as possible. The pinnules of the affected part and for a quarter of an inch on either side of the wound were cut away to prevent any possibility of contact communication between the parts on either side of the injury. The injured part was then painted all around very freely with strong nitric acid, the operation being repeated until fully half the thickness of the calcareous segments had been dissolved away. The wound was then washed freely with sea water and the animal returned to the tank. It fell at once to the bottom on its side with the injured arm and the other arm of the same pair stretched out horizontally, and the other arms rather strongly extended. After a few minutes it began to move slowly, and in 6 minutes had completely resumed the normal position. After half an hour's interval the distal end of the injured arm was sharply nipped with forceps, when strong active movements of all the arms at once resulted, the animal moving rapidly away from the source of irritation.

Experiment 14.-An active specimen was removed from the water, the dorsal surface of one of the arms carefully dried, and strong nitric acid applied with a fine brush to the dorsal surface of the fourth and fifth brachials, which were dissolved away until the axial cord was exposed and destroyed. If the arm were held during the operation it was usually thrown off, but if the disk only were held and the arm allowed merely to rest on the fingers the operation was always successful. The animal was then returned to the water, where it assumed almost at once the normal position. After half an hour's rest the distal end of the injured arm was nipped sharply with forceps; active movements of the irritated arm beyond the injury ensued, but no movement whatever of either the proximal part of the injured arm or of any of the other arms.

When in this experiment the ambulacral epithelium is left absolutely uninjured it responds to stimulation in a perfectly normal manner.

Experiment 15.-One of the arms of an active specimen was cut across at about its middle and the animal held in the tank so that the stump of the amputated arm was just above the surface of the water. The stump was carefully dried and the axial cord touched with a fine needle or with a finely pointed brush charged with nitric acid. Very violent movements of all the arms at once resulted. 
Similar stimulation of the ambulacral epithelium or of other parts of the section produced only very slight and local movements.

Experiment 16.-As in experiment 12 the soft parts were scraped away from the ventral surface of about a quarter of an inch of one of the arms an inch from the base. On being returned to the water the animal swam actively, all the arms moving vigorously and normally, including the injured one, which, however, was rather less active than the others, and a little stiff at the scraped part, probably from direct injury to the muscles.

Experiment 1\%.-The operation was the same as in experiment 14, the dorsal half of one of the arms about an inch from the disk being dissolved away by nitric acid until the axial cord was exposed and divided. The animal was then returned to the water, where it remained quiescent for a few seconds and then commenced to swim actively and spontaneously, all the arms moving perfectly normally except the injured one, the proximal end of which moved slightly while the distal part beyond the injury was perfectly motionless and flexed spirally into a coil. $\Lambda$ fter a short time the animal came to rest in a perfectly normal position, but for the spiral coiling of the distal part of the injured arm, which persisted. After a quarter of an hour's rest one of the uninjured arms was irritated, causing at once active movements of the uninjured arms and of the proximal part of the injured arm, but none whatever of its distal part.

Experiment 18.- In a fresh specimen two injuries, similar to that in experiment 17, were made in one of the arms at spots about an inch and a half apart. Stimulation of the arm itself, or of the pinnules, between the two wounds caused movements of the middle portion of the arm but none whatever of the proximal or distal portions.

Experiment 19.-One of the arms of a vigorous specimen was amputated by a snip of the scissors. The detached arm exhibited extremely active movements for about a quarter of an hour, coiling and uncoiling with great force and rapidity. After a time it became quiescent. It was then held in the tank with the proximal end just out of water. The end was carefully dried and the exposed section of the axial cord touched with a needle and a fine brush charged with nitric acid. The slightest irritation, whether mechanical or chemical, caused violent and repeated flexion of the arm. Stimulation applied to other parts of the cut end produced but very little effect.

Experiment 20.-A specimen was eviscerated and a needle passed down from the oral surface into the chambered organ and worked about so as to destroy as completely as possible the central capsule and chambered organ. The animal was then returned to the water and left at rest for half an hour. One of the arms was then suddenly nipped with forceps, when all the arms exhibited active movement, though the animal did not attempt to swim.

Experiment 21.-The same specimen was taken and the inside of the canal lying within the radials was freely painted with nitric acid until the pentagonal commissure was exposed and destroyed. The animal was then returned to the water and left for half an hour on its oral face, where it remained without any 
attempt to right itself or to swim. The arms were then strongly nipped with forceps one by one. Each arm when irritated responded by active movements, but none of the other arms stirred except the other arm of the pair to which the irritated arm belonged, which moved sometimes slightly, sometimes actively.

Experiment 22.-A pair of arms was cut off a specimen, the section passing between the radial and the $\mathrm{IBr}_{1}$. After half an hour's interval one of the arms was stimulated, when both arms moved actively.

Experiment 23.-Another specimen was eviscerated and a pair of arms removed, the section passing between the elements of the $\mathrm{IBr}$ series. All the soft parts were scraped from the basal portions of the arms, the basal pinnules were cut off, and the axillaries and proximal brachials freely scraped and painted with nitric acid, so that the sole connection between the two arms was through the substance of the axillary. After half an hour one of the arms was sharply nipped; the irritated arm moved freely, and the other arm slightly, but distinctly. The experiment was repeated with a second specimen, and an interval of three hours allowed between the operation and stimulation of the arm. In this case active and extensive movements of both arms followed on irritation of either one.

The preceding experiments show that $(a)$ the central capsule and its prolongations, the axial cords and their braches, constitute the main nervous system of Antedon; (b) the central capsule is especially connected with the complex coördinated movements of swimming and of righting when inverted; $(c)$ the axial cords act as both afferent and efferent nerves; $(d)$ the subepithelial bands are also nerves, but their exact function is a special and subordinate one in connection with the ambulacral tentacles and epithelium; $(e)$ evisceration apparently causes but little inconvenience to the animal, and the visceral mass is regenerated completely in a few weeks' time.

\section{COLOR OF CRINOIDS.}

Of all the animals in the sea there are none that exceed in beauty of coloration the shallow-water crinoids. Flowerlike in form and almost flowerlike in the fixity of their habit, they are also flowerlike in the variety and distribution of their pigments. But with depth the diversity of hue diminishes, so that we find the color range of the deeper water species relatively restricted, while the individuals themselves, losing the almost universal spottings and bandings of the littoral types, become comparatively plain.

Though crinoids resemble flowers in the diversity and brilliance of their colors, their color types are quite the reverse of flower-like. In a particolored flower the center or eye is more or less abruptly lighter or darker than the remaining portions, or the petals are longitudinally striped; cross banding of the petals is very rare. Among the crinoids particolored species are usually cross banded, regularly or irregularly, and though the pinnule tips may be of a different color from their bases, a true longitudinal striping of the arms is very rare, and a conspicuous eye is never developed. 
The coloration of specimens of the following species has been recorded:

[After the completion of this section Dr. H. L. Clark turned over to me a great number of color notes, mostly based upon specimens collected at Port Galera, Mindoro, Philippine Islands, by Dr. L. E. Griffin, in April, May, and June, 1912. These are given between brackets in the following pages, but have not been used in preparing the general conclusions regarding color.]

\section{Family COMASTERID $Æ$.}

\section{Subfamily CAPILLASTERINA.}

Comatella nigra.-(a) Bright red, the ventral perisome of the arms and pinnules yellow.

(b) Black.

[(c) The proximal half of the arms, with the pinnules, deep blood red on both surfaces; distal half dark orange red; disk and centrodorsal deep blood red; cirri deep blood red with silver tips.]

(d) Arms very dark wine red, covered with olive stippling; very long pinnule tips and encircling rings on the pinnule bases light yellowish green; centrodorsal orange yellow; cirri mostly light yellowish green, with occasional rings of very dark wine red, but with the tips yellowish green; disk deep wine red, with numerous spots of light yellowish green.

(e) Ground color dark wine red, the whole body with fine dots of very light slightly greenish yellow; pinnules long-tipped dorsally and short-tipped ventrally with light greenish yellow, becoming less greenish toward the tips; centrodorsal with a spot of light greenish yellow in the center, and cirri with much of the same color dorsally.

(f) Ground color of central portion, arms, and proximal two-thirds of the pinnules, a very dark wine red; pinnule tips orally light straw yellow, aborally spotted with the same color; centrodorsal straw yellow, with an interrupted line of dark wine red; cirri the same, with a slight washing of dark wine red; disk with numerous spots of light straw yellow with a slight greenish blue tinge; near the mouth are a few small papillæ basally light straw yellow with the tips deep wine red.

(g) Very dark wine red, except for the silver tips of the cirri.

(h) Entirely very dark wine color.

(i) Arms and pinnules aborally blackish wine color with blotches of yellowish white on the arms and on the basal half of the pinnules; entire oral surface, centrodorsal, and cirri blackish wine color, the last with glassy tips.

(j) Central portion reddish brown, becoming darker toward the ends of the arms.

(k) Dark brown, with numerous spots of very light straw yellow on the aboral surface of the arms, and the tips of the cirri silver.

(l) Rich dark chocolate brown. 
$(m)$ Ground color velvety brownish black; arms marked with pure white; under side of pinnules white.

$(n)$ Ground color black, covered with spots of yellowish grecn; a black line down the center of each arm.

(o) Central portion black, the outer portions of the arms shading into dull yellowish green.

$(p)$ Central portion on both surfaces, arms, and pinnules deep black, the arms in the terminal half with markings of very light straw yellow and certain of the pinnules deep blood red on the aboral side toward the base; cirri with a dark brown wash over silver.

(q) Entirely black.]

Comatella stelligera.-(a) Violet brown, becoming more reddish toward the arm tips, with a broad band, over an incls wide, of green, becoming greenish yellow in the center, in the middle of the arm; brachial perisome in the outer part of the arm bright red.

$[(b)$ Bright yellow, with a deep green center.

(c) Green, the pinnules with yellow tips.

(d) Yellow green and blackish.

(e) Greenish gray, browner orally.

(f) Rich red purple.

(g) Deep purple red.

(h) Red purple, the pinnules with yellow tips.

(i) Very deep red purple, the pinnules with yellow tips.

(j) Deep purple, the pinnules with yellowish green tips.

(k) Deep purple, the pinnules rusty red in marked contrast.

(l) Red purple, green and yellow.

(m) Purple and green, with the tips of the pinnules rusty.

(n) Uniformly black.]

Comatella decora.-Bright yellow, the ventral perisome slightly brownish. A very small specimen clear yellow, the cirri white.

Capillaster maria.-Brownish yellow, the pinnules grayish.

Capillaster multiradiata.-(a) White, with a broad band of dark maroon about. an inch wide just beyond the middle of the arm, and maroon marblings on the disk.

(b) Dorsal surface brown, the articulations much darker, heavily silvered or frosted with white, which extends also over the cirri; oral surface black.

[(c) Dark wine red, with brown.

(d) Arms maroon, with a slight reddish tinge; rest of body almost black brown.

(e) Brownish wine color.

( $f$ ) Arms dorsally very dark reddish chocolate, bccoming darker basally: ventral surface and dorsal surface of pinnules black clocolate; centrodorsal the same; cirri the same with silver tips, some with whitish dots in the median line and others with a drab tinge. 
(g) Proximal portion of arms dorsally orange brown, with transverse lines of silver, the arms then becoming alternate arcs of silver and dark orange brown, the latter becoming slightly lighter distally; pinnules in general corresponding in color to the arms, but toward the arm tips becoming bright orange; disk brownish orange; cirri deeper brownish orange, slightly lighter dorsally, with silver tips; centrodorsal silver with the center orange brown and five circular areas of the same color on the margin.

(h) Arms and pinnules crossed by transverse alternating bands of grayish and brown, the colors becoming lighter toward the arm tips; disk light brown; centrodorsal dark brown; cirri dark brown with white tips.

(i) Brown, with dark joints, orally black, silvered or frosted heavily with white.

(j) Black except for the articulations of the arms and cirri which are very dark chocolate with a very slight tinge of red; centrodorsal dark chocolate; tips of the cirri white.]

Capillaster clarki.-Arms and disk greenish, ornamented, the former with scattered, the latter with numerous, spots and dots; pinnules greenish black with a narrow white band on each segment; cirri yellow.

Nemaster iowensis. - (a) Sulphur yellow.

(b) Rich golden brown.

(c) Arms black, the pinnules lemon yellow at the tips, shading into black.

(d) Nearly black.

Nemaster discoidea.-(a) Very dark gray, the pinnules whitish banded with darker, the cirri whitish.

(b) Black, the pinnules yellow.

Comissia peregrina.-Olive green, the cirri blotched with lighter.

Comissia lütkeni.-Arms dark greenish yellow, the pinnules chrome yellow, the cirri dull greenish yellow with dusky bands.

Comissia horridus.-Yellowish brown.

Comissia hispida.-Yellow.

Comissia scitulus.-Greenish.

Leptonemaster venustus.-(a) Pale yellow, yellow, or greenish yellow.

(b) Brownish.

(c) White, each arm with from five to seven narrow cross bands of cadmium yellow; arm tips yellowish; cirri pale yellow.

\section{Subfamily Comactinine.}

Comatula rotalaria.-Purple.

Comatula purpurea.-Reddish purple.

$\lceil(b)$ Olive brown to black.]

[Comantula pectinata.-Bright carmine, the pinnules with white tips.]

Comatulella brachiolata.-Purplish red, the centrodorsal and first seven segments of the cirri darker and more brownish, the distal portion of the cirri bright red. 
Comactinia meridionalis.-(a) Light yellow.

(b) Dark yellow.

(c) Arms light yellow, the pinnules deep carmine, usually tipped with yellow.

(d) Dark rose pink, the pinnules pale yellow banded with burnt sienna, the cirri pale yellow.

(e) Rich carmine.

(f) Rich carmine with yellow spots, the pinnules orange yellow.

$(g)$ Deep carmine, the pinnules orange with red and yellow spots and tipped with yellow.

(h) Bright purple, the pinnules brighter purple.

(i) Deep mauve, the pinnules very pale straw yellow banded with grayish purple.

\section{Subfamily COMASTERINæ.}

Comaster fruticosus.-Brownish yellow.

Comaster taviana.-Chrome yellow ventrally, the dorsal skeleton yellowish white.

Comaster parvus.-Deep black, the tips of the pinnules yellow.

Comaster serrata.-Dull greenish yellow.

Comaster minima.-Chrome yellow, with numerous longitudinal narrow lines on the radials and division series, and transverse lines on the arms, of dark brown. yellow.]

[Comaster belli.-Deep purplish blue, the pinnules purple, the cirri lemon

[Comaster novaguinea.-(a) Arms olive; pimules blue, darker on the oral surface; disk dark blue; centrodorsal olive; cirri blue, darker toward the ends, with silver tips.

(b) Very dark dirty brown ventrally; dorsally very dark chocolate with burnt orange at the margins of the brachials and also small dots on the brachials and the pinnulars; centrodorsal dark chocolate with a white dot in the center and a few dots of burnt orange around it.

(c) Arms dorsally black brown except toward the base; pinnules the same, with long yellow tips; centrodorsal with a black brown margin and brown over silver center; cirri thin brown over silver, with silver tips.

(d) Wholly dark chocolate.]

Comantheria briareus.-(a) Yellow and black in cross bands.

(b) Dorsally dark green, with the articulations and some small spots greenish yellow; sides of the arms including the pinnules, and distally much of thcir dorsal surface, yellowish white; centrodorsal partly white; cirri ycllow: tips of the pinnules rusty red; oral surface very dark, but fincly mottled with ycllow green.

$[(c)$ Dark burnt orange, the centrodorsal and disk lightcr than the rest of the body.

(d) Dark winc red with just a suggestion of very dark brown; division series dark and dirty brown, as if abraded.

(e) Dark wine red. 
(f) Very dark wine red with just a suggestion of very dark chocolate, the ends of the arms much lighter than the rest of the body and with a tinge of brown, the tips of the pinnules with a suggestion of crimson.

(g) Dark wine red, with the ends of some of the arms light chestnut. dark red.

$(h)$ Dark wine red, with a tinge of dark brown, the tips of the pinnules

(i) Very dark brownish red, the tips of the pinnules very dark red.

(j) Rich chocolate brown, with a red tinge.

(k) Arms for about the proximal half dark orange brown, with a few median white spots near the centrodorsal, the pinnules the same ventrally, dorsally slightly lighter and with tips of light straw yellow; on some of the arms the terminal half is light chocolate, the pinnules the same with light straw yellow tips; other arms are transparent white or white with chestnut spots, and the pinnules are transparent white with light chestnut spots; oral pinnules chestnut with light straw yellow tips; disk chocolate in the center and chestnut on the margin.

(l) Arms in the proximal thirds on both surfaces brownish orange, becoming light olive green, and light yellowish green at the tips, the pinnules corresponding; arms and pinnules with a fine stipple of bright straw yellow; disk and centrodorsal brownish orange.

$(m)$ Arms dark brownish orange, slightly darker ventrally than dorsally, with a stipple of light orange yellow; pinnules dark brownish orange with numerous bands, and tips, of light orange yellow, slightly darker ventrally than dorsally; centrodorsal light orange yellow.

$(n)$ Fairly dark wine red with dorsally a coarse stipple of light straw yellow, the terminal thirds of the arms light straw yellow with a slight tinge of green.

(o) Dark wine red, regularly stippled all over, though increasingly less toward the arm tips, with bright straw yellow.

$(p)$ Very dark wine red tinged with dark brown and coarsely stippled with light straw yellow, the arms in the distal half becoming very dark olive with no stipple; tips of the pinnules light straw yellow.

(q) Stippled with golden yellow.

( $r$ ) Purplish wine color, the tips of the pinnules and spots on the arms bright straw yellow; cirri and centrodorsal bright straw yellow, the former with spots of dark wine color.]

[Comantheria alternans.-Orange brown, the young arms and the distal part of many of the old ones bright brownish orange.]

[Comantheria weberi.-(a) Arms ventrally light yellowish green, laterally and dorsally very dark brown, almost black; pinnules dark brown, tipped with light yellow; disk light brown; centrodorsal dark brown, almost black; cirri dark brown.

(b) Arms blue dorsally and very dark brown or black ventrally; pinnules the same; disk black; centrodorsal brown; cirri brown over silver.

(c) Wholly very dark brown.

(d) Entirely blackish brown except for the silver tips of the cirri.

(e) The same as the preceding, but darker.] 
C'omanthina schlegelii.-(a) Bright yellow.

[(b) Division series, centrodorsal and cirri light yellow, with dots of blackish brown at the margins of the ossieles and between them; most of the arns blaekish brown, dorsally with numerous oblong markings of light yellow along the median line, some entirely light yellow almost to the tips; pinnules mostly blackish brown dorsally, ventrally the same basally with the tip light yellow; disk blackish brown with irregular markings of light yellow.

(c) Ventral surface of arms and pinnules various shades of dark orange red; the dorsal surface of the arms white, the pinnules with a row of white spots dorsally and with the tips on both surfaces light straw yellow; elongated oral pinnules white dorsally and deep orange red ventrally; cẹntrodorsal slightly grayish.

(d) Dorsal side of arms in the proximal two-thirds white, the ventral and lateral portions and the disk dark orange red; some of the pinnules dark orange red, others white or very slightly pink; pinnules on basal half of arms with tips of light yellow; centrodorsal white.

(e) Arms dorsally white at the base with a thin wash of very dark orange red on the remainder of the dorsal and lateral surfaces, ventrally very light yellow; pinnules dorsally light yellow, ventrally deep orange red with light yellow tips; elongated oral pinnules light yellow, with spots of deep orange red; centrodorsal yellow with a broad white median pentagon and spots of dark reddish orange at the angles; disk thin dark reddish orange with irregular markings of very light transparent greenish yellow.

(f) Centrodorsal, cirri, and division series dull orange, the last with the joints almost white; arms moderately dark reddish orange; pinnules the same ventrally, dorsally brighter, tipped with bright orange yellow; some of the arms have areas, including also the adjacent pinnules, which are either solid white or mottled white and reddish orange; disk bright orange yellow.

(g) Division series bright yellow; some of the arms dorsally dull orange, others blackish brown; some of the arms in the distal two-thirds white, with the sides of others white and the remainder light straw yellow; pinnules in general corresponding to the color of the arms, but the pinnules arising from the white sides of the arms are dull orange; disk and proximal third of arms ventrally light straw yellow; centrodorsal and cirri white.

(h) Centrodorsal blackish brown and white; division series blackish brown, chestnut, and white, the interbrachial plating white; arms of various colors, white or very light chestnut dorsally and blackish brown laterally to light yellowish green dorsally and laterally with an irregular stipple of very dark orange brown; ventrally some of the arms are light yellowish green, others light olive, and still others blackish brown; arms that are brown dorsally or laterally are darker brown ventrally; on very light yellow or light greenish yellow arms the pinnules are mostly deep orange red ventrally, the basal third stippled with light olive, and stightly yellowish green dorsally; on the dark orange red portions of the arms the pinnules are of the same color as the latter on both surfaces and tipped with white except for a few that are all white or white mottled with dark orange 
red; a few of the pinnules on green or yellow green areas are white; elongated oral pinnules chestnut dorsally and chocolate ventrally; disk blackish brown and chocolate, the ambulacral groores light yellow.

(i) Very similar to the preceding. but with no white interbrachial plates; centrodorsal white; terminal half of the arms very light greenish yellow.]

[Comanthus bennetti.-(a) Division series and arms dull orange yellow with numerous small spots of dark orange; toward the middle of some of the arms the spots become darker, and lighter again toward the tips; the color of the pinnules in general corresponds to that of the arms; elongated oral pinnules dull orange with spots of dark reddish orange; ventrally some arms are very dark brown, while others are wholly or partly dull orange with spots of dark reddish orange; disk dark wine red.

(b) Division series greenish yellow with a thin stipple of very dark wine red; arms dorsally very dark wine red stippled with light orange yellow, the latter becoming more abundant at the margins of the brachials; pinnules dorsally in the basal third very dark wine red, heavily stippled with light orange yellow; ventral surface of disk and arms light orange yellow very finely stippled with very dark wine red, the stippling absent on the pinnules: centrodorsal dull orange yellow; cirri dorsally similar but in the terminal half light orange yellow stippled with very dark wine red; ends of the tips vitreous, the bases glassy over dark reddish orange.

(c) Centrodorsal chestnut with white dots; division series purplish; arms dark chocolate with two rows of alternating white spots on the ventral side of the arms and the tips of the pinnules light brown; disk creamy white; cirri with a tinge of purple and glassy tips.

(d) Centrodorsal and division series very dark reddish brown, with just a suggestion of dark purple, becoming lighter reddish brown in the terminal half, very closely stippled with light yellowish green; arms and pinnules dorsally dark reddish brown with a very light yellowish green stipple and ventrally the same with the ambulacral grooves chestnut; disk dark reddish brown with a purple tinge, with a very close stipple of light yellowish green; cirri dark reddish brown with a purple tinge, lighter proximally and distally, with silver tips.]

Comanthus solaster.-Dark purple, the disk, cirri: and pinnules brownish yellow.

Comanthus japonicus.-Bright yellow to deep yellow brown.

Comanthus wahthergii.-Dark violet to blackish.

[Comanthus samoana.-(a) Arms dorsally olive, slightly lighter ventrally; pinnules near the arm bases olive dorsally, slightly darker ventrally, toward the ends of the arms becoming yellowish, slightly darker ventrally; tips of the pinnules much lighter than their bases; centrodorsal dark olive with the center yellow; cirri light yellow, slightly darker dorsally than ventrally.

(b) Blue green.

(c) Purple, the pinnules with yellow tips.

(d) Brown, shading into green at the middle of the arms; tips of the arms yellow. 
(e) Brown, the tips of the arms greenish.

( $f$ ) Dark brown, lighter dorsally at the arm bases where there is much mottling with cream white; cirri white, marked with light brown.

(g) Similar, but the white very much predominates.

(h) Apparently uniform black.]

Comanthus annulata.-(a) Ranging from lemon yellow and brown to almost uniform dead black, with bewildering diversity.

(b) Dull green.

(c) Dorsal surface deep canary yellow, pinnules bright red.

$[(d)$ Dorsal surface white, the joints darker; cirri greenish white, the joints pure white, appearing as white spots; ventral surface brown, deepest on the disk and lightest at the tips of the arms.

(e) Chrome yellow, greener orally, the joints not much darker.

(f) Arms dorsally orange and white, laterally white, ventrally orange; some pinnules dull orange ventrally and white dorsally, others very dark chocolate ventrally and white dorsally; centrodorsal with a white center passing outwardly through dark drab to bright orange yellow; cirri very light orange yellow; disk dull orange with markings of slightly yellowish white.

(g) Arms dorsally silver with numerous transverse lines of dark orange, ventrally dark reddish orange; outer third or half of some of the arms light dull orange, slightly lighter dorsally than ventrally; pinnules dorsally silver, with numerous transverse marks of dull orange on the sides, ventrally deep orange, toward the arm tips corresponding to the color of the latter; centrodorsal dull orange; disk rather dark reddish orange.

(h) Yellowish green, the pinnules with white tips.

(i) Arms light yellowish green on both surfaces; pinnules varying from light yellowish green dorsally to india black ventrally, the tips soinewhat lighter; centrodorsal olive; rudimentary cirri light olive; disk light olive with black reticulations.

(j) Arms dark yellowish green; pinnules dorsally the same, shading to very light greenish yellow at the tips, ventrally blackish or bluish green; centrodorsal dark yellowish green; cirri greenish blue, slightly darker ventrally than dorsally, with silver tips.

(k) Centrodorsal and arms on both surfaces greenish yellow, becoming lighter toward the tips; pinnules light blue dorsally, very dark blue ventrally; cirri bluish dorsally, darker ventrally, with silver tips.

(l) Bright green.

( $m$ ) Arms leaf green dorsally, olive green ventrally; pinnules bright blue dorsally, dark bluish green ventrally; centrodorsal olive green streaked with brown; cirri blue; disk olive.

$(n)$ Arms dorsally golden green, the pinnules lighter yellowish green with the tips very light yellow for a long distance dorsally and a short distance ventrally.

(o) A rms olive, slightly darker dorsally than ventrally; pinnules light olive dorsally, dark blue ventrally; centrodorsal olive; cirri pale blue with silver tips; 
disk olive, slightly darker in the center than at the margins, with blackish brown reticulations.

( $p$ ) Arms olive, slightly darker ventrally than dorsally; pinnules proximally olive, shading to dark blue distally, slightly lighter dorsally than ventrally; centrodorsal olive; cirri bright blue with silver tips; disk olive with blackish brown reticulations.

(q) Arms olive on both surfaces; pinnules olive dorsally and blue ventrally; centrodorsal light olive; cirri light blue with white tips; disk olive with black reticulations.

( $r$ ) Arms olive on both surfaces, becoming somewhat blue on the bases ventrally; pinnules olive dorsally and blue ventrally; centrodorsal olive; cirri light blue with silver tips; disk olive.

(s) Arms dorsally very dark olive at the base, becoming very dark brown, ventrally very dark brown with light olive markings on alternate sides; pinnules blackish brown with brown tips; cirri silver olive dorsally and light olive ventrally with silver tips; disk blackish brown.

( $t$ ) Arms brownish olive dorsally, olive ventrally with a dark brown zigzag stripe; pinnules olive with extensive chocolate brown irregular markings ventrally; centrodorsal brownish olive; cirri olive at the base and with alternating areas of chestnut and olive; disk olive with irregular chestnut brown markings.

(u) Arms olive, slightly lighter ventrally than dorsally; pinnules light blue dorsally and dark blue ventrally; centrodorsal light olive; cirri light blue; disk dark olive.

(v) Dorsal surface pure olive with the joints and syzygies cream color; pinnules with white or pale cream-colored joints, appearing as white spots on their dorsal surface, and with brown orange tips; oral surface blackish; disk spotted with cream.

$(w)$ Arms dorsally olive, the pinnules light yellowish green, and ventrally olive with the ambulacral grooves dark blue; pinnules ventrally slightly grayish blue; disk dark olive with reticulations of blue black.

$(x)$ Arms olive, slightly lighter ventrally than dorsally; pinnules dorsally at the arm bases light yellowish green toward the arm tips, gradually becoming blackish blue dorsally, ventrally blackish blue; centrodorsal light olive; disk very dark olive with blackish blue reticulations; cirri light greenish blue.

(y) Similar, but the pinnules wholly bluish black.

(z) Arms and pinnules dorsally dull greenish yellow, ventrally black; disk very dark green; centrodorsal light greenish yellow; cirri dull greenish yellow with a slightly bluish tinge.

(aa) Arms yellowish olive dorsally with a median line of very light straw yellow, ventrally dirty light yellow with the ambulacral groove blackish brown; basal portion of the pinnules dorsally blackish brown with spots of light dirty yellow, becoming clear very light yellow toward the tips with a slight greenish tinge in the spots; pinnules ventrally blackish brown with spots of light clear and dirty yellow; centrodorsal yellowish olive with the central portion light yellow; cirri yellowish olive with spots of clear light yellow; disk the same. 
(bb) Bases of the arms reddish and whitish, the distal halves greenish yellow.

(cc) Disk and the basal portions of the arms ventrally bright rose purple, dorsally light yellowish brown, becoming dusky at the middle of the arms and in the terminal portion bright yellow with or without a transverse band of rose purple; cirri rose purple.

(dd) Very dark wine red.

(ee) Arms and centrodorsal very dark red; pinnules blackish brown with silver tips; disk blackish brown.

$(f f)$ Arms blackish brown on both surfaces, ventrally with a zigzag stippled olive stripe; pinnules blackish brown with long yellow tips; centrodorsal and cirri blackish brown; disk very dark brown.

(gg) Blackish brown.

(hh) Entirely very dark brown.

(ii) Black ventrally, bright yellow dorsally.

(jj) Black, the pinnules with yellow tips.

$(k k)$ Black, some of the arms and pinnules light brown terminally; cirri lighter dorsally than ventrally, with white tips; disk slightly yellowisl.

(Il) Pure velvety black except for the arm tips, which are canary yellow with the faintest tinge of green.

$(\mathrm{mm})$ Deep black, the cirri silvery with white tips.

$(n n)$ Arms chestnut brown dorsally, slightly darker ventrally; pinnules the same color as the arms, some of them with very short silver tips; centrodorsal chestnut; cirri light brown with silver tips; disk very dark brown with olive oblong spots.

(oo) Arms blackish brown; pinnules blackish brown with burnt orange tips; centrodorsal blackish brown with silver spots between the cirri; cirri partly blackish brown and partly silvery, with silvery tips.

$(p p)$ Arms dorsally light brown with a light olive median stripe, ventrally light olive with a blackish brown median stripe; pinnules light olive dorsally, dark blue ventrally, with short light yellow tips, some with alternate areas of olive and blackish brown orally; centrodorsal brown with five radial olive markings; cirri with alternate bands of brown and olive.

( $q q)$ Arms dorsally light brown, ventrally olive, slightly lighter toward the tips; pinnules olive with light ycllowish green tips, lighter dorsally than ventrally: centrodorsal with a white center; disk dark olive.

$(r r) \Lambda$ rms basally dark chestnut with markings of light bluish green, then bluish green, and the remainder to the tips blackish brown; in the first area the pinnules arc colored like the arm; in the sccond they are light greenish yellow with blackish brown spots; centrodorsal blackish brown with light bluish green spots; disk blackish brown with the ambulacral grooves light bluish green.

(88) Arms dorsally very dark olive or chocolate, the brachials bordered with black; pinnules black with a silver median line, the tips very light yellow; arms ventrally light olive, with the ambulacral grooves black, grcen, or brown; on certain arms the ventral surface of the pinnules is the same; on others they are silver with a median black line; they show pinkish, and are presumably filled 
with spermatoza; centrodorsal cream white, surrounded by light brown; disk silver with light brown and black specks.]

Comanthus parvicirra.-(a) Dark purple.

(b) Bright yellow brown; in some cases this is much darkened and has a greenish cast; rarely the tips of the pinnules are green or greenish yellow.

(c) Deep olive brown, the pinnules tipped with yellow.

(d) Brown, the pinnules green.

(e) Orange.

(f) Kose red and white.

[(g) General color bright canary yellow; dorsal surface of the arms with a central and two lateral lines of dark brown; brown transverse lines at the articulations; tips of the pinnules dark prussian blue.

(h) Greenish yellow and rich reddish purple.

(i) Arms red, the pinnules deep yellow; a broad white band across the bases of the arms dorsally and others at irregular intervals distally.

(j) Arms dorsally at the base yellow with dark brown longitudinal bands and spots, becoming distally yellowish green, ventrally olive with a median line of dark brown; pinnules dorsally banded with brown and yellow, ventrally dark brown with yellow transverse bands and near the base olive green patches; centrodorsal with yellow and brown spots; cirri banded brown and bright yellow; disk very dark brown with yellow and a few green areas.

(k) Delicate gray.

(l) Girayish.

$(m)$ Rather grayer than usual on the ventral surface.

$(n)$ Grayish brown with yellowish arm tips.

(o) Arme dorsally whitish, the joints and syzygies dark brown, ventrally delicate wood brown, most of them darker at the base; cirri yellow, banded with dusky.

(p) Light grayish brown.

(q) Light wood brown.

(r) Very brown.

(s) Entirely chocolate.

$(t)$ Dorsal surface dull whitish or pale grayish brown with each joint and syzygy black, the ventral blackish; pinnule segments almost white; cirri pale yellowish.

(u) Arms dorsally black, becoming olive distally, ventrally black; disk black over olive; centrodorsal light olive; cirri olive with cream-colored tips.

(v) Entirely deep blackish brown except the cirri, which are slightly silvery distally with silver tips.]

\section{Family ZYGOMETRIDÆ.}

Zygometra microdiscus, young.-(a) Whitish, marked with narrow irregular bands and spots of bright red; cirrus segments violet, distally bordered with white.

(b) Spotted with red violet and with broad white cross bands; cirri as before. 
Zygometra elegans. -The color in life is recorded as very variable, with no details. The black and white comatulids mentioned by von Willemoes-Suhm were probably this and the preceding species.

[Zygometra comata.-(a) Equally mixed spots of dark brown and canary yellow all over the body.

(b) Orange, the arms covered with darker spots which give them a bronzy appearance.]

Zygometra punctata.-(a) Dull red.

(b) Purple of a rather pale shade; pinnules yellowish at the tips; cirri more or less white.

Zygometra pristina.-Deep violet, the cirri white.

Catoptometra magnifica.- "Apparently bright yellow, with regular bands of bright red on the arms, like C. mebroflava."

Catoptometra mibroflava.-Brilliant yellow, the arms broadly banded with bright red; the cirri are dull orange red.

Catoptometra hartlaubi.--(a) Yellowish brown, the skeleton whitish.

(b) Young; bright yellow.

Catoptometra ophiura.-(a) Dull olive green, the disk ambulacra and the perisome of the pinnules dark brown.

(b) Bright yellow, the arms broadly banded with bright red.

\section{Family HIMEROMETRID 2 E.}

Himerometra magnipinna-(a) Uniform deep violet.

[(b) Arms transversely barred with brown, at the base whitish or light straw yellow; pinnules barred with whitish and brown; anal tube straw color, spotted with light brown.

(c) Division series dull ochre; the arms crimson, shading to rich chocolate at the tips.

(d) Arms dorsally wine red, becoming darker on the division series, regenerating arms tending to crimson, ventrally light pinkish gray with transverse lines; pinnules dorsally like the arms ventrally; enlarged proximal pinnules, disk, ambulacral groove of the arms, and the ventral surface of the pinnules dark wine red, tending toward crimson on regenerating arms; cirri ventrally colored like the division series, dorsally slightly lighter, and with silver tips.

(e) Dark wine red, the dorsal surface of the arms washed with silver; centrodorsal pink; cirri shightly lighter dorsally than ventrally, with white tips.

(f) Dark wine red with two rows of alternating white spots along the ventral surface of the arms.

(g) Medium dark wine red, the centrodorsal pink, the cirri dorsally slightly lighter with the tips white.]

Heterometra nematodon.-Dorsally light Hesh color; pinnules ventrally more or less violet; cirri dark violet, many of the segments dark in the middle, so that they appear ringed. 
Heterometra crenulata.-(a) Striped dark violet brown and yellow.

(b) Red and violet.

(c) Red brown and white in cross stripes, the disk with scattered triangular white spots between the ambulacral groores.

(d) Red.

Heterometra affinis.-Purplish black and white in alternating bands about a quarter of an inch wide.

Heterometra savignii.-(a) Purple and white.

(b) Brown and white.

(c) Whitish, with a violet tinge, and with patches of darker color and of yellow.

Heterometra bengalensis.-Black.

Amphimetra discoidea.-(a) Yellow brown, the perisome of the pinnules yellow.

(b) White, the ambulacral grooves and the cirri violet.

Homalometra denticulata.-Bright yellow and lavender in alternating bands about three-sixteenths of an inch wide.

\section{Family STEPHANOMETRIDEE.}

Stephanometra echinus.-(a) Dark purple.

$[(b)$ Orange yellow with a few areas of very dark chocolate wine, becoming lighter on the division series and very light on the arm tips.

(c) Burnt orange with the disk slightly yellowish; there are numerous small spots of dark wine red over the whole surface, becoming larger, darker, and more numerous on the ventral surface of certain arms, where they give the appearance of very dark chocolate.

(d) Arms dorsally alternating silver and bright red, ventrally silver and dark wine red; pinnules in general corresponding to the color of the arms at the point of origin; enlarged proximal pinnules and the tips of the others orange; centrodorsal silver, surrounded by rings of light red brown; disk light pink, with small spots of orange; cirri silver basally, with occasional areas of light red brown, and silver tips.

(e) Maroon, crimson, light cream color, and light chestrut; disk white, orange, and pink; centrodorsal cream color with a maroon margin; cirri white and orange.

( $f$ ) Wine red, the ends of the arms and regenerating arms bright red, almost crimson, the whole surface with fine silver markings.]

[Stephanometra oxyacantha.-(a) Proximal third of the arms silver with blackish brown lines at the articulations, the arms then becoming dorsally blackish brown with transverse lines of silver and ventrally blackish brown; enlarged oral pinnules silver, with a blackish brown stripe dorsally; centrodorsal very dark red with a median and five marginal white spots; cirri very dark red with silver tips; disk blackish brown.

(b) Arms chestnut, maroon, white, and chocolate, with transverse lines at the edges of the brachials; enlarged proximal pinnules with a wash of purple ven- 
trally and laterally, chestnut dorsally; disk white, chocolate, and chestnut; centrodorsal dark chestnut, with a white dot in the center; cirri with a chocolate wash ventrally and a faint trace of purple toward the base dorsally.

(c) Proximal third of the arms very dark reddish orange, beyond very light orange yellow, almost white, with transverse markings of very dark reddish orange; pinnules very light orange yellow with long tips washed with bright orange yellow; cirri dark reddish orange, slightly lighter dorsally.

(d) Light purplish gray except for bands of chestnut at the end of the basal third of the arms from which point purplish gray and chestnut alternate on the arms and pinnules; disk light crenm color.

(e) Arms olive dorsally and olive brown ventrally; pinnules blackish brown, slightly darker ventrally than dorsally, with yallow tips; centrodorsal and cirri dark olive.

(f) Arms and pinnules very dark reddish orange stippled with silver; centrodorsal the same, with a silver spot in the center and four marginal silver areas; cirri the same, slightly lighter dorsally than ventrally, with silver tips.

(g) Arms at the base dorsally deep reddish orange, with purple, washed with light gray; then come darker areas with dark reddish brown until about the middle of the arms, where the color is dark reddish orange with purple; toward the arm tips the color shades to very light purple with a wash of silver; on the basal half of the arms the color of the pinnules in general corresponds to that of the arms, but on the terminal half the pinnules are covered with rings of silver and dark reddish orange with purple, the latter becoming lighter toward the tips, and there are some areas where the pinnules are almost all white with only a few spots of this dark color; centrodorsal light dirty gray; cirri with a heavy wash of yellowish white over dark reddish orange, with slightly yellowish white bases and silver tips; disk light bluish gray with a trace of yellow on the ambulacral grooves.

(h) Arms with alternating areas of deep orange red and dull orange, with the edges of the brachials darker than the rest of their surface: pinnules corresponding in color to the arms in the lighter areas, in the darker with transverse bands of dull orange; centrodorsal white; cirri orange red, dorsally silvered; disk mottled rather deep reddlish orange and very light orange yellow.

(i) Arms and pinnules dorsally bright violet red with the joints darker, ventrally very light violet red, with alternating blotches of much darker; enlarged proximal pinuules light violet red; middle of centrorlorsal light violet red, the remainder very light orange yellow.

(j) Arms basally very dark red, with transverse silver marks ventrally, becoming silver with transverse lines dorsally; pinnules very dark red, the enlarged oral pinnules slightly lighter ventrally; disk, centrodorsal, and cirri very dark red, the centrodorsal with a silver center, the cirri lighter dorsally than ventrally and with silver tips.

(k) Light wine red, the enlarged oral pinnules ligliter; centrodorsal with a white median spot.

(l) Dark wine red with the enlarged oral pinnules slightly ligliter; centrodorsal with a median white spot. 
$(m)$ Wine red, slightly lighter ventrally than dorsally; tips of the cirri slightly silver.

(n) Dark wine red.

(o) Division series chocolate with a tinge of purple; arms dorsally reddish chestnut, the margins of the brachials chocolate, ventrally, with the pinnules and disk, dark chocolate; some of the pinnules dorsally dark reddish chocolate, and others with areas of very light chestnut; centrodorsal dark wine red; cirri purplish, darker ventrally, with silver tips.]

Stephanometra spicata.-(a) Uniform deep red-purple, except the cirri, which are nearly dull yellow at the base and only dark at the tips.

(b) Orange yellow, with the middle third of the arm orange red.

[(c) Cream yellow, with dark brown spots on the arms.

(d) White, with dark chocolate stripes on the arms and pinnules; white areas on the dorsal surface of the arms with grayish centers.

(e) Fine reddish purple.]

[Stephanometra monacantha.-Arms dorsally dark reddish brown with conspicuous cream-colored bands at irregular intervals, ventrally rusty red with an occasional cream-colored patch; pinnules dorsally rusty brown, ventrally rusty red; centrodorsal cream colored; cirri cream colored proximally, becoming gray distally ; disk rusty red, with cream-colored markings.]

\section{Family MARIAMETRIDE.}

Pontiometra andersoni--Purplish brown.

Oxymetra aranea.-Greenish yellow.

[Dichrometra bimaculata.-(a) Division series drab with a slightly purplish wash; arms with areas of light purplish and areas of white with a tinge of purple; pinnules dorsally chestnut with a tinge of purplish or white, ventrally chocolate or white; centrodorsal light muddy brown; cirri light purple with white tips; disk white with two chocolate papillæ on opposite sides of the central mouth.

(b) Arm bases dorsally very light dull orange, then lighter idull orange, followed by alternating areas of the latter and dark reddish orange, growing slightly lighter toward the arm tips; arms ventrally with alternating ill-defined areas of very light orange yellow and dark reddish orange; mouth and ambulacral grooves on the disk and arm bases bright straw yellow; pinnules in general corresponding in color to the arms, but those arising in areas of dark reddish orange have rings of very light orange yellow; elongated oral pinnules very light orange yellow in the basal half, dark reddish orange in the distal half; cirri dull orange ventrally, somerwhat silvery dorsally, with silvery tips.]

Dichrometra döderleini.-Light brownish yellow, the ventral perisome everywhere purple.

Lamprometra protectus.-(a) Rich purple, with the bases of the arms and a broad distal band white; pinnules often with yellowish or rusty tips; cirri cream color dorsally, deep brown ventrally.

(b) Bright green somewhat variegated with brown and white, and with a broad band of white crossing each arm distal to the middle which is particularly 
prominent on the oral surface; between this band and the disk are three or four narrow bands of green; pinnules, at least distally, with yellow tips.

(c) Green with an obscure yellowish band three-eighths of an inch wide in the distal part of the proximal third of the arm, and the terminal half inch of the arm yellow.

(d) Black and white.

[(e) Arms with alternating areas of very light yellow and bright orange yellow; pinnules on the lighter portions of the arms corresponding to the latter, on the darker partly very light yellow and partly bright orange vellow; centrodorsal white; cirri light dull violet red ventrally toward the tips, the remainder white. the cirri.

(f) Deep blood red, lighter on the centrodorsal and on the dorsal surface of

(g) Arms and pinnules alternating white and chocolate, the white shading into brownish gray; cirri ventrally on the terminal two-thirds chestnut, basally and dorsally white.

(h) Arms dorsally purplish brown, purplish gray and white; pinnules dark chocolate and white with an occasional purplish tinge; centrodorsal dirty white; cirri dirty hrown, dirty white dorsally at the base, with silver tips; disk dark chocolate and white.

(i) Arm bases dorsally white, with a row of spots of olive just at the side of the melian line; arms and pinnules ventrally at the base very light orange yellow, then dull light yellowish green with large blotches of greenish yellow, becoming lighter toward the pinnule tips, then a narrow area of very light orange yellow. and the rest blotched with very light orange yellow and very dark greenish yellow; elongated proximal pinnules very light orange yellow shading to olive with rings of the former distally; centrodorsal silver with five spots of olive; cirri ventrally in the terminal half dark yellowish green, dorsally and basally very light orange; disk silvery light dull yellow.

(j) Arms dorsally at the base white with small green spots, toward the middle and tips becoming dark olive in definite bands, which alternate with white areas, ventrally alternating olive and white in bands, the olive lighter than on the dorsal surface; pinnules corresponding to the color of the place of origin, in the olive areas being transversely banded with olive and white; elongated proximal pinnules white basally and olive distally, the olive being slightly more extensive dorsally than ventrally; centrodorsal white with olive spots; cirri ventrally banded with olive and white, dorsally white, with white tips; disk mottled olive and white.]

Lamprometra palmata.-(a) Black and white.

(b) Purple and yellowish white.

(c) Brown and white.

(d) Light brown and white.

(e) Uniform deep brown.

(f) I'redominently yellow.

Mariametra delicatissima.-Dorsally yellowish white with a narrow purple median line; ventrally light purplish gray. 


\section{Family COLOBOMETRIDA.}

[Cenometra unicornis.-Arms light brown with very dark brown or black spots; pinnules silver, with three or four very dark brown rings, wider ventrally than dorsally, some in the proximal half of the arms entirely very dark brown ventrally ; centrodorsal light brown; cirri dark brown, the dorsal half yellowish brown; disk gelatinous and transparent (probably regenerating) with oblong spots.]

Cenometra delicata.-Deep violet, the cirri, $\mathrm{P}_{2}$, and the dorsal side of the other pinnules bright yellow.

Cyllometra albopurpurea.- (a) Black and white in narrow alternating cross bands.

(b) Dark purple and yellow in narrow alternating cross bands.

(c) Arms dark purple as far as the last axillary, the remainder of the animal white.

(d) White, with a broad band of deep purple in the basal third of the arms and two or three narrower bands distally.

(e) Dull white, spotted more or less thickly with grayish or reddish purple.

Prometra chadwicki.-Purplish black, the arms of one specimen regularly striped with yellow.

Oligometrides adeona.-(a) Very variable, ranging from clear lemon or canary yellow, with bands or purple marks, through variegated purple and yellow, or variegated brown and white, to finely variegated shades of gray and white.

(b) Dark red, the terminal segments of the proximal pinnules and the arm tips with a silver sheen.

\section{Family TROPIUMETRIDÆ.}

Tropiometra afra.-Dark purplish brown.

Tropiometra macrodiscus.-(a) Shining deep purple.

(b) Bright yellow.

Tropiometra carinata.-Golden yellow or orange to somewhat brownish, with uniform black spots along the sides of the arms and cirri.

Tropiometra picta.-(a) Deep purple with large spots of yellowish white on the sides of the rays.

(b) Varying from a light yellowish brown to a deep violet, with many intermediate shades, specimens being usually banded with lighter and darler colorings, and scldom of uniform tint.

(c) "The first specimens of Tropiometra seen appeared to be uniformly dark purple, purplish brown, reddish brown, or bright brown, but a closer examination showed that uniform coloring was very rare. Almost always a longitudinal dorsal stripe on each arm, or transverse bands of more or lcss width, or both, are present. The color of these markings is yellow of some shade, often dull and buffy, but not rarely quite bright. In some individuals the pinnules are also cross banded with yellow, and the distal pinnules may be uniformly brownish yellow. The cirri are yellow brown, at least dorsally, but are often more or less dusky or purplish on 
the oral surface; in nearly all individuals, however, both young and old, the terminal two or three segments (except the claw) have a dusky spot on the oral side. This marking seems to be very constant in Tobagoan specimens. Occasional individuals are found in which the pinnules and dorsal side of the arms are plenteously besprinkled with silvery white, giving them an exceptionally handsome appearance.

"All of the small specimens found were brownish yellow or bright brown, more or less marked and banded with purple, and this general coloration is not rare in adults, particularly in those found under slabs of rock on Buccoo Reef and in similar shaded places. Some of these individuals were very handsome in their brilliant array of purple and gold, and it was hard to believe they were really identical with the dull-colored specimens from the shallows of Buccoo Bay. A natural inference from the specimens seen is that the young are uniformly yellow or brownish yellow, and that the purple pigment develops as they mature, in some individuals completely obliterating the original color, but usually appearing simply as spots, blotches, and cross bands. One could scarcely avoid the impression that the development of the pigment is associated with life in the open sunlight [as suggested by the present author in 1908], but there was no chance to secure an answer to the interesting question which suggests itself: Do the bright-colored individuals avoid the sun because they lack pigment, or do they lack pigment because they have never lived exposed to the sun?"

\section{Family CALOMETRIDÆ.}

Neometra conaminis.-White, with yellow bands on the arms and pinnules, more rarely on the cirri.

Neometra gorgonia.-White, with purple bars and blotches on the pinnules.

Neometra multicolor.-(a) Usually a delicate light grayish purple or lavender. with narrow bands of dull yellow on the arms. The cirri are light lavender, usually with a narrow band of yellow ahout the end cf each segment.

(b) One specimen is pure white, the arms crossed by a broad deep purple band near the middle and another near the tip.

Pectinometra flavopurpurea.-(a) Lavender, the arms crossed by bands of dull yellow; lower pinnules yellow, banded at alternate articulations with purple; cirri yellow.

(b) Arms as in the preceding; centrodorsal and division series orange; cirri purple.

(c) Arms clear yellow, sometimes faintly blotched with light purple; centrodorsal and division series orange; cirri deep purple, banded with white.

Gephyrometra propinqua.-Reddish and purplish brown, marbled with light yellow, the dark and the light in about equal proportions; division series and lower brachials purple, with a median line of white; two or three areas of white with purple spots distally on the arms.

Gephyrometra versicolor.-Rich deep purplish brown, the basal portion of the arms with a row of lateral yellow spots; division series yellow, transversely banded 
with purplish brown; cirri purplish brown, with the distal half yellow; disk purplish brown, marbled with yellow in the interambulacral areas.

Calometra discoidea.-Bright yellow, the cirri lighter.

Calometra callista. - White, a broad band of deep purple in the basal third of the arms and two or three narrower bands distally.

Calometra separata.-Bright yellow, banded with purple; lower brachials purple; cirri deep purple, or purple banded with white.

\section{Family THALASSOMETRIDE.}

\section{Subfamily PTILOMETRINa.}

Ptilometra macronema.-Purple, the cirri red.

Pterometra magnipeda.-Brownish yellow.

Pterometra pulcherrima.-(a) Bright red, more orange dorsally, with scatr tered small white spots on the pinnules and cirri.

(b) Yellow brown.

Pterometra venusta.-Dark red, the tips of the pinnules white.

Asterometra macropoda.-Light brownish yellow, the cirri white.

Asterometra anthus.-Dull brownish yellow, the cirri almost white.

\section{Subfamily THALASSOMETRINA.}

Crotalometra porrecta.-Yellow.

Crotalometra flava.-Bright yellow.

Oceanometra gigantea.-Arms light chocolate, eirri light chrome yellow.

Cosmiometra philippinensis.-Bright yellow.

Cosmiometra aster.-Bright yellow.

Stenometra diadema.-Bright yellow.

Daidalometra arachnoides.-Chrome yellow.

Daidalometra hana.-Bright yellow, sometimes banded with white; cirri white with a few narrow bands of yellow.

Parametra orion.-(a) Bright yellow, usually banded rather narrowly with white; cirri dull greenish basally, light yellow distally, the colors separated by a darker band.

(b) Some specimens, more often the larger ones, are grayish, the distal portion of the arms bright yellow.

Parametra fisheri.-Arms cadmium orange, darkest on the pinnules; cirri bright lemon yellow.

Lissometra alboflava.-Light yellow banded with white; cirri white.

Aglaometra propinqua.-Yellow.

Aglaometra eupedata.-Bright yellow, the cirri lighter.

Thalassometra villosa.-Light yellow.

Thalassometra lusitanica.-Bright yellow to brownish yellow.

Thalassometra omissa.-Bright yellow. 


\section{Family CHARITOMETRIDZE.}

Perissometra lata.-Yellowish brown.

Pachylometra levigata.-Yellow.

Calyptometra lateralis.-A rms ocher yellow; cirri clear lemon yellow.

Pacilometra scalaris.-Yellowish brown.

Chlorometra garrettiana.-Dull yellowish white.

Strotometra hepburniana.-Bright yellow.

\section{Family ANTEDONID死.}

\section{Subfamily ANTEDONINE.}

Antedon petasus.-(a) Red (varying from bright red to brown red); the cirri white.

(b) Banded red and white.

(c) Almost uniform red, with the basal portion and ends of the arms white.

(d) Almost uniform white, with the basal portion and ends of the arms red.

Antedon bifida.-( $a$ ) Deep purple.

(b) Uniform deep reddish purple.

(c) Rich brown.

(d) Reddish tawny.

(e) Rich damask (especially during the breeding ceason).

(f) Crimson.

(g) Red carmine.

(h) Coarse red.

(i) Scarlet.

(j) Vermillion.

(lc) Deep rose.

(l) Rose.

$(m)$ Rich orange.

(n) Orange.

(o) Yellow.

(p) Mottled, or mottled and spotted.

(q) Red, variegated with white on portions of the disk and arms.

(r) Clouded and spotted with rose, orange, and yellow.

(s) Rich orange variegated with crimson.

(t) Rich orange variegated with white.

(u) Rich orange variegated with bright sulphur yellow.

In the prebrachial or eystid stage the interior of the calyx is occupied by a reddish brown viseeral mass obscurely visible through the translucent walls.

In the fully grown pentacrinoid, according to Dr. W. B. Carpenter, the body and arins usually possess a decided color, which is sometimes sulphur yellow, sometime light crimson, sometimes an intermixture of both hues. This is usually more pronounced in the arms than in the body, and is entirely due to the develop. ment of pigmentary inatter in the pyriform resicles. 
Very young comatulids retain the original sulphur yellow color toward the ends of the arms, the proximal portion of the arms and the body assuming the characteristic red of the adults.

According to Hassall, the markings and coloring of young specimens are very beautiful and delicate, very different from the coarse red which distinguishes them when mature.

Antedon mediterranea.-(a) Chocolate brown (recorded from Naples).

(b) Carmine.

(c) Red.

(d) Orange.

(e) Chrome yellow.

( $f$ ) Bright yellow.

(g) Gray.

(h) Red, with gray or white spots (the only color type recorded from Villafranca).

(i) Orange, with gray or white spots.

Antedon adriatica.-(a) Brownish.

(b) Purple red.

(c) Red (the majority).

(d) Yellow.

(e) Sulphur yellow.

(f) Red, of various hues, spotted with lighter.

(g) Sulphur yellow, banded with white.

Toxometra paupera.-(a) Uniform dark purple.

(b) Brownish yellow, with the perisome dark brown.

Iridometra melpomene.-Light yellow brown, the sides of the arms and of the division series and the cirri white, the perisome dark purple.

Eumetra chamberlaini.-Brownish yellow, the cirri and pinnules blotched with purple.

Dorometra mauritiana.-Grayish green spotted with white.

Dorometra nana.- (a) Dull green, spotted and blotched with white.

(b) Purplish black with light brown cirri.

[(c) Dark chocolate, with markings of very light chestnut on the cirri and disk, and the tips of the pinnules very light chestnut, especially near the ends of the arms.]

Dorometra briseis.-Light yellowish brown, with broad bands of darker yellow brown on the arms.

Annametra occidentalis.-Uniform brownish yellow with olive green spots.

Subfamily THYSANOMETRINA.

Thysanometra tenelloides.-Grayish brown, the dorsal surface and the cirri nearly white. 


\section{Subfamily ZENOMETRINA.}

Sarametra triserialis.-Deep purple-vinaceous, the calyx and arm bases brownish.

Psathyrometra erythrizon.-Rather dark dull purple.

Psathyrometra fragilis.-Light purplish brown.

Balanometra elongata.-Arms purple, with a broad median line of white; pinnules and cirri white; centrodorsal purple.

Leptometra celtica.-(Xireen.

Leptometra phalangium.-(a) White.

(b) Gireen.

\section{Subfamily Perometrine.}

Perometra diomedea.-Rich reddish purple, spotted and blotched with white; division series and lower brachials white, the synarthrial tubercles purple, the division series with narrow purple transverse lines; cirri white, banded with purple.

Young examples are lighter in color, very small ones being nearly all white. Erythrometra australis.-Pale orange and yellow.

Erythrometra ruber.-Salmon red, the pinnules yellow, the cirri white.

Nanometra bowersi-- (a) Brownish yellow, the dorsal surface and the cirri nearly white.

(b) Light yellow.

\section{Subfamily HELIOMETRINE.}

IIeliometra glacialis.-(a) Arms brownish, the pinnules orange yellow.

(b) Bright yellow, the basal part of the cirri ventrally and the arm bases and pinnules dorsally washed with reddish purple.

(c) Bright yellow.

(d) Yellowish white.

l'romachocrinus kerguelensis.-(a) Violet.

(b) Giolden yellow.

b lorometra asperrima.-Yellow, the cirri whitish.

F'lorometra serratissima.-Yellow, the cirri whitish.

Florometra perplexa.-Yellow or brownish yellow, the cirri whitish.

Florometra maria.-Clear ycllow, the cirri lighter.

Florometra laodice.-(a) Bright yellow.

(b) Lemon yellow; the cirri lighter.

C'yclometra clio.-Light yellow banded with white, the cirri white with occasional narrow bands of yellow.

\section{Subfamily BATHYMETRINA.}

IIathrometra prolixa.-Arms brownish yellow, pinnules, with the gonads, yellowish red, disk light brown, cirri white.

IIathrometra tenella.-Dark green dotted with white, the disk grayish, the cirri white. 
Hathrometra sarsii.-Lively light grayish brown, with narrow darker bands. Trichometra vexator.-Yellow.

Trichometra isis.-Yellowish brown, the dorsal surface and cirri lighter.

Thaumatometra tenuis.-(a) Light purplish brown, lighter dorsally; cirri nearly white.

(b) Light yellow brown (young).

\section{Family PENTAMETROCRINIDE.}

Thaumatocrinus borealis.-Purplish brown, dorsally nearly white; disk black.

Pentametrocrinus varians.-Dull purplish brown, the dorsal surface and the cirri nearly white, the disk black.

Pentametrocrinus japonicus.-Practically the same as $P$. varians.

Pentametrocrinus diomedea. - Not distinguishable from $P$. japonicus.

In addition to the definite records given above the colors of a number of undetermined comatulids have been recorded.

Leach in 1815 gave a colored figure of his Alecto horrida.

Savile-Kent says that the variety of hues exhibited by the Barrier Reef species are legion, running through every gradation of tint from pale yellow to rose-pink, deep crimson and black, and including every conceivable intermixture of those colors. One especially handsome form obtained at Thursday Island had its fernlike arms resplendent with shades of old gold and bronze green. He gives two colored figures.

Captain Parfait records sulphur yellow comatulids from latitude $33^{\circ} 47^{\prime} \mathrm{N}$, longitude $11^{\circ} 23^{\prime} \mathrm{E}$., in 1,635 meters (probabaly Thalassometrinæ).

Professor Nutting says that on the "Pentacrinus grounds" off Habana bright yellow comatulids were fairly abundant, and white or nearly white ones were also secured. It occurred to him that Lieutenant-Commander Sigsbee may have had these in mind when giving the colors of the pentacrinites.

The same author states that at Barbados the masses of coral rock within which he found comatulids were often brilliantly colored by the assemblage of corallines, sponges, and gorgonians with which they were overgrown. The predominating colors of these were red and yellow, and these were the predominating colors of the comatulids also.

He mentions the following colors as occurring among the comatulids at Barbados: yellow and white, yellow and red, purple and white, black arms with yellowish pinnules, rich deep vermillion with bright yellow pinnules, lemon yellow with the dorsal surface of the arms black, grayish, violet, crimson, black with greenish yellow arms, magenta with dark yellowish arms, and dark gray, almost black, with whitish cirri. The species represented were Nemaster iowensis, Nemaster discoidea, Leptonemaster venustus, Comactinia meridionalis, Analcidometra armata, and Coccometra hagenii.

Speaking of the coloration of the deep-sea animals dredged between Central America and the Galápagos Islands, Mr. Alexander Agassiz said that there are a number of forms in which yellows prevail, as, for instance, in the comatulids 
(Florometra) and in Calamocrinus, the yellow in the latter passing to a greenish tinge, in the comatulids to a reddish tinge, or even to brilliant red as the principal tint.

Professor Chun records the discovery of a sulphur yellow Pentametrocrinus off the coast of Somaliland, in 1,289 meters.

For purposes of comparison the coloration in life of the stalked crinoids is given; but these are not considered in the discussion following.

\section{Family HOLOPODIDE.}

IIolopus rangii.-Whitish.

\section{Family PENTACRINITIDAE.}

Metacrinus acutus.-Grayish green.

Metacrinus angulatus.-Light yellow or light reddish orange, the column almost white.

Metacrinus cingulatus.-Light yellow or light reddish orange, the column almost white.

Metacrinus costatus.--Uniform dusky purple.

Metacrinus moseleyi.-Uniform dusky purple.

Metacrinus nobilis.-(a) Light yellow or light reddish orange, the column almost white.

(b) Deep sea green, the pinnules slightly lighter, the cirri still lighter and more grayish.

(c) Young examples are nearly white.

Metacrinus notilis sumatranus.-Brownish white.

Metacrinus nodosus.-Uniform dusky purple.

Metacrinus rotundus. - Sea green, the crown usually brown, often with nearly white bands across the arms.

Metacrinus varians.-Uniform dusky purple.

Metacrinus wyvillii.-Uniform dusky purple.

Isocrinus decorus.-(a) Purple.

(b) Yellow.

(c) White.

Endoxocrinus wyvillethomsoni.-(a) Dark green.

(b) Grass green.

Endoxocrinus alternicirms.-Slightly brownish white.

Comastrocrinus asper.-Olive green.

Uypalocrinus nuresianus. - (a) Dark olive green.

(b) Pink.

Isocrinus decomes and Endonocrinus parre.-Regarding these two species as brought up together by the dredge and tangles, Sigsbee wrote that some were white, some purple, some yellow: the latter was the color of the smaller and more delicate ones. From color notes taken shortly after the animals were placed in alcohol, 
Rathbun said that the color varies greatly; nearly half the specimens have a tinge of green, varying to bluish, this color being sometimes very light, at others dark; many specimens were very light purplish, purplish white or yellowish white; light shades of brown and gray also occurred, and several varieties of coloring may be found on the same specimen; the arm bases and calyx are generally darker than the rest of the body, being often of a dark olive color. He remarked that Endoxocrinus parre retains more of its natural color in alcohol than Isocrinus decorus. Professor Nutting found none that were either white or yellow, all being of some shade of light brown, usually with a purplish or violet tinge, and sometimes approaching a flesh color.

\section{Family PHRYNOCRINIDE.}

Phrynocrinus nudus.-Dull greenish yellow.

\section{Family BOURGUETICRINIDÆ.}

Bathycrinus pacificus.-Very light yellow.

Ilycrinus carpenteri.-Beautiful straw yellow throughout, the root being a little darker than the rest of the column. The crown is, perhaps, a little paler; but when the sexual organs contain the sexual products the pinnules are much darker.

Rhizocrinus lofotensis.-(a) Clear grayish brown.

(b) Clear grayish yellow.

(c) Whitish gray.

Democrinus rawsonii.-(a) Whitish.

(b) Column grayish yellow; arm tips and pinnules lemon yellow.

A brownish species of Rhizocrinus or Bythocrinus has been mentioned by Professor Nutting, and Mr. Alexander Agassiz says that "Rhizocrinus lofotensis" (probably a species of Bythocrinus) when alive is brownish chestnut, varying from that to a dirty white.

\section{Family APIOCRINID E.}

Proisocrinus miberrimus.-Brilliant uniform scarlet.

\section{Family PLICATOCRINIDE.}

Calamocrinus diomedw.-Brilliant lemon yellow, with a greenish tinge on the sides of the arms and along the ambulacral grooves.

Ptilocrinus pinnatus.-Bright yellow.

Ptilocrinus antarcticus.-Bright yellow.

Gephyrocrinus grimaldii.-Yellow.

Thalassocrinus pontifer.-Pale sulphur yellow, the lower end of the column becoming brownish.

\section{SUMMARY.}

Among the comatulids we have 213 records of the living colors, of which the present author is responsible, directly and indirectly, for 109 . These records refer to 130 species, and of these the author has handled living specimens of 49 . 
The colors of living crinoids have not only as a rule been recorded under conditions preventing an accurate color analysis, but also by observers not trained in color work, so that the names of the colors as given are in many cases to be regarded as somewhat indefinite. This is especially true in the case of the differentiation between red and purple, purple and violet, and violet and black.

As over 100 hues are mentioned, it seems advisable to simplify matters by reducing the list to reasonable limits through a combination of the colors as recorded under 10 readily differentiated heads, as follows:

Yellow, including yellowish white, cream, clear yellow, lemon yellow, yellow, yellowish, brilliant yellow, light yellow, sulphur yellow, dull yellow, gold, golden yellow, canary yellow, ocher yellow, light chrome yellow, chrome yellow, greenish yellow, and brownish yellow.

Orange, including orange yellow, orange, rich orange, cadmium orange, buffy, yellowish red, orange red, and rusty red.

Red, including rose, rose red, flesh pink, red, bright red, vermillion, scarlet, deep rose, coarse red, dull red, crimson, dark red, red carmine, purple red, salmon red, rich damask, reddish tawny, brown red, and red brown.

Purple, including reddish purple, deep red purple, purple vinaceous, purple, rich purple, purplish gray, grayish purple, dull purple, deep purple, dark purple, and maroon.

Violet, including violet white, violet, red violet, deep violet, dark violet, violet brown, and purplish black.

Black.

White, including whitish, silvery white, and white.

Gray, including grayish white, silver, and lavender.

Green, including yellowish green, grayish green, greenish, bright green, green, dull green, dark green, olive green, dull olive green, greenish brown, and greenish black.

Brown, including yellow brown, bright yellow brown, grayish brown, brownish, golden brown, light grayish brown, light purplish brown, purplish brown, light brown, bright brown, brown, light chocolate, chocolate brown, rich brown. dark brown, deep brown, and deep olive brown.

The following species are entirely yellow:

Comatella decora.

Comissia hispida.

Capillaster maria.

Comaster fruticosus.

Comaster serrata.

Comenthina schlegelii.

Comanthus annulata.

Catoptometra hartlaulbi, young.

Oxymetra aranea.

Lamprometra palmata.

Calometra discoidea.

Pterometra magnipeda. Asterometra macropoda. Asterometra anthus. Crotalometra porrecta. Crotalometra flava. Cosmiometra philippinensis. Cosmiometra aster. Stenometra diadema. Daidalometra arachnoides. Daidalometra hana. Parametra orion. 
Aglaometra propinqua.

Aglaometra eupedata.

Thalassometra villosa.

Thalassometru lusitanica.

Thalassometra omissa.

Pachylometra levigata.

Calyptometra lateralis.

Chlorometra garrettiana.

Strotometra hepburniana.

Antedon bifida.

Antedon mediterranea.
Antedon adriatica.

Toxometra paupera.

- Nanometra bowersi.

IIeliometra glacialis.

Promachocrinus kerguelensis.

Florometra asperrima.

Florometra serratissima.

Florometra perplexa.

Florometra maria.

Florometra laodice.

Trichometra vexator.

Pentametrocrinus, sp.

The following species are entirely brown:

Capillaster multiradiata.

$N$ emaster iowensis.

Comissia horridus.

Comanthus annulata.

Comanthus parvicirra.

Catoptometra havtlaubi.

Pontiometra andersoni.

Lamprometra palmata.

Tropiometra afra.

Tropiometra picta.

Pterometra pulcherrima.

Oceanometra gigantea.

The following species are entirely purple:

Comatula rotalaria.

Comatula purpurea.

Comanthus parvicirra.

Stephanometra echinus.

Stephanometra spicata.

'The following species are entirely red:

Comatulella brachiolata.

Heterometra crenulata.

Zygometra punctata.

Tropiometra picta.

The following species are entirely green:

Comissia peregrina.

Comissia scitulus.

Comanthus annulata.
Perissometra lata.

Pocilometra scalaris.

Antedon mediterranea.

Antedon adriatica.

Thysanometra tenelloides.

Psathyrometra fragitis.

Trichometra isis.

Thaumatometra tenuis.

Thaumatocrinus borealis.

Pentametrocrinus varians.

Pentametrocrinus japonicus.

Pentametrocrinus diomeder.
Tropiometra picta.

Antedon bifida.

Toxometra paupera.

Sarametra triserialis.

Psathyrometra erythrizon.

Antedon petasus.

Antedon bifida.

Antedon mediterranea.

Antedon adriatica.

Comanthus parvicirra.

Catoptometra ophiura.

Leptometra celtica. 
The following species are entirely violet:

Comatula rotalaria.

IIimerometra magnipinna.

Prometra chadwicki.

The following species are entirely orange:

Comanthus parvicirra.

Parametra crassicirra.
Tropiometra picta.

Dorometra nana.

Promachocrinus kerguelensis.

Parametra fisheri. Antedon bifida.

Antedon mediterranea.

The following species are entirely black:

Comatella nigra.

Comanthus annulata.

Heterometra bengalensis.

The following species is entirely gray: Antedon mediterranea.

Yellow occurs in combination in the following species:

Comatella nigra.

Capillaster clarki.

Comissia lütkeni.

Comaster parva.

Comaster minima.

Comantheria briareus.

Comanthus solaster.

Comanthus annulata.

Comanthus parvicirra.

Zygometra punctata.

Catoptometra magnifica.

PCatoptometra ophinera.

Catoptometra mibroflava.

IIeterometra crenulata.

Heterometra savignii.

Amphimetra discoidea.

IIomalometra denticulata.

Dichrometra döderleini.

Lamprometra protectus.

Lamprometra palmata.

Mariametra delicatissina.
Cenometra delicata.

Cyllometra albopurpurea.

Prometra chadwicki.

Oligometrides adeone.

Tropiometra pista.

Neometra conaminis.

Neometra multicolor.

Pectinometra flavopurpurea.

Gephyrometra versicolor.

Gephyrometra propinqua.

Calometra separata.

Oceanometra gigantea.

Daidalometra liana.

Parametra orion.

Lissometra alboflava.

Antedon bifida.

Antedon adriatica.

Eumetra chamberlaini.

Dorometra briseis.

Erythrometra miber.

Bathrometra prolixa.

IIeliometra glacialis.

White occurs in combination in the following species:

Capillaster multiradiata.

Capillaster clarki.

Comantheria briareus.

Comanthus parvicirra.

Zygometra microdiscus, young.

$Z_{\text {ygometra pristina. }}$

IIeterometra affinis.
Hetcrometra savignii.

Hetcrometra crenulata.

Amphimetra discoidea.

Lamprometra protectus.

Lamprometra palmata.

Cyllometra albopurpurea.

oligometrides adeona. 
Neometra conaminis.

Neometra gorgonia.

Neometra multicolor.

Pectinometra flavopurpurea.

Gephyrometra propinqua.

Calometra callista.

Calometra separata.

Pterometra pulcherrima.

Pterometra venusta.

Daidalometra hana.

Parametra orion.
Lissometra alboflava. Antedon petasus. Antedon bifida. Antedon mediterranea. Antedon adriatica.

Iridometra melpomene. Dorometra mauritiana. Dorometra nana.

Balanometra elongata. Perometra diomedece.

Erythrometra mubr.

\section{Hathrometra tenella.}

Purple occurs in combination in the following species:

Capillaster multiradiata.

Comanthus solaster.

Zygometra microdiscus, young.

Zygometra punctata.

Heterometra savignii.

Dichrometra döderleini.

Lamprometra protectus.

Lamprometra palmata.

Mariametra delicatissima.

Oligometrides adeona.

Tropiometra picta.

Neometra gorgonia.
Neometra multicolor.

Pectinometra flavopurpurea.

Calometra callista.

Gephyrometra propinqua.

Gephyrometra versicolor.

Calometra separata.

Ptilometra macronema.

Iridometra melpomene.

Eumetra chamberlaini.

Perometra diomedece.

Balanometra elongata.

Heliometra glacialis.

hed occurs in combination in the following species:

Comatella nigra.

Comantheria briareus.

Comanthus annulata.

Comanthus parvicirra.

Zygometra microdiscus, young.

Catoptometra magnifica.

-Catoptometra ophiura.

Catoptometra mubroflava.

Heterometra nematodon.

Heterometra crenulata.
Lamprometra protectus.

Oligometrides adeona.

Tropiometra picta.

Gephyrometra propinqua.

Pterometra pulcherrima.

Pterometra venusta.

Ptilonetra macronema.

Antedon petasus.

Antedon bifida.

Antedon mediterranea.

Erythrometra miber.

Brown occurs in combination in the following species:

Comaster minima.

Comaster parvus.

Comanthus parvicirra.

Heterometra savignii.

Amphimetra discoidea.

Lamprometra protectus.
Oligometrides adeonce.

Tropiometra picta.

Oceanometra gigantea.

Iridometra melpomene.

Dorometra briseis.

Heliometra glacialis. 
Violet occurs in combination in the following species:

Comatella stelligera.

Zygometra microdiscus, young.

$Z$ ygometra pristina.

Heterometra nematodon.

Heterometra affinis.

Heterometra crenulata.
Heterometra savignii. Amphimetra discoidea. Lamprometra protectus. ¿Lamprometra palmata. Cenometra delicata. Cyllometra albopurpurea.

Prometra chadwicki.

Green occurs in combination in the following species:

Comatella stelligera.

Capillaster clarki.

Comissia peregrina.

Comissia lütkeni.

Comantheria briareus.
Comanthus parvicirra.

Lamprometra protectus.

Dorometra mauritiana.

Dorometra nana.

Hathrometra tenella.

Orange occurs in combination in the following species:

Stephanometra spicata.

Pectinometra flavopurpurea.

Pterometra pulcherrima.

Antedon bifida.

Antedon mediterranea.

Antedon adriatica.

Heliometra glacialis.

IIathrometra prolixa.

Gray occurs in combination in the following species:

ISomalometra denticulata.

Oligometrides adeono.

Neometra multicolor.

Pcctinometra flavopurpurea.

Parametra orion.

Antedon mediterranea.

Black occurs in combination in the following species:

C'omaster parvus.

Comantheria briareus.
Lamprometra protectus.

Lamprometra palmata.

\section{Cyllometra albopurpurea.}

In the following species but one color occurs, which, however, is variegated with lighter and darker shades:

Orange : Stephanometra spicata.

Red: Antedon bifida, Antedon mediterranea, Antedon adriatica.

Brown: Dorometra briseis, II athrometra sarsii.

In the following species two colors occur:

Yellow and purple:

C'omanthus solaster.

Zygometra punctata.

Dichrometra döderlcini.

Lamprometra palmuta.

Cyllometra albopurpurea.

Yellow and red:

Comatella nigra.

Comanthus annulata.

Catoptometra magnifica.

Oligometrides adeonø.

Calometra separata.

Tropiometra picta.

Eumetra chamberlaini.

IIeliometra glacialis.

9 Catoptometra ophiura.

Catoptometra rubrofiava.

Tropiometra picta. 
White and red:

Comanthus parvicirra.

Pterometra venusta.

Heterometra crenulata. Antedon petasus.

Oligometrides adeona. Antedon bifida.

Antedon mediterranea.

White and violet:

Zygometra microdiscus, young. Amphimetra discoidea.

Zygometra pristina.

Lamprometra protectus.

Heterometra affinis.

Cyllometra albopurpurea.

White and purple:

Capillaster multiradiata.

Heterometra savignii.

I'eometra gorgonia.

White and yellow :

Veometrr conaminis.

Daidalometra hana.

Parametra orion.

Yellow and brown:

Comaster minima.

Comanthus parvicirra.

Amphimetra discoidea.

Yellow and violet:

Ileterometra crenulata.

Heterometra savignii.

Yellow and gray:

Homalometra denticulata.

Neometra multicolor.

White and brown:

IIeterometra snvignii.

White and green:

Capillaster clarki.

Hathrometra tenella.

White and black:

Lamprometra protectus, Lamprometra palmata, Cyllometra albopurpurea

Yellow and black: Comaster parvus, Comantheria briareus.

Yellow and green: Comissia lütkeni, Lamprometra protectus.

Yellow and orange: Antedon bifida, Hathrometra prolixa.

Orange and white: Antedon bifida, Antedon mediterranea.
Lissometra alboflava.

Antedon adriatica.

Cyclometra clio.

Tropiometra picta.

Gephyrometra versicolor.

Oceanometra gigantea.

Cenometra delicata.

Prometra chadwicki.

Pectinometra flavopurpurea.

Parametra orion.

Lamprometra palmata.

Dorometra mauritiana.

Dorometra nana. 
Red and violet: Heterometra nematodon, Heterometra crenulata.

Red and purple: Ptilometra macronema.

Red and orange: Antedon bifida.

Red and gray: Antedon mediterranea.

Green and violet: Comatella stelligera.

Green and brown: Comanthus parvicirra.

Brown and orange: Heliometra glacialis.

Orange and gray: Antedon mediterranea.

Gray and white: Oligometrides adeona.

In the following species three colors occur:

Yellow, red, and green: Comantheria briareus.

Yellow, red, and orange: Antedon bifida.

Yellow, purple, and white: Lamprometra protectus.

Yellow, purple, and violet: Mariametra delicatissima.

Red, white, and orange: Pterometra pulcherrima.

Red, white, and violet: Zygonetra microdiscus, young.

Brown, white, and purple: Iridometra melpomene.

In the following species four colors occur:

Yellow, orange, white, and purple: Pectinometra favopurpurea.

Yellow, brown, green, and white: Lamprometra protectus.

Yellow, brown, purple, and white: Lamprometra protectus.

Red, brown, purple, and white: Lamprometra protectus.

In the following species five colors occur :

Yellow, red, brown, purple, and white: Gephyrometra propinqua.

Thus white occurs in combination with

yellow, orange, red, purple, violet, black, gray, green, brown.

Yellow occurs in combination with

white. orange, red, purple, violet, l,lack, gray, brown, green.

Orange occurs in combination with

white, yellow, red, purple, gray, brown.

Red occurs in combination with

white, yellow, orange, purple, violet, gray, green, brown.

Purple occurs in combination with

white, yellow, orange, red, violet, brown.

Violet occurs in combination with white, yellow, red, purple, green.

Black occurs in combination with white, yellow.

Gray occurs in combination with

white, yellow, orange, red.

Green occurs in combination with

white, yellow, orange, red, violet, brown.

$\Lambda$ nd brown occurs in combination with

white, yellow, orange, purple, green. 
Expressing the above in different form it appears from the data at hand that, while white and yellow occur in all possible combinations, orange does not occur with violet, black, or green; red does not occur with black; purple does not occur with black, gray, or green; violet does not occur with orange, black, gray, or brown; black does not occur with orange, red, purple, violet, gray, green, or brown; gray does not occur with purple, vịolet, black, green, or brown; green does not occur with purple, black, or gray; and brown does not occur with red, violet, black, or gray.

It is of course true that this apparent incompatibility of colors is partly due to a lack of observations and to a misinterpretation of the colors as recorded, and the list must therefore be accepted with considerable reservation.

In particolored comatulids the distribution of the colors on the arms and pinnules falls into several well-marked types, which may be arranged as follows:

I. Arms and pinnules uniform in color:

(a) Arms and pinnules uniform in color, but differing in color from the cirri:

Lamprometra protectus.

Pectinometra flavopurpurea.

Ptilometra macronema. Antedon bifida. Antedon mediterranea. Antedon adriatica.

(b) Arms and pinnules uniform in color, but the ventral and dorsal surface of different colors:

Comatella nigra.

Capillaster multiradiata.

Dichrometra döderleini.

Heterometra nematodon. Amphimetra discoidea.

II. Pinnules of a different color from that of the arms :

(a) The distal portion of the pinnules (and usually also the arm tips) is of a different color from that of the proximal portion and the arms:

Comnster parvus.

Comantheria briareus.

Comanthus parvicirra.

Zygometra punctata.
Parametra orion.

Lamprometra protectus.

Cenometra delicata.

Oligometrides adeonw.

Pterometra venusta.

(b) All of the pinnules are of a color different from that of the arms:

Comissa lütkeni.

Comanthus solaster.

Comanthus parvicirra.

Hathrometra prolixa.

Balanometra elongata.

Heliometra glacialis.

Erythrometra ruber.

III. Arms and pinnules irregularly spotted, mottled, and blotched:

Zygometra microdiscus, young.

Heterometra sarignii.

Heterometra crenulata.

Lamprometra palmata.

Cyllometra albopurpurea.

Oligometrides aleona.

Tropiometra picta.

Giephyrometra propinqua.
Neometra gorgonia.

Antedon bifida.

Antedon mediterranea.

Antedon adriatica.

Dorometra mauritiana.

Dorometra nana.

Eumetra chamberlaini.

Perometra diomedece.

Hathrometra ienella. 
IV. Arms with more or less regular and uniform spots:

(a) Spots confined to the division series and arm bases:

Tropiometra picta.

Gephyrometra versicolor.

(b) Numerous small spots generally distributed:

Capillaster multiradiata.

Capillaster clarki.

Zygometra microdiscus, young.

Comantheria briareus.

Heterometra crenulata.

Pterometra pulcherrima.

Antedon mediterranea.

V. Arms with a median dorsal stripe:

(a) A broad median stripe, lighter or darker than the color on either side of it :

Comantheria briareus.

Tropiometra picta.

Gephyrometra propinqua.

Iridometra melpomene.

Balanometra elongata.

(b) A narrow median stripe, always very dark:

Comaster minima.

\section{Mariametra delicatissima.}

Oligometrides adeona.

VI. Arms conspicuously and regularly cross banded:

(a) With several more or less irregular broad bands:

Zygometra microdiscus, young. Calometra separata. Dorometra briseis.

(b) With a broad approximately central band:

Comatella stelligera.

Lamprometra protectus.

Capillaster multiradiata.

Neometra multicolor.

Stephanometra spicata.

Calometra callista.

Antedon petasus.

(c) With broad alternating bands of equal width:

Capillaster multiradiata.

Comantheria briareus.

Heterometra savignii.

Catoptometra magnifica.

iCatoptometra ophiura.

Catoptometra rubroflava.

(d) With narrow alternating bands of equal width:

Ileterometra crenulata.

Heterometra affinis.

IIomalometra denticulata.

Lamprometra protectus.

?Lamprometra palmata.

Cyllometri albopurpurea.

Neometra conaminis.
Neometra multicolor.

Pectinometra flavopurpurea.

Daidalometra hana.

Parametra orion.

Lissometra alboflava.

Antedon petasus.

Antedon adriatica.

Cyclometra clio.

(e) With narrow well-spaced bands:

Prometra chadwicki. Hathrometra sarsii. Tropiometra picta. 
From a cursory examination of preserved specimens it is evident that many additional species of which no color notes have been taken can be assigned to one or other of the classes given above, and also that specimens of a number of littoral species, chiefly belonging to the Stephanometridæ, occur in which each brachial bears a dark transverse band. The coloration of preserved specimens will be discussed later.

As a general rule the coloration of the pinnules follows that of the arms, but occasionally an abruptly different type is found:

I. Pinnules banded on each segment:

Capillaster clarki.

Pectinometra flavopurpurea.

This color type is found in a number of species as preserved, and in at least one case is a good specific character.

The cirri are usually unicolor, less commonly dull at the base, becoming gradually or abruptly brighter distally, and rarely show distinctive color types; when this occurs the color types are usually a reflection of the color types of the division series and arm bases, very rarely distinctive (Type I).

Particolored cirri, except those which are merely brighter distally, as in the case of the cirri of most of the species of Thalassometrinæ, fall into the following classes:

I. Each cirrus segment with a transverse band:

Zygometra microdiscus, young.

Zygometra punctata.

Heterometra nematodon. Calometra separata. Neometra multicolor.

II. Cirri unicolor, but of a color not found in the calyx or arms:

Zygometra pristina.

Ptilometra macronema.

Lamprometra protectus.

III. Cirri blotched or spotted:

Antedon petasus.

Oceanometra gigantea.

(a) Cirri with irregular blotches or irregular bands:

Comissia peregrina.

Comissia lütkeni.

Calometra separata.

Pectinometra flavopurpurea.

Daidalometra hana.

Neometra conaminis.

Cyclometra clio.

Eumetra chamberlaini.

Perometra diomedea.

(b) Cirri with small spots: Pterometra putchemima.

IV. Cirri longitudinally striped:

Lamprometra protectus.

Heliometra glacialis.

Longitudinal striping is characteristic of the cirri of a number of species of which no color notes have been taken.

The very young pentacrinoid is semiopaque, white or whitish, with the reddish brown visceral mass obscurely visible through the body wall. The first color to be assumed is usually yellowish white or yellow, and in Antedon bifida as the animal increases in size the body and the proximal portion of the arms gradually assume the characteristic red of the adults, while the distal portion of the arms remains sulphur yellow. 
This suggests that in Antedon we have a definite sequence of colors, from white through yellow to red, and later to reddish purple and purple, or to reddish brown and brown. But in certain other genera we find no such definite sequence of colors indicated; the very young apparently may develop almost any color directly from the white without passing through an intermediate hue.

This naturally suggests that it would be interesting to trace, so far as is possible, the development of one color from another, and thus to determine their relative ontogenetical and phylogenetical significance.

The regional distribution of the colors on the body of the adults offers a basis for such a study.

It is noticeable in the comatulids that the tips of the arms and of the outer pinnules, and the cirri, are usually less highly colored than the remaining portions of the animal, resembling in this respect regenerating arms.

It is reasonable to suppose that the color of the growing tip of the arm, which subsequently changes to the color of the earlier portion, represents a color phase through which the latter normally passes; in other words, that the general color of the animal is evolved through the color of the arm tips and of the tips of the distal pinnules.

The cirri are organs of very slow growth, and in unicolor species it is quite evident that the pigment develops much more slowly in the cirri than elsewhere. It is possible to assume, therefore, that the color of the cirri represents a stage through whicl the general color of the animal has passed; also it is possible to suppose that in the numerous cirri in which the outer portion is differently colored from the basal part the color of the latter, which is more highly developed, was derived through that of the former.

From the records given we deduce the following:

White arm and pinnule tips occur with the following colors:

$$
\text { Red ( } 2 \text { cases). }
$$

White cirri occur with the following colors:
Yellow (8 cases).
Purple ( 3 cases).
Red (2 cases).
Brown (5 cases).
Green ( 1 case).
Orange (1 case).
Violet (1 case).

Purple (1 case).

Yellow arm and pinnule tips occur with the following colors:
Purple (3 cases).
Black (1 case).
Green (2 cases).
Brown (1 case).
Violet (1 case).
Red (1 case).
Gray (1 case).

Yellow cirri nccur with the following colors:

Darker yellow ( 6 cases). Orange (1 case)

Purple (2 cases). Green (1 case).

Ornnge arm and pinnule tips occur with the following color:

Gray (1 case).

Brown (1 case).

Brown (1 case).

Orange cirri occur with the following color combination:

Red and yellow (1 case).

Red arm and pinnule tips occur with the following colors: Yellow (1 case).

Purple (1 case).

Violet (1 case).

Green (1 case). 
Red cirri occur with the following color:

Purple (2 cases).

Green arm and pinnule tips occur with the following color:

Brown cirri occur with the following color:

$$
\begin{aligned}
& \text { Brown (2 cases). } \\
& \text { following color: }
\end{aligned}
$$

Violet (1 case).

Yellow distal cirrus segments occur on basal segments which are

Purple, green, brown.

This gives us the following data:

Yellow is developed from (1) white in 8 cases;

(2) lighter yellow in 6 cases;

(3) red in 1 case.

Orange is developed from (1) white in 1 case;

(2) yellow in 1 case.

Red is developed from (1) white in 4 cases;

(2) yellow in 1 case.

Purple is developed from (1) yellow in 6 cases;

(2) white in 4 cases;

(3) red in 3 cases.

Violet is developed from (1) white in 1 case;

(2) yellow in 1 case;

(3) red in 1 case;

(4) brown in 1 case.

Black is developed from (1) yellow in 1 case.

(xray is developed from (1) yellow in 2 cases.

Green is developed from (1) yellow in 4 cases;

(2) brown in 2 cases;

(3) white in 1 case;

(4) red in 1 case.

Brown is developed from (1) white in 5 cases;

(2) yellow in 3 cases;

(3) orange in 1 case.

Or, expressed in the form of a table with the primary colors in columns and the derived colors listed vertically:

\begin{tabular}{|c|c|c|c|c|c|}
\hline & White. & Yellow. & Red. & Brown. & Orange. \\
\hline Yellow........... & 8 & 6 & 1 & & \\
\hline Brown............... & 5 & 3 & & & 1 \\
\hline Red .............. & 4 & 1 & & & \\
\hline $\begin{array}{l}\text { Purple } \ldots \ldots, \ldots, \ldots \\
\text { Green. . }\end{array}$ & $\begin{array}{l}4 \\
1\end{array}$ & $\begin{array}{l}6 \\
4\end{array}$ & $\begin{array}{l}3 \\
1\end{array}$ & $\cdots$ & \\
\hline Gray $\ldots \ldots \ldots \ldots$ & & 2 & & ....... & \\
\hline $\begin{array}{l}\text { Black........... } \\
\text { Violet........ }\end{array}$ & $i$ & 1 & & $\dddot{i}^{\cdots}$ & \\
\hline Orange.............. & 1 & 1 & & & \\
\hline
\end{tabular}


This would seem to indicate that all colors except gray and black may arise directly from white; and that yellow, red, and brown usually arise directly from white, while violet arises as often from white as from any other color.

All colors may develop (?secondarily through white) from yellow; gray and black arise only from yellow; and purple and green arise more frequently from yellow than from any other color.

Red frequently develops (?from white through yellow) into purple, and occasionally into yellow, violet, and green.

Brown develops into green and, less frequently, into violet.

Orange develops into brown.

It is worthy of mention that in Catoptometra rubroflava the cirri are orange-a color intermediate between the bright red and bright yellow of the arm bands.

The relative frequency of the different colors is shown in the following table:

Yellow occurs in a total of 88 species; alone in 45 ; combined in 43 .

White occurs in a total of 37 species; alone in 0 ; combined in 37 .

Brown occurs in a total of 36 species; alone in 24 ; combined in 12 .

Purple occurs in a total of 34 species; alone in 10 ; combined in 24.

Red occurs in a total of 20 species; alone in 8 ; combined in 21.

Violet occurs in a total of 19 species; alone in 6 ; combined in 13 .

Green occurs in a total of 17 species; alone in 7 ; conbined in 10.

Orange occurs in a total of 13 species; alone in 5 ; combined in 8 .

Black occurs in a total of 8 species; alone in 3 ; combined in 5 .

Gray occurs in a total of 7 species; alone in 1 ; combined in 6 .

At a depth of 55 fathoms in the sea the relative proportion of the red rays is considerably diminished, and at 300 fathoms they have almost completely disappeared. In a discussion of colors, color combinations, and color types and their relation to depth, therefore, it would seem that bathymetric divisions of $0-55$ fathoms, 55-300 fathoms, 300-600 fathoms, and 600 fathoms and over would be as satisfactory as any.

The bathymetrical distribution of the colors and color types is made clear in the following table:

\begin{tabular}{|c|c|c|c|c|c|c|c|c|c|c|c|c|}
\hline & \multicolumn{4}{|c|}{ Number of reeords. } & \multicolumn{4}{|c|}{ Pereentages. } & \multicolumn{4}{|c|}{$\begin{array}{l}\text { Percentage of all records for } \\
\text { the depth given. }\end{array}$} \\
\hline & $0-55$ & $\begin{array}{l}55- \\
300\end{array}$ & $\begin{array}{l}300- \\
600\end{array}$ & $\begin{array}{c}\text { Over } \\
600\end{array}$ & $0-55$ & $55-300$ & $300-600$ & $\underset{600}{\text { Over }}$ & $0-55$ & $55-300$ & $300-600$ & $\begin{array}{c}\text { Over } \\
600\end{array}$ \\
\hline $\begin{array}{l}\text { Tabulation of all the color } \\
\text { records.......................... }\end{array}$ & 121 & 70 & 30 & 13 & 51.7 & 30.0 & 12.8 & 5.5 & & & & \\
\hline $\begin{array}{l}\text { Entirely yellow species...... } \\
\text { Species with yellow in com- } \\
\text { bination......................... }\end{array}$ & $\begin{array}{l}19 \\
32\end{array}$ & $\begin{array}{l}23 \\
19\end{array}$ & $\begin{array}{r}12 \\
2\end{array}$ & $\begin{array}{l}8 \\
0\end{array}$ & $\begin{array}{l}30.6 \\
60.4\end{array}$ & $\begin{array}{l}37.1 \\
35.8\end{array}$ & $\begin{array}{r}19.4 \\
3.8\end{array}$ & $\begin{array}{r}12.9 \\
0\end{array}$ & $\begin{array}{l}15.7 \\
26.4\end{array}$ & $\begin{array}{l}32.9 \\
27.1\end{array}$ & $\begin{array}{r}40.0 \\
6.6\end{array}$ & 61.6 \\
\hline $\begin{array}{c}\text { Total occurrence of } \\
\text { yellow............... }\end{array}$ & 51 & 42 & 14 & 8 & 44.3 & 36.5 & 12.2 & 6.9 & 42.1 & 60.0 & 46.6 & 61.6 \\
\hline
\end{tabular}




\begin{tabular}{|c|c|c|c|c|c|c|c|c|c|c|c|c|}
\hline & \multicolumn{4}{|c|}{ Number of records. } & \multicolumn{4}{|c|}{ Percentages. } & \multicolumn{4}{|c|}{$\begin{array}{l}\text { Percentage of all records for } \\
\text { the depth given. }\end{array}$} \\
\hline & $0-55$ & $\begin{array}{l}55- \\
300\end{array}$ & $\begin{array}{r}300- \\
600\end{array}$ & $\begin{array}{c}\text { Over } \\
600\end{array}$ & $0-55$ & $55-300$ & $300-600$ & $\begin{array}{l}\text { Over } \\
600\end{array}$ & $0-55$ & $55-300$ & $300-600$ & $\begin{array}{l}\text { Over } \\
600\end{array}$ \\
\hline 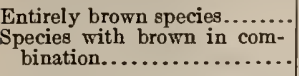 & $\begin{array}{r}11 \\
9\end{array}$ & 3 & 1 & 0 & $\begin{array}{l}36.6 \\
69.2\end{array}$ & $\begin{array}{l}23.3 \\
23.1\end{array}$ & $\begin{array}{r}30.0 \\
7.7\end{array}$ & 10.0 & $\begin{array}{l}9.1 \\
7.4\end{array}$ & $\begin{array}{r}10.0 \\
4.3\end{array}$ & $\begin{array}{r}30.0 \\
3.3\end{array}$ & 23.1 \\
\hline $\begin{array}{c}\text { Total occurrence of } \\
\text { brown............... }\end{array}$ & 20 & 10 & 10 & 3 & 46.5 & 23.3 & 23.3 & 6.9 & 16.5 & 14.3 & 33.3 & 23.1 \\
\hline $\begin{array}{l}\text { Entirely purple species........ } \\
\text { Speciss with purple in com- } \\
\text { bination........................ }\end{array}$ & $\begin{array}{r}8 \\
16\end{array}$ & $\begin{array}{r}1 \\
12\end{array}$ & 2 & $\begin{array}{l}0 \\
0\end{array}$ & $\begin{array}{l}72.7 \\
57.2\end{array}$ & $\begin{array}{r}9.1 \\
42.8\end{array}$ & $\begin{array}{r}18.2 \\
0\end{array}$ & 0 & $\begin{array}{r}6.6 \\
13.2\end{array}$ & $\begin{array}{r}1.4 \\
17.1\end{array}$ & $\begin{array}{r}6.6 \\
0\end{array}$ & 0 \\
\hline $\begin{array}{c}\text { Total occurrence of } \\
\text { purple............... }\end{array}$ & 24 & 13 & 2 & 0 & 61.5 & 33.3 & 5.1 & 0 & 19.8 & 18.5 & 6.6 & 0 \\
\hline 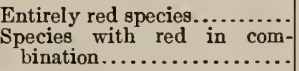 & 19 & $\begin{array}{l}0 \\
4\end{array}$ & 0 & $\begin{array}{l}0 \\
0\end{array}$ & $\begin{array}{r}100.0 \\
82.6\end{array}$ & 17.4 & 0 & 0 & $\begin{array}{r}6.6 \\
15.7\end{array}$ & 5.7 & $\begin{array}{l}0 \\
0\end{array}$ & 0 \\
\hline Total occurrence of red. & 27 & 4 & 0 & 0 & 87.1 & 12.9 & 0 & 0 & 22.3 & 5.7 & 0 & 0 \\
\hline $\begin{array}{l}\text { Entirely green species........ } \\
\text { Species with green in com- } \\
\text { bination..................... }\end{array}$ & $\begin{array}{r}5 \\
10\end{array}$ & $\begin{array}{l}5 \\
2\end{array}$ & 1 & 0 & $\begin{array}{l}45.5 \\
83.3\end{array}$ & $\begin{array}{l}45.5 \\
16.6\end{array}$ & $\begin{array}{r}9.0 \\
0\end{array}$ & 0 & $\begin{array}{l}4.1 \\
8.3\end{array}$ & $\begin{array}{l}7.1 \\
2.9\end{array}$ & $\begin{array}{r}3.3 \\
0\end{array}$ & 0 \\
\hline $\begin{array}{c}\text { Total occurrence of } \\
\text { green....................... }\end{array}$ & 15 & 7 & 1 & 0 & 65.2 & 30.4 & 4.4 & 0 & 12.4 & 10.0 & 3.3 & 0 \\
\hline $\begin{array}{l}\text { Entirely violet species......... } \\
\text { Species with violet in com- } \\
\text { bination........................ }\end{array}$ & $\begin{array}{r}5 \\
13\end{array}$ & $\begin{array}{l}1 \\
0\end{array}$ & $\begin{array}{l}0 \\
0\end{array}$ & $\begin{array}{l}0 \\
0\end{array}$ & $\begin{array}{r}83.3 \\
100.0\end{array}$ & $\begin{array}{r}16.6 \\
0\end{array}$ & 0 & 0 & $\begin{array}{r}4.1 \\
10.7\end{array}$ & $\begin{array}{r}1.4 \\
0\end{array}$ & $\begin{array}{l}0 \\
0\end{array}$ & 0 \\
\hline $\begin{array}{c}\text { Total occurrence of } \\
\text { violet............... }\end{array}$ & 18 & 1 & 0 & 0 & 94.7 & 5.3 & 0 & 0 & 14.8 & 1.4 & 0 & 0 \\
\hline $\begin{array}{l}\text { Entirely orange species........ } \\
\text { Species with orange in com- } \\
\text { bination................... }\end{array}$ & $\begin{array}{l}3 \\
7\end{array}$ & 3 & 1 & 0 & $\begin{array}{l}50.0 \\
70.0\end{array}$ & $\begin{array}{l}33.3 \\
30.0\end{array}$ & $\begin{array}{r}16.6 \\
0\end{array}$ & 0 & $\begin{array}{l}2.5 \\
5.5\end{array}$ & $\begin{array}{l}2.9 \\
4.3\end{array}$ & $\begin{array}{r}3.3 \\
0\end{array}$ & 0 \\
\hline $\begin{array}{c}\text { Total occurrence of } \\
\text { orange............... }\end{array}$ & 10 & 5 & 1 & 0 & 62.5 & 31.2 & 6.2 & 0 & 8.3 & 7.2 & 3.3 & 0 \\
\hline $\begin{array}{l}\text { Entirely black species........ } \\
\text { Species with black in com- } \\
\text { bination...................... }\end{array}$ & 3 & 0 & 0 & $\begin{array}{l}0 \\
0\end{array}$ & $\begin{array}{l}100.0 \\
100.0\end{array}$ & 0 & 0 & 0 & $\begin{array}{l}2.5 \\
4.1\end{array}$ & 0 & 0 & 0 \\
\hline $\begin{array}{l}\text { Total occurrence in } \\
\text { black................. }\end{array}$ & 8 & 0 & 0 & 0 & 100.0 & 0 & 0 & 0 & 6.6 & 0 & 0 & 0 \\
\hline 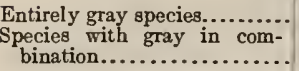 & 1 & $\begin{array}{l}0 \\
3\end{array}$ & 0 & 0 & $\begin{array}{r}100.0 \\
62.5\end{array}$ & 37.5 & 0 & 0 & 0.8 & 4.3 & 0 & 0 \\
\hline $\begin{array}{c}\text { Total occur } \\
\text { gray........ }\end{array}$ & 6 & 3 & 0 & 0 & 66.6 & 33.3 & 0 & 0 & 4.9 & 4.3 & 0 & 0 \\
\hline
\end{tabular}




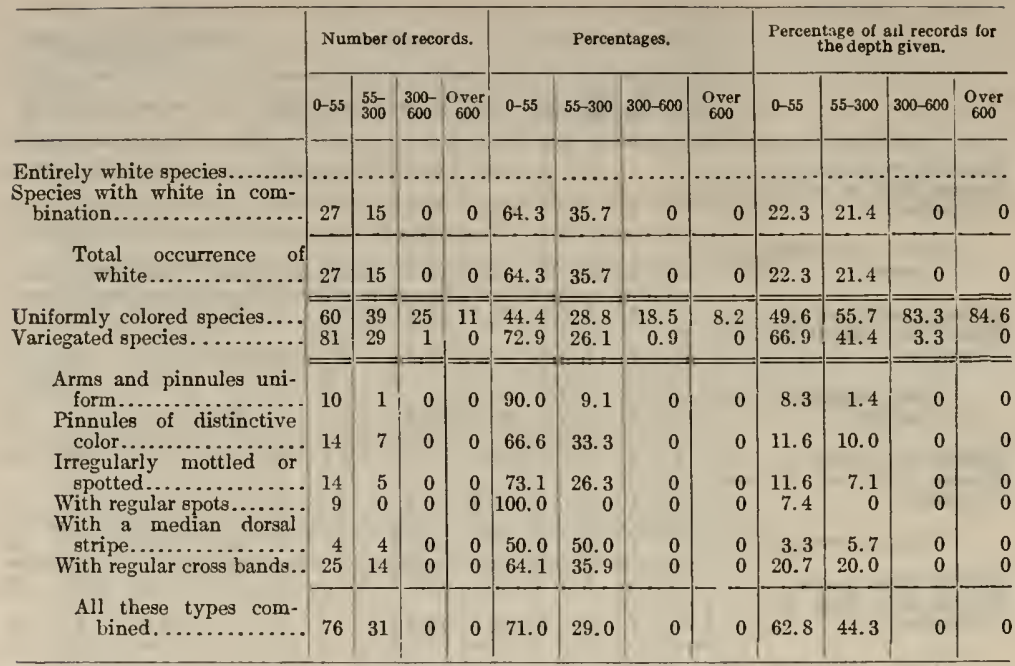

From this table it is evident that all colors occur in the littoral zone.

Black does not occur below 55 fathoms.

Red, violet, gray, and white do not occur below 300 fathoms.

Purple, green, and orange do not occur below 600 fathoms.

Yellow and brown occur at all depths.

Yellow and brown are relatively much more frequent below 300 fathoms than above.

Purple, green, orange, gray, and white occur in about the same relative proportions down to 300 fathoms, at that point decreasing abruptly or disappearing altogether.

Red, violet, and black decrease abruptly below 55 fathoms.

No colors are more frequent between 55 and 300 fathoms than clsewhere.

The proportion of uniformly colored species incrcases markedly with depth, while the corresponding decreasc in variegated species is even more abrupt.

All of the color types given occur only above 300 fathoms.

The median dorsal stripe is most common between 55 and 300 fathoms.

Distinctively colored pinnules and regular crossbands occur in about the same proportion down to 300 fathoms.

Distinctively colored cirri and irregular spotting or mottling are much more common above 55 fathoms than below.

Regular spotting occurs only above 55 fathouns.

No one color or combination of colors is of any definite systematic significance.

(ireen, however, is the distinctive color of many, most, or all specimens of a number of species scattered in widcly different groups. These are: 
Comissia scitulus.

Comaster serrata.

Comanthus annulata (many).

Catoptometra ophiura (most).

Lamprometra protectus (many).
Dorometra mauritiana.

Dorometra nana (most individuals).

Leptometra celtica.

Leptometra phalangium.

Hathrometra tenella.

Omitting these sporadic green species, we find yellow, deepening to brown, more rarely tending toward orange, often associated with white or nearly white cirri, to be characteristic of the following groups:

Antillean Capillasterinæ.

Thalassometrine (with few exceptions). Charitometridæ.

Thysanometrinæ.

Red, deepcning to purple and brown, is characteristic of the following group: Comactiniinæ.

Purple or purplish brown, with white cirri, is, except for the genus Leptometra, characteristic of the Zenometrinæ.

Mixed (either in the individual or in the species) yellow, red, purple, violet, white, and brown are characteristic of the following:

Zygometra.

Tropiometricle.

Ptilometrinæ.

Perometrine.

Red (deepening to purple) and ycllow (deepening to orange), with brown, gray, and white, are characteristic of

\section{Antedon.}

Red and yellow characterize most of the specimens of the species of Catoptometra.

Purple. white, brown. rellow. green. and black rharacterize, except for the genus Antedon, the

Antedoninæ.

Purple and yellow, deepening to orange and red,

Stephanomtridæ.

White, gray, yellow, orange. brown, and purple,

Calometridæ,

Eight or nine colors in all conceivable combinations:

Capillasterine (except West Indian). Himerometridx.

Comasterinae.

Mariametridæ.

Homalometra.

Colobometridæ (except West Indian).

Whereas the development of color in the crinoids seems to have a more or less definite relation to ilhmination, it appears to have no rclation whatever to the temperature of the water in which the crinoids live.

From the warm water of the tropical littoral the various colors range downward, as follows:

Yellow to $28.7^{\circ} \mathrm{F}$. White to $37.5^{\circ} \mathrm{F}$. Violet to $28.7^{\circ} \mathrm{F}$. Black to $37.5^{\circ} \mathrm{F}$.

$\operatorname{Red}$ to $40.6^{\circ} \mathrm{F}$.

Grity to $43.3^{\circ} \mathrm{F}$.

Brown to $32.8^{\circ} \mathrm{F}$. Green to $40.3^{\circ} \mathrm{F}$. Purple to $43.0^{\circ} \mathrm{F}$. 
The various color types are almost entirely confined to water of high or intermediate temperature. But this is undoubtedly due to the fact that the crinoids of the colder parts of the oceans belong to groups in which color patterns are not developed even in their tropical representatives.

This supposition is emphasized by the occurrence of several well-marked and beautiful colors types in the species of the genus Antedon, which are quite as well developed in the Scandinavian species as in those inhabiting the slores of northwestern Africa and the Mediterranean.

Antedon belongs to the subfamily Antedoninæ, which otherwise is confined to the Indo-Pacific region; and in its migration to the Atlantic basin it appears to have retained undiminished the group character of diversified coloration.

Geographically the maximum development of color diversity appears to be in the Malayan and north Australian region, and thence westward to Ceylon; but it is here also that the maximum development of littoral types is found. The whole littoral and intermediate fauna from east Africa to Oceania and southern Japan is notable for the diversity in the coloration of the endemic forms.

On the other hand, throughout the vast extent of the east and north Pacific we find the minimum diversity of crinoid coloration; all of the comatulids are unicolor, most of them yellow, becoming yellow brown, a few purplish brown; all of the stalked forms are yellow.

The crinoids of the Caribbean Sea, as known to-day, are much less lighlly colored than those of the Indo-Pacific region, and this holds good for stalked as well as for unstalked types. But here the groups which furnish the majority of the most variegated species, botl of the littoral and of the intermediate fauna, in the Indo-P'acific, the Comasterina, Zygometridæ, Himerometridæ, Stephanometridæ, Mariametridæ, Colobometridæ (except for the genus Analcidometra), Calometridæ, Ptilometrinie, and Antedoninæ (except for a single species of Antedon) are absent. The only littoral types are Antedon dïbenii, Tropiometra picta, which has a rather limited range and a fairly constant scheme of coloration, species of Nemaster which, so far as we know, are always uniform brown, and species of Comactinia which, as in the case of its eastern represcntatives, are practically unicolor.

In the remaining portions of the Atlantic (outside of the region of the Cape of Good Hope, where the Indo-Pacific fauna intrudes for a short distance) we note cspecially the presence of the highly colored species of Antedon, which range collectively from Rio de Janeiro to St. Thomas and from the Gulf of Guinea to Norway, including the Merliterranean basin; of the grcen species of Leptometra, which range from Madeira to Scotland, including the Mediterranean basin; and the sinall green or gray species of Mathrometru, which range from Chesapeake Bay and Portugal nortliward.

The coloring nutter of crinoids is freely soluble in fresh water and in alcoliol. It is possible to keep certain species for some time in water fresh enough to dissolve out a considerable amount of pigment without apparent injury, while many can be partially decolorized in a strean of fresh water while still alive. 
The solution given off in alcohol is often quite different in color from the animal itself. Thus the dark green Endoxocrinus wyvillethomsoni gives off a pink color, and the golden brown Nemaster iowensis a dark green color. A further discussion of these phenomena will be given in the section dealing with the coloring matter.

As a general rule comatulids preserved in alcohol, no matter what their original colors may have been, become brown, usually a yellowish, more rarely a purplish, reddish, or greenish brown, later slowly fading out to grayish white. The bands and spots often persist for some time, though with entirely changed color values. but they eventually disappear.

The color transformation undergone by specimens in alcohol is sometimes very striking. As instances I may mention that one of the most brilliant species with which I am acquainted in life, Catoptometra rubroflava, banded bright red and bright yellow, becomes a uniform reddish brown; the species of Antedon become uniform yellowish brown; and a brown and yellow specimen of Amphimetra discoidea became purplish brown and grayish white.

On account of the wonderful diversity of the colors in life and of the altogether extraordinary alteration of the colors by preservation, the greatest care is necessary in identifying living specimens, especially from descriptions based on preserved material, for the color may or may not be a good specific index; it usually is not. Several supposed species have been based upon color differences which would have remained undescribed had the specimens been allowed to fade before determination.

The color, and especially the color markings, of specimens in alcohol, which may or may not bear a definite relationship to the living colors, are always worth recording, for, strange as it may seem, they sometimes furnish an index of relationship more reliable than any which may be deduced from the far more diversified living colors.

From the evidence at hand the following conclusions seem justified:

1. White, which is the original color of the pentacrinoid young and occurs frequently in the adults, denotes the more or less complete absence of pigment.

2. (a) Yellow is the color of practically all of the more primitive forms, and of many of the more specialized, throughout life, and with very few exceptions (occurring in the brilliantly illuminated littoral), of small specimens and of advanced pentacrinoids.

(b) Orange or red, in reality an intensification of the yellow, is the color of a few primitive forms, and of nearly all the young which are not yellow.

3. After the full size has been reached a dusky factor makes its appearance which may be generally diffused or more or less localized, and deepens, alters, or obscures the original colors.

Apparently a careful distinction must be made between the greenish cast of such types as Phrynocrinus and Calamocrinus and the clear greenish yellow and green of the shallow-water species, and the "dusky purple" of certain pentacrinites and the brilliant purples and violets seen in littoral types. 
The greenish tinge in Phrynocrinus and Calamocrinus seems to result from the dusky age factor as seen through the normal brilliant yellow, while the "dusky purple" is possibly the age factor as modified by semiopaque white, and therefore comparable to the dusky purple spots seen in the eggs of such birds as the Tyrannidæ and Laridæ.

4. Illumination of the habitat results in

(a) An intensification of the natural colors and the rery early appearance of the dusky age factor.

The original color may be uniformly intensified, or the intensification may be more or less localized, resulting in the formation of blotches, spots, or bands.

Individuals from dark muddy bottoms or from deep holes or other sliaded situations are much lighter and less diversified in color than individuals of the same species from bottoms of broken shells, coral reefs, or other brilliantly illıminated locations. On coral reefs it has been noticed also that eren very small specimens a re often very dark in color.

(b) The appearance of a blue factor, resulting in the formation of bright greens, purples, and violet, which may deepen to black.

All the crinoids living below the limit of light penetration exhibit the basic colors, white, yellow, orange, or red only, which, though they may become more intense toward the calyx and arm bases, are never otherwise diversified. Each of these colors, however, may be modified by the dusky age factor, resulting in "dusky purple," greenish or brownish yellow, brown, orange brown, crimson, or red brown. The blue factor is absent from these species, but in the group as a whole it gradually increases from the limit of light penetration to the surface. causing the appearance of greens, purples, and violets of increasing intensity.

The development of color in the crinoids may be represented by the following scheme:

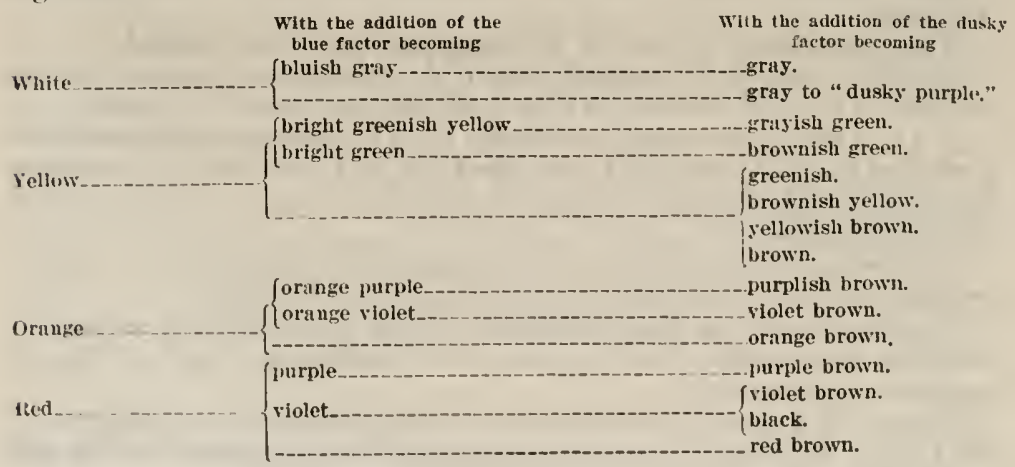

5. Temperature plays no part in the development of color in the crinoids. 
PIGMEN'T.

While on the Challenger in the East Indian region Prof. H. N. Moseley investigated the coloring matter of a number of comatulids and several pentacrinites. His facilities were necessarily limited, but he secured some very interesting results and was the first to demonstrate antedonin and pentacrinin. The value of his work was unfortunately somewhat lessened by the absence of definite identifications of the species he studied.

Some years later Krukenberg, in the course of his investigations at Trieste into the coloring matter of various marine invertebrates, made a detailed study of that of Antcdon adriatica; and in $1890 \mathrm{Dr}$. C. A. MacMunn published the results of numerous careful observations on such comatulid pigments as he was able to secure, including that of Antedon bifida.

From spectroscopic observations made during the voyage of the Challenger Professor Moseley determined the existence of three different pigments in the recent crinoids which he called purple pentacrinin, red pentacrinin, and antedonin.

Purple pentacrinin.-Spectroscopic observations were made on the pigment of the species listed below from the localities given:

Off the Kermadec Islands, 630 and 650 fathons: Hypalocrinus naresianus, Metacrinus nodosus, Metacrinus wyvillii.

Off the Kei Islands, 126 fathoms: Metacrinus angulatus, Metacrinus cingulatus, 9.1/etacrinus murrayi, Metacrinus nobilis, Metacrinus tuberosus.

Off Cebu, l'hilippines, 100 fathoms. $^{1}$

Between Panglao and Siquijor, Philippines, 375 fathoms; 9 Endoxocrinus alternicirus, ?IIypatocrinus naresianus, PMetacrinus murrayi. ${ }^{1}$

Off the Meangis Islands, 500 fathoms: Endoxocrinus alternicirrus, Hypatoerinus naresianus, Metacrinus costatus, Metacrinus moseleyi, ?Metacrinus murayi, . Metacrinus varians, Mctacrinus vyvillii.

Professor Moseley found that the majority of the specimens yielded a coloring matter which is extremely well defined by characteristic absorption spectra, and which he called pentacrinin.

When fresh the coloring matter is freely soluble in slightly acidified alcohol. and gires a solution which is of an intense pink color when viewed by transmitted light.

The solution when moderately intense gives a spectrum consisting of three bands. One of these, intensely black with sharply defined margins, covers the $\mathrm{D}$ line, extending for a rery short distance beyond the more refrangible side of that line, and for a greater distance on its other side toward the red, as was observed by viewing the spectrum with the bright sodium line in the field; the second, situated between $\mathrm{D}$ and $\mathrm{E}$, is most intense on its least refrangible border, and shades off toward the violet; the third band is a broad dim one stretching from $b$ to F. Very little of the red end of the spectrum is cut off. The whole of the violet is absorbed.

${ }_{1}$ In the Challenger report P. H. Carpenter does not mention the station off Cebu, and he questlons the correctness of the localfty of all three species said to have been obtalned off Panglao and Slquijor. Some or all of them may have come from off Cebu, as none of the specimens had definite locality laliels when they reached Carnenter's hands. 
In very intense solutions the absorption at the violet end spreads up to $b$ and unites with the third band, so that the light is entirely cut off up to $b$, where there is a defined dark edge; the second band is intensified and becomes blaek; the first band is black as before, but a paler band is added to it in continuation on its red side.

In more intense solutions the two principal bands broaden out and almost run together, being separated by a narrow interval of yellow.

The two principal bands coincide very nearly with those of turacin, ${ }^{1}$ the only difference being that the least refrangible band in turacin extends a little farther to the green side of $\mathrm{D}$ than does that of pentacrinin.

When the acid-alcohol solution is rendered alkaline by the addition of ammonia the solution bccomes of a bluish-green color, which shows a slight red fluorescence on the concentration of sunlight in it. The spectrum is also changed. An intensely black band now oecupies a space on the less refrangible side of $\mathrm{B}$; on the red side of $\mathrm{D}$ is a broad pale band, while the third band between $b$ and $\mathrm{F}$ remains as before, exeepting that it is intensified for rather more than lialf its breadth on its violet side. In very weak solutions the first and third bands remain visible after the middle one is lost.

The solution can be rendered acid or alkaline any number of times with corresponding changes in color and spectrum. By careful addition of ammonia in small quantities to the acid solution in a tall vessel one part of the solution ean be obtained green, while the remainder is still red. Thus the passage of one spectrum into the other may be seen at the junction of the two solutions. As the least refrangible band of the aeid spectrum fades it takes the form of a fine blaek line to the red side of $\mathrm{D}$ with a fainter margin extending just over $\mathrm{D}$ toward the green. As the ammoniacal portion of the solution is approached a dark broad band is seen to extend gradually toward the red from the least refrangible acid band up to the position of the least refrangible margin of the dark alkaline band in the extreme red. The least refrangible margin of the broad band darkens as the least refrangible acid band fades from view, and at length assumes the full intensity of the least refrangible alkaline band.

In a very strong solution or with weak transmitted light the broad band appears to extend the entire distance from the allaline band in the extreme red to D, while the entire violet and blue end of the spectrum is absorbed continuously as far as $b$.

l'y very careful neutralization of the solution a green fluid can be obtained which yields both acid and alkaline spectra showing four bands. In it the extreme red band of the alkaline solution and the intense band in the region of $D$ of the acid solution are seen of equal intensity, while the seeond band of the aeid spectrum is very faint. In the exactly neutral solution yielding four binds acil and alkaline peutacrinin appear to eoexist.

1 Turacin is the red or crimon coloring matter In the feathers of certain of the Musophagidip or planialn-eaters, a group of African blrd8. In solution It glves two absorption hands like thosc of oxyhnmoglobln. It is anld to contaln about o per cent of copper whlch can not be lsolated witbout destroylng tbe plgment. Turacin ts sald to wast ont of the fenthers rendily durfug the ralny scason, nnd also when the blrds bathe. 
The acid solution of pentacrinin when slowly evaporated and concentrated yields a precipitate, which, when collected and dried, appears as a dark violet amorphous powder. This substance, riewed by transmitted light as adhering to the filter paper and rendered transparent with glycerin, yields the same spectrum as the acid solution. The dried coloring matter is very sparingly soluble in absoulte alcohol, but freely soluble in this on the addition of a few drops of hydrochloric acid. It is not soluble in dilute hydrochloric acid alone, requiring the addition of alcohol to show the spectrum.

The fresh coloring matter is soluble in fresh water, but remains partly suspended, forming a slightly opaque dark purple solution, which gives, when quite fresh, a mixed acid and alkaline spectrum. When the aqueous solution is acidified the coloring matter becomes entirely dissolved and the fluid becomes clear and transparent and of a beautiful pink, yielding the same spectrum as the acidified alcoholic solution. When the intense watery solution is rendered alkaline a green flocculent precipitate is formed, and in a very intense solution the two outer bands, the most refrangible and the least refrangible, are lost, being encroached upon and included in the general absorption of the ends of the spectrum.

All the specimens obtained off the Kermadec Islands (representing Hypalocrinus naresianus, Metacrinus nodosus, and $M$. wyvillii) were of a uniform dusky purple when brought to the surface, being evidently colored by acid pentacrinin.

The specimens secured off the Meangis Islands represented seven species (Endoxocrinus alternicirnus, Hypalocrinus naresianus, Metacrinus costatus, $M$. moseleyi,,$M$. murrayi, $M$. varians, and $M$. wyvillii). Of these, three (Metacrinus costatus, $M$. varians, and $M$. wyvillii) were similarly colored uniform dusky purple, one being especially dark, while one (IIypalocrinus nareszanus) was of a light pinkish red and did not contain purple pentacrinin at all.

The specimens drcdged off the Kei Islands (representing Metacrinus angulatus, $M$. cingulatus, ?M. murrayi, $M$. nobilis, and $M$. tuberosus) when fresh had their stems almost white and their crowns light yellow or light reddish orange, showing no purple coloration at all.

Those obtained off Panglao and Siquijor (FEndoxocrinus alternicirmus, 9Hypalocrinus naresianus, and 9.Metacrinus murrayi) were almost colorless; nevertheless, when placed in alcohol they yielded a solution which was deeply colored sap green and which, when acidified, became of the usual deep pink of pentacrinin. Thus in these examples the pentacrinin, though present in great abundance, was entirely masked.

It is possible that these specimens would have shown an alkaline reaction in the fresh condition. Unfortunately the test was not made. The pentacrinin would be far less visible in the green alkaline condition.

Red pentacrinin.-Iypalocrinus naresianus gave a simple light red solution in absolute alcohol. This solution, when very intense, absorbed all the spectrum except a band of light between $\mathrm{E}$ and $\mathrm{B}$. When the solution was weaker it showed a single broad band in the region of $\mathrm{E}, b$, and $\mathrm{F}$, with some absorption of the ends of the spectrum. Addition of ammonia reduced the brightness of the color of the 
solution, and when added in quantity caused the absorption band to disappear. It lid not render the solution at all green.

Antedonin.-Moseley notes that the various species of comatulids appear to be usually either of a rose color or of an orange or yellow, running into a yellow brown, or of a dark purple. Both the rose or red and the yellow coloring matters are freely soluble in alcohol, and usually in fresh water.

The colored solutions obtained from a large number of such species dredged by the Challenger were examined, but none of them yielded a characteristic absorption spectrum showing bands. The Enropean species have similarly been found to yield a coloring matter free from bands. In the case of Antedon all the spectrum but the red is absorbed. Moseley found a purple species occurring at Suez (Tropiometra audouini) to yield a similar spectrum.

By dredging in from 8 to 12 fathoms in the channel between Somerset and Albany Island at Cape York, Queensland, a comatulid (probably Comatula rotalaria) was obtained in abundance which was of a dark purple color. The coloring matter was insoluble in glycerine, soluble to a large extent in fresh water, and abundantly soluble in weak spirits, and gives an intense fuchsin-colored solution. This, when compared with that obtained from a deep-sea holothurian found to contain the same coloring matter, is seen to be much redder, but it becomes pinker on dilution with alcohol, and at last quite pink and indistinguishable to the naked eye from that of the holothurian.

The solution when of moderate strength gives a spectrum consisting of three well-defined absorption bands. On using a very weak solution and gradually strengthening it the least refrangible band, being the most intense, appears first, and is visible in solutions which appear very slightly tinted indeed to the unassisted eye. The other two bands appear together. The midille band is at first darkest about $\mathrm{E}$. The most refrangible band, which is much less dark than the middle one, is of uniform intensity. Neither the red nor the violet ends of the spectrum are much absorbed.

When the solution is very strong all three bands become intense; the riolet disappears and all the light, except the red and yellow, becomes very faint. The bands remain as before, except that the middle band now appears of uniform intensity throughout. When the solution is renderel stronger still the least refrangible band extends gradually up toward $\mathrm{D}$, and the whole of the spectrum becomes absorbed except a band of light consisting of red with a little yellow.

On the addition of hydrochloric acid to the alcoholic solution the color changes to an orange, and the spectrum now consists of two bands, one lying to the red side of $\mathrm{E}$, the other to the violet side of $b$ and exterding to $\mathrm{F}$. These bands are in weak solutions separated by an interval of light. In very intense solutions the bands are joined by the absorption at the violet end of the spectrum, and the spectrum consists of a simple band of red, yellow, and green light. In solutions of internediate strength the two bands are connected by a clouding interrupted by brighter streaks. while the more refrangible band is dark just about the region of $F$, and has its main darkest mass separated from this dark narrow streak at $\mathrm{F}$ by a lighter interval. 
On the alcoholic solution being rendered alkaline by the addition of ammonia, it changes its color to a deep violet, and a flocculent purple precipitate is formed in it, which can readily be separated by filtration. The precipitate when dried appears as a violet amorphous powder which is insoluble in alcohol and oil of cloves, and can thus be rendered transparent and mounted in Canada balsam as adhering to the filter paper. This precipitate when dried yields the same spectrum as it does when suspended in solution, consisting of two bands.

The dried precipitate is insoluble in water, ether, and alcohol, but soluble in acidified alcohol, and then gives the original acid spectrum, and when this solution is carefully neutralized the original three-banded spectrum returns; but Moseley obtained it only faintly. Though a very large quantity of precipitate was removed by ammonia from a strong and original alcoholic solution, the solution still remained of a vivid color and gave its three bands. It was ouly after continuous addition of ammonia that the whole of the coloring matter was precipitated.

The coloring matter appears to require a proportionately increased quantity of ammonia to precipitate it as the solution becomes weaker. Both the dried coloring matter and the alcoholic solution have maintained their color and properties unimpaired after a lapse of two years.

Both pentacrinin and antedonin seem to be widely diffused in immense quantities throughout the tissues of the crinoids in which they occur.

Dr. C. A. MacMunn studied the coloring matter of a few species of comatulids. In particular Antedon bifida was examined, in order to settle the question of the presence of symbiotic algæe in the sacculi, this interpretation of these organs having been advanced by Vogt and Yung and vigorously denied by P. H. Carpenter and by Bury on histological grounds.

MacMunn says that the "pyriform oil cells" of Thomson, whiclı were supposed to be migrating amoboid spores of symbiotic algæ by Vogt and Yung, were easily seen by him, but that they are totally different in shape and structure from any symbiotic algæ which he has seen. They appear to him to be outgrowths from the surface of the pinnules, the flask-shaped ones being attached by the part representing the neck of the flask. Some which lie measured varied in size from about $10 \mu$ to $5 \mu$ in their long diameter, and from $6.25 \mu$ to $5 \mu$. in their short diameter. They are mostly homogeneous and yellowish green in color; some seemed to have granular contents, but these were of exceptional occurrence. MacMunn failed to find either starch or cellulose in these pyriform bodies.

Glycerine, water, and alcohol readily extracted the red coloring matter, but ether failed to do so, as it only became faintly yellow. The glycerine extract was a fine rose color. Spectroscopically a deep layer transmitted red and a little green, and in a shallow layer an ill-defined shading occupied the other half of the green. Ammonium sulphide discharged the color, leaving a faint yellowish tint, but no absorption bands were visible. Hydrochloric acid changed the color to pale yellow, the solution showing no bands, and ammonia changed it to a faint rose tint.

The aqueous solution gave the same kind of absorption as the glycerine solution, and showed in a thin layer only a faint shadow in the green. Ammonium sulphide discharged the color of such a solution, leaving only a faint reddish- 
yellow tint, and no bands appeared. Hydrochloric acid, as well as acetic acid, also destroyed the color of this solution.

The absolute alcohol solution was of a fine rose color; a deep layer transmitted the red rays and a little of the green, but in the deepest layers there was not a trace of a chloroplyyll band in the red. A shallower depth showed an ill-defined shading in the green, best marked toward its blue end. Ammonia discharged most of the color, leaving a faint reddish tint and some ill-defined shading at the blue end of the green. Hydrochloric acid destroyed the red color, changing it to yellow, and the solution now showed no bands.

The ether solution did not show a trace of a chlorophyll band in the red; it was of a pale yellow tint, and in a thin layer a faint, ill-defined band was seen at the blue end on the green. On evaporation it left a yellow residue, which becane a transient dirty green with sulphuric acid, and became more yellow with iodine in potassic iodide.

Therefore it would appear that the ether removed a yellow lipochrome and left the rose-red pigment untouched.

So far, then, it may be concluded that the intrinsic coloring matter of Antedon bificla is not identical with Moseley's antedonin, which will be described for purposes of comparison farther on, and that no chlorophyll is present. The absence of symbiotic algæ, threfore, may be safely inferred.

Krukenberg had previously examined the pigment of Antedon adriatica, and had referred to a band in the red evidently belonging to chlorophyll. He called the red pigment comatulin, and noticed that it, as well as the pigment of yellow and brown specimens, is soluble in sea water and in diluted alcohol, but insoluble in glycerine, ether, chloroform, benzol, carbon disulphide, turpentine, and almond oil, only going over into these solvents when water is present.

MacMunn remarks that it would appear that Krukenberg did not take the precaution of removing the contents of the stomach, which, when squeezed out, show the dominant and other chlorophyll bands well marked. He did not dry his specimens completely, which may account for the discrepancy in his results as compared with those of Krukenberg.

According to Krukenberg the red, brown, and yellow pigments from correspondingly colored specimens of comatulids are all related to each other, and none of them yield absorption bauls. He states that an extract of red comatulin becomes more yellowish by dilution, while an extract of yellow comatulin becomes more red by concentration. If a slightly purplish red solution of comatulin in dilute alcohol be evaporated on a water bath and the residue be cxposed to the light, the cherry red color changes first into an insignificant brownisl yellow, and this behaves exactly like the pigment obtained from brownish yellow species; later it gets lighter in color until finally it becomes bleached.

Diluted aqueous solutions of comatulin also undergo a similar change, but alcoholic solutions are more stable.

He also says that aqueons and alcoholic solutions are changed to orange or brownish yellow by lyylrochloric and acetic acids, and that the coloring matter 
separates; also that alkalies such as potash or ammonia precipitate the pigment with unchanged color.

PPtilometra mülleri.-An alcoholic solution of the coloring matter of what was probably this species was sent to Doctor MacMunn by Prof. F. J. Bell. It had a deep yellow color, being orange yellow by gaslight. It gave one band in orange and one in green, and strongly absorbed the violet end of the spectrum. A very deep layer transmitted only the red rays and showed a narrow faint band in red.

As the solution was too dilute for spcctroscopic observation it was evaporated in a vacuum. After some days' evaporation it left a fine red residue, which in thinner parts seemed yellow and had a pleasant smell, recalling that of Flustru foliacea. ${ }^{1}$

This residue went over easily into absolute alcohol, forming a fine red solution. A deep layer transmitted red only. A less deep layer gave definite bands, and a still shallower laycr somewhat different bands. These bands gave the following readings: First, $\lambda 598$ to $\lambda 589$; second, $\lambda 581$ to $\lambda 562$; and third, in a slightly more diluted solution, from $\lambda 549$ to $\lambda 520$.

On adding hydrochloric acid the color became more orange, less red, and the spectrum changed to that shown in his third figure; the bands reading, first $\lambda .589$ to $\lambda 580$, and second, probably composed of two bands, from about $\lambda 549$ to $\lambda .523$, the darker part about $\lambda 532-523$.

Ammonia added to an alcoholic solution made the color a darker red and caused slight precipitation. A deep layer transmitted red only, while in a shallower layer a broad ill-defined band in green was seen. When to this solution ammonium sulphide was added this band disappeared, but no new ones came into view. When an alcoholic solution was treated with ammonium sulphide the fluid seemed redder, and only general absorption of all rays except the red was seen. In thin layers a faint haze was seen in the green, but no bands.

On treating an alcoholic solution with acetic acid it became a lighter red, and the spectrum changed so that the bands read: First, from $\lambda 597$ to $\lambda 581$ and shading to $\lambda 562$, and, second, in its darker part from $\lambda 538$ to $\lambda 521.5$, the violet being abruptly absorbed.

Caustic soda changed the color of an alcoholic solution to a darker red, and on diluting still further the color became rose red. The spectrum was the same as with ammonia.

Nitric acid produced the same effect as hydrochloric, the color changing to orange, and bands like those in the third spectrum appearing, the dark part of the first band reading from $\lambda 589$ to $\lambda 579$ and having a shading on each side of it, and the second band extending from $\lambda 549$ to $\lambda .523$ with its half toward violet more shaded than that toward red.

Sulphuric acid also changed the color of an alcoholic solution to orange, and the bands were exactly the same as with nitric acid.

The acid spectrum could be changed into the alkaline by an excess of caustic soda.

${ }^{1}$ Alcohollc specimens of several specles are remarkable for their pleasant odor. Tropiometra picta, $T$. macrorliscus, and Ptilometra millleri and $P t$. macronema smell much like rlpe purple plums. 
The residue left by the evaporation of an alcoholic solution was freely soluble in ether, chloroform, carbon disulphide, benzine, and water, but insoluble in glycerin. It became a kind of violet with iodine in potassium iodide, a dirty yellow-brown with nitric acid, and a kind of orange with sulphuric acid.

l'alaocomatella difficilis, Calometra discoidea, Asterometra longicirra, Stenometra quinquecostata, Parametra compressa, Perissometra flexilis, P. patula, $P$. robusta, Strotometra parvipinna, C'yllometra manca, Adelometra angustiradia, and Perometra pusilla.-As this solution was very dilute it was evaporated in a vacuum, and left a deep yellow residue. Dissolved in alcohol this furnished a yellow solution approaching orange. In this no bands were visible, but it absorbed the violet end of the spectrum. The other characters resembled those of the pigment of Antedon bifida. The residue became a dark brown-violet with sulphuric acid, and was scarcely changed by nitric acid.

Aglaometra valida, Thalassometra pergracilis, Perissometra angusticalyx, Chondrometra aculeata, Pcecilometra accela, Nepiometra lavis, and Thaumatocrinus naresi.-The yellow solution on evaporation in a vacuum left a kind of purplish brown residue which dissolved in rectified spirits with an orange color. It strongly absorbed the violet end of the spectrum, but showed no distinct bands. There was a feehle shading present in green and a rery faint one at $\mathrm{D}$; the latter became more distinct on the addition of caustic potash, which made the fluid redder. There was not enough pigment left for further examination.

Comasterid from Banda. ${ }^{1}$ - Carpenter believes that it was from this that Professor Moseley obtained his antedonin. The solution had a faint yellowish red tint and showed two faint bands in the green, which MacMunn took for those of antedonin. On evaporation in a vacuum a dull red residue was left; this was soluble in alcohol and gave the antedonin bands faintly. By the action of acids and alkalines it was evident that antedonin, somewhat altered by time, was present. No lipochrome could be detected in the residue.

Large comasterid from Banda. ${ }^{1}$-The solution was yellow, and on evaporation in a vacuum left a violet brown residue soluble in alcohol, with a violet red color in deep layers, and orange in thinner ones. When dissolved in alcohol it strongly absorbed the violet end of the spectrum and showed no distinct bands. Hydrochloric acid made the color paler, approaching yellow, and no bands were seen. Caustic potash made the fluid redder and caused a faint shadow to appear at D, while a precipitate formed. The residue became yellow with nitric acid, and brown with sulphuric acid.

Comatula rotalaria from Cape York.-The alcoholic solution was deep yellow, and somewhat reddish in a deep layer. On evaporation in a vacuum it left a red residue containing crystals of chloride of sodium. The rectified spirit extract was reddish in deep and yellow in thin layers, and this gave a faint antedonin spectrum. The residue was also soluble in chloroform, the solution strongly absorbing the violet end of the spectrum and showing some faint bands in green.

${ }^{2}$ The comfsterids obtained by the Challengcr at Banda were Caplliaster nentosa, C. multiradiata, Comaster multbrachtata, Comantherfa briarcus, Comanthina schlegelt, Comanthus annulata, and C. parvicirra. 
It was also partially soluble in ether, the solution showing a faint antedonin spectrum. Hydrochloric acid changed the red color to yellow; caustic soda intensified the color, and then a feeble shading was seen close to D; ammonia produced the same change.

Comatella stelligera.-This gave a yellowish solution which on evaporation in a vacuum left a yellowish brown residue, soluble in rectified spirits with a yellow color; this absorbed the violet, but showed no bands. Hydrochloric acid left the color of the solution unchanged; with caustic potash it became a brownish yellow, but showed no bands. The residue failed to give the lipochrome reactions.

\section{ECONOMIC VAIUE OF THE RECENT CIRNOIDS.}

Economically the crinoids serve no useful purpose-at least up to now they have been put to none. They can not be eaten, and they are not eaten by any fish or other animal that serves as human food.

Owing to their ordinarily fixed mode of life it is possible that they might be used to furnish an index of the density of the finer plankton content of the water in which they live, though it is probable that other more generally distributed animals with more or less similar feeding habits would serve this purpose better.

Because of their beanty and delicacy of form, as well as on account of their rarity, they are frequently preserved and offered for sale as curios in Japan and China, and, less frequently, in India, Oceania, Australia, and the West Indies.

In southern Japan crinoids are frequently brought up on the long lines used for fishing in deep water in Sagami Bay. The unstalked crinoids, because of their beauty and delicacy of form, are called "komachi"-a name originally borne by an exceptionally well-favored lady of the court upward of a thousand years agro-while the stalked form (Metacrinus rotundus) is known as the "bird's foot." The former when well preserved are sometimes sold as curios, while the latter always meet with a ready sale at extraordinarily high prices on account of their rarity, combined with their palæontological interest.

In China comatulids are sometimes offered for sale which have been brought from a considerable distance.

At Barbados the local species of Isocrinus, especially 1. asteria, and Holopus rangii, are occasionally to be found in the curio shops.

A mong the slavic peoples red is the color about which all their abstract ideas of beauty, and hence of idealism, revolve. The delicate and often gorgeously colored red Adriatic Feather Star (Antedon adriatica) occurs more or less abundantly along the coasts of the largely slavic provinces of Istria and Dalmatia, where it is frequently found in the fishermen's nets and is sometimes brought up on their hooks. Its beauty of form, and particularly its red color, especially commend it to the local fishermen, who commonly take it to market and exhibit it along with the fish offered for sale. 



\title{
EXPLANATION OF PIATES.
}

Plate 1.

\author{
Radial Pentagons and Ratial Articular Faces of Various Comatulids.
}

Fra. 950.-Comatella stclligera, lateral view of radials and centrodorsal. (After P. H. Carpenter.)

951.-Same. (After P. H. Carpenter.)

952.-Same species, ventral view of radial pentagon. (After P. H. Carpenter.)

953.-Comatclla maculata, ventral view of radial pentagon. (After P. H. Carpenter.)

954.-Same, lateral view of radials and centrodorsal, (After P. H. Carpenter.)

955.-Neocomatella pulchella, two adjacent radial articular faces. (After P. H. Carpenter.)

956. -Nemaster rubiginosa, lateral riew of radials and centrodorsal. (After P. H. Carpenter.)

957.-Same, ventral view of radial pentagon. (After P. H. Carpenter.)

958. Comatula rotalaria, two adjacent radial articular faces. (After P. H. Carpenter.)

959.-Same, ventral view of radial pentagon. (After P. H. Carpenter.)

960,-Comatula solaris, lateral view of radials and centrodorsal. (After P. H. Carpenter.)

961.-Same, ventral view of radial pentagon. (After P. H. Carpenter.)

962.- Same, ventral riew of radial pentagon. (After I'. H. Carpenter.)

963.-Comactinia meridionalis, lateral view of radials and centrodorsal. (After P. H. Carpenter.)

964.-Same, ventral view of ridial pentagon. (After P. H. Carpenter.)

965.-Comanthus parvicirra, lateral view of radials and centrodorsal. penter.)

966.-Same, ventral view of radial pentagon. (After P. H. Carpenter.)

967.-Same. (After P. H. Carpenter.)

968.-Same. (After P. II. Carpenter.)

Plate 2.

\section{Radial Pentagons of Tarious Comatulids.}

F16. 969.-Cyllometra disciformis, lateral view of radials and centrodorsal. (After P. H. Carpenter.)

970.-Same, ventral riew of radial pentagon. (After P. H. Carpenter.)

971.-Tropiometra carinata, lateral view of radials and centrodorsal. penter.)

972.-Same, rentral view of radial pentagon. (After P. H. Carpenter.)

973.-Ptilometra maeronema, lateral view of radials and centrodorsal. penter.;

974. - Same, ventral view of radial pentagon. (After P. H. Carpenter.)

975.-Stiremetra breviradia, lateral view of radials and centrodorsal. penter.)

976.- Same, rentral view of radial pentagon. (After P. H. Carpenter.)

977.-Same, another specimen. lateral view of radials and centrodorsal. (After P. II. Carpenter.)

978. - Same specimen, ventral view of radial pentagon. (After P. H. Carpenter.)

979. - Stcnometra quinquecostata, lateral view of radials and centrodorsal. (After P. H. Carpenter.)

9S0.-Same, ventral view of radial pentagon. (After P. H. Carpenter.) 
Plate :.

Radial Pentagons of Various Comatulids.

1.1G. 981.-Thalassomctra agassizii, lateral view of radials and centrodorsal. (After Hartlaub.) 982.-Same, dorsal view of radial pentagon. (After Hartiaub.)

983. - Same, ventral view of centrodorsal. (After Hartlaub.)

9S4.-Perissometra angustical $/ / x$, lateral view of radials and centrodorsal. (After P. II. Carpenter.)

955.-Same, ventral view of radial pentagon. (After P. H. Carpenter.)

as6.-Pachulometra innqualis, lateral view of radials and centrodorsal. (After P. H. Carpenter.)

957.-Same, ventral view of radial pentagon. (After P. H. Carpenter.)

988. - Pocilometra accla, lateral view of radials and centrodorsil. (After P. I. Carpenter.) 989.-Same, ventrai view of radial pentagon. (After P. H. Carpenter.)

990.-Charitometra basirurra, lateral view of radials and centrodorsal. (After P. H. Carpenter.)

991.-Same, ventral view of radial pentagon. (After P. H. Carpenter.)

192.-Charitometra incisa, lateral riew of radials and centrodorsal. (After P. H. Carpenter.)

993.-Same, ventral view of radial pentagon. (After P. H. Carpenter.)

Plate 4.

Radial Pcntagons of V'arious Comatulids.

Fio. 994.-Antedon bifida, lateral view of radials and centrodorsul. (After P. H. Carpenter.) 995. - Same, ventral view of radial pentagon. (After W. B. Carpenter.)

996.-Same. (After P. H. Carpenter.)

997.-Solanomctra antarctica, lnteral vlew of radials and centrodorsal. (After P. II. Carpenter.)

998.-Same, ventral view of radial pentagon. (After P. H. Carpenter.)

999.-Heliometra glacialis, lateral view of radials and centrodorsal. (After P. II. Carpenter.)

1000.-Same, ventral view of radial pentagon. (After P. H. Carpenter.)

1001.-Promachocrinus kerguelensis, lateral view of radials and centrodorsal. (After P. H. Carpenter.)

1002.-Same, ventral view of radial pentagon. (After P. H. Carpenter.)

1003.-Leptometra celtica, lateral view of radials and centrodorsal. (After P. If. Carpenter.)

1004.- Inother specimen of same, lateral view of radials and centrodorsal. After P. H. Carpenter.)

1005.-Same, ventral view of radial pentagon. (After I. H. Curpenter.)

1006.-Pentametrocrinus semperi, lateral view of radials and centrodorsal. (After I'. H. Carpenter.)

100T.-Sime, ventral view of radial pentagon. (After P. II. Carpenter.)

I'XATE 5.

Radials and Centrodorsal of Florometra.

Fis. 1008.-Florometia tanneri, radiul articular face. (After IIartiaub.)

1000. - Florometra perplexa, radial articuiar face. (After IIartiaub.)

1010.- Same, Inner sile of radial, (After Hartlaub.)

1011. - Sane, laterai view of radials and centrodorsal, (After Inartlaub.)

1012.-. Same, ventral view of radial pentagon. (After Inartaub.)

1013. - Sume, ventral view of centrolorsal. (After Yartiaub.)

1014.- Same, fiorsil view of radlal nentagon, without rosette. (After IIartiaub.) 
Plate 6.

Arm structure of comatulids.

Fic. 1015.-Dorsal riew of proximal portion of specimen of Comanthus parvicirra, with homologies of ossicles Indlcated. (Adapted from P. H. Carpenter.)

1016.-Lateral view of proximal portion of specimen of Pentametrocrinus semperi, with homologies of ossicles Indicated. (Adapted from P. H. Carpenter.)

Plate 7.

Arm structure of comatulid8.

Fic. 1017.-Central portion of speclmen of Comanthus parvicirra in dorsal view, with atrophied left posterior arm. (After P. H. Carpenter.)

1018. - Central portion and part of an arm of type specimen of Antedon dïbenil in dorsal view, with homologies of ossicles indicated. (Adapted from P. H. Carpenter.)

Plate 8.

Arm structure of comatulid8.

Frg. 1019.-Central portion and part of arm of Comactinia meridionalis in dorsal view, with homologles of ossicles indicated. (Adapted from P. H. Carpenter.)

1020.-Central portion and part of two arms of specimen of Comatula rotalaria, with homologles of ossicles indicated. (Adapted from P. H. Carpenter.)

Plate 9.

Arm structure of comatulids.

FIG. 1021.-Dorsal view of proximal portion of specimen of Comantheria briareus, with bomologies of ossicies indicated. (Adapted from P. H. Carpenter.)

1022.-Dorsal vlew of proximal portion of speclmen of Capillaster multiradiata, with homologies of ossicles Indicated. (Adapted from P. H. Carpenter.)

1023.-Dorsal view of proximai portion of two post-radial series of Comaster novaguinea, with homologies of ossicles lndicated. (Adapted from I. H. Carpenter.)

Plate 10.

Arm structure of comatulids.

F16. 1024.-Dorsal view of proxlmal portion of speclmen of Comanthus trichoptera, with homologies of ossicles indicated. (Adapted from P. H. Carpenter.)

1025. -Dorsal view of proximal portlon of specimen of Comanthus parvicirra, with homologies of ossicles indicated. (Adapted from P. H. Carpenter.)

1026.-Dorsal view of proxlmal portion of specimen of Capillaster sentosa, with bomologies of ossicles indicated. (Adapted from P. H. Carpenter.)

Plate 11.

Arm structure of comatulids.

Fic. 1027.-Distal arm division in specimen of Dichrometra döderleini.

1028. - Centrodorsal and arms bases of specimen of Psathyrometra bigradata, showing (to the left) a regenerating arm. (After Hartlaub.)

1029.--Dorsal view of proximal portion of two post-radial series of specimen of Comaster multibrachtata, with homologies of ossicles indlcated. (Adapted from P. H. Carpenter.)

$142140-21-$ Buil. $82-50$ 
Plate 12.

Arms and pinnules of various comatulids.

Fua. 1030.-Arm and piunules of Comantheria briareus. (After P. H. Carpenter.)

1031.-Braehials of Capillaster 8cntosa. (After P. H. Carpenter.)

1032.-Braehlals of Capillaster multiradiata. (After P. H. Carpenter.)

1033.-Distal braehials of Pentametrocrinus semperi. (After P. H. Carpenter.)

1034. -Tip of posterior arm of Comanthus particirra, showing paired terminal pinnules and spherodes.

1035. -Tip of anterior arm of Comanthus parvlcirra.

1036. - Braehials of Comanthus trichoptera. (After P. H. Carpenter.)

1037.-Ventral view of portion of ungrooved posterior arm of Comanthus particirra. (After P. H. Carpenter.)

1038. - Ventral view of portion of normal arm of Comanthus pariviclra. (After P. H. Carpenter.)

1039.-Part of posterfor arm of Comanthus parviclrra, showing spherodes. (After P. H. Carpenter.)

1040.- $\mathrm{P}_{1}$ and $\mathrm{P}_{2}$ of Antedon dübenii. (After P. H. Carpenter.)

1011.-Bases of earler pinnules of Comatella stelligera, showing carinate proeesses on first two segments. (After P. H. Carpenter.)

1042. - Varletal form of second or third pinnule of Coccometra hagenii. (After Hartlaub.) 1043.- $\mathrm{P}_{1}$ of Capillaster multiradiata. (After P. H. Carpenter.)

1044.- Lower pinnules of Antedon bifida as earried in life. (After W. B. Carpenter.)

Plate 13.

Pinnules of various comatulids.

Fic. 1045.-Pinnule on $111 \mathrm{Br}$ series of Zygometra microdiscrs. (After P. H. Carpenter.) 1046. - $\mathrm{P}_{2}$ of pentacrinold of Hathrometra sarsii shown in fig. 1220. (After M. Sars.) 1047. $-\mathrm{P}_{1}$ of Coccometra hagenii. (After Hartlaub.)

1048.-Same. (After Hartlaub.)

1049. - Same. (After Hartlaub.)

1050.-Proximal plnnules of Thalas8ometra agassizii. (After Hartlaub.)

1051.- $\mathrm{P}_{2}$ of Capillaster sentosa. (After P. H. Carpenter.)

1052.-Basal pinnule of Zygometra microdiscus. (After P. H. Carpenter.)

1053.- $\mathrm{P}_{2}$ of Florometra perplesa. (After Hartlaub.)

1054.-Distal end of $P_{1}$ of Florometra tanneri. (After Hartlaub.)

Plate 14.

l'innules of various comatulids.

Fig. 1055.-Cunrooved genital pimule of Perissomctra angusticalyx. (After P. H. Carpenter.) 1056.- $\mathrm{P}_{2}$ of Coccometra hagenii. (After Hartlaub.)

1057. - Lateral view of genital pinuule of P'ccilometra acœh. (After I'. II. Curpenter.) 1058. - Ventrill rlew of genital plnnule of Pocilometra acala. (After I. H. Carpenter:) 1059. - P'innules of outer half of nrm of Thalas8onctra agassizii. (After Ifartlaub.)

1060.-Mlldle pinmule of Zygomctra microdiscus. (After P. H. Carpenter.)

1061.-Genltal plnnules of Pocilomctra acala. (After I'. H. Carienter.)

1062.-Grooved genitai plnnuie of Aglaometra incerta. (After P. 11. Carpenter.)

1063.-I'lnnule of 25th brachial of Coccometra hagcnii. (After Hartluub.)

10f.t.-P', of Coccometra hagenil. (After Hartlauh.)

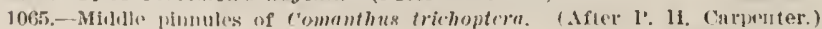


Plate 15.

Pinnules of various comatulids.

Frg. 1066.-Forked pinnule of Hathrometra prolixa. (After Mortensen.)

1067.-Base of same. (After Mortensen.)

1068.-Terminal pinnule of Capillaster multiradiata. (After P. H. Carpenter.)

1069.-Terminal pinnule of Capillaster sentosa. (After P. H. Carpenter.)

1070.-Middle pinnules of Florometra tanneri. (After Hartlaub.)

Plate 16.

Fic. 1071.-Antedon bifia, drawn from life. (After W. B. Carpenter.)

Plate 17.

Terminal combs of rarious comasterids.

FrG. 1072.-Comactinia meridionalis. (After P. H. Carpenter.) 1073.-Comaster multibrachiata. (After P. H. Carpenter.) 1074.-Comanthina schlegelii. (After P. H. Carpenter.) 1075.-Same. (After P. H. Carpenter.) 1076.-Comanthus annulata. (After P. H. Carpenter.) 1077.-Comantheria briareus. (After P. H. Carpenter.) 1078.-Comanthus trichoptera. (After P. H. Carpenter.) 1079.-Comanthus particirra. (After P. H. Carpenter.) 1080.-Same. (After P. H. Carpenter.) 1081.-Same. (After P. H. Carpenter.) 1082.-Same. (After P. H. Carpenter.)

\section{Plate 18.}

Prorimal brachials of Antedon bifida. (After W. B .Carpenter.)

Fic. 1083.-Second brachlal, dlstal articular face.

1084.-Same, proximal articular face.

1085.-Same, lateral face.

1086.-Same, ventral face.

1087.-Same, dorsal face.

10ss.- First syzygial pair (third and fourth brachials), proximal face.

1089.-Third brachial, distal face.

1090.-First syzygial pair, ventral frce.

1091.-Same, lateral Pace.

1092.-Same, dorsal face.

1093.-Fourth brachial, distal face.

1094.-Same, proximal face.

1095.-Same, lateral face.

1096.-Same, ventral face.

1097.-Same, dorsal face. 


\section{Plate 19}

Proximal brachials of Antedon bifda. (After W. B. Carpenter.)

Fro. 1098.- $\mathrm{IBr}_{1}$, proximai face.

1099.-Same, distal face.

1100. - Same, ventral face.

1101. - Same, dorsal face.

1102.- $-\mathrm{IBr}_{2}$ (axlllary), distai face.

1103.-Same, proximal face.

1104.-Same, ventral face.

1105.-Same, dorsal face.

1106. - First brachlal of the free undivided arm, proximal face.

1107.-Same, distal face.

1108.-Same, dorsal face.

1109.-Same, ventral face.

Plate 20.

Proximal brachials of Antedon bifia. (After W. B. Carpenter.)

Fro. 1110.-Fifth brachlal, distal face.

1111.-Same, proximal face.

1112.-Same, plnnule socket.

1113.-Same, veutral face.

1114. - Same, dorsal face.

1115. - Brachlal from about the middle of the a rm, proxlmal face.

1116. - Same, distal face.

1117.-Same, iateral vlew.

1118.-Radial, articular face.

1119.- $\mathrm{IRr}_{2}$ (axlilary) of pentacrinold at time of detachment from iarri column, exteruai view.

11:0.- Same, Internal vlew.

1121.- $\mathrm{IBr}_{1}$ of pentacrinold at time of detachment from larval column, internai vlew.

1122.- Same, external view.

Plate 21.

Proximal brachials of Comanthus parvicirra. (After P. H. Carpenter.)

Fit. 1123.- IBr $\mathrm{r}_{1}$, distal face.

1124.- Same, proximal face.

1125. - Sinme, ventral surface.

1126. - Sume, dorsal surface.

1127 . - IBr (first nxillary) proximui face.

1128.-Same, distai face.

1129.-Same, ventrai surface.

1130.- Sume, dorsal surface.

1131. - IBr $r_{1}$ of another varlety, distai face.

1132.-Same, proximal face.

1132. Sinme, ventrai surface.

1134. Snme, dorsal surface.

1135.- $\mathrm{IBr}_{2}$ (first axllinry) of another variets, proximal face.

1136. - Snme, distai face.

1137.-Same, ventral surface.

113. - Same, dorsal surface. 


\section{Plate 22.}

F10. 1139.-Portion of postradial series of specimen of Comanthus parricirra, showing light median line. (After P. H. Carpenter.)

1140.-Proximal portion of Thalassometra agassizii. (After Hartlaub.)

\section{Plate 23.}

Perisomic structures of various comatulids.

Fic. 1141.-Lateral view of young specimen of Thaumatocrinus rcnovatus, showing perisomic plates of disk. (After P. H. Carpenter.)

1142.-Peristome of dry disk of Comatula solaris, with origins of the ambulacra. (After P. H. Carpenter.)

1143.-Iateral view of young specimen of Tropiometra picta, showing interbrachial perisomic plates. (After P. H. Carpenter.)

1144.-Abnormal disk of Comatella stelligera with two mouths and two anal tubes. (After P. H. Carpenter.)

1145.-Perisomic interbrachials of Antcdon bifula. (After W. B. Carpenter.)

1146.-Same. (After W. B. Carpenter.)

1147.-Disk of Capillaster multiradiata with central mouth. (After P. H. Carpenter.)

1148.-Disk of Capillaster multiradiata with excentric month.

Plate 24.

Disks of rarious comasterids. (After P. H. Carpenter.)

Fro. 1149.-Comatula pectinata.

1150.-Comaster belli.

1151.-Comantheria magnifica.

1152.-Comanthus particirra.

1153.-Comanthina schlegelii.

Plate 25.

Disks of various comatulids. (After P. H. Carpenter.)

Fio. 1154.-Comanthus parvicirra.

1155.-Zygometra microdiscus.

1156.-Same.

1157. - Same.

1158.-Pentametrocrinus semperi.

Plate 26.

Disks of various comatulids. (After P. H. Carpenter.)

Fxo. 1159,-Perissometra angusticalyx.

1160.-Charitometra basicurva.

1161.-Pxcilometra acola.

1162.-Antedon bifida, with two mouths.

1163.-A telecrinus balanoides.

1164.-Atelecrinus wyvillii.

1165.-Vertical section through dry disk of Comatula solaris. 


\section{Plate 27.}

\section{Adambulacral deposits of various comatulids.}

FrG. 1166.-Aglaometra incerta, apparently from a dried specisuen. (After P. H. Curpenter.) 1167.-Charitomctra basicurva, lateral vlew of portlon of pinnule mounted iu dammar (After P. H. Carpenter.)

1168. - Pachylometra inargualis, lateral view of portlon of a pinnule, apparently drierl. (After P. H. Carpenter.)

1169.-Pacilometra accla, lateral view of portion of a pinnule, apparently dried. (After $\mathbf{P}$. H. Carpenter.)

1170.-Hathrometra prolixa, lateral view of portion of arm of pentacrinoid at time of first appearanee of pinnules and elrri, with tentacles omltted. (After Mortensen.)

1171. -Thalassometra agassizii, lateral view of portlon of plnnule, showing skeleton ouly. (After Hartlaub.)

1172. - Same. (After Hartlaub.)

1173.-Antedon bifida, lateral vlew of growing arm of yonng pentrcrinoid. (After Wyville Thomson.)

1174.-Hathrometra sarsii, portlon of arm of pentaerlnoid with six brachials developel. (After M. Sars.)

Plate 28.

Fggs and larre of certain comatulids.

Brg. 1175.-F'ortion of arm of speclmen of Comanthus parvicirra, showing eggs attaehed to bases of piuuules. (After P. H. Carpenter.)

1176.-Antedon bifila, young embryo seen through vitelline membrane. (After Wrrille Thomson.)

1177. - Same. (After Wyrille Thomson.)

1178. - Same. (After Wyville Thomson.)

1179.-Antedon bifda, embryo. (After Wyville Thouson.)

1180.-Antedon bifida, dorsal view of embryo shortly after rupture of vitelline membrane. (After Wyville Thomson.)

1181.-Antcdon bifua, ventral view of a slightly older embryo. (After Wyvlle Thomson.) 1182.-Antcdon mediterranea, surface view of larva of fifth day, still in vitellne menbrine, showing the yellow cells. (After Bury.)

1183.-Antedon mediterranea, surface vlew of free larva of sixth day, from right side. (After Rury.)

1184.-Antedon mediterranen, surface view of larva of seventh dits, from left side. (After Bury.)

1185.-Antedon meditcranca, surface view of larva eary on eighth day, from rentral side. (After Bury.)

$$
\text { PLAT: 2:. }
$$

\section{Larva of Antedom.}

Fio. 1186.-Antedon bifda, veutral vlew of embryo shortly hefore disuppearance of ciliated bands. (After Wyvllle Thomson.)

1187. - Iateral vlew of same. (After Wyvllle Thomson.)

1188.-Dorsal vlew of same. (After Wyvllle Thomson.)

1189.-Antedon bifida, dorsal vicw of embryo not long after rupture of vitelline membrine. (After Wyville Thomson.)

1190.-Antedon mediterranca, dlagram showing arrangement of skeletal plates in larva of seventh day. (After Bury.) 
Plate 30.

Larve of Antedon.

Fie. 1191.-Antedon bifida, young larva recently attached. (After Wyville Thomson.)

1192.- Same, somewhat more advanced. (After Wyvllle Thomson.)

1193.-Antedon bifida, pentacrinoid larva immediately after complete separation of oral valves, with cup closed. (After Wyvilie Thomson.)

1194.-Antedon mediterranea, larva of tenth day seen as transparent object; plates on farther side of body are omitted. (After Bury.)

Plate 31.

Larve of Antedon.

Fic. 1195.-Atrtedon bifida, a pentacrlnold before expansion of rentral disk with cup expanded and showing arrangement of nonextensile tentacles. (After Wyville Thomson.)

1196.-Antedon mediterranea, basal from larva of tenth day. (After Bury.)

1197.-Same, an infrabasal from larva of same age. (After Bury.)

1198.-One of uppermost columnals from same larva with rudimentary longitudinal processes. (After Bury.)

1199.-One of uppermost colunnals from larva of same species of seventh day. (After Bury.)

1200.-Infrabasal from same larva : this would equally well represent a basal some 24 hours earlier. (After Bury.)

I'LATE: 32.

Lar'ce of Antedon bifda. (After Wyville Tluomson.)

Fig. 1201.-Fentacrinoid larva immediately after complete separation of orals, expanded (fig. 1193.)

1202.-Portlon of oral disk of same stage in state of compiete expansion, seen from above.

1208.-Pentacrinold larra inimediately before expansion of ventral disk.

\section{Plate 33.}

Larve of Antedon bifda. (After W. B. Carpenter.)

Fio. 1204.-Group of pentacrinoid larvæ in different stages.

1205. - Skeleton of eariy pentacrinoid larva, from dried specimen, showing way in which calyx at that stage can be completely elosed in by folding together of orais.

1206. - Skeleton of young pentacrinold larva, showing inclpient development of dorsal cirri, and radlanal being lleted up from between radials.

\section{Plate 34.}

Pentacrinoid larva of various comatulids. (After P. H. Carpenter.)

Fio, 1207.-Crotalometra porrecta.

1208.-Same.

1209.-Same.

1210.- Hathrometra prolixa.

1211.-Glyptometra tuberosa.

1212.-Leptometra celtica.

1213.-Hathrometra prolixa.

1214. - ?Thaumatometra, sp.

1215.-Heliometra olacials. 
Plate 35.

\section{Pentacrinoid larve of Hathrometra sarsii. (After M. Sars.)}

F10. 1216.-Pentacrinoid at stage at which six brachinls are present.

1217.-Pentacrinoid at stage at which pinnules are just beginning to appear.

1218. - Pentacrinoid at stage at which cirri are beginning to appear.

1219.-Fuily developed pentacrinoid.

Plate 36.

\section{Pentacrinoid larte of Ilathrometra sarsii. (After M. Sars.)}

Fre. 1220.-Most highly dereloped pentacrinoid obtained by Professor Sars.

1221.-Part of arm of same individual taken from middle.

1222.-Summit of column of fully developed individual.

1223. -Tip of arm of young pentacrinoid, showing development of first pinnuie to appear.

1224. - Sixth pinnule of individual shown in fig. 1220.

1225.-Disk of fully developed pentacrinoid.

\section{Plate \$7.}

Fig. 1226.-Pentacrinoid of Heliometra glacialis. (After Levinsen.)

1227.-Pentacrinold of Hathrometra prolixa from Jan Mayen. (After P. H. Carpenter.)

1228.-Pentacrinoid of Ptilometra mülleri. (After H. I. Clark.)

1229.-Same. (After H. L. Clark.)

1230.-Same. (After H. L. Clark.)

1231.-Abnormal arm of a specimen of Heliometra glacialis. (After Levinsen.)

Plate 38.

Pentacrinoid larve and pinnules of viviparous comatulids. (After Th. Mortensen.)

Fro. 1232.-Thaumatometra nutrix, a fully grown pentacrinoid attacled to third segment of genital pinnule; in orary eggs are visible.

1233. - Thaumatometra nutrix, genital pinnule with young pentacrinoid attached to pinnule segment protruding through ofiening of the marsupium.

1234.-Thaumatometra nutrix, genital pinnule with two pentacinoids attached to third pinnule segment protruding from marsupium.

1235.-Thaumatometra nutrix, type specimen, viewed dorsally; on one of arms to the left is genital pinnule bearing large pentacrinoid.

1236. - Thaumatometra nutrix, genital pinnule with egg in nıarsupium.

1237.-Thaumatometra nutrix, genital pinnule with young pentacrinold attached to extreme edge of marsupium.

1238.-Isometra vivipara, genital pinnule viewed ventrally showing slitlike opening of marsupium.

1239.-Isometra vivipara, maie genital pinnule.

1240.-Isometra vivipara, proxinni portiou of arn, showing oral pinnuics and extra fourth pinnule.

PLATE 39.

Commensals of Crinotds.

Fios, 1241-1245.-Loxnsomella antedonis. (After Mortensen,)

1246-1248.-Pachylasma crinoidophilum. (After Pilsbry.)

1249, 1250.-Verruca nitida. (After Hoek.) 
Plate 40.

Myzostomes.

Fros. 1251-1253.-Afyzostomum crosslandi. (After Boulenger.)

1254.-M. tenuispinum. (After von Graff.)

1255-1262. $M$. costatum. (After Boulenger.)

1263.-M. rubrofasciatum. (After Boulenger.)

\section{Plate 41.}

Fio. 1264.-M. filicauda.

SIyzostomes. (After von Graff.)

1265. - MI. longicirrum.

1266.-11. ambiguum.

\section{Plate 42.}

Deformations caused by myzostomes.

Figs. 126i-1269. -Three riews of a cyst of Myzostomum villemoesii on arm of Pachylometra incrqualis. (After von Graff.)

1270-1272.-Three views of a large cyst of M. tenuispinum on arm of Perissometra angusticalyx. (After ron Graff.)

1273-1275.-Three cysts of $M$. tenuispinum on arms of Pachylomctra inærqualis. (After von Graff.)

1276.-Part of disk and arm bases of specimen of Promachocrinus kerguelensis, showing cyst of Ifyzostomum cysticolum, opened in order to show pair of myzostomes. (After Mortensen.)

Plate 43.

Deformations caused by myzostomes.

Figs. 1277-1279.-Three views of a cyst of Myzustomum aeformator on arm of Endoxocrinus alternicirrus; in fig. 1277 the cyst is shown broken open to show septum.

12S0, 1281.-Swollen pinnule of Endoxocrinus alternicirrus, inclosing M. deformator, seen from both sides.

1282.-Portion of arm of Fndoxocrinus altcrnicirrus, with pinnules of nearer side remored, showing base of enlarged pinnule upon which rests Myzostomum asymnctricum. (After von Graft.)

12S3-1285.-Thickened portion of arm of Endoxocrinus alternicirrus inclosing Myzostomum pentacrini. (After ron Graff.)

12S6, 1287.-Two views of cyst of Myzostomum platypus upon disk of Comanthina schlegelii. (After ron Graff.)

Plate 44.

Deformations caused by myzostomes and otherwise. (After von Graff.)

Fios. 1288-1290.-Three views of portion of arm of Perissonietra flexilis containing Myzostomum beardi.

1291.--Malformed pinnule of Pachylometra inæqualis containing Myzostomum willemoesii.

1292.-Malformed pinnule of Perissometra ficxilis containing Myzostomum willemoesii.

1293, 1294.-Dorsal (1293) and ventral (1294) view of cyst on arm of Comactinin meridionalis containing Mfyzostomum cysticolum.

1295.-Cyst on ventral surface of arm of Comactinia meridionalis containing M $y \approx 0-$ stomum cysticolum. 
FIGs. 1296, 1297.-Two views of cyst on arm of Comactinia meridionalis containing Myzostomum cysticolum.

129s, 1299.-Two cysts on arm of Pachylometra inaqualis containing Myzostomum tenuispinum.

1300.-Stalked cyst from disk of Adelometra angustiradia coutaining Myzostomum murrayi.

1301.-Cyst containing Myzostomum murrayi on specimen of Stiremetra breviradia.

1302-1304.-Tiıree views of cyst from arm of Pachylometra incequalis containing Myzostomum tenuispinum; fig. 1304 cyst broken open to show the female and the dwart male within.

1305.-Pinnule cyst not caused by myzostome from specimen of Antedon bifda from Keumaes Bay.

1306.-Egg-like contents of a pinnule cyst from specimen of Antedon bifida from Cumbrae: the right side is drawn in surface view, left side in optical section with cortical layer and the internal mass.

1307.-Pinnule cyst not caused by a myzostome from specimen of Antedon bifia from off Keumaes Bay.

1308. -Three deformities from specimen of an Antedon dredged by the Vettor Pisani at Gibraltar; $a$, groove-like deformity ; $b$, pinnule cyst; and $c$, arm swelling.

Plate 45.

FIG. 1309.- Skeleton of central portion of a young Antedon bifida viewed dorsally with centrodorsal removed, showing central canal entarged by absorption of part of original basals, tiough nearer cavity of calyx, still contracted by secondary endogenous growth; primary nerve stems and courses of their derivatives shown. (After W. B. Carpenter.)

1310.-Sane, viewed ventrally, with radianal added. (After W. B. Carpenter.)

1311. - Central portion of Leptometra celtica after removal of visceral mass. (After P. H. Carpenter.)

1312.-Arm of specimen of Antedon bifida in which the $\mathrm{IBr}_{3}$ (axillary) is lacking, first brachinl of free undivided arm immediately following $\mathrm{IBr}_{1}$. (After W. B. Carpenter.)

1313.-Dorsal view of skeleton of terminal portion of arm of mature pentacrinotd of Antedon bifida. (After W. B. Carpenter.)

1314.-Ventral view of same. (After W. B. Carpenter.)

\section{Plate 46.}

Fis. 1315.-Section of gastrula of Antedon mediterranea early on the second day. (After Bury.) 1316.-Longitudinal vertical section of later gnstrula (end of second day) of Antedon inediterranca, showing formation of mesoblast. (After Bury.)

1317.-Diagram of structure of adult sacculus. (After Bury.)

1318. - Pyriform sacs with refractive spherules from sacculi at different ages. (After Bnry.)

1819. - Transverse sections of two pyriform sacs from sacculi taken from adult specimens of Antedon mediterranea. (After Bury.)

1320.- lart of transverse section of elerenth day iarva, showing development of sacculus. (After Bury.)

1321. - Part of transverse section through same region about twentieth dns. (After Bury.) 1322. - Arm mir of fully grown pentacrinoid of Hathrometra sarsi, showing regenerating nrmi. (After M. Sars, )

\section{PiATe 47.}

Fin. 1823.- Itorizontai section of calyx and arm bases of Antedon bifida, fattened out, showing axlal canuls. (After W. B. Carpenter.)

1324.-- Central portion of Comatula pectinata after removal of viscerai mass. (After P. I. Carpenter.) 
Fig. 1325.-Radial pentagon of Antedon bifida after removal of dorsal surface in such a way as to lay open the radiating axial canals and thelr intercommunicating branches; around central space is irreguiar calcareous network formed by lnosculation of processes sent off from internal faces of the radials. (After W. B. Carpenter.)

\section{Plate 48.}

Fic. 1326.-Ventral muscle pairs of a young specimen of Antedon bifia. (After W. B. Carpenter.)

1327.-Proximal portion of arm pair with the lower pinnules of specimen of Antedon biffa with soft parts removed, showing disposition of ventral muscles. (After W. B. Carpenter.)

\section{Plate 49.}

Fig. 1328.-Tip and central portion of pinnule of Isometra vivipara, showing side and covering plates.

1329. - Side and corering plates along ambulacral furrow of arm of Notocrinus virilis; the irregular dark median area represents furrow.

1330.-Tip and central portion of a pinnule of Notocrinus virilis, showing the side and covering plates.

1331.- Splcules of the tentacles of Isometra vivipara. (After Mortensen.)

\section{Prate 50.}

Fro. 1332.-Dorsal view of specimen of Comatulella brachiolata; the stout pinnules with their tips coiled dorsally are ungroored; the much more slender pinnules alternating with them are grooved.

1333.-Specimen of Antedon biffa with regenerating postradial series and IIBr axillary bearing two arms growing upon the first brachials of the original single arm, which has been broken off at the synarthry between the first two brachials. (After W. B. Carpenter.)

1334. - Fragments of arms of Antedon bifda from near their termination, showing the elongate and almost cylindrical brachials. (After W. B. Carpenter.)

1335. - Skeleton of basal portlons of arms of mature pentacrinoid of Antedon bifda, showing the rery slightly developed perisomic plates. (After W. B. Carpenter.)

1336.-Vertical longitudinal section of an arm of Antedon bifda from near its base, showing arrangement of muscles and ligaments and interruption of these at syzygy. (After W. B. Carpenter.)

\section{Plate 51.}

Frg. 1337.- Sixteen pentacrinoids of Antedon mediterranea attached to the stem of Fucus, sp. from Naples. $\times 4$.

1338.-Pentacrinoid of Antedon mediterranea, from Napies. $\times 4$.

1339.-Pentacrinoid of Antedon mediterranea, from Naples. $\times 4$.

1340.-Pentacrinoid of Antedon mediterranea, from Naples. $\times 4$.

\section{Plate 52.}

Fro. 1341.- Specimen of Capillaster sentosa from Singapore to which is attached an Ophiomaza. Natural size.

1342.-Portion of the column of the type specimen of Mftacrinus batheri from the Malay Archipelago, 160 fathoms, upon which is growing a parasitic hydroid. Natural size.

1343.-Myгostomum filiferum. (After ron Graff.)

1344.- If yzostomum quadricaudatum. (After ron Graff.) 


\section{Plate 53.}

Frg. 1345.-An unusually large specimen of Stylometra spinifera from off northeru Cuba, $15 \pi$ fathoms (Albatross Station 2336), with a species of Scalpellum attached to the cirri. Natural size.

1346.-An unusually well-developed specimen of Ptilometra müllcri from Sydney, New South Wales, with Polytrcma miniaceum growing on two of the right-hand cirri. Natural size.

\section{Plate 54}

Fio. 1347.-A specimen of Calyptometra lateralis from off Nlibau, Hawalian Islands, 378-426 fathoms (Albatross Station 4179), showing, on the right profle, a large myzostome cyst. Natural size.

1348. - $\Lambda$ twelvearmed specimen of Heliometra maxima from off southeastern Snkhalln, 64 fathoms (Albatross Station 5017).

Plate 55.

Fro. 1349.-Notocrinus virilis, proximal portion of arm of a fully grown female, showiug the genital papillæ in the angles between the pinnules and the ambulacral furrow. (After Mortensen.)

1350.-Notocrinus virilis, proximal portion of arm of a male showing the swellng produced by the testes and the small genital pores in the angles between the pinnules and the ambulacral furrow; the lowest pinnules are ungrooved. (After Mortensen.)

1351.-Notocrinus virilis, proximal portion of arm of a female with the ventral surface re moved and the marsupia opened so as to slow the embryos withlu them: proximal to each marsupium is an ovary. (After Mortensen.)

1352.-Notocrinus virilis, proximal portion of arm of a male with the veutral surface partially removed to show the size and shape of the testes. (After Mortensen.)

Plate 56.

Fio. 1333.-Peutacinold larva of Hathrometra prolixa. (After Mortensen.)

1354.-Pentacrinoid larva of Hcliomctra glacialis. (After Mortensen.)

1355.-Pentacrinoid larra of Antedon petasus. (After Mortensen.)

\section{Puate 57.}

Fı. 1356.-Sabinclla ptilocrinicoln attached to calyx of Ptilocrinus pinnatus. (After Burtsch.) $\times 1 \frac{1}{2}$.

1357.-Sabinella ptilocrinicola attached to calyx of a large specimen of Ptilocrinus pinnatus, showing the distortion of the latter. (After Bartsch.) $\times 1 \frac{1}{2}$.

135.8. - Sabinella ptilocrinicola :ttached to ealyx of Ptilocrinus pinnatus. (After Bartsch.) $\times 1 \frac{1}{2}$.

1359.- Sabinella ptilocrinicola. (After Bartsch.) $\times$ about 6 .

3300.-Type spechnen of Sabinella ptilocrinicola. (After Bartscl.) $\times$ ahout 6.

1361.-Sabinella ptilocrinicola. (After Bartsch.) $\times$ about 6 .

13t2. - Stilifer (Mucronalia) bathymetru, attached to arn base of Bathymetra, sp. (After Hartlaub.) $\times 41$.

1363.-Portion of disk of specimen of Comanthina schlegclii with cyats of M/yzostomum platypus. (After F. H. Carpenter.) $\times 2$.

1304.-Disk of specimen of Comatula motalaria with an lsopod visible through the anal omening. (After 1. M. Carjenter.) $\times 2$. 
U. S. NATIONAL MUSEUM

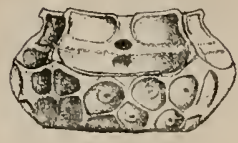

950
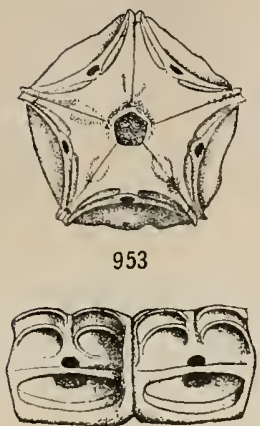

958

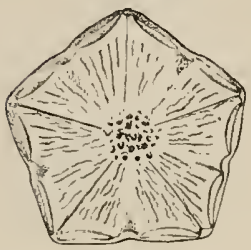

959

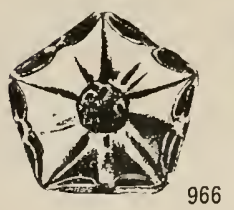

617 . 967

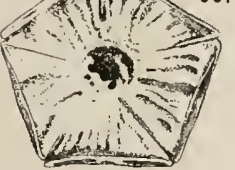

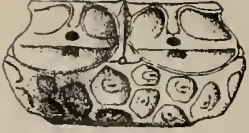

951

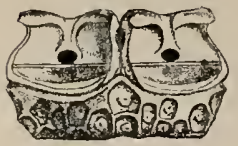

954

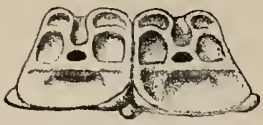

955

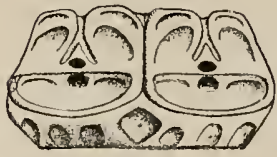

960

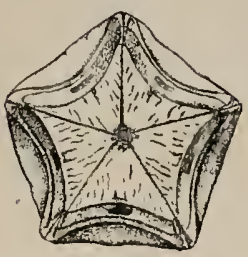

952

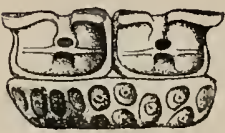

956

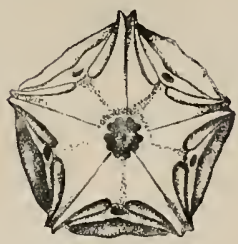

957
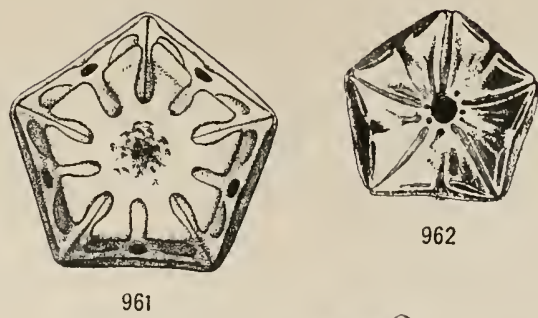

962

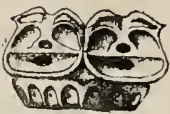

963
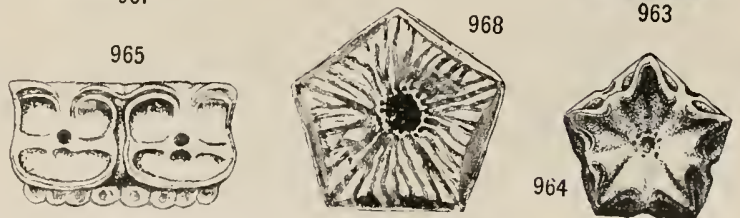

Radial Pentagons and Radial articular faces of Various comatulids

For EXPLANATION OF PLATE SEE PACF 757 
U. S, NATIONAL MUSEUM
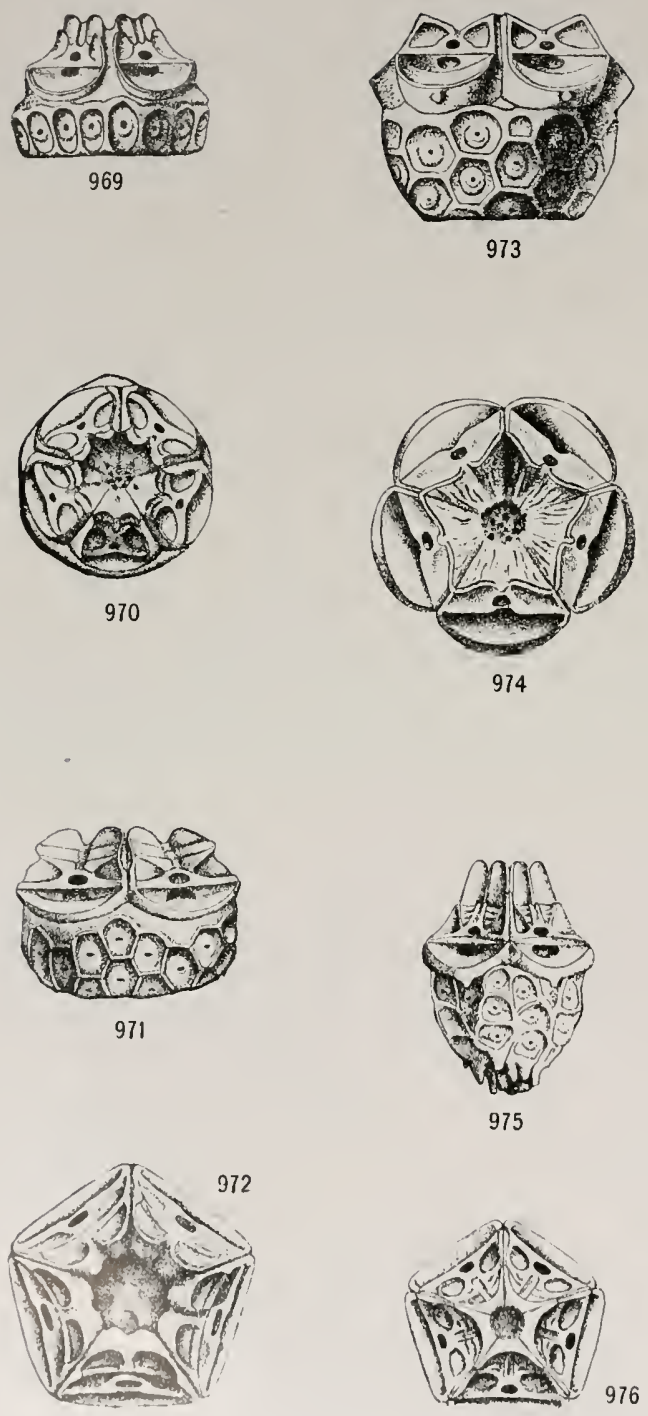
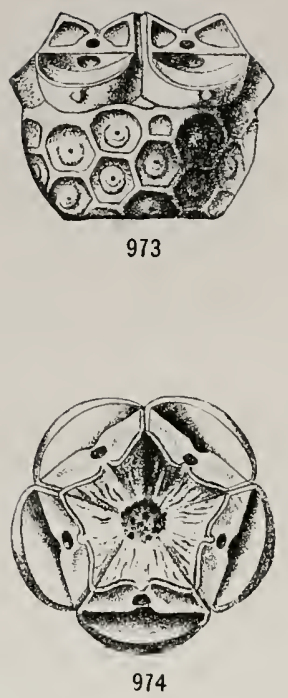

BULLETIN 82, PART 2 PL. 2
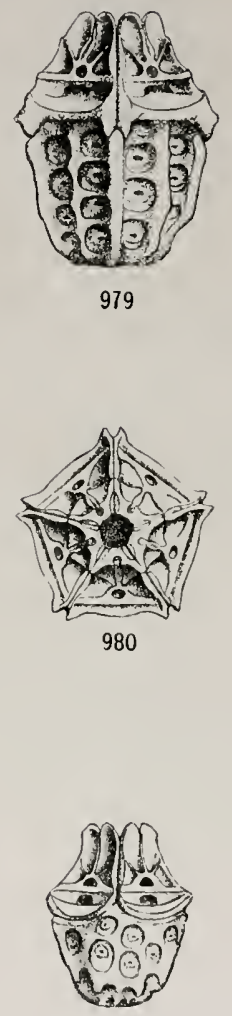

977

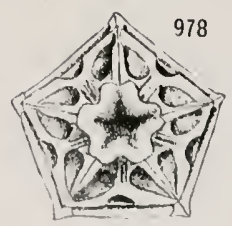

Fiadial pentagons of Various Comatulids 
U. S. NATIONAL MUSEUM

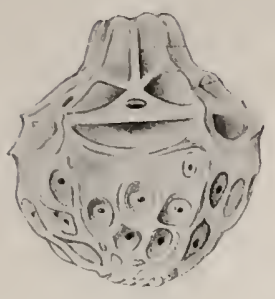

981

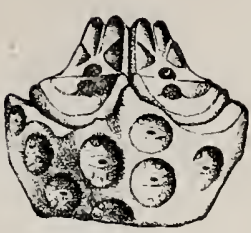

984
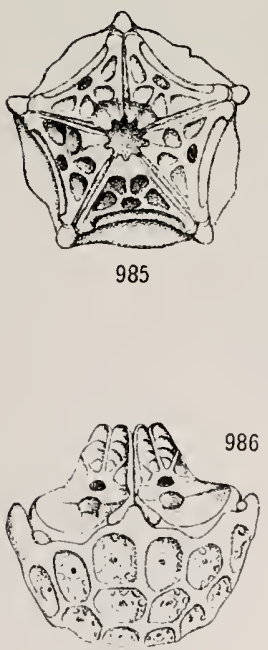

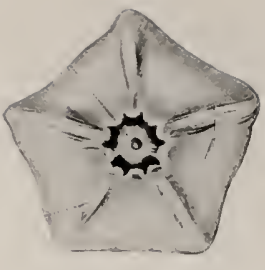

982

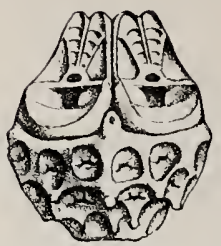

988
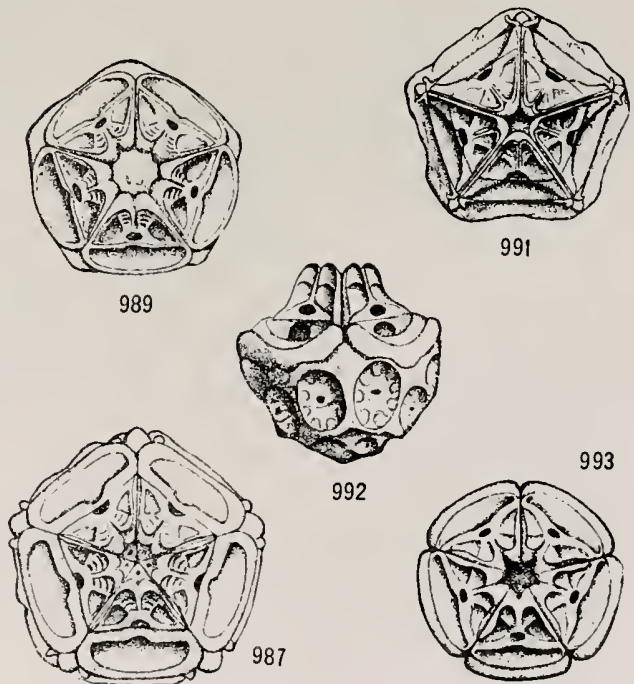

992

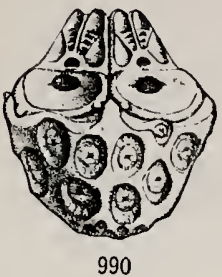

993

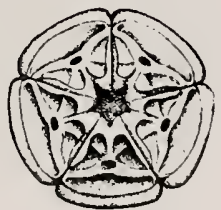

Radial PENTAgons of Various comatulids 

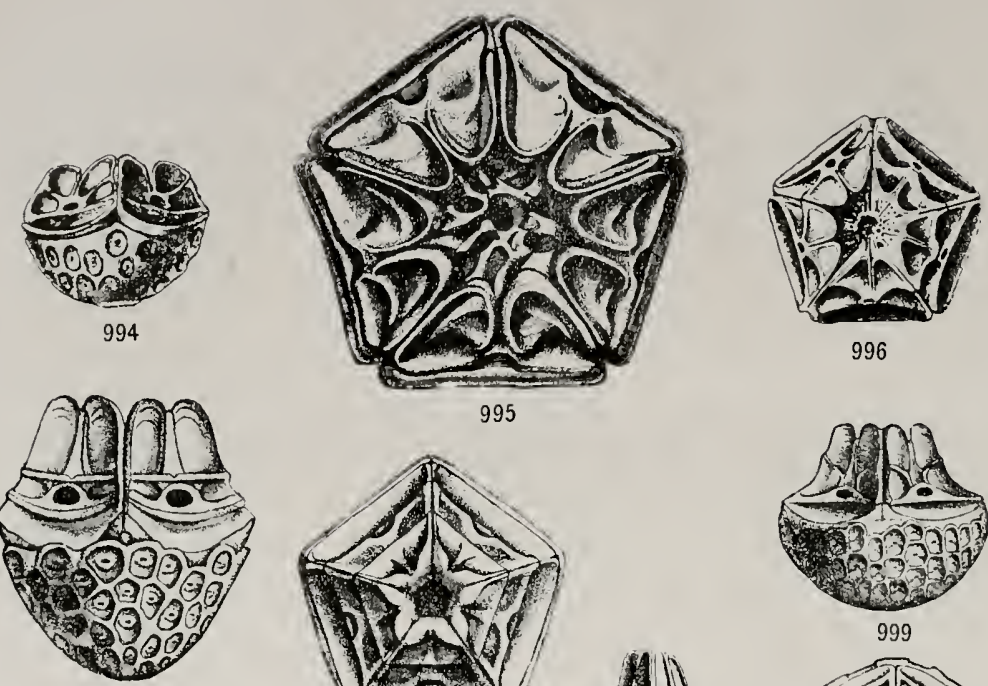

997
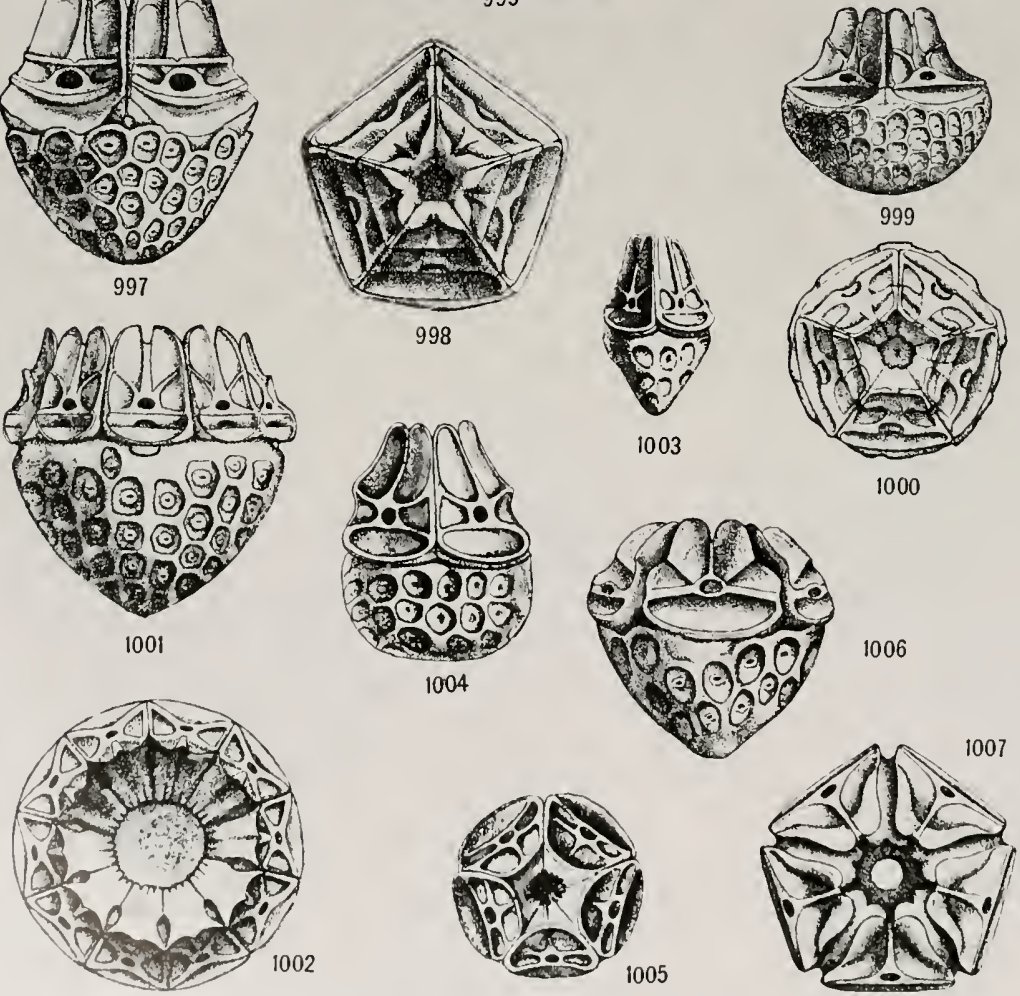

Radial PEntagons of Various Comatulids 
U. S. NATIONAL MUSEUM

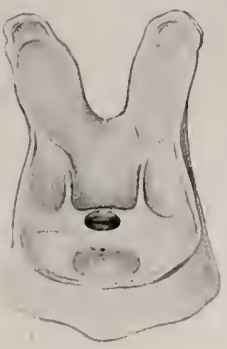

1008
BULLETIN 82, PART 2 PL. 5

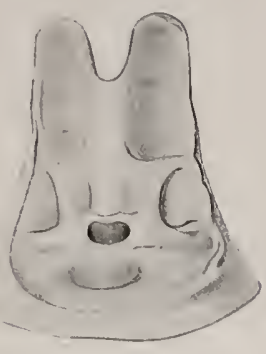

1009

1010

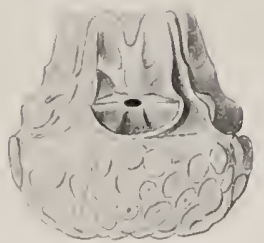

1011

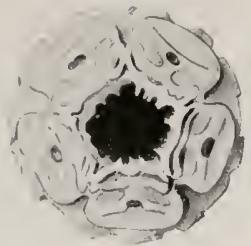

1012

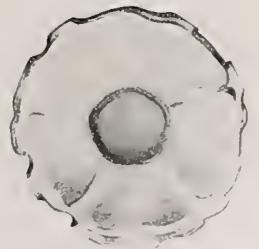

1013

1014

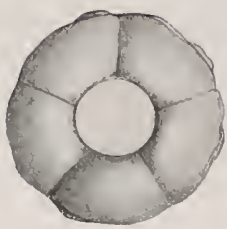

RADIALS AND CENTRODORSAL OF FLOROMETRA

For EXPLANATION OF PLATE SEE PAgE 758. 


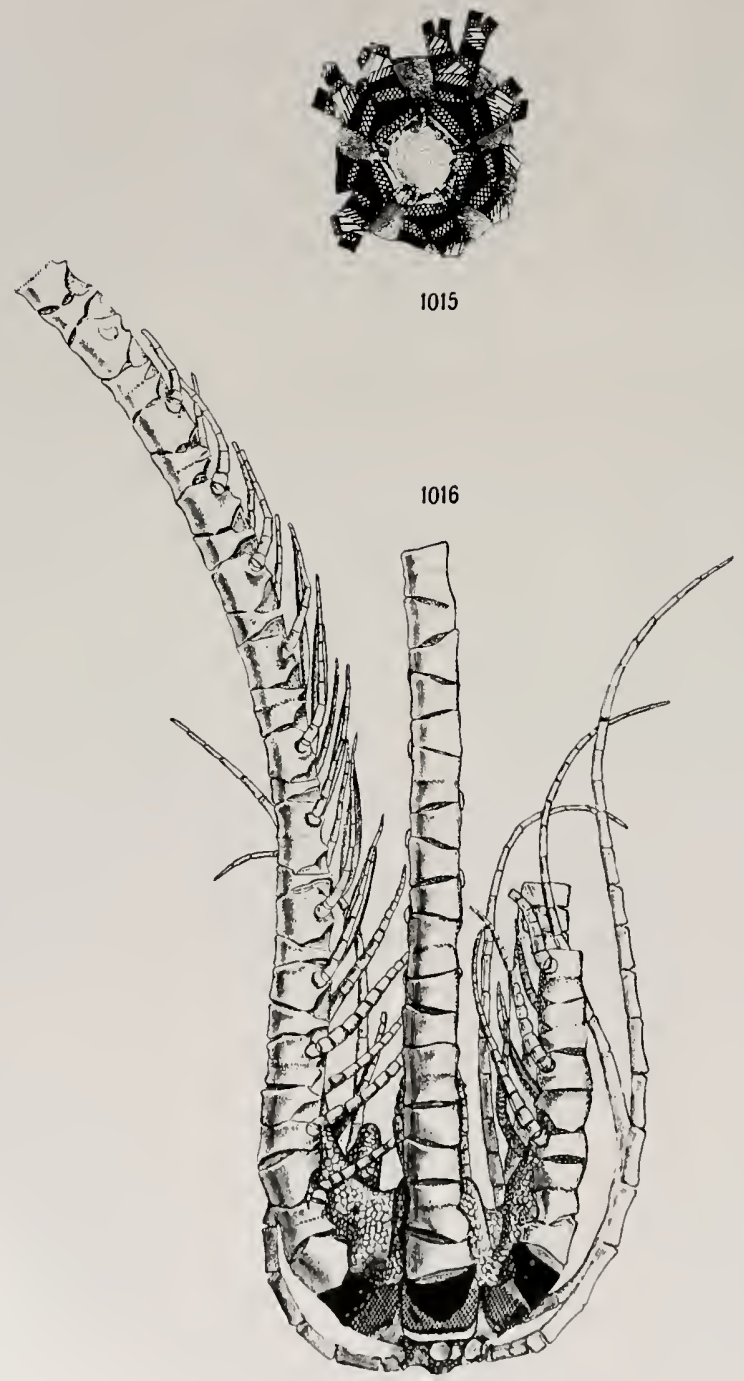

ARM StRUCTURE OF COMATULIDS 

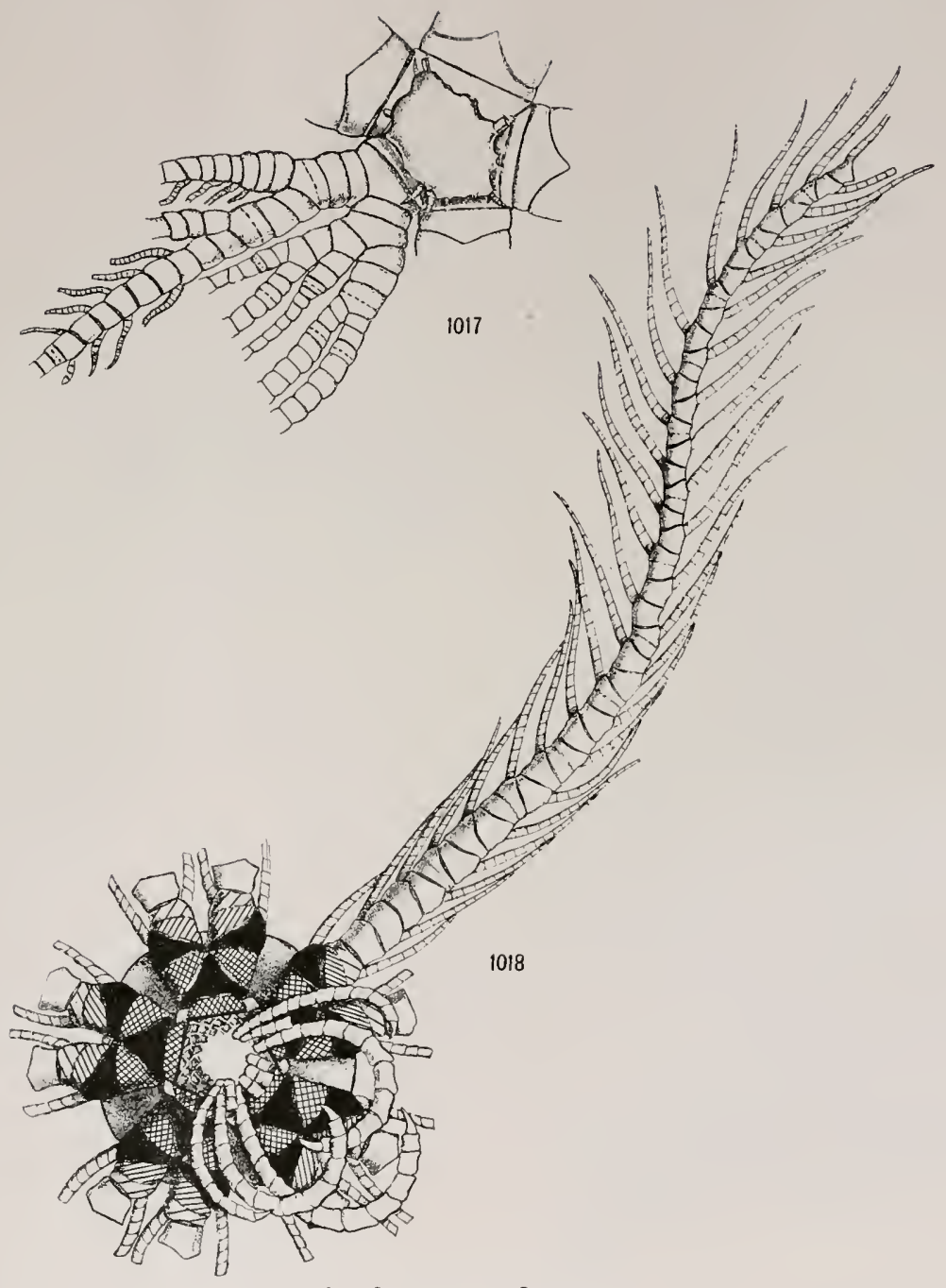

ARM STRUCTURE OF COMATULIDS

For EXPLANATION OF PLATE SEE PAgE 759. 

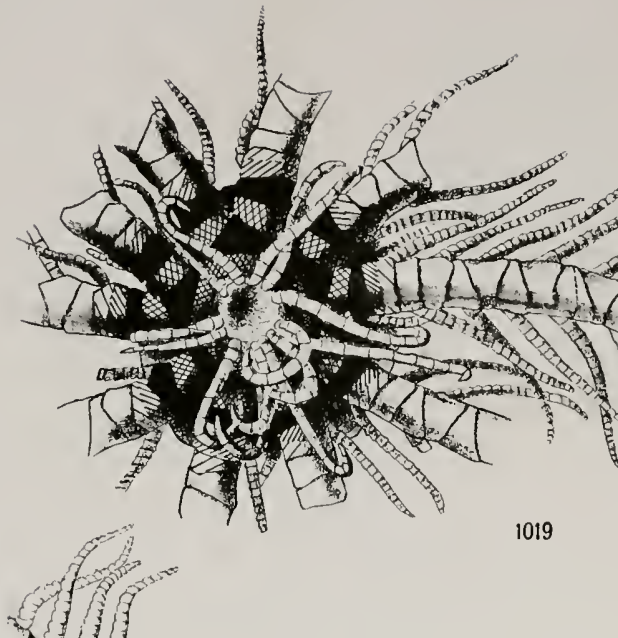

1019
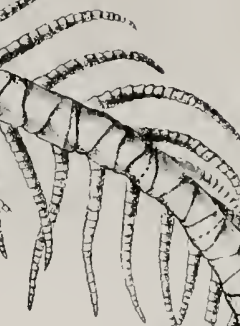

$\overrightarrow{3}$
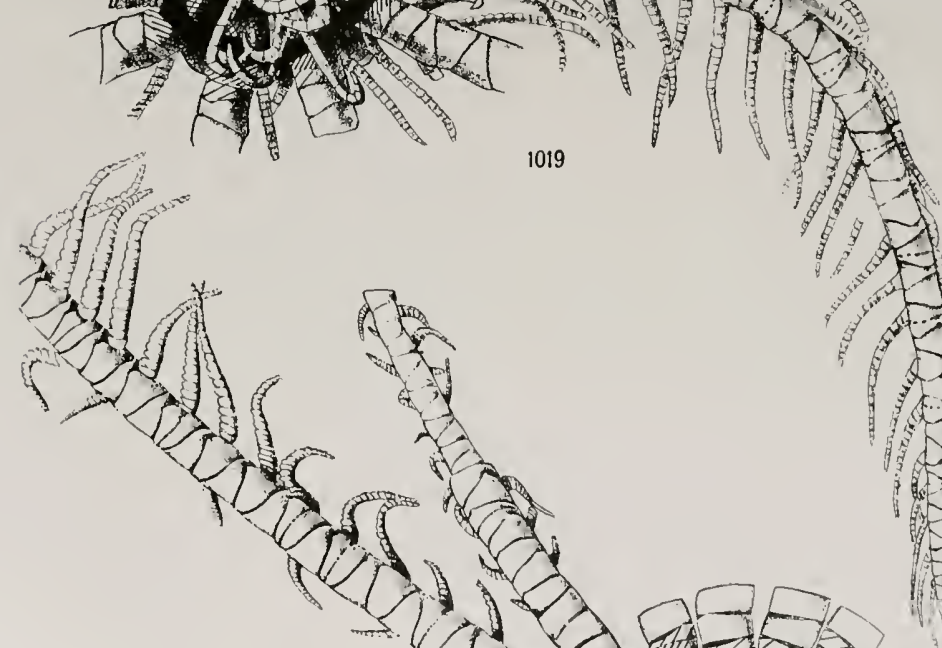

1020
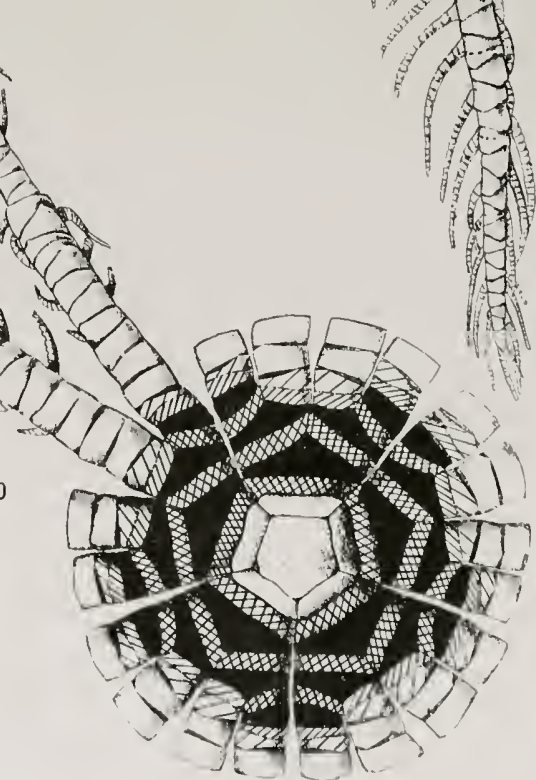


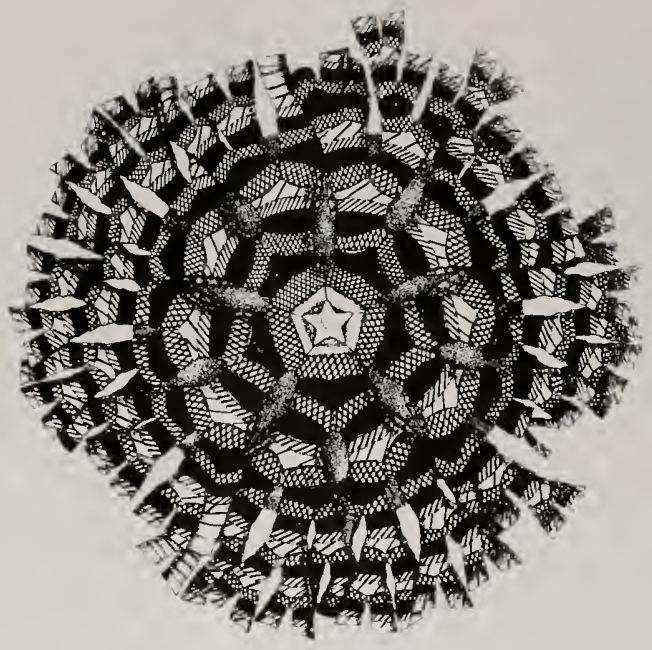

1021
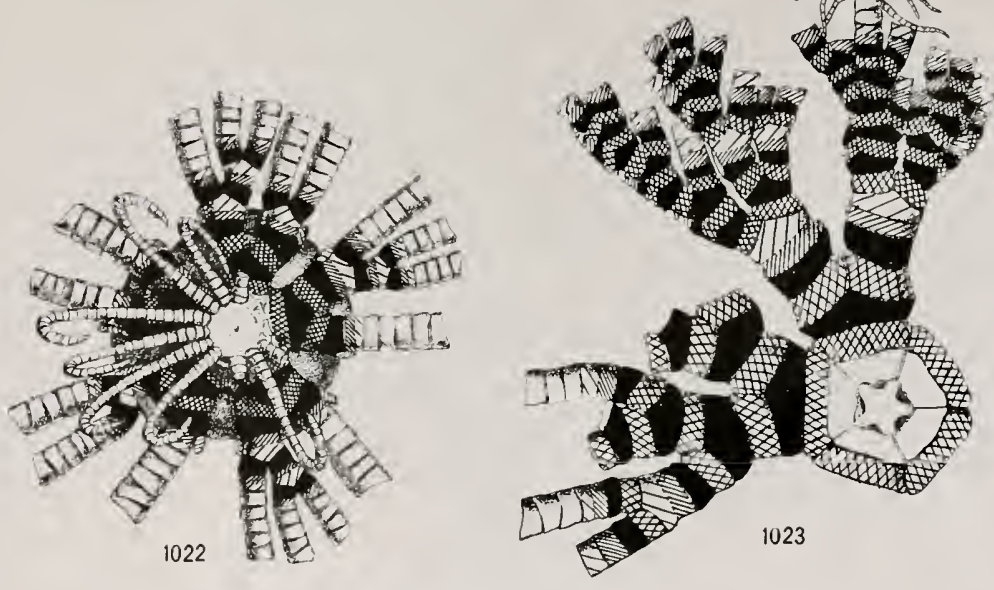

Arm Structure of COMATUlids 

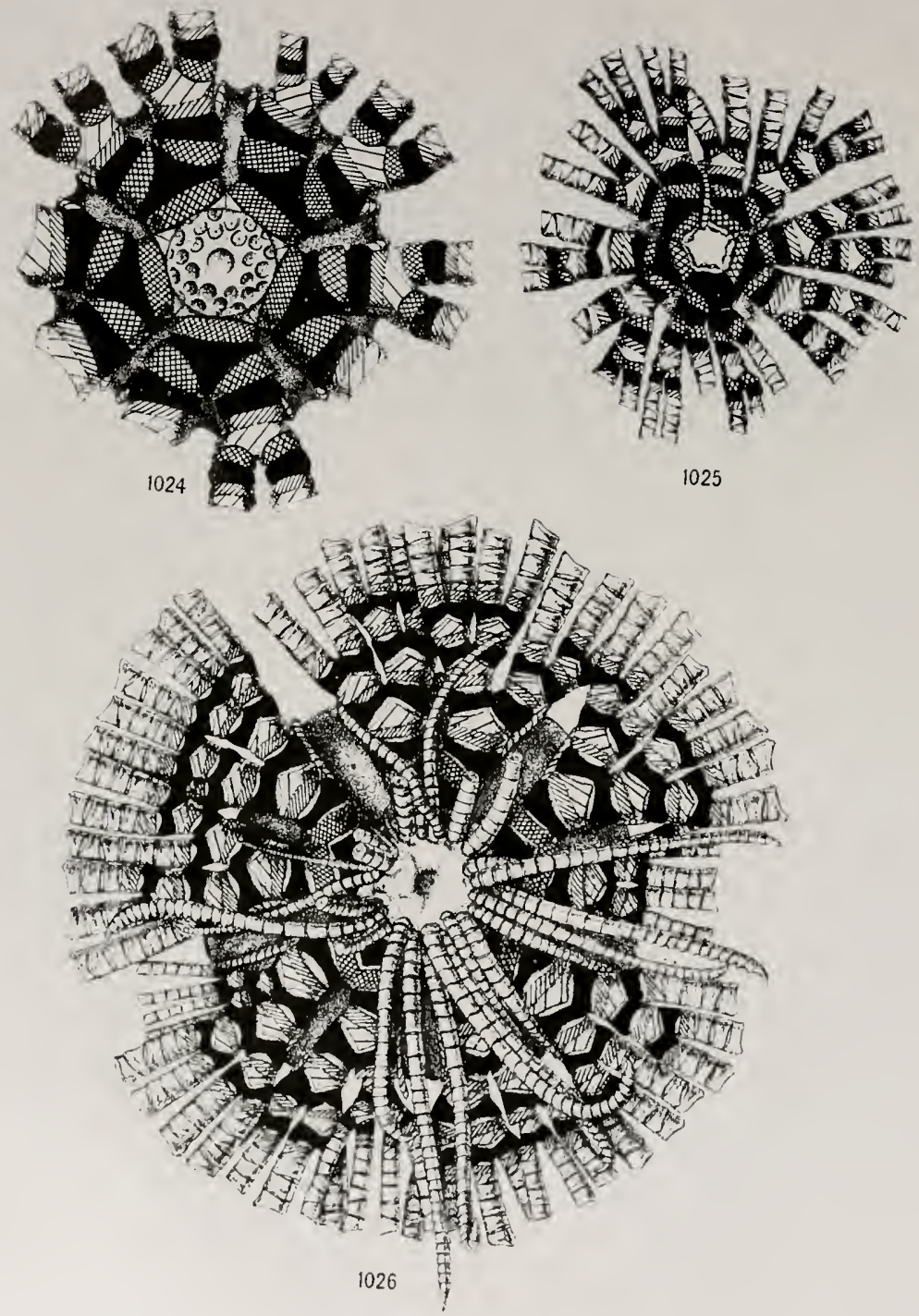


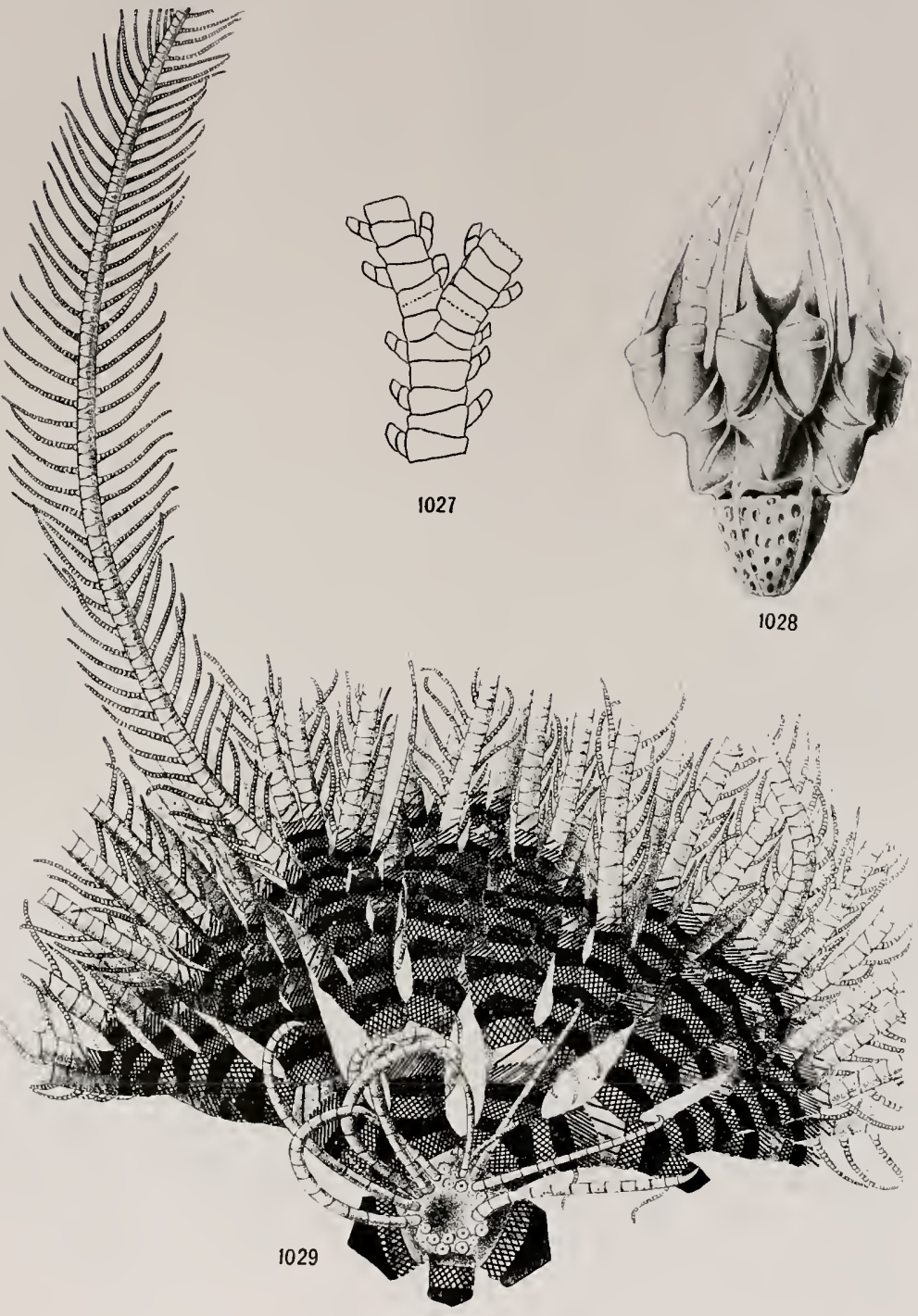

ARM STRUCTURE OF COMATULIOS 


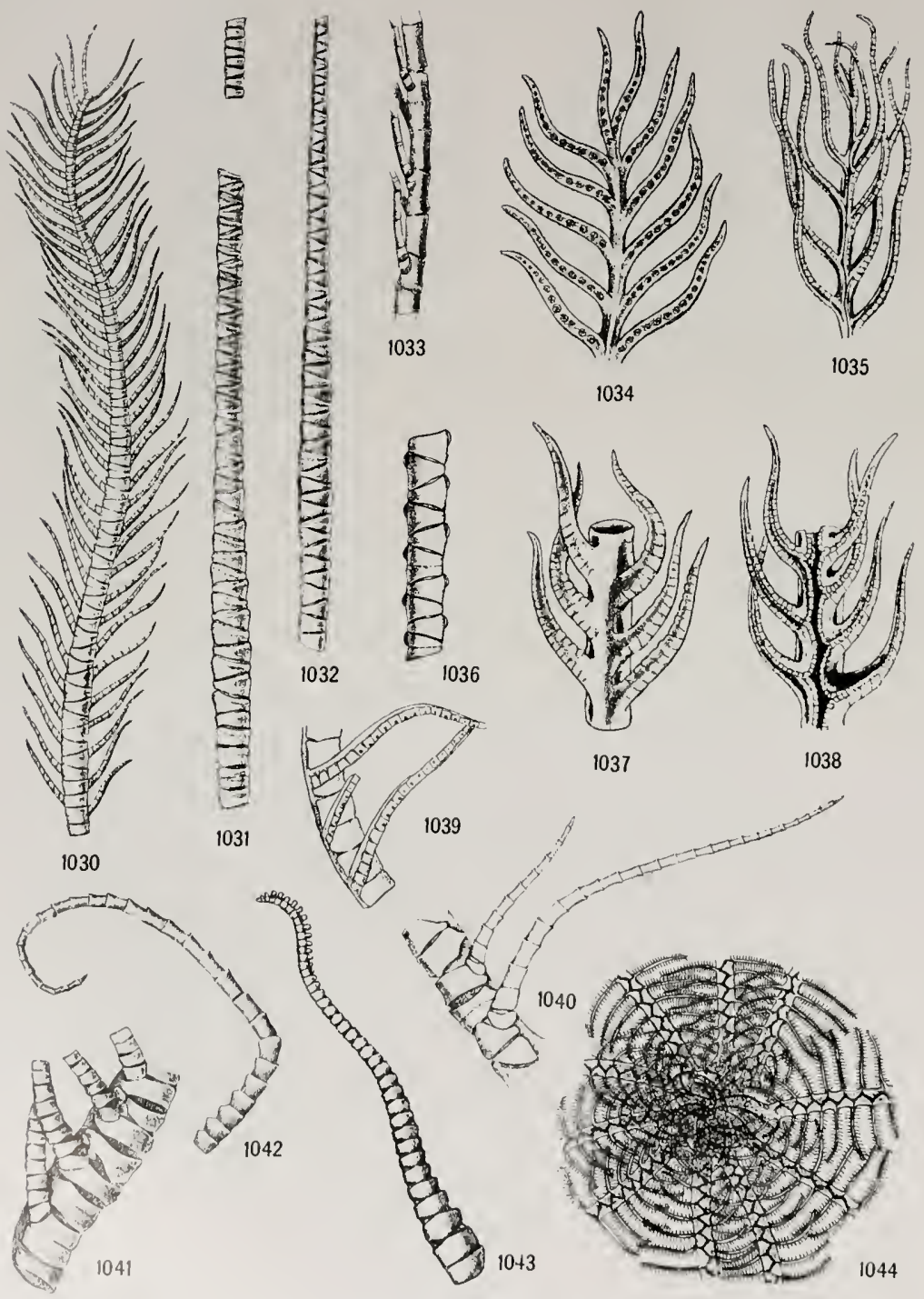


U. S. NATIONAL MUSEUM

BULLETIN 82, PART 2 PL, 13

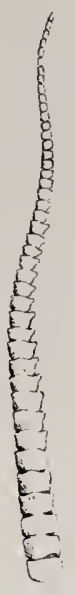

1045
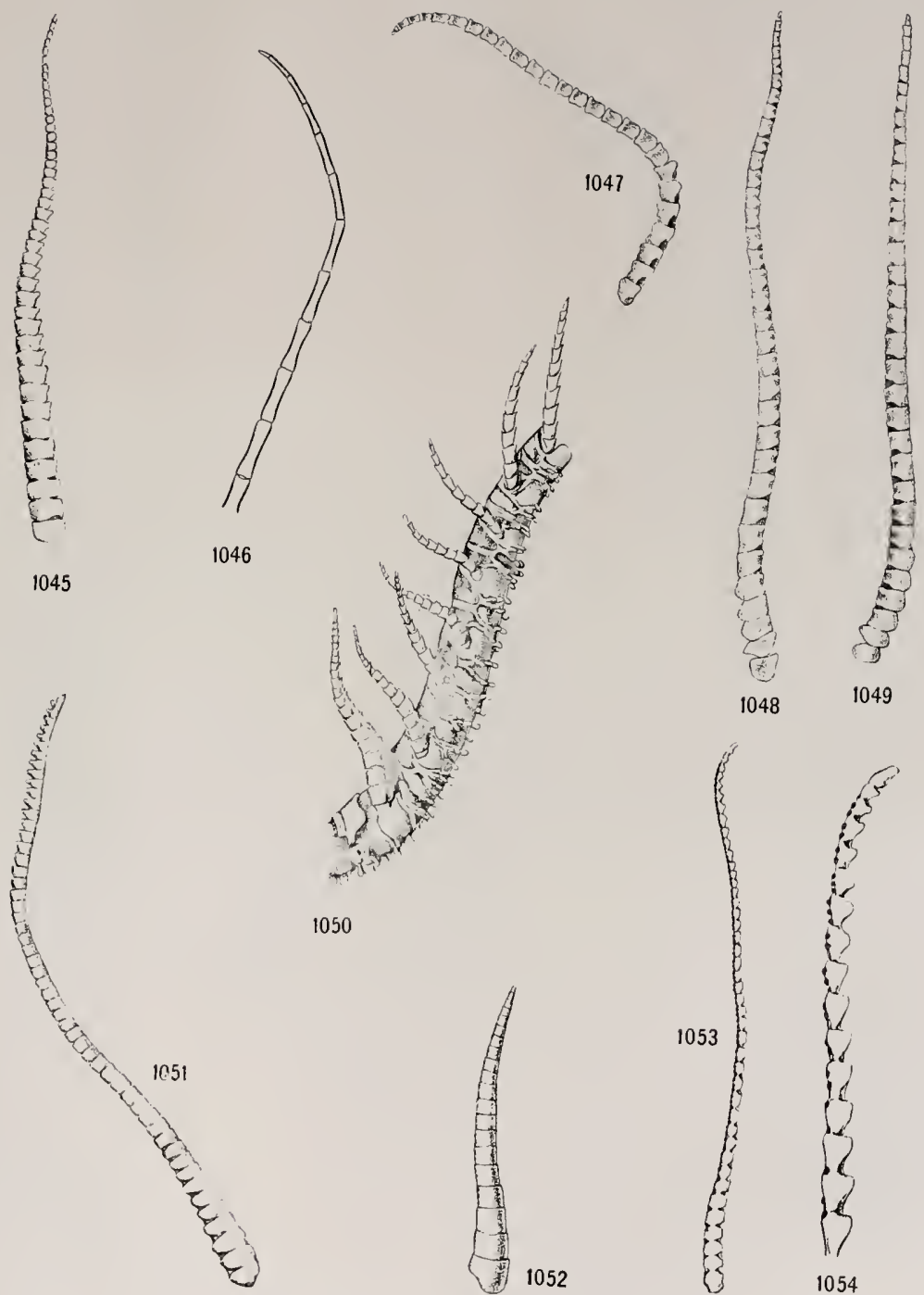

1048

1049

1050
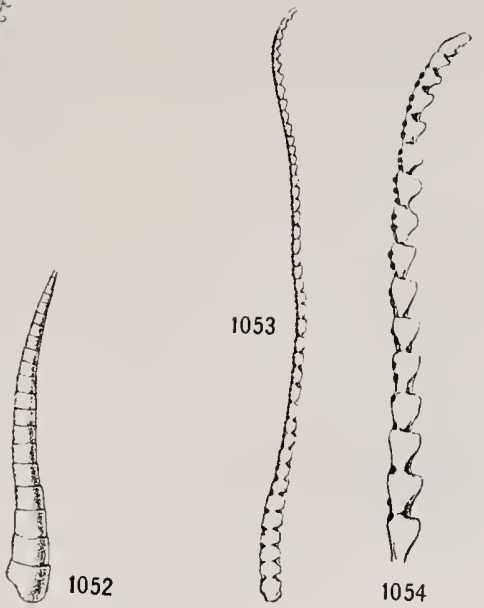

Pinnules of Various comatulids

For Explanation CF PLATE SEe page 760 


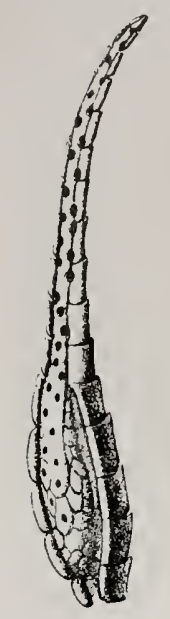

1055
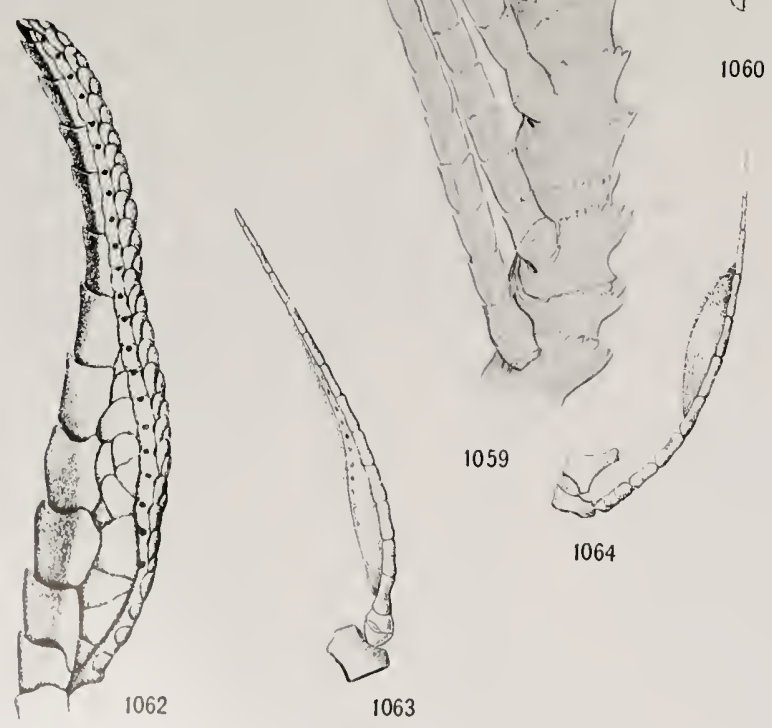

PinNules of Various Comatulidos
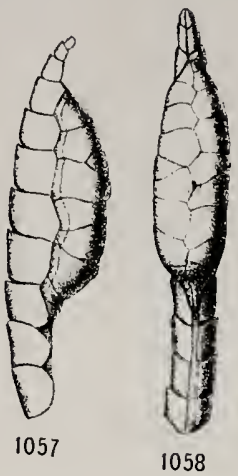

3
4
4
4
4

1060

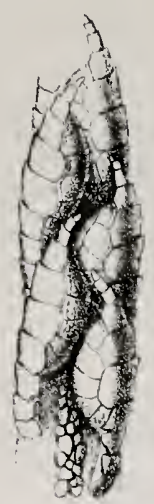

1061

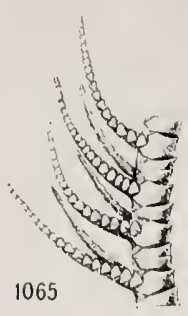




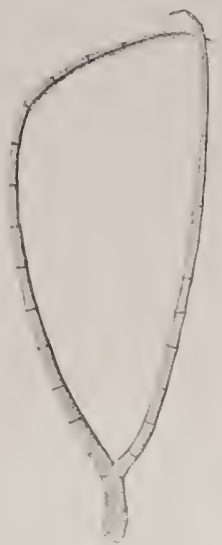

1066

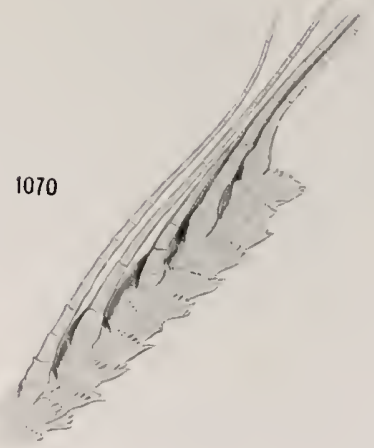

1067
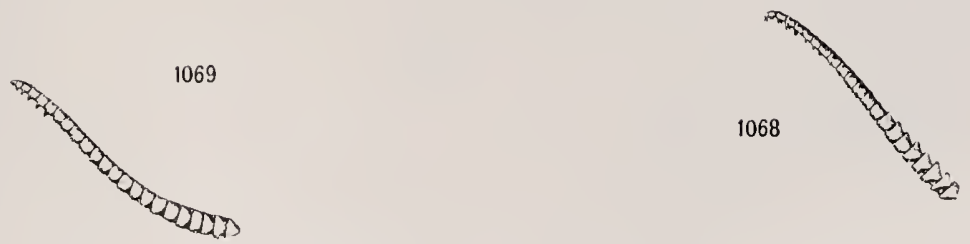

Pinnules of Various Comatulids

For Explanation of PLATE SEE PAGE 761. 


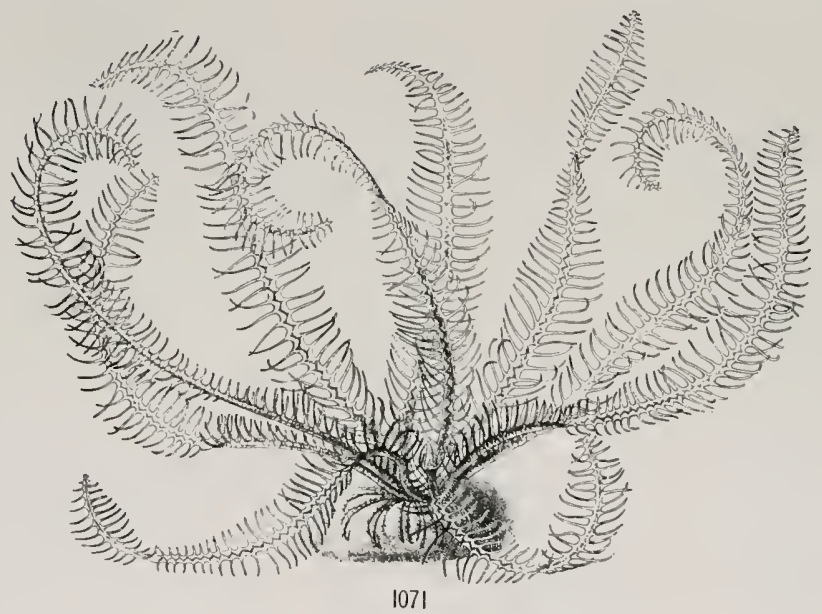

ANTEDON BIFIDA, DRAWN FROM LIFE

FOR EXPLANATION OT PLATE SEE PAOE 761. 
U. S. NATIONAL MUSEUM

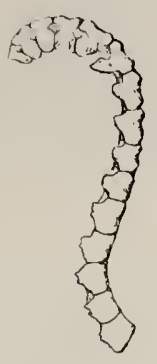

1072

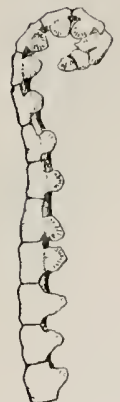

1076

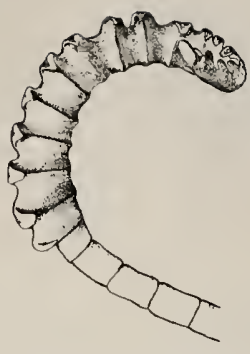

1073

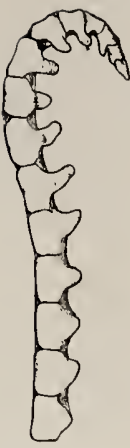

1074
BULLETIN 82, PART 2 PL. 17

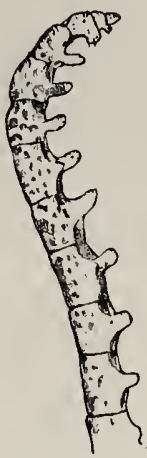

1075

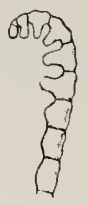

1077

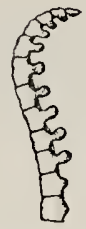

1078
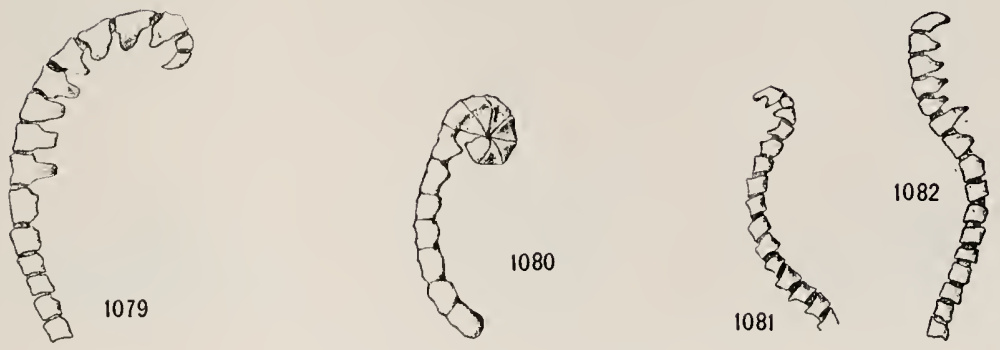

TERMINAL COMBS OF VARIOUS COMASTERIDS 
U. S. NATIONAL, MUSEUM

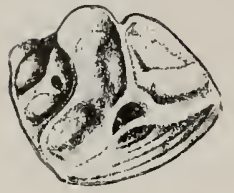

1083

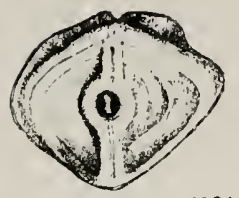

1084

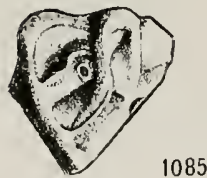

1085

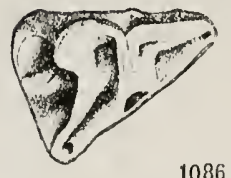

1086

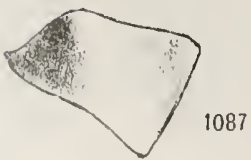

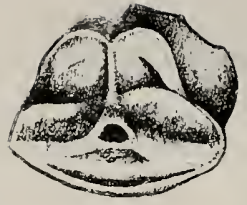

1088

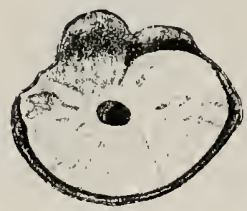

1089

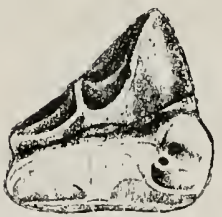

1090
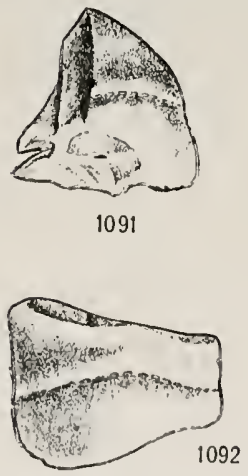

1097
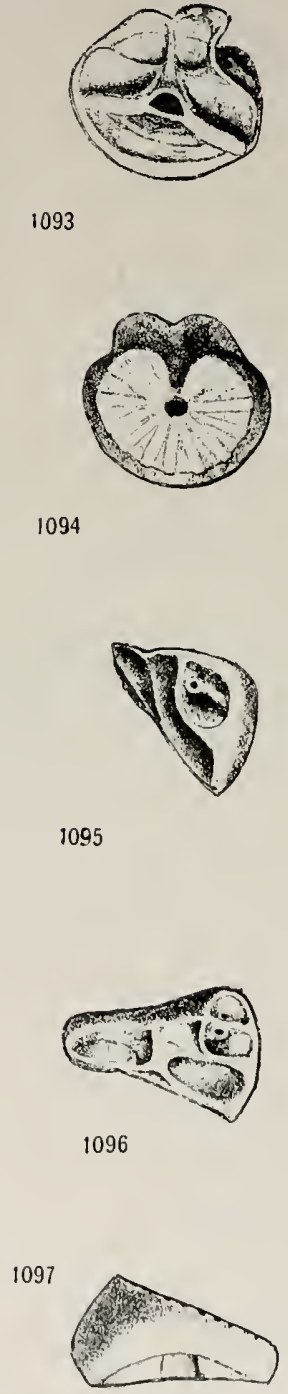

1093

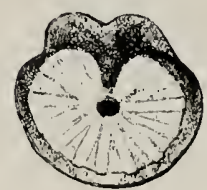

1094

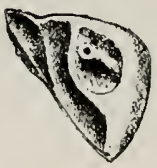

1095

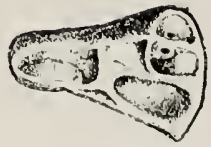

1096 
U. S. NATIONAL MUSEUM

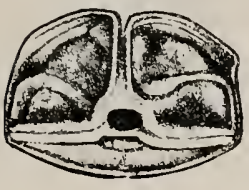

1098

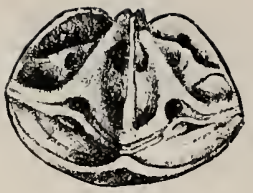

1102
BULLETIN 82, PART 2 PL. 19

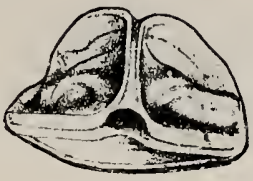

1106

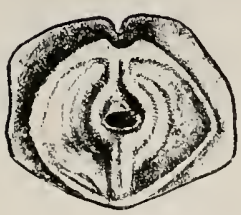

1099

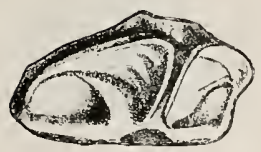

1100

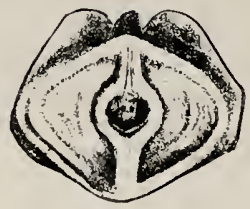

1103

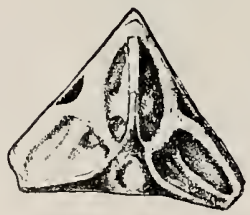

1104

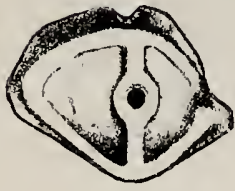

1107
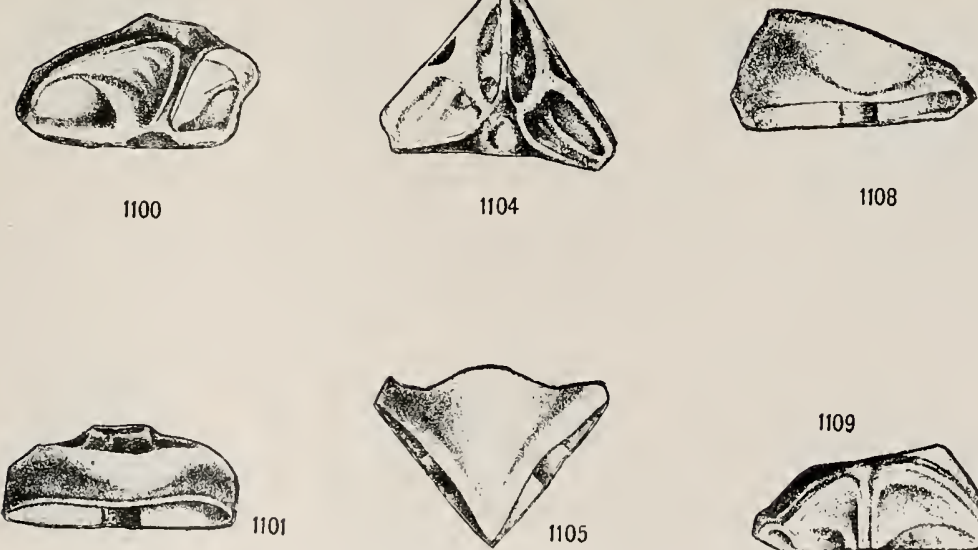

1108

1101

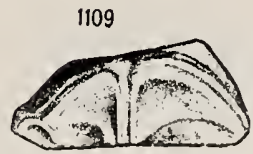

PROXIMAL BRACHIALS OF ANTEDON BIFIDA 
U. S. NATIONAL MUSEUM

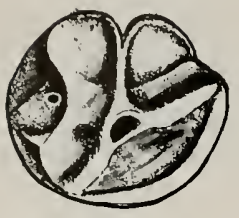

1110

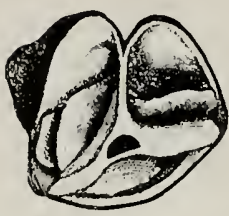

IIII

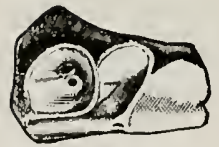

1112

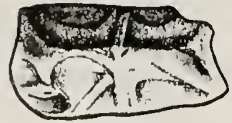

1113

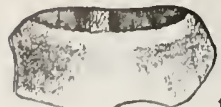

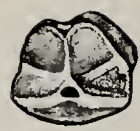

1115

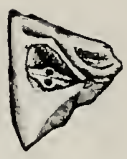

1117
BULLETIN 82, PART 2 PL. 20

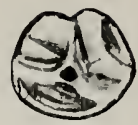

1116

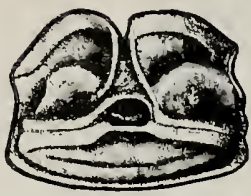

1118

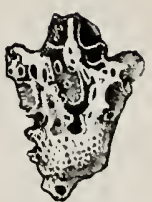

1119

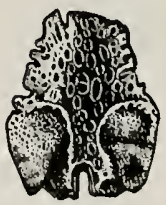

1121
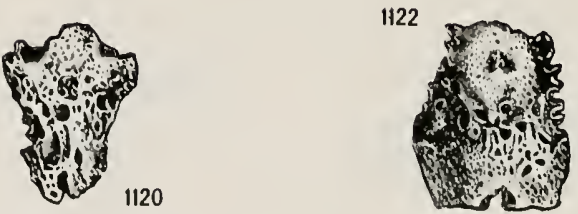

PROXIMAL BRACHIALS OF ANTEDON BIFIDA 
U. S. NATIONAL MUSEUM

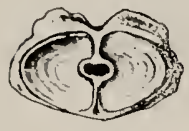

1123

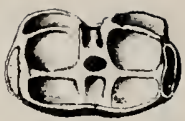

1124

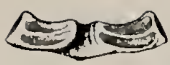

1125
BULLETIN 82, PART 2 PL. 21

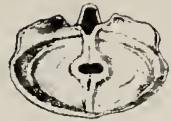

1127

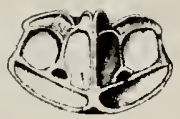

1128

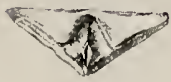

1129

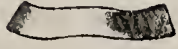

1126

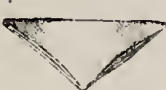

1130

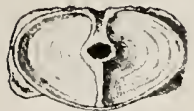

1131

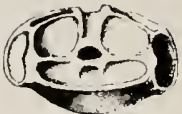

1132 cinninity

1133

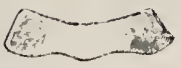

1134
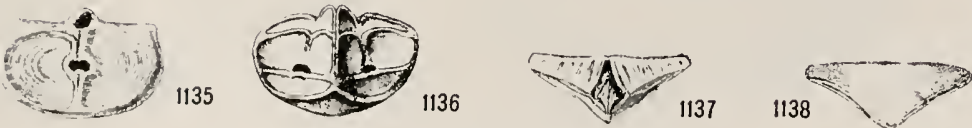

Proximal Brachials of Comanthus parVicirra

FOR EXPLANATION OF PLATE SEE PAGE 762 


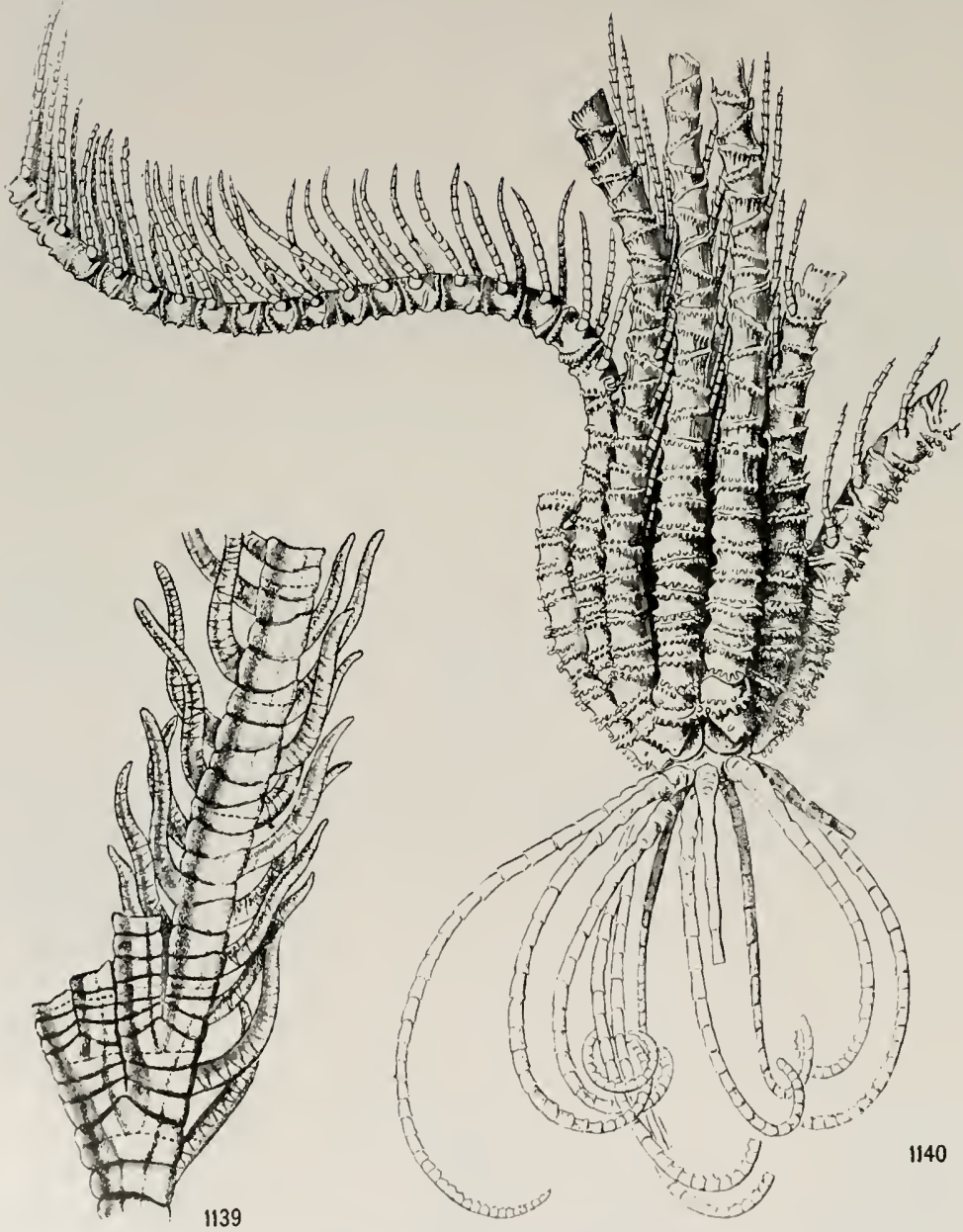

Part of POST-Radial Series of Comanthus PARVICIRRa, and Proximal Portion of THALASSOMETRA AGASSIZII 
U. S. NATIONAL MUSEUM

$\begin{array}{lll}\text { BULLETIN 82, PART } 2 & \text { PL. } 23\end{array}$

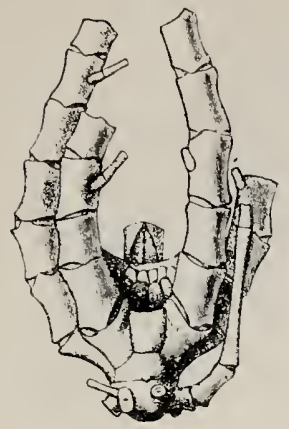

1142
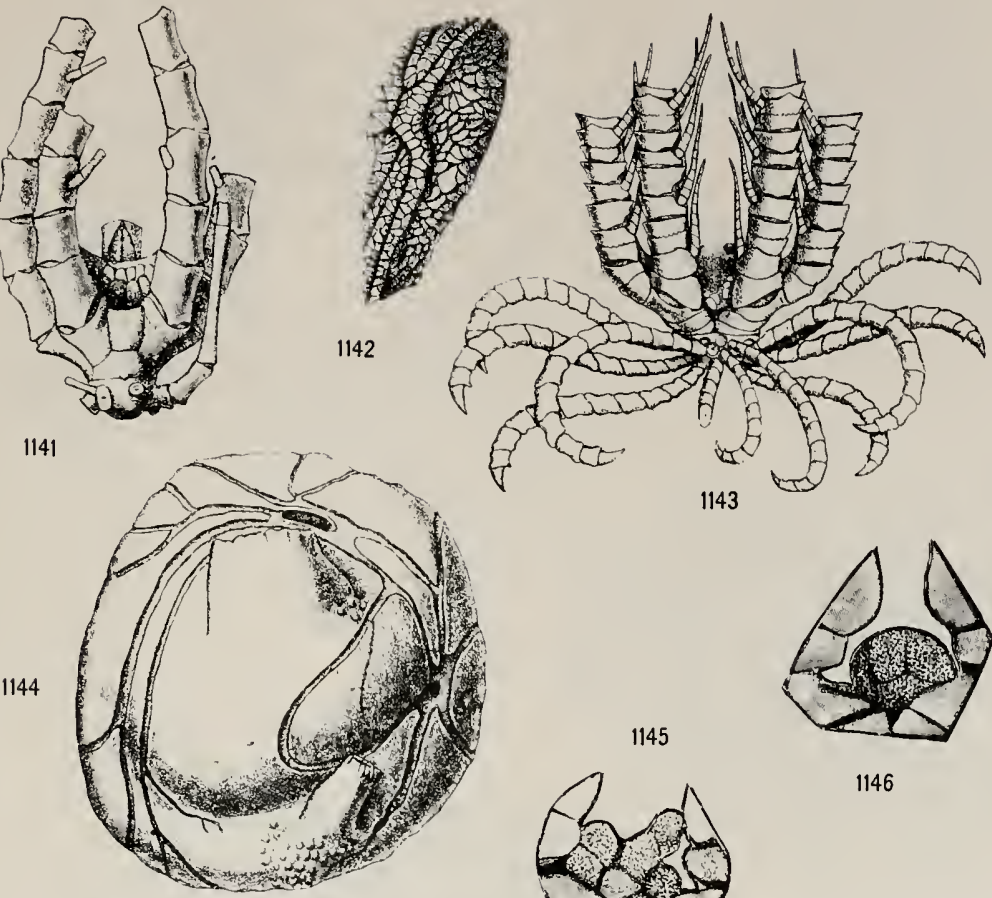

1145
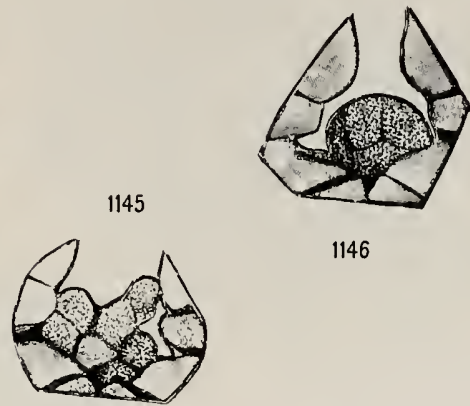

1146
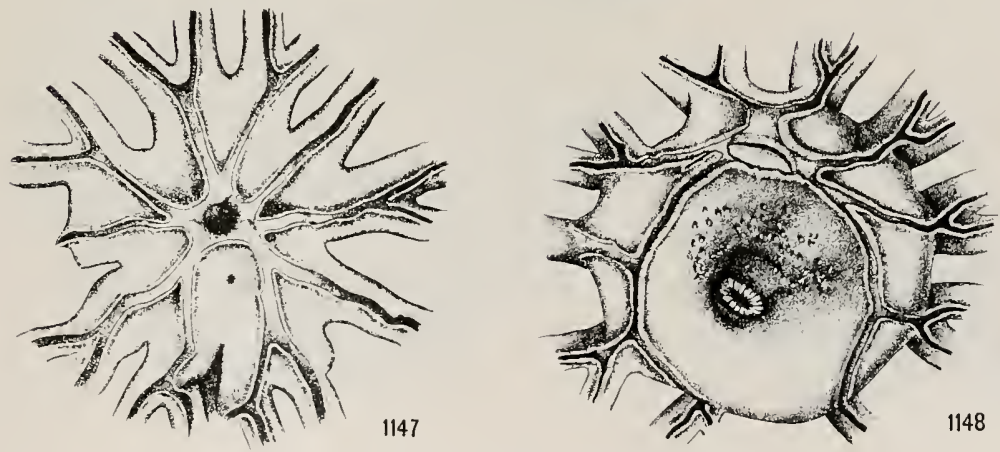

Perisomic structures of Various comatulids 
U. S. NATIONAL MUSEUM

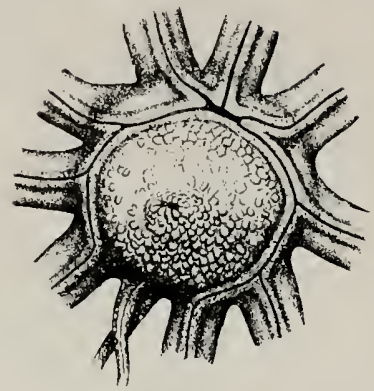

1149

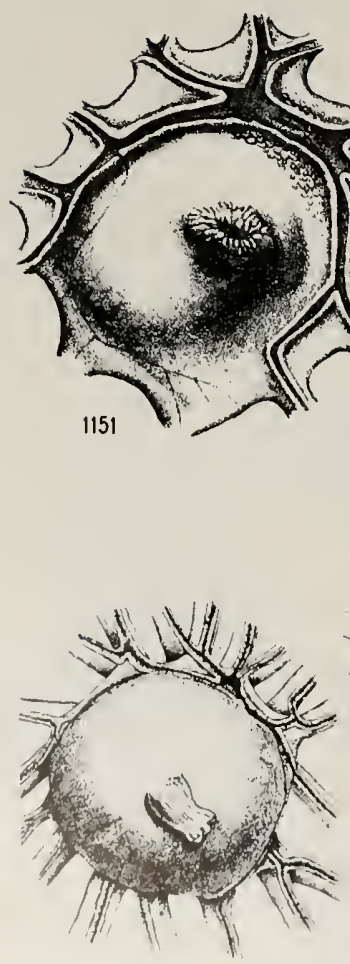

1152
BULLETIN 82, PART 2 PL. 24

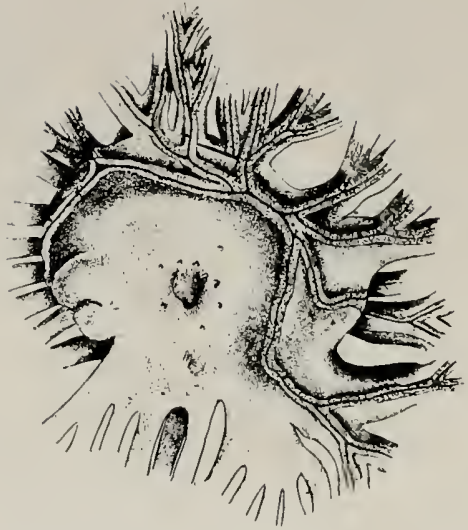

1150

DISKS OF VARIOUS COMASTERIDS 


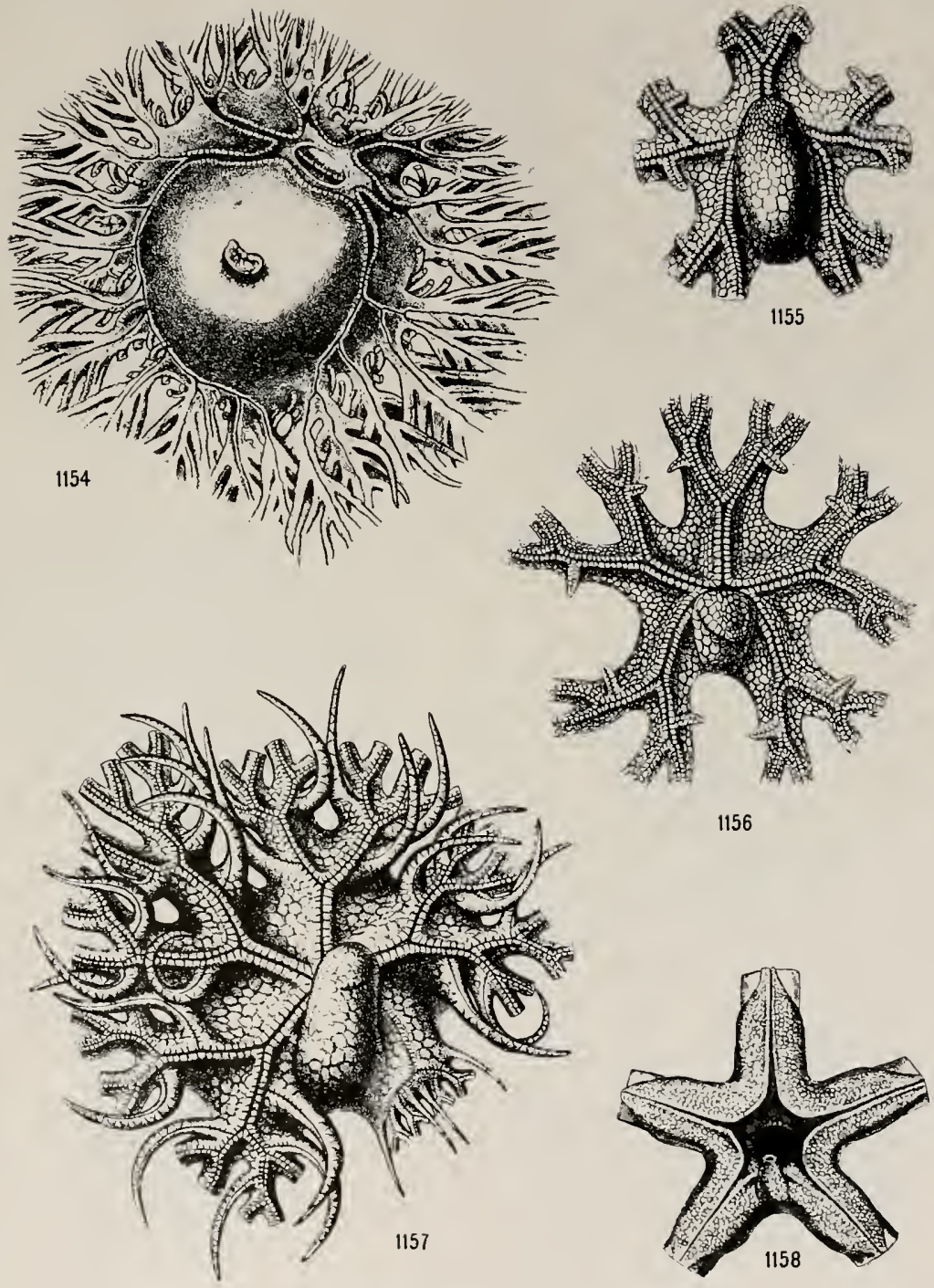

DISKS OF VARIOUS COMATULIDS 


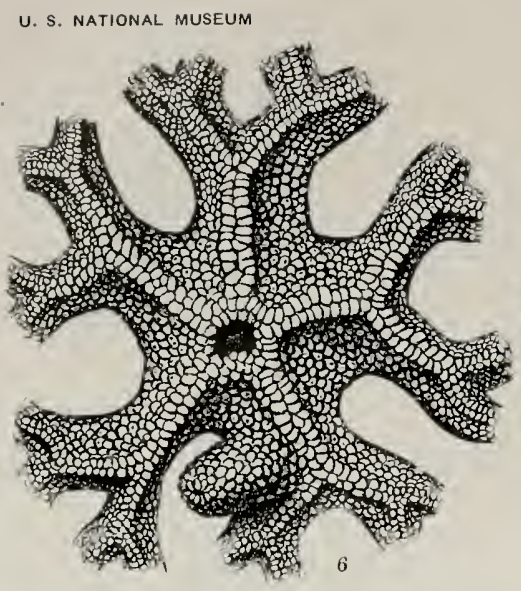

BULLETIN 82, PART 2 PL. 26
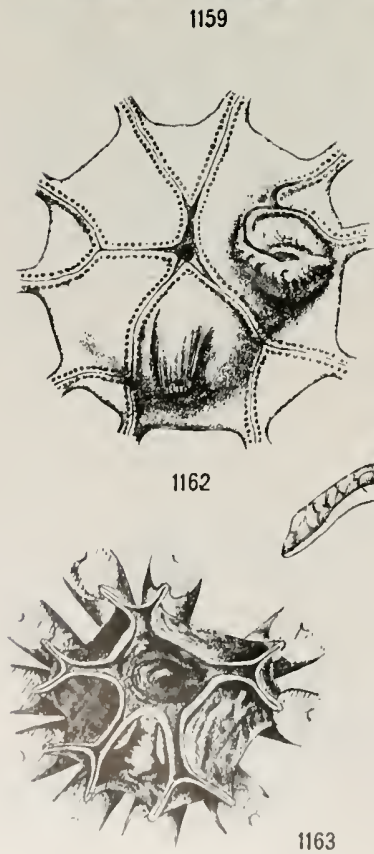

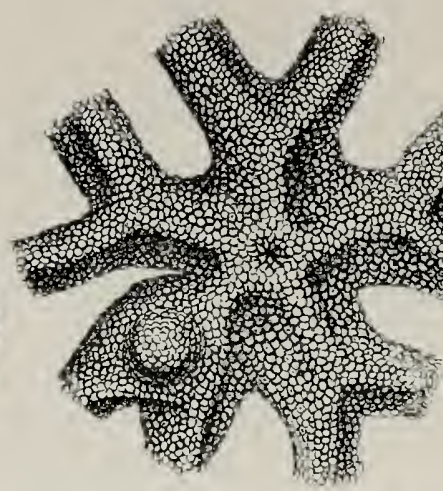

1160

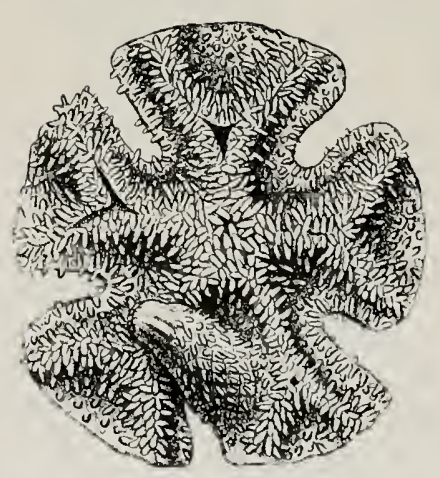

1161

1165

1163

1164

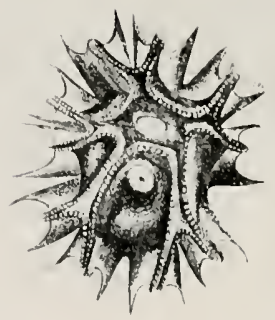

DISKS OF VARIOUS COMATULIDS 


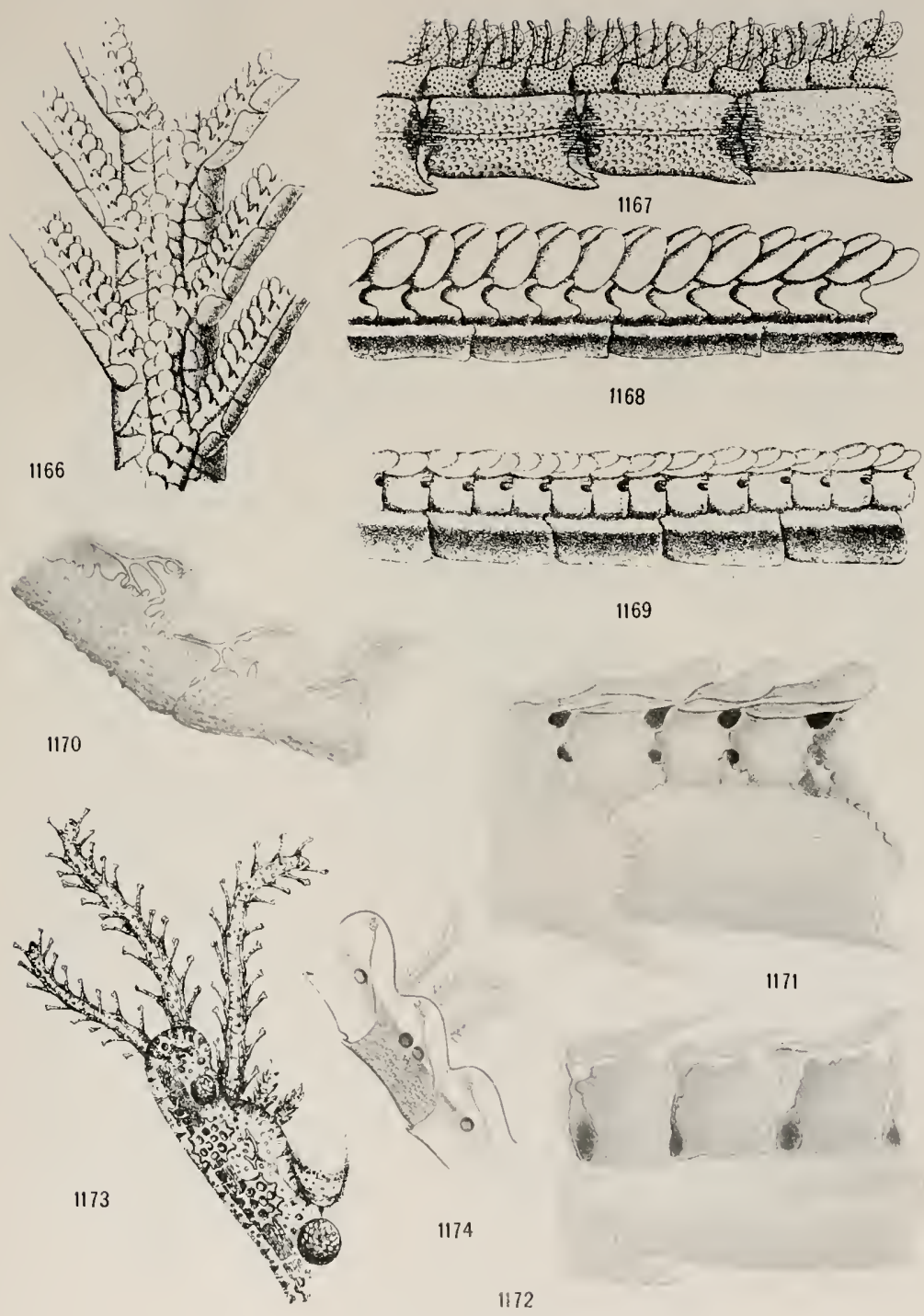

ADAMBULACRAL DEPOSITS OF VARIOUS COMATULIDS 

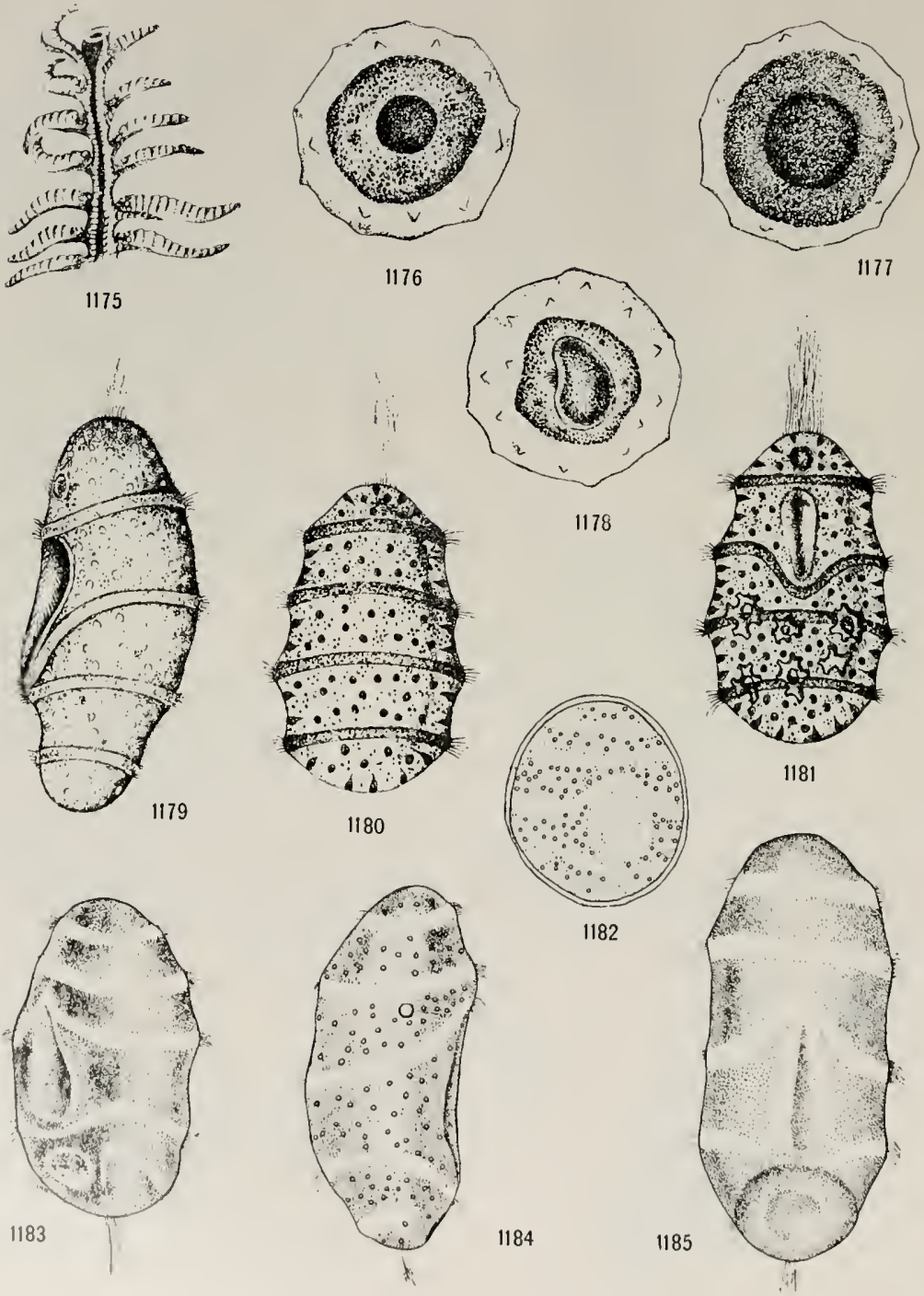

1179

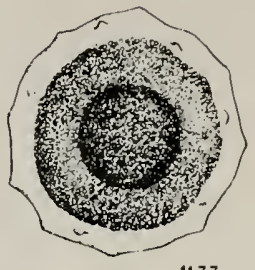

EgGS and LARVEe of CERTAIN COMATULIDS 


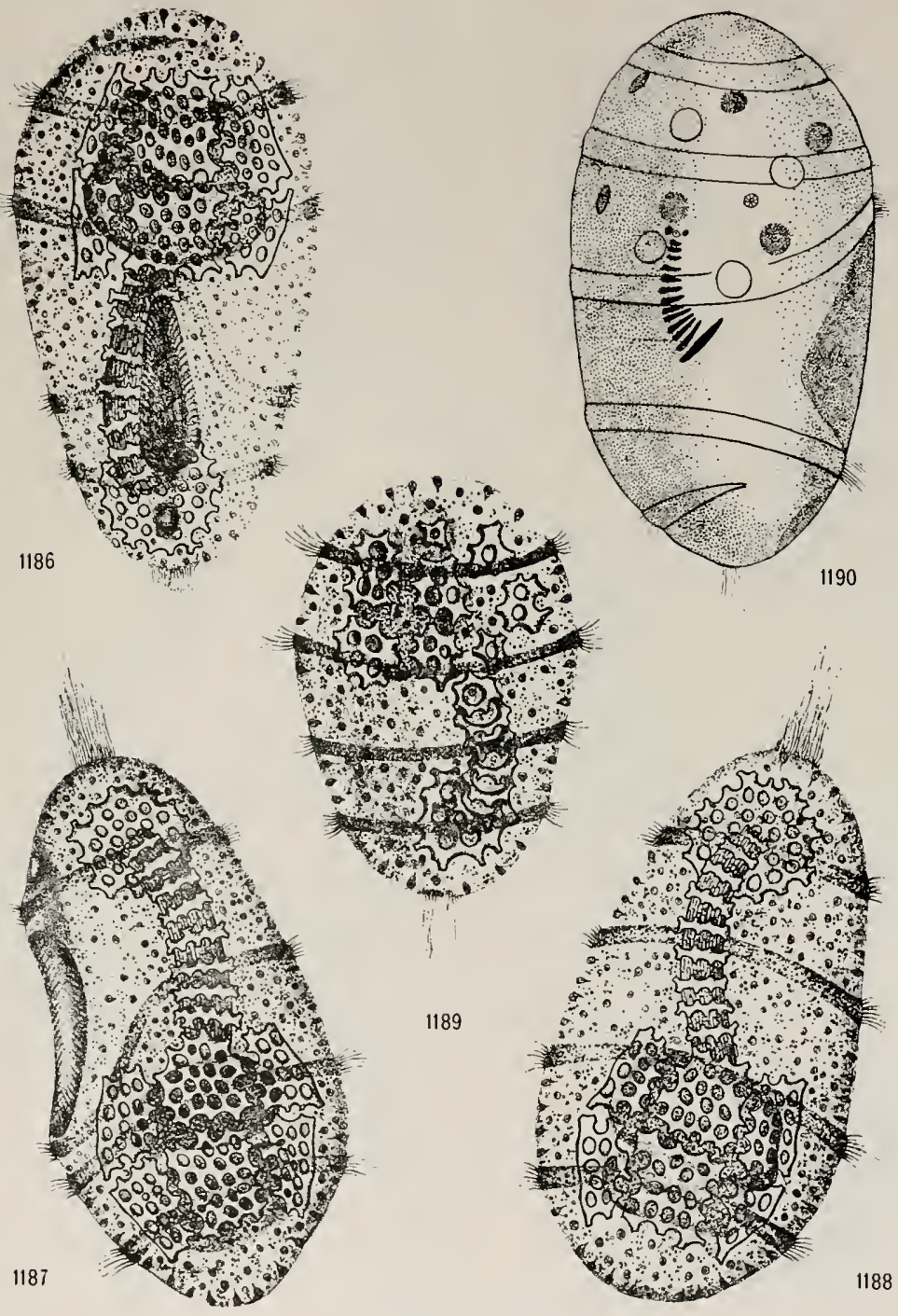

LARVAE OF ANTEDON 

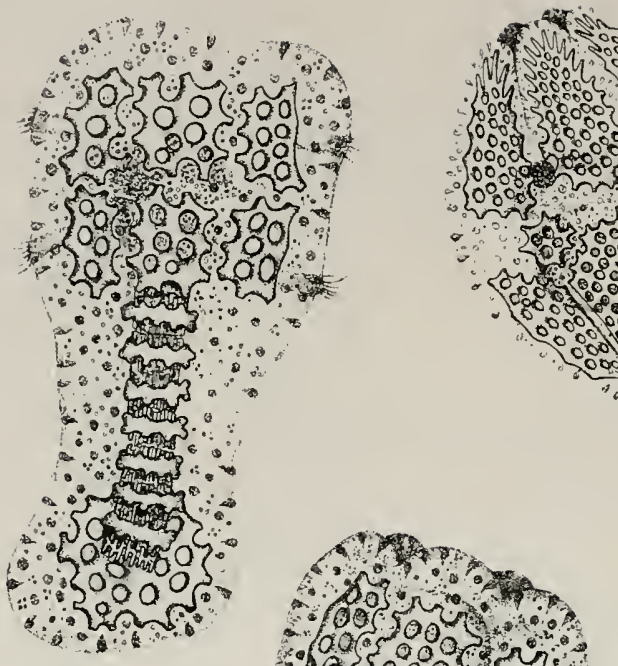

(1) 1004 1000

N 12000 2.000

$30 y+5000$. 0000

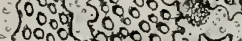

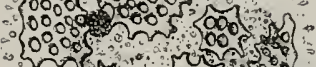

$7 \%$

2000

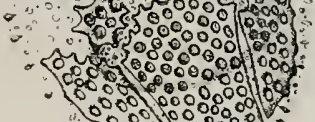

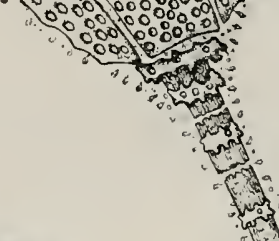

1193

1191

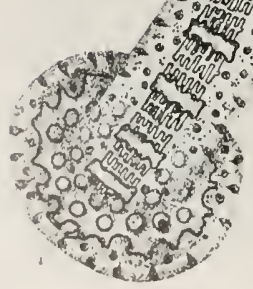

1192

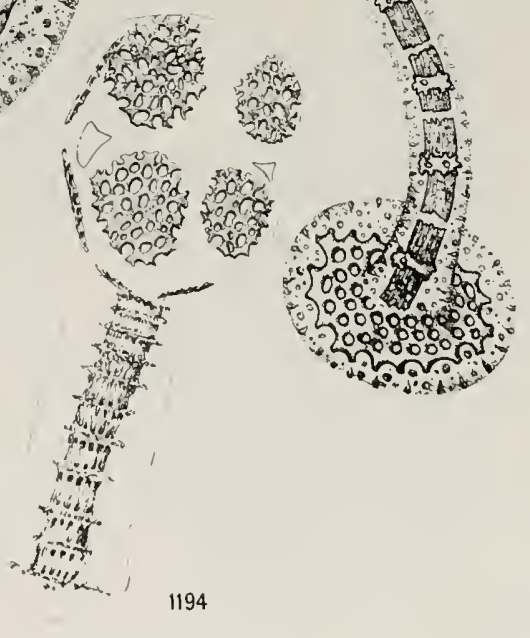

LARVIE OF ANTEDON 

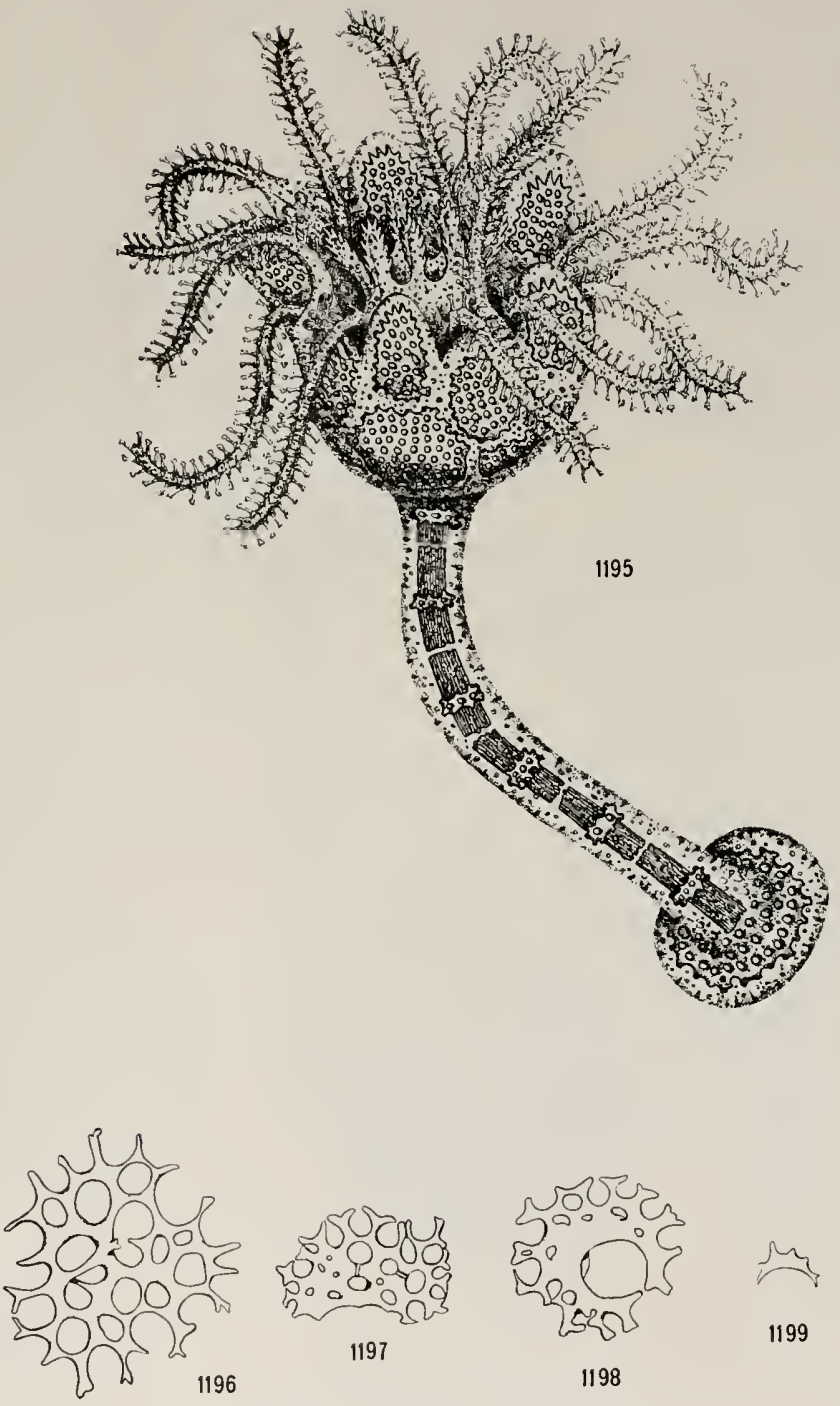

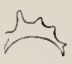

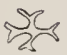




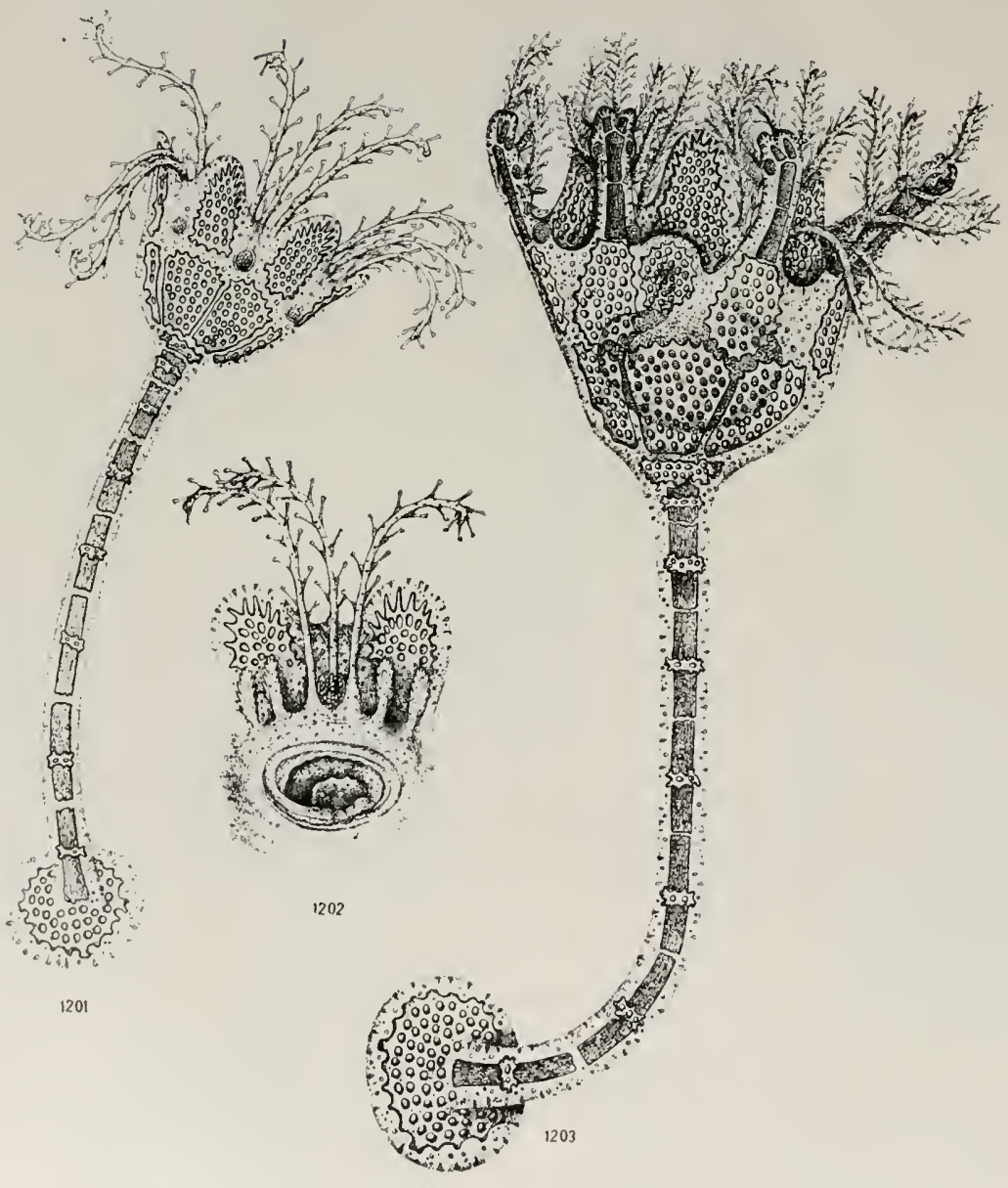

LARVAE OF ANTEDON BIFIDA 


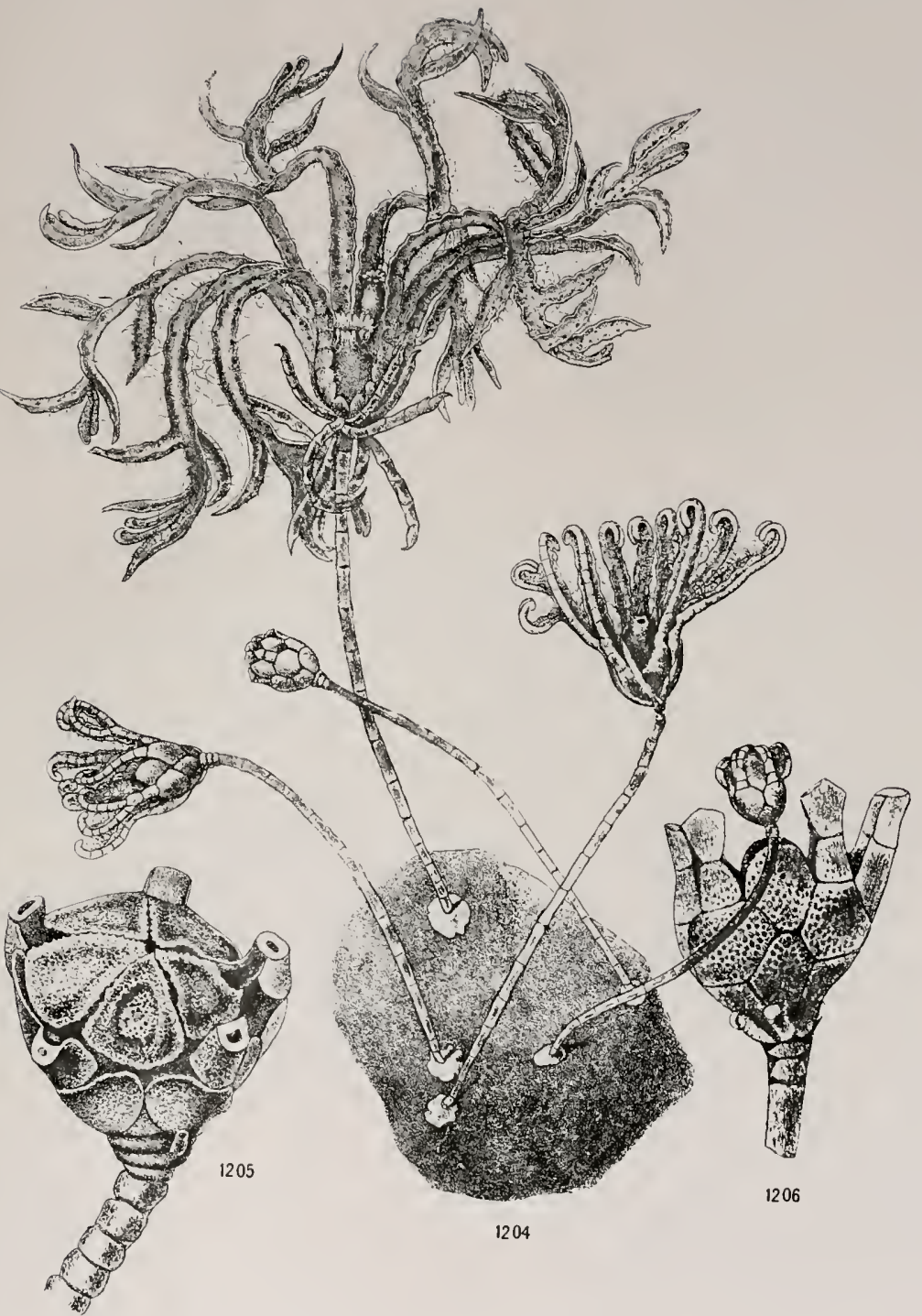




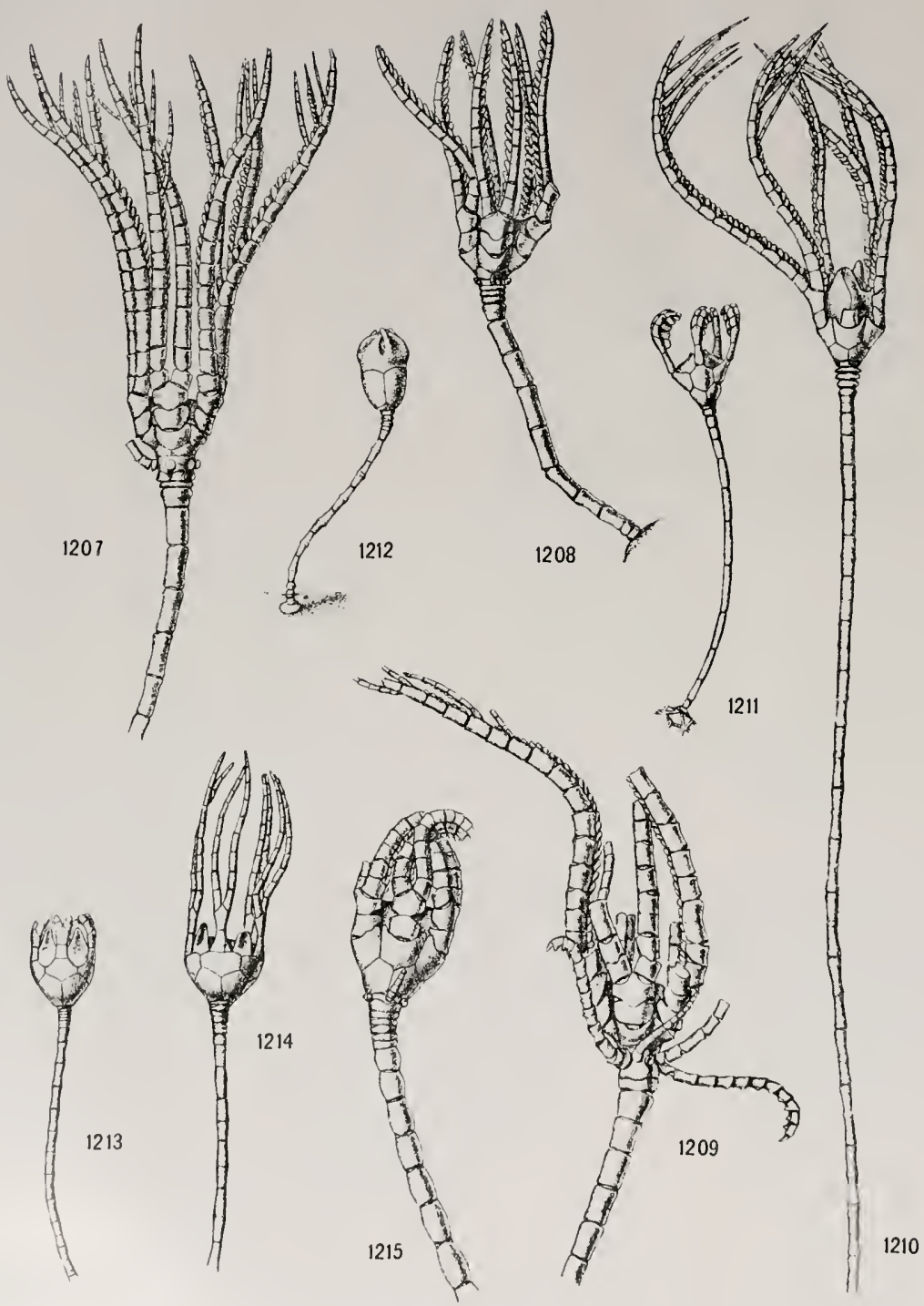




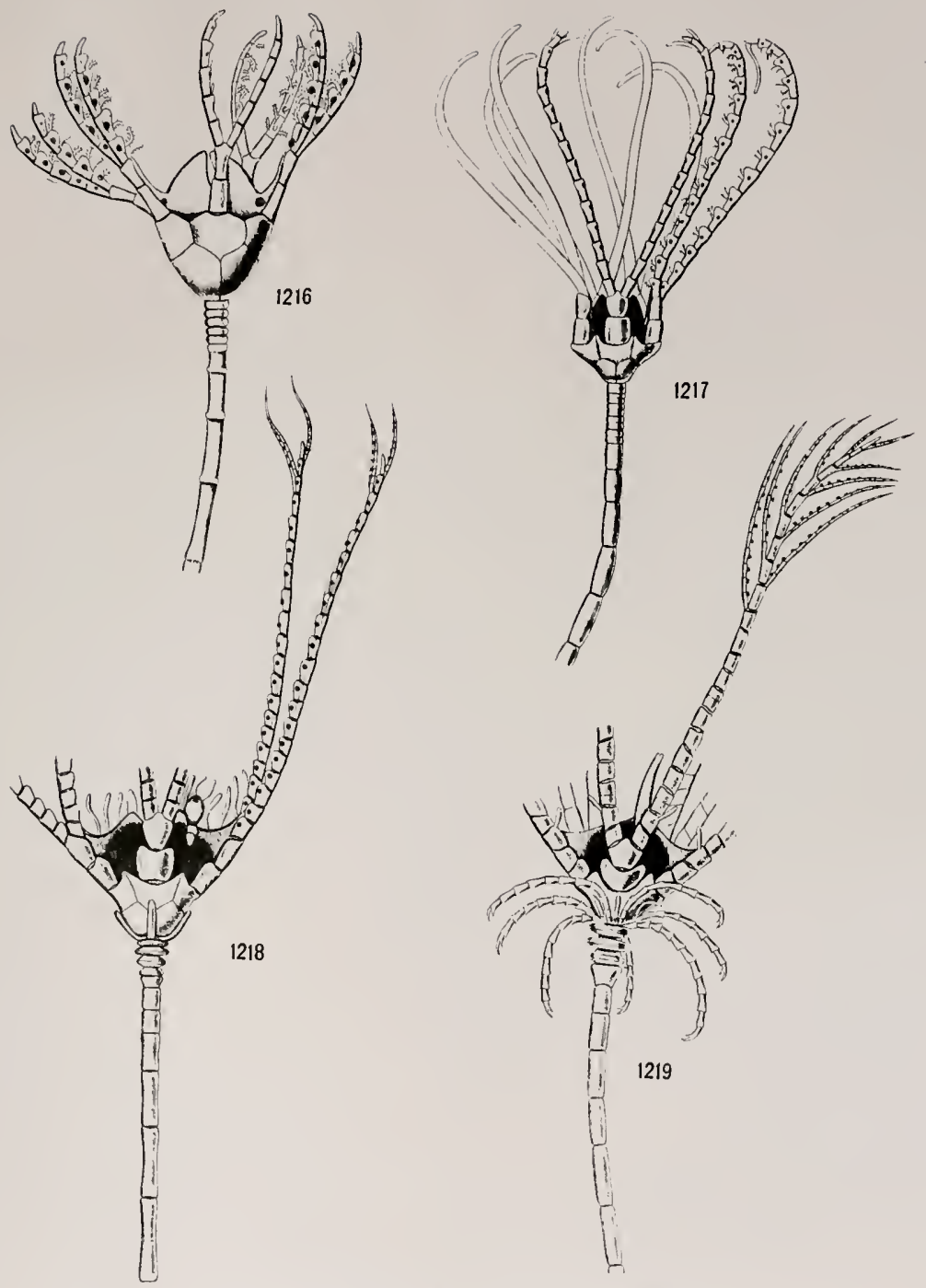

PENTACRINOID LARVAE OF HATHROMETRA SARSII 
U. S. NATIONAL MUSEUM

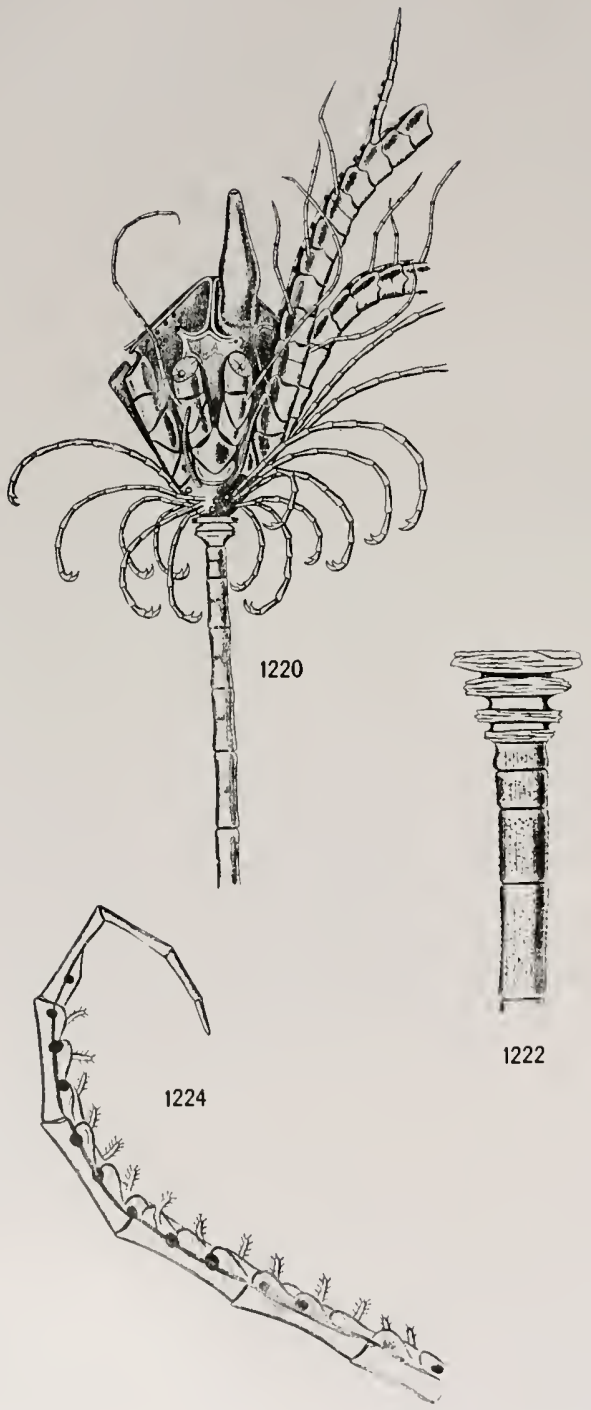

BULLETIN 82, PART 2 PL. 36
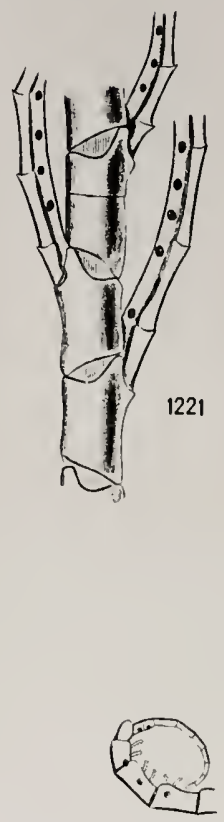

1223

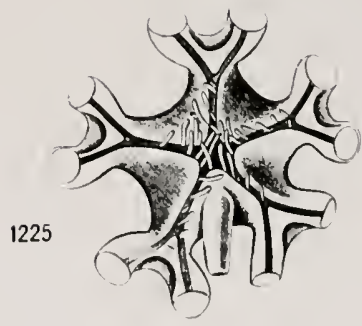

PENTACRINOID LaRVAE OF Hathrometra sarsiI 


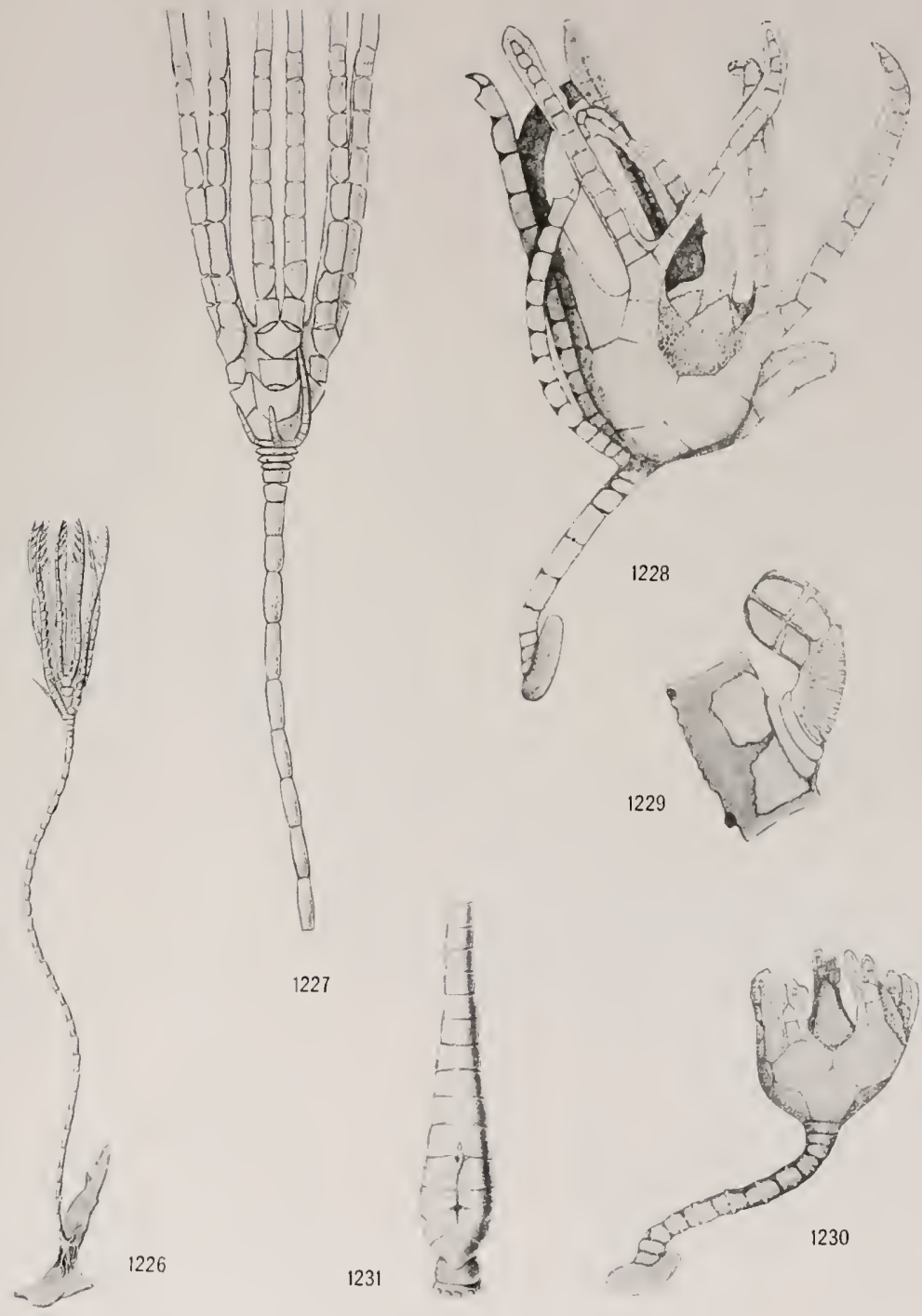

PEntacrinoid Larve of Various Comatulids, and an ABnormal arm of Heliometra GLACIALIS 


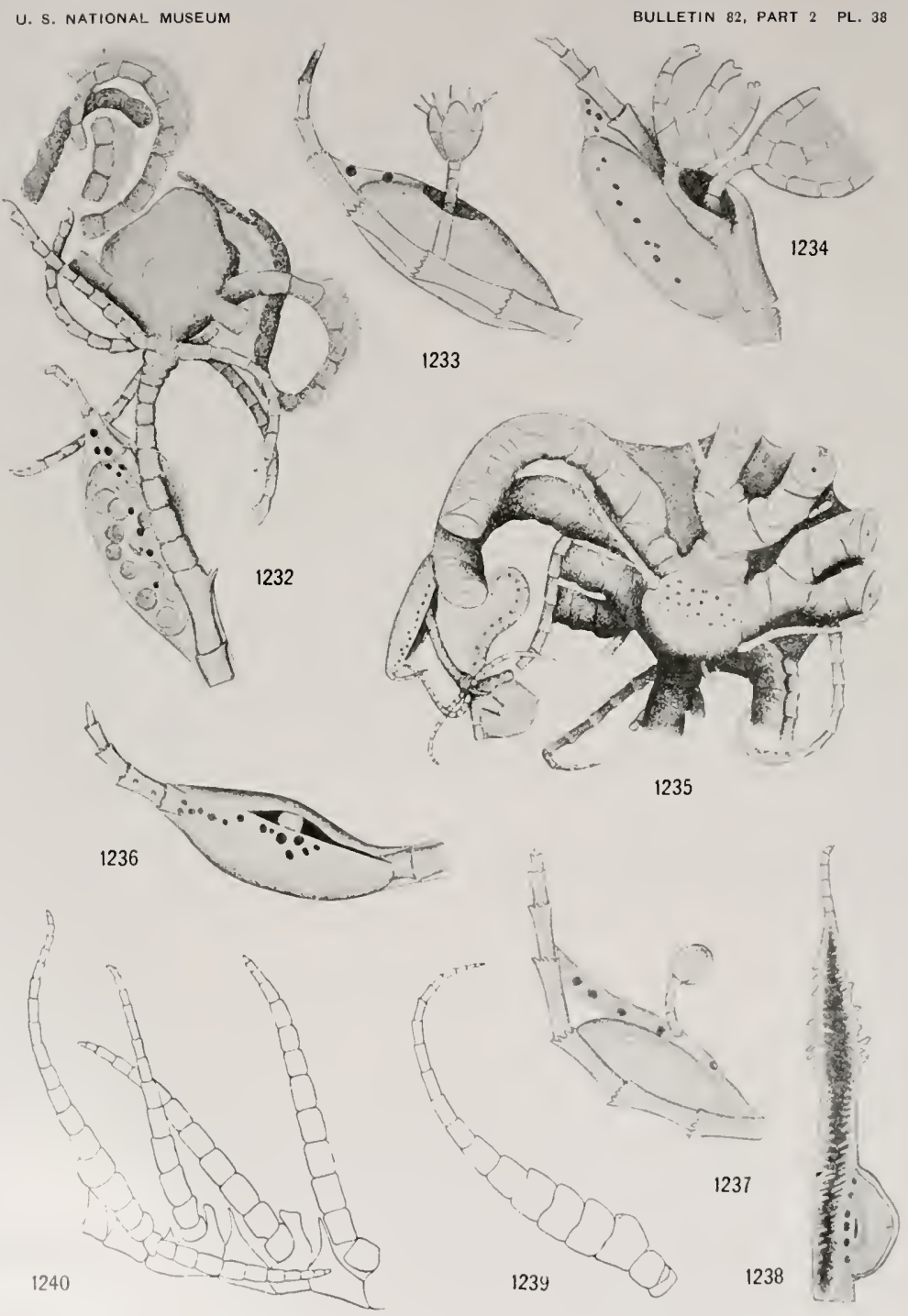

PENTACRINOID LARVAE AND PINNULES OF VIVIPAROUS COMATULIDS 


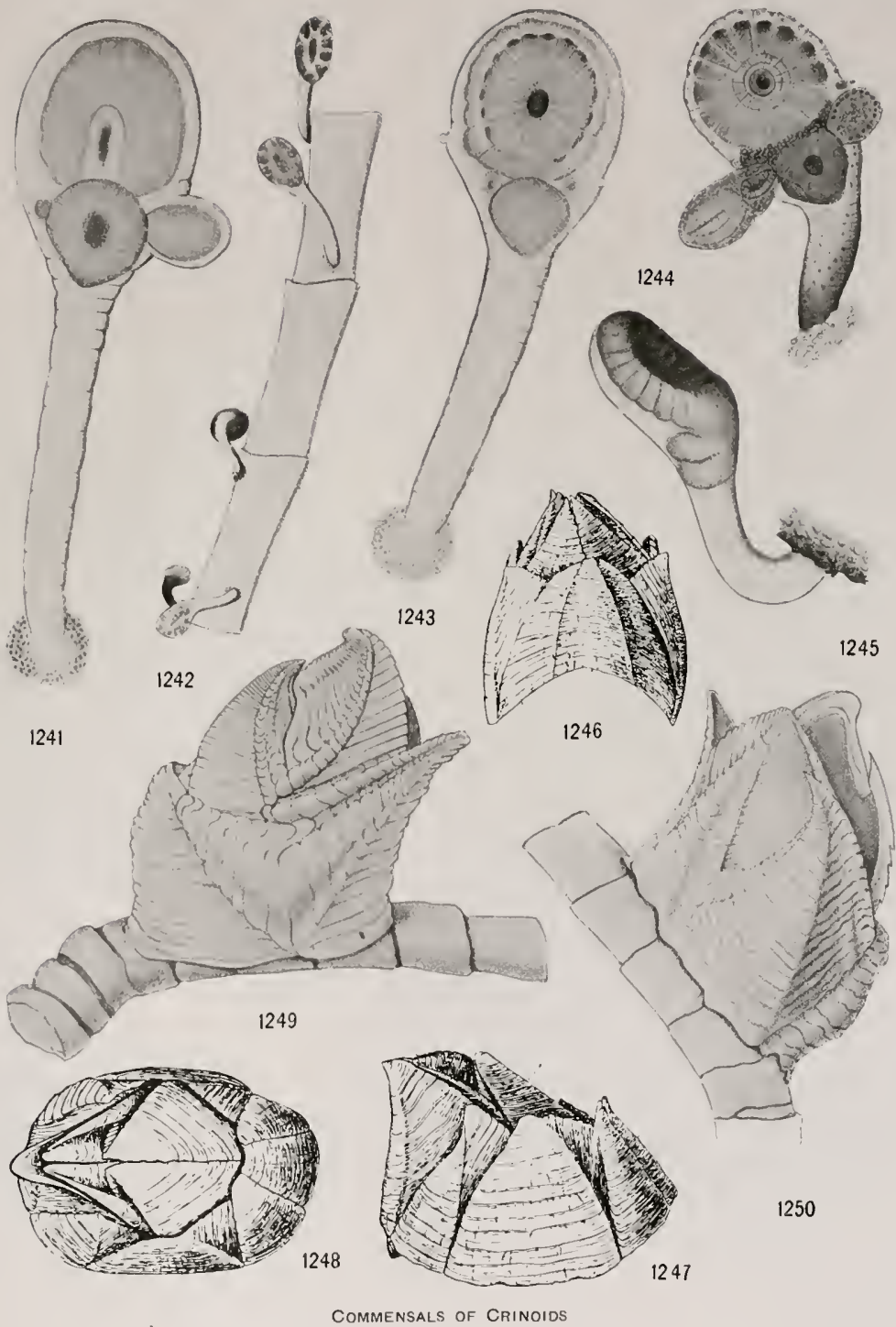

FOR EXPLANATION OF PLATE SEE PAGE 766. 


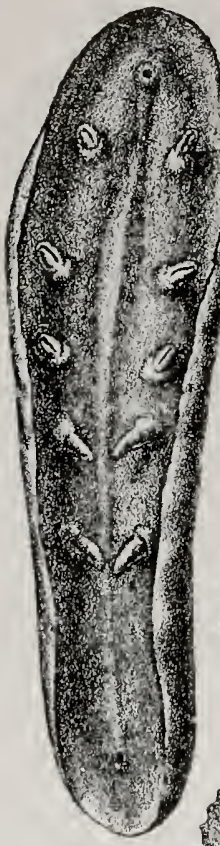

1251
1252

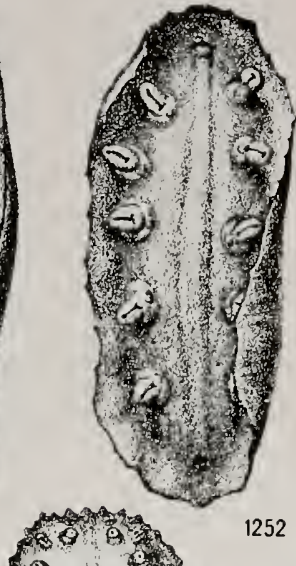

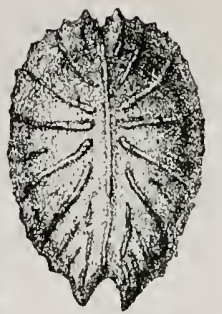

1257

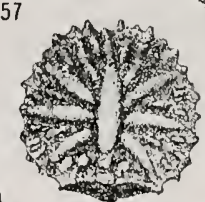

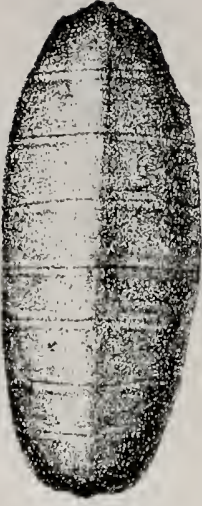

1253
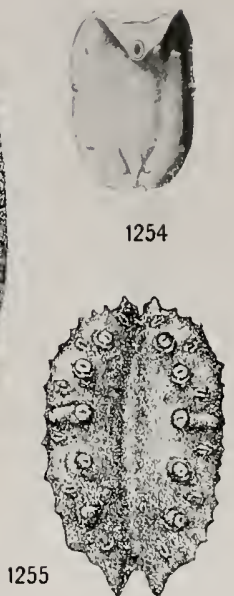

1259

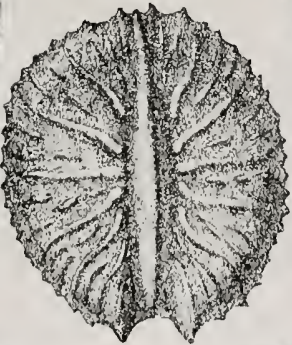

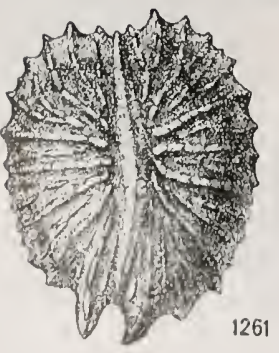

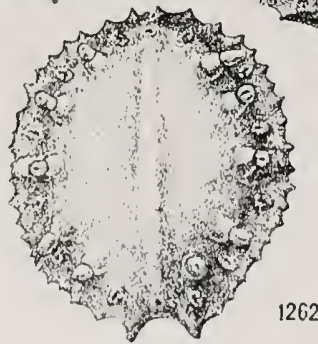

1262
1260

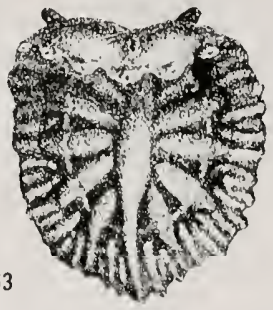

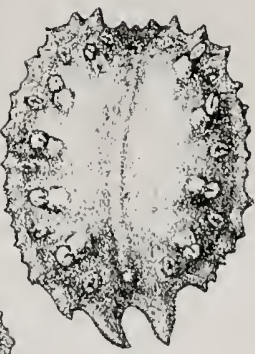

1258 
U. S. NATIONAL. MUSEUM

BULLETIN 82, PART 2 PL. 41

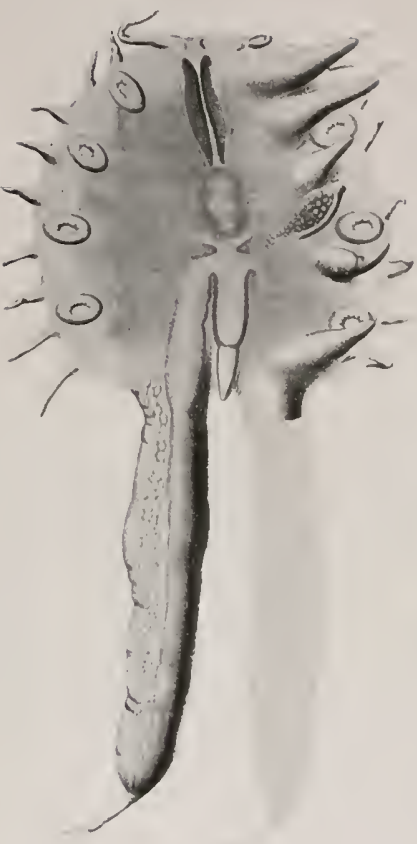

1265

1264

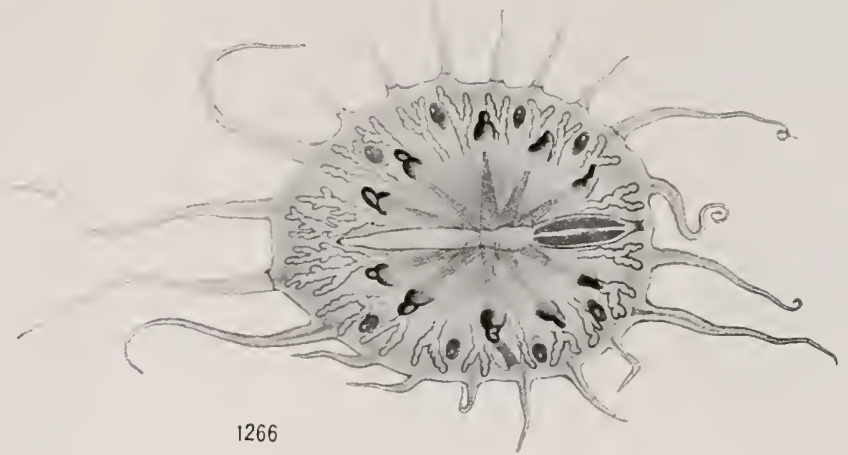

MYZOSTOMES

For Explanation of PLATE SEE PAGE 767. 
U. S. NATIONAL MUSEUM

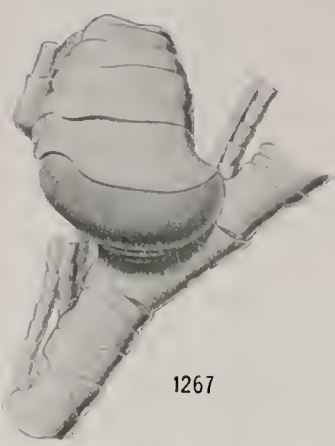

BULLETIN 82, PART 2

PL. 42
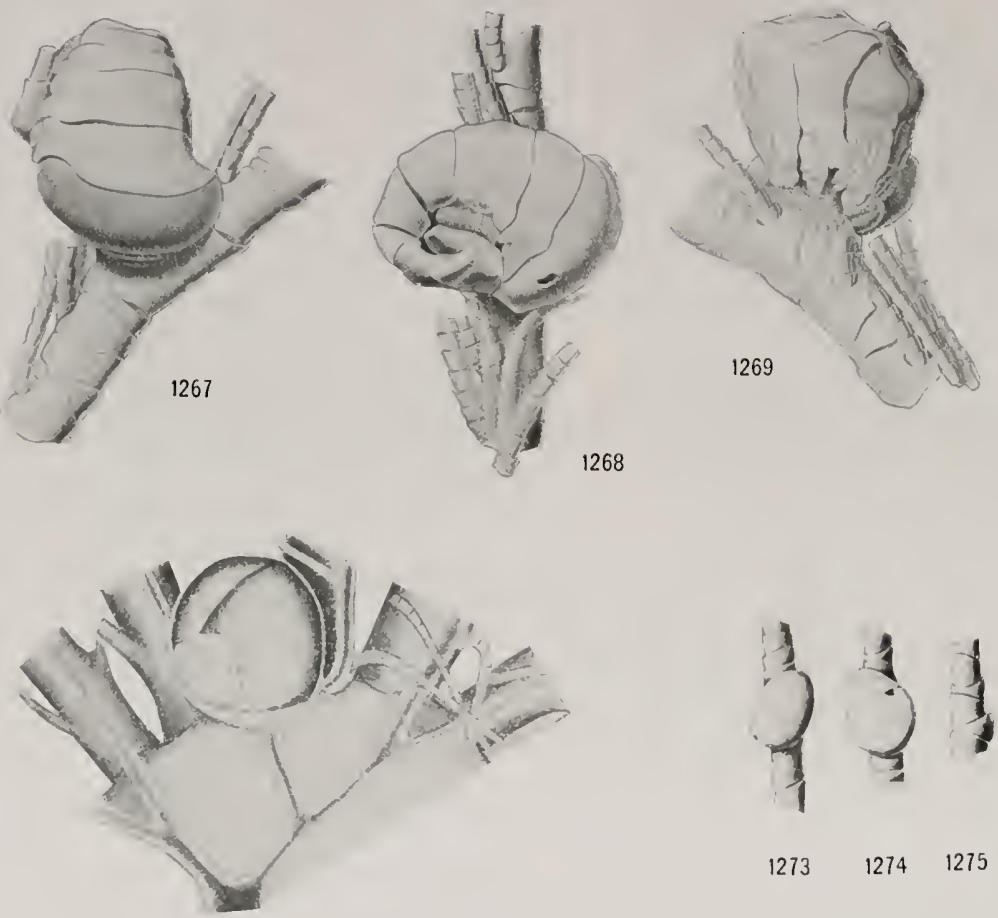

1276
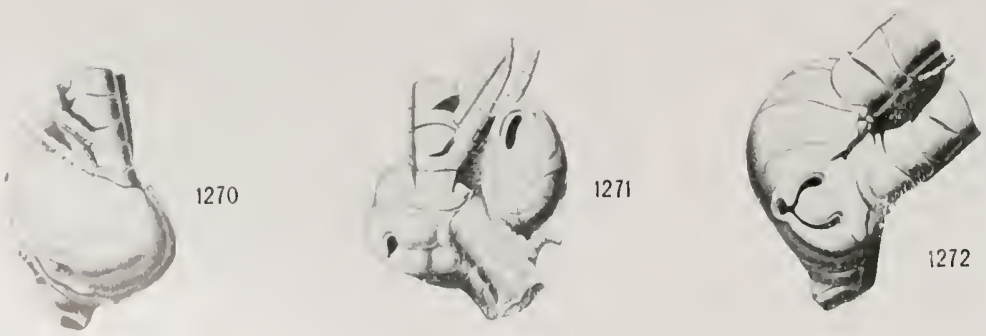

DEFoRMATIONS CAUSED BY MYZOSTOMES

For explanation of plate see page 707. 
U. S. NATIONAL MUSEUM
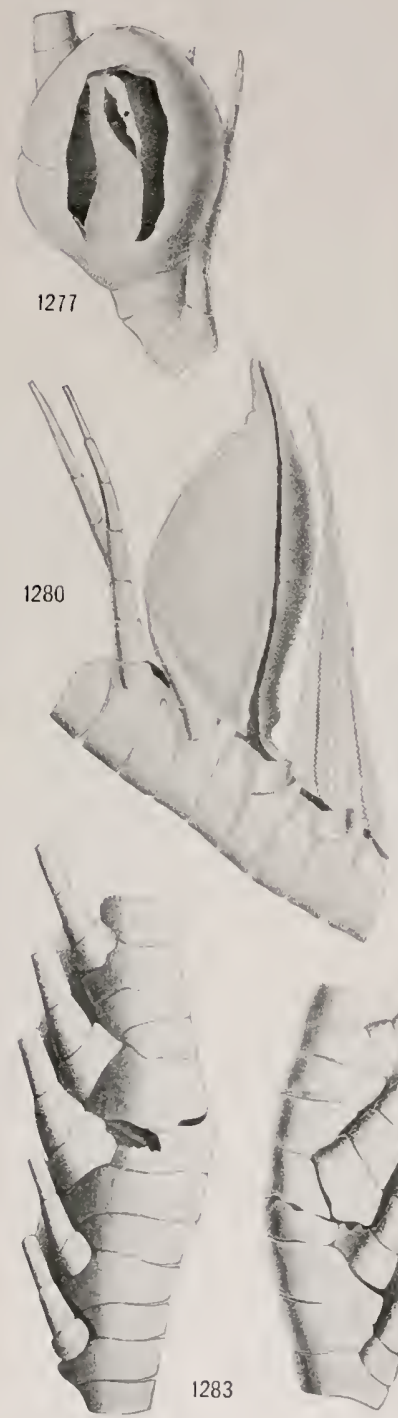

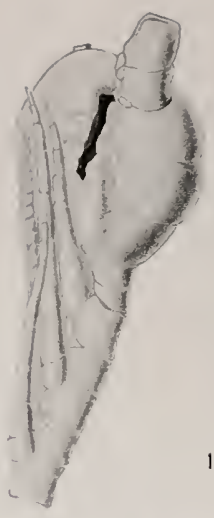

1278

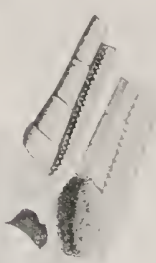

1282
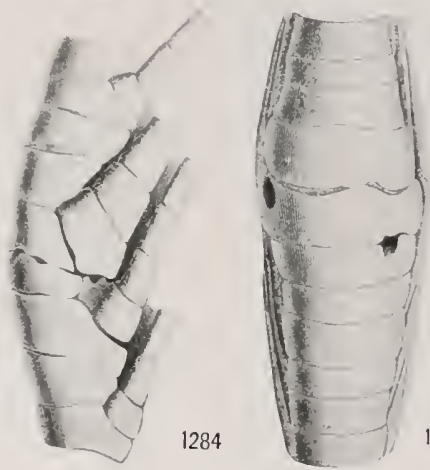

1285
BULLETIN 82, PART 2 PL. 43
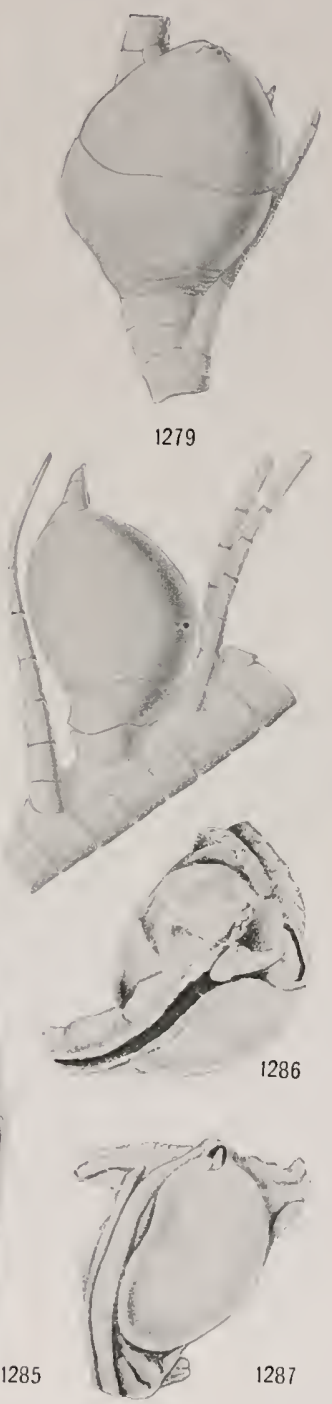

DEFORMATIONS CAUSED BY MYZOSTOMES 
U. S. NATIONAL MUSEUM

BULLETIN 82, PART 2 PL. 44

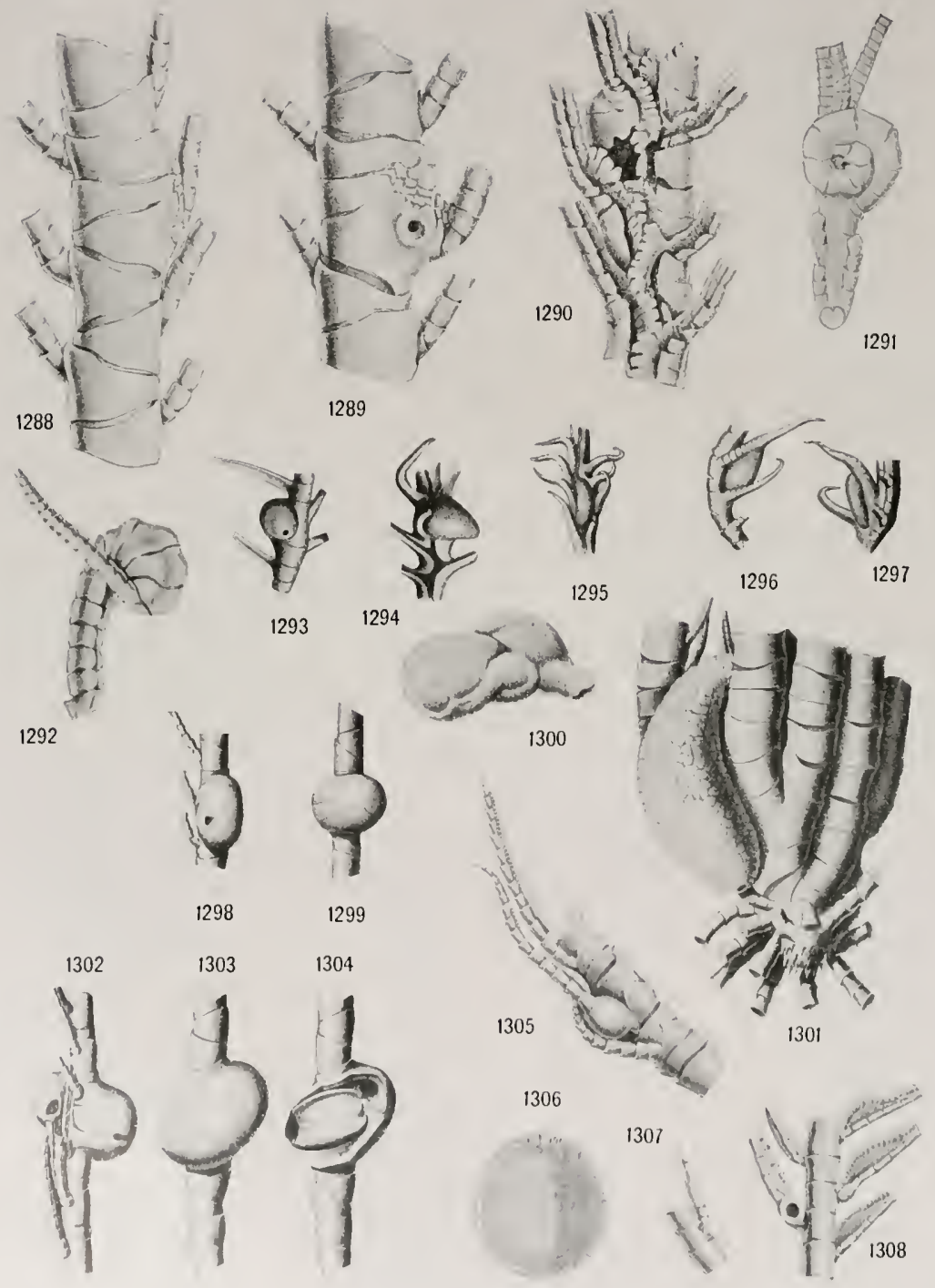

DEFORMATIONS CAUSED BY MYZOSTOMES AND OTHERWISE 


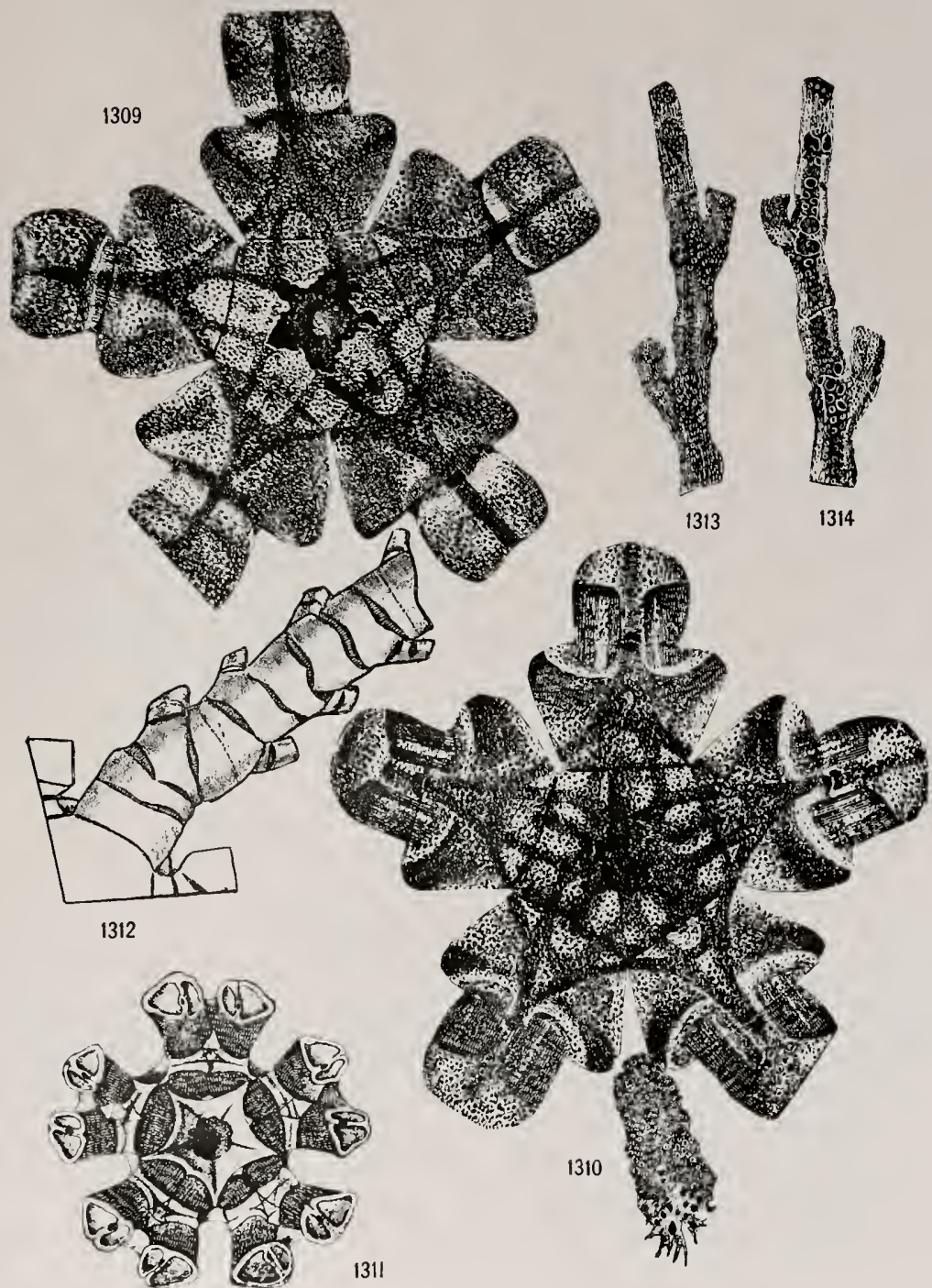

PORTIONS OF SKELETON OF YOUNG OF ANTEOON BIFIDA, AND AN ABNORMAL ARM FROM FULLY GROWN SPECIMEN. 

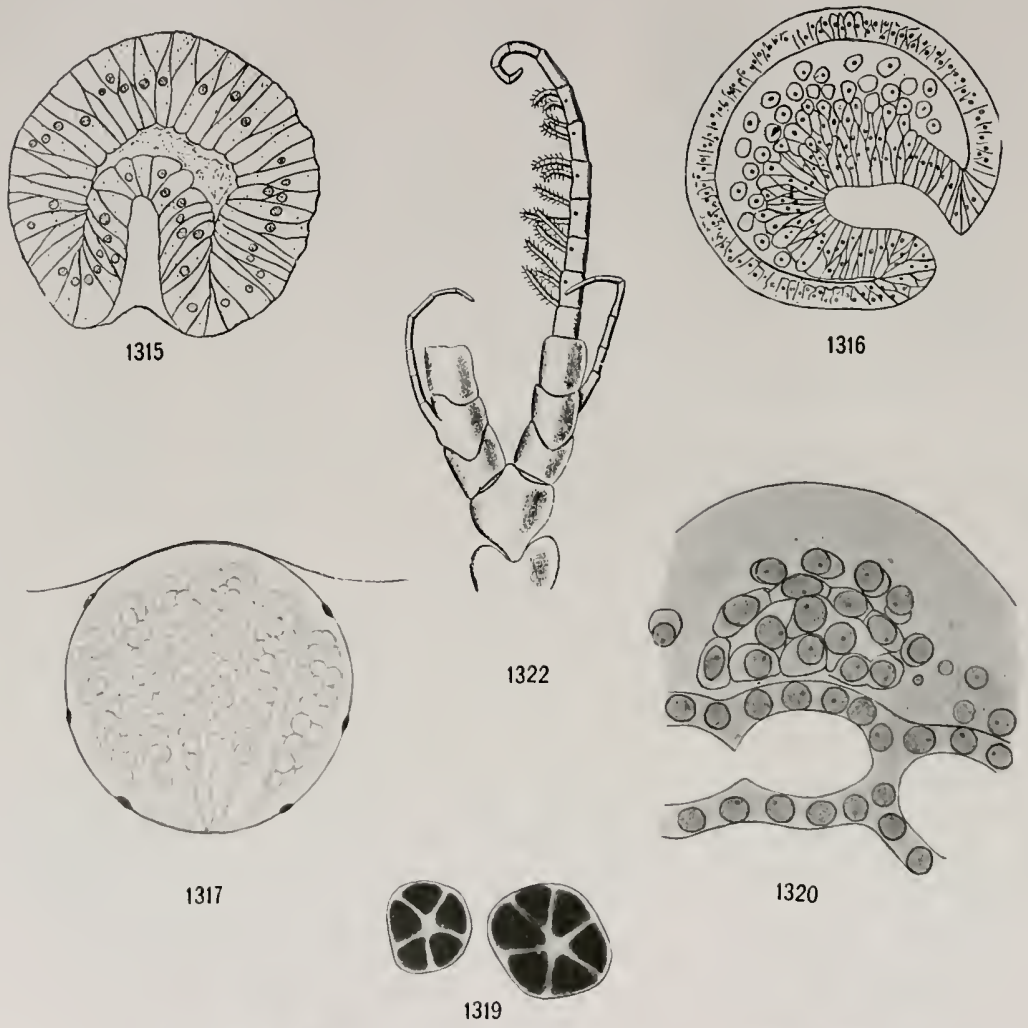

1320 


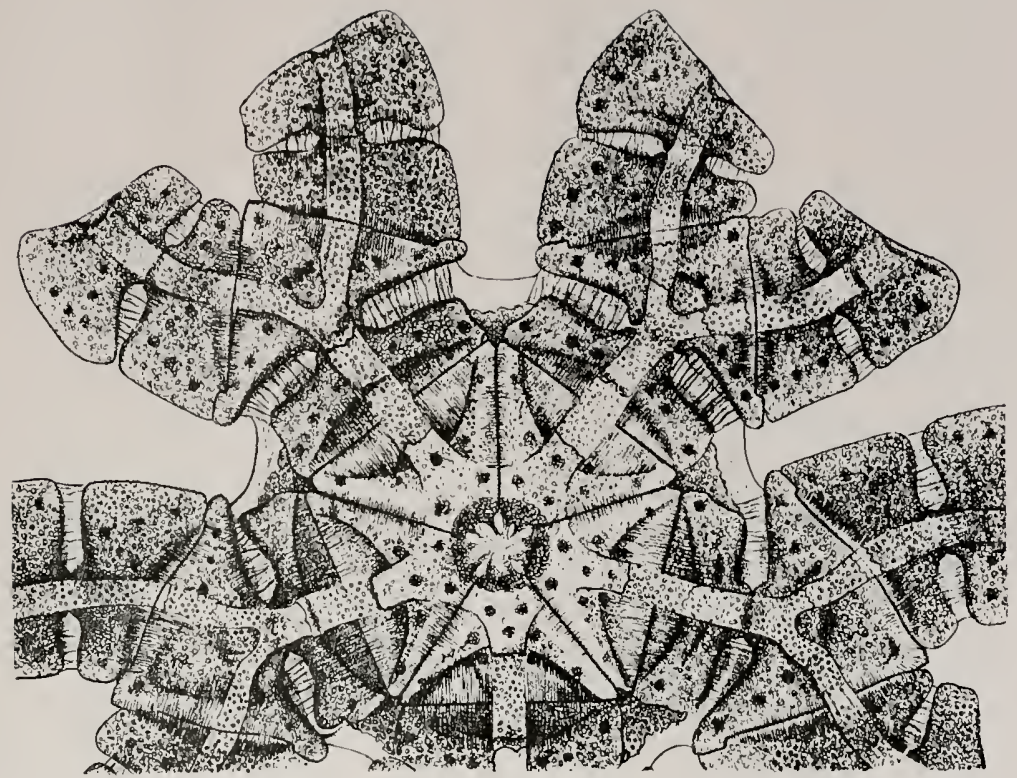

1323
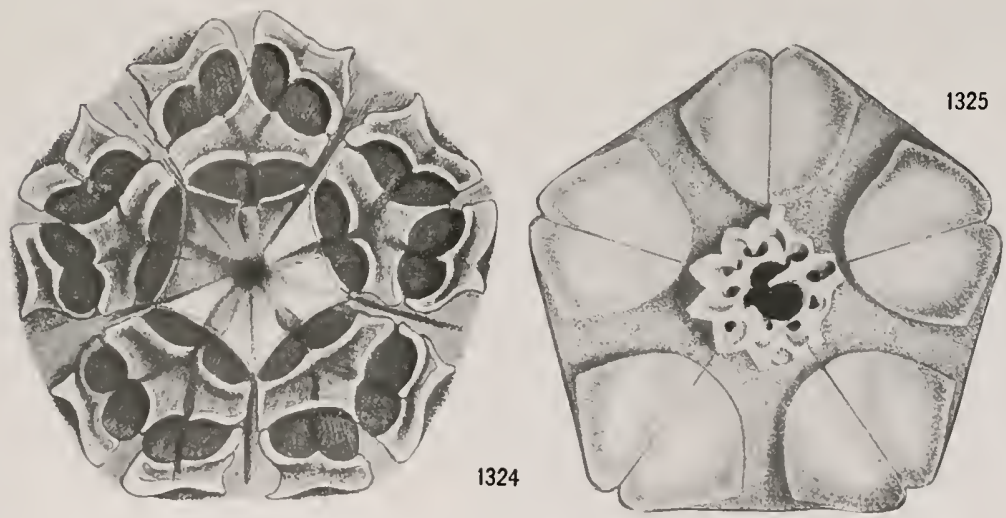

Structure of the CENTRAL PORTION OF ANTEDON BIFIDA. 


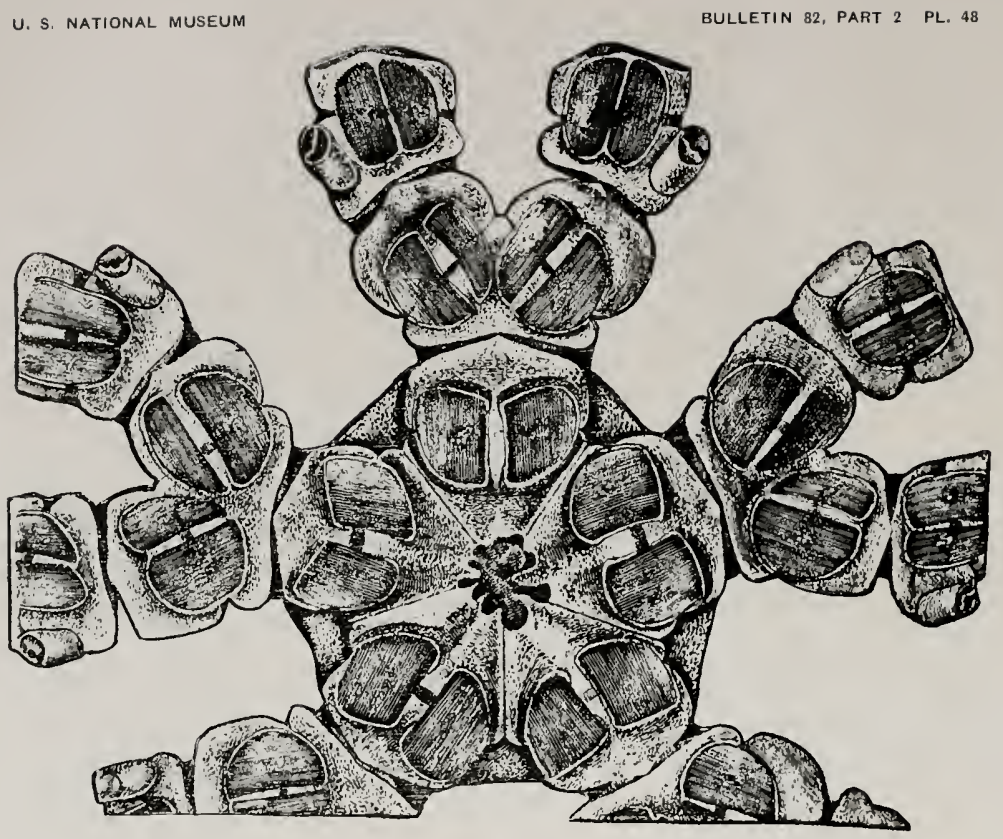

1320

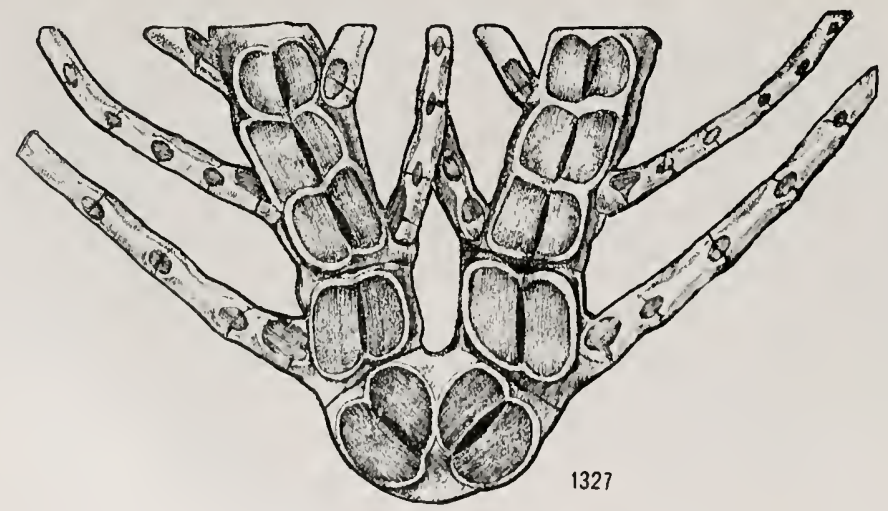

INTERBRACHIAL MUSCULATURE OF ANTEDON BIFIDA 

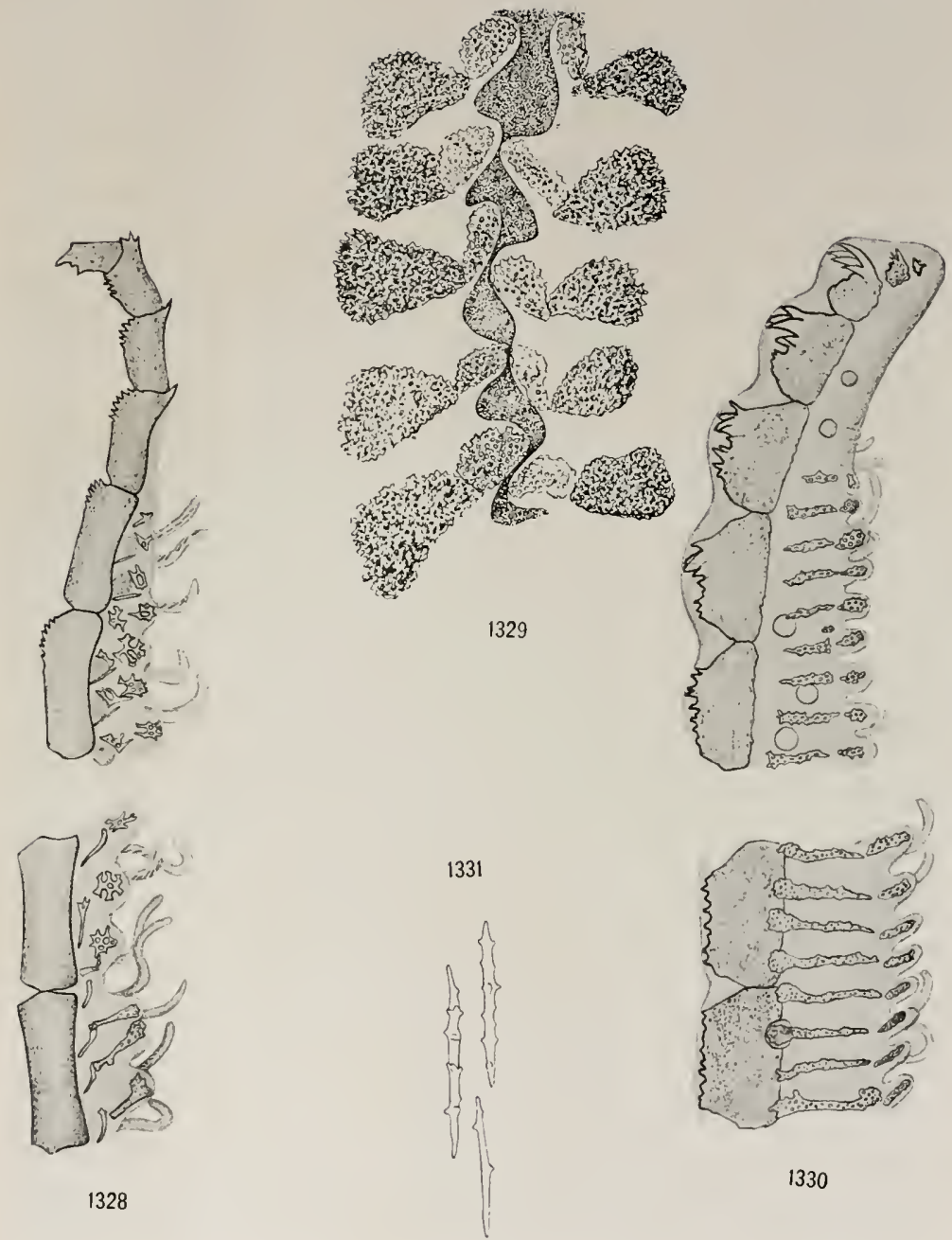

ADAMBULACRAL DEPOSITS OF VARIOUS COMATULIDS

for explanation of plate see page 769. 


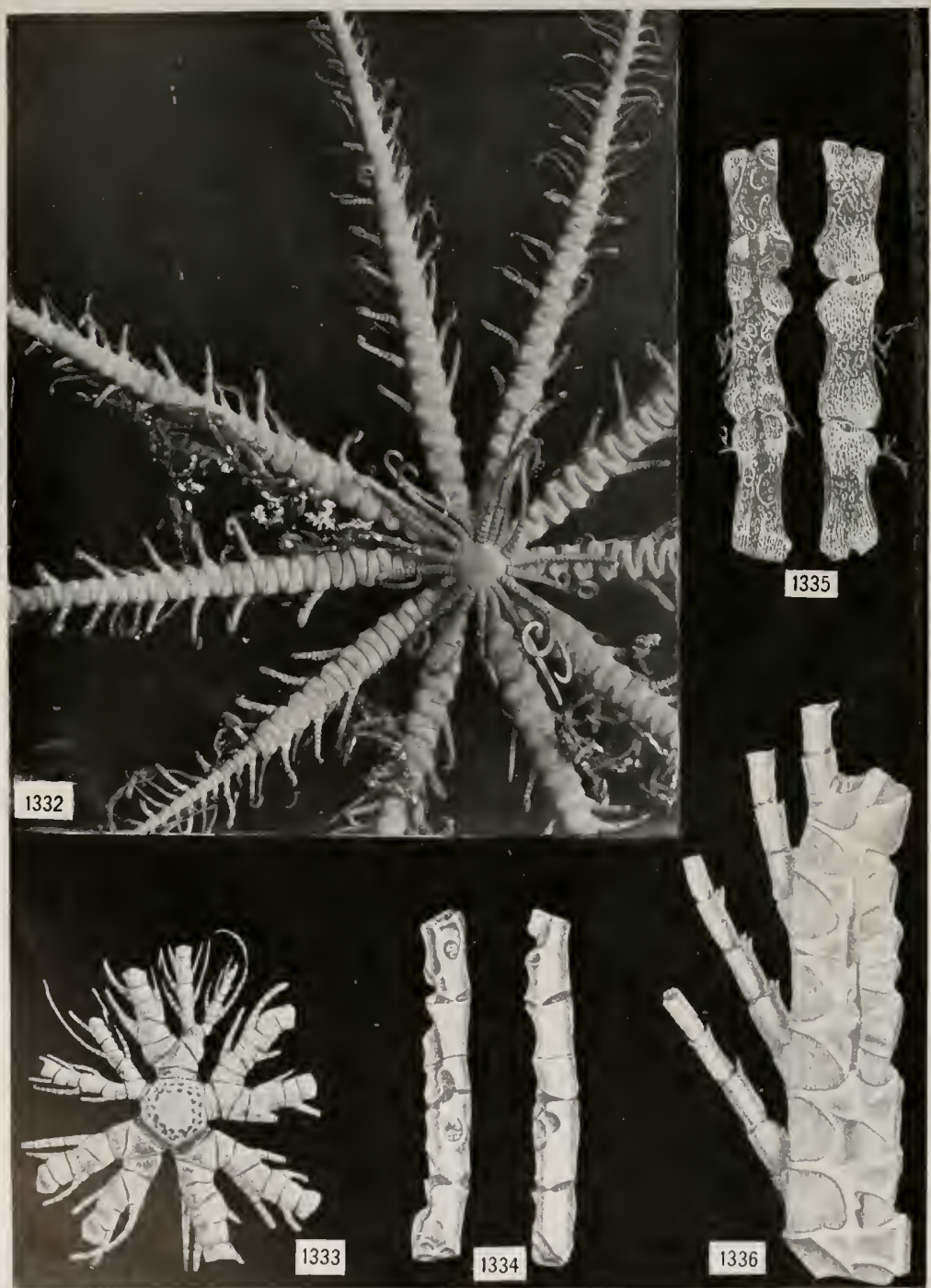




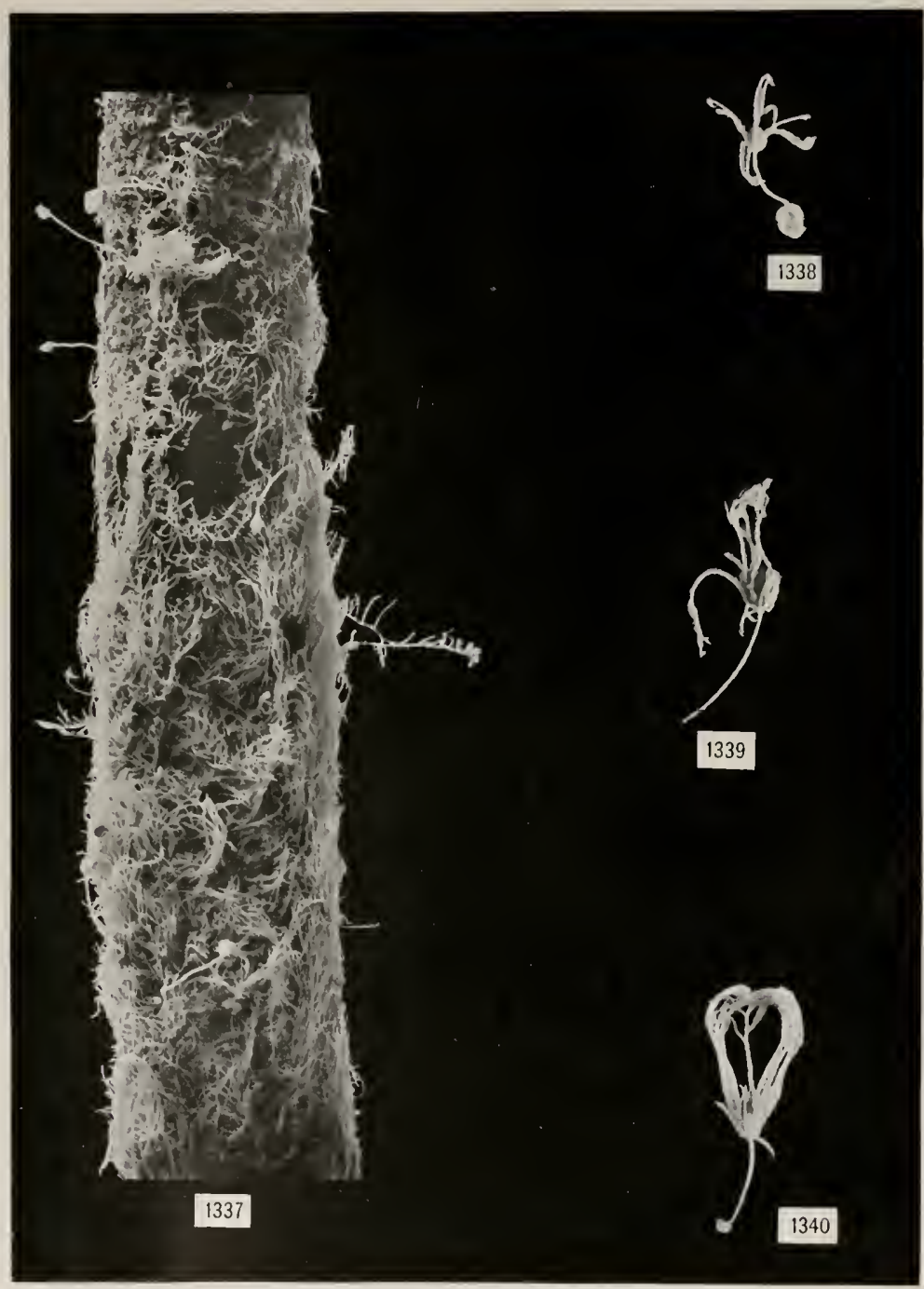

PENTACRINOIDS OF ANTEDON MEDITERRANEA

For EXPLANATION OF PLATE SEE PAgE 769. 

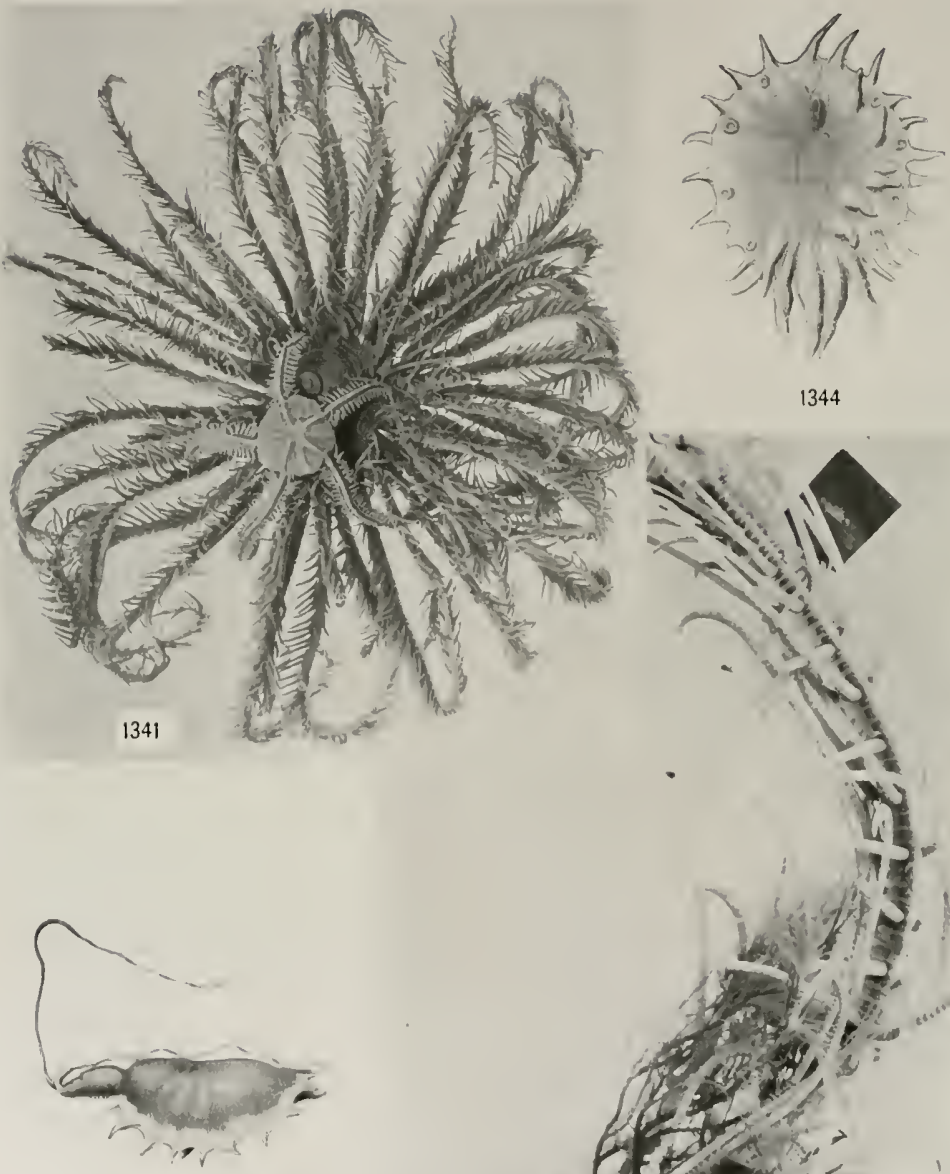

1343

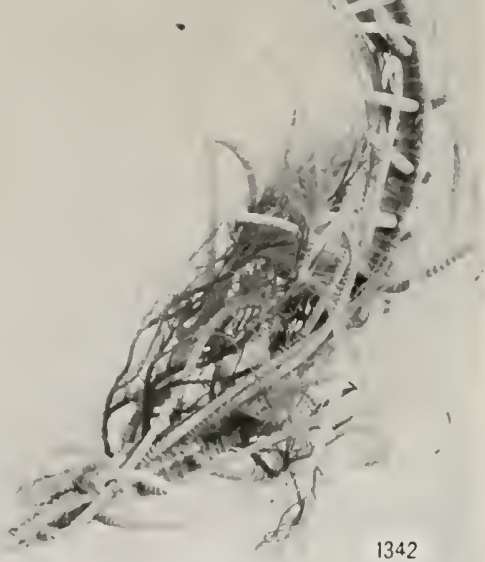




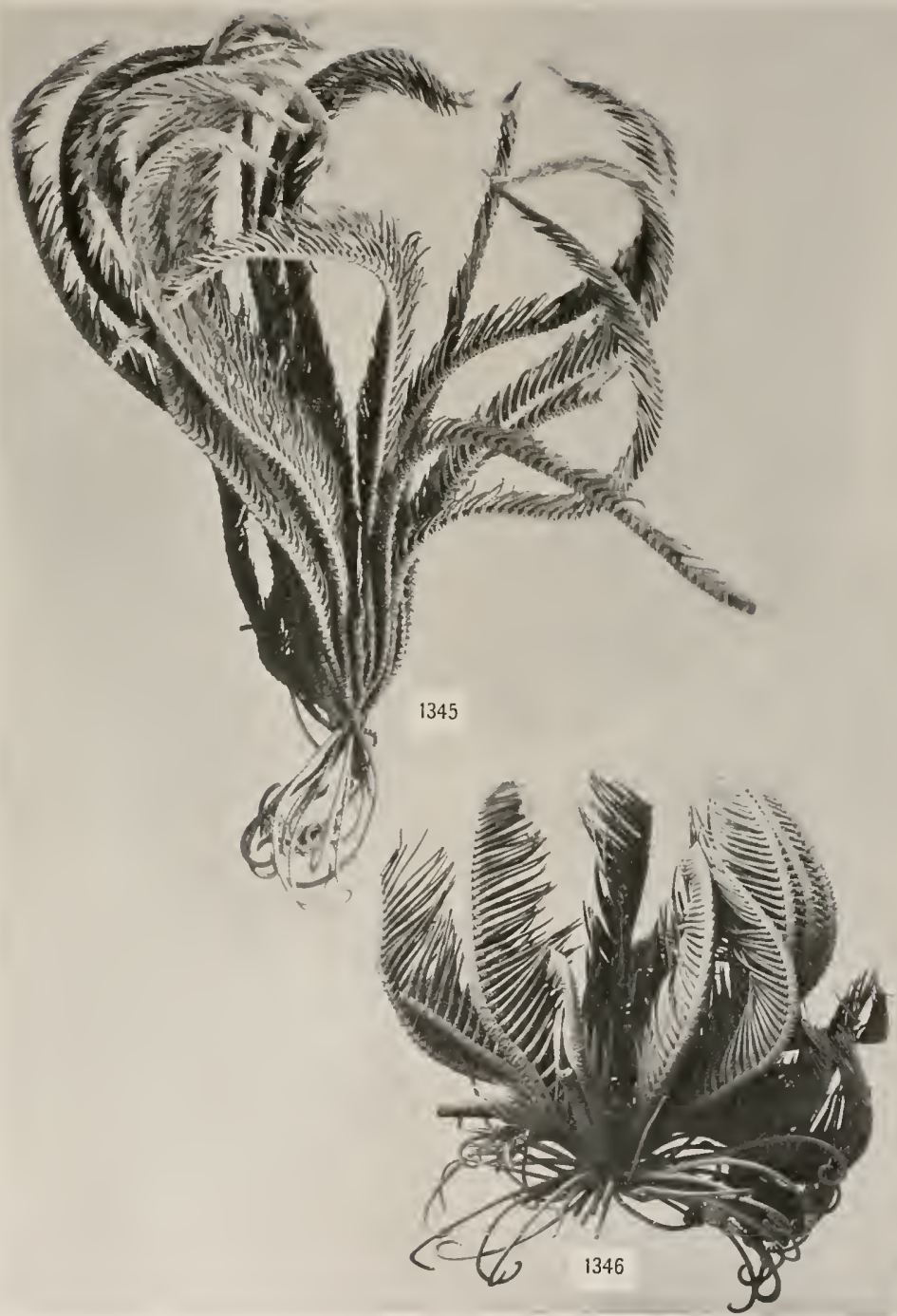

Stylometra SPINIfERA AND PTILOMETRA NüLlefi, WITH COMMENSALS ATTACHED TO CIRR! FoR EXPLANATION OF PLATE SEE PAOE 770. 


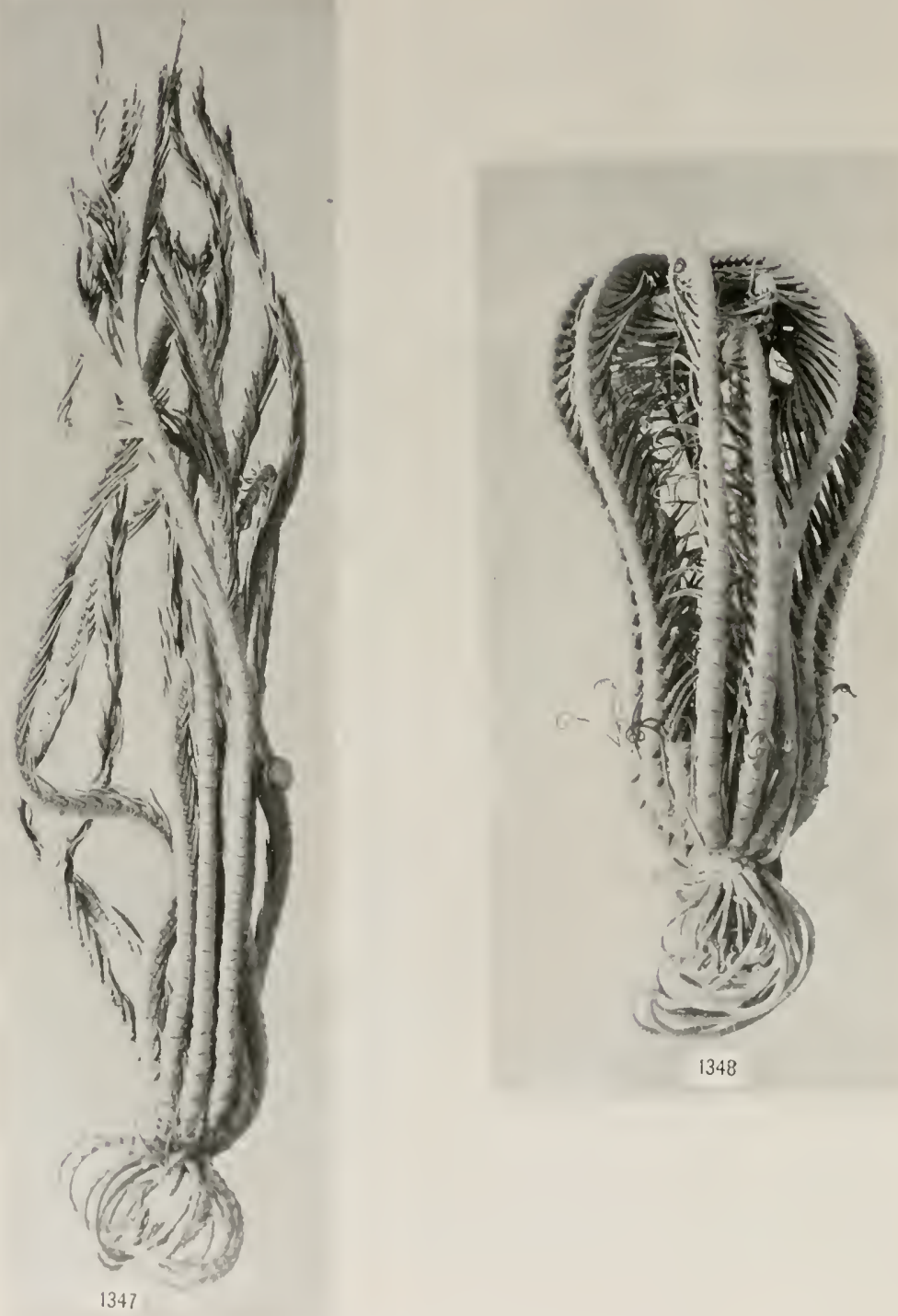



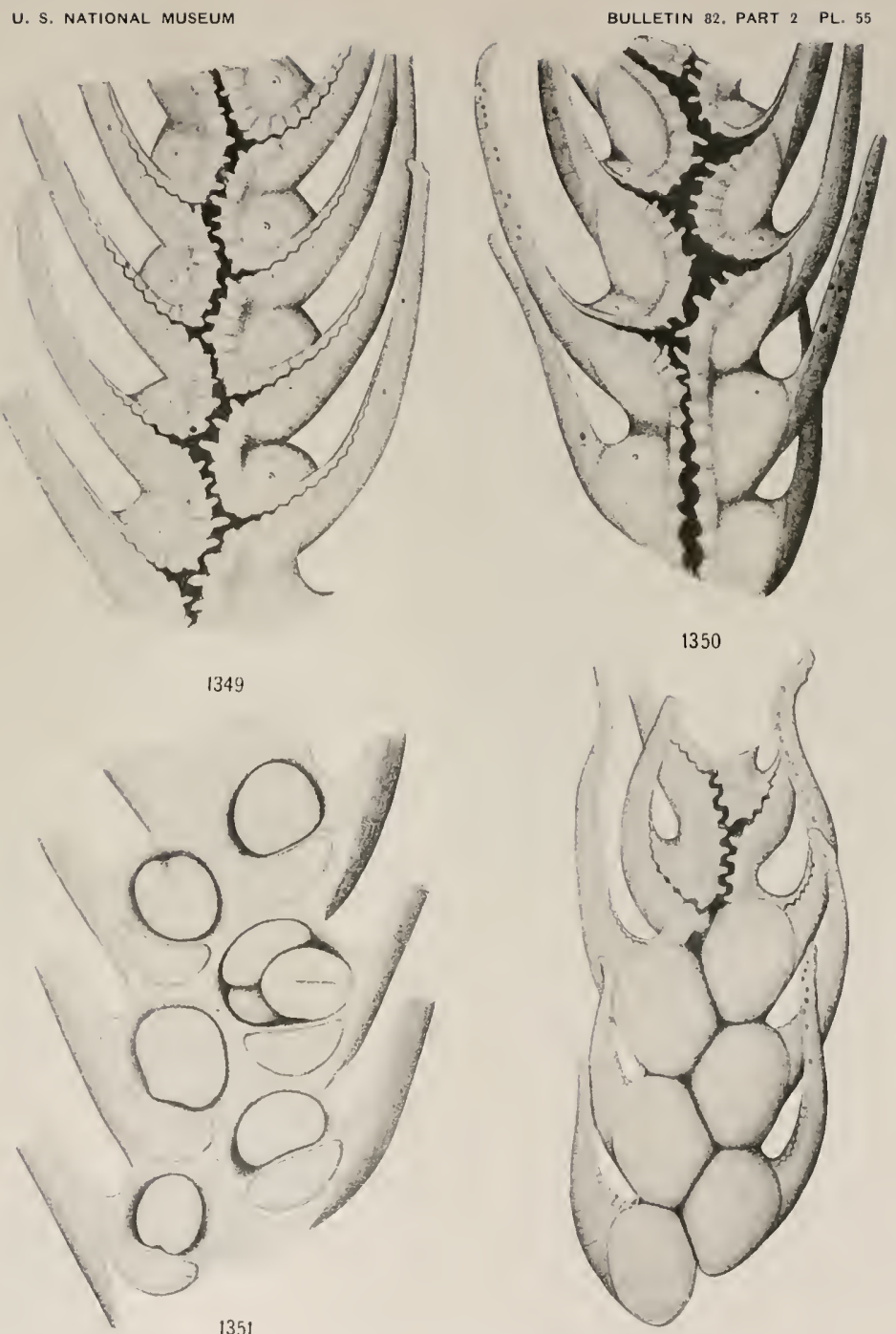

GENITAL ORgans of NOTOCRINUS VIRILIS

1352 

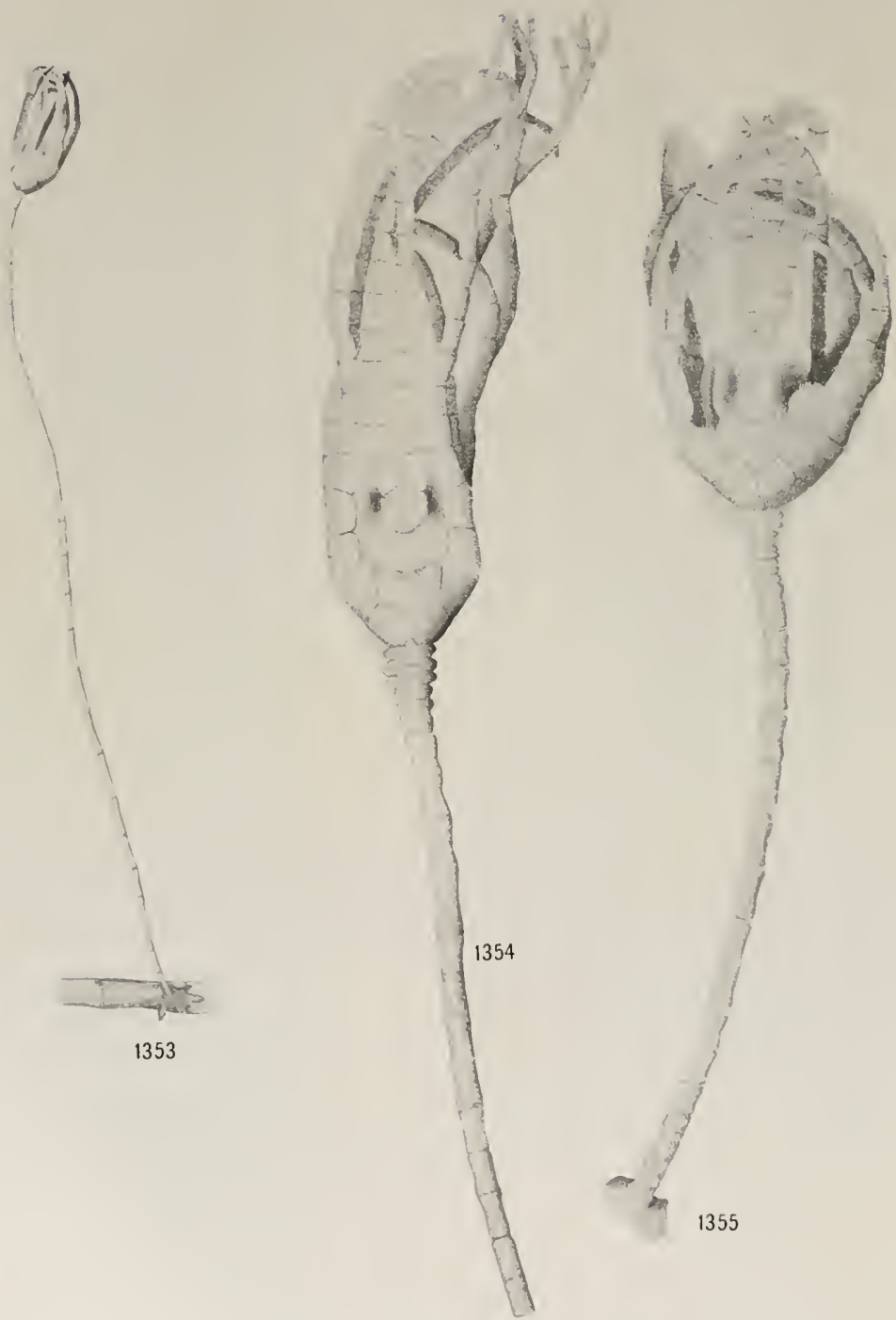

PEntacrinoid LaRVae of Hathrometra prolixa, Heliometra glacialis, and ANTEDON PETASUS. 
U. S. NATIONAL MUSEUM

BULLETIN 82, PART 2 PL. 57
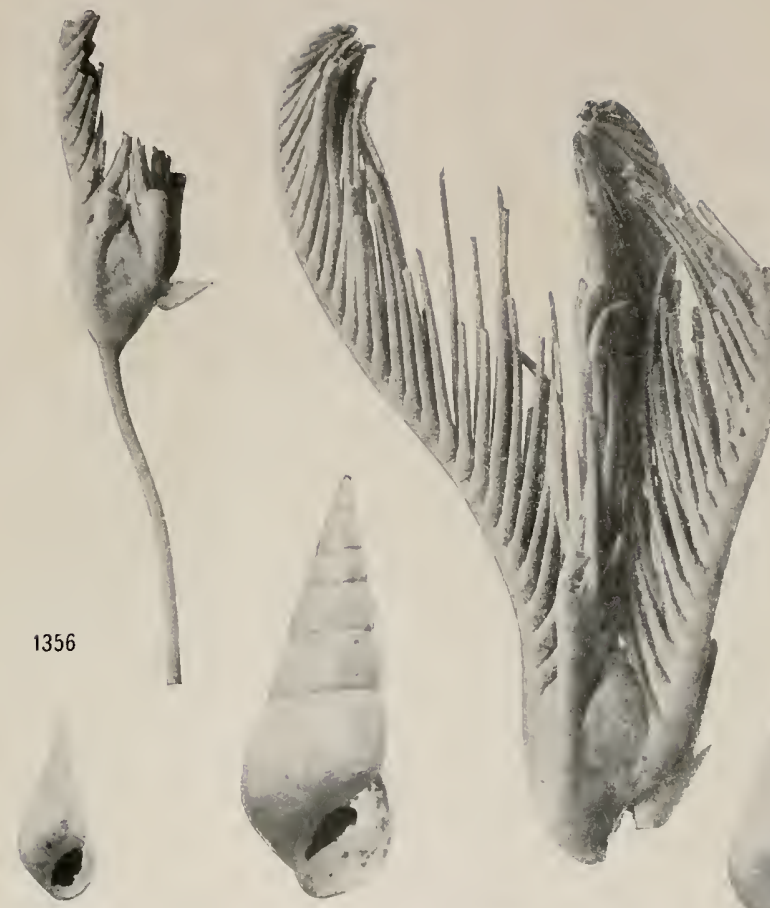

1357

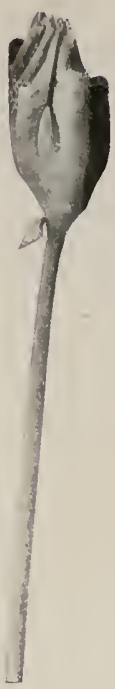

1358

1359
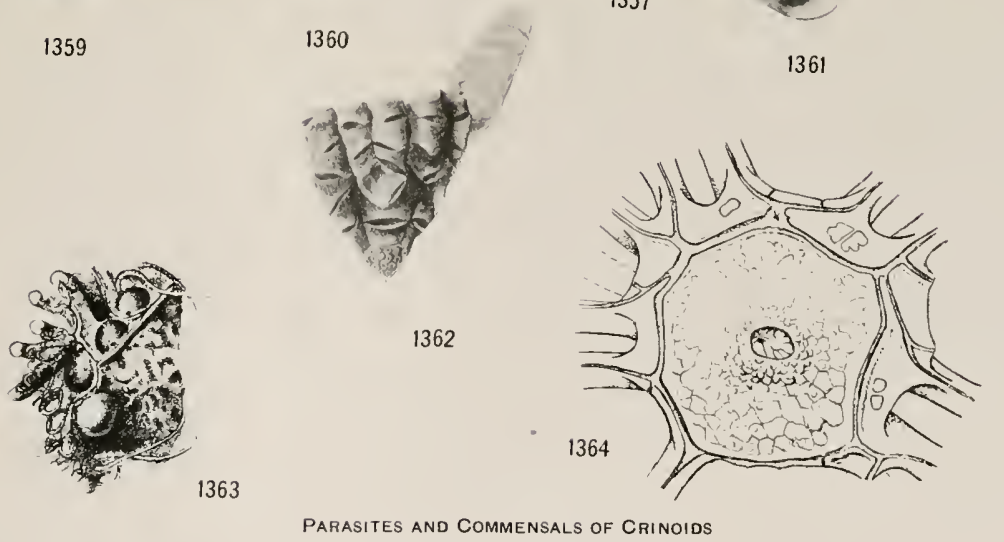

For EXPLANATION OF PLATE SEE PAgE 770 



\section{INDEX.}

abundans, Myzostomum.

Page. abyssicola, Rhabdammina 666,680 acanthaster, Neometra. $249,278,293$

Pectinometra 211 accla, Pœcilometra... 49, 75, 152, 228, 230, 359, 754 Acrothoracica.

Actiniaria.

Actinocyclus.

Actinometra

meridionalis var. quadrata........... nobilis.

notata......................

stelligera

676

612

78

662

670

178

178

n. p. ........................... 662

actinometræ, Ophiophthirius... . 614,641, 644, 680 aculeata, Chondrometra............... 754 acuticirra, Craspedometra............. 25, $26,83,88,239,261,280,293,346,595$ acutus, Metacrinus........ 83, 215, 643, 685, 726 Adelometra. $80,108,673,684,754$ angustiradia adeonæ, Oligometrides. ............. 246, 280,
$281,284,293,372,595,597,719$, $730,731,732,733,734,735,736$

Adinida. 677 adrestine, Iridometra. . .... 221, 227, 265, 281, 291 adriani, Anthometra...............268, 270, $280,292,297,299,300,549,557,578,579,580$, $581,583,584,585,588,589,590,670,672,685$ adriatica, Antedon........... 52, 53, 73, 95, 119 , $132,150,225,265,278,291,330,349,367$, $373,374,410,431,433,500,502,503,509$, $527,578,579,580,581,583,584,585,588$, $589,590,595,608,610,611,635,648,654$, $655,657,660,663,669,684,697,723,729$, $730,731,732,733,735,736,747,752,755$

ægyptica, Dorometra................ 596 affinis, Heterometra..... 595, 715, 730, 732, 733, 736 afra, Dichrometra............... 5 595, 597

Perometra .................... 80, 104

Tropiometra.................... 79,

$86,247,279,280,291,595,597,604,719,729$

africana, Heterometra................. 595 agassizii, Myzostomum.......... 664, 683, 681

Thalassometra............. 46, 230, 258
Aglaometra . . . . . . . . . . . . . . . eupedata........ 179, 216, 258, 279, 721,729 incerta.................. 152, 230,258 propinqua................... 721,729 valida......................... 754 alata, Neocomatella................. 231, $243,280,292,366,372,668$ alatum, Mfyzostomum................ 659, 684 alauda, Decametra.................. 596 alba, Polytrema miniaceum var........ 680 albatrossi, Synalpheus. ............ 623, 624 alboflava, Lissometra... 161, 721, 730, 731, 733, 736 albopurpurea, Cyllometra....... 33, 37, 75, 108, $147,244,278,280,281,284,291,292$, $366,596,719,730,732,733,735,736$

album, Scalpellum........... 614, $638,685,686$ Alecto horrida..................... 725 alecto, Neometra......... 248, 249, 278, 293, 405 Alpheidæ......................... 623 Alpheus comatularum............... 620,624 alternan8, Comantheria..... 86, 108, 109, 594, 707 alternicirrus, Endoxocrinus.......6.638, 639,662, $664,670,671,672,686,726,747,749$

ambiguum, Myzostomum. . ......666, 680, 681

amboinæ, Heterometra................ 595 Synalpheus...................... 623

Amœba........................ 407 myzostomatis................... 675

Amphianthus...................... 676

Amphicrinus....................... 204

Amphimetra...... 99, 110, 130, 145, 148, 210, 228 discoidea............. 147, 165, 205, 216, 223, $229,241,266,280,285,291,372,597$, $599,715,730,731,732,733,735,745$ ensifer..........26, 29, 72, 104, 216, 228, 595 jacquinoti.................... 595 laevipinna..................... 595 milberti....................... 595 molleri................. 595, 673, 674, 682 papuensis...........20, 20, 241, 281, 291, 595 parilis. . ..... 241, 280, 293, 371, 374, 595, 599 pinniformis...................... 595 schlegelii.................... 115, 228 spectabilis.................... 117, $147,241,278,291,371,374,595$ 
Amphipholis . . - $-3 . .$.

Amphipoda......................... 633

Amphiura......................... 642

Amphiura squamata.............. 636, 675, 678 amphiuræ, Philichthys.................. 636

Vorticella.......................... 678

Amphiuridæ......................... 642

Analcidometra......... 99, 145, 146, 194, 196, 744

armata.................. 596, 663,682, 725

anceps, Antedon..................... 108, 110

andersoni, Pontiometra... 30, 33, 83, 103, 120, 123, $124,138,180,181,205,213,228,242$ $279,285,291,346,372,595,717,729$

andromeda, Zygometra................ 595

Andrometra.......................... 141

indica.......................... 298

psyche..................... 265, 281, 292

angulatus, Metacrinus.. 638, $664,685,726,747,749$ angusticalyx, Perissometra........... 49, $75,101,152,224,230,359,672,683,754$ angustiradia, Adelometra .... 80, 108, 673, 684, 754 Anilocra $617,619,622,654$

sp....................6 614, 632, 680, 682 Anisocrinus......................... 204 Annametra......................... 618 occidentalis............ 647,648,681,723 annandalei, Oceanometra... 108, 173, 258, 279, 283 Annelida Polychæta................... 650 annulata, Asteroporpa.............. 615, 641, 686

Comanthus..................... 236 $278,291,371,594,597,604,624,625,626,628$, $629,631,632,633,642,643,644,650,655,656$, $681,709,728,729,730,731,732,736,743,754$ A nochanus........................ 369 Anomura, Decapoda.................. $\quad 630$ Anoplodium....................... 675 antarctica, Psathyrometra... 271, 281, 285, 292, 362

Solanometra................ 58,77,347 antarcticum, Myzostomum............ 670, 685 antarcticus, I'tilocrinus................ 727 Antedon..... 78, 82, 140, 169, 172, 191, 194, 196, 204, $210,219,222,230,282,304,306,307,310,312$, $313,314,315,316,318,320,328,330,331,332$, $336,340,347,351,352,353,354,355,357,359$, $361,365,375,386,387,396,401,403,406,407$, $413,414,417,430,432,433,503,507,510,511$, $517,525,528,562,565,577,578,584,587,591$, $592,597,599,600,601,607,608,609,636,654$, $656,657,677,688,702,738,743,744,745,750$ adriatica. . $52,53,73,95,119,132,150,225,265$, $278,291,330,349,367,373,374,410,431,433$, $500,502,503,509,527,578,579,580,581,583$, $584,585,588,589,590,595,608,610,611,635$,
Page.

Antedon adriatica ................ 648, 654 $655,657,660,663,669,684,697,723,729$, $730,731,732,733,735,736,747,752,755$

anceps......................... 108, 110

barentsi........................ 230

bifida........... 1, 52, 73, 80, 85, 87, 88, 92 , $95,103,106,110,114,119,121,150,185,188$, $219,222,225,228,265,278,291,295,312,320$, $324,330,342,349,357,371,374,376,377,410$, $413,418,420,421,424,431,432,448,502,509$, $523,524,525,526,528,555,560,562,572,577$, $578,579,580,581,583,584,585,586,588,589$, $590,595,597,599,600,601,607,608,609$, $610,611,612,628,632,640,656,660,663,677$, $678,684,687,688,689,694,696,722,729,730$, $731,732,733,734,735,737,747,751,752,754$ dúbenii................ 312, $595,597,744$ dubia......................... 664 hupferi..................... 298, 595 impinnata....... 184, 195, 618, $665,668,685$ insignis....................... 662 lovéni.......................... 662 mediterranea $52,53,73,95,119,150,219,225$, $315,316,320,321,324,325,330,331,337,339$, $342,343,344,345,348,350,351,355,359,360$, $367,373,374,375,409,410,411,413,414,416$, $418,424,430,431,432,433,497,499,509,526$, $527,578,579,580,581,582,583,584,585,588$, $589,590,595,609,610,611,622,646,648,654$, $660,663,677,678,684,690,694,695,696,697$, $723,729,730,731,732,733,734,735,736$ moroccana.................... 298, $312,431,432,509,526,581,595,597,610$ petasus..................... 51, 52,53, $73,91,95,103,132,150,197,215,220,225$, $264,278,281,284,291,298,349,366,523,524$, $577,578,579,580,581,583,585,588,589,590$, $595,660,663,684,722,729,731,733,736,737$ pourtalesii..................... 661 triqueta.............660,664, 665, 666, 667

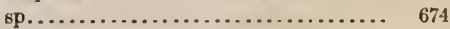
Antedonidæ...................... 50 $101,146,169,216,225,228,264,282,293$, $308,310,312,332,336,411,418,595,596,722$ Antedoninæ....... 50, 169, 595, 596, 722, 743, 744 antedonis, Hemispeiropsis.......... 614, 678, 684

Loxosomclla.............. 615, 650, 685

Trichodina....................... 678 antennatum, Myzostomum......... 666, 681, 686 Anthometra.................... $85,142,618$ adriani................... 268, 270 , $280,292,297,299,300,549,557,578,579,580$, $581,583,584,585,588,589,590,670,672,685$ 
Page. anthus, Asterometra . . . . . . 251, 252, 278, 721, 728 Apiocrinidæ

Apiocrinus....................... 580

Apoda........................... 637

appendiculosum, Arthrochordeumium..... 636 arabica, Decametra.................. 595

Arachnocrinus bulbosus............... 203 arachnoides, Daidalometra.... 349, 595, 721, 728 Aræasoma gracile................... 636 aranea, Oxymetra................... 242, $269,278,280,293,596,717,728$ archeri, Kallispongia............... 521, 527 arcticus, Gorgonocephalus. ........ 616, 658, 674 arenaria, Rhabdostyla............... 679 areolatum, Myzostomum.............662, 681 Arete dorsalis var. indicus .............. 623 maruteensis................... 623 armata, Analcidometra....... 596, 663, 682, 725 Arthrochordeumium appendiculosum...... 636 Articulata................... 125, 203, 580 articulata, Liparometra............. 145, 595 Ascidicolidx....................... 636 Ascomyzon comatule............. 635, 636 Ascomyzontidæ....................... 635 asper, Comastrocrinus................ 726 aspera, Heterometra.............. 209, 595 asperrims, Florometra............... 58, $60,62,66,74,85,221,227,270,281,285$, $292,297,298,299,300,362,672,724,729$ Aspirotricha...................... 677 aster, Cosmiometra.......... 159, 211, 721, 728 asteria, Isocrinus.............. 641, 686,755 asteriæ, Myzostomum.............657,673 Asterias......................... 616 richardi....................... 673 rubens........................ 679 asteriasi, Hemispeira................. 678 Astericola clausii..................... 636 Asteriidæ.

Asterina gibbosa. . . . . . . . . . . . . . . . asterisci, Cyclochæta.

Asterometra.

$85,87,88,99,101,105,147,169,212,214,217$ anthus............251, 252, 278, 721,728 cristata. . . . . . . . . . . . . . . 252, 278 lepida........................ 149 longicirra.................. 214, 754 macropoda..................... 43 , $44,74,215,252,278,283,285,385,721,728$ mirifica.................... 143, 145 Asteronyx loveni.................. 636 Asteroporpa annulata............ 615,641, 686 Astrocaneum..................... 641
Astroceras pergamena $\ldots \ldots$ Page.

Astrocharis gracilis................... 636

Astrocynodus. ...................... 641

Astrogomphus vallatus. . . . . . . 6 615,641, 686

Astropecten aurantiacus.............. 679

jonstoni. .................... 678

asymmetricum, Myzostomum..........670, 686

A telecrinidæ..... 3, 126, 163, 170, 188, 192, 202, 216, $228,277,284,312.30 \Omega, 310413,418$

Atelecrinus........ 85, 101, 103, 129, 131, 138, 142,

$148,184,192,194,202,225,284$

sulcatus...................... 277, 280

ater, Heterometra. .................. 595

atlanticus, Pentametrocrinus....... 225, 310, 312

Atopocrinus......... 87, 107, 110, 114, 116, 125,

$126,129,138,183,192,194$

sibogæ..................... 165, 166

attenuata, Thalassometra............ 283

audouini, Tropiometra.......... 595, 597,750

auerbachii, Lichnophora............... 678

aurantiacus, Astropecten............... 679

australis, Comatulides........... 233, 277, 291

Erythrometra..... 267, 281, 285, 292, 362, 724

Ilycrinus . . . . . . . . . . 662, 668, 674,686

Austrometra.................. 99, 146, 151

thetidis................. 227,229,273

A vicula..................... 615,649,686

Bacillaria........................ 612

Bærocrinus....................... 206

Balanidæ........................ 639

balanoides, Scalpellum........ 614,638,685, 686

Balanometra................. 101, 139, 184 elongata............ $724,731,733,735,736$

Balanus......................... 523 bartschi, Himerometra.... 146, 239, 280, 293, 595 basicurva, Charitometra............ 49, $75,209,230,264,672,683$ Basicurva group............... 80, 98, 101, 230 Bathycrinus....... 82, 160, 162, 176, 580,613, 618 pacificus..................... 727 Bathymetra................. 142, 618,646 sp.......................6.647,685

bathymetræ, Stilifer............... 614, 647

Stilifer (Mucronalia) . . . . . . . ..... 685 Bathymetrinæ............. 63, 170, 724, 743 beardi, Myzostomum . . . . . . . ........ 671, 683 bella, Cenometra.................. 131, 595 belli, Comaster ..................... 95, $211,220,222,255,312,323,594,706$

Myzostomum................ 671, 686 bengalensis, Heterometra. ............. 240 , $266,280,285,293,372,595,715,730$ benhami, Comanthus........236, 278, 292, 596 
bennetti, Comanthus Page. $149,257,321,594,665,666,668,681,709$

Benthopectinidæ.................... 143 bethellianus, Hyocrinus............... 674,687 bicaudatum, Myzostomum........... 668, 681 Bicellariidæ...................... $\quad 650$ bifida, Antedon...... 1, 52, $73,80,85,87,88,92,95$, $103,106,110,114,119,121,150$, $185,188,219,222,225,228,265$, $278,291,295,312,320,324,330$, $342,349,357,371,374,376,377$, $410,413,418,420,421,424,431$, $432,448,502,509,523,524,525$, $526,528,555,560,562,572,577$ $578,579,580,581,583,584,585$, $586,588,589,590,595,597,599$, $600,601,607,608,609,610,611$, $612,628,632,640,656,660,663$, $677,678,684,687,688,689,694$, $696,722,729,730,731,732,733$, $734,735,737,747,751,752,754$

Biloculina 595,717

bimaculata, Dichrometra binongcensis, Synalpheus carinatus....... 614 ,

blakei, Actinometra 662 Bonasa umbellata....................... 353 Bopyrus.......................... 637 borealis, Psathyrometra.......... 271, 281, 292 Thaumatocrinus. $280,281,292,353,725,729$ Bourgueticrinid:e ...... $82,164,580,727$ Bourgueticrinus hotessieri............. 646, 675 bowersi, Nanometra.......... 65, 67, 77, 267, 729 brachiatum, Myzostomum............ 663, 667, 680 brachiolata, Comatulella.............. 85, $91,96,136,158,594,705,729$ brevicirra, Decametra................ 595 brevicirrum, Myzostomum........... 663, 681 brevipes, Myzostomum.............. 661, 673, 683 breviradia, Stiremetra.......... 48, 75, 673, 683 briareus, Comantheria.............. 205, 234 . $278,292,594,706,730,731$, $732,733,734,735,736,754$ briseis, Dorometra...... 596, 723, 730, 731, 732, 736 brocketti, Periclimenes................ 614

Periclimenes (Cuapetes)............... 629

Bromeliacere......................... 615 brucei, Synalpheus.................. 614, $623,624,625,626,627,680,681$

brunnea, Cenometra................... 595 bucchichii, My zostomum............... 689, 684 bulbostu, Araclinocrimus.
Bythocrinus Page. (1) robustus................... 299, 300 sp.................. 647,648,675,687 cacaotica, Ophiomaza............... 614, $618,640,643,680,681,682$ var. picta, Ophiomaza..... 614, 641, 644, 681 Calamocrinus............. 165, 554, 726, 745, 746 diomedæ...................... 727 caledoniæ, Oligometra.............. 147,595 callista, Calometra.................. 227, $249,278,293,721,731,733,736$

Calometra........................... 78 callista... 227, 249, 278, 293, 721, 731, 733, 736 discoidea.....224, 249, 278, 293, 721, 728,754 separata... 133, $349,721,730,731,732,736,737$ Calometridæ... 41, 69, 78, 84, 89, 99, 110, 118, 119 , $131,132,133,134,135,136,144,147,149,151$, $156,157,169,210,211,214,218,220,226,228$, $230,248,251,282,285,293,294,308,310,3] 2$, $411,418,618,661,669,672,683,720,743,744$

Calpiocrinus ...................... 204 Calycella syringa................615, 676,685 calycotyle, Myzostomum.............. 662,686 Calyptometra................. 80, 105,216 lateralis................. 197, 223, 260, $279,293,338,371,374,425,722,729$

Camerata.............................. 208 Campanulariidæ..................... 676 Cancerilla tubulata.................... $\quad 636$ capensis, Eulima.................... 647 Melanella.............6 614, 616, 648, 681

Capillaster...... 87, 91, 110, 111, 113, 114, 116, 140 clarki.......... 594, 705, $730,732,733,736,737$ coccodistoma...........231, 277, 291, 594 gracilicirra....................... 595 macrobrachius..................... 594 mariæ................... 112, 594, 704, 728 multiradiata . . ........... $6,9,70,95,112$, $114,118,121,131,205,231,243$, $277,280,291,297,299,300,305$, $317,594,597,647,667,680,704$, $729,730,731,733,735,736,754$ sentoea............ $6,8,9,71,83,92,95$, $130,205,231,243,277,291,317$, $341,594,597,643,644,680,754$

tenuicirra.................... 595 capillastericola, Eulima............... 647

Sabinell a................. 614, 648, 680 Capillasterinæ.... 4, 211, 218, 312, 594, 595, 703, 743

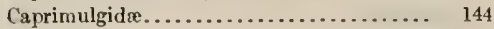
Capulidx....................... 645 carduum, Pectinometra..... 134, 249, 251, 278, 293 caribleanum, Myzostomum............ 665 
carinata, Tropiometra........ Page. $247,276,279,291,315,332$, $416,595,597,664,683,719$ carinatum, Myzostomum.... $618,668,680,681,685$ carinatus binongcensis, Synalpheus....... 614 , $623,624,625$

carinatus, Synalpheus.............. 623

Sy"nalpheus carinatus................. 623

ubianensis, Synal pheus.............. 623

carpenteri, llycrinus.................. 727

Myzostomum.................661, 685

Oligometra................... 147,

$148,211,247,281,291,596$

cataphracta, Ophiomaza.......... 614,641, 644 Catoptometra........ 87, 88, 99, 109, 110, 146. $226,308,310,411,417,743$

hartlaubi................ 20, 21, 70 , $238,281,292,293,596,714,728,729$

magnifica.................... 238, $278,291,596,714,730,731,732,736$

ophiura.................. 114, 239, $281,297,299,300,371,374,596$, $714,729,730,731,732,736,743$

rubroflava................. 238, 596 ,

$714,730,731,732,736,740,745$

Cellularia ternata var. gracilis........... 566 celtica, Leptometrq... $272,280,292,303,372,528$, $\overline{5} 77,578,579,581,584,585,589$, $608,659,662,684,724,729,743$

Cenometra

$104,145,147,210,308,418$

bella ........................... 131, 595

brunnea....................... 595

cornuta ...................... 596

delicata.................. 244, 278, 291,

$371,374,596,719,730,732,733,735$

emendatrix .............. 213, 418, 595

herdmani ............... 244, 278, 293, 630

unicornis .................. 33, 36, 79,

$205,213,244,278,291,292,596,719$

Ceramaster........................ 616

leptoceramus................... 673

ceratophthalmus, Periclimenes.......... 614

Periclimenes (Laomenes)............ 629

cerriferoidum, Myzostomum........ 663, 682, 683

chadwicki, Comissia................. 594

Prometra . .......... 246, 281, 291, 292,

$596,660,670,682,719,730,732,733,736$

chamberlaini, Eumetra........... 265, 280, $291,723,730,731,732,735,737$

Charitometra...................... 80

basicurva...... 49, 75, 209, 230, 264, 672, 683

incisa................. $659,672,673,684$

142140-21-Bull. 82-51
Charitometridæ................. 3, 41, 42, 48,

$75,80,84,99,101,105,108,110,118,119$,

$134,135,136,148,149,150,151,153,156$,

$157,169,209,210,216,218,220,224,225$,

$228,230,258,282,285,293,294,308,310$,

$312,333,335,344,410,413,418,722,743$

chelonium, Myzostomum............ 661, 683

chelonoidium, Myzostomum.......... 661, 683

Chilifera............................ 677

chinensis, Oligometra................ $\quad 595$

chinesicum, Myzostomum............ 695

Chlorometra.................. 80, 87, 151, 216 garrettiana......... 184, 264, 279, 722, 729

Cholocrinus.......................... 204

Chondrometra.................. 80, 151, 216

aculeata........................ 754

robusta .................... 216, 260, 279

rugosa.................... 297, 299, 300

Chordeumium obesum................ 636

Ciliata............................ 677

ciliata, Dichrometra . . ........ 242, 278, 293, 596

cinereus, Priofinus.................... 637

cingulatus, Metacrinus.............. 520,

$638,639,685,726,747,749$

circinatum, Myzostomum ........... 664, 686

Cirolana.......................... 617,619

lineata.................6 614, 621, 632, 681

Cirolanidx....................... $\quad 632$

cirriferum, Myzostomum.............. 616 , $653,654,655,663,684,685$

Cirripedia ......................... 637

cirripedium, Myzostomum........... 669, 686

Cladonema......................... 678

claræ, Petasometra................ 127, 595

clarki, Capillaster .. 594, 705, 730, 732, 733, 736, 737

Myzostomum .................. 671, 686

clausii. Astericola ....................... 636

Clausomyzon gracilicauda................ $\quad 636$

Cleistocrinus.......................... 206

Clidochirus........................ 206

clio, Cyclometra.... 271, 281, 292, 724, 733, 736, 737

clymene, Dorometra................ 596

Nanometra................... 267, 281

coccodistoma, Capillaster....... 231, 277, 291, 594

Coccometra.................... 136, 170,618

guttata....................... 267, 349

hagenii...... 55, 67, 77, 221, 227.267, 281, 292 . $349,373,374,649,664,665,668,684,725$

nigrolineata.........217, 267, 281, 373,374

Codium.......................... 582

Coelenterata........................ 675

cœruleus, Linckiomolgus................ $\quad 636$

Coleoptera........................... 144

Collocheres....................... 617, 636

Collocheres gracilicauda............ $614,635,684$ 
Page. $156,158,184,209,210,211,217,310$ diadema... 145, 147, 226, 227, 310, 312, 346, 595 discolor....... 33, 72, 246, 269, 281, 293, 595 perspinosa............. 595, 597,662,682 suavis. vepretum.......226, 246, 281, 293,346,595 Colobometridæ............... 35, 78, 99, 103 , $105,110,118,119,139,140,144$, $146,147,148,151,169,211,214$, $225,226,228,244,282,293,308$, $310,418,595,596,719,743,744$

columnaris, Zenometra................ 61 , $62,76,101,271,281,285,292,349,378$ Comactinia..... 176, 211, 312, 557, $587,606,618,744$ echinoptera. . . . . . . 14, 15, 71, 219.255, 323, $341,520,662,664,665,666,672,681$ meridionalis...........16, 220, 222, 225, 233, $280,291,312,341,370,374,509$, $513,514,518,549,555,577,578$, $579,580,581,582,583,584,585$, $586,588,589,590,596,662,663$, $665,666,668,672,681,706,725$

Comactiniinæ... 12, 211, 305, 310,594, 596, 705, 743 Comantheria. .................. 109, 110) alternans............ $86,108,109,594,707$ briareus................ 205, 234, 278, 292, $594,706,730,731,732,733,734,735,736,754$ grandicalyx................... 594 imbricata.................... 199,596 intermedia.................... 596 magnifica...................... 594 polycnemis.......... 79, 234,278, 291, 596 rotula....................... 594 weberi................... 596, 707 comanthi, Pontoniopsis. ......614,621,629,681 Comanthina............. 90,110,217, 222 schlegelii.................. 79,95 , $109,220,222,236,257,278,312,323,341$, $376,586,594,670,671,681,708,728,754$ Comanthus.... 98, 110, 209, 217,305, 606, 618,629 annulata.................... 236, $278,291,371,594,597,604,624,625,626,628$, $629,631,632,633,642,643,644,650,655,656$, $681,709,728,729,730,731,732,736,743,754$ benhami...............236, 278, 292, 596 bennetti................... 86 , $149,257,321,594,665,666,668,681,709$ japonica.................... 118, $236,278,291,370,374,594,613,664,681,709$ novæzealandiæ.................. 596 parvicirra................. 78, 79, $88,93,94,110,118,121,257,278,292,304,320$, $327,330,350,351,375,594,596,597,606,622$, $627,631,659,660,661,662,663,664,666,675$, $681,713,729,730,731,732,733,734,735,754$
118 ,

$149,199,236,245,278,291,341,594,666,681$ plectrophorum.................. 596 samoana..................... 135, $149,236,257,278,292,327,594,597,709$ solaster.................... 98, 149

$185,236,278,291,594,709,730,731,732,735$ tasmanix..................... 370 trichoptera.................. 79 $96,149,236,278,283,291,327,594$

wahlbergii................... 96 $236,278,292,341,514,578,582,594,709$

sp.......................... 681

Comaster.............. 31, 90, 91, 110, 135, 142,

$163,167,169,175,176,209,217,222,305,586$ belli.... $95,211,220,222,255,312,323,594,706$ delicata................. 234, 278, 596 distincta . . . . . . 234, 255, 278, 292, 323, 596 fruticosus................. 15, 16, 71,

$95,175,234,278,292,596,706,728$

gracilis..................... 594

minima.............. 106, 234, 278,

$291,292,596,706,730,731,733,736$

multibrachiata. ................ 234,

$255,278,280,292,341,594,754$

multifida............. 175, 220, 312, 594 novæguineæ............... 83, 87,90 , $175,176,220,233,277,292,312$, $341,594,597,599,659,681,706$ parvus.............. 17, 20,71,79, $199,234,257,278,292,323,341$, $596,706,730,731,732,733,735$

pulcher...................... 596 schönovi. . . ................. 594 serrata............ 341, 596, 706, 728,743 sibogæ...................... 596 taviana...... 175, 207, 234, 278, 292, 596, 706 Comasteridx.................. 4, 23, $70,78,93,94,95,96,97,98,103,110$, $118,131,132,135,136,138,142,143$, $144,146,148,149,150,151,156,157$, $169,178,201,209,210,211,212,214$, $226,228,230,231,282,284,293,294$, $304,305,306,307,308,310,312,314$, $315,316,330,333,336,339,340,343$, $344,352,354,355,417,518,586,592$, $594,595,596,603,606,619,644,703$ Comasterinæ................ 16, 113, $135,211,594,596,705,743,744$ Comastrocrinus.............. 176, 195, 410 asper........................... 726 comata, Zygometr............ 19, 20, 70, $83,88,238,280,284,292$, $346,366,595,674,682,714$ 
Page.

Comatella

$90,91,113,114,116,156,167,169,211$ decora.................. 595, 704, 728 maculata................... 7,71 ,

$83,231,277,291,594,597,602,604$ nigra............ 5, 6, 70, $83,90,205,231$, $235,237,277,291,309,330,348,369,374$, $594,597,667,680,703,730,731,732,735$ stelligera.................. 7,70 , $83,231,277,291,309,594,597,604$, $659,660,680,704,732,734,736,755$

Comatilia . $40,138,144$

$156,169,184,284,303,305,312,619$ iridometriformis............ 11, 15, 73, 98, $195,197,207,222,225,232,245$, $280,285,292,317,341,353,378$

Comatonia................. 144, 214, 305, 619 cristata...... 232, 281, 284, 292, 293, 372, 595 Comatula.................... $31,87,96$, $114,151,156,163,167,176$, $178,211,214,217,310,656$

cratera........................ 594 dubia......................... 664 etheridgei . .......... 124, 183, 194, 195, 596 micraster..... 13, 15, 71, 95, 207, 255, 319, 341 pectinata................ $12,15,71,86$, $95,100,102,176,177,233,245,250$, $280,291,292,341,519,594,597,705$ purpurea................ 95, 176, 177, $250,319,329,594,597,598,604$, $605,626,643,680,692,705,729$ rotalaria...... 12, $71,79,91,124,178,199,233$, $245,280,294,307,319,320,341,344,594$, $620,632,658,659,680,705,729,730,750,754$ solaris ................... 12, 70, 91, $94,176,177,205,207,220,233,245,280$, $294,319,350,351,519,594,597,620,632$, $644,658,659,660,661,665,666,668,680$ tenuicirra....................... 596 triqueta ............660, 664, 665, 666, 667 sp......................661,662, 664 comatulæ, Ascomyzon ...............6 635, 636 Enterognathus. . . . . . . . ..... 614, 636, 684 Hemispeiropsis . . . .............. 678 Comatularum group................. 623 comatularum, Alpheus.............6 620,624 Synalphcus....614, 618, 621, 623, 624, 625, 681 Comatulella brachiolata............... 85 . $91,96,136,158,594,705,729$ comatulicola, Stylina........ 614, $616,646,648,684$ Comatulides........................ 12,619 australis...................... 233, 277. 291 decameros.................... 341
Comissia.................. 156, 211, 305, 587 chadwicki .................... 594 hartmeyeri.............. 514, 582, 594, 597 hispida................. 595, 705, 728 horridus................... 595, 705, 729 ignota...................... 594, 597 littoralis . ................ 232, 277, 291, $370,374,513,578,579,580,581,582$, $584,585,586,588,589,590,594,597$

lütkeni ................. 197, 232, 277, $292,595,705,730,732,733,735,737$

pectinifer..................... 594 peregrina... 211, 232, 245, 595, 705, 729, 732, 737 scitulus . . . ............... 705, 729, 743 spanoschistum............... 369, 374, 595 spinosissima . ................... 595 commensalis, Periclimenes......... 614, 629, 681 Periclimenes (Periclimenes).......... 628 compressa, Parametra................ 754 compressum, Myzostomum.......... 662,686 Compsometra....................... 140,599 incommoda................. 265, 281, 293 iris ........................... 596 lovéni ....................... 52, 53, $76,265,281,292,373,374,375,527$, $577,578,579,581,584,585,589,595$

serrata . . .......221, 227, 229, 527, 581, 595 compta, Heterometra... 207, 240, 261, 280, 293, 596 conaminis, Neometra................ 249, $278,293,405,720,730,731,733,736,737$ concinna, Crinometra................ 53, $75,216,223,297,299,300,338$

Eumorphometra........... 271, 280, 292, 378 consobrinus, Synalpheus............... 623 Copepoda......................... 635 Corallina............................ 598 Corals............................. 676 cordatum, Echinocardium............... 679 coriaceum, Myzostomum................ 662, 682 cornuta, Cenometra................... 596 cornutum, Myzostomum...........618, 667, 685 cornutus, Periclimenes................. 614

Periclimenes (Laomenes)............ 629 coronatum, Myzostomum .............. 668,686 Coscinodiscus..................... 612 Cosmiometra......... 80, 88, 105, 212, 214, 217, 253 aster.................. 159, 211, 721, 728 crassicirra............ 155, 252, 279, 291, 405 delicata.................... 157, 253, 279 philippinensis.................. 721,728 costatum, Myzostomum........ 660, 680, 681, 682 costatus, Metacrinus .... 638, 639, 664, 686, 726, 749 
Page.

Cotylometra.............. 99, 140, 184, 210, 217 gracilicirra......... 214, 246, 281, 293, 595 ornata............ 129, 210,214, 273, 596 Craspedometra. $88,99,109,125,131,145,148,210$ acuticirra. $26,83,88,239,261,280,293,346,595$ crassicirra, Cosmiometra..... 155, 252, 279, 291, 405 crassispina, Ophiothrix.................. 646 cratera, Comatula.................... 594 crenatum, Myzostomum..............663,681 crenulata, Heterometra.............. 131, 147, $148,209,211,217,239,261,280,291$, $346,595,664,665,667,668,682,715$, $729,730,731,732,733,734,735,736$ crinoidicola, Polynoë. 614,650 crinoidophilum, Pachylasma...... 615, 639, 685 Crinometra.... 8 80, 88, 103, 105, 109, 110, 121, 151, $156,169,210,212,214,216,217,413,618,648$ concinna... 53, $75,216,223,297,299,300,338$ gemmata..................... 212, 338 imbricata..................... 223, 335 insculpta........48, 262, 279, 338, 663, 683 margaritacea.............. 216, 338, 349 mortenseni..................... 287 pulchra........................ 338 вр..................... 648, 661,683 Crisia denticulata 565,569 cristata, Comatonia $281,284,292,293,372,595$

Stenometra. $254,279,392$ crosslandi, Myzostomum............ 670,682 Crossometra....................80, 101, $109,110,129,151,180,210,216,217$ helius..................258, 259, 279, 419 investigatoris. $216,289,335$ septentrionalis 335 Crotalometra..................... 80,110 flava................ 150,287,721,728 porrecta........ 521, 522, 577, 578, 579, 580 $581,583,584,585,588,590,721,728$

rustica......................... 215 Crustacea........................... 623 crustaceans, Undetermined........6.614,631, 640 cryptopodium, Myzostomum ......... 671, 686 Ctenosculum........................ 645 (Cuapetes) brocketti, Periclimenes....... 629 pottei, Periclimenes.................. 629 cubanum, Myzostomum................ 670 cubensis, Trichometra............. 62, 65, 77, $101,275,281,285,292,362$ Cuspidella, sp............... 615,676,685

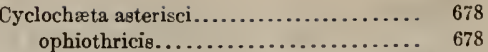
Cyclocirra thompsonii..............656, 663 Cyclometra clio... 271, 281, 292, 724, 733, 736, 737 Cyclotelson purpureum..............614,621,633, 681 Cyllometra................ 36,88, 99, 104, $139,140,145,147,184,210,217,308$ albopurpurea............ $33,37,75,108$, $147,244,278,280,281,284,291,292$, $366,596,719,730,732,733,735,736$

anomala...................... 108 disciformis... 37, 75, 244, 278, 281, 292, 595, 597 gracilis...................... 596 manca............ 147, 596, 669, 682, 754 soluta.................... 273, 596 Cymothoidæ...................... 652 cynips, Ophiuricola.............. 658, 675 Cyplopicera gracilicauda............ 635, 636 cypris, Thaumatometra..............667, 685 cysticolum, Myzostomum... $616,618,672,681,685$ var. cystihymenodes, Myzostomum .. 672,685 var. orientale, Myzostomum........ 672,683

Dactylocrinus..................... 204

Daidalometra............... 80, 132, 169, 214 arachnoides............. 349, 595, 721, 728 hana...................... 153, 256, 258 , $279,721,728,730,731,733,736,737$

deani, Myzostomum..................670, $6 \$ 5$ Decametra........ 99, 140, 145, 147, 148, 184, 210 alaudie........................ 596 arabica....................... 595 brevicirra...................... 595 informis..................... 596

lævipinna...................... 595

minima..................... 596

modica....................... 595

mollis......................... 595

mylitta............ 246, 280, 281, 293, 596 parva.............. 246, 281, 291, 293, 596 studeri..................... 147,596 taprobanes.......... 244, 269, 281, 293, 595 tigrina................ 246, 281, 292, 595 Decapoda A nomura ................... $\quad 630$ Macrura....................... 623 decora, Comatella............... 595, 704, 728 decorus, Isocrinus.................... 83 , $299,300,313,315,321,330,343,344,350$ $351,612,638,641,658,668,686,726,7: 7$ defecta, Hypalometra.............. 53 , $76,221,267,231,285,293,362$ deflexifrons, Galathea............ 620, 630 
deformator, Myzostom

Delesseria sanguinea

delicata, Cenometra...

$278,291,371,374,596,710,730,732,733,735$

Comaster.................. 234, 278, 596

Cosmiometra................ 157, 253, 279

Ophiactis..............6 614, 641, 642, 681

delicatissima, Mariametra.............. 244, $281,291,596,718,730,731,734,736$

Democrinus....................... 82

rawsonii....................... 727

dentatum, Myzostomum........ 665, 680, 681, 682

Prorocentrum...................... 677

denticulata, Crisia.................. 565, 569

Homalometra.................... 101,

$240,280,291,596,659,715,730,732,733,736$

deposita, Ophiothrix................... 646

diadema, Colobometra................. 145,

$147,226,227,310,312,346,595$

diana, Neometra.................. 130, 216 diceratum, Scalpellum......... 614, 621, 638, 686 Dichrometra...... 88, 99, 118, 145, 147, 148, 210, 214 afra........................ 595, 597 bimaculata................... 595, 717 ciliata................... 242, 278, 293, 596 dôderleini.................... 114, 223, $242,281,291,292,595,717,730,731,732,735$

dofleini...................... 596 flagellata..... 95, 242, 278, 291, 346, 595, 597 tenuicirra........................... 596

Didemnum.......................... $\quad 290$ difficilis, Palæocomatella................ $\quad 754$ digitata, Synapta..................... 679 digitiformis, Uronema.................. $\quad 677$ Dinoflagellata...................... $\quad 677$ diomedæ, Calamocrinus................. $\quad 727$ diomedeæ, Pentametrocrinus........... 725, 729

Perometra............ 39, 53, 56, 74, 104, $140,227,267,284,362,724,731,733,735,737$ disciformis, Cyllometra.............. 37, $75,244,278,281,292,595,597$ discoides, Amphimetra ............... 147,

$165,205,216,223,229,241,266,280,285,291$, $372,597,599,715,730,731,732,733,735,745$ Calometra..... 223, 249, 278, 293, 721, 728, 754 Nemaster................... 6, 9, $71,232,243,277,311,661,680,705,725$ discolor, Colobometra................ 33, $72,246,269,281,293,595$ distincta, Comaster..... 234, 255, 278, 292,323, 596

Pachylometra.. 199, 259, 260, 279, 335, 405, 412 Distoma myzostomatis................. $\quad 675$ döderleini, Dichrometra............... 114, 223 $242,281,291,292,595,717,730,731.732 .735$ dofleini, Dichrometra................ 596

Doris................................. 678

Dorometra........................ 141

ægyptica................... 596

briseis........... 596, 723, 730, 731, 732, 736

clymene........................ 596

gracilis........................ 596

mauritiana.................... 595 ,

$664,684,723,731,732,733,735,743$

nana.................... 298, 349, 595,

$596,597,607,723,730,731,732,733,735,743$

parvicirra.................. 265, 366, 595

dorsalis var. indicus, Arete........... 623

Drosophila....................... 144

dübenii, Antedon........... 312,595, 597, 744

dubia, Antedon..................... 664

Comatula....................... 664

dubium, Myzostomum............. 664, 682

duplex, Horæometra............ 227, 673, 683

Echimaster sepositus................ 677

echini, Uronema................... $\quad 677$

Echinocardium cordatum............... 679

flavescens........................ 679

Echinocheres globosus................ $\quad \mathbf{6 3 6}$

minutus....................... 636

violaceus...................... $\quad 636$

Echinoderma........................ 640

Echinometra mathæi.................... 623

echinoptera, Comactinia......... 14, 15, 71, 219, $255,323,341,520,662,664,665,666,672,681$

Echinus......................... 591, 59]

microtuberculatus................. 590

echinus, Myzostomum . . 659, 680, 681, 682, 683, 684

Stephanometra............. 79, 145, 147, $207,241,266,278,293,595,597,674,715,729$

electræ, Oligometra................. 596

Elegans group......................... 230

elegans, Galathea.........614, $618,621,630,681$

Myzostomum................. 618, 666, 681

Ophioæthiops...............614,641, 644

Zygometra...................... 238,

$278,291,346,595,620,658,659,667,682,714$ elongata, Balanometra..... 724, 731, 733, 735, 736

elongatum, Myzostomum............ 665, 682

emendatrix, Cenometra............ 213, 418, 595

encrinus, Tropiometra..........33, 38, 39, 74, 595

Endoxocrinus.............. 90, 162, 345, 410,613

alternicirrus.................... 638 , $639,662,664,670,671,672,686,726,747,749$

parræ.............. $79,299,300,726,727$

wyvillethomsoni.......... 160,343,726, 745

ensifer, Amphimetra... 26, 29, 72, 104, 216, 228, 595

Enterognathus....................616,617

comatulæ..................614, 636, 684 
Page.

Enteropneusta.................. 623

Enteroxenos...................... 645

Entocolax.............................. 645

Entoconcha....................... 645

Eolis............................ 678

Epimetra..................... 99, 139, 308

eremita; Myzostomum . . ............ 671, 686

erinacea, Oligometra................. 596

Oxymetra...................... 595

erythrizon, Psathyrometra...... 79, 221, 724, 729

Frythrometra.......... 140, 141, 184, 225, 312 australis.......... 267, 281, 285, $292,362,724$ ruber..................... 53, 57,76 , $267,281,292,329,349,724,730,731,733,735$

Eschrichti group.................... 230 etheridgei, Comatula....... 124, 183, 194, 195, 596

Euantedon moluccana................ 596 sinensis........................ 596 tahitiensis. .................... 595 eucnemis, Gorgonocephalus........ .616,658, 674 Eudiocrinus....................... 81 , $87,105,106,107,116,136,138,146,148,183$, $217,226,292,304,308,310,312,411,417,590$ gracilis.................... 109, 596 indivisus................ 238, 280, 596 junceus.............. 238, 280, 293, 366, 596 ornatus. . . . 20, 22, 70, 111, 209, 261, 346, 596 pinnatus.......... 238, 280, 284, 293, 366, 596 serripinna....................207, 596 variegatus................. 79, 207, 596 venustulus........... 112, 238, 280, 293, 596

Eulima capensis..................... 647 capillastericola................... 647 ptilocrinicola..................646,647

Fumetra......................... 141, 210 chamberlaini.................. 265, $280,291,723,730,731,732,735,737$

Eumorphometra..................... 284 concinna.............. 271, 280, 292, 378

hirsuta..................... 642,684 eupedata, Aglaometra... 179, 216, 258, 279, 721, 729 europæus, Pentacrinus...........431,432, 656 Euryocrinus....................... 204

Eutaxocrinus........................ 204 evermanni, Mfyzostomum . . . . . . . . . 666, 681 excisum, Myzostormum....... 618, 665, 684, 685 explicata, Fariometra ........... 275, 278, 292 Extracrinus....................... 116 falcatue, Synalpheus.................. 624 Fariometra explicata............ 275, 278, 292 fastigatum, Stegopoma.......... 615, 676, 685 filicauda, Myzostomum............. 668, 684 filiferum, Myzostomum............. 668, 682 fimbriatum, Myzostomum. . . . . . . . . 665, 685 finschii, Oxymetra.................. 95, $122,242,278,281,291,292,595$

fisheri, Myzostomum ................ 673

Parametra................ 164, 721, 730 fissum, Myzostomum............ 667, 682,683 Fistulata........................ 206 flagellata, Dichrometra............. 95, $242,278,291,346,595,597$

flagellifera, Mastigometra. . . . . . . . . . 349, 595 flava, Crotalometra........... 150, 287, 721, 728 flavescens, Echinocardium............. 679 flavopurpurea, Pectinometra... 197, 251, 278, 293, $349,720,730,731,732,733,734,735,736,737$

Flexibilia........................ 125, $160,194,195,198,200,201,202,204,509,557$

Impinnata.................. 191, 192, 194 flexilis, Perissometra...... 644, 671, 672, 683, 754 flora, Heterometra.................. 595 Florometra.............. 142, 230, 618, 726 asperrima.................... 58 , $60,62,66,74,85,221,227,270,281,285$, $292,297,298,299,300,362,672,724,729$ laodice. . . 221, 270, 281, 285, 292, 362, 724, 729 magellanica.......... 271, 281, 292, 298, 303 marix.......... 221, 270, 281, 292, 724, 729 perplexa...................... 60 , $62,74,79,107,303,670,685,724,729$ serratissima................. 271, $281,285,292,362,581,670,685,724,729$ tanneri...................... 60 Flustra foliacea..................... 753 Flustracea......................... 503 foliacea, Flustra.................... 753 folium, Myzostomum............... 669, 682 Foraminifera.................6 613, 679 Forbesiocrinus....................... 204 fragilis, Monachometra....... 262, 279, 286, 399

Ophiothrix...................... 678

Psathyrometra............... 61, 62, $77,271,281,292,299,300,373,374,724,729$ fruticosa, Lafoëa...............614, 676,685 fruticosus, Comaster................. 15, $16,71,95,175,234,278,292,596,706,728$

Fucus serratus..................... 600 vesiculosus....................... 600

furcatum, Myzostomum................... 668

Galathea...................... 617,619 deflexifrons. . . . . . . . . . . . . . . 620,630 elegans............. 614,618,621,630,681 
Galathea inflata longirostris. minuta

Galatheidæ

garrettiana, Chlorometra

Gasteropoda.

Gasterosiphon

Gemellaria loricata.

gemmata, Crinometra

Gephyra.

Gephyrocrinus.

grimaldii.

Page. $614,631,681$ .... 630 $614,631,681$ 630 729 645 Gephyrometra propinqua $278,293,720,730,731,734,735$

versicolor $720,730,731,733,736$ Gerardia.

gibbosa, Asterina

gigantea, Oceanometra

$108,168,214,215,227,229,256,258,279$ $288,292,419,721,729,730,731,733,737$,

giganteum, Myzostomum gigas, Myzostomum glabrum, Myzostomum $618,660,683,685$ .......... 654, 655, 660 glacialis, Heliometra............... 77, 91, $95,193,197,217,223,229,230,268,279,280$, $281,289,292,313,314,316,320,326,328$, $330,331,333,337,342,345,347,348,350$, $351,355,358,408,521,528,529,577,578$, $579,580,581,582,583,584,585,587,588$, $589,590,622,640,650,660,665,685$, $724,729,730,731,732,734.735,737$

Marthasterias $636,677,678$

Globigerina...................... 613 globosus, Echinocheres................. 636 Glyptometra $87,105,109,110,151,169,210,214,217$ tuberosa..... 216, 260, 279, 385, 523, 577, 578 , $579,580,581,584,585,588,674,683$

Gnorimocrinus.

204

Goniasteridæ ....................... 673

gonionotum, Scalpellum...........614, 638,685 gorgonia, Neometra.

$278,293,405,720,731,733,735$

Gorgonocephalida................ 641, 674

Gorgonocephalus arcticus . . . . . . . . 616, 658, 674

eucnemis................. 616,658, 674

gracile, Arseosoma................... 636

gracilicauda, Clausomyzon............. 636

Collocheres................. 614, 635, 684

Cyplopicera................. 635, 636

gracilicirra, Capillaster................ 595

Cotylometra.......... 214, 246, 281, 293, 595

gracilis, Astrocharis................ 636
566

Comaster.................... 594

Cyllometra..................... 596

Dorometra.................... 596

gracillima, Psathyrometra....... 271, 281, 292, 298

Eudiocrinus. . . . . . . . . . . . 109, 596

graff, Myzostomum.............661, 674, 685

grandicalyx, Comantheria............ 594

grandis, Liparometra.................. 596

Nemaster................... 232, 280

granularis, Sphærechinus............... 590

granulata, Parametra... 256, 279, 297, 299, 300, 435

Granulifera group ................. 80,98

gravieri, Heterometra................... $\quad 595$

Gregarinida....................... 679

grimaldii, Gephyrocrinus............... 727

group, Basicurva . ............. 80, 98, 101, 230

Comatularum................. 623

Elegans...................... 230

Eschrichti...................... 230

Granulifera.................. 80,98

Milberti ...................... 101

Parvicirra.................... 78

Spinifera.................... 80, 98

Valida......................... 78

guttata, Coccometra................ 267, 349

gyges, Lamprometra............... 145, 223,

$229,244,280,595,597$

hagenii, Coccometra.. 55, 67, 77, 221, 227, 267, 281 , $292,349,373,374,649,664,665,668,684.725$

Halilophus mirabilis.................. 623

Halimeda........................ 582, 598

Halosydna........................ 678

hana, Daidalometra................... 153, $256,258,279,721,728,730,731,733,736,737$

Harmocrinus. ...................... 204

hartlaubi, Catoptometra............. 20, 21,

$70,238,281,292,293,596,714,728,729$

hartmeyeri, Comissia. . ....... 514, 582, 594, 597

Hathrometra...................... 140,

$146,170,191,196,553,576,584,587,744$

prolixa........... $57,62,63,77,230,274$ $281,285,292,303,362,530,535,537,539,549$ $559,562,573,577,578,579,580,581,582,583$ $584,585,587,588,589,590,649,650,651,660$ $661,663,676,679,685,724,730,732,733,735$

sarsii..................... 228, 275,

$281,330,374,524,525,529,530,561,562$, $564,567,572,573,577,578,579,580,581$, $583,584,585,587,588,590,725,732,736$

tenella...................... 63 , $64,65,66,67,77,221,274,281,292,299,300$, $301,349,563,577,578,579,580,581,583,584$, $585,587,589,590,724,731,732,733,735,743$ 
hawaiiensis, Thalassometra.

Page.

helianthoides, Petasometra.

175

Heliometra . . . 85, 142, 170, 196, 224, 230, 302, 316, $331,332,347,365,375,403,553,584,618$

glacialis............... $77,91,95,193$, $197,217,223,229,230.268,279,280,281,289$, $292,313,314,316,320,326,328,330,331,333$, $337,342,345,347,348,350,351,355,358,408$, $521,528,529,577,578,579,580,581,582,583$, $584,585,587,588,589,590,622,640,650,660$, $665,685,724,729,730,731,732,734,735,737$ maxima..... 81, 86, 268, 281, 292, 296, 299, 300 Heliometrinæ.. 3, 58, 81, 103, 131, 135, 141, 144, 149, $150,170,216,282,304,312,724,743$

belius, Crossometra........... 258, 259, 279, 419

Hemieuryalidæ..................... 641

Hemispeira asteriasi ................. 678

Hemispeiropsis.................. 617

antedonis................. 614,678, 684

comatulæ..................... 678

Henricia. . . . . . . . . . . . . . . 637

sanguinolenta............. 547,550,554

hepburniana, Strotometra...... 192, 264, 722, 729

herdmani, Cenometra........ 244, 278, 293, 630

Heterocentrotus mamillatus............. 623

Heterometra...... 87, 88, 99, 109, 110, 118, 125,

$130,131,145,148,158,210$

affinis.......... 595, $715,730,732,733,736$

africana.................... 595

amboinæ..................... 595

aspera..................... 209,595

ater. ......................... 595

bengalensis................... 240,

$266,280,285,293,372,595,715,730$

compta......... 207, 240, 261, 280, 293, 596

crenulata......131, 147, 148, 209, 211, 217,

$239,261,280,291,346,595,664,665,667,668$,

$682,715,729,730,731,732,733,734,735,736$

flora....................... 595

gravieri. .................... 595

joubini........................ 595

madagascarensis................. 595

nematodon.... 595, 714, 731, 732, 734, 735, 737

philiberti...................... 20 ,

$28,72,131,217,239,261,280,293,595$

producta................. 95, 148, 211 propinqua.................... 595, 596 pulchra.............. 240,280, 291, 596 quinduplicava....... 108, 110, 240, 280, 293, $297,299,300,519,520,595$ reynaudii......... $26,27,72,240,261,280$, $293,595,643,647,648,682$
Page.

Heterometra savignii............ 239, 261, $280,293,595,622,642,645,660,670$, $682,715,730,731,732,733,735,736$

schlegelii..................... 595

singularis. ............... 207, 261, 595

varipinna................... 595

Himanthalia ..................... 600

lorea....................600,612

Himerometra........ 88, $90,95,99,109,110,118$, $130,131,145,146,147,181,194,196,209,228$ bartschi............ 146, 239, 280, 293, 595 magnipinna.

205 ,

$207,278,291,346,595,714,730$

martensi........... 25, 26, 70, 79, 89, 118 ,

$180,185,227,229,239,261,281,291,346,595$ persica................ 146, 207, 261, 595 robustipinna...... 207, 239, 278, 291, 346, 595 sol........................ 596

Himerometridæ...... 23, 25, 78, 90, 99, 101, 103, $110,118,119,144,146,148,169,209,210$ $211,214,225,228,239,282,284,293,294$, $308,310,312,417,595,596,714,743,744$

Hippasteria 637 Hippolyte. 627,628 sp....................... 615, 628

Hippolytidæ..................... 628 hirsuta, Eumorphometra............. 642, 684 hispida, Comissia . . . . . . . . . . 595, 705, 728 Holopodida................... 410,726

Holopus................ 164, 376,517,726 rangii . . . . . . . . . . . . . . 726,755

Holothuria ...................... 646 tubulosa....................... 679

holothurix, Syncystis................. 679

Holotrichous infusorian ............6 614,617

Homalocrinus............................. 204

Homalometra ................. 131, 743 denticulata................... 101, $240,280,291,596,659,715,730,732,733,736$

Horwometra . . . . . . . . . . . . . . . . . 80, 151 duplex................. 227, 673,683 horologium, Myzostomum ..... 620, 658, 680, 682 horrida, Alecto................... 725 horridus, Comissia............595, 705, 729 hotessieri, Bourgueticriuus........... 646, 675 hupferi, Antedon ................. 298, 595 Hybocrinus....................... 206 Jybometra senta. . . . . . . . . . . . . . . 596 hydroid, Parasitic. ............... 615, 687 IIygrosoma petersi................... 636 Hymenaster........................ 637 hyocrini, Stelechopus.............. 674, 687 
Hyocrinus $162,165,562$ bethellianus 674,687

Hypalocrinus. 195,410 naresianus. 86 , $299,300,638,639,664,686,726,747,749$ Hypalometra $101,139,142,184$ defecta $53,76,221,267,281,285,293,362$ hyperborea, Pectinaria 566

Hyponome sarsii 417,612

Ichthyocrinus. 206 ignota, Comissia. 594,597 Ilycrinus. $82,160,162$ australis $662,668,674,686$ carpenteri 727 imbricata, Comantheria ............ 199,596 Crinometra. 223,335 Oligometra 273,595 impinnata, Antedon.... 184, 195, 618, 665, 668, 685 impinnata, Flexibilia........... 191, 192, 194 inæqualis, Pachylometra $75,230,260,659,667,672,683$ incerta, Aglaometra.............. 152, 230,258 incisa, Charitometra.........659,672, 673, 684 incommoda, Compsometra......... 265, 281, 293 indica, Andrometra.

298

Stephanometra............. 147,595, 597

Tropiometra....... 248, 281, 291, 292, 595, 597 indicus, Arete dorsalis var............ 623 indivisus, Eudiocrinus............ 238, 280, 596 inflata, Galathea..............6 614, 631, 681 inflator, Myzostomum......... 618, 673, 680, 684 informis, Decametra................. 596 infusorian, Holotrichous............614,617 inhærens, Synapta...............673, 679 insculpta, Crinometra... 4 48, 262, 279, 338, 663, 683 insignis, Antedon. 662 Ophiosphæra. intermedia, Comantheria........................ 596 Prometra. 596 intermedium, Myzostomum......... 667, 682 internal worm, Parasitic.............. 617, 681 interruptus, Metacrinus.... . 638, 639, 649,671, 686 investigatoris, Crossometra......... 216, 289, 335 iowensis, Nemaster......... 112, 197, 230, 232, $243,280,311,594,661,680,705,725,729,745$

Iridometra.................... 141, 210 adrestine........... 221, 227, 265, 281,291 melpomene................... 265, $281,291,633,634,684,723,731,734,736$ iridometræ, Laphystiopsis......... 614, 634, 684 iridometriformis, Comatilia............ 11, $15,73,98,195,197,207,222,225,232$, $245,280,285,292,317,341,353,378$ iris, Compsometra. Page. irregulare, Myzostomum...........665, 681 irregularis, Nemaster............... 112, 594 isis, Trichometra................ 725,729 Isocrinus.................... 116 , $176,294,321,330,339,340,342,345,351$, $359,410,411,417,430,612,613,641,755$ asteria............... 641, 686,755 decorus.................... 83 , $299,300,313,315,321,330,343,344,350$, $351,612,638,641,658,668,686,726,727$

Isometra......................... 151, 284

vivipara.................... 153 $230,274,279,281,292,365,367,368$ $369,375,409,410,510,528,582,613$

Isopoda........................ 632

jacquinoti, Amphimetra. . . . . . . . . . $\quad 595$

japonica, Comanthus................. 118 , $236,278,291,370,374,594,613,664,681,709$

Oligometra................. 147, 595 japonicum, Myzostomum............ 618, 669 japonicus, Pentametrocrinus. . . . . 6. 67, 68, 76, $275,277,280,281,292,299,300,374,725,729$

jonstoni, Astropecten................. 678 joubini, Heterometra................. 595 junceus, Eudiocrinus...... 238, 280, 293, 366, 596 kæmpferi, Macrocheira............... 576 Kallispongia archeri. . . . . . . . . 521,527 kerguelensis, Promachocrinus....... 58, 77,81, $268,278,279,280,285,293,297$, $299,300,347,378,530,532,533$, $538,541,545,549,553,557,577$, $578,579,580,581,583,584,585$, $587,588,589,590,724,729,730$

labiatum, Myzostomum............. 659, 683 lævigata, Linckia.................. 636 lævipinna, Amphimetra. .............. 595 Decametra.................... 595 lævis, Nepiometra................... 754 Lafoëa fruticosa..............614, 676,685 Laminaria . . . . . . . . . . . . . . . 503, 600 Lamprometra...... 88, 99, 118, 145, 147, 148, 210 gyges........ 145, 223, 229, 244, 280,595, 597 palmata................... 244, 269, $278,291,292,595,597,622,650,660,682$, $718,728,729,730,731,732,733,735,736$ ?palmata.................. 732, 733 protectus................ 26, 34, 72 , $123,124,138,199,244,269,278$, $293,346,519,520,580,595,597$, $659,665,667,682,717,730,731$, $732,733,734,735,736,737,743$

?protectus.................. 577 , $578.579,580,583,584,585,589,590,732$ 
Lamprometra ?ap..................... $\quad{ }_{518}^{\text {Pge }}$

laodice, Florometra.................. 221, $270,281,285,292,362,724,729$

(Laomenes) ceratophthalmus, Periclimenes. cornutus, Periclimenes.

Laphystiopsidæ.

Laphystiopsis iridometræ $617,618,620,634$ planifrons. $614,634,684$ ?sp. 634,635

Laridx

larval cirripede, Obscure

Larviformia.

lata, Perissometra

216 ,

lateralis, Calyptometra

$223,259,260,279,329,722,729$

Lecanocrinus. $260,279,293,338,371,374,425,722,729$

Lepadid $x$

lepida, Asterometra

204

Lepidoptera

leptoceramus, Ceramaster.

Leptometra....... 77, 101, 141, 148, 562, 743, 744 celtica $292,303,372,528,577,578,579,581,584$, $585,589,608,659,662,684,724,729,743$ phalangium $227,272,373,374,375,528,582$, $659,662,684,696,724,729,743$

Leptonemaster.................. 156, 169,211 venustus. $6,10,70,73$ $106,197,232,245,280,284,292$, $293,305,341,366,594,705,725$

levigata, Pachylometra............. 335, 722, 729 Lichnophora auerbachii................ 678

lichnophoridæ

Linckia lævigata.

Linckiomolgus ccruleus.

678 lineata, Cirolana..............614, 621, 632, 681 Nemaster.................. 243,311,594 Sigsbeia. 641,643

Liparometra................. 99, 145, 210,417 articulata...................... 145, 595 grandis......................... 596 regalis......................... 595, 597

lissometra..................... 80, 105 alboflava........... 161, 721, $730,731,733,736$

Lithocrinus....................... 204

Lithocystis schneideri .................. 679

littoralis, Comissia................... 232, $277,291,370,374,513,578,579,580,581$, $582,584,585,586,588,589,590,59-1,597$ lividus, Paracentrotus............. 590,636, 677 lobatula, Truncatulina...........615, $622,679,685$ lobatum, Myzostomum Page. lofotensis, Rhizocrinus............... 82 , $564,622,623,646,647,648,687,727$ longicirra, A sterometra.............. 214, 754 longicirrum, Myzostomum............ 664,681 longipes, Myzostomum............... 659 longipinna, Prometra.................. 596 longirostris, Galathea................. 630 lores, Himanthalia . . ..............660,600, 612 loricata, Gemellaria............6 615,650,685 lovéni, Antedon....................... 662 Asteronyx...................... 636 Compsometra.............. 52, 53, 76, 265, $281,292,373,374,375,527,577$, $578,579,581,584,585,589,595$

Ioxosomatidæ.................... 650

Loxosomella antedonis...........6.615,650,685 lusitanica, Thalassometra........ 229, 721, 729 lütkeni, Comissia.................. 197, 232, $277,292,595,705,730,732,733,735,737$

Myzostomum..................661, 681 macrobrachius, Capillaster............... 594 Macrocheira krempferi................. 576 macrodiscus, Tropiometra.......... 33, 38, 74 , $213,223,247,279,280,285,291,292,370$, $371,372,374,510,581,595,654,719,753$ macronema, Ptilometra........... 44, 141, 251, $278,412,596,721,731,734,735,737,753$

Macrophreata................. 49,80, 81, $100,110,114,133,134,140,142,148,149,150$, $151,156,157,165,167,169,184,209,210,216$, $219,302,308,352,410,413,577,578,579,584$ macropoda, Asterometra............ 43, 44, $74,215,252,278,283,285,385,721,728$ Macrura, Decapoda................ 623 maculata, Comatella................ 7,71, $83,231,277,291,594,597,602,604$ madagascarensis, Heterometra........... 595 magellanica, Florometra.... 271, 281, 292, 298, 303 magna, Oceanometra................ 108, 171 magnifica, Catoptometra............... 238, $278,291,596,714,730,731,732,736$

Comantheria.................... 594

Pectinometra.................. 276,349 magnipeda, Pterometra........ 252, 278, 721, 728 magnipinna, Finerometra............. 205, $207,278,291,346,595,714,730$ maldiveusis, Synalpheus stimpsonii..... 614, $623,624,625$ mamillatus, leterocentrotus.......... 623 manca, Cyllometra........ 147, 596, 669. 682, 754 margaritacea, Crinometra.......... 216,338, 349 margaritifera, Nlariametra.... $79,125,217,269,346$ marginatum, Myzostomum............661, 680 
Page.

mariæ, Capillaster............ 112, 594, 704, 728 Florometra......221, 270, 281, 292, 724, 729 Mariametra.

$99,105,145,148,210,212,214,226,310$ delicatissima....................... 244, $281,291,596,718,730,731,734,736$ margaritifera........... 79, 125, 217, 269, 346 subcarinata................ 26,31,72,87, $199,216,242,278,291,338,346,596$

tuberculata................... 124,596 vicaria......................... 596

Mariametridæ...................... 23,

$30,78,99,105,118,144,146,148,169,209$, $210,211,225,226,228,242,282,293,294$, $308,310,417,595,596,603,717,743,744$ martensi, Himerometra..... 25, 26, 70, 79 \$9, 118 , $180,185,227,229,239,261,281,291,346,595$

Marthasterias glacialis...........6 636, 677, 678 maruteensis, Arete.

. Mastigometra.

$225,310,312,313$

flagellifera.................... 349,595

micropoda................... 298, 595

pacifica......................... 595

mathæi, Echinometra................. 623

mauritiana, Dorometra.............. 595, $664,684,723,731,732,733,735,743$

maxima, Heliometra................ 81 , $86,268,281,292,296,299,300$

maximus, Pecten................... 523 mediterranea, Antedon..... 52, 53, 73, 95, 119, 150 , $219,225,315,316,320,321,324,325,330$, $331,337,339,342,343,344,345,348,350$, $351,355,359,36 \mathrm{C}, 367,373,374,375,409$, $410,411,413,414,416,418,424,430,431$ $432,433,497,499,509,526,527,578,579$, $580,581,582,583,584,585,588,589,590$, $595,609,610,611,622,646,648,654,660$, $663,677,678,684,690,694,695,696,697$, $723,729,730,731,732,733,734,735,736$

Megadenus................... 645, 646

Melampyrum.................... 616

Melanella............. 616, $618,645,646,649$ capensis................ 614,616,648, 681

elongata....................... 648

sp...............6 614,648,649,683, 687 Melanellidæ......................616, 645 membranaceum, Myzostomum........ 669, 682 Membranipora..................... 503 meridionalis, Comactinia....... 16, 220, 222, 225, $233,280,291,312,341,370,374,509,513$, $514,518,549,555,577,578,579,580,581$, $582,583,584,585,586,588,589,590,596$, $662,663,665,666,668,672,681,706,725$

var. quadrata, Actinometra.......... 662
Meristocrinus....................... 206

Mespilocrinus....................... 204

metacrini, Myzostomum............670, 686

Metacrinus............. 114, 116, 183, 195, 344, $410,417,520,622,638,639,640,642,685$ acutus.............. $83,215,643,685,726$ angulatus........6 638, $664,685,726,747,749$ cingulatus. ... 520,638, $639,685,726,747,749$ costatus...........638, 639,664,686, 726,749 interruptus..........6 638, 639,649,671, 686 moseleyi..........638, 639,671, 686, 726,749 murrayi..................6 638,639 ?murrayi................ 638, 747,749 nobilis..........638, $639,686,726,747,749$ nobilis sumatranus............... 726 nodosus................. $726,747,749$ rotundus................ $84,170,296$, $300,376,657,666,669,670,671,686,726,755$ tuberosus.......... $638,645,686,747,749$ varians.........6 $638,639,686,726,747,749$ wyvillii.............. 638,639, $726 \quad 747,749$ zonatus................... 637,686 Metichthyocrinus................... 204 micans, Prorocentrum........ . ... 677,684 micraster, Comatula................ 13, $15,71,95,207,255,319,341$

Microcomatula.................... 305 microdiscus, Zygometra........... 79, 236, $278,291,297,299,300,413,417,595$, $612,620,632,658,659,667,682,713$, $730,731,732,733,734,735,736,737$

micropoda, Mastigometra............. 298, 595 microtuberculatus, Echinus............. 590 Milberti group..................... 101 milberti, Amphimetra............... 595 miniaceum, Polytrema.........615, 622, 676, 680 var. alba, Polytrema............. 680 minima, Decametra................... 596 minimus, Comaster................. 106, $234,278,291,292,596,706,730,731,733,736$ minuta, Galathea............. 614,631, 681 oculata, Polynoë........... 614,650,681 minutus, Echinocheres.............. 636 mirabilis, Ophiopholis........... 615,643, 685 Rhabdopleura....... 564,567, 615,623, 687 mirifica, Asterometra................ 143, 145 modica, Decametra................. 595 Modiola modiolus..................... 503 modiolus, Modiola.................. 503 moebianum, Myzostomum........ 664, 683, 684 morens, Ophiomaza............. 614, 641, 644 molleri, Amphimetra.......... 595, 673, 674, 682 mollis, Decametra................. 595 
Mollusca

moluccana, Euantedon.

Prge. 645 596 monacantha, Stephanometra........... 79, $118,145,147,223,241,266,278$ $291,346,519,520,595,597,717$

Monach ocrinus 82 sexradiatus 82,91

Monachometra. fragilis $80,217,282$

Monocystidea $262,279,286,399$ 679 moroccana, Antedon 298 , $312,431,432,509,526,581,595,597,610$ mortenseni, Crinometra................ 287 Mucronalia........................ 645, 646 mülleri, Ptilometra............. 42, 43, 72,86, $139,199,213,227,229,251,276,278,279,286$, $297,299,300,349,413,520,549,577,578,579$, $580,581,583,584,585,588,589,590,596,753$ Syncystis. 679 multibrachiata, Comaster 234 , $255,278,280,292,341,594,754$ multicolor, Neometra. $43,227,229,720,730,731,732,733,736,737$ multifida, Comaster......... 175, 220, 312, 594 multiradiata, Capillaster.............. 6, 9, 70 . $95,112,114,118,121,131,205,231,243,277$, $280,291,297,299,300,305,317,594,597,647$, $667,680,704,729,730,731,733,735,736,754$ multispina. Thalassometra............. 521, 522 murrayi, Metacrinus................. 638,639 ?murrayi, Metacrinus............ 638, 747, 749 murrayi, Myzostomum.......... 618, 673, 683, 684 murrhina, Sigsbeia...............615, 641, 686 Musophagidx...................... $\quad 748$ mylitla, Decametra........ 246, 280, 281, 293, 596 myzostoma, Trnia.................6 674, 675 myzostomatis, $\Lambda$ mocba................ 675

Distoma........................ 675

Myzostomida..................... 651 Myzostomum......... 342, 654, 656, 657, 670, 671 abundans...................... 666,680 agassizii.................... 664, 683, 684 alatum..................... 659, 684 ambiguum..................666, 680,681 antarcticum...................6670,685 antenuatum...............666,681, 686 areolatum.....................662,681 asteriie....................... 657,673 asymmetricum................6 670,686 beardi........................6671,683 belli......................... 671, 658 bicaurlatum.................. 668,681 brarhiatun................663,667,680
Myzostomum brevicirnume. brevipes bucchichii....................... 669, 684 calycotyle.................... 662, 686 caribbeanum.................... 665 carinatum...........6 618, 668, 680, 681, 685 carpenteri....................661, 685 cerriferoidum................663, 682, 683 chelonium.................. 661, 683 chelonoidium..................661,683 chinesicum....................... $\quad 659$ circinatum.................... 664, 686 cirriferum.... 616, $653,654,655,663,684,685$ cirripedium...................669,686 clarki.....................6671,686 compressum. ................ 662,686 coriaceum...................662, 682 cornutum................. 618, 667, 685 coronatum................. 668,686 costatum............ $660,680,681,682$ crenatum.................... 663,681 crosslandi......................670, 682 cryptopodium..................6 671, 686 cubanum........................ 670 cysticolum........... $616,618,672,681,685$ cysticolum var. cystihymenodes.... 672,685 orientale.........6 672,683 deani.........................6 670, 685 deformator....................6 672, 686 dentatum.............. 665, 680,681, 682 dubium................... 664, 682 echinus.........659,680,681, 682, 683, 684 elegans...................618, 666, 681 elongatum................... 665, 682 eremita.....................671, 686 evermanni...................666, 681 excisum................6 618, 665, 684, 685 filicauda................... 668, 684 filiferum.................... 668, 682 fimbriatum.................. 665,685 fisheri........................ 673 fissum...................667, 682, 683 folium..................... 669, 682 furcatum.................... 668 giganteum....................66, 660, 685 gigas................. $618,660,683,685$ glabrum................. 654, 655,660 grafti.................... 661, 674,685 horologium............ $620,658,680,682$ inflator...............618, $673,680,684$ intermedium.................. 667, 682 irregulare.................... 665, 681 japonicum.................. 618, 669 
Myzostomum labiatum .............. 659, 683

lobatum ................... 667,680

longicirrum................664, 681

longipes. . . . . . . . . . . . . . . . . . 659

lütkeni....................661,681

marginatum.................661, 680

membranaceum.............669,682

metacrini...................6.670,686

moebianum............... 664, 683, 684

murrayi..............618,673,683, 684

nanseni......................... 669

nigrescens................... 663, 681

oblongum.................... 666, 681

pallidum................661, 680,681

parasiticum......6 617, 653, 654, 660, 675, 684

pentacrini. ..................6 671,686

pictum.................... 663,683

platypus.................. $670,675,681$

plicatum................... 660,680

pulvinar........... $617,653,654,662,684$

quadricaudatum...............667,682

quadrifilum................ 667, 682

radiatum..................6.662,681

rotundum.................666,681

rubrofasciatum................. 660

schultzeanum.................. 663

smithi....................... 669, 683

tenuispinum ..............672, 683,684

testudo.................... 661, 680

thomsoni...................... 663

triste..................... 662,681

tuberculosum............... 655, 660

vastum............... $618,664,681$

verrucosum.................. 665

vincentinum ............... 668, 686

wheeleri....................669,686

willemoesii..................6 672,683

wyvillethomsoni............664, 685, 686

sp..............673,674,682,684, 685

nana, Dorometra................... 298, $349,595,596,597,607,723,730,731$

Nanometra........................ 101

bowersi............65,67,77,267,729

clymene.................... 267, 281

nanseni, Myzostomum.............. 669

naresi, Thaumatocrinus............... 754

naresianus, Hypalocrinus.............. 86, $299,300,638,639,664,686,726,747,749$

Navicula...................... 612

neglecta, Stolasterias................ 673

Nemaster...............88 87,91, 110, 111, $114,116,130,140,142,211,284,312,606,744$
Nemaster discoidea ................. 6 , $9,71,232,243,277,311,661,680,705,725$ grandis.................... 232, 280 iowensis............... 112, 197, 230, 232, $243,280,311,594,661,680,705,725,729,745$ irregularis.................... 112, 594 lineata................... 243, 311, 594 rubiginosa..................... 9, $71,96,111,232,277,280,285,366,661,680$ nematodon, Heterometra.............. 595, $714,731,732,734,735,737$ Neocomatella..................... 87 , $91,114,116,130,167,169,309,618$ alata........2 231, 243, 280, 292, 366, 372, 668 pulchella..........6, 7, 71, 81, 104, 231, 280, $285,292,314,315,320,356,376,666,673,680$

Neometra................... 11,418 acan thaster. . . . . . . . . . . 249, 278, 293 alecto............. 248, 249, 278, 293, 405 conaminis..................... 249, $278,293,405,720,730,731,733,736,737$

diana...................... 130, 216 gorgonia...................... 249, $278,293,405,720,731,733,735$

multicolor.................. 40,43, $227,229,720,730,731,732,733,736,737$

spinosissima................ 276, 353 Nepiometra læris. . . . . . . . . . . . . 754 nigra, Comatella........... 5, 6, 70, 83,90 , $205,231,235,237,277,291,309,330,348,369$, $374,594,597,667,680,703,730,731,732,735$ nigrescens, Myzostomum .......... 663, 681 nigrolineata, Coccometra... 217, 267, 281, 373, 374 Nipterocrinus..................... 204 nitida, Verruca. . . . . . . . . . 614,639, 685 nobilis, Actinometra.............. 670 Metacrinus......6 $638,639,686,726,747,749$

sumatranus, Metacrinus............. 726 nodosus, Metacrinus........... 726, 747, 749 notata, Actinometra................ 178 Notocrinus..................... 151 virilis . . . . . . . . . . . . . $279,320,367,368,369,511,616,618,675,684$ novæguiner, Comaster ......... 83, 87, 90 , $175,176,220,233,277,292,312$, $341,594,597,599,659,681,706$ novæzealandiæ, Comanthus........... 596 nudus, Phrvnocrinus............... 727 nutrix, Thaumatometra......... 230, 275, 278, $292,368,369,408,575,578,579,580,581,583$ obesum, Chordeumium.............. 636 oblongum, Myzostomum...........666, 681 
obscura, Ophiocnemis............... $\quad \begin{array}{r}\text { Page. } \\ 640\end{array}$ Ophiomaza...........6 614, 641, 644,680, 681 Obscure larval cirripede.............. 639 occidentalis, Annametra....... 647, 648, 681, 723 Oligometra................ 595, 664, 683 Oceanometra........ $\$ 0,110,211,212,214,282$ annandalei...........108, 173, 258, 279, 283 gigantea.................... 83,105 , $108,168,214,215,227,229,256,258,279$, $288,292,419,721,729,730,731,733,737$ magna...................... 108, 171 oculata, Polynoë minuta. . . . . . . 614, 650, 681 odontophorus, Synalpheus............ 623 cedipus, Ophiocreas. . . . . . . . . . . . . . . . 669 Oligometra...... 35, 36, 99, 140, 145, 158, 184, 210 caledoniæ...................... 147, 595 carpenteri..... 147, 148, 211, 247, 281, 291, 596 chinensis....................... 595 electræ....................... 596 erinacea........................ 596 imbricata. . . . . . . . . . . . . . . 273, 595 japonica.................... 147, 595 occidentalis............... 595, 664,683 serripinna................... 33, 37 , $72,147,148,211,217,227,247$, $273,278,281,292,293,366,595$

Oligometrides.................. 99, 145, 146 adeonæ...................... 246, $280,281,284,293,372,595,597,719$, $730,731,732,733,734,735,736$

Oligophreata...................... 50 , $97,100,110,114,134,140,142$, $144,148,149,151,157,165,167$, $169,184,209,211,216,302,308$, $352,410,577,578,579,584$ omissa, Thalassometra............ 721, 729 Onychocrinus........................ 204 Ophiacantha sphærulata.............. 678 spp................... 615,642,685 Ophiacanthidæ.................... 642 Ophiactis.............. 617,619,641,642,643 delicata................614,641, 642, 681 sp..................6.615,641, 642, 682

Ophioxthiops....................617,619 elegans.................... 614,641, 644 unicolor.................... 614,641,644

Ophiocnemis olsecura.................. 640 Ophiocoma, sp............ 615,641, 642,681 ophiocoms, Urceolaria............... 678

Vorticella....................... 678

Ophiocomidse...................... 642

Ophiocrcas cedipus.................... 669

Ophioglypha tumulosa................. 675
Ophiolebes scorteus............ 615,642,684

Ophiolepididæ....................... 644

Ophiomaza..........617, 619,620,640,641, 643 cacaotica...... 614,618,640,643,680,681, 682 cacaotica var. picta.........614,641,644,681 cataphracta...............614,641, 644 mœrens................... 614,641, 644 obscura............ 614,611,644,680,681

Ophiomusium, sp............ 615,644, 683

Ophiopholis...................... 642 mirabilis................ 615,643,685

Ophiophthirius................ 617,619 actinometræ...........6 614,641, 644, 680

Opliosphæra................... 617,619 insignis.................6 614,641, 644

ophiothricis, Cyclochæta............ 678

Ophiothrix........................ 643

crassispina...................... 646

deposita....................... 646

fragilis........................ 678

Ophiotrichidæ..................... 643

ophiura, Catoptometra............... 114, 239, $281,297,299,300,371,374,596$, $714,729,730,731,732,736,743$

Ophiuran pluteus................. 645, 686

Ophiuricola cynips.............. 658,675

Ophiuroidea........................ 640

Orchidacex....................... 615

Orcometra...................... 110 orientale, Myzostomum cysticolum var... 672,683 orion, Parametra.......43,47, 74, 163, 199.256, $279,349,721,728,730,731,732,733,735,736$ ornata, Cotylometra ...... 129, 210, 214, 273, 596 Orthonectidie...................... 675 Ostracoda......................... 637 ostracod, Parasitic.............. 614, 617,686 owstoni, Prometra........... 221, 227, 229, 596 oxyacantha, Stephanometra .... 145, 595, 674, 715 Oxymetra...................... 99, 214 aranea.... 242, 269, 278, 280, 293, 596, 717, 728 erinacea...................... 595 finschii.... 95, 122, 242, 278, 281, 291, 292, 595 tenuicirra . . ................... 596

Pachylasma crinoidophilum . . . . . . 615, 639, 685 Pachylometra.................... 80,87, $88,101,109,110,129,151,169,210,216,217$ distincta . . . . 199, 259, 260, 279, 335, 405, 412 inxqualis ....49, $75,230,260,659,667,672,683$ levigata. . . . . . . . . . . . 335, 722,729 pacifica, Mastigometra................ 595 pacificus, Bathycrinus............... 727 Palizocomatella..................... 114, 116 difficilis....................... 754 
Page.

pallidum, Myzostomum ..........661, 680, 681

palmata, Lamprometra . . . . . . . . . . . . . . 244, $269,278,291,292,595,597,622,650,660,682$, $718,728,729,730,731,732,733,735,736$ ?Lamprometra ............... 732, 733 papuensis, Amphimetra... 20, 72, 241, 281, 291, 595

Paracentrotus........................ 591 lividus................... 590, 636, 677

Parametra ....... 80 80,87, 88, 99, 105, 156, 214, 217 compressa....................... 754

crassicirra.................... 730 fisheri................. 164, 721, 730 granulata........ 256, 279, 297, 299, 300, 435 orion . . ......... 43, $47,74,163,199,256$, $279,349,721,728,730,731,732,733,735,736$ Parasitic gasteropod .................. 649 hydroid ................... 615, 687 internal worm ................ 617,681 ostracod .................. 614,617,686 parasiticum, Myzostomum............ 617, Parichthyocrinus _. $653,654,600,675,684$ parilis, Amphimetra. 241, 280, 293, 371, 374, 595, 599 parre, Endoxocrinus....... . . 79, 299, 300, 726, 727 parva, Decametra . . . . . . . 246, 281, 291, 293, 596 Parvicirra group.................... 78 parvicirra, Comanthus........... 78, 79, 88, 93, $94,110,118,121,257,278,292,304,320,327$, $330,344,350,351,375,594,596,597,606,622$, $627,631,659,660,661,662,663,664,666,675$, $681,713,729,730,731,732,733,734,735,754$

Dorometra ............... 265, 366,595 parvipinna, Strotometra............. 191, 754 parvus, Comaster.. 17, 20, 71, 79, 199, 234, 257, 278, $292,323,341,596,706,730,731,732,733,735$ patula, Perissometra................ 209, $259,260,279,297,299,300,754$ paupera, Toxometra................ 265, $281,285,291,362,595,723,729$

Pecten maximus.................. 523

Pectinaria hyperborea................. 566 pectinata, Comatula............... 12, $15,71,86,95,100,102,176,177,233,245$, $250,280,291,292,341,519,594,597,705$

pectinifer, Comissia.................. 594

Pectinometra........................ 210

acanthaster.................... 211

carduum............ 134, 249, 251, 278, 293

flavopurpurea.......... 197, 251, 278, 293, $349,720,730,731,732,733,734,735,736,737$ magnifica................... 276, 349

Pedicularis......................... 616

Pelseneeria..................... 645, 646

Peltogaster...................... 637
Page. pentacrinarum, Scalpellum..... 614,621, 638, 686 pentacrini, Myzostomum............ 671; 686 Pentacrinitidx.................... 726 Pentacrinus................ 116, 183, 725 europreus................. 431, 432,656

Pentametrocrinidæ................. 3, 68, $80,81,107,114,116,126,129,131,141$, $144,156,170,183,192,202,216,225,228$, $275,282,302,308,310,375,418,725,743$

Pentametrocrinus....... 76, 87, 107, 110, 125, 138 , $142,180,181,184,194,224,304,310,312,726$ atlanticus............... 225,310,312 diomedex.................. 725,729 japonicus................. 67, 68, 76, $275,277,280,281,292,299,300,374,725,729$ semperi......... 69, 76, 225, 228, 310, 312 tuberculatus........ 79, 197, 277, 280, 281, 374 varians...................... 215, $277,280,281,285,292,353,374,378,725,729$ sp...................... 329, 590,729 peregrina, Comissia................ 211, $232,245,595,705,729,732,737$

pergamena, Astroceras................ 669 pergracilis, Thalassomctra........... 754 Periclimenes. . . . . . . . . . . . . . 616, 617, 619 brocketti...................... 614 ceratophthalmus................. 614 commensalis...............6 614,629,681 cornutus...................... 614 (Cuapetes) brocketti. . . . . . . . . . . 629 pottsi..................... 629

(Laomenes) ceratophthalmus......... 629 cornutus.................. 629

(Periclimenes) commensalis......... 628 pottsi.....................614,68I

(Periclimenes) commensalis, Periclimenes.. 628

Peridinium tripos.................. 612

Perisiphonida.................. 676

Perissometra.............. 80, 87, 88, 101, $105,109,110,129,151,152,210,214,216,217$ angusticalyx................... 49, 75 , $101,152,224,230,359,672,683,754$ flexilis............644,671, 672, 683, 754 lata...... 216, 223, 259, 260, 279, 329, 722, 729 macilenta.................... 287, 335 patula.... 209, 259, 260, 279, 297, 299, 300, 754 robusta..................... 754 selene..... 182, 216, 259, 279, 287, 353, 385, 392

Peritricha. ...................... 678

Perometra........... 101, 141, 147, 184, 216, 217 afra........................ 80, 104 diomedeæ............. 39, 53, 56, 74, 104, $140,227,267,284,362,724,731,733,735,737$ pusilla.................... 101, 754 
Page.

Perometrinæ. 56, 80, 101, 105, 139, 140, 169, 724, 743 perplexa, Florometra.............. 60,62 $74,79,107,303,670,685,724,729$ persica, Himerometra.......... 146, 207, 261, 595 perspinosa, Colobometra....... 595, 597, 662, 682 Petasometra................... 99, 110,184 clare......................... 127, 595

helianthoides..................... 596 petasus, Antedon....... 51, 52, 53, 73, 91, 95, 103 $132,150,197,215,220,225,264,278,281^{\prime}$ $284,291,298,349,366,523,524,577,578^{\prime}$ $579,580,581,583,585,588,589,590,595$ ', $660,663,684,722,729,731,733,736,737$

petersi, Hygrosoma.................. ${ }^{626}$ phalangium, Leptometra... 221, 227, 272, 373, 374, $375,528,582,659,662,684,696,724,729,743$ philiberti, Heterometra ............... 20, 28, $72,131,217,239,261,280,293,595$ Philichthys amphiuræ................. 636 phlippinensis, Cosmiometra........... 721, 728 phormosom $x$, Pionodesmodes............ 636 Phrynocrinide...................... 727 Phrynocrinus.............. 165, 580, 745, 746 nudus........................ 727 picta, Ophiomaza cacaotica var.. $614,641,644,681$ Tropiometra................. 33, 40, 74, $81,82,87,89,114,183,221,248$, $280,281,291,297,299,300,301$, $330,332,344,346,371,374,376$, $410,416,510,520,581,593,594$, $595,597,598,606,613,660,683$, $689,691,692,693,694,719,729$, $730,731,732,733,736,744,753$ pictum, Myzostomum................663, 683 pinguis, Comanthus.............. 118, 149, 199, $236,245,278,291,341,594,666,681$ Pinna.............................. 46, 48 pinnatus, Ptilocrinus................. 299, $300,646,647,648,687,727$

pinniformis, Amphimetra................ $\quad 595$ Pionodesmodes phormosomæ............ $\quad 636$ Pionosyllis........................ 678 planifrons, Laphystiopsis............. 634,635 platypus, Mryzostomum..........670,675, 681 plectrophorum, Comanthus............... 596 Plicatocrinidx................ 165, 410,580,727 plicatum, Myzostomum............. 660,680 pluteus, Ophiuran................... 645, 686 Pocilometra........................ 80, $100,105,151,210,224,226,282,375$ acola........... 49, 75, 152, 228, 230, 359, 754 scalaris................... 79, 186, 221, $263,279,286,289,293,412,722,729$
Polychæta, Annelida.................. $\quad 650$ polycnemis, Comantheria.... 79, 234, 278, 291, 596 polynephris, Protomyzostoma....... 617, 658, 674 Polynoë............. 617, 618, 619, $620,622,650$ crinoidicola...................6 614,650 minuta oculata............6 614, 650,681 Polynoidze......................... 650 Polynoid worm.................... 682 Polytrema miniaceum......... $615,622,676,680$ miniaceum var. alba.............. 680

Polyzoa............................ $\quad 649$ pontifer, Thalassocrinus............... 727 Pontiometra............. $30,31,69,88,99,140$, $146,180,181,214,217,226,282,417$ andersoni............ 30, 33, 83, 103, 120, 123 , $124,138,180,181,205,213,228,242$, $279,285,291,346,372,595,717,729$

Pontoniidæ...................... 622, 628

Pontoniopsis....................... 617, 619 comanthi...............6 614, 621, 629,681

Porifera.............................. 676

Porites.......................... 598 porrecta, Crotalometra............. 521, 522, $577,57 \mathrm{~S}, 579,580,581,583$, $584,585,588,590,721,728$

Posidonia........................ 695 pottsi, Periclimenes............... 614, 681

Periclimenes (Cuapetes) ............ 629 pourtalesii, Antedon................. 661 Priofinus cinereus................... 637 pristina, Zygometra.... 174, 714, 730, 732, 733, 737 producta, Heterometra............ 95, 148, 211 Proisocrinus...................... 165 ruberrimus..................... 727 prolixa, Hathrometra... 57, 62, 63, $77,230,274,281$, $284,285,292,303,362,530,535,537,539,549$, $559,562,573,577,578,579,580,591,582,583$, $584,585,587,588,589,590,649,650,651,660$, $661,663,676,679,685,724,730,732,733,735$

Promachocrinus............ $81,82,85,105$, $116,142,169,204,206,310,347,554$, $555,556,558,559,563,544,587,593$

kerguelensis.. $58,77,81,269,278,279,280,285$, $293,297,299,300,347,378,530,532,533,538$, $541,545,549,553,557,577,578,579,580,581$, $583,584,585,587,588,589,590,724,729,730$

Prometra................ 99, 140, 158, 184 chadwicki................. 246, 2\$1, 291, $292,596,660,670,682,719,730,732,733,736$ intermedia.................... 596 longipinna..................... 596 owstoni............... 221, 227, 229, 596 propinqua, Aglaometra............. 721,729 
propinqua, Gephyrometra............ 249 , $278,293,720,730,731,734,735$

Heterometra.................. 595, 596

Prorocentridæ.................... 677

Prorocentrum....................... $\quad 677$

dentatum.................... 677

micans...................... 677, 684

rostratum....................... 677

sp.............................. 677

Protaxocrinus........................ 206

protectus, Lamprometra.......... 26, 34, 72,123 ,

$124,138,199,244,269,278,293,346,519$, $520,580,595,597,659,665,667,682,717$, $730,731,732,733,734,735,736,737,743$

?Lamprometra................ 577, $578,579,580,583,584,585,589,590,732$

Protomyzostoma polynephris....... 617, 658, 674

Psathyrometra.............. 148, 216, 284,576

antarctica........... 271, 281, 285, 292, 362

borealis.................... 271, 281, 292

erythrizon............... 79, 221, 724,729

fragilis...................61, 62 , $77,271,281,292,299,300,373,374,724,729$

gracillima..............271, 281, 292, 298

psyche, Andrometra.............. 265, 281, 292

Psygnobranchus...................... 678

Pterometra......................... 80 ,

$88,99,101,147,169,211,214,217$

magnipeda............... 252, 278, 721, 728

pulcherrima.................... 252,

$278,721,729,731,732,734,736,737$

splendida................... 252, 278

trichopoda......... 137, 214, 252, 276, 278, 329

venusta................ 72I, 731, 733, 735

Pterosyllis....................... 678

ptilocrinicola, Eulima................. 646, 647

Sabinella.................. 614, 648,687

Ptilocrinus................. 160, 162, 165, 517

antarcticus................... 727

pinnatus...... 299, $300,646,647,648,687,727$

Ptilometra....................... 80 ,

$85,87,88,90,99,147,169,217,252,302,413$

macronema ................ 44, 141, $251,278,412,596,721,731,734,735,737,753$

mülleri.................. 42, 43, 72,86 , $139,199,213,227,229,251,276,278,279,286$, $297,299,300,349,413,520,549,577,578,579$, $580,581,583,584,585,588,589,590,596,753$

Ptilometrinæ................... 42, 105, $128,131,132,133,134,135,149,152$, $169,214,282,308,596,721,743,744$ pubescens, Thalassometra......... 177, 227, 229 pulcher, Comaster................... 596 142140-21-Bull. $82-52$ pulcherrima, Pterometra........ Page. $278,721,729,731,732,734,736,737$

pulchra, Crinometra.................. 338

Heterometra............ 240, 280, 291, 596 pulvinar, Myzostomum...... 617, 653, 654, 662, 684 punctata, Zygometra.................. 596, $597,599,714,729,730,731,732,735,737$

purpturea, Comatula................... 95, $176,177,250,319,329,594,597,598$, $604,605,626,643,680,692,705,729$

purpureum, Cyclotelson......... 614, 621, 633, 681 purpureus, Spatangus................. 679 pusilla, Perometra................... 101, 754 Pycnosaccus........................ 204 quadrata, Actinometra meridionalis var... 662 quadricaudatum, Myzostomum......... 667, 682 quadrifilum, Myzoetomum............ 667, 682 quincunciale, Sperosoma.............. 636 quinduplicava, Heterometra............ 108, $110,240,280,293,297,299,300,519,520,595$ quinquecostata, Stenometra............ 48 , $75,254,256,279,754$ radiatum, Myzostomum................ 662, 681 rangii, Holopus.................... 726, 755 rawsonii, Democrinus................... 727 regalis, Liparometra............... 595, 597 renovatus, Thaumatocrinus............. 81, $220,225,312,517,590$ reynaudii, Heterometra.............. 26, 27, $72,240,261,280,293,595,643,647,648,682$

Rhabdammina abyssicola............ 561, 568

Rhabdopleura...................... 615 mirabilis............ 564, 567, 615, 623, 687

Rhabdostyla arenaria................. 679 sp........................... 679

Rhizocephala..................... 637

Rhizocrinus..................... 82 , $160,162,200,497,554,569,580,613,618,727$ lofotensis..................... 82 , $564,622,623,646,647,648,687,727$ verrilli................... 82, 649, 687 Rhopalura......................... $\quad 675$

Rhynchonella.......................... 561

richardi, Asterias...................... 673 robusta, Chondrometra........... 216, 260, 279

Perissometra.................... 754 robustipinna, Himerometra........... 207, $239,278,291,346,595$ robustus, Bythocrinus................. 299, 300 rostratum, Prorocentrum............. 677 rotalaria, Comatula..... 12, 71, 79, 91, 124, 178, 199, $233,245,280,294,307,319,320,341,344,594$. $620,632,658,659,680,705,729,730,750,754$ 
Rotaliidæ..................... $\quad{ }_{679}$

rotula, Comantheria................... 594 rotundum, Myzostomum.............666, 681 rotundus, Metacrinus............ $84,170,296$, $300,376,657,666,669,670,671,686,726,755$ rubens, Asterias. 679 ruber, Erythrometra............. 53, 57, 76, $267,281,292,329,349,724,730,731,733,735$ ruberrimus, Proisocrinus............... 727 rubiginosa, Nemaster.............. 9, 71, $96,111,232,277,280,285,366,661,680$ rubrofasciatum, Мyzostomum.......... 660 rubroflava, Catoptometra............ 238, $596,714,730,731,732,736,740,745$ rugosa, Chondrometra........... 297, 299, 300 rugosus, Thaumatocrinus.......... 275, 278, 292 rustica, Crotalometra................. 215 Sabinella............ 616, 617, 618, 645, 646, 647 capillastericola.............614,648, 680 ptilocrinicola.............6 614,648, 687 sp....................6 614,648, 682

Sagenocrinus...................... 204 Salicornaria....................... 503 samoana, Comanthus................. 135, $149,236,257,278,292,327,594,597,709$ sanguinea, Delesseria................ 503 sanguinolenta, Henricia.......... 547, 550, 554 Santalaceæ......................... 616 Sarametra.............. 105, 212, 282, 284, 378 triserialis...... 221, 271, 280, 285, 292, 724, 729 Sargassum......................... 582 sarsii, Hathrometra................ 228, 275, $281,303,374,524,525,529,530,561,562$, $564,567,572,573,577,578,579,580,581$, $583,584,585,587,588,590,725,732,736$

Hyponome.................. 417,612 savignii, Heterometra............. 239, 261, $280,293,595,622,642,645,660,670$, $682,715,730,731,732,733,735,736$ scalaris, Pocilometra............79, 186, 221, $263,279,286,289,293,412,722,729$

Scalpellinx....................... 638

Scalpellum album. . . . . . . . 614, 638, 685,686 balanoides............. 614, $638,685,686$ diceratum.............614,621,638, 686 gonionotum................ 614, 638,685 pentacrinarum..........614,621,638, 686 weltnerianum.............. 614,638,685 sp............... 614, 638, 639,683, 686 schlegelii, Comanthina............... 79, 95, $109,220,222,236,257,278,312,323,341$, $376,586,594,670,671,681,708,728,754$
Page. schneideri, Lithocystis................ 679 schönovi, Comaster................... 594 schultzeanum, Myzostomum.......... 663 scitulus, Comissia............... 705, 729, 743 scorteus, Ophiolebes............. 615, 642, 684 Scrophulariaceæ................... 616 selene, Perissometra................. 182, $216,259,279,287,353,385,392$ semperi, Pentametrocrinus 69, 76, 225, 228, 310, 312 senta, Hybometra..................... 596 sentosa, Capillaster.................. 6 , $8,9,71,83,92,95,130,205,231,243,277$, $291,317,341,594,597,643,644,680,754$ separata, Calometra................ 133, $349,721,730,731,732,736,737$ sepositus, Echinaster............... 677 septentrionalis, Crossometra.............. 335 Serpula.......................... 607 Serpulidæ..................... 615, 651 serrata, Comaster......... 341, 596, 706, 728, 743

Compsometra...... 221, 227, 229, 527, 581, 595 serratissima, Florometra............. 271, $281,285,292,362,581,670,685,724,729$

serratus, Fucus.................... 600 serripinna, Eudiocrinus............ 207, 596 Oligometra....... 33, 37, 72, 147, 148, 211, 217 , $227,247,273,278,281,292,293,366,595$

Sertularia......................... 503 sexradiatus, Monachocrinus............ 82, 91 sibogæe, Atopocrinus............... 165, 166 Comaster...................... 596

Sigsbeia lineata.................... 641, 643 murrhina............... 615, 641, 686 sinensis, Euantedon.................... 596 gingularis, Heterometra .......... 207, 261, 595 smithi, Myzostomum.................. 669, 683 socialis, Uintacrinus.................. 83 sol, Himerometra...................... 596 Solanometra................ 85, 142, 170, 230 antarctica................ 58, 77,347 solaris, Comatula......... 12, 70, 91, 94, 176, 177, $205,207,220,233,245,280,294,319$, $350,351,519,594,597,620,632,641$, $658,659,660,661,665,666,668,680$

Solaster.......................... 637

solaster, Comanthus................. 98, $149,185,236,278,291,594,709,731,732,735$ Solenocaulon....................... 623 soluta, Cyllometra................. 273, 596 spanoschistum, Comissia.......... 369, 374, 595 Spatangus purpureus.................. $\quad 679$ spectabilis, Amphimetra................ 117 , $147,241,278,291,371,374,595$ 
Sperosoma quincunciale.

Page.

636

Sphærechinus.

granularis

591

590

sphærulata, Ophiacantha

678

${ }^{8}$ picata, Stephanometra..... 145, 147,519, 520, 595, $597,659,665,667,669,682,717,729,732,736$

Spinifera group..................... 80, 98 spinifera, Stylometra.......44, 46, 74, 79, 88, 166 , $227,229,253,279,283,349,639,663,664,683$

spinipinna, Stephanometra............ 595

spinosissima, Comissia................. 595

Spirorbis.......................... 503

Spirotricha.......................... 678

splendida, Pterometra................ 252, 278

Sporozoa........................... 679

squamata, Amphiura............... 636,675, 678

Stegopoma fastigatum............ $615,676,685$

Stelechopus...................... 617,652

hyocrini......................674, 687

stelligera, Actinometra............... 178

Comatella .... 7, 70, 83, 231, 277, 291, 309, 594, $597,604,659,660,680,704,732,734,736,755$

Stenometra.................. 132, 169, 214 cristata................. 254, 279, 392 diadema... 1.52, 254, 279, 647, 649, 683, 721, 728 quinquecostata...... 48, 75, 254, 256, 279, 754

Stephanactis........................ 676

Stephanometra................... 8s,

$104,118,135,145,147,210,211,602$ echinus............. $79,145,147,207,241$, $266,278,293,595,597,674,715,729$ indica................... 147, 595, 597 monacantha............... 79, 118, 145, $147,223,241,266,278,291$, $346,519,520,595,597,717$ oxyacantha............. 145, 595, 674, 715 spicata.................. 145, 147, 519, $520,595,597,659,665,667$, $669,682,717,729,732,736$

spinipinna...................... 595 tenuipinna........... 88, 145, 147, 266, 595 Stephanometridæ............... 78, 99, 105, $144,146,148,149,169,211,214$, $228,241,282,293,308,310,411$ $418,595,603,715,737,743,744$ Stilifer.......... 616, $618,622,645,646,647,648$ bathymetræ.................614,647 (Mucronalia) bathymetræ........... 685 sp..................614,647,648, 687 stimpsonii maldivensis, Synalpheus..... 614, $623,624,625$

stimpsonii, Synalpheus............... 623

Synalpheus stimpsonii............. 623 $80,105,169,214$ breviradia............... 48, 75, 673, 683

Stolasterias.......................... 610 neglecta...................... 673

Strotometra........... 80, 100, 151, 375, 385, 418 hepburniana............ 192, 264, 722, 729 ornatissima.................... 209 parvipinna.................... 191, 754 priamus....................... 188 studeri, Decametra............... 147, 596 Stylina..............616, 617, $622,645,646$ comatulicola......... 614, 616, 646, 648, 684 Stylometra.... 41, 80, 99, 105, 212, 214, 217, 226, 282 spinifera............ 43, 46, 74, $79,88,166$, $227,229,253,279,283$, $349,639,663,664,683$

suavis, Colobometra................. 596 subcarinata, Mariametra........ 26, 31, 72, 87 , $199,216,242,278$, $291,338,346,596$

sulcatus, Atelecrinus................ 277, 280 sumatranus, Metarrinus nobilis.......... 726 Synalpheus.............. $616,617,619,620$, $622,623,626,627,630,632$

albatrossi..................... 623, 624 amboinæ......................... 623 brucei...................... 614,623 , $624,625,626,627,680,681$

carinatus binongcensis...... 614, 623, 624,625 carinatus................... 623 ubianensis. .................... 623 comatularum... 614, 618, 621, 623, 624, 625, 681 consobrinus...................... 623 falcatus........................ 624 odontophorus.................... 623 stimpsonii maldivensis...... $614,623,624,625$ stimpsonii.................. 623 sp......................614, 627,681 Synapa digitata....................... 679 inhærens..................... 678, 679 synaptæ, Syncystis.................... 679

Trichodina......................... 678

Synaptocrinus........................ 204

Syncystis holothurix.................. 679

mülleri........................... 679

synaptx............................ 679

Synerocrinus............................ 204 syringa, Calycella............... 615, 676,685 Tænia myzostoma................. 674,675 tahitiensis, Euantedon................... 595 taprobanes, Decametra..... 244, 269, 281, 293, 595 tasmaniæ, Comanthus.................. 370 taviana, Comaster... 175, 207, 234, 278, 292, 595, 706 
Taxocrinus.

Page.

Temnocrinus

tenella, Hathrometra.

206 (64, 65, 66, 67, 77, 221, 274, 281, 292, 299, 300, $301,349,563,577,578,579,580,581,583,584$, $585,587,589,590,724,731,732,733,735,743$ tenelloides, Thysanometra................ 54, $62,73,131,215,265,279,292,349,723$ tenuicirra, Capillaster

Comatula.

Dichrometra.

Oxymetra. 595 596 596 tenuipinna, Stephanometra... 88, 145, 147, 266, 595 tenuis, Thaumatometra............... 66, $67,76,79,275,293,674,685,729$ tenuispinum, Myzostomum........... 672, 683, 684 ternata var. gracilis, Cellularia ........... 566 testudo, Myzostomum................661,680 Tethya............................ 612 Thalassocrinus.................... 162, 165 pontifer........................... 727 Thalassometra............... 80,87,88, 99, $103,105,109,110,209,210,212,214,217,230$ agassizii................... 46, 230, 258 attenuata......................... 283 hawaïiensis....................... 175 lusitanica................. 229, 721, 729 multispina..................... 521, 522 omissa......................... 721, 729 pergracilis.......................... 754 pubescens.................. 177, 227, 229 villosa. $43,45,75,227,229,279,392,435,721,729$ Thalassometridæ............ 3, 41, 42, 80, 84, 99, $101,102,108,110,118,119,127,136$, $147,148,149,150,151,156,157,169$, $210,212,214,218,220,225,226,228$, $230,251,258,282,285,293,294,310$, $312,410,413,418,595,596,637,721$

Th alas8ometrinæ........ 45, 105, 132, 134, 135, 146, $148,149,153,209,308,595,721,725,743$

Thaumatocrinus...... $81,82,85,87,105,107,110$, $116,125,138,184,194,304,312,587,593$ borealis......275, 280, 281, 292, 353, 725, 729 naresi....................... 754 renovatus......... $81,220,225,312,517,590$ rugosus.................... 275, 278, 292 s1........................... 114

Thrumatometra............... 170, 284, 576 cypris......................667, 685, nutrix............... 230, 275, 278, 292, $308,369,408,575,578,579,580,581,583$ tenuis...... 66i, 67, 76, 79, 275, 293, 674, 685, 729 ?⿻p. thetidis, Austrometra............. 227, 229, 273

Thiolliericrinus...................... 578

thompsonii, Cyclocirra. . . . .........656, 663

Thyca.............................. 645

Thysanometra................ 136, 170, 284

tenelloides.................... 54 ,

$62,73,131,215,265,279,292,349,723$

Thysanometrinæ.... 54, 141, 144, 170, 723, 729, 743

Thysanozoon...................... 678

tigrina, Decametra........... 246, 281, 292, 595

Toxometra.......................... 141 paupera.... 265, 281, 285, 291, 362, 595, 723, 729

Trichasteridr.................... 641, 669

Trichodina antedonis................. 678

synaptæ......................... 678

Trichometra............... 101, 140, 146, 170 cubensis.. $62,65,77,101,275,281,285,292,362$ isis.......................... 725,729 vexator.............2 275, 278, 292, 725, 729 trichopoda, Pterometra.. 137, 214, 252, 276, 278, 329 trichoptera, Comanthus............... 79, $96,149,236,278,283,291,327,594$

Trichostomata..................... 677 tripos, Peridinium.................. 612 triqueta, Antedon........660,664, 665, 666, 667 Comatula..........660,664, 665, 666, 667 triserialis, Sarametra................. 221, $271,280,285,292,724,729$ triste, 'Myzostomum.................. 662, 681 Tropiometra........ $73,82,99,104,169,214,302$, $304,332,365,413,594,618,689,719$ afra........................ 79,86 , $247,279,280,291,595,597,604,719,729$ audouini.................. 595, 597,750 carinata............... 40, 74, 247, 276, $279,291,315,332,416,595,597,664,683,719$ encrinus................ $33,38,39,74,595$ indica...........248, 281, 291, 292, 595, 597 macrodiscus.................. 33, 38, 74 , $213,223,247,279,280,285,291,292,370$, $371,372,374,510,581,595,654,719,753$ picta........... $33,40,74,81,82,87,89,114$, $183,221,248,280,281,291,297,299,300$, $301,330,332,344,346,371,374,376,410$, $416,510,520,581,593,594,595,597,598$, $606,613,660,683,689,691,692,693,694$, $719,729,730,731,732,733,736,744,753$

?picta........................ 416 Tropiometride ....................... 38, $99,131,136,147,148,149,150$, $152,169,214,228,247,282,284$, $308,310,312,418,595,719,743$ Truncatuliua lolatula......... 615, $622,679,685$ 
tuberculata, Mariametra.

Page. $197,277,280,281,374$

tuberculosum, Myzostomum.........655, 660 tuberosa, Glyptometra................ 216, $260,279,385,523,577,578,579$, $580,581,584,585,588,674,683$ tuberosus, Metacrinus......638, 645, 686, 747, 749 tubulata, Cancerilla.................. 636 tubulosa, Holothuria................ 679 tumulosa, Ophioglypha............... 675

Tunicata......................... 623

Tyrannidæ......................... 746 ubianensis, Synalpheus carinatus......... 623 Unitacrinus................ 85, 105, 106, 107 socialis....................... 83

umbellata, Bonasa................... 353 Undetermined crustacean..........614,631, 640 worm........................614,675

Unicellular organisms................ 676 unicolor, Ophioæthiops...........614,641, 644 unicornis, Cenometra................. 33, $36,79,205,213,244,278,291,292,596,719$

Urceolaria ophiocomæ................ 678 Urceolariidæ........................ 678

Uronema digitiformis................. $\quad 677$ echini......................... 677

Valida group........................ 78 valida, Aglaometra................... 754 vallatus, Astrogomphus. ..........615,641, 686 varians, Metacrinus..... 638, 639, 686, 726, 747, 749 Pentametrocrinus................ 215, $277,280,281,285,292,353,374,378,725,729$ variegatus, Eudiocrinus............. 79, 207, 596 variipinna, Heterometra............... 595 vastum, Myzostomum............ 618, 664, 681 venusta, Pterometra........... 721, 731, 733, 735 venustulus, Eudiocrinus.... 112, 238, 280, 293, 596 venustus, Leptonemaster.......... 6, 10, 70, 73 , $106,197,232,245,280,284,292$, $293,305,341,366,594,705,725$ vepretum, Colobometra....................226, $246,281,293,346,595$ verrilli, Rhizocrinus.............. 82,649, 687 Verruca............................ 639 nitida. .................. 614, 639,685 sp....................614, 639, 685, 686 Verrucidæ......................... $\quad 639$ verrucosum, Myzostomum............. 665 versicolor, Gephyrometra... 720, 730, 731, 733, 736 vesiculosus, Fucus...
Page. vexator, Trichometra...... 275, 278, 292, 725, 729 vicaria, Mariametra................. 596 villosa, Thalassometra........ 43, 45, 75, 227, 229, $279,392,435,721,729$

vincentinum, Myzostomum........... 668, 686 violaceus, Echinocheres................. 636 virilis, Notocrinus............... 230, 272, $279,320,367,368,369,511,616,618,675,684$ vivipara, Isometra................ 153, $230,274,279,281,292,365,367,368$, $369,375,409,410,510,528,582,613$

Vorticella 525 amphiuræ......................... 678 ophiocomæ....................... 678 sp............................. 678 Vorticellidæ.......................... 678 Wachsmuthicrinus...................... 204 wahlbergii, Comanthus................ 96, $239,278,292,341,514,578,582,594,709$ weberi, Comantheria............... 596, 707 weltnerianum, Scalpellum.......... 614, 638, 685 wheeleri, Myzostomum.............669,686 willemoesii, Myzostomum............. 672, 683 worm, Parasitic internal............617,681

Polynoid........................ 682

Undetermined.................... 614,675 wyvillethomsoni, Endoxocrinus.......... 160, $343,726,745$

Myzostomum............... 664, 685, 686 wy villii, Metacrinus....... 638, 639, 726, 747, 749 Zenometra................. 101, 148, 212, 282 Zenometra columnaris.................. 61, $62,76,101,271,281,285,292,349,378$ Zenometrinæ.......6 60,80, 139, 170, 216, 724, 743 Zostera........................ 598, 600 Zygometra................... 88, 95, 109, 110 , $146,209,226,230,308,310,413,417,659,743$ andromeda.................... 595 comata................ 19, 20, 70, 83,88 , $238,280,284,292,346,366,595,674,682,714$ elegans....................... 238, $278,291,346,595,620,658,659,667,682,714$ microdiscus........ $79,236,278,291,297,299$, $300,413,417,595,612,620,632,658,659,667$, $682,713,730,731,732,733,774,735,736,737$ pristina........... $174,714,730,732,733,737$ punctata..................... 596, $597,599,714,729,730,731,732,735,737$

Zygometridæ.................. 18, 49, 70, 78 , $99,105,110,118,148,167,169,174,175,209$, $210,211,214,220,225,228,236,282,293,294$, $308,310,312,411,417,418,595,596,713,744$ 


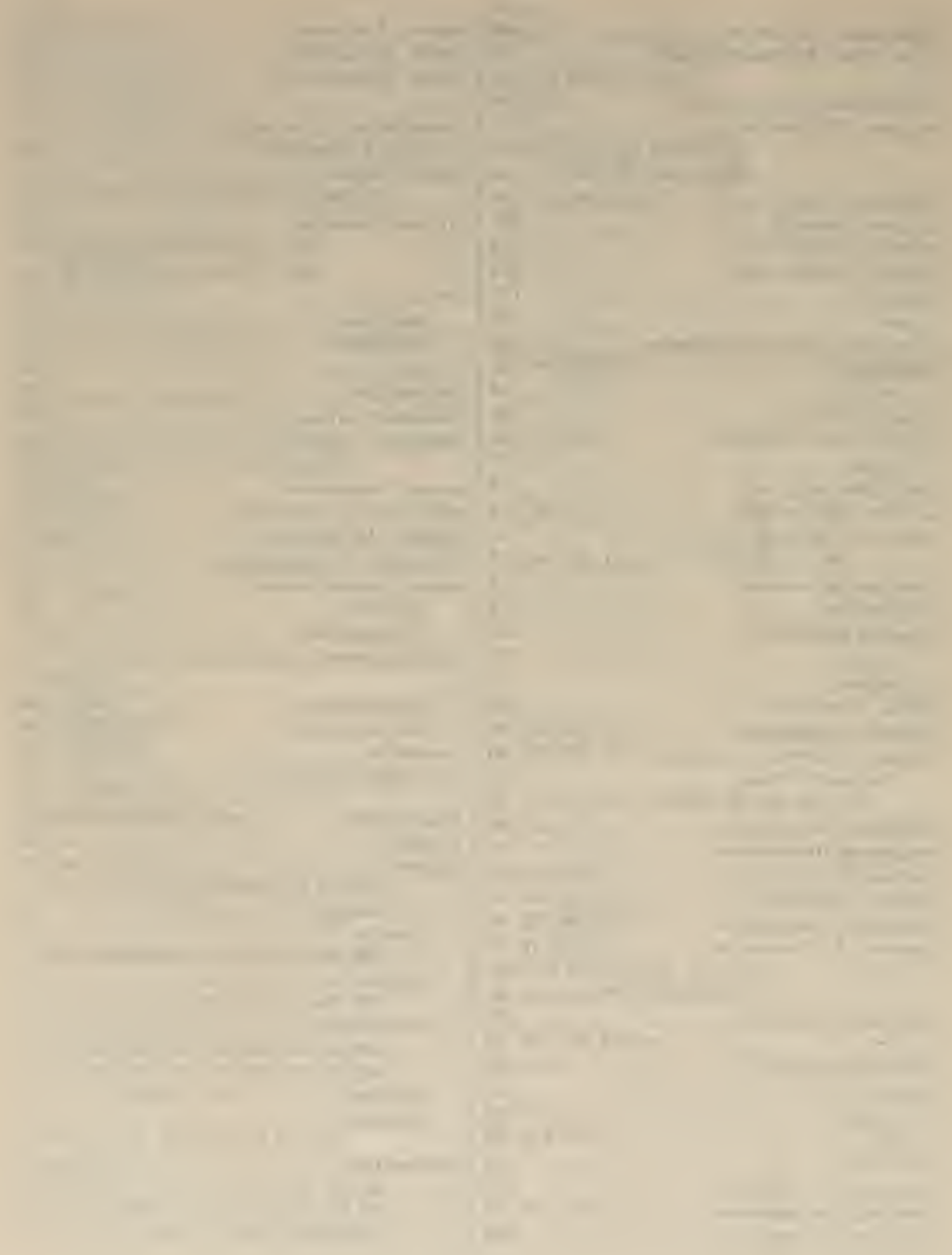





$T$ 




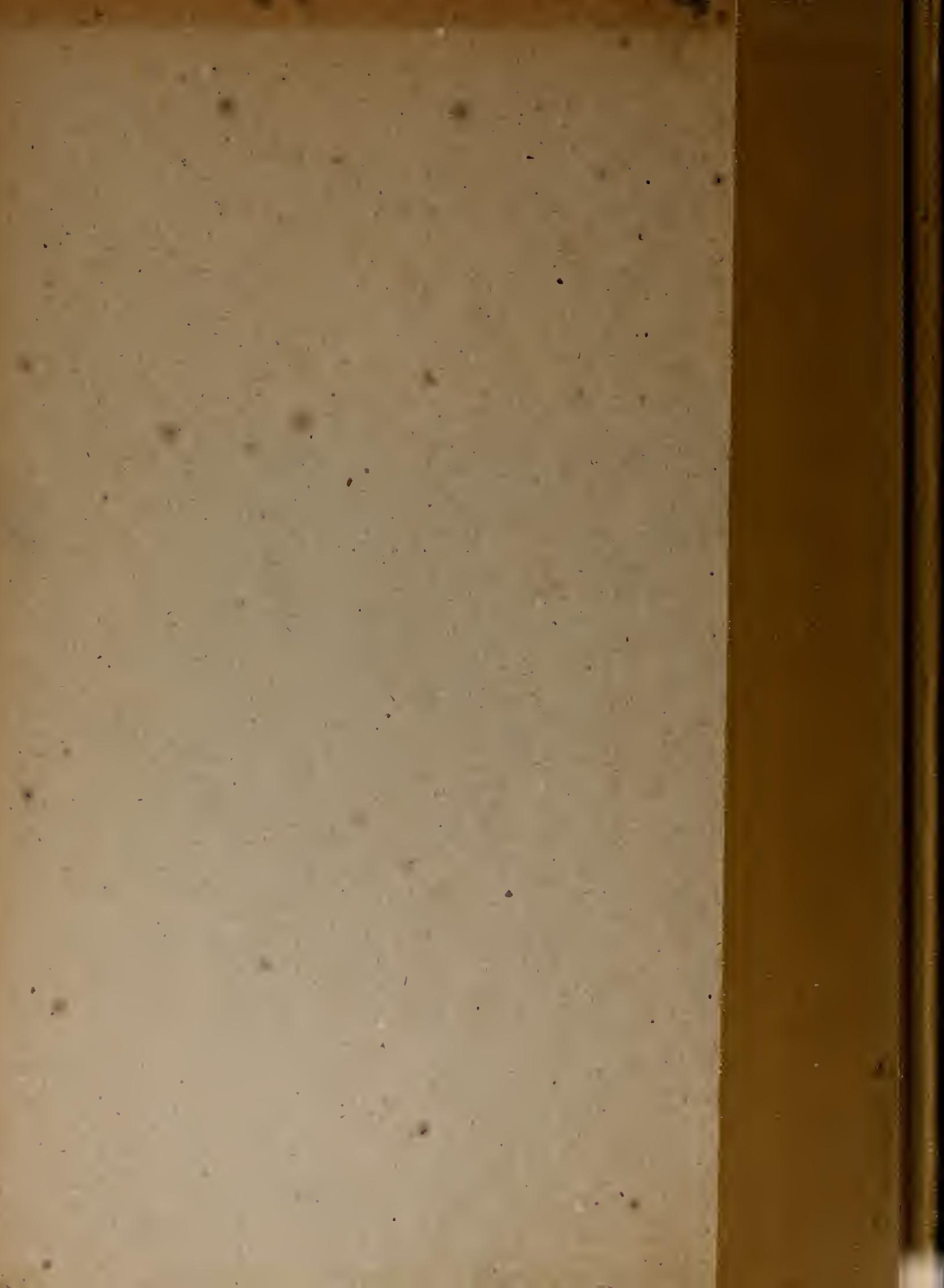

